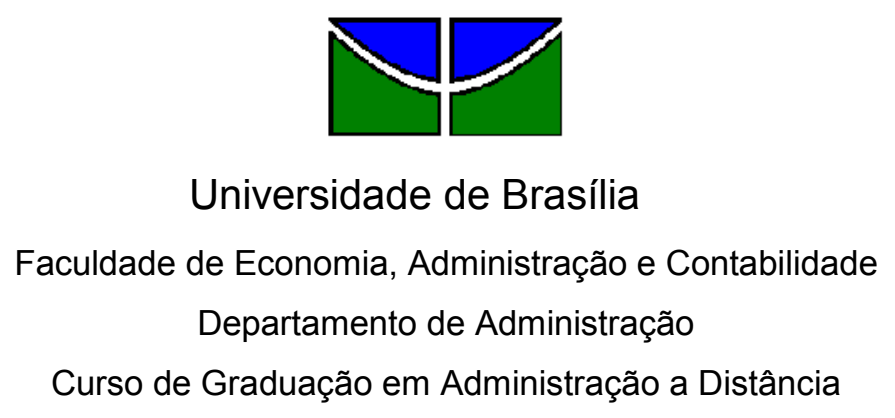

CLAUDIANA GOMES DE SOUZA

\title{
EFICIÊNCIA, EFETIVIDADE E EFICÁCIA DA POLÍTICA PÚBLICA DE FORMAÇÃO DE AGENTES DE ATER, DE 2004 A 2009
}

\author{
Brasília - DF \\ 2010
}




\section{EFICIÊNCIA, EFETIVIDADE E EFICÁCIA DA POLÍTICA PÚBLICA DE FORMAÇÃO DE AGENTES DE ATER, DE 2004} A 2009.

Monografia apresentada a Universidade de Brasília (UnB) como requisito parcial para obtenção do grau de Bacharel em Administração.

Professor Orientador: Prof. Dr. Eduardo Raupp de Vargas Professor Co-Orientador: Prof. MsC. André Luís Arantes 
Souza, Claudiana Gomes de.

Eficiência, Efetividade e Eficácia da Política Pública de Formação de Agentes de Ater, de 2004 a 2009 / Claudiana Gomes de Souza. - Brasília, 2010.

1616 f. : il.

Monografia (bacharelado) - Universidade de Brasília, Departamento de Administração - EaD, 2010.

Orientador: Prof Dr Eduardo Raupp de Vargas, Departamento de Administração. 


\section{EFICIÊNCIA, EFETIVIDADE E EFICÁCIA DA POLÍTICA PÚBLICA DE FORMAÇÃO DE AGENTES DE ATER, DE 2004 A 2009.}

A Comissão Examinadora, abaixo identificada, aprova o Trabalho de Conclusão do Curso de Administração da Universidade de Brasília da aluna

\section{Claudiana Gomes de Souza}

Prof Dr Eduardo Raupp de Vargas

Professor-Orientador

Prof. MsC. André Luís Arantes

Professor-Examinador 
Dedico esse trabalho a Deus, que me mostra os caminhos e me conduz pelas mãos e a meus pais, Anaiza e Joaquim, pelo esforço e apoio em todos os momentos desta e de outras caminhadas. 
Agradeço à Deus, pois o que seria de mim sem ele? Aos meus amados pais, Anaiza e Joaquim, e irmão, Carlos André, que com muito carinho me acompanham nas grandes e pequenas lutas e a quem digo: as vitórias não são minhas, são nossas. Ao Professor e orientador André Luís Arantes, pelo respeito ao meu ritmo de trabalho e pela paciência com uma orientanda ausente.

Ao Professor, chefe e amigo Francisco Roberto Caporal, por quatro anos de exemplo e inspiração no amadurecimento de meus conhecimentos e conceitos: quase tudo que escrevi aqui aprendi contigo.

À querida amiga Roberta Maçada Lange Kutscher, por ter generosamente dividido comigo seus anos de experiência e a memória dessa política pública. 


\section{Lista de Gráficos}

GRÁFICO 1 - AgRICULTURA FAMILIAR X AgRICULTURA PATRONAL - TOTAL DE

ESTABELECIMENTOS E ÁREA TOTAL OCUPADA

GRÁFICO 2 - AGRICULTURA FAMILIAR X AGRICULTURA PATRONAL - MÃO DE OBRA OCUPADA

GRÁFICO 3 - AGRICULTURA FAMILIAR - PRODUÇÃO DE ALIMENTOS/GRÃOS 20

GRÁFICO 4 - AGRICULTURA FAMILIAR - PRODUÇÃO DE PROTEÍNA ANIMAL.

GRÁFICO 5 - EVOLUÇÃO DE RECURSOS APLICADOS NA FORMAÇÃO DE AGENTES DE ATER 2007-2009 42

GRÁFICO 7 - QUESTIONÁRIOS RECEBIDOS POR REGIÃO (PORCENTAGEM) 54

GRÁFICO 8 - PERFIL DOS QUESTIONÁRIOS A NÍVEL NACIONAL - GÊNERO 56

GRÁFICO 9 - PERFIL DOS QUESTIONÁRIOS ANALISADOS POR REGIÃO - GÊNERO. 56

GRÁFICO 10 - PERFIL DOS QUESTIONÁRIOS A NÍVEL NACIONAL - ESCOLARIDADE 57

GRÁFICO 11 - PERFIL DOS QUESTIONÁRIOS ANALISADOS POR REGIÃO - ESCOLARIDADE ... 58 GRÁFICO 12 - PERFIL dOS QUESTIONÁRIOS ANALISADOS A NÍVEL NACIONAL - INSTITUIÇÃO

DE ORIGEM

GRÁFICO 13 - PERFIL dOS QUESTIONÁRIOS ANALISAdOS A NÍVEL NACIONAL - ÁREA DE

ATUAÇÃO.

GRÁFICO 14 - PERFIL DOS QUESTIONÁRIOS ANALISADOS POR REGIÃO - ÁREA DE ATUAÇÃO

GRÁFICO 15 - APLICAÇÃO DOS CONHECIMENTOS A CAMPO 72

GRÁFICO 16 - ÍNDICE DE APLICAÇÃO DOS CONHECIMENTOS A CAMPO ............................ 73

GRÁFICO 17 - ADEQUAÇÃO DOS CONTEÚDOS ................................................. 74

GRÁFICO 18 - RAZÕES INDICADAS PARA NÃO APLICAÇÃO DOS CONTEÚDOS .................... 75

GRÁFICO 19 - APOIO A ATIVIDADES DE FORMAÇÃO - PERCENTUAIS A NÍVEL NACIONAL ...... 77

GRÁFICO 20 - APOIO A ATIVIDADES DE FORMAÇÃO - PERCENTUAIS POR REGIÃO ............... 77

GRÁFICO 21 - ATUAÇÃO COMO MULTIPLICADORES - PERCENTUAIS A NÍVEL NACIONAL ...... 78

GRÁFICO 22 - ATUAÇÃO COMO MULTIPLICADORES - PERCENTUAIS POR REGIÃO ...............78

GRÁFICO 23 - MUDANÇA NO PERFIL DE ATUAÇÃO DOS TÉCNICOS ............................... 82

GRÁFICO 24 - INFLUÊNCIA SOBRE AS ORIENTAÇÕES DAS INSTITUIÇÕES DE ORIGEM .......... 83 


\section{Lista de Tabelas}

TABELA 1: AgRICULtURA PATRONAL X AgRICULTURA FamiLIAR ................................... 17

TABELA 3 - ITENS A SEREM AVALIADOS X INDICADORES ……..................................... 40

TABELA 4 - ORIENTAÇÕES ESTRATÉGICAS PARA AS AÇÕES DA ATER PÚBLICA .................... 45

TABELA 5 - TEMAS PARA FORMAÇÃO: LEVANTAMENTO DE DEMANDA 2006 ...................... 48

TABELA 6 - TEMAS PARA FORMAÇÃO: LEVANTAMENTO DE DEMANDA 2008 ....................... 51

TABELA 7 - NÚMERO DE QUESTIONÁRIOS RECEBIDOS POR REGIÃO................................. 54

TABELA 8 - NÚMERO DE EVENTOS REALIZADOS X POR REGIÃO DE ABRANGÊNCIA .............. 54

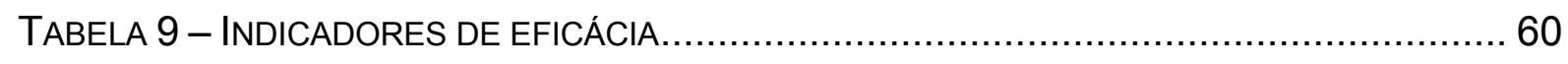

TABELA 10 - EVENTOS REALIZAdos X TEMAS DA PNATER X DEMANDAS APRESENTADAS 64

TABELA 11 - NÚMERO DE EVENTOS REALIZADOS POR MACROTEMA ……....................... 69

TABELA 12 - ESTRATÉGIAS DE FORMAÇÃO, NÚMERO DE EVENTOS E NÚMERO DE AGENTES

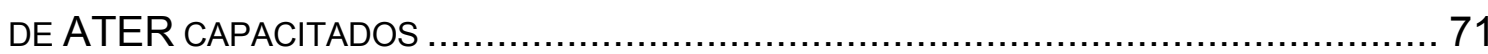

TABELA 13 - FATORES RELACIONADOS A NÃO APLICAÇÃO DOS CONHECIMENTOS - POR

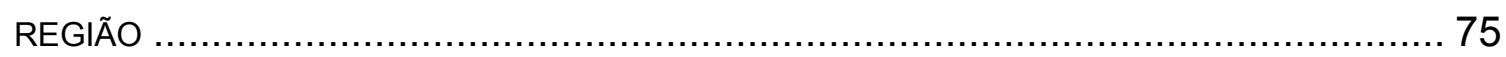

TABELA 14 - INDICADORES DE EFICIÊNCIA …………........................................... 79

TABELA 15 - EXECUÇÃO FINANCEIRA - RECURSOS PREVISTOS X RECURSOS EMPENHADOS 80

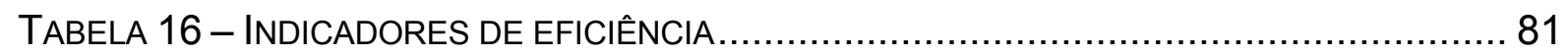

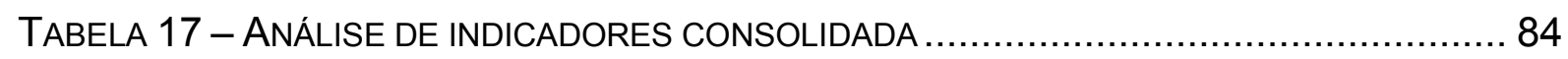




\section{Lista de Siglas}

Assessoria Técnica e Social à Reforma Agrária - ATES

Assistência Técnica e Extensão Rural - ATER

Conselho Nacional de Desenvolvimento Rural Sustentável - CONDRAF

Departamento de Assistência Técnica e Extensão Rural - DATER

Food and Agriculture Organization of the United Nations - FAO

Instituto Nacional de Colonização e Reforma Agrária - INCRA

Ministério do Desenvolvimento Agrário - MDA

Política Nacional de Assistência Técnica e Extensão Rural - Pnater

Programa de Aquisição de Alimentos - PAA

Programa Nacional de Fortalecimento da Agricultura Familiar - PRONAF

Secretaria da Agricultura Familiar - SAF

Sistema Nacional de Assistência Técnica e Extensão Rural - Sibrater

Sistema Integrado de Administração Financeira do Governo Federal - SIAFI 


\section{SUMÁRIO}

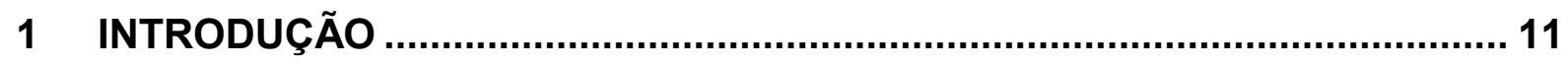

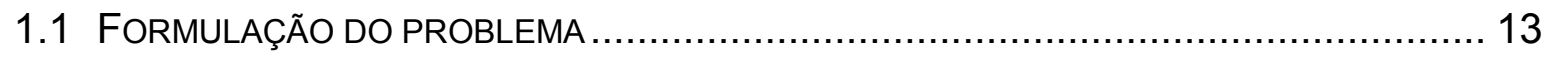

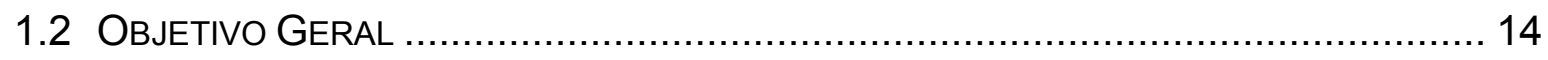

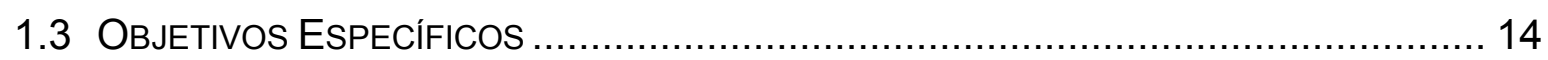

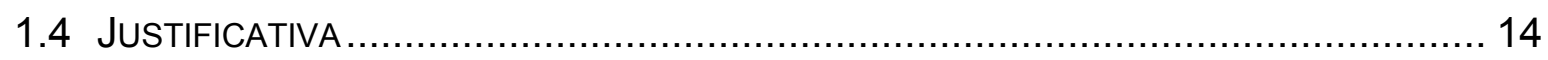

2 REFERENCIAL TEÓRICO.......................................................................... 17

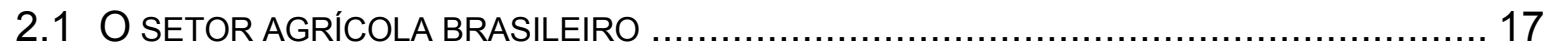

2.1.1 Agricultura Familiar x Agricultura Patronal...................................... 17

2.1.2 Perfil da Agricultura Familiar Brasileira ........................................... 18

2.1.3 A Evolução dos serviços de Assistência Técnica no Brasil e a Política

Nacional de Assistência Técnica e Extensão Rural - Pnater........................... 22

2.2 A FormaçÃo de Agentes de AssistênCIA TÉCNICA E EXTENSÃo RuRAL COMO

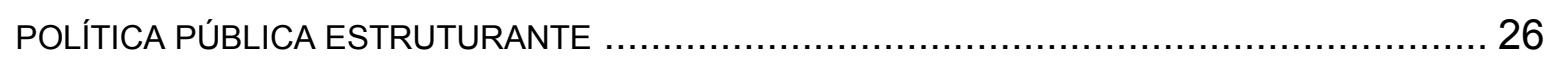

2.2.1 Por que formar agentes de Assistência Técnica e Extensão Rural -

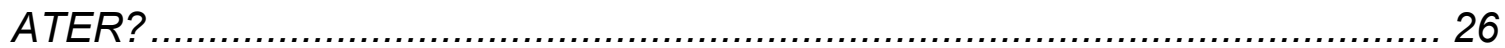

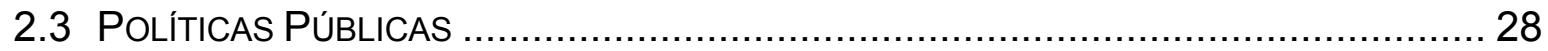

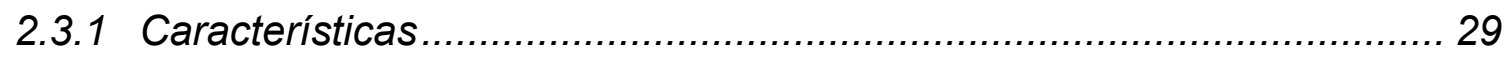

2.3.2 Ciclo das políticas públicas..................................................... 30

2.3.3 Avaliação de Políticas Públicas ................................................. 30

3 MÉTODOS E TÉCNICAS DE PESQUISA ................................................ 33

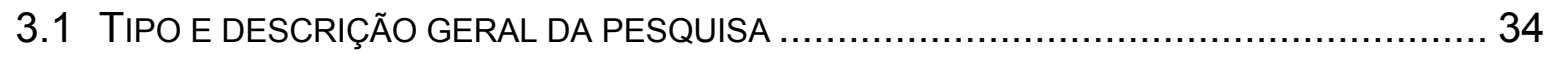

3.2 CARACTERIZAÇÃO DA ORGANIZAÇÃO, SETOR OU ÁREA DO OBJETO DE ESTUdO ...... 35

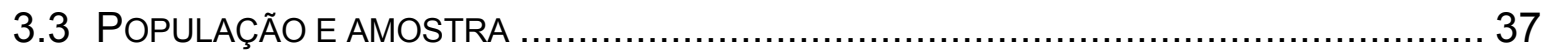

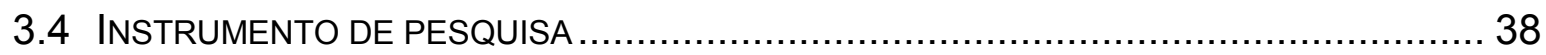

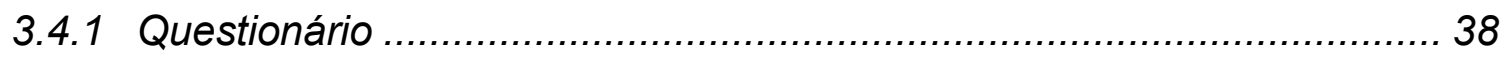

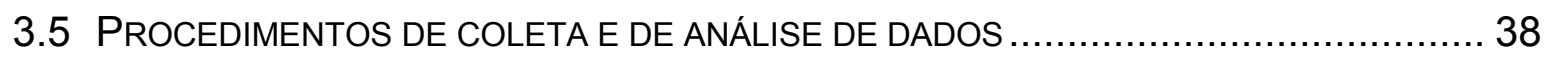

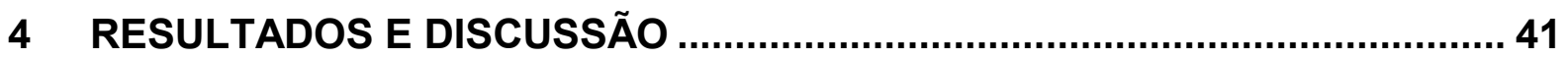

4.1 A AÇÃo ORÇAMENTÁRIA 4448 - FormaÇÃo de AgENTES DE ATER NOS PLANOS PluRIANUAIS 2004 - 2007 E 2008 - 2011 
4.2 As orientaÇÕES PARA um PRograma de FormaÇÃo de AgENTES dE ATER ..... 42

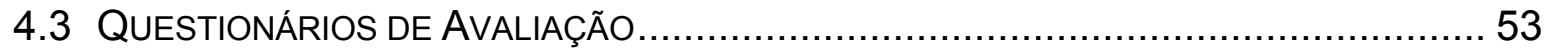

4.3.1 Perfil dos técnicos formados.................................................... 55

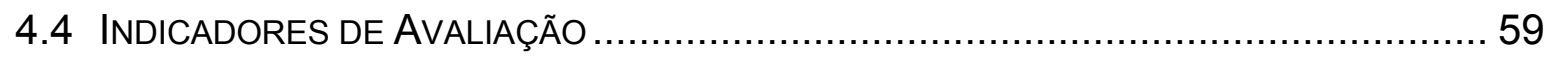

4.4.1 Eficácia das ações de formação promovidas.................................... 59

4.4.2 Eficiência das ações de formação ................................................ 79

4.4.3 Efetividade das ações de formação promovidas ................................ 80

4.5 CONSOLIDAÇÃO DOS DADOS .............................................................. 84

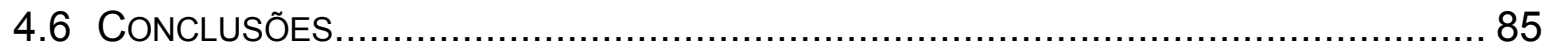

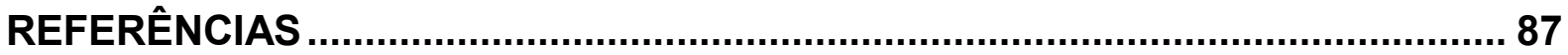

ANEXO I - QUESTIONÁRIO DE PESQUISA ................................................... 90

ANEXO II - SISTEMATIZAÇÃO GERAL DOS QUESTIONÁRIOS RECEBIDOS... 94

ANEXO III - QUESTIONÁRIOS RECEBIDOS ................................................ 96 


\section{INTRODUÇÃO}

A agricultura familiar brasileira inclui pequenos e médios proprietários e representa a maioria de produtores rurais no Brasil. Esse segmento caracteriza-se por uma grande diversidade, tanto em termos de tipos de produtores, vocações produtivas das áreas que ocupam, disponibilidade de infraestrutura e até mesmo renda econômica. Historicamente, a agricultura familiar enfrenta um conjunto de problemas que incluem desde o acesso e posse de terras, dificuldades tecnológicas e produtivas, acesso ao crédito, à comercialização de seus produtos, dentre outros. Socialmente, a agricultura familiar caracteriza-se pelos altos índices de analfabetismo, acesso deficitário à energia elétrica, saúde e aos meios de comunicação.

Apesar dos entraves enfrentados, segundo o documento Agricultura Familiar no Brasil e o Censo Agropecuário 2006, que captou dados específicos sobre a este segmento, adotando como critério a definição estabelecida na Lei $n^{\circ}$ 11.326, de 24 de julho de 2006, a agricultura familiar brasileira representa um importante setor produtivo, que gera renda, é responsável por $74 \%$ da força de trabalho ocupada no campo e garante a segurança alimentar do país. Além disso, a agricultura familiar é responsável por $38 \%$ do PIB da agropecuária brasileira.

Nessa conjuntura, os serviços de Assistência Técnica e Extensão Rural ATER representam um instrumento de apoio e de fortalecimento para a agricultura familiar, tanto em termos de superação de entraves produtivos, quanto em questões tecnológicas, sociais, organizativas e ambientais.

A Política Nacional de Assistência Técnica e Extensão Rural - Pnater, lançada em 2003, se constituiu em um marco histórico importante para a retomada dos serviços de ATER, os quais passaram por um sistemático processo de desmonte desde o início da década de 90. Por meio de uma ampla discussão, que envolveu representantes das esferas federal e estadual, representantes de organizações governamentais e não governamentais, movimentos sociais, organizações de agricultores, entre outros setores, foram estabelecidos os parâmetros para uma nova extensão rural, que tinha como objetivo fazer frente aos problemas identificados no espaço rural e enfrentados pelos agricultores familiares. 
Com a Pnater, propunha-se "um novo paradigma, orientado para o desenvolvimento rural sustentável e ao estabelecimento de estilos de agricultura sustentável, com base nos princípios da Agroecologia" (MDA, 2003), que superasse o modelo extensionista baseado na "Teoria da Difusão de Inovações" e que trabalhasse com enfoques pedagógicos e metodológicos diferenciados, promovendo o empoderamento dos agricultores familiares.

Considerando este novo paradigma baseado no uso de metodologias participativas de trabalho, em novas relações sociais entre técnicos e agricultores e na Agroecologia como fundamento tecnológico, um dos principais desafios para efetiva implementação da Pnater é a disponibilidade de profissionais com formação e conhecimentos necessários para entender os princípios e diretrizes preconizados na mesma e colocarem em prática novas premissas. Dessa forma, a própria Política assinalou a necessidade de um processo de "capacitação para transição", o qual envolveria a "capacitação massiva de extensionistas e assessores técnicos" (MDA, 2003). Esse processo deveria adotar "um conteúdo capaz de formar os profissionais para atuarem como agentes de desenvolvimento local, com condições de investigar, identificar e disponibilizar aos agricultores, demais públicos da extensão e ao conjunto das pessoas que vivem no meio rural um conjunto de opções técnicas e não técnicas, compatíveis com as necessidades dos beneficiários e com o espaço territorial onde estejam inseridos." (MDA, 2003).

Assim, desde 2004, o Departamento de Assistência Técnica e Extensão Rural da Secretaria da Agricultura Familiar do Ministério do Desenvolvimento Agrário DATER/SAF/MDA vem implementando um amplo processo de Formação de Agentes de ATER, oportunizado a formação do quadro de profissionais das entidades governamentais e não governamentais de ATER, de todos os estados, desde o nível de capacitação básica sobre os conceitos e orientações estabelecidos na Pnater até o nível de especialização. As estratégias de formação envolvem oficinas de nivelamento conceitual, cursos de aperfeiçoamento presenciais, cursos em regime de alternância, cursos a distância e cursos de especialização (DATER, 2007).

Todo esse processo de formação justifica-se pela necessidade da qualificação da ação extensionista, em termos de apreensão de novos conteúdos que possam ser aplicados de forma a conduzir a um desenvolvimento rural 
sustentável, a partir da construção de uma nova postura de interação junto aos agricultores familiares.

É nesse contexto que surge o Programa de Formação de Agentes ATER, o qual tem por objetivo "a formação de extensionistas para a implementação qualificada das políticas do MDA e para que venham a ser referência nos seus municípios, estados e nas diferentes regiões do país, para apoiar ações de ATER e atividades de capacitação de técnicos e agricultores com base nas orientações das políticas do MDA, da SAF e na Pnater" (DATER, 2007).

Considerando esse objetivo, a avaliação da eficácia, eficiência e efetividade das ações desenvolvidas no período entre 2004 e 2009, e que constituem a política pública de formação de agentes de ATER, é um importante instrumental para medir o impacto das mesmas e orientar o planejamento de novas ações.

\subsection{Formulação do problema}

Desde 2004 um grande volume de recursos públicos tem sido aplicado na implementação da política pública de formação de Agentes de Assistência Técnica e Extensão Rural - ATER. O objetivo dessa política pública é qualificar os serviços de ATER prestados aos agricultores familiares de forma a promover o desenvolvimento rural sustentável, com base nos princípios e diretrizes da Política Nacional de Assistência Técnica e Extensão Rural - Pnater. Além de qualificar a atuação dos extensionistas, também é objetivo dessa política pública que os mesmos passem a atuar como multiplicadores de conhecimento.

As ações de formação executadas ao longo dos últimos seis anos podem ser divididas em duas categorias: a execução direta, coordenada pelo Departamento de Assistência Técnica e Extensão Rural - DATER, na qual as atividades de capacitação são planejadas e executadas com o acompanhamento sistemático da equipe de formação deste Departamento e a execução indireta, na qual recursos são repassados a entidades prestadoras de serviços de ATER nos estados, as quais executam a formação de técnicos, bem como de agricultores, de acordo com certas diretrizes estabelecidas pelo DATER, mas de forma mais ou menos autônoma. 
Problema de Pesquisa: As ações de formação implementadas diretamente pelo Departamento de Assistência Técnica e Extensão Rural da Secretaria de Agricultura Familiar do Ministério do Desenvolvimento Agrário, no período entre 2004 a 2009, têm sido eficazes, eficientes e efetivas?

\subsection{Objetivo Geral}

Objetivo Geral: Avaliar a eficiência, eficácia e efetividade das ações de formação implementadas diretamente pelo Departamento de Assistência Técnica e Extensão Rural da Secretaria de Agricultura Familiar do Ministério do Desenvolvimento Agrário - DATER/SAF/MDA no período entre 2004 a 2009.

\subsection{Objetivos Específicos}

a) Descrever as estratégias e ações de formação desenvolvidas de 2004 a 2009;

b) Relacionar as ações de formação desenvolvidas de 2004 a 2009 à Política Nacional de Assistência Técnica e Extensão Rural - Pnater;

c) Realizar pesquisa avaliativa para identificar o impacto das ações de formação na atuação extensionista;

d) Analisar os dados coletados de forma a identificar a eficiência, eficácia e efetividade da política de formação de agentes de ATER implementada no período de 2004 a 2009.

\subsection{Justificativa}

A definição de agricultura familiar ainda enfrenta diversas contradições, sendo muitas vezes encarada como sinônimo de "agricultura pouco eficiente" ou mesmo agricultura de subsistência. No entanto, e apesar dos diversos problemas enfrentados pela mesma, a agricultura familiar tem uma significativa importância 
econômica, respondendo por 38\% do Valor Bruto da Produção gerado no meio rural, ainda que ocupe apenas $24 \%$ da área total da agricultura (CENSO AGROPECUÁRIO, 2006). Além disso, a agricultura familiar tem um importante papel na preservação ambiental do país, na garantia da segurança alimentar, pela diversidade de produtos cultivados e na contenção do êxodo rural. Ainda segundo o Censo Agropecuário 2006, "o número total de pessoas ocupadas na agricultura familiar em 2006 é mais de duas vezes superior ao número de ocupações geradas pela construção civil”. Ademais, de cada 10 pessoas ocupadas na agricultura, quase 8 estão na agricultura familiar, o que ressalta a importância social deste setor.

Nesse contexto, nos últimos oito anos, o Ministério do Desenvolvimento Agrário tem implementado um conjunto de políticas públicas voltadas para o fortalecimento da agricultura familiar. Esse leque de políticas reflete a compreensão de que a agricultura familiar se constitui em um segmento diferenciado da agricultura patronal com características e necessidades complexas que exigem a ação efetiva e particularizada do poder público. Reflete ainda a compreensão de que esse setor exerce um papel significativo na economia brasileira. Segundo Telles et al (2008), de maneira geral, dois importantes fatores motivaram o surgimento e crescimento das políticas públicas voltadas para esse segmento: "a crescente necessidade de intervenção estatal frente ao quadro de exclusão social e o fortalecimento dos movimentos sociais do campo".

Essas políticas incluem desde o aumento progressivo de recursos financeiros e das Linhas de Crédito PRONAF, políticas de regularização fundiária, seguros climáticos e de preço da produção até políticas de comercialização.

Para que essas políticas públicas realmente sejam acessadas pelo público a que se destinam, os agricultores familiares, é fundamental a atuação dos agentes de assistência técnica e extensão rural - ATER. Esses agentes têm o papel de desenvolver junto aos agricultores familiares um

\footnotetext{
serviço de educação não formal, de caráter continuado, no meio rural, que promove processos de gestão, produção, beneficiamento e comercialização das atividades e dos serviços agropecuários e não agropecuários, inclusive das atividades agroextrativistas, florestais e artesanais. (BRASIL, 2010).
}

Além disso, a atuação dos agentes de ATER deve ser caracterizada por uma prática que respeite os diferentes sistemas culturais presentes na agricultura 
familiar, e que na mesma medida contribuam para "melhorar os patamares de sustentabilidade ambiental dos agroecossistemas, a conservação e recuperação dos recursos naturais e, ao mesmo tempo, assegure a produção de alimentos limpos, com melhor qualidade biológica e acessíveis ao conjunto da população" (AGUIAR, 2008).

Para que os agentes de ATER possam realmente exercer esse papel, desde 2004, um grande volume de recursos públicos tem sido aplicado na implementação da política pública de formação de Agentes de Assistência Técnica e Extensão Rural. O objetivo dessa política pública é qualificar os serviços de ATER, prestados aos agricultores familiares, de forma a promover $\mathrm{O}$ desenvolvimento rural sustentável, com base nos princípios e diretrizes da Política Nacional de Assistência Técnica e Extensão Rural - Pnater.

Após seis anos de implementação da política de formação de agentes ATER, torna-se imperativo verificar se a mesma tem alcançado os objetivos a que se propõe e em que medida os impactos causados justificam o gasto do recurso público empenhado e do esforço dispendido.

Outro ponto relevante a ser identificado através da avaliação refere-se à viabilidade e necessidade da manutenção dessa política, bem como a necessidade de reformulações e ajustes que otimizem os resultados esperados.

Segundo Cunha (2006), a "decisão de aplicar recursos públicos em uma ação pressupõe a atribuição de valor e legitimidade aos seus objetivos, e a avaliação deve verificar o cumprimento das metas estabelecidas", tornando-se assim de fundamental importância que a mesma seja efetuada de forma sistemática e periódica, razão pela qual justifica-se a elaboração da presente pesquisa. 


\section{REFERENCIAL TEÓRICO}

\subsection{0 setor agrícola brasileiro}

\subsubsection{Agricultura Familiar x Agricultura Patronal}

A agricultura é, historicamente, umas das principais bases da economia do país, contribuindo para a produção de alimentos e para o equilíbrio da balança comercial brasileira com a exportação de commodities. Dentro do amplo conceito de agricultura, podem-se distinguir duas grandes categorias: a agricultura patronal e a agricultura familiar. Segundo Veiga (1996), as principais diferenças entre a agricultura familiar e agricultura patronal podem ser assim resumidas:

Tabela 1: Agricultura Patronal x Agricultura Familiar

\begin{tabular}{|c|c|}
\hline Modelo Patronal & Modelo Familiar \\
\hline Completa separação entre gestão e trabalho & Trabalho e gestão intimamente relacionados \\
\hline Organização centralizada & $\begin{array}{l}\text { Direção do processo produtivo assegurada } \\
\text { diretamente pelos proprietários }\end{array}$ \\
\hline Ênfase na especialização & Ênfase na diversificação \\
\hline Ênfase em práticas agrícolas padronizáveis & Ênfase na durabilidade dos recursos naturais \\
\hline Trabalho assalariado predominante & Trabalho assalariado complementar \\
\hline $\begin{array}{l}\text { Tecnologias dirigidas à eliminação das } \\
\text { decisões "de terreno" e "de momento" }\end{array}$ & $\begin{array}{l}\text { Decisões imediatas, adequadas ao alto grau de } \\
\text { imprevisibilidade do processo produtivo }\end{array}$ \\
\hline $\begin{array}{l}\text { Tecnologias voltadas principalmente à redução } \\
\text { das necessidades de mão-de-obra }\end{array}$ & $\begin{array}{c}\text { Tomada de decisões in loco, condicionadas pelas } \\
\text { especificidades do processo produtivo }\end{array}$ \\
\hline Pesada dependência de insumos externos & Ênfase no uso de insumos internos \\
\hline
\end{tabular}

Fonte: FAO (1994) e MDA/Pronaf (BRASIL, 1994). 
Analisando-se o quadro apresentado, pode-se perceber que o modelo patronal relaciona-se particularmente ao chamado agronegócio, voltado para a produção de monocultivos e commodities com o uso massivo de máquinas e insumos, tais como adubos químicos e pesticidas, ou para a pecuária em larga escala. Segundo o artigo "O atendimento à agricultura empresarial", publicado pela Diretoria de Agronegócos do Banco do Brasil, a agricultura patronal concentra-se em culturas voltadas à exportação "dentro de uma visão mais empresarial do negócio". Por outro lado, o modelo familiar caracteriza-se por uma maior diversificação da produção, conforme será analisado no item seguinte.

\subsubsection{Perfil da Agricultura Familiar Brasileira}

Segundo Denardi (2001), "o conceito de agricultura familiar e, principalmente, as políticas públicas específicas para este segmento majoritário e heterogêneo da agricultura são ainda bastante recentes no Brasil”.

De maneira geral, o conceito de agricultura familiar estabeleceu-se com a criação do Programa Nacional de Fortalecimento da Agricultura Familiar - Pronaf, em 1996, no governo Fernando Henrique Cardoso e foi consolidado a partir da Lei 11.326, de 24 de julho de 2006, utilizando parâmetros econômicos, sociais e trabalhistas. Em seu Art. $3^{\circ}$ a referida lei estabelece:

Art. 3o Para os efeitos desta Lei, considera-se agricultor familiar e
empreendedor familiar rural aquele que pratica atividades no meio rural,
atendendo, simultaneamente, aos seguintes requisitos:
I - não detenha, a qualquer título, área maior do que 4 (quatro) módulos
fiscais;
II - utilize predominantemente mão-de-obra da própria família nas
atividades econômicas do seu estabelecimento ou empreendimento;
III - tenha renda familiar predominantemente originada de atividades
econômicas vinculadas ao próprio estabelecimento ou empreendimento;
IV - dirija seu estabelecimento ou empreendimento com sua família.
(BRASIL, 2006)

A esta lei inclui ainda na categoria de agricultores familiares:

I - silvicultores que atendam simultaneamente a todos os requisitos de que trata o caput deste artigo, cultivem florestas nativas ou exóticas e que promovam o manejo sustentável daqueles ambientes;

II - aquicultores que atendam simultaneamente a todos os requisitos de que trata o caput deste artigo e explorem reservatórios hídricos com superfície 
total de até 2 ha (dois hectares) ou ocupem até $500 \mathrm{~m}^{3}$ (quinhentos metros cúbicos) de água, quando a exploração se efetivar em tanques-rede;

III - extrativistas que atendam simultaneamente aos requisitos previstos nos incisos II, III e IV do caput deste artigo e exerçam essa atividade artesanalmente no meio rural, excluídos os garimpeiros e faiscadores;

IV - pescadores que atendam simultaneamente aos requisitos previstos nos incisos I, II, III e IV do caput deste artigo e exerçam a atividade pesqueira artesanalmente. (BRASIL, 2006)

Esse universo diversificado abrange, segundo o Censo Agropecuário de 2006, 4.367.902 estabelecimentos, os quais correspondem a $84,4 \%$ dos estabelecimentos rurais embora detenham apenas $24,3 \%$ da área ocupada pela agricultura no país.

Gráfico 1 - Agricultura Familiar x Agricultura Patronal - total de estabelecimentos e área total ocupada
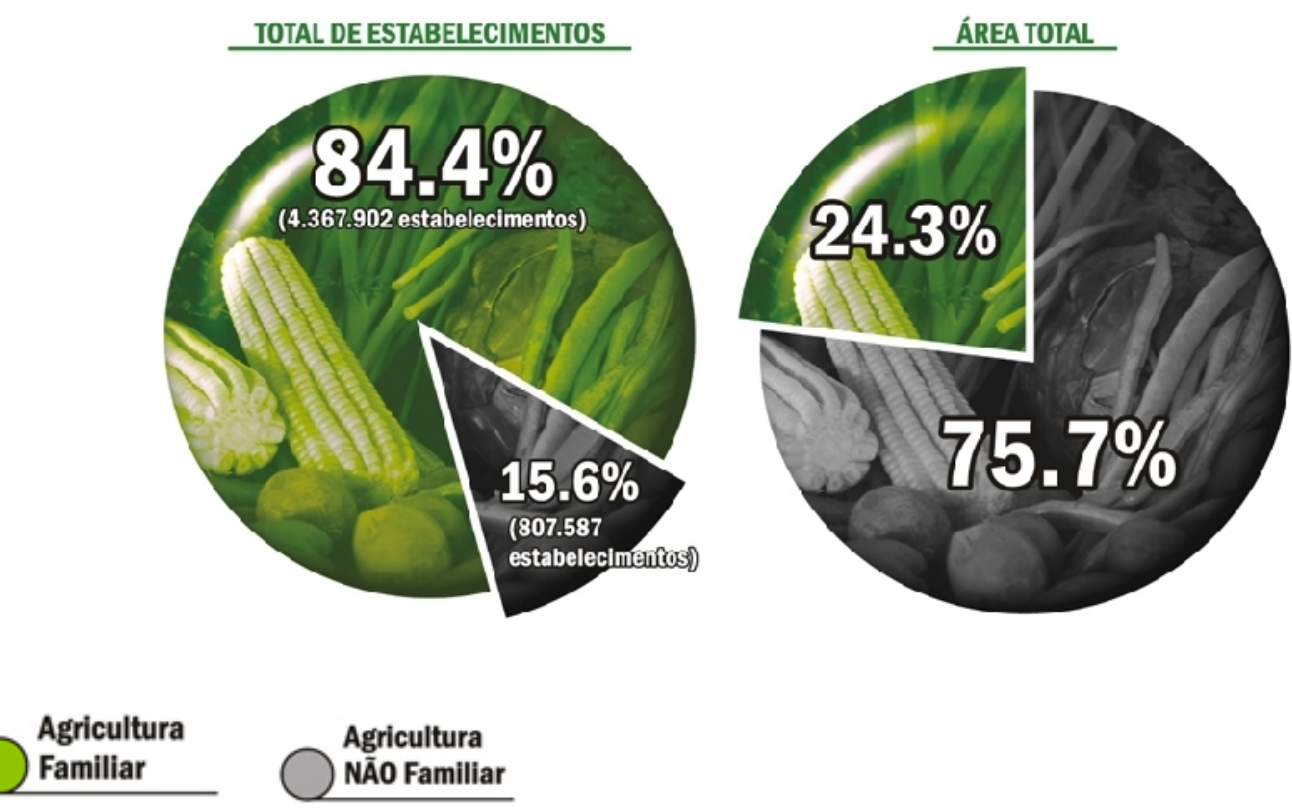

Fonte: Agricultura Familiar no Brasil e o Censo Agropecuário 2006.

Apesar de ocupar apenas $24,3 \%$ da área total destinada à agricultura no Brasil, a agricultura familiar responde por $38 \%$ do valor bruto da produção (VBP) e por $74,4 \%$ da mão de obra empregada no setor agropecuário brasileiro, o que corresponde a 12,3 milhões de pessoas ocupadas. 
Gráfico 2 - Agricultura Familiar x Agricultura Patronal - mão de obra ocupada

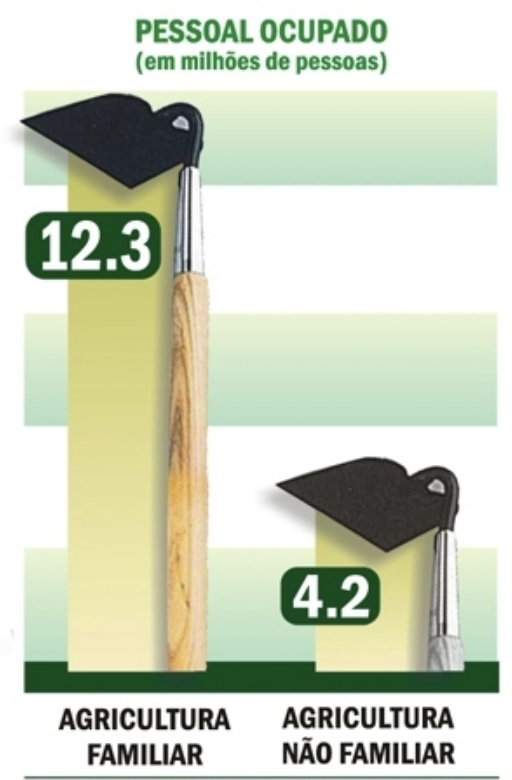

Fonte: Agricultura Familiar no Brasil e o Censo Agropecuário 2006.

Da mesma forma, a agricultura familiar é a principal fornecedora de alimentos básicos para a população brasileira, incluindo produção de grãos e de proteína animal.

Gráfico 3 - Agricultura Familiar - produção de alimentos/grãos

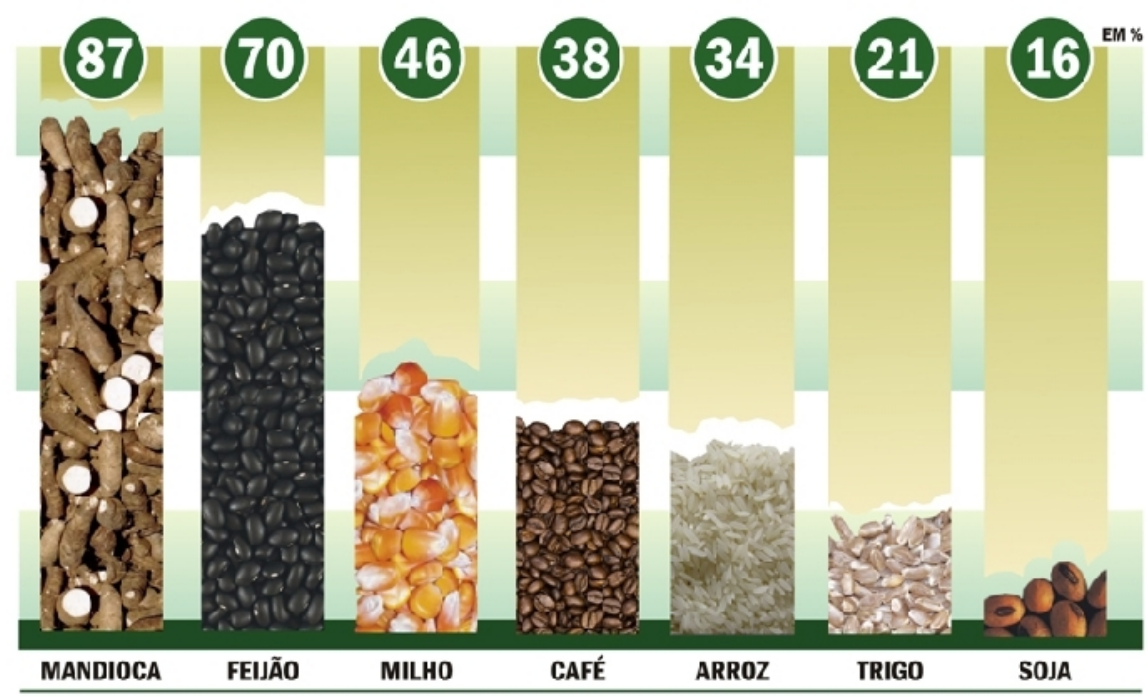

Fonte: Agricultura Familiar no Brasil e o Censo Agropecuário 2006. 
Gráfico 4 - Agricultura Familiar - produção de proteína animal

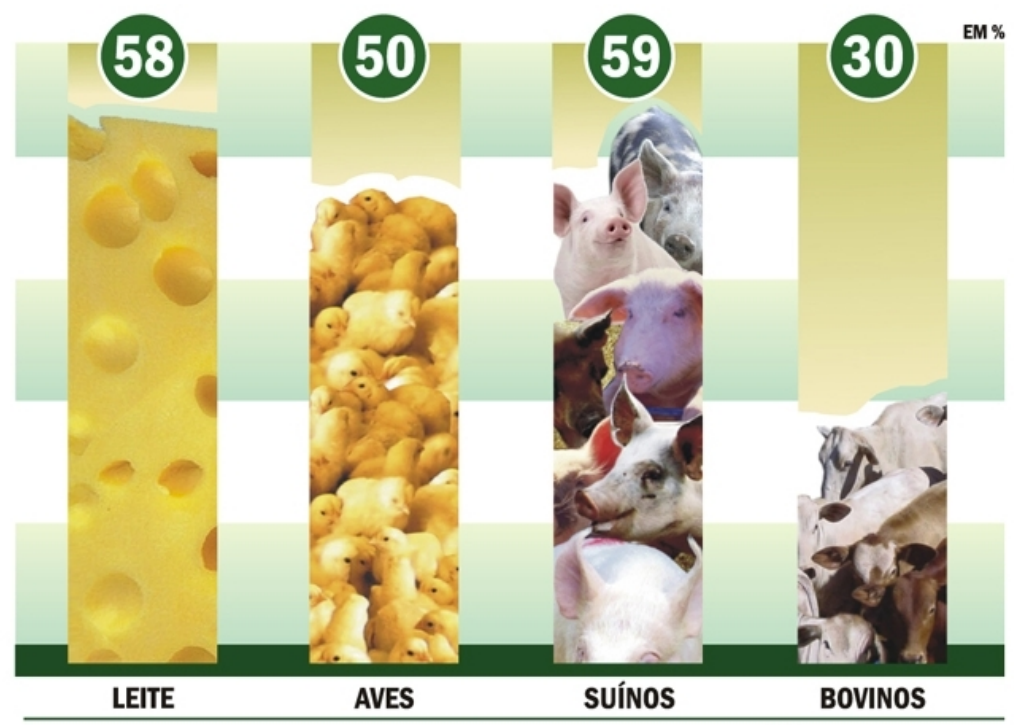

Fonte: Agricultura Familiar no Brasil e o Censo Agropecuário 2006.

Os dados são impressionantes, especialmente se for considerado que, via de regra, os estabelecimentos familiares ficam restritos a áreas menos produtivas, 0 acesso a crédito ainda não é universalizado, os agricultores familiares, em grande parte, possuem baixo índice de escolaridade e enfrentam dificuldades de acesso aos canais de comercialização e transporte.

Segundo Fernandes (2009), o fortalecimento da agricultura familiar deve ser promovido através de políticas públicas que não se configurem em uma ação governamental que tenham como objetivo

\footnotetext{
"compensar" ações setoriais excludentes, mas que possibilite atender às demandas dos agricultores familiares, ou seja, as necessidades reais, transformando numa política nacional de caráter permanente.

I. familiar. Ajustar políticas públicas para atender à realidade da agricultura

II. Viabilizar a infra-estrutura rural necessária à melhoria do desempenho produtivo e da qualidade de vida da população rural.

III. Fortalecer os serviços de apoio ao desenvolvimento da agricultura familiar.

IV. Elevar os níveis de profissionalização dos agricultores familiares.

V. Propiciando-lhes novos padrões tecnológicos e de gestão. (FERNANDES, 2009)
}

Conforme já colocado, nos últimos oito anos, o Ministério do Desenvolvimento Agrário, vem priorizando a implementação de um conjunto de políticas públicas voltadas para o fortalecimento da agricultura familiar. O leque de políticas criadas e/ou aperfeiçoadas nesse período é grande e inclui desde o aumento progressivo 
das Linhas de Crédito PRONAF até políticas de comercialização e seguros da produção. Porém, dentre todas essas políticas, provavelmente nenhuma representa um avanço tão grande nem obteve um impacto tão forte junto aos agricultores familiares quanto a ampliação dos serviços de assistência técnica e extensão rural ATER nos moldes estabelecidos pela Política Nacional de Assistência Técnica e Extensão Rural - Pnater.

\subsubsection{A Evolução dos serviços de Assistência Técnica no Brasil e a Política Nacional de Assistência Técnica e Extensão Rural - Pnater}

Conforme o documento Resultado do Seminário Nacional de ATER (MDA, 2008) e de maneira resumida, a Extensão Rural no Brasil passou por algumas fases diferenciadas e com características bem marcantes:

A primeira delas, iniciada por volta de 1948, teve como principal característica a crença de que o conhecimento tecnológico, bem como a difusão de novas técnicas agropecuárias e, principalmente, o apoio financeiro através do crédito levariam, automaticamente, ao aumento da produção e a melhoria das condições de vida dos agricultores familiares.

Por volta de 1952, essa concepção começou a se modificar e o serviço de extensão passou a adotar um enfoque mais educativo. Nesse período, a extensão rural apresentou um significativo crescimento, o que levou a criação, em 1956, de um órgão central com a função de coordenar o sistema: a Associação Brasileira de Crédito e Assistência Rural - ABCAR.

Posteriormente, já na década de 70 e acompanhando a fase desenvolvimentista do Brasil e o "milagre econômico", foi criada, pelo Decreto $\mathrm{n}^{\circ}$ 75.373, de 14 de fevereiro de 1975, a Empresa Brasileira de Assistência Técnica e Extensão Rural - Embrater. Durante esse período construiu-se a idéia de que era necessário superar o atraso na agricultura. Nesse contexto, os agricultores familiares foram induzidos, com o apoio do crédito rural subsidiado, a adquirir equipamentos e insumos industrializados sob o pretexto de implantar um modelo de produção mais moderno e eficiente. Esse modelo tecnicista tinha como objetivo inserir os agricultores familiares na lógica de mercado e, para tanto, privilegiava a produtividade a qualquer custo. 
Durante a década de 80, em função da profunda crise econômica atravessada pelo país, os serviços de ATER passam por uma fase acentuada de desmonte, caracterizada pelo corte de verbas e sucateamento das empresas públicas prestadoras de serviços de ATER, resultando na extinção da Embrater, no início dos anos 90. Apesar disso, foi também na década de 80 , que, sob influência da pedagogia de Paulo Freire, começou a se delinear o novo paradigma que, em parte, ainda hoje é perseguido pela ATER e que preconiza uma relação de reflexão dialética com o agricultor e a busca do desenvolvimento rural sustentável.

A década de 90 foi caracterizada por sucessivas alterações institucionais criando um ambiente de indefinição em relação às ações de assistência técnica e extensão rural a nível nacional. Segundo a Pnater:

\begin{abstract}
$\mathrm{Na}$ ausência do apoio federal aos serviços oficiais de Ater e diante da inexistência de uma política nacional para o setor, alguns estados da federação, num esforço de manutenção deste importante instrumento de política pública, reestruturaram os serviços dando-lhes diversas formas institucionais e criando novos mecanismos de financiamento e operacionalização das empresas oficiais, além de apoiarem outras entidades emergentes. Nesse mesmo período, surgiram e se expandiram várias iniciativas, visando suprir a carência e o vácuo deixado pelo Estado, destacando-se aquelas patrocinadas por prefeituras municipais, por organizações não-governamentais e por organizações de agricultores, entre outras. (MDA, 2003).
\end{abstract}

A partir do ano de 1997, com a realização de Workshop promovido pela Confederação Nacional dos Trabalhadores na Agricultura - CONTAG e pela Federação Nacional dos Trabalhadores da Assistência Técnica e do Setor Público Agrícola do Brasil - FASER foram iniciados esforços para retomar o efetivo fortalecimento dos serviços de ATER e em 2003, por meio do Decreto $n^{\circ} 4.739$, de 13 de junho de 2003, foram transferidas do Ministério da Agricultura, Pecuária e Abastecimento - MAPA para o Ministério do Desenvolvimento Agrário - MDA as competências relativas à organização do sistema e a prestação dos serviços de ATER. Em 2004, o Decreto $n^{\circ} 5.033$, de 05 de abril de 2004, cria o Departamento de Assistência Técnica e Extensão Rural - DATER no âmbito da Secretaria da Agricultura Familiar - SAF/MDA para, entre outras competências, coordenar a nível nacional os serviços de ATER. 
Figura 1 - Linha do tempo da Extensão Rural Brasileira

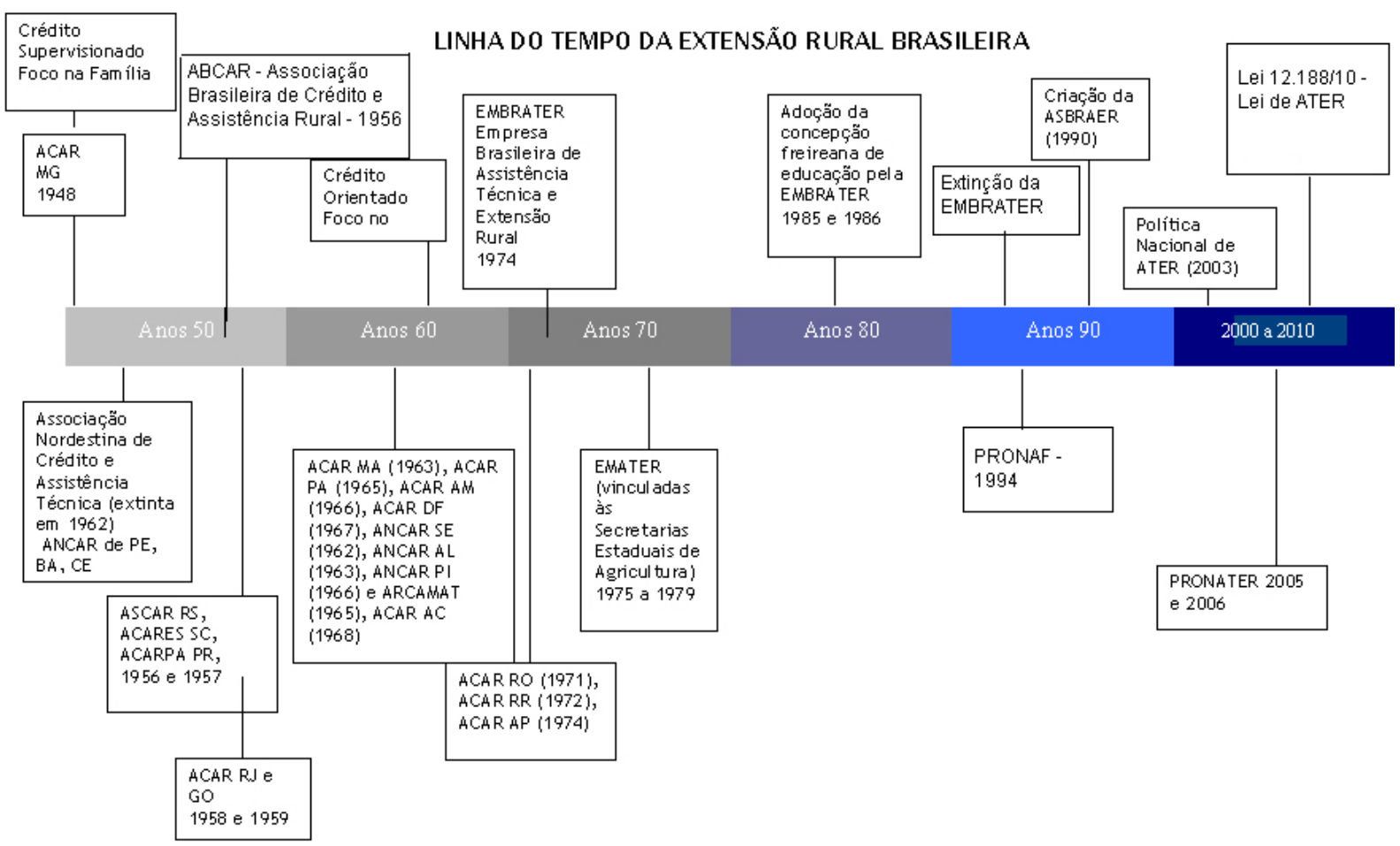

Fonte: Academia Brasileira de Extensão Rural - com adaptações.

Dentre as iniciativas adotadas pelo DATER para disciplinar e organizar a retomada de um Sistema Nacional de Assistência Técnica e Extensão Rural Sibrater destaca-se a coordenação de um processo de reflexão e construção coletiva em todo o país que deu origem à Política Nacional de Assistência Técnica e Extensão Rural - Pnater.

Segundo Aguiar (2008), a Pnater, lançada em 2003, se constituiu em um marco histórico importante para a retomada dos serviços de Assistência Técnica e Extensão Rural - ATER, que desde o início da década de 90 vinham passando por um sistemático processo de desmonte.

Por meio de uma discussão, da qual participaram representantes das esferas federal e estadual, representantes de organizações governamentais e não governamentais, movimentos sociais, organizações de agricultores, entre outros setores, emergiram novos parâmetros para a extensão rural destacando aspectos tais como a inclusão social, o respeito à pluralidade e diversidade sociais, étnicas, culturais e ambientais e o enfoque de gênero, de geração, de raça e etnia. Pretendia-se então a emergência de uma nova extensão rural, que fosse capaz de 
fazer frente aos grandes problemas identificados no espaço rural e enfrentados pelos agricultores familiares, tanto nos aspectos ambientais, sociais e econômicos.

Com a Pnater, propunha-se "um novo paradigma, orientado para o desenvolvimento rural sustentável e ao estabelecimento de estilos de agricultura sustentável, com base nos princípios da Agroecologia" (MDA, 2003), que superasse o modelo extensionista baseado na "Teoria da Difusão de Inovações" e que trabalhasse com enfoques pedagógicos e metodológicos diferenciados, promovendo o empoderamento dos agricultores familiares. A Pnater estabelece os princípios e diretrizes que devem nortear os serviços de Assistência Técnica e Extensão Rural ATER de forma a promover o desenvolvimento rural sustentável. Nela são apresentados também os objetivos dos serviços públicos de ATER, as orientações estratégicas e metodológicas para a ATER pública, bem como os princípios que devem permear esses serviços. São eles:

a) garantir a prestação de serviços de ATER em quantidade e qualidade suficientes para os agricultores familiares, beneficiários de reforma agrária, extrativistas, ribeirinhos, indígenas, quilombolas, pescadores artesanais e aquicultores;

b) contribuir para a promoção do desenvolvimento rural sustentável;

c) adotar uma abordagem multidisciplinar e interdisciplinar, com enfoque no uso de metodologias participativas e no paradigma tecnológico baseado nos princípios da Agroecologia;

d) estabelecer mecanismos de gestão que permitam a democratização das informações e o controle social das ações;

e) desenvolver processos de formação permanentes e continuados. (MDA, 2003)

Estes princípios norteiam a prestação de serviços de Assistência Técnica e Extensão Rural - ATER que são desenvolvidos com recursos do Ministério do Desenvolvimento Agrário - MDA, através de iniciativas como o Programa Nacional de Assistência Técnica e Extensão Rural - Pronater e o Programa Nacional de Assessoria Técnica e Social à Reforma Agrária - ATES, no âmbito do Instituto Nacional de Colonização e Reforma Agrária - INCRA.

Em 2010, os serviços de ATER ganharam destaque no cenário político nacional, com a promulgação de Lei $n^{\circ} 12.188$, de 11 de janeiro de 2010, a qual institui a Política Nacional de Assistência Técnica e Extensão Rural para a Agricultura Familiar e Reforma Agrária - Pnater e o Programa Nacional de Assistência Técnica e Extensão Rural na Agricultura Familiar e na Reforma Agrária Pronater, o que demonstra o reconhecimento da importância desses serviços. 


\subsection{A Formação de Agentes de Assistência Técnica e Extensão Rural como política pública estruturante}

\subsubsection{Por que formar agentes de Assistência Técnica e Extensão Rural - ATER?}

De acordo com a Pnater, o serviço de ATER público deve estabelecer uma nova dinâmica na atuação junto aos agricultores familiares e um compromisso com "os resultados econômicos e socioambientais relacionados e derivados de sua ação" (MDA, 2003).

Em última análise, o objetivo maior da Pnater é ofertar aos Agricultores Familiares um serviço de ATER qualificado, que possibilite a eles melhores condições de vida, tanto nos aspectos financeiros e econômicos, quanto sociais e ambientais, bem como o acesso às políticas públicas que possam contribuir para esse objetivo.

Os agentes de ATER desempenham um papel fundamental para que as diversas políticas públicas voltadas especificamente para a agricultura familiar sejam acessadas. Além dessa atribuição e segundo a Lei no 12.188, de 11 de janeiro de 2010, esses agentes têm ainda a função de facilitar junto aos agricultores, todo um processo de desenvolvimento, não apenas econômico, mas também social e ambiental através de um

\footnotetext{
serviço de educação não formal, de caráter continuado, no meio rural, que promove processos de gestão, produção, beneficiamento e comercialização das atividades e dos serviços agropecuários e não agropecuários, inclusive das atividades agroextrativistas, florestais e artesanais. (BRASIL, 2010).
}

Porém, a implantação desse novo paradigma proposto pela Pnater e que reveste o trabalho da extensão rural de um novo significado, que propõe uma dinâmica de trabalho baseada no uso de metodologias participativas, que reconhece a necessidade de que se construam novas relações sociais entre técnicos e agricultores e que adotem a Agroecologia como fundamento tecnológico, requer também um novo profissional com formação e conhecimentos necessários para entender os princípios e diretrizes preconizados na mesma. 
Essa necessidade já era prevista em 2003, desde o momento de discussão e construção da Pnater, o que levou a se prever um processo de "capacitação para transição", o qual envolveria a "capacitação massiva de extensionistas e assessores técnicos". Esse processo deveria adotar "um conteúdo capaz de formar os profissionais para atuarem como agentes de desenvolvimento local, com condições de investigar, identificar e disponibilizar aos agricultores, demais públicos da extensão e ao conjunto das pessoas que vivem no meio rural um conjunto de opções técnicas e não técnicas, compatíveis com as necessidades dos beneficiários e com o espaço territorial onde estejam inseridos." (MDA, 2004)

Outro aspecto importante a ser considerado quando se fala a respeito da formação de agentes de ATER diz respeito ao fato de que as Universidades e escolas agrotécncias, em grande medida, não preparam extensionistas para atuar a campo e ignoram que a extensão rural é uma

\begin{abstract}
especialidade essencialmente interdisciplinar. Ela se fundamenta teórica e metodologicamente em diversas subáreas das chamadas ciências sociais aplicadas e das ciências humanas, e aplica estes conhecimentos, no âmbito das ciências agrárias, aos problemas da extensão voltada ao meio rural. Algumas destas subáreas são a própria Extensão Rural, a Economia Rural, a Administração Rural, a Sociologia Rural, a Antropologia Rural, a Comunicação Rural, dentre outras. (DOULA E SOUZA, 2006)
\end{abstract}

Considerando esse caráter multidisciplinar da extensão rural, os profissionais extensionista devem repensar seu modelo de atuação, se afastando da proposta difusionista que caracterizou por muito tempo os serviços de ATER.

Nesse contexto, desde 2004, o Departamento de Assistência Técnica e Extensão Rural da Secretaria da Agricultura Familiar do Ministério do Desenvolvimento Agrário - DATER/SAF/MDA vem conduzindo diversas ações de formação destinadas a capacitar o quadro de extensionistas das entidades governamentais e não governamentais de ATER, de todos os estados. Essas ações têm sido planejadas e executadas de forma a oportunizar o aperfeiçoamento desses técnicos desde o nível de capacitação básica sobre os conceitos e orientações estabelecidos na Política Nacional de Assistência Técnica e Extensão Rural - Pnater até cursos de especialização. As estratégias de formação foram diversificadas em termos de conteúdos, de tipologias e cargas horárias de forma a atender aos diferentes perfis encontrados no ambiente extensionista.

O volume de recursos públicos aplicados na implementação da política pública de Formação de Agentes de Assistência Técnica e Extensão Rural tem sido 
considerável ao longo dos últimos anos. e vem se justificando pela necessidade da qualificação da ação extensionista, em termos de apreensão de novos conteúdos que possam ser aplicados de forma a conduzir a um desenvolvimento rural sustentável e em termos da construção de uma nova postura de interação junto aos agricultores familiares. Porém, após seis anos de implementação dessa política, fazse necessária uma avaliação que identifique se a mesma tem alcançado os objetivos a que se propõe e em que medida os impactos causados justificam o gasto do recurso público empenhado.

A viabilidade e necessidade da manutenção dessa política, bem como a necessidade de reformulações e ajustes que otimizem os resultados esperados também são aspectos a serem considerados e que justificam a realização desse estudo.

\subsection{Políticas Públicas}

A política surgiu da necessidade do homem de regular suas atividades e suas relações, sendo, portanto, fruto da própria sociedade. De maneira geral, a política está de tal forma integrada na vida social do homem que muitas vezes nem mesmo nos apercebemos de sua influência. Desde os relacionamentos familiares, até as relações de trabalho e de gestão nacional, tudo é permeado por um jogo de interesses e vontades, por vezes antagônicas e irreconciliáveis. Segundo MatiasPereira (2007), a política consiste exatamente na mediação para organizar e regular esses interesses, de modo a beneficiar certo número de pessoas. Dessa forma, o conceito de política, entre outros aspectos, relaciona-se sobremaneira ao poder. Seja o poder de decisão ou o poder físico.

Ainda segundo Matias-Pereira (2007) a política "compreende um elenco de ações e procedimentos que visam à resolução pacífica de conflitos em torno da alocação de bens e recursos públicos", os quais são sempre insuficientes em face de uma demanda sempre crescente. De maneira geral, as políticas públicas correspondem à materialização de ações estratégicas que fazem frente a uma demanda social específica. 
Para Guareschi et al (2004), políticas públicas consistem em um "conjunto de ações coletivas voltadas para a garantia dos direitos sociais, configurando um compromisso público que visa dar conta de determinada demanda, em diversas áreas. Expressa a transformação daquilo que é do âmbito privado em ações coletivas no espaço público".

O estudo das Políticas Públicas enquanto campo do conhecimento apresentou nas últimas décadas um significativo crescimento. Segundo Souza (2006), esse panorama favorável pode ser explicado, entre outras razões, pela necessidade crescente de um equilíbrio no orçamento entre receita e despesa, o que implica em uma política restritiva de gastos. Essa política tem como conseqüência a necessidade de uma administração pública capaz de gerir os seus recursos públicos e equacionar os bens em benefício de sua população, de modo incluir os excluídos. Nesse sentido, o moderno gestor público enfrenta diversos desafios, dentre os quais o seguinte: conciliar a maior participação dos cidadãos com a eficiência nos processos de gestão das políticas públicas.

Nesse sentido, o presente estudo procura esclarecer essa equação complexa, e que por vezes aparece como uma disputa de interesses. Esse não parece ser o caso da Política de Formação de Agentes de ATER, desde que há uma convergência de opiniões na direção da sua importância. Entretanto, a avaliação permitirá indicar até que ponto a alocação dos recursos (gestão) coincide com os indicadores d eficiência, eficácia e efetividade dessa política pública.

\subsubsection{Características}

De acordo com Matias-Pereira (2007), podem-se identificar algumas características básicas referentes às políticas públicas:

\footnotetext{
a) As mesmas implicam em decisões tomadas pelo poder público em função de demandas sociais significativas;

b) Tem um caráter imperativo, uma vez que são implementadas pelo estado;

c) São outputs, resultantes da atividade política e geradas por inputs originários do meio ambiente e do próprio sistema político (withinputs). (MATIAS-PEREIRA, 2007)
} 


\subsubsection{Ciclo das políticas públicas}

Ainda segundo Matias-Pereira (2006), no Brasil as políticas públicas passam por algumas fases:

a) Formação da agenda política, que corresponde ao surgimento e consolidação de demandas que exigem políticas públicas definidas;

b) Formulação efetiva da política pública, que envolve a elaboração da política e os processos decisórios que levam a essa elaboração;

c) Implementação da política, que corresponde a execução propriamente dita das decisões e ações planejadas referentes à política pública em questão;

d) Avaliação da política pública, fase na qual "consideram-se padrões distributivos das políticas resultantes, isto, é, quem recebe o que, quando e como, e que diferença fez com relação à situação anterior à implementação. (MATIAS-PEREIRA, 2006)

\subsubsection{Avaliação de Políticas Públicas}

Entende-se avaliação como "um processo sistemático de análise de uma atividade, fatos, ou coisas que permite compreender, de forma contextualizada, todas as suas dimensões e implicações, com vistas a estimular seu aperfeiçoamento" (Belloni et all, 2007). Ainda segundo os autores, esse processo deve envolver não apenas uma análise sobre metas pré-definidas, mas sim "os processos de formulação e desenvolvimento, as ações implementadas ou fatos ocorridos, assim como os resultados alcançados, histórica e socialmente contextualizados".

\subsubsection{Por que avaliar as políticas públicas?}

De maneira geral, a aplicação sistemática da avaliação de políticas públicas e programas governamentais ainda é uma prática recente na administração pública brasileira. No entanto, a avaliação das políticas públicas é fundamental não apenas para a melhoria dos gastos públicos, mas também para que se possa aferir a qualidade das ações governamentais. De acordo com Barreira (2000), a avaliação "é fundamental para aferir o grau de eficiência, efetividade e eficácia que os serviços sociais apresentam e em conseqüência realimentar decisões e ações no campo da política social". 
Considerando esse aspecto, a avaliação não deve ser feita apenas ao final da implementação de uma política pública, como forma de aferir se as metas estabelecidas inicialmente foram alcançadas, mas sim durante todo o processo de implementação, de forma a fornecer aos gestores públicos dados que possibilitem o redirecionamento ou mesmo a reformulação das mesmas. Daí conclui-se que o ciclo das políticas públicas deve ser visto como um processo dinâmico e retro alimentado, com uma necessidade constante da avaliação.

Da mesma forma, Fagundes e Moura (2009), argumentam que o "conhecimento dos programas por dentro, suas dificuldades, os obstáculos de implementação, seus fatores gerenciais e operacionais, e ainda como estes realmente produzem efeitos esperados e não-esperados, é um instrumento de poderoso uso para a melhoria do desempenho das organizações públicas, em qualquer escala do governo. As organizações, ao lançarem mão de instrumentos adequados de avaliação dos seus programas, estariam, ao menos em tese, movendo-se na direção de uma maior qualidade no uso de recursos públicos".

Independente da profusão de definições e segundo o artigo Como avaliar Políticas Públicas e Programas Governamentais, uma avaliação é considerada boa quando é "útil (isto é, quando possui relevância), é oportuna (isto é, realizada em tempo hábil para auxiliar decisões), é ética (isto é, realizada com medidas e critérios justos) e é precisa (isto é, feita com cautela e com procedimentos adequados que garantem sua legitimidade)".

\subsubsection{Como avaliar as políticas públicas?}

Segundo Fagundes e Moura (2009), "é certo que qualquer forma de avaliação envolve necessariamente um julgamento, vale dizer, trata-se precipuamente de atribuir um valor, uma medida de aprovação ou desaprovação a uma política ou programa público." Da mesma forma, afirmam ser impossível realizar uma avaliação completamente neutra, uma vez que a mesma será sempre influenciada por "opções valorativas pessoais". Daí a necessidade de se estabelecer critérios claros e objetivos para o processo de avaliação, de forma a evitar que se confundam "opção pessoal com resultados de avaliação" (ARRETCHE \& BRANT, 2006). 
Esses critérios passam necessariamente pela definição do que se espera de determinada política pública de modo a se estabelecer os parâmetros da eficiência, eficácia e efetividade da política pública a ser avaliada.

Para Matias-Pereira (2007) a eficiência consiste no

"esforço holístico da organização no que se refere ao emprego e otimização dos recursos comparando-o com os resultados obtidos. Uma organização é eficiente quando otimiza a relação custo/produto". (MATIAS-PEREIRA, 2007)

Já a eficácia

"pode ser aceita como os esforços das ações governamentais ou de uma organização para ofertar adequadamente os bens e serviços esperados, previamente definidos em seus objetivos e metas. Nesse sentido, o que importa nesses esforços é conseguir que os efeitos de uma ação correspondam ao desejado". (MATIAS-PEREIRA, 2007).

Por fim, a efetividade é

"a soma da eficiência e da eficácia. Assim a efetividade ocorre quando os bens e serviços resultantes de determinada ação alcançam os resultados mais benéficos para a sociedade." (MATIAS-PEREIRA, 2007).

É com base nesses três pilares que os indicadores de avaliação de políticas públicas devem ser construídos. 


\section{MÉTOdOS E TÉCNICAS DE PESQUISA}

A metodologia para realização deste trabalho baseou-se no levantamento das ações de Formação diretas realizadas pelo Departamento de Assistência Técnica e Extensão Rural - DATER/SAF/MDA, no período de 2004 a 2009, a partir de dados disponibilizados pelo próprio Departamento. Após a sistematização dessas informações, foi encaminhado aos participantes das referidas formações um questionário estruturado, conforme modelo apresentado no Anexo I. Esse formulário foi elaborado pela Equipe de Formação do DATER em 2007 e adaptado às necessidades desta pesquisa. Nesse sentido, o questionário foi validado através de aplicação a dez pessoas de maneira aleatória.

A coleta de dados para elaboração da análise da eficácia, eficiência e efetividade das ações de formação foi composta por três etapas:

a) coleta de informações junto ao Departamento de Assistência Técnica e Extensão Rural:

- entrevista com a equipe da Coordenação de Formação de Agentes de Ater do Departamento de Assistência Técnica e Extensão Rural, com o objetivo de identificar as principais características do processo de formação implementado no período 2004 -2009;

- coleta de informações relativas ao volume de recursos investidos na formação de agentes de ATER no período 2004-2009, através do Sistema Integrado de Administração Financeira do Governo Federal - SIAFI;

- resgate de dados sobre as atividades de formações realizadas: os dados referentes às diversas atividades executadas durante o período, tais como cursos, seminários, oficinas, encontros, as especificidades de cada evento, bem como carga-horária, foram sistematizados e analisados de forma diferenciada, uma vez que o conteúdo de cada atividade é composto por um nível de profundidade e deve corresponder a determinada necessidade identificada;

b) coleta de informações junto aos participantes das ações de formação realizadas;

- através de envio de questionário aos participantes. 
c) sistematização dos dados coletados - tabulação dos questionários retornados pelos participantes;

d) interpretação dos dados coletados.

A partir da sistematização dos dados coletados acima foi realizada uma análise quantitativa e qualitativa sobre as ações de Formação com o objetivo de se identificar em que medida essas ações, como parte de um processo educativo contínuo, contribuíram para a formação de profissionais que possam ser capazes de adotar estratégias de promoção do desenvolvimento rural sustentável, de atuar junto aos agricultores através de metodologias e processos que favoreçam 0 empoderamento dos agricultores e capacitados a qualificar do acesso às políticas públicas e agriculturas de base ecológica.

\subsection{Tipo e descrição geral da pesquisa}

Segundo Minayo (2005), a "avaliação, enquanto técnica e estratégia investigativa, é um processo sistemático de fazer perguntas sobre o mérito e a relevância de determinado assunto, proposta ou programa". Nesse sentido, a presente pesquisa teve como objetivo identificar a relevância do Programa de Formação de Agentes de ATER através da interpretação de dados quantitativos e qualitativos coletados diretamente junto a Coordenação de Formação de Agentes de ATER do Ministério do Desenvolvimento Agrário.

A análise qualitativa refere-se a identificação de em que medida as ações de formação realizadas foram eficazes considerando os seguintes parâmetros:

a) relevância para o aperfeiçoamento profissional - busca identificar em que medida os cursos oferecidos foram condizentes com as necessidades encontradas pelos técnicos em sua atuação extensionista e contribuíram para esse aperfeiçoamento;

b) relevância dos conteúdos abordados - busca identificar em que medida os conteúdos ministrados durante os cursos foram importantes para a formação dos técnicos; 
c) aplicabilidade dos conteúdos na atuação profissional - refere-se a relação entre os conteúdos e a realidade extensionista, aferindo se os mesmos são passíveis de serem aplicados na realidade onde atuam os técnicos pesquisados;

d) índice de replicabilidade dos conteúdos - busca identificar em que medida o DATER/SAF/MDA efetivamente tem contribuído para a formação de "formadores", ou seja, têm instrumentalizado os técnicos formados de forma que os mesmos repassem os conteúdos apreendidos a outros técnicos;

e) adequação dos conteúdos às orientações da Pnater.

A análise quantitativa referiu-se a identificação da relação recursos investidos na formação de agentes de ATER e do número de técnicos formados, de forma a identificar a variável referente ao custo benefício dessa ação. Essa análise foi importante para identificar a eficiência dessa política pública.

\subsection{Caracterização da organização, setor ou área do objeto de estudo}

O Ministério do Desenvolvimento Agrário - MDA foi criado em 1990 e possui a seguinte estrutura organizacional instituída pelo Decreto $N^{\circ} 7.255$, de 4 de Agosto de 2010, em seu anexo I, Art. $2^{\circ}$.

Art. $2^{\circ}$ O Ministério do Desenvolvimento Agrário tem a seguinte estrutura organizacional:

I - órgãos de assistência direta e imediata ao Ministro de Estado:

a) Gabinete;

b) Secretaria-Executiva:

1. Diretoria de Políticas para as Mulheres Rurais e Quilombolas;

2. Núcleo de Estudos Agrários e Desenvolvimento Rural;

3. Ouvidoria Agrária Nacional; e

4. Subsecretaria de Planejamento, Orçamento e Administração; e

c) Consultoria Jurídica;

II - órgãos específicos singulares:

a) Secretaria de Reordenamento Agrário: Departamento de Crédito Fundiário; 
b) Secretaria da Agricultura Familiar:

1. Departamento de Financiamento e Proteção da Produção;

2. Departamento de Assistência Técnica e Extensão Rural; e

3. Departamento de Geração de Renda e Agregação de Valor;

c) Secretaria de Desenvolvimento Territorial: Departamento de Ações de Desenvolvimento Territorial; e

d) Secretaria Extraordinária de Regularização Fundiária na Amazônia Legal: Departamento de Planejamento, Monitoramento e Avaliação da Regularização Fundiária na Amazônia Legal;

III - unidades descentralizadas: Delegacias Federais de Desenvolvimento Agrário;

IV - órgão colegiado: Conselho Nacional de Desenvolvimento Rural Sustentável - CONDRAF; e

V - entidade vinculada: Instituto Nacional de Colonização e Reforma Agrária - INCRA.(MDA, 2010)

Dentre as atribuições deste Ministério lista-se a prestação gratuita e qualificada de serviços de Assistência Técnica e Extensão Rural - ATER, cujo objetivo é melhorar a renda e a qualidade de vida das famílias agricultoras, aperfeiçoando os dos sistemas de produção, de mecanismo de acesso a recursos, serviços e renda, de forma sustentável.

Para coordenar as ações de ATER, a Secretaria da Agricultura Familiar (SAF/MDA) conta com o Departamento de Assistência Técnica e Extensão Rural (DATER), o qual é composto por três coordenações: Fomento à Assistência Técnica e Extensão Rural, Formação de Agentes de Assistência Técnica e Extensão Rural e Gestão do Sibrater.

A Coordenação de Formação de Agentes de ATER desenvolve iniciativas de "capacitação de extensionistas rurais na perspectiva do desenvolvimento rural sustentável, como forma de apoio às organizações governamentais e não governamentais. O objetivo é qualificar a oferta dos serviços de assistência técnica e extensão rural, integrar e socializar informações sobre políticas públicas para o fortalecimento da agricultura familiar." (Site MDA, 2010)

Segundo o site do MDA, entre as ações de formação promovidas incluem-se o apoio a eventos nos estados, a oferta periódica de cursos de curta e média duração e de especialização, por meio de parcerias. Além disso, são produzidas e apoiadas publicações voltadas à formação de agentes e outros materiais de consulta 
úteis para o aprofundamento dos diversos temas considerados prioritários pelo MDA.

\subsection{População e amostra}

A presente pesquisa envolveu técnicos pertencentes às instituições estaduais prestadoras de serviços de assistência técnica e extensão rural, governamentais e não governamentais, sindicatos, prefeituras, entre outras, que tenham participado de uma ou mais atividades de formação, promovidas e executadas diretamente pelo Departamento de Assistência Técnica e Extensão Rural, através de sua Coordenação de Formação - DATER no período entre 2004 e 2009.

A principal característica desses agentes é a atuação direta junto aos agricultores familiares, prestando serviços de orientação técnica nos campos produtivos, organizativos, ambientais e sociais.

De maneira geral, o perfil dos técnicos envolve profissionais de diferentes níveis de formação acadêmica, desde nível médio ou técnico até mestrado e doutorado, em diferentes áreas, abrangendo desde as ciências agrárias (técnicos(as) agrícolas, agrônomos (as), veterinários (as), entre outros) até as ciências sociais (pedagogos(as), economistas domésticos, assistentes sociais, entre outros).

Dados da Coordenação de Formação apontam para um número de aproximadamente 12.193 (doze mil cento e noventa e três) técnicos formados pelo DATER, com repetição, nesse período, o que indicou a necessidade de extrair uma amostragem a ser analisada nesta pesquisa.

A definição da amostra a ser analisada levou em consideração tanto questões práticas, como a disponibilidade de recursos financeiros e tempo, assim como a possibilidade de coletar, tabular e analisar grandes quantidades de dados, quanto questões de natureza estatística, considerando-se que uma análise qualificada exige uma amostra significativa.

Dessa forma, em termos estatísticos, e considerando-se o fator tempo, foram coletados nesta pesquisa dados de aproximadamente $3 \%$ do universo de 12.193 
técnicos, o que correspondeu a 390 técnicos participantes das ações de formação promovidas pelo DATER, através de questionário objetivo.

De forma a se evitar distorções, se optou por contabilizar o número de questionários por região, de forma que àquelas regiões onde foram realizados mais cursos também apresentassem um maior número de questionários.

\subsection{Instrumento de pesquisa}

Para coleta de dados junto aos participantes dos cursos realizados, foi utilizado questionário com perguntas objetivas.

\subsubsection{Questionário}

O questionário, que se encontra no Anexo I, foi enviado por e-mail, aos participantes das ações de formação e é composto por dez questões. Algumas destas questões são excludentes, outras possuem um caráter mais abrangente admitindo uma ou mais respostas. Este formulário foi adaptado de instrumento produzido pela Equipe de Formação do Departamento de Assistência Técnica e Extensão Rural - DATER, em 2007 e validado através de aplicação a dez pessoas de maneira aleatória de forma a aferir possíveis inconsistências e corrigi-las. As perguntas elaboradas tiveram como objetivo identificar em que medida as ações de formação desenvolvidas tiveram impactos ou não junto ao público beneficiário e conseqüentemente junto aos agricultores familiares. Considerando esse aspecto, esperou-se aferir através das respostas ao questionário em que medida as ações de formação alcançaram o objetivo a que se propunham, ou seja, espera-se verificar a eficácia e efetividade das ações desenvolvidas no âmbito desta política pública.

\subsection{Procedimentos de coleta e de análise de dados}

Conforme já explicitado a coleta de dados foi realizada de três formas: i) através de entrevistas com profissionais da Coordenação de Formação de ATER do MDA; ii) através de dados coletados através do Sistema de Finanças do Governo 
Federal - SIAFI e; iii) através de questionário enviado aos participantes das ações de formação.

Os dados foram analisados em função de indicadores de forma a expressar, da forma mais simples possível, a situação do item a ser avaliado. Tem-se consciência, entretanto, de que os indicadores ilustram apenas um aspecto específico de uma realidade muito mais complexa, apresentando portanto limitações. Segundo Brisolla (1998), a dificuldade teórica no estabelecimento de indicadores adequados é grande, assim como são grandes as dificuldades práticas em construir um conjunto confiável de indicadores.

Com relação a Política Pública de Formação de Agentes de ATER, entendese que a mesma tem por objetivo qualificar a ação extensionista através de um processo continuado. Dessa forma, os indicadores podem apontar diversos estágios de consolidação dessa política, razão pela qual optou-se por se estabelecer grandientes que indicassem o estado ou o estágio de consolidação dos indicadores escolhidos.

Para a valoração de cada indicador foram utilizados os seguintes gradientes, estabelecidos arbitrariamente:

a) Índice acima de $75 \%$ - indicador consolidado;

b) Índice entre 60 a 74\% - indicador em processo de consolidação;

c) Índice entre 0 a 59\% - indicador não consolidado.

Outro aspecto importante com relação a essa política pública, é que a mesma não produz resultados quantificáveis diretamente, ou seja, não se pode mensurá-la apenas através do número de agentes formados, uma vez que o objetivo da mesma é colocar em movimento um processo que a longo prazo produz benefícios para o país e para os agricultores familiares. O seu resultado não é mensurável em benefícios diretos aos técnicos formados, mas sim na medida em que a atuação dos mesmos produz resultados diferenciados a campo. Considerando-se essas especificidades, foram estabelecidos os seguintes indicadores: 
Tabela 3 - Itens a serem avaliados $\mathrm{x}$ indicadores

Item a ser avaliado

\begin{tabular}{|c|c|}
\hline Item a ser avaliado & Indicador \\
\hline Eficácia & $\begin{array}{l}\text { a) Adequação do público formado; } \\
\text { b) Adequação dos conteúdos das formações às } \\
\text { orientações da Pnater; } \\
\text { c) Aplicação dos conteúdos pelos técnicos } \\
\text { formados em suas atividades profissionais; } \\
\text { d) Apoio a atividades de formação; } \\
\text { e) Atuação dos técnicos como formadores/ } \\
\text { multiplicadores. }\end{array}$ \\
\hline Eficiência & $\begin{array}{l}\text { a) Número de agentes formados x recursos } \\
\text { investidos (custo/beneficiário); } \\
\text { b) Aplicação dos recursos. }\end{array}$ \\
\hline Efetividade & $\begin{array}{l}\text { a) Mudança do perfil de trabalho dos técnicos } \\
\text { (adoção de Metodologias Participativas, } \\
\text { orientação para práticas de agricultura } \\
\text { ecológica, etc.); } \\
\text { b) Mudança no perfil da instituição em que } \\
\text { atuam, a partir da influência dos técnicos } \\
\text { formados. }\end{array}$ \\
\hline
\end{tabular}

\section{Indicador}

Fonte: Elaboração própria 


\section{RESULTADOS E DISCUSSÃO}

\subsection{A Ação Orçamentária 4448 - Formação de Agentes de ATER nos Planos Plurianuais 2004 - 2007 e 2008 - 2011}

A Ação Orçamentária 4448 foi incluída no Plano Plurianual - PPA 2004 2007, mas na época destinava-se a Capacitação de Agricultores Familiares e não de técnicos. Em 2007, essa ação passou a ser destinada à Capacitação de Agentes de ATER, mas apenas a partir do PPA 2008-2011, esta ação orçamentária foi reestruturada para Formação de Agentes de ATER e incorporada ao Programa Nacional de Assistência Técnica e Extensão Rural - Pronater. Essa alteração de finalidade respondeu a necessidade crescente de formação dos técnicos que prestam serviços aos Agricultores Familiares, de forma a qualificar a ação extensionista.

Segundo o PPA 2008-2011 essa ação orçamentária tem por finalidade:

"formar Agentes de ATER que estão ou virão a estar atuando junto a Agricultura Familiar, com base nos princípios da Política Nacional de Assistência Técnica e Extensão Rural - Pnater, visando à construção de novos conhecimentos e a qualificação dos serviços prestados aos agricultores." (PPA 2008-2011)

Para alcançar essa finalidade, deveriam ser promovidas ações de

"formulação e coordenação, em parceria com as organizações de ensino formal e não formal, da elaboração e a publicação de materiais informativos e a realização de atividades de formação inicial e avançada, de forma continuada para os Agentes de ATER". (PPA 2008-2011)

Embora não houvesse uma fonte orçamentária específica para a Formação de Agentes de ATER, atividades de formação voltadas para técnicos foram executadas no período de 2004 a 2006 com recursos provenientes da Ação Orçamentária 4260, destinada a Assistência Técnica e Extensão Rural.

Em termos financeiros, os recursos disponibilizados especificamente para a Formação de Agentes de ATER no período 2007-2009, são apresentados no gráfico a seguir: 
Gráfico 5 - Evolução de recursos aplicados na formação de Agentes de ATER 2007-2009

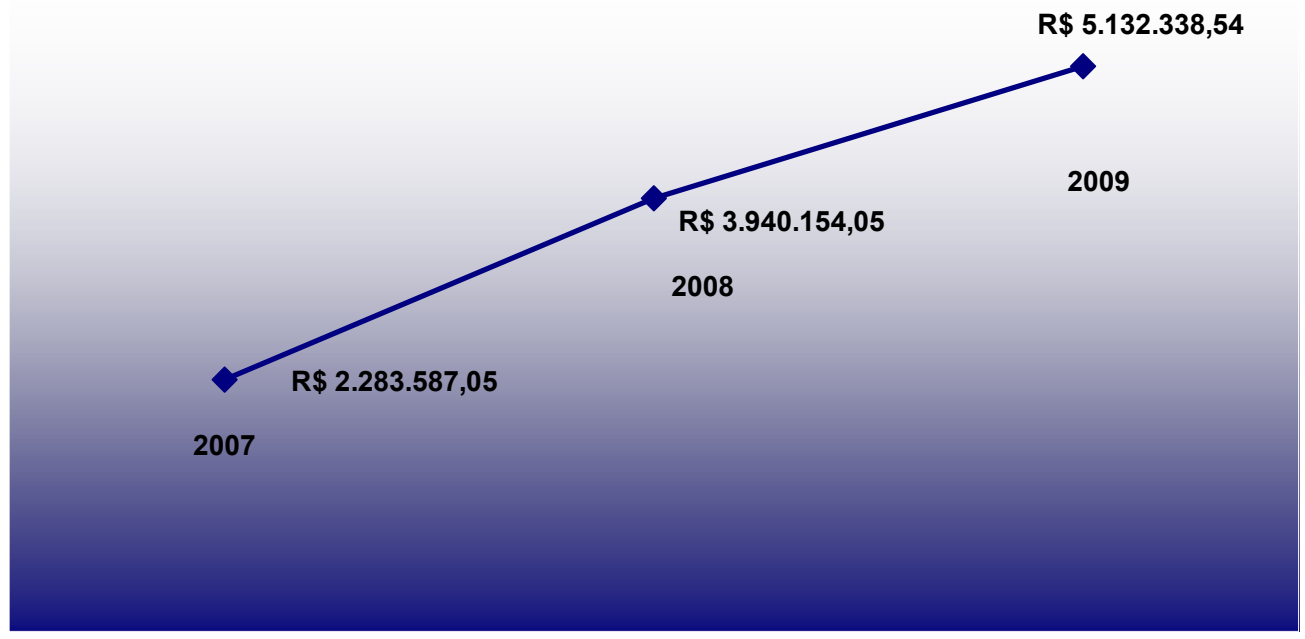

Fonte: SIAFI

A impossibilidade de se aferir dados concretos a respeito do volume de recursos aplicados na formação direta de agentes de ATER no período 2004 a 2006, uma vez que não havia rubrica orçamentária específica destinada a essa ação dificultam a análise referente a relação custo/benefício das ações desenvolvidas, naquele período.

\subsection{As orientações para um Programa de Formação de Agentes de ATER}

As ações de capacitação executadas diretamente pela Coordenação de Formação do DATER/MDA envolveram diferentes tipos de atividades, com diferentes cargas horárias e metodologias. As ações realizadas tiveram como objetivo "formar agentes de ATER nos temas identificados como prioritários pela Política, de forma que se pudesse avançar na implementação dos princípios e diretrizes da mesma, e também atender à demanda apresentada pelos próprios 
agentes como resultado de consultas realizadas pela Equipe de Formação do DATER." (Equipe de Formação DATER).

A formação concentrou-se em dois seguimentos distintos:

a) formação de formadores - segundo a Coordenação de Formação do DATER, a formação de formadores tem por objetivo capacitar técnicos de modo que estes venham a se tornar referência em seus estados, apoiando atividades de capacitação para outros técnicos e agricultores, tendo como base as orientações das políticas do MDA, da Secretaria da Agricultura Familiar e da Pnater.

b) formação de Agentes de Ater - tem por objetivo qualificar a ação extensionista junto aos agricultores familiares, promovendo 0 aperfeiçoamento técnico e conceitual dos mesmos.

\subsubsection{Temas prioritários}

Os temas tratados nas formações de Agentes de Ater necessariamente deveriam estar vinculados a duas fontes de legitimação: conteúdos originados da Pnater e a demanda qualificada apresentada pelos próprios agentes beneficiários dessas formações.

\subsubsection{A Pnater}

Para a Pnater a formação consiste em um "processo de avanço do conhecimento e da consciência, capaz de despertar e fortalecer habilidades, dinamizar o saber local apropriado pelos atores envolvidos, criar novos conhecimentos e disseminar informações úteis para os objetivos de cada grupo social, de modo a permitir mudanças de comportamento e de atitudes a partir da leitura crítica da realidade concreta" (MDA, 2003). Nesse contexto a Pnater estabeleceu como prioridade a necessidade de se "desenvolver processos educativos permanentes e continuados, a partir de um enfoque dialético, humanista e construtivista, visando a formação de competências, mudanças de atitudes e procedimentos dos atores sociais, que potencializem os objetivos de melhoria da qualidade de vida e de promoção do desenvolvimento rural sustentável" (MDA, 2003). 
As orientações estratégicas para as ações da Ater pública estabelecidas pela Pnater estão listadas no quadro a seguir e classificadas em macrotemas orientadores para a formação de Agentes de ATER. 
Tabela 4 - Orientações estratégicas para as ações da Ater pública

\section{Orientações estratégicas para as ações da Ater pública}

- Orientar a construção de sistemas produtivos e estratégias de desenvolvimento rural sustentável norteados pelos princípios da Agroecologia, considerando a amplitude conceitual deste novo enfoque científico.

- Incentivar e apoiar sistemas alimentares regionalmente adaptados, estimulando a produção de subsistência, assim como a diversificação de cultivos, visando à busca da Segurança Alimentar e Nutricional Sustentável da população.

- Adotar o planejamento das ações com base no território rural, sempre considerando as dimensões econômicas, ambientais, sociais, culturais e políticas do desenvolvimento sustentável, num contexto de relações de trabalho e de vida.

- Considerar a complexidade e o dinamismo dos sistemas e das cadeias de produção, assim como os limites econômicos e socioambientais em que se desenvolvem, de modo a contribuir para o redimensionamento, redesenho e uso adequado dos meios de produção disponíveis e ao alcance dos agricultores familiares e demais públicos da extensão rural.

- Restabelecer a articulação da Ater com as instituições de ensino e de pesquisa, buscando a formação de redes, fóruns regionais, territoriais e outras formas de integração entre a Ater, o ensino e a pesquisa, que assegurem a participação dos agentes de Ater e dos agricultores familiares e suas organizações na definição de linhas de pesquisa avaliação, validação e recomendação de tecnologias apropriadas, compatíveis com a Política Nacional de Ater.
Macrotemas relacionados

Subtemas

- Produção de base ecológica

- Diversificação produtiva;

- Agroecologia

- Desenvolvimento Rural Sustentável.

- Sistemas Agroflorestais SAF's.

- Segurança Alimentar e Nutricional.

- Produção para subsistência;

- Valorização da cultura alimentar regional;

- Diversificação produtiva.

Desenvolvimento Rural Sustentável;

- Enfoque sistêmico.

- Desenvolvimento Territorial

- Planejamento participativo.

- Cadeias Produtivas Arranjos Produtivos Locais.

- Identificação de mercados comercialização

- Associativismo Cooperativismo;
- Articulação

Interinstitucional

•




\begin{tabular}{|c|c|c|}
\hline Orientações estratégicas para as ações da Ater pública & Macrotemas relacionados & Subtemas \\
\hline $\begin{array}{l}\text { - Incorporar às ações de Ater os princípios da Economia Solidária e da } \\
\text { Segurança Alimentar e Nutricional Sustentável. }\end{array}$ & $\begin{array}{l}\text { - Economia Solidária; } \\
\text { - Segurança Alimentar } \\
\text { e Nutricional. }\end{array}$ & $\begin{array}{l}\text { - Comércio Justo e Solidário; } \\
\text { - } \quad \text { e } \\
\text { - } \quad \text { Paociaticiativismoção e empoderamento; }\end{array}$ \\
\hline $\begin{array}{l}\text { - Apoiar o estabelecimento de redes solidárias de cooperação que ajudem a } \\
\text { potencializar e articular o conhecimento necessário para estabelecer } \\
\text { processos sustentáveis de desenvolvimento local e territorial. }\end{array}$ & - Redes. & $\begin{array}{l}\text { - Dinâmica de interação e } \\
\text { trabalho em redes. }\end{array}$ \\
\hline $\begin{array}{l}\text { - Estimular a democratização dos processos de tomada de decisão, assim } \\
\text { como a participação de todos os membros da família na gestão da } \\
\text { unidade familiar e nas estratégias de desenvolvimento das comunidades e } \\
\text { territórios. }\end{array}$ & 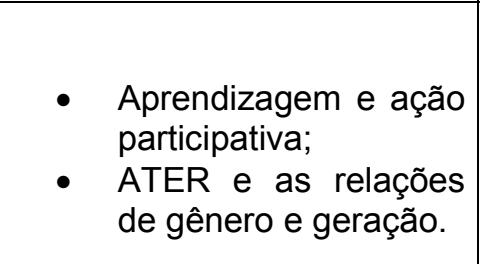 & $\begin{array}{l}\text { - Empoderamento; } \\
\text { - Valorização do papel da mulher, } \\
\text { dos jovens e dos idosos; } \\
\text { - Participação; } \\
\text { - Enfoques metodológicos } \\
\text { participativos. }\end{array}$ \\
\hline $\begin{array}{l}\text { - Contribuir na orientação dos processos organizativos e de capacitação de } \\
\text { jovens e de mulheres trabalhadoras rurais, considerando suas } \\
\text { especificidades socioculturais. }\end{array}$ & $\begin{array}{l}\text { - ATER e as relações } \\
\text { de gênero e geração. }\end{array}$ & $\begin{array}{l}\text { - Valorização do papel da mulher, } \\
\text { dos jovens e dos idosos; }\end{array}$ \\
\hline
\end{tabular}

(Continuação) 
Orientações estratégicas para as ações da Ater pública

- Fortalecer iniciativas educacionais apropriadas para agricultura familiar, tendo como referência a Pedagogia da Alternância, assim como outras experiências educacionais construídas a partir da realidade dos agricultores familiares.

- Desenvolver ações que possibilitem e garantam o resgate de sementes e de raças tradicionais de animais, contribuindo diretamente para evitar a erosão genética e para assegurar a preservação da biodiversidade.

- Promover abordagens metodológicas que sejam participativas e utilizem técnicas vivenciais, estabelecendo estreita relação entre teoria e prática, propiciando a construção coletiva de saberes, o intercâmbio de conhecimentos e o protagonismo dos atores na tomada de decisões.
Macrotemas relacionados

Subtemas

- Pedagogia Alternância.

da

- Preservação genética e da biodiversidade

- Agroecologia.

Resgate de sementes crioulas

- Construção coletiva de Saberes

Valorização dos conhecimentos tradicionais;

- Aprendizagem e ação participativa.
- Empoderamento;

- Metodologias Participativas

Fonte: Pnater com adaptações

(Concluído) 


\subsubsection{Levantamento de demandas}

No período entre 2004 e 2009 a Coordenação de Formação do DATER realizou dois levantamentos de demandas junto aos técnicos beneficiários: o primeiro em 2006 e o segundo em 2008. O objetivo desses levantamentos foi identificar em quais temas as formações promovidas pelo DATER deveriam se concentrar.

O levantamento realizado em 2006 foi, em grande medida, realizado de maneira informal, via Grupo de discussão NOVATER BRASIL, hospedado no Yahoo e moderado pelo Coordenador de Formação do DATER. Atualmente, cerca de 1500 participantes acompanham o NOVATER BRASIL. Segundo informações disponíveis na página do grupo, o objetivo do mesmo é "ser um espaço destinado ao intercâmbio de conhecimentos e experiências que possam ser úteis para a qualificação das ações de ATER no Brasil. Ao mesmo tempo, espera-se que venha a ser um canal democrático para a troca de informações cotidianas sobre os temas: Extensão Rural, Agroecologia, Agricultura Familiar, Desenvolvimento Sustentável, Questões de Gênero, Raça e Etnia, Agricultura Sustentável, Políticas Públicas e afins." (Descrição disponível na página do grupo).

Esse levantamento obteve resposta de 93 técnicos de diferentes regiões e foi mais superficial em termos de aferição de dados. $O$ resultado desse levantamento está sistematizado no quadro a seguir:

Tabela 5 - Temas para formação: levantamento de demanda 2006

\begin{tabular}{|c|c|c|c|}
\hline $\begin{array}{l}\text { TEMAS PARA } \\
\text { CAPACITAÇÃO }\end{array}$ & $\begin{array}{l}\text { ESTADOI } \\
\text { REGIÃO }\end{array}$ & SUGESTÕES DE CONTEÚDOS A SEREM ABORDADOS & $\begin{array}{l}N^{0} \text { de vezes } \\
\text { em que o tema } \\
\text { foi indicado }\end{array}$ \\
\hline Metodologias Participativas & Todas & & 11 \\
\hline $\begin{array}{l}\text { Assistência e Extensão } \\
\text { Pesqueira }\end{array}$ & Pará/ Norte & 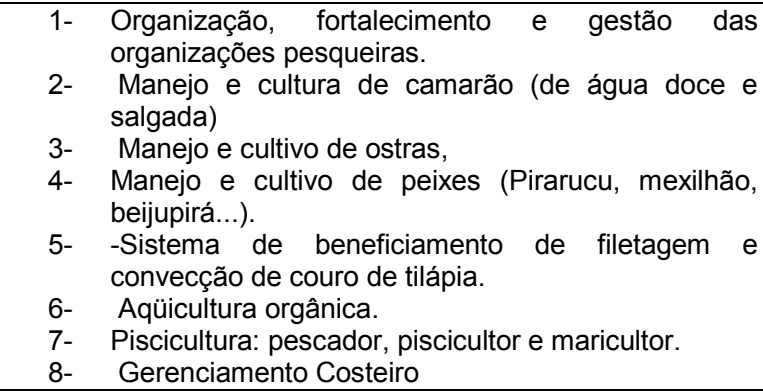 & 9 \\
\hline
\end{tabular}

(Continua) 


\begin{tabular}{|c|c|c|c|}
\hline TEMAS PARA CAPACITAÇÃO & $\begin{array}{l}\text { ESTADOI } \\
\text { REGIÃO }\end{array}$ & $\begin{array}{l}\text { SUGESTÕES DE CONTEÚDOS A SEREM } \\
\text { ABORDADOS }\end{array}$ & $\begin{array}{l}N^{\circ} \text { de vezes que } \\
\text { o tema foi } \\
\text { indicado }\end{array}$ \\
\hline Cooperativismo e associativismo & & 1 - Curso Básico; & 6 \\
\hline Sistemas Agroflorestais & Alagoas & 1- Bioma Caatinga. & 4 \\
\hline Comercialização e abastecimento & Todas & 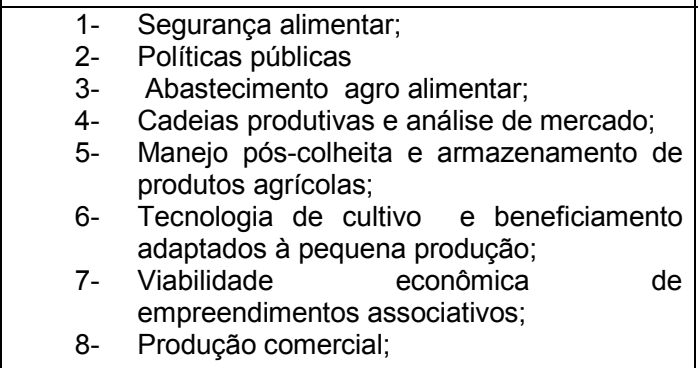 & 4 \\
\hline Economia Solidária & & $\begin{array}{l}\text { 1. Estratégia e política para desenvolvimento } \\
\text { sustentável }\end{array}$ & 3 \\
\hline $\begin{array}{l}\text { Planejamento, gestão, ciclos de } \\
\text { projetos e políticas públicas }\end{array}$ & Todas & & 3 \\
\hline Agroecologia & $\begin{array}{c}\text { Rio Grande } \\
\text { do Sul }\end{array}$ & & 3 \\
\hline Desenvolvimento territorial & & & 3 \\
\hline Quilombolas & Bahia & & 3 \\
\hline Monitoramento e Avaliação & & & 3 \\
\hline Pedagogia da alternância & $\begin{array}{l}\text { Mato Grosso } \\
\text { do Sul }\end{array}$ & $\begin{array}{l}\text { 1. Experiências das Casas Familiares e das } \\
\text { Escolas das Famílias Agrícolas. }\end{array}$ & 3 \\
\hline $\begin{array}{l}\text { Produção de mudas silvestres e } \\
\text { viveirismo }\end{array}$ & Paraíba & Sucessão natural de espécies & 2 \\
\hline $\begin{array}{l}\text { As questões de gênero, raça e } \\
\text { etnia }\end{array}$ & & $\begin{array}{l}\text { A. A ser abordado como temática dentro de } \\
\text { outros cursos. }\end{array}$ & 2 \\
\hline Legislação Ambiental & & $\begin{array}{l}\text { 1. Licenciamento e impacto ambiental nas } \\
\text { atividades rurais }\end{array}$ & 2 \\
\hline $\begin{array}{lll}\text { Elaboração } & \text { Participativa } & \text { de } \\
\text { Projetos } & & \end{array}$ & & & 1 \\
\hline $\begin{array}{l}\text { Planejamento participativo do } \\
\text { desenvolvimento local sustentável }\end{array}$ & Pará & & 1 \\
\hline $\begin{array}{l}\text { Organização Social e gestão } \\
\text { participativa de projetos de geração } \\
\text { de emprego e renda }\end{array}$ & Pará & & 1 \\
\hline Pós- DRP & & & 1 \\
\hline $\begin{array}{l}\text { Formação Política de Agentes de } \\
\text { ATER }\end{array}$ & Sul & $\begin{array}{l}\text { 1. Perfil e atuação do agente no contexto da } \\
\text { Agricultura Familiar, } \\
\text { 2. Territorialidade, } \\
\text { 3. Economia, } \\
\text { 4. Políticas públicas, etc. }\end{array}$ & 1 \\
\hline $\begin{array}{l}\text { Atuação do agente de ATER junto } \\
\text { a comunidades ribeirinhas e de } \\
\text { zona de fronteira }\end{array}$ & $\begin{array}{l}\text { Rondônia/ } \\
\text { Norte }\end{array}$ & & 1 \\
\hline $\begin{array}{l}\text { A nova Pnater e o perfil desejável } \\
\text { do extensionista rural }\end{array}$ & Pará & & 1 \\
\hline
\end{tabular}

(continuação) 


\begin{tabular}{|c|c|c|c|}
\hline TEMAS PARA CAPACITAÇÃO & $\begin{array}{l}\text { ESTADO/ } \\
\text { REGIÃO }\end{array}$ & $\begin{array}{l}\text { SUGESTÕES DE CONTEÚDOS A SEREM } \\
\text { ABORDADOS }\end{array}$ & $\begin{array}{l}N^{0} \text { de vezes em } \\
\text { que o tema foi } \\
\text { indicado }\end{array}$ \\
\hline Lideranças comunitárias & & & 1 \\
\hline $\begin{array}{l}\text { Integração entre extensionistas e } \\
\text { os movimentos sociais }\end{array}$ & $\begin{array}{l}\text { Espírito } \\
\text { Santo }\end{array}$ & & 1 \\
\hline Sistemas de Informação de ATER & Pará & 1. Softwares desenvolvidos e em uso & 1 \\
\hline Agro extrativismo & Nordeste & $\begin{array}{l}\text { 1. Agroextrativismo nos biomas cerrado e } \\
\text { Amazônia. }\end{array}$ & 1 \\
\hline Diagnóstico de agrossistemas & & & 1 \\
\hline $\begin{array}{l}\text { Plano de manejo e utilização de } \\
\text { produtos florestais não madeireiros }\end{array}$ & Norte & & 1 \\
\hline $\begin{array}{l}\text { Projetos de Assentamento } \\
\text { Florestais }\end{array}$ & $\begin{array}{l}\text { Rondônia, } \\
\text { Acre e Mato } \\
\text { Grosso }\end{array}$ & & 1 \\
\hline $\begin{array}{l}\text { Sistematização de experiências } \\
\text { agroecológicas }\end{array}$ & & & 1 \\
\hline Arranjos Produtivos Locais & Pará & & 1 \\
\hline 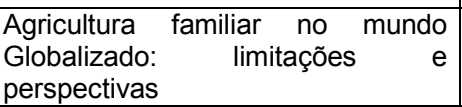 & Pará & $\begin{array}{l}\text { Temas: agronegócio e o uso sustentável dos } \\
\text { recursos naturais }\end{array}$ & 1 \\
\hline $\begin{array}{l}\text { Georreferenciamento } \\
\text { propriedades rurais }\end{array}$ & Pará & & 1 \\
\hline $\begin{array}{l}\text { Comunicação e Marketing em } \\
\text { extensão Rural }\end{array}$ & Pará & & 1 \\
\hline \begin{tabular}{lccr|}
$\begin{array}{l}\text { Visão de } \\
\text { negócios, } \\
\text { negociação }\end{array}$ & $\begin{array}{c}\text { mercado, visão } \\
\text { administração }\end{array}$ & $\begin{array}{r}\text { de } \\
\text { e }\end{array}$ \\
\end{tabular} & $\begin{array}{l}\text { Maranhão - } \\
\text { Nordeste }\end{array}$ & $\begin{array}{l}\text { Objetivando prepara os agentes para apoiar o } \\
\text { agricultor na hora de decidir o que é melhor plantar e } \\
\text { como negociar seus produtos. }\end{array}$ & 1 \\
\hline $\begin{array}{l}\text { Agroindústrias } \quad \text { familiares } \quad \mathrm{e} \\
\text { artesanais }\end{array}$ & & & 1 \\
\hline Agregação de valor & & & 1 \\
\hline Agroenergia & & & 1 \\
\hline $\begin{array}{l}\text { Filosofia da ciência e teoria da } \\
\text { complexidade }\end{array}$ & & & 1 \\
\hline $\begin{array}{l}\text { Manejo comunitário de recursos } \\
\text { naturais }\end{array}$ & & & 1 \\
\hline $\begin{array}{l}\text { Enfoques pedagógicos para o meio } \\
\text { rural }\end{array}$ & & & 1 \\
\hline Legislação trabalhista e tributária & & & 1 \\
\hline Legislação agrária & & & 1 \\
\hline Direito agrário e fluxo administrativo & & & 1 \\
\hline Segurança alimentar e nutricional & & & 1 \\
\hline Cadeia produtiva da mandioca & & & 1 \\
\hline Processamento de hortaliças & & & 1 \\
\hline
\end{tabular}

Fonte: Enquête realizada através do Grupo NOVATER BRASIL (Concluído) 
O levantamento realizado em 2008 utilizou formulário estruturado, com temas específicos, o qual foi encaminhado a diferentes empresas prestadoras de assistência técnica, governamentais e não governamentais, bem como a técnicos de prefeituras, sindicatos, escolas família agrícola, entre outros, e atingiu diferentes perfis e necessidades de formação. Além dos temas elencados no formulário, foi solicitado aos agentes que informassem em que outras temáticas tinham interesse.

Os temas que obtiveram maior manifestação de interesse foram: Análise de mercado, visão de negócios e administração da pequena propriedade, com uma taxa de manifestação de interesse de $86,07 \%$ dos formulários recebidos, e Agroecologia e Desenvolvimento Rural Sustentável com 85,37\%. A maior parte dos temas propostos apresentou uma taxa de interesse entre $70 \%$ e $79 \%$.

Os temas que apresentaram as menores taxas de interesse foram Ater com Comunidades Indígenas, com $24,73 \%$ e Ater com Comunidades Quilombolas, com $28,99 \%$, o que pode ser explicado pelo baixo número de técnicos que trabalham com esses públicos específicos.

No quadro a seguir os temas propostos foram priorizados de acordo com os seguintes parâmetros:

$\leq 75 \%$ prioridade alta

$50 \%-74 \%$ prioridade média

$>50 \%$ - prioridade baixa

Tabela 6 - Temas para formação: levantamento de demanda 2008

\begin{tabular}{|c|c|c|}
\hline Prioridade & Class. & Tema \\
\hline \multirow{8}{*}{ Alta } & 1 & $\begin{array}{l}\text { Análise de mercado, visão de negócios e administração da pequena } \\
\text { propriedade }\end{array}$ \\
\hline & 2 & Agroecologia e Desenvolvimento Rural Sustentável \\
\hline & 3 & Cadeias Produtivas e APL's \\
\hline & 4 & PNATER \\
\hline & 4 & Cooperativismo e Associativismo \\
\hline & 5 & Agroindústria \\
\hline & 6 & PAA \\
\hline & 7 & Metodologias Participativas \\
\hline
\end{tabular}

(continua) 


\begin{tabular}{|c|c|l|}
\hline Prioridade & Class. & \multicolumn{1}{c|}{ Tema } \\
\hline \multirow{4}{*}{ Alta } & 8 & Produção Agrícola e Pecuária Ecológica \\
\cline { 2 - 3 } & 1 & Políticas de crédito e financiamento da produção \\
\cline { 2 - 3 } & 1 & Manejo Ecológico de Solos \\
\cline { 2 - 3 } & 2 & Segurança e Soberania Alimentar \\
\cline { 2 - 3 } & 3 & Certificação Sócio-participativa \\
\cline { 2 - 3 } & 4 & Sistemas Agrosilvipastoris e SAF's \\
\cline { 2 - 3 } & 5 & Relações Sociais de Gênero \\
\cline { 2 - 3 } & 7 & Sociobiodiversidade \\
\hline \multirow{4}{*}{ Baixa } & 1 & Atividades não Agrícolas \\
\cline { 2 - 3 } & 2 & Ater com Pescadores artesanais e aqüicultores \\
\cline { 2 - 3 } & 3 & Ater com Quilombolas \\
\cline { 2 - 3 } & 4 & Ater com indígenas \\
\hline
\end{tabular}

Fonte: Coordenação de Formação do DATER

(Concluído)

Os macrotemas identificados na Pnater e a sistematização das demandas apresentadas pelos técnicos foram utilizados como parâmetros para análise da adequação das ações de formação promovidas pelo DATER no período entre 2004 a 2009 aos dois instrumentos de legitimação. Essa análise será feita no item "Eficácia das ações de formação promovidas".

\subsubsection{Tipologia e metodologias de atividades de formação}

Segundo as orientações da Pnater, as atividades de formação devem necessariamente estar pautadas no uso de metodologias que favoreçam a reflexão sobre a realidade de atuação do agente de ATER, favorecendo o processo de construção e reconstrução de conhecimentos não apenas técnicos e científicos mas também no que se refere às relações de poder presentes na atuação junto ao agricultor. No que tange a essas relações, é fundamental a reflexão sobre o papel do extensionista como promotor do "envolvimento consciente dos atores sociais" (MDA, 2003) e sobre a mudança dos mecanismos que permeiam essa relação. Uma 
mudança nesses mecanismos implica não apenas no uso indiscriminado de ferramentas ditas "participativas", mas na própria conscientização do técnico de seu papel de facilitador e não de condutor do processo de desenvolvimento rural sustentável.

Nesse contexto, é impossível promover um processo crítico de formação, repetindo mecanicamente idéias ou se utilizando do que Freire (1977) chamou de "educação bancária". Da mesma forma, é impossível promover uma educação democrática sem considerar as necessidades, potencialidades e possibilidades diferenciadas do público a ser formado.

Considerando isso, um programa de formação de Agentes de ATER deve estruturar atividades de capacitação diferenciadas, que permitam diferentes níveis de formação e um aprofundamento contínuo sobre temas relevantes. As mesmas devem adotar diferentes tipologias, diferentes cargas horárias e diferentes veículos de interação de forma a alcançarem o leque mais amplo possível de participantes.

Em linhas gerais são essas as principais orientações para a análise da eficiência, eficácia e efetividade das ações de formação promovidas pelo DATER no período em estudo.

\subsection{Questionários de Avaliação}

No total foram recebidos e analisados $390^{1}$ questionários, preenchidos por técnicos participantes de diferentes eventos de formação realizados diretamente pelo DATER no período entre 2004 e 2009, distribuídos por região, conforme tabela a seguir:

\footnotetext{
${ }^{1}$ Este número atende ao necessário para validação estatística de pesquisa, considerando que a amostra válida é composta por 387 questionários. Os questionários compõem o Anexo III.
} 
Tabela 7 - Número de questionários recebidos por região

\begin{tabular}{|c|c|c|c|c|c|c|}
\hline & \multicolumn{5}{|c|}{ Região } & Total \\
\cline { 2 - 8 } & Nordeste Sudeste & $\begin{array}{c}\text { Centro } \\
\text { Oeste }\end{array}$ & Sul & Norte & \\
\hline $\begin{array}{c}\text { Número de } \\
\text { questionários recebidos }\end{array}$ & 66 & 51 & 23 & 70 & 180 & 390 \\
\hline
\end{tabular}

Fonte: Elaboração própria

Gráfico 7 - Questionários recebidos por região (porcentagem)

Porcentagem dos questionários recebidos por região

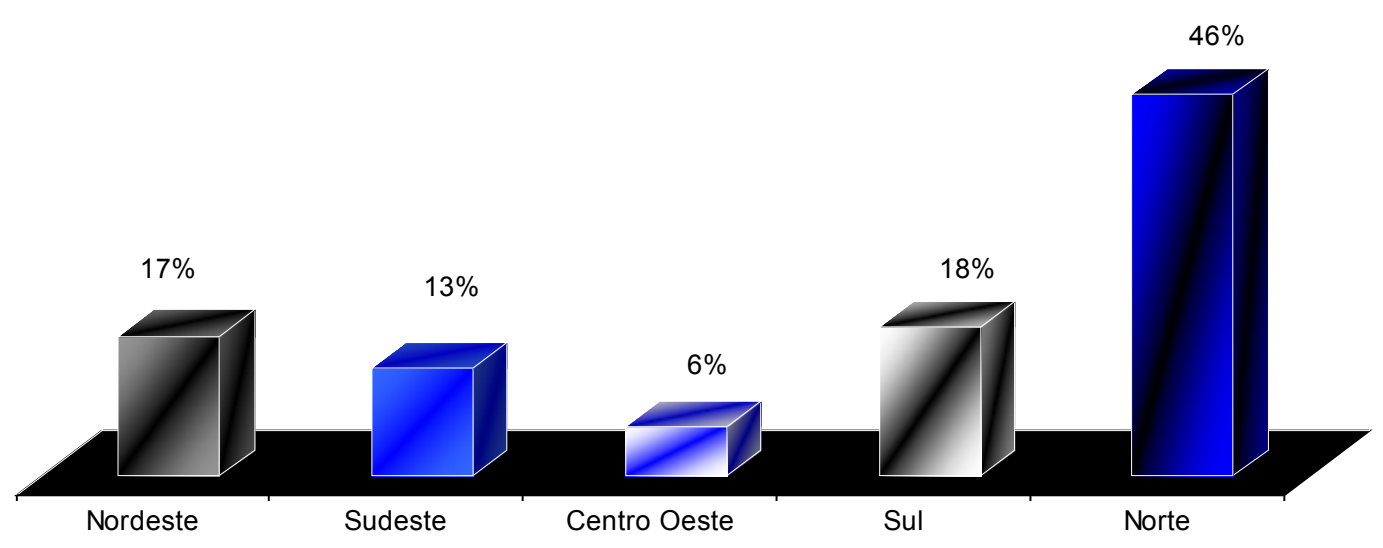

Fonte: questionários recebidos

Percebe-se que as regiões Norte, Nordeste e Sul foram responsáveis, conjuntamente, por $81 \%$ dos questionários recebidos. Esse percentual reflete em grande parte a distribuição dos cursos realizados nesse período, os quais se concentraram especialmente nessas regiões. Segundo dados da Coordenação de Formação do DATER, 77\% dos cursos regionalizados realizados entre 2004 a 2009 foram destinados a essas três regiões, conforme tabela abaixo.

Tabela 8 - Número de eventos realizados x por região de abrangência Região de Abrangência dos cursos $\mathbf{N}^{\circ}$. de eventos

\begin{tabular}{|c|c|}
\hline Nacional & 152 \\
\hline Centro Oeste & 12 \\
\hline Sudeste & 14 \\
\hline Sul & 19 \\
\hline
\end{tabular}




\begin{tabular}{|c|c|}
\hline Norte & 26 \\
\hline Nordeste & 44 \\
\hline Total & $\mathbf{2 6 7}$ \\
\hline
\end{tabular}

Fonte: Coordenação de Formação - DATER/SAF/MDA

A realização da maior quantidade de eventos de formação nas regiões Norte e Nordeste justifica-se pelo número de estados que as compõem, bem como pela demanda acentuada nessas regiões, até mesmo em função das desigualdades regionais existentes.

As regiões Centro-Oeste e Sudeste foram em parte penalizadas em função da dificuldade em se estabelecer parcerias que possibilitassem a realização das atividades de formação nas mesmas.

\subsubsection{Perfil dos técnicos formados}

\section{a) Gênero}

Dos 390 questionários recebidos 119 foram respondidos por mulheres e 271 por homens, o que representa 31 (trinta e um) e 69\% (sessenta e nove por cento) do total, respectivamente. Essa análise torna-se importante no contexto de que uma das orientações da Pnater diz respeito não apenas a abordagem de conteúdos referentes às relações de gênero nas atividades de formação, mas também a adoção de ações afirmativas no sentido de garantir a participação de mulheres nesses espaços. Dessa forma, um dos critérios de seleção adotados pelo DATER para participação em atividades de formação é de que pelo menos 30\% (trinta por cento) das vagas disponíveis sejam destinadas às mulheres, desde que respeitados demais critérios técnicos estabelecidos. 
Gráfico 8 - Perfil dos questionários a nível nacional - gênero

\section{Perfil dos Agentes de ATER formados - Gênero}

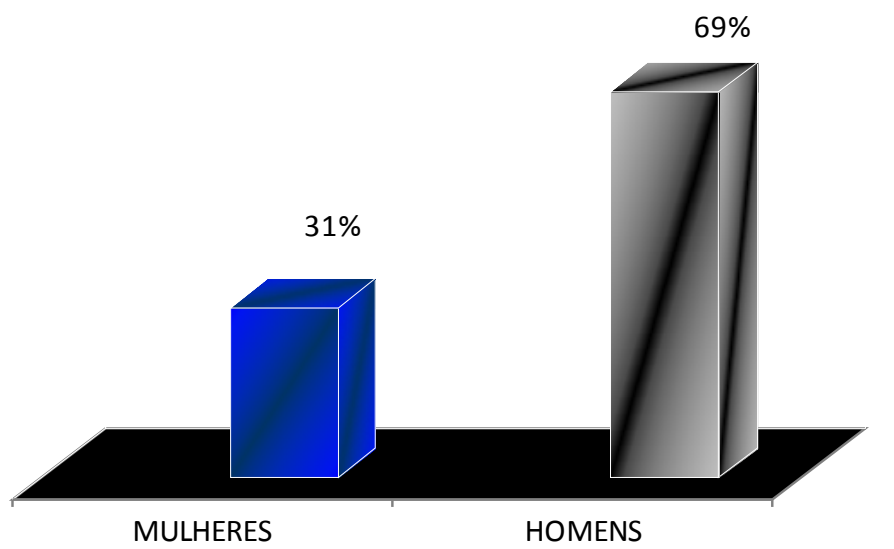

Fonte: questionários recebidos

Se considerarmos estatisticamente válido o universo analisado, e que o mesmo reflete a realidade do número de agentes formados, percebe-se que os questionários respondidos indicam que a meta de $30 \%$ de vagas para mulheres, foi alcançada a nível nacional. Por outro lado, ao analisarem-se os dados estratificados por região, conforme gráfico abaixo, percebe-se que essa meta não foi alcançada nas regiões Sul, Norte e Centro Oeste.

Gráfico 9 - Perfil dos questionários analisados por região - gênero

\section{Perfil dos Agentes de ATER formados por região - Gênero}

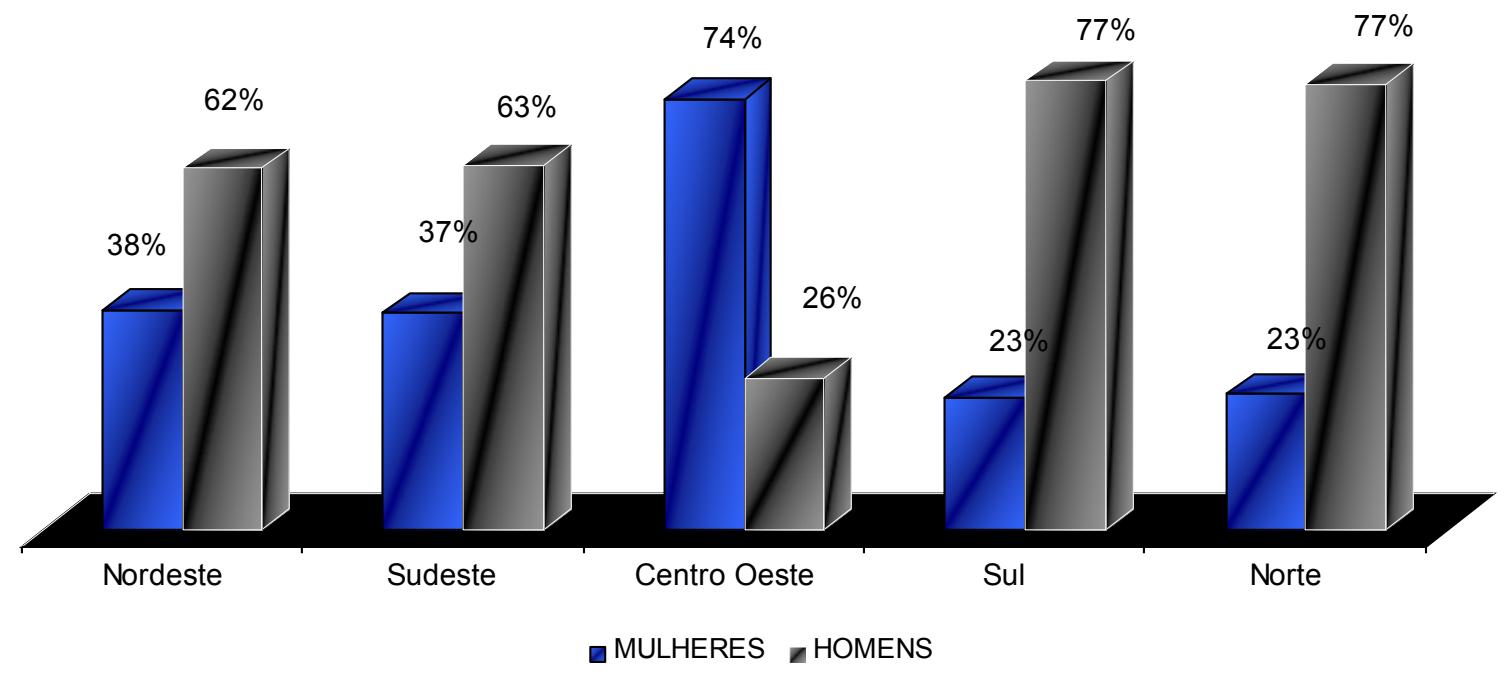

Fonte: questionários recebidos 


\section{b) Escolaridade/ formação acadêmica}

Tradicionalmente, o perfil dos profissionais da extensão rural concentrou-se nas áreas vinculadas às ciências agrárias (agronomia, veterinária, técnicos agrícolas, entre outros) e à assistência social. Com o passar dos anos, porém, diversos outros campos do conhecimento passaram a atuar nas entidades de extensão rural, contribuindo para o aperfeiçoamento dos serviços prestados.

Prova desse novo panorama são os concursos realizados nos últimos anos pelas instituições estaduais de ATER, que incorporaram profissionais em formações diversas tais como Engenharia de Alimentos, Sociologia, Pedagogia, História, Antropologia, Ciências Sociais Aplicadas, Ciências Humanas, entre outras².

Considerando a variedade de formações que atuam na extensão rural, a Coordenação de Formação do DATER não restringe seus cursos a determinados campos do saber. Algumas formações realizadas, no entanto, foram direcionadas a profissionais de nível superior, como foi o caso dos Cursos de Especialização e os Cursos de Aperfeiçoamento em Agroecologia a distância.

Gráfico 10 - Perfil dos questionários a nível nacional - escolaridade

\section{Perfil dos dos Agentes de ATER formados - escolaridade}

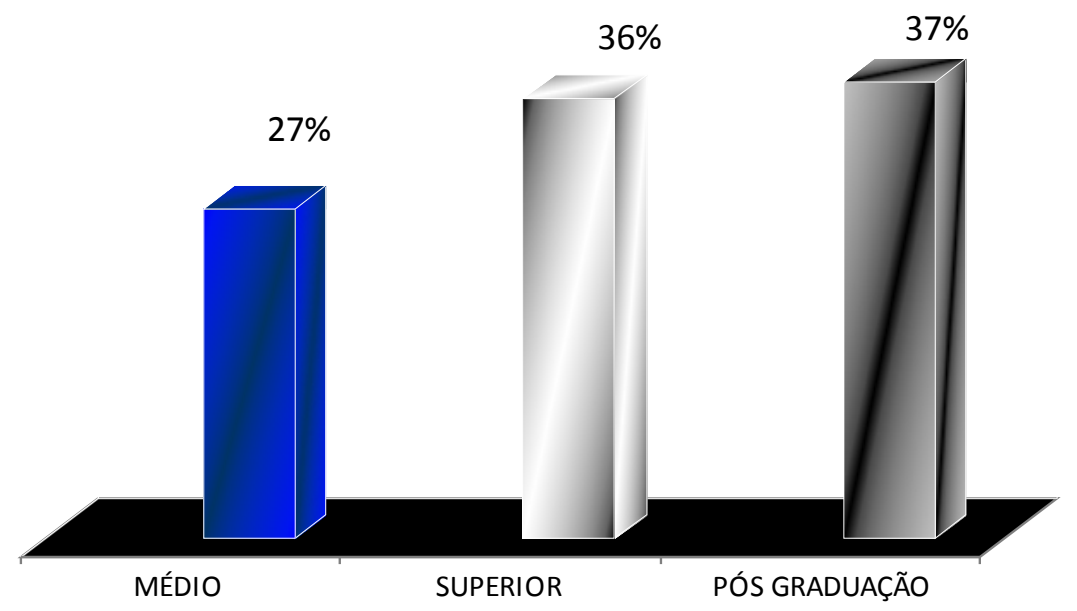

Fonte: questionários recebidos

\footnotetext{
${ }^{2}$ Informações colhidas em editais de concursos das Empresas de Assistência Técnica e Extensão Rural do Pará, do Rio Grande do Sul, Espírito Santo e Minas Gerais, considerando apenas cargos para vagas de extensionistas rurais ou cargos similares.
} 
Pelos dados apresentados no gráfico acima se percebe que $73 \%$ (setenta e três por cento) dos Agentes de ATER que participaram das atividades de formação promovidas pela Coordenação de Formação do DATER possuem nível superior e número considerável dos mesmos possui pós-graduação, o que pode ser considerado um indicador de qualidade dos serviços prestados.

Ao se estratificar os dados por região percebe-se que essa análise reflete a realidade de quatro regiões brasileiras: Sul, Sudeste, Centro-Oeste e Nordeste, mas não a realidade da região Norte, onde $48 \%$ dos Agentes formados informaram possuir apenas nível médio.

Gráfico 11 - Perfil dos questionários analisados por região - escolaridade

Perfil dos Agentes de ATER formados - escolaridade

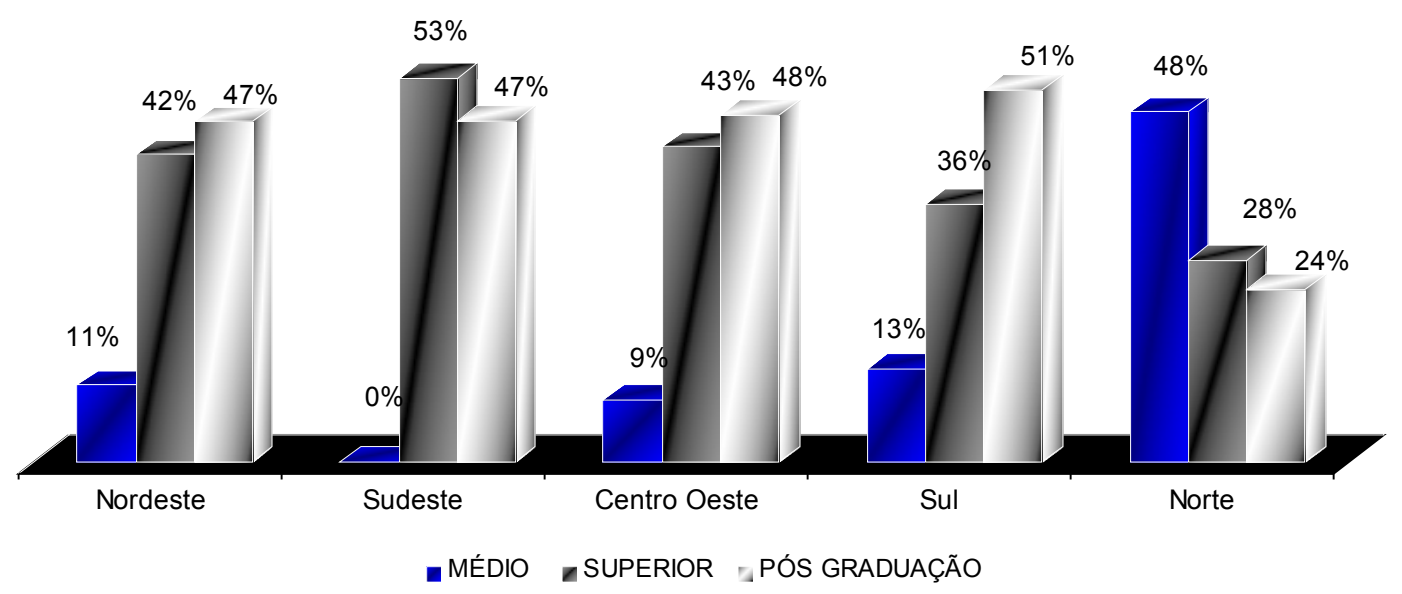

Fonte: questionários recebidos

Essa análise é importante na medida em que as ações de formação devem ser planejadas considerando-se o público a que se destinam, de forma a apresentar conteúdos, linguagem e ferramentas de construção de conhecimento adequadas ao perfil cognitivo dos mesmos.

c) Instituições a que estão vinculados

Com relação ao perfil das instituições de origem desses técnicos, do total de 390 questionários recebidos, 298 pertencem às instituições estaduais de ATER, 38 pertencem a organizações não governamentais e 54 pertencem a sindicatos, 
prefeituras, associações e outras instituições prestadoras de serviços de assistência técnica.

Gráfico 12 - Perfil dos questionários analisados a nível nacional - instituição de origem

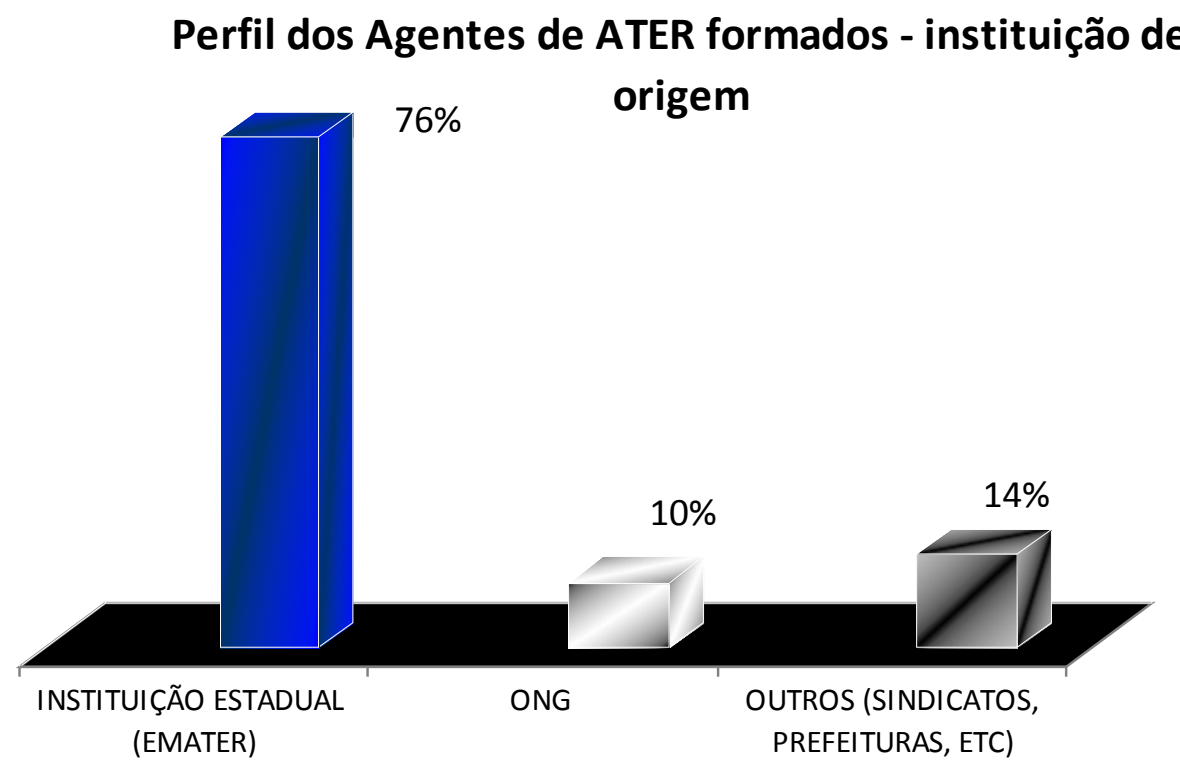

Fonte: questionários recebidos

Esse panorama reflete a realidade presente nos estados, considerando-se que a maior parte do capital humano atuante nos serviços de assistência técnica e extensão rural pertencem aos quadros das instituições estaduais de ATER. Segundo dados da Associação Brasileira das Entidades Estaduais de Assistência Técnica e Extensão Rural - ASBRAER, em 2008, haviam 26.871 profissionais vinculados às suas associadas prestando serviços de ATER.

\subsection{Indicadores de Avaliação}

\subsubsection{Eficácia das ações de formação promovidas}

Conforme já discutido, a eficácia das políticas públicas está relacionada aos "esforços das ações governamentais ou de uma organização para ofertar adequadamente os bens e serviços esperados, previamente definidos em seus objetivos". Segundo os dados coletados junto à Coordenação de Formação do 
DATER/SAF/MDA, os objetivos estabelecidos para essa ação governamental foram os seguintes:

a) Formar Agentes de ATER que atuam junto aos Agricultores Familiares: dessa forma, o público alvo prioritário das ações promovidas deve estar diretamente envolvido em atividades de extensão, preferencialmente atuando a campo e não em atividades administrativas;

b) Promover a articulação da Ater com as instituições de ensino e de pesquisa;

c) Formar Agentes de ATER em temas priorizados pela Política Nacional de Assistência Técnica e Extensão Rural - Pnater;

d) Promover a construção e o compartilhamento de novos conhecimentos: além da realização direta de ações de formação pelo DATER/SAF/MDA, esperavase que os participantes dessas atividades atuassem como formadores/ multiplicadores de conhecimento junto a outros técnicos, de forma a se estabelecer uma rede de troca experiências, potencializando as ações realizadas;

e) Qualificar os serviços prestados aos agricultores por meio da aplicação dos conhecimentos compartilhados nas atividades de formação

A partir dos objetivos identificados estabeleceram-se os seguintes indicadores de eficácia para essa política:

Tabela 9 - Indicadores de eficácia

Item a ser avaliado

\begin{tabular}{|l|l|}
\hline & a) Adequação do público formado; \\
b) Adequação dos conteúdos das formações às \\
Eficácia & orientações da Pnater; \\
& c) Aplicação dos conteúdos pelos técnicos \\
& formados em suas atividades profissionais; \\
d) Apoio a atividades de formação; \\
e) Atuação dos técnicos como formadores/ \\
multiplicadores.
\end{tabular}

\section{Indicador}

Fonte: Elaboração própria

\subsubsection{Adequação do público formado}

Com relação à área de atuação dos profissionais formados pelo DATER identificou-se através dos questionários analisados que 92\% (noventa e dois por cento) dos mesmos trabalham diretamente com extensão rural, $7 \%$ (sete por cento) 
trabalham na área de pesquisa, 5\% (cinco por cento) na área de ensino e 6\% (seis por cento) em outras áreas não identificadas. Observa-se também que 10\% dos agentes de ATER que responderam ao questionário atuam em mais de uma área.

Gráfico 13 - Perfil dos questionários analisados a nível nacional - área de atuação

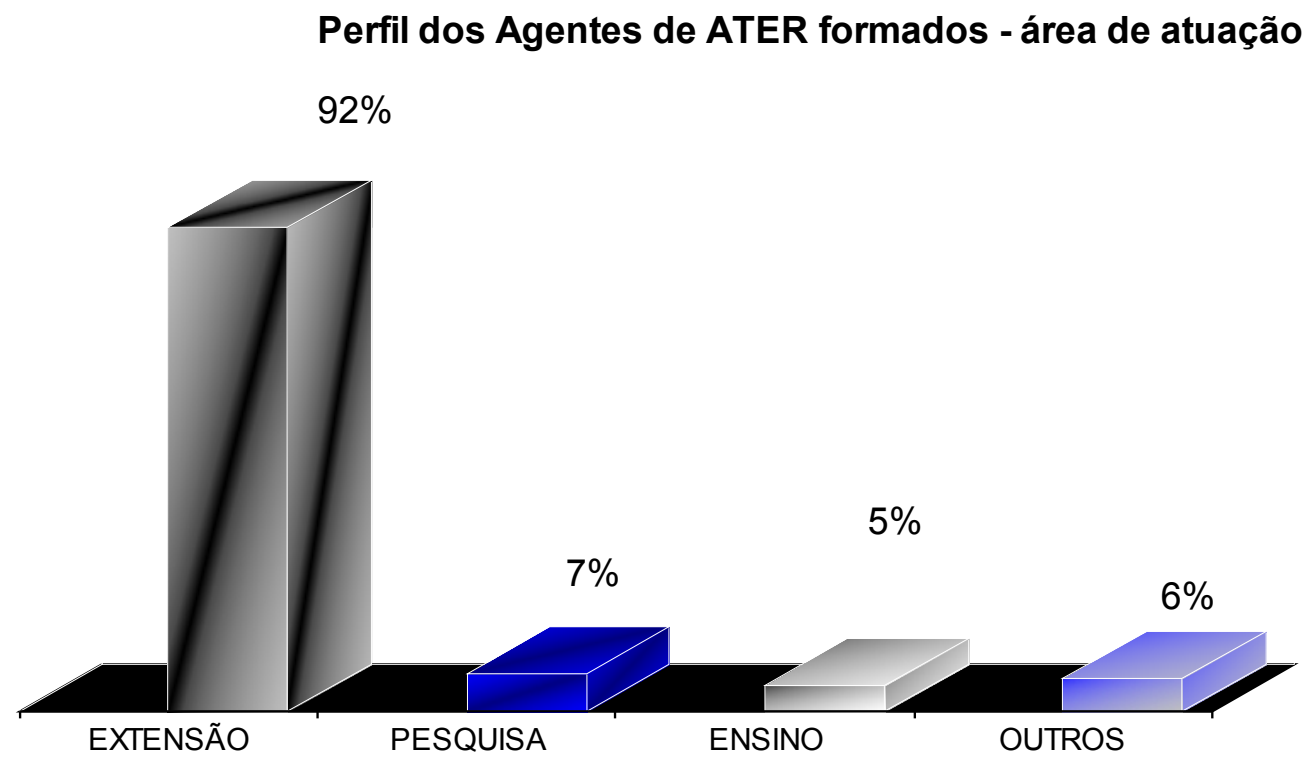

Fonte: questionários recebidos

Pelos dados apresentados, conclui-se que esse item corresponde aos objetivos estabelecidos para essa ação governamental, uma vez que não se verifica desvio do público beneficiário da mesma, a nível nacional.

Outro aspecto relevante diz respeito a participação de profissionais que atuam na área de pesquisa e ensino nas atividades de formação realizadas, o que em certa medida pode contribuir para uma maior interação entre essas áreas e a extensão, levando a definição de linhas de pesquisa de tecnologias apropriadas à agricultura familiar, conforme recomenda a Pnater. Ademais, sabe-se que muitos profissionais de pesquisa e do ensino também atuam na área da extensão, especialmente àqueles vinculados às Organizações Estaduais de Pesquisa Agropecuária - OEPAS e à extensão universitária.

$\mathrm{Na}$ análise regionalizada percebe-se que nas regiões Norte, Nordeste, Sudeste e Sul acima de $80 \%$ (oitenta por cento) dos agentes formados atuam diretamente na extensão rural, enquanto que na região Centro Oeste identifica-se uma maior participação da pesquisa e do ensino: 26\% (vinte e seis por cento), cada. 
Gráfico 14 - Perfil dos questionários analisados por região - área de atuação

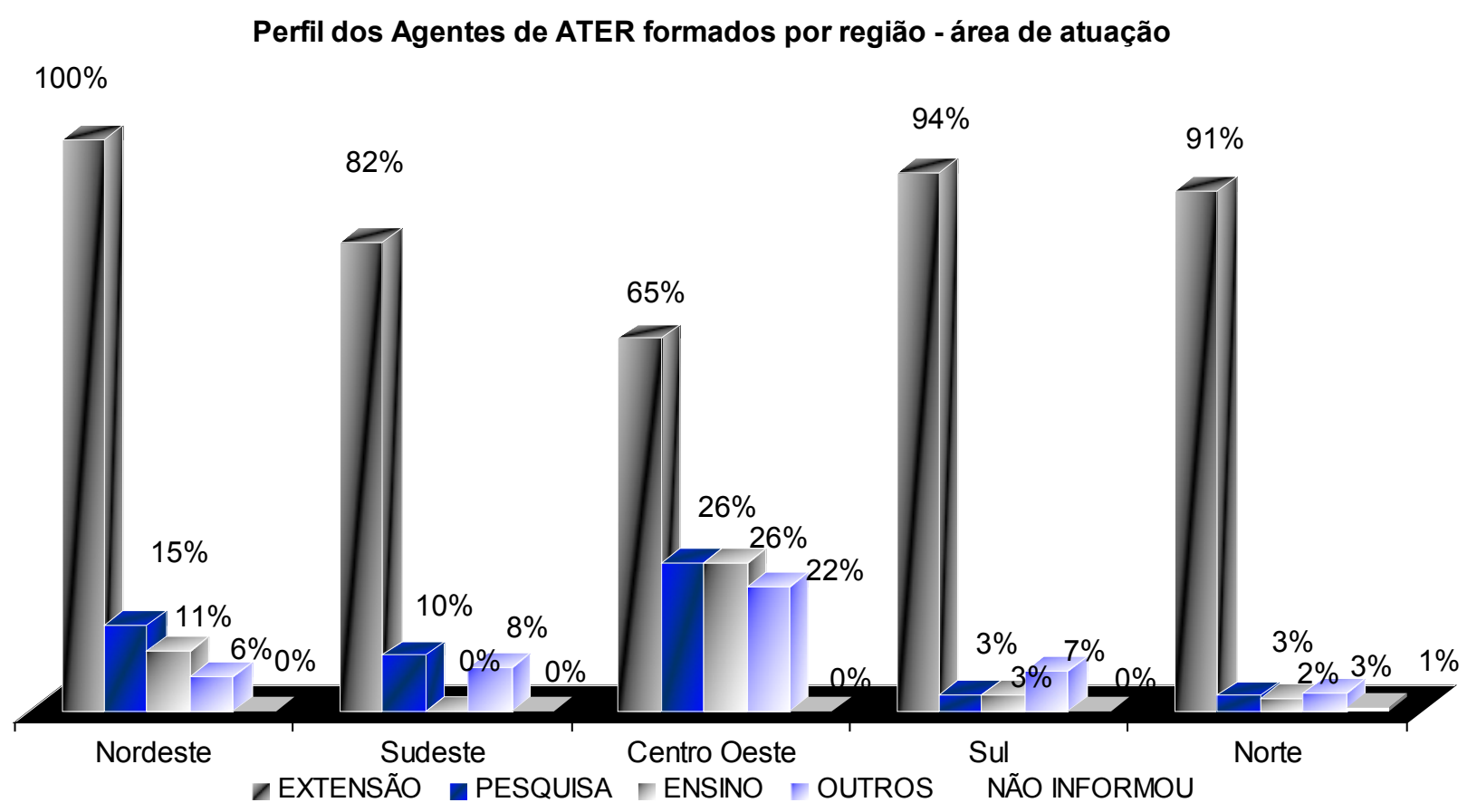

Fonte: questionários recebidos

\subsubsection{Adequação dos conteúdos das formações às orientações da Política Nacional de ATER}

Pela análise da tabela abaixo, verifica-se que no período entre 2004 e 2005 as ações de formação concentraram-se nitidamente no esforço de promover um amplo nivelamento conceitual sobre a própria Política Nacional de Assistência Técnica e Extensão Rural: no ano de 2004, das 17 atividades de formação realizadas, 08 foram referentes ao nivelamento conceitual sobre a Pnater e em 2005, das 162 atividades realizadas, 135 abordaram esse tema. A partir de 2006 ocorreu uma reorientação de esforços e as ações de formação passaram a se concentrar em temas conceituais.

Identifica-se também que $99 \%$ as atividades realizadas encontram-se relacionadas a um macrotema priorizado pela Pnater ou pela demanda apresentada pelos próprios técnicos, estando portanto coerentes com as metas estabelecidas 
para essa política. A única exceção foi a Oficina de Sistematização de Experiências realizada em 2009 . 
Tabela 10 - Eventos realizados X Temas da PNATER X Demandas apresentadas

\begin{tabular}{|c|c|c|c|c|c|c|c|}
\hline Ano & Tipologia & $\begin{array}{c}\text { Macrotema identificado pela } \\
\text { PNATER }\end{array}$ & Tema demandado pelos técnicos & Eventos realizados & $\begin{array}{c}\mathrm{n}^{\circ} \text { de } \\
\text { eventos }\end{array}$ & \begin{tabular}{|c|}
$\mathbf{n}^{\circ}$ de \\
participantes
\end{tabular} & $\begin{array}{l}\text { Carga } \\
\text { horária }\end{array}$ \\
\hline \multirow{9}{*}{2004} & Oficina & Nivelamento Conceitual & $\begin{array}{c}\text { A nova Pnater e o perfil desejável } \\
\text { do extensionista rural }\end{array}$ & Oficina de Nivelamento Conceitual sobre a PNATER & 8 & 289 & 40 \\
\hline & Curso & $\begin{array}{l}\text { Agroecologia/ Produção de Base } \\
\text { Ecológica }\end{array}$ & Agroecologia & Curso Bases Agroecológicas da Agricultura Sustentável & 2 & 100 & 40 \\
\hline & Curso & $\begin{array}{c}\text { ATER com públicos específicos } \\
\text { (Indígenas, Quilombolas, Pescadores } \\
\text { Artesanais) }\end{array}$ & & $\begin{array}{l}\text { Curso de Agentes de ATER que atuam com } \\
\text { Comunidades Indígenas }\end{array}$ & 1 & 41 & 40 \\
\hline & Curso & $\begin{array}{c}\text { Agroecologia/ Produção de Base } \\
\text { Ecológica }\end{array}$ & Agroecologia & $\begin{array}{c}\text { Curso de Agroecologia Manejo Sustentável dos } \\
\text { Agroecossistemas das Regiões Brasileiras Produtoras } \\
\text { de Cacau }\end{array}$ & 1 & 80 & 40 \\
\hline & Oficina & $\begin{array}{c}\text { ATER com públicos específicos } \\
\text { (Indígenas, Quilombolas, Pescadores } \\
\text { Artesanais) }\end{array}$ & Assistência e Extensão Pesqueira & $\begin{array}{c}\text { Oficina de Agentes de Ater que atuam com pescadores } \\
\text { artesanais e aqüicultores familiares }\end{array}$ & 2 & 74 & 40 \\
\hline & Seminário & Nivelamento Conceitual & $\begin{array}{c}\text { A nova Pnater e o perfil desejável } \\
\text { do extensionista rural }\end{array}$ & $\begin{array}{c}\text { Seminário Nacional de Assistência Técnica e Extensão } \\
\text { Rural }\end{array}$ & 1 & 178 & 16 \\
\hline & $\begin{array}{c}\text { Vídeo } \\
\text { Conferência }\end{array}$ & $\begin{array}{l}\text { Agroecologia/ Produção de Base } \\
\text { Ecológica }\end{array}$ & Agroecologia & Vídeo Conferência sobre Agroecologia & 1 & 223 & 8 \\
\hline & \multirow[t]{2}{*}{ Seminário } & $\begin{array}{l}\text { Agroecologia/ Produção de Base } \\
\text { Ecológica }\end{array}$ & Agroecologia & $\begin{array}{c}\text { Seminário Agroecologia como Enfoque Científico para o } \\
\text { Desenvolvimento Rural Sustentável }\end{array}$ & 1 & 152 & 8 \\
\hline & & & & Total 2004 & 17 & 1137 & \\
\hline
\end{tabular}

(Continua) 


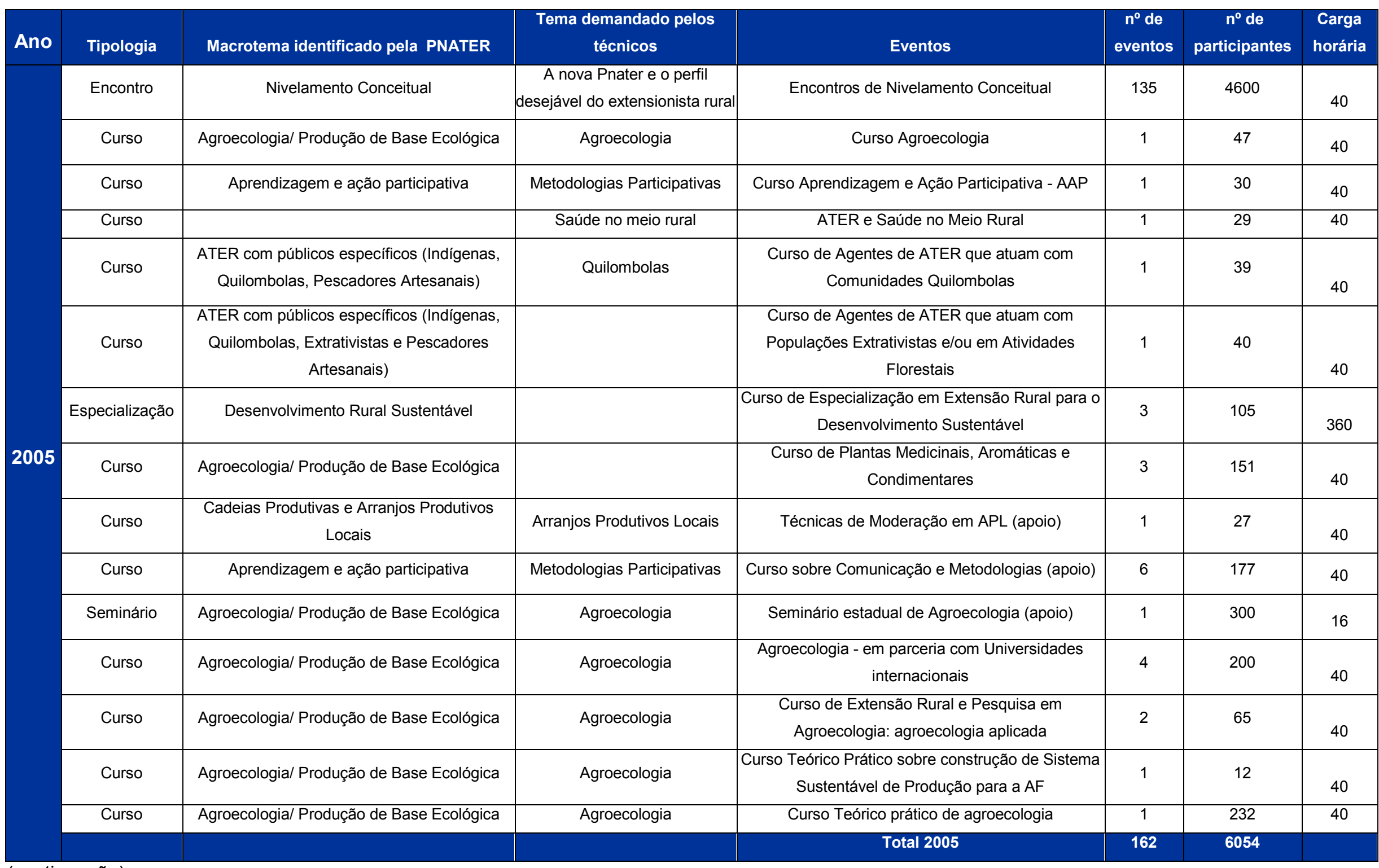

(continuação) 


\begin{tabular}{|c|c|c|c|c|c|c|}
\hline Ano Tipologia & Macrotema identificado pela PNATER & $\begin{array}{l}\text { Tema demandado pelos } \\
\text { técnicos }\end{array}$ & Eventos & $\begin{array}{l}\mathrm{n}^{0} \text { de } \\
\text { eventos }\end{array}$ & $\begin{array}{c}\mathrm{n}^{\circ} \text { de } \\
\text { participantes }\end{array}$ & $\begin{array}{l}\text { Carga } \\
\text { horária }\end{array}$ \\
\hline Curso & Agroecologia/ Produção de Base Ecológica & Agroecologia & Agroecologia e Produção de Base Ecológica & 2 & 75 & 40 \\
\hline Curso & $\begin{array}{l}\text { ATER com públicos específicos (Indígenas, } \\
\text { Quilombolas, Pescadores Artesanais) }\end{array}$ & Assistência e Extensão Pesqueira & Pesca Artesanal e Aquícultura & 2 & 64 & 40 \\
\hline Curso & Agroecologia/ Produção de Base Ecológica & $\begin{array}{c}\text { Agroecologia/ Produção de Base } \\
\text { Ecológica }\end{array}$ & Sistemas Agroflorestais (Caatinga e Mata Atlântica) & 2 & 66 & 40 \\
\hline Curso & Aprendizagem e ação participativa & Metodologias Participativas & Metodologias Participativas - $40 \mathrm{~h}$ (DRP) & 6 & 188 & 40 \\
\hline Curso & Aprendizagem e ação participativa & Metodologias Participativas & Metodologias Participativas - $80 \mathrm{~h}$ & 1 & 40 & 80 \\
\hline Curso & Agroecologia/ Produção de Base Ecológica & & Pecuária Ecológica & 1 & 38 & 40 \\
\hline specialização & Desenvolvimento Rural Sustentável & & $\begin{array}{c}\text { Curso de Especialização em Extensão Rural para o } \\
\text { Desenvolvimento Sustentável (apoio) }\end{array}$ & 1 & 60 & 360 \\
\hline Curso & Desenvolvimento Rural Sustentável & & $\begin{array}{c}\text { Cursos para agentes de desenvolvimento rural em } \\
\text { parceria com o BB - ADR }\end{array}$ & 4 & 564 & 40 \\
\hline & & Total 2006 & & 19 & 1095 & \\
\hline Alternância & Agroecologia/ Produção de Base Ecológica & $\begin{array}{c}\text { Agroecologia/ Produção de Base } \\
\text { Ecológica }\end{array}$ & Sistemas Agroflorestais (Cerrado - 135 h) & 1 & 40 & 135 \\
\hline Curso & Agroecologia/ Produção de Base Ecológica & Agroecologia & Agroecologia & 1 & 40 & 40 \\
\hline Curso & & Gestão e Políticas Públicas & Políticas da SAF & 1 & 40 & 40 \\
\hline Curso & $\begin{array}{l}\text { Cadeias Produtivas e Arranjos Produtivos } \\
\text { Locais }\end{array}$ & & Manejo de Trilhas & 1 & 40 & 40 \\
\hline A distância & Agroecologia/ Produção de Base Ecológica & Agroecologia & Agroecologia a distância & 2 & 1080 & 40 \\
\hline pecialização & Desenvolvimento Rural Sustentável & & $\begin{array}{c}\text { Curso de Especialização em Extensão Rural para o } \\
\text { Desenvolvimento Rural Sustentável (apoio) }\end{array}$ & 1 & 40 & 360 \\
\hline & & Total 2007 & & 7 & 1280 & \\
\hline
\end{tabular}

(continuação) 


\begin{tabular}{|c|c|c|c|c|c|c|c|}
\hline Ano & Tipologia & Macrotema identificado pela PNATER & Tema demandado pelos técnicos & Eventos & $\begin{array}{l}\mathrm{n}^{0} \text { de } \\
\text { eventos }\end{array}$ & $\begin{array}{c}\mathrm{n}^{0} \text { de } \\
\text { participantes }\end{array}$ & Carga horária \\
\hline \multirow{14}{*}{2008} & Seminário & Segurança Alimentar e Nutricional. & Segurança alimentar e nutricional & $\begin{array}{l}\text { Seminário Nivelamento Conceitual sobre } \\
\text { Segurança Alimentar e Nutricional no âmbito da } \\
\text { Assistência Técnica e Extensão Rural }\end{array}$ & 1 & 74 & 4 \\
\hline & Curso & Economia Solidária & & Mini Curso de Economia Ecológica & 1 & 25 & 24 \\
\hline & Oficina & & & $\begin{array}{l}\text { Oficina de Sistematização de Experiências (Rede } \\
\text { de Agroecologia) }\end{array}$ & 1 & 25 & 16 \\
\hline & Alternância & Agroecologia/ Produção de Base Ecológica & & $\begin{array}{c}\text { Curso de aperfeiçoamento por alternância em } \\
\text { Agroecologia na Região Norte }\end{array}$ & 1 & 100 & 120 \\
\hline & Curso & Agroecologia/ Produção de Base Ecológica & & $\begin{array}{c}\text { Agroecologia e Produção Agrícola e Pecuária de } \\
\text { Base Ecológica }\end{array}$ & 4 & 140 & 80 \\
\hline & Curso & Aprendizagem e ação participativa & Metodologias Participativas & Aprendizagem e Ação Participativa - AAP & 4 & 120 & 80 \\
\hline & Curso & $\begin{array}{c}\text { ATER com públicos especificos (Indígenas, } \\
\text { Quilombolas, Pescadores Artesanais) }\end{array}$ & Assistência e Extensão Pesqueira & Ater com Pescadores Artesanais e Aqüicultores & 3 & 105 & 80 \\
\hline & Curso & Agroecologia/ Produção de Base Ecológica & Sistemas Agroflorestais & Sistemas Agroflorestais & 4 & 140 & 80 \\
\hline & Curso & $\begin{array}{c}\text { ATER com públicos específicos (Indígenas, } \\
\text { Quilombolas, Pescadores Artesanais) }\end{array}$ & Ater com indígenas & Ater com Comunidades Indígenas & 2 & 80 & 80 \\
\hline & Curso & $\begin{array}{c}\text { ATER com públicos especificos (Indigenas, } \\
\text { Quilombolas, Pescadores Artesanais) }\end{array}$ & & Ater com Comunidades Quilombolas & 4 & 160 & 80 \\
\hline & Curso & $\begin{array}{c}\text { Cadeias Produtivas e Arranjos Produtivos } \\
\text { Locais }\end{array}$ & Comercialização e abastecimento & Cadeias Produtivas e Arranjos Produtivos Locais & 4 & 140 & 80 \\
\hline & Curso & & Gestão e Políticas Públicas & $\begin{array}{c}\text { Curso de Formação de Formadores do Projeto } \\
\text { Cultivando Saberes }\end{array}$ & 1 & 27 & 80 \\
\hline & Curso & & $\begin{array}{c}\text { Políticas de crédito e financiamento } \\
\text { da produção }\end{array}$ & Curso de ATER no Pronaf $B$ & 13 & 558 & 24 \\
\hline & & & Total 2008 & & 43 & 1694 & \\
\hline
\end{tabular}

(continuação) 


\begin{tabular}{|c|c|c|c|c|c|c|c|}
\hline \multirow[t]{3}{*}{ Ano } & Tipologia & $\begin{array}{c}\text { Macrotema identificado pela } \\
\text { PNATER }\end{array}$ & Tema demandado pelos técnicos & Eventos & $\begin{array}{c}\mathrm{n}^{\circ} \text { de } \\
\text { eventos }\end{array}$ & $\begin{array}{c}\mathrm{n}^{0} \text { de } \\
\text { participantes }\end{array}$ & $\begin{array}{c}\text { Carga } \\
\text { horária }\end{array}$ \\
\hline & Curso & & Gestão e Políticas Públicas & $\begin{array}{l}\text { Curso de Formação de Formadores do Projeto } \\
\text { Cultivando Saberes }\end{array}$ & 1 & 25 & 80 \\
\hline & Curso & & $\begin{array}{l}\text { Políticas de crédito e financiamento } \\
\text { da produção }\end{array}$ & Curso sobre o Pronaf Sistêmico & 4 & 135 & 80 \\
\hline \multirow[t]{5}{*}{2009} & Curso & & Gestão e Políticas Públicas & $\begin{array}{l}\text { Qualificação em Políticas Públicas de Apoio a } \\
\text { Diversificação em Municípios Fumicultores }\end{array}$ & 3 & 139 & 24 \\
\hline & Curso & & Gestão e Políticas Públicas & $\begin{array}{c}\text { Curso de Formação de Formadores para enfrentamento } \\
\text { das Gripes Suina, Equina e Aviária }\end{array}$ & 2 & 89 & 40 \\
\hline & Curso & & $\begin{array}{l}\text { Políticas de crédito e financiamento } \\
\text { da produção }\end{array}$ & Curso de ATER no Pronaf B & 9 & 545 & 24 \\
\hline & & & Total 2009 & & 19 & 933 & \\
\hline & & & Total Geral - 2004 a 2009 & & 267 & 12193 & \\
\hline
\end{tabular}

Fonte: Coordenação de Formação do DATER (concluído) 
Verifica-se também, pela tabela abaixo que dentre os temas conceituais abordados nas formações nos últimos seis anos os que mais se destacam são Agroecologia/Agriculturas de Ecológica e Políticas Públicas voltadas para a Agricultura Familiar.

Tabela 11 - Número de eventos realizados por macrotema

\begin{tabular}{|c|c|}
\hline Macrotema & Número de Eventos \\
\hline Agroecologia/ Produção de Base Ecológica & 36 \\
\hline ATER com públicos específicos (Indígenas, Quilombolas, Pescadores Artesanais) & 16 \\
\hline Aprendizagem e ação participativa & 18 \\
\hline Políticas Públicas & 9 \\
\hline Desenvolvimento Rural Sustentável & 6 \\
\hline Cadeias Produtivas e Arranjos Produtivos Locais & 1 \\
\hline Segurança Alimentar e Nutricional & 1 \\
\hline Economia Solidária & $122^{3}$ \\
\hline TOTAL & 9 \\
\hline
\end{tabular}

Fonte: Coordenação de Formação do DATER

\section{Tipologias de atividades realizadas}

A diversidade de ações realizadas deve buscar a qualificação da atuação dos profissionais de ATER, bem como formar multiplicadores em diversos temas. As ações planejadas pelo DATER/SAF/MDA foram executadas através das seguintes tipologias de eventos:

a) Cursos de Especialização: cursos de 360 horas destinados a técnicos de nível superior. Foram realizados cinco cursos mediante acordos com universidades e instituições públicas estatais de ATER.

Para a Coordenação de Formação do DATER os cursos de especialização correspondem a:

atividade coletiva, de caráter educativo, com duração mínima de 360 horas. São direcionadas a profissionais de nível superior que atendam às exigências das instituições de ensino. Deve proporcionar a ampliação, aprofundamento, desenvolvimento de conhecimentos teóricos e propiciar uma reflexão críticoteórico da prática extensionista, levando em consideração a complexidade e diversidade da agricultura familiar. Seu conteúdo deve estar em consonância

${ }^{3}$ Do total de atividades realizadas 122 foram conceituais, 144 de nivelamento conceitual e 1 não se encaixou em nenhum macrotema 
com as diretrizes da PNATER. Sua realização deve incorporar atividades didático-pedagógicas e dialogar com os conhecimentos e experiências do público participante. Pode ser realizado em uma única etapa ou em forma modular, utilizando metodologia de alternância, combinando atividades presenciais, semi-presenciais ou a distância. Deve ser realizada por instituições de ensino superior e por entidades credenciadas que atendam as normas legais do Ministério da Educação e Cultura. As atividades podem ser realizadas em parceria com organizações e instituições de ATER. As turmas devem ter no mínimo 30 e no máximo 40 participantes. (DATER, 2009).

b) Cursos em Regime de Alternância: consistem em atividades de formação com módulos presenciais, entremeados por atividades de campo e/ou interatividade via internet. Foram realizados dois cursos voltados para técnicos de nível médio e superior que atendessem aos requisitos estabelecidos (disponibilidade de acesso à Internet, habilidade para comunicação virtual, entre outras). Esse tipo de atividade teve como objetivo integrar os conteúdos aplicados presencialmente à realidade vivenciada pelos técnicos em sua dinâmica de trabalho. Os cursos tiveram carga horária de 120 horas e 135 horas respectivamente.

c) Cursos de Aperfeiçoamento (Curta e Média duração): foram realizados cursos de 40 a 88 horas, presenciais, destinados a formar técnicos de nível médio ou superior em temas específicos. Segundo a Coordenação de Formação do DATER o curso de aperfeiçoamento corresponde a uma:

atividade coletiva, de caráter educativo, de curta ou média duração (de 40 até 360 horas) para profissionais de nível técnico ou superior atuantes nos serviços de extensão rural, visando adquirir, ampliar, aprofundar, refletir e desenvolver conhecimentos teóricos e práticos da extensão rural, da reforma agrária e da complexidade e diversidade da agricultura familiar. Seu conteúdo deve estar em consonância com as diretrizes da PNATER. Sua realização deve incorporar atividades didático-pedagógicas e dialogar com os conhecimentos e experiências do público participante. Sua realização poderá ser efetuada por instituições de educação formal e não-formal. (DATER, 2009)

d) Cursos a distância: $O$ diferencial dessa modalidade de formação se encontra essencialmente na possibilidade de beneficiar um grande número de técnicos com um recurso relativamente reduzido, bem como possibilitar a participação dos beneficiários sem que os mesmos se ausentassem do ambiente de trabalho. Foram realizados cursos de 130 e 250 horas, a distância, para a formação de Agentes de Ater de nível médio e superior, com o objetivo de favoreceram a "construção de conhecimentos, habilidades e atitudes necessárias, de forma a contribuírem com os agricultores familiares na implementação de práticas agroecológicas e para atuarem junto às organizações governamentais e não 
governamentais na assessoria e na formulação de políticas públicas". (DATER, 2008)

e) Seminários, encontros, congressos, oficinas, vídeo conferências e outros: nesse período foram apoiados também eventos de troca de experiências e de conhecimentos técnico-científicos, entre técnicos, estudantes, pesquisadores e agricultores. Estes eventos apresentaram carga horária mais restrita e um público geralmente maior.

Tabela 12 - Estratégias de formação, número de eventos e número de Agentes de ATER capacitados

\begin{tabular}{|l|c|c|}
\hline \multicolumn{1}{|c|}{ Estratégias de Formação } & $\begin{array}{c}\text { Número de } \\
\text { eventos }\end{array}$ & $\begin{array}{c}\text { No. de Agentes de } \\
\text { ATER capacitados }\end{array}$ \\
\hline Cursos de Especialização & 5 & 205 \\
\hline Cursos em Regime de Alternância & 2 & 140 \\
\hline Cursos de Curta e Média duração & 107 & 4853 \\
\hline Cursos a distância & 2 & 1080 \\
\hline Seminários & 3 & 526 \\
\hline Oficinas & 11 & 388 \\
\hline Vídeo Conferência & 1 & 223 \\
\hline Conferência & 1 & 178 \\
\hline Encontro & 135 & 12.193 \\
\hline
\end{tabular}

Fonte: Coordenação de Formação do DATER

Considerando-se a diversidade de temas abordados bem como a multiplicidade de tipologias adotadas, conclui-se que esse item corresponde aos objetivos estabelecidos para essa ação governamental.

\subsubsection{Aplicação dos conteúdos pelos técnicos formados em suas atividades profissionais}


O terceiro indicador de eficácia diz respeito ao índice de aplicabilidade dos conteúdos a campo pelos técnicos formados. Essa aplicabilidade depende de fatores tais como adequação dos conteúdos abordados às reais necessidades identificadas pelos agentes a campo, do aprofundamento dos temas de modo que o técnico se sinta suficientemente seguro a respeito do conhecimento adquirido/reconstruído para incorporá-lo a sua prática, do apoio e incentivo recebido pelo técnico em sua instituição, da sensibilidade do mesmo ao tema abordado e da disponibilidade em adotar esse conhecimento em seu trabalho cotidiano. Dependem ainda da realidade, necessidades, prioridades e demandas das famílias agricultoras com que os técnicos estejam trabalhando em determinado momento.

Dos 390 questionários recebidos, 343 agentes afirmaram estar aplicando os conhecimentos adquiridos/reconstruídos em sua prática cotidiana, o que corresponde a $88 \%$ do universo pesquisado.

Gráfico 15 - Aplicação dos conhecimentos a campo

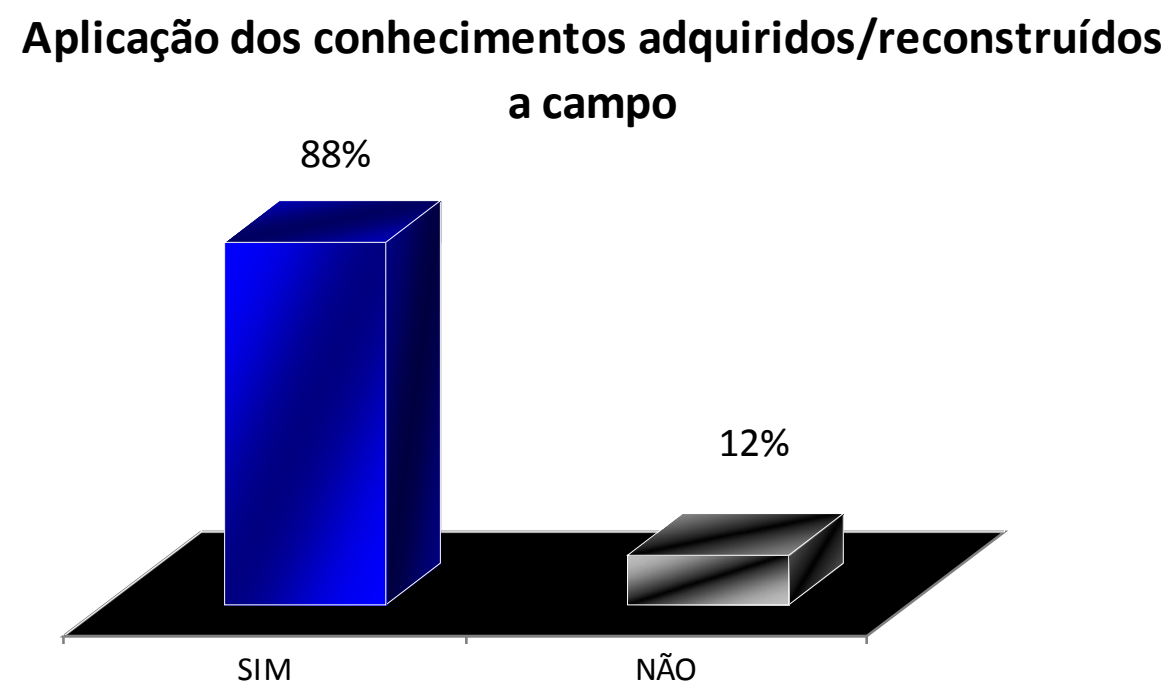

Fonte: questionários recebidos

Dentre o total de agentes que afirmaram estar aplicando os conhecimentos a campo, foi solicitado que os mesmos indicassem qual o grau dessa aplicação: se muito aplicados, medianamente aplicados ou pouco aplicados. O resultado dessa análise encontra-se no gráfico a seguir: 
Gráfico 16 - Índice de aplicação dos conhecimentos a campo

\section{Grau de aplicabilidade dos conhecimentos adquiridos/reconstruídos}

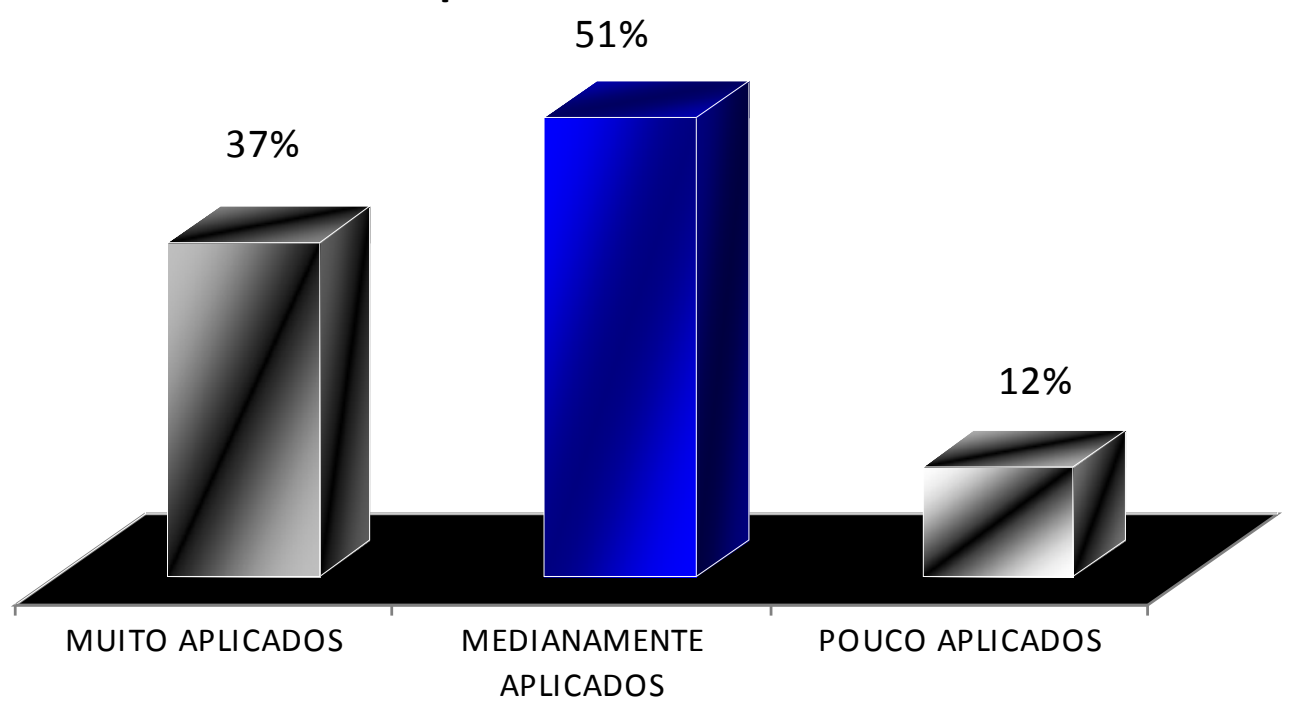

Fonte: questionários recebidos

A aplicabilidade dos conhecimentos adquiridos, reconstruídos ou aperfeiçoados dialoga em grande medida com a adequação dos conteúdos abordados nas formações às necessidades vivenciadas pelos técnicos em seu cotidiano. Nesse sentido o gráfico abaixo demonstra a coerência entre o índice de aplicabilidade identificado e o grau e adequação dos conteúdos apontados pelos técnicos em sua avaliação: $75 \%$ (setenta e cinco por cento) dos técnicos consideraram os conteúdos condizentes com as suas demandas de trabalho junto aos agricultores familiares e $22 \%$ (vinte e dois por cento), os consideraram ao menos parcialmente condizentes com essas demandas. 
Gráfico 17 - Adequação dos conteúdos

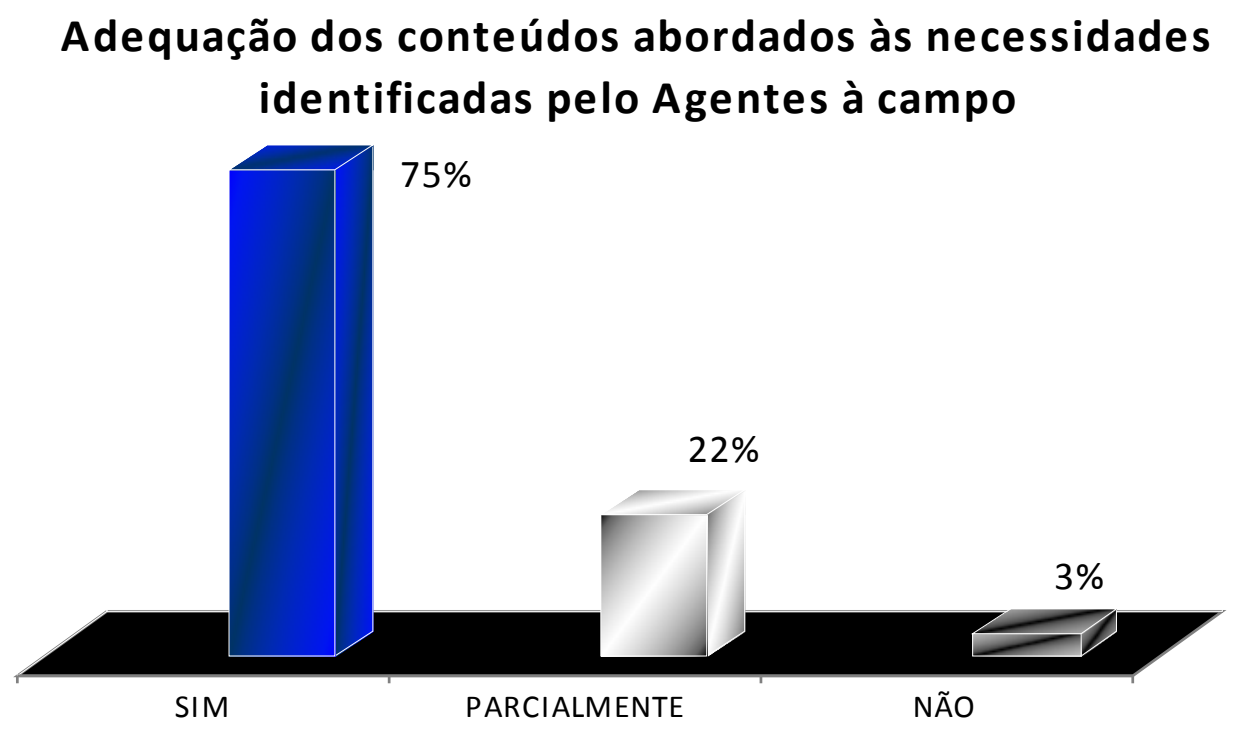

Fonte: questionários recebidos

Por outro lado, aos 47 agentes que responderam não estar aplicando os conhecimentos adquiridos ( $12 \%$ do total participante da pesquisa) foi solicitado que os mesmos apontassem os motivos que levaram a essa não aplicação. Embora o índice dos que apontaram não ter aplicado os conhecimentos tenha sido relativamente baixo, essa análise é importante na medida em que contribui para a correção, por parte dos gestores públicos, dos entraves que levaram a esse panorama. Ressalte-se que algumas das causas apontadas fogem da governança dos gestores responsáveis pela implementação dessa política pública e envolvem outras ações que não um planejamento mais adequado das ações de formação. É o caso, por exemplo, da falta de apoio da instituição a qual o técnico está vinculado, seja com relação ao tema de formação especificamente, seja em função da fragilidade do sistema de ATER como um todo no estado de atuação do técnico.

Dentre os 47 agentes que informaram não terem incorporado os conteúdos a sua prática cotidiana, $10 \%$ (dez por cento) identificaram como a principal causa a incompatibilidade entre os mesmos e a necessidade específica da região em que esses técnicos atuam, 38 \% (trinta e oito por cento) informaram não se sentir adequadamente esclarecidos sobre os temas abordados, uma vez que os conteúdos não foram aprofundados o suficiente para possibilitar uma prática eficaz, 33\% (trinta e três por cento) apontaram a falta de apoio por parte da instituição de origem como 
causa para a não aplicação dos conhecimentos e 19\% (dezenove por cento indicaram a falta de incentivo às ações de Ater como a principal causa.

Gráfico 18 - Razões indicadas para não aplicação dos conteúdos

Razões que levaram a não aplicação dos conhecimentos adquiridos/reconstruídos $38 \%$

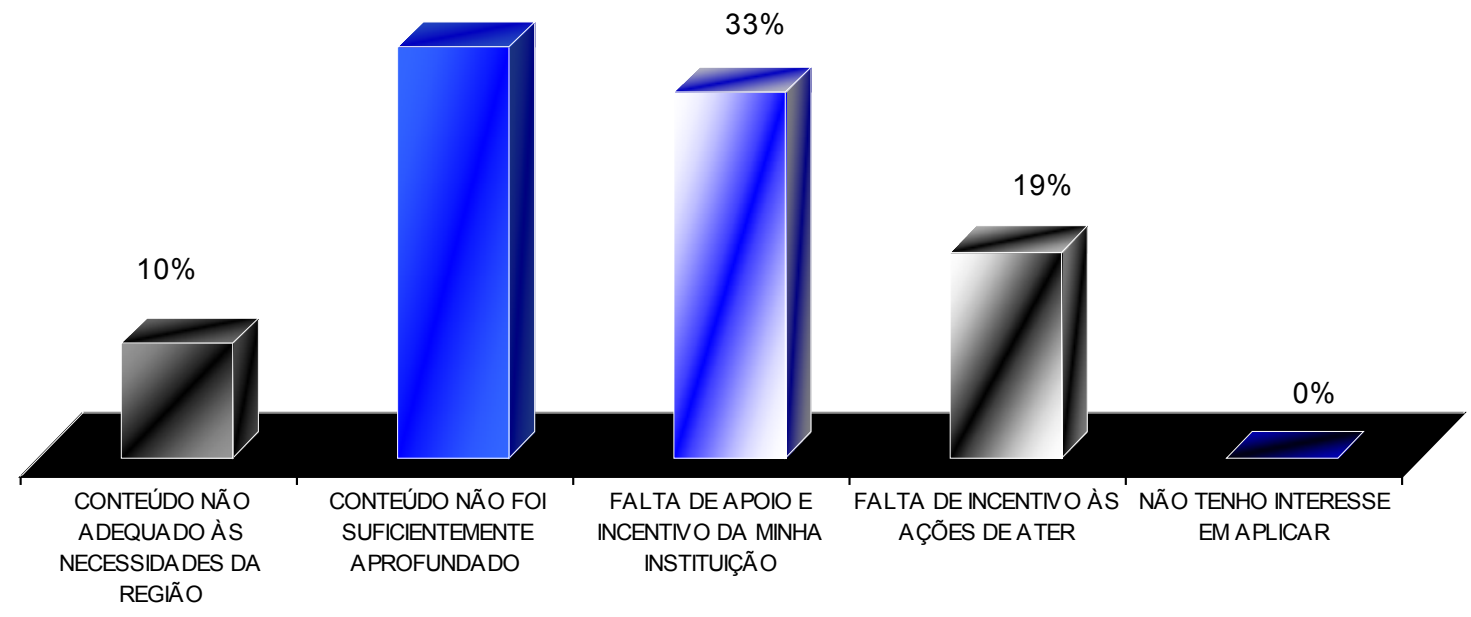

Fonte: questionários recebidos

A sistematização regionalizada dos dados apresentada na tabela a seguir mostra alguns cruzamentos interessantes, na medida em que revela os principais fatores da não aplicabilidade dos novos conhecimentos por região:

Tabela 13 - Fatores relacionados a não aplicação dos conhecimentos - por região

\begin{tabular}{|c|c|c|c|c|c|c|}
\hline \multirow{2}{*}{\multicolumn{2}{|c|}{ INDICADORES }} & \multicolumn{5}{|c|}{ Região } \\
\hline & & Nordeste & Sudeste & $\begin{array}{l}\text { Centro } \\
\text { Oeste }\end{array}$ & Sul & Norte \\
\hline \multirow{5}{*}{$\begin{array}{c}\text { Não aplicação } \\
\text { dos } \\
\text { conhecimentos } \\
\text { às atividades } \\
\text { cotidianas a } \\
\text { campo }\end{array}$} & $\begin{array}{l}\text { Conteúdo não adequado às necessidades da } \\
\text { região }\end{array}$ & $19 \%$ & $25 \%$ & $0 \%$ & $0 \%$ & $7 \%$ \\
\hline & Conteúdo não foi suficientemente aprofundado & $6 \%$ & $50 \%$ & $0 \%$ & $70 \%$ & $53 \%$ \\
\hline & Falta de apoio e incentivo da minha instituição & $50 \%$ & $0 \%$ & $75 \%$ & $30 \%$ & $13 \%$ \\
\hline & Falta de incentivo às ações de ater & $25 \%$ & $25 \%$ & $25 \%$ & $0 \%$ & $20 \%$ \\
\hline & Não tenho interesse em aplicar & $0 \%$ & $0 \%$ & $0 \%$ & $0 \%$ & $0 \%$ \\
\hline PORCENT & GEM TOTAL DE QUESTIONÁ & $100 \%$ & $100 \%$ & $100 \%$ & $100 \%$ & $100 \%$ \\
\hline
\end{tabular}

Fonte: questionários recebidos 
No caso das regiões Nordeste e Centro Oeste as principais causas apontadas referem-se à falta de incentivo por parte da instituição ao tema específico (50 e 75\% respectivamente) e ao pouco incentivo às ações de ATER de uma forma geral.

Por outro lado, nas regiões Norte, Sul e Sudeste, a principal causa apontada refere-se ao nível de aprofundamento do conteúdo, o que indica a necessidade de adequação dos mesmos no momento do planejamento das ações para essas regiões.

De maneira geral, porém, observa-se que as ações de formação executadas nesse período possuem um nível de aplicabilidade de conteúdos elevado, e por conseqüência tem sido eficaz, no que tange a esse indicador.

\subsubsection{Atuação dos técnicos como formadores/multiplicadores;}

Considerando-se o universo de agentes que atuam a campo, o número de ações de formação necessárias para promover uma mudança significativa na postura extensionista excede em muito a capacidade operacional da Coordenação de Formação de Agentes de ATER do DATER/SAF/MDA. Foi a partir dessa realidade que a proposta de formação adotada por essa coordenação, nos últimos seis anos, incluiu entre seus objetivos a formação de formadores/multiplicadores de conhecimento. Por essa razão a atuação dos técnicos como formadores/ multiplicadores foi estabelecida como o quarto indicador de eficácia da política pública de formação.

Para melhor análise, esse indicador foi dividido em duas categorias:

a) o apoio a atividades de formação, aqui entendido como a participação no planejamento (identificação de demandas, elaboração de ementas, seleção de participantes e facilitadores/palestrantes, etc) e realização de cursos, seminários e outras atividades de formação, seja na própria instituição ou em instituições parceiras;

b) a atuação como palestrante/facilitador nos mesmos temas e/ou conteúdos abordados na formação da qual participou.

Com relação ao apoio às atividades de formação, dos 390 questionários recebidos 266 afirmaram ter apoiado atividades de formação, 122 não apoiaram e 2 não informaram. 
Gráfico 19 - Apoio a atividades de formação - percentuais a nível nacional

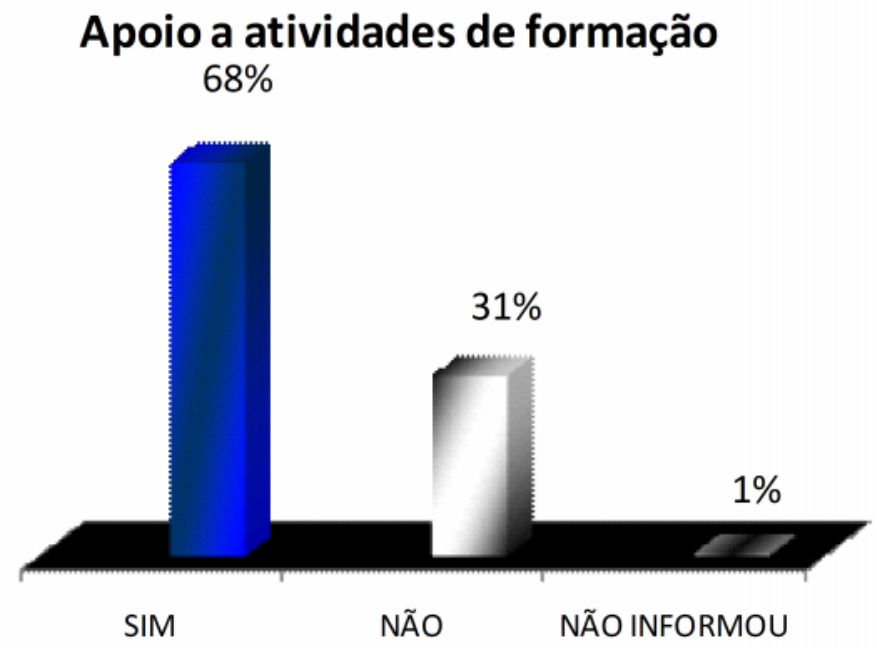

Fonte: questionários recebidos

A análise por região demonstra que as regiões Sul, Sudeste e Centro Oeste apresentam um nível mais elevado de consolidação nesse indicador.

Gráfico 20 - Apoio a atividades de formação - percentuais por região

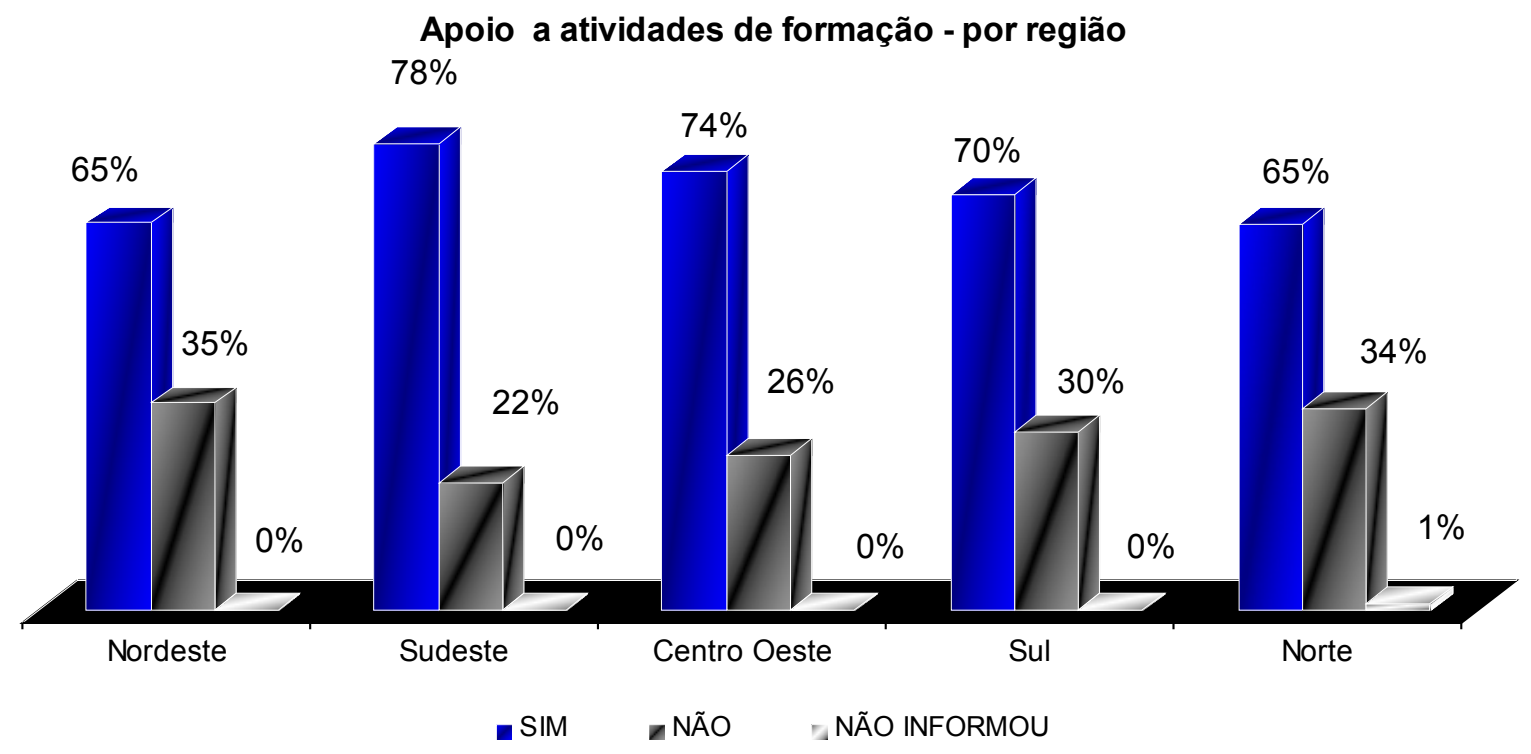

Fonte: questionários recebidos

Com relação à atuação como facilitador/palestrante em atividades com temas relacionados ao curso do qual participaram, dos 390 questionários recebidos 203 
informaram ter ministrado cursos ou outras atividades de formação, 183 não atuaram como multiplicadores e 4 não informaram.

Gráfico 21 - Atuação como multiplicadores - percentuais a nível nacional

Atuação como multiplicadores/facilitadores

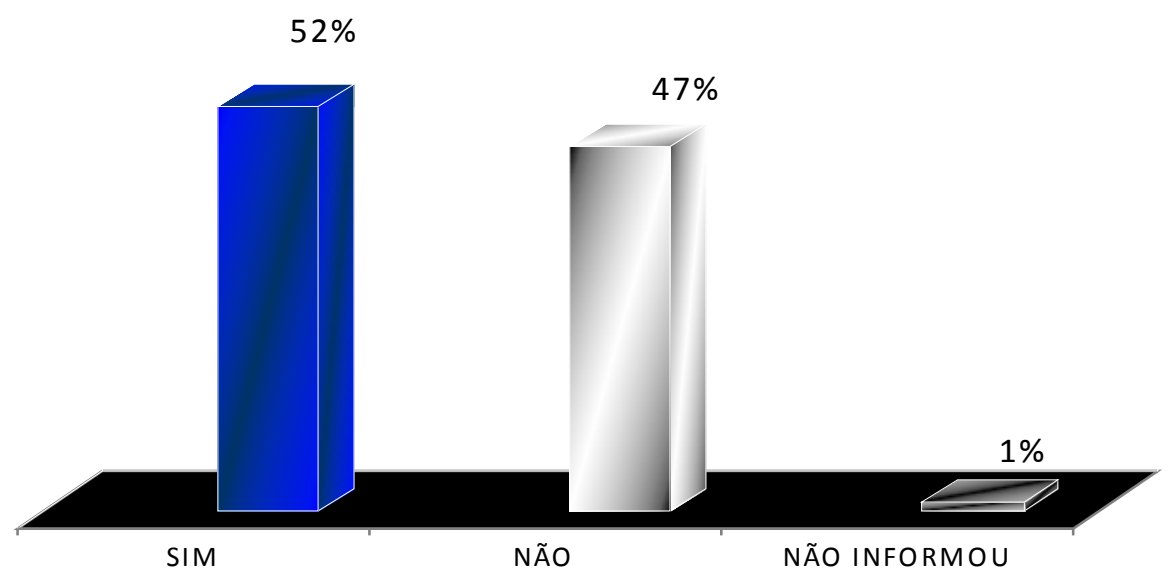

Fonte: questionários recebidos

Considerando a estratificação por região identifica-se que as regiões Norte e Centro Oeste apresentaram o menor índice de multiplicação de conhecimentos.

Gráfico 22 - Atuação como multiplicadores - percentuais por região

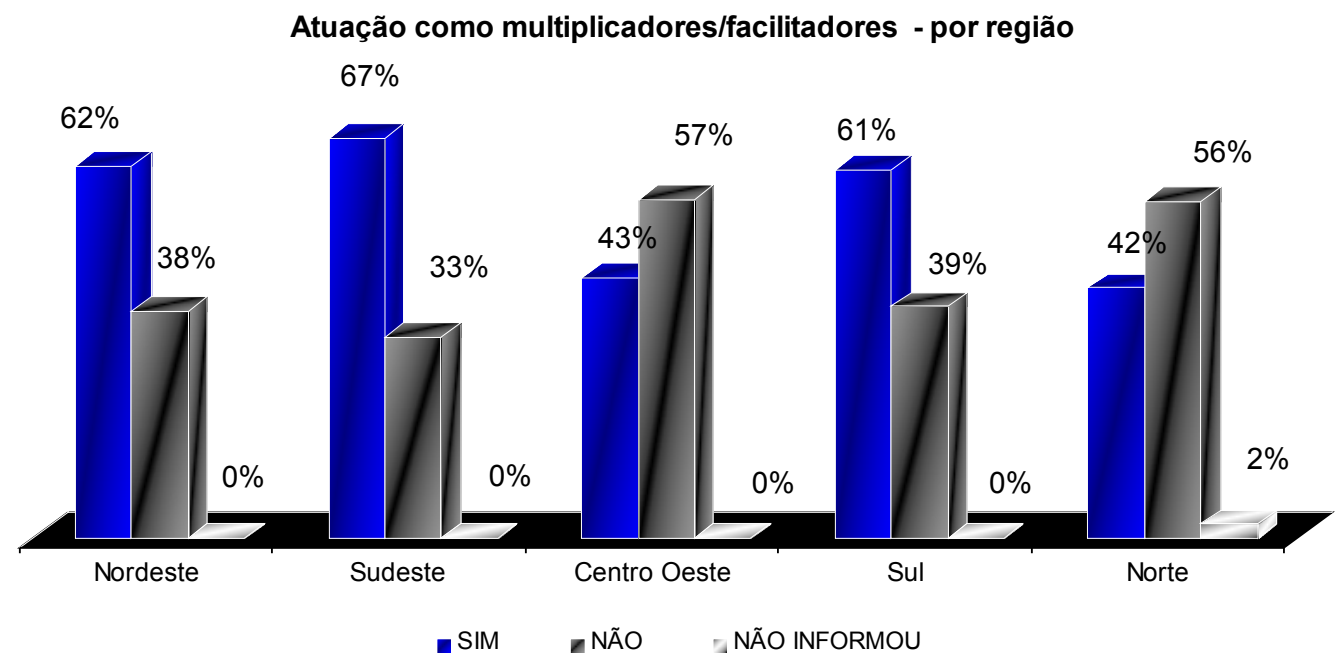

Fonte: questionários recebidos

De acordo com os dados analisados no que se refere a esse indicador, o mesmo apresentou um desempenho aquém do índice estabelecido para que se 
considere o indicador consolidado, o que demonstra que a política de formação adotada tem sido pouco eficaz nesse aspecto. Por outro lado, percebe-se que em três regiões (Nordeste, Sudeste e Sul) o índice encontra-se no gradiente estabelecido para "indicador em processo de consolidação".

Em uma leitura da conjuntura que pode explicar esse desempenho abaixo do esperado pode apontar dois fatores:

a) Considerando-se que os eventos realizados em sua maioria foram de curta e média duração (40 a 88 horas) e que os temas abordados são, em muitos casos, bastante complexos, identifica-se que o número de horas/aula não seria suficiente para uma formação aprofundada de modo que os técnicos se sentissem habilitados a atuarem com multiplicadores.

b) Outro aspecto a ser considerado refere-se às oportunidades para atuarem como formadores, o que depende, em grande medida do apoio das instituições nos estados.

\subsubsection{Eficiência das ações de formação}

A eficiência está relacionada a indicadores econômicos e referem-se a em que medida os recursos públicos tem sido "bem gastos". Para essa avaliação estabeleceuse como indicador de eficiência das ações de formação a razão entre o número de agentes formador e o volume de recursos gastos para isso.

Tabela 14 - Indicadores de eficiência

\begin{tabular}{|c|c|}
\hline Item a ser avaliado & Indicador \\
\hline \multirow{2}{*}{ Eficiência } & a) Aplicação dos recursos \\
\hline & $\begin{array}{l}\text { b) Número de agentes formados } x \text { recursos } \\
\text { investidos (Custo/beneficiário). }\end{array}$ \\
\hline
\end{tabular}

Fonte: Elaboração própria

\subsubsection{1 - Aplicação dos recursos}

A análise deste item fica em grande parte distorcida em função da dificuldade em se identificar valores aplicados nessa ação antes de 2007 , uma vez que não existia rubrica orçamentária específica para a formação de agentes de ATER e estas eram financiadas com recursos provenientes da Ação Orçamentária 4260. 
De acordo com os dados apresentados na tabela abaixo se verifica um crescimento constante dos recursos destinados à formação de Agentes de ATER. Considerando-se que em todos os anos o índice de aplicação dos recursos foi superior a $75 \%$, percentual mínimo estabelecido para "indicador consolidado", considera-se que sob esse aspecto a Política de Formação de Agentes de ATER tem sido eficiente.

Tabela 15 - Execução Financeira - recursos previstos x recursos empenhados

\begin{tabular}{|c|c|c|c|}
\hline Ano & Orçamento previsto & Orçamento Executado & $\%$ \\
\hline $\mathbf{2 0 0 7}$ & $\mathrm{R} \$ 3.000 .000,00$ & $\mathrm{R} \$ 2.283 .587,05$ & 76,12 \\
\hline $\mathbf{2 0 0 8}$ & $\mathrm{R} \$ 4.800 .000,00$ & $\mathrm{R} \$ 3.940 .154,05$ & 82,09 \\
\hline $\mathbf{2 0 0 9}$ & $\mathrm{R} \$ 6.500 .000,00$ & $\mathrm{R} \$ 5.132 .338,54$ & 78,96 \\
\hline
\end{tabular}

Fonte: SIAFI - recurso empenhado

\subsubsection{2 - Número de agentes formados $x$ recursos investidos (Custo/beneficiário)}

De 2007 a 2009 foram empenhados $\mathrm{R} \$ 11.356 .079,64$ (onze milhões, trezentos e cinqüenta e seis mil, setenta e nove reais e sessenta e quatro centavos) na Ação Orçamentária 4448 e foram formados nesse período 3.907 Agentes de ATER, o que indica um custo de $\mathrm{R} \$ 2.906,60$ por beneficiário. Esse valor mostra-se razoável na medida em que as ações realizadas em sua maioria foram de 80 horas ou mais e que esse valor inclui despesas referentes à hospedagem, alimentação, disponibilização de material didático aos participantes e, em muitos casos, deslocamento dos mesmos aos locais de realização dos cursos.

\subsubsection{Efetividade das ações de formação promovidas}

Segundo Matias-Pereira (2007), a efetividade ocorre "quando os bens e serviços resultantes de determinada ação alcançam os resultados mais benéficos para a sociedade". Além disso, uma política pública só é efetiva na medida em que se perpetua e se sustenta a longo prazo. Considerando esse conceito e as particularidades da política pública em questão, a efetividade da política de formação 
de agentes de ATER é dada pela sua capacidade de alterar os paradigmas ou posturas estabelecidos até o momento de sua proposição.

O paradigma vigente até a Pnater estava, em grande medida, atrelado à visão mercadológica, tecnicista e produtivista da Revolução Verde. A partir das orientações previstas para o estabelecimento de uma nova relação no campo foram definidos indicadores relacionados a mudanças, tanto no que diz respeito ao perfil de atuação dos próprios agentes, quanto das instituições aos quais os mesmos estão vinculados. Esses indicadores são importantes no sentido de que apontam para a consolidação de um novo paradigma e para a permanência do mesmo.

Tabela 16 - Indicadores de eficiência

\begin{tabular}{|c|l|}
\hline Item a ser avaliado & \multicolumn{2}{|c|}{ Indicador } \\
\hline \multirow{2}{*}{ Efetividade } & a) $\begin{array}{l}\text { Mudança do perfil de trabalho dos técnicos } \\
\text { (adoção de Metodologias Participativas, } \\
\text { orientação para práticas de agricultura } \\
\text { ecológica, etc.); } \\
\text { b) Mudança no perfil da instituição em que atuam, } \\
\text { a partir da influência dos técnicos formados. }\end{array}$ \\
\end{tabular}

Fonte: Elaboração própria

\subsubsection{Mudança do perfil de trabalho dos técnicos}

Dentre os 390 questionários avaliados, 14 agentes consideraram que a atividade de formação da qual participaram não teve influência nenhuma sobre a forma de atuação, 263 agentes consideraram que a partir da capacitação seu trabalho passou a contribuir mais com os agricultores familiares, 117 agentes passaram a trabalhar utilizando metodologias participativas e 67 identificaram um aumento nas áreas de agricultura de base ecológica nas comunidades nas quais prestam serviços de assistência técnica.

Outro indicador interessante se refere ao interesse dos mesmos em continuar se aperfeiçoando nos temas abordados. Do total de 390 agentes participantes desta pesquisa 212 informaram que após a atividade de formação promovida pelo DATER buscaram outras fontes para se aprofundarem nos temas. Esse dado indica que, mesmo quando os eventos de capacitação dos quais participaram não atingiram a 
profundidade desejada, esses técnicos foram sensibilizados a respeito da necessária mudança de postura e de paradigma na ação extensionistas, a ponto de tomarem a iniciativa de buscar mais conhecimentos.

Apesar disso, no que se refere a esse indicador, o mesmo apresentou um desempenho aquém do necessário para que se considere o mesmo consolidado, o que demonstra que a política de formação adotada tem sido pouco efetiva nesse aspecto.

Gráfico 23 - Mudança no perfil de atuação dos técnicos

\section{Mudança no perfil de atuação dos técnicos}

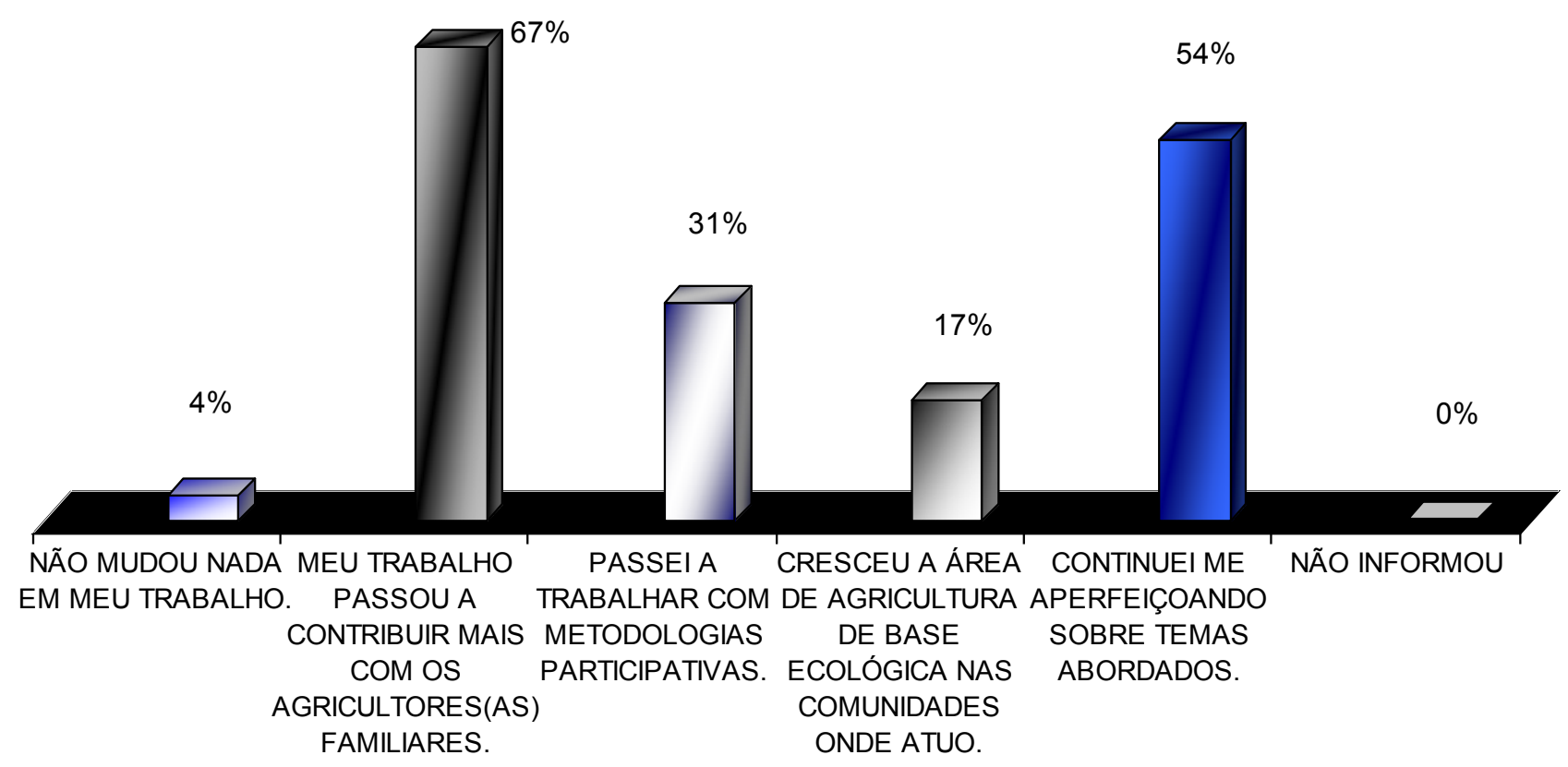

Fonte: questionários recebidos

\subsubsection{Mudança no perfil de trabalho das instituições, a partir da influência dos técnicos formados}

As Empresas de Assistência Técnica e Extensão Rural - ATER, via de regra, trazem em sua Missão Institucional a prestação de serviços qualificados de assistência técnica e extensão rural aos agricultores familiares de forma a promover o desenvolvimento rural sustentável.

O desafio dessas instituições, porém, consiste em superar um modo ultrapassado de fazer extensão, passando a atuar na perspectiva de que a ATER é um 
processo de educação não formal a ser conduzido por meio de um dialogar contínuo entre os saberes técnicos e os tradicionais, através de momentos complementares e não estanques de interação entre técnicos e agricultores, de forma que os técnicos possam refletir sobre a realidade em que atuam, re-significar o seu trabalho, buscar novas formas de enfrentamento das dificuldades e comprometer-se com a transformação da prática cotidiana e os agricultores familiares possam se tornar sujeitos empoderados no processo de desenvolvimento sustentável.

Com esse indicador procurou-se aferir em que medida os técnicos formados conseguiram influenciar de alguma forma as orientações adotadas por suas instituições, fazendo com que as práticas institucionais se aproximassem do proposto pela Pnater.

Dentre o total de 390 questionários recebidos, 117 informaram ter conseguido influenciar as orientações de sua instituição, o que representa 30\% (trinta por cento) dos técnicos participantes desta pesquisa.

De acordo com os parâmetros definidos inicialmente para aferição dos indicadores, considera-se esse percentual aquém do necessário para que se considere essa política pública efetiva.

Gráfico 24 - Influência sobre as orientações das instituições de origem

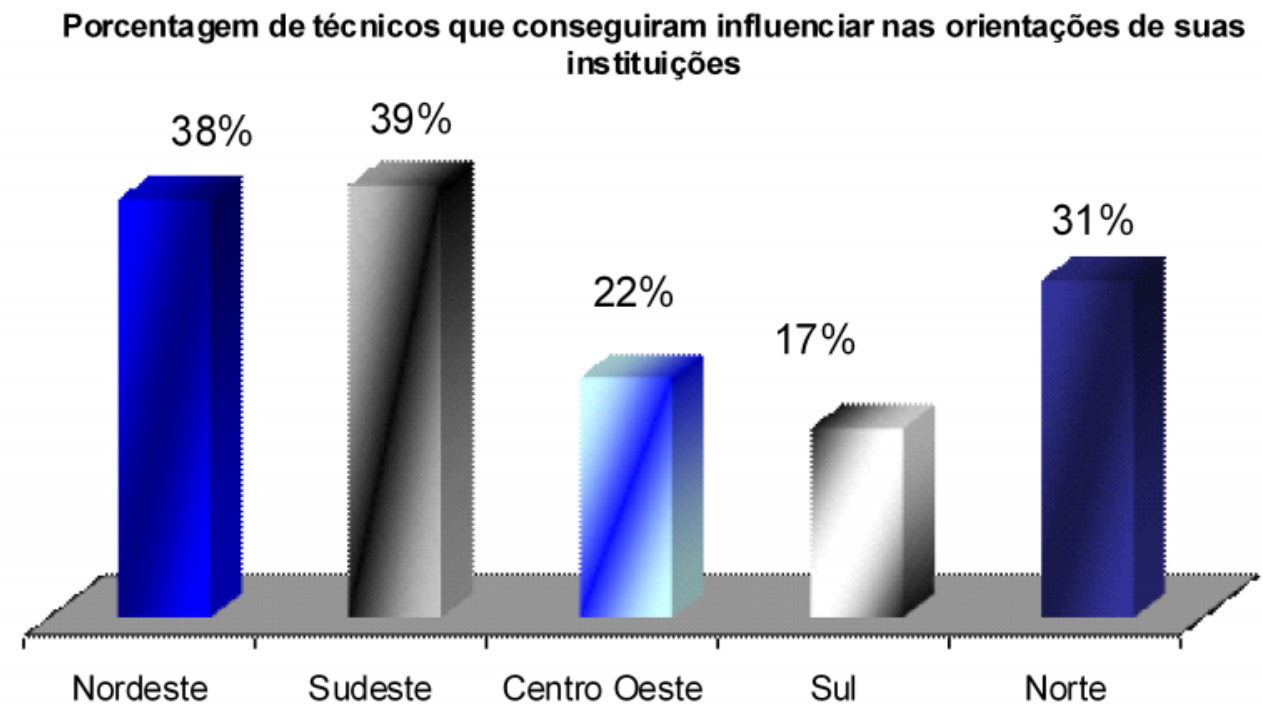

Fonte: questionários recebidos 


\subsection{Consolidação dos dados}

De acordo com o discutido até o momento, os índices de consolidação são apresentados no quadro a seguir:

Tabela 17 - Análise de indicadores consolidada

\begin{tabular}{|c|c|c|}
\hline $\begin{array}{l}\text { Item a ser } \\
\text { avaliado }\end{array}$ & Indicador & Índice de consolidação \\
\hline \multirow{5}{*}{ Eficácia } & a) Adequação do público formado; & $92 \%$ - indicador consolidado \\
\hline & $\begin{array}{l}\text { b) Adequação dos conteúdos das } \\
\text { formações às orientações da } \\
\text { Pnater; }\end{array}$ & $99 \%$ - indicador consolidado \\
\hline & $\begin{array}{l}\text { c) Aplicação dos conteúdos pelos } \\
\text { técnicos formados em suas } \\
\text { atividades profissionais; }\end{array}$ & $88 \%$ - indicador consolidado \\
\hline & d) Apoio a atividades de formação; & $\begin{array}{l}68 \% \text { - indicador em processo } \\
\text { de consolidação }\end{array}$ \\
\hline & $\begin{array}{l}\text { e) Atuação dos técnicos como } \\
\text { formadores/ multiplicadores. }\end{array}$ & \begin{tabular}{|lll}
$52 \%$ & - & indicador \\
consolidado & &
\end{tabular} \\
\hline \multirow[b]{2}{*}{ Eficiência } & a) Aplicação dos recursos; & $79 \%$ - indicador consolidado \\
\hline & $\begin{array}{l}\text { b) } \mathrm{N}^{\circ} \text { de agentes formados } \mathrm{x} \text { recursos } \\
\text { investidos (custo/beneficiário). }\end{array}$ & Custo/beneficiário aceitável \\
\hline \multirow[t]{2}{*}{ Efetividade } & $\begin{array}{l}\text { a) Mudança do perfil de trabalho dos } \\
\text { técnicos (adoção de Metodologias } \\
\text { Participativas, orientação para } \\
\text { práticas de agricultura ecológica, } \\
\text { etc.); }\end{array}$ & $\begin{array}{l}>\text { que } 60 \% \text { em todos os itens } \\
\text { avaliados - indicador não } \\
\text { consolidado }\end{array}$ \\
\hline & $\begin{array}{l}\text { b) Mudança no perfil da instituição em } \\
\text { que atuam, a partir da influência } \\
\text { dos técnicos formados. }\end{array}$ & $\begin{array}{l}30 \% \text { - indicador não } \\
\text { consolidado }\end{array}$ \\
\hline
\end{tabular}

Fonte: Elaboração própria 


\subsection{Conclusões}

Retomando-se o problema proposto para essa pesquisa e considerando-se os parâmetros estabelecidos para análise dos indicadores construídos de modo a aferir a eficiência, eficácia e a efetividade das ações de formação, classificados na tabela apresentada no item 4.5 - Consolidação dos dados de acordo com os índices de consolidação identificados, conclui-se que a Política de Formação de Agentes de ATER, no período entre 2004 e 2009 foi:

a) eficaz, uma vez que dentre os cinco indicadores estabelecidos para esse item, três apresentaram índice de consolidação acima de 85\% (oitenta e cinco por cento), um dentro do índice de processo em consolidação (68\% sessenta e oito por cento) e apenas um não consolidado (52\% por cento);

A política de formação de agentes de ATER tem sido eficaz na medida em que manteve o foco em um público muito bem delimitado; restringiu os temas abordados em suas atividades àqueles priorizados pela Pnater ou demandados legitimamente pelos beneficiários dessa política e procurou adequar os conteúdos às reais necessidades dos técnicos, de forma que estes conteúdos tivessem aplicabilidade na atividade cotidiana dos técnicos.

Por outro lado identifica-se que a formação de multiplicadores, outro indicador de eficácia, ainda não se encontra consolidada. Com relação a esse indicador recomendase a ampliação da carga horária das capacitações que tenham como objetivo formar multiplicadores, de forma que os mesmos sejam realmente instrumentalizados de forma a se sentirem aptos a compartilhar o conhecimento construído/reconstruído através das formações.

Outra recomendação pertinente a esse indicador diz respeito a um trabalho de conscientização junto às instituições de origem dos técnicos formados, de modo que as mesmas passem a valorizar àqueles técnicos que buscam se aperfeiçoar e que tenham aptidão para atuar como formadores dentro dessas instituições, oportunizando a eles a possibilidade de atuarem como tal.

b) eficiente, uma vez que o índice de aplicação dos recursos foi em média de $79 \%$ (setenta e nove por cento) no período de 2007 a 2009 e considerando que o custo/beneficiário está dentro de um valor aceitável; 
Com relação aos indicadores de eficiência recomenda-se um controle mais cuidadoso no que diz respeito à organização dos dados referentes aos recursos empenhados, uma vez que a base de dados referente a esses valores se resume basicamente ao SIAFI.

c) não efetiva, considerando que os dois indicadores estabelecidos para esse item obtiveram desempenho inferior ao estipulado para a consolidação dos mesmos.

A efetividade entendida como em que medida a Política Pública de Formação de Agentes de ATER conseguiu modificar o perfil de atuação dos técnicos e das instituições não foi consolidada.

Com relação ao perfil de atuação dos técnicos destacam-se basicamente dois aspectos: a utilização de metodologias participativas e o aumento de áreas de agricultura de base ecológica nas localidades de atuação dos mesmos. Outros pontos também foram avaliados, mas esses itens são os mais significativos, na medida em que são os mais representativos em função dos princípios e diretrizes preconizados pela Pnater.

Apesar do grande número de eventos realizados no período de 2004 a 2009, (trinta a seis eventos sobre Agroecologia/Agriculturas de base ecológica e dezoito sobre Aprendizagem e Ação Participativa), verificou-se que apenas 17\% dezessete por cento dos técnicos identificaram um real aumento das áreas de agricultura de base ecológica e somente $31 \%$ passaram a trabalhar com metodologias participativas.

A incorporação sistemática dos conhecimentos nesses dois temas são fundamentais para caracterizar a mudança de postura e a consolidação de um novo paradigma de forma a se aferir a efetividade dessa política pública, principalmente na medida em que indicam a perpetuação dos princípios e diretrizes da Pnater.

Com relação ao perfil das instituições as quais os técnicos estão vinculados, o impacto das ações de formação identificado ainda é muito incipiente, o que indica a necessidade de uma atuação mais focada para a formação e sensibilização também de núcleos gerenciais e não apenas de técnicos, de forma que essa política se torne perene, mesmo sem o incentivo do governo federal. 


\section{REFERÊNCIAS ${ }^{4}$}

AGUIAR, Maria Virgínia de Almeida. Proposta de avaliação de impacto dos cursos de formação realizados pelo DATER. Brasília, 2008.

ARRETCHE, Marta T. S.; BRANT, Maria do C. Tendências no estudo sobre avaliação. In: RICO, Elizabeth Melo (Org.). Avaliação de política sociais: uma questão em debate. São Paulo: Cortez, IEE, 2006.

BARREIRA, Maria Cecília R. N. Avaliação participativa de programas sociais. São Paulo: Veras, 2000.

BELLONI, Isaura et al. Metodologia de Avaliação em Políticas Públicas. $4^{\circ} \mathrm{Ed}$. São Paulo: Cortez, 2007.

BRASIL, Banco do Brasil, Diretoria de Agronegócios. $\mathbf{O}$ atendimento à agricultura empresarial. Revista de Política Agrícola Ano XIII - No 4 - Out./Nov./Dez. 2004.

Disponível em: http://www.agronegociose.com.br/agr/down/artigos/Pol Agr 4 Artigo 04.pdf . Acesso em: 18 de junho de 2010.

BRASIL. Lei $n^{\circ}$ 11.326, de 24 de julho de 2006. Estabelece as diretrizes para a formulação da Política Nacional da Agricultura Familiar e Empreendimentos Familiares Rurais. Diário Oficial da União, Brasília No 141, p. 1, 25 de julho de 2006.

BRASIL. Lei n⿳0 12.188, de 11 de janeiro de 2010. Institui a Política Nacional de Assistência Técnica e Extensão Rural para a Agricultura Familiar e Reforma Agrária PNATER e o Programa Nacional de Assistência Técnica e Extensão Rural na Agricultura Familiar e na Reforma Agrária - PRONATER, altera a Lei no 8.666, de 21 de junho de 1993, e dá outras providências. Diário Oficial da União, Brasília Nº 7, p. 1, 12 de janeiro de 2010.

BRASIL. Ministério do Desenvolvimento Agrário (MDA), Secretaria de Agricultura Familiar (SAF). 2004. Política Nacional de Assistência Técnica e Extensão Rural. Disponível em: < http://portal.mda.gov.br/portal/saf/>. Acesso em 23/04/2010.

BRASIL. Ministério do Desenvolvimento Agrário (MDA), Secretaria de Agricultura Familiar (SAF), Departamento de Assistência Técnica e Extensão Rural (DATER). 2007. Subprograma de formação de agentes de Ater.

BRISOLLA, Sandra Negraes. Indicadores para apoio à tomada de decisão. 1998. Ci. Inf., Ci. Inf., Brasília, v. 27, n. 2, p. 221-225, maio/ago. 1998. Disponível em: http://www.scielo.br/pdf/ci/v27n2/brisolla.pdf . Acesso em: 07 de novembro de 2010.

\footnotetext{
${ }^{4}$ De acordo com a Associação Brasileira de Normas Técnicas. NBR 6023
} 
CAMARGO, Leonidas Lopes de. Uso de indicadores da qualidade para o gerenciamento estratégico de empresas do ramo comercial. 2000.109p. Dissertação de Mestrado - Universidade Federal de Santa Catarina, Florianópolis, 2000.

CUNHA, Carla Giane Soares da. Avaliação de Políticas Públicas e Programas Governamentais: tendências recentes e experiências no Brasil. 2006. Disponível em: http://www.espacopublico.blog.br/?p=5626. Acesso em: 06 de maio de 2010.

DENARDI, Reni. Agricultura Familiar e Políticas Públicas: alguns dilemas e desafios para o desenvolvimento rural sustentável. Disponível em: http://www.emater.tche.br/docs/agroeco/revista/ano2 n3/revista agroecologia ano2 n um3 parte12 artigo.pdf. Acesso em 13 de maio de 2010.

DOULA,Sheila Maria; SOUZA, Renato Santos de. A Pós-Graduação em Extensão Rural no Brasil: perfil, dificuldades e perspectivas R B P G, Brasília, v. 3, n. 6, p. 282-299, dez. 2006. Disponível em: http://www2.capes.gov.br/rbpg/images/stories/downloads/RBPG/Vol.3 $6 \mathrm{dez} 2006$ /De b Artigo2 n6.pdf. Acesso em: 08 de novembro de 2010.

FAGUNDES, Helenara; MOURA, Alessandra Ballinhas de. Avaliação de programas e políticas públicas In: Revista Textos \& Contextos Porto Alegre v. 8 n.1 p. 89-103. jan./jun. 2009. Disponível em: < http://revistaseletronicas.pucrs.br/ojs/index.php/fass/article/viewFile/5676/412 >. Acesso em 23/04/2010.

FERNANDES, Ângela. O perfil da agricultura familiar brasileira. 2009. Disponível em: http://www.webartigos.com/articles/16496/1/O-PERFIL-DA-AGRICULTURAFAMILIAR-BRASILEIRA/pagina1.html . Acesso em: 14 de maio de 2010.

FREIRE, Paulo Extensão ou Comunicação? São Paulo: Paz e Terra. $12^{\mathrm{a}}$ edição. 1977.

GUARESCHI, Neuza. Et al. Problematizando as práticas psicológicas no modo de entender a violência. In: STREY, Marelene N.; AZAMBUJA, Mariana P. Ruwer; JAEGER, Fernanda Pires. (Orgs). Violência, Gênero e Políticas Públicas. Porto Alegre- RS: Ed. EDIPUCRS, 2004.

KREJCIE, RV. \& MORGAN, DW. Determining sample size for research activities. Educational and Psychological Measurement, 607-610, 1970.

LIMA, Reginaldo Silveira de. Resultado do I Seminário Nacional de ATER. Brasília: MDA, 2008.

MATIAS-PEREIRA, José. Manual de gestão pública contemporânea. São Paulo: Atlas, 2007. 
Atlas, 2006.

Finanças Públicas: a política orçamentária no Brasil. 3. ed. São Paulo:

MARTINS, Roberto de Andrade. $\mathbf{O}$ sistema de arquivos da universidade e a memória científica. Anais do I Seminário Nacional de Arquivos Universitários. Campinas: UNICAMP, 1992, pp. 27-48. Disponível em:

http://www.ifi.unicamp.br/ ghtc/ram-pub.htm . Acesso em 20 de junho de 2010.

MIGLIOLI, José Ricardo. Um Retrato da Extensão Rural Brasileira. Brasília: ASBRAER, 2009

MINAYO, Maria Cecília de Souza. Conceito de avaliação por triangulação de métodos. In: Minayo, Maria Cecília de Souza (Org.). Avaliação por triangulação de métodos: abordagens de programas sociais. Rio de Janeiro: Editora Fiocruz, 2005.

SOUZA, Celina. Políticas Públicas: uma revisão da literatura. IN Sociologias $\mathrm{n}^{\circ} 16$. Junho/dezembro 2006, p. 20-45. Disponível em:

http://www.scielo.br/scielo.php?script=sci arttext\&pid=S1517-

45222006000200003\&lng=pt\&nrm=iso. Acesso em: 16 de maio de 2010.

STUFFLEBEAM, D. L.; SHINKFIELD, A. J. El metodo evaluativo de Scriven orientado hacia el consumidor. In: . Evaluación sistemática: guía teórica y práctica. Barcelona: Paidós, 1987.

TELLES, Tiago Santos . Et al.Agricultura familiar: pecuária leiteira como locus das políticas públicas paranaenses. Anais do Seminário: Ciências Agrárias, Londrina, v. 29, n.3, p. 579-590, jul./set. 2008. Disponível em:

http://www.uel.br/revistas/uel/index.php/semagrarias/article/viewFile/2798/2382 .

Acesso em 25 de outubro de 2010.

VEIGA, J. E. da. Debates: Agricultura familiar e sustentabilidade. Cadernos de Ciência e Tecnologia, Brasília, v.13, n.3, p. 383-404, 1996.

Como avaliar Políticas Públicas e Programas Governamentais. Disponível em: http://redeodm.pbh.gov.br/index.php?option=com content\&view=article\&id=101\&ltemid $=176 \&$ limitstart=5 Acesso em: 16 de maio de 2010.

www.mda.gov.br

http://br.dir.groups.yahoo.com/group/novaterbrasil/?tab=s 


\section{ANEXO I - Questionário de pesquisa}

\section{PESQUISA - IMPACTO DAS AÇÕES DE FORMAÇÃO REALIZADAS PELO DATER/SAF/MDA NO PERÍODO 2004-2009}

Caros colaboradores,

Contamos com a sua atenção para preencher o formulário abaixo.

O mesmo tem por objetivo fornecer informações para avaliação da Eficiência, Efetividade e Eficácia da Política Pública de Formação de Agentes de Ater adotada pelo Departamento de Assistência Técnica e Extensão Rural, da Secretaria de Agricultura Familiar do Ministério do Desenvolvimento - DATER/SAF/MDA, no período de 2004 a 2009, tema escolhido para Monografia a ser apresentada à Universidade de

Brasília (UnB) como requisito parcial para obtenção do grau de Bacharel em Administração.

Você poderá ou não se identificar no questionário e garantimos que todas as informações fornecidas serão confidenciais e utilizadas apenas de forma sistematizada.

IDENTIFICAÇÃO

\begin{tabular}{|l|l|}
\hline Nome: (opcional) & $\begin{array}{l}\text { Sexo: } \\
(\quad) \text { masculino } \quad(\quad \text { ) feminino }\end{array}$ \\
\hline $\begin{array}{l}\text { Instituição (nome e tipo de instituição: ONG, } \\
\text { Empresa Pública, Cooperativa,etc.): }\end{array}$ & Local de trabalho (Cidade e Estado): \\
\hline $\begin{array}{l}\text { Curso/Encontro/Oficina do qual participou (caso tenha participado de mais de um } \\
\text { evento de formação, preencha um formulário para cada um deles): }\end{array}$ \\
\hline Data do Curso/Encontro/Oficina/Seminário (pelo menos mês e ano): \\
\hline
\end{tabular}

1) Indique sua área de atuação? (As opções não são excludentes: você poderá marcar mais de uma opção). 


\begin{tabular}{|c|c|}
\hline & EXTENSÃO RURAL \\
\hline & PESQUISA \\
\hline & ENSINO \\
\hline & OUTROS \\
\hline
\end{tabular}

2) Qual o seu nível de escolaridade? (Considere apenas o nível mais alto)

\begin{tabular}{|c|c|}
\hline & NÍVEL MÉDIO \\
\hline & NÍVEL SUPERIOR \\
\hline & PÓS-GRADUAÇÃO \\
\hline
\end{tabular}

3) Os conteúdos abordados na formação foram condizentes com as demandas do seu dia-a-dia?

\begin{tabular}{|c|c|}
\hline & SIM \\
\hline & PARCIALMENTE \\
\hline & NÃO \\
\hline
\end{tabular}

4) O curso ou atividade de formação da qual você participou contribuiu para o seu aperfeiçoamento profissional?

\begin{tabular}{|c|c|}
\hline & SIM \\
\hline & NÃO \\
\hline
\end{tabular}

5) Os conhecimentos adquiridos nesta formação estão sendo aplicados no seu trabalho? Em caso afirmativo, indique em que grau estes conhecimentos estão sendo aplicados. Em caso negativo, indique por que razão isto não ocorre: (Em caso negativo, as respostas não são excludentes: você poderá marcar mais de uma opção).

\begin{tabular}{|l|l|l|l|}
\hline $\begin{array}{l}\text { SIM (indique ao lado } \\
\text { em que grau) }\end{array}$ & & \multicolumn{1}{c|}{ MUITO APLICADOS } \\
\cline { 2 - 3 } & & MEDIAMENTE APLICADOS \\
\hline
\end{tabular}




\begin{tabular}{|c|c|c|c|}
\hline & & POUCO APLICADOS \\
\hline \multirow{4}{*}{$\begin{array}{c}\text { NÃo (indique ao lado } \\
\text { a razão da não } \\
\text { aplicação) }\end{array}$} & & $\begin{array}{c}\text { CONTEÚDO NÃO ADEQUADO ȦS } \\
\text { NECESSIDADES ESPECÍFICAS DA REGIÃO }\end{array}$ \\
\cline { 3 - 3 } & & $\begin{array}{c}\text { CONTEÚDO NÃO FOI SUFICIENTEMENTE } \\
\text { APROFUNDADO PARA PERMITIR UMA } \\
\end{array}$ & APLICAÇÃO EFICAZ E EFICIENTE \\
\cline { 3 - 4 } & & FALTA DE APOIO E INCENTIVO DA MINHA \\
& & INSTITUIÇÃO \\
\cline { 3 - 4 } & & NÃO TENHO INTERESSE EM APLICAR \\
\hline
\end{tabular}

6) A partir do evento de formação do qual você participou: (As respostas não são excludentes: você poderá marcar mais de uma opção).

\begin{tabular}{|c|c|}
\hline & NÃO MUDOU NADA EM MEU TRABALHO. \\
\hline & MEU TRABALHO PASSOU A CONTRIBUIR MAIS COM OS \\
AGRICULTORES(AS) FAMILIARES.
\end{tabular}

7) Depois do evento de capacitação do qual participou, você apoiou atividades de capacitação de técnicos e/ou agricultores com base nos princípios e diretrizes da Pnater? (Considere como apoio a atividades de capacitação a participação no planejamento, elaboração de ementas, seleção de participantes e de palestrantes.)

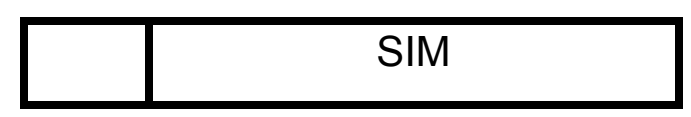




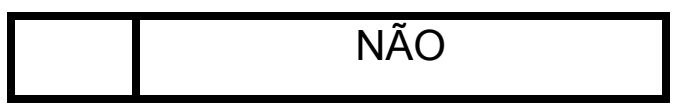

8) Usou os conhecimentos adquiridos para ministrar outros eventos de formação com o mesmo conteúdo ou conteúdos semelhantes?

\begin{tabular}{|c|c|}
\hline & SIM \\
\hline & NÃO \\
\hline
\end{tabular}

9) Marque o seu grau de satisfação com relação a atividade de formação oferecida pelo DATER: (Considere a seguinte pontuação: 1 - MUITO RUIM; 2 - RUIM; 3 REGULAR; 4 - BOM; 5 - MUITO BOM)

\begin{tabular}{|l|l|l|l|l|}
\hline 1 & 2 & 3 & 4 & 5 \\
\hline
\end{tabular}

10) Marque seu grau de satisfação com relação ao DATER: (Considere a seguinte pontuação: 1 - MUITO RUIM; 2 - RUIM; 3 - REGULAR; 4 - BOM; 5 - MUITO BOM)

\begin{tabular}{|l|l|l|l|l|}
\hline 1 & 2 & 3 & 4 & 5 \\
\hline
\end{tabular}




\section{Anexo II - Sistematização Geral dos questionários recebidos}

\begin{tabular}{|c|c|c|c|c|c|c|c|c|}
\hline \multirow{2}{*}{\multicolumn{3}{|c|}{ INDICADORES }} & \multicolumn{5}{|c|}{ Região } & \multirow{3}{*}{$\begin{array}{r}\text { Total } \\
119\end{array}$} \\
\hline & & & \multirow{2}{*}{$\begin{array}{c}\text { Nordeste } \\
25\end{array}$} & \multirow{2}{*}{\begin{tabular}{|c|} 
Sudeste \\
19
\end{tabular}} & \multirow{2}{*}{\begin{tabular}{|c|}
$\begin{array}{c}\text { Centro } \\
\text { Oeste }\end{array}$ \\
17 \\
\end{tabular}} & \multirow{2}{*}{\begin{tabular}{|c|} 
Sul \\
16
\end{tabular}} & \multirow{2}{*}{\begin{tabular}{|c|} 
Norte \\
42 \\
\end{tabular}} & \\
\hline GENER & & MULHERES & & & & & & \\
\hline GETVENU & & HOMENS & 41 & 32 & 6 & 54 & 138 & 271 \\
\hline \multirow{5}{*}{ ÁREA DE ATUAÇÃO } & & EXTENSÃO & 66 & 48 & 15 & 66 & 164 & 359 \\
\hline & & ESQUISA & 10 & 5 & 6 & 2 & 5 & 28 \\
\hline & & ENSINO & 7 & 0 & 6 & 2 & 4 & 19 \\
\hline & & OUTROS & 4 & 4 & 5 & 5 & 6 & 24 \\
\hline & & O INFORMOU & 0 & 0 & 0 & 0 & 1 & 1 \\
\hline \multirow{4}{*}{ ESCOLARIDADE } & & MÉDIO & 7 & 0 & 2 & 9 & 87 & 105 \\
\hline & & SUPERIOR & 28 & 27 & 10 & 25 & 50 & 140 \\
\hline & PÓs & GRADUAÇÃO & 31 & 24 & 11 & 36 & 43 & 145 \\
\hline & & O INFORMOU & 0 & 0 & 0 & 0 & 0 & 0 \\
\hline \multirow{3}{*}{ TIPO DE INSTITUIÇÃO } & INSTITUIÇÃC & ESTADUAL (EMATER) & 49 & 39 & 13 & 35 & 162 & 298 \\
\hline & & ONG & 9 & 5 & 2 & 18 & 4 & 38 \\
\hline & $\begin{array}{c}\text { OUTRC } \\
\text { PREF }\end{array}$ & $\begin{array}{l}\text { S (SINDICATOS, } \\
\text { EITURAS, ETC) }\end{array}$ & 8 & 7 & 8 & 17 & 14 & 54 \\
\hline \multirow{4}{*}{$\begin{array}{l}\text { CONTEÚDOS } \\
\text { CONDIZENTES }\end{array}$} & & SIM & 44 & 40 & 16 & 38 & 154 & 292 \\
\hline & & RCIALMENTE & 22 & 11 & 6 & 30 & 16 & 85 \\
\hline & & NÃO & 0 & 0 & 1 & 2 & 10 & 13 \\
\hline & & O INFORMOU & 0 & 0 & 0 & 0 & 0 & 0 \\
\hline \multirow{3}{*}{$\begin{array}{l}\text { APERFEIÇOAMENTO } \\
\text { PROFISSIONAL }\end{array}$} & & SIM & 65 & 49 & 23 & 70 & 168 & 375 \\
\hline & & NÃO & 1 & 2 & 0 & 0 & 2 & 5 \\
\hline & & O INFORMOU & 0 & 0 & 0 & 0 & 10 & 10 \\
\hline \multirow{9}{*}{$\begin{array}{l}\text { APLICACCÃO DOS } \\
\text { CONHECIMENTOS }\end{array}$} & \multirow{3}{*}{ SIM } & MUITO APLICADOS & 25 & 24 & 7 & 19 & 52 & 127 \\
\hline & & $\begin{array}{l}\text { MEDIANAMENTE } \\
\text { APLICADOS }\end{array}$ & 24 & 18 & 9 & 34 & 89 & 174 \\
\hline & & POUCO APLICADOS & 9 & 5 & 4 & 8 & 16 & 42 \\
\hline & \multirow{5}{*}{ NÃO } & $\begin{array}{c}\text { CONTEUDO NĀO } \\
\text { ADEQUADO ÁS } \\
\text { NECESSIDADES DA REGIÃO }\end{array}$ & 3 & 1 & 0 & 0 & 1 & 5 \\
\hline & & $\begin{array}{l}\text { CONTEUDO NAOO FOI } \\
\text { SUFIIINTEMENE } \\
\text { APROFUNDADO }\end{array}$ & 1 & 2 & 0 & 7 & 8 & 18 \\
\hline & & $\begin{array}{l}\text { FALA DE APOIO E } \\
\text { INCENTIVO DA MINHA } \\
\text { INSTITUIÇAO }\end{array}$ & 8 & 0 & 3 & 3 & 2 & 16 \\
\hline & & $\begin{array}{l}\text { FALTA DE INCENTIVO Ás } \\
\text { AÇOEES DE ATER }\end{array}$ & 4 & 1 & 1 & 0 & 3 & 9 \\
\hline & & $\begin{array}{c}\text { NÃO TENHO INTERESSE EM } \\
\text { APLICAR }\end{array}$ & 0 & 0 & 0 & 0 & 0 & 0 \\
\hline & \multicolumn{2}{|l|}{$\begin{array}{l}\text { NÃO } \\
\text { INFORMOU }\end{array}$} & 0 & 0 & 0 & 0 & 1 & 1 \\
\hline \multirow{7}{*}{$\begin{array}{l}\text { INFLUÊNCIA DO } \\
\text { CURSO }\end{array}$} & \multicolumn{2}{|c|}{ NÃO MUDOU NADA EM MEU TRABALHO. } & 2 & 3 & 4 & 3 & 2 & 14 \\
\hline & \multicolumn{2}{|c|}{$\begin{array}{c}\text { MEU TRABALHO PASSOU A CONTRIBUUR MAIS } \\
\text { COM OS AGRICULTORES(AS) FAMILIARES. }\end{array}$} & 48 & 35 & 11 & 38 & 131 & 263 \\
\hline & \multicolumn{2}{|c|}{$\begin{array}{l}\text { CONSEGUI INELUENCIAR NAS ORIIENTAÇÕES } \\
\text { DA MINHA INSTITUIÇĀO. }\end{array}$} & 25 & 20 & 5 & 12 & 55 & 117 \\
\hline & \multicolumn{2}{|c|}{$\begin{array}{l}\text { PASSEI A TRABALHAR COM METODOLOGIAS } \\
\text { PARTICIPATIVAS. }\end{array}$} & 16 & 12 & 10 & 18 & 65 & 121 \\
\hline & \multicolumn{2}{|c|}{$\begin{array}{l}\text { CRESCEU A ÁREA DE AGRICULTURA DE BASE } \\
\text { ECOLOGGICA NAS COMUNIDADES ONDE ATUO. }\end{array}$} & 10 & 5 & 2 & 11 & 39 & 67 \\
\hline & \multicolumn{2}{|c|}{$\begin{array}{l}\text { CONTINUEI ME APERFEICICANDO SOBRE } \\
\text { TEMAS ABORDADOS. }\end{array}$} & 49 & 29 & 10 & 42 & 82 & 212 \\
\hline & \multicolumn{2}{|c|}{ NÃO INFORMOU } & 0 & 0 & 0 & 1 & 0 & 1 \\
\hline
\end{tabular}




\begin{tabular}{|c|c|c|c|c|c|c|c|}
\hline \multirow{3}{*}{$\begin{array}{l}\text { APOIO A ATIVIDADES } \\
\text { DE CAPACITAÇÃO }\end{array}$} & SIM & 43 & 40 & 17 & 49 & 117 & 266 \\
\hline & NÃO & 23 & 11 & 6 & 21 & 61 & 122 \\
\hline & NÃO INFORMOU & 0 & 0 & 0 & 0 & 2 & 2 \\
\hline \multirow{3}{*}{ MINISTROU CURSOS } & SIM & 41 & 34 & 10 & 43 & 75 & 203 \\
\hline & NÃO & 25 & 17 & 13 & 27 & 101 & 183 \\
\hline & NÃO INFORMOU & 0 & 0 & 0 & 0 & 4 & 4 \\
\hline \multirow{6}{*}{$\begin{array}{c}\text { GRAU DE SATISFAÇÃO } \\
\text { COM RELAÇÃO AO } \\
\text { CURSO }\end{array}$} & 1 - MUITO RUIM & 2 & 1 & 0 & 1 & 0 & 4 \\
\hline & 2-RUIM & 0 & 0 & 0 & 6 & 0 & 6 \\
\hline & 3 - REGULAR & 7 & 7 & 1 & 15 & 12 & 42 \\
\hline & 4 - BOM & 20 & 24 & 17 & 33 & 89 & 183 \\
\hline & 5 - MUITO ВОМ & 37 & 19 & 5 & 15 & 74 & 150 \\
\hline & NÃO INFORMOU & 0 & 0 & 0 & 0 & 5 & 5 \\
\hline \multirow{6}{*}{$\begin{array}{c}\text { GRAU DE SATISFAÇÃO } \\
\text { COM RELAÇÃO AO } \\
\text { DATER }\end{array}$} & 1 - MUITO RUIM & 0 & 0 & 0 & 0 & 0 & 0 \\
\hline & 2-RUIM & 0 & 0 & 1 & 3 & 3 & 7 \\
\hline & 3 - REGULAR & 8 & 7 & 2 & 9 & 16 & 42 \\
\hline & 4 - BOM & 28 & 22 & 10 & 38 & 80 & 178 \\
\hline & 5 - MUITO BOM & 30 & 22 & 9 & 19 & 77 & 157 \\
\hline & NÃO INFORMOU & 0 & 0 & 1 & 1 & 4 & 6 \\
\hline \multicolumn{2}{|c|}{ TOTAL DE QUESTIONÁRIOS RECEBIDOS } & 66 & 51 & 23 & 70 & 180 & 390 \\
\hline
\end{tabular}




\section{Anexo III - Questionários recebidos}

\section{PESQUISA - IMPACTO DAS AÇÕES DE FORMAÇÃO REALIZADAS PELO DATER/SAF/MDA NO PERÍODO 2004-2009}

Caros colaboradores,

Contamos com a sua atenção para preencher o formulário abaixo.

O mesmo tem por objetivo fornecer informações para avaliação da Eficiência, Efetividade e Eficácia da Política Pública de Formação de Agentes de Ater adotada pelo Departamento de Assistência Técnica e Extensão Rural, da Secretaria de Agricultura Familiar do Ministério do Desenvolvimento - DATER/SAF/MDA, no período de 2004 a 2009, tema escolhido para Monografia a ser apresentada à Universidade de Brasília (UnB) como requisito parcial para obtenção do grau de Bacharel em Administração.

Você poderá ou não se identificar no questionário e garantimos que todas as informações fornecidas serão confidenciais e utilizadas apenas de forma sistematizada.

\section{IDENTIFICAÇÃO}

\begin{tabular}{|l|l|}
\hline $\begin{array}{l}\text { Nome: } \\
\text { ADALBERTO DE CARVALHO SENA }\end{array}$ & $\begin{array}{l}\text { Sexo: } \\
(\mathrm{x}) \text { masculino } \quad(\quad) \text { feminino }\end{array}$ \\
\hline $\begin{array}{l}\text { Instituição : DEAGRO - Depto. Estadual de } \\
\text { Desenvolvimento Agropecuário de Sergipe }\end{array}$ & $\begin{array}{l}\text { Local de trabalho : } \\
\text { Ribeirópolis - Se }\end{array}$ \\
\hline $\begin{array}{l}\text { Curso/Encontro/Oficina do qual participou : } \\
\text { Encontro de Multiplicadores de ATER }\end{array}$ & \\
\hline $\begin{array}{l}\text { Data do Curso/Encontro/Oficina : } \\
11 \text { a 15/09/2006 - Estancia/Se. }\end{array}$ \\
\hline
\end{tabular}

Indique sua área de atuação? (As opções não são excludentes: você poderá marcar mais de uma opção).

\begin{tabular}{|l|l|}
\hline$x$ & EXTENSÃO RURAL \\
\hline & PESQUISA \\
\hline
\end{tabular}




\begin{tabular}{|l|l|} 
& ENSINO \\
\hline & OUTROS \\
\hline
\end{tabular}

2) Qual o seu nível de escolaridade? ( Considere apenas o nível mais alto)

\begin{tabular}{|l|l|}
\hline$x$ & NÍVEL MÉDIO \\
\hline & NÍVEL SUPERIOR \\
\hline & PÓS-GRADUAÇÃO \\
\hline
\end{tabular}

3) Os conteúdos abordados foram condizentes com as demandas do seu dia-a-dia?

\begin{tabular}{|l|l|}
\hline$x$ & SIM \\
\hline & PARCIALMENTE \\
\hline & NÃO \\
\hline
\end{tabular}

3) O curso contribuiu para o seu aperfeiçoamento profissional?

\begin{tabular}{|l|l|}
\hline$x$ & SIM \\
\hline & NÃO \\
\hline
\end{tabular}

5) Os conhecimentos adquiridos estão sendo aplicados no seu trabalho? Em caso afirmativo, indique em que grau estes conhecimentos estão sendo aplicados. Em caso negativo, indique por que razão isto não ocorre: (As respostas não são excludentes: você poderá marcar mais de uma opção).

\begin{tabular}{|c|c|c|c|}
\hline \multirow{3}{*}{$x$} & \multirow{3}{*}{$\begin{array}{l}\text { SIM (indique ao lado em } \\
\text { que grau) }\end{array}$} & & MUITO APLICADOS \\
\hline & & $x$ & MEDIAMENTE APLICADOS \\
\hline & & & POUCO APLICADOS \\
\hline & \multirow{2}{*}{$\begin{array}{l}\text { NÃO (indique ao lado a } \\
\text { razão da não aplicação) }\end{array}$} & & CONTEÚDO NÃO ADEQUADO ÀS NECESSIDADES \\
\hline & & & $\begin{array}{llll}\text { CONTEÚDO NÂOO } & \text { FOI } & \text { SUFICIENTEMENTE } \\
\text { APROFUNDADO } & \text { PARA } & \text { PERMITIR } & \text { UMA } \\
\text { APLICAÇÃO }\end{array}$ \\
\hline
\end{tabular}




\begin{tabular}{|l|l|l|}
\multirow{5}{*}{$\mid$\begin{tabular}{l|l|} 
FALTA DE APOIO E INCENTIVO DA MINHA \\
INSTITUICÃO
\end{tabular}} \\
\cline { 2 - 3 } & FALTA DE INCENTIVO ÀS AÇÕES DE ATER \\
\cline { 2 - 3 } & NÃO TENHO INTERESSE EM APLICAR \\
\hline
\end{tabular}

6) A partir deste curso: (As opções não são excludentes: você poderá marcar mais de uma opção).

\begin{tabular}{|l|l|}
\hline & NÃO MUDOU NADA EM MEU TRABALHO. \\
\hline$x$ & $\begin{array}{l}\text { MEU TRABALHO PASSOU A CONTRIBUIR MAIS COM OS AGRICULTORES(AS) } \\
\text { FAMILIARES. }\end{array}$ \\
\hline & CONSEGUI INFLUENCIAR NAS ORIENTAÇÕES DA MINHA INSTITUIÇÃO. \\
\hline & $\begin{array}{l}\text { CRESCEU A ÁREA DE AGRICULTURA DE BASE ECOLÓGICA NAS COMUNIDADES } \\
\text { ONDE ATUO. }\end{array}$ \\
\hline$x$ & CONTINUEI ME APERFEIÇOANDO SOBRE TEMAS ABORDADOS. \\
\hline
\end{tabular}

7) Depois do curso você apoiou atividades de capacitação de técnicos e agricultores com base nos princípios e diretrizes da Pnater? ? (Considere como apoio a atividades de capacitação a participação no planejamento, elaboração de ementas, seleção de participantes e de palestrantes.)

\begin{tabular}{|l|l|}
\hline$x$ & SIM \\
\hline & NÃO \\
\hline
\end{tabular}

8) Usou os conhecimentos para ministrar outros cursos com o mesmo conteúdo ou conteúdos semelhantes?

\begin{tabular}{|l|l|}
\hline$x$ & SIM \\
\hline & NÃO \\
\hline
\end{tabular}

9) Marque o seu grau de satisfação com relação ao curso oferecido pelo DATER: (Considere a seguinte pontuação: 1 - MUITO RUIM; 2 - RUIM; 3 - REGULAR; 4 - BOM; 5 - MUITO BOM) 


\begin{tabular}{|l|l|l|l|l|}
\hline 1 & 2 & 3 & $4 \times$ & 5 \\
\hline
\end{tabular}

10) Marque seu grau de satisfação com relação ao DATER: (Considere a seguinte pontuação:

1 - MUITO RUIM; 2 - RUIM; 3 - REGULAR; 4 - BOM; 5 - MUITO BOM)

\begin{tabular}{|l|l|l|l|l|}
\hline 1 & 2 & 3 & $4 \times$ & 5 \\
\hline
\end{tabular}


PESQUISA - IMPACTO DAS AÇÕES DE FORMAÇÃO REALIZADAS PELO DATER/SAF/MDA NO PERÍODO 2004-2009

Caros colaboradores,

Contamos com a sua atenção para preencher o formulário abaixo.

O mesmo tem por objetivo fornecer informações para avaliação da Eficiência, Efetividade e Eficácia da Política Pública de Formação de Agentes de Ater adotada pelo Departamento de Assistência Técnica e Extensão Rural, da Secretaria de Agricultura Familiar do Ministério do Desenvolvimento - DATER/SAF/MDA, no período de 2004 a 2009, tema escolhido para Monografia a ser apresentada à Universidade de Brasília (UnB) como requisito parcial para obtenção do grau de Bacharel em Administração.

Você poderá ou não se identificar no questionário e garantimos que todas as informações fornecidas serão confidenciais e utilizadas apenas de forma sistematizada.

\section{IDENTIFICAÇÃO}

\begin{tabular}{|l|l|}
\hline Nome: Abderval Júnior & $\begin{array}{l}\text { Sexo: } \\
(x) \text { masculino } \quad(\quad) \text { feminino }\end{array}$ \\
\hline Instituição: AGERP MA & Local de trabalho: São Luis \\
\hline $\begin{array}{l}\text { Curso/Encontro/Oficina do qual participou (caso tenha participado de mais de um curso, preencha } \\
\text { um formulário para cada um deles): Crédito Rural }\end{array}$ \\
\hline Data do Curso/Encontro/Oficina: 2008
\end{tabular}

Indique sua área de atuação? (As opções não são excludentes: você poderá marcar mais de uma opção).

\begin{tabular}{|l|l|}
\hline$X$ & EXTENSÃO RURAL \\
\hline & PESQUISA \\
\hline & ENSINO \\
\hline & OUTROS \\
\hline
\end{tabular}

2) Qual o seu nível de escolaridade? ( Considere apenas o nível mais alto) 


\begin{tabular}{|l|l|}
\hline & NÍVEL MÉDIO \\
\hline$x$ & NÍVEL SUPERIOR \\
\hline & PÓS-GRADUAÇÃO \\
\hline
\end{tabular}

3) Os conteúdos abordados foram condizentes com as demandas do seu dia-a-dia?

\begin{tabular}{|l|l|}
\hline & SIM \\
\hline$x$ & PARCIALMENTE \\
\hline & NÃO \\
\hline
\end{tabular}

3) O curso contribuiu para o seu aperfeiçoamento profissional?

\begin{tabular}{|l|l|}
\hline$X$ & SIM \\
\hline & NÃO \\
\hline
\end{tabular}

5) Os conhecimentos adquiridos estão sendo aplicados no seu trabalho? Em caso afirmativo, indique em que grau estes conhecimentos estão sendo aplicados. Em caso negativo, indique por que razão isto não ocorre: (As respostas não são excludentes: você poderá marcar mais de uma opção).

\begin{tabular}{|c|c|c|}
\hline \multirow{3}{*}{$\begin{array}{l}\text { SIM (indique ao lado em } \\
\text { que grau) }\end{array}$} & & MUITO APLICADOS \\
\hline & $\mathrm{x}$ & MEDIAMENTE APLICADOS \\
\hline & & POUCO APLICADOS \\
\hline \multirow{4}{*}{$\begin{array}{l}\text { NÃO (indique ao lado a } \\
\text { razão da não aplicação) }\end{array}$} & & $\begin{array}{l}\text { CONTEÚDO NĀO ADEQUADO ȦS NECESSIDADES } \\
\text { ESPECÍFICAS DA REGIÃO }\end{array}$ \\
\hline & & $\begin{array}{lccr}\text { CONTEÚDO } & \text { NÃO } & \text { FOI } & \text { SUFICIENTEMENTE } \\
\text { APROFUNDADO PARA } & \text { PERMITIR UMA APLICAÇÃO } \\
\text { EFICAZ E EFICIENTE }\end{array}$ \\
\hline & & 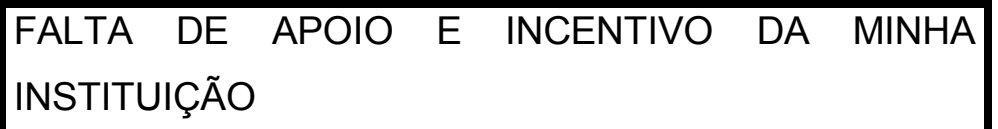 \\
\hline & & FALTA DE INCENTIVO ÀS AÇÕES DE ATER \\
\hline
\end{tabular}




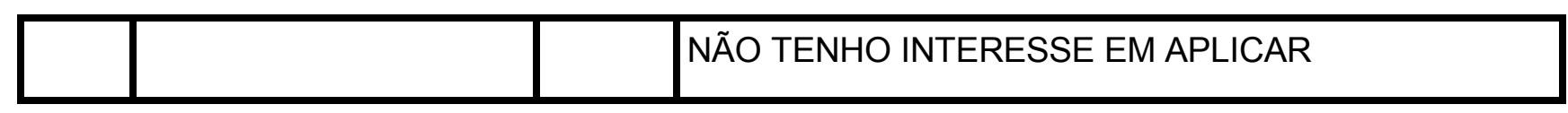

6) A partir deste curso: (As opções não são excludentes: você poderá marcar mais de uma opção).

\begin{tabular}{|l|l|}
\hline$x$ & $\begin{array}{l}\text { NÃO MUDOU NADA EM MEU TRABALHO. } \\
\text { FAMILIARES. }\end{array}$ \\
\hline & CONSEGUI INFLUENCIAR NAS ORIENTAÇÕES DA MINHA INSTITUIÇÃO. \\
\hline & PASSEI A TRABALHAR COM METODOLOGIAS PARTICIPATIVAS. \\
\hline & $\begin{array}{l}\text { CRESCEU A ÁREA DE AGRICULTURA DE BASE ECOLÓGICA NAS COMUNIDADES } \\
\text { ONDE ATUO. }\end{array}$ \\
\hline & CONTINUEI ME APERFEIÇOANDO SOBRE TEMAS ABORDADOS. \\
\hline
\end{tabular}

7) Depois do curso você apoiou atividades de capacitação de técnicos e agricultores com base nos princípios e diretrizes da Pnater? (Considere como apoio a atividades de capacitação a participação no planejamento, elaboração de ementas, seleção de participantes e de palestrantes.)

\begin{tabular}{|l|l|}
\hline & SIM \\
\hline$x$ & NÃO \\
\hline
\end{tabular}

8) Usou os conhecimentos para ministrar outros cursos com o mesmo conteúdo ou conteúdos semelhantes?

\begin{tabular}{|l|l|}
\hline$x$ & SIM \\
\hline & NÃO \\
\hline
\end{tabular}

9) Marque o seu grau de satisfação com relação ao curso oferecido pelo DATER: (Considere a seguinte pontuação: 1 - MUITO RUIM; 2 - RUIM; 3 - REGULAR; 4 - BOM; 5 - MUITO BOM) 


\begin{tabular}{|l|l|l|l|l|}
\hline 1 & 2 & 3 & $4 \times$ & 5 \\
\hline
\end{tabular}

10) Marque seu grau de satisfação com relação ao DATER: (Considere a seguinte pontuação: 1 - MUITO RUIM; 2 - RUIM; 3 - REGULAR; 4 - BOM; 5 - MUITO BOM)

\begin{tabular}{|l|l|l|l|l|}
\hline 1 & 2 & 3 & $4 x$ & 5 \\
\hline
\end{tabular}


PESQUISA - IMPACTO DAS AÇÕES DE FORMAÇÃO REALIZADAS PELO DATER/SAF/MDA NO PERÍODO 2004-2009

Caros colaboradores,

Contamos com a sua atenção para preencher o formulário abaixo.

O mesmo tem por objetivo fornecer informações para avaliação da Eficiência, Efetividade e Eficácia da Política Pública de Formação de Agentes de Ater adotada pelo Departamento de Assistência Técnica e Extensão Rural, da Secretaria de Agricultura Familiar do Ministério do Desenvolvimento - DATER/SAF/MDA, no período de 2004 a 2009, tema escolhido para Monografia a ser apresentada à Universidade de Brasília (UnB) como requisito parcial para obtenção do grau de Bacharel em Administração.

Você poderá ou não se identificar no questionário e garantimos que todas as informações fornecidas serão confidenciais e utilizadas apenas de forma sistematizada.

\section{IDENTIFICAÇÃO}

\begin{tabular}{|l|l|}
\hline Nome: Adalberto Soares de Oliveira & $\begin{array}{l}\text { Sexo: } \\
(\mathrm{x}) \text { masculino } \quad(\quad) \text { feminino }\end{array}$ \\
\hline Instituição : EMATER PI & Local de trabalho : SÃO JOÃO DO PIAUÍ \\
\hline $\begin{array}{l}\text { Curso/Encontro/Oficina do qual participou : Formação de Formadores do Projeto Cultivando } \\
\text { Saberes }\end{array}$ \\
\hline Data do Curso/Encontro/Oficina: julho 2009 \\
\hline
\end{tabular}

1. Indique sua área de atuação? (As opções não são excludentes: você poderá marcar mais de uma opção).

\begin{tabular}{|l|l|}
\hline$x$ & EXTENSÃO RURAL \\
\hline & PESQUISA \\
\hline & ENSINO \\
\hline & OUTROS \\
\hline
\end{tabular}


2) Qual o seu nível de escolaridade? (Considere apenas o nível mais alto)

\begin{tabular}{|l|l|}
\hline & NÍVEL MÉDIO \\
\hline$x$ & NÍVEL SUPERIOR \\
\hline & PÓS-GRADUAÇÃO \\
\hline
\end{tabular}

3) Os conteúdos abordados foram condizentes com as demandas do seu dia-a-dia?

\begin{tabular}{|l|l|}
\hline$x$ & SIM \\
\hline & PARCIALMENTE \\
\hline & NÃO \\
\hline
\end{tabular}

3) O curso contribuiu para o seu aperfeiçoamento profissional?

\begin{tabular}{|l|l|}
\hline$x$ & SIM \\
\hline & NÃO \\
\hline
\end{tabular}

5) Os conhecimentos adquiridos estão sendo aplicados no seu trabalho? Em caso afirmativo, indique em que grau estes conhecimentos estão sendo aplicados. Em caso negativo, indique por que razão isto não ocorre: (As respostas não são excludentes: você poderá marcar mais de uma opção).

\begin{tabular}{|l|l|l|}
\hline \multirow{2}{*}{$\begin{array}{l}\text { SIM (indique ao lado em } \\
\text { que grau) }\end{array}$} & MUITO APLICADOS \\
\cline { 2 - 3 } & & MEDIAMENTE APLICADOS \\
\hline $\begin{array}{l}\text { NÃO (indique ao lado a } \\
\text { razão da não aplicação) }\end{array}$ & $\begin{array}{l}\text { CONTEÚDO NÃO ADEQUADO ȦS NECESSIDADES } \\
\text { ESPECÍFICAS DA REGIÃO }\end{array}$ \\
\hline
\end{tabular}




\begin{tabular}{|l|l|l|}
\hline \multirow{10}{*}{} & & $\begin{array}{l}\text { CONTEÚDO NÃO FOI SUFICIENTEMENTE } \\
\text { APROFUNDADO PARA PERMITIR UMA APLICAÇÃO } \\
\text { EFICAZ E EFICIENTE }\end{array}$ \\
\cline { 2 - 5 } & $\begin{array}{l}\text { FALTA DE APOIO E INCENTIVO DA MINHA } \\
\text { INSTITUIÇÃO }\end{array}$ \\
\cline { 2 - 4 } & FALTA DE INCENTIVO ÀS AÇÕES DE ATER \\
\hline & NÃO TENHO INTERESSE EM APLICAR \\
\hline
\end{tabular}

6) A partir deste curso: (As opções não são excludentes: você poderá marcar mais de uma opção).

\begin{tabular}{|l|l|}
\hline$X$ & NÃO MUDOU NADA EM MEU TRABALHO. \\
\hline & $\begin{array}{l}\text { MEU TRABALHO PASSOU A CONTRIBUIR MAIS COM OS AGRICULTORES(AS) } \\
\text { FAMILIARES. }\end{array}$ \\
\hline & CONSEGUI INFLUENCIAR NAS ORIENTAÇÕES DA MINHA INSTITUIÇÃO. \\
\hline & $\begin{array}{l}\text { CRESESE A TRABALHAR COM METODOLOGIAS PARTICIPATIVAS. } \\
\text { ONDE ATUO. ÁREA DE AGRICULTURA DE BASE ECOLÓGICA NAS COMUNIDADES }\end{array}$ \\
\hline & CONTINUEI ME APERFEIÇOANDO SOBRE TEMAS ABORDADOS. \\
\hline
\end{tabular}

7) Depois do curso você apoiou atividades de capacitação de técnicos e agricultores com base nos princípios e diretrizes da Pnater? (Considere como apoio a atividades de capacitação a participação no planejamento, elaboração de ementas, seleção de participantes e de palestrantes.)

\begin{tabular}{|l|l|}
\hline & SIM \\
\hline$X$ & NÃO \\
\hline
\end{tabular}

8) Usou os conhecimentos para ministrar outros cursos com o mesmo conteúdo ou conteúdos semelhantes? 


\begin{tabular}{|l|l|}
\hline & SIM \\
\hline$X$ & NÃO \\
\hline
\end{tabular}

9) Marque o seu grau de satisfação com relação ao curso oferecido pelo DATER: (Considere a seguinte pontuação: 1 - MUITO RUIM; 2 - RUIM; 3 - REGULAR; 4 - BOM; 5 - MUITO BOM)

\begin{tabular}{|l|l|l|l|l|}
\hline 1 & 2 & 3 & 4 & $x 5$ \\
\hline
\end{tabular}

10) Marque seu grau de satisfação com relação ao DATER: (Considere a seguinte pontuação: 1 - MUITO RUIM; 2 - RUIM; 3 - REGULAR; 4 - BOM; 5 - MUITO BOM)

\begin{tabular}{|l|l|l|l|l|}
\hline 1 & 2 & 3 & 4 & $x 5$ \\
\hline
\end{tabular}


PESQUISA - IMPACTO DAS AÇÕES DE FORMAÇÃO REALIZADAS PELO DATER/SAF/MDA NO PERÍODO 2004-2009

Caros colaboradores,

Contamos com a sua atenção para preencher o formulário abaixo.

O mesmo tem por objetivo fornecer informações para avaliação da Eficiência, Efetividade e Eficácia da Política Pública de Formação de Agentes de Ater adotada pelo Departamento de Assistência Técnica e Extensão Rural, da Secretaria de Agricultura Familiar do Ministério do Desenvolvimento - DATER/SAF/MDA, no período de 2004 a 2009, tema escolhido para Monografia a ser apresentada à Universidade de Brasília (UnB) como requisito parcial para obtenção do grau de Bacharel em Administração.

Você poderá ou não se identificar no questionário e garantimos que todas as informações fornecidas serão confidenciais e utilizadas apenas de forma sistematizada.

IDENTIFICAÇÃO

\begin{tabular}{|l|l|}
\hline Nome: Alexandre Mees & $\begin{array}{l}\text { Sexo: } \\
(\mathrm{x}) \text { masculino } \quad(\quad) \text { feminino }\end{array}$ \\
\hline Instituição: AGERP MA & Local de trabalho: Codó - MA \\
\hline $\begin{array}{l}\text { Curso/Encontro/Oficina do qual participou (caso tenha participado de mais de um curso, preencha } \\
\text { um formulário para cada um deles): Cadeias Produtivas e Arranjos Produtivos Locais }\end{array}$ \\
\hline Data do Curso/Encontro/Oficina: 2009 \\
\hline
\end{tabular}

Indique sua área de atuação? (As opções não são excludentes: você poderá marcar mais de uma opção).

\begin{tabular}{|l|l|}
\hline$X$ & EXTENSÃO RURAL \\
\hline$X$ & PESQUISA \\
\hline & ENSINO \\
\hline & OUTROS \\
\hline
\end{tabular}

2) Qual o seu nível de escolaridade? (Considere apenas o nível mais alto) 


\begin{tabular}{|l|l|}
\hline$X$ & NÍVEL MÉDIO \\
\hline & NÍVEL SUPERIOR \\
\hline & PÓS-GRADUAÇÃO \\
\hline
\end{tabular}

3) Os conteúdos abordados foram condizentes com as demandas do seu dia-a-dia?

\begin{tabular}{|l|l|}
\hline & SIM \\
\hline$x$ & PARCIALMENTE \\
\hline & NÃO \\
\hline
\end{tabular}

3) O curso contribuiu para o seu aperfeiçoamento profissional?

\begin{tabular}{|l|l|}
\hline$X$ & SIM \\
\hline & NÃO \\
\hline
\end{tabular}

5) Os conhecimentos adquiridos estão sendo aplicados no seu trabalho? Em caso afirmativo, indique em que grau estes conhecimentos estão sendo aplicados. Em caso negativo, indique por que razão isto não ocorre: (As respostas não são excludentes: você poderá marcar mais de uma opção).

\begin{tabular}{|c|c|c|}
\hline \multirow{3}{*}{$\begin{array}{l}\text { SIM (indique ao lado em } \\
\text { que grau) }\end{array}$} & & MUITO APLICADOS \\
\hline & & MEDIAMENTE APLICADOS \\
\hline & $\mathrm{X}$ & POUCO APLICADOS \\
\hline \multirow{3}{*}{$\begin{array}{l}\text { NÃO (indique ao lado a } \\
\text { razão da não aplicação) }\end{array}$} & & $\begin{array}{l}\text { CONTEÚDO NÃO ADEQUADO ȦS NECESSIDADES } \\
\text { ESPECÍFICAS DA REGIÃO }\end{array}$ \\
\hline & & $\begin{array}{l}\text { CONTEÚDO NÃO } \quad \text { FOI SUFICIENTEMENTE } \\
\text { APROFUNDADO PARA } \\
\text { PERMITIR UMA APLICAÇÃO } \\
\text { EFICAZ E EFICIENTE }\end{array}$ \\
\hline & & $\begin{array}{l}\text { FALTA DE APOIO } \\
\text { INSTITUIÇÃO }\end{array}$ \\
\hline
\end{tabular}




\begin{tabular}{|l|l|l|}
\hline \multirow{2}{*}{} & & FALTA DE INCENTIVO ÀS AÇÕES DE ATER \\
\cline { 3 - 4 } & & NÃO TENHO INTERESSE EM APLICAR \\
\hline
\end{tabular}

6) A partir deste curso: (As opções não são excludentes: você poderá marcar mais de uma opção).

\begin{tabular}{|l|l|}
\hline$x$ & $\begin{array}{l}\text { NÃO MUDOU NADA EM MEU TRABALHO. } \\
\text { FAMILIARES. }\end{array}$ \\
\hline & CONSEGUI INFLUENCIAR NAS ORIENTAÇÕES DA MINHA INSTITUIÇÃO. \\
\hline & PASSEI A TRABALHAR COM METODOLOGIAS PARTICIPATIVAS. \\
\hline & $\begin{array}{l}\text { CRESCEU A ÁREA DE AGRICULTURA DE BASE ECOLÓGICA NAS COMUNIDADES } \\
\text { ONDE ATUO. }\end{array}$ \\
\hline & CONTINUEI ME APERFEIÇOANDO SOBRE TEMAS ABORDADOS. \\
\hline
\end{tabular}

7) Depois do curso você apoiou atividades de capacitação de técnicos e agricultores com base nos princípios e diretrizes da Pnater? (Considere como apoio a atividades de capacitação a participação no planejamento, elaboração de ementas, seleção de participantes e de palestrantes.)

\begin{tabular}{|l|l|}
\hline & SIM \\
\hline$x$ & NÃO \\
\hline
\end{tabular}

8) Usou os conhecimentos para ministrar outros cursos com o mesmo conteúdo ou conteúdos semelhantes?

\begin{tabular}{|l|l|}
\hline & SIM \\
\hline$X$ & NÃO \\
\hline
\end{tabular}

9) Marque o seu grau de satisfação com relação ao curso oferecido pelo DATER: (Considere a seguinte pontuação: 1 - MUITO RUIM; 2 - RUIM; 3 - REGULAR; 4 - BOM; 5 - MUITO BOM) 


\begin{tabular}{|l|l|l|l|l|}
\hline 1 & 2 & 3 & 4 & $\times 5$ \\
\hline
\end{tabular}

10) Marque seu grau de satisfação com relação ao DATER: (Considere a seguinte pontuação: 1 - MUITO RUIM; 2 - RUIM; 3 - REGULAR; 4 - BOM; 5 - MUITO BOM)

\begin{tabular}{|l|l|l|l|l|}
\hline 1 & 2 & 3 & 4 & $X 5$ \\
\hline
\end{tabular}


PESQUISA - IMPACTO DAS AÇÕES DE FORMAÇÃO REALIZADAS PELO DATER/SAF/MDA NO PERÍODO 2004-2009

Caros colaboradores,

Contamos com a sua atenção para preencher o formulário abaixo.

O mesmo tem por objetivo fornecer informações para avaliação da Eficiência, Efetividade e Eficácia da Política Pública de Formação de Agentes de Ater adotada pelo Departamento de Assistência Técnica e Extensão Rural, da Secretaria de Agricultura Familiar do Ministério do Desenvolvimento - DATER/SAF/MDA, no período de 2004 a 2009, tema escolhido para Monografia a ser apresentada à Universidade de Brasília (UnB) como requisito parcial para obtenção do grau de Bacharel em Administração.

Você poderá ou não se identificar no questionário e garantimos que todas as informações fornecidas serão confidenciais e utilizadas apenas de forma sistematizada.

IDENTIFICAÇÃO

\begin{tabular}{|c|c|}
\hline $\begin{array}{lllll}\text { Nome: } & \text { ALEIDE } & \text { MARGARETE } & \text { GODE } & \text { DE } \\
\text { VASCONCELOS } & & & \\
\end{array}$ & $\begin{array}{l}\text { Sexo: } \\
(\quad) \text { masculino } \quad(x) \text { feminino }\end{array}$ \\
\hline $\begin{array}{l}\text { Instituição (nome e tipo de instituição: ONG, } \\
\text { Empresa Pública, etc.): } \\
\text { IPA - EMPRESA PERNAMBUCANA DE } \\
\text { PESQUISA AGROPECUARIA }\end{array}$ & $\begin{array}{l}\text { Local de trabalho (Cidade e Estado): } \\
\text { TABIRA-PE }\end{array}$ \\
\hline \multicolumn{2}{|c|}{$\begin{array}{l}\text { Curso/Encontro/Oficina do qual participou (caso tenha participado de mais de um curso, preencha } \\
\text { um formulário para cada um deles): } \\
\text { PLANTAS MEDICINAIS, CONDIMENTARES E AROMÁTICAS }\end{array}$} \\
\hline $\begin{array}{l}\text { Data do Curso/Encontro/Oficina (pelo menos mês e } \\
\text { 10/2005 }\end{array}$ & \\
\hline
\end{tabular}

Indique sua área de atuação? (As opções não são excludentes: você poderá marcar mais de uma opção).

\begin{tabular}{|l|l|}
\hline$X$ & EXTENSÃO RURAL \\
\hline & PESQUISA \\
\hline & ENSINO \\
\hline
\end{tabular}




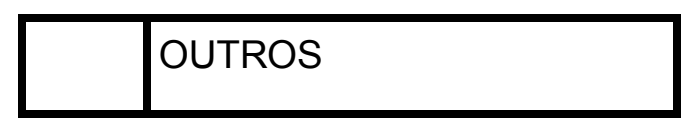

2) Qual o seu nível de escolaridade? ( Considere apenas o nível mais alto)

\begin{tabular}{|l|l|}
\hline & NÍVEL MÉDIO \\
\hline & NÍVEL SUPERIOR \\
\hline$x$ & $\begin{array}{l}\text { PÓS-GRADUAÇĀO } \\
\text { (ESPECIALIZAÇÃO) }\end{array}$ \\
\hline
\end{tabular}

3) Os conteúdos abordados foram condizentes com as demandas do seu dia-a-dia?

\begin{tabular}{|l|l|}
\hline$X$ & SIM \\
\hline & PARCIALMENTE \\
\hline & NÃO \\
\hline
\end{tabular}

3) O curso contribuiu para o seu aperfeiçoamento profissional?

\begin{tabular}{|l|l|}
\hline$X$ & SIM \\
\hline & NÃO \\
\hline
\end{tabular}

5) Os conhecimentos adquiridos estão sendo aplicados no seu trabalho? Em caso afirmativo, indique em que grau estes conhecimentos estão sendo aplicados. Em caso negativo, indique por que razão isto não ocorre: (As respostas não são excludentes: você poderá marcar mais de uma opção).

\begin{tabular}{|l|l|l|l|}
\hline \multirow{2}{*}{$\begin{array}{l}\text { SIM (indique ao lado em } \\
\text { que grau) }\end{array}$} & $X$ & MUITO APLICADOS \\
\cline { 2 - 3 } & & MEDIAMENTE APLICADOS \\
\hline & $\begin{array}{l}\text { NÃO (indique ao lado a } \\
\text { razão da não aplicação) }\end{array}$ & & $\begin{array}{l}\text { CONTEÚDO NÃO ADEQUADO ȦS NECESSIDADES } \\
\text { ESPECÍFICAS DA REGIÃO }\end{array}$ \\
\hline
\end{tabular}




\begin{tabular}{|l|l|l|}
\hline \multirow{10}{*}{} & & $\begin{array}{l}\text { CONTEÚDO NÃO FOI SUFICIENTEMENTE } \\
\text { APROFUNDADO PARA PERMITIR UMA APLICAÇÃO } \\
\text { EFICAZ E EFICIENTE }\end{array}$ \\
\cline { 2 - 5 } & $\begin{array}{l}\text { FALTA DE APOIO E INCENTIVO DA MINHA } \\
\text { INSTITUIÇÃO }\end{array}$ \\
\cline { 2 - 4 } & FALTA DE INCENTIVO ÀS AÇÕES DE ATER \\
\hline & NÃO TENHO INTERESSE EM APLICAR \\
\hline
\end{tabular}

6) A partir deste curso: (As opções não são excludentes: você poderá marcar mais de uma opção).

\begin{tabular}{|l|l|}
\hline$x$ & $\begin{array}{l}\text { NÃO MUDOU NADA EM MEU TRABALHO. } \\
\text { FAMILIARES. }\end{array}$ \\
\hline & CONSEGUI INFLUENCIAR NAS ORIENTAÇÕES DA MINHA INSTITUIÇÃO. \\
\hline & PASSEI A TRABALHAR COM METODOLOGIAS PARTICIPATIVAS. \\
\hline & $\begin{array}{l}\text { ORESCEU A ÁREA DE AGRICULTURA DE BASE ECOLÓGICA NAS COMUNIDADES } \\
\text { CONTINUEI ME APERFEIÇOANDO SOBRE TEMAS ABORDADOS. }\end{array}$ \\
\hline
\end{tabular}

7) Depois do curso você apoiou atividades de capacitação de técnicos e agricultores com base nos princípios e diretrizes da Pnater? (Considere como apoio a atividades de capacitação a participação no planejamento, elaboração de ementas, seleção de participantes e de palestrantes.)

\begin{tabular}{|l|l|}
\hline & SIM \\
\hline$X$ & NÃO \\
\hline
\end{tabular}

8) Usou os conhecimentos para ministrar outros cursos com o mesmo conteúdo ou conteúdos semelhantes? 


\begin{tabular}{|l|l|}
\hline$X$ & SIM \\
\hline & NÃO \\
\hline
\end{tabular}

9) Marque o seu grau de satisfação com relação ao curso oferecido pelo DATER: (Considere a seguinte pontuação: 1 - MUITO RUIM; 2 - RUIM; 3 - REGULAR; 4 - BOM; 5 - MUITO BOM)

\begin{tabular}{|l|l|l|l|l|}
\hline 1 & 2 & 3 & 4 & $5 X$ \\
\hline
\end{tabular}

10) Marque seu grau de satisfação com relação ao DATER: (Considere a seguinte pontuação: 1 - MUITO RUIM; 2 - RUIM; 3 - REGULAR; 4 - BOM; 5 - MUITO BOM)

\begin{tabular}{|l|l|l|l|l|}
\hline 1 & 2 & 3 & 4 & $5 X$ \\
\hline
\end{tabular}


PESQUISA - IMPACTO DAS AÇÕES DE FORMAÇÃO REALIZADAS PELO DATER/SAF/MDA NO PERÍODO 2004-2009

Caros colaboradores,

Contamos com a sua atenção para preencher o formulário abaixo.

O mesmo tem por objetivo fornecer informações para avaliação da Eficiência, Efetividade e Eficácia da Política Pública de Formação de Agentes de Ater adotada pelo Departamento de Assistência Técnica e Extensão Rural, da Secretaria de Agricultura Familiar do Ministério do Desenvolvimento - DATER/SAF/MDA, no período de 2004 a 2009, tema escolhido para Monografia a ser apresentada à Universidade de Brasília (UnB) como requisito parcial para obtenção do grau de Bacharel em Administração.

Você poderá ou não se identificar no questionário e garantimos que todas as informações fornecidas serão confidenciais e utilizadas apenas de forma sistematizada.

IDENTIFICAÇÃO

\begin{tabular}{|l|l|}
\hline Nome: & Sexo: \\
ALEXANDRE CORTEZ DE SOUZA & $(\mathrm{x})$ masculino $\quad(\quad$ ) feminino \\
\hline $\begin{array}{l}\text { Instituição (nome e tipo de instituição: ONG, } \\
\text { Empresa Pública, etc.): }\end{array}$ & Local de trabalho (Cidade e Estado): \\
EMATERCE & FORTALEZA - CE \\
\hline $\begin{array}{l}\text { Curso/Encontro/Oficina do qual participou (caso tenha participado de mais de um curso, preencha } \\
\text { um formulário para cada um deles): } \\
\text { Curso de Especialização em Extensão Rural, Agroecologia e Desenvolvimento Sustentável }\end{array}$ \\
\hline \begin{tabular}{l} 
Data do Curso/Encontro/Oficina (pelo menos mês e ano): maio a dezembro de 2006 \\
\hline
\end{tabular}
\end{tabular}

Indique sua área de atuação? (As opções não são excludentes: você poderá marcar mais de uma opção).

\begin{tabular}{|l|l|}
\hline$X$ & EXTENSÃO RURAL \\
\hline$X$ & PESQUISA \\
\hline & ENSINO \\
\hline
\end{tabular}




\section{OUTROS}

2) Qual o seu nível de escolaridade? ( Considere apenas o nível mais alto)

\begin{tabular}{|l|l|}
\hline & NÍVEL MÉDIO \\
\hline & NÍVEL SUPERIOR \\
\hline$X$ & PÓS-GRADUAÇÃO \\
\hline
\end{tabular}

3) Os conteúdos abordados foram condizentes com as demandas do seu dia-a-dia?

\begin{tabular}{|l|l|}
\hline$X$ & SIM \\
\hline & PARCIALMENTE \\
\hline & NÃO \\
\hline
\end{tabular}

4) O curso contribuiu para o seu aperfeiçoamento profissional?

\begin{tabular}{|l|l|}
\hline$X$ & SIM \\
\hline & NÃO \\
\hline
\end{tabular}

5) Os conhecimentos adquiridos estão sendo aplicados no seu trabalho? Em caso afirmativo, indique em que grau estes conhecimentos estão sendo aplicados. Em caso negativo, indique por que razão isto não ocorre: (As respostas não são excludentes: você poderá marcar mais de uma opção).

\begin{tabular}{|c|c|c|}
\hline \multirow{3}{*}{$\begin{array}{l}\text { SIM (indique ao lado em } \\
\text { que grau) }\end{array}$} & $x$ & MUITO APLICADOS \\
\hline & & MEDIAMENTE APLICADOS \\
\hline & & POUCO APLICADOS \\
\hline \multirow{3}{*}{$\begin{array}{l}\text { NÃO (indique ao lado a } \\
\text { razão da não aplicação) }\end{array}$} & & CONTEÚDO NÃO ADEQUADO ȦS NECESSIDADES \\
\hline & & $\begin{array}{llll}\text { CONTEÚDO NÂOO } & \text { FOI SUFICIENTEMENTE } \\
\text { APROFUNDADO } & \text { PARA } & \text { PERMITIR UMA } & \text { APLICAÇÃO }\end{array}$ \\
\hline & & $\begin{array}{lcccccc}\text { FALTA } & \text { DE } & \text { APOIO } & \text { E } & \text { INCENTIVO } & \text { DA } & \text { MINHA } \\
\text { INSTITUICÃO } & & & & & \\
\end{array}$ \\
\hline
\end{tabular}




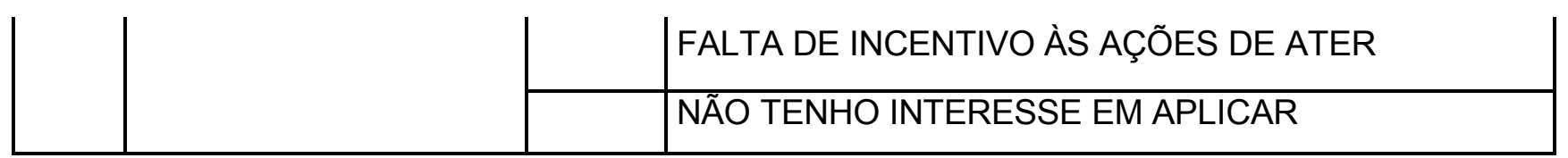

6) A partir deste curso: (As opções não são excludentes: você poderá marcar mais de uma opção).

\begin{tabular}{|l|l|}
\hline & NÃO MUDOU NADA EM MEU TRABALHO. \\
\hline$X$ & $\begin{array}{l}\text { MEU TRABALHO PASSOU A CONTRIBUIR MAIS COM OS AGRICULTORES(AS) } \\
\text { FAMILIARES. }\end{array}$ \\
\hline$X$ & CONSEGUI INFLUENCIAR NAS ORIENTAÇÕES DA MINHA INSTITUIÇÃO. \\
\hline & $\begin{array}{l}\text { CRASSEI A TRABALHAR COM METODOLOGIAS PARTICIPATIVAS. } \\
\text { ONDE ATUO. }\end{array}$ \\
\hline$X$ & CONTINUEI ME APERFEIÇOANDO SOBRE TEMAS ABORDADOS. \\
\hline
\end{tabular}

7) Depois do curso você apoiou atividades de capacitação de técnicos e agricultores com base nos princípios e diretrizes da Pnater? (Considere como apoio a atividades de capacitação a participação no planejamento, elaboração de ementas, seleção de participantes e de palestrantes.)

\begin{tabular}{|l|l|}
\hline$X$ & SIM \\
\hline & NÃO \\
\hline
\end{tabular}

8) Usou os conhecimentos para ministrar outros cursos com o mesmo conteúdo ou conteúdos semelhantes?

\begin{tabular}{|l|l|}
\hline & SIM \\
\hline$X$ & NÃO \\
\hline
\end{tabular}

9) Marque o seu grau de satisfação com relação ao curso oferecido pelo DATER: (Considere a seguinte pontuação: 1 - MUITO RUIM; 2 - RUIM; 3 - REGULAR; 4 - BOM; 5 - MUITO BOM) 


\begin{tabular}{|l|l|l|l|l|}
\hline 1 & 2 & $3 X$ & 4 & 5 \\
\hline
\end{tabular}

10) Marque seu grau de satisfação com relação ao DATER: (Considere a seguinte pontuação:

1 - MUITO RUIM; 2 - RUIM; 3 - REGULAR; 4 - BOM; 5 - MUITO BOM)

\begin{tabular}{|l|l|l|l|l|}
\hline 1 & 2 & 3 & 4 & $5 X$ \\
\hline
\end{tabular}


PESQUISA - IMPACTO DAS AÇÕES DE FORMAÇÃO REALIZADAS PELO DATER/SAF/MDA NO PERÍODO 2004-2009

Caros colaboradores,

Contamos com a sua atenção para preencher o formulário abaixo.

O mesmo tem por objetivo fornecer informações para avaliação da Eficiência, Efetividade e Eficácia da Política Pública de Formação de Agentes de Ater adotada pelo Departamento de Assistência Técnica e Extensão Rural, da Secretaria de Agricultura Familiar do Ministério do Desenvolvimento - DATER/SAF/MDA, no período de 2004 a 2009, tema escolhido para Monografia a ser apresentada à Universidade de Brasília (UnB) como requisito parcial para obtenção do grau de Bacharel em Administração.

Você poderá ou não se identificar no questionário e garantimos que todas as informações fornecidas serão confidenciais e utilizadas apenas de forma sistematizada. IDENTIFICAÇÃO

\begin{tabular}{|c|c|}
\hline Nome: Anselmo Vital Matos & $\begin{array}{l}\text { Sexo: } \\
(x) \text { masculino } \quad(\quad) \text { feminino }\end{array}$ \\
\hline Instituição: FETAG (movimento social) & Local de trabalho: Salvador - Bahia \\
\hline $\begin{array}{l}\text { Curso/Encontro/Oficina do qual participou: Curso } \\
\text { Paraíba }\end{array}$ & Sistemas Silviagropastoris para Caatinga - \\
\hline Data do Curso/Encontro/Oficina: Novembro - 2006 & \\
\hline
\end{tabular}

1.Indique sua área de atuação? (As opções não são excludentes: você poderá marcar mais de uma opção).

\begin{tabular}{|l|l|}
\hline$X$ & EXTENSÃO RURAL \\
\hline & PESQUISA \\
\hline & ENSINO \\
\hline & OUTROS \\
\hline
\end{tabular}

2) Qual o seu nível de escolaridade? ( Considere apenas o nível mais alto) 


\begin{tabular}{|c|l|}
\hline & NÍVEL MÉDIO \\
\hline$X$ & NÍVEL SUPERIOR \\
\hline & PÓS-GRADUAÇÃO \\
\hline
\end{tabular}

3) Os conteúdos abordados foram condizentes com as demandas do seu dia-a-dia?

\begin{tabular}{|l|l|}
\hline$X$ & SIM \\
\hline & PARCIALMENTE \\
\hline & NÃO \\
\hline
\end{tabular}

3) O curso contribuiu para o seu aperfeiçoamento profissional?

\begin{tabular}{|l|l|}
\hline$X$ & SIM \\
\hline & NÃO \\
\hline
\end{tabular}

5) Os conhecimentos adquiridos estão sendo aplicados no seu trabalho? Em caso afirmativo, indique em que grau estes conhecimentos estão sendo aplicados. Em caso negativo, indique por que razão isto não ocorre: (As respostas não são excludentes: você poderá marcar mais de uma opção).

\begin{tabular}{|c|c|c|}
\hline \multirow{3}{*}{$\begin{array}{l}\text { SIM (indique ao lado em } \\
\text { que grau) }\end{array}$} & & MUITO APLICADOS \\
\hline & $\bar{X}$ & MEDIAMENTE APLICADOS \\
\hline & & POUCO APLICADOS \\
\hline \multirow{2}{*}{$\begin{array}{l}\text { NÃO (indique ao lado a } \\
\text { razão da não aplicação) }\end{array}$} & & $\begin{array}{l}\text { CONTEÚDO NĀO ADEQUADO ȦS NECESSIDADES } \\
\text { ESPECÍFICAS DA REGIÃO }\end{array}$ \\
\hline & & $\begin{array}{l}\text { CONTEÚDO NÃO FOI SUFICIENTEMENTE } \\
\text { APROFUNDADO PARA PERMITIR UMA APLICAÇÃO } \\
\text { EFICAZ E EFICIENTE }\end{array}$ \\
\hline
\end{tabular}




\begin{tabular}{|l|l|l|}
\hline \multirow{2}{*}{} & & $\begin{array}{l}\text { FALTA DE APOIO E INCENTIVO DA MINHA } \\
\text { INSTITUIÇÃO }\end{array}$ \\
\cline { 2 - 3 } & & FALTA DE INCENTIVO ÀS AÇÕES DE ATER \\
\cline { 2 - 3 } & NÃO TENHO INTERESSE EM APLICAR \\
\hline
\end{tabular}

6) A partir deste curso: (As opções não são excludentes: você poderá marcar mais de uma opção).

\begin{tabular}{|c|l|}
\hline$x$ & $\begin{array}{l}\text { NẼO MUDOU NADA EM MEU TRABALHO. } \\
\text { FAMILIARES. }\end{array}$ \\
\hline & CONSEGUI INFLUENCIAR NAS ORIENTAÇÕES DA MINHA INSTITUIÇÃO. \\
\hline & PASSEI A TRABALHAR COM METODOLOGIAS PARTICIPATIVAS. \\
\hline & $\begin{array}{l}\text { CRESCEU A ÁREA DE AGRICULTURA DE BASE ECOLÓGICA NAS COMUNIDADES } \\
\text { ONDE ATUO. }\end{array}$ \\
\hline & CONTINUEI ME APERFEIÇOANDO SOBRE TEMAS ABORDADOS. \\
\hline
\end{tabular}

7) Depois do curso você apoiou atividades de capacitação de técnicos e agricultores com base nos princípios e diretrizes da Pnater? (Considere como apoio a atividades de capacitação a participação no planejamento, elaboração de ementas, seleção de participantes e de palestrantes.)

\begin{tabular}{|l|l|}
\hline & SIM \\
\hline$X$ & NÃO \\
\hline
\end{tabular}

8) Usou os conhecimentos para ministrar outros cursos com o mesmo conteúdo ou conteúdos semelhantes?

\begin{tabular}{|l|l|}
\hline$X$ & SIM \\
\hline & NÃO \\
\hline
\end{tabular}


9) Marque o seu grau de satisfação com relação ao curso oferecido pelo DATER: (Considere a seguinte pontuação: 1 - MUITO RUIM; 2 - RUIM; 3 - REGULAR; 4 - BOM; 5 - MUITO BOM)

\begin{tabular}{|l|l|l|l|l|}
\hline 1 & 2 & 3 & $4 \times X$ & 5 \\
\hline
\end{tabular}

10) Marque seu grau de satisfação com relação ao DATER: (Considere a seguinte pontuação: 1 - MUITO RUIM; 2 - RUIM; 3 - REGULAR; 4 - BOM; 5 - MUITO BOM)

\begin{tabular}{|l|l|l|l|l|}
\hline 1 & 2 & 3 & $4 X X$ & 5 \\
\hline
\end{tabular}


PESQUISA - IMPACTO DAS AÇÕES DE FORMAÇÃO REALIZADAS PELO DATER/SAF/MDA NO PERÍODO 2004-2009

Caros colaboradores,

Contamos com a sua atenção para preencher o formulário abaixo.

O mesmo tem por objetivo fornecer informações para avaliação da Eficiência, Efetividade e Eficácia da Política Pública de Formação de Agentes de Ater adotada pelo Departamento de Assistência Técnica e Extensão Rural, da Secretaria de Agricultura Familiar do Ministério do Desenvolvimento - DATER/SAF/MDA, no período de 2004 a 2009, tema escolhido para Monografia a ser apresentada à Universidade de Brasília (UnB) como requisito parcial para obtenção do grau de Bacharel em Administração.

Você poderá ou não se identificar no questionário e garantimos que todas as informações fornecidas serão confidenciais e utilizadas apenas de forma sistematizada.

\section{IDENTIFICAÇÃO}

\begin{tabular}{|l|l|}
\hline Nome: Antonieta Alves da Costa & $\begin{array}{l}\text { Sexo: } \\
(\mathrm{f}) \text { masculino } \quad(\mathrm{x} \text { ) feminino }\end{array}$ \\
\hline $\begin{array}{l}\text { Instituição (nome e tipo de instituição: ONG, } \\
\text { Empresa Pública, etc.): Secretaria de Agricultura, }\end{array}$ & $\begin{array}{l}\text { Local de trabalho (Cidade e Estado): } \\
\text { Abastecimento e Pesca - Pública }\end{array}$ \\
\hline $\begin{array}{l}\text { Curso/Encontro/Oficina do qual participou (caso tenha participado de mais de um curso, preencha } \\
\text { um formulário para cada um deles): Curso de Formadores da ATER }\end{array}$ \\
\hline Data do Curso/Encontro/Oficina (pelo menos mês e ano): dezembro de 2006 \\
\hline
\end{tabular}

Indique sua área de atuação? (As opções não são excludentes: você poderá marcar mais de uma opção).

\begin{tabular}{|l|l|}
\hline$x$ & EXTENSÃO RURAL \\
\hline & PESQUISA \\
\hline & ENSINO \\
\hline & OUTROS \\
\hline
\end{tabular}


2) Qual o seu nível de escolaridade? (Considere apenas o nível mais alto)

\begin{tabular}{|l|l|}
\hline & NÍVEL MÉDIO \\
\hline$x$ & NÍVEL SUPERIOR \\
\hline & PÓS-GRADUAÇÃO \\
\hline
\end{tabular}

3) Os conteúdos abordados foram condizentes com as demandas do seu dia-a-dia?

\begin{tabular}{|l|l|}
\hline & SIM \\
\hline$x$ & PARCIALMENTE \\
\hline & NÃO \\
\hline
\end{tabular}

3) O curso contribuiu para o seu aperfeiçoamento profissional?

\begin{tabular}{|l|l|}
\hline$x$ & SIM \\
\hline & NÃO \\
\hline
\end{tabular}

5) Os conhecimentos adquiridos estão sendo aplicados no seu trabalho? Em caso afirmativo, indique em que grau estes conhecimentos estão sendo aplicados. Em caso negativo, indique por que razão isto não ocorre: (As respostas não são excludentes: você poderá marcar mais de uma opção).

\begin{tabular}{|l|l|l|l|}
\hline \multirow{2}{*}{$\begin{array}{l}\text { SIM (indique ao lado em } \\
\text { que grau) }\end{array}$} & & MUITO APLICADOS \\
\cline { 3 - 4 } & & MEDIAMENTE APLICADOS \\
\hline \multirow{2}{*}{$\begin{array}{l}\text { NÃO (indique ao lado a } \\
\text { razão da não aplicação) }\end{array}$} & & $\begin{array}{l}\text { COUCO APLICADOS } \\
\text { ESPECÍFICAS DA REGIÃO }\end{array}$ \\
\cline { 3 - 4 } & & $\begin{array}{l}\text { CONTEÚDO NÃO FOI SUFICIENTEMENTE } \\
\text { APROFUNDADO PARA PERMITIR UMA APLICAÇÃO } \\
\text { EFICAZ E EFICIENTE }\end{array}$ \\
\hline
\end{tabular}




\begin{tabular}{|l|l|l|l|}
\hline \multirow{2}{*}{} & $x$ & $\begin{array}{l}\text { FALTA DE APOIO E INCENTIVO DA MINHA } \\
\text { INSTITUIÇÃO }\end{array}$ \\
\hline & $x$ & FALTA DE INCENTIVO ÀS AÇÕES DE ATER \\
\hline & NÃO TENHO INTERESSE EM APLICAR \\
\hline
\end{tabular}

6) A partir deste curso: (As opções não são excludentes: você poderá marcar mais de uma opção).

\begin{tabular}{|l|l|}
\hline & NÃO MUDOU NADA EM MEU TRABALHO. \\
\hline & $\begin{array}{l}\text { MEU TRABALHO PASSOU A CONTRIBUIR MAIS COM OS AGRICULTORES(AS) } \\
\text { FAMILIARES. }\end{array}$ \\
\hline & CONSEGUI INFLUENCIAR NAS ORIENTAÇÕES DA MINHA INSTITUIÇÃO. \\
\hline & PASSEI A TRABALHAR COM METODOLOGIAS PARTICIPATIVAS. \\
\hline & $\begin{array}{l}\text { CRESCEU A ÁREA DE AGRICULTURA DE BASE ECOLÓGICA NAS COMUNIDADES } \\
\text { ONDE ATUO. }\end{array}$ \\
\hline & CONTINUEI ME APERFEIÇOANDO SOBRE TEMAS ABORDADOS. \\
\hline
\end{tabular}

7) Depois do curso você apoiou atividades de capacitação de técnicos e agricultores com base nos princípios e diretrizes da Pnater? (Considere como apoio a atividades de capacitação a participação no planejamento, elaboração de ementas, seleção de participantes e de palestrantes.)

\begin{tabular}{|l|l|}
\hline & SIM \\
\hline$x$ & NÃO \\
\hline
\end{tabular}

8) Usou os conhecimentos para ministrar outros cursos com o mesmo conteúdo ou conteúdos semelhantes?

\begin{tabular}{|l|l|}
\hline & SIM \\
\hline$x$ & NÃO \\
\hline
\end{tabular}


9) Marque o seu grau de satisfação com relação ao curso oferecido pelo DATER: (Considere a seguinte pontuação: 1 - MUITO RUIM; 2 - RUIM; 3 - REGULAR; 4 - BOM; 5 - MUITO BOM)

\begin{tabular}{|l|l|l|l|l|}
\hline 1 & 2 & 3 & 4 & 5 \\
\hline
\end{tabular}

10) Marque seu grau de satisfação com relação ao DATER: (Considere a seguinte pontuação: 1 - MUITO RUIM; 2 - RUIM; 3 - REGULAR; 4 - BOM; 5 - MUITO BOM)

\begin{tabular}{|l|l|l|l|l|}
\hline 1 & 2 & 3 & 4 & 5 \\
\hline
\end{tabular}


PESQUISA - IMPACTO DAS AÇÕES DE FORMAÇÃO REALIZADAS PELO DATER/SAF/MDA NO PERÍODO 2004-2009

Caros colaboradores,

Contamos com a sua atenção para preencher o formulário abaixo.

O mesmo tem por objetivo fornecer informações para avaliação da Eficiência, Efetividade e Eficácia da Política Pública de Formação de Agentes de Ater adotada pelo Departamento de Assistência Técnica e Extensão Rural, da Secretaria de Agricultura Familiar do Ministério do Desenvolvimento - DATER/SAF/MDA, no período de 2004 a 2009, tema escolhido para Monografia a ser apresentada à Universidade de Brasília (UnB) como requisito parcial para obtenção do grau de Bacharel em Administração.

Você poderá ou não se identificar no questionário e garantimos que todas as informações fornecidas serão confidenciais e utilizadas apenas de forma sistematizada.

\section{IDENTIFICAÇÃO}

\begin{tabular}{|l|l|}
\hline Nome: Antonieta Alves da Costa & $\begin{array}{l}\text { Sexo: } \\
(\quad) \text { masculino } \quad(\mathrm{x}) \text { feminino }\end{array}$ \\
\hline $\begin{array}{l}\text { Instituição (nome e tipo de instituição: ONG, } \\
\text { Empresa Pública, etc.): Secretaria de Agricultura, } \\
\text { Abastecimento e Pesca - Pública }\end{array}$ & $\begin{array}{l}\text { Palmeira dos Índios - AL } \\
\text { Curso/Encontro/Oficina do qual participou (caso tenha participado de mais de um curso, preencha } \\
\text { um formulário para cada um deles): Curso de Plantas Medicinais e Condimentares }\end{array}$ \\
\hline Data do Curso/Encontro/Oficina (pelo menos mês e ano): novembro de 2005 \\
\hline
\end{tabular}

Indique sua área de atuação? (As opções não são excludentes: você poderá marcar mais de uma opção).

\begin{tabular}{|l|l|}
\hline$x$ & EXTENSÃO RURAL \\
\hline & PESQUISA \\
\hline & ENSINO \\
\hline & OUTROS \\
\hline
\end{tabular}


2) Qual o seu nível de escolaridade? ( Considere apenas o nível mais alto)

\begin{tabular}{|l|l|}
\hline & NÍVEL MÉDIO \\
\hline$x$ & NÍVEL SUPERIOR \\
\hline & PÓS-GRADUAÇÃO \\
\hline
\end{tabular}

3) Os conteúdos abordados foram condizentes com as demandas do seu dia-a-dia?

\begin{tabular}{|l|l|}
\hline & SIM \\
\hline$x$ & PARCIALMENTE \\
\hline & NÃO \\
\hline
\end{tabular}

4) O curso contribuiu para o seu aperfeiçoamento profissional?

\begin{tabular}{|l|l|}
\hline$x$ & SIM \\
\hline & NÃO \\
\hline
\end{tabular}

5) Os conhecimentos adquiridos estão sendo aplicados no seu trabalho? Em caso afirmativo, indique em que grau estes conhecimentos estão sendo aplicados. Em caso negativo, indique por que razão isto não ocorre: (As respostas não são excludentes: você poderá marcar mais de uma opção).

\begin{tabular}{|c|c|c|c|}
\hline \multirow{3}{*}{$x$} & \multirow{3}{*}{$\begin{array}{l}\text { SIM (indique ao lado em } \\
\text { que grau) }\end{array}$} & & MUITO APLICADOS \\
\hline & & & MEDIAMENTE APLICADOS \\
\hline & & $x$ & POUCO APLICADOS \\
\hline & \multirow{2}{*}{$\begin{array}{l}\text { NÃO (indique ao lado a } \\
\text { razão da não aplicação) }\end{array}$} & & $\begin{array}{l}\text { CONTEÚDO NÃO ADEQUADO ȦS NECESSIDADES } \\
\text { ESPECÍFICAS DA REGIÃO }\end{array}$ \\
\hline & & & $\begin{array}{llcr}\text { CONTEÚDO NÃO } & \text { FOI SUFICIENTEMENTE } \\
\text { APROFUNDADO PARA } & \text { PERMITIR UMA APLICAÇÃO } \\
\text { EFICAZ E EFICIENTE }\end{array}$ \\
\hline
\end{tabular}




\begin{tabular}{|l|l|l|}
\hline \multirow{2}{*}{} & & $\begin{array}{l}\text { FALTA DE APOIO E INCENTIVO DA MINHA } \\
\text { INSTITUIÇÃO }\end{array}$ \\
\cline { 2 - 3 } & & FALTA DE INCENTIVO ÀS AÇÕES DE ATER \\
\cline { 2 - 3 } & NÃO TENHO INTERESSE EM APLICAR \\
\hline
\end{tabular}

6) A partir deste curso: (As opções não são excludentes: você poderá marcar mais de uma opção).

\begin{tabular}{|l|l|}
\hline$x$ & $\begin{array}{l}\text { NÃO MUDOU NADA EM MEU TRABALHO. } \\
\text { FAMILIARES. }\end{array}$ \\
\hline & CONSEGUI INFLUENCIAR NAS ORIENTAÇÕES DA MINHA INSTITUIÇÃO. \\
\hline & PASSEI A TRABALHAR COM METODOLOGIAS PARTICIPATIVAS. \\
\hline & $\begin{array}{l}\text { CRESCEU A ÁREA DE AGRICULTURA DE BASE ECOLÓGICA NAS COMUNIDADES } \\
\text { ONDE ATUO. }\end{array}$ \\
\hline$x$ & CONTINUEI ME APERFEIÇOANDO SOBRE TEMAS ABORDADOS. \\
\hline
\end{tabular}

7) Depois do curso você apoiou atividades de capacitação de técnicos e agricultores com base nos princípios e diretrizes da Pnater? (Considere como apoio a atividades de capacitação a participação no planejamento, elaboração de ementas, seleção de participantes e de palestrantes.)

\begin{tabular}{|l|l|}
\hline & SIM \\
\hline$x$ & NÃO \\
\hline
\end{tabular}

8) Usou os conhecimentos para ministrar outros cursos com o mesmo conteúdo ou conteúdos semelhantes?

\begin{tabular}{|l|l|}
\hline$x$ & SIM \\
\hline & NÃO \\
\hline
\end{tabular}


9) Marque o seu grau de satisfação com relação ao curso oferecido pelo DATER: (Considere a seguinte pontuação: 1 - MUITO RUIM; 2 - RUIM; 3 - REGULAR; 4 - BOM; 5 - MUITO BOM)

\begin{tabular}{|l|l|l|l|l|}
\hline 1 & 2 & 3 & 4 & 5 \\
\hline
\end{tabular}

10) Marque seu grau de satisfação com relação ao DATER: (Considere a seguinte pontuação: 1 - MUITO RUIM; 2 - RUIM; 3 - REGULAR; 4 - BOM; 5 - MUITO BOM)

\begin{tabular}{|l|l|l|l|l|}
\hline 1 & 2 & 3 & 4 & 5 \\
\hline
\end{tabular}


PESQUISA - IMPACTO DAS AÇÕES DE FORMAÇÃO REALIZADAS PELO DATER/SAF/MDA NO PERÍODO 2004-2009

Caros colaboradores,

Contamos com a sua atenção para preencher o formulário abaixo.

O mesmo tem por objetivo fornecer informações para avaliação da Eficiência, Efetividade e Eficácia da Política Pública de Formação de Agentes de Ater adotada pelo Departamento de Assistência Técnica e Extensão Rural, da Secretaria de Agricultura Familiar do Ministério do Desenvolvimento - DATER/SAF/MDA, no período de 2004 a 2009, tema escolhido para Monografia a ser apresentada à Universidade de Brasília (UnB) como requisito parcial para obtenção do grau de Bacharel em Administração.

Você poderá ou não se identificar no questionário e garantimos que todas as informações fornecidas serão confidenciais e utilizadas apenas de forma sistematizada.

IDENTIFICAÇÃO

\begin{tabular}{|c|c|}
\hline $\begin{array}{l}\text { Nome: } \\
\text { ANTÔNIO TARCISO COELHO PINTO }\end{array}$ & $\begin{array}{l}\text { Sexo: } \\
(\mathrm{x}) \text { masculino } \quad(\quad) \text { feminino }\end{array}$ \\
\hline $\begin{array}{l}\text { Instituição (nome e tipo de instituição: ONG, } \\
\text { Empresa Pública, etc.): } \\
\text { EMATERCE }\end{array}$ & $\begin{array}{l}\text { Local de trabalho (Cidade e Estado): } \\
\text { FORTALEZA - CEARÁ }\end{array}$ \\
\hline \multicolumn{2}{|c|}{$\begin{array}{l}\text { Curso/Encontro/Oficina do qual participou (caso tenha participado de mais de um curso, preencha } \\
\text { um formulário para cada um deles): } \\
\text { TREINAMENTO EM DESENVOLVIMENTO GERENCIAL DE PROJETOS. }\end{array}$} \\
\hline $\begin{array}{l}\text { Data do Curso/Encontro/Oficina (pelo menos mês } \\
19 \text { a 22/03/2006 }\end{array}$ & no): \\
\hline
\end{tabular}

Indique sua área de atuação? (As opções não são excludentes: você poderá marcar mais de uma opção).

\begin{tabular}{|l|l|}
\hline$X$ & EXTENSÃO RURAL \\
\hline & PESQUISA \\
\hline & ENSINO \\
\hline & OUTROS \\
\hline
\end{tabular}


2) Qual o seu nível de escolaridade? (Considere apenas o nível mais alto)

\begin{tabular}{|l|l|}
\hline & NÍVEL MÉDIO \\
\hline$X$ & NÍVEL SUPERIOR \\
\hline & PÓS-GRADUAÇÃO \\
\hline
\end{tabular}

3) Os conteúdos abordados foram condizentes com as demandas do seu dia-a-dia?

\begin{tabular}{|l|l|}
\hline$X$ & SIM \\
\hline & PARCIALMENTE \\
\hline & NÃO \\
\hline
\end{tabular}

4) O curso contribuiu para o seu aperfeiçoamento profissional?

\begin{tabular}{|l|l|}
\hline$X$ & SIM \\
\hline & NÃO \\
\hline
\end{tabular}

5) Os conhecimentos adquiridos estão sendo aplicados no seu trabalho? Em caso afirmativo, indique em que grau estes conhecimentos estão sendo aplicados. Em caso negativo, indique por que razão isto não ocorre: (As respostas não são excludentes: você poderá marcar mais de uma opção).

\begin{tabular}{|c|c|c|c|}
\hline \multirow{3}{*}{$\mathrm{x}$} & \multirow{3}{*}{$\begin{array}{l}\text { SIM (indique ao lado em } \\
\text { que grau) }\end{array}$} & & MUITO APLICADOS \\
\hline & & & MEDIAMENTE APLICADOS \\
\hline & & $x$ & POUCO APLICADOS \\
\hline & \multirow{2}{*}{$\begin{array}{l}\text { NÃO (indique ao lado a } \\
\text { razão da não aplicação) }\end{array}$} & & $\begin{array}{l}\text { CONTEÚDO NĀO ADEQUADO ȦS NECESSIDADES } \\
\text { ESPECÍFICAS DA REGIÃO }\end{array}$ \\
\hline & & & $\begin{array}{l}\text { CONTEÚDO NÃO FOI SUFICIENTEMENTE } \\
\text { APROFUNDADO PARA PERMITIR UMA APLICAÇÃO } \\
\text { EFICAZ E EFICIENTE }\end{array}$ \\
\hline
\end{tabular}




\begin{tabular}{|l|l|l|}
\hline \multirow{2}{*}{} & & $\begin{array}{l}\text { FALTA DE APOIO E INCENTIVO DA MINHA } \\
\text { INSTITUIÇÃO }\end{array}$ \\
\cline { 2 - 3 } & & FALTA DE INCENTIVO ÀS AÇÕES DE ATER \\
\cline { 2 - 3 } & NÃO TENHO INTERESSE EM APLICAR \\
\hline
\end{tabular}

6) A partir deste curso: (As opções não são excludentes: você poderá marcar mais de uma opção).

\begin{tabular}{|l|l|}
\hline & NÃO MUDOU NADA EM MEU TRABALHO. \\
\hline & $\begin{array}{l}\text { MEU TRABALHO PASSOU A CONTRIBUIR MAIS COM OS AGRICULTORES (AS) } \\
\text { FAMILIARES. }\end{array}$ \\
\hline & CONSEGUI INFLUENCIAR NAS ORIENTAÇÕES DA MINHA INSTITUIÇÃO. \\
\hline & $\begin{array}{l}\text { CRESCEI A TRABALHAR COM METODOLOGIAS PARTICIPATIVAS. } \\
\text { ONDE ATUO. ÁREA DE AGRICULTURA DE BASE ECOLÓGICA NAS COMUNIDADES }\end{array}$ \\
\hline$X$ & CONTINUEI ME APERFEIÇOANDO SOBRE TEMAS ABORDADOS. \\
\hline
\end{tabular}

7) Depois do curso você apoiou atividades de capacitação de técnicos e agricultores com base nos princípios e diretrizes da Pnater(Considere como apoio a atividades de capacitação a participação no planejamento, elaboração de ementas, seleção de participantes e de palestrantes.)

\begin{tabular}{|l|l|}
\hline$X$ & SIM \\
\hline & NÃO \\
\hline
\end{tabular}

8) Usou os conhecimentos para ministrar outros cursos com o mesmo conteúdo ou conteúdos semelhantes?

\begin{tabular}{|l|l|}
\hline$X$ & SIM \\
\hline & NÃO \\
\hline
\end{tabular}


9) Marque o seu grau de satisfação com relação ao curso oferecido pelo DATER: (Considere a seguinte pontuação: 1 - MUITO RUIM; 2 - RUIM; 3 - REGULAR; 4 - BOM; 5 - MUITO BOM)

\begin{tabular}{|l|l|l|l|l|}
\hline 1 & 2 & 3 & 4 & 5 \\
\hline
\end{tabular}

10) Marque seu grau de satisfação com relação ao DATER: (Considere a seguinte pontuação: 1 - MUITO RUIM; 2 - RUIM; 3 - REGULAR; 4 - BOM; 5 - MUITO BOM)

\begin{tabular}{|l|l|l|l|l|}
\hline 1 & 2 & 3 & 4 & 5 \\
\hline
\end{tabular}


PESQUISA - IMPACTO DAS AÇÕES DE FORMAÇÃO REALIZADAS PELO DATER/SAF/MDA NO PERÍODO 2004-2009

Caros colaboradores,

Contamos com a sua atenção para preencher o formulário abaixo.

O mesmo tem por objetivo fornecer informações para avaliação da Eficiência, Efetividade e Eficácia da Política Pública de Formação de Agentes de Ater adotada pelo Departamento de Assistência Técnica e Extensão Rural, da Secretaria de Agricultura Familiar do Ministério do Desenvolvimento - DATER/SAF/MDA, no período de 2004 a 2009, tema escolhido para Monografia a ser apresentada à Universidade de Brasília (UnB) como requisito parcial para obtenção do grau de Bacharel em Administração.

Você poderá ou não se identificar no questionário e garantimos que todas as informações fornecidas serão confidenciais e utilizadas apenas de forma sistematizada.

IDENTIFICAÇÃO

\begin{tabular}{|l|l|}
\hline $\begin{array}{l}\text { Nome: } \\
\text { ANTÔNIO TARCISO COELHO PINTO }\end{array}$ & $\begin{array}{l}\text { Sexo: } \\
(\mathrm{x}) \text { masculino } \quad(\quad) \text { feminino }\end{array}$ \\
\hline $\begin{array}{l}\text { Instituição (nome e tipo de instituição: ONG, } \\
\text { Empresa Pública, etc.): }\end{array}$ & $\begin{array}{l}\text { Local de trabalho (Cidade e Estado): } \\
\text { EMATERCE }\end{array}$ \\
\hline $\begin{array}{l}\text { Curso/Encontro/Oficina do qual participou (caso tenha participado de mais de um curso, preencha } \\
\text { um formulário para cada um deles): } \\
\text { ELABORAÇÃO E ANÁLISE DE PROJETOS E CAPTAÇÃO DE RECURSOS. }\end{array}$ \\
\hline $\begin{array}{l}\text { Data do Curso/Encontro/Oficina (pelo menos mês e ano): } \\
\text { 06 a 10/02/2006 }\end{array}$ \\
\hline
\end{tabular}

1. Indique sua área de atuação? (As opções não são excludentes: você poderá marcar mais de uma opção).

\begin{tabular}{|l|l|}
\hline$X$ & EXTENSÃO RURAL \\
\hline & PESQUISA \\
\hline & ENSINO \\
\hline & OUTROS \\
\hline
\end{tabular}


2) Qual o seu nível de escolaridade? ( Considere apenas o nível mais alto)

\begin{tabular}{|l|l|}
\hline & NÍVEL MÉDIO \\
\hline$X$ & NÍVEL SUPERIOR \\
\hline & PÓS-GRADUAÇÃO \\
\hline
\end{tabular}

3) Os conteúdos abordados foram condizentes com as demandas do seu dia-a-dia?

\begin{tabular}{|l|l|}
\hline$X$ & SIM \\
\hline & PARCIALMENTE \\
\hline & NÃO \\
\hline
\end{tabular}

3) O curso contribuiu para o seu aperfeiçoamento profissional?

\begin{tabular}{|l|l|}
\hline & SIM \\
\hline$X$ & NÃO \\
\hline
\end{tabular}

5) Os conhecimentos adquiridos estão sendo aplicados no seu trabalho? Em caso afirmativo, indique em que grau estes conhecimentos estão sendo aplicados. Em caso negativo, indique por que razão isto não ocorre: (As respostas não são excludentes: você poderá marcar mais de uma opção).

\begin{tabular}{|c|c|c|c|}
\hline & \multirow{3}{*}{$\begin{array}{l}\text { SIM (indique ao lado em } \\
\text { que grau) }\end{array}$} & & MUITO APLICADOS \\
\hline & & & MEDIAMENTE APLICADOS \\
\hline & & & POUCO APLICADOS \\
\hline \multirow[b]{2}{*}{$x$} & \multirow{2}{*}{$\begin{array}{l}\text { NÃO (indique ao lado a } \\
\text { razão da não aplicação) }\end{array}$} & & $\begin{array}{l}\text { CONTEÚDO NĀO ADEQUADO ȦS NECESSIDADES } \\
\text { ESPECÍFICAS DA REGIÃO }\end{array}$ \\
\hline & & $\mathrm{x}$ & $\begin{array}{l}\text { CONTEÚDO NÃO FOI SUFICIENTEMENTE } \\
\text { APROFUNDADO PARA PERMITIR UMA APLICAÇÃO } \\
\text { EFICAZ E EFICIENTE }\end{array}$ \\
\hline
\end{tabular}




\begin{tabular}{|l|l|l|}
\hline \multirow{2}{*}{} & & $\begin{array}{l}\text { FALTA DE APOIO E INCENTIVO DA MINHA } \\
\text { INSTITUIÇÃO }\end{array}$ \\
\cline { 2 - 3 } & & FALTA DE INCENTIVO ÀS AÇÕES DE ATER \\
\cline { 2 - 3 } & NÃO TENHO INTERESSE EM APLICAR \\
\hline
\end{tabular}

6) A partir deste curso: (As opções não são excludentes: você poderá marcar mais de uma opção).

\begin{tabular}{|l|l|}
\hline$X$ & NÃO MUDOU NADA EM MEU TRABALHO. \\
\hline & $\begin{array}{l}\text { MEU TRABALHO PASSOU A CONTRIBUIR MAIS COM OS AGRICULTORES (AS) } \\
\text { FAMILIARES. }\end{array}$ \\
\hline & CONSEGUI INFLUENCIAR NAS ORIENTAÇÕES DA MINHA INSTITUIÇÃO. \\
\hline & $\begin{array}{l}\text { CRESEEI A TRABALHAR COM METODOLOGIAS PARTICIPATIVAS. } \\
\text { ONDE ATUO. ÁREA DE AGRICULTURA DE BASE ECOLÓGICA NAS COMUNIDADES }\end{array}$ \\
\hline & CONTINUEI ME APERFEIÇOANDO SOBRE TEMAS ABORDADOS. \\
\hline
\end{tabular}

7) Depois do curso você apoiou atividades de capacitação de técnicos e agricultores com base nos princípios e diretrizes da Pnater (Considere como apoio a atividades de capacitação a participação no planejamento, elaboração de ementas, seleção de participantes e de palestrantes).

\begin{tabular}{|l|l|}
\hline & SIM \\
\hline$X$ & NÃO \\
\hline
\end{tabular}

8) Usou os conhecimentos para ministrar outros cursos com o mesmo conteúdo ou conteúdos semelhantes?

\begin{tabular}{|l|l|}
\hline & SIM \\
\hline$X$ & NÃO \\
\hline
\end{tabular}


9) Marque o seu grau de satisfação com relação ao curso oferecido pelo DATER: (Considere a seguinte pontuação: 1 - MUITO RUIM; 2 - RUIM; 3 - REGULAR; 4 - BOM; 5 - MUITO BOM)

\begin{tabular}{|l|l|l|l|l|}
\hline 1 & 2 & 3 & 4 & 5 \\
\hline
\end{tabular}

10) Marque seu grau de satisfação com relação ao DATER: (Considere a seguinte pontuação: 1 - MUITO RUIM; 2 - RUIM; 3 - REGULAR; 4 - BOM; 5 - MUITO BOM)

\begin{tabular}{|l|l|l|l|l|}
\hline 1 & 2 & 3 & 4 & 5 \\
\hline
\end{tabular}

11) Informações Complementares:

Lamentavelmente, os instrutores não se prepararam devidamente para ministrar o curso. Por conta disto, não proporcionaram aos participantes, condições mínimas para aplicação imediata dos conteúdos apresentados durante o curso. O material didático de péssima qualidade em todos os sentidos. Idem para a didática apresentada pelos instrutores. Enfim, esse curso não me acrescentou nada, inclusive para os outros participantes, evidenciado pelas manifestações dos mesmos, durante a realização do supracitado curso. 
PESQUISA - IMPACTO DAS AÇÕES DE FORMAÇÃO REALIZADAS PELO DATER/SAF/MDA NO PERÍODO 2004-2009

Caros colaboradores,

Contamos com a sua atenção para preencher o formulário abaixo.

O mesmo tem por objetivo fornecer informações para avaliação da Eficiência, Efetividade e Eficácia da Política Pública de Formação de Agentes de Ater adotada pelo Departamento de Assistência Técnica e Extensão Rural, da Secretaria de Agricultura Familiar do Ministério do Desenvolvimento - DATER/SAF/MDA, no período de 2004 a 2009, tema escolhido para Monografia a ser apresentada à Universidade de Brasília (UnB) como requisito parcial para obtenção do grau de Bacharel em Administração.

Você poderá ou não se identificar no questionário e garantimos que todas as informações fornecidas serão confidenciais e utilizadas apenas de forma sistematizada.

\section{IDENTIFICAÇÃO}

\begin{tabular}{|l|l|}
\hline Nome: Cleusa Almeida Barbosa & $\begin{array}{l}\text { Sexo: } \\
(\quad) \text { masculino } \quad(\mathrm{x}) \text { feminino }\end{array}$ \\
\hline $\begin{array}{l}\text { Instituição (nome e tipo de instituição: ONG, } \\
\text { Empresa Pública, etc.): Secretaria de Agricultura, } \\
\text { Abastecimento e Pesca - Pública }\end{array}$ & $\begin{array}{l}\text { Palmeira dos Índios - AL } \\
\text { Curso/Encontro/Oficina do qual participou (caso tenha participado de mais de um curso, preencha } \\
\text { um formulário para cada um deles): Curso de Formadores da ATER }\end{array}$ \\
\hline Data do Curso/Encontro/Oficina (pelo menos mês e ano): dezembro de 2006 \\
\hline
\end{tabular}

Indique sua área de atuação? (As opções não são excludentes: você poderá marcar mais de uma opção).

\begin{tabular}{|l|l|}
\hline$x$ & EXTENSÃO RURAL \\
\hline & PESQUISA \\
\hline & ENSINO \\
\hline & OUTROS \\
\hline
\end{tabular}

2) Qual o seu nível de escolaridade? (Considere apenas o nível mais alto) 


\begin{tabular}{|l|l|}
\hline & NÍVEL MÉDIO \\
\hline$x$ & NÍVEL SUPERIOR \\
\hline & PÓS-GRADUAÇÃO \\
\hline
\end{tabular}

3) Os conteúdos abordados foram condizentes com as demandas do seu dia-a-dia?

\begin{tabular}{|l|l|}
\hline & SIM \\
\hline$x$ & PARCIALMENTE \\
\hline & NÃO \\
\hline
\end{tabular}

4) O curso contribuiu para o seu aperfeiçoamento profissional?

\begin{tabular}{|l|l|}
\hline$x$ & SIM \\
\hline & NÃO \\
\hline
\end{tabular}

5) Os conhecimentos adquiridos estão sendo aplicados no seu trabalho? Em caso afirmativo, indique em que grau estes conhecimentos estão sendo aplicados. Em caso negativo, indique por que razão isto não ocorre: (As respostas não são excludentes: você poderá marcar mais de uma opção).

\begin{tabular}{|c|c|c|c|}
\hline & \multirow{3}{*}{$\begin{array}{l}\text { SIM (indique ao lado em } \\
\text { que grau) }\end{array}$} & & MUITO APLICADOS \\
\hline & & & MEDIAMENTE APLICADOS \\
\hline & & & POUCO APLICADOS \\
\hline \multirow{3}{*}{ x } & \multirow{3}{*}{$\begin{array}{l}\text { NÃO (indique ao lado a } \\
\text { razão da não aplicação) }\end{array}$} & & $\begin{array}{l}\text { CONTEÚDO NĀO ADEQUADO ȦS NECESSIDADES } \\
\text { ESPECÍFICAS DA REGIÃO }\end{array}$ \\
\hline & & & $\begin{array}{l}\text { CONTEÚDO NÃO FOI SUFICIENTEMENTE } \\
\text { APROFUNDADO PARA PERMITIR UMA APLICAÇÃO } \\
\text { EFICAZ E EFICIENTE }\end{array}$ \\
\hline & & $\mathrm{x}$ & $\begin{array}{lllllll}\text { FALTA } & \text { DE } & \text { APOIO } & \text { E } & \text { INCENTIVO } & \text { DA } & \text { MINHA } \\
\text { INSTITUIÇÃO } & & & & & \\
\end{array}$ \\
\hline
\end{tabular}




\begin{tabular}{|l|l|l|l|}
\hline \multirow{2}{*}{} & & $x$ & FALTA DE INCENTIVO ÀS AÇÕES DE ATER \\
\cline { 3 - 4 } & & NÃO TENHO INTERESSE EM APLICAR \\
\hline
\end{tabular}

6) A partir deste curso: (As opções não são excludentes: você poderá marcar mais de uma opção).

\begin{tabular}{|l|l|}
\hline & NÃO MUDOU NADA EM MEU TRABALHO. \\
\hline & $\begin{array}{l}\text { MEU TRABALHO PASSOU A CONTRIBUIR MAIS COM OS AGRICULTORES(AS) } \\
\text { FAMILIARES. }\end{array}$ \\
\hline & CONSEGUI INFLUENCIAR NAS ORIENTAÇÕES DA MINHA INSTITUIÇÃO. \\
\hline & $\begin{array}{l}\text { CRESSEI A TRABALHAR COM METODOLOGIAS PARTICIPATIVAS. } \\
\text { ONDE ATUO. }\end{array}$ \\
\hline $\mathrm{x}$ & CONTINUEI ME APERFEIÇOANDO SOBRE TEMAS ABORDADOS. \\
\hline
\end{tabular}

7) Depois do curso você apoiou atividades de capacitação de técnicos e agricultores com base nos princípios e diretrizes da Pnater? (Considere como apoio a atividades de capacitação a participação no planejamento, elaboração de ementas, seleção de participantes e de palestrantes.)

\begin{tabular}{|l|l|}
\hline & SIM \\
\hline$x$ & NÃO \\
\hline
\end{tabular}

8) Usou os conhecimentos para ministrar outros cursos com o mesmo conteúdo ou conteúdos semelhantes?

\begin{tabular}{|l|l|}
\hline & SIM \\
\hline$x$ & NÃO \\
\hline
\end{tabular}

9) Marque o seu grau de satisfação com relação ao curso oferecido pelo DATER: (Considere a seguinte pontuação: 1 - MUITO RUIM; 2 - RUIM; 3 - REGULAR; 4 - BOM; 5 - MUITO BOM) 


\begin{tabular}{|l|l|l|l|l|}
\hline 1 & 2 & 3 & 4 & 5 \\
\hline
\end{tabular}

10) Marque seu grau de satisfação com relação ao DATER: (Considere a seguinte pontuação:

1 - MUITO RUIM; 2 - RUIM; 3 - REGULAR; 4 - BOM; 5 - MUITO BOM)

\begin{tabular}{|l|l|l|l|l|}
\hline 1 & 2 & 3 & 4 & 5 \\
\hline
\end{tabular}


PESQUISA - IMPACTO DAS AÇÕES DE FORMAÇÃO REALIZADAS PELO DATER/SAF/MDA NO PERÍODO 2004-2009

Caros colaboradores,

Contamos com a sua atenção para preencher o formulário abaixo.

O mesmo tem por objetivo fornecer informações para avaliação da Eficiência, Efetividade e Eficácia da Política Pública de Formação de Agentes de Ater adotada pelo Departamento de Assistência Técnica e Extensão Rural, da Secretaria de Agricultura Familiar do Ministério do Desenvolvimento - DATER/SAF/MDA, no período de 2004 a 2009, tema escolhido para Monografia a ser apresentada à Universidade de Brasília (UnB) como requisito parcial para obtenção do grau de Bacharel em Administração.

Você poderá ou não se identificar no questionário e garantimos que todas as informações fornecidas serão confidenciais e utilizadas apenas de forma sistematizada.

\section{IDENTIFICAÇÃO}

\begin{tabular}{|l|l|}
\hline Nome: Cleusa Almeida Barbosa & $\begin{array}{l}\text { Sexo: } \\
(\quad) \text { masculino } \quad(\mathrm{x}) \text { feminino }\end{array}$ \\
\hline $\begin{array}{l}\text { Instituição (nome e tipo de instituição: ONG, } \\
\text { Empresa Pública, etc.): Secretaria de Agricultura, } \\
\text { Abastecimento e Pesca - Pública }\end{array}$ & $\begin{array}{l}\text { Palmeira dos Índios - AL } \\
\text { Curso/Encontro/Oficina do qual participou (caso tenha participado de mais de um curso, preencha } \\
\text { um formulário para cada um deles): Curso de Plantas Medicinais e Condimentares }\end{array}$ \\
\hline Data do Curso/Encontro/Oficina (pelo menos mês e ano): novembro de 2005 \\
\hline
\end{tabular}

1) Indique sua área de atuação? (As opções não são excludentes: você poderá marcar mais de uma opção).

\begin{tabular}{|l|l|}
\hline$x$ & EXTENSÃO RURAL \\
\hline & PESQUISA \\
\hline & ENSINO \\
\hline & OUTROS \\
\hline
\end{tabular}


2) Qual o seu nível de escolaridade? (Considere apenas o nível mais alto)

\begin{tabular}{|l|l|}
\hline & NÍVEL MÉDIO \\
\hline$x$ & NÍVEL SUPERIOR \\
\hline & PÓS-GRADUAÇÃO \\
\hline
\end{tabular}

3) Os conteúdos abordados foram condizentes com as demandas do seu dia-a-dia?

\begin{tabular}{|l|l|}
\hline & SIM \\
\hline$x$ & PARCIALMENTE \\
\hline & NÃO \\
\hline
\end{tabular}

4) O curso contribuiu para o seu aperfeiçoamento profissional?

\begin{tabular}{|l|l|}
\hline$x$ & SIM \\
\hline & NÃO \\
\hline
\end{tabular}

5) Os conhecimentos adquiridos estão sendo aplicados no seu trabalho? Em caso afirmativo, indique em que grau estes conhecimentos estão sendo aplicados. Em caso negativo, indique por que razão isto não ocorre: (As respostas não são excludentes: você poderá marcar mais de uma opção).

\begin{tabular}{|c|c|c|c|}
\hline \multirow{3}{*}{$x$} & \multirow{3}{*}{$\begin{array}{l}\text { SIM (indique ao lado em } \\
\text { que grau) }\end{array}$} & & MUITO APLICADOS \\
\hline & & & MEDIAMENTE APLICADOS \\
\hline & & $x$ & POUCO APLICADOS \\
\hline & & & $\begin{array}{l}\text { CONTEÚDO NÃO ADEQUADO ȦS NECESSIDADES } \\
\text { ESPECÍFICAS DA REGIÃO }\end{array}$ \\
\hline & $\begin{array}{l}\text { NÃO (indique ao lado a } \\
\text { razão da não aplicação) }\end{array}$ & & $\begin{array}{l}\text { CONTEÚDO NÃO } \quad \text { FOI SUFICIENTEMENTE } \\
\text { APROFUNDADO PARA } \\
\text { PERMITIR UMA APLICAÇÃO } \\
\text { EFICAZ E EFICIENTE }\end{array}$ \\
\hline & & & $\begin{array}{l}\text { FALTA DE APOIO } \\
\text { INSTITUIÇÃO }\end{array}$ \\
\hline
\end{tabular}




\begin{tabular}{|l|l|l|}
\hline \multirow{2}{*}{} & & FALTA DE INCENTIVO ÀS AÇÕES DE ATER \\
\cline { 3 - 4 } & & NÃO TENHO INTERESSE EM APLICAR \\
\hline
\end{tabular}

6) A partir deste curso: (As opções não são excludentes: você poderá marcar mais de uma opção).

\begin{tabular}{|l|l|}
\hline$x$ & $\begin{array}{l}\text { NÃO MUDOU NADA EM MEU TRABALHO. } \\
\text { FAMILIARES. }\end{array}$ \\
\hline & CONSEGUI INFLUENCIAR NAS ORIENTAÇÕES DA MINHA INSTITUIÇÃO. \\
\hline & PASSEI A TRABALHAR COM METODOLOGIAS PARTICIPATIVAS. \\
\hline & $\begin{array}{l}\text { CRESCEU A ÁREA DE AGRICULTURA DE BASE ECOLÓGICA NAS COMUNIDADES } \\
\text { ONDE ATUO. }\end{array}$ \\
\hline$x$ & CONTINUEI ME APERFEIÇOANDO SOBRE TEMAS ABORDADOS. \\
\hline
\end{tabular}

7) Depois do curso você apoiou atividades de capacitação de técnicos e agricultores com base nos princípios e diretrizes da Pnater? (Considere como apoio a atividades de capacitação a participação no planejamento, elaboração de ementas, seleção de participantes e de palestrantes.)

\begin{tabular}{|l|l|}
\hline & SIM \\
\hline$x$ & NÃO \\
\hline
\end{tabular}

8) Usou os conhecimentos para ministrar outros cursos com o mesmo conteúdo ou conteúdos semelhantes?

\begin{tabular}{|l|l|}
\hline$x$ & SIM \\
\hline & NÃO \\
\hline
\end{tabular}

9) Marque o seu grau de satisfação com relação ao curso oferecido pelo DATER: (Considere a seguinte pontuação: 1 - MUITO RUIM; 2 - RUIM; 3 - REGULAR; 4 - BOM; 5 - MUITO BOM) 


\begin{tabular}{|l|l|l|l|l|}
\hline 1 & 2 & 3 & 4 & 5 \\
\hline
\end{tabular}

10) Marque seu grau de satisfação com relação ao DATER: (Considere a seguinte pontuação:

1 - MUITO RUIM; 2 - RUIM; 3 - REGULAR; 4 - BOM; 5 - MUITO BOM)

\begin{tabular}{|l|l|l|l|l|}
\hline 1 & 2 & 3 & 4 & 5 \\
\hline
\end{tabular}


PESQUISA - IMPACTO DAS AÇÕES DE FORMAÇÃO REALIZADAS PELO DATER/SAF/MDA NO PERÍODO 2004-2009

Caros colaboradores,

Contamos com a sua atenção para preencher o formulário abaixo.

O mesmo tem por objetivo fornecer informações para avaliação da Eficiência, Efetividade e Eficácia da Política Pública de Formação de Agentes de Ater adotada pelo Departamento de Assistência Técnica e Extensão Rural, da Secretaria de Agricultura Familiar do Ministério do Desenvolvimento - DATER/SAF/MDA, no período de 2004 a 2009, tema escolhido para Monografia a ser apresentada à Universidade de Brasília (UnB) como requisito parcial para obtenção do grau de Bacharel em Administração.

Você poderá ou não se identificar no questionário e garantimos que todas as informações fornecidas serão confidenciais e utilizadas apenas de forma sistematizada.

IDENTIFICAÇÃO

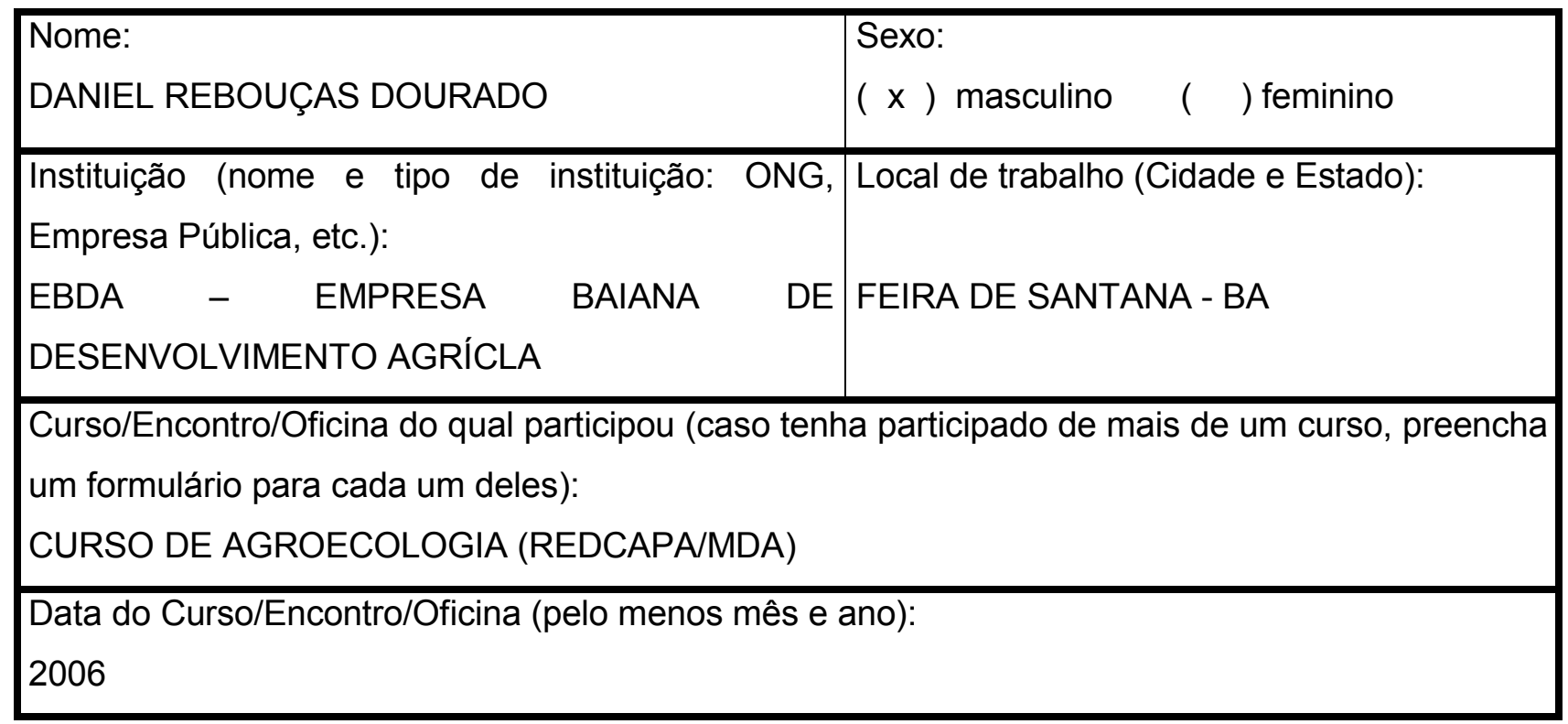

1. Indique sua área de atuação? (As opções não são excludentes: você poderá marcar mais de uma opção).

\begin{tabular}{|l|l|}
\hline$X$ & EXTENSÃO RURAL \\
\hline & PESQUISA \\
\hline & ENSINO \\
\hline & OUTROS \\
\hline
\end{tabular}


2) Qual o seu nível de escolaridade? (Considere apenas o nível mais alto)

\begin{tabular}{|l|l|}
\hline & NÍVEL MÉDIO \\
\hline & NÍVEL SUPERIOR \\
\hline$X$ & PÓS-GRADUAÇÃO \\
\hline
\end{tabular}

3) Os conteúdos abordados foram condizentes com as demandas do seu dia-a-dia?

\begin{tabular}{|l|l|}
\hline$X$ & SIM \\
\hline & PARCIALMENTE \\
\hline & NÃO \\
\hline
\end{tabular}

4) O curso contribuiu para o seu aperfeiçoamento profissional?

\begin{tabular}{|l|l|}
\hline$X$ & SIM \\
\hline & NÃO \\
\hline
\end{tabular}

5) Os conhecimentos adquiridos estão sendo aplicados no seu trabalho? Em caso afirmativo, indique em que grau estes conhecimentos estão sendo aplicados. Em caso negativo, indique por que razão isto não ocorre: (As respostas não são excludentes: você poderá marcar mais de uma opção).

\begin{tabular}{|c|c|c|c|}
\hline \multirow{3}{*}{$\mathrm{x}$} & \multirow{3}{*}{$\begin{array}{l}\text { SIM (indique ao lado em } \\
\text { que grau) }\end{array}$} & $\mathrm{X}$ & MUITO APLICADOS \\
\hline & & & MEDIAMENTE APLICADOS \\
\hline & & & POUCO APLICADOS \\
\hline & & & $\begin{array}{l}\text { CONTEÚDO NĀO ADEQUADO ȦS NECESSIDADES } \\
\text { ESPECÍFICAS DA REGIÃO }\end{array}$ \\
\hline & razão da não aplicação) & & $\begin{array}{l}\text { CONTEÚDO NÃO FOI SUFICIENTEMENTE } \\
\text { APROFUNDADO PARA PERMITIR UMA APLICAÇÃO } \\
\text { EFICAZE EFICIENTE }\end{array}$ \\
\hline
\end{tabular}




\begin{tabular}{|l|l|l|}
\hline \multirow{2}{*}{} & & $\begin{array}{l}\text { FALTA DE APOIO E INCENTIVO DA MINHA } \\
\text { INSTITUIÇÃO }\end{array}$ \\
\cline { 2 - 3 } & & FALTA DE INCENTIVO ÀS AÇÕES DE ATER \\
\cline { 2 - 3 } & & NÃO TENHO INTERESSE EM APLICAR \\
\hline
\end{tabular}

6) A partir deste curso: (As opções não são excludentes: você poderá marcar mais de uma opção).

\begin{tabular}{|l|l|}
\hline & NÃO MUDOU NADA EM MEU TRABALHO. \\
\hline & $\begin{array}{l}\text { MEU TRABALHO PASSOU A CONTRIBUIR MAIS COM OS AGRICULTORES(AS) } \\
\text { FAMILIARES. }\end{array}$ \\
\hline & CONSEGUI INFLUENCIAR NAS ORIENTAÇÕES DA MINHA INSTITUIÇÃO. \\
\hline & $\begin{array}{l}\text { CRESCEU A ÁREA DE AGRICULTURA DE BASE ECOLÓGICA NAS COMUNIDADES } \\
\text { ONDE ATUO. }\end{array}$ \\
\hline$X$ & CONTINUEI ME APERFEIÇOANDO SOBRE TEMAS ABORDADOS. \\
\hline
\end{tabular}

7) Depois do curso você apoiou atividades de capacitação de técnicos e agricultores com base nos princípios e diretrizes da Pnater? (Considere como apoio a atividades de capacitação a participação no planejamento, elaboração de ementas, seleção de participantes e de palestrantes.)

\begin{tabular}{|l|l|}
\hline$X$ & SIM \\
\hline & NÃO \\
\hline
\end{tabular}

8) Usou os conhecimentos para ministrar outros cursos com o mesmo conteúdo ou conteúdos semelhantes?

\begin{tabular}{|l|l|}
\hline$X$ & SIM \\
\hline & NÃO \\
\hline
\end{tabular}

9) Marque o seu grau de satisfação com relação ao curso oferecido pelo DATER: (Considere a seguinte pontuação: 1 - MUITO RUIM; 2 - RUIM; 3 - REGULAR; 4 - BOM; 5 - MUITO BOM) 


\begin{tabular}{|l|l|l|l|l|}
\hline 1 & 2 & 3 & 4 & 5 \\
\hline
\end{tabular}

10) Marque seu grau de satisfação com relação ao DATER: (Considere a seguinte pontuação: 1 - MUITO RUIM; 2 - RUIM; 3 - REGULAR; 4 - BOM; 5 - MUITO BOM)

\begin{tabular}{|l|l|l|l|l|}
\hline 1 & 2 & 3 & 4 & 5 \\
\hline
\end{tabular}


PESQUISA - IMPACTO DAS AÇÕES DE FORMAÇÃO REALIZADAS PELO DATER/SAF/MDA NO PERÍODO 2004-2009

Caros colaboradores,

Contamos com a sua atenção para preencher o formulário abaixo.

O mesmo tem por objetivo fornecer informações para avaliação da Eficiência, Efetividade e Eficácia da Política Pública de Formação de Agentes de Ater adotada pelo Departamento de Assistência Técnica e Extensão Rural, da Secretaria de Agricultura Familiar do Ministério do Desenvolvimento - DATER/SAF/MDA, no período de 2004 a 2009, tema escolhido para Monografia a ser apresentada à Universidade de Brasília (UnB) como requisito parcial para obtenção do grau de Bacharel em Administração.

Você poderá ou não se identificar no questionário e garantimos que todas as informações fornecidas serão confidenciais e utilizadas apenas de forma sistematizada.

\section{IDENTIFICAÇÃO}

\begin{tabular}{|c|c|}
\hline Nome: Denise Soledade Pereira Costa & $\begin{array}{l}\text { Sexo: } \\
(\quad) \text { masculino } \quad(x) \text { feminino }\end{array}$ \\
\hline $\begin{array}{lll}\text { Instituição: } & \text { Organização } & \text { Sócio-ambientalista } \\
\text { Joguelimpo } & & \end{array}$ & $\begin{array}{l}\text { Local de trabalho: Região metropolitana de } \\
\text { Salvador }\end{array}$ \\
\hline \multicolumn{2}{|c|}{$\begin{array}{l}\text { Curso/Encontro/Oficina do qual participou: Curso de Agentes de Ater que atuam com Pescadores } \\
\text { Artesanais e Aquicultores }\end{array}$} \\
\hline ata do Curso/Encontro/Oficina: 25 a 29 de outubrc & e 2004 \\
\hline
\end{tabular}

1. Indique sua área de atuação? (As opções não são excludentes: você poderá marcar mais de uma opção).

\begin{tabular}{|c|l|}
\hline$X$ & EXTENSÃO RURAL \\
\hline$X$ & PESQUISA \\
\hline & ENSINO \\
\hline & OUTROS \\
\hline
\end{tabular}


2) Qual o seu nível de escolaridade? (Considere apenas o nível mais alto)

\begin{tabular}{|l|l|}
\hline & NÍVEL MÉDIO \\
\hline & NÍVEL SUPERIOR \\
\hline$X$ & PÓS-GRADUAÇÃO \\
\hline
\end{tabular}

3) Os conteúdos abordados foram condizentes com as demandas do seu dia-a-dia?

\begin{tabular}{|l|l|}
\hline$X$ & SIM \\
\hline & PARCIALMENTE \\
\hline & NÃO \\
\hline
\end{tabular}

4) O curso contribuiu para o seu aperfeiçoamento profissional?

\begin{tabular}{|l|l|}
\hline$X$ & SIM \\
\hline & NÃO \\
\hline
\end{tabular}

5) Os conhecimentos adquiridos estão sendo aplicados no seu trabalho? Em caso afirmativo, indique em que grau estes conhecimentos estão sendo aplicados. Em caso negativo, indique por que razão isto não ocorre: (As respostas não são excludentes: você poderá marcar mais de uma opção).

\begin{tabular}{|c|c|c|c|}
\hline \multirow{3}{*}{$\mathrm{x}$} & \multirow{3}{*}{$\begin{array}{l}\text { SIM (indique ao lado em } \\
\text { que grau) }\end{array}$} & $\bar{X}$ & MUITO APLICADOS \\
\hline & & & MEDIAMENTE APLICADOS \\
\hline & & & POUCO APLICADOS \\
\hline & \multirow{3}{*}{$\begin{array}{l}\text { NÃO (indique ao lado a } \\
\text { razão da não aplicação) }\end{array}$} & & $\begin{array}{l}\text { CONTEÚDO NĀO ADEQUADO ȦS NECESSIDADES } \\
\text { ESPECÍFICAS DA REGIÃO }\end{array}$ \\
\hline & & & $\begin{array}{l}\text { CONTEÚDO NÃO FOI SUFICIENTEMENTE } \\
\text { APROFUNDADO PARA PERMITIR UMA APLICAÇÃOO } \\
\text { EFICAZ E EFICIENTE }\end{array}$ \\
\hline & & & $\begin{array}{lllllll}\text { FALTA } & \text { DE } & \text { APOIO } & \text { E } & \text { INCENTIVO } & \text { DA } & \text { MINHA } \\
\text { INSTITUIÇÃO } & & & & \end{array}$ \\
\hline
\end{tabular}




\begin{tabular}{|l|l|l|}
\hline \multirow{2}{*}{} & & FALTA DE INCENTIVO ÀS AÇÕES DE ATER \\
\cline { 3 - 4 } & & NÃO TENHO INTERESSE EM APLICAR \\
\hline
\end{tabular}

6) A partir deste curso: (As opções não são excludentes: você poderá marcar mais de uma opção).

\begin{tabular}{|c|l|}
\hline$x$ & $\begin{array}{l}\text { NÃO MUDOU NADA EM MEU TRABALHO. } \\
\text { FAMILIARES. }\end{array}$ \\
\hline$X$ & CONSEGUI INFLUENCIAR NAS ORIENTAÇÕES DA MINHA INSTITUIÇÃO. \\
\hline & PASSEI A TRABALHAR COM METODOLOGIAS PARTICIPATIVAS. \\
\hline & $\begin{array}{l}\text { CRESCEU A ÁREA DE AGRICULTURA DE BASE ECOLÓGICA NAS COMUNIDADES } \\
\text { ONDE ATUO. }\end{array}$ \\
\hline$X$ & CONTINUEI ME APERFEIÇOANDO SOBRE TEMAS ABORDADOS. \\
\hline
\end{tabular}

7) Depois do curso você apoiou atividades de capacitação de técnicos e agricultores com base nos princípios e diretrizes da Pnater? (Considere como apoio a atividades de capacitação a participação no planejamento, elaboração de ementas, seleção de participantes e de palestrantes.)

\begin{tabular}{|l|l|}
\hline$X$ & SIM \\
\hline & NÃO \\
\hline
\end{tabular}

8) Usou os conhecimentos para ministrar outros cursos com o mesmo conteúdo ou conteúdos semelhantes?

\begin{tabular}{|l|l|}
\hline & SIM \\
\hline$X$ & NÃO \\
\hline
\end{tabular}

9) Marque o seu grau de satisfação com relação ao curso oferecido pelo DATER: (Considere a seguinte pontuação: 1 - MUITO RUIM; 2 - RUIM; 3 - REGULAR; 4 - BOM; 5 - MUITO BOM) 


\begin{tabular}{|l|l|l|l|l|}
\hline 1 & 2 & 3 & 4 & 5 \\
\hline
\end{tabular}

10) Marque seu grau de satisfação com relação ao DATER: (Considere a seguinte pontuação: 1 - MUITO RUIM; 2 - RUIM; 3 - REGULAR; 4 - BOM; 5 - MUITO BOM)

\begin{tabular}{|l|l|l|l|l|}
\hline 1 & 2 & 3 & 4 & 5 \\
\hline
\end{tabular}

OBS.: Gostaria de aproveitar a oportunidade para manifestar a minha insatisfação por não ter participado do último curso que me inscrevi, e que fui selecionada, que foi o de Metodologia Participativa - DRP, realizado em João Pessoa em dezembro de 2006.

Infelizmente, por razões pessoais, não pude estar presente. Tenho certeza que o curso seria bastante útil para o meu trabalho, contribuindo ainda mais com as minhas ações de campo.

Fiquei sabendo, por conhecidos da área, e que participaram do curso, o quanto foi válido e enriquecedor.

Fico agora torcendo para que eu tenha outra chance de participar de um outro evento como esse, e aproveito também para parabenizá-los pela iniciativa de contribuir com a formação dos assistentes técnicos que estão no trabalho de campo, junto às comunidades rurais.

Atenciosamente,

Denise Soledade P. Costa 
PESQUISA - IMPACTO DAS AÇÕES DE FORMAÇÃO REALIZADAS PELO DATER/SAF/MDA NO PERÍODO 2004-2009

Caros colaboradores,

Contamos com a sua atenção para preencher o formulário abaixo.

O mesmo tem por objetivo fornecer informações para avaliação da Eficiência, Efetividade e Eficácia da Política Pública de Formação de Agentes de Ater adotada pelo Departamento de Assistência Técnica e Extensão Rural, da Secretaria de Agricultura Familiar do Ministério do Desenvolvimento - DATER/SAF/MDA, no período de 2004 a 2009, tema escolhido para Monografia a ser apresentada à Universidade de Brasília (UnB) como requisito parcial para obtenção do grau de Bacharel em Administração.

Você poderá ou não se identificar no questionário e garantimos que todas as informações fornecidas serão confidenciais e utilizadas apenas de forma sistematizada.

IDENTIFICAÇÃO

\begin{tabular}{|c|c|}
\hline Nome: Djalma de Lima Duarte & $\begin{array}{l}\text { Sexo: } \\
(\mathrm{x}) \text { masculino } \quad(\quad) \text { feminino }\end{array}$ \\
\hline $\begin{array}{l}\text { Instituição (nome e tipo de instituição: ONG, } \\
\text { Empresa Pública, etc.): COOPAGEL E UNICAFES }\end{array}$ & $\begin{array}{l}\text { Local de trabalho (Cidade e Estado): } \\
\text { Recife/PE }\end{array}$ \\
\hline \multicolumn{2}{|c|}{$\begin{array}{l}\text { Curso/Encontro/Oficina do qual participou (caso tenha participado de mais de um curso, preencha } \\
\text { um formulário para cada um deles): Curso Formação de Formadores em Metodologias } \\
\text { Participativas para a Extensão Rural - Campinas - SP }\end{array}$} \\
\hline $\begin{array}{l}\text { Data do Curso/Encontro/Oficina (pelo menos mês e } \\
2006\end{array}$ & ano): 20 de novembro a 01 de dezembro de \\
\hline
\end{tabular}

Indique sua área de atuação? (As opções não são excludentes: você poderá marcar mais de uma opção).

\begin{tabular}{|l|l|}
\hline$X$ & EXTENSÃO RURAL \\
\hline & PESQUISA \\
\hline & ENSINO \\
\hline & OUTROS \\
\hline
\end{tabular}


2) Qual o seu nível de escolaridade? ( Considere apenas o nível mais alto)

\begin{tabular}{|l|l|}
\hline & NÍVEL MÉDIO \\
\hline & NÍVEL SUPERIOR \\
\hline$X$ & PÓS-GRADUAÇÃO \\
\hline
\end{tabular}

3) Os conteúdos abordados foram condizentes com as demandas do seu dia-a-dia?

\begin{tabular}{|l|l|}
\hline$X$ & SIM \\
\hline & PARCIALMENTE \\
\hline & NÃO \\
\hline
\end{tabular}

3) O curso contribuiu para o seu aperfeiçoamento profissional?

\begin{tabular}{|l|l|}
\hline$X$ & SIM \\
\hline & NÃO \\
\hline
\end{tabular}

5) Os conhecimentos adquiridos estão sendo aplicados no seu trabalho? Em caso afirmativo, indique em que grau estes conhecimentos estão sendo aplicados. Em caso negativo, indique por que razão isto não ocorre: (As respostas não são excludentes: você poderá marcar mais de uma opção).

\begin{tabular}{|c|c|c|}
\hline \multirow{3}{*}{$\begin{array}{l}\text { SIM (indique ao lado em } \\
\text { que grau) }\end{array}$} & $\mathrm{X}$ & MUITO APLICADOS \\
\hline & & MEDIAMENTE APLICADOS \\
\hline & & POUCO APLICADOS \\
\hline \multirow{2}{*}{$\begin{array}{l}\text { NÃO (indique ao lado a } \\
\text { razão da não aplicação) }\end{array}$} & & $\begin{array}{l}\text { CONTEÚDO NĀO ADEQUADO ȦS NECESSIDADES } \\
\text { ESPECÍFICAS DA REGIÃO }\end{array}$ \\
\hline & & $\begin{array}{l}\text { CONTEÚDO NÃO FOI SUFICIENTEMENTE } \\
\text { APROFUNDADO PARA PERMITIR UMA APLICAÇÃO } \\
\text { EFICAZ E EFICIENTE }\end{array}$ \\
\hline
\end{tabular}




\begin{tabular}{|l|l|l|}
\hline \multirow{2}{*}{} & & $\begin{array}{l}\text { FALTA DE APOIO E INCENTIVO DA MINHA } \\
\text { INSTITUIÇÃO }\end{array}$ \\
\cline { 2 - 3 } & & FALTA DE INCENTIVO ÀS AÇÕES DE ATER \\
\cline { 2 - 3 } & NÃO TENHO INTERESSE EM APLICAR \\
\hline
\end{tabular}

6) A partir deste curso: (As opções não são excludentes: você poderá marcar mais de uma opção).

\begin{tabular}{|l|l|}
\hline$x$ & $\begin{array}{l}\text { NÃO MUDOU NADA EM MEU TRABALHO. } \\
\text { FAMILIARES. }\end{array}$ \\
\hline & CONSEGUI INFLUENCIAR NAS ORIENTAÇÕES DA MINHA INSTITUIÇÃO. \\
\hline & PASSEI A TRABALHAR COM METODOLOGIAS PARTICIPATIVAS. \\
\hline & $\begin{array}{l}\text { CRESCEU A ÁREA DE AGRICULTURA DE BASE ECOLÓGICA NAS COMUNIDADES } \\
\text { ONDE ATUO. }\end{array}$ \\
\hline$X$ & CONTINUEI ME APERFEIÇOANDO SOBRE TEMAS ABORDADOS. \\
\hline
\end{tabular}

7) Depois do curso você apoiou atividades de capacitação de técnicos e agricultores com base nos princípios e diretrizes da Pnater? (Considere como apoio a atividades de capacitação a participação no planejamento, elaboração de ementas, seleção de participantes e de palestrantes.)

\begin{tabular}{|l|l|}
\hline$X$ & SIM \\
\hline & NÃO \\
\hline
\end{tabular}

8) Usou os conhecimentos para ministrar outros cursos com o mesmo conteúdo ou conteúdos semelhantes?

\begin{tabular}{|l|l|}
\hline$X$ & SIM \\
\hline & NÃO \\
\hline
\end{tabular}


9) Marque o seu grau de satisfação com relação ao curso oferecido pelo DATER: (Considere a seguinte pontuação: 1 - MUITO RUIM; 2 - RUIM; 3 - REGULAR; 4 - BOM; 5 - MUITO BOM)

\begin{tabular}{|l|l|l|l|l|}
\hline 1 & 2 & 3 & 4 & $\times 5$ \\
\hline
\end{tabular}

10) Marque seu grau de satisfação com relação ao DATER: (Considere a seguinte pontuação: 1 - MUITO RUIM; 2 - RUIM; 3 - REGULAR; 4 - BOM; 5 - MUITO BOM)

\begin{tabular}{|l|l|l|l|l|}
\hline 1 & 2 & 3 & 4 & $\times 5$ \\
\hline
\end{tabular}


PESQUISA - IMPACTO DAS AÇÕES DE FORMAÇÃO REALIZADAS PELO DATER/SAF/MDA NO PERÍODO 2004-2009

Caros colaboradores,

Contamos com a sua atenção para preencher o formulário abaixo.

O mesmo tem por objetivo fornecer informações para avaliação da Eficiência, Efetividade e Eficácia da Política Pública de Formação de Agentes de Ater adotada pelo Departamento de Assistência Técnica e Extensão Rural, da Secretaria de Agricultura Familiar do Ministério do Desenvolvimento - DATER/SAF/MDA, no período de 2004 a 2009, tema escolhido para Monografia a ser apresentada à Universidade de Brasília (UnB) como requisito parcial para obtenção do grau de Bacharel em Administração.

Você poderá ou não se identificar no questionário e garantimos que todas as informações fornecidas serão confidenciais e utilizadas apenas de forma sistematizada.

IDENTIFICAÇÃO

\begin{tabular}{|l|l|}
\hline Nome: Dorival Silva Araujo & $\begin{array}{l}\text { Sexo: } \\
(\mathrm{x}) \text { masculino } \quad(\quad) \text { feminino }\end{array}$ \\
\hline $\begin{array}{l}\text { Instituição (nome e tipo de instituição: ONG, } \\
\text { Empresa Pública, etc.): SEAGRO }\end{array}$ & Local de trabalho (Cidade e Estado): \\
São Luis- MA \\
\hline \begin{tabular}{l} 
Curso/Encontro/Oficina do qual participou (caso tenha participado de mais de um curso, preencha \\
\hline Data do Curso/Encontro/Oficina (pelo menos mês e ano): 11 a 15 de abril de 2005
\end{tabular} \\
\hline
\end{tabular}

Indique sua área de atuação? (As opções não são excludentes: você poderá marcar mais de uma opção).

\begin{tabular}{|l|l|}
\hline & EXTENSÃO RURAL \\
\hline & PESQUISA \\
\hline & ENSINO \\
\hline$X$ & OUTROS \\
\hline
\end{tabular}

2) Qual o seu nível de escolaridade? (Considere apenas o nível mais alto) 


\begin{tabular}{|c|l|}
\hline & NÍVEL MÉDIO \\
\hline & NÍVEL SUPERIOR \\
\hline$X$ & PÓS-GRADUAÇÃO \\
\hline
\end{tabular}

3) Os conteúdos abordados foram condizentes com as demandas do seu dia-a-dia?

\begin{tabular}{|l|l|}
\hline$X$ & SIM \\
\hline & PARCIALMENTE \\
\hline & NÃO \\
\hline
\end{tabular}

4) O curso contribuiu para o seu aperfeiçoamento profissional?

\begin{tabular}{|l|l|}
\hline$X$ & SIM \\
\hline & NÃO \\
\hline
\end{tabular}

5) Os conhecimentos adquiridos estão sendo aplicados no seu trabalho? Em caso afirmativo, indique em que grau estes conhecimentos estão sendo aplicados. Em caso negativo, indique por que razão isto não ocorre: (As respostas não são excludentes: você poderá marcar mais de uma opção).

\begin{tabular}{|c|c|c|}
\hline \multirow{3}{*}{$\begin{array}{l}\text { SIM (indique ao lado em } \\
\text { que grau) }\end{array}$} & $x$ & MUITO APLICADOS \\
\hline & & MEDIAMENTE APLICADOS \\
\hline & & POUCO APLICADOS \\
\hline \multirow{3}{*}{$\begin{array}{l}\text { NÃO (indique ao lado a } \\
\text { razão da não aplicação) }\end{array}$} & & $\begin{array}{l}\text { CONTEÚDO NÃO ADEQUADO ȦS NECESSIDADES } \\
\text { ESPECÍFICAS DA REGIÃO }\end{array}$ \\
\hline & & $\begin{array}{l}\text { CONTEÚDO NÃO FOI SUFICIENTEMENTE } \\
\text { APROFUNDADO PARA PERMITIR UMA APLICAÇÃO } \\
\text { EFICAZ E EFICIENTE }\end{array}$ \\
\hline & & 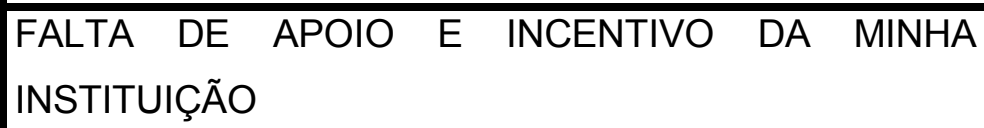 \\
\hline
\end{tabular}




\begin{tabular}{|l|l|l|}
\hline \multirow{2}{*}{} & & FALTA DE INCENTIVO ÀS AÇÕES DE ATER \\
\cline { 3 - 4 } & & NÃO TENHO INTERESSE EM APLICAR \\
\hline
\end{tabular}

6) A partir deste curso: (As opções não são excludentes: você poderá marcar mais de uma opção).

\begin{tabular}{|l|l|}
\hline$x$ & $\begin{array}{l}\text { NÃO MUDOU NADA EM MEU TRABALHO. } \\
\text { FAMILIARES. }\end{array}$ \\
\hline & CONSEGUI INFLUENCIAR NAS ORIENTAÇÕES DA MINHA INSTITUIÇÃO. \\
\hline & PASSEI A TRABALHAR COM METODOLOGIAS PARTICIPATIVAS. \\
\hline & \begin{tabular}{l} 
CRESCEU A ÁREA DE AGRICULTURA DE BASE ECOLÓGICA NAS COMUNIDADES \\
ONDE ATUO. \\
\hline
\end{tabular} \\
\hline
\end{tabular}

7) Depois do curso você apoiou atividades de capacitação de técnicos e agricultores com base nos princípios e diretrizes da Pnater? (Considere como apoio a atividades de capacitação a participação no planejamento, elaboração de ementas, seleção de participantes e de palestrantes.)

\begin{tabular}{|l|l|}
\hline$X$ & SIM \\
\hline & NÃO \\
\hline
\end{tabular}

8) Usou os conhecimentos para ministrar outros cursos com o mesmo conteúdo ou conteúdos semelhantes?

\begin{tabular}{|l|l|}
\hline$X$ & SIM \\
\hline & NÃO \\
\hline
\end{tabular}

9) Marque o seu grau de satisfação com relação ao curso oferecido pelo DATER: (Considere a seguinte pontuação: 1 - MUITO RUIM; 2 - RUIM; 3 - REGULAR; 4 - BOM; 5 - MUITO BOM) 


\begin{tabular}{|l|l|l|l|l|}
\hline 1 & 2 & 3 & $4 X$ & 5 \\
\hline
\end{tabular}

10) Marque seu grau de satisfação com relação ao DATER: (Considere a seguinte pontuação:

1 - MUITO RUIM; 2 - RUIM; 3 - REGULAR; 4 - BOM; 5 - MUITO BOM)

\begin{tabular}{|l|l|l|l|l|}
\hline 1 & 2 & 3 & $4 X$ & 5 \\
\hline
\end{tabular}


PESQUISA - IMPACTO DAS AÇÕES DE FORMAÇÃO REALIZADAS PELO DATER/SAF/MDA NO PERÍODO 2004-2009

Caros colaboradores,

Contamos com a sua atenção para preencher o formulário abaixo.

O mesmo tem por objetivo fornecer informações para avaliação da Eficiência, Efetividade e Eficácia da Política Pública de Formação de Agentes de Ater adotada pelo Departamento de Assistência Técnica e Extensão Rural, da Secretaria de Agricultura Familiar do Ministério do Desenvolvimento - DATER/SAF/MDA, no período de 2004 a 2009, tema escolhido para Monografia a ser apresentada à Universidade de Brasília (UnB) como requisito parcial para obtenção do grau de Bacharel em Administração.

Você poderá ou não se identificar no questionário e garantimos que todas as informações fornecidas serão confidenciais e utilizadas apenas de forma sistematizada.

\section{IDENTIFICAÇÃO}

\begin{tabular}{|l|l|}
\hline Nome: Djair Brandão Maracajá & $\begin{array}{l}\text { Sexo: } \\
(\mathrm{x}) \text { masculino } \quad(\quad) \text { feminino }\end{array}$ \\
\hline $\begin{array}{l}\text { Instituição (nome e tipo de instituição: ONG, } \\
\text { Empresa Pública, etc.): EBDA }\end{array}$ & Local de trabalho (Cidade e Estado): \\
& Serrinha BA \\
\hline $\begin{array}{l}\text { Curso/Encontro/Oficina do qual participou (caso tenha participado de mais de um curso, preencha } \\
\text { um formulário para cada um deles): Cultivando Saberes }\end{array}$ \\
\hline Data do Curso/Encontro/Oficina (pelo menos mês e ano): 2009 \\
\hline
\end{tabular}

Indique sua área de atuação? (As opções não são excludentes: você poderá marcar mais de uma opção).

\begin{tabular}{|l|l|}
\hline$x$ & EXTENSÃO RURAL \\
\hline$x$ & PESQUISA \\
\hline & ENSINO \\
\hline & OUTROS \\
\hline
\end{tabular}


2) Qual o seu nível de escolaridade? ( Considere apenas o nível mais alto)

\begin{tabular}{|l|l|}
\hline & NÍVEL MÉDIO \\
\hline & NÍVEL SUPERIOR \\
\hline$X$ & PÓS-GRADUAÇÃO \\
\hline
\end{tabular}

3) Os conteúdos abordados foram condizentes com as demandas do seu dia-a-dia?

\begin{tabular}{|l|l|}
\hline & SIM \\
\hline$x$ & PARCIALMENTE \\
\hline & NÃO \\
\hline
\end{tabular}

4) O curso contribuiu para o seu aperfeiçoamento profissional?

\begin{tabular}{|l|l|}
\hline$X$ & SIM \\
\hline & NÃO \\
\hline
\end{tabular}

5) Os conhecimentos adquiridos estão sendo aplicados no seu trabalho? Em caso afirmativo, indique em que grau estes conhecimentos estão sendo aplicados. Em caso negativo, indique por que razão isto não ocorre: (As respostas não são excludentes: você poderá marcar mais de uma opção).

\begin{tabular}{|l|l|l|l|}
\hline \multirow{2}{*}{$\begin{array}{l}\text { SIM (indique ao lado em } \\
\text { que grau) }\end{array}$} & & MUITO APLICADOS \\
\cline { 3 - 4 } & & MEDIAMENTE APLICADOS \\
\cline { 2 - 3 } $\begin{array}{l}\text { NÃO (indique ao lado a } \\
\text { razão da não aplicação) }\end{array}$ & & $\begin{array}{l}\text { CONTEÚDO NÃO ADEQUADO ÁS NECESSIDADES } \\
\text { ESPECÍFICAS DA REGIÃO }\end{array}$ \\
\cline { 3 - 4 } & $\begin{array}{l}\text { CONTEÚDO NÃO FOI SUFICIENTEMENTE } \\
\text { APROFUNDADO PARA PERMITIR UMA APLICAÇÃO } \\
\text { EFICAZ E EFICIENTE }\end{array}$ \\
\hline
\end{tabular}




\begin{tabular}{|l|l|l|}
\hline \multirow{2}{*}{} & & $\begin{array}{l}\text { FALTA DE APOIO E INCENTIVO DA MINHA } \\
\text { INSTITUIÇÃO }\end{array}$ \\
\cline { 2 - 3 } & & FALTA DE INCENTIVO ÀS AÇÕES DE ATER \\
\cline { 2 - 3 } & NÃO TENHO INTERESSE EM APLICAR \\
\hline
\end{tabular}

6) A partir deste curso: (As opções não são excludentes: você poderá marcar mais de uma opção).

\begin{tabular}{|l|l|}
\hline & NÃO MUDOU NADA EM MEU TRABALHO. \\
\hline$x$ & $\begin{array}{l}\text { MEU TRABALHO PASSOU A CONTRIBUIR MAIS COM OS AGRICULTORES(AS) } \\
\text { FAMILIARES. }\end{array}$ \\
\hline$x$ & CONSEGUI INFLUENCIAR NAS ORIENTAÇÕES DA MINHA INSTITUIÇÃO. \\
\hline$x$ & $\begin{array}{l}\text { CRESCEU A TRABALHAR COM METODOLOGIAS PARTICIPATIVAS. } \\
\text { ONDE ATUO. }\end{array}$ \\
\hline$x$ & CONTINUEI ME APERFEIÇOANDO SOBRE TEMAS ABORDADOS. \\
\hline
\end{tabular}

7) Depois do curso você apoiou atividades de capacitação de técnicos e agricultores com base nos princípios e diretrizes da Pnater? (Considere como apoio a atividades de capacitação a participação no planejamento, elaboração de ementas, seleção de participantes e de palestrantes.)

\begin{tabular}{|l|l|}
\hline$X$ & SIM \\
\hline & NÃO \\
\hline
\end{tabular}

8) Usou os conhecimentos para ministrar outros cursos com o mesmo conteúdo ou conteúdos semelhantes?

\begin{tabular}{|l|l|}
\hline$X$ & SIM \\
\hline & NÃO \\
\hline
\end{tabular}

9) Marque o seu grau de satisfação com relação ao curso oferecido pelo DATER: (Considere a seguinte pontuação: 1 - MUITO RUIM; 2 - RUIM; 3 - REGULAR; 4 - BOM; 5 - MUITO BOM) 


\begin{tabular}{|l|l|l|l|l|}
\hline 1 & 2 & 3 & 4 & $5 x$ \\
\hline
\end{tabular}

10) Marque seu grau de satisfação com relação ao DATER: (Considere a seguinte pontuação:

1 - MUITO RUIM; 2 - RUIM; 3 - REGULAR; 4 - BOM; 5 - MUITO BOM)

\begin{tabular}{|l|l|l|l|l|}
\hline 1 & 2 & 3 & 4 & $5 x$ \\
\hline
\end{tabular}


PESQUISA - IMPACTO DAS AÇÕES DE FORMAÇÃO REALIZADAS PELO DATER/SAF/MDA NO PERÍODO 2004-2009

Caros colaboradores,

Contamos com a sua atenção para preencher o formulário abaixo.

O mesmo tem por objetivo fornecer informações para avaliação da Eficiência, Efetividade e Eficácia da Política Pública de Formação de Agentes de Ater adotada pelo Departamento de Assistência Técnica e Extensão Rural, da Secretaria de Agricultura Familiar do Ministério do Desenvolvimento - DATER/SAF/MDA, no período de 2004 a 2009, tema escolhido para Monografia a ser apresentada à Universidade de Brasília (UnB) como requisito parcial para obtenção do grau de Bacharel em Administração.

Você poderá ou não se identificar no questionário e garantimos que todas as informações fornecidas serão confidenciais e utilizadas apenas de forma sistematizada.

IDENTIFICAÇÃO

\begin{tabular}{|l|l|}
\hline $\begin{array}{l}\text { Nome: } \\
\text { Edson Falcão Lima }\end{array}$ & $\begin{array}{l}\text { Sexo: } \\
(\mathrm{x}) \text { masculino } \quad(\quad) \text { feminino }\end{array}$ \\
\hline $\begin{array}{l}\text { Instituição; } \\
\text { Extensão Rural do Piauí - EMATER. }\end{array}$ & $\begin{array}{l}\text { Local de trabalho; } \\
\text { Curso/Encontro/Oficina do qual participou: } \\
\text { Curso de Agente de Assistência Técnica e Extensão Rural }\end{array}$ \\
\hline Data do Curso/Encontro/Oficina: de 25 a 29/Outubro de 2004
\end{tabular}

Indique sua área de atuação? (As opções não são excludentes: você poderá marcar mais de uma opção).

\begin{tabular}{|l|l|}
\hline$X$ & EXTENSÃO RURAL \\
\hline & PESQUISA \\
\hline & ENSINO \\
\hline & OUTROS \\
\hline
\end{tabular}

2) Qual o seu nível de escolaridade? (Considere apenas o nível mais alto) 


\begin{tabular}{|c|l|}
\hline & NÍVEL MÉDIO \\
\hline$X$ & NÍVEL SUPERIOR \\
\hline & PÓS-GRADUAÇÃO \\
\hline
\end{tabular}

3) Os conteúdos abordados foram condizentes com as demandas do seu dia-a-dia?

\begin{tabular}{|l|l|}
\hline$X$ & SIM \\
\hline & PARCIALMENTE \\
\hline & NÃO \\
\hline
\end{tabular}

4) O curso contribuiu para o seu aperfeiçoamento profissional?

\begin{tabular}{|l|l|}
\hline$X$ & SIM \\
\hline & NÃO \\
\hline
\end{tabular}

5) Os conhecimentos adquiridos estão sendo aplicados no seu trabalho? Em caso afirmativo, indique em que grau estes conhecimentos estão sendo aplicados. Em caso negativo, indique por que razão isto não ocorre: (As respostas não são excludentes: você poderá marcar mais de uma opção).

\begin{tabular}{|c|c|c|c|}
\hline \multirow{3}{*}{$\mathrm{x}$} & \multirow{3}{*}{$\begin{array}{l}\text { SIM (indique ao lado em } \\
\text { que grau) }\end{array}$} & $\mathrm{X}$ & MUITO APLICADOS \\
\hline & & & MEDIAMENTE APLICADOS \\
\hline & & & POUCO APLICADOS \\
\hline & \multirow{5}{*}{$\begin{array}{l}\text { NÃO (indique ao lado a } \\
\text { razão da não aplicação) }\end{array}$} & & $\begin{array}{l}\text { CONTEÜDO NĀO ADEQUADO ȦS NECESSIDADES } \\
\text { ESPECÍFICAS DA REGIÃO }\end{array}$ \\
\hline & & & $\begin{array}{l}\text { CONTEÚDO NÃO FOI SUFICIENTEMENTE } \\
\text { APROFUNDADO PARA PERMITIR UMA APLICAÇÃO } \\
\text { EFICAZ E EFICIENTE }\end{array}$ \\
\hline & & & $\begin{array}{lllllll}\text { FALTA } & \text { DE } & \text { APOIO } & \text { E } & \text { INCENTIVO } & \text { DA } & \text { MINHA } \\
\text { INSTITUIÇÃO } & & & & \\
\end{array}$ \\
\hline & & & FALTA DE INCENTIVO ÀS AÇÕES DE ATER \\
\hline & & & NÃO TENHO INTERESSE EM APLICAR \\
\hline
\end{tabular}


6) A partir deste curso: (As opções não são excludentes: você poderá marcar mais de uma opção).

\begin{tabular}{|r|l|}
\hline$x$ & $\begin{array}{l}\text { NẼO MUDOU NADA EM MEU TRABALHO. } \\
\text { FAMILIARES. }\end{array}$ \\
\hline$X$ & CONSEGUI INFLUENCIAR NAS ORIENTAÇÕES DA MINHA INSTITUIÇÃO. \\
\hline$X$ & PASSEI A TRABALHAR COM METODOLOGIAS PARTICIPATIVAS. \\
\hline$X$ & $\begin{array}{l}\text { CRESCEU A ÁREA DE AGRICULTURA DE BASE ECOLÓGICA NAS COMUNIDADES } \\
\text { ONDE ATUO. }\end{array}$ \\
\hline$X$ & CONTINUEI ME APERFEIÇOANDO SOBRE TEMAS ABORDADOS. \\
\hline
\end{tabular}

7) Depois do curso você apoiou atividades de capacitação de técnicos e agricultores com base nos princípios e diretrizes da Pnater? (Considere como apoio a atividades de capacitação a participação no planejamento, elaboração de ementas, seleção de participantes e de palestrantes.)

\begin{tabular}{|l|l|}
\hline$X$ & SIM \\
\hline & NÃO \\
\hline
\end{tabular}

8) Usou os conhecimentos para ministrar outros cursos com o mesmo conteúdo ou conteúdos semelhantes?

\begin{tabular}{|l|l|}
\hline$X$ & SIM \\
\hline & NÃO \\
\hline
\end{tabular}

9) Marque o seu grau de satisfação com relação ao curso oferecido pelo DATER: (Considere a seguinte pontuação: 1 - MUITO RUIM; 2 - RUIM; 3 - REGULAR; 4 - BOM; 5 - MUITO BOM)

\begin{tabular}{|l|l|l|l|l|}
\hline 1 & 2 & 3 & $X$ & 5 \\
\hline
\end{tabular}

10) Marque seu grau de satisfação com relação ao DATER: (Considere a seguinte pontuação: 1 - MUITO RUIM; 2 - RUIM; 3 - REGULAR; 4 - BOM; 5 - MUITO BOM)

\begin{tabular}{|l|l|l|l|l|}
\hline 1 & 2 & 3 & $x$ & 5 \\
\hline
\end{tabular}


PESQUISA - IMPACTO DAS AÇÕES DE FORMAÇÃO REALIZADAS PELO DATER/SAF/MDA NO PERÍODO 2004-2009

Caros colaboradores,

Contamos com a sua atenção para preencher o formulário abaixo.

O mesmo tem por objetivo fornecer informações para avaliação da Eficiência, Efetividade e Eficácia da Política Pública de Formação de Agentes de Ater adotada pelo Departamento de Assistência Técnica e Extensão Rural, da Secretaria de Agricultura Familiar do Ministério do Desenvolvimento - DATER/SAF/MDA, no período de 2004 a 2009, tema escolhido para Monografia a ser apresentada à Universidade de Brasília (UnB) como requisito parcial para obtenção do grau de Bacharel em Administração.

Você poderá ou não se identificar no questionário e garantimos que todas as informações fornecidas serão confidenciais e utilizadas apenas de forma sistematizada.

IDENTIFICAÇÃO

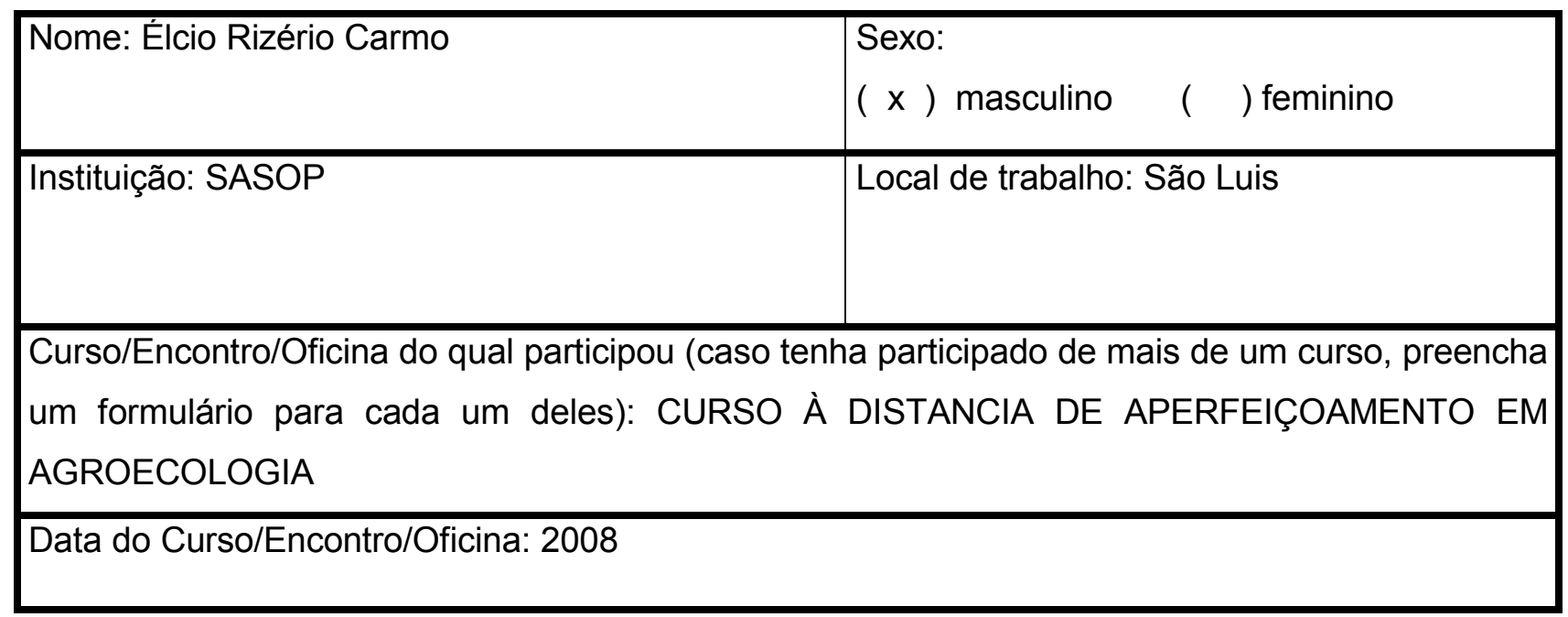

1. Indique sua área de atuação? (As opções não são excludentes: você poderá marcar mais de uma opção).

\begin{tabular}{|l|l|}
\hline$X$ & EXTENSÃO RURAL \\
\hline$X$ & PESQUISA \\
\hline & ENSINO \\
\hline & OUTROS \\
\hline
\end{tabular}


2) Qual o seu nível de escolaridade? (Considere apenas o nível mais alto)

\begin{tabular}{|c|l|}
\hline & NÍVEL MÉDIO \\
\hline$x$ & NÍVEL SUPERIOR \\
\hline & PÓS-GRADUAÇÃO \\
\hline
\end{tabular}

3) Os conteúdos abordados foram condizentes com as demandas do seu dia-a-dia?

\begin{tabular}{|l|l|}
\hline & SIM \\
\hline$x$ & PARCIALMENTE \\
\hline & NÃO \\
\hline
\end{tabular}

4) O curso contribuiu para o seu aperfeiçoamento profissional?

\begin{tabular}{|l|l|}
\hline$X$ & SIM \\
\hline & NÃO \\
\hline
\end{tabular}

5) Os conhecimentos adquiridos estão sendo aplicados no seu trabalho? Em caso afirmativo, indique em que grau estes conhecimentos estão sendo aplicados. Em caso negativo, indique por que razão isto não ocorre: (As respostas não são excludentes: você poderá marcar mais de uma opção).

\begin{tabular}{|c|c|c|}
\hline \multirow{3}{*}{$\begin{array}{l}\text { SIM (indique ao lado em } \\
\text { que grau) }\end{array}$} & & MUITO APLICADOS \\
\hline & & MEDIAMENTE APLICADOS \\
\hline & $\mathrm{X}$ & POUCO APLICADOS \\
\hline \multirow{2}{*}{$\begin{array}{l}\text { NÃO (indique ao lado a } \\
\text { razão da não aplicação) }\end{array}$} & & $\begin{array}{l}\text { CONTEÚDO NĀO ADEQUADO ȦS NECESSIDADES } \\
\text { ESPECÍFICAS DA REGIÃO }\end{array}$ \\
\hline & & $\begin{array}{l}\text { CONTEÚDO NÃO } \text { FOI SUFICIENTEMENTE } \\
\text { APROFUNDADO PARA PERMITIR UMA APLICAÇÃO } \\
\text { EFICAZ E EFICIENTE }\end{array}$ \\
\hline
\end{tabular}




\begin{tabular}{|l|l|l|}
\hline \multirow{2}{*}{} & & $\begin{array}{l}\text { FALTA DE APOIO E INCENTIVO DA MINHA } \\
\text { INSTITUIÇÃO }\end{array}$ \\
\cline { 2 - 3 } & & FALTA DE INCENTIVO ÀS AÇÕES DE ATER \\
\cline { 2 - 3 } & NÃO TENHO INTERESSE EM APLICAR \\
\hline
\end{tabular}

6) A partir deste curso: (As opções não são excludentes: você poderá marcar mais de uma opção).

\begin{tabular}{|l|l|}
\hline$x$ & $\begin{array}{l}\text { NÃO MUDOU NADA EM MEU TRABALHO. } \\
\text { FAMILIARES. }\end{array}$ \\
\hline & CONSEGUI INFLUENCIAR NAS ORIENTAÇÕES DA MINHA INSTITUIÇÃO. \\
\hline & PASSEI A TRABALHAR COM METODOLOGIAS PARTICIPATIVAS. \\
\hline$x$ & $\begin{array}{l}\text { CRESCEU A ÁREA DE AGRICULTURA DE BASE ECOLÓGICA NAS COMUNIDADES } \\
\text { ONDE ATUO. }\end{array}$ \\
\hline & CONTINUEI ME APERFEIÇOANDO SOBRE TEMAS ABORDADOS. \\
\hline
\end{tabular}

7) Depois do curso você apoiou atividades de capacitação de técnicos e agricultores com base nos princípios e diretrizes da Pnater? (Considere como apoio a atividades de capacitação a participação no planejamento, elaboração de ementas, seleção de participantes e de palestrantes.)

\begin{tabular}{|l|l|}
\hline & SIM \\
\hline$x$ & NÃO \\
\hline
\end{tabular}

8) Usou os conhecimentos para ministrar outros cursos com o mesmo conteúdo ou conteúdos semelhantes?

\begin{tabular}{|l|l|}
\hline & SIM \\
\hline$X$ & NÃO \\
\hline
\end{tabular}


9) Marque o seu grau de satisfação com relação ao curso oferecido pelo DATER: (Considere a seguinte pontuação: 1 - MUITO RUIM; 2 - RUIM; 3 - REGULAR; 4 - BOM; 5 - MUITO BOM)

\begin{tabular}{|l|l|l|l|l|}
\hline 1 & 2 & $x 3$ & 4 & 5 \\
\hline
\end{tabular}

10) Marque seu grau de satisfação com relação ao DATER: (Considere a seguinte pontuação: 1 - MUITO RUIM; 2 - RUIM; 3 - REGULAR; 4 - BOM; 5 - MUITO BOM)

\begin{tabular}{|l|l|l|l|l|}
\hline 1 & 2 & 3 & $x 4$ & 5 \\
\hline
\end{tabular}


PESQUISA - IMPACTO DAS AÇÕES DE FORMAÇÃO REALIZADAS PELO DATER/SAF/MDA NO PERÍODO 2004-2009

Caros colaboradores,

Contamos com a sua atenção para preencher o formulário abaixo.

O mesmo tem por objetivo fornecer informações para avaliação da Eficiência, Efetividade e Eficácia da Política Pública de Formação de Agentes de Ater adotada pelo Departamento de Assistência Técnica e Extensão Rural, da Secretaria de Agricultura Familiar do Ministério do Desenvolvimento - DATER/SAF/MDA, no período de 2004 a 2009, tema escolhido para Monografia a ser apresentada à Universidade de Brasília (UnB) como requisito parcial para obtenção do grau de Bacharel em Administração.

Você poderá ou não se identificar no questionário e garantimos que todas as informações fornecidas serão confidenciais e utilizadas apenas de forma sistematizada.

\section{IDENTIFICAÇÃO}

Nome: (opcional)

EVANILDO LIMA

Instituição (nome e tipo de instituição: ONG, Local de trabalho (Cidade e Estado):

Empresa Pública, Cooperativa,etc.):

SENHOR DO BONFIM

COMISSÃO PASTORAL DA TERRA

Curso/Encontro/Oficina do qual participou (caso tenha participado de mais de um evento de formação, preencha um formulário para cada um deles):

CURSO MANEJO AGROFLORESTA EM RECIFE/PE

Data do Curso/Encontro/Oficina/Seminário (pelo menos mês e ano): 2009

1) Indique sua área de atuação? (As opções não são excludentes: você poderá marcar mais de uma opção).

\begin{tabular}{|l|l|}
\hline$X$ & EXTENSÃO RURAL \\
\hline & PESQUISA \\
\hline & ENSINO \\
\hline & OUTROS \\
\hline
\end{tabular}


2) Qual o seu nível de escolaridade? (Considere apenas o nível mais alto)

\begin{tabular}{|l|l|}
\hline & NÍVEL MÉDIO \\
\hline & NÍVEL SUPERIOR \\
\hline$x$ & PÓS-GRADUAÇÃO \\
\hline
\end{tabular}

3) Os conteúdos abordados na formação foram condizentes com as demandas do seu dia-adia?

\begin{tabular}{|l|l|}
\hline & SIM \\
\hline$X$ & PARCIALMENTE \\
\hline & NÃO \\
\hline
\end{tabular}

4) O curso ou atividade de formação da qual você participou contribuiu para o seu aperfeiçoamento profissional?

\begin{tabular}{|l|l|}
\hline$x$ & SIM \\
\hline & NÃO \\
\hline
\end{tabular}

5) Os conhecimentos adquiridos nesta formação estão sendo aplicados no seu trabalho? Em caso afirmativo, indique em que grau estes conhecimentos estão sendo aplicados. Em caso negativo, indique por que razão isto não ocorre: (As respostas não são excludentes: você poderá marcar mais de uma opção).

\begin{tabular}{|c|c|c|}
\hline \multirow{3}{*}{$\begin{array}{l}\text { SIM (indique ao lado } \\
\text { em que grau) }\end{array}$} & & MUITO APLICADOS \\
\hline & & MEDIAMENTE APLICADOS \\
\hline & & POUCO APLICADOS \\
\hline \multirow{3}{*}{$\begin{array}{l}\text { NÃO (indique ao lado a } \\
\text { razão } \quad \text { da } \\
\text { aplicação) }\end{array}$} & $x$ & $\begin{array}{l}\text { CONTEÚDO NÃO ADEQUADO ȦS NECESSIDADES } \\
\text { ESPECÍFICAS DA REGIÃO }\end{array}$ \\
\hline & & \begin{tabular}{lccc|} 
CONTEÚDO & NÃO & FOI & SUFICIENTEMENTE \\
APROFUNDADO & PARA & PERMITIR & UMA \\
APLICAÇÃO EFICAZ E EFICIENTE &
\end{tabular} \\
\hline & & \begin{tabular}{|llllll} 
FALTA DE APOIO & E & INCENTIVO & DA & MINHA \\
INSTITUIÇÃO & & & & \\
\end{tabular} \\
\hline
\end{tabular}




\begin{tabular}{|l|l|l|}
\hline \multirow{2}{*}{} & & FALTA DE INCENTIVO ÀS AÇÕES DE ATER \\
\cline { 3 - 4 } & & NÃO TENHO INTERESSE EM APLICAR \\
\hline
\end{tabular}

6) A partir do evento de formação do qual você participou: (As respostas não são excludentes: você poderá marcar mais de uma opção).

\begin{tabular}{|l|l|}
\hline & NÃO MUDOU NADA EM MEU TRABALHO. \\
\hline & $\begin{array}{l}\text { MEU TRABALHO PASSOU A CONTRIBUIR MAIS COM OS AGRICULTORES(AS) } \\
\text { FAMILIARES. }\end{array}$ \\
\hline & CONSEGUI INFLUENCIAR NAS ORIENTAÇÕES DA MINHA INSTITUIÇÃO. \\
\hline & PASSEI A TRABALHAR COM METODOLOGIAS PARTICIPATIVAS. \\
\hline & $\begin{array}{l}\text { CRESCEU A ÁREA DE AGRICULTURA DE BASE ECOLÓGICA NAS } \\
\text { COMUNIDADES ONDE ATUO. }\end{array}$ \\
\hline$X$ & CONTINUEI ME APERFEIÇOANDO SOBRE TEMAS ABORDADOS. \\
\hline
\end{tabular}

7) Depois do evento de capacitação do qual participou, você apoiou atividades de capacitação de técnicos e/ou agricultores com base nos princípios e diretrizes da Pnater?

\begin{tabular}{|l|l|}
\hline$X$ & SIM \\
\hline & NÃO \\
\hline
\end{tabular}

8) Usou os conhecimentos para ministrar outros eventos de formação com o mesmo conteúdo ou conteúdos semelhantes?

\begin{tabular}{|l|l|}
\hline & SIM \\
\hline$X$ & NÃO \\
\hline
\end{tabular}

9) Marque o seu grau de satisfação com relação a atividade de formação oferecida pelo DATER: (Considere a seguinte pontuação: 1 - MUITO RUIM; 2 - RUIM; 3 - REGULAR; 4 BOM; 5 - MUITO BOM) 


\begin{tabular}{|l|l|l|l|l|}
\hline 1 & 2 & $\times 3$ & 4 & 5 \\
\hline
\end{tabular}

10) Marque seu grau de satisfação com relação ao DATER: (Considere a seguinte pontuação: 1 - MUITO RUIM; 2 - RUIM; 3 - REGULAR; 4 - BOM; 5 - MUITO BOM)

\begin{tabular}{|l|l|l|l|l|}
\hline 1 & 2 & 3 & $X 4$ & 5 \\
\hline
\end{tabular}


PESQUISA - IMPACTO DAS AÇÕES DE FORMAÇÃO REALIZADAS PELO DATER/SAF/MDA NO PERÍODO 2004-2009

Caros colaboradores,

Contamos com a sua atenção para preencher o formulário abaixo.

O mesmo tem por objetivo fornecer informações para avaliação da Eficiência, Efetividade e Eficácia da Política Pública de Formação de Agentes de Ater adotada pelo Departamento de Assistência Técnica e Extensão Rural, da Secretaria de Agricultura Familiar do Ministério do Desenvolvimento - DATER/SAF/MDA, no período de 2004 a 2009, tema escolhido para Monografia a ser apresentada à Universidade de Brasília (UnB) como requisito parcial para obtenção do grau de Bacharel em Administração.

Você poderá ou não se identificar no questionário e garantimos que todas as informações fornecidas serão confidenciais e utilizadas apenas de forma sistematizada.

\section{IDENTIFICAÇÃO}

\begin{tabular}{|l|l|}
\hline Nome: Francisco Sales Sousa Filho & $\begin{array}{l}\text { Sexo: } \\
(\mathrm{x}) \text { masculino } \quad(\quad) \text { feminino }\end{array}$ \\
\hline Instituição: AGERP MA & Local de trabalho: São Luis \\
\hline $\begin{array}{l}\text { Curso/Encontro/Oficina do qual participou (caso tenha participado de mais de um curso, preencha } \\
\text { um formulário para cada um deles): Pronaf Sistemico }\end{array}$ \\
\hline Data do Curso/Encontro/Oficina: 2009
\end{tabular}

1. Indique sua área de atuação? (As opções não são excludentes: você poderá marcar mais de uma opção).

\begin{tabular}{|l|l|}
\hline$X$ & EXTENSÃO RURAL \\
\hline & PESQUISA \\
\hline & ENSINO \\
\hline & OUTROS \\
\hline
\end{tabular}


2) Qual o seu nível de escolaridade? (Considere apenas o nível mais alto)

\begin{tabular}{|l|l|}
\hline & NÍVEL MÉDIO \\
\hline$X$ & NÍVEL SUPERIOR \\
\hline & PÓS-GRADUAÇÃO \\
\hline
\end{tabular}

3) Os conteúdos abordados foram condizentes com as demandas do seu dia-a-dia?

\begin{tabular}{|l|l|}
\hline & SIM \\
\hline$X$ & PARCIALMENTE \\
\hline & NÃO \\
\hline
\end{tabular}

3) O curso contribuiu para o seu aperfeiçoamento profissional?

\begin{tabular}{|l|l|}
\hline$X$ & SIM \\
\hline & NÃO \\
\hline
\end{tabular}

5) Os conhecimentos adquiridos estão sendo aplicados no seu trabalho? Em caso afirmativo, indique em que grau estes conhecimentos estão sendo aplicados. Em caso negativo, indique por que razão isto não ocorre: (As respostas não são excludentes: você poderá marcar mais de uma opção).

\begin{tabular}{|l|l|l|l|}
\hline \multirow{2}{*}{$\begin{array}{l}\text { SIM (indique ao lado em } \\
\text { que grau) }\end{array}$} & & MUITO APLICADOS \\
\cline { 3 - 4 } & & MEDIAMENTE APLICADOS \\
\hline \multirow{2}{*}{$\begin{array}{l}\text { NÃO (indique ao lado a } \\
\text { razão da não aplicação) }\end{array}$} & & $\begin{array}{l}\text { CONCO APLICADOS } \\
\text { ESPECÍFICAS DA REGIÃO }\end{array}$ \\
\cline { 3 - 4 } & $\begin{array}{l}\text { CONTEÚDO NÃO FOI SUFICIENTEMENTEE } \\
\text { APROFUNDADO PARA PERMITIR UMA APLICAÇÃO } \\
\text { EFICAZ E EFICIENTE }\end{array}$ \\
\hline
\end{tabular}




\begin{tabular}{|l|l|l|}
\hline \multirow{2}{*}{} & & $\begin{array}{l}\text { FALTA DE APOIO E INCENTIVO DA MINHA } \\
\text { INSTITUIÇÃO }\end{array}$ \\
\cline { 2 - 3 } & & FALTA DE INCENTIVO ÀS AÇÕES DE ATER \\
\cline { 2 - 3 } & NÃO TENHO INTERESSE EM APLICAR \\
\hline
\end{tabular}

6) A partir deste curso: (As opções não são excludentes: você poderá marcar mais de uma opção).

\begin{tabular}{|l|l|}
\hline$x$ & $\begin{array}{l}\text { NÃO MUDOU NADA EM MEU TRABALHO. } \\
\text { FAMILIARES. }\end{array}$ \\
\hline & CONSEGUI INFLUENCIAR NAS ORIENTAÇÕES DA MINHA INSTITUIÇÃO. \\
\hline & PASSEI A TRABALHAR COM METODOLOGIAS PARTICIPATIVAS. \\
\hline & \begin{tabular}{l} 
ORESCEU A ÁREA DE AGRICULTURA DE BASE ECOLÓGICA NAS COMUNIDADES \\
\hline
\end{tabular} \\
\hline
\end{tabular}

7) Depois do curso você apoiou atividades de capacitação de técnicos e agricultores com base nos princípios e diretrizes da Pnater? (Considere como apoio a atividades de capacitação a participação no planejamento, elaboração de ementas, seleção de participantes e de palestrantes.)

\begin{tabular}{|l|l|}
\hline & SIM \\
\hline$x$ & NÃO \\
\hline
\end{tabular}

8) Usou os conhecimentos para ministrar outros cursos com o mesmo conteúdo ou conteúdos semelhantes?

\begin{tabular}{|l|l|}
\hline & SIM \\
\hline$x$ & NÃO \\
\hline
\end{tabular}


9) Marque o seu grau de satisfação com relação ao curso oferecido pelo DATER: (Considere a seguinte pontuação: 1 - MUITO RUIM; 2 - RUIM; 3 - REGULAR; 4 - BOM; 5 - MUITO BOM)

\begin{tabular}{|l|l|l|l|l|}
\hline 1 & 2 & 3 & $x 4$ & 5 \\
\hline
\end{tabular}

10) Marque seu grau de satisfação com relação ao DATER: (Considere a seguinte pontuação: 1 - MUITO RUIM; 2 - RUIM; 3 - REGULAR; 4 - BOM; 5 - MUITO BOM)

\begin{tabular}{|l|l|l|l|l|}
\hline 1 & 2 & 3 & $X 4$ & 5 \\
\hline
\end{tabular}


PESQUISA - IMPACTO DAS AÇÕES DE FORMAÇÃO REALIZADAS PELO DATER/SAF/MDA NO PERÍODO 2004-2009

Caros colaboradores,

Contamos com a sua atenção para preencher o formulário abaixo.

O mesmo tem por objetivo fornecer informações para avaliação da Eficiência, Efetividade e Eficácia da Política Pública de Formação de Agentes de Ater adotada pelo Departamento de Assistência Técnica e Extensão Rural, da Secretaria de Agricultura Familiar do Ministério do Desenvolvimento - DATER/SAF/MDA, no período de 2004 a 2009, tema escolhido para Monografia a ser apresentada à Universidade de Brasília (UnB) como requisito parcial para obtenção do grau de Bacharel em Administração.

Você poderá ou não se identificar no questionário e garantimos que todas as informações fornecidas serão confidenciais e utilizadas apenas de forma sistematizada.

IDENTIFICAÇÃO

\begin{tabular}{|c|c|}
\hline $\begin{array}{l}\text { Nome: } \\
\text { FRANCISCO } \\
\text { CAVALCANTE }\end{array}$ & $\begin{array}{l}\text { Sexo: } \\
(x) \text { masculino } \quad(\quad) \text { feminino }\end{array}$ \\
\hline $\begin{array}{l}\text { Instituição } \\
\qquad \text { EMATERCE (EMPRESA PÚBLICA) }\end{array}$ & $\begin{array}{l}\text { Local de trabalho } \\
\text { ITAPIÚNA-CEARÁ }\end{array}$ \\
\hline \multicolumn{2}{|l|}{$\begin{array}{l}\text { Curso/Encontro/Oficina do qual participou } \\
\text { AGROECOLOGIA E EXTENSÃO RURAL. }\end{array}$} \\
\hline Data do Curso/Encontro/Oficina (pelo menos mês & ano): 21 A 23/08/2006 \\
\hline
\end{tabular}

1. Indique sua área de atuação? (As opções não são excludentes: você poderá marcar mais de uma opção).

\begin{tabular}{|l|l|}
\hline$X$ & EXTENSÃO RURAL \\
\hline & PESQUISA \\
\hline & ENSINO \\
\hline & OUTROS \\
\hline
\end{tabular}

2) Qual o seu nível de escolaridade? ( Considere apenas o nível mais alto) 


\begin{tabular}{|l|l|}
\hline$X$ & NÍVEL MÉDIO \\
\hline & NÍVEL SUPERIOR \\
\hline & PÓS-GRADUAÇÃO \\
\hline
\end{tabular}

3) Os conteúdos abordados foram condizentes com as demandas do seu dia-a-dia?

\begin{tabular}{|l|l|}
\hline$X$ & SIM \\
\hline & PARCIALMENTE \\
\hline & NÃO \\
\hline
\end{tabular}

4) O curso contribuiu para o seu aperfeiçoamento profissional?

\begin{tabular}{|l|l|}
\hline$X$ & SIM \\
\hline & NÃO \\
\hline
\end{tabular}

5) Os conhecimentos adquiridos estão sendo aplicados no seu trabalho? Em caso afirmativo, indique em que grau estes conhecimentos estão sendo aplicados. Em caso negativo, indique por que razão isto não ocorre: (As respostas não são excludentes: você poderá marcar mais de uma opção).

\begin{tabular}{|c|c|c|c|}
\hline \multirow{3}{*}{$X$} & \multirow{3}{*}{$\begin{array}{l}\text { SIM (indique ao lado em } \\
\text { que grau) }\end{array}$} & & MUITO APLICADOS \\
\hline & & $\mathrm{X}$ & MEDIAMENTE APLICADOS \\
\hline & & & POUCO APLICADOS \\
\hline & \multirow{2}{*}{$\begin{array}{l}\text { NÃO (indique ao lado a } \\
\text { razão da não aplicação) }\end{array}$} & & $\begin{array}{l}\text { CONTEÚDO NÃO ADEQUADO ȦS NECESSIDADES } \\
\text { ESPECÍFICAS DA REGIÃO }\end{array}$ \\
\hline & & & $\begin{array}{l}\text { CONTEÚDO NÃO } \quad \text { FOI SUFICIENTEMENTE } \\
\text { APROFUNDADO PARA } \\
\text { PERMITIR UMA APLICAÇÃO } \\
\text { EFICAZ E EFICIENTE }\end{array}$ \\
\hline
\end{tabular}




\begin{tabular}{|l|l|l|}
\hline \multirow{2}{*}{} & & $\begin{array}{l}\text { FALTA DE APOIO E INCENTIVO DA MINHA } \\
\text { INSTITUIÇÃO }\end{array}$ \\
\cline { 2 - 3 } & & FALTA DE INCENTIVO ÀS AÇÕES DE ATER \\
\cline { 2 - 3 } & NÃO TENHO INTERESSE EM APLICAR \\
\hline
\end{tabular}

6) A partir deste curso: (As opções não são excludentes: você poderá marcar mais de uma opção).

\begin{tabular}{|l|l|}
\hline$x$ & $\begin{array}{l}\text { NÃO MUDOU NADA EM MEU TRABALHO. } \\
\text { FAMILIARES. }\end{array}$ \\
\hline & CONSEGUI INFLUENCIAR NAS ORIENTAÇÕES DA MINHA INSTITUIÇÃO. \\
\hline & PASSEI A TRABALHAR COM METODOLOGIAS PARTICIPATIVAS. \\
\hline & $\begin{array}{l}\text { CRESCEU A ÁREA DE AGRICULTURA DE BASE ECOLÓGICA NAS COMUNIDADES } \\
\text { ONDE ATUO. }\end{array}$ \\
\hline & CONTINUEI ME APERFEIÇOANDO SOBRE TEMAS ABORDADOS. \\
\hline
\end{tabular}

7) Depois do curso você apoiou atividades de capacitação de técnicos e agricultores com base nos princípios e diretrizes da Pnater? (Considere como apoio a atividades de capacitação a participação no planejamento, elaboração de ementas, seleção de participantes e de palestrantes.)

\begin{tabular}{|l|l|}
\hline & SIM \\
\hline$X$ & NÃO \\
\hline
\end{tabular}

8) Usou os conhecimentos para ministrar outros cursos com o mesmo conteúdo ou conteúdos semelhantes?

\begin{tabular}{|l|l|}
\hline & SIM \\
\hline$X$ & NÃO \\
\hline
\end{tabular}


9) Marque o seu grau de satisfação com relação ao curso oferecido pelo DATER: (Considere a seguinte pontuação: 1 - MUITO RUIM; 2 - RUIM; 3 - REGULAR; 4 - BOM; 5 - MUITO BOM)

\begin{tabular}{|l|l|l|l|l|}
\hline 1 & 2 & 3 & $4 X$ & 5 \\
\hline
\end{tabular}

10) Marque seu grau de satisfação com relação ao DATER: (Considere a seguinte pontuação: 1 - MUITO RUIM; 2 - RUIM; 3 - REGULAR; 4 - BOM; 5 - MUITO BOM)

\begin{tabular}{|l|l|l|l|l|}
\hline 1 & 2 & 3 & $4 X$ & 5 \\
\hline
\end{tabular}


PESQUISA - IMPACTO DAS AÇÕES DE FORMAÇÃO REALIZADAS PELO DATER/SAF/MDA NO PERÍODO 2004-2009

Caros colaboradores,

Contamos com a sua atenção para preencher o formulário abaixo.

O mesmo tem por objetivo fornecer informações para avaliação da Eficiência, Efetividade e Eficácia da Política Pública de Formação de Agentes de Ater adotada pelo Departamento de Assistência Técnica e Extensão Rural, da Secretaria de Agricultura Familiar do Ministério do Desenvolvimento - DATER/SAF/MDA, no período de 2004 a 2009, tema escolhido para Monografia a ser apresentada à Universidade de Brasília (UnB) como requisito parcial para obtenção do grau de Bacharel em Administração.

Você poderá ou não se identificar no questionário e garantimos que todas as informações fornecidas serão confidenciais e utilizadas apenas de forma sistematizada.

IDENTIFICAÇÃO

\begin{tabular}{|c|c|}
\hline $\begin{array}{l}\text { Nome: } \\
\text { FRANCISCO } \\
\text { CAVALCANTE }\end{array}$ & $\begin{array}{l}\text { Sexo: } \\
(x) \text { masculino } \quad(\quad) \text { feminino }\end{array}$ \\
\hline $\begin{array}{l}\text { Instituição } \\
\qquad \text { EMATERCE ( EMPRESA PÚBLICA) }\end{array}$ & $\begin{array}{l}\text { Local de trabalho } \\
\text { ITAPIÚNA-CEARÁ }\end{array}$ \\
\hline \multicolumn{2}{|l|}{ Curso/Encontro/Oficina do qual participou } \\
\hline Data do Curso/Encontro/Oficina (pelo menos mês $\epsilon$ & ano): 21 A 23/08/2006 \\
\hline
\end{tabular}

1. Indique sua área de atuação? (As opções não são excludentes: você poderá marcar mais de uma opção).

\begin{tabular}{|l|l|}
\hline$X$ & EXTENSÃO RURAL \\
\hline & PESQUISA \\
\hline & ENSINO \\
\hline & OUTROS \\
\hline
\end{tabular}

2) Qual o seu nível de escolaridade? ( Considere apenas o nível mais alto) 


\begin{tabular}{|l|l|}
\hline$X$ & NÍVEL MÉDIO \\
\hline & NÍVEL SUPERIOR \\
\hline & PÓS-GRADUAÇÃO \\
\hline
\end{tabular}

3) Os conteúdos abordados foram condizentes com as demandas do seu dia-a-dia?

\begin{tabular}{|l|l|}
\hline$X$ & SIM \\
\hline & PARCIALMENTE \\
\hline & NÃO \\
\hline
\end{tabular}

4) O curso contribuiu para o seu aperfeiçoamento profissional?

\begin{tabular}{|l|l|}
\hline$X$ & SIM \\
\hline & NÃO \\
\hline
\end{tabular}

5) Os conhecimentos adquiridos estão sendo aplicados no seu trabalho? Em caso afirmativo, indique em que grau estes conhecimentos estão sendo aplicados. Em caso negativo, indique por que razão isto não ocorre: (As respostas não são excludentes: você poderá marcar mais de uma opção).

\begin{tabular}{|c|c|c|c|}
\hline \multirow{3}{*}{$X$} & \multirow{3}{*}{$\begin{array}{l}\text { SIM (indique ao lado em } \\
\text { que grau) }\end{array}$} & & MUITO APLICADOS \\
\hline & & $\mathrm{X}$ & MEDIAMENTE APLICADOS \\
\hline & & & POUCO APLICADOS \\
\hline & \multirow{2}{*}{$\begin{array}{l}\text { NÃO (indique ao lado a } \\
\text { razão da não aplicação) }\end{array}$} & & $\begin{array}{l}\text { CONTEÚDO NÃO ADEQUADO ȦS NECESSIDADES } \\
\text { ESPECÍFICAS DA REGIÃO }\end{array}$ \\
\hline & & & $\begin{array}{l}\text { CONTEÚDO NÃO } \quad \text { FOI SUFICIENTEMENTE } \\
\text { APROFUNDADO PARA } \\
\text { PERMITIR UMA APLICAÇÃO } \\
\text { EFICAZ E EFICIENTE }\end{array}$ \\
\hline
\end{tabular}




\begin{tabular}{|l|l|l|}
\hline \multirow{2}{*}{} & & $\begin{array}{l}\text { FALTA DE APOIO E INCENTIVO DA MINHA } \\
\text { INSTITUIÇÃO }\end{array}$ \\
\cline { 2 - 4 } & & FALTA DE INCENTIVO ÀS AÇÕES DE ATER \\
\cline { 2 - 3 } & & NÃO TENHO INTERESSE EM APLICAR \\
\hline
\end{tabular}

6) A partir deste curso: (As opções não são excludentes: você poderá marcar mais de uma opção).

\begin{tabular}{|l|l|}
\hline$x$ & $\begin{array}{l}\text { NÃO MUDOU NADA EM MEU TRABALHO. } \\
\text { FAMILIARES. }\end{array}$ \\
\hline & CONSEGUI INFLUENCIAR NAS ORIENTAÇÕES DA MINHA INSTITUIÇÃO. \\
\hline & PASSEI A TRABALHAR COM METODOLOGIAS PARTICIPATIVAS. \\
\hline & $\begin{array}{l}\text { CRESCEU A ÁREA DE AGRICULTURA DE BASE ECOLÓGICA NAS COMUNIDADES } \\
\text { ONDE ATUO. }\end{array}$ \\
\hline & CONTINUEI ME APERFEIÇOANDO SOBRE TEMAS ABORDADOS. \\
\hline
\end{tabular}

7) Depois do curso você apoiou atividades de capacitação de técnicos e agricultores com base nos princípios e diretrizes da Pnater? (Considere como apoio a atividades de capacitação a participação no planejamento, elaboração de ementas, seleção de participantes e de palestrantes.)

\begin{tabular}{|l|l|}
\hline & SIM \\
\hline$X$ & NÃO \\
\hline
\end{tabular}

8) Usou os conhecimentos para ministrar outros cursos com o mesmo conteúdo ou conteúdos semelhantes?

\begin{tabular}{|l|l|}
\hline & SIM \\
\hline$X$ & NÃO \\
\hline
\end{tabular}


9) Marque o seu grau de satisfação com relação ao curso oferecido pelo DATER: (Considere a seguinte pontuação: 1 - MUITO RUIM; 2 - RUIM; 3 - REGULAR; 4 - BOM; 5 - MUITO BOM)

\begin{tabular}{|l|l|l|l|l|}
\hline 1 & 2 & 3 & $4 X$ & 5 \\
\hline
\end{tabular}

10) Marque seu grau de satisfação com relação ao DATER: (Considere a seguinte pontuação: 1 - MUITO RUIM; 2 - RUIM; 3 - REGULAR; 4 - BOM; 5 - MUITO BOM)

\begin{tabular}{|l|l|l|l|l|}
\hline 1 & 2 & 3 & $4 X$ & 5 \\
\hline
\end{tabular}


PESQUISA - IMPACTO DAS AÇÕES DE FORMAÇÃO REALIZADAS PELO DATER/SAF/MDA NO PERÍODO 2004-2009

Caros colaboradores,

Contamos com a sua atenção para preencher o formulário abaixo.

O mesmo tem por objetivo fornecer informações para avaliação da Eficiência, Efetividade e Eficácia da Política Pública de Formação de Agentes de Ater adotada pelo Departamento de Assistência Técnica e Extensão Rural, da Secretaria de Agricultura Familiar do Ministério do Desenvolvimento - DATER/SAF/MDA, no período de 2004 a 2009, tema escolhido para Monografia a ser apresentada à Universidade de Brasília (UnB) como requisito parcial para obtenção do grau de Bacharel em Administração.

Você poderá ou não se identificar no questionário e garantimos que todas as informações fornecidas serão confidenciais e utilizadas apenas de forma sistematizada.

IDENTIFICAÇÃO

\begin{tabular}{|c|c|}
\hline $\begin{array}{l}\text { Nome: } \\
\text { Maria Góes de Oliveira Alencar }\end{array}$ & $\begin{array}{l}\text { Sexo: } \\
(\quad) \text { masculino }(x) \text { feminino }\end{array}$ \\
\hline $\begin{array}{l}\text { Instituição (nome e tipo de instituição): } \\
\text { Instituto de Assistência Técnica e Extensão Ruaral } \\
\text { do Piauí }\end{array}$ & $\begin{array}{l}\text { Local de trabalho (Município, Região): } \\
\text { Teresina - Piauí }\end{array}$ \\
\hline \multicolumn{2}{|c|}{$\begin{array}{l}\text { Curso/Encontro/Oficina do qual participou (caso tenha participado de mais de um curso, preencha } \\
\text { um formulário para cada um deles): } \\
\text { Curso para agentes de ATER sobre: Técnicas para aprendizagem e ação participativa - DRP. }\end{array}$} \\
\hline $\begin{array}{l}\text { Data do Curso/Encontro/Oficina (pelo menos mês e } \\
\text { Período } 06 \text { a } 10 \text { de Novembro 2006, São Luis - Mara }\end{array}$ & $\begin{array}{l}\text { ano): } \\
\text { anhão. }\end{array}$ \\
\hline
\end{tabular}

1. Indique sua área de atuação? (As opções não são excludentes: você poderá marcar mais de uma opção).

\begin{tabular}{|l|l|}
\hline$X$ & EXTENSÃO RURAL \\
\hline & PESQUISA \\
\hline & ENSINO \\
\hline & OUTRO \\
\hline
\end{tabular}


2) Qual o seu nível de escolaridade? ( Considere apenas o nível mais alto)

\begin{tabular}{|l|l|}
\hline & NÍVEL MÉDIO \\
\hline & NÍVEL SUPERIOR \\
\hline$X$ & PÓS-GRADUAÇÃO \\
\hline & OUTRO \\
\hline
\end{tabular}

3) Os conteúdos abordados foram condizentes com as demandas do seu dia-a-dia?

\begin{tabular}{|l|l|}
\hline$X$ & SIM \\
\hline & PARCIALMENTE \\
\hline & NÃO \\
\hline
\end{tabular}

4) O curso contribuiu para o seu aperfeiçoamento profissional?

\begin{tabular}{|l|l|}
\hline$X$ & SIM \\
\hline & NÃO \\
\hline
\end{tabular}

5) Os conhecimentos adquiridos estão sendo aplicados no seu trabalho? Em caso afirmativo, indique em que grau estes conhecimentos estão sendo aplicados. Em caso negativo, indique por que razão isto não ocorre: (As respostas não são excludentes: você poderá marcar mais de uma opção).

\begin{tabular}{|c|c|c|c|}
\hline \multirow{3}{*}{$\mathrm{x}$} & \multirow{3}{*}{$\begin{array}{l}\text { SIM (indique ao lado em } \\
\text { que grau) }\end{array}$} & & MUITO APLICADOS \\
\hline & & $\mathrm{X}$ & MEDIAMENTE APLICADOS \\
\hline & & & POUCO APLICADOS \\
\hline & & & $\begin{array}{l}\text { CONTEÚDO NÃO ADEQUADO ÀS NECESSIDADES } \\
\text { ESPECÍFICAS DA REGIÃO }\end{array}$ \\
\hline & razão da não aplicação) & & $\begin{array}{l}\text { CONTEÚDO NÃO FOI SUFICIENTEMENTE } \\
\text { APROFUNDADO PARA PERMITIR UMA APLICAÇÃO } \\
\text { EFICAZE EFICIENTE }\end{array}$ \\
\hline
\end{tabular}




\begin{tabular}{|l|l|l|}
\hline \multirow{2}{*}{} & & $\begin{array}{l}\text { FALTA DE APOIO E INCENTIVO DA MINHA } \\
\text { INSTITUIÇÃO }\end{array}$ \\
\cline { 2 - 3 } & & FALTA DE INCENTIVO ÀS AÇÕES DE ATER \\
\cline { 2 - 3 } & & NÃO TENHO INTERESSE EM APLICAR \\
\hline
\end{tabular}

6) A partir deste curso: (As opções não são excludentes: você poderá marcar mais de uma opção).

\begin{tabular}{|l|l|}
\hline & NÃDA MUDA EM MEU TRABALHO. \\
\hline$X$ & $\begin{array}{l}\text { MEU TRABALHO PASSOU A CONTRIBUIR MAIS COM OS AGRICULTORES(AS) } \\
\text { FAMILIARES. }\end{array}$ \\
\hline$X$ & CONSIGUI INFLUENCIAR NAS ORIENTAÇÕES DA MINHA INSTITUIÇÃO. \\
\hline$X$ & PASSEI A TRABALHAR COM METODOLOGIAS PARTICIPATIVAS. \\
\hline & $\begin{array}{l}\text { CRESCEU A ÁREA DE AGRICULTURA DE BASE ECOLÓGICA NAS COMUNIDADES } \\
\text { ONDE ATUO. }\end{array}$ \\
\hline$X$ & CONTINUEI ME APERFEIÇOANDO SOBRE TEMAS ABORDADOS. \\
\hline
\end{tabular}

7) Depois do curso você apoiou atividades de capacitação de técnicos e agricultores com base nos princípios e diretrizes da Pnater? (Considere como apoio a atividades de capacitação a participação no planejamento, elaboração de ementas, seleção de participantes e de palestrantes.)

\begin{tabular}{|l|l|}
\hline$X$ & SIM \\
\hline & NÃO \\
\hline
\end{tabular}

8) Usou os conhecimentos para ministrar outros cursos com o mesmo conteúdo ou conteúdos semelhantes?

\begin{tabular}{|l|l|}
\hline$X$ & SIM \\
\hline & NÃO \\
\hline
\end{tabular}


9) Marque o seu grau de satisfação com relação ao curso oferecido pelo DATER: (Considere a seguinte pontuação: 1 - MUITO RUIM; 2 - RUIM; 3 - REGULAR; 4 - BOM; 5 - MUITO BOM)

\begin{tabular}{|l|l|l|l|l|}
\hline 1 & 2 & 3 & 4 & $X$ \\
\hline
\end{tabular}

10) Marque seu grau de satisfação com relação ao DATER: (Considere a seguinte pontuação: 1 - MUITO RUIM; 2 - RUIM; 3 - REGULAR; 4 - BOM; 5 - MUITO BOM)

\begin{tabular}{|l|l|l|l|l|}
\hline 1 & 2 & 3 & 4 & $x$ \\
\hline
\end{tabular}


PESQUISA - IMPACTO DAS AÇÕES DE FORMAÇÃO REALIZADAS PELO DATER/SAF/MDA NO PERÍODO 2004-2009

Caros colaboradores,

Contamos com a sua atenção para preencher o formulário abaixo.

O mesmo tem por objetivo fornecer informações para avaliação da Eficiência, Efetividade e Eficácia da Política Pública de Formação de Agentes de Ater adotada pelo Departamento de Assistência Técnica e Extensão Rural, da Secretaria de Agricultura Familiar do Ministério do Desenvolvimento - DATER/SAF/MDA, no período de 2004 a 2009, tema escolhido para Monografia a ser apresentada à Universidade de Brasília (UnB) como requisito parcial para obtenção do grau de Bacharel em Administração.

Você poderá ou não se identificar no questionário e garantimos que todas as informações fornecidas serão confidenciais e utilizadas apenas de forma sistematizada.

IDENTIFICAÇÃO

\begin{tabular}{|l|l|}
\hline Nome: Hélio José P F Pinheiro & $\begin{array}{l}\text { Sexo: } \\
(\mathrm{x}) \text { masculino } \quad(\quad) \text { feminino }\end{array}$ \\
\hline $\begin{array}{l}\text { Instituição (nome e tipo de instituição: ONG, } \\
\text { Empresa Pública, etc.): SEARA }\end{array}$ & $\begin{array}{l}\text { Local de trabalho (Cidade e Estado): } \\
\text { Natal/RN }\end{array}$ \\
\hline $\begin{array}{l}\text { Curso/Encontro/Oficina do qual participou (caso tenha participado de mais de um curso, preencha } \\
\text { um formulário para cada um deles): Agroecologia }\end{array}$ \\
\hline Data do Curso/Encontro/Oficina (pelo menos mês e ano): 2006 \\
\hline
\end{tabular}

1. Indique sua área de atuação? (As opções não são excludentes: você poderá marcar mais de uma opção).

\begin{tabular}{|l|l|}
\hline$X$ & EXTENSÃO RURAL \\
\hline & PESQUISA \\
\hline$X$ & ENSINO \\
\hline$X$ & OUTROS \\
\hline
\end{tabular}

2) Qual o seu nível de escolaridade? ( Considere apenas o nível mais alto) 


\begin{tabular}{|c|l|}
\hline & NÍVEL MÉDIO \\
\hline & NÍVEL SUPERIOR \\
\hline$X$ & PÓS-GRADUAÇÃO \\
\hline
\end{tabular}

3) Os conteúdos abordados foram condizentes com as demandas do seu dia-a-dia?

\begin{tabular}{|l|l|}
\hline & SIM \\
\hline$X$ & PARCIALMENTE \\
\hline & NÃO \\
\hline
\end{tabular}

4) O curso contribuiu para o seu aperfeiçoamento profissional?

\begin{tabular}{|l|l|}
\hline$X$ & SIM \\
\hline & NÃO \\
\hline
\end{tabular}

5) Os conhecimentos adquiridos estão sendo aplicados no seu trabalho? Em caso afirmativo, indique em que grau estes conhecimentos estão sendo aplicados. Em caso negativo, indique por que razão isto não ocorre: (As respostas não são excludentes: você poderá marcar mais de uma opção).

\begin{tabular}{|c|c|c|}
\hline \multirow{3}{*}{$\begin{array}{l}\text { SIM (indique ao lado em } \\
\text { que grau) }\end{array}$} & & MUITO APLICADOS \\
\hline & & MEDIAMENTE APLICADOS \\
\hline & & POUCO APLICADOS \\
\hline \multirow{3}{*}{$\begin{array}{l}\text { NÃO (indique ao lado a } \\
\text { razão da não aplicação) }\end{array}$} & & $\begin{array}{l}\text { CONTEÚDO NÃO ADEQUADO ÀS NECESSIDADES } \\
\text { ESPECÍFICAS DA REGIÃO }\end{array}$ \\
\hline & & $\begin{array}{l}\text { CONTEÚDO NÃO } \quad \text { FOI SUFICIENTEMENTE } \\
\text { APROFUNDADO PARA PERMITIR UMA APLICAÇÃO } \\
\text { EFICAZ E EFICIENTE }\end{array}$ \\
\hline & $x$ & $\begin{array}{lccccc}\text { FALTA DE } & \text { APOIO } & \text { E } & \text { INCENTIVO } & \text { DA } & \text { MINHA } \\
\text { INSTITUIÇÃO } & & & & & \\
\end{array}$ \\
\hline
\end{tabular}




\begin{tabular}{|l|l|l|}
\hline \multirow{2}{*}{} & & FALTA DE INCENTIVO ÀS AÇÕES DE ATER \\
\cline { 3 - 4 } & & NÃO TENHO INTERESSE EM APLICAR \\
\hline
\end{tabular}

6) A partir deste curso: (As opções não são excludentes: você poderá marcar mais de uma opção).

\begin{tabular}{|r|l|}
\hline$x$ & $\begin{array}{l}\text { NÃO MUDOU NADA EM MEU TRABALHO. } \\
\text { FAMILIARES. }\end{array}$ \\
\hline & CONSEGUI INFLUENCIAR NAS ORIENTAÇÕES DA MINHA INSTITUIÇÃO. \\
\hline$X$ & PASSEI A TRABALHAR COM METODOLOGIAS PARTICIPATIVAS. \\
\hline & $\begin{array}{l}\text { CRESCEU A ÁREA DE AGRICULTURA DE BASE ECOLÓGICA NAS COMUNIDADES } \\
\text { ONDE ATUO. }\end{array}$ \\
\hline$X$ & CONTINUEI ME APERFEIÇOANDO SOBRE TEMAS ABORDADOS. \\
\hline
\end{tabular}

7) Depois do curso você apoiou atividades de capacitação de técnicos e agricultores com base nos princípios e diretrizes da Pnater? (Considere como apoio a atividades de capacitação a participação no planejamento, elaboração de ementas, seleção de participantes e de palestrantes.)

\begin{tabular}{|l|l|}
\hline$X$ & SIM \\
\hline & NÃO \\
\hline
\end{tabular}

8) Usou os conhecimentos para ministrar outros cursos com o mesmo conteúdo ou conteúdos semelhantes?

\begin{tabular}{|l|l|}
\hline$X$ & SIM \\
\hline & NÃO \\
\hline
\end{tabular}

9) Marque o seu grau de satisfação com relação ao curso oferecido pelo DATER: (Considere a seguinte pontuação: 1 - MUITO RUIM; 2 - RUIM; 3 - REGULAR; 4 - BOM; 5 - MUITO BOM) 


\begin{tabular}{|l|l|l|l|l|}
\hline 1 & 2 & $3 X$ & 4 & 5 \\
\hline
\end{tabular}

10) Marque seu grau de satisfação com relação ao DATER: (Considere a seguinte pontuação: 1 - MUITO RUIM; 2 - RUIM; 3 - REGULAR; 4 - BOM; 5 - MUITO BOM)

\begin{tabular}{|l|l|l|l|l|}
\hline 1 & 2 & 3 & $4 X$ & 5 \\
\hline
\end{tabular}


PESQUISA - IMPACTO DAS AÇÕES DE FORMAÇÃO REALIZADAS PELO DATER/SAF/MDA NO PERÍODO 2004-2009

Caros colaboradores,

Contamos com a sua atenção para preencher o formulário abaixo.

O mesmo tem por objetivo fornecer informações para avaliação da Eficiência, Efetividade e Eficácia da Política Pública de Formação de Agentes de Ater adotada pelo Departamento de Assistência Técnica e Extensão Rural, da Secretaria de Agricultura Familiar do Ministério do Desenvolvimento - DATER/SAF/MDA, no período de 2004 a 2009, tema escolhido para Monografia a ser apresentada à Universidade de Brasília (UnB) como requisito parcial para obtenção do grau de Bacharel em Administração.

Você poderá ou não se identificar no questionário e garantimos que todas as informações fornecidas serão confidenciais e utilizadas apenas de forma sistematizada.

\section{IDENTIFICAÇÃO}

\begin{tabular}{|c|c|}
\hline $\begin{array}{l}\text { Nome:FRANCISCO JADER DE ALBUQEURQUE } \\
\text { ENDEREÇO: Rua Maria Cesarina Lopes Barreto, } \\
231 \text { Campo dos Velhos } \\
\quad 62.040-700 \text { Sobral - Ceará }\end{array}$ & $\begin{array}{l}\text { Sexo: } \\
(x) \text { masculino }\end{array}$ \\
\hline $\begin{array}{l}\text { Instituição (nome e tipo de instituição: ONG, } \\
\text { Empresa Pública, etc.):EMATER-CEARÁ }\end{array}$ & $\begin{array}{|lccc|}\text { Local de trabalho } & \text { (Cidade } & \text { e } \\
\text { Estado):COREAÚ-CEARÁ } & & \\
\end{array}$ \\
\hline \multicolumn{2}{|c|}{$\begin{array}{l}\text { Curso/Encontro/Oficina do qual participou (caso tenha participado de mais de um curso, preencha } \\
\text { um formulário para cada um deles):CURSO DE APERFEIÇOAMENTO EM AGROECOLOGIA - } \\
\text { NÃO RECEBí O CERTIFICADO(sou do Ceará fui inscrito na turma do Rio Grande do Norte. }\end{array}$} \\
\hline Data do Curso/Encontro/Oficina (pelo menos mês $\epsilon$ & mon \\
\hline
\end{tabular}

Indique sua área de atuação? (As opções não são excludentes: você poderá marcar mais de uma opção).

\begin{tabular}{|l|l|}
\hline$x$ & EXTENSÃO RURAL \\
\hline & PESQUISA \\
\hline & ENSINO \\
\hline
\end{tabular}




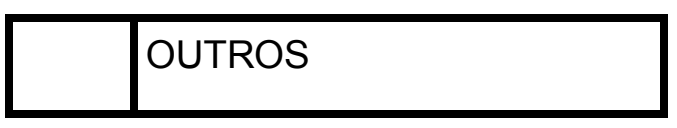

2) Qual o seu nível de escolaridade? ( Considere apenas o nível mais alto)

\begin{tabular}{|l|l|}
\hline & NÍVEL MÉDIO \\
\hline$x$ & NÍVEL SUPERIOR \\
\hline & PÓS-GRADUAÇÃO \\
\hline
\end{tabular}

3) Os conteúdos abordados foram condizentes com as demandas do seu dia-a-dia?

\begin{tabular}{|l|l|}
\hline$x$ & SIM \\
\hline & PARCIALMENTE \\
\hline & NÃO \\
\hline
\end{tabular}

4) O curso contribuiu para o seu aperfeiçoamento profissional?

\begin{tabular}{|l|l|}
\hline$x$ & SIM \\
\hline & NÃO \\
\hline
\end{tabular}

5) Os conhecimentos adquiridos estão sendo aplicados no seu trabalho? Em caso afirmativo, indique em que grau estes conhecimentos estão sendo aplicados. Em caso negativo, indique por que razão isto não ocorre: (As respostas não são excludentes: você poderá marcar mais de uma opção).

\begin{tabular}{|l|l|l|l|}
\hline \multirow{2}{*}{$\times$} & $\begin{array}{l}\text { SIM (indique ao lado em } \\
\text { que grau) }\end{array}$ & $\mathrm{x}$ & MUITO APLICADOS \\
\cline { 2 - 4 } & $\begin{array}{l}\text { NÃO (indique ao lado a } \\
\text { razão da não aplicação) }\end{array}$ & $\begin{array}{l}\text { CONTEÚDO NÃO ADEQUADO ȦS NECESSIDADES } \\
\text { ESPECÍFICAS DA REGIÃO }\end{array}$ \\
\hline
\end{tabular}




\begin{tabular}{|l|l|l|}
\hline \multirow{10}{*}{} & $\begin{array}{l}\text { CONTEÚDO NÃO FOI SUFICIENTEMENTE } \\
\text { APROFUNDADO PARA PERMITIR UMA APLICAÇÃO } \\
\text { EFICAZ E EFICIENTE }\end{array}$ \\
\cline { 2 - 4 } & $\begin{array}{l}\text { FALTA DE APOIO E INCENTIVO DA MINHA } \\
\text { INSTITUIÇÃO }\end{array}$ \\
\cline { 2 - 4 } & FALTA DE INCENTIVO ÀS AÇÕES DE ATER \\
\hline & NÃO TENHO INTERESSE EM APLICAR \\
\hline
\end{tabular}

6) A partir deste curso: (As opções não são excludentes: você poderá marcar mais de uma opção).

\begin{tabular}{|l|l|}
\hline$x$ & $\begin{array}{l}\text { NÃO MUDOU NADA EM MEU TRABALHO. } \\
\text { FAMILIARES. }\end{array}$ \\
\hline & CONSEGUI INFLUENCIAR NAS ORIENTAÇÕES DA MINHA INSTITUIÇÃO. \\
\hline & PASSEI A TRABALHAR COM METODOLOGIAS PARTICIPATIVAS. \\
\hline & $\begin{array}{l}\text { CRESCEU A ÁREA DE AGRICULTURA DE BASE ECOLÓGICA NAS COMUNIDADES } \\
\text { ONDE ATUO. }\end{array}$ \\
\hline & CONTINUEI ME APERFEIÇOANDO SOBRE TEMAS ABORDADOS. \\
\hline
\end{tabular}

7) Depois do curso você apoiou atividades de capacitação de técnicos e agricultores com base nos princípios e diretrizes da Pnater? (Considere como apoio a atividades de capacitação a participação no planejamento, elaboração de ementas, seleção de participantes e de palestrantes.)

\begin{tabular}{|l|l|}
\hline$x$ & SIM \\
\hline & NÃO \\
\hline
\end{tabular}

8) Usou os conhecimentos para ministrar outros cursos com o mesmo conteúdo ou conteúdos semelhantes? 


\begin{tabular}{|l|l|}
\hline & SIM \\
\hline$x$ & NÃO \\
\hline
\end{tabular}

9) Marque o seu grau de satisfação com relação ao curso oferecido pelo DATER: (Considere a seguinte pontuação: 1 - MUITO RUIM; 2 - RUIM; 3 - REGULAR; 4 - BOM; 5 - MUITO BOM)

\begin{tabular}{|l|l|l|l|l|}
\hline 1 & 2 & 3 & 4 & $5-X$ \\
\hline
\end{tabular}

10) Marque seu grau de satisfação com relação ao DATER: (Considere a seguinte pontuação: 1 - MUITO RUIM; 2 - RUIM; 3 - REGULAR; 4 - BOM; 5 - MUITO BOM)

\begin{tabular}{|l|l|l|l|l|}
\hline 1 & 2 & 3 & 4 & $5-X$ \\
\hline
\end{tabular}


PESQUISA - IMPACTO DAS AÇÕES DE FORMAÇÃO REALIZADAS PELO DATER/SAF/MDA NO PERÍODO 2004-2009

Caros colaboradores,

Contamos com a sua atenção para preencher o formulário abaixo.

O mesmo tem por objetivo fornecer informações para avaliação da Eficiência, Efetividade e Eficácia da Política Pública de Formação de Agentes de Ater adotada pelo Departamento de Assistência Técnica e Extensão Rural, da Secretaria de Agricultura Familiar do Ministério do Desenvolvimento - DATER/SAF/MDA, no período de 2004 a 2009, tema escolhido para Monografia a ser apresentada à Universidade de Brasília (UnB) como requisito parcial para obtenção do grau de Bacharel em Administração.

Você poderá ou não se identificar no questionário e garantimos que todas as informações fornecidas serão confidenciais e utilizadas apenas de forma sistematizada.

IDENTIFICAÇÃO

\begin{tabular}{|l|l|}
\hline Nome: JADIEL & $\begin{array}{l}\text { Sexo: } \\
(\mathrm{x}) \text { masculino } \quad(\quad) \text { feminino }\end{array}$ \\
\hline Instituição: AGERP MA & $\begin{array}{l}\text { Local de trabalho: REGIONAL DO } \\
\text { MUNIM/LENÇOIS MARANHENSES } \\
\text { ESCRITORIO DE BARREIRINHAS }\end{array}$ \\
\hline $\begin{array}{l}\text { Curso/Encontro/Oficina do qual participou (caso tenha participado de mais de um curso, preencha } \\
\text { um formulário para cada um deles): Credito do seguro da Agricultura Familiar }\end{array}$ \\
\hline Data do Curso/Encontro/Oficina: 2009
\end{tabular}

1. Indique sua área de atuação? (As opções não são excludentes: você poderá marcar mais de uma opção).

\begin{tabular}{|l|l|}
\hline$X$ & EXTENSÃO RURAL \\
\hline & PESQUISA \\
\hline & ENSINO \\
\hline & OUTROS \\
\hline
\end{tabular}


2) Qual o seu nível de escolaridade? ( Considere apenas o nível mais alto)

\begin{tabular}{|c|l|}
\hline & NÍVEL MÉDIO \\
\hline & NÍVEL SUPERIOR \\
\hline$X$ & PÓS-GRADUAÇÃO \\
\hline
\end{tabular}

3) Os conteúdos abordados foram condizentes com as demandas do seu dia-a-dia?

\begin{tabular}{|l|l|}
\hline$X$ & SIM \\
\hline & PARCIALMENTE \\
\hline & NÃO \\
\hline
\end{tabular}

4) O curso contribuiu para o seu aperfeiçoamento profissional?

\begin{tabular}{|l|l|}
\hline$X$ & SIM \\
\hline & NÃO \\
\hline
\end{tabular}

5) Os conhecimentos adquiridos estão sendo aplicados no seu trabalho? Em caso afirmativo, indique em que grau estes conhecimentos estão sendo aplicados. Em caso negativo, indique por que razão isto não ocorre: (As respostas não são excludentes: você poderá marcar mais de uma opção).

\begin{tabular}{|c|c|c|}
\hline \multirow{3}{*}{$\begin{array}{l}\text { SIM (indique ao lado em } \\
\text { que grau) }\end{array}$} & & MUITO APLICADOS \\
\hline & $\mathrm{X}$ & MEDIAMENTE APLICADOS \\
\hline & & POUCO APLICADOS \\
\hline \multirow{2}{*}{$\begin{array}{l}\text { NÃO (indique ao lado a } \\
\text { razão da não aplicação) }\end{array}$} & & $\begin{array}{l}\text { CONTEÚDO NÃO ADEQUADO ȦS NECESSIDADES } \\
\text { ESPECÍFICAS DA REGIÃO }\end{array}$ \\
\hline & & $\begin{array}{l}\text { CONTEÚDO NÃO } \quad \text { FOI } \quad \text { SUFICIENTEMENTE } \\
\text { APROFUNDADO PARA } \\
\text { EERMITIR UMA APLICAÇÃO } \\
\text { EFICAZ E EFICIENTE }\end{array}$ \\
\hline
\end{tabular}




\begin{tabular}{|l|l|l|}
\hline \multirow{2}{*}{} & & $\begin{array}{l}\text { FALTA DE APOIO E INCENTIVO DA MINHA } \\
\text { INSTITUIÇÃO }\end{array}$ \\
\cline { 2 - 3 } & & FALTA DE INCENTIVO ÀS AÇÕES DE ATER \\
\cline { 2 - 3 } & NÃO TENHO INTERESSE EM APLICAR \\
\hline
\end{tabular}

6) A partir deste curso: já trabalhava com metodologias participativas (As opções não são excludentes: você poderá marcar mais de uma opção).

\begin{tabular}{|l|l|}
\hline$x$ & $\begin{array}{l}\text { NÃO MUDOU NADA EM MEU TRABALHO. } \\
\text { FAMILIARES. }\end{array}$ \\
\hline & CONSEGUI INFLUENCIAR NAS ORIENTAÇÕES DA MINHA INSTITUIÇÃO. \\
\hline & PASSEI A TRABALHAR COM METODOLOGIAS PARTICIPATIVAS. \\
\hline & $\begin{array}{l}\text { CRESCEU A ÁREA DE AGRICULTURA DE BASE ECOLÓGICA NAS COMUNIDADES } \\
\text { ONDE ATUO. }\end{array}$ \\
\hline$X$ & CONTINUEI ME APERFEIÇOANDO SOBRE TEMAS ABORDADOS. \\
\hline
\end{tabular}

7) Depois do curso você apoiou atividades de capacitação de técnicos e agricultores com base nos princípios e diretrizes da Pnater?

\begin{tabular}{|l|l|}
\hline & SIM \\
\hline$x$ & NÃO \\
\hline
\end{tabular}

8) Usou os conhecimentos para ministrar outros cursos com o mesmo conteúdo ou conteúdos semelhantes?

\begin{tabular}{|l|l|}
\hline & SIM \\
\hline$X$ & NÃO \\
\hline
\end{tabular}

9) Marque o seu grau de satisfação com relação ao curso oferecido pelo DATER: (Considere a seguinte pontuação: 1 - MUITO RUIM; 2 - RUIM; 3 - REGULAR; 4 - BOM; 5 - MUITO BOM) 


\begin{tabular}{|l|l|l|l|l|}
\hline 1 & 2 & 3 & $X 4$ & 5 \\
\hline
\end{tabular}

10) Marque seu grau de satisfação com relação ao DATER: (Considere a seguinte pontuação:

1 - MUITO RUIM; 2 - RUIM; 3 - REGULAR; 4 - BOM; 5 - MUITO BOM)

\begin{tabular}{|l|l|l|l|l|}
\hline 1 & 2 & 3 & $X 4$ & 5 \\
\hline
\end{tabular}


PESQUISA - IMPACTO DAS AÇÕES DE FORMAÇÃO REALIZADAS PELO DATER/SAF/MDA NO PERÍODO 2004-2009

Caros colaboradores,

Contamos com a sua atenção para preencher o formulário abaixo.

O mesmo tem por objetivo fornecer informações para avaliação da Eficiência, Efetividade e Eficácia da Política Pública de Formação de Agentes de Ater adotada pelo Departamento de Assistência Técnica e Extensão Rural, da Secretaria de Agricultura Familiar do Ministério do Desenvolvimento - DATER/SAF/MDA, no período de 2004 a 2009, tema escolhido para Monografia a ser apresentada à Universidade de Brasília (UnB) como requisito parcial para obtenção do grau de Bacharel em Administração.

Você poderá ou não se identificar no questionário e garantimos que todas as informações fornecidas serão confidenciais e utilizadas apenas de forma sistematizada.

\section{IDENTIFICAÇÃO}

\begin{tabular}{|l|l|}
\hline Nome: Jailson Damasceno Bezerra & $\begin{array}{l}\text { Sexo: } \\
(\mathrm{x}) \text { masculino } \quad(\quad) \text { feminino }\end{array}$ \\
\hline Instituição: EMATER RN & Local de trabalho: Natal \\
\hline $\begin{array}{l}\text { Curso/Encontro/Oficina do qual participou (caso tenha participado de mais de um curso, preencha } \\
\text { um formulário para cada um deles): Pronaf Sistêmico }\end{array}$ \\
\hline Data do Curso/Encontro/Oficina: 2009
\end{tabular}

1. Indique sua área de atuação? (As opções não são excludentes: você poderá marcar mais de uma opção).

\begin{tabular}{|l|l|}
\hline$X$ & EXTENSÃO RURAL \\
\hline & PESQUISA \\
\hline & ENSINO \\
\hline & OUTROS \\
\hline
\end{tabular}


2) Qual o seu nível de escolaridade? ( Considere apenas o nível mais alto)

\begin{tabular}{|l|l|}
\hline$X$ & NÍVEL MÉDIO \\
\hline & NÍVEL SUPERIOR \\
\hline & PÓS-GRADUAÇÃO \\
\hline
\end{tabular}

3) Os conteúdos abordados foram condizentes com as demandas do seu dia-a-dia?

\begin{tabular}{|l|l|}
\hline & SIM \\
\hline$x$ & PARCIALMENTE \\
\hline & NÃO \\
\hline
\end{tabular}

3) O curso contribuiu para o seu aperfeiçoamento profissional?

\begin{tabular}{|l|l|}
\hline$X$ & SIM \\
\hline & NÃO \\
\hline
\end{tabular}

5) Os conhecimentos adquiridos estão sendo aplicados no seu trabalho? Em caso afirmativo, indique em que grau estes conhecimentos estão sendo aplicados. Em caso negativo, indique por que razão isto não ocorre: (As respostas não são excludentes: você poderá marcar mais de uma opção).

\begin{tabular}{|c|c|c|}
\hline \multirow{3}{*}{$\begin{array}{l}\text { SIM (indique ao lado em } \\
\text { que grau) }\end{array}$} & & MUITO APLICADOS \\
\hline & & MEDIAMENTE APLICADOS \\
\hline & $\mathrm{X}$ & POUCO APLICADOS \\
\hline \multirow{2}{*}{$\begin{array}{l}\text { NÃO (indique ao lado a } \\
\text { razão da não aplicação) }\end{array}$} & & $\begin{array}{l}\text { CONTEÚDO NÃO ADEQUADO ȦS NECESSIDADES } \\
\text { ESPECÍFICAS DA REGIÃO }\end{array}$ \\
\hline & & $\begin{array}{l}\text { CONTEÚDO NÃO } \quad \text { FOI SUFICIENTEMENTE } \\
\text { APROFUNDADO PARA } \\
\text { PERMITIR UMA APLICAÇÃO } \\
\text { EFICAZ E EFICIENTE }\end{array}$ \\
\hline
\end{tabular}




\begin{tabular}{|l|l|l|}
\hline \multirow{2}{*}{} & & $\begin{array}{l}\text { FALTA DE APOIO E INCENTIVO DA MINHA } \\
\text { INSTITUIÇÃO }\end{array}$ \\
\cline { 2 - 3 } & & FALTA DE INCENTIVO ÀS AÇÕES DE ATER \\
\cline { 2 - 3 } & NÃO TENHO INTERESSE EM APLICAR \\
\hline
\end{tabular}

6) A partir deste curso: (As opções não são excludentes: você poderá marcar mais de uma opção).

\begin{tabular}{|l|l|}
\hline & NÃO MUDOU NADA EM MEU TRABALHO. \\
\hline & $\begin{array}{l}\text { MEU TRABALHO PASSOU A CONTRIBUIR MAIS COM OS AGRICULTORES(AS) } \\
\text { FAMILIARES. }\end{array}$ \\
\hline & CONSEGUI INFLUENCIAR NAS ORIENTAÇÕES DA MINHA INSTITUIÇÃO. \\
\hline & $\begin{array}{l}\text { CRESESE A TRABALHAR COM METODOLOGIAS PARTICIPATIVAS. } \\
\text { ONDE ATUO. ÁREA DE AGRICULTURA DE BASE ECOLÓGICA NAS COMUNIDADES }\end{array}$ \\
\hline$x$ & CONTINUEI ME APERFEIÇOANDO SOBRE TEMAS ABORDADOS. \\
\hline
\end{tabular}

7) Depois do curso você apoiou atividades de capacitação de técnicos e agricultores com base nos princípios e diretrizes da Pnater? (Considere como apoio a atividades de capacitação a participação no planejamento, elaboração de ementas, seleção de participantes e de palestrantes.)

\begin{tabular}{|l|l|}
\hline & SIM \\
\hline$x$ & NÃO \\
\hline
\end{tabular}

8) Usou os conhecimentos para ministrar outros cursos com o mesmo conteúdo ou conteúdos semelhantes?

\begin{tabular}{|l|l|}
\hline & SIM \\
\hline$X$ & NÃO \\
\hline
\end{tabular}


9) Marque o seu grau de satisfação com relação ao curso oferecido pelo DATER: (Considere a seguinte pontuação: 1 - MUITO RUIM; 2 - RUIM; 3 - REGULAR; 4 - BOM; 5 - MUITO BOM)

\begin{tabular}{|l|l|l|l|l|}
\hline 1 & 2 & 3 & $x 4$ & 5 \\
\hline
\end{tabular}

10) Marque seu grau de satisfação com relação ao DATER: (Considere a seguinte pontuação: 1 - MUITO RUIM; 2 - RUIM; 3 - REGULAR; 4 - BOM; 5 - MUITO BOM)

\begin{tabular}{|l|l|l|l|l|}
\hline 1 & 2 & 3 & $x 4$ & 5 \\
\hline
\end{tabular}


PESQUISA - IMPACTO DAS AÇÕES DE FORMAÇÃO REALIZADAS PELO DATER/SAF/MDA NO PERÍODO 2004-2009

Caros colaboradores,

Contamos com a sua atenção para preencher o formulário abaixo.

O mesmo tem por objetivo fornecer informações para avaliação da Eficiência, Efetividade e Eficácia da Política Pública de Formação de Agentes de Ater adotada pelo Departamento de Assistência Técnica e Extensão Rural, da Secretaria de Agricultura Familiar do Ministério do Desenvolvimento - DATER/SAF/MDA, no período de 2004 a 2009, tema escolhido para Monografia a ser apresentada à Universidade de Brasília (UnB) como requisito parcial para obtenção do grau de Bacharel em Administração.

Você poderá ou não se identificar no questionário e garantimos que todas as informações fornecidas serão confidenciais e utilizadas apenas de forma sistematizada.

\section{IDENTIFICAÇÃO}

\begin{tabular}{|l|l|}
\hline $\begin{array}{l}\text { Nome: } \\
\text { JOSE JOAQUIM DOS SANTOS NETO }\end{array}$ & $\begin{array}{l}\text { Sexo: } \\
(\mathrm{x}) \text { masculino } \quad(\quad) \text { feminino }\end{array}$ \\
\hline $\begin{array}{l}\text { Instituição : DEAGRO - Depto. Estadual de } \\
\text { Desenvolvimento Agropecuário de Sergipe }\end{array}$ & $\begin{array}{l}\text { Local de trabalho : } \\
\text { Ribeirópolis - Se }\end{array}$ \\
\hline $\begin{array}{l}\text { Curso/Encontro/Oficina do qual participou : } \\
\text { Encontro de Multiplicadores de ATER }\end{array}$ & \\
\hline $\begin{array}{l}\text { Data do Curso/Encontro/Oficina : } \\
11 \text { a 15/09/2006 - Estancia/Se. }\end{array}$ & \\
\hline
\end{tabular}

1. Indique sua área de atuação? (As opções não são excludentes: você poderá marcar mais de uma opção).

\begin{tabular}{|l|l|}
\hline$x$ & EXTENSÃO RURAL \\
\hline & PESQUISA \\
\hline & ENSINO \\
\hline & OUTROS \\
\hline
\end{tabular}


2) Qual o seu nível de escolaridade? ( Considere apenas o nível mais alto)

\begin{tabular}{|l|l|}
\hline$x$ & NÍVEL MÉDIO \\
\hline & NÍVEL SUPERIOR \\
\hline & PÓS-GRADUAÇÃO \\
\hline
\end{tabular}

3) Os conteúdos abordados foram condizentes com as demandas do seu dia-a-dia?

\begin{tabular}{|l|l|}
\hline$x$ & SIM \\
\hline & PARCIALMENTE \\
\hline & NÃO \\
\hline
\end{tabular}

4) O curso contribuiu para o seu aperfeiçoamento profissional?

\begin{tabular}{|l|l|}
\hline$x$ & SIM \\
\hline & NÃO \\
\hline
\end{tabular}

5) Os conhecimentos adquiridos estão sendo aplicados no seu trabalho? Em caso afirmativo, indique em que grau estes conhecimentos estão sendo aplicados. Em caso negativo, indique por que razão isto não ocorre: (As respostas não são excludentes: você poderá marcar mais de uma opção).

\begin{tabular}{|c|c|c|c|}
\hline \multirow{3}{*}{$x$} & \multirow{3}{*}{$\begin{array}{l}\text { SIM (indique ao lado em } \\
\text { que grau) }\end{array}$} & & MUITO APLICADOS \\
\hline & & $x$ & MEDIAMENTE APLICADOS \\
\hline & & & POUCO APLICADOS \\
\hline & \multirow{5}{*}{$\begin{array}{l}\text { NÃO (indique ao lado a } \\
\text { razão da não aplicação) }\end{array}$} & & CONTEÚDO NÃO ADEQUADO ÀS NECESSIDADES \\
\hline & & & $\begin{array}{llll}\text { CONTEÚDO NÂO } & \text { FOI SUFICIENTEMENTE } \\
\text { APROFUNDADO } & \text { PARA } & \text { PERMITIR UMA APLICACÃO }\end{array}$ \\
\hline & & & 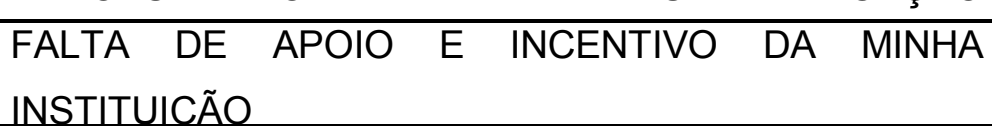 \\
\hline & & & FALTA DE INCENTIVO ÀS AÇÕES DE ATER \\
\hline & & & NÃO TENHO INTERESSE EM APLICAR \\
\hline
\end{tabular}


6) A partir deste curso: (As opções não são excludentes: você poderá marcar mais de uma opção).

\begin{tabular}{|l|l|}
\hline$x$ & $\begin{array}{l}\text { NÃO MUDOU NADA EM MEU TRABALHO. } \\
\text { FAMILIARES. }\end{array}$ \\
\hline$x$ & CONSEGUI INFLUENCIAR NAS ORIENTAÇÕES DA MINHA INSTITUIÇÃO. \\
\hline & PASSEI A TRABALHAR COM METODOLOGIAS PARTICIPATIVAS. \\
\hline & $\begin{array}{l}\text { CRESCEU A ÁREA DE AGRICULTURA DE BASE ECOLÓGICA NAS COMUNIDADES } \\
\mathrm{X}\end{array}$ \\
\hline
\end{tabular}

7) Depois do curso você apoiou atividades de capacitação de técnicos e agricultores com base nos princípios e diretrizes da Pnater? (Considere como apoio a atividades de capacitação a participação no planejamento, elaboração de ementas, seleção de participantes e de palestrantes.)

\begin{tabular}{|l|l|}
\hline$x$ & SIM \\
\hline & NÃO \\
\hline
\end{tabular}

8) Usou os conhecimentos para ministrar outros cursos com o mesmo conteúdo ou conteúdos semelhantes?

\begin{tabular}{|l|l|}
\hline$x$ & SIM \\
\hline & NÃO \\
\hline
\end{tabular}

9) Marque o seu grau de satisfação com relação ao curso oferecido pelo DATER: (Considere a seguinte pontuação: 1 - MUITO RUIM; 2 - RUIM; 3 - REGULAR; 4 - BOM; 5 - MUITO BOM)

\begin{tabular}{|l|l|l|l|l|}
\hline 1 & 2 & 3 & $4 x$ & 5 \\
\hline
\end{tabular}


10) Marque seu grau de satisfação com relação ao DATER: (Considere a seguinte pontuação: 1 - MUITO RUIM; 2 - RUIM; 3 - REGULAR; 4 - BOM; 5 - MUITO BOM)

\begin{tabular}{|l|l|l|l|l|}
\hline 1 & 2 & 3 & $4 x$ & 5 \\
\hline
\end{tabular}


PESQUISA - IMPACTO DAS AÇÕES DE FORMAÇÃO REALIZADAS PELO DATER/SAF/MDA NO PERÍODO 2004-2009

Caros colaboradores,

Contamos com a sua atenção para preencher o formulário abaixo.

O mesmo tem por objetivo fornecer informações para avaliação da Eficiência, Efetividade e Eficácia da Política Pública de Formação de Agentes de Ater adotada pelo Departamento de Assistência Técnica e Extensão Rural, da Secretaria de Agricultura Familiar do Ministério do Desenvolvimento - DATER/SAF/MDA, no período de 2004 a 2009, tema escolhido para Monografia a ser apresentada à Universidade de Brasília (UnB) como requisito parcial para obtenção do grau de Bacharel em Administração.

Você poderá ou não se identificar no questionário e garantimos que todas as informações fornecidas serão confidenciais e utilizadas apenas de forma sistematizada.

\section{IDENTIFICAÇÃO}

\begin{tabular}{|l|l|}
\hline Nome: Karissa Erre & $\begin{array}{l}\text { Sexo: } \\
(\quad) \text { masculino } \quad(\quad \mathrm{x}) \text { feminino }\end{array}$ \\
\hline Instituição: AGERP MA & Local de trabalho: São Luis \\
\hline $\begin{array}{l}\text { Curso/Encontro/Oficina do qual participou (caso tenha participado de mais de um curso, preencha } \\
\text { um formulário para cada um deles): Formação de Formadores Cultivando Saberes }\end{array}$ \\
\hline Data do Curso/Encontro/Oficina: 2009
\end{tabular}

Indique sua área de atuação? (As opções não são excludentes: você poderá marcar mais de uma opção).

\begin{tabular}{|l|l|}
\hline$X$ & EXTENSÃO RURAL \\
\hline & PESQUISA \\
\hline & ENSINO \\
\hline & OUTROS \\
\hline
\end{tabular}


2) Qual o seu nível de escolaridade? ( Considere apenas o nível mais alto)

\begin{tabular}{|l|l|}
\hline & NÍVEL MÉDIO \\
\hline & NÍVEL SUPERIOR \\
\hline$X$ & PÓS-GRADUAÇÃO \\
\hline
\end{tabular}

3) Os conteúdos abordados foram condizentes com as demandas do seu dia-a-dia?

\begin{tabular}{|l|l|}
\hline$X$ & SIM \\
\hline & PARCIALMENTE \\
\hline & NÃO \\
\hline
\end{tabular}

4) O curso contribuiu para o seu aperfeiçoamento profissional?

\begin{tabular}{|l|l|}
\hline$X$ & SIM \\
\hline & NÃO \\
\hline
\end{tabular}

5) Os conhecimentos adquiridos estão sendo aplicados no seu trabalho? Em caso afirmativo, indique em que grau estes conhecimentos estão sendo aplicados. Em caso negativo, indique por que razão isto não ocorre: (As respostas não são excludentes: você poderá marcar mais de uma opção).

\begin{tabular}{|c|c|c|}
\hline \multirow{3}{*}{$\begin{array}{l}\text { SIM (indique ao lado em } \\
\text { que grau) }\end{array}$} & $x$ & MUITO APLICADOS \\
\hline & & MEDIAMENTE APLICADOS \\
\hline & & POUCO APLICADOS \\
\hline \multirow{2}{*}{$\begin{array}{l}\text { NÃO (indique ao lado a } \\
\text { razão da não aplicação) }\end{array}$} & & $\begin{array}{l}\text { CONTEÚDO NÃO ADEQUADO ȦS NECESSIDADES } \\
\text { ESPECÍFICAS DA REGIÃO }\end{array}$ \\
\hline & & $\begin{array}{l}\text { CONTEÚDO NÃO } \quad \text { FOI SUFICIENTEMENTE } \\
\text { APROFUNDADO PARA } \\
\text { PERMITIR UMA APLICAÇÃO } \\
\text { EFICAZ E EFICIENTE }\end{array}$ \\
\hline
\end{tabular}




\begin{tabular}{|l|l|l|}
\hline \multirow{2}{*}{} & & $\begin{array}{l}\text { FALTA DE APOIO E INCENTIVO DA MINHA } \\
\text { INSTITUIÇÃO }\end{array}$ \\
\cline { 2 - 3 } & & FALTA DE INCENTIVO ÀS AÇÕES DE ATER \\
\cline { 2 - 3 } & NÃO TENHO INTERESSE EM APLICAR \\
\hline
\end{tabular}

6) A partir deste curso: (As opções não são excludentes: você poderá marcar mais de uma opção).

\begin{tabular}{|c|l|}
\hline & NÃO MUDOU NADA EM MEU TRABALHO. \\
\hline & $\begin{array}{l}\text { MEU TRABALHO PASSOU A CONTRIBUIR MAIS COM OS AGRICULTORES(AS) } \\
\text { FAMILIARES. }\end{array}$ \\
\hline$x$ & CONSEGUI INFLUENCIAR NAS ORIENTAÇÕES DA MINHA INSTITUIÇÃO. \\
\hline & PASSEI A TRABALHAR COM METODOLOGIAS PARTICIPATIVAS. \\
\hline & ORESCEU A ÁREA DE AGRICULTURA DE BASE ECOLÓGICA NAS COMUNIDADES \\
\hline$x$ & CONTINUEI ME APERFEIÇOANDO SOBRE TEMAS ABORDADOS. \\
\hline
\end{tabular}

7) Depois do curso você apoiou atividades de capacitação de técnicos e agricultores com base nos princípios e diretrizes da Pnater? (Considere como apoio a atividades de capacitação a participação no planejamento, elaboração de ementas, seleção de participantes e de palestrantes.)

\begin{tabular}{|l|l|}
\hline$x$ & SIM \\
\hline & NÃO \\
\hline
\end{tabular}

8) Usou os conhecimentos para ministrar outros cursos com o mesmo conteúdo ou conteúdos semelhantes?

\begin{tabular}{|l|l|}
\hline$x$ & SIM \\
\hline & NÃO \\
\hline
\end{tabular}


9) Marque o seu grau de satisfação com relação ao curso oferecido pelo DATER: (Considere a seguinte pontuação: 1 - MUITO RUIM; 2 - RUIM; 3 - REGULAR; 4 - BOM; 5 - MUITO BOM)

\begin{tabular}{|l|l|l|l|l|}
\hline 1 & 2 & 3 & $4 \times$ & 5 \\
\hline
\end{tabular}

10) Marque seu grau de satisfação com relação ao DATER: (Considere a seguinte pontuação: 1 - MUITO RUIM; 2 - RUIM; 3 - REGULAR; 4 - BOM; 5 - MUITO BOM)

\begin{tabular}{|l|l|l|l|l|}
\hline 1 & 2 & 3 & $4 \times$ & 5 \\
\hline
\end{tabular}


PESQUISA - IMPACTO DAS AÇÕES DE FORMAÇÃO REALIZADAS PELO DATER/SAF/MDA NO PERÍODO 2004-2009

Caros colaboradores,

Contamos com a sua atenção para preencher o formulário abaixo.

O mesmo tem por objetivo fornecer informações para avaliação da Eficiência, Efetividade e Eficácia da Política Pública de Formação de Agentes de Ater adotada pelo Departamento de Assistência Técnica e Extensão Rural, da Secretaria de Agricultura Familiar do Ministério do Desenvolvimento - DATER/SAF/MDA, no período de 2004 a 2009, tema escolhido para Monografia a ser apresentada à Universidade de Brasília (UnB) como requisito parcial para obtenção do grau de Bacharel em Administração.

Você poderá ou não se identificar no questionário e garantimos que todas as informações fornecidas serão confidenciais e utilizadas apenas de forma sistematizada.

IDENTIFICAÇÃO

\begin{tabular}{|c|c|}
\hline $\begin{array}{l}\text { Nome: } \\
\text { LIDUÍNA MARIA CALHEIROS DE ALENCAR }\end{array}$ & $\begin{array}{l}\text { Sexo: } \\
(\quad) \text { masculino }\end{array}$ \\
\hline $\begin{array}{l}\text { Instituição (nome e tipo de instituição: ONG, } \\
\text { Empresa Pública, etc.): } \\
\text { SEAGRI-AL }\end{array}$ & $\begin{array}{l}\text { Local de trabalho (Cidade e Estado): } \\
\text { MACEIÓ-ALAGOAS }\end{array}$ \\
\hline \multicolumn{2}{|c|}{$\begin{array}{l}\text { Curso/Encontro/Oficina do qual participou (caso tenha participado de mais de um curso, preencha } \\
\text { um formulário para cada um deles): } \\
\text { Formação Inicial para agentes de ATER }\end{array}$} \\
\hline menos mês & רo): fev 2005 \\
\hline
\end{tabular}

1. Indique sua área de atuação? (As opções não são excludentes: você poderá marcar mais de uma opção).

\begin{tabular}{|l|l|}
\hline$X$ & EXTENSÃO RURAL \\
\hline & PESQUISA \\
\hline & ENSINO \\
\hline & OUTROS \\
\hline
\end{tabular}


2) Qual o seu nível de escolaridade? ( Considere apenas o nível mais alto)

\begin{tabular}{|l|l|}
\hline & NÍVEL MÉDIO \\
\hline & NÍVEL SUPERIOR \\
\hline$X$ & PÓS-GRADUAÇÃO \\
\hline
\end{tabular}

3) Os conteúdos abordados foram condizentes com as demandas do seu dia-a-dia?

\begin{tabular}{|l|l|}
\hline$X$ & SIM \\
\hline & PARCIALMENTE \\
\hline & NÃO \\
\hline
\end{tabular}

4) O curso contribuiu para o seu aperfeiçoamento profissional?

\begin{tabular}{|l|l|}
\hline$X$ & SIM \\
\hline & NÃO \\
\hline
\end{tabular}

5) Os conhecimentos adquiridos estão sendo aplicados no seu trabalho? Em caso afirmativo, indique em que grau estes conhecimentos estão sendo aplicados. Em caso negativo, indique por que razão isto não ocorre: (As respostas não são excludentes: você poderá marcar mais de uma opção).

\begin{tabular}{|c|c|c|c|}
\hline \multirow{3}{*}{$\mathrm{x}$} & \multirow{3}{*}{$\begin{array}{l}\text { SIM (indique ao lado em } \\
\text { que grau) }\end{array}$} & $\mathrm{X}$ & MUITO APLICADOS \\
\hline & & & MEDIAMENTE APLICADOS \\
\hline & & & POUCO APLICADOS \\
\hline & & & $\begin{array}{l}\text { CONTEÚDO NĀO ADEQUADO ȦS NECESSIDADES } \\
\text { ESPECÍFICAS DA REGIÃO }\end{array}$ \\
\hline & razão da não aplicação) & & $\begin{array}{l}\text { CONTEÚDO NÃO FOI SUFICIENTEMENTE } \\
\text { APROFUNDADO PARA PERMITIR UMA APLICAÇÃO } \\
\text { EFICAZE EFICIENTE }\end{array}$ \\
\hline
\end{tabular}




\begin{tabular}{|l|l|l|}
\hline \multirow{2}{*}{} & & $\begin{array}{l}\text { FALTA DE APOIO E INCENTIVO DA MINHA } \\
\text { INSTITUIÇÃO }\end{array}$ \\
\cline { 2 - 3 } & & FALTA DE INCENTIVO ÀS AÇÕES DE ATER \\
\cline { 2 - 3 } & & NÃO TENHO INTERESSE EM APLICAR \\
\hline
\end{tabular}

6) A partir deste curso:

\begin{tabular}{|l|l|}
\hline & NÃO MUDOU NADA EM MEU TRABALHO. \\
\hline & $\begin{array}{l}\text { MEU TRABALHO PASSOU A CONTRIBUIR MAIS COM OS AGRICULTORES(AS) } \\
\text { FAMILIARES. }\end{array}$ \\
\hline$x$ & CONSEGUI INFLUENCIAR NAS ORIENTAÇÕES DA MINHA INSTITUIÇÃO. \\
\hline$x$ & $\begin{array}{l}\text { CRESCEU A ÁREA DE AGRICULTURA DE BASE ECOLÓGICA NAS COMUNIDADES } \\
\text { ONDE ATUO. }\end{array}$ \\
\hline & CONTINUEI ME APERFEIÇOANDO SOBRE TEMAS ABORDADOS. \\
\hline
\end{tabular}

7) Depois do curso você apoiou atividades de capacitação de técnicos e agricultores com base nos princípios e diretrizes da Pnater? (Considere como apoio a atividades de capacitação a participação no planejamento, elaboração de ementas, seleção de participantes e de palestrantes.)

\begin{tabular}{|l|l|}
\hline$X$ & SIM \\
\hline & NÃO \\
\hline
\end{tabular}

8) Usou os conhecimentos para ministrar outros cursos com o mesmo conteúdo ou conteúdos semelhantes?

\begin{tabular}{|l|l|}
\hline$X$ & SIM \\
\hline & NÃO \\
\hline
\end{tabular}


9) Marque o seu grau de satisfação com relação ao curso oferecido pelo DATER: (Considere a seguinte pontuação: 1 - MUITO RUIM; 2 - RUIM; 3 - REGULAR; 4 - BOM; 5 - MUITO BOM)

\begin{tabular}{|l|l|l|l|l|}
\hline$x 1$ & 2 & 3 & 4 & 5 \\
\hline
\end{tabular}

10) Marque seu grau de satisfação com relação ao DATER: (Considere a seguinte pontuação: 1 - MUITO RUIM; 2 - RUIM; 3 - REGULAR; 4 - BOM; 5 - MUITO BOM)

\begin{tabular}{|l|l|l|l|l|}
\hline 1 & 2 & $X 3$ & 4 & 5 \\
\hline
\end{tabular}


PESQUISA - IMPACTO DAS AÇÕES DE FORMAÇÃO REALIZADAS PELO DATER/SAF/MDA NO PERÍODO 2004-2009

Caros colaboradores,

Contamos com a sua atenção para preencher o formulário abaixo.

O mesmo tem por objetivo fornecer informações para avaliação da Eficiência, Efetividade e Eficácia da Política Pública de Formação de Agentes de Ater adotada pelo Departamento de Assistência Técnica e Extensão Rural, da Secretaria de Agricultura Familiar do Ministério do Desenvolvimento - DATER/SAF/MDA, no período de 2004 a 2009, tema escolhido para Monografia a ser apresentada à Universidade de Brasília (UnB) como requisito parcial para obtenção do grau de Bacharel em Administração.

Você poderá ou não se identificar no questionário e garantimos que todas as informações fornecidas serão confidenciais e utilizadas apenas de forma sistematizada.

IDENTIFICAÇÃO

\begin{tabular}{|c|c|}
\hline $\begin{array}{l}\text { Nome: } \\
\text { LIDUÍNA MARIA CALHEIROS DE ALENCAR }\end{array}$ & $\begin{array}{l}\text { Sexo: } \\
(\quad) \text { masculino } \quad(x) \text { feminino }\end{array}$ \\
\hline $\begin{array}{l}\text { Instituição (nome e tipo de instituição: ONG, } \\
\text { Empresa Pública, etc.): } \\
\text { SEAGRI-AL }\end{array}$ & $\begin{array}{l}\text { Local de trabalho (Cidade e Estado): } \\
\text { MACEIÓ-ALAGOAS }\end{array}$ \\
\hline \multicolumn{2}{|c|}{$\begin{array}{l}\text { Curso/Encontro/Oficina do qual participou (caso tenha participado de mais de um curso, preencha } \\
\text { um formulário para cada um deles): } \\
\text { CURSO DE AGROECOLOGIA (Fortaleza-CE) }\end{array}$} \\
\hline Data do Cu & o): 1 \\
\hline
\end{tabular}

1. Indique sua área de atuação? (As opções não são excludentes: você poderá marcar mais de uma opção).

\begin{tabular}{|l|l|}
\hline$X$ & EXTENSÃO RURAL \\
\hline$X$ & PESQUISA \\
\hline$X$ & ENSINO \\
\hline & OUTROS \\
\hline
\end{tabular}

2) Qual o seu nível de escolaridade? ( Considere apenas o nível mais alto) 


\begin{tabular}{|l|l|}
\hline & NÍVEL MÉDIO \\
\hline & NÍVEL SUPERIOR \\
\hline$X$ & PÓS-GRADUAÇÃO \\
\hline
\end{tabular}

3) Os conteúdos abordados foram condizentes com as demandas do seu dia-a-dia?

\begin{tabular}{|l|l|}
\hline$X$ & SIM \\
\hline & PARCIALMENTE \\
\hline & NÃO \\
\hline
\end{tabular}

4) O curso contribuiu para o seu aperfeiçoamento profissional?

\begin{tabular}{|l|l|}
\hline$X$ & SIM \\
\hline & NÃO \\
\hline
\end{tabular}

5) Os conhecimentos adquiridos estão sendo aplicados no seu trabalho? Em caso afirmativo, indique em que grau estes conhecimentos estão sendo aplicados. Em caso negativo, indique por que razão isto não ocorre: (As respostas não são excludentes: você poderá marcar mais de uma opção).

\begin{tabular}{|c|c|c|}
\hline \multirow{3}{*}{$\begin{array}{l}\text { SIM (indique ao lado em } \\
\text { que grau) }\end{array}$} & $\mathrm{X}$ & MUITO APLICADOS \\
\hline & & MEDIAMENTE APLICADOS \\
\hline & & POUCO APLICADOS \\
\hline \multirow{3}{*}{$\begin{array}{l}\text { NÃO (indique ao lado a } \\
\text { razão da não aplicação) }\end{array}$} & & $\begin{array}{l}\text { CONTEÚDO NĀO ADEQUADO ȦS NECESSIDADES } \\
\text { ESPECÍFICAS DA REGIÃO }\end{array}$ \\
\hline & & $\begin{array}{l}\text { CONTEÚDO NÃO FOI SUFICIENTEMENTE } \\
\text { APROFUNDADO PARA PERMITIR UMA APLICAÇÃO } \\
\text { EFICAZ E EFICIENTE }\end{array}$ \\
\hline & & $\begin{array}{lccccc}\text { FALTA DE } & \text { APOIO } & \text { E } & \text { INCENTIVO } & \text { DA } & \text { MINHA } \\
\text { INSTITUIÇÃO } & & & & \end{array}$ \\
\hline
\end{tabular}




\begin{tabular}{|l|l|l|}
\hline \multirow{2}{*}{} & & FALTA DE INCENTIVO ÀS AÇÕES DE ATER \\
\cline { 3 - 4 } & & NÃO TENHO INTERESSE EM APLICAR \\
\hline
\end{tabular}

6) A partir deste curso: (As opções não são excludentes: você poderá marcar mais de uma opção).

\begin{tabular}{|l|l|}
\hline & NÃO MUDOU NADA EM MEU TRABALHO. \\
\hline & $\begin{array}{l}\text { MEU TRABALHO PASSOU A CONTRIBUIR MAIS COM OS AGRICULTORES(AS) } \\
\text { FAMILIARES. }\end{array}$ \\
\hline & CONSEGUI INFLUENCIAR NAS ORIENTAÇÕES DA MINHA INSTITUIÇÃO. \\
\hline & $\begin{array}{l}\text { CRESSEI A TRABALHAR COM METODOLOGIAS PARTICIPATIVAS. } \\
\text { ONDE ATUO. }\end{array}$ \\
\hline$X$ & CONTINUEI DE AGRICULTURA DE BASE ECOLÓGICA NAS COMUNIDADES \\
\hline
\end{tabular}

7) Depois do curso você apoiou atividades de capacitação de técnicos e agricultores com base nos princípios e diretrizes da Pnater? (Considere como apoio a atividades de capacitação a participação no planejamento, elaboração de ementas, seleção de participantes e de palestrantes.)

\begin{tabular}{|l|l|}
\hline$X$ & SIM \\
\hline & NÃO \\
\hline
\end{tabular}

8) Usou os conhecimentos para ministrar outros cursos com o mesmo conteúdo ou conteúdos semelhantes?

\begin{tabular}{|l|l|}
\hline$X$ & SIM \\
\hline & NÃO \\
\hline
\end{tabular}

9) Marque o seu grau de satisfação com relação ao curso oferecido pelo DATER: (Considere a seguinte pontuação: 1 - MUITO RUIM; 2 - RUIM; 3 - REGULAR; 4 - BOM; 5 - MUITO BOM) 


\begin{tabular}{|l|l|l|l|l|}
\hline 1 & 2 & 3 & $x$ & 5 \\
\hline
\end{tabular}

10) Marque seu grau de satisfação com relação ao DATER: (Considere a seguinte pontuação:

1 - MUITO RUIM; 2 - RUIM; 3 - REGULAR; 4 - BOM; 5 - MUITO BOM)

\begin{tabular}{|l|l|l|l|l|}
\hline 1 & 2 & 3 & $x$ & 5 \\
\hline
\end{tabular}


PESQUISA - IMPACTO DAS AÇÕES DE FORMAÇÃO REALIZADAS PELO DATER/SAF/MDA NO PERÍODO 2004-2009

Caros colaboradores,

Contamos com a sua atenção para preencher o formulário abaixo.

O mesmo tem por objetivo fornecer informações para avaliação da Eficiência, Efetividade e Eficácia da Política Pública de Formação de Agentes de Ater adotada pelo Departamento de Assistência Técnica e Extensão Rural, da Secretaria de Agricultura Familiar do Ministério do Desenvolvimento - DATER/SAF/MDA, no período de 2004 a 2009, tema escolhido para Monografia a ser apresentada à Universidade de Brasília (UnB) como requisito parcial para obtenção do grau de Bacharel em Administração.

Você poderá ou não se identificar no questionário e garantimos que todas as informações fornecidas serão confidenciais e utilizadas apenas de forma sistematizada.

IDENTIFICAÇÃO

\begin{tabular}{|l|l|}
\hline Nome: Lidya Bandeira de Miranda & $\begin{array}{l}\text { Sexo: } \\
(\quad) \text { masculino } \quad(x) \text { feminino }\end{array}$ \\
\hline Instituição : Seagri - AL & Local de trabalho : Maceió - AL \\
\hline $\begin{array}{l}\text { Curso/Encontro/Oficina do qual participou : Formação de Formadores do Projeto Cultivando } \\
\text { Saberes }\end{array}$ \\
\hline Data do Curso/Encontro/Oficina: julho 2009
\end{tabular}

Indique sua área de atuação? (As opções não são excludentes: você poderá marcar mais de uma opção).

\begin{tabular}{|l|l|}
\hline$x$ & EXTENSÃO RURAL \\
\hline & PESQUISA \\
\hline & ENSINO \\
\hline & OUTROS \\
\hline
\end{tabular}

2) Qual o seu nível de escolaridade? ( Considere apenas o nível mais alto) 


\begin{tabular}{|l|l|}
\hline & NÍVEL MÉDIO \\
\hline$x$ & NÍVEL SUPERIOR \\
\hline & PÓS-GRADUAÇÃO \\
\hline
\end{tabular}

3) Os conteúdos abordados foram condizentes com as demandas do seu dia-a-dia?

\begin{tabular}{|l|l|}
\hline & SIM \\
\hline$x$ & PARCIALMENTE \\
\hline & NÃO \\
\hline
\end{tabular}

4) O curso contribuiu para o seu aperfeiçoamento profissional?

\begin{tabular}{|l|l|}
\hline$x$ & SIM \\
\hline & NÃO \\
\hline
\end{tabular}

5) Os conhecimentos adquiridos estão sendo aplicados no seu trabalho? Em caso afirmativo, indique em que grau estes conhecimentos estão sendo aplicados. Em caso negativo, indique por que razão isto não ocorre: (As respostas não são excludentes: você poderá marcar mais de uma opção).

\begin{tabular}{|c|c|c|}
\hline \multirow{3}{*}{$\begin{array}{l}\text { SIM (indique ao lado em } \\
\text { que grau) }\end{array}$} & & MUITO APLICADOS \\
\hline & & MEDIAMENTE APLICADOS \\
\hline & & POUCO APLICADOS \\
\hline \multirow{3}{*}{$\begin{array}{l}\text { NÃO (indique ao lado a } \\
\text { razão da não aplicação) }\end{array}$} & & $\begin{array}{l}\text { CONTEÚDO NÃO ADEQUADO ȦS NECESSIDADES } \\
\text { ESPECÍFICAS DA REGIÃO }\end{array}$ \\
\hline & & $\begin{array}{l}\text { CONTEÚDO NÃO } \quad \text { FOI SUFICIENTEMENTE } \\
\text { APROFUNDADO PARA } \\
\text { PERMITIR UMA APLICAÇÃO } \\
\text { EFICAZ E EFICIENTE }\end{array}$ \\
\hline & $x$ & $\begin{array}{l}\text { FALTA DE APOIO } \\
\text { INSTITUIÇÃO }\end{array}$ \\
\hline
\end{tabular}




\begin{tabular}{|l|l|l|}
\hline \multirow{2}{*}{} & & FALTA DE INCENTIVO ÀS AÇÕES DE ATER \\
\cline { 3 - 4 } & & NÃO TENHO INTERESSE EM APLICAR \\
\hline
\end{tabular}

6) A partir deste curso: (As opções não são excludentes: você poderá marcar mais de uma opção).

\begin{tabular}{|l|l|}
\hline & NÃO MUDOU NADA EM MEU TRABALHO. \\
\hline & $\begin{array}{l}\text { MEU TRABALHO PASSOU A CONTRIBUIR MAIS COM OS AGRICULTORES(AS) } \\
\text { FAMILIARES. }\end{array}$ \\
\hline & CONSEGUI INFLUENCIAR NAS ORIENTAÇÕES DA MINHA INSTITUIÇÃO. \\
\hline & $\begin{array}{l}\text { CRESCEU A ÁREA DE AGRICULTURA DE BASE ECOLÓGICA NAS COMUNIDADES } \\
\text { ONDE ATUO. }\end{array}$ \\
\hline$x$ & CONTINUEI ME APERFEIÇOANDO SOBRE TEMAS ABORDADOS. \\
\hline
\end{tabular}

7) Depois do curso você apoiou atividades de capacitação de técnicos e agricultores com base nos princípios e diretrizes da Pnater? (Considere como apoio a atividades de capacitação a participação no planejamento, elaboração de ementas, seleção de participantes e de palestrantes.)

\begin{tabular}{|l|l|}
\hline & SIM \\
\hline$x$ & NÃO \\
\hline
\end{tabular}

8) Usou os conhecimentos para ministrar outros cursos com o mesmo conteúdo ou conteúdos semelhantes?

\begin{tabular}{|l|l|}
\hline & SIM \\
\hline$x$ & NÃO \\
\hline
\end{tabular}

9) Marque o seu grau de satisfação com relação ao curso oferecido pelo DATER: (Considere a seguinte pontuação: 1 - MUITO RUIM; 2 - RUIM; 3 - REGULAR; 4 - BOM; 5 - MUITO BOM) 


\begin{tabular}{|l|l|l|l|l|}
\hline 1 & 2 & 3 & $\times 4$ & 5 \\
\hline
\end{tabular}

10) Marque seu grau de satisfação com relação ao DATER: (Considere a seguinte pontuação:

1 - MUITO RUIM; 2 - RUIM; 3 - REGULAR; 4 - BOM; 5 - MUITO BOM)

\begin{tabular}{|l|l|l|l|l|}
\hline 1 & 2 & $\times 3$ & 4 & 5 \\
\hline
\end{tabular}


PESQUISA - IMPACTO DAS AÇÕES DE FORMAÇÃO REALIZADAS PELO DATER/SAF/MDA NO PERÍODO 2004-2009

Caros colaboradores,

Contamos com a sua atenção para preencher o formulário abaixo.

O mesmo tem por objetivo fornecer informações para avaliação da Eficiência, Efetividade e Eficácia da Política Pública de Formação de Agentes de Ater adotada pelo Departamento de Assistência Técnica e Extensão Rural, da Secretaria de Agricultura Familiar do Ministério do Desenvolvimento - DATER/SAF/MDA, no período de 2004 a 2009, tema escolhido para Monografia a ser apresentada à Universidade de Brasília (UnB) como requisito parcial para obtenção do grau de Bacharel em Administração.

Você poderá ou não se identificar no questionário e garantimos que todas as informações fornecidas serão confidenciais e utilizadas apenas de forma sistematizada.

IDENTIFICAÇÃO

\begin{tabular}{|c|c|}
\hline $\begin{array}{l}\text { Nome: } \\
\text { Luciana do Nascimento Mendes }\end{array}$ & $\begin{array}{l}\text { Sexo: } \\
(\quad) \text { masculino } \quad(x) \text { feminino }\end{array}$ \\
\hline $\begin{array}{l}\text { Instituição (nome e tipo de instituição: ONG, } \\
\text { Empresa Pública, etc.): } \\
\text { Emater-RN }\end{array}$ & $\begin{array}{l}\text { Local de trabalho (Cidade e Estado): } \\
\text { Assu-RN }\end{array}$ \\
\hline \multicolumn{2}{|c|}{$\begin{array}{l}\text { Curso/Encontro/Oficina do qual participou (caso tenha participado de mais de um curso, preencha } \\
\text { um formulário para cada um deles): } \\
\text { Curso para Agentes de Assistência Técnica e Extensão Rural em atividades da Pesca Artesanal } \\
\text { e Aqüicola }\end{array}$} \\
\hline $\begin{array}{l}\text { Data do Curso/Encontro/Oficina (pelo menos mês e } \\
06 \text { a } 10 \text { de novembro de } 2006 \text { em Natal-RN }\end{array}$ & \\
\hline
\end{tabular}

1. Indique sua área de atuação? (As opções não são excludentes: você poderá marcar mais de uma opção).

\begin{tabular}{|l|l|}
\hline$x$ & EXTENSÃO RURAL \\
\hline & PESQUISA \\
\hline
\end{tabular}




\begin{tabular}{|l|l|}
\hline & ENSINO \\
\hline & OUTROS \\
\hline
\end{tabular}

2) Qual o seu nível de escolaridade? ( Considere apenas o nível mais alto)

\begin{tabular}{|l|l|}
\hline & NÍVEL MÉDIO \\
\hline & NÍVEL SUPERIOR \\
\hline$x$ & PÓS-GRADUAÇÃO \\
\hline
\end{tabular}

3) Os conteúdos abordados foram condizentes com as demandas do seu dia-a-dia?

\begin{tabular}{|l|l|}
\hline & SIM \\
\hline$x$ & PARCIALMENTE \\
\hline & NÃO \\
\hline
\end{tabular}

4) O curso contribuiu para o seu aperfeiçoamento profissional?

\begin{tabular}{|l|l|}
\hline$x$ & SIM \\
\hline & NÃO \\
\hline
\end{tabular}

5) Os conhecimentos adquiridos estão sendo aplicados no seu trabalho? Em caso afirmativo, indique em que grau estes conhecimentos estão sendo aplicados. Em caso negativo, indique por que razão isto não ocorre: (As respostas não são excludentes: você poderá marcar mais de uma opção).

\begin{tabular}{|l|l|l|l|}
\hline \multirow{2}{*}{$\begin{array}{l}\text { SIM (indique ao lado em } \\
\text { que grau) }\end{array}$} & & MUITO APLICADOS \\
\cline { 3 - 4 } & & & MEDIAMENTE APLICADOS \\
\hline$x$ & $\begin{array}{l}\text { NÃO (indique ao lado a } \\
\text { razão da não aplicação) }\end{array}$ & $x$ & $\begin{array}{l}\text { CONTEÚDO NÃO ADEQUADO ȦS NECESSIDADES } \\
\text { ESPECÍFICAS DA REGIÃO }\end{array}$ \\
\hline
\end{tabular}




\begin{tabular}{|l|l|l|}
\hline \multirow{10}{*}{} & $\begin{array}{l}\text { CONTEÚDO NÃO FOI SUFICIENTEMENTE } \\
\text { APROFUNDADO PARA PERMITIR UMA APLICAÇÃO } \\
\text { EFICAZ E EFICIENTE }\end{array}$ \\
\cline { 2 - 4 } & $\begin{array}{l}\text { FALTA DE APOIO E INCENTIVO DA MINHA } \\
\text { INSTITUIÇÃO }\end{array}$ \\
\cline { 2 - 4 } & FALTA DE INCENTIVO ÀS AÇÕES DE ATER \\
\hline & NÃO TENHO INTERESSE EM APLICAR \\
\hline
\end{tabular}

6) A partir deste curso: (As opções não são excludentes: você poderá marcar mais de uma opção).

\begin{tabular}{|l|l|}
\hline & NÃO MUDOU NADA EM MEU TRABALHO. \\
\hline & $\begin{array}{l}\text { MEU TRABALHO PASSOU A CONTRIBUIR MAIS COM OS AGRICULTORES(AS) } \\
\text { FAMILIARES. }\end{array}$ \\
\hline$x$ & CONSEGUI INFLUENCIAR NAS ORIENTAÇÕES DA MINHA INSTITUIÇÃO. \\
\hline & $\begin{array}{l}\text { CASSEI A TRABALHAR COM METODOLOGIAS PARTICIPATIVAS. } \\
\text { ONDE ATUO. }\end{array}$ \\
\hline$x$ & CONTINUEI ME APERFEIÇOANDO SOBRE TEMAS ABORDADOS. \\
\hline
\end{tabular}

7) Depois do curso você apoiou atividades de capacitação de técnicos e agricultores com base nos princípios e diretrizes da Pnater? (Considere como apoio a atividades de capacitação a participação no planejamento, elaboração de ementas, seleção de participantes e de palestrantes.)

\begin{tabular}{|l|l|}
\hline & SIM \\
\hline$x$ & NÃO \\
\hline
\end{tabular}

8) Usou os conhecimentos para ministrar outros cursos com o mesmo conteúdo ou conteúdos semelhantes? 


\begin{tabular}{|l|l|}
\hline$x$ & SIM \\
\hline & NÃO \\
\hline
\end{tabular}

9) Marque o seu grau de satisfação com relação ao curso oferecido pelo DATER: (Considere a seguinte pontuação: 1 - MUITO RUIM; 2 - RUIM; 3 - REGULAR; 4 - BOM; 5 - MUITO BOM)

\begin{tabular}{|l|l|l|l|l|}
\hline 1 & 2 & 3 & 4 & 5 \\
\hline
\end{tabular}

10) Marque seu grau de satisfação com relação ao DATER: (Considere a seguinte pontuação: 1 - MUITO RUIM; 2 - RUIM; 3 - REGULAR; 4 - BOM; 5 - MUITO BOM)

\begin{tabular}{|l|l|l|l|l|}
\hline 1 & 2 & 3 & 4 & 5 \\
\hline
\end{tabular}


PESQUISA - IMPACTO DAS AÇÕES DE FORMAÇÃO REALIZADAS PELO DATER/SAF/MDA NO PERÍODO 2004-2009

Caros colaboradores,

Contamos com a sua atenção para preencher o formulário abaixo.

O mesmo tem por objetivo fornecer informações para avaliação da Eficiência, Efetividade e Eficácia da Política Pública de Formação de Agentes de Ater adotada pelo Departamento de Assistência Técnica e Extensão Rural, da Secretaria de Agricultura Familiar do Ministério do Desenvolvimento - DATER/SAF/MDA, no período de 2004 a 2009, tema escolhido para Monografia a ser apresentada à Universidade de Brasília (UnB) como requisito parcial para obtenção do grau de Bacharel em Administração.

Você poderá ou não se identificar no questionário e garantimos que todas as informações fornecidas serão confidenciais e utilizadas apenas de forma sistematizada.

IDENTIFICAÇÃO

\begin{tabular}{|c|c|}
\hline $\begin{array}{l}\text { Nome: } \\
\text { MANOEL SARAIVA MARQUES }\end{array}$ & $\begin{array}{l}\text { Sexo: } \\
(x) \text { masculino } \quad(\quad) \text { feminino }\end{array}$ \\
\hline $\begin{array}{l}\text { Instituição (nome e tipo de } \text { instituição: ONG, } \\
\text { Empresa Pública, etc.): } \\
\text { SINTAPE /FASER- PE } \quad\left(\begin{array}{lll}\text { Sindicato } & \text { de } \\
\text { trabalhadores públicos na Agric. E meio -Ambiente) }\end{array}\right.\end{array}$ & $\begin{array}{l}\text { Local de trabalho (Cidade e Estado): } \\
\text { RECIFE /PE }\end{array}$ \\
\hline $\begin{array}{l}\text { Curso/Encontro/Oficina do qual participou (caso tenh } \\
\text { um formulário para cada um deles): } \\
\text { CURSO DE ESPECIALIZAÇÃO EM EXTENSÃO } \\
\text { SUSTENTÁVEL }\end{array}$ & RURAL PARA O DESENVOLVIMENTO \\
\hline \multicolumn{2}{|l|}{$\begin{array}{l}\text { Data do Curso/Encontro/Oficina (pelo menos mês e ano): } \\
\text { MARÇO/2005 a JUNHO } 2006\end{array}$} \\
\hline
\end{tabular}

Indique sua área de atuação? (As opções não são excludentes: você poderá marcar mais de uma opção).

\begin{tabular}{|l|l|}
\hline$X$ & EXTENSÃO RURAL \\
\hline & PESQUISA \\
\hline
\end{tabular}




\begin{tabular}{|l|l|}
\hline & ENSINO \\
\hline & OUTROS \\
\hline
\end{tabular}

2) Qual o seu nível de escolaridade? ( Considere apenas o nível mais alto)

\begin{tabular}{|l|l|}
\hline & NÍVEL MÉDIO \\
\hline$X$ & NÍVEL SUPERIOR \\
\hline & PÓS-GRADUAÇÃO \\
\hline
\end{tabular}

3) Os conteúdos abordados foram condizentes com as demandas do seu dia-a-dia?

\begin{tabular}{|l|l|}
\hline$X$ & SIM \\
\hline & PARCIALMENTE \\
\hline & NÃO \\
\hline
\end{tabular}

4) O curso contribuiu para o seu aperfeiçoamento profissional?

\begin{tabular}{|l|l|}
\hline$X$ & SIM \\
\hline & NÃO \\
\hline
\end{tabular}

5) Os conhecimentos adquiridos estão sendo aplicados no seu trabalho? Em caso afirmativo, indique em que grau estes conhecimentos estão sendo aplicados. Em caso negativo, indique por que razão isto não ocorre: (As respostas não são excludentes: você poderá marcar mais de uma opção).

\begin{tabular}{|l|l|l|}
\hline \multirow{2}{*}{$\begin{array}{l}\text { SIM (indique ao lado em } \\
\text { que grau) }\end{array}$} & MUITO APLICADOS \\
\cline { 2 - 3 } & & MEDIAMENTE APLICADOS \\
\hline $\begin{array}{l}\text { NÃO (indique ao lado a } \\
\text { razão da não aplicação) }\end{array}$ & $\begin{array}{l}\text { CONTEÚDO NÃO ADEQUADO ÀS NECESSIDADES } \\
\text { ESPECÍFICAS DA REGIÃO }\end{array}$ \\
\hline
\end{tabular}




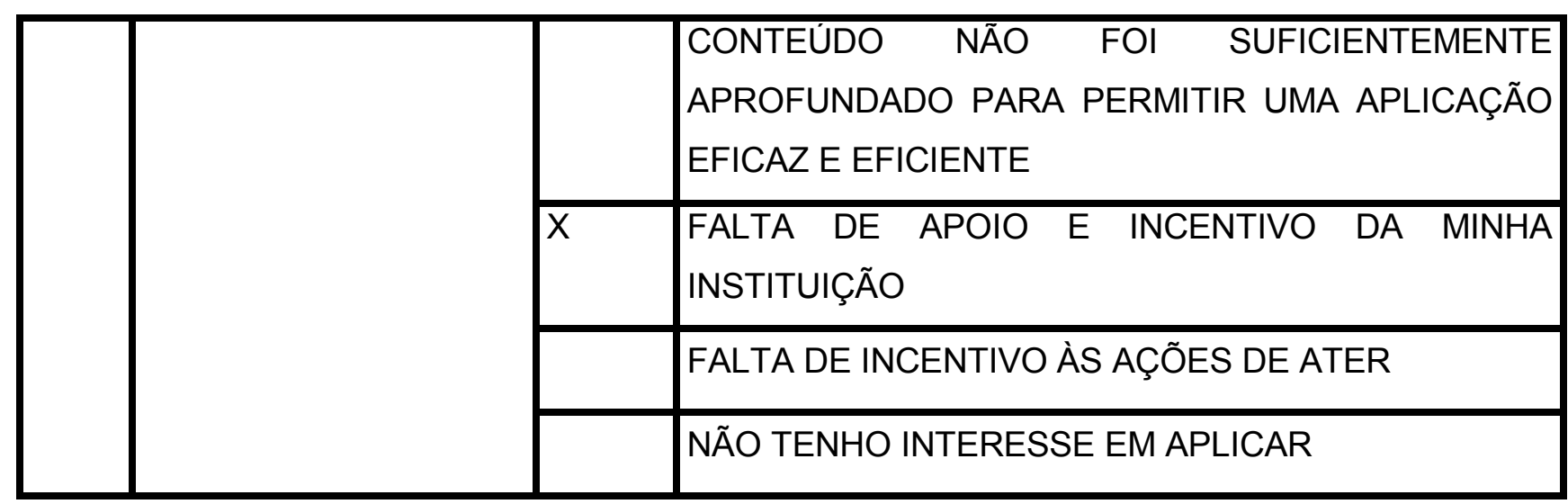

6) A partir deste curso: (As opções não são excludentes: você poderá marcar mais de uma opção).

\begin{tabular}{|l|l|}
\hline & NÃO MUDOU NADA EM MEU TRABALHO. \\
\hline & $\begin{array}{l}\text { MEU TRABALHO PASSOU A CONTRIBUIR MAIS COM OS AGRICULTORES(AS) } \\
\text { FAMILIARES. }\end{array}$ \\
\hline$X$ & CONSEGUI INFLUENCIAR NAS ORIENTAÇÕES DA MINHA INSTITUIÇÃO. \\
\hline & $\begin{array}{l}\text { CASSEI A TRABALHAR COM METODOLOGIAS PARTICIPATIVAS. } \\
\text { ONDE ATUO. }\end{array}$ \\
\hline$X$ & CONTINUEI ME APERFEIÇOANDO SOBRE TEMAS ABORDADOS. \\
\hline
\end{tabular}

7) Depois do curso você apoiou atividades de capacitação de técnicos e agricultores com base nos princípios e diretrizes da Pnater? (Considere como apoio a atividades de capacitação a participação no planejamento, elaboração de ementas, seleção de participantes e de palestrantes.)

\begin{tabular}{|l|l|}
\hline$X$ & SIM \\
\hline & NÃO \\
\hline
\end{tabular}

8) Usou os conhecimentos para ministrar outros cursos com o mesmo conteúdo ou conteúdos semelhantes? 


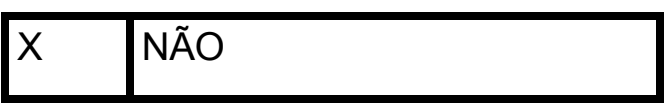

9) Marque o seu grau de satisfação com relação ao curso oferecido pelo DATER: (Considere a seguinte pontuação: 1 - MUITO RUIM; 2 - RUIM; 3 - REGULAR; 4 - BOM; 5 - MUITO BOM)

\begin{tabular}{|l|l|l|l|l|}
\hline 1 & 2 & 3 & 4 & $5 \times$ \\
\hline
\end{tabular}

10) Marque seu grau de satisfação com relação ao DATER: (Considere a seguinte pontuação: 1 - MUITO RUIM; 2 - RUIM; 3 - REGULAR; 4 - BOM; 5 - MUITO BOM)

\begin{tabular}{|l|l|l|l|l|}
\hline 1 & 2 & 3 & 4 & $5 \times$ \\
\hline
\end{tabular}


PESQUISA - IMPACTO DAS AÇÕES DE FORMAÇÃO REALIZADAS PELO DATER/SAF/MDA NO PERÍODO 2004-2009

Caros colaboradores,

Contamos com a sua atenção para preencher o formulário abaixo.

O mesmo tem por objetivo fornecer informações para avaliação da Eficiência, Efetividade e Eficácia da Política Pública de Formação de Agentes de Ater adotada pelo Departamento de Assistência Técnica e Extensão Rural, da Secretaria de Agricultura Familiar do Ministério do Desenvolvimento - DATER/SAF/MDA, no período de 2004 a 2009, tema escolhido para Monografia a ser apresentada à Universidade de Brasília (UnB) como requisito parcial para obtenção do grau de Bacharel em Administração.

Você poderá ou não se identificar no questionário e garantimos que todas as informações fornecidas serão confidenciais e utilizadas apenas de forma sistematizada.

\section{IDENTIFICAÇÃO}

\begin{tabular}{|c|c|}
\hline $\begin{array}{l}\text { Nome: } \\
\text { Marcélia Cristina Rocha Zuza }\end{array}$ & $\begin{array}{l}\text { Sexo: } \\
(\quad) \text { masculino } \quad(x) \text { feminino }\end{array}$ \\
\hline $\begin{array}{l}\text { Instituição (nome e tipo de instituição: ONG, } \\
\text { Empresa Pública, etc.): } \\
\text { Casa da Agricultura Familiar }\end{array}$ & $\begin{array}{l}\text { Local de trabalho (Cidade e Estado): } \\
\text { Zé Doca - MA }\end{array}$ \\
\hline \multicolumn{2}{|c|}{$\begin{array}{l}\text { Curso/Encontro/Oficina do qual participou (caso tenha participado de mais de um curso, preencha } \\
\text { um formulário para cada um deles): }\end{array}$} \\
\hline $\begin{array}{l}\text { Data do Curso/Encontro/Oficina (pelo menos mês } € \\
21 \text { a } 25 \text { de novembro de } 2005 \text {. }\end{array}$ & \\
\hline
\end{tabular}

1. Indique sua área de atuação? (As opções não são excludentes: você poderá marcar mais de uma opção).

\begin{tabular}{|l|l|}
\hline$x$ & EXTENSÃO RURAL \\
\hline$x$ & PESQUISA \\
\hline & ENSINO \\
\hline
\end{tabular}




\section{OUTROS}

2) Qual o seu nível de escolaridade? ( Considere apenas o nível mais alto)

\begin{tabular}{|l|l|}
\hline & NÍVEL MÉDIO \\
\hline$x$ & NÍVEL SUPERIOR \\
\hline & PÓS-GRADUAÇÃO \\
\hline
\end{tabular}

3) Os conteúdos abordados foram condizentes com as demandas do seu dia-a-dia?

\begin{tabular}{|l|l|}
\hline & SIM \\
\hline$x$ & PARCIALMENTE \\
\hline & NÃO \\
\hline
\end{tabular}

4) O curso contribuiu para o seu aperfeiçoamento profissional?

\begin{tabular}{|l|l|}
\hline$x$ & SIM \\
\hline & NÃO \\
\hline
\end{tabular}

5) Os conhecimentos adquiridos estão sendo aplicados no seu trabalho? Em caso afirmativo, indique em que grau estes conhecimentos estão sendo aplicados. Em caso negativo, indique por que razão isto não ocorre: (As respostas não são excludentes: você poderá marcar mais de uma opção).

\begin{tabular}{|l|l|l|l|}
\hline \multirow{2}{*}{$\begin{array}{l}\text { SIM (indique ao lado em } \\
\text { que grau) }\end{array}$} & $\mathrm{x}$ & MUITO APLICADOS \\
\cline { 2 - 4 } & $\begin{array}{l}\text { NÃO (indique ao lado a } \\
\text { razão da não aplicação) }\end{array}$ & $\begin{array}{l}\text { CONTEÚDO NÃO ADLICADOS } \\
\text { ESPECÍFICAS DA REGIÃO }\end{array}$ \\
\hline
\end{tabular}




\begin{tabular}{|l|l|l|}
\hline \multirow{10}{*}{} & & $\begin{array}{l}\text { CONTEÚDO NÃO FOI SUFICIENTEMENTE } \\
\text { APROFUNDADO PARA PERMITIR UMA APLICAÇÃO } \\
\text { EFICAZ E EFICIENTE }\end{array}$ \\
\cline { 2 - 5 } & $\begin{array}{l}\text { FALTA DE APOIO E INCENTIVO DA MINHA } \\
\text { INSTITUIÇÃO }\end{array}$ \\
\cline { 2 - 4 } & FALTA DE INCENTIVO ÀS AÇÕES DE ATER \\
\hline & NÃO TENHO INTERESSE EM APLICAR \\
\hline
\end{tabular}

6) A partir deste curso: (As opções não são excludentes: você poderá marcar mais de uma opção).

\begin{tabular}{|l|l|}
\hline & NÃO MUDOU NADA EM MEU TRABALHO. \\
\hline & $\begin{array}{l}\text { MEU TRABALHO PASSOU A CONTRIBUIR MAIS COM OS AGRICULTORES(AS) } \\
\text { FAMILIARES. }\end{array}$ \\
\hline & CONSEGUI INFLUENCIAR NAS ORIENTAÇÕES DA MINHA INSTITUIÇÃO. \\
\hline$X$ & $\begin{array}{l}\text { CRESCEU A ÁREA DE AGRICULTURA DE BASE ECOLÓGICA NAS COMUNIDADES } \\
\text { ONDE ATUO. }\end{array}$ \\
\hline$x$ & CONTINUEI ME APERFEIÇOANDO SOBRE TEMAS ABORDADOS. \\
\hline
\end{tabular}

7) Depois do curso você apoiou atividades de capacitação de técnicos e agricultores com base nos princípios e diretrizes da Pnater? (Considere como apoio a atividades de capacitação a participação no planejamento, elaboração de ementas, seleção de participantes e de palestrantes.)

\begin{tabular}{|l|l|}
\hline & SIM \\
\hline$x$ & NÃO \\
\hline
\end{tabular}

8) Usou os conhecimentos para ministrar outros cursos com o mesmo conteúdo ou conteúdos semelhantes? 


\begin{tabular}{|l|l|}
\hline$x$ & NÃO \\
\hline
\end{tabular}

9) Marque o seu grau de satisfação com relação ao curso oferecido pelo DATER: (Considere a seguinte pontuação: 1 - MUITO RUIM; 2 - RUIM; 3 - REGULAR; 4 - BOM; 5 - MUITO BOM)

\begin{tabular}{|l|l|l|l|l|}
\hline 1 & 2 & 3 & $4 x$ & 5 \\
\hline
\end{tabular}

10) Marque seu grau de satisfação com relação ao DATER: (Considere a seguinte pontuação: 1 - MUITO RUIM; 2 - RUIM; 3 - REGULAR; 4 - BOM; 5 - MUITO BOM)

\begin{tabular}{|l|l|l|l|l|}
\hline 1 & 2 & 3 & $4 x$ & 5 \\
\hline
\end{tabular}


PESQUISA - IMPACTO DAS AÇÕES DE FORMAÇÃO REALIZADAS PELO DATER/SAF/MDA NO PERÍODO 2004-2009

Caros colaboradores,

Contamos com a sua atenção para preencher o formulário abaixo.

O mesmo tem por objetivo fornecer informações para avaliação da Eficiência, Efetividade e Eficácia da Política Pública de Formação de Agentes de Ater adotada pelo Departamento de Assistência Técnica e Extensão Rural, da Secretaria de Agricultura Familiar do Ministério do Desenvolvimento - DATER/SAF/MDA, no período de 2004 a 2009, tema escolhido para Monografia a ser apresentada à Universidade de Brasília (UnB) como requisito parcial para obtenção do grau de Bacharel em Administração.

Você poderá ou não se identificar no questionário e garantimos que todas as informações fornecidas serão confidenciais e utilizadas apenas de forma sistematizada.

\section{IDENTIFICAÇÃO}

\begin{tabular}{|l|l|}
\hline Nome:Luis Otavio Brito da Silva & $\begin{array}{l}\text { Sexo: } \\
(\mathrm{x}) \text { masculino } \quad(\quad) \text { feminino }\end{array}$ \\
\hline $\begin{array}{l}\text { Instituição (nome e tipo de instituição: ONG, } \\
\text { Empresa Pública, etc.): IPA }\end{array}$ & $\begin{array}{l}\text { Local de trabalho (Cidade e Estado): } \\
\text { Carpina-PE }\end{array}$ \\
\hline $\begin{array}{l}\text { Curso/Encontro/Oficina do qual participou (caso tenha participado de mais de um curso, preencha } \\
\text { um formulário para cada um deles): Extensão Pesqueira/Natal }\end{array}$ \\
\hline Data do Curso/Encontro/Oficina (pelo menos mês e ano): \\
\hline
\end{tabular}

1. Indique sua área de atuação? (As opções não são excludentes: você poderá marcar mais de uma opção).

\begin{tabular}{|l|l|}
\hline$x$ & EXTENSÃO RURAL \\
\hline & PESQUISA \\
\hline & ENSINO \\
\hline & OUTROS \\
\hline
\end{tabular}

2) Qual o seu nível de escolaridade? ( Considere apenas o nível mais alto) 


\begin{tabular}{|l|l|}
\hline & NÍVEL MÉDIO \\
\hline & NÍVEL SUPERIOR \\
\hline$x$ & PÓS-GRADUAÇÃO \\
\hline
\end{tabular}

3) Os conteúdos abordados foram condizentes com as demandas do seu dia-a-dia?

\begin{tabular}{|l|l|}
\hline & SIM \\
\hline$X$ & PARCIALMENTE \\
\hline & NÃO \\
\hline
\end{tabular}

4) O curso contribuiu para o seu aperfeiçoamento profissional?

\begin{tabular}{|l|l|}
\hline$X$ & SIM \\
\hline & NÃO \\
\hline
\end{tabular}

5) Os conhecimentos adquiridos estão sendo aplicados no seu trabalho? Em caso afirmativo, indique em que grau estes conhecimentos estão sendo aplicados. Em caso negativo, indique por que razão isto não ocorre: (As respostas não são excludentes: você poderá marcar mais de uma opção).

\begin{tabular}{|l|l|l|}
\hline \multirow{2}{*}{} & & MUITO APLICADOS \\
\cline { 3 - 4 } & $\mathrm{X}$ & MEDIAMENTE APLICADOS \\
\hline & & POUCO APLICADOS \\
\hline \multirow{2}{*}{} & & $\begin{array}{l}\text { CONTEÚDO NÃO ADEQUADO ȦS NECESSIDADES } \\
\text { ESPECIFICAS DA REGIÃO }\end{array}$ \\
\hline & $\begin{array}{l}\text { CONTEÚDO NÃO FOI SUFICIENTEMENTE } \\
\text { APROFUNDADO PARA PERMITIR UMA APLICAÇÃO } \\
\text { EFICAZ E EFICIENTE }\end{array}$ \\
\hline
\end{tabular}




\begin{tabular}{|l|l|l|}
\hline \multirow{2}{*}{} & & $\begin{array}{l}\text { FALTA DE APOIO E INCENTIVO DA MINHA } \\
\text { INSTITUIÇÃO }\end{array}$ \\
\cline { 2 - 3 } & & FALTA DE INCENTIVO ÀS AÇÕES DE ATER \\
\cline { 2 - 3 } & NÃO TENHO INTERESSE EM APLICAR \\
\hline
\end{tabular}

6) A partir deste curso: (As opções não são excludentes: você poderá marcar mais de uma opção).

\begin{tabular}{|l|l|}
\hline$x$ & $\begin{array}{l}\text { NÃO MUDOU NADA EM MEU TRABALHO. } \\
\text { FAMILIARES. }\end{array}$ \\
\hline & CONSEGUI INFLUENCIAR NAS ORIENTAÇÕES DA MINHA INSTITUIÇÃO. \\
\hline & PASSEI A TRABALHAR COM METODOLOGIAS PARTICIPATIVAS. \\
\hline & $\begin{array}{l}\text { CRESCEU A ÁREA DE AGRICULTURA DE BASE ECOLÓGICA NAS COMUNIDADES } \\
\text { ONDE ATUO. }\end{array}$ \\
\hline & CONTINUEI ME APERFEIÇOANDO SOBRE TEMAS ABORDADOS. \\
\hline
\end{tabular}

7) Depois do curso você apoiou atividades de capacitação de técnicos e agricultores com base nos princípios e diretrizes da Pnater? (Considere como apoio a atividades de capacitação a participação no planejamento, elaboração de ementas, seleção de participantes e de palestrantes.)

\begin{tabular}{|l|l|}
\hline$X$ & SIM \\
\hline & NÃO \\
\hline
\end{tabular}

8) Usou os conhecimentos para ministrar outros cursos com o mesmo conteúdo ou conteúdos semelhantes?

\begin{tabular}{|l|l|}
\hline & SIM \\
\hline$X$ & NÃO \\
\hline
\end{tabular}


9) Marque o seu grau de satisfação com relação ao curso oferecido pelo DATER: (Considere a seguinte pontuação: 1 - MUITO RUIM; 2 - RUIM; 3 - REGULAR; 4 - BOM; 5 - MUITO BOM)

\begin{tabular}{|l|l|l|l|l|}
\hline 1 & 2 & 3 & $4 X$ & 5 \\
\hline
\end{tabular}

10) Marque seu grau de satisfação com relação ao DATER: (Considere a seguinte pontuação: 1 - MUITO RUIM; 2 - RUIM; 3 - REGULAR; 4 - BOM; 5 - MUITO BOM)

\begin{tabular}{|l|l|l|l|l|}
\hline 1 & 2 & 3 & 4 & $5 X$ \\
\hline
\end{tabular}


PESQUISA - IMPACTO DAS AÇÕES DE FORMAÇÃO REALIZADAS PELO DATER/SAF/MDA NO PERÍODO 2004-2009

Caros colaboradores,

Contamos com a sua atenção para preencher o formulário abaixo.

O mesmo tem por objetivo fornecer informações para avaliação da Eficiência, Efetividade e Eficácia da Política Pública de Formação de Agentes de Ater adotada pelo Departamento de Assistência Técnica e Extensão Rural, da Secretaria de Agricultura Familiar do Ministério do Desenvolvimento - DATER/SAF/MDA, no período de 2004 a 2009, tema escolhido para Monografia a ser apresentada à Universidade de Brasília (UnB) como requisito parcial para obtenção do grau de Bacharel em Administração.

Você poderá ou não se identificar no questionário e garantimos que todas as informações fornecidas serão confidenciais e utilizadas apenas de forma sistematizada.

IDENTIFICAÇÃO

\begin{tabular}{|l|l|}
\hline Nome: Marco Aurélio Pires & $\begin{array}{l}\text { Sexo: } \\
(x) \text { masculino } \quad(\quad) \text { feminino }\end{array}$ \\
\hline Instituição: AGERP MA & Local de trabalho: São Luis \\
\hline $\begin{array}{l}\text { Curso/Encontro/Oficina do qual participou (caso tenha participado de mais de um curso, preencha } \\
\text { um formulário para cada um deles): Crédito Rural }\end{array}$ \\
\hline Data do Curso/Encontro/Oficina: 2008
\end{tabular}

Indique sua área de atuação? (As opções não são excludentes: você poderá marcar mais de uma opção).

\begin{tabular}{|l|l|}
\hline$X$ & EXTENSÃO RURAL \\
\hline & PESQUISA \\
\hline & ENSINO \\
\hline & OUTROS \\
\hline
\end{tabular}

2) Qual o seu nível de escolaridade? ( Considere apenas o nível mais alto) 


\begin{tabular}{|l|l|}
\hline & NÍVEL MÉDIO \\
\hline$x$ & NÍVEL SUPERIOR \\
\hline & PÓS-GRADUAÇÃO \\
\hline
\end{tabular}

3) Os conteúdos abordados foram condizentes com as demandas do seu dia-a-dia?

\begin{tabular}{|l|l|}
\hline & SIM \\
\hline$x$ & PARCIALMENTE \\
\hline & NÃO \\
\hline
\end{tabular}

4) O curso contribuiu para o seu aperfeiçoamento profissional?

\begin{tabular}{|l|l|}
\hline$X$ & SIM \\
\hline & NÃO \\
\hline
\end{tabular}

5) Os conhecimentos adquiridos estão sendo aplicados no seu trabalho? Em caso afirmativo, indique em que grau estes conhecimentos estão sendo aplicados. Em caso negativo, indique por que razão isto não ocorre: (As respostas não são excludentes: você poderá marcar mais de uma opção).

\begin{tabular}{|c|c|c|}
\hline \multirow{3}{*}{$\begin{array}{l}\text { SIM (indique ao lado em } \\
\text { que grau) }\end{array}$} & $x$ & MUITO APLICADOS \\
\hline & & MEDIAMENTE APLICADOS \\
\hline & & POUCO APLICADOS \\
\hline \multirow{2}{*}{$\begin{array}{l}\text { NÃO (indique ao lado a } \\
\text { razão da não aplicação) }\end{array}$} & & $\begin{array}{l}\text { CONTEÚDO NÃO ADEQUADO ȦS NECESSIDADES } \\
\text { ESPECÍFICAS DA REGIÃO }\end{array}$ \\
\hline & & $\begin{array}{l}\text { CONTEÚDO NÃO } \quad \text { FOI SUFICIENTEMENTE } \\
\text { APROFUNDADO PARA } \\
\text { PERMITIR UMA APLICAÇÃO } \\
\text { EFICAZ E EFICIENTE }\end{array}$ \\
\hline
\end{tabular}




\begin{tabular}{|l|l|l|}
\hline \multirow{2}{*}{} & & $\begin{array}{l}\text { FALTA DE APOIO E INCENTIVO DA MINHA } \\
\text { INSTITUIÇÃO }\end{array}$ \\
\cline { 2 - 4 } & & FALTA DE INCENTIVO ÀS AÇÕES DE ATER \\
\cline { 2 - 4 } & NÃO TENHO INTERESSE EM APLICAR \\
\hline
\end{tabular}

6) A partir deste curso: (As opções não são excludentes: você poderá marcar mais de uma opção).

\begin{tabular}{|l|l|}
\hline$x$ & $\begin{array}{l}\text { NÃO MUDOU NADA EM MEU TRABALHO. } \\
\text { FAMILIARES. }\end{array}$ \\
\hline & CONSEGUI INFLUENCIAR NAS ORIENTAÇÕES DA MINHA INSTITUIÇÃO. \\
\hline & PASSEI A TRABALHAR COM METODOLOGIAS PARTICIPATIVAS. \\
\hline & $\begin{array}{l}\text { CRESCEU A ÁREA DE AGRICULTURA DE BASE ECOLÓGICA NAS COMUNIDADES } \\
\text { ONDE ATUO. }\end{array}$ \\
\hline & CONTINUEI ME APERFEIÇOANDO SOBRE TEMAS ABORDADOS. \\
\hline
\end{tabular}

7) Depois do curso você apoiou atividades de capacitação de técnicos e agricultores com base nos princípios e diretrizes da Pnater? (Considere como apoio a atividades de capacitação a participação no planejamento, elaboração de ementas, seleção de participantes e de palestrantes.)

\begin{tabular}{|l|l|}
\hline & SIM \\
\hline$x$ & NÃO \\
\hline
\end{tabular}

8) Usou os conhecimentos para ministrar outros cursos com o mesmo conteúdo ou conteúdos semelhantes?

\begin{tabular}{|l|l|}
\hline & SIM \\
\hline$x$ & NÃO \\
\hline
\end{tabular}


9) Marque o seu grau de satisfação com relação ao curso oferecido pelo DATER: (Considere a seguinte pontuação: 1 - MUITO RUIM; 2 - RUIM; 3 - REGULAR; 4 - BOM; 5 - MUITO BOM)

\begin{tabular}{|l|l|l|l|l|}
\hline 1 & 2 & 3 & $4 x$ & 5 \\
\hline
\end{tabular}

10) Marque seu grau de satisfação com relação ao DATER: (Considere a seguinte pontuação: 1 - MUITO RUIM; 2 - RUIM; 3 - REGULAR; 4 - BOM; 5 - MUITO BOM)

\begin{tabular}{|l|l|l|l|l|}
\hline 1 & 2 & 3 & 4 & $5 x$ \\
\hline
\end{tabular}


PESQUISA - IMPACTO DAS AÇÕES DE FORMAÇÃO REALIZADAS PELO DATER/SAF/MDA NO PERÍODO 2004-2009

Caros colaboradores,

Contamos com a sua atenção para preencher o formulário abaixo.

O mesmo tem por objetivo fornecer informações para avaliação da Eficiência, Efetividade e Eficácia da Política Pública de Formação de Agentes de Ater adotada pelo Departamento de Assistência Técnica e Extensão Rural, da Secretaria de Agricultura Familiar do Ministério do Desenvolvimento - DATER/SAF/MDA, no período de 2004 a 2009, tema escolhido para Monografia a ser apresentada à Universidade de Brasília (UnB) como requisito parcial para obtenção do grau de Bacharel em Administração.

Você poderá ou não se identificar no questionário e garantimos que todas as informações fornecidas serão confidenciais e utilizadas apenas de forma sistematizada.

IDENTIFICAÇÃO

\begin{tabular}{|l|l|}
\hline Nome: Marco Aurélio Pires & $\begin{array}{l}\text { Sexo: } \\
(x) \text { masculino } \quad(\quad) \text { feminino }\end{array}$ \\
\hline Instituição: AGERP MA & Local de trabalho: São Luis \\
\hline $\begin{array}{l}\text { Curso/Encontro/Oficina do qual participou (caso tenha participado de mais de um curso, preencha } \\
\text { um formulário para cada um deles): Crédito Rural }\end{array}$ \\
\hline Data do Curso/Encontro/Oficina: 2008
\end{tabular}

1. Indique sua área de atuação? (As opções não são excludentes: você poderá marcar mais de uma opção).

\begin{tabular}{|l|l|}
\hline$X$ & EXTENSÃO RURAL \\
\hline & PESQUISA \\
\hline & ENSINO \\
\hline & OUTROS \\
\hline
\end{tabular}

2) Qual o seu nível de escolaridade? ( Considere apenas o nível mais alto) 


\begin{tabular}{|l|l|}
\hline & NÍVEL MÉDIO \\
\hline$x$ & NÍVEL SUPERIOR \\
\hline & PÓS-GRADUAÇÃO \\
\hline
\end{tabular}

3) Os conteúdos abordados foram condizentes com as demandas do seu dia-a-dia?

\begin{tabular}{|l|l|}
\hline & SIM \\
\hline$x$ & PARCIALMENTE \\
\hline & NÃO \\
\hline
\end{tabular}

4) O curso contribuiu para o seu aperfeiçoamento profissional?

\begin{tabular}{|l|l|}
\hline$X$ & SIM \\
\hline & NÃO \\
\hline
\end{tabular}

5) Os conhecimentos adquiridos estão sendo aplicados no seu trabalho? Em caso afirmativo, indique em que grau estes conhecimentos estão sendo aplicados. Em caso negativo, indique por que razão isto não ocorre: (As respostas não são excludentes: você poderá marcar mais de uma opção).

\begin{tabular}{|c|c|c|}
\hline \multirow{3}{*}{$\begin{array}{l}\text { SIM (indique ao lado em } \\
\text { que grau) }\end{array}$} & $x$ & MUITO APLICADOS \\
\hline & & MEDIAMENTE APLICADOS \\
\hline & & POUCO APLICADOS \\
\hline \multirow{3}{*}{$\begin{array}{l}\text { NÃO (indique ao lado a } \\
\text { razão da não aplicação) }\end{array}$} & & $\begin{array}{l}\text { CONTEÚDO NÃO ADEQUADO ȦS NECESSIDADES } \\
\text { ESPECÍFICAS DA REGIÃO }\end{array}$ \\
\hline & & $\begin{array}{l}\text { CONTEÚDO NÃO } \quad \text { FOI SUFICIENTEMENTE } \\
\text { APROFUNDADO PARA } \\
\text { PERMITIR UMA APLICAÇÃO } \\
\text { EFICAZ E EFICIENTE }\end{array}$ \\
\hline & & $\begin{array}{l}\text { FALTA DE APOIO } \\
\text { INSTITUIÇÃO }\end{array}$ \\
\hline
\end{tabular}




\begin{tabular}{|l|l|l|}
\hline \multirow{2}{*}{} & & FALTA DE INCENTIVO ÀS AÇÕES DE ATER \\
\cline { 3 - 4 } & & NÃO TENHO INTERESSE EM APLICAR \\
\hline
\end{tabular}

6) A partir deste curso: (As opções não são excludentes: você poderá marcar mais de uma opção).

\begin{tabular}{|l|l|}
\hline$x$ & $\begin{array}{l}\text { NÃO MUDOU NADA EM MEU TRABALHO. } \\
\text { FAMILIARES. }\end{array}$ \\
\hline & CONSEGUI INFLUENCIAR NAS ORIENTAÇÕES DA MINHA INSTITUIÇÃO. \\
\hline & PASSEI A TRABALHAR COM METODOLOGIAS PARTICIPATIVAS. \\
\hline & $\begin{array}{l}\text { CRESCEU A ÁREA DE AGRICULTURA DE BASE ECOLÓGICA NAS COMUNIDADES } \\
\text { ONDE ATUO. }\end{array}$ \\
\hline & CONTINUEI ME APERFEIÇOANDO SOBRE TEMAS ABORDADOS. \\
\hline
\end{tabular}

7) Depois do curso você apoiou atividades de capacitação de técnicos e agricultores com base nos princípios e diretrizes da Pnater? (Considere como apoio a atividades de capacitação a participação no planejamento, elaboração de ementas, seleção de participantes e de palestrantes.)

\begin{tabular}{|l|l|}
\hline & SIM \\
\hline$x$ & NÃO \\
\hline
\end{tabular}

8) Usou os conhecimentos para ministrar outros cursos com o mesmo conteúdo ou conteúdos semelhantes?

\begin{tabular}{|l|l|}
\hline & SIM \\
\hline$x$ & NÃO \\
\hline
\end{tabular}

9) Marque o seu grau de satisfação com relação ao curso oferecido pelo DATER: (Considere a seguinte pontuação: 1 - MUITO RUIM; 2 - RUIM; 3 - REGULAR; 4 - BOM; 5 - MUITO BOM) 


\begin{tabular}{|l|l|l|l|l|}
\hline 1 & 2 & 3 & $4 x$ & 5 \\
\hline
\end{tabular}

10) Marque seu grau de satisfação com relação ao DATER: (Considere a seguinte pontuação:

1 - MUITO RUIM; 2 - RUIM; 3 - REGULAR; 4 - BOM; 5 - MUITO BOM)

\begin{tabular}{|l|l|l|l|l|}
\hline 1 & 2 & 3 & 4 & $5 x$ \\
\hline
\end{tabular}


PESQUISA - IMPACTO DAS AÇÕES DE FORMAÇÃO REALIZADAS PELO DATER/SAF/MDA NO PERÍODO 2004-2009

Caros colaboradores,

Contamos com a sua atenção para preencher o formulário abaixo.

O mesmo tem por objetivo fornecer informações para avaliação da Eficiência, Efetividade e Eficácia da Política Pública de Formação de Agentes de Ater adotada pelo Departamento de Assistência Técnica e Extensão Rural, da Secretaria de Agricultura Familiar do Ministério do Desenvolvimento - DATER/SAF/MDA, no período de 2004 a 2009, tema escolhido para Monografia a ser apresentada à Universidade de Brasília (UnB) como requisito parcial para obtenção do grau de Bacharel em Administração.

Você poderá ou não se identificar no questionário e garantimos que todas as informações fornecidas serão confidenciais e utilizadas apenas de forma sistematizada.

IDENTIFICAÇÃO

\begin{tabular}{|c|c|}
\hline Nome: Maria Cristina Pontes Vieira & $\begin{array}{l}\text { Sexo: } \\
(\quad) \text { masculino } \quad(x) \text { feminino }\end{array}$ \\
\hline $\begin{array}{l}\text { Instituição (nome e tipo de instituição: ONG, } \\
\text { Empresa Pública, etc.): EMATERCE }\end{array}$ & $\begin{array}{l}\text { Local de trabalho (Cidade e Estado): } \\
\text { Fortaleza - Ceará }\end{array}$ \\
\hline \multicolumn{2}{|c|}{$\begin{array}{l}\text { Curso/Encontro/Oficina do qual participou (caso tenha participado de mais de um curso, preencha } \\
\text { um formulário para cada um deles): } \\
\text { SAF da Caatinga - Paraíba }\end{array}$} \\
\hline $\begin{array}{l}\text { Data do Curso/Encontro/Oficina (pelo menos mês } \\
16 \text { a 20/10/2006 }\end{array}$ & no): \\
\hline
\end{tabular}

1. Indique sua área de atuação? (As opções não são excludentes: você poderá marcar mais de uma opção).

\begin{tabular}{|l|l|}
\hline$x$ & EXTENSÃO RURAL \\
\hline & PESQUISA \\
\hline & ENSINO \\
\hline & OUTROS \\
\hline
\end{tabular}


2) Qual o seu nível de escolaridade? ( Considere apenas o nível mais alto)

\begin{tabular}{|l|l|}
\hline & NÍVEL MÉDIO \\
\hline & NÍVEL SUPERIOR \\
\hline$x$ & PÓS-GRADUAÇÃO \\
\hline
\end{tabular}

3) Os conteúdos abordados foram condizentes com as demandas do seu dia-a-dia?

\begin{tabular}{|l|l|}
\hline$x$ & SIM \\
\hline & PARCIALMENTE \\
\hline & NÃO \\
\hline
\end{tabular}

4) O curso contribuiu para o seu aperfeiçoamento profissional?

\begin{tabular}{|l|l|}
\hline$x$ & SIM \\
\hline & NÃO \\
\hline
\end{tabular}

5) Os conhecimentos adquiridos estão sendo aplicados no seu trabalho? Em caso afirmativo, indique em que grau estes conhecimentos estão sendo aplicados. Em caso negativo, indique por que razão isto não ocorre: (As respostas não são excludentes: você poderá marcar mais de uma opção).

\begin{tabular}{|c|c|c|c|}
\hline \multirow{3}{*}{$x$} & \multirow{3}{*}{$\begin{array}{l}\text { SIM (indique ao lado em } \\
\text { que grau) }\end{array}$} & $x$ & MUITO APLICADOS \\
\hline & & & MEDIAMENTE APLICADOS \\
\hline & & & POUCO APLICADOS \\
\hline & \multirow{2}{*}{$\begin{array}{l}\text { NÃO (indique ao lado a } \\
\text { razão da não aplicação) }\end{array}$} & & $\begin{array}{l}\text { CONTEU்DO NÃO ADEQUADO ȦS NECESSIDADES } \\
\text { ESPECÍFICAS DA REGIÃO }\end{array}$ \\
\hline & & & $\begin{array}{l}\text { CONTEÚDO NÃO } \quad \text { FOI SUFICIENTEMENTE } \\
\text { APROFUNDADO PARA } \\
\text { PERMITIR UMA APLICAÇÃO } \\
\text { EFICAZ E EFICIENTE }\end{array}$ \\
\hline
\end{tabular}




\begin{tabular}{|l|l|l|}
\hline \multirow{2}{*}{} & & $\begin{array}{l}\text { FALTA DE APOIO E INCENTIVO DA MINHA } \\
\text { INSTITUIÇÃO }\end{array}$ \\
\cline { 2 - 3 } & & FALTA DE INCENTIVO ÀS AÇÕES DE ATER \\
\cline { 2 - 3 } & NÃO TENHO INTERESSE EM APLICAR \\
\hline
\end{tabular}

6) A partir deste curso: (As opções não são excludentes: você poderá marcar mais de uma opção).

\begin{tabular}{|l|l|}
\hline & NÃO MUDOU NADA EM MEU TRABALHO. \\
\hline$x$ & $\begin{array}{l}\text { MEU TRABALHO PASSOU A CONTRIBUIR MAIS COM OS AGRICULTORES(AS) } \\
\text { FAMILIARES. }\end{array}$ \\
\hline$x$ & CONSEGUI INFLUENCIAR NAS ORIENTAÇÕES DA MINHA INSTITUIÇÃO. \\
\hline$x$ & PASSEI A TRABALHAR COM METODOLOGIAS PARTICIPATIVAS. \\
\hline & $\begin{array}{l}\text { CRESCEU A ÁREA DE AGRICULTURA DE BASE ECOLÓGICA NAS COMUNIDADES } \\
\text { ONDE ATUO. }\end{array}$ \\
\hline$x$ & CONTINUEI ME APERFEIÇOANDO SOBRE TEMAS ABORDADOS. \\
\hline
\end{tabular}

7) Depois do curso você apoiou atividades de capacitação de técnicos e agricultores com base nos princípios e diretrizes da Pnater? (Considere como apoio a atividades de capacitação a participação no planejamento, elaboração de ementas, seleção de participantes e de palestrantes.)

\begin{tabular}{|l|l|}
\hline$x$ & SIM \\
\hline & NÃO \\
\hline
\end{tabular}

8) Usou os conhecimentos para ministrar outros cursos com o mesmo conteúdo ou conteúdos semelhantes?

\begin{tabular}{|l|l|}
\hline & SIM \\
\hline$x$ & NÃO \\
\hline
\end{tabular}


9) Marque o seu grau de satisfação com relação ao curso oferecido pelo DATER: (Considere a seguinte pontuação: 1 - MUITO RUIM; 2 - RUIM; 3 - REGULAR; 4 - BOM; 5 - MUITO BOM)

\begin{tabular}{|l|l|l|l|l|}
\hline 1 & 2 & 3 & 4 & $5 x$ \\
\hline
\end{tabular}

10) Marque seu grau de satisfação com relação ao DATER: (Considere a seguinte pontuação: 1 - MUITO RUIM; 2 - RUIM; 3 - REGULAR; 4 - BOM; 5 - MUITO BOM)

\begin{tabular}{|l|l|l|l|l|}
\hline 1 & 2 & 3 & 4 & $5 x$ \\
\hline
\end{tabular}


PESQUISA - IMPACTO DAS AÇÕES DE FORMAÇÃO REALIZADAS PELO DATER/SAF/MDA NO PERÍODO 2004-2009

Caros colaboradores,

Contamos com a sua atenção para preencher o formulário abaixo.

O mesmo tem por objetivo fornecer informações para avaliação da Eficiência, Efetividade e Eficácia da Política Pública de Formação de Agentes de Ater adotada pelo Departamento de Assistência Técnica e Extensão Rural, da Secretaria de Agricultura Familiar do Ministério do Desenvolvimento - DATER/SAF/MDA, no período de 2004 a 2009, tema escolhido para Monografia a ser apresentada à Universidade de Brasília (UnB) como requisito parcial para obtenção do grau de Bacharel em Administração.

Você poderá ou não se identificar no questionário e garantimos que todas as informações fornecidas serão confidenciais e utilizadas apenas de forma sistematizada.

IDENTIFICAÇÃO

\begin{tabular}{|c|c|}
\hline $\begin{array}{l}\text { Nome: } \\
\text { MARIA JOSÉ ALVES DE FREITAS OLIVEIRA }\end{array}$ & $\begin{array}{l}\text { Sexo: } \\
\left(\begin{array}{l}\text { ( }) \text { masculino }(x) \text { feminino }\end{array}\right.\end{array}$ \\
\hline $\begin{array}{l}\text { Instituição (nome e tipo de instituição: ONG, } \\
\text { Empresa Pública, etc.): } \\
\text { EMATERCE }\end{array}$ & $\begin{array}{l}\text { Local de trabalho (Cidade e Estado): } \\
\text { FORTALEZA - CE }\end{array}$ \\
\hline \multicolumn{2}{|c|}{$\begin{array}{l}\text { Curso/Encontro/Oficina do qual participou (caso tenha participado de mais de um curso, preencha } \\
\text { um formulário para cada um deles): } \\
\text { Curso de Formadores de Agentes de Desenvolvimento Rural - ADR }\end{array}$} \\
\hline $\begin{array}{l}\text { ta do Curso/Encontrc } \\
\text { tembro de } 2006\end{array}$ & \\
\hline
\end{tabular}

1. Indique sua área de atuação?

\begin{tabular}{|l|l|}
\hline$X$ & EXTENSÃO RURAL \\
\hline & PESQUISA \\
\hline & ENSINO \\
\hline & OUTROS \\
\hline
\end{tabular}


2) Qual o seu nível de escolaridade?

\begin{tabular}{|l|l|}
\hline & NÍVEL MÉDIO \\
\hline & NÍVEL SUPERIOR \\
\hline$X$ & PÓS-GRADUAÇÃO \\
\hline
\end{tabular}

3) Os conteúdos abordados foram condizentes com as demandas do seu dia-a-dia?

\begin{tabular}{|l|l|}
\hline$X$ & SIM \\
\hline & PARCIALMENTE \\
\hline & NÃO \\
\hline
\end{tabular}

4) O curso contribuiu para o seu aperfeiçoamento profissional?

\begin{tabular}{|l|l|}
\hline$X$ & SIM \\
\hline & NÃO \\
\hline
\end{tabular}

5) Os conhecimentos adquiridos estão sendo aplicados no seu trabalho? Em caso afirmativo, indique em que grau estes conhecimentos estão sendo aplicados. Em caso negativo, indique por que razão isto não ocorre:

\begin{tabular}{|c|c|c|}
\hline \multirow{3}{*}{$\begin{array}{l}\text { SIM (indique ao lado em } \\
\text { que grau) }\end{array}$} & $x$ & MUITO APLICADOS \\
\hline & & MEDIAMENTE APLICADOS \\
\hline & & POUCO APLICADOS \\
\hline \multirow{5}{*}{$\begin{array}{l}\text { NÃO (indique ao lado a } \\
\text { razão da não aplicação) }\end{array}$} & & $\begin{array}{l}\text { CONTEÚDO NÃO ADEQUADO ÀS NECESSIDADES } \\
\text { FSPFCÍFICAS RA RFGIÃO }\end{array}$ \\
\hline & & $\begin{array}{llll}\text { CONTEÜDO NÂO } & \text { FOI } & \text { SUFICIENTEMENTE } \\
\text { APROFUNDADO } & \text { PARA } & \text { PERMITIR UMA APLICAÇÃO }\end{array}$ \\
\hline & & $\begin{array}{lcccccc}\text { FALTA } & \text { DE } & \text { APOIO } & \text { E } & \text { INCENTIVO } & \text { DA } & \text { MINHA } \\
\text { INSTITUICÃO } & & & & & \\
\end{array}$ \\
\hline & & FALTA DE INCENTIVO ÀS AÇÕES DE ATER \\
\hline & & NÃO TENHO INTERESSE EM APLICAR \\
\hline
\end{tabular}

6) A partir deste curso: 


\begin{tabular}{|l|l|}
\hline & NÃO MUDOU NADA EM MEU TRABALHO. \\
\hline$X$ & $\begin{array}{l}\text { MEU TRABALHO PASSOU A CONTRIBUIR MAIS COM OS AGRICULTORES(AS) } \\
\text { FAMILIARES. }\end{array}$ \\
\hline$X$ & CONSEGUI INFLUENCIAR NAS ORIENTAÇÕES DA MINHA INSTITUIÇÃO. \\
\hline$X$ & PASSEI A TRABALHAR COM METODOLOGIAS PARTICIPATIVAS. \\
\hline & $\begin{array}{l}\text { CRESCEU A ÁREA DE AGRICULTURA DE BASE ECOLÓGICA NAS COMUNIDADES } \\
\text { ONDE ATUO. }\end{array}$ \\
\hline$X$ & CONTINUEI ME APERFEIÇOANDO SOBRE TEMAS ABORDADOS. \\
\hline
\end{tabular}

7) Depois do curso você apoiou atividades de capacitação de técnicos e agricultores com base nos princípios e diretrizes da Pnater?

\begin{tabular}{|l|l|}
\hline$X$ & SIM \\
\hline & NÃO \\
\hline
\end{tabular}

8) Usou os conhecimentos para ministrar outros cursos com o mesmo conteúdo ou conteúdos semelhantes?

\begin{tabular}{|l|l|}
\hline$X$ & SIM \\
\hline & NÃO \\
\hline
\end{tabular}

9) Marque o seu grau de satisfação com relação ao curso oferecido pelo DATER:

\begin{tabular}{|l|l|l|l|l|}
\hline 1 & 2 & 3 & 4 & $5 X$ \\
\hline
\end{tabular}

10) Marque seu grau de satisfação com relação ao DATER:

\begin{tabular}{|l|l|l|l|l|}
\hline 1 & 2 & 3 & 4 & $5 X$ \\
\hline
\end{tabular}


PESQUISA - IMPACTO DAS AÇÕES DE FORMAÇÃO REALIZADAS PELO DATER/SAF/MDA NO PERÍODO 2004-2009

Caros colaboradores,

Contamos com a sua atenção para preencher o formulário abaixo.

O mesmo tem por objetivo fornecer informações para avaliação da Eficiência, Efetividade e Eficácia da Política Pública de Formação de Agentes de Ater adotada pelo Departamento de Assistência Técnica e Extensão Rural, da Secretaria de Agricultura Familiar do Ministério do Desenvolvimento - DATER/SAF/MDA, no período de 2004 a 2009, tema escolhido para Monografia a ser apresentada à Universidade de Brasília (UnB) como requisito parcial para obtenção do grau de Bacharel em Administração.

Você poderá ou não se identificar no questionário e garantimos que todas as informações fornecidas serão confidenciais e utilizadas apenas de forma sistematizada.

\section{IDENTIFICAÇÃO}

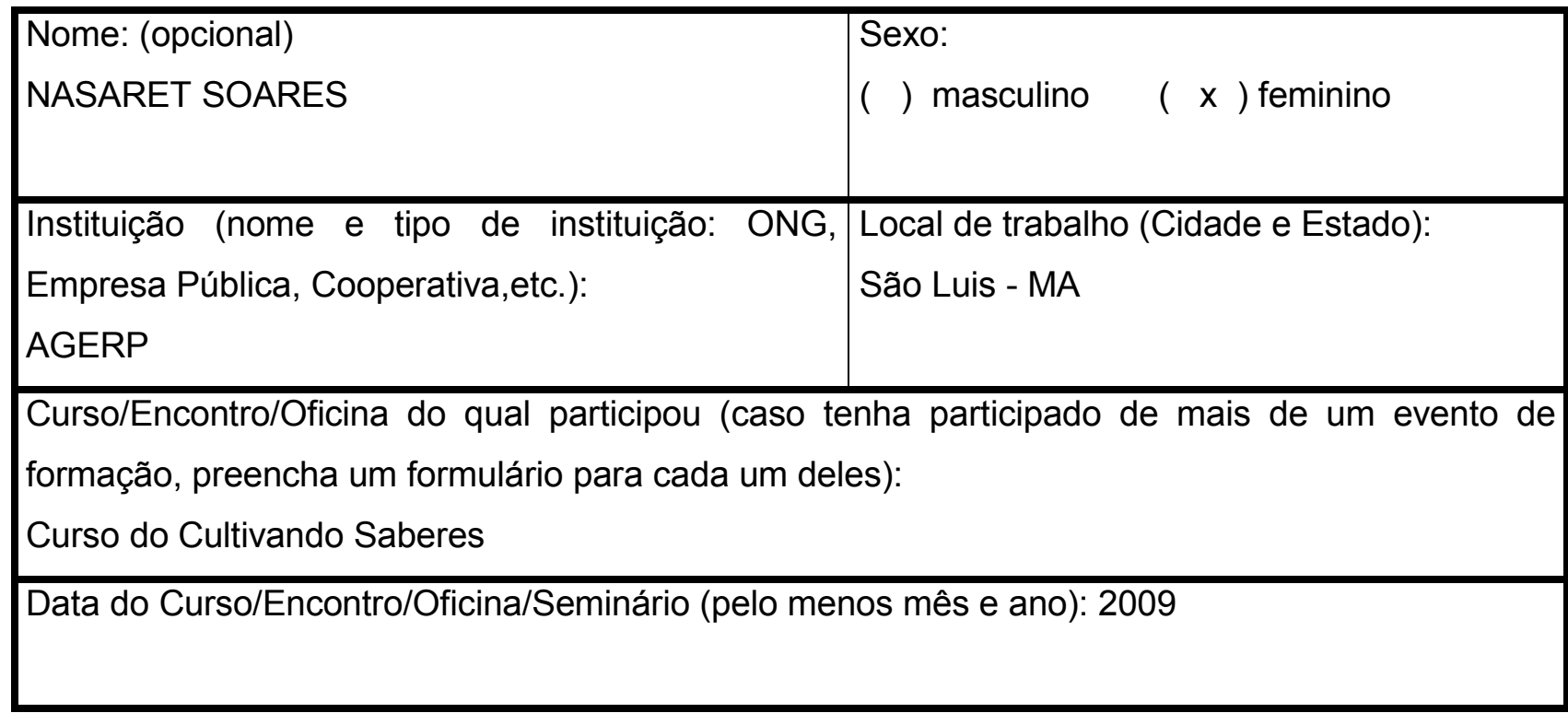

1) Indique sua área de atuação? (As opções não são excludentes: você poderá marcar mais de uma opção).

\begin{tabular}{|l|l|}
\hline$x$ & EXTENSÃO RURAL \\
\hline$x$ & PESQUISA \\
\hline$x$ & ENSINO \\
\hline & OUTROS \\
\hline
\end{tabular}


2) Qual o seu nível de escolaridade? (Considere apenas o nível mais alto)

\begin{tabular}{|l|l|}
\hline & NÍVEL MÉDIO \\
\hline & NÍVEL SUPERIOR \\
\hline$x$ & PÓS-GRADUAÇÃO \\
\hline
\end{tabular}

3) Os conteúdos abordados na formação foram condizentes com as demandas do seu dia-adia?

\begin{tabular}{|l|l|}
\hline$X$ & SIM \\
\hline & PARCIALMENTE \\
\hline & NÃO \\
\hline
\end{tabular}

4) O curso ou atividade de formação da qual você participou contribuiu para o seu aperfeiçoamento profissional?

\begin{tabular}{|l|l|}
\hline$x$ & SIM \\
\hline & NÃO \\
\hline
\end{tabular}

5) Os conhecimentos adquiridos nesta formação estão sendo aplicados no seu trabalho? Em caso afirmativo, indique em que grau estes conhecimentos estão sendo aplicados. Em caso negativo, indique por que razão isto não ocorre: (As respostas não são excludentes: você poderá marcar mais de uma opção).

\begin{tabular}{|c|c|c|}
\hline \multirow{3}{*}{$\begin{array}{l}\text { SIM (indique ao lado } \\
\text { em que grau) }\end{array}$} & $x$ & MUITO APLICADOS \\
\hline & & MEDIAMENTE APLICADOS \\
\hline & & POUCO APLICADOS \\
\hline \multirow{2}{*}{$\begin{array}{l}\text { NÃO (indique ao lado a } \\
\text { razão da não } \\
\text { aplicação) }\end{array}$} & & $\begin{array}{l}\text { CONTEÚDO NÃO ADEQUADO ÀS NECESSIDADES } \\
\text { ESPECÍFICAS DA REGIÃO }\end{array}$ \\
\hline & & $\begin{array}{lccc}\text { CONTEÚDO NÃO } & \text { FOI } & \text { SUFICIENTEMENTE } \\
\text { APROFUNDADO } & \text { PARA } & \text { PERMITIR } & \text { UMA } \\
\text { APLICAÇÃO EFICAZ E EFICIENTE } & \end{array}$ \\
\hline
\end{tabular}




\begin{tabular}{|l|l|l|}
\hline \multirow{2}{*}{} & & $\begin{array}{l}\text { FALTA DE APOIO E INCENTIVO DA MINHA } \\
\text { INSTITUIÇÃO }\end{array}$ \\
\cline { 2 - 3 } & FALTA DE INCENTIVO ÀS AÇÕES DE ATER \\
\hline & NÃO TENHO INTERESSE EM APLICAR \\
\hline
\end{tabular}

6) A partir do evento de formação do qual você participou: (As respostas não são excludentes: você poderá marcar mais de uma opção).

\begin{tabular}{|l|l|}
\hline & NÃO MUDOU NADA EM MEU TRABALHO. \\
\hline & $\begin{array}{l}\text { MEU TRABALHO PASSOU A CONTRIBUIR MAIS COM OS AGRICULTORES(AS) } \\
\text { FAMILIARES. }\end{array}$ \\
\hline & CONSEGUI INFLUENCIAR NAS ORIENTAÇÕES DA MINHA INSTITUIÇÃO. \\
\hline & $\begin{array}{l}\text { CRESSEI A TRABALHAR COM METODOLOGIAS PARTICIPATIVAS. } \\
\text { COMUNIDADES ONDE ATUO. AREA DE AGRICULTURA DE BASE ECOLÓGICA NAS }\end{array}$ \\
\hline$X$ & CONTINUEI ME APERFEIÇOANDO SOBRE TEMAS ABORDADOS. \\
\hline
\end{tabular}

7) Depois do evento de capacitação do qual participou, você apoiou atividades de capacitação de técnicos e/ou agricultores com base nos princípios e diretrizes da Pnater?

\begin{tabular}{|l|l|}
\hline$X$ & SIM \\
\hline & NÃO \\
\hline
\end{tabular}

8) Usou os conhecimentos para ministrar outros eventos de formação com o mesmo conteúdo ou conteúdos semelhantes?

\begin{tabular}{|l|l|}
\hline$X$ & SIM \\
\hline & NÃO \\
\hline
\end{tabular}


9) Marque o seu grau de satisfação com relação a atividade de formação oferecida pelo DATER: (Considere a seguinte pontuação: 1 - MUITO RUIM; 2 - RUIM; 3 - REGULAR; 4 BOM; 5 - MUITO BOM)

\begin{tabular}{|l|l|l|l|l|}
\hline 1 & 2 & 3 & 4 & $\times 5$ \\
\hline
\end{tabular}

10) Marque seu grau de satisfação com relação ao DATER: (Considere a seguinte pontuação: 1 - MUITO RUIM; 2 - RUIM; 3 - REGULAR; 4 - BOM; 5 - MUITO BOM)

\begin{tabular}{|l|l|l|l|l|}
\hline 1 & 2 & 3 & 4 & $\times 5$ \\
\hline
\end{tabular}


PESQUISA - IMPACTO DAS AÇÕES DE FORMAÇÃO REALIZADAS PELO DATER/SAF/MDA NO PERÍODO 2004-2009

Caros colaboradores,

Contamos com a sua atenção para preencher o formulário abaixo.

O mesmo tem por objetivo fornecer informações para avaliação da Eficiência, Efetividade e Eficácia da Política Pública de Formação de Agentes de Ater adotada pelo Departamento de Assistência Técnica e Extensão Rural, da Secretaria de Agricultura Familiar do Ministério do Desenvolvimento - DATER/SAF/MDA, no período de 2004 a 2009, tema escolhido para Monografia a ser apresentada à Universidade de Brasília (UnB) como requisito parcial para obtenção do grau de Bacharel em Administração.

Você poderá ou não se identificar no questionário e garantimos que todas as informações fornecidas serão confidenciais e utilizadas apenas de forma sistematizada.

\section{IDENTIFICAÇÃO}

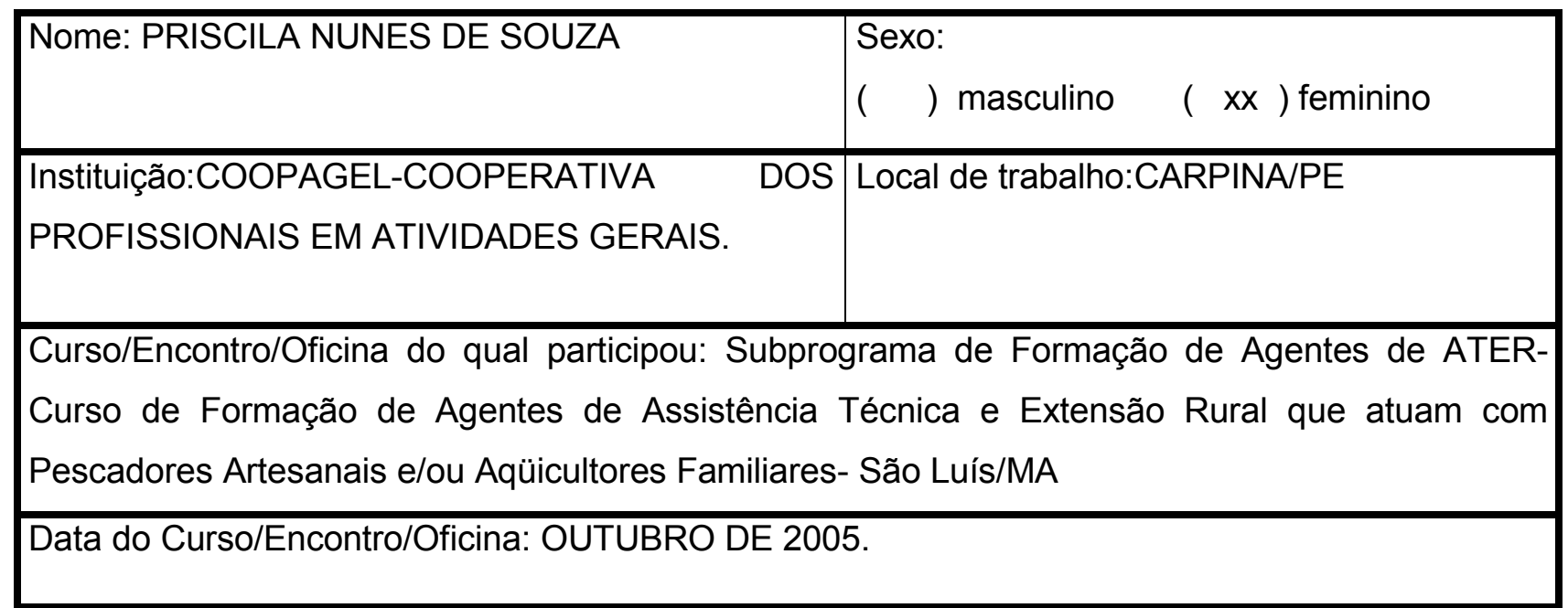

Indique sua área de atuação? (As opções não são excludentes: você poderá marcar mais de uma opção).

\begin{tabular}{|l|l|}
\hline$X$ & EXTENSÃO RURAL \\
\hline & PESQUISA \\
\hline & ENSINO \\
\hline & OUTROS \\
\hline
\end{tabular}


2) Qual o seu nível de escolaridade? ( Considere apenas o nível mais alto)

\begin{tabular}{|c|l|}
\hline & NÍVEL MÉDIO \\
\hline$X$ & NÍVEL SUPERIOR \\
\hline & PÓS-GRADUAÇÃO \\
\hline
\end{tabular}

3) Os conteúdos abordados foram condizentes com as demandas do seu dia-a-dia?

\begin{tabular}{|l|l|}
\hline$X$ & SIM \\
\hline & PARCIALMENTE \\
\hline & NÃO \\
\hline
\end{tabular}

4) O curso contribuiu para o seu aperfeiçoamento profissional?

\begin{tabular}{|l|l|}
\hline$X$ & SIM \\
\hline & NÃO \\
\hline
\end{tabular}

5) Os conhecimentos adquiridos estão sendo aplicados no seu trabalho? Em caso afirmativo, indique em que grau estes conhecimentos estão sendo aplicados. Em caso negativo, indique por que razão isto não ocorre: (As respostas não são excludentes: você poderá marcar mais de uma opção).

\begin{tabular}{|c|c|c|c|}
\hline \multirow{3}{*}{$X$} & \multirow{3}{*}{$\begin{array}{l}\text { SIM (indique ao lado em } \\
\text { que grau) }\end{array}$} & & MUITO APLICADOS \\
\hline & & $\mathrm{X}$ & MEDIAMENTE APLICADOS \\
\hline & & & POUCO APLICADOS \\
\hline & \multirow{2}{*}{$\begin{array}{l}\text { NÃO (indique ao lado a } \\
\text { razão da não aplicação) }\end{array}$} & & $\begin{array}{l}\text { CONTEÚDO NÃO ADEQUADO ȦS NECESSIDADES } \\
\text { ESPECÍFICAS DA REGIÃO }\end{array}$ \\
\hline & & & $\begin{array}{l}\text { CONTEÚDO NÃO } \quad \text { FOI SUFICIENTEMENTE } \\
\text { APROFUNDADO PARA } \\
\text { PERMITIR UMA APLICAÇÃO } \\
\text { EFICAZ E EFICIENTE }\end{array}$ \\
\hline
\end{tabular}




\begin{tabular}{|l|l|l|}
\hline \multirow{2}{*}{} & & $\begin{array}{l}\text { FALTA DE APOIO E INCENTIVO DA MINHA } \\
\text { INSTITUIÇÃO }\end{array}$ \\
\cline { 2 - 3 } & & FALTA DE INCENTIVO ÀS AÇÕES DE ATER \\
\cline { 2 - 3 } & NÃO TENHO INTERESSE EM APLICAR \\
\hline
\end{tabular}

6) A partir deste curso: (As opções não são excludentes: você poderá marcar mais de uma opção).

\begin{tabular}{|c|l|}
\hline$x$ & $\begin{array}{l}\text { NÃO MUDOU NADA EM MEU TRABALHO. } \\
\text { FAMILIARES. }\end{array}$ \\
\hline$X$ & CONSEGUI INFLUENCIAR NAS ORIENTAÇÕES DA MINHA INSTITUIÇÃO. \\
\hline & PASSEI A TRABALHAR COM METODOLOGIAS PARTICIPATIVAS. \\
\hline & $\begin{array}{l}\text { CRESCEU A ÁREA DE AGRICULTURA DE BASE ECOLÓGICA NAS COMUNIDADES } \\
\text { ONDE ATUO. }\end{array}$ \\
\hline$X$ & CONTINUEI ME APERFEIÇOANDO SOBRE TEMAS ABORDADOS. \\
\hline
\end{tabular}

7) Depois do curso você apoiou atividades de capacitação de técnicos e agricultores com base nos princípios e diretrizes da Pnater? (Considere como apoio a atividades de capacitação a participação no planejamento, elaboração de ementas, seleção de participantes e de palestrantes.)

\begin{tabular}{|l|l|}
\hline$X$ & SIM \\
\hline & NÃO \\
\hline
\end{tabular}

8) Usou os conhecimentos para ministrar outros cursos com o mesmo conteúdo ou conteúdos semelhantes?

\begin{tabular}{|l|l|}
\hline$X$ & SIM \\
\hline & NÃO \\
\hline
\end{tabular}


9) Marque o seu grau de satisfação com relação ao curso oferecido pelo DATER: (Considere a seguinte pontuação: 1 - MUITO RUIM; 2 - RUIM; 3 - REGULAR; 4 - BOM; 5 - MUITO BOM)

\begin{tabular}{|l|l|l|l|l|}
\hline 1 & 2 & 3 & 4 & $5 \times$ \\
\hline
\end{tabular}

10) Marque seu grau de satisfação com relação ao DATER: (Considere a seguinte pontuação: 1 - MUITO RUIM; 2 - RUIM; 3 - REGULAR; 4 - BOM; 5 - MUITO BOM)

\begin{tabular}{|l|l|l|l|l|}
\hline 1 & 2 & 3 & 4 & $5 \times$ \\
\hline
\end{tabular}


PESQUISA - IMPACTO DAS AÇÕES DE FORMAÇÃO REALIZADAS PELO DATER/SAF/MDA NO PERÍODO 2004-2009

Caros colaboradores,

Contamos com a sua atenção para preencher o formulário abaixo.

O mesmo tem por objetivo fornecer informações para avaliação da Eficiência, Efetividade e Eficácia da Política Pública de Formação de Agentes de Ater adotada pelo Departamento de Assistência Técnica e Extensão Rural, da Secretaria de Agricultura Familiar do Ministério do Desenvolvimento - DATER/SAF/MDA, no período de 2004 a 2009, tema escolhido para Monografia a ser apresentada à Universidade de Brasília (UnB) como requisito parcial para obtenção do grau de Bacharel em Administração.

Você poderá ou não se identificar no questionário e garantimos que todas as informações fornecidas serão confidenciais e utilizadas apenas de forma sistematizada.

IDENTIFICAÇÃO

\begin{tabular}{|l|l|}
\hline Nome: Maria das Graças Silva & $\begin{array}{l}\text { Sexo: } \\
(\quad) \text { masculino ( xx ) feminino }\end{array}$ \\
\hline Instituição : EMDAGRO - SE & Local de trabalho : ARACAJU - SE \\
\hline $\begin{array}{l}\text { Curso/Encontro/Oficina do qual participou : Formação de Formadores do Projeto Cultivando } \\
\text { Saberes }\end{array}$ & \\
\hline Data do Curso/Encontro/Oficina: julho 2009
\end{tabular}

1. Indique sua área de atuação? (As opções não são excludentes: você poderá marcar mais de uma opção).

\begin{tabular}{|l|l|}
\hline$x$ & EXTENSÃO RURAL \\
\hline & PESQUISA \\
\hline & ENSINO \\
\hline & OUTROS \\
\hline
\end{tabular}


2) Qual o seu nível de escolaridade? ( Considere apenas o nível mais alto)

\begin{tabular}{|l|l|}
\hline & NÍVEL MÉDIO \\
\hline$x$ & NÍVEL SUPERIOR \\
\hline & PÓS-GRADUAÇÃO \\
\hline
\end{tabular}

3) Os conteúdos abordados foram condizentes com as demandas do seu dia-a-dia?

\begin{tabular}{|l|l|}
\hline$X$ & SIM \\
\hline & PARCIALMENTE \\
\hline & NÃO \\
\hline
\end{tabular}

4) O curso contribuiu para o seu aperfeiçoamento profissional?

\begin{tabular}{|l|l|}
\hline$x$ & SIM \\
\hline & NÃO \\
\hline
\end{tabular}

5) Os conhecimentos adquiridos estão sendo aplicados no seu trabalho? Em caso afirmativo, indique em que grau estes conhecimentos estão sendo aplicados. Em caso negativo, indique por que razão isto não ocorre: (As respostas não são excludentes: você poderá marcar mais de uma opção).

\begin{tabular}{|c|c|c|}
\hline \multirow{3}{*}{$\begin{array}{l}\text { SIM (indique ao lado em } \\
\text { que grau) }\end{array}$} & & MUITO APLICADOS \\
\hline & & MEDIAMENTE APLICADOS \\
\hline & $\mathrm{X}$ & POUCO APLICADOS \\
\hline \multirow{2}{*}{$\begin{array}{l}\text { NÃO (indique ao lado a } \\
\text { razão da não aplicação) }\end{array}$} & & $\begin{array}{l}\text { CONTEÚDO NÃO ADEQUADO ȦS NECESSIDADES } \\
\text { ESPECÍFICAS DA REGIÃO }\end{array}$ \\
\hline & & $\begin{array}{l}\text { CONTEÚDO NÃO } \quad \text { FOI SUFICIENTEMENTE } \\
\text { APROFUNDADO PARA } \\
\text { PERMITIR UMA APLICAÇÃO } \\
\text { EFICAZ E EFICIENTE }\end{array}$ \\
\hline
\end{tabular}




\begin{tabular}{|l|l|l|}
\hline \multirow{2}{*}{} & & $\begin{array}{l}\text { FALTA DE APOIO E INCENTIVO DA MINHA } \\
\text { INSTITUIÇÃO }\end{array}$ \\
\cline { 3 - 4 } & & FALTA DE INCENTIVO ÀS AÇÕES DE ATER \\
\cline { 2 - 4 } & NÃO TENHO INTERESSE EM APLICAR \\
\hline
\end{tabular}

6) A partir deste curso: (As opções não são excludentes: você poderá marcar mais de uma opção).

\begin{tabular}{|l|l|}
\hline$x$ & $\begin{array}{l}\text { NÃO MUDOU NADA EM MEU TRABALHO. } \\
\text { FAMILIARES. }\end{array}$ \\
\hline & CONSEGUI INFLUENCIAR NAS ORIENTAÇÕES DA MINHA INSTITUIÇÃO. \\
\hline & PASSEI A TRABALHAR COM METODOLOGIAS PARTICIPATIVAS. \\
\hline & $\begin{array}{l}\text { CRESCEU A ÁREA DE AGRICULTURA DE BASE ECOLÓGICA NAS COMUNIDADES } \\
\text { ONDE ATUO. }\end{array}$ \\
\hline$x$ & CONTINUEI ME APERFEIÇOANDO SOBRE TEMAS ABORDADOS. \\
\hline
\end{tabular}

7) Depois do curso você apoiou atividades de capacitação de técnicos e agricultores com base nos princípios e diretrizes da Pnater? (Considere como apoio a atividades de capacitação a participação no planejamento, elaboração de ementas, seleção de participantes e de palestrantes.)

\begin{tabular}{|l|l|}
\hline$x$ & SIM \\
\hline & NÃO \\
\hline
\end{tabular}

8) Usou os conhecimentos para ministrar outros cursos com o mesmo conteúdo ou conteúdos semelhantes?

\begin{tabular}{|l|l|}
\hline$x$ & SIM \\
\hline & NÃO \\
\hline
\end{tabular}


9) Marque o seu grau de satisfação com relação ao curso oferecido pelo DATER: (Considere a seguinte pontuação: 1 - MUITO RUIM; 2 - RUIM; 3 - REGULAR; 4 - BOM; 5 - MUITO BOM)

\begin{tabular}{|l|l|l|l|l|}
\hline 1 & 2 & 3 & 4 & $\times 5$ \\
\hline
\end{tabular}

10) Marque seu grau de satisfação com relação ao DATER: (Considere a seguinte pontuação: 1 - MUITO RUIM; 2 - RUIM; 3 - REGULAR; 4 - BOM; 5 - MUITO BOM)

\begin{tabular}{|l|l|l|l|l|}
\hline 1 & 2 & 3 & $x 4$ & 5 \\
\hline
\end{tabular}


PESQUISA - IMPACTO DAS AÇÕES DE FORMAÇÃO REALIZADAS PELO DATER/SAF/MDA NO PERÍODO 2004-2009

Caros colaboradores,

Contamos com a sua atenção para preencher o formulário abaixo.

O mesmo tem por objetivo fornecer informações para avaliação da Eficiência, Efetividade e Eficácia da Política Pública de Formação de Agentes de Ater adotada pelo Departamento de Assistência Técnica e Extensão Rural, da Secretaria de Agricultura Familiar do Ministério do Desenvolvimento - DATER/SAF/MDA, no período de 2004 a 2009, tema escolhido para Monografia a ser apresentada à Universidade de Brasília (UnB) como requisito parcial para obtenção do grau de Bacharel em Administração.

Você poderá ou não se identificar no questionário e garantimos que todas as informações fornecidas serão confidenciais e utilizadas apenas de forma sistematizada.

IDENTIFICAÇÃO

\begin{tabular}{|l|l|}
\hline $\begin{array}{l}\text { Nome: } \\
\text { MARIO JOSE CAIRES SILVA VIANA }\end{array}$ & $\begin{array}{l}\text { Sexo: } \\
(\mathrm{x}) \text { masculino } \quad(\quad) \text { feminino }\end{array}$ \\
\hline $\begin{array}{l}\text { Instituição : DEAGRO - Depto. Estadual de } \\
\text { Desenvolvimento Agropecuário de Sergipe }\end{array}$ & $\begin{array}{l}\text { Local de trabalho : } \\
\text { Ribeirópolis - Se }\end{array}$ \\
\hline $\begin{array}{l}\text { Curso/Encontro/Oficina do qual participou : } \\
\text { Cursos para Agentes de ATER em Sistemas Agro florestais nos Biomas Caatingas }\end{array}$ \\
\hline $\begin{array}{l}\text { Data do Curso/Encontro/Oficina : } \\
20 \text { a 24/11/2006 - Lagoa Seca/PB }\end{array}$ \\
\hline
\end{tabular}

1. Indique sua área de atuação? (As opções não são excludentes: você poderá marcar mais de uma opção).

\begin{tabular}{|l|l|}
\hline$x$ & EXTENSÃO RURAL \\
\hline & PESQUISA \\
\hline & ENSINO \\
\hline & OUTROS \\
\hline
\end{tabular}


2) Qual o seu nível de escolaridade? ( Considere apenas o nível mais alto)

\begin{tabular}{|l|l|}
\hline & NÍVEL MÉDIO \\
\hline$x$ & NÍVEL SUPERIOR \\
\hline$x$ & PÓS-GRADUAÇÃO \\
\hline
\end{tabular}

3) Os conteúdos abordados foram condizentes com as demandas do seu dia-a-dia?

\begin{tabular}{|l|l|}
\hline$x$ & SIM \\
\hline & PARCIALMENTE \\
\hline & NÃO \\
\hline
\end{tabular}

4) O curso contribuiu para o seu aperfeiçoamento profissional?

\begin{tabular}{|l|l|}
\hline$x$ & SIM \\
\hline & NÃO \\
\hline
\end{tabular}

5) Os conhecimentos adquiridos estão sendo aplicados no seu trabalho? Em caso afirmativo, indique em que grau estes conhecimentos estão sendo aplicados. Em caso negativo, indique por que razão isto não ocorre: (As respostas não são excludentes: você poderá marcar mais de uma opção).

\begin{tabular}{|c|c|c|c|}
\hline \multirow{3}{*}{$x$} & \multirow{3}{*}{$\begin{array}{l}\text { SIM (indique ao lado em } \\
\text { que grau) }\end{array}$} & & MUITO APLICADOS \\
\hline & & $x$ & MEDIAMENTE APLICADOS \\
\hline & & & POUCO APLICADOS \\
\hline & \multirow{6}{*}{$\begin{array}{l}\text { NÃO (indique ao lado a } \\
\text { razão da não aplicação) }\end{array}$} & & CONTEÚDO NÃO ADEQUADO ÀS NECESSIDADES \\
\hline & & & CONTEÚDO NÂO FOI SUFICIENTEMENTE \\
\hline & & & 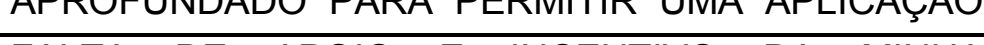 \\
\hline & & & $\begin{array}{lcccccc}\text { FALTA } & \text { DE } & \text { APOIO } & \text { E } & \text { INCENTIVO } & \text { DA } & \text { MINHA } \\
\text { INSTITUICÃO } & & & & & \\
\end{array}$ \\
\hline & & & FALTA DE INCENTIVO ÀS AÇÕES DE ATER \\
\hline & & & NÃO TENHO INTERESSE EM APLICAR \\
\hline
\end{tabular}


6) A partir deste curso: (As opções não são excludentes: você poderá marcar mais de uma opção).

\begin{tabular}{|l|l|}
\hline & \multicolumn{2}{l|}{ NÃO MUDOU NADA EM MEU TRABALHO. } \\
\hline$x$ & $\begin{array}{l}\text { MEU TRABALHO PASSOU A CONTRIBUIR MAIS COM OS AGRICULTORES(AS) } \\
\text { FAMILIARES. }\end{array}$ \\
\hline$x$ & CONSEGUI INFLUENCIAR NAS ORIENTAÇÕES DA MINHA INSTITUIÇÃO. \\
\hline & $\begin{array}{l}\text { PASSEI A TRABALHAR COM METODOLOGIAS PARTICIPATIVAS. } \\
\text { ONDE ATUO. }\end{array}$ \\
\hline$x$ & CONTINUEI ME APERFEIÇOANDO SOBRE TEMAS ABORDADOS. \\
\hline
\end{tabular}

7) Depois do curso você apoiou atividades de capacitação de técnicos e agricultores com base nos princípios e diretrizes da Pnater? (Considere como apoio a atividades de capacitação a participação no planejamento, elaboração de ementas, seleção de participantes e de palestrantes.)

\begin{tabular}{|l|l|}
\hline$x$ & SIM \\
\hline & NÃO \\
\hline
\end{tabular}

8) Usou os conhecimentos para ministrar outros cursos com o mesmo conteúdo ou conteúdos semelhantes?

\begin{tabular}{|l|l|}
\hline & SIM \\
\hline$x$ & NÃO \\
\hline
\end{tabular}

9) Marque o seu grau de satisfação com relação ao curso oferecido pelo DATER: (Considere a seguinte pontuação: 1 - MUITO RUIM; 2 - RUIM; 3 - REGULAR; 4 - BOM; 5 - MUITO BOM)

\begin{tabular}{|l|l|l|l|l|}
\hline 1 & 2 & 3 & 4 & $5 \times$ \\
\hline
\end{tabular}


10) Marque seu grau de satisfação com relação ao DATER: (Considere a seguinte pontuação: 1 - MUITO RUIM; 2 - RUIM; 3 - REGULAR; 4 - BOM; 5 - MUITO BOM)

\begin{tabular}{|l|l|l|l|l|}
\hline 1 & 2 & 3 & $4 x$ & 5 \\
\hline
\end{tabular}


PESQUISA - IMPACTO DAS AÇÕES DE FORMAÇÃO REALIZADAS PELO DATER/SAF/MDA NO PERÍODO 2004-2009

Caros colaboradores,

Contamos com a sua atenção para preencher o formulário abaixo.

O mesmo tem por objetivo fornecer informações para avaliação da Eficiência, Efetividade e Eficácia da Política Pública de Formação de Agentes de Ater adotada pelo Departamento de Assistência Técnica e Extensão Rural, da Secretaria de Agricultura Familiar do Ministério do Desenvolvimento - DATER/SAF/MDA, no período de 2004 a 2009, tema escolhido para Monografia a ser apresentada à Universidade de Brasília (UnB) como requisito parcial para obtenção do grau de Bacharel em Administração.

Você poderá ou não se identificar no questionário e garantimos que todas as informações fornecidas serão confidenciais e utilizadas apenas de forma sistematizada.

\section{IDENTIFICAÇÃO}

\begin{tabular}{|l|l|}
\hline Nome: Mario José Caíres Silva Viana & $\begin{array}{l}\text { Sexo: } \\
(x) \text { masculino } \quad(\quad) \text { feminino }\end{array}$ \\
\hline Instituição : EMDAGRO - SE & Local de trabalho : RIBEIRÓPOLIS - SE \\
\hline $\begin{array}{l}\text { Curso/Encontro/Oficina do qual participou : Formação de Formadores do Projeto Cultivando } \\
\text { Saberes }\end{array}$ \\
\hline Data do Curso/Encontro/Oficina: julho 2009
\end{tabular}

1. Indique sua área de atuação? (As opções não são excludentes: você poderá marcar mais de uma opção).

\begin{tabular}{|l|l|}
\hline$x$ & EXTENSÃO RURAL \\
\hline & PESQUISA \\
\hline & ENSINO \\
\hline & OUTROS \\
\hline
\end{tabular}


2) Qual o seu nível de escolaridade? ( Considere apenas o nível mais alto)

\begin{tabular}{|l|l|}
\hline & NÍVEL MÉDIO \\
\hline & NÍVEL SUPERIOR \\
\hline$x$ & PÓS-GRADUAÇÃO \\
\hline
\end{tabular}

3) Os conteúdos abordados foram condizentes com as demandas do seu dia-a-dia?

\begin{tabular}{|l|l|}
\hline & SIM \\
\hline$X$ & PARCIALMENTE \\
\hline & NÃO \\
\hline
\end{tabular}

4) O curso contribuiu para o seu aperfeiçoamento profissional?

\begin{tabular}{|l|l|}
\hline$x$ & SIM \\
\hline & NÃO \\
\hline
\end{tabular}

5) Os conhecimentos adquiridos estão sendo aplicados no seu trabalho? Em caso afirmativo, indique em que grau estes conhecimentos estão sendo aplicados. Em caso negativo, indique por que razão isto não ocorre: (As respostas não são excludentes: você poderá marcar mais de uma opção).

\begin{tabular}{|c|c|c|}
\hline \multirow{3}{*}{$\begin{array}{l}\text { SIM (indique ao lado em } \\
\text { que grau) }\end{array}$} & & MUITO APLICADOS \\
\hline & $\mathrm{X}$ & MEDIAMENTE APLICADOS \\
\hline & & POUCO APLICADOS \\
\hline \multirow{2}{*}{$\begin{array}{l}\text { NÃO (indique ao lado a } \\
\text { razão da não aplicação) }\end{array}$} & & $\begin{array}{l}\text { CONTEÚDO NÃO ADEQUADO ȦS NECESSIDADES } \\
\text { ESPECÍFICAS DA REGIÃO }\end{array}$ \\
\hline & & $\begin{array}{l}\text { CONTEÚDO NÃO } \quad \text { FOI } \quad \text { SUFICIENTEMENTE } \\
\text { APROFUNDADO PARA } \\
\text { EERMITIR UMA APLICAÇÃO } \\
\text { EFICAZ E EFICIENTE }\end{array}$ \\
\hline
\end{tabular}




\begin{tabular}{|l|l|l|}
\hline \multirow{2}{*}{} & & $\begin{array}{l}\text { FALTA DE APOIO E INCENTIVO DA MINHA } \\
\text { INSTITUIÇÃO }\end{array}$ \\
\cline { 3 - 4 } & & FALTA DE INCENTIVO ÀS AÇÕES DE ATER \\
\cline { 2 - 4 } & NÃO TENHO INTERESSE EM APLICAR \\
\hline
\end{tabular}

6) A partir deste curso: (As opções não são excludentes: você poderá marcar mais de uma opção).

\begin{tabular}{|c|l|}
\hline & NÃO MUDOU NADA EM MEU TRABALHO. \\
\hline & $\begin{array}{l}\text { MEU TRABALHO PASSOU A CONTRIBUIR MAIS COM OS AGRICULTORES(AS) } \\
\text { FAMILIARES. }\end{array}$ \\
\hline$x$ & CONSEGUI INFLUENCIAR NAS ORIENTAÇÕES DA MINHA INSTITUIÇÃO. \\
\hline$x$ & PASSEI A TRABALHAR COM METODOLOGIAS PARTICIPATIVAS. \\
\hline & $\begin{array}{l}\text { CRESCEU A ÁREA DE AGRICULTURA DE BASE ECOLÓGICA NAS COMUNIDADES } \\
\text { ONDE ATUO. }\end{array}$ \\
\hline$x$ & CONTINUEI ME APERFEIÇOANDO SOBRE TEMAS ABORDADOS. \\
\hline
\end{tabular}

7) Depois do curso você apoiou atividades de capacitação de técnicos e agricultores com base nos princípios e diretrizes da Pnater? (Considere como apoio a atividades de capacitação a participação no planejamento, elaboração de ementas, seleção de participantes e de palestrantes.)

\begin{tabular}{|l|l|}
\hline$x$ & SIM \\
\hline & NÃO \\
\hline
\end{tabular}

8) Usou os conhecimentos para ministrar outros cursos com o mesmo conteúdo ou conteúdos semelhantes?

\begin{tabular}{|l|l|}
\hline$x$ & SIM \\
\hline & NÃO \\
\hline
\end{tabular}

9) Marque o seu grau de satisfação com relação ao curso oferecido pelo DATER: (Considere a seguinte pontuação: 1 - MUITO RUIM; 2 - RUIM; 3 - REGULAR; 4 - BOM; 5 - MUITO BOM) 


\begin{tabular}{|l|l|l|l|l|}
\hline 1 & 2 & $\times 3$ & 4 & 5 \\
\hline
\end{tabular}

10) Marque seu grau de satisfação com relação ao DATER: (Considere a seguinte pontuação: 1 - MUITO RUIM; 2 - RUIM; 3 - REGULAR; 4 - BOM; 5 - MUITO BOM)

\begin{tabular}{|l|l|l|l|l|}
\hline 1 & 2 & 3 & $X 4$ & 5 \\
\hline
\end{tabular}


PESQUISA - IMPACTO DAS AÇÕES DE FORMAÇÃO REALIZADAS PELO DATER/SAF/MDA NO PERÍODO 2004-2009

Caros colaboradores,

Contamos com a sua atenção para preencher o formulário abaixo.

O mesmo tem por objetivo fornecer informações para avaliação da Eficiência, Efetividade e Eficácia da Política Pública de Formação de Agentes de Ater adotada pelo Departamento de Assistência Técnica e Extensão Rural, da Secretaria de Agricultura Familiar do Ministério do Desenvolvimento - DATER/SAF/MDA, no período de 2004 a 2009, tema escolhido para Monografia a ser apresentada à Universidade de Brasília (UnB) como requisito parcial para obtenção do grau de Bacharel em Administração.

Você poderá ou não se identificar no questionário e garantimos que todas as informações fornecidas serão confidenciais e utilizadas apenas de forma sistematizada.

\section{IDENTIFICAÇÃO}

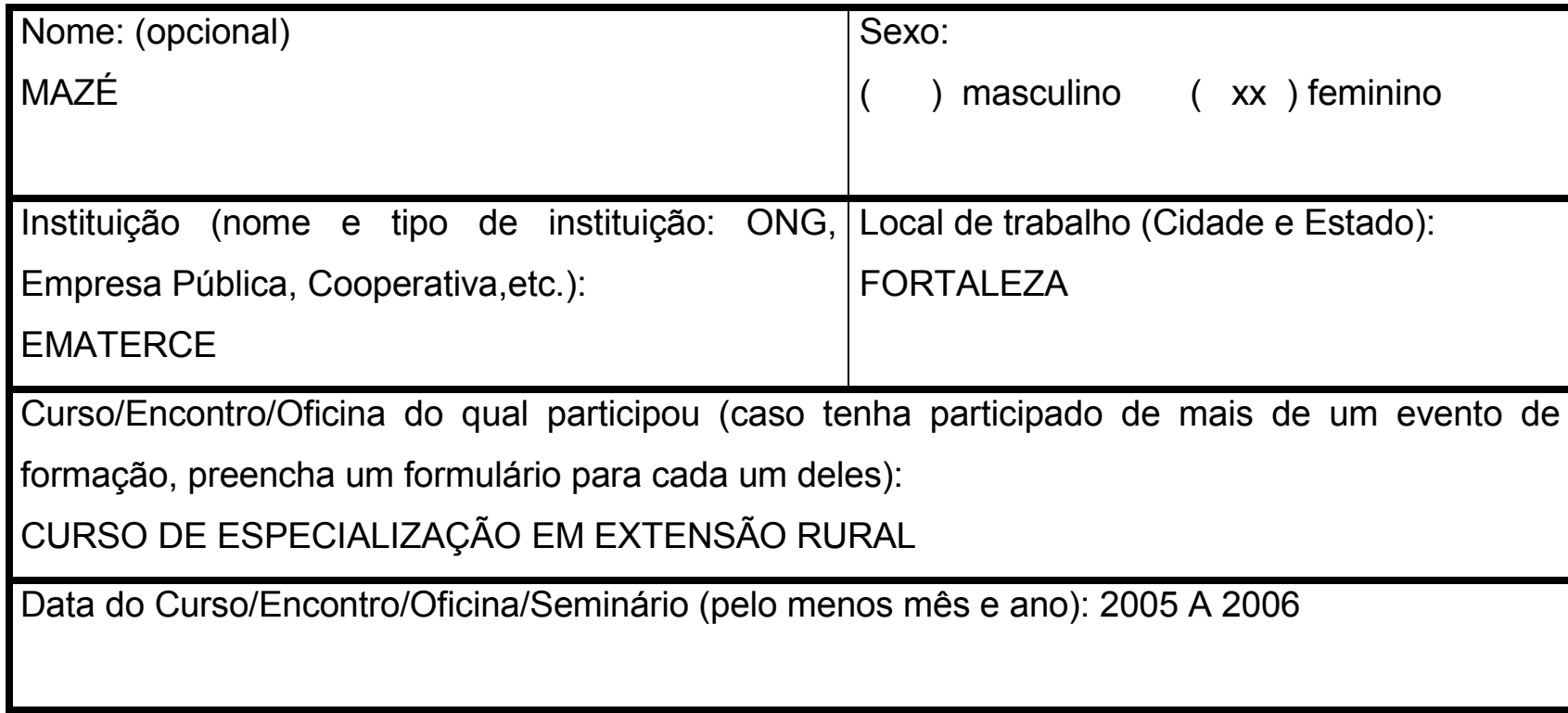

1) Indique sua área de atuação? (As opções não são excludentes: você poderá marcar mais de uma opção).

\begin{tabular}{|l|l|}
\hline$X$ & EXTENSÃO RURAL \\
\hline & PESQUISA \\
\hline & ENSINO \\
\hline & OUTROS \\
\hline
\end{tabular}


2) Qual o seu nível de escolaridade? (Considere apenas o nível mais alto)

\begin{tabular}{|l|l|}
\hline & NÍVEL MÉDIO \\
\hline & NÍVEL SUPERIOR \\
\hline$x$ & PÓS-GRADUAÇÃO \\
\hline
\end{tabular}

3) Os conteúdos abordados na formação foram condizentes com as demandas do seu dia-adia?

\begin{tabular}{|l|l|}
\hline$X$ & SIM \\
\hline & PARCIALMENTE \\
\hline & NÃO \\
\hline
\end{tabular}

4) O curso ou atividade de formação da qual você participou contribuiu para o seu aperfeiçoamento profissional?

\begin{tabular}{|l|l|}
\hline$x$ & SIM \\
\hline & NÃO \\
\hline
\end{tabular}

5) Os conhecimentos adquiridos nesta formação estão sendo aplicados no seu trabalho? Em caso afirmativo, indique em que grau estes conhecimentos estão sendo aplicados. Em caso negativo, indique por que razão isto não ocorre: (As respostas não são excludentes: você poderá marcar mais de uma opção).

\begin{tabular}{|c|c|c|}
\hline \multirow{3}{*}{$\begin{array}{l}\text { SIM (indique ao lado } \\
\text { em que grau) }\end{array}$} & & MUITO APLICADOS \\
\hline & $x$ & MEDIAMENTE APLICADOS \\
\hline & & POUCO APLICADOS \\
\hline \multirow{2}{*}{$\begin{array}{l}\text { NÃO (indique ao lado a } \\
\text { razão da não } \\
\text { aplicação) }\end{array}$} & & $\begin{array}{l}\text { CONTEÚDO NÃO ADEQUADO ÀS NECESSIDADES } \\
\text { ESPECÍFICAS DA REGIÃO }\end{array}$ \\
\hline & & $\begin{array}{lccc}\text { CONTEÚDO NÃO } & \text { FOI } & \text { SUFICIENTEMENTE } \\
\text { APROFUNDADO } & \text { PARA } & \text { PERMITIR } & \text { UMA } \\
\text { APLICAÇÃO EFICAZ E EFICIENTE } & \end{array}$ \\
\hline
\end{tabular}




\begin{tabular}{|l|l|l|}
\hline \multirow{2}{*}{} & & $\begin{array}{l}\text { FALTA DE APOIO E INCENTIVO DA MINHA } \\
\text { INSTITUIÇÃO }\end{array}$ \\
\hline & FALTA DE INCENTIVO ÀS AÇÕES DE ATER \\
\hline & NÃO TENHO INTERESSE EM APLICAR \\
\hline
\end{tabular}

6) A partir do evento de formação do qual você participou: (As respostas não são excludentes: você poderá marcar mais de uma opção).

\begin{tabular}{|l|l|}
\hline & NÃO MUDOU NADA EM MEU TRABALHO. \\
\hline$x$ & $\begin{array}{l}\text { MEU TRABALHO PASSOU A CONTRIBUIR MAIS COM OS AGRICULTORES(AS) } \\
\text { FAMILIARES. }\end{array}$ \\
\hline$X$ & CONSEGUI INFLUENCIAR NAS ORIENTAÇÕES DA MINHA INSTITUIÇÃO. \\
\hline$X$ & PASSEI A TRABALHAR COM METODOLOGIAS PARTICIPATIVAS. \\
\hline & $\begin{array}{l}\text { CRESCEU A ÁREA DE AGRICULTURA DE BASE ECOLÓGICA NAS } \\
\text { COMUNIDADES ONDE ATUO. }\end{array}$ \\
\hline$X$ & CONTINUEI ME APERFEIÇOANDO SOBRE TEMAS ABORDADOS. \\
\hline
\end{tabular}

7) Depois do evento de capacitação do qual participou, você apoiou atividades de capacitação de técnicos e/ou agricultores com base nos princípios e diretrizes da Pnater? (Considere como apoio a atividades de capacitação a participação no planejamento, elaboração de ementas, seleção de participantes e de palestrantes.)

\begin{tabular}{|l|l|}
\hline$X$ & SIM \\
\hline & NÃO \\
\hline
\end{tabular}

8) Usou os conhecimentos para ministrar outros eventos de formação com o mesmo conteúdo ou conteúdos semelhantes?

\begin{tabular}{|l|l|}
\hline$X$ & SIM \\
\hline & NÃO \\
\hline
\end{tabular}


9) Marque o seu grau de satisfação com relação a atividade de formação oferecida pelo DATER: (Considere a seguinte pontuação: 1 - MUITO RUIM; 2 - RUIM; 3 - REGULAR; 4 BOM; 5 - MUITO BOM)

\begin{tabular}{|l|l|l|l|l|}
\hline 1 & 2 & 3 & 4 & $\times 5$ \\
\hline
\end{tabular}

10) Marque seu grau de satisfação com relação ao DATER: (Considere a seguinte pontuação: 1 - MUITO RUIM; 2 - RUIM; 3 - REGULAR; 4 - BOM; 5 - MUITO BOM)

\begin{tabular}{|l|l|l|l|l|}
\hline 1 & 2 & 3 & 4 & $\times 5$ \\
\hline
\end{tabular}


PESQUISA - IMPACTO DAS AÇÕES DE FORMAÇÃO REALIZADAS PELO DATER/SAF/MDA NO PERÍODO 2004-2009

Caros colaboradores,

Contamos com a sua atenção para preencher o formulário abaixo.

O mesmo tem por objetivo fornecer informações para avaliação da Eficiência, Efetividade e Eficácia da Política Pública de Formação de Agentes de Ater adotada pelo Departamento de Assistência Técnica e Extensão Rural, da Secretaria de Agricultura Familiar do Ministério do Desenvolvimento - DATER/SAF/MDA, no período de 2004 a 2009, tema escolhido para Monografia a ser apresentada à Universidade de Brasília (UnB) como requisito parcial para obtenção do grau de Bacharel em Administração.

Você poderá ou não se identificar no questionário e garantimos que todas as informações fornecidas serão confidenciais e utilizadas apenas de forma sistematizada.

\section{IDENTIFICAÇÃO}

\begin{tabular}{|l|l|}
\hline Nome: Miryam Terezinha Silva Belo & $\begin{array}{l}\text { Sexo: } \\
(\quad) \text { masculino ( xx ) feminino }\end{array}$ \\
\hline $\begin{array}{l}\text { Instituição: atualmente estou na Comissão Pastoral } \\
\text { da Terra (CPT), mas quando fiz o curso de }\end{array}$ & $\begin{array}{l}\text { Local de trabalho: CPT (Salvador/BA) } \\
\text { CACTUS (Sr. Do Bonfim/Salvador/BA) }\end{array}$ \\
\hline Curoecologia estava na CACTUS/BA (ONG). & \\
um formulário para cada um deles): Agroecologia (REDCAPA) \\
\hline Data do Curso/Encontro/Oficina: 2006
\end{tabular}

1. Indique sua área de atuação? (As opções não são excludentes: você poderá marcar mais de uma opção).Atualmente assessoria, lembrando que neste período estava na coordenação do ATES em uma conveniada na Bahia.

\begin{tabular}{|l|l|}
\hline$X$ & EXTENSÃO RURAL \\
\hline & PESQUISA \\
\hline & ENSINO \\
\hline$X$ & OUTROS \\
\hline
\end{tabular}


2) Qual o seu nível de escolaridade? ( Considere apenas o nível mais alto)

\begin{tabular}{|l|l|}
\hline & NÍVEL MÉDIO \\
\hline & NÍVEL SUPERIOR \\
\hline$X$ & PÓS-GRADUAÇÃO \\
\hline
\end{tabular}

3) Os conteúdos abordados foram condizentes com as demandas do seu dia-a-dia?

\begin{tabular}{|l|l|}
\hline$X$ & SIM \\
\hline & PARCIALMENTE \\
\hline & NÃO \\
\hline
\end{tabular}

4) O curso contribuiu para o seu aperfeiçoamento profissional?

\begin{tabular}{|l|l|}
\hline$X$ & SIM \\
\hline & NÃO \\
\hline
\end{tabular}

5) Os conhecimentos adquiridos estão sendo aplicados no seu trabalho? Em caso afirmativo, indique em que grau estes conhecimentos estão sendo aplicados. Em caso negativo, indique por que razão isto não ocorre: (As respostas não são excludentes: você poderá marcar mais de uma opção).

\begin{tabular}{|c|c|c|}
\hline \multirow{3}{*}{$\begin{array}{l}\text { SIM (indique ao lado em } \\
\text { que grau) }\end{array}$} & $x$ & MUITO APLICADOS \\
\hline & & MEDIAMENTE APLICADOS \\
\hline & & POUCO APLICADOS \\
\hline \multirow{2}{*}{$\begin{array}{l}\text { NÃO (indique ao lado a } \\
\text { razão da não aplicação) }\end{array}$} & & $\begin{array}{l}\text { CONTEÚDO NÃO ADEQUADO ȦS NECESSIDADES } \\
\text { ESPECÍFICAS DA REGIÃO }\end{array}$ \\
\hline & & $\begin{array}{l}\text { CONTEÚDO NÃO } \quad \text { FOI SUFICIENTEMENTE } \\
\text { APROFUNDADO PARA } \\
\text { PERMITIR UMA APLICAÇÃO } \\
\text { EFICAZ E EFICIENTE }\end{array}$ \\
\hline
\end{tabular}




\begin{tabular}{|l|l|l|}
\hline \multirow{2}{*}{} & & $\begin{array}{l}\text { FALTA DE APOIO E INCENTIVO DA MINHA } \\
\text { INSTITUIÇÃO }\end{array}$ \\
\cline { 2 - 3 } & & FALTA DE INCENTIVO ÀS AÇÕES DE ATER \\
\cline { 2 - 3 } & NÃO TENHO INTERESSE EM APLICAR \\
\hline
\end{tabular}

6) A partir deste curso: (As opções não são excludentes: você poderá marcar mais de uma opção).

\begin{tabular}{|c|l|}
\hline$x$ & $\begin{array}{l}\text { NÃO MUDOU NADA EM MEU TRABALHO. } \\
\text { FAMILIARES. }\end{array}$ \\
\hline$x$ & CONSEGUI INFLUENCIAR NAS ORIENTAÇÕES DA MINHA INSTITUIÇÃO. \\
\hline & PASSEI A TRABALHAR COM METODOLOGIAS PARTICIPATIVAS. \\
\hline$x$ & $\begin{array}{l}\text { CRESCEU A ÁREA DE AGRICULTURA DE BASE ECOLÓGICA NAS COMUNIDADES } \\
\text { ONDE ATUO. }\end{array}$ \\
\hline$x$ & CONTINUEI ME APERFEIÇOANDO SOBRE TEMAS ABORDADOS. \\
\hline
\end{tabular}

7) Depois do curso você apoiou atividades de capacitação de técnicos e agricultores com base nos princípios e diretrizes da Pnater? (Considere como apoio a atividades de capacitação a participação no planejamento, elaboração de ementas, seleção de participantes e de palestrantes.)

\begin{tabular}{|l|l|}
\hline$x$ & SIM \\
\hline & NÃO \\
\hline
\end{tabular}

8) Usou os conhecimentos para ministrar outros cursos com o mesmo conteúdo ou conteúdos semelhantes?

\begin{tabular}{|l|l|}
\hline$x$ & SIM \\
\hline & NÃO \\
\hline
\end{tabular}


9) Marque o seu grau de satisfação com relação ao curso oferecido pelo DATER: (Considere a seguinte pontuação: 1 - MUITO RUIM; 2 - RUIM; 3 - REGULAR; 4 - BOM; 5 - MUITO BOM)

\begin{tabular}{|l|l|l|l|l|}
\hline 1 & 2 & 3 & $4 \times$ & 5 \\
\hline
\end{tabular}

10) Marque seu grau de satisfação com relação ao DATER: (Considere a seguinte pontuação: 1 - MUITO RUIM; 2 - RUIM; 3 - REGULAR; 4 - BOM; 5 - MUITO BOM)

\begin{tabular}{|l|l|l|l|l|}
\hline 1 & 2 & 3 & $4 \times$ & 5 \\
\hline
\end{tabular}


PESQUISA - IMPACTO DAS AÇÕES DE FORMAÇÃO REALIZADAS PELO DATER/SAF/MDA NO PERÍODO 2004-2009

Caros colaboradores,

Contamos com a sua atenção para preencher o formulário abaixo.

O mesmo tem por objetivo fornecer informações para avaliação da Eficiência, Efetividade e Eficácia da Política Pública de Formação de Agentes de Ater adotada pelo Departamento de Assistência Técnica e Extensão Rural, da Secretaria de Agricultura Familiar do Ministério do Desenvolvimento - DATER/SAF/MDA, no período de 2004 a 2009, tema escolhido para Monografia a ser apresentada à Universidade de Brasília (UnB) como requisito parcial para obtenção do grau de Bacharel em Administração.

Você poderá ou não se identificar no questionário e garantimos que todas as informações fornecidas serão confidenciais e utilizadas apenas de forma sistematizada.

IDENTIFICAÇÃO

\begin{tabular}{|l|l|}
\hline Nome:Orlando Sampaio Freire de Melo & $\begin{array}{l}\text { Sexo: } \\
(x \quad) \text { masculino } \quad(\quad \text { ) feminino }\end{array}$ \\
\hline Instituição (nome e tipo de instituição: ONG, & Local de trabalho (Cidade e Estado): \\
Empresa Pública, etc.):Sindicato dos Trabalhadores & Retirolândia-Ba \\
Rurais de Retirolãndia
\end{tabular}

1. Indique sua área de atuação? (As opções não são excludentes: você poderá marcar mais de uma opção).

\begin{tabular}{|l|l|}
\hline$x$ & EXTENSÃO RURAL \\
\hline & PESQUISA \\
\hline$x$ & ENSINO \\
\hline & OUTROS \\
\hline
\end{tabular}


2) Qual o seu nível de escolaridade? ( Considere apenas o nível mais alto)

\begin{tabular}{|l|l|}
\hline & NÍVEL MÉDIO \\
\hline$x$ & NÍVEL SUPERIOR \\
\hline & PÓS-GRADUAÇÃO \\
\hline
\end{tabular}

3) Os conteúdos abordados foram condizentes com as demandas do seu dia-a-dia?

\begin{tabular}{|l|l|}
\hline & SIM \\
\hline$x$ & PARCIALMENTE \\
\hline & NÃO \\
\hline
\end{tabular}

4) O curso contribuiu para o seu aperfeiçoamento profissional?

\begin{tabular}{|l|l|}
\hline$x$ & SIM \\
\hline & NÃO \\
\hline
\end{tabular}

5) Os conhecimentos adquiridos estão sendo aplicados no seu trabalho? Em caso afirmativo, indique em que grau estes conhecimentos estão sendo aplicados. Em caso negativo, indique por que razão isto não ocorre: (As respostas não são excludentes: você poderá marcar mais de uma opção).

\begin{tabular}{|c|c|c|c|}
\hline \multirow{3}{*}{$x$} & \multirow{3}{*}{$\begin{array}{l}\text { SIM (indique ao lado em } \\
\text { que grau) }\end{array}$} & & MUITO APLICADOS \\
\hline & & $x$ & MEDIAMENTE APLICADOS \\
\hline & & & POUCO APLICADOS \\
\hline & \multirow{2}{*}{$\begin{array}{l}\text { NÃO (indique ao lado a } \\
\text { razão da não aplicação) }\end{array}$} & & $\begin{array}{l}\text { CONTEU்DO NÃO ADEQUADO ȦS NECESSIDADES } \\
\text { ESPECÍFICAS DA REGIÃO }\end{array}$ \\
\hline & & & $\begin{array}{l}\text { CONTEÚDO NÃO } \quad \text { FOI SUFICIENTEMENTE } \\
\text { APROFUNDADO PARA } \\
\text { PERMITIR UMA APLICAÇÃO } \\
\text { EFICAZ E EFICIENTE }\end{array}$ \\
\hline
\end{tabular}




\begin{tabular}{|l|l|l|}
\hline \multirow{2}{*}{} & & $\begin{array}{l}\text { FALTA DE APOIO E INCENTIVO DA MINHA } \\
\text { INSTITUIÇÃO }\end{array}$ \\
\cline { 2 - 3 } & & FALTA DE INCENTIVO ÀS AÇÕES DE ATER \\
\cline { 2 - 3 } & NÃO TENHO INTERESSE EM APLICAR \\
\hline
\end{tabular}

6) A partir deste curso: (As opções não são excludentes: você poderá marcar mais de uma opção).

\begin{tabular}{|l|l|}
\hline & NÃO MUDOU NADA EM MEU TRABALHO. \\
\hline$x$ & $\begin{array}{l}\text { MEU TRABALHO PASSOU A CONTRIBUIR MAIS COM OS AGRICULTORES(AS) } \\
\text { FAMILIARES. }\end{array}$ \\
\hline & CONSEGUI INFLUENCIAR NAS ORIENTAÇÕES DA MINHA INSTITUIÇÃO. \\
\hline$x$ & $\begin{array}{l}\text { CRESCEI A TRABALHAR COM METODOLOGIAS PARTICIPATIVAS. } \\
\text { ONDE ATUO. ÁREA DE AGRICULTURA DE BASE ECOLÓGICA NAS COMUNIDADES }\end{array}$ \\
\hline$x$ & CONTINUEI ME APERFEIÇOANDO SOBRE TEMAS ABORDADOS. \\
\hline
\end{tabular}

7) Depois do curso você apoiou atividades de capacitação de técnicos e agricultores com base nos princípios e diretrizes da Pnater? (Considere como apoio a atividades de capacitação a participação no planejamento, elaboração de ementas, seleção de participantes e de palestrantes.)

\begin{tabular}{|l|l|}
\hline$x$ & SIM \\
\hline & NÃO \\
\hline
\end{tabular}

8) Usou os conhecimentos para ministrar outros cursos com o mesmo conteúdo ou conteúdos semelhantes?

\begin{tabular}{|l|l|}
\hline$x$ & SIM \\
\hline & NÃO \\
\hline
\end{tabular}


9) Marque o seu grau de satisfação com relação ao curso oferecido pelo DATER: (Considere a seguinte pontuação: 1 - MUITO RUIM; 2 - RUIM; 3 - REGULAR; 4 - BOM; 5 - MUITO BOM)

\begin{tabular}{|l|l|l|l|l|}
\hline 1 & 2 & 3 & 4 & 5 \\
\hline
\end{tabular}

10) Marque seu grau de satisfação com relação ao DATER: (Considere a seguinte pontuação: 1 - MUITO RUIM; 2 - RUIM; 3 - REGULAR; 4 - BOM; 5 - MUITO BOM)

\begin{tabular}{|l|l|l|l|l|}
\hline 1 & 2 & 3 & 4 & 5 \\
\hline
\end{tabular}


PESQUISA - IMPACTO DAS AÇÕES DE FORMAÇÃO REALIZADAS PELO DATER/SAF/MDA NO PERÍODO 2004-2009

Caros colaboradores,

Contamos com a sua atenção para preencher o formulário abaixo.

O mesmo tem por objetivo fornecer informações para avaliação da Eficiência, Efetividade e Eficácia da Política Pública de Formação de Agentes de Ater adotada pelo Departamento de Assistência Técnica e Extensão Rural, da Secretaria de Agricultura Familiar do Ministério do Desenvolvimento - DATER/SAF/MDA, no período de 2004 a 2009, tema escolhido para Monografia a ser apresentada à Universidade de Brasília (UnB) como requisito parcial para obtenção do grau de Bacharel em Administração.

Você poderá ou não se identificar no questionário e garantimos que todas as informações fornecidas serão confidenciais e utilizadas apenas de forma sistematizada.

IDENTIFICAÇÃO

\begin{tabular}{|c|c|}
\hline Nome:Orlando Sampaio Freire de Melo & $\begin{array}{l}\text { Sexo: } \\
(x \quad) \text { masculino } \quad(\quad) \text { feminino }\end{array}$ \\
\hline $\begin{array}{l}\text { Instituição (nome e tipo de instituição: ONG, } \\
\text { Empresa Pública, etc.):Sindicato dos Trabalhadores } \\
\text { Rurais de Retirolãndia }\end{array}$ & $\begin{array}{l}\text { Local de trabalho (Cidade e Estado): } \\
\text { Retirolândia-Ba }\end{array}$ \\
\hline \multicolumn{2}{|c|}{$\begin{array}{l}\text { Curso/Encontro/Oficina do qual participou (caso tenha participado de mais de um curso, preencha } \\
\text { um formulário para cada um deles): } \\
\text { OFICINA DE NIVELAMENTO CONCEITUAL SOBRE A POLITICA NACIONAL DE ATER }\end{array}$} \\
\hline \multicolumn{2}{|l|}{$\begin{array}{l}\text { Data do Curso/Encontro/Oficina (pelo menos mês e ano): } \\
\text { PERÍODO: } 16 \text { A 20/08/2004 }\end{array}$} \\
\hline
\end{tabular}

1. Indique sua área de atuação? (As opções não são excludentes: você poderá marcar mais de uma opção).

\begin{tabular}{|l|l|}
\hline$x$ & EXTENSÃO RURAL \\
\hline & PESQUISA \\
\hline$x$ & ENSINO \\
\hline
\end{tabular}




\section{OUTROS}

2) Qual o seu nível de escolaridade? ( Considere apenas o nível mais alto)

\begin{tabular}{|l|l|}
\hline & NÍVEL MÉDIO \\
\hline$x$ & NÍVEL SUPERIOR \\
\hline & PÓS-GRADUAÇÃO \\
\hline
\end{tabular}

3) Os conteúdos abordados foram condizentes com as demandas do seu dia-a-dia?

\begin{tabular}{|l|l|}
\hline & SIM \\
\hline$x$ & PARCIALMENTE \\
\hline & NÃO \\
\hline
\end{tabular}

4) O curso contribuiu para o seu aperfeiçoamento profissional?

\begin{tabular}{|l|l|}
\hline$x$ & SIM \\
\hline & NÃO \\
\hline
\end{tabular}

5) Os conhecimentos adquiridos estão sendo aplicados no seu trabalho? Em caso afirmativo, indique em que grau estes conhecimentos estão sendo aplicados. Em caso negativo, indique por que razão isto não ocorre: (As respostas não são excludentes: você poderá marcar mais de uma opção).

\begin{tabular}{|l|l|l|l|}
\hline$x$ & $\begin{array}{l}\text { SIM (indique ao lado em } \\
\text { que grau) }\end{array}$ & $x$ & MUITO APLICADOS \\
\cline { 2 - 4 } & & POUCO APLICADOS \\
\hline & $\begin{array}{l}\text { NÃO (indique ao lado a } \\
\text { razão da não aplicação) }\end{array}$ & $\begin{array}{l}\text { CONTEÚDO NÃO ADEQUADO ȦS NECESSIDADES } \\
\text { ESPECÍFICAS DA REGIÃO }\end{array}$ \\
\hline
\end{tabular}




\begin{tabular}{|l|l|l|}
\hline \multirow{10}{*}{} & $\begin{array}{l}\text { CONTEÚDO NÃO FOI SUFICIENTEMENTE } \\
\text { APROFUNDADO PARA PERMITIR UMA APLICAÇÃO } \\
\text { EFICAZ E EFICIENTE }\end{array}$ \\
\cline { 2 - 4 } & $\begin{array}{l}\text { FALTA DE APOIO E INCENTIVO DA MINHA } \\
\text { INSTITUIÇÃO }\end{array}$ \\
\hline & FALTA DE INCENTIVO ÀS AÇÕES DE ATER \\
\cline { 2 - 4 } & NÃO TENHO INTERESSE EM APLICAR \\
\hline
\end{tabular}

6) A partir deste curso: (As opções não são excludentes: você poderá marcar mais de uma opção).

\begin{tabular}{|l|l|}
\hline & NÃO MUDOU NADA EM MEU TRABALHO. \\
\hline$x$ & $\begin{array}{l}\text { MEU TRABALHO PASSOU A CONTRIBUIR MAIS COM OS AGRICULTORES(AS) } \\
\text { FAMILIARES. }\end{array}$ \\
\hline & CONSEGUI INFLUENCIAR NAS ORIENTAÇÕES DA MINHA INSTITUIÇÃO. \\
\hline$x$ & $\begin{array}{l}\text { CRESCEU A ÁREA DE AGRICULTURA DE BASE ECOLÓGICA NAS COMUNIDADES } \\
\text { ONDE ATUO. }\end{array}$ \\
\hline$x$ & CONTINUEI ME APERFEIÇOANDO SOBRE TEMAS ABORDADOS. \\
\hline
\end{tabular}

7) Depois do curso você apoiou atividades de capacitação de técnicos e agricultores com base nos princípios e diretrizes da Pnater? (Considere como apoio a atividades de capacitação a participação no planejamento, elaboração de ementas, seleção de participantes e de palestrantes.)

\begin{tabular}{|l|l|}
\hline$x$ & SIM \\
\hline & NÃO \\
\hline
\end{tabular}

8) Usou os conhecimentos para ministrar outros cursos com o mesmo conteúdo ou conteúdos semelhantes? 


\begin{tabular}{|l|l|}
\hline$x$ & SIM \\
\hline & NÃO \\
\hline
\end{tabular}

9) Marque o seu grau de satisfação com relação ao curso oferecido pelo DATER: (Considere a seguinte pontuação: 1 - MUITO RUIM; 2 - RUIM; 3 - REGULAR; 4 - BOM; 5 - MUITO BOM)

\begin{tabular}{|l|l|l|l|l|}
\hline 1 & 2 & 3 & 4 & 5 \\
\hline
\end{tabular}

10) Marque seu grau de satisfação com relação ao DATER: (Considere a seguinte pontuação: 1 - MUITO RUIM; 2 - RUIM; 3 - REGULAR; 4 - BOM; 5 - MUITO BOM)

\begin{tabular}{|l|l|l|l|l|}
\hline 1 & 2 & 3 & 4 & 5 \\
\hline
\end{tabular}


PESQUISA - IMPACTO DAS AÇÕES DE FORMAÇÃO REALIZADAS PELO DATER/SAF/MDA NO PERÍODO 2004-2009

Caros colaboradores,

Contamos com a sua atenção para preencher o formulário abaixo.

O mesmo tem por objetivo fornecer informações para avaliação da Eficiência, Efetividade e Eficácia da Política Pública de Formação de Agentes de Ater adotada pelo Departamento de Assistência Técnica e Extensão Rural, da Secretaria de Agricultura Familiar do Ministério do Desenvolvimento - DATER/SAF/MDA, no período de 2004 a 2009, tema escolhido para Monografia a ser apresentada à Universidade de Brasília (UnB) como requisito parcial para obtenção do grau de Bacharel em Administração.

Você poderá ou não se identificar no questionário e garantimos que todas as informações fornecidas serão confidenciais e utilizadas apenas de forma sistematizada.

\section{IDENTIFICAÇÃO}

\begin{tabular}{|l|l|}
\hline Nome: Pedro Pascoal de Sousa Filho & $\begin{array}{l}\text { Sexo: } \\
(x) \text { masculino } \quad(\quad \text { ) feminino }\end{array}$ \\
\hline Instituição: AGERP MA & Local de trabalho: São Luis \\
\hline $\begin{array}{l}\text { Curso/Encontro/Oficina do qual participou (caso tenha participado de mais de um curso, preencha } \\
\text { um formulário para cada um deles): Pronaf Sistemico }\end{array}$ \\
\hline Data do Curso/Encontro/Oficina: 2009
\end{tabular}

Indique sua área de atuação? (As opções não são excludentes: você poderá marcar mais de uma opção).

\begin{tabular}{|l|l|}
\hline$X$ & EXTENSÃO RURAL \\
\hline & PESQUISA \\
\hline & ENSINO \\
\hline & OUTROS \\
\hline
\end{tabular}


2) Qual o seu nível de escolaridade? ( Considere apenas o nível mais alto)

\begin{tabular}{|l|l|}
\hline & NÍVEL MÉDIO \\
\hline$x$ & NÍVEL SUPERIOR \\
\hline & PÓS-GRADUAÇÃO \\
\hline
\end{tabular}

3) Os conteúdos abordados foram condizentes com as demandas do seu dia-a-dia?

\begin{tabular}{|l|l|}
\hline$X$ & SIM \\
\hline & PARCIALMENTE \\
\hline & NÃO \\
\hline
\end{tabular}

4) O curso contribuiu para o seu aperfeiçoamento profissional?

\begin{tabular}{|l|l|}
\hline$X$ & SIM \\
\hline & NÃO \\
\hline
\end{tabular}

5) Os conhecimentos adquiridos estão sendo aplicados no seu trabalho? Em caso afirmativo, indique em que grau estes conhecimentos estão sendo aplicados. Em caso negativo, indique por que razão isto não ocorre: (As respostas não são excludentes: você poderá marcar mais de uma opção).

\begin{tabular}{|c|c|c|}
\hline \multirow{3}{*}{$\begin{array}{l}\text { SIM (indique ao lado em } \\
\text { que grau) }\end{array}$} & $x$ & MUITO APLICADOS \\
\hline & & MEDIAMENTE APLICADOS \\
\hline & & POUCO APLICADOS \\
\hline \multirow{2}{*}{$\begin{array}{l}\text { NÃO (indique ao lado a } \\
\text { razão da não aplicação) }\end{array}$} & & $\begin{array}{l}\text { CONTEÚDO NÃO ADEQUADO ȦS NECESSIDADES } \\
\text { ESPECÍFICAS DA REGIÃO }\end{array}$ \\
\hline & & $\begin{array}{l}\text { CONTEÚDO NÃO } \quad \text { FOI SUFICIENTEMENTE } \\
\text { APROFUNDADO PARA } \\
\text { PERMITIR UMA APLICAÇÃO } \\
\text { EFICAZ E EFICIENTE }\end{array}$ \\
\hline
\end{tabular}




\begin{tabular}{|l|l|l|}
\hline \multirow{2}{*}{} & & $\begin{array}{l}\text { FALTA DE APOIO E INCENTIVO DA MINHA } \\
\text { INSTITUIÇÃO }\end{array}$ \\
\cline { 2 - 3 } & & FALTA DE INCENTIVO ÀS AÇÕES DE ATER \\
\cline { 2 - 3 } & NÃO TENHO INTERESSE EM APLICAR \\
\hline
\end{tabular}

6) A partir deste curso: (As opções não são excludentes: você poderá marcar mais de uma opção).

\begin{tabular}{|l|l|}
\hline$x$ & NÃO MUDOU NADA EM MEU TRABALHO. \\
\hline$x$ & $\begin{array}{l}\text { MEU TRABALHO PASSOU A CONTRIBUIR MAIS COM OS AGRICULTORES(AS) } \\
\text { FAMILIARES. }\end{array}$ \\
\hline & CONSEGUI INFLUENCIAR NAS ORIENTAÇÕES DA MINHA INSTITUIÇÃO. \\
\hline & PASSEI A TRABALHAR COM METODOLOGIAS PARTICIPATIVAS. \\
\hline $\mathrm{C}$ & ONDECEU A ÁREA DE AGRICULTURA DE BASE ECOLÓGICA NAS COMUNIDADES \\
\hline$X$ & CONTINUEI ME APERFEIÇOANDO SOBRE TEMAS ABORDADOS. \\
\hline
\end{tabular}

7) Depois do curso você apoiou atividades de capacitação de técnicos e agricultores com base nos princípios e diretrizes da Pnater? (Considere como apoio a atividades de capacitação a participação no planejamento, elaboração de ementas, seleção de participantes e de palestrantes.)

\begin{tabular}{|l|l|}
\hline & SIM \\
\hline$x$ & NÃO \\
\hline
\end{tabular}

8) Usou os conhecimentos para ministrar outros cursos com o mesmo conteúdo ou conteúdos semelhantes?

\begin{tabular}{|l|l|}
\hline & SIM \\
\hline$x$ & NÃO \\
\hline
\end{tabular}


9) Marque o seu grau de satisfação com relação ao curso oferecido pelo DATER: (Considere a seguinte pontuação: 1 - MUITO RUIM; 2 - RUIM; 3 - REGULAR; 4 - BOM; 5 - MUITO BOM)

\begin{tabular}{|l|l|l|l|l|}
\hline 1 & 2 & $\times 3$ & 4 & 5 \\
\hline
\end{tabular}

10) Marque seu grau de satisfação com relação ao DATER: (Considere a seguinte pontuação: 1 - MUITO RUIM; 2 - RUIM; 3 - REGULAR; 4 - BOM; 5 - MUITO BOM)

\begin{tabular}{|l|l|l|l|l|}
\hline 1 & 2 & $\times 3$ & 4 & 5 \\
\hline
\end{tabular}


PESQUISA - IMPACTO DAS AÇÕES DE FORMAÇÃO REALIZADAS PELO DATER/SAF/MDA NO PERÍODO 2004-2009

Caros colaboradores,

Contamos com a sua atenção para preencher o formulário abaixo.

O mesmo tem por objetivo fornecer informações para avaliação da Eficiência, Efetividade e Eficácia da Política Pública de Formação de Agentes de Ater adotada pelo Departamento de Assistência Técnica e Extensão Rural, da Secretaria de Agricultura Familiar do Ministério do Desenvolvimento - DATER/SAF/MDA, no período de 2004 a 2009, tema escolhido para Monografia a ser apresentada à Universidade de Brasília (UnB) como requisito parcial para obtenção do grau de Bacharel em Administração.

Você poderá ou não se identificar no questionário e garantimos que todas as informações fornecidas serão confidenciais e utilizadas apenas de forma sistematizada.

\section{IDENTIFICAÇÃO}

\begin{tabular}{|l|l|}
\hline Nome: Pedro Pascoal de Sousa Filho & $\begin{array}{l}\text { Sexo: } \\
(x) \text { masculino } \quad(\quad \text { ) feminino }\end{array}$ \\
\hline Instituição: AGERP MA & Local de trabalho: São Luis \\
\hline $\begin{array}{l}\text { Curso/Encontro/Oficina do qual participou (caso tenha participado de mais de um curso, preencha } \\
\text { um formulário para cada um deles): Pronaf Sistemico }\end{array}$ \\
\hline Data do Curso/Encontro/Oficina: 2009
\end{tabular}

Indique sua área de atuação? (As opções não são excludentes: você poderá marcar mais de uma opção).

\begin{tabular}{|l|l|}
\hline$X$ & EXTENSÃO RURAL \\
\hline & PESQUISA \\
\hline & ENSINO \\
\hline & OUTROS \\
\hline
\end{tabular}


2) Qual o seu nível de escolaridade? ( Considere apenas o nível mais alto)

\begin{tabular}{|l|l|}
\hline & NÍVEL MÉDIO \\
\hline$x$ & NÍVEL SUPERIOR \\
\hline & PÓS-GRADUAÇÃO \\
\hline
\end{tabular}

3) Os conteúdos abordados foram condizentes com as demandas do seu dia-a-dia?

\begin{tabular}{|l|l|}
\hline$X$ & SIM \\
\hline & PARCIALMENTE \\
\hline & NÃO \\
\hline
\end{tabular}

4) O curso contribuiu para o seu aperfeiçoamento profissional?

\begin{tabular}{|l|l|}
\hline$X$ & SIM \\
\hline & NÃO \\
\hline
\end{tabular}

5) Os conhecimentos adquiridos estão sendo aplicados no seu trabalho? Em caso afirmativo, indique em que grau estes conhecimentos estão sendo aplicados. Em caso negativo, indique por que razão isto não ocorre: (As respostas não são excludentes: você poderá marcar mais de uma opção).

\begin{tabular}{|c|c|c|}
\hline \multirow{3}{*}{$\begin{array}{l}\text { SIM (indique ao lado em } \\
\text { que grau) }\end{array}$} & $x$ & MUITO APLICADOS \\
\hline & & MEDIAMENTE APLICADOS \\
\hline & & POUCO APLICADOS \\
\hline \multirow{2}{*}{$\begin{array}{l}\text { NÃO (indique ao lado a } \\
\text { razão da não aplicação) }\end{array}$} & & $\begin{array}{l}\text { CONTEÚDO NÃO ADEQUADO ȦS NECESSIDADES } \\
\text { ESPECÍFICAS DA REGIÃO }\end{array}$ \\
\hline & & $\begin{array}{l}\text { CONTEÚDO NÃO } \quad \text { FOI SUFICIENTEMENTE } \\
\text { APROFUNDADO PARA } \\
\text { PERMITIR UMA APLICAÇÃO } \\
\text { EFICAZ E EFICIENTE }\end{array}$ \\
\hline
\end{tabular}




\begin{tabular}{|l|l|l|}
\hline \multirow{2}{*}{} & & $\begin{array}{l}\text { FALTA DE APOIO E INCENTIVO DA MINHA } \\
\text { INSTITUIÇÃO }\end{array}$ \\
\cline { 2 - 3 } & & FALTA DE INCENTIVO ÀS AÇÕES DE ATER \\
\cline { 2 - 3 } & NÃO TENHO INTERESSE EM APLICAR \\
\hline
\end{tabular}

6) A partir deste curso: (As opções não são excludentes: você poderá marcar mais de uma opção).

\begin{tabular}{|l|l|}
\hline$x$ & $\begin{array}{l}\text { NÃO MUDOU NADA EM MEU TRABALHO. } \\
\text { FAMILIARES. }\end{array}$ \\
\hline & CONSEGUI INFLUENCIAR NAS ORIENTAÇÕES DA MINHA INSTITUIÇÃO. \\
\hline & PASSEI A TRABALHAR COM METODOLOGIAS PARTICIPATIVAS. \\
\hline & $\begin{array}{l}\text { CRESCEU A ÁREA DE AGRICULTURA DE BASE ECOLÓGICA NAS COMUNIDADES } \\
\text { ONDE ATUO. }\end{array}$ \\
\hline$X$ & CONTINUEI ME APERFEIÇOANDO SOBRE TEMAS ABORDADOS. \\
\hline
\end{tabular}

7) Depois do curso você apoiou atividades de capacitação de técnicos e agricultores com base nos princípios e diretrizes da Pnater? (Considere como apoio a atividades de capacitação a participação no planejamento, elaboração de ementas, seleção de participantes e de palestrantes.)

\begin{tabular}{|l|l|}
\hline & SIM \\
\hline$x$ & NÃO \\
\hline
\end{tabular}

8) Usou os conhecimentos para ministrar outros cursos com o mesmo conteúdo ou conteúdos semelhantes?

\begin{tabular}{|l|l|}
\hline & SIM \\
\hline$x$ & NÃO \\
\hline
\end{tabular}


9) Marque o seu grau de satisfação com relação ao curso oferecido pelo DATER: (Considere a seguinte pontuação: 1 - MUITO RUIM; 2 - RUIM; 3 - REGULAR; 4 - BOM; 5 - MUITO BOM)

\begin{tabular}{|l|l|l|l|l|}
\hline 1 & 2 & $\times 3$ & 4 & 5 \\
\hline
\end{tabular}

10) Marque seu grau de satisfação com relação ao DATER: (Considere a seguinte pontuação: 1 - MUITO RUIM; 2 - RUIM; 3 - REGULAR; 4 - BOM; 5 - MUITO BOM)

\begin{tabular}{|l|l|l|l|l|}
\hline 1 & 2 & $\times 3$ & 4 & 5 \\
\hline
\end{tabular}


PESQUISA - IMPACTO DAS AÇÕES DE FORMAÇÃO REALIZADAS PELO DATER/SAF/MDA NO PERÍODO 2004-2009

Caros colaboradores,

Contamos com a sua atenção para preencher o formulário abaixo.

O mesmo tem por objetivo fornecer informações para avaliação da Eficiência, Efetividade e Eficácia da Política Pública de Formação de Agentes de Ater adotada pelo Departamento de Assistência Técnica e Extensão Rural, da Secretaria de Agricultura Familiar do Ministério do Desenvolvimento - DATER/SAF/MDA, no período de 2004 a 2009, tema escolhido para Monografia a ser apresentada à Universidade de Brasília (UnB) como requisito parcial para obtenção do grau de Bacharel em Administração.

Você poderá ou não se identificar no questionário e garantimos que todas as informações fornecidas serão confidenciais e utilizadas apenas de forma sistematizada.

IDENTIFICAÇÃO

\begin{tabular}{|c|c|}
\hline $\begin{array}{lllll}\text { Nome: } & \text { PEDRO } & \text { JEOVA } & \text { DE } & \text { MOURA } \\
\text { ALBUQUERQUE } & & & \\
\end{array}$ & $\begin{array}{l}\text { Sexo: } \\
(x \quad) \text { masculino } \quad(\quad) \text { feminino }\end{array}$ \\
\hline $\begin{array}{l}\text { Instituição (nome e tipo de instituição: ONG, } \\
\text { Empresa Pública, etc.): PREFEITURA MUNICIPAL } \\
\text { DE MARAGOGI }\end{array}$ & $\begin{array}{l}\text { Local de trabalho (Cidade e Estado): } \\
\text { MARAGOGI ALAGOAS }\end{array}$ \\
\hline \multicolumn{2}{|c|}{$\begin{array}{l}\text { Curso/Encontro/Oficina do qual participou (caso tenha participado de mais de um curso, preencha } \\
\text { um formulário para cada um deles): NIVELAMENTO DA ATER NA CIDADE DO RECIFE }\end{array}$} \\
\hline Data do Curso/Encontro/Oficina (pelo menos mês & 10): JU \\
\hline
\end{tabular}

1. Indique sua área de atuação? (As opções não são excludentes: você poderá marcar mais de uma opção).

\begin{tabular}{|l|l|}
\hline$X$ & EXTENSÃO RURAL \\
\hline & PESQUISA \\
\hline & ENSINO \\
\hline & OUTROS \\
\hline
\end{tabular}

2) Qual o seu nível de escolaridade? ( Considere apenas o nível mais alto) 


\begin{tabular}{|l|l|}
\hline$X$ & NÍVEL MÉDIO \\
\hline & NÍVEL SUPERIOR \\
\hline & PÓS-GRADUAÇÃO \\
\hline
\end{tabular}

3) Os conteúdos abordados foram condizentes com as demandas do seu dia-a-dia?

\begin{tabular}{|l|l|}
\hline$X$ & SIM \\
\hline & PARCIALMENTE \\
\hline & NÃO \\
\hline
\end{tabular}

4) O curso contribuiu para o seu aperfeiçoamento profissional?

\begin{tabular}{|l|l|}
\hline$X$ & SIM \\
\hline & NÃO \\
\hline
\end{tabular}

5) Os conhecimentos adquiridos estão sendo aplicados no seu trabalho? Em caso afirmativo, indique em que grau estes conhecimentos estão sendo aplicados. Em caso negativo, indique por que razão isto não ocorre: (As respostas não são excludentes: você poderá marcar mais de uma opção).

\begin{tabular}{|c|c|c|}
\hline \multirow{3}{*}{$\begin{array}{l}\text { SIM (indique ao lado em } \\
\text { que grau) }\end{array}$} & & MUITO APLICADOS \\
\hline & $X$ & MEDIAMENTE APLICADOS \\
\hline & & POUCO APLICADOS \\
\hline \multirow{2}{*}{$\begin{array}{l}\text { NÃO (indique ao lado a } \\
\text { razão da não aplicação) }\end{array}$} & & $\begin{array}{l}\text { CONTEÚDO NÃO ADEQUADO ȦS NECESSIDADES } \\
\text { ESPECÍFICAS DA REGIÃO }\end{array}$ \\
\hline & & $\begin{array}{l}\text { CONTEÚDO NÃO } \quad \text { FOI SUFICIENTEMENTE } \\
\text { APROFUNDADO PARA } \\
\text { PERMITIR UMA APLICAÇÃO } \\
\text { EFICAZ E EFICIENTE }\end{array}$ \\
\hline
\end{tabular}




\begin{tabular}{|l|l|l|}
\hline \multirow{2}{*}{} & X & $\begin{array}{l}\text { FALTA DE APOIO E INCENTIVO DA MINHA } \\
\text { INSTITUIÇÃO }\end{array}$ \\
\cline { 2 - 4 } & & FALTA DE INCENTIVO ÀS AÇÕES DE ATER \\
\cline { 2 - 4 } & & NÃO TENHO INTERESSE EM APLICAR \\
\hline
\end{tabular}

6) A partir deste curso: (As opções não são excludentes: você poderá marcar mais de uma opção).

\begin{tabular}{|l|l|}
\hline$x$ & $\begin{array}{l}\text { NÃO MUDOU NADA EM MEU TRABALHO. } \\
\text { FAMILIARES. }\end{array}$ \\
\hline & CONSEGUI INFLUENCIAR NAS ORIENTAÇÕES DA MINHA INSTITUIÇÃO. \\
\hline & PASSEI A TRABALHAR COM METODOLOGIAS PARTICIPATIVAS. \\
\hline & $\begin{array}{l}\text { CRESCEU A ÁREA DE AGRICULTURA DE BASE ECOLÓGICA NAS COMUNIDADES } \\
\text { ONDE ATUO. }\end{array}$ \\
\hline & CONTINUEI ME APERFEIÇOANDO SOBRE TEMAS ABORDADOS. \\
\hline
\end{tabular}

7) Depois do curso você apoiou atividades de capacitação de técnicos e agricultores com base nos princípios e diretrizes da Pnater? (Considere como apoio a atividades de capacitação a participação no planejamento, elaboração de ementas, seleção de participantes e de palestrantes.)

\begin{tabular}{|l|l|}
\hline & SIM \\
\hline$X$ & NÃO \\
\hline
\end{tabular}

8) Usou os conhecimentos para ministrar outros cursos com o mesmo conteúdo ou conteúdos semelhantes?

\begin{tabular}{|l|l|}
\hline & SIM \\
\hline$X$ & NÃO \\
\hline
\end{tabular}


9) Marque o seu grau de satisfação com relação ao curso oferecido pelo DATER: (Considere a seguinte pontuação: 1 - MUITO RUIM; 2 - RUIM; 3 - REGULAR; 4 - BOM; 5 - MUITO BOM)

\begin{tabular}{|l|l|l|l|l|}
\hline 1 & 2 & 3 & 4 & $5 X$ \\
\hline
\end{tabular}

10) Marque seu grau de satisfação com relação ao DATER: (Considere a seguinte pontuação: 1 - MUITO RUIM; 2 - RUIM; 3 - REGULAR; 4 - BOM; 5 - MUITO BOM)

\begin{tabular}{|l|l|l|l|l|}
\hline 1 & 2 & 3 & 4 & $5 X$ \\
\hline
\end{tabular}


PESQUISA - IMPACTO DAS AÇÕES DE FORMAÇÃO REALIZADAS PELO DATER/SAF/MDA NO PERÍODO 2004-2009

Caros colaboradores,

Contamos com a sua atenção para preencher o formulário abaixo.

O mesmo tem por objetivo fornecer informações para avaliação da Eficiência, Efetividade e Eficácia da Política Pública de Formação de Agentes de Ater adotada pelo Departamento de Assistência Técnica e Extensão Rural, da Secretaria de Agricultura Familiar do Ministério do Desenvolvimento - DATER/SAF/MDA, no período de 2004 a 2009, tema escolhido para Monografia a ser apresentada à Universidade de Brasília (UnB) como requisito parcial para obtenção do grau de Bacharel em Administração.

Você poderá ou não se identificar no questionário e garantimos que todas as informações fornecidas serão confidenciais e utilizadas apenas de forma sistematizada.

\section{IDENTIFICAÇÃO}

\begin{tabular}{|c|c|}
\hline Nome: & $\begin{array}{l}\text { Sexo: } \\
(x \quad) \text { masculino } \quad(\quad) \text { feminino }\end{array}$ \\
\hline $\begin{array}{llll}\text { Instituição: } & \text { PREFEITURA } & \text { MUNICIPAL } & \text { DE } \\
\text { SOBRAL } & & \\
\end{array}$ & Local de trabalho: CE \\
\hline \multicolumn{2}{|c|}{$\begin{array}{l}\text { Curso/Encontro/Oficina do qual participou (caso tenha participado de mais de um curso, preencha } \\
\text { um formulário para cada um deles): Curso Formação de Agentes de Assistência Técnica e } \\
\text { Extensão Rural (ATER) }\end{array}$} \\
\hline Data do Curso/Encontro/Oficina: 2008 & \\
\hline
\end{tabular}

1. Indique sua área de atuação? (As opções não são excludentes: você poderá marcar mais de uma opção)

\begin{tabular}{|l|l|}
\hline$X$ & EXTENSÃO RURAL \\
\hline & PESQUISA \\
\hline & ENSINO \\
\hline & OUTROS \\
\hline
\end{tabular}


2) Qual o seu nível de escolaridade? ( Considere apenas o nível mais alto)

\begin{tabular}{|c|l|}
\hline & NÍVEL MÉDIO \\
\hline$X$ & NÍVEL SUPERIOR \\
\hline & PÓS-GRADUAÇÃO \\
\hline
\end{tabular}

3) Os conteúdos abordados foram condizentes com as demandas do seu dia-a-dia?

\begin{tabular}{|l|l|}
\hline & SIM \\
\hline$X$ & PARCIALMENTE \\
\hline & NÃO \\
\hline
\end{tabular}

4) O curso contribuiu para o seu aperfeiçoamento profissional?

\begin{tabular}{|l|l|}
\hline$X$ & SIM \\
\hline & NÃO \\
\hline
\end{tabular}

5) Os conhecimentos adquiridos estão sendo aplicados no seu trabalho? Em caso afirmativo, indique em que grau estes conhecimentos estão sendo aplicados. Em caso negativo, indique por que razão isto não ocorre: (As respostas não são excludentes: você poderá marcar mais de uma opção).

\begin{tabular}{|c|c|c|}
\hline \multirow{3}{*}{$\begin{array}{l}\text { SIM (indique ao lado em } \\
\text { que grau) }\end{array}$} & & MUITO APLICADOS \\
\hline & & MEDIAMENTE APLICADOS \\
\hline & & POUCO APLICADOS \\
\hline \multirow{2}{*}{$\begin{array}{l}\text { NÃO (indique ao lado a } \\
\text { razão da não aplicação) }\end{array}$} & $\mathrm{X}$ & $\begin{array}{l}\text { CONTEÚDO NÃO ADEQUADO ȦS NECESSIDADES } \\
\text { ESPECÍFICAS DA REGIÃO }\end{array}$ \\
\hline & & $\begin{array}{llcr}\text { CONTEÚDO NÃO } & \text { FOI SUFICIENTEMENTE } \\
\text { APROFUNDADO PARA } & \text { PERMITIR UMA APLICAÇÃO } \\
\text { EFICAZ E EFICIENTE }\end{array}$ \\
\hline
\end{tabular}




\begin{tabular}{|l|l|l|}
\hline \multirow{2}{*}{} & $X$ & $\begin{array}{l}\text { FALTA DE APOIO E INCENTIVO DA MINHA } \\
\text { INSTITUIÇÃO }\end{array}$ \\
\cline { 2 - 4 } & $X$ & FALTA DE INCENTIVO ÀS AÇÕES DE ATER \\
\cline { 2 - 4 } & & NÃO TENHO INTERESSE EM APLICAR \\
\hline
\end{tabular}

6) A partir deste curso: (As opções não são excludentes: você poderá marcar mais de uma opção)

\begin{tabular}{|l|l|}
\hline$x$ & $\begin{array}{l}\text { NÃO MUDOU NADA EM MEU TRABALHO. } \\
\text { FAMILIARES. }\end{array}$ \\
\hline & CONSEGUI INFLUENCIAR NAS ORIENTAÇÕES DA MINHA INSTITUIÇÃO. \\
\hline & PASSEI A TRABALHAR COM METODOLOGIAS PARTICIPATIVAS. \\
\hline$x$ & $\begin{array}{l}\text { CRESCEU A ÁREA DE AGRICULTURA DE BASE ECOLÓGICA NAS COMUNIDADES } \\
\text { ONDE ATUO. }\end{array}$ \\
\hline$x$ & CONTINUEI ME APERFEIÇOANDO SOBRE TEMAS ABORDADOS. \\
\hline
\end{tabular}

7) Depois do curso você apoiou atividades de capacitação de técnicos e agricultores com base nos princípios e diretrizes da Pnater? (Considere como apoio a atividades de capacitação a participação no planejamento, elaboração de ementas, seleção de participantes e de palestrantes.)

\begin{tabular}{|l|l|}
\hline & SIM \\
\hline$X$ & NÃO \\
\hline
\end{tabular}

8) Usou os conhecimentos para ministrar outros cursos com o mesmo conteúdo ou conteúdos semelhantes?

\begin{tabular}{|l|l|}
\hline & SIM \\
\hline$X$ & NÃO \\
\hline
\end{tabular}


9) Marque o seu grau de satisfação com relação ao curso oferecido pelo DATER: (Considere a seguinte pontuação: 1 - MUITO RUIM; 2 - RUIM; 3 - REGULAR; 4 - BOM; 5 - MUITO BOM)

\begin{tabular}{|l|l|l|l|l|}
\hline 1 & 2 & $X 3$ & 4 & 5 \\
\hline
\end{tabular}

10) Marque seu grau de satisfação com relação ao DATER: (Considere a seguinte pontuação: 1 - MUITO RUIM; 2 - RUIM; 3 - REGULAR; 4 - BOM; 5 - MUITO BOM)

\begin{tabular}{|l|l|l|l|l|}
\hline 1 & 2 & $X 3$ & 4 & 5 \\
\hline
\end{tabular}


PESQUISA - IMPACTO DAS AÇÕES DE FORMAÇÃO REALIZADAS PELO DATER/SAF/MDA NO PERÍODO 2004-2009

Caros colaboradores,

Contamos com a sua atenção para preencher o formulário abaixo.

O mesmo tem por objetivo fornecer informações para avaliação da Eficiência, Efetividade e Eficácia da Política Pública de Formação de Agentes de Ater adotada pelo Departamento de Assistência Técnica e Extensão Rural, da Secretaria de Agricultura Familiar do Ministério do Desenvolvimento - DATER/SAF/MDA, no período de 2004 a 2009, tema escolhido para Monografia a ser apresentada à Universidade de Brasília (UnB) como requisito parcial para obtenção do grau de Bacharel em Administração.

Você poderá ou não se identificar no questionário e garantimos que todas as informações fornecidas serão confidenciais e utilizadas apenas de forma sistematizada.

\begin{tabular}{|l|l|}
\hline Nome: Ramon Coelho Bezerra & $\begin{array}{l}\text { Sexo: } \\
(\mathrm{x}) \text { masculino } \quad(\quad) \text { feminino }\end{array}$ \\
\hline Instituição : Ipa & Local de trabalho : Bonito - PE \\
\hline $\begin{array}{l}\text { Curso/Encontro/Oficina do qual participou : Formação de Formadores do Projeto Cultivando } \\
\text { Saberes }\end{array}$ & \\
\hline Data do Curso/Encontro/Oficina: julho 2009
\end{tabular}

1. Indique sua área de atuação? (As opções não são excludentes: você poderá marcar mais de uma opção).

\begin{tabular}{|l|l|}
\hline$x$ & EXTENSÃO RURAL \\
\hline & PESQUISA \\
\hline & ENSINO \\
\hline & OUTROS \\
\hline
\end{tabular}

2) Qual o seu nível de escolaridade? ( Considere apenas o nível mais alto) 


\begin{tabular}{|l|l|}
\hline & NÍVEL MÉDIO \\
\hline$x$ & NÍVEL SUPERIOR \\
\hline & PÓS-GRADUAÇÃO \\
\hline
\end{tabular}

3) Os conteúdos abordados foram condizentes com as demandas do seu dia-a-dia?

\begin{tabular}{|l|l|}
\hline$x$ & SIM \\
\hline & PARCIALMENTE \\
\hline & NÃO \\
\hline
\end{tabular}

4) O curso contribuiu para o seu aperfeiçoamento profissional?

\begin{tabular}{|l|l|}
\hline$x$ & SIM \\
\hline & NÃO \\
\hline
\end{tabular}

5) Os conhecimentos adquiridos estão sendo aplicados no seu trabalho? Em caso afirmativo, indique em que grau estes conhecimentos estão sendo aplicados. Em caso negativo, indique por que razão isto não ocorre: (As respostas não são excludentes: você poderá marcar mais de uma opção).

\begin{tabular}{|c|c|c|}
\hline \multirow{3}{*}{$\begin{array}{l}\text { SIM (indique ao lado em } \\
\text { que grau) }\end{array}$} & $x$ & MUITO APLICADOS \\
\hline & & MEDIAMENTE APLICADOS \\
\hline & & POUCO APLICADOS \\
\hline \multirow{4}{*}{$\begin{array}{l}\text { NÃO (indique ao lado a } \\
\text { razão da não aplicação) }\end{array}$} & & $\begin{array}{l}\text { CONTEÜDO NĀO ADEQUADO ȦS NECESSIDADES } \\
\text { ESPECÍFICAS DA REGIÃO }\end{array}$ \\
\hline & & $\begin{array}{l}\text { CONTEÚDO NÃO } \text { FOI SUFICIENTEMENTE } \\
\text { APROFUNDADO PARA PERMITIR UMA APLICAÇÃO } \\
\text { EFICAZ E EFICIENTE }\end{array}$ \\
\hline & & $\begin{array}{lllllll}\text { FALTA } & \text { DE } & \text { APOIO } & \text { E } & \text { INCENTIVO } & \text { DA } & \text { MINHA } \\
\text { INSTITUIÇÃO } & & & & \\
\end{array}$ \\
\hline & & FALTA DE INCENTIVO ÀS AÇÕES DE ATER \\
\hline
\end{tabular}




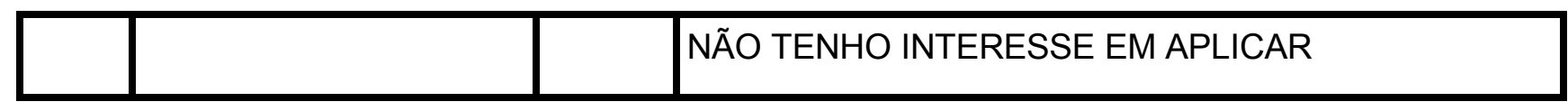

6) A partir deste curso: (As opções não são excludentes: você poderá marcar mais de uma opção).

\begin{tabular}{|c|l|}
\hline$x$ & $\begin{array}{l}\text { NÃO MUDOU NADA EM MEU TRABALHO. } \\
\text { FAMILIARES. }\end{array}$ \\
\hline$x$ & CONSEGUI INFLUENCIAR NAS ORIENTAÇÕES DA MINHA INSTITUIÇÃO. \\
\hline & PASSEI A TRABALHAR COM METODOLOGIAS PARTICIPATIVAS. \\
\hline & $\begin{array}{l}\text { CRESCEU A ÁREA DE AGRICULTURA DE BASE ECOLÓGICA NAS COMUNIDADES } \\
\text { ONDE ATUO. }\end{array}$ \\
\hline$x$ & CONTINUEI ME APERFEIÇOANDO SOBRE TEMAS ABORDADOS. \\
\hline
\end{tabular}

7) Depois do curso você apoiou atividades de capacitação de técnicos e agricultores com base nos princípios e diretrizes da Pnater? (Considere como apoio a atividades de capacitação a participação no planejamento, elaboração de ementas, seleção de participantes e de palestrantes.)

\begin{tabular}{|l|l|}
\hline$x$ & SIM \\
\hline & NÃO \\
\hline
\end{tabular}

8) Usou os conhecimentos para ministrar outros cursos com o mesmo conteúdo ou conteúdos semelhantes?

\begin{tabular}{|l|l|}
\hline$x$ & SIM \\
\hline & NÃO \\
\hline
\end{tabular}

9) Marque o seu grau de satisfação com relação ao curso oferecido pelo DATER: (Considere a seguinte pontuação: 1 - MUITO RUIM; 2 - RUIM; 3 - REGULAR; 4 - BOM; 5 - MUITO BOM) 


\begin{tabular}{|l|l|l|l|l|}
\hline 1 & 2 & 3 & 4 & $x 5$ \\
\hline
\end{tabular}

10) Marque seu grau de satisfação com relação ao DATER: (Considere a seguinte pontuação: 1 - MUITO RUIM; 2 - RUIM; 3 - REGULAR; 4 - BOM; 5 - MUITO BOM)

\begin{tabular}{|l|l|l|l|l|}
\hline 1 & 2 & 3 & 4 & $x 5$ \\
\hline
\end{tabular}


PESQUISA - IMPACTO DAS AÇÕES DE FORMAÇÃO REALIZADAS PELO DATER/SAF/MDA NO PERÍODO 2004-2009

Caros colaboradores,

Contamos com a sua atenção para preencher o formulário abaixo.

O mesmo tem por objetivo fornecer informações para avaliação da Eficiência, Efetividade e Eficácia da Política Pública de Formação de Agentes de Ater adotada pelo Departamento de Assistência Técnica e Extensão Rural, da Secretaria de Agricultura Familiar do Ministério do Desenvolvimento - DATER/SAF/MDA, no período de 2004 a 2009, tema escolhido para Monografia a ser apresentada à Universidade de Brasília (UnB) como requisito parcial para obtenção do grau de Bacharel em Administração.

Você poderá ou não se identificar no questionário e garantimos que todas as informações fornecidas serão confidenciais e utilizadas apenas de forma sistematizada.

\section{IDENTIFICAÇÃO}

\begin{tabular}{|c|c|}
\hline Nome: Raynald de Oliveira Miranda & $\begin{array}{l}\text { Sexo: } \\
(x \quad) \text { masculino } \quad(\quad) \text { feminino }\end{array}$ \\
\hline $\begin{array}{l}\text { Instituição (nome e tipo de instituição: ONG, } \\
\text { Empresa Pública, etc.): } \\
\text { Visão Mundial - ONG }\end{array}$ & $\begin{array}{l}\text { Local de trabalho (Cidade e Estado): } \\
\text { Mossoró - RN }\end{array}$ \\
\hline \multicolumn{2}{|c|}{$\begin{array}{l}\text { Curso/Encontro/Oficina do qual participou (caso tenha participado de mais de um curso, preencha } \\
\text { um formulário para cada um deles): } \\
\text { Curso de Aperfeiçoamento em Agroecologia }\end{array}$} \\
\hline $\begin{array}{l}\text { Data do Curso/Encontro/Oficina (pelo menos mês e } \\
\text { De março a junho de } 2006\end{array}$ & \\
\hline
\end{tabular}

Indique sua área de atuação? (As opções não são excludentes: você poderá marcar mais de uma opção).

\begin{tabular}{|l|l|}
\hline$X$ & EXTENSÃO RURAL \\
\hline & PESQUISA \\
\hline & ENSINO \\
\hline$X$ & OUTROS \\
\hline
\end{tabular}


2) Qual o seu nível de escolaridade? ( Considere apenas o nível mais alto)

\begin{tabular}{|l|l|}
\hline & NÍVEL MÉDIO \\
\hline$X$ & NÍVEL SUPERIOR \\
\hline & PÓS-GRADUAÇÃO \\
\hline
\end{tabular}

3) Os conteúdos abordados foram condizentes com as demandas do seu dia-a-dia?

\begin{tabular}{|l|l|}
\hline$X$ & SIM \\
\hline & PARCIALMENTE \\
\hline & NÃO \\
\hline
\end{tabular}

4) O curso contribuiu para o seu aperfeiçoamento profissional?

\begin{tabular}{|l|l|}
\hline$X$ & SIM \\
\hline & NÃO \\
\hline
\end{tabular}

5) Os conhecimentos adquiridos estão sendo aplicados no seu trabalho? Em caso afirmativo, indique em que grau estes conhecimentos estão sendo aplicados. Em caso negativo, indique por que razão isto não ocorre: (As respostas não são excludentes: você poderá marcar mais de uma opção).

\begin{tabular}{|c|c|c|}
\hline \multirow{3}{*}{$\begin{array}{l}\text { SIM (indique ao lado em } \\
\text { que grau) }\end{array}$} & $\mathrm{X}$ & MUITO APLICADOS \\
\hline & & MEDIAMENTE APLICADOS \\
\hline & & POUCO APLICADOS \\
\hline \multirow{2}{*}{$\begin{array}{l}\text { NÃO (indique ao lado a } \\
\text { razão da não aplicação) }\end{array}$} & & $\begin{array}{l}\text { CONTEÚDO NÃO ADEQUADO ȦS NECESSIDADES } \\
\text { ESPECÍFICAS DA REGIÃO }\end{array}$ \\
\hline & & $\begin{array}{llcr}\text { CONTEÚDO NÃO } & \text { FOI } & \text { SUFICIENTEMENTE } \\
\text { APROFUNDADO PARA } & \text { PERMITIR UMA APLICAÇÃO } \\
\text { EFICAZ E EFICIENTE } & \end{array}$ \\
\hline
\end{tabular}




\begin{tabular}{|l|l|l|}
\hline \multirow{2}{*}{} & & $\begin{array}{l}\text { FALTA DE APOIO E INCENTIVO DA MINHA } \\
\text { INSTITUIÇÃO }\end{array}$ \\
\cline { 2 - 3 } & & FALTA DE INCENTIVO ÀS AÇÕES DE ATER \\
\cline { 2 - 3 } & NÃO TENHO INTERESSE EM APLICAR \\
\hline
\end{tabular}

6) A partir deste curso: (As opções não são excludentes: você poderá marcar mais de uma opção).

\begin{tabular}{|l|l|}
\hline & NÃO MUDOU NADA EM MEU TRABALHO. \\
\hline$X$ & $\begin{array}{l}\text { MEU TRABALHO PASSOU A CONTRIBUIR MAIS COM OS AGRICULTORES(AS) } \\
\text { FAMILIARES. }\end{array}$ \\
\hline$X$ & CONSEGUI INFLUENCIAR NAS ORIENTAÇÕES DA MINHA INSTITUIÇÃO. \\
\hline & PASSEI A TRABALHAR COM METODOLOGIAS PARTICIPATIVAS. \\
\hline & \begin{tabular}{l} 
ORESCEU A ÁREA DE AGRICULTURA DE BASE ECOLÓGICA NAS COMUNIDADES \\
\hline$X$
\end{tabular} \\
\hline
\end{tabular}

7) Depois do curso você apoiou atividades de capacitação de técnicos e agricultores com base nos princípios e diretrizes da Pnater? (Considere como apoio a atividades de capacitação a participação no planejamento, elaboração de ementas, seleção de participantes e de palestrantes.)

\begin{tabular}{|l|l|}
\hline$X$ & SIM \\
\hline & NÃO \\
\hline
\end{tabular}

8) Usou os conhecimentos para ministrar outros cursos com o mesmo conteúdo ou conteúdos semelhantes?

\begin{tabular}{|l|l|}
\hline$X$ & SIM \\
\hline & NÃO \\
\hline
\end{tabular}


9) Marque o seu grau de satisfação com relação ao curso oferecido pelo DATER: (Considere a seguinte pontuação: 1 - MUITO RUIM; 2 - RUIM; 3 - REGULAR; 4 - BOM; 5 - MUITO BOM)

\begin{tabular}{|l|l|l|l|l|}
\hline 1 & 2 & 3 & 4 & 5 \\
\hline
\end{tabular}

10) Marque seu grau de satisfação com relação ao DATER: (Considere a seguinte pontuação: 1 - MUITO RUIM; 2 - RUIM; 3 - REGULAR; 4 - BOM; 5 - MUITO BOM)

\begin{tabular}{|l|l|l|l|l|}
\hline 1 & 2 & 3 & 4 & 5 \\
\hline
\end{tabular}


PESQUISA - IMPACTO DAS AÇÕES DE FORMAÇÃO REALIZADAS PELO DATER/SAF/MDA NO PERÍODO 2004-2009

Caros colaboradores,

Contamos com a sua atenção para preencher o formulário abaixo.

O mesmo tem por objetivo fornecer informações para avaliação da Eficiência, Efetividade e Eficácia da Política Pública de Formação de Agentes de Ater adotada pelo Departamento de Assistência Técnica e Extensão Rural, da Secretaria de Agricultura Familiar do Ministério do Desenvolvimento - DATER/SAF/MDA, no período de 2004 a 2009, tema escolhido para Monografia a ser apresentada à Universidade de Brasília (UnB) como requisito parcial para obtenção do grau de Bacharel em Administração.

Você poderá ou não se identificar no questionário e garantimos que todas as informações fornecidas serão confidenciais e utilizadas apenas de forma sistematizada.

\section{IDENTIFICAÇÃO}

\begin{tabular}{|c|c|}
\hline $\begin{array}{l}\text { Nome: } \\
\text { Maria Rita de Cássia Dantas }\end{array}$ & $\begin{array}{l}\text { Sexo: } \\
\left(\begin{array}{l}\text { ( ) masculino } \quad(x x) \text { feminino }\end{array}\right.\end{array}$ \\
\hline $\begin{array}{l}\text { Instituição (nome e tipo de instituição): } \\
\text { Instituto de Assistência Técnica e Extensão Ruaral } \\
\text { do Piauí }\end{array}$ & $\begin{array}{l}\text { Local de trabalho (Município, Região): } \\
\text { Teresina - Piauí }\end{array}$ \\
\hline \multicolumn{2}{|c|}{$\begin{array}{l}\text { Curso/Encontro/Oficina do qual participou (caso tenha participado de mais de um curso, preencha } \\
\text { um formulário para cada um deles): } \\
\text { Oficina de Nivelamento Conceitual sobre Política Nacional de ATER }\end{array}$} \\
\hline Data do Curso/Encontro/Oficina (pelo menos mês e & ano): \\
\hline
\end{tabular}

Indique sua área de atuação? (As opções não são excludentes: você poderá marcar mais de uma opção

\begin{tabular}{|l|l|}
\hline$X$ & EXTENSÃO RURAL \\
\hline & PESQUISA \\
\hline & ENSINO \\
\hline
\end{tabular}




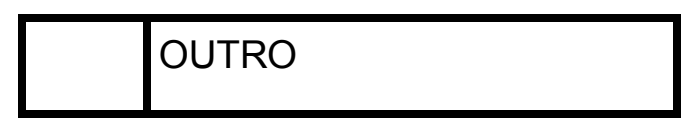

2) Qual o seu nível de escolaridade? ( Considere apenas o nível mais alto)

\begin{tabular}{|l|l|}
\hline & NÍVEL MÉDIO \\
\hline$X$ & NÍVEL SUPERIOR \\
\hline & PÓS-GRADUAÇÃO \\
\hline & OUTRO \\
\hline
\end{tabular}

3) Os conteúdos abordados foram condizentes com as demandas do seu dia-a-dia?

\begin{tabular}{|l|l|}
\hline$X$ & SIM \\
\hline & PARCIALMENTE \\
\hline & NÃO \\
\hline
\end{tabular}

4) O curso contribuiu para o seu aperfeiçoamento profissional?

\begin{tabular}{|l|l|}
\hline$X$ & SIM \\
\hline & NÃO \\
\hline
\end{tabular}

5) Os conhecimentos adquiridos estão sendo aplicados no seu trabalho? Em caso afirmativo, indique em que grau estes conhecimentos estão sendo aplicados. Em caso negativo, indique por que razão isto não ocorre: (As respostas não são excludentes: você poderá marcar mais de uma opção).

\begin{tabular}{|l|l|l|l|}
\hline X & $\begin{array}{l}\text { SIM (indique ao lado em } \\
\text { que grau) }\end{array}$ & $X$ & MUITO APLICADOS \\
\cline { 2 - 4 } & & MEDIAMENTE APLICADOS \\
\hline & $\begin{array}{l}\text { NÃO (indique ao lado a } \\
\text { razão da não aplicação) }\end{array}$ & & $\begin{array}{l}\text { CONTEÚDO NÃO ADEQUADO ȦS NECESSIDADES } \\
\text { ESPECÍFICAS DA REGIÃO }\end{array}$ \\
\hline
\end{tabular}




\begin{tabular}{|l|l|l|}
\hline \multirow{10}{*}{} & $\begin{array}{l}\text { CONTEÚDO NÃO FOI SUFICIENTEMENTE } \\
\text { APROFUNDADO PARA PERMITIR UMA APLICAÇÃO } \\
\text { EFICAZ E EFICIENTE }\end{array}$ \\
\cline { 2 - 4 } & $\begin{array}{l}\text { FALTA DE APOIO E INCENTIVO DA MINHA } \\
\text { INSTITUIÇÃO }\end{array}$ \\
\cline { 2 - 4 } & FALTA DE INCENTIVO ÀS AÇÕES DE ATER \\
\hline & NÃO TENHO INTERESSE EM APLICAR \\
\hline
\end{tabular}

6) A partir deste curso: (As opções não são excludentes: você poderá marcar mais de uma opção)

\begin{tabular}{|l|l|}
\hline & NÃDA MUDA EM MEU TRABALHO. \\
\hline$X$ & $\begin{array}{l}\text { MEU TRABALHO PASSOU A CONTRIBUIR MAIS COM OS AGRICULTORES(AS) } \\
\text { FAMILIARES. }\end{array}$ \\
\hline$X$ & CONSIGUI INFLUENCIAR NAS ORIENTAÇÕES DA MINHA INSTITUIÇÃO. \\
\hline$X$ & $\begin{array}{l}\text { CASSEI A TRABALHAR COM METODOLOGIAS PARTICIPATIVAS. } \\
\text { ONDE ATUO. }\end{array}$ \\
\hline & CONTINUEI ME APERFEIÇOANDO SOBRE TEMAS ABORDADOS. \\
\hline
\end{tabular}

7) Depois do curso você apoiou atividades de capacitação de técnicos e agricultores com base nos princípios e diretrizes da Pnater? (Considere como apoio a atividades de capacitação a participação no planejamento, elaboração de ementas, seleção de participantes e de palestrantes.)

\begin{tabular}{|l|l|}
\hline$X$ & SIM \\
\hline & NÃO \\
\hline
\end{tabular}

8) Usou os conhecimentos para ministrar outros cursos com o mesmo conteúdo ou conteúdos semelhantes? 


\begin{tabular}{|l|l|}
\hline$X$ & SIM \\
\hline & NÃO \\
\hline
\end{tabular}

9) Marque o seu grau de satisfação com relação ao curso oferecido pelo DATER: (Considere a seguinte pontuação: 1 - MUITO RUIM; 2 - RUIM; 3 - REGULAR; 4 - BOM; 5 - MUITO BOM)

\begin{tabular}{|l|l|l|l|l|}
\hline 1 & 2 & 3 & 4 & $x$ \\
\hline
\end{tabular}

10) Marque seu grau de satisfação com relação ao DATER: (Considere a seguinte pontuação: 1 - MUITO RUIM; 2 - RUIM; 3 - REGULAR; 4 - BOM; 5 - MUITO BOM)

\begin{tabular}{|l|l|l|l|l|}
\hline 1 & 2 & 3 & 4 & $x$ \\
\hline
\end{tabular}


PESQUISA - IMPACTO DAS AÇÕES DE FORMAÇÃO REALIZADAS PELO DATER/SAF/MDA NO PERÍODO 2004-2009

Caros colaboradores,

Contamos com a sua atenção para preencher o formulário abaixo.

O mesmo tem por objetivo fornecer informações para avaliação da Eficiência, Efetividade e Eficácia da Política Pública de Formação de Agentes de Ater adotada pelo Departamento de Assistência Técnica e Extensão Rural, da Secretaria de Agricultura Familiar do Ministério do Desenvolvimento - DATER/SAF/MDA, no período de 2004 a 2009, tema escolhido para Monografia a ser apresentada à Universidade de Brasília (UnB) como requisito parcial para obtenção do grau de Bacharel em Administração.

Você poderá ou não se identificar no questionário e garantimos que todas as informações fornecidas serão confidenciais e utilizadas apenas de forma sistematizada.

\section{IDENTIFICAÇÃO}

\begin{tabular}{|l|l|}
\hline Nome: Robi Tabolka dos Santos & $\begin{array}{l}\text { Sexo: } \\
(x) \text { masculino } \quad(\quad) \text { feminino }\end{array}$ \\
\hline Instituição: EMATER PB & Local de trabalho: JOÃO PESSOA \\
\hline $\begin{array}{l}\text { Curso/Encontro/Oficina do qual participou (caso tenha participado de mais de um curso, preencha } \\
\text { um formulário para cada um deles): Pronaf Sistemico }\end{array}$ \\
\hline Data do Curso/Encontro/Oficina: 2009
\end{tabular}

1. Indique sua área de atuação? (As opções não são excludentes: você poderá marcar mais de uma opção)

\begin{tabular}{|l|l|}
\hline$X$ & EXTENSÃO RURAL \\
\hline & PESQUISA \\
\hline & ENSINO \\
\hline & OUTROS \\
\hline
\end{tabular}


2) Qual o seu nível de escolaridade? ( Considere apenas o nível mais alto)

\begin{tabular}{|c|l|}
\hline & NÍVEL MÉDIO \\
\hline & NÍVEL SUPERIOR \\
\hline$X$ & PÓS-GRADUAÇÃO \\
\hline
\end{tabular}

3) Os conteúdos abordados foram condizentes com as demandas do seu dia-a-dia?

\begin{tabular}{|l|l|}
\hline & SIM \\
\hline$X$ & PARCIALMENTE \\
\hline & NÃO \\
\hline
\end{tabular}

4) O curso contribuiu para o seu aperfeiçoamento profissional?

\begin{tabular}{|l|l|}
\hline$X$ & SIM \\
\hline & NÃO \\
\hline
\end{tabular}

5) Os conhecimentos adquiridos estão sendo aplicados no seu trabalho? Em caso afirmativo, indique em que grau estes conhecimentos estão sendo aplicados. Em caso negativo, indique por que razão isto não ocorre: (As respostas não são excludentes: você poderá marcar mais de uma opção).

\begin{tabular}{|c|c|c|}
\hline \multirow{3}{*}{$\begin{array}{l}\text { SIM (indique ao lado em } \\
\text { que grau) }\end{array}$} & & MUITO APLICADOS \\
\hline & & MEDIAMENTE APLICADOS \\
\hline & $\mathrm{X}$ & POUCO APLICADOS \\
\hline \multirow{3}{*}{$\begin{array}{l}\text { NÃO (indique ao lado a } \\
\text { razão da não aplicação) }\end{array}$} & & $\begin{array}{l}\text { CONTEÚDO NÃO ADEQUADO ȦS NECESSIDADES } \\
\text { ESPECÍFICAS DA REGIÃO }\end{array}$ \\
\hline & & $\begin{array}{l}\text { CONTEÚDO NÃO } \quad \text { FOI SUFICIENTEMENTE } \\
\text { APROFUNDADO PARA } \\
\text { PERMITIR UMA APLICAÇÃO } \\
\text { EFICAZ E EFICIENTE }\end{array}$ \\
\hline & & $\begin{array}{l}\text { FALTA DE APOIO } \\
\text { INSTITUIÇÃO }\end{array}$ \\
\hline
\end{tabular}




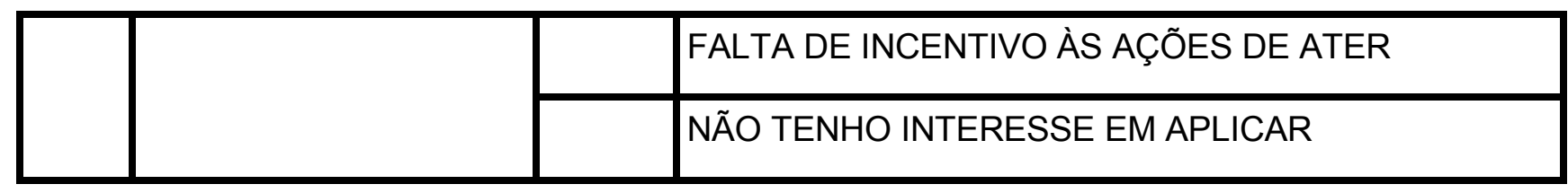

6) A partir deste curso: (As opções não são excludentes: você poderá marcar mais de uma opção)

\begin{tabular}{|l|l|}
\hline$x$ & $\begin{array}{l}\text { NÃO MUDOU NADA EM MEU TRABALHO. } \\
\text { FAMILIARES. }\end{array}$ \\
\hline & CONSEGUI INFLUENCIAR NAS ORIENTAÇÕES DA MINHA INSTITUIÇÃO. \\
\hline & PASSEI A TRABALHAR COM METODOLOGIAS PARTICIPATIVAS. \\
\hline & $\begin{array}{l}\text { CRESCEU A ÁREA DE AGRICULTURA DE BASE ECOLÓGICA NAS COMUNIDADES } \\
\text { ONDE ATUO. }\end{array}$ \\
\hline$X$ & CONTINUEI ME APERFEIÇOANDO SOBRE TEMAS ABORDADOS. \\
\hline
\end{tabular}

7) Depois do curso você apoiou atividades de capacitação de técnicos e agricultores com base nos princípios e diretrizes da Pnater? (Considere como apoio a atividades de capacitação a participação no planejamento, elaboração de ementas, seleção de participantes e de palestrantes.)

\begin{tabular}{|l|l|}
\hline & SIM \\
\hline$X$ & NÃO \\
\hline
\end{tabular}

8) Usou os conhecimentos para ministrar outros cursos com o mesmo conteúdo ou conteúdos semelhantes?

\begin{tabular}{|l|l|}
\hline$X$ & SIM \\
\hline & NÃO \\
\hline
\end{tabular}

9) Marque o seu grau de satisfação com relação ao curso oferecido pelo DATER: (Considere a seguinte pontuação: 1 - MUITO RUIM; 2 - RUIM; 3 - REGULAR; 4 - BOM; 5 - MUITO BOM) 


\begin{tabular}{|l|l|l|l|l|}
\hline 1 & 2 & 3 & $X 4$ & 5 \\
\hline
\end{tabular}

10) Marque seu grau de satisfação com relação ao DATER: (Considere a seguinte pontuação:

1 - MUITO RUIM; 2 - RUIM; 3 - REGULAR; 4 - BOM; 5 - MUITO BOM)

\begin{tabular}{|l|l|l|l|l|}
\hline 1 & 2 & 3 & 4 & $x 5$ \\
\hline
\end{tabular}


PESQUISA - IMPACTO DAS AÇÕES DE FORMAÇÃO REALIZADAS PELO DATER/SAF/MDA NO PERÍODO 2004-2009

Caros colaboradores,

Contamos com a sua atenção para preencher o formulário abaixo.

O mesmo tem por objetivo fornecer informações para avaliação da Eficiência, Efetividade e Eficácia da Política Pública de Formação de Agentes de Ater adotada pelo Departamento de Assistência Técnica e Extensão Rural, da Secretaria de Agricultura Familiar do Ministério do Desenvolvimento - DATER/SAF/MDA, no período de 2004 a 2009, tema escolhido para Monografia a ser apresentada à Universidade de Brasília (UnB) como requisito parcial para obtenção do grau de Bacharel em Administração.

Você poderá ou não se identificar no questionário e garantimos que todas as informações fornecidas serão confidenciais e utilizadas apenas de forma sistematizada.

\section{IDENTIFICAÇÃO}

\begin{tabular}{|l|l|}
\hline Nome: Robi Tabolka dos Santos & $\begin{array}{l}\text { Sexo: } \\
(x) \text { masculino } \quad(\quad) \text { feminino }\end{array}$ \\
\hline Instituição: EMATER PB & Local de trabalho: JOÃO PESSOA \\
\hline $\begin{array}{l}\text { Curso/Encontro/Oficina do qual participou (caso tenha participado de mais de um curso, preencha } \\
\text { um formulário para cada um deles): Pronaf Sistemico }\end{array}$ \\
\hline Data do Curso/Encontro/Oficina: 2009
\end{tabular}

Indique sua área de atuação? (As opções não são excludentes: você poderá marcar mais de uma opção)

\begin{tabular}{|l|l|}
\hline$X$ & EXTENSÃO RURAL \\
\hline & PESQUISA \\
\hline & ENSINO \\
\hline & OUTROS \\
\hline
\end{tabular}


2) Qual o seu nível de escolaridade? ( Considere apenas o nível mais alto)

\begin{tabular}{|c|l|}
\hline & NÍVEL MÉDIO \\
\hline & NÍVEL SUPERIOR \\
\hline$X$ & PÓS-GRADUAÇÃO \\
\hline
\end{tabular}

3) Os conteúdos abordados foram condizentes com as demandas do seu dia-a-dia?

\begin{tabular}{|l|l|}
\hline & SIM \\
\hline$X$ & PARCIALMENTE \\
\hline & NÃO \\
\hline
\end{tabular}

4) O curso contribuiu para o seu aperfeiçoamento profissional?

\begin{tabular}{|l|l|}
\hline$X$ & SIM \\
\hline & NÃO \\
\hline
\end{tabular}

5) Os conhecimentos adquiridos estão sendo aplicados no seu trabalho? Em caso afirmativo, indique em que grau estes conhecimentos estão sendo aplicados. Em caso negativo, indique por que razão isto não ocorre: (As respostas não são excludentes: você poderá marcar mais de uma opção).

\begin{tabular}{|c|c|c|}
\hline \multirow{3}{*}{$\begin{array}{l}\text { SIM (indique ao lado em } \\
\text { que grau) }\end{array}$} & & MUITO APLICADOS \\
\hline & & MEDIAMENTE APLICADOS \\
\hline & $\mathrm{X}$ & POUCO APLICADOS \\
\hline \multirow{2}{*}{$\begin{array}{l}\text { NÃO (indique ao lado a } \\
\text { razão da não aplicação) }\end{array}$} & & $\begin{array}{l}\text { CONTEÚDO NÃO ADEQUADO ȦS NECESSIDADES } \\
\text { ESPECÍFICAS DA REGIÃO }\end{array}$ \\
\hline & & $\begin{array}{l}\text { CONTEÚDO NÃO } \quad \text { FOI SUFICIENTEMENTE } \\
\text { APROFUNDADO PARA } \\
\text { PERMITIR UMA APLICAÇÃO } \\
\text { EFICAZ E EFICIENTE }\end{array}$ \\
\hline
\end{tabular}




\begin{tabular}{|l|l|l|}
\hline \multirow{2}{*}{} & & $\begin{array}{l}\text { FALTA DE APOIO E INCENTIVO DA MINHA } \\
\text { INSTITUIÇÃO }\end{array}$ \\
\cline { 2 - 3 } & & FALTA DE INCENTIVO ÀS AÇÕES DE ATER \\
\cline { 2 - 3 } & NÃO TENHO INTERESSE EM APLICAR \\
\hline
\end{tabular}

6) A partir deste curso: (As opções não são excludentes: você poderá marcar mais de uma opção)

\begin{tabular}{|l|l|}
\hline$x$ & $\begin{array}{l}\text { NÃO MUDOU NADA EM MEU TRABALHO. } \\
\text { FAMILIARES. }\end{array}$ \\
\hline & CONSEGUI INFLUENCIAR NAS ORIENTAÇÕES DA MINHA INSTITUIÇÃO. \\
\hline & PASSEI A TRABALHAR COM METODOLOGIAS PARTICIPATIVAS. \\
\hline & $\begin{array}{l}\text { CRESCEU A ÁREA DE AGRICULTURA DE BASE ECOLÓGICA NAS COMUNIDADES } \\
\text { ONDE ATUO. }\end{array}$ \\
\hline$X$ & CONTINUEI ME APERFEIÇOANDO SOBRE TEMAS ABORDADOS. \\
\hline
\end{tabular}

7) Depois do curso você apoiou atividades de capacitação de técnicos e agricultores com base nos princípios e diretrizes da Pnater? (Considere como apoio a atividades de capacitação a participação no planejamento, elaboração de ementas, seleção de participantes e de palestrantes.)

\begin{tabular}{|l|l|}
\hline & SIM \\
\hline$x$ & NÃO \\
\hline
\end{tabular}

8) Usou os conhecimentos para ministrar outros cursos com o mesmo conteúdo ou conteúdos semelhantes?

\begin{tabular}{|l|l|}
\hline$X$ & SIM \\
\hline & NÃO \\
\hline
\end{tabular}


9) Marque o seu grau de satisfação com relação ao curso oferecido pelo DATER: (Considere a seguinte pontuação: 1 - MUITO RUIM; 2 - RUIM; 3 - REGULAR; 4 - BOM; 5 - MUITO BOM)

\begin{tabular}{|l|l|l|l|l|}
\hline 1 & 2 & 3 & $X 4$ & 5 \\
\hline
\end{tabular}

10) Marque seu grau de satisfação com relação ao DATER: (Considere a seguinte pontuação: 1 - MUITO RUIM; 2 - RUIM; 3 - REGULAR; 4 - BOM; 5 - MUITO BOM)

\begin{tabular}{|l|l|l|l|l|}
\hline 1 & 2 & 3 & 4 & $\times 5$ \\
\hline
\end{tabular}


PESQUISA - IMPACTO DAS AÇÕES DE FORMAÇÃO REALIZADAS PELO DATER/SAF/MDA NO PERÍODO 2004-2009

Caros colaboradores,

Contamos com a sua atenção para preencher o formulário abaixo.

O mesmo tem por objetivo fornecer informações para avaliação da Eficiência, Efetividade e Eficácia da Política Pública de Formação de Agentes de Ater adotada pelo Departamento de Assistência Técnica e Extensão Rural, da Secretaria de Agricultura Familiar do Ministério do Desenvolvimento - DATER/SAF/MDA, no período de 2004 a 2009, tema escolhido para Monografia a ser apresentada à Universidade de Brasília (UnB) como requisito parcial para obtenção do grau de Bacharel em Administração.

Você poderá ou não se identificar no questionário e garantimos que todas as informações fornecidas serão confidenciais e utilizadas apenas de forma sistematizada.

\section{IDENTIFICAÇÃO}

\begin{tabular}{|c|c|}
\hline Nome: Rosalia Ferreira Machado Galvão & $\begin{array}{l}\text { Sexo: } \\
(\quad) \text { masculino } \quad(x x) \text { feminino }\end{array}$ \\
\hline $\begin{array}{l}\text { Instituição (nome e tipo de instituição: ONG, } \\
\text { Empresa Pública, etc.): Empresa Baiana de } \\
\text { Desenvolvimento Agrícola S. A. - EBDA }\end{array}$ & $\begin{array}{l}\text { Local de trabalho (Cidade e Estado): } \\
\text { Gerência Regional da EBDA em Teixeira de } \\
\text { Freitas/BA }\end{array}$ \\
\hline \multicolumn{2}{|c|}{$\begin{array}{l}\text { Curso/Encontro/Oficina do qual participou (caso tenha participado de mais de um curso, preencha } \\
\text { um formulário para cada um deles): Ater, Plantas Medicinais, Condimentares e Aromáticas }\end{array}$} \\
\hline ienc & 005 \\
\hline
\end{tabular}

1. Indique sua área de atuação? (As opções não são excludentes: você poderá marcar mais de uma opção)

\begin{tabular}{|l|l|}
\hline$x$ & EXTENSÃO RURAL \\
\hline & PESQUISA \\
\hline & ENSINO \\
\hline & OUTROS \\
\hline
\end{tabular}


2) Qual o seu nível de escolaridade? ( Considere apenas o nível mais alto)

\begin{tabular}{|l|l|}
\hline & NÍVEL MÉDIO \\
\hline & NÍVEL SUPERIOR \\
\hline$x$ & PÓS-GRADUAÇÃO \\
\hline
\end{tabular}

3) Os conteúdos abordados foram condizentes com as demandas do seu dia-a-dia?

\begin{tabular}{|l|l|}
\hline$x$ & SIM \\
\hline & PARCIALMENTE \\
\hline & NÃO \\
\hline
\end{tabular}

4) O curso contribuiu para o seu aperfeiçoamento profissional?

\begin{tabular}{|l|l|}
\hline$x$ & SIM \\
\hline & NÃO \\
\hline
\end{tabular}

5) Os conhecimentos adquiridos estão sendo aplicados no seu trabalho? Em caso afirmativo, indique em que grau estes conhecimentos estão sendo aplicados. Em caso negativo, indique por que razão isto não ocorre: (As respostas não são excludentes: você poderá marcar mais de uma opção).

\begin{tabular}{|l|l|l|l|}
\hline \multirow{2}{*}{$\begin{array}{l}\text { SIM (indique ao lado em } \\
\text { que grau) }\end{array}$} & & MUITO APLICADOS \\
\cline { 3 - 4 } & & MEDIAMENTE APLICADOS \\
\hline \multirow{2}{*}{$\begin{array}{l}\text { NÃO (indique ao lado a } \\
\text { razão da não aplicação) }\end{array}$} & & $\begin{array}{l}\text { COUCO APLICADOS } \\
\text { ESPECÍFICAS DA REGIÃO }\end{array}$ \\
\cline { 3 - 4 } & & $\begin{array}{l}\text { CONTEÚDO NÃO FOI SUFICIENTEMENTE } \\
\text { APROFUNDADO PARA PERMITIR UMA APLICAÇÃO } \\
\text { EFICAZ E EFICIENTE }\end{array}$ \\
\hline
\end{tabular}




\begin{tabular}{|l|l|l|}
\hline \multirow{2}{*}{} & & $\begin{array}{l}\text { FALTA DE APOIO E INCENTIVO DA MINHA } \\
\text { INSTITUIÇÃO }\end{array}$ \\
\cline { 2 - 3 } & & FALTA DE INCENTIVO ÀS AÇÕES DE ATER \\
\cline { 2 - 3 } & NÃO TENHO INTERESSE EM APLICAR \\
\hline
\end{tabular}

6) A partir deste curso: (As opções não são excludentes: você poderá marcar mais de uma opção)

\begin{tabular}{|l|l|}
\hline & NÃO MUDOU NADA EM MEU TRABALHO. \\
\hline & $\begin{array}{l}\text { MEU TRABALHO PASSOU A CONTRIBUIR MAIS COM OS AGRICULTORES(AS) } \\
\text { FAMILIARES. }\end{array}$ \\
\hline & CONSEGUI INFLUENCIAR NAS ORIENTAÇÕES DA MINHA INSTITUIÇÃO. \\
\hline & $\begin{array}{l}\text { CRESEI A TRABALHAR COM METODOLOGIAS PARTICIPATIVAS. } \\
\text { ONDE ATUO. ÁREA DE AGRICULTURA DE BASE ECOLÓGICA NAS COMUNIDADES }\end{array}$ \\
\hline$x$ & CONTINUEI ME APERFEIÇOANDO SOBRE TEMAS ABORDADOS. \\
\hline
\end{tabular}

7) Depois do curso você apoiou atividades de capacitação de técnicos e agricultores com base nos princípios e diretrizes da Pnater? (Considere como apoio a atividades de capacitação a participação no planejamento, elaboração de ementas, seleção de participantes e de palestrantes.)

\begin{tabular}{|l|l|}
\hline$x$ & SIM \\
\hline & NÃO \\
\hline
\end{tabular}

8) Usou os conhecimentos para ministrar outros cursos com o mesmo conteúdo ou conteúdos semelhantes?

\begin{tabular}{|l|l|}
\hline$x$ & SIM \\
\hline & NÃO \\
\hline
\end{tabular}


9) Marque o seu grau de satisfação com relação ao curso oferecido pelo DATER: (Considere a seguinte pontuação: 1 - MUITO RUIM; 2 - RUIM; 3 - REGULAR; 4 - BOM; 5 - MUITO BOM)

\begin{tabular}{|l|l|l|l|l|}
\hline 1 & 2 & 3 & 4 & $5 \times$ \\
\hline
\end{tabular}

10) Marque seu grau de satisfação com relação ao DATER: (Considere a seguinte pontuação: 1 - MUITO RUIM; 2 - RUIM; 3 - REGULAR; 4 - BOM; 5 - MUITO BOM)

\begin{tabular}{|l|l|l|l|l|}
\hline 1 & 2 & 3 & 4 & $5 x$ \\
\hline
\end{tabular}


PESQUISA - IMPACTO DAS AÇÕES DE FORMAÇÃO REALIZADAS PELO DATER/SAF/MDA NO PERÍODO 2004-2009

Caros colaboradores,

Contamos com a sua atenção para preencher o formulário abaixo.

O mesmo tem por objetivo fornecer informações para avaliação da Eficiência, Efetividade e Eficácia da Política Pública de Formação de Agentes de Ater adotada pelo Departamento de Assistência Técnica e Extensão Rural, da Secretaria de Agricultura Familiar do Ministério do Desenvolvimento - DATER/SAF/MDA, no período de 2004 a 2009, tema escolhido para Monografia a ser apresentada à Universidade de Brasília (UnB) como requisito parcial para obtenção do grau de Bacharel em Administração.

Você poderá ou não se identificar no questionário e garantimos que todas as informações fornecidas serão confidenciais e utilizadas apenas de forma sistematizada.

IDENTIFICAÇÃO

\begin{tabular}{|l|l|}
\hline $\begin{array}{l}\text { Nome: } \\
\text { SIDÔNIO FRAGOSO VIEIRA }\end{array}$ & $\begin{array}{l}\text { Sexo: } \\
(x \quad) \text { masculino } \quad(\quad \text { ) feminino }\end{array}$ \\
\hline $\begin{array}{l}\text { Instituição (nome e tipo de instituição: ONG, } \\
\text { Empresa Pública, etc.): } \\
\text { Empresa de Assistência Técnica e Extensão Rural de trabalho (Cidade e Estado): } \\
\text { do Ceará - EMATERCE }\end{array}$ & BOA VIAGEM - CEARÁ \\
\hline $\begin{array}{l}\text { Curso/Encontro/Oficina do qual participou (caso tenha participado de mais de um curso, preencha } \\
\text { um formulário para cada um deles): } \\
\text { CURSO SOBRE SISTEMA AGROFLORESTA DO BIOMA CAATINGA }\end{array}$ \\
\hline \begin{tabular}{l} 
Data do Curso/Encontro/Oficina (pelo menos mês e ano): NOVEMBRO/2006 \\
\hline
\end{tabular}
\end{tabular}

1. Indique sua área de atuação? (As opções não são excludentes: você poderá marcar mais de uma opção)

\begin{tabular}{|l|l|}
\hline$X$ & EXTENSÃO RURAL \\
\hline & PESQUISA \\
\hline
\end{tabular}




\begin{tabular}{|l|l|}
\hline & ENSINO \\
\hline & OUTROS \\
\hline
\end{tabular}

2) Qual o seu nível de escolaridade? ( Considere apenas o nível mais alto)

\begin{tabular}{|c|l|}
\hline & NÍVEL MÉDIO \\
\hline & NÍVEL SUPERIOR \\
\hline$X$ & PÓS-GRADUAÇÃO \\
\hline
\end{tabular}

3) Os conteúdos abordados foram condizentes com as demandas do seu dia-a-dia?

\begin{tabular}{|l|l|}
\hline$X$ & SIM \\
\hline & PARCIALMENTE \\
\hline & NÃO \\
\hline
\end{tabular}

4) O curso contribuiu para o seu aperfeiçoamento profissional?

\begin{tabular}{|l|l|}
\hline$X$ & SIM \\
\hline & NÃO \\
\hline
\end{tabular}

5) Os conhecimentos adquiridos estão sendo aplicados no seu trabalho? Em caso afirmativo, indique em que grau estes conhecimentos estão sendo aplicados. Em caso negativo, indique por que razão isto não ocorre: (As respostas não são excludentes: você poderá marcar mais de uma opção).

\begin{tabular}{|l|l|l|l|}
\hline \multirow{2}{*}{$\begin{array}{l}\text { SIM (indique ao lado em } \\
\text { que grau) }\end{array}$} & $X$ & MUITO APLICADOS \\
\cline { 2 - 4 } & & MEDIAMENTE APLICADOS \\
\cline { 2 - 4 } & & POUCO APLICADOS \\
\hline
\end{tabular}




\begin{tabular}{|c|c|}
\hline \multirow{5}{*}{$\begin{array}{l}\text { NÃO (indique ao lado a } \\
\text { razão da não aplicação) }\end{array}$} & $\begin{array}{l}\text { CONTEÚDO NÃO ADEQUADO ÀS NECESSIDADES } \\
\text { ESPECÍFICAS DA REGIÃO }\end{array}$ \\
\hline & $\begin{array}{l}\text { CONTEÚDO NÃO FOI SUFICIENTEMENTE } \\
\text { APROFUNDADO PARA } \\
\text { PERMITIR UMA APLICAÇÃO } \\
\text { EFICAZ E EFICIENTE }\end{array}$ \\
\hline & $\begin{array}{lcccccc}\text { FALTA DE } & \text { APOIO } & \text { E } & \text { INCENTIVO } & \text { DA } & \text { MINHA } \\
\text { INSTITUIÇÃO } & & & & & \end{array}$ \\
\hline & FALTA DE INCENTIVO ÀS AÇÕES DE ATER \\
\hline & NÃO TENHO INTERESSE EM APLICAR \\
\hline
\end{tabular}

6) A partir deste curso: (As opções não são excludentes: você poderá marcar mais de uma opção)

\begin{tabular}{|c|l|}
\hline$x$ & $\begin{array}{l}\text { NÃO MUDOU NADA EM MEU TRABALHO. } \\
\text { FAMILIARES. }\end{array}$ \\
\hline & CONSEGUI INFLUENCIAR NAS ORIENTAÇÕES DA MINHA INSTITUIÇÃO. \\
\hline$X$ & PASSEI A TRABALHAR COM METODOLOGIAS PARTICIPATIVAS. \\
\hline & $\begin{array}{l}\text { CRESCEU A ÁREA DE AGRICULTURA DE BASE ECOLÓGICA NAS COMUNIDADES } \\
\text { ONDE ATUO. }\end{array}$ \\
\hline$X$ & CONTINUEI ME APERFEIÇOANDO SOBRE TEMAS ABORDADOS. \\
\hline
\end{tabular}

7) Depois do curso você apoiou atividades de capacitação de técnicos e agricultores com base nos princípios e diretrizes da Pnater? (Considere como apoio a atividades de capacitação a participação no planejamento, elaboração de ementas, seleção de participantes e de palestrantes.)

\begin{tabular}{|l|l|}
\hline$X$ & SIM \\
\hline & NÃO \\
\hline
\end{tabular}

8) Usou os conhecimentos para ministrar outros cursos com o mesmo conteúdo ou conteúdos semelhantes? 


\begin{tabular}{|l|l|}
\hline$X$ & SIM \\
\hline & NÃO \\
\hline
\end{tabular}

9) Marque o seu grau de satisfação com relação ao curso oferecido pelo DATER: (Considere a seguinte pontuação: 1 - MUITO RUIM; 2 - RUIM; 3 - REGULAR; 4 - BOM; 5 - MUITO BOM)

\begin{tabular}{|l|l|l|l|l|}
\hline 1 & 2 & 3 & 4 & $5 \times$ \\
\hline
\end{tabular}

10) Marque seu grau de satisfação com relação ao DATER: (Considere a seguinte pontuação: 1 - MUITO RUIM; 2 - RUIM; 3 - REGULAR; 4 - BOM; 5 - MUITO BOM)

\begin{tabular}{|l|l|l|l|l|}
\hline 1 & 2 & 3 & $4 \times$ & 5 \\
\hline
\end{tabular}


PESQUISA - IMPACTO DAS AÇÕES DE FORMAÇÃO REALIZADAS PELO DATER/SAF/MDA NO PERÍODO 2004-2009

Caros colaboradores,

Contamos com a sua atenção para preencher o formulário abaixo.

O mesmo tem por objetivo fornecer informações para avaliação da Eficiência, Efetividade e Eficácia da Política Pública de Formação de Agentes de Ater adotada pelo Departamento de Assistência Técnica e Extensão Rural, da Secretaria de Agricultura Familiar do Ministério do Desenvolvimento - DATER/SAF/MDA, no período de 2004 a 2009, tema escolhido para Monografia a ser apresentada à Universidade de Brasília (UnB) como requisito parcial para obtenção do grau de Bacharel em Administração.

Você poderá ou não se identificar no questionário e garantimos que todas as informações fornecidas serão confidenciais e utilizadas apenas de forma sistematizada.

IDENTIFICAÇÃO

\begin{tabular}{|c|c|}
\hline $\begin{array}{l}\text { Nome: } \\
\text { SIDÔNIO FRAGOSO VIEIRA }\end{array}$ & $\begin{array}{l}\text { Sexo: } \\
(x \quad) \text { masculino } \quad(\quad) \text { feminino }\end{array}$ \\
\hline $\begin{array}{l}\text { Instituição (nome e tipo de instituição: ONG, } \\
\text { Empresa Pública, etc.): } \\
\text { Empresa de Assistência Técnica e Extensão Rural } \\
\text { do Ceará - EMATERCE }\end{array}$ & Local de trabalho (Cidade e Estado): \\
\hline \multicolumn{2}{|c|}{$\begin{array}{l}\text { Curso/Encontro/Oficina do qual participou (caso tenha participado de mais de um curso, preencha } \\
\text { um formulário para cada um deles): } \\
\text { CURSO SOBRE SISTEMA AGROFLORESTA DO BIOMA CAATINGA }\end{array}$} \\
\hline Data do Curso/Encontro/Oficina (pelo menos mês e a & ano): NOVEMBRO/2006 \\
\hline
\end{tabular}

1 Indique sua área de atuação? (As opções não são excludentes: você poderá marcar mais de uma opção)

\begin{tabular}{|l|l|}
\hline$X$ & EXTENSÃO RURAL \\
\hline & PESQUISA \\
\hline
\end{tabular}




\begin{tabular}{|l|l|}
\hline & ENSINO \\
\hline & OUTROS \\
\hline
\end{tabular}

2) Qual o seu nível de escolaridade? ( Considere apenas o nível mais alto)

\begin{tabular}{|c|l|}
\hline & NÍVEL MÉDIO \\
\hline & NÍVEL SUPERIOR \\
\hline$X$ & PÓS-GRADUAÇÃO \\
\hline
\end{tabular}

3) Os conteúdos abordados foram condizentes com as demandas do seu dia-a-dia?

\begin{tabular}{|l|l|}
\hline$X$ & SIM \\
\hline & PARCIALMENTE \\
\hline & NÃO \\
\hline
\end{tabular}

4) O curso contribuiu para o seu aperfeiçoamento profissional?

\begin{tabular}{|l|l|}
\hline$X$ & SIM \\
\hline & NÃO \\
\hline
\end{tabular}

5) Os conhecimentos adquiridos estão sendo aplicados no seu trabalho? Em caso afirmativo, indique em que grau estes conhecimentos estão sendo aplicados. Em caso negativo, indique por que razão isto não ocorre: (As respostas não são excludentes: você poderá marcar mais de uma opção).

\begin{tabular}{|l|l|c|l|}
\hline \multirow{2}{*}{$\begin{array}{l}\text { SIM (indique ao lado em } \\
\text { que grau) }\end{array}$} & $X$ & MUITO APLICADOS \\
\cline { 3 - 4 } & & MEDIAMENTE APLICADOS \\
\cline { 2 - 4 } & & POUCO APLICADOS \\
\hline
\end{tabular}




\begin{tabular}{|c|c|}
\hline \multirow{5}{*}{$\begin{array}{l}\text { NÃO (indique ao lado a } \\
\text { razão da não aplicação) }\end{array}$} & $\begin{array}{l}\text { CONTEÚDO NÃO ADEQUADO ȦS NECESSIDADES } \\
\text { ESPECÍFICAS DA REGIÃO }\end{array}$ \\
\hline & $\begin{array}{l}\text { CONTEÚDO NÃO FOI SUFICIENTEMENTE } \\
\text { APROFUNDADO PARA } \\
\text { PERMITIR UMA APLICAÇÃO } \\
\text { EFICAZ E EFICIENTE }\end{array}$ \\
\hline & $\begin{array}{l}\text { FALTA DE APOIO } \\
\text { INSTITUIÇÃO }\end{array}$ \\
\hline & FALTA DE INCENTIVO ÀS AÇÕES DE ATER \\
\hline & NÃO TENHO INTERESSE EM APLICAR \\
\hline
\end{tabular}

6) A partir deste curso: (As opções não são excludentes: você poderá marcar mais de uma opção)

\begin{tabular}{|c|l|}
\hline$x$ & $\begin{array}{l}\text { NÃO MUDOU NADA EM MEU TRABALHO. } \\
\text { FAMILIARES. }\end{array}$ \\
\hline & CONSEGUI INFLUENCIAR NAS ORIENTAÇÕES DA MINHA INSTITUIÇÃO. \\
\hline$X$ & PASSEI A TRABALHAR COM METODOLOGIAS PARTICIPATIVAS. \\
\hline & $\begin{array}{l}\text { CRESCEU A ÁREA DE AGRICULTURA DE BASE ECOLÓGICA NAS COMUNIDADES } \\
\text { ONDE ATUO. }\end{array}$ \\
\hline$X$ & CONTINUEI ME APERFEIÇOANDO SOBRE TEMAS ABORDADOS. \\
\hline
\end{tabular}

7) Depois do curso você apoiou atividades de capacitação de técnicos e agricultores com base nos princípios e diretrizes da Pnater? (Considere como apoio a atividades de capacitação a participação no planejamento, elaboração de ementas, seleção de participantes e de palestrantes.)

\begin{tabular}{|l|l|}
\hline$X$ & SIM \\
\hline & NÃO \\
\hline
\end{tabular}

8) Usou os conhecimentos para ministrar outros cursos com o mesmo conteúdo ou conteúdos semelhantes? 


\begin{tabular}{|l|l|}
\hline$X$ & SIM \\
\hline & NÃO \\
\hline
\end{tabular}

9) Marque o seu grau de satisfação com relação ao curso oferecido pelo DATER: (Considere a seguinte pontuação: 1 - MUITO RUIM; 2 - RUIM; 3 - REGULAR; 4 - BOM; 5 - MUITO BOM)

\begin{tabular}{|l|l|l|l|l|}
\hline 1 & 2 & 3 & 4 & $5 \times$ \\
\hline
\end{tabular}

10) Marque seu grau de satisfação com relação ao DATER: (Considere a seguinte pontuação: 1 - MUITO RUIM; 2 - RUIM; 3 - REGULAR; 4 - BOM; 5 - MUITO BOM)

\begin{tabular}{|l|l|l|l|l|}
\hline 1 & 2 & 3 & $4 \times$ & 5 \\
\hline
\end{tabular}


PESQUISA - IMPACTO DAS AÇÕES DE FORMAÇÃO REALIZADAS PELO DATER/SAF/MDA NO PERÍODO 2004-2009

Caros colaboradores,

Contamos com a sua atenção para preencher o formulário abaixo.

O mesmo tem por objetivo fornecer informações para avaliação da Eficiência, Efetividade e Eficácia da Política Pública de Formação de Agentes de Ater adotada pelo Departamento de Assistência Técnica e Extensão Rural, da Secretaria de Agricultura Familiar do Ministério do Desenvolvimento - DATER/SAF/MDA, no período de 2004 a 2009, tema escolhido para Monografia a ser apresentada à Universidade de Brasília (UnB) como requisito parcial para obtenção do grau de Bacharel em Administração.

Você poderá ou não se identificar no questionário e garantimos que todas as informações fornecidas serão confidenciais e utilizadas apenas de forma sistematizada.

IDENTIFICAÇÃO

\begin{tabular}{|c|c|}
\hline $\begin{array}{l}\text { Nome: } \\
\text { SIDÔNIO FRAGOSO VIEIRA }\end{array}$ & $\begin{array}{l}\text { Sexo: } \\
(x \quad) \text { masculino } \quad(\quad) \text { feminino }\end{array}$ \\
\hline $\begin{array}{l}\text { Instituição (nome e tipo de instituição: ONG, } \\
\text { Empresa Pública, etc.): } \\
\text { Empresa de Assistência Técnica e Extensão Rural } \\
\text { do Ceará - EMATERCE }\end{array}$ & $\begin{array}{l}\text { Local de trabalho (Cidade e Estado): } \\
\text { BOA VIAGEM - CEARÁ }\end{array}$ \\
\hline $\begin{array}{l}\text { Curso/Encontro/Oficina do qual participou (caso tenh } \\
\text { um formulário para cada um deles): } \\
\text { CURSO DE ESPECIALIZAÇÃO EM EXTENSÃO } \\
\text { SUSTENTÁVEL }\end{array}$ & $\begin{array}{l}\text { a participado de mais de um curso, preencha } \\
\text { RURAL PARA O DESENVOLVIMENTO }\end{array}$ \\
\hline $\begin{array}{l}\text { Data do Curso/Encontro/Oficina (pelo menos mês } \\
\text { JULHO, AGOSTO E NOVEMBRO/2005 }\end{array}$ & \\
\hline
\end{tabular}

1. Indique sua área de atuação? (As opções não são excludentes: você poderá marcar mais de uma opção)

\begin{tabular}{|l|l|}
\hline$X$ & EXTENSÃO RURAL \\
\hline & PESQUISA \\
\hline
\end{tabular}




\begin{tabular}{|l|l|}
\hline & ENSINO \\
\hline & OUTROS \\
\hline
\end{tabular}

2) Qual o seu nível de escolaridade? ( Considere apenas o nível mais alto)

\begin{tabular}{|c|l|}
\hline & NÍVEL MÉDIO \\
\hline & NÍVEL SUPERIOR \\
\hline$X$ & PÓS-GRADUAÇÃO \\
\hline
\end{tabular}

3) Os conteúdos abordados foram condizentes com as demandas do seu dia-a-dia?

\begin{tabular}{|l|l|}
\hline$X$ & SIM \\
\hline & PARCIALMENTE \\
\hline & NÃO \\
\hline
\end{tabular}

4) O curso contribuiu para o seu aperfeiçoamento profissional?

\begin{tabular}{|l|l|}
\hline$X$ & SIM \\
\hline & NÃO \\
\hline
\end{tabular}

5) Os conhecimentos adquiridos estão sendo aplicados no seu trabalho? Em caso afirmativo, indique em que grau estes conhecimentos estão sendo aplicados. Em caso negativo, indique por que razão isto não ocorre: (As respostas não são excludentes: você poderá marcar mais de uma opção).

\begin{tabular}{|l|l|c|l|}
\hline \multirow{3}{*}{$\begin{array}{l}\text { SIM (indique ao lado em } \\
\text { que grau) }\end{array}$} & $X$ & MUITO APLICADOS \\
\cline { 3 - 4 } & & & MEDIAMENTE APLICADOS \\
\cline { 2 - 4 } & & POUCO APLICADOS \\
\hline
\end{tabular}




\begin{tabular}{|c|c|}
\hline \multirow{5}{*}{$\begin{array}{l}\text { NÃO (indique ao lado a } \\
\text { razão da não aplicação) }\end{array}$} & $\begin{array}{l}\text { CONTEÚDO NÃO ADEQUADO ȦS NECESSIDADES } \\
\text { ESPECÍFICAS DA REGIÃO }\end{array}$ \\
\hline & $\begin{array}{l}\text { CONTEÚDO NÃO FOI SUFICIENTEMENTE } \\
\text { APROFUNDADO PARA } \\
\text { PERMITIR UMA APLICAÇÃO } \\
\text { EFICAZ E EFICIENTE }\end{array}$ \\
\hline & $\begin{array}{l}\text { FALTA DE APOIO } \\
\text { INSTITUIÇÃO }\end{array}$ \\
\hline & FALTA DE INCENTIVO ÀS AÇÕES DE ATER \\
\hline & NÃO TENHO INTERESSE EM APLICAR \\
\hline
\end{tabular}

6) A partir deste curso: (As opções não são excludentes: você poderá marcar mais de uma opção)

\begin{tabular}{|c|l|}
\hline$x$ & $\begin{array}{l}\text { NÃO MUDOU NADA EM MEU TRABALHO. } \\
\text { FAMILIARES. }\end{array}$ \\
\hline & CONSEGUI INFLUENCIAR NAS ORIENTAÇÕES DA MINHA INSTITUIÇÃO. \\
\hline$X$ & PASSEI A TRABALHAR COM METODOLOGIAS PARTICIPATIVAS. \\
\hline & $\begin{array}{l}\text { CRESCEU A ÁREA DE AGRICULTURA DE BASE ECOLÓGICA NAS COMUNIDADES } \\
\text { ONDE ATUO. }\end{array}$ \\
\hline$X$ & CONTINUEI ME APERFEIÇOANDO SOBRE TEMAS ABORDADOS. \\
\hline
\end{tabular}

7) Depois do curso você apoiou atividades de capacitação de técnicos e agricultores com base nos princípios e diretrizes da Pnater? (Considere como apoio a atividades de capacitação a participação no planejamento, elaboração de ementas, seleção de participantes e de palestrantes.)

\begin{tabular}{|l|l|}
\hline$X$ & SIM \\
\hline & NÃO \\
\hline
\end{tabular}

8) Usou os conhecimentos para ministrar outros cursos com o mesmo conteúdo ou conteúdos semelhantes? 


\begin{tabular}{|l|l|}
\hline$X$ & SIM \\
\hline & NÃO \\
\hline
\end{tabular}

9) Marque o seu grau de satisfação com relação ao curso oferecido pelo DATER: (Considere a seguinte pontuação: 1 - MUITO RUIM; 2 - RUIM; 3 - REGULAR; 4 - BOM; 5 - MUITO BOM)

\begin{tabular}{|l|l|l|l|l|}
\hline 1 & 2 & 3 & 4 & $5 \times$ \\
\hline
\end{tabular}

10) Marque seu grau de satisfação com relação ao DATER: (Considere a seguinte pontuação: 1 - MUITO RUIM; 2 - RUIM; 3 - REGULAR; 4 - BOM; 5 - MUITO BOM)

\begin{tabular}{|l|l|l|l|l|}
\hline 1 & 2 & 3 & $4 \times$ & 5 \\
\hline
\end{tabular}


PESQUISA - IMPACTO DAS AÇÕES DE FORMAÇÃO REALIZADAS PELO DATER/SAF/MDA NO PERÍODO 2004-2009

Caros colaboradores,

Contamos com a sua atenção para preencher o formulário abaixo.

O mesmo tem por objetivo fornecer informações para avaliação da Eficiência, Efetividade e Eficácia da Política Pública de Formação de Agentes de Ater adotada pelo Departamento de Assistência Técnica e Extensão Rural, da Secretaria de Agricultura Familiar do Ministério do Desenvolvimento - DATER/SAF/MDA, no período de 2004 a 2009, tema escolhido para Monografia a ser apresentada à Universidade de Brasília (UnB) como requisito parcial para obtenção do grau de Bacharel em Administração.

Você poderá ou não se identificar no questionário e garantimos que todas as informações fornecidas serão confidenciais e utilizadas apenas de forma sistematizada.

IDENTIFICAÇÃO

\begin{tabular}{|l|l|}
\hline Nome: Jose Wilson Cabral & $\begin{array}{l}\text { Sexo: } \\
(x) \text { masculino } \quad(\quad) \text { feminino }\end{array}$ \\
\hline Instituição: EMATER RN & Local de trabalho: Natal RN \\
\hline $\begin{array}{l}\text { Curso/Encontro/Oficina do qual participou (caso tenha participado de mais de um curso, preencha } \\
\text { um formulário para cada um deles): Cultivando Saberes }\end{array}$ \\
\hline Data do Curso/Encontro/Oficina: 2008
\end{tabular}

1. Indique sua área de atuação? (As opções não são excludentes: você poderá marcar mais de uma opção).

\begin{tabular}{|l|l|}
\hline$X$ & EXTENSÃO RURAL \\
\hline$X$ & PESQUISA \\
\hline & ENSINO \\
\hline & OUTROS \\
\hline
\end{tabular}


2) Qual o seu nível de escolaridade? ( Considere apenas o nível mais alto)

\begin{tabular}{|c|l|}
\hline & NÍVEL MÉDIO \\
\hline & NÍVEL SUPERIOR \\
\hline$x$ & PÓS-GRADUAÇÃO \\
\hline
\end{tabular}

3) Os conteúdos abordados foram condizentes com as demandas do seu dia-a-dia?

\begin{tabular}{|l|l|}
\hline$x$ & SIM \\
\hline & PARCIALMENTE \\
\hline & NÃO \\
\hline
\end{tabular}

3) O curso contribuiu para o seu aperfeiçoamento profissional?

\begin{tabular}{|l|l|}
\hline$X$ & SIM \\
\hline & NÃO \\
\hline
\end{tabular}

5) Os conhecimentos adquiridos estão sendo aplicados no seu trabalho? Em caso afirmativo, indique em que grau estes conhecimentos estão sendo aplicados. Em caso negativo, indique por que razão isto não ocorre: (As respostas não são excludentes: você poderá marcar mais de uma opção).

\begin{tabular}{|c|c|c|}
\hline \multirow{3}{*}{$\begin{array}{l}\text { SIM (indique ao lado em } \\
\text { que grau) }\end{array}$} & $x$ & MUITO APLICADOS \\
\hline & & MEDIAMENTE APLICADOS \\
\hline & & POUCO APLICADOS \\
\hline \multirow{2}{*}{$\begin{array}{l}\text { NÃO (indique ao lado a } \\
\text { razão da não aplicação) }\end{array}$} & & $\begin{array}{l}\text { CONTEÚDO NÃO ADEQUADO ȦS NECESSIDADES } \\
\text { ESPECÍFICAS DA REGIÃO }\end{array}$ \\
\hline & & $\begin{array}{l}\text { CONTEÚDO NÃO } \quad \text { FOI SUFICIENTEMENTE } \\
\text { APROFUNDADO PARA } \\
\text { PERMITIR UMA APLICAÇÃO } \\
\text { EFICAZ E EFICIENTE }\end{array}$ \\
\hline
\end{tabular}




\begin{tabular}{|l|l|l|}
\hline \multirow{2}{*}{} & & $\begin{array}{l}\text { FALTA DE APOIO E INCENTIVO DA MINHA } \\
\text { INSTITUIÇÃO }\end{array}$ \\
\cline { 2 - 3 } & & FALTA DE INCENTIVO ÀS AÇÕES DE ATER \\
\cline { 2 - 3 } & NÃO TENHO INTERESSE EM APLICAR \\
\hline
\end{tabular}

6) A partir deste curso: (As opções não são excludentes: você poderá marcar mais de uma opção).

\begin{tabular}{|c|l|}
\hline$x$ & $\begin{array}{l}\text { NÃO MUDOU NADA EM MEU TRABALHO. } \\
\text { FAMILIARES. }\end{array}$ \\
\hline$x$ & CONSEGUI INFLUENCIAR NAS ORIENTAÇÕES DA MINHA INSTITUIÇÃO. \\
\hline & PASSEI A TRABALHAR COM METODOLOGIAS PARTICIPATIVAS. \\
\hline$x$ & $\begin{array}{l}\text { CRESCEU A ÁREA DE AGRICULTURA DE BASE ECOLÓGICA NAS COMUNIDADES } \\
\text { ONDE ATUO. }\end{array}$ \\
\hline$x$ & CONTINUEI ME APERFEIÇOANDO SOBRE TEMAS ABORDADOS. \\
\hline
\end{tabular}

7) Depois do curso você apoiou atividades de capacitação de técnicos e agricultores com base nos princípios e diretrizes da Pnater? (Considere como apoio a atividades de capacitação a participação no planejamento, elaboração de ementas, seleção de participantes e de palestrantes.)

\begin{tabular}{|l|l|}
\hline$x$ & SIM \\
\hline & NÃO \\
\hline
\end{tabular}

8) Usou os conhecimentos para ministrar outros cursos com o mesmo conteúdo ou conteúdos semelhantes?

\begin{tabular}{|l|l|}
\hline$x$ & SIM \\
\hline & NÃO \\
\hline
\end{tabular}


9) Marque o seu grau de satisfação com relação ao curso oferecido pelo DATER: (Considere a seguinte pontuação: 1 - MUITO RUIM; 2 - RUIM; 3 - REGULAR; 4 - BOM; 5 - MUITO BOM)

\begin{tabular}{|l|l|l|l|l|}
\hline 1 & 2 & 3 & 4 & $x 5$ \\
\hline
\end{tabular}

10) Marque seu grau de satisfação com relação ao DATER: (Considere a seguinte pontuação: 1 - MUITO RUIM; 2 - RUIM; 3 - REGULAR; 4 - BOM; 5 - MUITO BOM)

\begin{tabular}{|l|l|l|l|l|}
\hline 1 & 2 & 3 & $x 4$ & 5 \\
\hline
\end{tabular}


PESQUISA - IMPACTO DAS AÇÕES DE FORMAÇÃO REALIZADAS PELO DATER/SAF/MDA NO PERÍODO 2004-2009

Caros colaboradores,

Contamos com a sua atenção para preencher o formulário abaixo.

O mesmo tem por objetivo fornecer informações para avaliação da Eficiência, Efetividade e Eficácia da Política Pública de Formação de Agentes de Ater adotada pelo Departamento de Assistência Técnica e Extensão Rural, da Secretaria de Agricultura Familiar do Ministério do Desenvolvimento - DATER/SAF/MDA, no período de 2004 a 2009, tema escolhido para Monografia a ser apresentada à Universidade de Brasília (UnB) como requisito parcial para obtenção do grau de Bacharel em Administração.

Você poderá ou não se identificar no questionário e garantimos que todas as informações fornecidas serão confidenciais e utilizadas apenas de forma sistematizada.

\section{IDENTIFICAÇÃO}

\begin{tabular}{|c|c|}
\hline Nome: Suelzir Enio da Silva Costa & $\begin{array}{l}\text { Sexo: } \\
(\mathrm{x} \quad) \text { masculino }\end{array}$ \\
\hline $\begin{array}{l}\text { Instituição (MMT (Movimento Minha Terra } \\
\text { instituição: ONG, Empresa Pública, etc.):Ong sem } \\
\text { fins lucrativos }\end{array}$ & $\begin{array}{llll}\text { Local de trabalho } & \text { (Cidade e } \\
\text { Estado):Maceió-AL } & & \end{array}$ \\
\hline \multicolumn{2}{|c|}{$\begin{array}{l}\text { Curso/Encontro/Oficina do qual participou Nivelamento Conceitua da Nova Política de ATER - } \\
\text { Salvador maio/2005 e encontro para agentes formadores de comunidades indígenas } \\
\text { dezembro/2005. }\end{array}$} \\
\hline os mês & \\
\hline
\end{tabular}

Indique sua área de atuação? (As opções não são excludentes: você poderá marcar mais de uma opção).

\begin{tabular}{|l|l|}
\hline$x$ & EXTENSÃO RURAL \\
\hline & PESQUISA \\
\hline & ENSINO \\
\hline & OUTROS \\
\hline
\end{tabular}


2) Qual o seu nível de escolaridade? ( Considere apenas o nível mais alto)

\begin{tabular}{|l|l|}
\hline & NÍVEL MÉDIO \\
\hline & NÍVEL SUPERIOR \\
\hline$X$ & PÓS-GRADUAÇÃO \\
\hline
\end{tabular}

3) Os conteúdos abordados foram condizentes com as demandas do seu dia-a-dia?

\begin{tabular}{|l|l|}
\hline$X$ & SIM \\
\hline & PARCIALMENTE \\
\hline & NÃO \\
\hline
\end{tabular}

4) O curso contribuiu para o seu aperfeiçoamento profissional?

\begin{tabular}{|l|l|}
\hline$X$ & SIM \\
\hline & NÃO \\
\hline
\end{tabular}

5) Os conhecimentos adquiridos estão sendo aplicados no seu trabalho? Em caso afirmativo, indique em que grau estes conhecimentos estão sendo aplicados. Em caso negativo, indique por que razão isto não ocorre: (As respostas não são excludentes: você poderá marcar mais de uma opção).

\begin{tabular}{|c|c|c|c|}
\hline \multirow{3}{*}{$\mathrm{x}$} & \multirow{3}{*}{$\begin{array}{l}\text { SIM (indique ao lado em } \\
\text { que grau) }\end{array}$} & $\mathrm{X}$ & MUITO APLICADOS \\
\hline & & & MEDIAMENTE APLICADOS \\
\hline & & & POUCO APLICADOS \\
\hline & \multirow{2}{*}{$\begin{array}{l}\text { NÃO (indique ao lado a } \\
\text { razão da não aplicação) }\end{array}$} & & $\begin{array}{l}\text { CONTEÚDO NĀO ADEQUADO ȦS NECESSIDADES } \\
\text { ESPECÍFICAS DA REGIÃO }\end{array}$ \\
\hline & & & $\begin{array}{l}\text { CONTEÚDO NÃO FOI SUFICIENTEMENTE } \\
\text { APROFUNDADO PARA PERMITIR UMA APLICAÇÃO } \\
\text { EFICAZ E EFICIENTE }\end{array}$ \\
\hline
\end{tabular}




\begin{tabular}{|l|l|l|}
\hline \multirow{2}{*}{} & & $\begin{array}{l}\text { FALTA DE APOIO E INCENTIVO DA MINHA } \\
\text { INSTITUIÇÃO }\end{array}$ \\
\cline { 2 - 3 } & & FALTA DE INCENTIVO ÀS AÇÕES DE ATER \\
\cline { 2 - 3 } & NÃO TENHO INTERESSE EM APLICAR \\
\hline
\end{tabular}

6) A partir deste curso: (As opções não são excludentes: você poderá marcar mais de uma opção).

\begin{tabular}{|l|l|}
\hline$x$ & $\begin{array}{l}\text { NÃO MUDOU NADA EM MEU TRABALHO. } \\
\text { FAMILIARES. }\end{array}$ \\
\hline & CONSEGUI INFLUENCIAR NAS ORIENTAÇÕES DA MINHA INSTITUIÇÃO. \\
\hline & PASSEI A TRABALHAR COM METODOLOGIAS PARTICIPATIVAS. \\
\hline & $\begin{array}{l}\text { CRESCEU A ÁREA DE AGRICULTURA DE BASE ECOLÓGICA NAS COMUNIDADES } \\
\text { ONDE ATUO. }\end{array}$ \\
\hline & CONTINUEI ME APERFEIÇOANDO SOBRE TEMAS ABORDADOS. \\
\hline
\end{tabular}

7) Depois do curso você apoiou atividades de capacitação de técnicos e agricultores com base nos princípios e diretrizes da Pnater? (Considere como apoio a atividades de capacitação a participação no planejamento, elaboração de ementas, seleção de participantes e de palestrantes.)

\begin{tabular}{|l|l|}
\hline$X$ & SIM \\
\hline & NÃO \\
\hline
\end{tabular}

8) Usou os conhecimentos para ministrar outros cursos com o mesmo conteúdo ou conteúdos semelhantes?

\begin{tabular}{|l|l|}
\hline$X$ & SIM \\
\hline & NÃO \\
\hline
\end{tabular}


9) Marque o seu grau de satisfação com relação ao curso oferecido pelo DATER: (Considere a seguinte pontuação: 1 - MUITO RUIM; 2 - RUIM; 3 - REGULAR; 4 - BOM; 5 - MUITO BOM)

\begin{tabular}{|l|l|l|l|l|}
\hline 1 & 2 & 3 & 4 & 5 \\
\hline
\end{tabular}

10) Marque seu grau de satisfação com relação ao DATER: (Considere a seguinte pontuação: 1 - MUITO RUIM; 2 - RUIM; 3 - REGULAR; 4 - BOM; 5 - MUITO BOM)

\begin{tabular}{|l|l|l|l|l|}
\hline 1 & 2 & 3 & 4 & 5 \\
\hline
\end{tabular}


PESQUISA - IMPACTO DAS AÇÕES DE FORMAÇÃO REALIZADAS PELO DATER/SAF/MDA NO PERÍODO 2004-2009

Caros colaboradores,

Contamos com a sua atenção para preencher o formulário abaixo.

O mesmo tem por objetivo fornecer informações para avaliação da Eficiência, Efetividade e Eficácia da Política Pública de Formação de Agentes de Ater adotada pelo Departamento de Assistência Técnica e Extensão Rural, da Secretaria de Agricultura Familiar do Ministério do Desenvolvimento - DATER/SAF/MDA, no período de 2004 a 2009, tema escolhido para Monografia a ser apresentada à Universidade de Brasília (UnB) como requisito parcial para obtenção do grau de Bacharel em Administração.

Você poderá ou não se identificar no questionário e garantimos que todas as informações fornecidas serão confidenciais e utilizadas apenas de forma sistematizada.

IDENTIFICAÇÃO

\begin{tabular}{|l|l|}
\hline $\begin{array}{l}\text { Nome: } \\
\text { ADALBERTO DE CARVALHO SENA }\end{array}$ & $\begin{array}{l}\text { Sexo: } \\
(\mathrm{x}) \text { masculino } \quad(\quad) \text { feminino }\end{array}$ \\
\hline $\begin{array}{l}\text { Instituição : DEAGRO - Depto. Estadual de } \\
\text { Desenvolvimento Agropecuário de Sergipe }\end{array}$ & $\begin{array}{l}\text { Local de trabalho: } \\
\text { Ribeirópolis }- \text { Se }\end{array}$ \\
\hline $\begin{array}{l}\text { Curso/Encontro/Oficina do qual participou: } \\
\text { Encontro de Multiplicadores de ATER }\end{array}$ & \\
\hline $\begin{array}{l}\text { Data do Curso/Encontro/Oficina : } \\
11 \text { a 15/09/2006 - Estancia/Se. }\end{array}$ \\
\hline
\end{tabular}

1. Indique sua área de atuação? (As opções não são excludentes: você poderá marcar mais de uma opção).

\begin{tabular}{|l|l|}
\hline$x$ & EXTENSÃO RURAL \\
\hline & PESQUISA \\
\hline & ENSINO \\
\hline & OUTROS \\
\hline
\end{tabular}


2) Qual o seu nível de escolaridade? ( Considere apenas o nível mais alto)

\begin{tabular}{|l|l|}
\hline$x$ & NÍVEL MÉDIO \\
\hline & NÍVEL SUPERIOR \\
\hline & PÓS-GRADUAÇÃO \\
\hline
\end{tabular}

3) Os conteúdos abordados foram condizentes com as demandas do seu dia-a-dia?

\begin{tabular}{|l|l|}
\hline$x$ & SIM \\
\hline & PARCIALMENTE \\
\hline & NÃO \\
\hline
\end{tabular}

3) O curso contribuiu para o seu aperfeiçoamento profissional?

\begin{tabular}{|l|l|}
\hline$x$ & SIM \\
\hline & NÃO \\
\hline
\end{tabular}

5) Os conhecimentos adquiridos estão sendo aplicados no seu trabalho? Em caso afirmativo, indique em que grau estes conhecimentos estão sendo aplicados. Em caso negativo, indique por que razão isto não ocorre: (As respostas não são excludentes: você poderá marcar mais de uma opção).

\begin{tabular}{|c|c|c|c|}
\hline \multirow{3}{*}{$x$} & \multirow{3}{*}{$\begin{array}{l}\text { SIM (indique ao lado em } \\
\text { que grau) }\end{array}$} & & MUITO APLICADOS \\
\hline & & $x$ & MEDIAMENTE APLICADOS \\
\hline & & & POUCO APLICADOS \\
\hline & \multirow{6}{*}{$\begin{array}{l}\text { NÃO (indique ao lado a } \\
\text { razão da não aplicação) }\end{array}$} & & CONTEÚDO NÃO ADEQUADO ÀS NECESSIDADES \\
\hline & & & CONTEÚDO NÂO FOI SUFICIENTEMENTE \\
\hline & & & 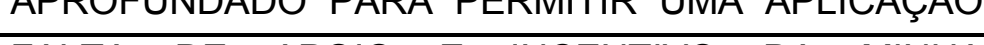 \\
\hline & & & $\begin{array}{lcccccc}\text { FALTA } & \text { DE } & \text { APOIO } & \text { E } & \text { INCENTIVO } & \text { DA } & \text { MINHA } \\
\text { INSTITUICÃO } & & & & & \\
\end{array}$ \\
\hline & & & FALTA DE INCENTIVO ÀS AÇÕES DE ATER \\
\hline & & & NÃO TENHO INTERESSE EM APLICAR \\
\hline
\end{tabular}


6) A partir deste curso: (As opções não são excludentes: você poderá marcar mais de uma opção).

\begin{tabular}{|l|l|}
\hline & NÃO MUDOU NADA EM MEU TRABALHO. \\
\hline$x$ & $\begin{array}{l}\text { MEU TRABALHO PASSOU A CONTRIBUIR MAIS COM OS AGRICULTORES(AS) } \\
\text { FAMILIARES. }\end{array}$ \\
\hline & CONSEGUI INFLUENCIAR NAS ORIENTAÇÕES DA MINHA INSTITUIÇÃO. \\
\hline & $\begin{array}{l}\text { CRESCEU A ÁREA DE AGRICULTURA DE BASE ECOLÓGICA NAS COMUNIDADES } \\
\text { ONDE ATUO. }\end{array}$ \\
\hline$x$ & CONTINUEI ME APERFEIÇOANDO SOBRE TEMAS ABORDADOS. \\
\hline
\end{tabular}

7) Depois do curso você apoiou atividades de capacitação de técnicos e agricultores com base nos princípios e diretrizes da Pnater? ? (Considere como apoio a atividades de capacitação a participação no planejamento, elaboração de ementas, seleção de participantes e de palestrantes.)

\begin{tabular}{|l|l|}
\hline$x$ & SIM \\
\hline & NÃO \\
\hline
\end{tabular}

8) Usou os conhecimentos para ministrar outros cursos com o mesmo conteúdo ou conteúdos semelhantes?

\begin{tabular}{|l|l|}
\hline$x$ & SIM \\
\hline & NÃO \\
\hline
\end{tabular}

9) Marque o seu grau de satisfação com relação ao curso oferecido pelo DATER: (Considere a seguinte pontuação: 1 - MUITO RUIM; 2 - RUIM; 3 - REGULAR; 4 - BOM; 5 - MUITO BOM)

\begin{tabular}{|l|l|l|l|l|}
\hline 1 & 2 & 3 & $4 x$ & 5 \\
\hline
\end{tabular}

10) Marque seu grau de satisfação com relação ao DATER: (Considere a seguinte pontuação: 1 - MUITO RUIM; 2 - RUIM; 3 - REGULAR; 4 - BOM; 5 - MUITO BOM)

\begin{tabular}{|l|l|l|l|l|}
\hline 1 & 2 & 3 & $4 x$ & 5 \\
\hline
\end{tabular}


PESQUISA - IMPACTO DAS AÇÕES DE FORMAÇÃO REALIZADAS PELO DATER/SAF/MDA NO PERÍODO 2004-2009

Caros colaboradores,

Contamos com a sua atenção para preencher o formulário abaixo.

O mesmo tem por objetivo fornecer informações para avaliação da Eficiência, Efetividade e Eficácia da Política Pública de Formação de Agentes de Ater adotada pelo Departamento de Assistência Técnica e Extensão Rural, da Secretaria de Agricultura Familiar do Ministério do Desenvolvimento - DATER/SAF/MDA, no período de 2004 a 2009, tema escolhido para Monografia a ser apresentada à Universidade de Brasília (UnB) como requisito parcial para obtenção do grau de Bacharel em Administração.

Você poderá ou não se identificar no questionário e garantimos que todas as informações fornecidas serão confidenciais e utilizadas apenas de forma sistematizada.

IDENTIFICAÇÃO

\begin{tabular}{|l|l|}
\hline Nome: Adalberto Soares de Oliveira & $\begin{array}{l}\text { Sexo: } \\
(x) \text { masculino } \quad(\quad) \text { feminino }\end{array}$ \\
\hline Instituição : EMATER PI & Local de trabalho : SÃO JOÃO DO PIAUÍ \\
\hline $\begin{array}{l}\text { Curso/Encontro/Oficina do qual participou : Formação de Formadores do Projeto Cultivando } \\
\text { Saberes }\end{array}$ & \\
\hline Data do Curso/Encontro/Oficina: julho 2009 &
\end{tabular}

1. Indique sua área de atuação? (As opções não são excludentes: você poderá marcar mais de uma opção).

\begin{tabular}{|l|l|}
\hline$x$ & EXTENSÃO RURAL \\
\hline & PESQUISA \\
\hline & ENSINO \\
\hline & OUTROS \\
\hline
\end{tabular}

2) Qual o seu nível de escolaridade? ( Considere apenas o nível mais alto) 


\begin{tabular}{|l|l|}
\hline & NÍVEL MÉDIO \\
\hline$x$ & NÍVEL SUPERIOR \\
\hline & PÓS-GRADUAÇÃO \\
\hline
\end{tabular}

3) Os conteúdos abordados foram condizentes com as demandas do seu dia-a-dia?

\begin{tabular}{|l|l|}
\hline$x$ & SIM \\
\hline & PARCIALMENTE \\
\hline & NÃO \\
\hline
\end{tabular}

4) O curso contribuiu para o seu aperfeiçoamento profissional?

\begin{tabular}{|l|l|}
\hline$x$ & SIM \\
\hline & NÃO \\
\hline
\end{tabular}

5) Os conhecimentos adquiridos estão sendo aplicados no seu trabalho? Em caso afirmativo, indique em que grau estes conhecimentos estão sendo aplicados. Em caso negativo, indique por que razão isto não ocorre: (As respostas não são excludentes: você poderá marcar mais de uma opção).

\begin{tabular}{|c|c|c|}
\hline \multirow{3}{*}{$\begin{array}{l}\text { SIM (indique ao lado em } \\
\text { que grau) }\end{array}$} & & MUITO APLICADOS \\
\hline & & MEDIAMENTE APLICADOS \\
\hline & & POUCO APLICADOS \\
\hline \multirow{4}{*}{$\begin{array}{l}\text { NÃO (indique ao lado a } \\
\text { razão da não aplicação) }\end{array}$} & & $\begin{array}{l}\text { CONTEÚDO NĀO ADEQUADO ȦS NECESSIDADES } \\
\text { ESPECÍFICAS DA REGIÃO }\end{array}$ \\
\hline & & $\begin{array}{l}\text { CONTEÚDO NÃO FOI SUFICIENTEMENTE } \\
\text { APROFUNDADO PARA } \\
\text { EFICAZMITIR UMA APLICAÇÃO EFICIENTE }\end{array}$ \\
\hline & & 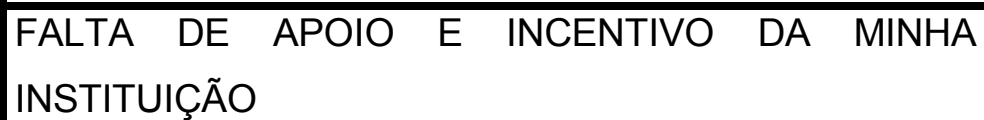 \\
\hline & $\bar{x}$ & FALTA DE INCENTIVO ÀS AÇÕES DE ATER \\
\hline
\end{tabular}




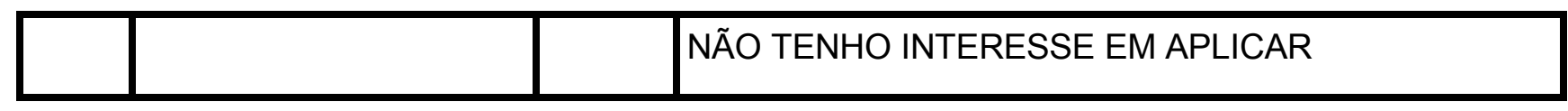

6) A partir deste curso: (As opções não são excludentes: você poderá marcar mais de uma opção).

\begin{tabular}{|l|l|}
\hline$X$ & NÃO MUDOU NADA EM MEU TRABALHO. \\
\hline & $\begin{array}{l}\text { MEU TRABALHO PASSOU A CONTRIBUIR MAIS COM OS AGRICULTORES(AS) } \\
\text { FAMILIARES. }\end{array}$ \\
\hline & CONSEGUI INFLUENCIAR NAS ORIENTAÇÕES DA MINHA INSTITUIÇÃO. \\
\hline & $\begin{array}{l}\text { CRESEI A TRABALHAR COM METODOLOGIAS PARTICIPATIVAS. } \\
\text { ONDE ATUO. ÁREA DE AGRICULTURA DE BASE ECOLÓGICA NAS COMUNIDADES }\end{array}$ \\
\hline & CONTINUEI ME APERFEIÇOANDO SOBRE TEMAS ABORDADOS. \\
\hline
\end{tabular}

7) Depois do curso você apoiou atividades de capacitação de técnicos e agricultores com base nos princípios e diretrizes da Pnater? (Considere como apoio a atividades de capacitação a participação no planejamento, elaboração de ementas, seleção de participantes e de palestrantes.)

\begin{tabular}{|l|l|}
\hline & SIM \\
\hline$X$ & NÃO \\
\hline
\end{tabular}

8) Usou os conhecimentos para ministrar outros cursos com o mesmo conteúdo ou conteúdos semelhantes?

\begin{tabular}{|l|l|}
\hline & SIM \\
\hline$X$ & NÃO \\
\hline
\end{tabular}

9) Marque o seu grau de satisfação com relação ao curso oferecido pelo DATER: (Considere a seguinte pontuação: 1 - MUITO RUIM; 2 - RUIM; 3 - REGULAR; 4 - BOM; 5 - MUITO BOM)

\begin{tabular}{|l|l|l|l|l|}
\hline 1 & 2 & 3 & 4 & $x 5$ \\
\hline
\end{tabular}


10) Marque seu grau de satisfação com relação ao DATER: (Considere a seguinte pontuação: 1 - MUITO RUIM; 2 - RUIM; 3 - REGULAR; 4 - BOM; 5 - MUITO BOM)

\begin{tabular}{|l|l|l|l|l|}
\hline 1 & 2 & 3 & 4 & $x 5$ \\
\hline
\end{tabular}


PESQUISA - IMPACTO DAS AÇÕES DE FORMAÇÃO REALIZADAS PELO DATER/SAF/MDA NO PERÍODO 2004-2009

Caros colaboradores,

Contamos com a sua atenção para preencher o formulário abaixo.

O mesmo tem por objetivo fornecer informações para avaliação da Eficiência, Efetividade e Eficácia da Política Pública de Formação de Agentes de Ater adotada pelo Departamento de Assistência Técnica e Extensão Rural, da Secretaria de Agricultura Familiar do Ministério do Desenvolvimento - DATER/SAF/MDA, no período de 2004 a 2009, tema escolhido para Monografia a ser apresentada à Universidade de Brasília (UnB) como requisito parcial para obtenção do grau de Bacharel em Administração.

Você poderá ou não se identificar no questionário e garantimos que todas as informações fornecidas serão confidenciais e utilizadas apenas de forma sistematizada.

IDENTIFICAÇÃO

\begin{tabular}{|c|c|}
\hline $\begin{array}{lllll}\text { Nome: } & \text { ALEIDE } & \text { MARGARETE } & \text { GODE } & \text { DE } \\
\text { VASCONCELOS } & & & \\
\end{array}$ & $\begin{array}{l}\text { Sexo: } \\
(\quad) \text { masculino }\end{array}$ \\
\hline $\begin{array}{l}\text { Instituição (nome e tipo de instituição: ONG, } \\
\text { Empresa Pública, etc.): } \\
\text { IPA - EMPRESA PERNAMBUCANA } \\
\text { PESQUISA AGROPECUARIA }\end{array}$ & $\begin{array}{l}\text { Local de trabalho (Cidade e Estado): } \\
\text { TABIRA-PE }\end{array}$ \\
\hline \multicolumn{2}{|c|}{$\begin{array}{l}\text { Curso/Encontro/Oficina do qual participou (caso tenha participado de mais de um curso, preencha } \\
\text { um formulário para cada um deles): } \\
\text { PLANTAS MEDICINAIS, CONDIMENTARES E AROMÁTICAS }\end{array}$} \\
\hline $\begin{array}{l}\text { Data do Curso/Encontro/Oficina (pelo menos mês } \\
\text { 10/2005 }\end{array}$ & \\
\hline
\end{tabular}

1. Indique sua área de atuação? (As opções não são excludentes: você poderá marcar mais de uma opção).

\begin{tabular}{|l|l|}
\hline$X$ & EXTENSÃO RURAL \\
\hline & PESQUISA \\
\hline & ENSINO \\
\hline
\end{tabular}




\section{OUTROS}

2) Qual o seu nível de escolaridade? ( Considere apenas o nível mais alto)

\begin{tabular}{|l|l|}
\hline & NÍVEL MÉDIO \\
\hline & NÍVEL SUPERIOR \\
\hline$x$ & $\begin{array}{l}\text { PÓS-GRADUAÇĀO } \\
\text { (ESPECIALIZAÇÃO) }\end{array}$ \\
\hline
\end{tabular}

3) Os conteúdos abordados foram condizentes com as demandas do seu dia-a-dia?

\begin{tabular}{|l|l|}
\hline$X$ & SIM \\
\hline & PARCIALMENTE \\
\hline & NÃO \\
\hline
\end{tabular}

4) O curso contribuiu para o seu aperfeiçoamento profissional?

\begin{tabular}{|l|l|}
\hline$X$ & SIM \\
\hline & NÃO \\
\hline
\end{tabular}

5) Os conhecimentos adquiridos estão sendo aplicados no seu trabalho? Em caso afirmativo, indique em que grau estes conhecimentos estão sendo aplicados. Em caso negativo, indique por que razão isto não ocorre: (As respostas não são excludentes: você poderá marcar mais de uma opção).

\begin{tabular}{|l|l|l|l|}
\hline \multirow{2}{*}{$\begin{array}{l}\text { SIM (indique ao lado em } \\
\text { que grau) }\end{array}$} & & MUITO APLICADOS \\
\cline { 2 - 4 } & $\begin{array}{l}\text { NÃO (indique ao lado a } \\
\text { razão da não aplicação) }\end{array}$ & $\begin{array}{l}\text { MEDIAMENTE APLICADOS } \\
\text { ESPECÍFICAS DA REGIÃO }\end{array}$ \\
\hline
\end{tabular}




\begin{tabular}{|l|l|l|}
\hline \multirow{10}{*}{} & $\begin{array}{l}\text { CONTEÚDO NÃO FOI SUFICIENTEMENTE } \\
\text { APROFUNDADO PARA PERMITIR UMA APLICAÇÃO } \\
\text { EFICAZ E EFICIENTE }\end{array}$ \\
\cline { 2 - 4 } & $\begin{array}{l}\text { FALTA DE APOIO E INCENTIVO DA MINHA } \\
\text { INSTITUIÇÃO }\end{array}$ \\
\cline { 2 - 4 } & FALTA DE INCENTIVO ÀS AÇÕES DE ATER \\
\hline & NÃO TENHO INTERESSE EM APLICAR \\
\hline
\end{tabular}

6) A partir deste curso: (As opções não são excludentes: você poderá marcar mais de uma opção).

\begin{tabular}{|l|l|}
\hline$x$ & $\begin{array}{l}\text { NÃO MUDOU NADA EM MEU TRABALHO. } \\
\text { FAMILIARES. }\end{array}$ \\
\hline & CONSEGUI INFLUENCIAR NAS ORIENTAÇÕES DA MINHA INSTITUIÇÃO. \\
\hline & PASSEI A TRABALHAR COM METODOLOGIAS PARTICIPATIVAS. \\
\hline & \begin{tabular}{l} 
CRESCEU A ÁREA DE AGRICULTURA DE BASE ECOLÓGICA NAS COMUNIDADES \\
ONDE ATUO. \\
\hline
\end{tabular} \\
\hline
\end{tabular}

7) Depois do curso você apoiou atividades de capacitação de técnicos e agricultores com base nos princípios e diretrizes da Pnater? (Considere como apoio a atividades de capacitação a participação no planejamento, elaboração de ementas, seleção de participantes e de palestrantes.)

\begin{tabular}{|l|l|}
\hline & SIM \\
\hline$X$ & NÃO \\
\hline
\end{tabular}

8) Usou os conhecimentos para ministrar outros cursos com o mesmo conteúdo ou conteúdos semelhantes? 


\begin{tabular}{|l|l|}
\hline$X$ & SIM \\
\hline & NÃO \\
\hline
\end{tabular}

9) Marque o seu grau de satisfação com relação ao curso oferecido pelo DATER: (Considere a seguinte pontuação: 1 - MUITO RUIM; 2 - RUIM; 3 - REGULAR; 4 - BOM; 5 - MUITO BOM)

\begin{tabular}{|l|l|l|l|l|}
\hline 1 & 2 & 3 & 4 & $5 X$ \\
\hline
\end{tabular}

10) Marque seu grau de satisfação com relação ao DATER: (Considere a seguinte pontuação: 1 - MUITO RUIM; 2 - RUIM; 3 - REGULAR; 4 - BOM; 5 - MUITO BOM)

\begin{tabular}{|l|l|l|l|l|}
\hline 1 & 2 & 3 & 4 & $5 X$ \\
\hline
\end{tabular}




\section{PESQUISA - IMPACTO DAS AÇÕES DE FORMAÇÃO REALIZADAS PELO \\ DATER/SAF/MDA NO PERÍODO 2004-2009}

Caros colaboradores,

Contamos com a sua atenção para preencher o formulário abaixo.

O mesmo tem por objetivo fornecer informações para avaliação da Eficiência, Efetividade e Eficácia da Política Pública de Formação de Agentes de Ater adotada pelo Departamento de Assistência Técnica e Extensão Rural, da Secretaria de Agricultura Familiar do Ministério do Desenvolvimento - DATER/SAF/MDA, no período de 2004 a 2009, tema escolhido para Monografia a ser apresentada à Universidade de Brasília (UnB) como requisito parcial para obtenção do grau de Bacharel em Administração.

Você poderá ou não se identificar no questionário e garantimos que todas as informações fornecidas serão confidenciais e utilizadas apenas de forma sistematizada.

\section{IDENTIFICAÇÃO}

\begin{tabular}{|l|l|}
\hline Nome: Alexandre Mees & $\begin{array}{l}\text { Sexo: } \\
(\mathrm{x}) \text { masculino } \quad(\quad) \text { feminino }\end{array}$ \\
\hline Instituição: AGERP MA & Local de trabalho: Codó - MA \\
\hline $\begin{array}{l}\text { Curso/Encontro/Oficina do qual participou (caso tenha participado de mais de um curso, preencha } \\
\text { um formulário para cada um deles): Cadeias Produtivas e Arranjos Produtivos Locais }\end{array}$ \\
\hline Data do Curso/Encontro/Oficina: 2009
\end{tabular}

1. Indique sua área de atuação? (As opções não são excludentes: você poderá marcar mais de uma opção).

\begin{tabular}{|l|l|}
\hline$X$ & EXTENSÃO RURAL \\
\hline$X$ & PESQUISA \\
\hline & ENSINO \\
\hline & OUTROS \\
\hline
\end{tabular}


2) Qual o seu nível de escolaridade? ( Considere apenas o nível mais alto)

\begin{tabular}{|l|l|}
\hline$X$ & NÍVEL MÉDIO \\
\hline & NÍVEL SUPERIOR \\
\hline & PÓS-GRADUAÇÃO \\
\hline
\end{tabular}

3) Os conteúdos abordados foram condizentes com as demandas do seu dia-a-dia?

\begin{tabular}{|l|l|}
\hline & SIM \\
\hline$x$ & PARCIALMENTE \\
\hline & NÃO \\
\hline
\end{tabular}

4) O curso contribuiu para o seu aperfeiçoamento profissional?

\begin{tabular}{|l|l|}
\hline$X$ & SIM \\
\hline & NÃO \\
\hline
\end{tabular}

5) Os conhecimentos adquiridos estão sendo aplicados no seu trabalho? Em caso afirmativo, indique em que grau estes conhecimentos estão sendo aplicados. Em caso negativo, indique por que razão isto não ocorre: (As respostas não são excludentes: você poderá marcar mais de uma opção).

\begin{tabular}{|c|c|c|}
\hline \multirow{3}{*}{$\begin{array}{l}\text { SIM (indique ao lado em } \\
\text { que grau) }\end{array}$} & & MUITO APLICADOS \\
\hline & & MEDIAMENTE APLICADOS \\
\hline & $\mathrm{X}$ & POUCO APLICADOS \\
\hline \multirow{2}{*}{$\begin{array}{l}\text { NÃO (indique ao lado a } \\
\text { razão da não aplicação) }\end{array}$} & & $\begin{array}{l}\text { CONTEÚDO NÃO ADEQUADO ȦS NECESSIDADES } \\
\text { ESPECÍFICAS DA REGIÃO }\end{array}$ \\
\hline & & $\begin{array}{l}\text { CONTEÚDO NÃO } \text { FOI SUFICIENTEMENTE } \\
\text { APROFUNDADO PARA } \\
\text { PERMITIR UMA APLICAÇÃO } \\
\text { EFICAZ E EFICIENTE }\end{array}$ \\
\hline
\end{tabular}




\begin{tabular}{|l|l|l|}
\hline \multirow{2}{*}{} & & $\begin{array}{l}\text { FALTA DE APOIO E INCENTIVO DA MINHA } \\
\text { INSTITUIÇÃO }\end{array}$ \\
\cline { 2 - 3 } & & FALTA DE INCENTIVO ÀS AÇÕES DE ATER \\
\cline { 2 - 3 } & NÃO TENHO INTERESSE EM APLICAR \\
\hline
\end{tabular}

6) A partir deste curso: (As opções não são excludentes: você poderá marcar mais de uma opção).

\begin{tabular}{|l|l|}
\hline$x$ & $\begin{array}{l}\text { NÃO MUDOU NADA EM MEU TRABALHO. } \\
\text { FAMILIARES. }\end{array}$ \\
\hline & CONSEGUI INFLUENCIAR NAS ORIENTAÇÕES DA MINHA INSTITUIÇÃO. \\
\hline & PASSEI A TRABALHAR COM METODOLOGIAS PARTICIPATIVAS. \\
\hline & $\begin{array}{l}\text { CRESCEU A ÁREA DE AGRICULTURA DE BASE ECOLÓGICA NAS COMUNIDADES } \\
\text { ONDE ATUO. }\end{array}$ \\
\hline & CONTINUEI ME APERFEIÇOANDO SOBRE TEMAS ABORDADOS. \\
\hline
\end{tabular}

7) Depois do curso você apoiou atividades de capacitação de técnicos e agricultores com base nos princípios e diretrizes da Pnater? (Considere como apoio a atividades de capacitação a participação no planejamento, elaboração de ementas, seleção de participantes e de palestrantes.)

\begin{tabular}{|l|l|}
\hline & SIM \\
\hline$x$ & NÃO \\
\hline
\end{tabular}

8) Usou os conhecimentos para ministrar outros cursos com o mesmo conteúdo ou conteúdos semelhantes?

\begin{tabular}{|l|l|}
\hline & SIM \\
\hline$X$ & NÃO \\
\hline
\end{tabular}


9) Marque o seu grau de satisfação com relação ao curso oferecido pelo DATER: (Considere a seguinte pontuação: 1 - MUITO RUIM; 2 - RUIM; 3 - REGULAR; 4 - BOM; 5 - MUITO BOM)

\begin{tabular}{|l|l|l|l|l|}
\hline 1 & 2 & 3 & 4 & $\times 5$ \\
\hline
\end{tabular}

10) Marque seu grau de satisfação com relação ao DATER: (Considere a seguinte pontuação: 1 - MUITO RUIM; 2 - RUIM; 3 - REGULAR; 4 - BOM; 5 - MUITO BOM)

\begin{tabular}{|l|l|l|l|l|}
\hline 1 & 2 & 3 & 4 & $\mathrm{X} 5$ \\
\hline
\end{tabular}




\section{PESQUISA - IMPACTO DAS AÇÕES DE FORMAÇÃO REALIZADAS PELO \\ DATER/SAF/MDA NO PERÍODO 2004-2009}

Caros colaboradores,

Contamos com a sua atenção para preencher o formulário abaixo.

O mesmo tem por objetivo fornecer informações para avaliação da Eficiência, Efetividade e Eficácia da Política Pública de Formação de Agentes de Ater adotada pelo Departamento de Assistência Técnica e Extensão Rural, da Secretaria de Agricultura Familiar do Ministério do Desenvolvimento - DATER/SAF/MDA, no período de 2004 a 2009, tema escolhido para Monografia a ser apresentada à Universidade de Brasília (UnB) como requisito parcial para obtenção do grau de Bacharel em Administração.

Você poderá ou não se identificar no questionário e garantimos que todas as informações fornecidas serão confidenciais e utilizadas apenas de forma sistematizada.

\section{IDENTIFICAÇÃO}

\begin{tabular}{|c|c|}
\hline $\begin{array}{l}\text { Nome: } \\
\text { ALEXANDRE CORTEZ DE SOUZA }\end{array}$ & $\begin{array}{l}\text { Sexo: } \\
(x) \text { masculino } \quad(\quad) \text { feminino }\end{array}$ \\
\hline $\begin{array}{l}\text { Instituição (nome e tipo de instituição: ONG, } \\
\text { Empresa Pública, etc.): } \\
\text { EMATERCE }\end{array}$ & $\begin{array}{l}\text { Local de trabalho (Cidade e Estado): } \\
\text { FORTALEZA - CE }\end{array}$ \\
\hline \multicolumn{2}{|c|}{$\begin{array}{l}\text { Curso/Encontro/Oficina do qual participou (caso tenha participado de mais de um curso, preencha } \\
\text { um formulário para cada um deles): } \\
\text { Curso de Especialização em Extensão Rural, Agroecologia e Desenvolvimento Sustentável }\end{array}$} \\
\hline
\end{tabular}

1. Indique sua área de atuação? (As opções não são excludentes: você poderá marcar mais de uma opção).

\begin{tabular}{|l|l|}
\hline$X$ & EXTENSÃO RURAL \\
\hline$X$ & PESQUISA \\
\hline & ENSINO \\
\hline
\end{tabular}




\section{OUTROS}

2) Qual o seu nível de escolaridade? ( Considere apenas o nível mais alto)

\begin{tabular}{|l|l|}
\hline & NÍVEL MÉDIO \\
\hline & NÍVEL SUPERIOR \\
\hline$X$ & PÓS-GRADUAÇÃO \\
\hline
\end{tabular}

3) Os conteúdos abordados foram condizentes com as demandas do seu dia-a-dia?

\begin{tabular}{|l|l|}
\hline$X$ & SIM \\
\hline & PARCIALMENTE \\
\hline & NÃO \\
\hline
\end{tabular}

4) O curso contribuiu para o seu aperfeiçoamento profissional?

\begin{tabular}{|l|l|}
\hline$X$ & SIM \\
\hline & NÃO \\
\hline
\end{tabular}

5) Os conhecimentos adquiridos estão sendo aplicados no seu trabalho? Em caso afirmativo, indique em que grau estes conhecimentos estão sendo aplicados. Em caso negativo, indique por que razão isto não ocorre: (As respostas não são excludentes: você poderá marcar mais de uma opção).

\begin{tabular}{|c|c|c|}
\hline \multirow{3}{*}{$\begin{array}{l}\text { SIM (indique ao lado em } \\
\text { que grau) }\end{array}$} & $x$ & MUITO APLICADOS \\
\hline & & MEDIAMENTE APLICADOS \\
\hline & & POUCO APLICADOS \\
\hline \multirow{3}{*}{$\begin{array}{l}\text { NÃO (indique ao lado a } \\
\text { razão da não aplicação) }\end{array}$} & & CONTEÚDO NÃO ADEQUADO ȦS NECESSIDADES \\
\hline & & $\begin{array}{llll}\text { CONTEÚDO NÂOO } & \text { FOI SUFICIENTEMENTE } \\
\text { APROFUNDADO } & \text { PARA } & \text { PERMITIR UMA } & \text { APLICAÇÃO }\end{array}$ \\
\hline & & $\begin{array}{lcccccc}\text { FALTA } & \text { DE } & \text { APOIO } & \text { E } & \text { INCENTIVO } & \text { DA } & \text { MINHA } \\
\text { INSTITUICÃO } & & & & & \\
\end{array}$ \\
\hline
\end{tabular}


FALTA DE INCENTIVO ÀS AÇÕES DE ATER NÃO TENHO INTERESSE EM APLICAR

6) A partir deste curso: (As opções não são excludentes: você poderá marcar mais de uma opção).

\begin{tabular}{|l|l|}
\hline & NÃO MUDOU NADA EM MEU TRABALHO. \\
\hline$X$ & $\begin{array}{l}\text { MEU TRABALHO PASSOU A CONTRIBUIR MAIS COM OS AGRICULTORES(AS) } \\
\text { FAMILIARES. }\end{array}$ \\
\hline$X$ & CONSEGUI INFLUENCIAR NAS ORIENTAÇÕES DA MINHA INSTITUIÇÃO. \\
\hline & $\begin{array}{l}\text { CRASSEI A TRABALHAR COM METODOLOGIAS PARTICIPATIVAS. } \\
\text { ONDE ATUO. }\end{array}$ \\
\hline$X$ & CONTINUEI ME APERFEIÇOANDO SOBRE TEMAS ABORDADOS. \\
\hline
\end{tabular}

7) Depois do curso você apoiou atividades de capacitação de técnicos e agricultores com base nos princípios e diretrizes da Pnater? (Considere como apoio a atividades de capacitação a participação no planejamento, elaboração de ementas, seleção de participantes e de palestrantes.)

\begin{tabular}{|l|l|}
\hline$X$ & SIM \\
\hline & NÃO \\
\hline
\end{tabular}

8) Usou os conhecimentos para ministrar outros cursos com o mesmo conteúdo ou conteúdos semelhantes?

\begin{tabular}{|l|l|}
\hline & SIM \\
\hline$X$ & NÃO \\
\hline
\end{tabular}

9) Marque o seu grau de satisfação com relação ao curso oferecido pelo DATER: (Considere a seguinte pontuação: 1 - MUITO RUIM; 2 - RUIM; 3 - REGULAR; 4 - BOM; 5 - MUITO BOM) 


\begin{tabular}{|l|l|l|l|l|}
\hline 1 & 2 & $3 X$ & 4 & 5 \\
\hline
\end{tabular}

10) Marque seu grau de satisfação com relação ao DATER: (Considere a seguinte pontuação: 1 - MUITO RUIM; 2 - RUIM; 3 - REGULAR; 4 - BOM; 5 - MUITO BOM)

\begin{tabular}{|l|l|l|l|l|}
\hline 1 & 2 & 3 & 4 & $5 X$ \\
\hline
\end{tabular}




\section{PESQUISA - IMPACTO DAS AÇÕES DE FORMAÇÃO REALIZADAS PELO \\ DATER/SAF/MDA NO PERÍODO 2004-2009}

Caros colaboradores,

Contamos com a sua atenção para preencher o formulário abaixo.

O mesmo tem por objetivo fornecer informações para avaliação da Eficiência, Efetividade e Eficácia da Política Pública de Formação de Agentes de Ater adotada pelo Departamento de Assistência Técnica e Extensão Rural, da Secretaria de Agricultura Familiar do Ministério do Desenvolvimento - DATER/SAF/MDA, no período de 2004 a 2009, tema escolhido para Monografia a ser apresentada à Universidade de Brasília (UnB) como requisito parcial para obtenção do grau de Bacharel em Administração.

Você poderá ou não se identificar no questionário e garantimos que todas as informações fornecidas serão confidenciais e utilizadas apenas de forma sistematizada.

IDENTIFICAÇÃO

\begin{tabular}{|l|l|}
\hline Nome: Anselmo Vital Matos & $\begin{array}{l}\text { Sexo: } \\
(\mathrm{x}) \text { masculino } \quad(\quad) \text { feminino }\end{array}$ \\
\hline Instituição: FETAG (movimento social) & Local de trabalho: Salvador - Bahia \\
\hline $\begin{array}{l}\text { Curso/Encontro/Oficina do qual participou: Curso Sistemas Silviagropastoris para Caatinga - } \\
\text { Paraíba }\end{array}$ & \\
\hline Data do Curso/Encontro/Oficina: Novembro - 2006
\end{tabular}

1. Indique sua área de atuação? (As opções não são excludentes: você poderá marcar mais de uma opção).

\begin{tabular}{|l|l|}
\hline$X$ & EXTENSÃO RURAL \\
\hline & PESQUISA \\
\hline & ENSINO \\
\hline & OUTROS \\
\hline
\end{tabular}

2) Qual o seu nível de escolaridade? ( Considere apenas o nível mais alto) 


\begin{tabular}{|c|l|}
\hline & NÍVEL MÉDIO \\
\hline$X$ & NÍVEL SUPERIOR \\
\hline & PÓS-GRADUAÇÃO \\
\hline
\end{tabular}

3) Os conteúdos abordados foram condizentes com as demandas do seu dia-a-dia?

\begin{tabular}{|l|l|}
\hline$X$ & SIM \\
\hline & PARCIALMENTE \\
\hline & NÃO \\
\hline
\end{tabular}

4) O curso contribuiu para o seu aperfeiçoamento profissional?

\begin{tabular}{|l|l|}
\hline$X$ & SIM \\
\hline & NÃO \\
\hline
\end{tabular}

5) Os conhecimentos adquiridos estão sendo aplicados no seu trabalho? Em caso afirmativo, indique em que grau estes conhecimentos estão sendo aplicados. Em caso negativo, indique por que razão isto não ocorre: (As respostas não são excludentes: você poderá marcar mais de uma opção).

\begin{tabular}{|c|c|c|}
\hline \multirow{3}{*}{$\begin{array}{l}\text { SIM (indique ao lado em } \\
\text { que grau) }\end{array}$} & & MUITO APLICADOS \\
\hline & $\mathrm{X}$ & MEDIAMENTE APLICADOS \\
\hline & & POUCO APLICADOS \\
\hline \multirow{2}{*}{$\begin{array}{l}\text { NÃO (indique ao lado a } \\
\text { razão da não aplicação) }\end{array}$} & & $\begin{array}{l}\text { CONTEÚDO NÃO ADEQUADO ȦS NECESSIDADES } \\
\text { ESPECÍFICAS DA REGIÃO }\end{array}$ \\
\hline & & $\begin{array}{l}\text { CONTEÚDO NÃO } \text { FOI SUFICIENTEMENTE } \\
\text { APROFUNDADO PARA } \\
\text { PERMITIR UMA APLICAÇÃO } \\
\text { EFICAZ E EFICIENTE }\end{array}$ \\
\hline
\end{tabular}




\begin{tabular}{|l|l|l|}
\hline \multirow{2}{*}{} & & $\begin{array}{l}\text { FALTA DE APOIO E INCENTIVO DA MINHA } \\
\text { INSTITUIÇÃO }\end{array}$ \\
\cline { 2 - 3 } & & FALTA DE INCENTIVO ÀS AÇÕES DE ATER \\
\cline { 2 - 3 } & NÃO TENHO INTERESSE EM APLICAR \\
\hline
\end{tabular}

6) A partir deste curso: (As opções não são excludentes: você poderá marcar mais de uma opção).

\begin{tabular}{|c|l|}
\hline$x$ & $\begin{array}{l}\text { NÃO MUDOU NADA EM MEU TRABALHO. } \\
\text { FAMILIARES. }\end{array}$ \\
\hline & CONSEGUI INFLUENCIAR NAS ORIENTAÇÕES DA MINHA INSTITUIÇÃO. \\
\hline & PASSEI A TRABALHAR COM METODOLOGIAS PARTICIPATIVAS. \\
\hline & $\begin{array}{l}\text { CRESCEU A ÁREA DE AGRICULTURA DE BASE ECOLÓGICA NAS COMUNIDADES } \\
\text { ONDE ATUO. }\end{array}$ \\
\hline & CONTINUEI ME APERFEIÇOANDO SOBRE TEMAS ABORDADOS. \\
\hline
\end{tabular}

7) Depois do curso você apoiou atividades de capacitação de técnicos e agricultores com base nos princípios e diretrizes da Pnater? (Considere como apoio a atividades de capacitação a participação no planejamento, elaboração de ementas, seleção de participantes e de palestrantes.)

\begin{tabular}{|l|l|}
\hline & SIM \\
\hline$X$ & NÃO \\
\hline
\end{tabular}

8) Usou os conhecimentos para ministrar outros cursos com o mesmo conteúdo ou conteúdos semelhantes?

\begin{tabular}{|l|l|}
\hline$X$ & SIM \\
\hline & NÃO \\
\hline
\end{tabular}


9) Marque o seu grau de satisfação com relação ao curso oferecido pelo DATER: (Considere a seguinte pontuação: 1 - MUITO RUIM; 2 - RUIM; 3 - REGULAR; 4 - BOM; 5 - MUITO BOM)

\begin{tabular}{|l|l|l|l|l|}
\hline 1 & 2 & 3 & $4 \times X$ & 5 \\
\hline
\end{tabular}

10) Marque seu grau de satisfação com relação ao DATER: (Considere a seguinte pontuação: 1 - MUITO RUIM; 2 - RUIM; 3 - REGULAR; 4 - BOM; 5 - MUITO BOM)

\begin{tabular}{|l|l|l|l|l|}
\hline 1 & 2 & 3 & $4 X X$ & 5 \\
\hline
\end{tabular}




\section{PESQUISA - IMPACTO DAS AÇÕES DE FORMAÇÃO REALIZADAS PELO \\ DATER/SAF/MDA NO PERÍODO 2004-2009}

Caros colaboradores,

Contamos com a sua atenção para preencher o formulário abaixo.

O mesmo tem por objetivo fornecer informações para avaliação da Eficiência, Efetividade e Eficácia da Política Pública de Formação de Agentes de Ater adotada pelo Departamento de Assistência Técnica e Extensão Rural, da Secretaria de Agricultura Familiar do Ministério do Desenvolvimento - DATER/SAF/MDA, no período de 2004 a 2009, tema escolhido para Monografia a ser apresentada à Universidade de Brasília (UnB) como requisito parcial para obtenção do grau de Bacharel em Administração.

Você poderá ou não se identificar no questionário e garantimos que todas as informações fornecidas serão confidenciais e utilizadas apenas de forma sistematizada.

\section{IDENTIFICAÇÃO}

\begin{tabular}{|l|l|}
\hline Nome: Antonieta Alves da Costa & $\begin{array}{l}\text { Sexo: } \\
(\quad) \text { masculino } \quad(x \text { ) feminino }\end{array}$ \\
\hline Instituição (nome e tipo de instituição: ONG, & $\begin{array}{l}\text { Local de trabalho (Cidade e Estado): } \\
\text { Empresa Pública, etc.): Secretaria de Agricultura, } \\
\text { Palmeira dos Índios - AL }\end{array}$ \\
Abastecimento e Pesca - Pública & \\
\hline Curso/Encontro/Oficina do qual participou (caso tenha participado de mais de um curso, preencha \\
um formulário para cada um deles): Curso de Formadores da ATER \\
\hline Data do Curso/Encontro/Oficina (pelo menos mês e ano): dezembro de 2006 \\
\hline
\end{tabular}

1. Indique sua área de atuação? (As opções não são excludentes: você poderá marcar mais de uma opção).

\begin{tabular}{|l|l|}
\hline$x$ & EXTENSÃO RURAL \\
\hline & PESQUISA \\
\hline & ENSINO \\
\hline & OUTROS \\
\hline
\end{tabular}


2) Qual o seu nível de escolaridade? ( Considere apenas o nível mais alto)

\begin{tabular}{|l|l|}
\hline & NÍVEL MÉDIO \\
\hline$x$ & NÍVEL SUPERIOR \\
\hline & PÓS-GRADUAÇÃO \\
\hline
\end{tabular}

3) Os conteúdos abordados foram condizentes com as demandas do seu dia-a-dia?

\begin{tabular}{|l|l|}
\hline & SIM \\
\hline$x$ & PARCIALMENTE \\
\hline & NÃO \\
\hline
\end{tabular}

4) O curso contribuiu para o seu aperfeiçoamento profissional?

\begin{tabular}{|l|l|}
\hline$x$ & SIM \\
\hline & NÃO \\
\hline
\end{tabular}

5) Os conhecimentos adquiridos estão sendo aplicados no seu trabalho? Em caso afirmativo, indique em que grau estes conhecimentos estão sendo aplicados. Em caso negativo, indique por que razão isto não ocorre: (As respostas não são excludentes: você poderá marcar mais de uma opção).

\begin{tabular}{|c|c|c|}
\hline & \multirow{3}{*}{$\begin{array}{l}\text { SIM (indique ao lado em } \\
\text { que grau) }\end{array}$} & MUITO APLICADOS \\
\hline & & MEDIAMENTE APLICADOS \\
\hline & & POUCO APLICADOS \\
\hline \multirow[b]{2}{*}{$x$} & \multirow{2}{*}{$\begin{array}{l}\text { NÃO (indique ao lado a } \\
\text { razão da não aplicação) }\end{array}$} & $\begin{array}{l}\text { CONTEÚDO NÃO ADEQUADO ȦS NECESSIDADES } \\
\text { ESPECÍFICAS DA REGIÃO }\end{array}$ \\
\hline & & $\begin{array}{l}\text { CONTEÚDO NÃO FOI SUFICIENTEMENTE } \\
\text { APROFUNDADO PARA } \\
\text { PERMITIR UMA APLICAÇÃO } \\
\text { EFICAZ E EFICIENTE }\end{array}$ \\
\hline
\end{tabular}




\begin{tabular}{|l|l|l|}
\hline \multirow{2}{*}{} & $x$ & $\begin{array}{l}\text { FALTA DE APOIO E INCENTIVO DA MINHA } \\
\text { INSTITUIÇÃO }\end{array}$ \\
\cline { 2 - 4 } & $x$ & FALTA DE INCENTIVO ÀS AÇÕES DE ATER \\
\cline { 2 - 3 } & & NÃO TENHO INTERESSE EM APLICAR \\
\hline
\end{tabular}

6) A partir deste curso: (As opções não são excludentes: você poderá marcar mais de uma opção).

\begin{tabular}{|l|l|}
\hline & NÃO MUDOU NADA EM MEU TRABALHO. \\
\hline & $\begin{array}{l}\text { MEU TRABALHO PASSOU A CONTRIBUIR MAIS COM OS AGRICULTORES(AS) } \\
\text { FAMILIARES. }\end{array}$ \\
\hline & CONSEGUI INFLUENCIAR NAS ORIENTAÇÕES DA MINHA INSTITUIÇÃO. \\
\hline & $\begin{array}{l}\text { CRASSEI A TRABALHAR COM METODOLOGIAS PARTICIPATIVAS. } \\
\text { ONDE ATUO. ÁREA DE AGRICULTURA DE BASE ECOLÓGICA NAS COMUNIDADES }\end{array}$ \\
\hline$x$ & CONTINUEI ME APERFEIÇOANDO SOBRE TEMAS ABORDADOS. \\
\hline
\end{tabular}

7) Depois do curso você apoiou atividades de capacitação de técnicos e agricultores com base nos princípios e diretrizes da Pnater? (Considere como apoio a atividades de capacitação a participação no planejamento, elaboração de ementas, seleção de participantes e de palestrantes.)

\begin{tabular}{|l|l|}
\hline & SIM \\
\hline$x$ & NÃO \\
\hline
\end{tabular}

8) Usou os conhecimentos para ministrar outros cursos com o mesmo conteúdo ou conteúdos semelhantes?

\begin{tabular}{|l|l|}
\hline & SIM \\
\hline$x$ & NÃO \\
\hline
\end{tabular}


9) Marque o seu grau de satisfação com relação ao curso oferecido pelo DATER: (Considere a seguinte pontuação: 1 - MUITO RUIM; 2 - RUIM; 3 - REGULAR; 4 - BOM; 5 - MUITO BOM)

\begin{tabular}{|l|l|l|l|l|}
\hline 1 & 2 & 3 & 4 & 5 \\
\hline
\end{tabular}

10) Marque seu grau de satisfação com relação ao DATER: (Considere a seguinte pontuação: 1 - MUITO RUIM; 2 - RUIM; 3 - REGULAR; 4 - BOM; 5 - MUITO BOM)

\begin{tabular}{|l|l|l|l|l|}
\hline 1 & 2 & 3 & 4 & 5 \\
\hline
\end{tabular}




\section{PESQUISA - IMPACTO DAS AÇÕES DE FORMAÇÃO REALIZADAS PELO \\ DATER/SAF/MDA NO PERÍODO 2004-2009}

Caros colaboradores,

Contamos com a sua atenção para preencher o formulário abaixo.

O mesmo tem por objetivo fornecer informações para avaliação da Eficiência, Efetividade e Eficácia da Política Pública de Formação de Agentes de Ater adotada pelo Departamento de Assistência Técnica e Extensão Rural, da Secretaria de Agricultura Familiar do Ministério do Desenvolvimento - DATER/SAF/MDA, no período de 2004 a 2009, tema escolhido para Monografia a ser apresentada à Universidade de Brasília (UnB) como requisito parcial para obtenção do grau de Bacharel em Administração.

Você poderá ou não se identificar no questionário e garantimos que todas as informações fornecidas serão confidenciais e utilizadas apenas de forma sistematizada.

\section{IDENTIFICAÇÃO}

\begin{tabular}{|l|l|}
\hline Nome: Antonieta Alves da Costa & $\begin{array}{l}\text { Sexo: } \\
(\quad) \text { masculino } \quad(\mathrm{x}) \text { feminino }\end{array}$ \\
\hline $\begin{array}{l}\text { Instituição (nome e tipo de instituição: ONG, } \\
\text { Empresa Pública, etc.): Secretaria de Agricultura, } \\
\text { Abastecimento e Pesca - Pública }\end{array}$ & $\begin{array}{l}\text { Palmeira dos Índios - AL } \\
\text { Curso/Encontro/Oficina do qual participou (caso tenha participado de mais de um curso, preencha } \\
\text { um formulário para cada um deles): Curso de Plantas Medicinais e Condimentares }\end{array}$ \\
\hline Data do Curso/Encontro/Oficina (pelo menos mês e ano): novembro de 2005 \\
\hline
\end{tabular}

Indique sua área de atuação? (As opções não são excludentes: você poderá marcar mais de uma opção).

\begin{tabular}{|l|l|}
\hline$x$ & EXTENSÃO RURAL \\
\hline & PESQUISA \\
\hline & ENSINO \\
\hline & OUTROS \\
\hline
\end{tabular}


2) Qual o seu nível de escolaridade? ( Considere apenas o nível mais alto)

\begin{tabular}{|l|l|}
\hline & NÍVEL MÉDIO \\
\hline$x$ & NÍVEL SUPERIOR \\
\hline & PÓS-GRADUAÇÃO \\
\hline
\end{tabular}

3) Os conteúdos abordados foram condizentes com as demandas do seu dia-a-dia?

\begin{tabular}{|l|l|}
\hline & SIM \\
\hline$x$ & PARCIALMENTE \\
\hline & NÃO \\
\hline
\end{tabular}

4) O curso contribuiu para o seu aperfeiçoamento profissional?

\begin{tabular}{|l|l|}
\hline$x$ & SIM \\
\hline & NÃO \\
\hline
\end{tabular}

5) Os conhecimentos adquiridos estão sendo aplicados no seu trabalho? Em caso afirmativo, indique em que grau estes conhecimentos estão sendo aplicados. Em caso negativo, indique por que razão isto não ocorre: (As respostas não são excludentes: você poderá marcar mais de uma opção).

\begin{tabular}{|c|c|c|c|}
\hline \multirow{3}{*}{$x$} & \multirow{3}{*}{$\begin{array}{l}\text { SIM (indique ao lado em } \\
\text { que grau) }\end{array}$} & & MUITO APLICADOS \\
\hline & & & MEDIAMENTE APLICADOS \\
\hline & & $x$ & POUCO APLICADOS \\
\hline & \multirow{2}{*}{$\begin{array}{l}\text { NÃO (indique ao lado a } \\
\text { razão da não aplicação) }\end{array}$} & & $\begin{array}{l}\text { CONTEÚDO NÃO ADEQUADO ȦS NECESSIDADES } \\
\text { ESPECÍFICAS DA REGIÃO }\end{array}$ \\
\hline & & & $\begin{array}{l}\text { CONTEÚDO NÃO } \quad \text { FOI } \quad \text { SUFICIENTEMENTE } \\
\text { APROFUNDADO PARA } \\
\text { EERMITIR UMA APLICAÇÃO } \\
\text { EFICAZ E EFICIENTE }\end{array}$ \\
\hline
\end{tabular}




\begin{tabular}{|l|l|l|}
\hline \multirow{2}{*}{} & & $\begin{array}{l}\text { FALTA DE APOIO E INCENTIVO DA MINHA } \\
\text { INSTITUIÇÃO }\end{array}$ \\
\cline { 2 - 3 } & & FALTA DE INCENTIVO ÀS AÇÕES DE ATER \\
\cline { 2 - 3 } & NÃO TENHO INTERESSE EM APLICAR \\
\hline
\end{tabular}

6) A partir deste curso: (As opções não são excludentes: você poderá marcar mais de uma opção).

\begin{tabular}{|l|l|}
\hline$x$ & $\begin{array}{l}\text { NÃO MUDOU NADA EM MEU TRABALHO. } \\
\text { FAMILIARES. }\end{array}$ \\
\hline & CONSEGUI INFLUENCIAR NAS ORIENTAÇÕES DA MINHA INSTITUIÇÃO. \\
\hline & PASSEI A TRABALHAR COM METODOLOGIAS PARTICIPATIVAS. \\
\hline & $\begin{array}{l}\text { CRESCEU A ÁREA DE AGRICULTURA DE BASE ECOLÓGICA NAS COMUNIDADES } \\
\text { ONDE ATUO. }\end{array}$ \\
\hline$x$ & CONTINUEI ME APERFEIÇOANDO SOBRE TEMAS ABORDADOS. \\
\hline
\end{tabular}

7) Depois do curso você apoiou atividades de capacitação de técnicos e agricultores com base nos princípios e diretrizes da Pnater? (Considere como apoio a atividades de capacitação a participação no planejamento, elaboração de ementas, seleção de participantes e de palestrantes.)

\begin{tabular}{|l|l|}
\hline & SIM \\
\hline$x$ & NÃO \\
\hline
\end{tabular}

8) Usou os conhecimentos para ministrar outros cursos com o mesmo conteúdo ou conteúdos semelhantes?

\begin{tabular}{|l|l|}
\hline$x$ & SIM \\
\hline & NÃO \\
\hline
\end{tabular}


9) Marque o seu grau de satisfação com relação ao curso oferecido pelo DATER: (Considere a seguinte pontuação: 1 - MUITO RUIM; 2 - RUIM; 3 - REGULAR; 4 - BOM; 5 - MUITO BOM)

\begin{tabular}{|l|l|l|l|l|}
\hline 1 & 2 & 3 & 4 & 5 \\
\hline
\end{tabular}

10) Marque seu grau de satisfação com relação ao DATER: (Considere a seguinte pontuação: 1 - MUITO RUIM; 2 - RUIM; 3 - REGULAR; 4 - BOM; 5 - MUITO BOM)

\begin{tabular}{|l|l|l|l|l|}
\hline 1 & 2 & 3 & 4 & 5 \\
\hline
\end{tabular}




\section{PESQUISA - IMPACTO DAS AÇÕES DE FORMAÇÃO REALIZADAS PELO \\ DATER/SAF/MDA NO PERÍODO 2004-2009}

Caros colaboradores,

Contamos com a sua atenção para preencher o formulário abaixo.

O mesmo tem por objetivo fornecer informações para avaliação da Eficiência, Efetividade e Eficácia da Política Pública de Formação de Agentes de Ater adotada pelo Departamento de Assistência Técnica e Extensão Rural, da Secretaria de Agricultura Familiar do Ministério do Desenvolvimento - DATER/SAF/MDA, no período de 2004 a 2009, tema escolhido para Monografia a ser apresentada à Universidade de Brasília (UnB) como requisito parcial para obtenção do grau de Bacharel em Administração.

Você poderá ou não se identificar no questionário e garantimos que todas as informações fornecidas serão confidenciais e utilizadas apenas de forma sistematizada.

\section{IDENTIFICAÇÃO}

\begin{tabular}{|c|c|}
\hline $\begin{array}{l}\text { Nome: } \\
\text { ANTÔNIO TARCISO COELHO PINTO }\end{array}$ & $\begin{array}{l}\text { Sexo: } \\
(\mathrm{x}) \text { masculino } \quad(\quad) \text { feminino }\end{array}$ \\
\hline $\begin{array}{l}\text { Instituição (nome e tipo de instituição: ONG, } \\
\text { Empresa Pública, etc.): } \\
\text { EMATERCE }\end{array}$ & $\begin{array}{l}\text { Local de trabalho (Cidade e Estado): } \\
\text { FORTALEZA - CEARÁ }\end{array}$ \\
\hline \multicolumn{2}{|c|}{$\begin{array}{l}\text { Curso/Encontro/Oficina do qual participou (caso tenha participado de mais de um curso, preencha } \\
\text { um formulário para cada um deles): } \\
\text { TREINAMENTO EM DESENVOLVIMENTO GERENCIAL DE PROJETOS. }\end{array}$} \\
\hline $\begin{array}{l}\text { Data do Curso/Encontro/Oficina (pelo menos mês } \\
19 \text { a 22/03/2006 }\end{array}$ & no): \\
\hline
\end{tabular}

1. Indique sua área de atuação? (As opções não são excludentes: você poderá marcar mais de uma opção).

\begin{tabular}{|l|l|}
\hline$X$ & EXTENSÃO RURAL \\
\hline & PESQUISA \\
\hline & ENSINO \\
\hline
\end{tabular}




\section{OUTROS}

2) Qual o seu nível de escolaridade? ( Considere apenas o nível mais alto)

\begin{tabular}{|l|l|}
\hline & NÍVEL MÉDIO \\
\hline$X$ & NÍVEL SUPERIOR \\
\hline & PÓS-GRADUAÇÃO \\
\hline
\end{tabular}

3) Os conteúdos abordados foram condizentes com as demandas do seu dia-a-dia?

\begin{tabular}{|l|l|}
\hline$X$ & SIM \\
\hline & PARCIALMENTE \\
\hline & NÃO \\
\hline
\end{tabular}

4) O curso contribuiu para o seu aperfeiçoamento profissional?

\begin{tabular}{|l|l|}
\hline$X$ & SIM \\
\hline & NÃO \\
\hline
\end{tabular}

5) Os conhecimentos adquiridos estão sendo aplicados no seu trabalho? Em caso afirmativo, indique em que grau estes conhecimentos estão sendo aplicados. Em caso negativo, indique por que razão isto não ocorre: (As respostas não são excludentes: você poderá marcar mais de uma opção).

\begin{tabular}{|l|l|l|l|}
\hline \multirow{2}{*}{$X$} & $\begin{array}{l}\text { SIM (indique ao lado em } \\
\text { que grau) }\end{array}$ & & MUITO APLICADOS \\
\cline { 2 - 4 } & $\begin{array}{l}\text { NÃO (indique ao lado a } \\
\text { razão da não aplicação) }\end{array}$ & MEDIAMENTE APLICADOS \\
\hline & $\begin{array}{l}\text { CONTEÚDO NÃO ADEQUADO ȦS NECESSIDADES } \\
\text { ESPECÍFICAS DA REGIÃO }\end{array}$ \\
\hline
\end{tabular}




\begin{tabular}{|l|l|l|}
\hline \multirow{10}{*}{} & $\begin{array}{l}\text { CONTEÚDO NÃO FOI SUFICIENTEMENTE } \\
\text { APROFUNDADO PARA PERMITIR UMA APLICAÇÃO } \\
\text { EFICAZ E EFICIENTE }\end{array}$ \\
\cline { 2 - 4 } & $\begin{array}{l}\text { FALTA DE APOIO E INCENTIVO DA MINHA } \\
\text { INSTITUIÇÃO }\end{array}$ \\
\cline { 2 - 4 } & FALTA DE INCENTIVO ÀS AÇÕES DE ATER \\
\hline & NÃO TENHO INTERESSE EM APLICAR \\
\hline
\end{tabular}

6) A partir deste curso: (As opções não são excludentes: você poderá marcar mais de uma opção).

\begin{tabular}{|l|l|}
\hline & NÃO MUDOU NADA EM MEU TRABALHO. \\
\hline & $\begin{array}{l}\text { MEU TRABALHO PASSOU A CONTRIBUIR MAIS COM OS AGRICULTORES (AS) } \\
\text { FAMILIARES. }\end{array}$ \\
\hline & CONSEGUI INFLUENCIAR NAS ORIENTAÇÕES DA MINHA INSTITUIÇÃO. \\
\hline & $\begin{array}{l}\text { CRESCEI A TRABALHAR COM METODOLOGIAS PARTICIPATIVAS. } \\
\text { ONDE ATUO. ÁREA DE AGRICULTURA DE BASE ECOLÓGICA NAS COMUNIDADES }\end{array}$ \\
\hline$X$ & CONTINUEI ME APERFEIÇOANDO SOBRE TEMAS ABORDADOS. \\
\hline
\end{tabular}

7) Depois do curso você apoiou atividades de capacitação de técnicos e agricultores com base nos princípios e diretrizes da Pnater(Considere como apoio a atividades de capacitação a participação no planejamento, elaboração de ementas, seleção de participantes e de palestrantes.)

\begin{tabular}{|l|l|}
\hline$X$ & SIM \\
\hline & NÃO \\
\hline
\end{tabular}

8) Usou os conhecimentos para ministrar outros cursos com o mesmo conteúdo ou conteúdos semelhantes? 


\begin{tabular}{|l|l|}
\hline$X$ & SIM \\
\hline & NÃO \\
\hline
\end{tabular}

9) Marque o seu grau de satisfação com relação ao curso oferecido pelo DATER: (Considere a seguinte pontuação: 1 - MUITO RUIM; 2 - RUIM; 3 - REGULAR; 4 - BOM; 5 - MUITO BOM)

\begin{tabular}{|l|l|l|l|l|}
\hline 1 & 2 & 3 & 4 & 5 \\
\hline
\end{tabular}

10) Marque seu grau de satisfação com relação ao DATER: (Considere a seguinte pontuação: 1 - MUITO RUIM; 2 - RUIM; 3 - REGULAR; 4 - BOM; 5 - MUITO BOM)

\begin{tabular}{|l|l|l|l|l|}
\hline 1 & 2 & 3 & 4 & 5 \\
\hline
\end{tabular}




\section{PESQUISA - IMPACTO DAS AÇÕES DE FORMAÇÃO REALIZADAS PELO \\ DATER/SAF/MDA NO PERÍODO 2004-2009}

Caros colaboradores,

Contamos com a sua atenção para preencher o formulário abaixo.

O mesmo tem por objetivo fornecer informações para avaliação da Eficiência, Efetividade e Eficácia da Política Pública de Formação de Agentes de Ater adotada pelo Departamento de Assistência Técnica e Extensão Rural, da Secretaria de Agricultura Familiar do Ministério do Desenvolvimento - DATER/SAF/MDA, no período de 2004 a 2009, tema escolhido para Monografia a ser apresentada à Universidade de Brasília (UnB) como requisito parcial para obtenção do grau de Bacharel em Administração.

Você poderá ou não se identificar no questionário e garantimos que todas as informações fornecidas serão confidenciais e utilizadas apenas de forma sistematizada.

IDENTIFICAÇÃO

\begin{tabular}{|l|l|}
\hline $\begin{array}{l}\text { Nome: } \\
\text { AFFONSO AUGUSTO BULCÃO FLACH }\end{array}$ & $\begin{array}{l}\text { Sexo: } \\
(x) \text { masculino } \quad(\quad) \text { feminino }\end{array}$ \\
\hline $\begin{array}{l}\text { Instituição (nome e tipo de instituição: ONG, } \\
\text { Empresa Pública, etc.): }\end{array}$ & Local de trabalho (Cidade e Estado): \\
CRESOL CENTRAL SC / RS & CHAPEĆ \\
Um formulário para cada um deles): \\
METODOLOGIAS PARTICIPATIVAS- CAMPINAS -SP \\
\hline $\begin{array}{l}\text { Data do Curso/Encontro/Oficina (pelo menos mês e ano): } \\
\text { NOVEMBRO/2006 }\end{array}$ \\
\hline
\end{tabular}

1)Indique sua área de atuação? (As opções não são excludentes: você poderá marcar mais de uma opção).

\begin{tabular}{|l|l|}
\hline$X$ & EXTENSÃO RURAL \\
\hline & PESQUISA \\
\hline
\end{tabular}




\begin{tabular}{|l|l|} 
& ENSINO \\
\hline & OUTROS \\
\hline
\end{tabular}

2) Qual o seu nível de escolaridade? (Considere apenas o nível mais alto)

\begin{tabular}{|l|l|}
\hline & NÍVEL MÉDIO \\
\hline$X$ & NÍVEL SUPERIOR \\
\hline & PÓS-GRADUAÇÃO \\
\hline
\end{tabular}

3) Os conteúdos abordados foram condizentes com as demandas do seu dia-a-dia?

\begin{tabular}{|l|l|}
\hline$X$ & SIM \\
\hline & PARCIALMENTE \\
\hline & NÃO \\
\hline
\end{tabular}

4) O curso contribuiu para o seu aperfeiçoamento profissional?

\begin{tabular}{|l|l|}
\hline$X$ & SIM \\
\hline & NÃO \\
\hline
\end{tabular}

5) Os conhecimentos adquiridos estão sendo aplicados no seu trabalho? Em caso afirmativo, indique em que grau estes conhecimentos estão sendo aplicados. Em caso negativo, indique por que razão isto não ocorre: (As respostas não são excludentes: você poderá marcar mais de uma opção).

\begin{tabular}{|c|c|c|}
\hline \multirow{3}{*}{$\begin{array}{l}\text { SIM (indique ao lado em } \\
\text { que grau) }\end{array}$} & & MUITO APLICADOS \\
\hline & $\mathrm{X}$ & MEDIAMENTE APLICADOS \\
\hline & & POUCO APLICADOS \\
\hline \multirow{2}{*}{$\begin{array}{l}\text { NÃO (indique ao lado a } \\
\text { razão da não aplicação) }\end{array}$} & & $\begin{array}{l}\text { CONTEÚDO NÃO ADEQUADO ÀS NECESSIDADES } \\
\text { ESPECÍEICAS RA REGIÕ }\end{array}$ \\
\hline & & $\begin{array}{llll}\text { CONTEÚDO NÂOO } & \text { FOI SUFICIENTEMENTE } \\
\text { APROFUNDADO PARA } & \text { PERMITIR UMA APLICAÇÃO }\end{array}$ \\
\hline
\end{tabular}




\begin{tabular}{|l|l|l|}
\multirow{5}{*}{} & $\begin{array}{l}\text { FALTA DE APOIO E INCENTIVO DA MINHA } \\
\text { INSTITUICÃO }\end{array}$ \\
\cline { 2 - 3 } & \begin{tabular}{l} 
FALTA DE INCENTIVO ÀS AÇÕES DE ATER \\
\cline { 2 - 3 }
\end{tabular} & NÃO TENHO INTERESSE EM APLICAR \\
\hline
\end{tabular}

6) A partir deste curso:

\begin{tabular}{|l|l|}
\hline & NÃO MUDOU NADA EM MEU TRABALHO. \\
\hline & $\begin{array}{l}\text { MEU TRABALHO PASSOU A CONTRIBUIR MAIS COM OS AGRICULTORES(AS) } \\
\text { FAMILIARES. }\end{array}$ \\
\hline$X$ & CONSEGUI INFLUENCIAR NAS ORIENTAÇÕES DA MINHA INSTITUIÇÃO. \\
\hline & $\begin{array}{l}\text { CASSEI A TRABALHAR COM METODOLOGIAS PARTICIPATIVAS. } \\
\text { ONDE ATUO. }\end{array}$ \\
\hline$X$ & CONTINUEI ME APERFEIÇOANDO SOBRE TEMAS ABORDADOS. \\
\hline
\end{tabular}

7) Depois do curso você apoiou atividades de capacitação de técnicos e agricultores com base nos princípios e diretrizes da Pnater? (Considere como apoio a atividades de capacitação a participação no planejamento, elaboração de ementas, seleção de participantes e de palestrantes.)

\begin{tabular}{|l|l|}
\hline$X$ & SIM \\
\hline & NÃO \\
\hline
\end{tabular}

8) Usou os conhecimentos para ministrar outros cursos com o mesmo conteúdo ou conteúdos semelhantes?

\begin{tabular}{|l|l|}
\hline$X$ & SIM \\
\hline & NÃO \\
\hline
\end{tabular}

9) Marque o seu grau de satisfação com relação ao curso oferecido pelo DATER: (Considere a seguinte pontuação: 1 - MUITO RUIM; 2 - RUIM; 3 - REGULAR; 4 - BOM; 5 - MUITO BOM) 


\begin{tabular}{|l|l|l|l|l|}
\hline 1 & 2 & 3 & $4 X$ & 5 \\
\hline
\end{tabular}

10) Marque seu grau de satisfação com relação ao DATER: (Considere a seguinte pontuação: 1 - MUITO RUIM; 2 - RUIM; 3 - REGULAR; 4 - BOM; 5 - MUITO BOM)

\begin{tabular}{|l|l|l|l|l|}
\hline 1 & 2 & 3 & 4 & $5 X$ \\
\hline
\end{tabular}




\section{PESQUISA - IMPACTO DAS AÇÕES DE FORMAÇÃO REALIZADAS PELO \\ DATER/SAF/MDA NO PERÍODO 2004-2009}

Caros colaboradores,

Contamos com a sua atenção para preencher o formulário abaixo.

O mesmo tem por objetivo fornecer informações para avaliação da Eficiência, Efetividade e Eficácia da Política Pública de Formação de Agentes de Ater adotada pelo Departamento de Assistência Técnica e Extensão Rural, da Secretaria de Agricultura Familiar do Ministério do Desenvolvimento - DATER/SAF/MDA, no período de 2004 a 2009, tema escolhido para Monografia a ser apresentada à Universidade de Brasília (UnB) como requisito parcial para obtenção do grau de Bacharel em Administração.

Você poderá ou não se identificar no questionário e garantimos que todas as informações fornecidas serão confidenciais e utilizadas apenas de forma sistematizada.

IDENTIFICAÇÃO

\begin{tabular}{|c|c|}
\hline Nome: Jefferson Vinicius Meister & $\begin{array}{l}\text { Sexo: } \\
(x \quad) \text { masculino } \quad(\quad) \text { feminino }\end{array}$ \\
\hline $\begin{array}{l}\text { Instituição (nome e tipo de instituição: ONG, } \\
\text { Empresa Pública, etc.): } \\
\text { COTRARA }\end{array}$ & $\begin{array}{l}\text { Local de trabalho (Cidade e Estado): } \\
\text { Região Centro-Sul do Paraná }\end{array}$ \\
\hline \multicolumn{2}{|c|}{$\begin{array}{l}\text { Curso/Encontro/Oficina do qual participou (caso tenha participado de mais de um curso, preencha } \\
\text { um formulário para cada um deles): } \\
\text { Curso de Pecuária Ecológica }\end{array}$} \\
\hline Data do Curso/Encontro/Oficina (pelo menos mês e & ano): 08/2006 \\
\hline
\end{tabular}

1. Indique sua área de atuação? (As opções não são excludentes: você poderá marcar mais de uma opção).

\begin{tabular}{|l|l|}
\hline$X$ & EXTENSÃO RURAL \\
\hline & PESQUISA \\
\hline & ENSINO \\
\hline & OUTROS \\
\hline
\end{tabular}


2) Qual o seu nível de escolaridade? (Considere apenas o nível mais alto)

\begin{tabular}{|l|l|}
\hline & NÍVEL MÉDIO \\
\hline$X$ & NÍVEL SUPERIOR \\
\hline & PÓS-GRADUAÇÃO \\
\hline
\end{tabular}

3) Os conteúdos abordados foram condizentes com as demandas do seu dia-a-dia?

\begin{tabular}{|l|l|}
\hline$X$ & SIM \\
\hline & PARCIALMENTE \\
\hline & NÃO \\
\hline
\end{tabular}

4) O curso contribuiu para o seu aperfeiçoamento profissional?

\begin{tabular}{|l|l|}
\hline$X$ & SIM \\
\hline & NÃO \\
\hline
\end{tabular}

5) Os conhecimentos adquiridos estão sendo aplicados no seu trabalho? Em caso afirmativo, indique em que grau estes conhecimentos estão sendo aplicados. Em caso negativo, indique por que razão isto não ocorre:

\begin{tabular}{|c|c|c|}
\hline \multirow{3}{*}{$\begin{array}{l}\text { SIM (indique ao lado em } \\
\text { que grau) }\end{array}$} & & MUITO APLICADOS \\
\hline & $X$ & MEDIAMENTE APLICADOS \\
\hline & & POUCO APLICADOS \\
\hline \multirow{2}{*}{$\begin{array}{l}\text { NÃO (indique ao lado a } \\
\text { razão da não aplicação) }\end{array}$} & & $\begin{array}{l}\text { CONTEÚDO NÃO ADEQUADO ȦS NECESSIDADES } \\
\text { ESPECÍFICAS DA REGIÃO }\end{array}$ \\
\hline & & $\begin{array}{l}\text { CONTEÚDO NÃO } \quad \text { FOI SUFICIENTEMENTE } \\
\text { APROFUNDADO PARA PERMITIR UMA APLICAÇÃO } \\
\text { EFICAZ E EFICIENTE }\end{array}$ \\
\hline
\end{tabular}




\begin{tabular}{|l|l|l|}
\hline \multirow{2}{*}{} & & $\begin{array}{l}\text { FALTA DE APOIO E INCENTIVO DA MINHA } \\
\text { INSTITUIÇÃO }\end{array}$ \\
\cline { 2 - 3 } & & FALTA DE INCENTIVO ÀS AÇÕES DE ATER \\
\cline { 2 - 3 } & & NÃO TENHO INTERESSE EM APLICAR \\
\hline
\end{tabular}

6) A partir deste curso: (As opções não são excludentes: você poderá marcar mais de uma opção).

\begin{tabular}{|l|l|}
\hline & NÃO MUDOU NADA EM MEU TRABALHO. \\
\hline & $\begin{array}{l}\text { MEU TRABALHO PASSOU A CONTRIBUIR MAIS COM OS AGRICULTORES(AS) } \\
\text { FAMILIARES. }\end{array}$ \\
\hline & CONSEGUI INFLUENCIAR NAS ORIENTAÇÕES DA MINHA INSTITUIÇÃO. \\
\hline & $\begin{array}{l}\text { CRESCEI A TRABALHAR COM METODOLOGIAS PARTICIPATIVAS. } \\
\text { ONDE ATUO. ÁREA DE AGRICULTURA DE BASE ECOLÓGICA NAS COMUNIDADES }\end{array}$ \\
\hline$X$ & CONTINUEI ME APERFEIÇOANDO SOBRE TEMAS ABORDADOS. \\
\hline
\end{tabular}

7) Depois do curso você apoiou atividades de capacitação de técnicos e agricultores com base nos princípios e diretrizes da Pnater? (Considere como apoio a atividades de capacitação a participação no planejamento, elaboração de ementas, seleção de participantes e de palestrantes.)

\begin{tabular}{|l|l|}
\hline$X$ & SIM \\
\hline & NÃO \\
\hline
\end{tabular}

8) Usou os conhecimentos para ministrar outros cursos com o mesmo conteúdo ou conteúdos semelhantes? 


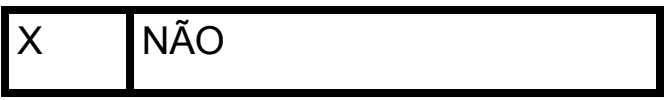

9) Marque o seu grau de satisfação com relação ao curso oferecido pelo DATER: (Considere a seguinte pontuação: 1 - MUITO RUIM; 2 - RUIM; 3 - REGULAR; 4 - BOM; 5 - MUITO BOM)

\begin{tabular}{|l|l|l|l|l|}
\hline 1 & 2 & 3 & $\times 4$ & 5 \\
\hline
\end{tabular}

10) Marque seu grau de satisfação com relação ao DATER: (Considere a seguinte pontuação: 1 - MUITO RUIM; 2 - RUIM; 3 - REGULAR; 4 - BOM; 5 - MUITO BOM)

\begin{tabular}{|l|l|l|l|l|}
\hline 1 & 2 & 3 & $\times 4$ & 5 \\
\hline
\end{tabular}




\section{PESQUISA - IMPACTO DAS AÇÕES DE FORMAÇÃO REALIZADAS PELO \\ DATER/SAF/MDA NO PERÍODO 2004-2009}

Caros colaboradores,

Contamos com a sua atenção para preencher o formulário abaixo.

O mesmo tem por objetivo fornecer informações para avaliação da Eficiência, Efetividade e Eficácia da Política Pública de Formação de Agentes de Ater adotada pelo Departamento de Assistência Técnica e Extensão Rural, da Secretaria de Agricultura Familiar do Ministério do Desenvolvimento - DATER/SAF/MDA, no período de 2004 a 2009, tema escolhido para Monografia a ser apresentada à Universidade de Brasília (UnB) como requisito parcial para obtenção do grau de Bacharel em Administração.

Você poderá ou não se identificar no questionário e garantimos que todas as informações fornecidas serão confidenciais e utilizadas apenas de forma sistematizada.

\section{IDENTIFICAÇÃO}

\begin{tabular}{|l|l|}
\hline Nome: Éder de Oliveira & $\begin{array}{l}\text { Sexo: } \\
(x) \text { masculino } \quad(\quad) \text { feminino }\end{array}$ \\
\hline $\begin{array}{l}\text { Instituição (nome e tipo de instituição: ONG, Local de trabalho (Cidade e Estado): Nova } \\
\text { Ompresa Pública, etc.): Instituto EMATER }\end{array}$ \\
\hline $\begin{array}{l}\text { Ourso/Encontro/Oficina do qual participou (caso tenha participado de mais de um curso, preencha } \\
\text { um formulário para cada um deles): Formação de agentes de ATER }\end{array}$ \\
\hline Data do Curso/Encontro/Oficina (pelo menos mês e ano): Junho 2008 \\
\hline
\end{tabular}

1. Indique sua área de atuação? (As opções não são excludentes: você poderá marcar mais de uma opção).

\begin{tabular}{|l|l|}
\hline$X$ & EXTENSÃO RURAL \\
\hline & PESQUISA \\
\hline & ENSINO \\
\hline & OUTROS \\
\hline
\end{tabular}


2) Qual o seu nível de escolaridade? ( Considere apenas o nível mais alto)

\begin{tabular}{|l|l|}
\hline & NÍVEL MÉDIO \\
\hline$X$ & NÍVEL SUPERIOR \\
\hline & PÓS-GRADUAÇÃO \\
\hline
\end{tabular}

3) Os conteúdos abordados foram condizentes com as demandas do seu dia-a-dia?

\begin{tabular}{|l|l|}
\hline$X$ & SIM \\
\hline & PARCIALMENTE \\
\hline & NÃO \\
\hline
\end{tabular}

4) O curso contribuiu para o seu aperfeiçoamento profissional?

\begin{tabular}{|l|l|}
\hline$X$ & SIM \\
\hline & NÃO \\
\hline
\end{tabular}

5) Os conhecimentos adquiridos estão sendo aplicados no seu trabalho? Em caso afirmativo, indique em que grau estes conhecimentos estão sendo aplicados. Em caso negativo, indique por que razão isto não ocorre:

\begin{tabular}{|c|c|}
\hline \multirow{3}{*}{$\begin{array}{l}\text { SIM (indique ao lado em } \\
\text { que grau) }\end{array}$} & MUITO APLICADOS \\
\hline & MEDIAMENTE APLICADOS \\
\hline & POUCO APLICADOS \\
\hline \multirow{6}{*}{$\begin{array}{l}\text { NÃO (indique ao lado a } \\
\text { razão da não aplicação) }\end{array} \mid$} & $\begin{array}{l}\text { CONTEÚDO NÃO ADEQUADO ÀS NECESSIDADES } \\
\text { ESPFCÍFICAS DA RFGIÃO }\end{array}$ \\
\hline & $\begin{array}{llll}\text { CONTEÚDO NÂO } & \text { FOI } & \text { SUFICIENTEMENTE }\end{array}$ \\
\hline & APROFUNDADO PARA PERMITIR UMA APLICAÇÃO \\
\hline & 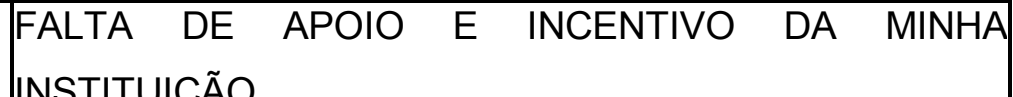 \\
\hline & FALTA DE INCENTIVO ÀS AÇÕES DE ATER \\
\hline & NÃO TENHO INTERESSE EM APLICAR \\
\hline
\end{tabular}

6) A partir deste curso: (As opções não são excludentes: você poderá marcar mais de uma opção). 


\begin{tabular}{|c|l|}
\hline$x$ & \begin{tabular}{l} 
NÃO MUDOU NADA EM MEU TRABALHO. \\
FAMILIARES. \\
\hline
\end{tabular} \\
\hline & CONSEGUI INFLUENCIAR NAS ORIENTAÇÕES DA MINHA INSTITUIÇÃO. \\
\hline & $\begin{array}{l}\text { CRESCEU A ÁREA DE AGRICULTURA DE BASE ECOLÓGICA NAS COMUNIDADES } \\
\text { ONDE ATUO. }\end{array}$ \\
\hline & CONTINUEI ME APERFEIÇOANDO SOBRE TEMAS ABORDADOS. \\
\hline
\end{tabular}

7) Depois do curso você apoiou atividades de capacitação de técnicos e agricultores com base nos princípios e diretrizes da Pnater? (Considere como apoio a atividades de capacitação a participação no planejamento, elaboração de ementas, seleção de participantes e de palestrantes.)

\begin{tabular}{|l|l|}
\hline$X$ & SIM \\
\hline & NÃO \\
\hline
\end{tabular}

8) Usou os conhecimentos para ministrar outros cursos com o mesmo conteúdo ou conteúdos semelhantes?

\begin{tabular}{|l|l|}
\hline$X$ & SIM \\
\hline & NÃO \\
\hline
\end{tabular}

9) Marque o seu grau de satisfação com relação ao curso oferecido pelo DATER: (Considere a seguinte pontuação: 1 - MUITO RUIM; 2 - RUIM; 3 - REGULAR; 4 - BOM; 5 - MUITO BOM)

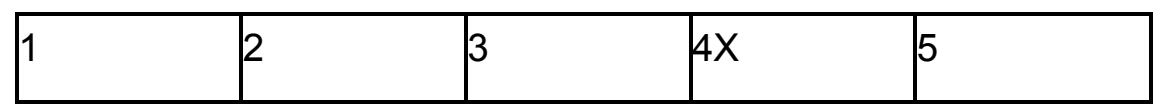

10) Marque seu grau de satisfação com relação ao DATER: (Considere a seguinte pontuação: 1 - MUITO RUIM; 2 - RUIM; 3 - REGULAR; 4 - BOM; 5 - MUITO BOM)

\begin{tabular}{|l|l|l|l|l|}
\hline 1 & 2 & 3 & $4 X$ & 5 \\
\hline
\end{tabular}




\section{PESQUISA - IMPACTO DAS AÇÕES DE FORMAÇÃO REALIZADAS PELO \\ DATER/SAF/MDA NO PERÍODO 2004-2009}

Caros colaboradores,

Contamos com a sua atenção para preencher o formulário abaixo.

O mesmo tem por objetivo fornecer informações para avaliação da Eficiência, Efetividade e Eficácia da Política Pública de Formação de Agentes de Ater adotada pelo Departamento de Assistência Técnica e Extensão Rural, da Secretaria de Agricultura Familiar do Ministério do Desenvolvimento - DATER/SAF/MDA, no período de 2004 a 2009, tema escolhido para Monografia a ser apresentada à Universidade de Brasília (UnB) como requisito parcial para obtenção do grau de Bacharel em Administração.

Você poderá ou não se identificar no questionário e garantimos que todas as informações fornecidas serão confidenciais e utilizadas apenas de forma sistematizada.

\section{IDENTIFICAÇÃO}

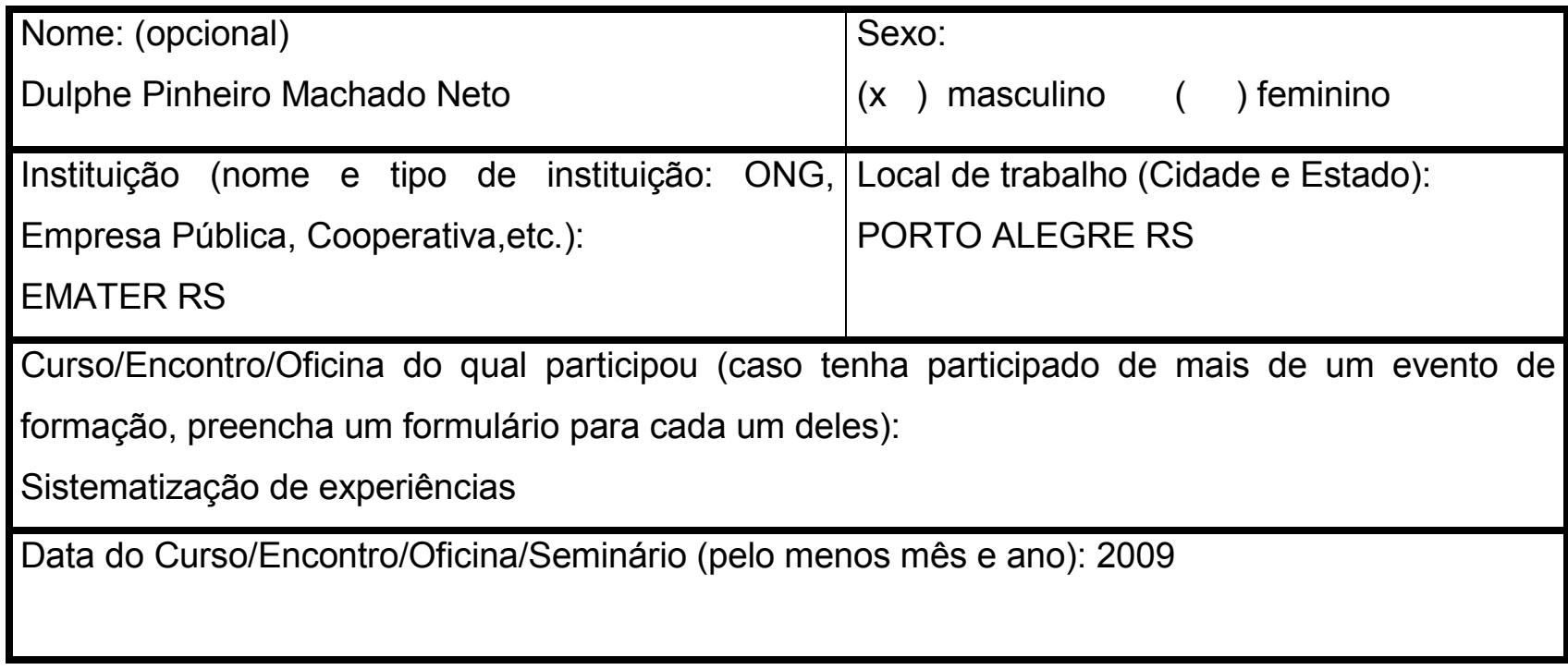

1) Indique sua área de atuação? (As opções não são excludentes: você poderá marcar mais de uma opção).

\begin{tabular}{|l|l|}
\hline$X$ & EXTENSÃO RURAL \\
\hline & PESQUISA \\
\hline & ENSINO \\
\hline & OUTROS \\
\hline
\end{tabular}


2) Qual o seu nível de escolaridade? (Considere apenas o nível mais alto)

\begin{tabular}{|l|l|}
\hline & NÍVEL MÉDIO \\
\hline & NÍVEL SUPERIOR \\
\hline$X$ & PÓS-GRADUAÇÃO \\
\hline
\end{tabular}

3) Os conteúdos abordados na formação foram condizentes com as demandas do seu dia-adia?

\begin{tabular}{|l|l|}
\hline & SIM \\
\hline$x$ & PARCIALMENTE \\
\hline & NÃO \\
\hline
\end{tabular}

4) O curso ou atividade de formação da qual você participou contribuiu para o seu aperfeiçoamento profissional?

\begin{tabular}{|l|l|}
\hline$x$ & SIM \\
\hline & NÃO \\
\hline
\end{tabular}

5) Os conhecimentos adquiridos nesta formação estão sendo aplicados no seu trabalho? Em caso afirmativo, indique em que grau estes conhecimentos estão sendo aplicados. Em caso negativo, indique por que razão isto não ocorre: (As respostas não são excludentes: você poderá marcar mais de uma opção).

\begin{tabular}{|c|c|c|}
\hline \multirow{3}{*}{$\begin{array}{l}\text { SIM (indique ao lado } \\
\text { em que grau) }\end{array}$} & & MUITO APLICADOS \\
\hline & $\mathrm{X}$ & MEDIAMENTE APLICADOS \\
\hline & & POUCO APLICADOS \\
\hline \multirow{2}{*}{$\begin{array}{l}\text { NÃO (indique ao lado a } \\
\text { razão da não } \\
\text { aplicação) }\end{array}$} & & $\begin{array}{l}\text { CONTEÚDO NÃO ADEQUADO ÀS NECESSIDADES } \\
\text { ESPECÍFICAS DA REGIÃO }\end{array}$ \\
\hline & & $\begin{array}{llll}\text { CONTEÚDO NÃO } & \text { FOI } & \text { SUFICIENTEMENTE } \\
\text { APROFUNDADO } & \text { PARA } & \text { PERMITIR } & \text { UMA } \\
\text { APLICAÇÃO EFICAZ E EFICIENTE } & \end{array}$ \\
\hline
\end{tabular}




\begin{tabular}{|l|l|l|}
\hline \multirow{2}{*}{} & & $\begin{array}{l}\text { FALTA DE APOIO E INCENTIVO DA MINHA } \\
\text { INSTITUIÇÃO }\end{array}$ \\
\hline & & FALTA DE INCENTIVO ÀS AÇÕES DE ATER \\
\hline & NÃO TENHO INTERESSE EM APLICAR \\
\hline
\end{tabular}

6) A partir do evento de formação do qual você participou: (As respostas não são excludentes: você poderá marcar mais de uma opção).

\begin{tabular}{|l|l|}
\hline$x$ & NÃO MUDOU NADA EM MEU TRABALHO. \\
\hline & $\begin{array}{l}\text { MEU TRABALHO PASSOU A CONTRIBUIR MAIS COM OS AGRICULTORES(AS) } \\
\text { FAMILIARES. }\end{array}$ \\
\hline & CONSEGUI INFLUENCIAR NAS ORIENTAÇÕES DA MINHA INSTITUIÇÃO. \\
\hline & $\begin{array}{l}\text { CRESCEU A TRABALHAR COM METODOLOGIAS PARTICIPATIVAS. } \\
\text { COMUNIDADES ONEA DE AGRICULTURA DE BASE ECOLÓGICA NAS }\end{array}$ \\
\hline & CONTINUEI ME APERFEIÇOANDO SOBRE TEMAS ABORDADOS. \\
\hline
\end{tabular}

7) Depois do evento de capacitação do qual participou, você apoiou atividades de capacitação de técnicos e/ou agricultores com base nos princípios e diretrizes da Pnater? (Considere como apoio a atividades de capacitação a participação no planejamento, elaboração de ementas, seleção de participantes e de palestrantes.)

\begin{tabular}{|l|l|}
\hline$X$ & SIM \\
\hline & NÃO \\
\hline
\end{tabular}

8) Usou os conhecimentos para ministrar outros eventos de formação com o mesmo conteúdo ou conteúdos semelhantes?

\begin{tabular}{|l|l|}
\hline$X$ & SIM \\
\hline & NÃO \\
\hline
\end{tabular}


9) Marque o seu grau de satisfação com relação a atividade de formação oferecida pelo DATER: (Considere a seguinte pontuação: 1 - MUITO RUIM; 2 - RUIM; 3 - REGULAR; 4 BOM; 5 - MUITO BOM)

\begin{tabular}{|l|l|l|l|l|}
\hline 1 & 2 & 3 & $X 4$ & 5 \\
\hline
\end{tabular}

10) Marque seu grau de satisfação com relação ao DATER: (Considere a seguinte pontuação: 1 - MUITO RUIM; 2 - RUIM; 3 - REGULAR; 4 - BOM; 5 - MUITO BOM)

\begin{tabular}{|l|l|l|l|l|}
\hline 1 & 2 & 3 & $\times 4$ & 5 \\
\hline
\end{tabular}




\section{PESQUISA - IMPACTO DAS AÇÕES DE FORMAÇÃO REALIZADAS PELO \\ DATER/SAF/MDA NO PERÍODO 2004-2009}

Caros colaboradores,

Contamos com a sua atenção para preencher o formulário abaixo.

O mesmo tem por objetivo fornecer informações para avaliação da Eficiência, Efetividade e Eficácia da Política Pública de Formação de Agentes de Ater adotada pelo Departamento de Assistência Técnica e Extensão Rural, da Secretaria de Agricultura Familiar do Ministério do Desenvolvimento - DATER/SAF/MDA, no período de 2004 a 2009, tema escolhido para Monografia a ser apresentada à Universidade de Brasília (UnB) como requisito parcial para obtenção do grau de Bacharel em Administração.

Você poderá ou não se identificar no questionário e garantimos que todas as informações fornecidas serão confidenciais e utilizadas apenas de forma sistematizada.

IDENTIFICAÇÃO

\begin{tabular}{|l|l|}
\hline Nome: Éder de Oliveira & $\begin{array}{l}\text { Sexo: } \\
(x) \text { masculino } \quad(\quad) \text { feminino }\end{array}$ \\
\hline $\begin{array}{l}\text { Instituição (nome e tipo de instituição: ONG, } \\
\text { Empresa Pública, etc.): Instituto EMATER } \\
\text { Olímpia-PR }\end{array}$ \\
\hline $\begin{array}{l}\text { Curso/Encontro/Oficina do qual participou (caso tenha participado de mais de um curso, preencha } \\
\text { um formulário para cada um deles): Formação de agentes de ATER }\end{array}$ \\
\hline Data do Curso/Encontro/Oficina (pelo menos mês e ano): Junho 2008 \\
\hline
\end{tabular}

1. Indique sua área de atuação? (As opções não são excludentes: você poderá marcar mais de uma opção).

\begin{tabular}{|l|l|}
\hline$X$ & EXTENSÃO RURAL \\
\hline & PESQUISA \\
\hline & ENSINO \\
\hline & OUTROS \\
\hline
\end{tabular}

2) Qual o seu nível de escolaridade? ( Considere apenas o nível mais alto) 


\begin{tabular}{|l|l|}
\hline & NÍVEL MÉDIO \\
\hline$X$ & NÍVEL SUPERIOR \\
\hline & PÓS-GRADUAÇÃO \\
\hline
\end{tabular}

3) Os conteúdos abordados foram condizentes com as demandas do seu dia-a-dia?

\begin{tabular}{|l|l|}
\hline$X$ & SIM \\
\hline & PARCIALMENTE \\
\hline & NÃO \\
\hline
\end{tabular}

4) O curso contribuiu para o seu aperfeiçoamento profissional?

\begin{tabular}{|l|l|}
\hline$X$ & SIM \\
\hline & NÃO \\
\hline
\end{tabular}

5) Os conhecimentos adquiridos estão sendo aplicados no seu trabalho? Em caso afirmativo, indique em que grau estes conhecimentos estão sendo aplicados. Em caso negativo, indique por que razão isto não ocorre:

\begin{tabular}{|c|c|}
\hline \multirow{3}{*}{$\begin{array}{l}\text { SIM (indique ao lado em, } \\
\text { que grau) }\end{array}$} & MUITO APLICADOS \\
\hline & MEDIAMENTE APLICADOS \\
\hline & POUCO APLICADOS \\
\hline \multirow{5}{*}{$\begin{array}{l}\text { NÃO (indique ao lado a } \\
\text { razão da não aplicação) }\end{array}$} & $\begin{array}{l}\text { CONTEÚDO NÃO ADEQUADO ÀS NECESSIDADES } \\
\text { ESPECíFICAS SA REGIÃO }\end{array}$ \\
\hline & 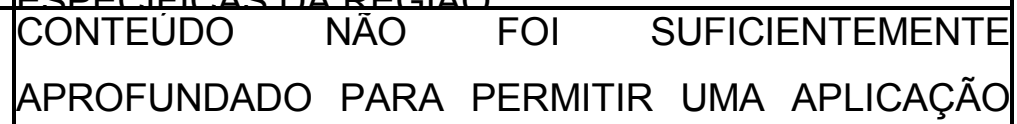 \\
\hline & 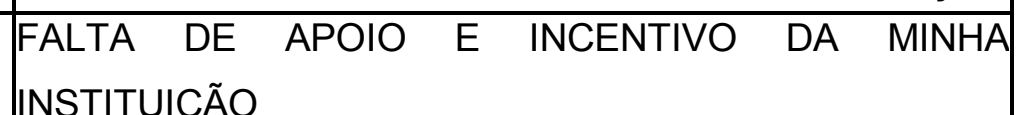 \\
\hline & FALTA DE INCENTIVO ÀS AÇÕES DE ATER \\
\hline & NÃO TENHO INTERESSE EM APLICAR \\
\hline
\end{tabular}

6) A partir deste curso: (As opções não são excludentes: você poderá marcar mais de uma opção). 


\begin{tabular}{|c|l|}
\hline$x$ & \begin{tabular}{l} 
NÃO MUDOU NADA EM MEU TRABALHO. \\
FAMILIARES. \\
\hline
\end{tabular} \\
\hline & CONSEGUI INFLUENCIAR NAS ORIENTAÇÕES DA MINHA INSTITUIÇÃO. \\
\hline & $\begin{array}{l}\text { CRESCEU A ÁREA DE AGRICULTURA DE BASE ECOLÓGICA NAS COMUNIDADES } \\
\text { ONDE ATUO. }\end{array}$ \\
\hline & CONTINUEI ME APERFEIÇOANDO SOBRE TEMAS ABORDADOS. \\
\hline
\end{tabular}

7) Depois do curso você apoiou atividades de capacitação de técnicos e agricultores com base nos princípios e diretrizes da Pnater? (Considere como apoio a atividades de capacitação a participação no planejamento, elaboração de ementas, seleção de participantes e de palestrantes.)

\begin{tabular}{|l|l|}
\hline$X$ & SIM \\
\hline & NÃO \\
\hline
\end{tabular}

8) Usou os conhecimentos para ministrar outros cursos com o mesmo conteúdo ou conteúdos semelhantes?

\begin{tabular}{|l|l|}
\hline$X$ & SIM \\
\hline & NÃO \\
\hline
\end{tabular}

9) Marque o seu grau de satisfação com relação ao curso oferecido pelo DATER: (Considere a seguinte pontuação: 1 - MUITO RUIM; 2 - RUIM; 3 - REGULAR; 4 - BOM; 5 - MUITO BOM)

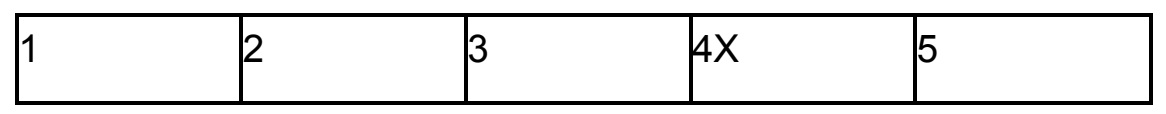

10) Marque seu grau de satisfação com relação ao DATER: (Considere a seguinte pontuação: 1 - MUITO RUIM; 2 - RUIM; 3 - REGULAR; 4 - BOM; 5 - MUITO BOM)

\begin{tabular}{|l|l|l|l|l|}
\hline 1 & 2 & 3 & $4 X$ & 5 \\
\hline
\end{tabular}




\section{PESQUISA - IMPACTO DAS AÇÕES DE FORMAÇÃO REALIZADAS PELO \\ DATER/SAF/MDA NO PERÍODO 2004-2009}

Caros colaboradores,

Contamos com a sua atenção para preencher o formulário abaixo.

O mesmo tem por objetivo fornecer informações para avaliação da Eficiência, Efetividade e Eficácia da Política Pública de Formação de Agentes de Ater adotada pelo Departamento de Assistência Técnica e Extensão Rural, da Secretaria de Agricultura Familiar do Ministério do Desenvolvimento - DATER/SAF/MDA, no período de 2004 a 2009, tema escolhido para Monografia a ser apresentada à Universidade de Brasília (UnB) como requisito parcial para obtenção do grau de Bacharel em Administração.

Você poderá ou não se identificar no questionário e garantimos que todas as informações fornecidas serão confidenciais e utilizadas apenas de forma sistematizada.

\section{IDENTIFICAÇÃO}

\begin{tabular}{|l|l|l|}
\hline Nome: Ediene C S Ruiz & $\begin{array}{l}\text { Sexo: } \\
(\quad) \text { masculino } \quad(\mathrm{x}) \text { feminino }\end{array}$ \\
\hline $\begin{array}{l}\text { Instituição (nome e tipo de instituição: ONG, } \\
\text { Empresa Pública, etc.): Centro de apoio ao } \\
\text { Pequeno Agricultor- CAPA/ ONG }\end{array}$ & Pelotas -RS \\
\hline $\begin{array}{l}\text { Curso/Encontro/Oficina do qual participou (caso tenha participado de mais de um curso, preencha } \\
\text { um formulário para cada um deles): METODOLOGIAS PARTICIPATIVAS/ Diagnostico } \\
\text { Participativo }\end{array}$ \\
\hline Data do Curso/Encontro/Oficina (pelo menos mês e ano): abril de 2008 \\
\hline
\end{tabular}

1 Indique sua área de atuação? (As opções não são excludentes: você poderá marcar mais de uma opção).

\begin{tabular}{|l|l|}
\hline$X$ & EXTENSÃO RURAL \\
\hline & PESQUISA \\
\hline & ENSINO \\
\hline & OUTROS \\
\hline
\end{tabular}

2) Qual o seu nível de escolaridade? ( Considere apenas o nível mais alto) 


\begin{tabular}{|l|l|}
\hline & NÍVEL MÉDIO \\
\hline & NÍVEL SUPERIOR \\
\hline$X$ & PÓS-GRADUAÇÃO \\
\hline
\end{tabular}

3) Os conteúdos abordados foram condizentes com as demandas do seu dia-a-dia?

\begin{tabular}{|l|l|}
\hline$X$ & SIM \\
\hline & PARCIALMENTE \\
\hline & NÃO \\
\hline
\end{tabular}

4) O curso contribuiu para o seu aperfeiçoamento profissional?

\begin{tabular}{|l|l|}
\hline$X$ & SIM \\
\hline & NÃO \\
\hline
\end{tabular}

5) Os conhecimentos adquiridos estão sendo aplicados no seu trabalho? Em caso afirmativo, indique em que grau estes conhecimentos estão sendo aplicados. Em caso negativo, indique por que razão isto não ocorre:

\begin{tabular}{|c|c|c|c|}
\hline \multirow{3}{*}{$x$} & \multirow{3}{*}{$\begin{array}{l}\text { SIM (indique ao lado em } \\
\text { que grau) }\end{array}$} & & MUITO APLICADOS \\
\hline & & $\mathrm{X}$ & MEDIAMENTE APLICADOS \\
\hline & & & POUCO APLICADOS \\
\hline & \multirow{5}{*}{$\begin{array}{l}\text { NÃO (indique ao lado a } \\
\text { razão da não aplicação) }\end{array}$} & & $\begin{array}{l}\text { CONTEÚDO NÃO ADEQUADO ÀS NECESSIDADES } \\
\text { FSPECÍFICAS }\end{array}$ \\
\hline & & & $\begin{array}{llll}\text { CONTEUDO } & \text { NÃO } & \text { FOI } & \text { SUFICIENTEMENTE } \\
\text { APROFUNDADO } & \text { PARA } & \text { PERMITIR UMA } & \text { APLICAÇÃO }\end{array}$ \\
\hline & & & 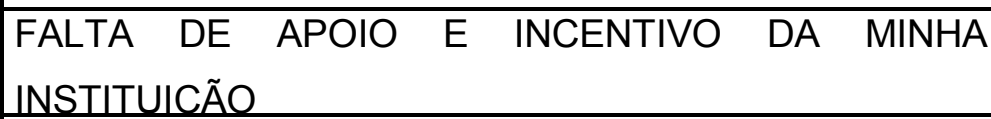 \\
\hline & & & FALTA DE INCENTIVO ÀS AÇÕES DE ATER \\
\hline & & & NÃO TENHO INTERESSE EM APLICAR \\
\hline
\end{tabular}

6) A partir deste curso: (As opções não são excludentes: você poderá marcar mais de uma opção). 


\begin{tabular}{|l|l|}
\hline & NÃO MUDOU NADA EM MEU TRABALHO. \\
\hline$X$ & $\begin{array}{l}\text { MEU TRABALHO PASSOU A CONTRIBUIR MAIS COM OS AGRICULTORES(AS) } \\
\text { FAMILIARES. }\end{array}$ \\
\hline & CONSEGUI INFLUENCIAR NAS ORIENTAÇÕES DA MINHA INSTITUIÇÃO. \\
\hline & PASSEI A TRABALHAR COM METODOLOGIAS PARTICIPATIVAS. \\
\hline & $\begin{array}{l}\text { CRESCEU A ÁREA DE AGRICULTURA DE BASE ECOLÓGICA NAS COMUNIDADES } \\
\text { ONDE ATUO. }\end{array}$ \\
\hline & CONTINUEI ME APERFEIÇOANDO SOBRE TEMAS ABORDADOS. \\
\hline
\end{tabular}

7) Depois do curso você apoiou atividades de capacitação de técnicos e agricultores com base nos princípios e diretrizes da Pnater? (Considere como apoio a atividades de capacitação a participação no planejamento, elaboração de ementas, seleção de participantes e de palestrantes.)

\begin{tabular}{|l|l|}
\hline & SIM \\
\hline$X$ & NÃO \\
\hline
\end{tabular}

8) Usou os conhecimentos para ministrar outros cursos com o mesmo conteúdo ou conteúdos semelhantes?

\begin{tabular}{|l|l|}
\hline & SIM \\
\hline$X$ & NÃO \\
\hline
\end{tabular}

9) Marque o seu grau de satisfação com relação ao curso oferecido pelo DATER: (Considere a seguinte pontuação: 1 - MUITO RUIM; 2 - RUIM; 3 - REGULAR; 4 - BOM; 5 - MUITO BOM)

\begin{tabular}{|l|l|l|l|l|}
\hline 1 & 2 & 3 & 4 & $5 X$ \\
\hline
\end{tabular}

10) Marque seu grau de satisfação com relação ao DATER: (Considere a seguinte pontuação: 1 - MUITO RUIM; 2 - RUIM; 3 - REGULAR; 4 - BOM; 5 - MUITO BOM)

\begin{tabular}{|l|l|l|l|l|}
\hline 1 & 2 & 3 & 4 & $5 X$ \\
\hline
\end{tabular}




\section{PESQUISA - IMPACTO DAS AÇÕES DE FORMAÇÃO REALIZADAS PELO \\ DATER/SAF/MDA NO PERÍODO 2004-2009}

Caros colaboradores,

Contamos com a sua atenção para preencher o formulário abaixo.

O mesmo tem por objetivo fornecer informações para avaliação da Eficiência, Efetividade e Eficácia da Política Pública de Formação de Agentes de Ater adotada pelo Departamento de Assistência Técnica e Extensão Rural, da Secretaria de Agricultura Familiar do Ministério do Desenvolvimento - DATER/SAF/MDA, no período de 2004 a 2009, tema escolhido para Monografia a ser apresentada à Universidade de Brasília (UnB) como requisito parcial para obtenção do grau de Bacharel em Administração.

Você poderá ou não se identificar no questionário e garantimos que todas as informações fornecidas serão confidenciais e utilizadas apenas de forma sistematizada.

\section{IDENTIFICAÇÃO}

\begin{tabular}{|l|l|}
\hline Nome: Fábio Melo Pontes & $\begin{array}{l}\text { Sexo: } \\
(x) \text { masculino } \quad(\quad) \text { feminino }\end{array}$ \\
\hline $\begin{array}{l}\text { Instituição (nome e tipo de instituição: ONG, } \\
\text { Empresa Pública, etc.): SEAB - EMATER } \\
\text { Procópio - Paraná }\end{array}$ \\
\hline $\begin{array}{l}\text { Curso/Encontro/Oficina do qual participou (caso tenha participado de mais de um curso, preencha } \\
\text { um formulário para cada um deles): Formação de Agentes de ATER - Sistemas Agroflorestais }\end{array}$ \\
\hline $\begin{array}{l}\text { Data do Curso/Encontro/Oficina (pelo menos mês e ano): 05/05 a 16/05/2008 realizado no CETRE - } \\
\text { Centro de Treinamento da EPAGRI - Florianópolis SC. }\end{array}$ \\
\hline
\end{tabular}

1. Indique sua área de atuação? (As opções não são excludentes: você poderá marcar mais de uma opção).

\begin{tabular}{|l|l|}
\hline$X$ & EXTENSÃO RURAL \\
\hline & PESQUISA \\
\hline & ENSINO \\
\hline & OUTROS \\
\hline
\end{tabular}

2) Qual o seu nível de escolaridade? (Considere apenas o nível mais alto) 


\begin{tabular}{|l|l|}
\hline & NÍVEL MÉDIO \\
\hline$X$ & NÍVEL SUPERIOR \\
\hline$X$ & PÓS-GRADUAÇÃO \\
\hline
\end{tabular}

3) Os conteúdos abordados foram condizentes com as demandas do seu dia-a-dia?

\begin{tabular}{|l|l|}
\hline$X$ & SIM \\
\hline & PARCIALMENTE \\
\hline & NÃO \\
\hline
\end{tabular}

4) O curso contribuiu para o seu aperfeiçoamento profissional?

\begin{tabular}{|l|l|}
\hline$X$ & SIM \\
\hline & NÃO \\
\hline
\end{tabular}

5) Os conhecimentos adquiridos estão sendo aplicados no seu trabalho? Em caso afirmativo, indique em que grau estes conhecimentos estão sendo aplicados. Em caso negativo, indique por que razão isto não ocorre:

\begin{tabular}{|c|c|}
\hline \multirow{3}{*}{$\begin{array}{l}\text { SIM (indique ao lado em } \\
\text { que grau) }\end{array}$} & MUITO APLICADOS \\
\hline & MEDIAMENTE APLICADOS \\
\hline & POUCO APLICADOS \\
\hline \multirow{6}{*}{$\begin{array}{l}\text { NÃO (indique ao lado a } \\
\text { razão da não aplicação) }\end{array}$} & $\begin{array}{l}\text { CONTEÚDO NÃO ADEQUADO ÀS NECESSIDADES } \\
\text { ESPECÍEICAS RA RFGIÃO }\end{array}$ \\
\hline & $\begin{array}{lllr}\text { CONTEUDDO } & \text { NÃO } & \text { FOI } & \text { SUFICIENTEMENTE } \\
\text { APROFUNDADO } & \text { PARA } & \text { PERMITIR UMA } & \text { APLICACÃO }\end{array}$ \\
\hline & FALTA DE APOIO E INCENTIVO DA MINHA \\
\hline & INSTITUICÃO \\
\hline & FALTA DE INCENTIVO ÀS AÇÕES DE ATER \\
\hline & NÃO TENHO INTERESSE EM APLICAR \\
\hline
\end{tabular}


6) A partir deste curso: (As opções não são excludentes: você poderá marcar mais de uma opção).

\begin{tabular}{|l|l|}
\hline & NÃO MUDOU NADA EM MEU TRABALHO. \\
\hline$X$ & $\begin{array}{l}\text { MEU TRABALHO PASSOU A CONTRIBUIR MAIS COM OS AGRICULTORES(AS) } \\
\text { FAMILIARES. }\end{array}$ \\
\hline & CONSEGUI INFLUENCIAR NAS ORIENTAÇÕES DA MINHA INSTITUIÇÃO. \\
\hline & $\begin{array}{l}\text { CASSEI A TRABALHAR COM METODOLOGIAS PARTICIPATIVAS. } \\
\text { ONDE ATUO. }\end{array}$ \\
\hline$X$ & CONTINUEI ME APERFEIÇOANDO SOBRE TEMAS ABORDADOS. \\
\hline
\end{tabular}

7) Depois do curso você apoiou atividades de capacitação de técnicos e agricultores com base nos princípios e diretrizes da Pnater? (Considere como apoio a atividades de capacitação a participação no planejamento, elaboração de ementas, seleção de participantes e de palestrantes.)

\begin{tabular}{|l|l|}
\hline$X$ & SIM \\
\hline & NÃO \\
\hline
\end{tabular}

8) Usou os conhecimentos para ministrar outros cursos com o mesmo conteúdo ou conteúdos semelhantes?

\begin{tabular}{|l|l|}
\hline & SIM \\
\hline$X$ & NÃO \\
\hline
\end{tabular}

9) Marque o seu grau de satisfação com relação ao curso oferecido pelo DATER: (Considere a seguinte pontuação: 1 - MUITO RUIM; 2 - RUIM; 3 - REGULAR; 4 - BOM; 5 - MUITO BOM)

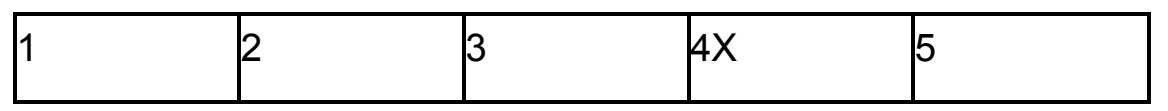

10) Marque seu grau de satisfação com relação ao DATER: (Considere a seguinte pontuação:

1 - MUITO RUIM; 2 - RUIM; 3 - REGULAR; 4 - BOM; 5 - MUITO BOM)

\begin{tabular}{|l|l|l|l|l|}
\hline 1 & 2 & 3 & $4 X$ & 5 \\
\hline
\end{tabular}




\section{PESQUISA - IMPACTO DAS AÇÕES DE FORMAÇÃO REALIZADAS PELO \\ DATER/SAF/MDA NO PERÍODO 2004-2009}

Caros colaboradores,

Contamos com a sua atenção para preencher o formulário abaixo.

O mesmo tem por objetivo fornecer informações para avaliação da Eficiência, Efetividade e Eficácia da Política Pública de Formação de Agentes de Ater adotada pelo Departamento de Assistência Técnica e Extensão Rural, da Secretaria de Agricultura Familiar do Ministério do Desenvolvimento - DATER/SAF/MDA, no período de 2004 a 2009, tema escolhido para Monografia a ser apresentada à Universidade de Brasília (UnB) como requisito parcial para obtenção do grau de Bacharel em Administração.

Você poderá ou não se identificar no questionário e garantimos que todas as informações fornecidas serão confidenciais e utilizadas apenas de forma sistematizada.

\section{IDENTIFICAÇÃO}

\begin{tabular}{|l|l|}
\hline Nome: Frank Silvano Lagos & $\begin{array}{l}\text { Sexo: } \\
(x \quad) \text { masculino } \quad(\quad \text { ) feminino }\end{array}$ \\
\hline Instituição Instituto Maytenus & $\begin{array}{l}\text { Local de trabalho Região Sudoeste do } \\
\text { Estado do Paraná }\end{array}$ \\
\hline Curso/Encontro/Oficina do qual participou Curso de Aperfeiçoamento em Agroecologia (Redcapa) \\
\hline Data do Curso/Encontro/Oficina (pelo menos mês e ano): março a junho/2006 \\
\hline
\end{tabular}

1. Indique sua área de atuação? (As opções não são excludentes: você poderá marcar mais de uma opção).

\begin{tabular}{|l|l|}
\hline$x$ & EXTENSÃO RURAL \\
\hline & PESQUISA \\
\hline & ENSINO \\
\hline$x$ & consultoria \\
\hline
\end{tabular}

2) Qual o seu nível de escolaridade? (Considere apenas o nível mais alto) 


\begin{tabular}{|l|l|}
\hline & NÍVEL MÉDIO \\
\hline & NÍVEL SUPERIOR \\
\hline$x$ & PÓS-GRADUAÇÃO \\
\hline
\end{tabular}

3) Os conteúdos abordados foram condizentes com as demandas do seu dia-a-dia?

\begin{tabular}{|l|l|}
\hline & SIM \\
\hline$x$ & PARCIALMENTE \\
\hline & NÃO \\
\hline
\end{tabular}

4) O curso contribuiu para o seu aperfeiçoamento profissional?

\begin{tabular}{|l|l|}
\hline$x$ & SIM \\
\hline & NÃO \\
\hline
\end{tabular}

5) Os conhecimentos adquiridos estão sendo aplicados no seu trabalho? Em caso afirmativo, indique em que grau estes conhecimentos estão sendo aplicados. Em caso negativo, indique por que razão isto não ocorre:

\begin{tabular}{|c|c|c|}
\hline \multirow{3}{*}{$\begin{array}{l}\text { SIM (indique ao lado em } \\
\text { que grau) }\end{array}$} & & MUITO APLICADOS \\
\hline & $x$ & MEDIAMENTE APLICADOS \\
\hline & & POUCO APLICADOS \\
\hline \multirow{5}{*}{$\begin{array}{l}\text { NÃO (indique ao lado a } \\
\text { razão da não aplicação) }\end{array}$} & & $\begin{array}{l}\text { CONTEÚDO NÃO ADEQUADO ȦS NECESSIDADES } \\
\text { ESPECÍFICAS DA REGIÃO }\end{array}$ \\
\hline & & $\begin{array}{l}\text { CONTEÚDO NÃO FOI SUFICIENTEMENTE } \\
\text { APROFUNDADO PARA PERMITIR UMA APLICAÇÃO } \\
\text { EFICAZ E EFICIENTE }\end{array}$ \\
\hline & & $\begin{array}{lcccccc}\text { FALTA } & \text { DE } & \text { APOIO } & \text { E } & \text { INCENTIVO } & \text { DA } & \text { MINHA } \\
\text { INSTITUIÇÃO } & & & & & \\
\end{array}$ \\
\hline & & FALTA DE INCENTIVO ÀS AÇÕES DE ATER \\
\hline & & NÃO TENHO INTERESSE EM APLICAR \\
\hline
\end{tabular}


6) A partir deste curso: (As opções não são excludentes: você poderá marcar mais de uma opção).

\begin{tabular}{|l|l|}
\hline & NÃO MUDOU NADA EM MEU TRABALHO. \\
\hline & $\begin{array}{l}\text { MEU TRABALHO PASSOU A CONTRIBUIR MAIS COM OS AGRICULTORES(AS) } \\
\text { FAMILIARES. }\end{array}$ \\
\hline & CONSEGUI INFLUENCIAR NAS ORIENTAÇÕES DA MINHA INSTITUIÇÃO. \\
\hline & PASSEI A TRABALHAR COM METODOLOGIAS PARTICIPATIVAS. \\
\hline & ONESCEU A ÁREA DE AGRICULTURA DE BASE ECOLÓGICA NAS COMUNIDADES \\
\hline$x$ & CONTINUEI ME APERFEIÇOANDO SOBRE TEMAS ABORDADOS. \\
\hline
\end{tabular}

7) Depois do curso você apoiou atividades de capacitação de técnicos e agricultores com base nos princípios e diretrizes da Pnater? (Considere como apoio a atividades de capacitação a participação no planejamento, elaboração de ementas, seleção de participantes e de palestrantes.)

\begin{tabular}{|l|l|}
\hline$x$ & SIM \\
\hline & NÃO \\
\hline
\end{tabular}

8) Usou os conhecimentos para ministrar outros cursos com o mesmo conteúdo ou conteúdos semelhantes?

\begin{tabular}{|l|l|}
\hline$x$ & SIM \\
\hline & NÃO \\
\hline
\end{tabular}

9) Marque o seu grau de satisfação com relação ao curso oferecido pelo DATER: (Considere a seguinte pontuação: 1 - MUITO RUIM; 2 - RUIM; 3 - REGULAR; 4 - BOM; 5 - MUITO BOM)

\begin{tabular}{|l|l|l|l|l|}
\hline 1 & $x$ & 3 & 4 & 5 \\
\hline
\end{tabular}


10) Marque seu grau de satisfação com relação ao DATER: (Considere a seguinte pontuação: 1 - MUITO RUIM; 2 - RUIM; 3 - REGULAR; 4 - BOM; 5 - MUITO BOM)

\begin{tabular}{|l|l|l|l|l|}
\hline 1 & 2 & $x$ & 4 & 5 \\
\hline
\end{tabular}




\section{PESQUISA - IMPACTO DAS AÇÕES DE FORMAÇÃO REALIZADAS PELO \\ DATER/SAF/MDA NO PERÍODO 2004-2009}

Caros colaboradores,

Contamos com a sua atenção para preencher o formulário abaixo.

O mesmo tem por objetivo fornecer informações para avaliação da Eficiência, Efetividade e Eficácia da Política Pública de Formação de Agentes de Ater adotada pelo Departamento de Assistência Técnica e Extensão Rural, da Secretaria de Agricultura Familiar do Ministério do Desenvolvimento - DATER/SAF/MDA, no período de 2004 a 2009, tema escolhido para Monografia a ser apresentada à Universidade de Brasília (UnB) como requisito parcial para obtenção do grau de Bacharel em Administração.

Você poderá ou não se identificar no questionário e garantimos que todas as informações fornecidas serão confidenciais e utilizadas apenas de forma sistematizada.

\section{IDENTIFICAÇÃO}

\begin{tabular}{|l|l|}
\hline Nome: João Paulo Dornelles Reck & $\begin{array}{l}\text { Sexo: } \\
(x) \text { masculino } \quad(\quad) \text { feminino }\end{array}$ \\
\hline $\begin{array}{l}\text { Instituição (nome e tipo de instituição: ONG, } \\
\text { Empresa Pública, etc.): Epagri }\end{array}$ & $\begin{array}{l}\text { Local de trabalho (Cidade e Estado): } \\
\text { Rio Fortuna }\end{array}$ \\
\hline $\begin{array}{l}\text { Curso/Encontro/Oficina do qual participou (caso tenha participado de mais de um curso, preencha } \\
\text { um formulário para cada um deles): Sistemas Agroflorestais }\end{array}$ \\
\hline Data do Curso/Encontro/Oficina (pelo menos mês e ano): 05/2008 \\
\hline
\end{tabular}

1. Indique sua área de atuação? (As opções não são excludentes: você poderá marcar mais de uma opção).

\begin{tabular}{|l|l|}
\hline$X$ & EXTENSÃO RURAL \\
\hline & PESQUISA \\
\hline & ENSINO \\
\hline & OUTROS \\
\hline
\end{tabular}

2) Qual o seu nível de escolaridade? (Considere apenas o nível mais alto) 


\begin{tabular}{|l|l|}
\hline & NÍVEL MÉDIO \\
\hline$X$ & NÍVEL SUPERIOR \\
\hline & PÓS-GRADUAÇÃO \\
\hline
\end{tabular}

3) Os conteúdos abordados foram condizentes com as demandas do seu dia-a-dia?

\begin{tabular}{|l|l|}
\hline & SIM \\
\hline$x$ & PARCIALMENTE \\
\hline & NÃO \\
\hline
\end{tabular}

4) O curso contribuiu para o seu aperfeiçoamento profissional?

\begin{tabular}{|l|l|}
\hline$x$ & SIM \\
\hline & NÃO \\
\hline
\end{tabular}

5) Os conhecimentos adquiridos estão sendo aplicados no seu trabalho? Em caso afirmativo, indique em que grau estes conhecimentos estão sendo aplicados. Em caso negativo, indique por que razão isto não ocorre:

\begin{tabular}{|c|c|c|c|}
\hline $\mathrm{x}$ & \multirow{3}{*}{$\begin{array}{l}\text { SIM (indique ao lado em } \\
\text { que grau) }\end{array}$} & & MUITO APLICADOS \\
\hline \multirow[t]{2}{*}{$x$} & & & MEDIAMENTE APLICADOS \\
\hline & & $\bar{x}$ & POUCO APLICADOS \\
\hline & \multirow{5}{*}{$\begin{array}{l}\text { NÃO (indique ao lado a } \\
\text { razão da não aplicação) }\end{array}$} & & CONTEÚDO NÃO ADEQUADO ÀS NECESSIDADES \\
\hline & & & $\begin{array}{llll}\text { CONTEUUDO } & \text { NÂO } & \text { FOI SUFICIENTEMENTE } \\
\text { APROFUNDADO } & \text { PARA } & \text { PERMITIR UMA APLICAÇÃO }\end{array}$ \\
\hline & & & 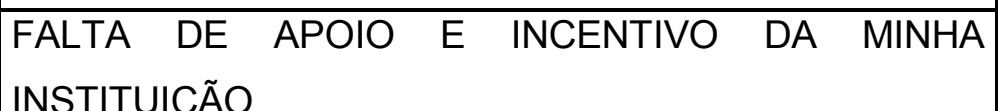 \\
\hline & & & FALTA DE INCENTIVO ÀS AÇÕES DE ATER \\
\hline & & & \begin{tabular}{|l|} 
NÃO TENHO INTERESSE EM APLICAR \\
\end{tabular} \\
\hline
\end{tabular}

6) A partir deste curso: 


\begin{tabular}{|l|l|}
\hline$x$ & $\begin{array}{l}\text { NÃO MUDOU NADA EM MEU TRABALHO. } \\
\text { FAMILIARES. }\end{array}$ \\
\hline & CONSEGUI INFLUENCIAR NAS ORIENTAÇÕES DA MINHA INSTITUIÇÃO. \\
\hline & PASSEI A TRABALHAR COM METODOLOGIAS PARTICIPATIVAS. \\
& $\begin{array}{l}\text { ORESCEU A ÁREA DE AGRICULTURA DE BASE ECOLÓGICA NAS COMUNIDADES } \\
\text { CONTINUEI ME APERFEIÇOANDO SOBRE TEMAS ABORDADOS. }\end{array}$ \\
\hline
\end{tabular}

7) Depois do curso você apoiou atividades de capacitação de técnicos e agricultores com base nos princípios e diretrizes da Pnater? (Considere como apoio a atividades de capacitação a participação no planejamento, elaboração de ementas, seleção de participantes e de palestrantes.)

\begin{tabular}{|l|l|}
\hline & SIM \\
\hline$x$ & NÃO \\
\hline
\end{tabular}

8) Usou os conhecimentos para ministrar outros cursos com o mesmo conteúdo ou conteúdos semelhantes?

\begin{tabular}{|l|l|}
\hline & SIM \\
\hline$x$ & NÃO \\
\hline
\end{tabular}

9) Marque o seu grau de satisfação com relação ao curso oferecido pelo DATER: (Considere a seguinte pontuação: 1 - MUITO RUIM; 2 - RUIM; 3 - REGULAR; 4 - BOM; 5 - MUITO BOM)

\begin{tabular}{|l|l|l|l|l|}
\hline$x$ & 2 & 3 & 4 & 5 \\
\hline
\end{tabular}

10) Marque seu grau de satisfação com relação ao DATER: (Considere a seguinte pontuação: 1 - MUITO RUIM; 2 - RUIM; 3 - REGULAR; 4 - BOM; 5 - MUITO BOM)

\begin{tabular}{|l|l|l|l|l|}
\hline 1 & $x$ & 3 & 4 & 5 \\
\hline
\end{tabular}




\section{PESQUISA - IMPACTO DAS AÇÕES DE FORMAÇÃO REALIZADAS PELO \\ DATER/SAF/MDA NO PERÍODO 2004-2009}

Caros colaboradores,

Contamos com a sua atenção para preencher o formulário abaixo.

O mesmo tem por objetivo fornecer informações para avaliação da Eficiência, Efetividade e Eficácia da Política Pública de Formação de Agentes de Ater adotada pelo Departamento de Assistência Técnica e Extensão Rural, da Secretaria de Agricultura Familiar do Ministério do Desenvolvimento - DATER/SAF/MDA, no período de 2004 a 2009, tema escolhido para Monografia a ser apresentada à Universidade de Brasília $(U n B)$ como requisito parcial para obtenção do grau de Bacharel em Administração.

Você poderá ou não se identificar no questionário e garantimos que todas as informações fornecidas serão confidenciais e utilizadas apenas de forma sistematizada.

\section{IDENTIFICAÇÃO}

\begin{tabular}{|l|l|}
\hline Nome: Altino Jacinto & $\begin{array}{l}\text { Sexo: } \\
(x) \text { masculino } \quad(\quad) \text { feminino }\end{array}$ \\
\hline $\begin{array}{l}\text { Instituição (nome e tipo de instituição: ONG, } \\
\text { Empresa Pública, etc.): Epagri }\end{array}$ & $\begin{array}{l}\text { Local de trabalho (Cidade e Estado): Apiúna } \\
- \text { SC }\end{array}$ \\
\hline $\begin{array}{l}\text { Curso/Encontro/Oficina do qual participou (caso tenha participado de mais de um curso, preencha } \\
\text { um formulário para cada um deles): Formação de agentes de ATER }\end{array}$ \\
\hline Data do Curso/Encontro/Oficina (pelo menos mês e ano): Junho 2008 \\
\hline
\end{tabular}

1. Indique sua área de atuação? (As opções não são excludentes: você poderá marcar mais de uma opção).

\begin{tabular}{|l|l|}
\hline$X$ & EXTENSÃO RURAL \\
\hline & PESQUISA \\
\hline & ENSINO \\
\hline & OUTROS \\
\hline
\end{tabular}


2) Qual o seu nível de escolaridade? (Considere apenas o nível mais alto)

\begin{tabular}{|l|l|}
\hline$X$ & NÍVEL MÉDIO \\
\hline & NÍVEL SUPERIOR \\
\hline & PÓS-GRADUAÇÃO \\
\hline
\end{tabular}

3) Os conteúdos abordados foram condizentes com as demandas do seu dia-a-dia?

\begin{tabular}{|l|l|}
\hline$X$ & SIM \\
\hline & PARCIALMENTE \\
\hline & NÃO \\
\hline
\end{tabular}

4) O curso contribuiu para o seu aperfeiçoamento profissional?

\begin{tabular}{|l|l|}
\hline$X$ & SIM \\
\hline & NÃO \\
\hline
\end{tabular}

5) Os conhecimentos adquiridos estão sendo aplicados no seu trabalho? Em caso afirmativo, indique em que grau estes conhecimentos estão sendo aplicados. Em caso negativo, indique por que razão isto não ocorre:

\begin{tabular}{|c|c|c|}
\hline \multirow{3}{*}{$\begin{array}{l}\text { SIM (indique ao lado em } \\
\text { que grau) }\end{array}$} & $\mathrm{X}$ & MUITO APLICADOS \\
\hline & & MEDIAMENTE APLICADOS \\
\hline & & POUCO APLICADOS \\
\hline \multirow{5}{*}{$\begin{array}{l}\text { NÃO (indique ao lado a } \\
\text { razão da não aplicação) }\end{array}$} & & CONTEÚDO NÃO ADEQUADO ȦS NECESSIDADES \\
\hline & & $\begin{array}{llll}\text { CONTEUUDO NÂO } & \text { FOI SUFICIENTEMENTE } \\
\text { APROFUNDADO PARA } & \text { PERMITIR UMA APLICAÇÃO }\end{array}$ \\
\hline & & \begin{tabular}{lcccccc|} 
FALTA & DE & APOIO & E & INCENTIVO & DA & MINHA \\
INSTITUICÃO & & & & & \\
\end{tabular} \\
\hline & & FALTA DE INCENTIVO ÀS AÇÕES DE ATER \\
\hline & & 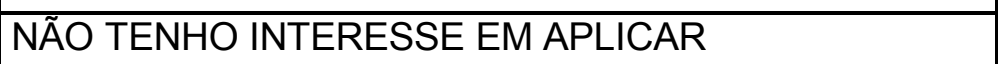 \\
\hline
\end{tabular}


6) A partir deste curso: (As opções não são excludentes: você poderá marcar mais de uma opção).

\begin{tabular}{|l|l|}
\hline & NÃO MUDOU NADA EM MEU TRABALHO. \\
\hline & $\begin{array}{l}\text { MEU TRABALHO PASSOU A CONTRIBUIR MAIS COM OS AGRICULTORES(AS) } \\
\text { FAMILIARES. }\end{array}$ \\
\hline & CONSEGUI INFLUENCIAR NAS ORIENTAÇÕES DA MINHA INSTITUIÇÃO. \\
\hline & $\begin{array}{l}\text { CRESCEU A ÁREA DE AGRICULTURA DE BASE ECOLÓGICA NAS COMUNIDADES } \\
\text { ONDE ATUO. }\end{array}$ \\
\hline$X$ & CONTINUEI ME APERFEIÇOANDO SOBRE TEMAS ABORDADOS. \\
\hline
\end{tabular}

7) Depois do curso você apoiou atividades de capacitação de técnicos e agricultores com base nos princípios e diretrizes da Pnater? (Considere como apoio a atividades de capacitação a participação no planejamento, elaboração de ementas, seleção de participantes e de palestrantes.)

\begin{tabular}{|l|l|}
\hline$X$ & SIM \\
\hline & NÃO \\
\hline
\end{tabular}

8) Usou os conhecimentos para ministrar outros cursos com o mesmo conteúdo ou conteúdos semelhantes?

\begin{tabular}{|l|l|}
\hline$X$ & SIM \\
\hline & NÃO \\
\hline
\end{tabular}

9) Marque o seu grau de satisfação com relação ao curso oferecido pelo DATER: (Considere a seguinte pontuação: 1 - MUITO RUIM; 2 - RUIM; 3 - REGULAR; 4 - BOM; 5 - MUITO BOM)

\begin{tabular}{|l|l|l|l|l|}
\hline 1 & 2 & 3 & $4 \mathrm{X}$ & 5 \\
\hline
\end{tabular}

10) Marque seu grau de satisfação com relação ao DATER: (Considere a seguinte pontuação:

1 - MUITO RUIM; 2 - RUIM; 3 - REGULAR; 4 - BOM; 5 - MUITO BOM)

\begin{tabular}{|l|l|l|l|l|}
\hline 1 & 2 & 3 & $4 \mathrm{X}$ & 5 \\
\hline
\end{tabular}




\section{PESQUISA - IMPACTO DAS AÇÕES DE FORMAÇÃO REALIZADAS PELO \\ DATER/SAF/MDA NO PERÍODO 2004-2009}

Caros colaboradores,

Contamos com a sua atenção para preencher o formulário abaixo.

O mesmo tem por objetivo fornecer informações para avaliação da Eficiência, Efetividade e Eficácia da Política Pública de Formação de Agentes de Ater adotada pelo Departamento de Assistência Técnica e Extensão Rural, da Secretaria de Agricultura Familiar do Ministério do Desenvolvimento - DATER/SAF/MDA, no período de 2004 a 2009, tema escolhido para Monografia a ser apresentada à Universidade de Brasília (UnB) como requisito parcial para obtenção do grau de Bacharel em Administração.

Você poderá ou não se identificar no questionário e garantimos que todas as informações fornecidas serão confidenciais e utilizadas apenas de forma sistematizada.

\section{IDENTIFICAÇÃO}

\begin{tabular}{|l|l|}
\hline Nome: Jacinto Geraldo Tamiozzo & $\begin{array}{l}\text { Sexo: } \\
(x \quad) \text { masculino } \quad(\quad \text { ) feminino }\end{array}$ \\
\hline $\begin{array}{l}\text { Instituição (nome e tipo de instituição: ONG, } \\
\text { Empresa Pública, etc.): ASCAR/EMATER - RS }\end{array}$ & $\begin{array}{l}\text { Local de trabalho (Cidade e Estado): Pirapó } \\
- \text { Rio Grande do Sul }\end{array}$ \\
\hline $\begin{array}{l}\text { Curso/Encontro/Oficina do qual participou (caso tenha participado de mais de um curso, preencha } \\
\text { um formulário para cada um deles): Diagnóstico Rural Participativo DRP }\end{array}$ \\
\hline Data do Curso/Encontro/Oficina (pelo menos mês e ano): 16 a 27 de Outubro de 2006 \\
\hline
\end{tabular}

1. Indique sua área de atuação? (As opções não são excludentes: você poderá marcar mais de uma opção).

\begin{tabular}{|l|l|}
\hline$X$ & EXTENSÃO RURAL \\
\hline & PESQUISA \\
\hline & ENSINO \\
\hline & OUTROS \\
\hline
\end{tabular}


2) Qual o seu nível de escolaridade? (Considere apenas o nível mais alto)

\begin{tabular}{|l|l|}
\hline & NÍVEL MÉDIO \\
\hline & NÍVEL SUPERIOR \\
\hline$X$ & PÓS-GRADUAÇÃO \\
\hline
\end{tabular}

3) Os conteúdos abordados foram condizentes com as demandas do seu dia-a-dia?

\begin{tabular}{|l|l|}
\hline$X$ & SIM \\
\hline & PARCIALMENTE \\
\hline & NÃO \\
\hline
\end{tabular}

4) O curso contribuiu para o seu aperfeiçoamento profissional?

\begin{tabular}{|l|l|}
\hline$X$ & SIM \\
\hline & NÃO \\
\hline
\end{tabular}

5) Os conhecimentos adquiridos estão sendo aplicados no seu trabalho? Em caso afirmativo, indique em que grau estes conhecimentos estão sendo aplicados. Em caso negativo, indique por que razão isto não ocorre:

\begin{tabular}{|c|c|c|c|}
\hline \multirow{3}{*}{$X$} & \multirow{3}{*}{$\begin{array}{l}\text { SIM (indique ao lado em } \\
\text { que grau) }\end{array}$} & $\mathrm{X}$ & MUITO APLICADOS \\
\hline & & & MEDIAMENTE APLICADOS \\
\hline & & & POUCO APLICADOS \\
\hline & \multirow{3}{*}{$\begin{array}{l}\text { NÃO (indique ao lado a } \\
\text { razão da não aplicação) }\end{array}$} & & $\begin{array}{l}\text { CONTEÚDO NÃO ADEQUADO ȦS NECESSIDADES } \\
\text { ESPECÍFICAS DA REGIÃO }\end{array}$ \\
\hline & & & $\begin{array}{l}\text { CONTEÚDO NÃO } \quad \text { FOI SUFICIENTEMENTE } \\
\text { APROFUNDADO PARA } \\
\text { PERMITIR UMA APLICAÇÃO } \\
\text { EFICAZ E EFICIENTE }\end{array}$ \\
\hline & & & $\begin{array}{l}\text { FALTA DE APOIO } \\
\text { INSTITUIÇÃO }\end{array}$ \\
\hline
\end{tabular}




\begin{tabular}{|l|l|l|}
\hline \multirow{2}{*}{} & & FALTA DE INCENTIVO ÀS AÇÕES DE ATER \\
\cline { 3 - 4 } & & NÃO TENHO INTERESSE EM APLICAR \\
\hline
\end{tabular}

6) A partir deste curso: (As opções não são excludentes: você poderá marcar mais de uma opção).

\begin{tabular}{|l|l|}
\hline$x$ & NÃO MUDOU NADA EM MEU TRABALHO. \\
\hline$X$ & $\begin{array}{l}\text { MEU TRABALHO PASSOU A CONTRIBUIR MAIS COM OS AGRICULTORES(AS) } \\
\text { FAMILIARES. }\end{array}$ \\
\hline & CONSEGUI INFLUENCIAR NAS ORIENTAÇÕES DA MINHA INSTITUIÇÃO. \\
\hline$X$ & $\begin{array}{l}\text { CRESCEU A ÁREA DE AGRICULTURA DE BASE ECOLÓGICA NAS COMUNIDADES } \\
\text { ONDE ATUO. }\end{array}$ \\
\hline$X$ & CONTINUEI ME APERFEIÇOANDO SOBRE TEMAS ABORDADOS. \\
\hline
\end{tabular}

7) Depois do curso você apoiou atividades de capacitação de técnicos e agricultores com base nos princípios e diretrizes da Pnater? (Considere como apoio a atividades de capacitação a participação no planejamento, elaboração de ementas, seleção de participantes e de palestrantes.)

\begin{tabular}{|l|l|}
\hline$X$ & SIM \\
\hline & NÃO \\
\hline
\end{tabular}

8) Usou os conhecimentos para ministrar outros cursos com o mesmo conteúdo ou conteúdos semelhantes?

\begin{tabular}{|l|l|}
\hline$X$ & SIM \\
\hline & NÃO \\
\hline
\end{tabular}

9) Marque o seu grau de satisfação com relação ao curso oferecido pelo DATER: (Considere a seguinte pontuação: 1 - MUITO RUIM; 2 - RUIM; 3 - REGULAR; 4 - BOM; 5 - MUITO BOM) 


\begin{tabular}{|l|l|l|l|l|}
\hline 1 & 2 & 3 & $4 X$ & 5 \\
\hline
\end{tabular}

10) Marque seu grau de satisfação com relação ao DATER: (Considere a seguinte pontuação:

1 - MUITO RUIM; 2 - RUIM; 3 - REGULAR; 4 - BOM; 5 - MUITO BOM)

\begin{tabular}{|l|l|l|l|l|}
\hline 1 & 2 & 3 & 4 & $5 \mathrm{X}$ \\
\hline
\end{tabular}




\section{PESQUISA - IMPACTO DAS AÇÕES DE FORMAÇÃO REALIZADAS PELO \\ DATER/SAF/MDA NO PERÍODO 2004-2009}

Caros colaboradores,

Contamos com a sua atenção para preencher o formulário abaixo.

O mesmo tem por objetivo fornecer informações para avaliação da Eficiência, Efetividade e Eficácia da Política Pública de Formação de Agentes de Ater adotada pelo Departamento de Assistência Técnica e Extensão Rural, da Secretaria de Agricultura Familiar do Ministério do Desenvolvimento - DATER/SAF/MDA, no período de 2004 a 2009, tema escolhido para Monografia a ser apresentada à Universidade de Brasília (UnB) como requisito parcial para obtenção do grau de Bacharel em Administração.

Você poderá ou não se identificar no questionário e garantimos que todas as informações fornecidas serão confidenciais e utilizadas apenas de forma sistematizada.

IDENTIFICAÇÃO

\begin{tabular}{|l|l|}
\hline Nome: Jefferson Vinicius Meister & $\begin{array}{l}\text { Sexo: } \\
(x) \text { masculino } \quad(\quad \text { ) feminino }\end{array}$ \\
\hline $\begin{array}{l}\text { Instituição (nome e tipo de instituição: ONG, } \\
\text { Empresa Pública, etc.): } \\
\text { COTRARA }\end{array}$ & $\begin{array}{l}\text { Local de trabalho (Cidade e Estado): } \\
\text { Região Centro-Sul do Paraná }\end{array}$ \\
\hline $\begin{array}{l}\text { Curso/Encontro/Oficina do qual participou (caso tenha participado de mais de um curso, preencha } \\
\text { um formulário para cada um deles): } \\
\text { Curso de Pecuária Ecológica }\end{array}$ \\
\hline \begin{tabular}{l} 
Data do Curso/Encontro/Oficina (pelo menos mês e ano): 08/2006 \\
\hline
\end{tabular}
\end{tabular}

1. Indique sua área de atuação? (As opções não são excludentes: você poderá marcar mais de uma opção).

\begin{tabular}{|l|l|}
\hline$X$ & EXTENSÃO RURAL \\
\hline & PESQUISA \\
\hline & ENSINO \\
\hline & OUTROS \\
\hline
\end{tabular}

2) Qual o seu nível de escolaridade? (Considere apenas o nível mais alto) 


\begin{tabular}{|c|l|}
\hline & NÍVEL MÉDIO \\
\hline$X$ & NÍVEL SUPERIOR \\
\hline & PÓS-GRADUAÇÃO \\
\hline
\end{tabular}

3) Os conteúdos abordados foram condizentes com as demandas do seu dia-a-dia?

\begin{tabular}{|l|l|}
\hline$X$ & SIM \\
\hline & PARCIALMENTE \\
\hline & NÃO \\
\hline
\end{tabular}

4) O curso contribuiu para o seu aperfeiçoamento profissional?

\begin{tabular}{|l|l|}
\hline$X$ & SIM \\
\hline & NÃO \\
\hline
\end{tabular}

5) Os conhecimentos adquiridos estão sendo aplicados no seu trabalho? Em caso afirmativo, indique em que grau estes conhecimentos estão sendo aplicados. Em caso negativo, indique por que razão isto não ocorre:

\begin{tabular}{|c|c|c|}
\hline \multirow{3}{*}{$\begin{array}{l}\text { SIM (indique ao lado em } \\
\text { que grau) }\end{array}$} & & MUITO APLICADOS \\
\hline & $\bar{X}$ & MEDIAMENTE APLICADOS \\
\hline & & POUCO APLICADOS \\
\hline \multirow{5}{*}{$\begin{array}{l}\text { NÃO (indique ao lado a } \\
\text { razão da não aplicação) }\end{array}$} & & $\begin{array}{l}\text { CONTEÚDO NÃO ADEQUADO ȦS NECESSIDADES } \\
\text { ESPECÍFICAS DA REGIÃO }\end{array}$ \\
\hline & & $\begin{array}{l}\text { CONTEÚDO NÃO } \quad \text { FOI SUFICIENTEMENTE } \\
\text { APROFUNDADO PARA } \\
\text { EERMITIR UMA APLICAÇÃO } \\
\text { EFICAZ E EFICIENTE }\end{array}$ \\
\hline & & $\begin{array}{lcccccc}\text { FALTA } & \text { DE } & \text { APOIO } & \text { E } & \text { INCENTIVO } & \text { DA } & \text { MINHA } \\
\text { INSTITUIÇÃO } & & & & & \end{array}$ \\
\hline & & FALTA DE INCENTIVO ÀS AÇÕES DE ATER \\
\hline & & NÃO TENHO INTERESSE EM APLICAR \\
\hline
\end{tabular}


6) A partir deste curso: (As opções não são excludentes: você poderá marcar mais de uma opção).

\begin{tabular}{|l|l|}
\hline & NÃO MUDOU NADA EM MEU TRABALHO. \\
\hline & $\begin{array}{l}\text { MEU TRABALHO PASSOU A CONTRIBUIR MAIS COM OS AGRICULTORES(AS) } \\
\text { FAMILIARES. }\end{array}$ \\
\hline & CONSEGUI INFLUENCIAR NAS ORIENTAÇÕES DA MINHA INSTITUIÇÃO. \\
\hline & $\begin{array}{l}\text { CRESCEU A TRABALHAR COM METODOLOGIAS PARTICIPATIVAS. } \\
\text { ONDE ATUO. }\end{array}$ \\
\hline$X$ & CONTINUEI ME APERFEIÇOANDO SOBRE TEMAS ABORDADOS. \\
\hline
\end{tabular}

7) Depois do curso você apoiou atividades de capacitação de técnicos e agricultores com base nos princípios e diretrizes da Pnater? (Considere como apoio a atividades de capacitação a participação no planejamento, elaboração de ementas, seleção de participantes e de palestrantes.)

\begin{tabular}{|l|l|}
\hline$X$ & SIM \\
\hline & NÃO \\
\hline
\end{tabular}

8) Usou os conhecimentos para ministrar outros cursos com o mesmo conteúdo ou conteúdos semelhantes?

\begin{tabular}{|l|l|}
\hline & SIM \\
\hline$X$ & NÃO \\
\hline
\end{tabular}

9) Marque o seu grau de satisfação com relação ao curso oferecido pelo DATER: (Considere a seguinte pontuação: 1 - MUITO RUIM; 2 - RUIM; 3 - REGULAR; 4 - BOM; 5 - MUITO BOM)

\begin{tabular}{|l|l|l|l|l|}
\hline 1 & 2 & 3 & $\times 4$ & 5 \\
\hline
\end{tabular}

10) Marque seu grau de satisfação com relação ao DATER: (Considere a seguinte pontuação: 1 - MUITO RUIM; 2 - RUIM; 3 - REGULAR; 4 - BOM; 5 - MUITO BOM)

\begin{tabular}{|l|l|l|l|l|}
\hline 1 & 2 & 3 & $\times 4$ & 5 \\
\hline
\end{tabular}




\section{PESQUISA - IMPACTO DAS AÇÕES DE FORMAÇÃO REALIZADAS PELO \\ DATER/SAF/MDA NO PERÍODO 2004-2009}

Caros colaboradores,

Contamos com a sua atenção para preencher o formulário abaixo.

O mesmo tem por objetivo fornecer informações para avaliação da Eficiência, Efetividade e Eficácia da Política Pública de Formação de Agentes de Ater adotada pelo Departamento de Assistência Técnica e Extensão Rural, da Secretaria de Agricultura Familiar do Ministério do Desenvolvimento - DATER/SAF/MDA, no período de 2004 a 2009, tema escolhido para Monografia a ser apresentada à Universidade de Brasília (UnB) como requisito parcial para obtenção do grau de Bacharel em Administração.

Você poderá ou não se identificar no questionário e garantimos que todas as informações fornecidas serão confidenciais e utilizadas apenas de forma sistematizada.

IDENTIFICAÇÃO

\begin{tabular}{|l|l|}
\hline Nome: Jefferson Vinicius Meister & $\begin{array}{l}\text { Sexo: } \\
(x) \text { masculino } \quad(\quad \text { ) feminino }\end{array}$ \\
\hline $\begin{array}{l}\text { Instituição (nome e tipo de instituição: ONG, } \\
\text { Empresa Pública, etc.): } \\
\text { COTRARA }\end{array}$ & $\begin{array}{l}\text { Local de trabalho (Cidade e Estado): } \\
\text { Região Centro-Sul do Paraná }\end{array}$ \\
\hline $\begin{array}{l}\text { Curso/Encontro/Oficina do qual participou (caso tenha participado de mais de um curso, preencha } \\
\text { um formulário para cada um deles): } \\
\text { Curso de Pecuária Ecológica }\end{array}$ \\
\hline \begin{tabular}{l} 
Data do Curso/Encontro/Oficina (pelo menos mês e ano): 08/2006 \\
\hline
\end{tabular}
\end{tabular}

1. Indique sua área de atuação? (As opções não são excludentes: você poderá marcar mais de uma opção).

\begin{tabular}{|l|l|}
\hline$X$ & EXTENSÃO RURAL \\
\hline & PESQUISA \\
\hline & ENSINO \\
\hline & OUTROS \\
\hline
\end{tabular}

2) Qual o seu nível de escolaridade? (Considere apenas o nível mais alto) 


\begin{tabular}{|c|l|}
\hline & NÍVEL MÉDIO \\
\hline$X$ & NÍVEL SUPERIOR \\
\hline & PÓS-GRADUAÇÃO \\
\hline
\end{tabular}

3) Os conteúdos abordados foram condizentes com as demandas do seu dia-a-dia?

\begin{tabular}{|l|l|}
\hline$X$ & SIM \\
\hline & PARCIALMENTE \\
\hline & NÃO \\
\hline
\end{tabular}

4) O curso contribuiu para o seu aperfeiçoamento profissional?

\begin{tabular}{|l|l|}
\hline$X$ & SIM \\
\hline & NÃO \\
\hline
\end{tabular}

5) Os conhecimentos adquiridos estão sendo aplicados no seu trabalho? Em caso afirmativo, indique em que grau estes conhecimentos estão sendo aplicados. Em caso negativo, indique por que razão isto não ocorre:

\begin{tabular}{|c|c|c|}
\hline \multirow{3}{*}{$\begin{array}{l}\text { SIM (indique ao lado em } \\
\text { que grau) }\end{array}$} & & MUITO APLICADOS \\
\hline & $X$ & MEDIAMENTE APLICADOS \\
\hline & & POUCO APLICADOS \\
\hline \multirow{5}{*}{$\begin{array}{l}\text { NÃO (indique ao lado a } \\
\text { razão da não aplicação) }\end{array}$} & & $\begin{array}{l}\text { CONTEÚDO NĀO ADEQUADO ȦS NECESSIDADES } \\
\text { ESPECÍFICAS DA REGIÃO }\end{array}$ \\
\hline & & $\begin{array}{l}\text { CONTEÚDO NÃO FOI SUFICIENTEMENTE } \\
\text { APROFUNDADO PARA PERMITIR UMA APLICAÇÃO } \\
\text { EFICAZ E EFICIENTE }\end{array}$ \\
\hline & & $\begin{array}{lcccccc}\text { FALTA } & \text { DE } & \text { APOIO } & \text { E } & \text { INCENTIVO } & \text { DA } & \text { MINHA } \\
\text { INSTITUIÇÃO } & & & & \\
\end{array}$ \\
\hline & & FALTA DE INCENTIVO ÀS AÇÕES DE ATER \\
\hline & & NÃO TENHO INTERESSE EM APLICAR \\
\hline
\end{tabular}


6) A partir deste curso: (As opções não são excludentes: você poderá marcar mais de uma opção).

\begin{tabular}{|l|l|}
\hline & NÃO MUDOU NADA EM MEU TRABALHO. \\
\hline & $\begin{array}{l}\text { MEU TRABALHO PASSOU A CONTRIBUIR MAIS COM OS AGRICULTORES(AS) } \\
\text { FAMILIARES. }\end{array}$ \\
\hline & CONSEGUI INFLUENCIAR NAS ORIENTAÇÕES DA MINHA INSTITUIÇÃO. \\
\hline & $\begin{array}{l}\text { CRESEI A TRABALHAR COM METODOLOGIAS PARTICIPATIVAS. } \\
\text { ONDE ATUO. ÁREA DE AGRICULTURA DE BASE ECOLÓGICA NAS COMUNIDADES }\end{array}$ \\
\hline$X$ & CONTINUEI ME APERFEIÇOANDO SOBRE TEMAS ABORDADOS. \\
\hline
\end{tabular}

7) Depois do curso você apoiou atividades de capacitação de técnicos e agricultores com base nos princípios e diretrizes da Pnater? (Considere como apoio a atividades de capacitação a participação no planejamento, elaboração de ementas, seleção de participantes e de palestrantes.)

\begin{tabular}{|l|l|}
\hline$X$ & SIM \\
\hline & NÃO \\
\hline
\end{tabular}

8) Usou os conhecimentos para ministrar outros cursos com o mesmo conteúdo ou conteúdos semelhantes?

\begin{tabular}{|l|l|}
\hline & SIM \\
\hline$X$ & NÃO \\
\hline
\end{tabular}

9) Marque o seu grau de satisfação com relação ao curso oferecido pelo DATER: (Considere a seguinte pontuação: 1 - MUITO RUIM; 2 - RUIM; 3 - REGULAR; 4 - BOM; 5 - MUITO BOM)

\begin{tabular}{|l|l|l|l|l|}
\hline 1 & 2 & 3 & $\times 4$ & 5 \\
\hline
\end{tabular}

10) Marque seu grau de satisfação com relação ao DATER: (Considere a seguinte pontuação: 1 - MUITO RUIM; 2 - RUIM; 3 - REGULAR; 4 - BOM; 5 - MUITO BOM)

\begin{tabular}{|l|l|l|l|l|}
\hline 1 & 2 & 3 & $X 4$ & 5 \\
\hline
\end{tabular}




\section{PESQUISA - IMPACTO DAS AÇÕES DE FORMAÇÃO REALIZADAS PELO \\ DATER/SAF/MDA NO PERÍODO 2004-2009}

Caros colaboradores,

Contamos com a sua atenção para preencher o formulário abaixo.

O mesmo tem por objetivo fornecer informações para avaliação da Eficiência, Efetividade e Eficácia da Política Pública de Formação de Agentes de Ater adotada pelo Departamento de Assistência Técnica e Extensão Rural, da Secretaria de Agricultura Familiar do Ministério do Desenvolvimento - DATER/SAF/MDA, no período de 2004 a 2009, tema escolhido para Monografia a ser apresentada à Universidade de Brasília (UnB) como requisito parcial para obtenção do grau de Bacharel em Administração.

Você poderá ou não se identificar no questionário e garantimos que todas as informações fornecidas serão confidenciais e utilizadas apenas de forma sistematizada.

\section{IDENTIFICAÇÃO}

\begin{tabular}{|l|l|l|}
\hline Nome: João Luiz Veiga Silva Filho & $\begin{array}{l}\text { Sexo: } \\
(x) \text { masculino } \quad(\quad \text { ) feminino }\end{array}$ \\
\hline $\begin{array}{l}\text { Instituição (nome e tipo de instituição: ONG, } \\
\text { Empresa Pública, etc.): Instituto Terra }\end{array}$ & $\begin{array}{l}\operatorname{Pr} \\
\text { Mater/Ygaribá }\end{array}$ \\
\hline $\begin{array}{l}\text { Curso/Encontro/Oficina do qual participou (caso tenha participado de mais de um curso, preencha } \\
\text { um formulário para cada um deles): Cadeias Produtivas }\end{array}$ \\
\hline Data do Curso/Encontro/Oficina (pelo menos mês e ano): 1- 05/2008 2- $08 / 2008$ \\
\hline
\end{tabular}

1 Indique sua área de atuação? (As opções não são excludentes: você poderá marcar mais de uma opção).

\begin{tabular}{|l|l|}
\hline$x$ & EXTENSÃO RURAL \\
\hline & PESQUISA \\
\hline & ENSINO \\
\hline & OUTROS \\
\hline
\end{tabular}

2) Qual o seu nível de escolaridade? (Considere apenas o nível mais alto) 


\begin{tabular}{|l|l|}
\hline & NÍVEL MÉDIO \\
\hline & NÍVEL SUPERIOR \\
\hline$x$ & PÓS-GRADUAÇÃO \\
\hline
\end{tabular}

3) Os conteúdos abordados foram condizentes com as demandas do seu dia-a-dia?

\begin{tabular}{|l|l|}
\hline & SIM \\
\hline$x$ & PARCIALMENTE \\
\hline & NÃO \\
\hline
\end{tabular}

4) O curso contribuiu para o seu aperfeiçoamento profissional?

\begin{tabular}{|l|l|}
\hline$x$ & SIM \\
\hline & NÃO \\
\hline
\end{tabular}

5) Os conhecimentos adquiridos estão sendo aplicados no seu trabalho? Em caso afirmativo, indique em que grau estes conhecimentos estão sendo aplicados. Em caso negativo, indique por que razão isto não ocorre:

\begin{tabular}{|c|c|c|c|}
\hline \multirow{3}{*}{$\mathrm{x}$} & \multirow{3}{*}{$\begin{array}{l}\text { SIM (indique ao lado em } \\
\text { que grau) }\end{array}$} & & MUITO APLICADOS \\
\hline & & $x$ & MEDIAMENTE APLICADOS \\
\hline & & & \begin{tabular}{|l} 
POUCO APLICADOS \\
\end{tabular} \\
\hline & \multirow{5}{*}{$\begin{array}{l}\text { NÃO (indique ao lado a } \\
\text { razão da não aplicação) }\end{array}$} & & CONTEÚDO NÃO ADEQUADO ÀS NECESSIDADES \\
\hline & & & $\begin{array}{llll}\text { CONTEUUDO } & \text { NÂO } & \text { FOI SUFICIENTEMENTE } \\
\text { APROFUNDADO } & \text { PARA } & \text { PERMITIR UMA APLICAÇÃO }\end{array}$ \\
\hline & & & 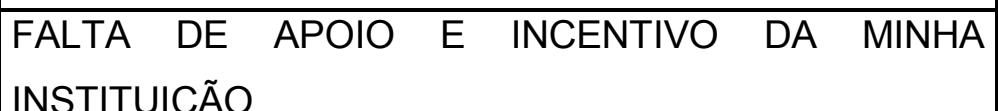 \\
\hline & & & FALTA DE INCENTIVO ÀS AÇÕES DE ATER \\
\hline & & & \begin{tabular}{|l|} 
NÃO TENHO INTERESSE EM APLICAR \\
\end{tabular} \\
\hline
\end{tabular}

6) A partir deste curso: (As opções não são excludentes: você poderá marcar mais de uma opção). 


\begin{tabular}{|l|l|}
\hline & NÃO MUDOU NADA EM MEU TRABALHO. \\
\hline & $\begin{array}{l}\text { MEU TRABALHO PASSOU A CONTRIBUIR MAIS COM OS AGRICULTORES(AS) } \\
\text { FAMILIARES. }\end{array}$ \\
\hline & CONSEGUI INFLUENCIAR NAS ORIENTAÇÕES DA MINHA INSTITUIÇÃO. \\
\hline & $\begin{array}{l}\text { PASSEI A TRABALHAR COM METODOLOGIAS PARTICIPATIVAS. } \\
\text { ONDE ATUO. }\end{array}$ \\
\hline$x$ & CONTINUEI ME APERFEIÇOANDO SOBRE TEMAS ABORDADOS. \\
\hline
\end{tabular}

7) Depois do curso você apoiou atividades de capacitação de técnicos e agricultores com base nos princípios e diretrizes da Pnater? (Considere como apoio a atividades de capacitação a participação no planejamento, elaboração de ementas, seleção de participantes e de palestrantes.)

\begin{tabular}{|l|l|}
\hline & SIM \\
\hline$x$ & NÃO \\
\hline
\end{tabular}

8) Usou os conhecimentos para ministrar outros cursos com o mesmo conteúdo ou conteúdos semelhantes?

\begin{tabular}{|l|l|}
\hline$x$ & SIM \\
\hline & NÃO \\
\hline
\end{tabular}

9) Marque o seu grau de satisfação com relação ao curso oferecido pelo DATER: (Considere a seguinte pontuação: 1 - MUITO RUIM; 2 - RUIM; 3 - REGULAR; 4 - BOM; 5 - MUITO BOM)

\begin{tabular}{|l|l|l|l|l|}
\hline 1 & $\mathrm{x} 2$ & 3 & 4 & 5 \\
\hline
\end{tabular}

10) Marque seu grau de satisfação com relação ao DATER: (Considere a seguinte pontuação: 1 - MUITO RUIM; 2 - RUIM; 3 - REGULAR; 4 - BOM; 5 - MUITO BOM)

\begin{tabular}{|l|l|l|l|l|}
\hline 1 & $x 2$ & 3 & 4 & 5 \\
\hline
\end{tabular}




\section{PESQUISA - IMPACTO DAS AÇÕES DE FORMAÇÃO REALIZADAS PELO \\ DATER/SAF/MDA NO PERÍODO 2004-2009}

Caros colaboradores,

Contamos com a sua atenção para preencher o formulário abaixo.

O mesmo tem por objetivo fornecer informações para avaliação da Eficiência, Efetividade e Eficácia da Política Pública de Formação de Agentes de Ater adotada pelo Departamento de Assistência Técnica e Extensão Rural, da Secretaria de Agricultura Familiar do Ministério do Desenvolvimento - DATER/SAF/MDA, no período de 2004 a 2009, tema escolhido para Monografia a ser apresentada à Universidade de Brasília (UnB) como requisito parcial para obtenção do grau de Bacharel em Administração.

Você poderá ou não se identificar no questionário e garantimos que todas as informações fornecidas serão confidenciais e utilizadas apenas de forma sistematizada.

\section{IDENTIFICAÇÃO}

\begin{tabular}{|l|l|l|}
\hline Nome: João Luiz Veiga Silva Filho & $\begin{array}{l}\text { Sexo: } \\
(x) \text { masculino } \quad(\quad \text { ) feminino }\end{array}$ \\
\hline $\begin{array}{l}\text { Instituição (nome e tipo de instituição: ONG, } \\
\text { Empresa Pública, etc.): Instituto Terra }\end{array}$ & $\begin{array}{l}\operatorname{Pr} \\
\text { Mater/Ygaribá }\end{array}$ \\
\hline $\begin{array}{l}\text { Curso/Encontro/Oficina do qual participou (caso tenha participado de mais de um curso, preencha } \\
\text { um formulário para cada um deles): Sistemas Agroflorestais }\end{array}$ \\
\hline Data do Curso/Encontro/Oficina (pelo menos mês e ano): 1- 05/2008 2- 08/2008 \\
\hline
\end{tabular}

1 Indique sua área de atuação? (As opções não são excludentes: você poderá marcar mais de uma opção).

\begin{tabular}{|l|l|}
\hline$x$ & EXTENSÃO RURAL \\
\hline & PESQUISA \\
\hline & ENSINO \\
\hline & OUTROS \\
\hline
\end{tabular}

2) Qual o seu nível de escolaridade? (Considere apenas o nível mais alto) 


\begin{tabular}{|l|l|}
\hline & NÍVEL MÉDIO \\
\hline & NÍVEL SUPERIOR \\
\hline$x$ & PÓS-GRADUAÇÃO \\
\hline
\end{tabular}

3) Os conteúdos abordados foram condizentes com as demandas do seu dia-a-dia?

\begin{tabular}{|l|l|}
\hline & SIM \\
\hline$x$ & PARCIALMENTE \\
\hline & NÃO \\
\hline
\end{tabular}

4) O curso contribuiu para o seu aperfeiçoamento profissional?

\begin{tabular}{|l|l|}
\hline$x$ & SIM \\
\hline & NÃO \\
\hline
\end{tabular}

5) Os conhecimentos adquiridos estão sendo aplicados no seu trabalho? Em caso afirmativo, indique em que grau estes conhecimentos estão sendo aplicados. Em caso negativo, indique por que razão isto não ocorre:

\begin{tabular}{|c|c|c|c|}
\hline \multirow{3}{*}{$x$} & \multirow{3}{*}{$\begin{array}{l}\text { SIM (indique ao lado em } \\
\text { que grau) }\end{array}$} & & MUITO APLICADOS \\
\hline & & $x$ & MEDIAMENTE APLICADOS \\
\hline & & & POUCO APLICADOS \\
\hline & \multirow{6}{*}{$\begin{array}{l}\text { NÃO (indique ao lado a } \\
\text { razão da não aplicação) }\end{array}$} & & CONTEÚDO NÃO ADEQUADO ÀS NECESSIDADES \\
\hline & & & $\begin{array}{llll}\text { CONTEÚDO } & \text { NÃO } & \text { FOI } & \text { SUFICIENTEMENTE }\end{array}$ \\
\hline & & & APROFUNDADO PARA PERMITIR UMA APLICAÇÃO \\
\hline & & & $\begin{array}{|lllllll|}\text { FALTA } & \text { DE } & \text { APOIO } & \text { E } & \text { INCENTIVO } & \text { DA } & \text { MINHA } \\
\end{array}$ \\
\hline & & & FALTA DE INCENTIVO ÀS AÇÕES DE ATER \\
\hline & & & NÃO TENHO INTERESSE EM APLICAR \\
\hline
\end{tabular}

6) A partir deste curso: (As opções não são excludentes: você poderá marcar mais de uma opção). 


\begin{tabular}{|l|l|}
\hline & NÃO MUDOU NADA EM MEU TRABALHO. \\
\hline & $\begin{array}{l}\text { MEU TRABALHO PASSOU A CONTRIBUIR MAIS COM OS AGRICULTORES(AS) } \\
\text { FAMILIARES. }\end{array}$ \\
\hline & CONSEGUI INFLUENCIAR NAS ORIENTAÇÕES DA MINHA INSTITUIÇÃO. \\
\hline & $\begin{array}{l}\text { CRESSEI A TRABALHAR COM METODOLOGIAS PARTICIPATIVAS. } \\
\text { ONDE ATUO. AREA DE AGRICULTURA DE BASE ECOLÓGICA NAS COMUNIDADES }\end{array}$ \\
\hline$x$ & CONTINUEI ME APERFEIÇOANDO SOBRE TEMAS ABORDADOS. \\
\hline
\end{tabular}

7) Depois do curso você apoiou atividades de capacitação de técnicos e agricultores com base nos princípios e diretrizes da Pnater? (Considere como apoio a atividades de capacitação a participação no planejamento, elaboração de ementas, seleção de participantes e de palestrantes.)

\begin{tabular}{|l|l|}
\hline & SIM \\
\hline$x$ & NÃO \\
\hline
\end{tabular}

8) Usou os conhecimentos para ministrar outros cursos com o mesmo conteúdo ou conteúdos semelhantes?

\begin{tabular}{|l|l|}
\hline$x$ & SIM \\
\hline & NÃO \\
\hline
\end{tabular}

9) Marque o seu grau de satisfação com relação ao curso oferecido pelo DATER: (Considere a seguinte pontuação: 1 - MUITO RUIM; 2 - RUIM; 3 - REGULAR; 4 - BOM; 5 - MUITO BOM)

\begin{tabular}{|l|l|l|l|l|}
\hline 1 & $\mathrm{x} 2$ & 3 & 4 & 5 \\
\hline
\end{tabular}

10) Marque seu grau de satisfação com relação ao DATER: (Considere a seguinte pontuação: 1 - MUITO RUIM; 2 - RUIM; 3 - REGULAR; 4 - BOM; 5 - MUITO BOM)

\begin{tabular}{|l|l|l|l|l|}
\hline 1 & $x 2$ & 3 & 4 & 5 \\
\hline
\end{tabular}




\section{PESQUISA - IMPACTO DAS AÇÕES DE FORMAÇÃO REALIZADAS PELO \\ DATER/SAF/MDA NO PERÍODO 2004-2009}

Caros colaboradores,

Contamos com a sua atenção para preencher o formulário abaixo.

O mesmo tem por objetivo fornecer informações para avaliação da Eficiência, Efetividade e Eficácia da Política Pública de Formação de Agentes de Ater adotada pelo Departamento de Assistência Técnica e Extensão Rural, da Secretaria de Agricultura Familiar do Ministério do Desenvolvimento - DATER/SAF/MDA, no período de 2004 a 2009, tema escolhido para Monografia a ser apresentada à Universidade de Brasília (UnB) como requisito parcial para obtenção do grau de Bacharel em Administração.

Você poderá ou não se identificar no questionário e garantimos que todas as informações fornecidas serão confidenciais e utilizadas apenas de forma sistematizada.

\section{IDENTIFICAÇÃO}

\begin{tabular}{|c|c|}
\hline JOÃO DE RIBEIRO REIS JUNIOR & $\begin{array}{l}\text { Sexo: } \\
(x \quad) \text { masculino } \quad(\quad) \text { feminino }\end{array}$ \\
\hline $\begin{array}{l}\text { Instituição (nome e tipo de instituição: ONG, } \\
\text { Empresa Pública, etc.): } \\
\text { EMATER }\end{array}$ & Local de trabalho (Cidade e Estado): \\
\hline \multicolumn{2}{|c|}{$\begin{array}{l}\text { Curso/Encontro/Oficina do qual participou (caso tenha participado de mais de um curso, preencha } \\
\text { um formulário para cada um deles): } \\
\text { CURSO DE PECUARIA ECOLOGICA - FLORIANÓPOLIS-SC }\end{array}$} \\
\hline \multicolumn{2}{|l|}{$\begin{array}{l}\text { Data do Curso/Encontro/Oficina (pelo menos mês e ano): } \\
\text { DE } 21 \text { A } 25 \text { DE AGOSTO DE } 2006\end{array}$} \\
\hline
\end{tabular}

1. Indique sua área de atuação? (As opções não são excludentes: você poderá marcar mais de uma opção).

\begin{tabular}{|l|l|}
\hline$X$ & EXTENSÃO RURAL \\
\hline & PESQUISA \\
\hline & ENSINO \\
\hline & OUTROS \\
\hline
\end{tabular}


2) Qual o seu nível de escolaridade? (Considere apenas o nível mais alto)

\begin{tabular}{|c|l|}
\hline & NÍVEL MÉDIO \\
\hline$X$ & NÍVEL SUPERIOR \\
\hline & PÓS-GRADUAÇÃO \\
\hline
\end{tabular}

3) Os conteúdos abordados foram condizentes com as demandas do seu dia-a-dia?

\begin{tabular}{|l|l|}
\hline & SIM \\
\hline$X$ & PARCIALMENTE \\
\hline & NÃO \\
\hline
\end{tabular}

4) O curso contribuiu para o seu aperfeiçoamento profissional?

\begin{tabular}{|l|l|}
\hline$X$ & SIM \\
\hline & NÃO \\
\hline
\end{tabular}

5) Os conhecimentos adquiridos estão sendo aplicados no seu trabalho? Em caso afirmativo, indique em que grau estes conhecimentos estão sendo aplicados. Em caso negativo, indique por que razão isto não ocorre:

\begin{tabular}{|c|c|c|c|}
\hline \multirow{3}{*}{$X$} & \multirow{3}{*}{$\begin{array}{l}\text { SIM (indique ao lado em } \\
\text { que grau) }\end{array}$} & & MUITO APLICADOS \\
\hline & & $\mathrm{X}$ & MEDIAMENTE APLICADOS \\
\hline & & & POUCO APLICADOS \\
\hline & \multirow{3}{*}{$\begin{array}{l}\text { NÃO (indique ao lado a } \\
\text { razão da não aplicação) }\end{array}$} & & $\begin{array}{l}\text { CONTEÚDO NÃO ADEQUADO ȦS NECESSIDADES } \\
\text { ESPECÍFICAS DA REGIÃO }\end{array}$ \\
\hline & & & $\begin{array}{l}\text { CONTEÚDO NÃO } \quad \text { FOI SUFICIENTEMENTE } \\
\text { APROFUNDADO PARA } \\
\text { PERMITIR UMA APLICAÇÃO } \\
\text { EFICAZ E EFICIENTE }\end{array}$ \\
\hline & & & $\begin{array}{l}\text { FALTA DE APOIO } \\
\text { INSTITUIÇÃO }\end{array}$ \\
\hline
\end{tabular}




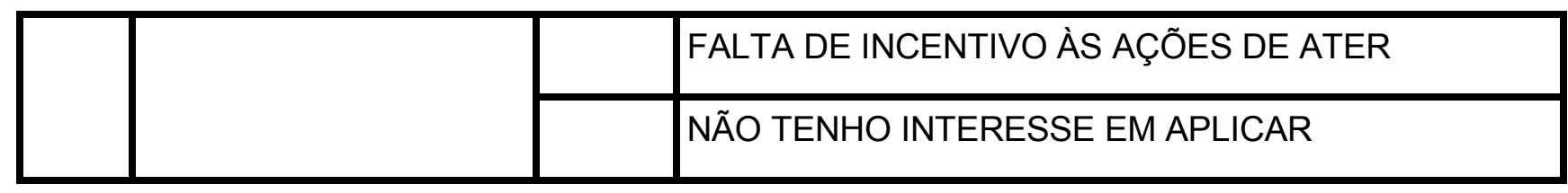

6) A partir deste curso: (As opções não são excludentes: você poderá marcar mais de uma opção).

\begin{tabular}{|l|l|}
\hline$x$ & NÃO MUDOU NADA EM MEU TRABALHO. \\
\hline$x$ & $\begin{array}{l}\text { MEU TRABALHO PASSOU A CONTRIBUIR MAIS COM OS AGRICULTORES(AS) } \\
\text { FAMILIARES. }\end{array}$ \\
\hline & CONSEGUI INFLUENCIAR NAS ORIENTAÇÕES DA MINHA INSTITUIÇÃO. \\
\hline & PASSEI A TRABALHAR COM METODOLOGIAS PARTICIPATIVAS. \\
\hline & $\begin{array}{l}\text { CRESCEU A ÁREA DE AGRICULTURA DE BASE ECOLÓGICA NAS COMUNIDADES } \\
\text { ONDE ATUO. }\end{array}$ \\
\hline$X$ & CONTINUEI ME APERFEIÇOANDO SOBRE TEMAS ABORDADOS. \\
\hline
\end{tabular}

7) Depois do curso você apoiou atividades de capacitação de técnicos e agricultores com base nos princípios e diretrizes da Pnater? (Considere como apoio a atividades de capacitação a participação no planejamento, elaboração de ementas, seleção de participantes e de palestrantes.)

\begin{tabular}{|l|l|}
\hline$X$ & SIM \\
\hline & NÃO \\
\hline
\end{tabular}

8) Usou os conhecimentos para ministrar outros cursos com o mesmo conteúdo ou conteúdos semelhantes?

\begin{tabular}{|l|l|}
\hline$X$ & SIM \\
\hline & NÃO \\
\hline
\end{tabular}

9) Marque o seu grau de satisfação com relação ao curso oferecido pelo DATER: (Considere a seguinte pontuação: 1 - MUITO RUIM; 2 - RUIM; 3 - REGULAR; 4 - BOM; 5 - MUITO BOM) 


\begin{tabular}{|l|l|l|l|l|}
\hline 1 & 2 & $3 x$ & 4 & 5 \\
\hline
\end{tabular}

10) Marque seu grau de satisfação com relação ao DATER: (Considere a seguinte pontuação:

1 - MUITO RUIM; 2 - RUIM; 3 - REGULAR; 4 - BOM; 5 - MUITO BOM)

\begin{tabular}{|l|l|l|l|l|}
\hline 1 & 2 & $3 \times$ & 4 & 5 \\
\hline
\end{tabular}




\section{PESQUISA - IMPACTO DAS AÇÕES DE FORMAÇÃO REALIZADAS PELO \\ DATER/SAF/MDA NO PERÍODO 2004-2009}

Caros colaboradores,

Contamos com a sua atenção para preencher o formulário abaixo.

O mesmo tem por objetivo fornecer informações para avaliação da Eficiência, Efetividade e Eficácia da Política Pública de Formação de Agentes de Ater adotada pelo Departamento de Assistência Técnica e Extensão Rural, da Secretaria de Agricultura Familiar do Ministério do Desenvolvimento - DATER/SAF/MDA, no período de 2004 a 2009, tema escolhido para Monografia a ser apresentada à Universidade de Brasília (UnB) como requisito parcial para obtenção do grau de Bacharel em Administração.

Você poderá ou não se identificar no questionário e garantimos que todas as informações fornecidas serão confidenciais e utilizadas apenas de forma sistematizada.

\section{IDENTIFICAÇÃO}

\begin{tabular}{|l|l|}
\hline Nome: José Giovani Farias & $\begin{array}{l}\text { Sexo: } \\
(x) \text { masculino } \quad(\quad) \text { feminino }\end{array}$ \\
\hline $\begin{array}{l}\text { Instituição: Empresa de Pesquisa e Extensão Rural } \\
\text { de Santa Catarina - EPAGRI. }\end{array}$ & Local de trabalho: Florianópolis, SC. \\
\hline Curso/Encontro/Oficina do qual participou: Aprendizagem e Ação Participativa - AAP. \\
\hline Data do Curso/Encontro/Oficina: Abril de 2008. \\
\hline
\end{tabular}

1 Indique sua área de atuação? (As opções não são excludentes: você poderá marcar mais de uma opção).

\begin{tabular}{|l|l|}
\hline$X$ & EXTENSÃO RURAL \\
\hline & PESQUISA \\
\hline & ENSINO \\
\hline & OUTROS \\
\hline
\end{tabular}

2) Qual o seu nível de escolaridade? (Considere apenas o nível mais alto) 


\begin{tabular}{|c|l|}
\hline & NÍVEL MÉDIO \\
\hline & NÍVEL SUPERIOR \\
\hline$X$ & PÓS-GRADUAÇÃO \\
\hline
\end{tabular}

3) Os conteúdos abordados foram condizentes com as demandas do seu dia-a-dia?

\begin{tabular}{|l|l|}
\hline$X$ & SIM \\
\hline & PARCIALMENTE \\
\hline & NÃO \\
\hline
\end{tabular}

4) O curso contribuiu para o seu aperfeiçoamento profissional?

\begin{tabular}{|l|l|}
\hline$X$ & SIM \\
\hline & NÃO \\
\hline
\end{tabular}

5) Os conhecimentos adquiridos estão sendo aplicados no seu trabalho? Em caso afirmativo, indique em que grau estes conhecimentos estão sendo aplicados. Em caso negativo, indique por que razão isto não ocorre:

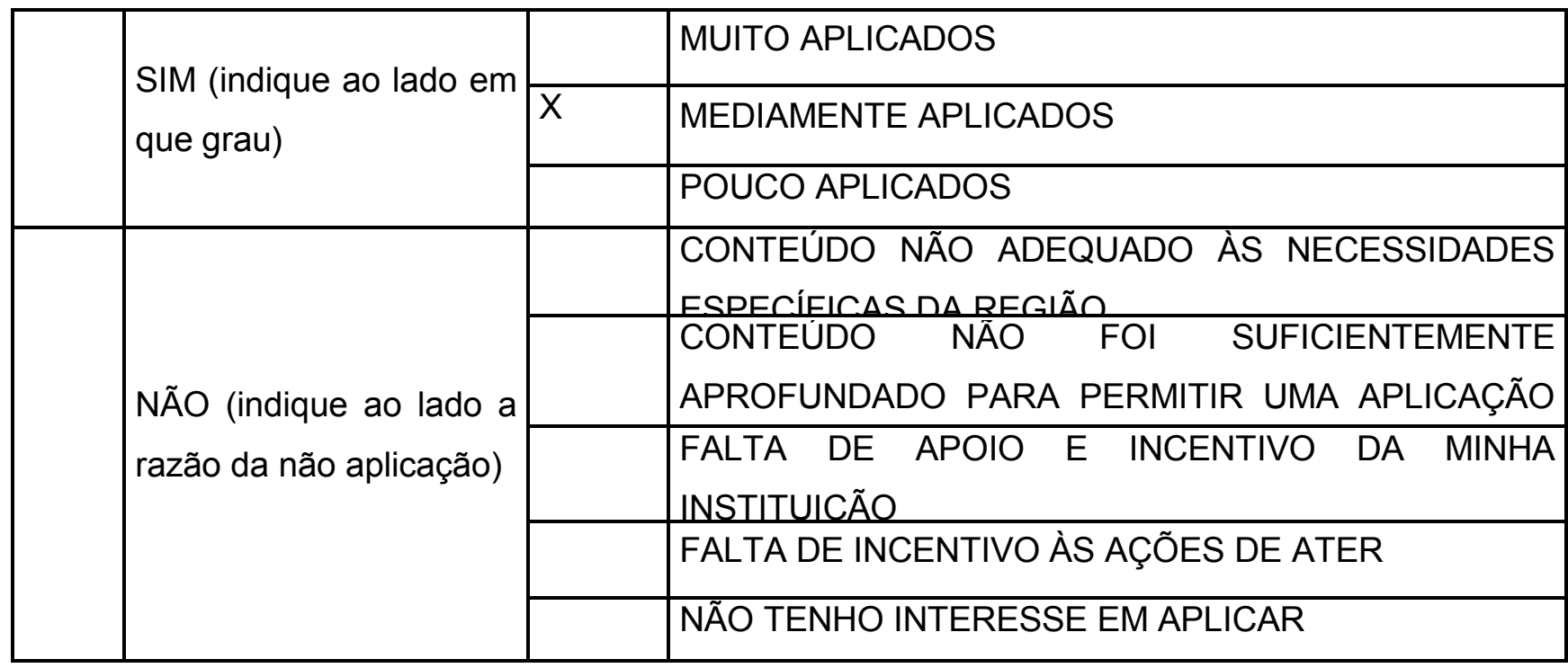

6) A partir deste curso: (As opções não são excludentes: você poderá marcar mais de uma opção). 


\begin{tabular}{|c|l|}
\hline$x$ & $\begin{array}{l}\text { NÃO MUDOU NADA EM MEU TRABALHO. } \\
\text { FAMILIARES. }\end{array}$ \\
\hline$X$ & CONSEGUI INFLUENCIAR NAS ORIENTAÇÕES DA MINHA INSTITUIÇÃO. \\
\hline & PASSEI A TRABALHAR COM METODOLOGIAS PARTICIPATIVAS. \\
\hline & $\begin{array}{l}\text { CRESCEU A ÁREA DE AGRICULTURA DE BASE ECOLÓGICA NAS COMUNIDADES } \\
\text { ONDE ATUO. }\end{array}$ \\
\hline$X$ & CONTINUEI ME APERFEIÇOANDO SOBRE TEMAS ABORDADOS. \\
\hline
\end{tabular}

7) Depois do curso você apoiou atividades de capacitação de técnicos e agricultores com base nos princípios e diretrizes da Pnater? (Considere como apoio a atividades de capacitação a participação no planejamento, elaboração de ementas, seleção de participantes e de palestrantes.)

\begin{tabular}{|l|l|}
\hline$X$ & SIM \\
\hline & NÃO \\
\hline
\end{tabular}

8) Usou os conhecimentos para ministrar outros cursos com o mesmo conteúdo ou conteúdos semelhantes?

\begin{tabular}{|l|l|}
\hline$X$ & SIM \\
\hline & NÃO \\
\hline
\end{tabular}

9) Marque o seu grau de satisfação com relação ao curso oferecido pelo DATER: (Considere a seguinte pontuação: 1 - MUITO RUIM; 2 - RUIM; 3 - REGULAR; 4 - BOM; 5 - MUITO BOM)

\begin{tabular}{|l|l|l|l|l|}
\hline 1 & 2 & 3 & 4 & $\times 5$ \\
\hline
\end{tabular}

10) Marque seu grau de satisfação com relação ao DATER: (Considere a seguinte pontuação: 1 - MUITO RUIM; 2 - RUIM; 3 - REGULAR; 4 - BOM; 5 - MUITO BOM)

\begin{tabular}{|l|l|l|l|l|}
\hline 1 & 2 & 3 & $\times 4$ & 5 \\
\hline
\end{tabular}




\section{PESQUISA - IMPACTO DAS AÇÕES DE FORMAÇÃO REALIZADAS PELO \\ DATER/SAF/MDA NO PERÍODO 2004-2009}

Caros colaboradores,

Contamos com a sua atenção para preencher o formulário abaixo.

O mesmo tem por objetivo fornecer informações para avaliação da Eficiência, Efetividade e Eficácia da Política Pública de Formação de Agentes de Ater adotada pelo Departamento de Assistência Técnica e Extensão Rural, da Secretaria de Agricultura Familiar do Ministério do Desenvolvimento - DATER/SAF/MDA, no período de 2004 a 2009, tema escolhido para Monografia a ser apresentada à Universidade de Brasília (UnB) como requisito parcial para obtenção do grau de Bacharel em Administração.

Você poderá ou não se identificar no questionário e garantimos que todas as informações fornecidas serão confidenciais e utilizadas apenas de forma sistematizada.

IDENTIFICAÇÃO

\begin{tabular}{|c|c|}
\hline $\begin{array}{l}\text { Nome: } \\
\text { Jovania Maria Muller }\end{array}$ & $\begin{array}{l}\text { Sexo: } \\
(\quad) \text { masculino } \quad(x x x) \text { feminino }\end{array}$ \\
\hline $\begin{array}{l}\text { Instituição (nome e tipo de instituição: ONG, } \\
\text { Empresa Pública, etc.): } \\
\text { INCRA }\end{array}$ & Local de trabalho (Cidade e Estado): \\
\hline \multicolumn{2}{|c|}{$\begin{array}{l}\text { Curso/Encontro/Oficina do qual participou (caso tenha participado de mais de um curso, preencha } \\
\text { um formulário para cada um deles): } \\
\text { Curso de Aperfeiçoamento em Agroecologia }\end{array}$} \\
\hline $\begin{array}{l}\text { Data do Curso/Encontro/Oficina (pelo menos mês e } \\
\text { Março a junho/2006 }\end{array}$ & \\
\hline
\end{tabular}

1 Indique sua área de atuação? (As opções não são excludentes: você poderá marcar mais de uma opção).

\begin{tabular}{|l|l|}
\hline$X$ & EXTENSÃO RURAL \\
\hline & PESQUISA \\
\hline & ENSINO \\
\hline & OUTROS \\
\hline
\end{tabular}


2) Qual o seu nível de escolaridade? (Considere apenas o nível mais alto)

\begin{tabular}{|c|l|}
\hline & NÍVEL MÉDIO \\
\hline & NÍVEL SUPERIOR \\
\hline$X$ & PÓS-GRADUAÇÃO \\
\hline
\end{tabular}

3) Os conteúdos abordados foram condizentes com as demandas do seu dia-a-dia?

\begin{tabular}{|l|l|}
\hline$X$ & SIM \\
\hline & PARCIALMENTE \\
\hline & NÃO \\
\hline
\end{tabular}

4) O curso contribuiu para o seu aperfeiçoamento profissional?

\begin{tabular}{|l|l|}
\hline$X$ & SIM \\
\hline & NÃO \\
\hline
\end{tabular}

5) Os conhecimentos adquiridos estão sendo aplicados no seu trabalho? Em caso afirmativo, indique em que grau estes conhecimentos estão sendo aplicados. Em caso negativo, indique por que razão isto não ocorre:

\begin{tabular}{|c|c|c|}
\hline \multirow{3}{*}{$\begin{array}{l}\text { SIM (indique ao lado em } \\
\text { que grau) }\end{array}$} & & MUITO APLICADOS \\
\hline & & MEDIAMENTE APLICADOS \\
\hline & & POUCO APLICADOS \\
\hline \multirow{3}{*}{$\begin{array}{l}\text { NÃO (indique ao lado a } \\
\text { razão da não aplicação) }\end{array}$} & & $\begin{array}{l}\text { CONTEÚDO NÃO ADEQUADO ȦS NECESSIDADES } \\
\text { ESPECÍFICAS DA REGIÃO }\end{array}$ \\
\hline & & $\begin{array}{l}\text { CONTEÚDO NÃO } \quad \text { FOI SUFICIENTEMENTE } \\
\text { APROFUNDADO PARA } \\
\text { PERMITIR UMA APLICAÇÃO } \\
\text { EFICAZ E EFICIENTE }\end{array}$ \\
\hline & $X$ & $\begin{array}{l}\text { FALTA DE APOIO } \\
\text { INSTITUIÇÃO }\end{array}$ \\
\hline
\end{tabular}




\begin{tabular}{|l|l|l|}
\hline \multirow{2}{*}{} & & FALTA DE INCENTIVO ÀS AÇÕES DE ATER \\
\cline { 3 - 4 } & & NÃO TENHO INTERESSE EM APLICAR \\
\hline
\end{tabular}

6) A partir deste curso: (As opções não são excludentes: você poderá marcar mais de uma opção).

\begin{tabular}{|l|l|}
\hline & NÃO MUDOU NADA EM MEU TRABALHO. \\
\hline & $\begin{array}{l}\text { MEU TRABALHO PASSOU A CONTRIBUIR MAIS COM OS AGRICULTORES(AS) } \\
\text { FAMILIARES. }\end{array}$ \\
\hline & CONSEGUI INFLUENCIAR NAS ORIENTAÇÕES DA MINHA INSTITUIÇÃO. \\
\hline & PASSEI A TRABALHAR COM METODOLOGIAS PARTICIPATIVAS. \\
\hline $\mathrm{X}$ & ONESCEU A ÁREA DE AGRICULTURA DE BASE ECOLÓGICA NAS COMUNIDADES \\
\hline$X$ & CONTINUEI ME APERFEIÇOANDO SOBRE TEMAS ABORDADOS. \\
\hline
\end{tabular}

7) Depois do curso você apoiou atividades de capacitação de técnicos e agricultores com base nos princípios e diretrizes da Pnater? (Considere como apoio a atividades de capacitação a participação no planejamento, elaboração de ementas, seleção de participantes e de palestrantes.)

\begin{tabular}{|l|l|}
\hline & SIM \\
\hline$X$ & NÃO \\
\hline
\end{tabular}

8) Usou os conhecimentos para ministrar outros cursos com o mesmo conteúdo ou conteúdos semelhantes?

\begin{tabular}{|l|l|}
\hline & SIM \\
\hline$X$ & NÃO \\
\hline
\end{tabular}

9) Marque o seu grau de satisfação com relação ao curso oferecido pelo DATER: (Considere a seguinte pontuação: 1 - MUITO RUIM; 2 - RUIM; 3 - REGULAR; 4 - BOM; 5 - MUITO BOM) 


\begin{tabular}{|l|l|l|l|l|}
\hline 1 & 2 & 3 & $\times 4$ & 5 \\
\hline
\end{tabular}

10) Marque seu grau de satisfação com relação ao DATER: (Considere a seguinte pontuação: 1 - MUITO RUIM; 2 - RUIM; 3 - REGULAR; 4 - BOM; 5 - MUITO BOM)

\begin{tabular}{|l|l|l|l|l|}
\hline 1 & 2 & 3 & $\times 4$ & 5 \\
\hline
\end{tabular}




\section{PESQUISA - IMPACTO DAS AÇÕES DE FORMAÇÃO REALIZADAS PELO \\ DATER/SAF/MDA NO PERÍODO 2004-2009}

Caros colaboradores,

Contamos com a sua atenção para preencher o formulário abaixo.

O mesmo tem por objetivo fornecer informações para avaliação da Eficiência, Efetividade e Eficácia da Política Pública de Formação de Agentes de Ater adotada pelo Departamento de Assistência Técnica e Extensão Rural, da Secretaria de Agricultura Familiar do Ministério do Desenvolvimento - DATER/SAF/MDA, no período de 2004 a 2009, tema escolhido para Monografia a ser apresentada à Universidade de Brasília (UnB) como requisito parcial para obtenção do grau de Bacharel em Administração.

Você poderá ou não se identificar no questionário e garantimos que todas as informações fornecidas serão confidenciais e utilizadas apenas de forma sistematizada.

\section{IDENTIFICAÇÃO}

\begin{tabular}{|c|c|}
\hline Nome: JUSSARA DE JESUS KÖNIG & $\begin{array}{l}\text { Sexo: } \\
\left(\begin{array}{l}) \text { masculino } \quad(x) \text { feminino }\end{array}\right.\end{array}$ \\
\hline $\begin{array}{l}\text { Instituição (nome e tipo de instituição: ONG, } \\
\text { Empresa Pública, etc.): } \\
\text { CESAP - Centro de Elaborações Assessoria e } \\
\text { Desenvolvimento de Projetos }\end{array}$ & $\begin{array}{l}\text { Local de trabalho (Cidade e Estado): O } \\
\text { CESAP tem trabalho em vários municípios } \\
\text { de SC, PR e RS. }\end{array}$ \\
\hline \multicolumn{2}{|c|}{$\begin{array}{l}\text { Curso/Encontro/Oficina do qual participou (caso tenha participado de mais de um curso, preencha } \\
\text { um formulário para cada um deles): II CURSO DE APERFEIÇOAMENTO EM AGROECOLOGIA A } \\
\text { DISTÂNCIA. }\end{array}$} \\
\hline
\end{tabular}

1) Indique sua área de atuação? (As opções não são excludentes: você poderá marcar mais de uma opção).

\begin{tabular}{|l|l|}
\hline$X$ & EXTENSÃO RURAL \\
\hline & PESQUISA \\
\hline & ENSINO \\
\hline
\end{tabular}




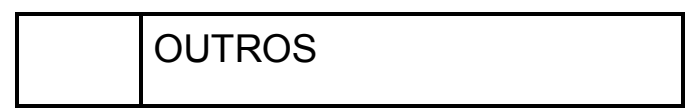

2) Qual o seu nível de escolaridade? (Considere apenas o nível mais alto)

\begin{tabular}{|l|l|}
\hline & NÍVEL MÉDIO \\
\hline$X$ & NÍVEL SUPERIOR \\
\hline & PÓS-GRADUAÇÃO \\
\hline
\end{tabular}

3) Os conteúdos abordados foram condizentes com as demandas do seu dia-a-dia?

\begin{tabular}{|l|l|}
\hline$X$ & SIM \\
\hline & PARCIALMENTE \\
\hline & NÃO \\
\hline
\end{tabular}

4) O curso contribuiu para o seu aperfeiçoamento profissional?

\begin{tabular}{|l|l|}
\hline$X$ & SIM \\
\hline & NÃO \\
\hline
\end{tabular}

5) Os conhecimentos adquiridos estão sendo aplicados no seu trabalho? Em caso afirmativo, indique em que grau estes conhecimentos estão sendo aplicados. Em caso negativo, indique por que razão isto não ocorre:

\begin{tabular}{|c|c|c|}
\hline \multirow{3}{*}{$\begin{array}{l}\text { SIM (indique ao lado em } \\
\text { que grau) }\end{array}$} & $\mathrm{X}$ & MUITO APLICADOS \\
\hline & & MEDIAMENTE APLICADOS \\
\hline & & POUCO APLICADOS \\
\hline \multirow{4}{*}{$\begin{array}{l}\text { NÃO (indique ao lado a } \\
\text { razão da não aplicação) }\end{array}$} & & CONTEÚDO NÃO ADEQUADO ÀS NECESSIDADES \\
\hline & & $\begin{array}{llll}\text { CONTEÚDO NÂO } & \text { FOI } & \text { SUFICIENTEMENTE } \\
\text { APROFUNDADO } & \text { PARA } & \text { PERMITIR UMA APLICAÇÃO }\end{array}$ \\
\hline & & $\begin{array}{lcccccc}\text { FALTA } & \text { DE } & \text { APOIO } & \text { E } & \text { INCENTIVO } & \text { DA } & \text { MINHA } \\
\text { INSTITUICÃO } & & & & & \\
\end{array}$ \\
\hline & & FALTA DE INCENTIVO ÀS AÇÕES DE ATER \\
\hline
\end{tabular}




\begin{tabular}{|l|l|l|l|}
\hline & & & NÃO TENHO INTERESSE EM APLICAR \\
\hline
\end{tabular}

6) A partir deste curso:

(As opções não são excludentes: você poderá marcar mais de uma opção).

\begin{tabular}{|l|l|}
\hline & NÃO MUDOU NADA EM MEU TRABALHO. \\
\hline$X$ & $\begin{array}{l}\text { MEU TRABALHO PASSOU A CONTRIBUIR MAIS COM OS AGRICULTORES(AS) } \\
\text { FAMILIARES. }\end{array}$ \\
\hline$X$ & CONSEGUI INFLUENCIAR NAS ORIENTAÇÕES DA MINHA INSTITUIÇÃO. \\
\hline$X$ & PASSEI A TRABALHAR COM METODOLOGIAS PARTICIPATIVAS. \\
\hline & $\begin{array}{l}\text { CRESCEU A ÁREA DE AGRICULTURA DE BASE ECOLÓGICA NAS COMUNIDADES } \\
\text { ONDE ATUO. }\end{array}$ \\
\hline & CONTINUEI ME APERFEIÇOANDO SOBRE TEMAS ABORDADOS. \\
\hline
\end{tabular}

7) Depois do curso você apoiou atividades de capacitação de técnicos e agricultores com base nos princípios e diretrizes da Pnater? (Considere como apoio a atividades de capacitação a participação no planejamento, elaboração de ementas, seleção de participantes e de palestrantes.)

\begin{tabular}{|l|l|}
\hline & SIM \\
\hline$X$ & NÃO \\
\hline
\end{tabular}

8) Usou os conhecimentos para ministrar outros cursos com o mesmo conteúdo ou conteúdos semelhantes?

\begin{tabular}{|l|l|}
\hline$X$ & SIM \\
\hline & NÃO \\
\hline
\end{tabular}

9) Marque o seu grau de satisfação com relação ao curso oferecido pelo DATER: (Considere a seguinte pontuação: 1 - MUITO RUIM; 2 - RUIM; 3 - REGULAR; 4 - BOM; 5 - MUITO BOM) 


\begin{tabular}{|l|l|l|l|l|}
\hline 1 & 2 & 3 & 4 & $5-X$ \\
\hline
\end{tabular}

10) Marque seu grau de satisfação com relação ao DATER: (Considere a seguinte pontuação: 1 - MUITO RUIM; 2 - RUIM; 3 - REGULAR; 4 - BOM; 5 - MUITO BOM)

\begin{tabular}{|l|l|l|l|l|}
\hline 1 & 2 & 3 & 4 & $5-X$ \\
\hline
\end{tabular}




\section{PESQUISA - IMPACTO DAS AÇÕES DE FORMAÇÃO REALIZADAS PELO \\ DATER/SAF/MDA NO PERÍODO 2004-2009}

Caros colaboradores,

Contamos com a sua atenção para preencher o formulário abaixo.

O mesmo tem por objetivo fornecer informações para avaliação da Eficiência, Efetividade e Eficácia da Política Pública de Formação de Agentes de Ater adotada pelo Departamento de Assistência Técnica e Extensão Rural, da Secretaria de Agricultura Familiar do Ministério do Desenvolvimento - DATER/SAF/MDA, no período de 2004 a 2009, tema escolhido para Monografia a ser apresentada à Universidade de Brasília (UnB) como requisito parcial para obtenção do grau de Bacharel em Administração.

Você poderá ou não se identificar no questionário e garantimos que todas as informações fornecidas serão confidenciais e utilizadas apenas de forma sistematizada.

IDENTIFICAÇÃO

\begin{tabular}{|l|l|}
\hline Nome: Kenji Oscar Asami & $\begin{array}{l}\text { Sexo: } \\
(x) \text { masculino } \quad(\quad) \text { feminino }\end{array}$ \\
\hline $\begin{array}{l}\text { Instituição (nome e tipo de instituição: ONG, } \\
\text { Empresa Pública, etc.): Instituição Pública - Emater }\end{array}$ & $\begin{array}{l}\text { Local de trabalho (Cidade e Estado): } \\
\text { Campo Mourão - Pr }\end{array}$ \\
\hline $\begin{array}{l}\text { Curso/Encontro/Oficina do qual participou (caso tenha participado de mais de um curso, preencha } \\
\text { um formulário para cada um deles): Curso em APRENDIZAGEM E AÇÃO PARTICIPATIVA: } \\
\text { TEORIA E PRÁTICA SOBRE DIAGNÓSTICO, PLANEJAMENTO E AÇÃO PARTICIPATIVA EM } \\
\text { EXTENSÃO RURAL. }\end{array}$ \\
\hline Data do Curso/Encontro/Oficina (pelo menos mês e ano): 07 a 18 de abril de 2008 \\
\hline
\end{tabular}

1. Indique sua área de atuação? (As opções não são excludentes: você poderá marcar mais de uma opção).

\begin{tabular}{|l|l|}
\hline$X$ & EXTENSÃO RURAL \\
\hline & PESQUISA \\
\hline & ENSINO \\
\hline
\end{tabular}




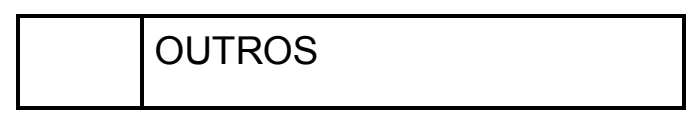

2) Qual o seu nível de escolaridade? (Considere apenas o nível mais alto)

\begin{tabular}{|l|l|}
\hline & NÍVEL MÉDIO \\
\hline & NÍVEL SUPERIOR \\
\hline$X$ & PÓS-GRADUAÇÃO \\
\hline
\end{tabular}

3) Os conteúdos abordados foram condizentes com as demandas do seu dia-a-dia?

\begin{tabular}{|l|l|}
\hline$X$ & SIM \\
\hline & PARCIALMENTE \\
\hline & NÃO \\
\hline
\end{tabular}

4) O curso contribuiu para o seu aperfeiçoamento profissional?

\begin{tabular}{|l|l|}
\hline$X$ & SIM \\
\hline & NÃO \\
\hline
\end{tabular}

5) Os conhecimentos adquiridos estão sendo aplicados no seu trabalho? Em caso afirmativo, indique em que grau estes conhecimentos estão sendo aplicados. Em caso negativo, indique por que razão isto não ocorre:

\begin{tabular}{|c|c|c|c|}
\hline \multirow{3}{*}{$x$} & \multirow{3}{*}{$\begin{array}{l}\text { SIM (indique ao lado em } \\
\text { que grau) }\end{array}$} & & MUITO APLICADOS \\
\hline & & $\bar{X}$ & MEDIAMENTE APLICADOS \\
\hline & & & POUCO APLICADOS \\
\hline & & & $\begin{array}{l}\text { CONTEÚDO NÃO ADEQUADO ÀS NECESSIDADES } \\
\text { ESPECÍEICASA REGIÃO }\end{array}$ \\
\hline & $\begin{array}{l}\text { NÃO (indique ao lado a } \\
\text { razão da não aplicacão) }\end{array}$ & & $\begin{array}{llll}\text { CONTEUUDO NÂO } & \text { FOI } & \text { SUFICIENTEMENTE } \\
\text { APROFUNDADO PARA PERMITIR UMA APLICACÃO }\end{array}$ \\
\hline & & & $\begin{array}{lcccccc}\text { FALTA } & \text { DE } & \text { APOIO } & \text { E } & \text { INCENTIVO } & \text { DA } & \text { MINHA } \\
\text { INSTITUICÃO } & & & & & \\
\end{array}$ \\
\hline
\end{tabular}




\begin{tabular}{|l|l|l|l|}
\hline \multirow{2}{*}{} & & & FALTA DE INCENTIVO ÀS AÇÕES DE ATER \\
\cline { 3 - 3 } & & NÃO TENHO INTERESSE EM APLICAR \\
\hline
\end{tabular}

6) A partir deste curso:

\begin{tabular}{|l|l|}
\hline & NÃO MUDOU NADA EM MEU TRABALHO. \\
\hline & $\begin{array}{l}\text { MEU TRABALHO PASSOU A CONTRIBUIR MAIS COM OS AGRICULTORES(AS) } \\
\text { FAMILIARES. }\end{array}$ \\
\hline$X$ & CONSEGUI INFLUENCIAR NAS ORIENTAÇÕES DA MINHA INSTITUIÇÃO. \\
\hline & $\begin{array}{l}\text { PASSEI A TRABALHAR COM METODOLOGIAS PARTICIPATIVAS. } \\
\text { ONDE ATUO. }\end{array}$ \\
\hline & CONTINUEI ME APERFEIÇOANDO SOBRE TEMAS ABORDADOS. \\
\hline
\end{tabular}

7) Depois do curso você apoiou atividades de capacitação de técnicos e agricultores com base nos princípios e diretrizes da Pnater? (Considere como apoio a atividades de capacitação a participação no planejamento, elaboração de ementas, seleção de participantes e de palestrantes.)

\begin{tabular}{|l|l|}
\hline & SIM \\
\hline$X$ & NÃO \\
\hline
\end{tabular}

8) Usou os conhecimentos para ministrar outros cursos com o mesmo conteúdo ou conteúdos semelhantes?

\begin{tabular}{|l|l|}
\hline$X$ & SIM \\
\hline & NÃO \\
\hline
\end{tabular}

9) Marque o seu grau de satisfação com relação ao curso oferecido pelo DATER: (Considere a seguinte pontuação: 1 - MUITO RUIM; 2 - RUIM; 3 - REGULAR; 4 - BOM; 5 - MUITO BOM)

\begin{tabular}{|l|l|l|l|l|}
\hline 1 & 2 & 3 & $4 \times$ & 5 \\
\hline
\end{tabular}


10) Marque seu grau de satisfação com relação ao DATER: (Considere a seguinte pontuação: 1 - MUITO RUIM; 2 - RUIM; 3 - REGULAR; 4 - BOM; 5 - MUITO BOM)

\begin{tabular}{|l|l|l|l|l|}
\hline 1 & 2 & 3 & 4 & $5 X$ \\
\hline
\end{tabular}




\section{PESQUISA - IMPACTO DAS AÇÕES DE FORMAÇÃO REALIZADAS PELO \\ DATER/SAF/MDA NO PERÍODO 2004-2009}

Caros colaboradores,

Contamos com a sua atenção para preencher o formulário abaixo.

O mesmo tem por objetivo fornecer informações para avaliação da Eficiência, Efetividade e Eficácia da Política Pública de Formação de Agentes de Ater adotada pelo Departamento de Assistência Técnica e Extensão Rural, da Secretaria de Agricultura Familiar do Ministério do Desenvolvimento - DATER/SAF/MDA, no período de 2004 a 2009, tema escolhido para Monografia a ser apresentada à Universidade de Brasília (UnB) como requisito parcial para obtenção do grau de Bacharel em Administração.

Você poderá ou não se identificar no questionário e garantimos que todas as informações fornecidas serão confidenciais e utilizadas apenas de forma sistematizada.

\section{IDENTIFICAÇÃO}

\begin{tabular}{|c|c|}
\hline Nome: Luciana Barros Roldão & $\begin{array}{l}\text { Sexo: } \\
\left(\begin{array}{l}\quad) \text { masculino } \quad(\quad x) \text { feminino }\end{array}\right.\end{array}$ \\
\hline $\begin{array}{l}\text { Instituição (nome e tipo de instituição: ONG, } \\
\text { Empresa Pública, etc.): Fundação Universidade } \\
\text { Federal do Rio Grande - FURG }\end{array}$ & $\begin{array}{l}\text { Local de trabalho (Cidade e Estado): } \\
\text { Rio Grande - RS }\end{array}$ \\
\hline \multicolumn{2}{|c|}{$\begin{array}{l}\text { Curso/Encontro/Oficina do qual participou (caso tenha participado de mais de um curso, preencha } \\
\text { um formulário para cada um deles): } \\
\text { Agentes de Assistência Técnica e Extensão Rural. }\end{array}$} \\
\hline \multicolumn{2}{|l|}{$\begin{array}{l}\text { Data do Curso/Encontro/Oficina (pelo menos mês e ano): } \\
\text { Novembro de } 2004\end{array}$} \\
\hline
\end{tabular}

1. Indique sua área de atuação? (As opções não são excludentes: você poderá marcar mais de uma opção).

\begin{tabular}{|l|l|}
\hline$x$ & EXTENSÃO RURAL \\
\hline & PESQUISA \\
\hline & ENSINO \\
\hline
\end{tabular}




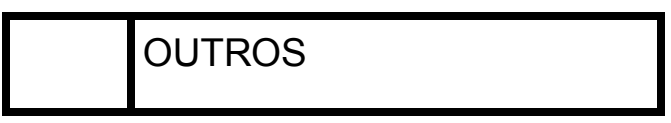

2) Qual o seu nível de escolaridade? (Considere apenas o nível mais alto)

\begin{tabular}{|l|l|}
\hline & NÍVEL MÉDIO \\
\hline$x$ & NÍVEL SUPERIOR \\
\hline & PÓS-GRADUAÇÃO \\
\hline
\end{tabular}

3) Os conteúdos abordados foram condizentes com as demandas do seu dia-a-dia?

\begin{tabular}{|l|l|}
\hline$x$ & SIM \\
\hline & PARCIALMENTE \\
\hline & NÃO \\
\hline
\end{tabular}

4) O curso contribuiu para o seu aperfeiçoamento profissional?

\begin{tabular}{|l|l|}
\hline$x$ & SIM \\
\hline & NÃO \\
\hline
\end{tabular}

5) Os conhecimentos adquiridos estão sendo aplicados no seu trabalho? Em caso afirmativo, indique em que grau estes conhecimentos estão sendo aplicados. Em caso negativo, indique por que razão isto não ocorre:

\begin{tabular}{|c|c|c|c|}
\hline \multirow{3}{*}{$x$} & \multirow{3}{*}{$\begin{array}{l}\text { SIM (indique ao lado em } \\
\text { que grau) }\end{array}$} & $x$ & MUITO APLICADOS \\
\hline & & & MEDIAMENTE APLICADOS \\
\hline & & & POUCO APLICADOS \\
\hline & \multirow{2}{*}{$\begin{array}{l}\text { NÃO (indique ao lado a } \\
\text { razão da não aplicação) }\end{array}$} & & $\begin{array}{l}\text { CONTEÚDO NÃO ADEQUADO ȦS NECESSIDADES } \\
\text { ESPECÍFICAS DA REGIÃO }\end{array}$ \\
\hline & & & $\begin{array}{l}\text { CONTEÚDO NÃO } \text { FOI SUFICIENTEMENTE } \\
\text { APROFUNDADO PARA } \\
\text { PERMITIR UMA APLICAÇÃO } \\
\text { EFICAZ E EFICIENTE }\end{array}$ \\
\hline
\end{tabular}




\begin{tabular}{|l|l|l|}
\hline \multirow{2}{*}{} & & $\begin{array}{l}\text { FALTA DE APOIO E INCENTIVO DA MINHA } \\
\text { INSTITUIÇÃO }\end{array}$ \\
\cline { 2 - 3 } & & FALTA DE INCENTIVO ÀS AÇÕES DE ATER \\
\cline { 2 - 3 } & NÃO TENHO INTERESSE EM APLICAR \\
\hline
\end{tabular}

6) A partir deste curso: (As opções não são excludentes: você poderá marcar mais de uma opção).

\begin{tabular}{|l|l|}
\hline & NÃO MUDOU NADA EM MEU TRABALHO. \\
\hline & $\begin{array}{l}\text { MEU TRABALHO PASSOU A CONTRIBUIR MAIS COM OS AGRICULTORES(AS) } \\
\text { FAMILIARES. }\end{array}$ \\
\hline $\mathrm{x}$ & CONSEGUI INFLUENCIAR NAS ORIENTAÇÕES DA MINHA INSTITUIÇÃO. \\
\hline & $\begin{array}{l}\text { CRESCEU A ÁREA DE AGRICULTURA DE BASE ECOLÓGICA NAS COMUNIDADES } \\
\text { ONDE ATUO. }\end{array}$ \\
\hline $\mathrm{x}$ & CONTINUEI ME APERFEIÇOANDO SOBRE TEMAS ABORDADOS. \\
\hline
\end{tabular}

7) Depois do curso você apoiou atividades de capacitação de técnicos e agricultores com base nos princípios e diretrizes da Pnater? (Considere como apoio a atividades de capacitação a participação no planejamento, elaboração de ementas, seleção de participantes e de palestrantes.)

\begin{tabular}{|l|l|}
\hline$x$ & SIM \\
\hline & NÃO \\
\hline
\end{tabular}

8) Usou os conhecimentos para ministrar outros cursos com o mesmo conteúdo ou conteúdos semelhantes?

\begin{tabular}{|l|l|}
\hline$x$ & SIM \\
\hline & NÃO \\
\hline
\end{tabular}


9) Marque o seu grau de satisfação com relação ao curso oferecido pelo DATER: (Considere a seguinte pontuação: 1 - MUITO RUIM; 2 - RUIM; 3 - REGULAR; 4 - BOM; 5 - MUITO BOM)

\begin{tabular}{|l|l|l|l|l|}
\hline 1 & 2 & 3 & 4 & $x 5$ \\
\hline
\end{tabular}

10) Marque seu grau de satisfação com relação ao DATER: (Considere a seguinte pontuação: 1 - MUITO RUIM; 2 - RUIM; 3 - REGULAR; 4 - BOM; 5 - MUITO BOM)

\begin{tabular}{|l|l|l|l|l|}
\hline 1 & 2 & 3 & 4 & $x 5$ \\
\hline
\end{tabular}




\section{PESQUISA - IMPACTO DAS AÇÕES DE FORMAÇÃO REALIZADAS PELO \\ DATER/SAF/MDA NO PERÍODO 2004-2009}

Caros colaboradores,

Contamos com a sua atenção para preencher o formulário abaixo.

O mesmo tem por objetivo fornecer informações para avaliação da Eficiência, Efetividade e Eficácia da Política Pública de Formação de Agentes de Ater adotada pelo Departamento de Assistência Técnica e Extensão Rural, da Secretaria de Agricultura Familiar do Ministério do Desenvolvimento - DATER/SAF/MDA, no período de 2004 a 2009, tema escolhido para Monografia a ser apresentada à Universidade de Brasília (UnB) como requisito parcial para obtenção do grau de Bacharel em Administração.

Você poderá ou não se identificar no questionário e garantimos que todas as informações fornecidas serão confidenciais e utilizadas apenas de forma sistematizada.

\section{IDENTIFICAÇÃO}

\begin{tabular}{|l|l|l|l|}
\hline Nome: Luis Fernando Tividini de Oliveira & $\left.\begin{array}{l}\text { Sexo: } \\
(x)\end{array}\right)$ masculino $\quad(\quad$ ) feminino \\
\hline Instituição Federação dos & Trabalhadores na & Local de trabalho (Cidade e Estado): \\
Agricultura $\quad$ Familiar da & Região Sul & - & Região Sul \\
FETRAFSUL/CUT & & \\
\hline $\begin{array}{l}\text { Curso/Encontro/Oficina do qual participou: Oficina de construção de metodologias participativas } \\
\text { de ATER para agricultura familiar. }\end{array}$ \\
\hline Data do Curso/Encontro/Oficina: Mês de novembro de 2005, em Vitória/ES \\
\hline
\end{tabular}

1 Indique sua área de atuação? (As opções não são excludentes: você poderá marcar mais de uma opção).

\begin{tabular}{|l|l|}
\hline$x$ & EXTENSÃO RURAL \\
\hline & PESQUISA \\
\hline & ENSINO \\
\hline & OUTROS \\
\hline
\end{tabular}

2) Qual o seu nível de escolaridade? (Considere apenas o nível mais alto) 


\begin{tabular}{|l|l|}
\hline & NÍVEL MÉDIO \\
\hline & NÍVEL SUPERIOR \\
\hline$x$ & PÓS-GRADUAÇÃO \\
\hline
\end{tabular}

3) Os conteúdos abordados foram condizentes com as demandas do seu dia-a-dia?

\begin{tabular}{|l|l|}
\hline$x$ & SIM \\
\hline & PARCIALMENTE \\
\hline & NÃO \\
\hline
\end{tabular}

4) O curso contribuiu para o seu aperfeiçoamento profissional?

\begin{tabular}{|l|l|}
\hline$x$ & SIM \\
\hline & NÃO \\
\hline
\end{tabular}

5) Os conhecimentos adquiridos estão sendo aplicados no seu trabalho? Em caso afirmativo, indique em que grau estes conhecimentos estão sendo aplicados. Em caso negativo, indique por que razão isto não ocorre:

\begin{tabular}{|c|c|c|c|}
\hline \multirow{3}{*}{$x$} & \multirow{3}{*}{$\begin{array}{l}\text { SIM (indique ao lado em } \\
\text { que grau) }\end{array}$} & $\mathrm{x}$ & MUITO APLICADOS \\
\hline & & & MEDIAMENTE APLICADOS \\
\hline & & & POUCO APLICADOS \\
\hline & \multirow{4}{*}{$\begin{array}{l}\text { NÃO (indique ao lado a } \\
\text { razão da não aplicação) }\end{array}$} & & $\begin{array}{l}\text { CONTEÚDO NĀO ADEQUADO ȦS NECESSIDADES } \\
\text { ESPECÍFICAS DA REGIÃO }\end{array}$ \\
\hline & & & $\begin{array}{l}\text { CONTEÚDO NÃO } \text { FOI SUFICIENTEMENTE } \\
\text { APROFUNDADO PARA PERMITIR UMA APLICAÇÃO } \\
\text { EFICAZ E EFICIENTE }\end{array}$ \\
\hline & & & $\begin{array}{lllllll}\text { FALTA DE } & \text { APOIO } & \text { E } & \text { INCENTIVO } & \text { DA } & \text { MINHA } \\
\text { INSTITUIÇÃO } & & & & \end{array}$ \\
\hline & & & FALTA DE INCENTIVO ÀS AÇÕES DE ATER \\
\hline
\end{tabular}




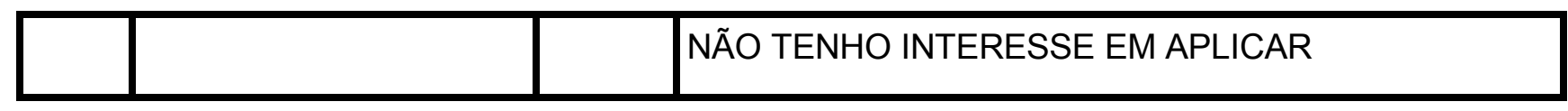

6) A partir deste curso:

\begin{tabular}{|l|l|}
\hline$x$ & $\begin{array}{l}\text { NÃO MUDOU NADA EM MEU TRABALHO. } \\
\text { FAMILIARES. }\end{array}$ \\
\hline & CONSEGUI INFLUENCIAR NAS ORIENTAÇÕES DA MINHA INSTITUIÇÃO. \\
\hline & PASSEI A TRABALHAR COM METODOLOGIAS PARTICIPATIVAS. \\
\hline & $\begin{array}{l}\text { ORESCEU A ÁREA DE AGRICULTURA DE BASE ECOLÓGICA NAS COMUNIDADES } \\
\text { CONTINUEI ME APERFEIÇOANDO SOBRE TEMAS ABORDADOS. }\end{array}$ \\
\hline
\end{tabular}

7) Depois do curso você apoiou atividades de capacitação de técnicos e agricultores com base nos princípios e diretrizes da Pnater? (Considere como apoio a atividades de capacitação a participação no planejamento, elaboração de ementas, seleção de participantes e de palestrantes.)

\begin{tabular}{|l|l|}
\hline$x$ & SIM \\
\hline & NÃO \\
\hline
\end{tabular}

8) Usou os conhecimentos para ministrar outros cursos com o mesmo conteúdo ou conteúdos semelhantes?

\begin{tabular}{|l|l|}
\hline$x$ & SIM \\
\hline & NÃO \\
\hline
\end{tabular}

9) Marque o seu grau de satisfação com relação ao curso oferecido pelo DATER: (Considere a seguinte pontuação: 1 - MUITO RUIM; 2 - RUIM; 3 - REGULAR; 4 - BOM; 5 - MUITO BOM) 


\begin{tabular}{|l|l|l|l|l|}
\hline 1 & 2 & 3 & $4 \times$ & 5 \\
\hline
\end{tabular}

10) Marque seu grau de satisfação com relação ao DATER: (Considere a seguinte pontuação: 1 - MUITO RUIM; 2 - RUIM; 3 - REGULAR; 4 - BOM; 5 - MUITO BOM)

\begin{tabular}{|l|l|l|l|l|}
\hline 1 & 2 & 3 & $4 x$ & 5 \\
\hline
\end{tabular}




\section{PESQUISA - IMPACTO DAS AÇÕES DE FORMAÇÃO REALIZADAS PELO \\ DATER/SAF/MDA NO PERÍODO 2004-2009}

Caros colaboradores,

Contamos com a sua atenção para preencher o formulário abaixo.

O mesmo tem por objetivo fornecer informações para avaliação da Eficiência, Efetividade e Eficácia da Política Pública de Formação de Agentes de Ater adotada pelo Departamento de Assistência Técnica e Extensão Rural, da Secretaria de Agricultura Familiar do Ministério do Desenvolvimento - DATER/SAF/MDA, no período de 2004 a 2009, tema escolhido para Monografia a ser apresentada à Universidade de Brasília (UnB) como requisito parcial para obtenção do grau de Bacharel em Administração.

Você poderá ou não se identificar no questionário e garantimos que todas as informações fornecidas serão confidenciais e utilizadas apenas de forma sistematizada.

IDENTIFICAÇÃO

\begin{tabular}{|c|c|}
\hline Nome: ANTONIO MACCALI & $\begin{array}{l}\text { Sexo: } \\
(x \quad) \text { masculino } \quad(\quad) \text { feminino }\end{array}$ \\
\hline $\begin{array}{l}\text { Instituição (nome e tipo de instituição: ONG, } \\
\text { Empresa Pública, etc.): } \\
\text { EMATER- RS/ASCAR }\end{array}$ & $\begin{array}{l}\text { Local de trabalho (Cidade e Estado): } \\
\text { IMIGRANTE, RS }\end{array}$ \\
\hline \multicolumn{2}{|c|}{$\begin{array}{l}\text { Curso/Encontro/Oficina do qual participou (caso tenha participado de mais de um curso, preencha } \\
\text { um formulário para cada um deles): } \\
\text { SISTEMAS AGROFLORESTAIS - BIOMA MATA ATLANTIDA }\end{array}$} \\
\hline $\begin{array}{l}\text { Data do Curso/Encontro/Oficina (pelo menos mês } \\
11 \text { a } 15 \text { de dezembro de } 2006\end{array}$ & no): \\
\hline
\end{tabular}

1 Indique sua área de atuação? (As opções não são excludentes: você poderá marcar mais de uma opção).

\begin{tabular}{|l|l|}
\hline$X$ & EXTENSÃO RURAL \\
\hline & PESQUISA \\
\hline & ENSINO \\
\hline & OUTROS \\
\hline
\end{tabular}


2) Qual o seu nível de escolaridade? (Considere apenas o nível mais alto)

\begin{tabular}{|l|l|}
\hline$X$ & NÍVEL MÉDIO \\
\hline & NÍVEL SUPERIOR \\
\hline & PÓS-GRADUAÇÃO \\
\hline
\end{tabular}

3) Os conteúdos abordados foram condizentes com as demandas do seu dia-a-dia?

\begin{tabular}{|l|l|}
\hline & SIM \\
\hline$X$ & PARCIALMENTE \\
\hline & NÃO \\
\hline
\end{tabular}

4) O curso contribuiu para o seu aperfeiçoamento profissional?

\begin{tabular}{|l|l|}
\hline$X$ & SIM \\
\hline & NÃO \\
\hline
\end{tabular}

5) Os conhecimentos adquiridos estão sendo aplicados no seu trabalho? Em caso afirmativo, indique em que grau estes conhecimentos estão sendo aplicados. Em caso negativo, indique por que razão isto não ocorre:

\begin{tabular}{|l|l|l|l|}
\hline \multirow{2}{*}{$\begin{array}{l}\text { SIM (indique ao lado em } \\
\text { que grau) }\end{array}$} & & MUITO APLICADOS \\
\cline { 2 - 3 } & & MEDIAMENTE APLICADOS \\
\hline \multirow{2}{*}{$\begin{array}{l}\text { NÃO (indique ao lado a } \\
\text { razão da não aplicação) }\end{array}$} & $\mathrm{X}$ & $\begin{array}{l}\text { CONTEU்DO NÃO ADEQUADO ȦS NECESSIDADES } \\
\text { ESPECÍFICAS DA REGIÃO }\end{array}$ \\
\hline & $\begin{array}{l}\text { CONTEÚDO NÃO FOI SUFICIENTEMENTE } \\
\text { EFICAZ E EFICIENTE }\end{array}$ \\
\hline
\end{tabular}




\begin{tabular}{|l|l|l|}
\hline \multirow{2}{*}{} & & $\begin{array}{l}\text { FALTA DE APOIO E INCENTIVO DA MINHA } \\
\text { INSTITUIÇÃO }\end{array}$ \\
\cline { 2 - 3 } & & FALTA DE INCENTIVO ÀS AÇÕES DE ATER \\
\cline { 2 - 3 } & NÃO TENHO INTERESSE EM APLICAR \\
\hline
\end{tabular}

6) A partir deste curso: (As opções não são excludentes: você poderá marcar mais de uma opção).

\begin{tabular}{|l|l|}
\hline & NÃO MUDOU NADA EM MEU TRABALHO. \\
\hline & $\begin{array}{l}\text { MEU TRABALHO PASSOU A CONTRIBUIR MAIS COM OS AGRICULTORES(AS) } \\
\text { FAMILIARES. }\end{array}$ \\
\hline & CONSEGUI INFLUENCIAR NAS ORIENTAÇÕES DA MINHA INSTITUIÇÃO. \\
\hline & $\begin{array}{l}\text { CRESCEI A TRABALHAR COM METODOLOGIAS PARTICIPATIVAS. } \\
\text { ONDE ATUO. }\end{array}$ \\
\hline$X$ & CONTINUEI ME APERFEIÇOANDO SOBRE TEMAS ABORDADOS. \\
\hline
\end{tabular}

7) Depois do curso você apoiou atividades de capacitação de técnicos e agricultores com base nos princípios e diretrizes da Pnater? (Considere como apoio a atividades de capacitação a participação no planejamento, elaboração de ementas, seleção de participantes e de palestrantes.)

\begin{tabular}{|l|l|}
\hline & SIM \\
\hline$X$ & NÃO \\
\hline
\end{tabular}

8) Usou os conhecimentos para ministrar outros cursos com o mesmo conteúdo ou conteúdos semelhantes?

\begin{tabular}{|l|l|}
\hline & SIM \\
\hline$X$ & NÃO \\
\hline
\end{tabular}


9) Marque o seu grau de satisfação com relação ao curso oferecido pelo DATER: (Considere a seguinte pontuação: 1 - MUITO RUIM; 2 - RUIM; 3 - REGULAR; 4 - BOM; 5 - MUITO BOM)

\begin{tabular}{|l|l|l|l|l|}
\hline 1 & 2 & $x$ & 4 & 5 \\
\hline
\end{tabular}

10) Marque seu grau de satisfação com relação ao DATER: (Considere a seguinte pontuação: 1 - MUITO RUIM; 2 - RUIM; 3 - REGULAR; 4 - BOM; 5 - MUITO BOM)

\begin{tabular}{|l|l|l|l|l|}
\hline 1 & 2 & 3 & $x$ & 5 \\
\hline
\end{tabular}




\section{PESQUISA - IMPACTO DAS AÇÕES DE FORMAÇÃO REALIZADAS PELO \\ DATER/SAF/MDA NO PERÍODO 2004-2009}

Caros colaboradores,

Contamos com a sua atenção para preencher o formulário abaixo.

O mesmo tem por objetivo fornecer informações para avaliação da Eficiência, Efetividade e Eficácia da Política Pública de Formação de Agentes de Ater adotada pelo Departamento de Assistência Técnica e Extensão Rural, da Secretaria de Agricultura Familiar do Ministério do Desenvolvimento - DATER/SAF/MDA, no período de 2004 a 2009, tema escolhido para Monografia a ser apresentada à Universidade de Brasília (UnB) como requisito parcial para obtenção do grau de Bacharel em Administração.

Você poderá ou não se identificar no questionário e garantimos que todas as informações fornecidas serão confidenciais e utilizadas apenas de forma sistematizada.

\section{IDENTIFICAÇÃO}

\begin{tabular}{|c|c|}
\hline Nome: MARCELO XAVIER TOZZI & $\begin{array}{l}\text { Sexo: } \\
(x \quad) \text { masculino } \quad(\quad) \text { feminino }\end{array}$ \\
\hline $\begin{array}{l}\text { Instituição (nome e tipo de instituição: ONG, } \\
\text { Empresa Pública, etc.): ASCAR -EMATER / RS }\end{array}$ & $\begin{array}{l}\text { Local de trabalho (Cidade e Estado): ITATI } \\
\text { - RS }\end{array}$ \\
\hline \multicolumn{2}{|c|}{$\begin{array}{l}\text { Curso/Encontro/Oficina do qual participou (caso tenha participado de mais de um curso, preencha } \\
\text { um formulário para cada um deles): CURSO DE FORMAÇÃO DE SISTEMAS } \\
\text { AGROFLORESTAIS PARA A MATA ATLÂNTICA }\end{array}$} \\
\hline rso/Encontro/Oficina (pelc & o): $12 / 2006$ \\
\hline
\end{tabular}

1. Indique sua área de atuação? (As opções não são excludentes: você poderá marcar mais de uma opção).

\begin{tabular}{|l|l|}
\hline$X$ & EXTENSÃO RURAL \\
\hline & PESQUISA \\
\hline & ENSINO \\
\hline
\end{tabular}




\section{OUTROS}

2) Qual o seu nível de escolaridade? (Considere apenas o nível mais alto)

\begin{tabular}{|l|l|}
\hline & NÍVEL MÉDIO \\
\hline & NÍVEL SUPERIOR \\
\hline$X$ & PÓS-GRADUAÇÃO \\
\hline
\end{tabular}

3) Os conteúdos abordados foram condizentes com as demandas do seu dia-a-dia?

\begin{tabular}{|l|l|}
\hline$X$ & SIM \\
\hline & PARCIALMENTE \\
\hline & NÃO \\
\hline
\end{tabular}

4) O curso contribuiu para o seu aperfeiçoamento profissional?

\begin{tabular}{|l|l|}
\hline$X$ & SIM \\
\hline & NÃO \\
\hline
\end{tabular}

5) Os conhecimentos adquiridos estão sendo aplicados no seu trabalho? Em caso afirmativo, indique em que grau estes conhecimentos estão sendo aplicados. Em caso negativo, indique por que razão isto não ocorre:

\begin{tabular}{|c|c|c|}
\hline \multirow{3}{*}{$\begin{array}{l}\text { SIM (indique ao lado em } \\
\text { que grau) }\end{array}$} & & MUITO APLICADOS \\
\hline & $\mathrm{X}$ & MEDIAMENTE APLICADOS \\
\hline & & POUCO APLICADOS \\
\hline \multirow{2}{*}{$\begin{array}{l}\text { NÃO (indique ao lado a } \\
\text { razão da não aplicação) }\end{array}$} & & $\begin{array}{l}\text { CONTEÚDO NÃO ADEQUADO ȦS NECESSIDADES } \\
\text { ESPECÍFICAS DA REGIÃO }\end{array}$ \\
\hline & & $\begin{array}{l}\text { CONTEÚDO NÃO } \quad \text { FOI SUFICIENTEMENTE } \\
\text { APROFUNDADO PARA } \\
\text { PERMITIR UMA APLICAÇÃO } \\
\text { EFICAZ E EFICIENTE }\end{array}$ \\
\hline
\end{tabular}




\begin{tabular}{|l|l|l|}
\hline \multirow{2}{*}{} & & $\begin{array}{l}\text { FALTA DE APOIO E INCENTIVO DA MINHA } \\
\text { INSTITUIÇÃO }\end{array}$ \\
\cline { 2 - 3 } & & FALTA DE INCENTIVO ÀS AÇÕES DE ATER \\
\cline { 2 - 3 } & NÃO TENHO INTERESSE EM APLICAR \\
\hline
\end{tabular}

6) A partir deste curso:

\begin{tabular}{|l|l|}
\hline & NÃO MUDOU NADA EM MEU TRABALHO. \\
\hline & $\begin{array}{l}\text { MEU TRABALHO PASSOU A CONTRIBUIR MAIS COM OS AGRICULTORES(AS) } \\
\text { FAMILIARES. }\end{array}$ \\
\hline & CONSEGUI INFLUENCIAR NAS ORIENTAÇÕES DA MINHA INSTITUIÇÃO. \\
\hline & $\begin{array}{l}\text { CRESESE A TRABALHAR COM METODOLOGIAS PARTICIPATIVAS. } \\
\text { ONDE ATUO. ÁREA DE AGRICULTURA DE BASE ECOLÓGICA NAS COMUNIDADES }\end{array}$ \\
\hline$X$ & CONTINUEI ME APERFEIÇOANDO SOBRE TEMAS ABORDADOS. \\
\hline
\end{tabular}

7) Depois do curso você apoiou atividades de capacitação de técnicos e agricultores com base nos princípios e diretrizes da Pnater? (Considere como apoio a atividades de capacitação a participação no planejamento, elaboração de ementas, seleção de participantes e de palestrantes.)

\begin{tabular}{|l|l|}
\hline & SIM \\
\hline$X$ & NÃO \\
\hline
\end{tabular}

8) Usou os conhecimentos para ministrar outros cursos com o mesmo conteúdo ou conteúdos semelhantes?

\begin{tabular}{|l|l|}
\hline & SIM \\
\hline$X$ & NÃO \\
\hline
\end{tabular}


9) Marque o seu grau de satisfação com relação ao curso oferecido pelo DATER: (Considere a seguinte pontuação: 1 - MUITO RUIM; 2 - RUIM; 3 - REGULAR; 4 - BOM; 5 - MUITO BOM)

\begin{tabular}{|l|l|l|l|l|}
\hline 1 & 2 & $x$ & 4 & 5 \\
\hline
\end{tabular}

10) Marque seu grau de satisfação com relação ao DATER: (Considere a seguinte pontuação: 1 - MUITO RUIM; 2 - RUIM; 3 - REGULAR; 4 - BOM; 5 - MUITO BOM)

\begin{tabular}{|l|l|l|l|l|}
\hline 1 & 2 & 3 & $x$ & 5 \\
\hline
\end{tabular}




\section{PESQUISA - IMPACTO DAS AÇÕES DE FORMAÇÃO REALIZADAS PELO \\ DATER/SAF/MDA NO PERÍODO 2004-2009}

Caros colaboradores,

Contamos com a sua atenção para preencher o formulário abaixo.

O mesmo tem por objetivo fornecer informações para avaliação da Eficiência, Efetividade e Eficácia da Política Pública de Formação de Agentes de Ater adotada pelo Departamento de Assistência Técnica e Extensão Rural, da Secretaria de Agricultura Familiar do Ministério do Desenvolvimento - DATER/SAF/MDA, no período de 2004 a 2009, tema escolhido para Monografia a ser apresentada à Universidade de Brasília (UnB) como requisito parcial para obtenção do grau de Bacharel em Administração.

Você poderá ou não se identificar no questionário e garantimos que todas as informações fornecidas serão confidenciais e utilizadas apenas de forma sistematizada.

\section{IDENTIFICAÇÃO}

\begin{tabular}{|l|l|}
\hline Nome: Marcelo Barbosa Spaolonse & $\begin{array}{l}\text { Sexo: } \\
(x) \text { masculino } \quad(\quad) \text { feminino }\end{array}$ \\
\hline Instituição INCRA & Local de trabalho Florianópolis - SC \\
\hline $\begin{array}{l}\text { Curso/Encontro/Oficina do qual participou: } \\
\text { ATER para comunidades quilombolas }\end{array}$ \\
\hline Data do Curso/Encontro/Oficina (pelo menos mês e ano): setembro/2008 \\
\hline
\end{tabular}

Indique sua área de atuação? (As opções não são excludentes: você poderá marcar mais de uma opção).

\begin{tabular}{|l|l|}
\hline & EXTENSÃO RURAL \\
\hline & PESQUISA \\
\hline & ENSINO \\
\hline$X$ & OUTROS \\
\hline
\end{tabular}

2) Qual o seu nível de escolaridade? (Considere apenas o nível mais alto) 


\begin{tabular}{|l|l|}
\hline & NÍVEL MÉDIO \\
\hline & NÍVEL SUPERIOR \\
\hline$X$ & PÓS-GRADUAÇÃO \\
\hline
\end{tabular}

3) Os conteúdos abordados foram condizentes com as demandas do seu dia-a-dia?

\begin{tabular}{|l|l|}
\hline$X$ & SIM \\
\hline & PARCIALMENTE \\
\hline & NÃO \\
\hline
\end{tabular}

4) O curso contribuiu para o seu aperfeiçoamento profissional?

\begin{tabular}{|l|l|}
\hline$X$ & SIM \\
\hline & NÃO \\
\hline
\end{tabular}

5) Os conhecimentos adquiridos estão sendo aplicados no seu trabalho? Em caso afirmativo, indique em que grau estes conhecimentos estão sendo aplicados. Em caso negativo, indique por que razão isto não ocorre:

\begin{tabular}{|c|c|c|}
\hline \multirow{3}{*}{$\begin{array}{l}\text { SIM (indique ao lado em } \\
\text { que grau) }\end{array}$} & & MUITO APLICADOS \\
\hline & $\mathrm{X}$ & MEDIAMENTE APLICADOS \\
\hline & & POUCO APLICADOS \\
\hline \multirow{5}{*}{$\begin{array}{l}\text { NÃO (indique ao lado a } \\
\text { razão da não aplicação) }\end{array}$} & & $\begin{array}{l}\text { CONTEÚDO NÃO ADEQUADO ÀS NECESSIDADES } \\
\text { FSPFCÍFICAS DA RFGIÃO }\end{array}$ \\
\hline & & $\begin{array}{llll}\text { CONTEUDO NÂO } & \text { FOI } & \text { SUFICIENTEMENTE } \\
\text { APROFUNDADO } & \text { PARA } & \text { PERMITIR UMA } & \text { APLICAÇÃO }\end{array}$ \\
\hline & & $\begin{array}{lllllll}\text { FALTA } & \text { DE } & \text { APOIO } & \text { E } & \text { INCENTIVO } & \text { DA } & \text { MINHA } \\
\text { INSTITUICÃO } & & & & & \\
\end{array}$ \\
\hline & & FALTA DE INCENTIVO ÀS AÇÕES DE ATER \\
\hline & & NÃO TENHO INTERESSE EM APLICAR \\
\hline
\end{tabular}

6) A partir deste curso: 


\begin{tabular}{|l|l|}
\hline & NÃO MUDOU NADA EM MEU TRABALHO. \\
\hline & $\begin{array}{l}\text { MEU TRABALHO PASSOU A CONTRIBUIR MAIS COM OS AGRICULTORES(AS) } \\
\text { FAMILIARES. }\end{array}$ \\
\hline$X$ & CONSEGUI INFLUENCIAR NAS ORIENTAÇÕES DA MINHA INSTITUIÇÃO. \\
\hline & $\begin{array}{l}\text { CRASSEI A TRABALHAR COM METODOLOGIAS PARTICIPATIVAS. } \\
\text { ONDE ATUO. }\end{array}$ \\
\hline & CONTINUEI ME APERFEIÇOANDO SOBRE TEMAS ABORDADOS. \\
\hline
\end{tabular}

7) Depois do curso você apoiou atividades de capacitação de técnicos e agricultores com base nos princípios e diretrizes da Pnater? (Considere como apoio a atividades de capacitação a participação no planejamento, elaboração de ementas, seleção de participantes e de palestrantes.)

\begin{tabular}{|l|l|}
\hline$X$ & SIM \\
\hline & NÃO \\
\hline
\end{tabular}

8) Usou os conhecimentos para ministrar outros cursos com o mesmo conteúdo ou conteúdos semelhantes?

\begin{tabular}{|l|l|}
\hline & SIM \\
\hline$X$ & NÃO \\
\hline
\end{tabular}

9) Marque o seu grau de satisfação com relação ao curso oferecido pelo DATER: (Considere a seguinte pontuação: 1 - MUITO RUIM; 2 - RUIM; 3 - REGULAR; 4 - BOM; 5 - MUITO BOM)

\begin{tabular}{|l|l|l|l|l|}
\hline 1 & 2 & 3 & 4 & 5 \\
\hline
\end{tabular}

10) Marque seu grau de satisfação com relação ao DATER: (Considere a seguinte pontuação: 1 - MUITO RUIM; 2 - RUIM; 3 - REGULAR; 4 - BOM; 5 - MUITO BOM)

\begin{tabular}{|l|l|l|l|l|}
\hline 1 & 2 & 3 & 4 & 5 \\
\hline
\end{tabular}




\section{PESQUISA - IMPACTO DAS AÇÕES DE FORMAÇÃO REALIZADAS PELO \\ DATER/SAF/MDA NO PERÍODO 2004-2009}

Caros colaboradores,

Contamos com a sua atenção para preencher o formulário abaixo.

O mesmo tem por objetivo fornecer informações para avaliação da Eficiência, Efetividade e Eficácia da Política Pública de Formação de Agentes de Ater adotada pelo Departamento de Assistência Técnica e Extensão Rural, da Secretaria de Agricultura Familiar do Ministério do Desenvolvimento - DATER/SAF/MDA, no período de 2004 a 2009, tema escolhido para Monografia a ser apresentada à Universidade de Brasília (UnB) como requisito parcial para obtenção do grau de Bacharel em Administração.

Você poderá ou não se identificar no questionário e garantimos que todas as informações fornecidas serão confidenciais e utilizadas apenas de forma sistematizada.

\section{IDENTIFICAÇÃO}

\begin{tabular}{|c|c|}
\hline MARCELO BIASSUSI & $\begin{array}{l}\text { Sexo: } \\
(x \quad) \text { masculino } \quad(\quad) \text { feminino }\end{array}$ \\
\hline $\begin{array}{l}\text { Instituição (nome e tipo de instituição: ONG, } \\
\text { Empresa Pública, etc.): } \\
\qquad \text { ASCAR - EMATER/RS }\end{array}$ & CERRO GRANDE DO SUL - RS \\
\hline \multicolumn{2}{|c|}{$\begin{array}{l}\text { Curso/Encontro/Oficina do qual participou (caso tenha participado de mais de um curso, } \\
\text { preencha um formulário para cada um deles): } \\
\text { CURSO DE APERFEIÇOAMENTO EM AGROECOLOGIA }\end{array}$} \\
\hline $\begin{array}{l}\text { Data do Curso/Encontro/Oficina (pelo menos } n \\
\text { de março a junho de } 2006\end{array}$ & s e ano): \\
\hline
\end{tabular}

1. Indique sua área de atuação? (As opções não são excludentes: você poderá marcar mais de uma opção).

\begin{tabular}{|l|l|}
\hline$X$ & EXTENSÃO RURAL \\
\hline & PESQUISA \\
\hline & ENSINO \\
\hline & OUTROS \\
\hline
\end{tabular}


2) Qual o seu nível de escolaridade? (Considere apenas o nível mais alto)

\begin{tabular}{|l|l|}
\hline & NÍVEL MÉDIO \\
\hline & NÍVEL SUPERIOR \\
\hline$X$ & PÓS-GRADUAÇÃO \\
\hline
\end{tabular}

3) Os conteúdos abordados foram condizentes com as demandas do seu dia-a-dia?

\begin{tabular}{|l|l|}
\hline$X$ & SIM \\
\hline & PARCIALMENTE \\
\hline & NÃO \\
\hline
\end{tabular}

4) O curso contribuiu para o seu aperfeiçoamento profissional?

\begin{tabular}{|l|l|}
\hline$X$ & SIM \\
\hline & NÃO \\
\hline
\end{tabular}

5) Os conhecimentos adquiridos estão sendo aplicados no seu trabalho? Em caso afirmativo, indique em que grau estes conhecimentos estão sendo aplicados. Em caso negativo, indique por que razão isto não ocorre:

\begin{tabular}{|c|c|c|}
\hline \multirow{3}{*}{$\begin{array}{l}\text { SIM (indique ao } \\
\text { lado em que grau) }\end{array}$} & $x$ & MUITO APLICADOS \\
\hline & & MEDIAMENTE APLICADOS \\
\hline & & POUCO APLICADOS \\
\hline \multirow{3}{*}{$\begin{array}{ll}\text { NÃO (indique } & \text { ao } \\
\text { lado a razão da } \\
\text { não aplicação) }\end{array}$} & & $\begin{array}{l}\text { CONTEÚDO NÃO ADEQUADO ȦS NECESSIDADES } \\
\text { ESPECÍFICAS DA REGIÃO }\end{array}$ \\
\hline & & 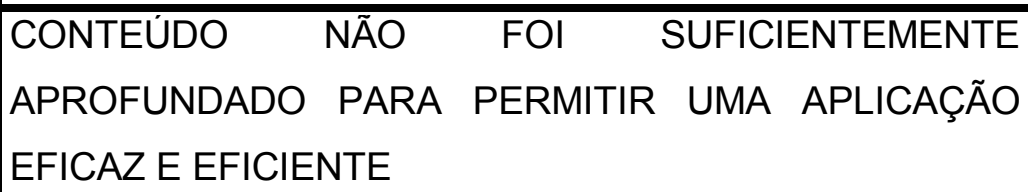 \\
\hline & & $\begin{array}{lcccccc}\text { FALTA } & \text { DE } & \text { APOIO } & \text { E } & \text { INCENTIVO } & \text { DA } & \text { MINHA } \\
\text { INSTITUIÇÃO } & & & & & & \end{array}$ \\
\hline
\end{tabular}




\begin{tabular}{|l|l|l|}
\hline \multirow{2}{*}{} & & FALTA DE INCENTIVO ÀS AÇÕES DE ATER \\
\cline { 3 - 3 } & & NÃO TENHO INTERESSE EM APLICAR \\
\hline
\end{tabular}

6) A partir deste curso:

\begin{tabular}{|l|l|}
\hline & NÃO MUDOU NADA EM MEU TRABALHO. \\
\hline & $\begin{array}{l}\text { MEU TRABALHO PASSOU A CONTRIBUIR MAIS COM OS AGRICULTORES(AS) } \\
\text { FAMILIARES. }\end{array}$ \\
\hline$x$ & PANSEGUI INFLUENCIAR NAS ORIENTAÇÕES DA MINHA INSTITUIÇÃO. \\
\hline$X$ & $\begin{array}{l}\text { CRESCEU A ÁREA DE AGRICULTURA DE BASE ECOLÓGICA NAS COMUNIDADES } \\
\text { ONDE ATUO. }\end{array}$ \\
\hline$X$ & CONTINUEI ME APERFEIÇOANDO SOBRE TEMAS ABORDADOS. \\
\hline
\end{tabular}

7) Depois do curso você apoiou atividades de capacitação de técnicos e agricultores com base nos princípios e diretrizes da Pnater? (Considere como apoio a atividades de capacitação a participação no planejamento, elaboração de ementas, seleção de participantes e de palestrantes.)

\begin{tabular}{|l|l|}
\hline$X$ & SIM \\
\hline & NÃO \\
\hline
\end{tabular}

8) Usou os conhecimentos para ministrar outros cursos com o mesmo conteúdo ou conteúdos semelhantes?

\begin{tabular}{|l|l|}
\hline$X$ & SIM \\
\hline & NÃO \\
\hline
\end{tabular}

9) Marque o seu grau de satisfação com relação ao curso oferecido pelo DATER: (Considere a seguinte pontuação: 1 - MUITO RUIM; 2 - RUIM; 3 - REGULAR; 4 - BOM; 5 - MUITO BOM) 


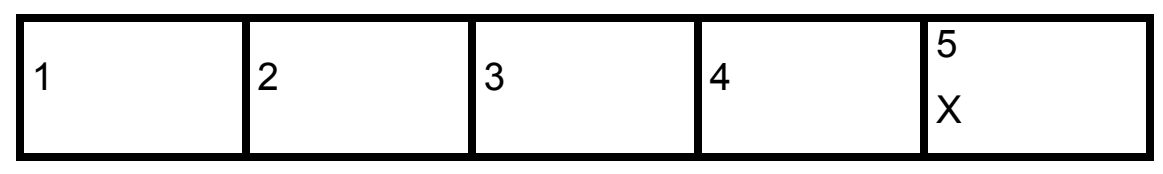

10) Marque seu grau de satisfação com relação ao DATER: (Considere a seguinte pontuação: 1 - MUITO RUIM; 2 - RUIM; 3 - REGULAR; 4 - BOM; 5 - MUITO BOM)

\begin{tabular}{|l|l|l|l|l|}
\hline 1 & 2 & 3 & 4 & $\begin{array}{l}5 \\
x\end{array}$ \\
\hline
\end{tabular}




\section{PESQUISA - IMPACTO DAS AÇÕES DE FORMAÇÃO REALIZADAS PELO \\ DATER/SAF/MDA NO PERÍODO 2004-2009}

Caros colaboradores,

Contamos com a sua atenção para preencher o formulário abaixo.

O mesmo tem por objetivo fornecer informações para avaliação da Eficiência, Efetividade e Eficácia da Política Pública de Formação de Agentes de Ater adotada pelo Departamento de Assistência Técnica e Extensão Rural, da Secretaria de Agricultura Familiar do Ministério do Desenvolvimento - DATER/SAF/MDA, no período de 2004 a 2009, tema escolhido para Monografia a ser apresentada à Universidade de Brasília (UnB) como requisito parcial para obtenção do grau de Bacharel em Administração.

Você poderá ou não se identificar no questionário e garantimos que todas as informações fornecidas serão confidenciais e utilizadas apenas de forma sistematizada.

IDENTIFICAÇÃO

\begin{tabular}{|c|c|}
\hline $\begin{array}{l}\text { Nome: } \\
\text { Marilac Priscila Vivan }\end{array}$ & $\begin{array}{l}\text { Sexo: } \\
(\quad) \text { masculino } \quad(x \quad) \text { feminino }\end{array}$ \\
\hline $\begin{array}{l}\text { Instituição (nome e tipo de instituição: ONG, } \\
\text { Empresa Pública, etc.): } \\
\text { Prefeitura Municipal de Blumenau }\end{array}$ & $\begin{array}{l}\text { Local de trabalho (Cidade e Estado): } \\
\text { Blumenau - SC }\end{array}$ \\
\hline \multicolumn{2}{|c|}{$\begin{array}{l}\text { Curso/Encontro/Oficina do qual participou (caso tenha participado de mais de um curso, preencha } \\
\text { um formulário para cada um deles): } \\
\text { Curso de Pecuária Ecológica }\end{array}$} \\
\hline \multicolumn{2}{|l|}{$\begin{array}{l}\text { Data do Curso/Encontro/Oficina (pelo menos mês e ano): } \\
\text { Agosto/2006 }\end{array}$} \\
\hline
\end{tabular}

1. Indique sua área de atuação? (As opções não são excludentes: você poderá marcar mais de uma opção).

\begin{tabular}{|l|l|}
\hline$x$ & EXTENSÃO RURAL \\
\hline & PESQUISA \\
\hline & ENSINO \\
\hline & OUTROS \\
\hline
\end{tabular}


2) Qual o seu nível de escolaridade? (Considere apenas o nível mais alto)

\begin{tabular}{|l|l|}
\hline & NÍVEL MÉDIO \\
\hline & NÍVEL SUPERIOR \\
\hline$x$ & PÓS-GRADUAÇÃO \\
\hline
\end{tabular}

3) Os conteúdos abordados foram condizentes com as demandas do seu dia-a-dia?

\begin{tabular}{|l|l|}
\hline & SIM \\
\hline$x$ & PARCIALMENTE \\
\hline & NÃO \\
\hline
\end{tabular}

4) O curso contribuiu para o seu aperfeiçoamento profissional?

\begin{tabular}{|l|l|}
\hline$x$ & SIM \\
\hline & NÃO \\
\hline
\end{tabular}

5) Os conhecimentos adquiridos estão sendo aplicados no seu trabalho? Em caso afirmativo, indique em que grau estes conhecimentos estão sendo aplicados. Em caso negativo, indique por que razão isto não ocorre:

\begin{tabular}{|c|c|c|}
\hline \multirow{3}{*}{$\begin{array}{l}\text { SIM (indique ao lado em } \\
\text { que grau) }\end{array}$} & & MUITO APLICADOS \\
\hline & & MEDIAMENTE APLICADOS \\
\hline & & POUCO APLICADOS \\
\hline \multirow{3}{*}{$\begin{array}{l}\text { NÃO (indique ao lado a } \\
\text { razão da não aplicação) }\end{array}$} & & $\begin{array}{l}\text { CONTEÚDO NÃO ADEQUADO ȦS NECESSIDADES } \\
\text { ESPECÍFICAS DA REGIÃO }\end{array}$ \\
\hline & $x$ & $\begin{array}{l}\text { CONTEÚDO NÃO } \quad \text { FOI SUFICIENTEMENTE } \\
\text { APROFUNDADO PARA } \\
\text { PERMITIR UMA APLICAÇÃO } \\
\text { EFICAZ E EFICIENTE }\end{array}$ \\
\hline & & $\begin{array}{l}\text { FALTA DE APOIO } \\
\text { INSTITUIÇÃO }\end{array}$ \\
\hline
\end{tabular}




\begin{tabular}{|l|l|l|}
\hline \multirow{2}{*}{} & & FALTA DE INCENTIVO ÀS AÇÕES DE ATER \\
\cline { 3 - 4 } & & NÃO TENHO INTERESSE EM APLICAR \\
\hline
\end{tabular}

6) A partir deste curso:

\begin{tabular}{|l|l|}
\hline & NÃO MUDOU NADA EM MEU TRABALHO. \\
\hline & $\begin{array}{l}\text { MEU TRABALHO PASSOU A CONTRIBUIR MAIS COM OS AGRICULTORES(AS) } \\
\text { FAMILIARES. }\end{array}$ \\
\hline & CONSEGUI INFLUENCIAR NAS ORIENTAÇÕES DA MINHA INSTITUIÇÃO. \\
\hline & PASSEI A TRABALHAR COM METODOLOGIAS PARTICIPATIVAS. \\
\hline & $\begin{array}{l}\text { ORESCEU A ÁREA DE AGRICULTURA DE BASE ECOLÓGICA NAS COMUNIDADES } \\
\text { CONTINUEI ME APERFEIÇOANDO SOBRE TEMAS ABORDADOS. }\end{array}$ \\
\hline
\end{tabular}

7) Depois do curso você apoiou atividades de capacitação de técnicos e agricultores com base nos princípios e diretrizes da Pnater? (Considere como apoio a atividades de capacitação a participação no planejamento, elaboração de ementas, seleção de participantes e de palestrantes.)

\begin{tabular}{|l|l|}
\hline & SIM \\
\hline$x$ & NÃO \\
\hline
\end{tabular}

8) Usou os conhecimentos para ministrar outros cursos com o mesmo conteúdo ou conteúdos semelhantes?

\begin{tabular}{|l|l|}
\hline & SIM \\
\hline$x$ & NÃO \\
\hline
\end{tabular}

9) Marque o seu grau de satisfação com relação ao curso oferecido pelo DATER: (Considere a seguinte pontuação: 1 - MUITO RUIM; 2 - RUIM; 3 - REGULAR; 4 - BOM; 5 - MUITO BOM) 


\begin{tabular}{|l|l|l|l|l|}
\hline 1 & 2 & $3 x$ & 4 & 5 \\
\hline
\end{tabular}

10) Marque seu grau de satisfação com relação ao DATER: (Considere a seguinte pontuação: 1 - MUITO RUIM; 2 - RUIM; 3 - REGULAR; 4 - BOM; 5 - MUITO BOM)

\begin{tabular}{|l|l|l|l|l|}
\hline 1 & 2 & 3 & 4 & $5 x$ \\
\hline
\end{tabular}




\section{PESQUISA - IMPACTO DAS AÇÕES DE FORMAÇÃO REALIZADAS PELO \\ DATER/SAF/MDA NO PERÍODO 2004-2009}

Caros colaboradores,

Contamos com a sua atenção para preencher o formulário abaixo.

O mesmo tem por objetivo fornecer informações para avaliação da Eficiência, Efetividade e Eficácia da Política Pública de Formação de Agentes de Ater adotada pelo Departamento de Assistência Técnica e Extensão Rural, da Secretaria de Agricultura Familiar do Ministério do Desenvolvimento - DATER/SAF/MDA, no período de 2004 a 2009, tema escolhido para Monografia a ser apresentada à Universidade de Brasília (UnB) como requisito parcial para obtenção do grau de Bacharel em Administração.

Você poderá ou não se identificar no questionário e garantimos que todas as informações fornecidas serão confidenciais e utilizadas apenas de forma sistematizada

IDENTIFICAÇÃO

\begin{tabular}{|l|l|}
\hline Nome: Daniel José de Souza Mol & $\begin{array}{l}\text { Sexo: } \\
(\mathrm{x}) \text { masculino } \quad(\quad \text { ) feminino }\end{array}$ \\
\hline $\begin{array}{l}\text { Instituição (nome e tipo de instituição: ONG, } \\
\text { Empresa Pública, etc.): Biolabore }\end{array}$ & $\begin{array}{l}\text { Local de trabalho (Cidade e Estado): Guaira } \\
\text { PR }\end{array}$ \\
\hline $\begin{array}{l}\text { Curso/Encontro/Oficina do qual participou (caso tenha participado de mais de um curso, preencha } \\
\text { um formulário para cada um deles): Sistemas Agroflorestais }\end{array}$ \\
\hline Data do Curso/Encontro/Oficina (pelo menos mês e ano): 05-16 de maio de 2008 \\
\hline
\end{tabular}

1. Indique sua área de atuação?

\begin{tabular}{|l|l|}
\hline$X$ & EXTENSÃO RURAL \\
\hline & PESQUISA \\
\hline & ENSINO \\
\hline & OUTROS \\
\hline
\end{tabular}

2) Qual o seu nível de escolaridade? (Considere apenas o nível mais alto) 


\begin{tabular}{|l|l|}
\hline & NÍVEL MÉDIO \\
\hline$X$ & NÍVEL SUPERIOR \\
\hline & PÓS-GRADUAÇÃO \\
\hline
\end{tabular}

3) Os conteúdos abordados foram condizentes com as demandas do seu dia-a-dia?

\begin{tabular}{|l|l|}
\hline & SIM \\
\hline & PARCIALMENTE \\
\hline$X$ & NÃO \\
\hline
\end{tabular}

4) O curso contribuiu para o seu aperfeiçoamento profissional?

\begin{tabular}{|l|l|}
\hline$X$ & SIM \\
\hline & NÃO \\
\hline
\end{tabular}

5) Os conhecimentos adquiridos estão sendo aplicados no seu trabalho? Em caso afirmativo, indique em que grau estes conhecimentos estão sendo aplicados. Em caso negativo, indique por que razão isto não ocorre:

\begin{tabular}{|c|c|c|}
\hline \multirow{3}{*}{$\begin{array}{l}\text { SIM (indique ao lado em } \\
\text { que grau) }\end{array}$} & & MUITO APLICADOS \\
\hline & & MEDIAMENTE APLICADOS \\
\hline & & POUCO APLICADOS \\
\hline \multirow{5}{*}{$\begin{array}{l}\text { NÃO (indique ao lado a } \\
\text { razão da não aplicação) }\end{array}$} & & $\begin{array}{l}\text { CONTEÚDO NÃO ADEQUADO ÀS NECESSIDADES } \\
\text { ESPECÍFICAS } R \text { A REGIÃم }\end{array}$ \\
\hline & $\bar{x}$ & $\begin{array}{|lccr|}\text { CONTEÜDO } & \text { NÄO } & \text { FOI } & \text { SUFICIENTEMENTE } \\
\text { APROFUNDADO } & \text { PARA } & \text { PERMITIR UMA } & \text { APLICAÇÃO }\end{array}$ \\
\hline & & 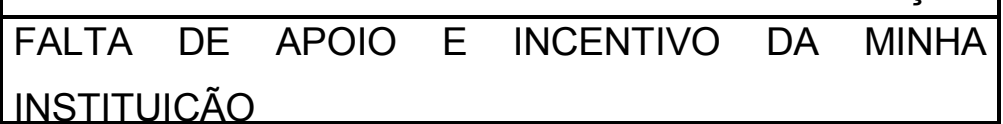 \\
\hline & & FALTA DE INCENTIVO ÀS AÇÕES DE ATER \\
\hline & & NÃO TENHO INTERESSE EM APLICAR \\
\hline
\end{tabular}

6) A partir deste curso: 


\begin{tabular}{|l|l|}
\hline$X$ & $\begin{array}{l}\text { MEU TRABALHO PASSOU A CONTRIBUIR MAIS COM OS AGRICULTORES(AS) } \\
\text { FAMILIARES. }\end{array}$ \\
\hline & CONSEGUI INFLUENCIAR NAS ORIENTAÇÕES DA MINHA INSTITUIÇÃO. \\
\hline & $\begin{array}{l}\text { PASSEI A TRABALHAR COM METODOLOGIAS PARTICIPATIVAS. } \\
\text { ONDE ATUO. }\end{array}$ \\
\hline$X$ & CONTINUEI ME APERFEIÇOANDO SOBRE TEMAS ABORDADOS. \\
\hline
\end{tabular}

7) Depois do curso você apoiou atividades de capacitação de técnicos e agricultores com base nos princípios e diretrizes da Pnater? (Considere como apoio a atividades de capacitação a participação no planejamento, elaboração de ementas, seleção de participantes e de palestrantes.)

\begin{tabular}{|l|l|}
\hline$X$ & SIM \\
\hline & NÃO \\
\hline
\end{tabular}

8) Usou os conhecimentos para ministrar outros cursos com o mesmo conteúdo ou conteúdos semelhantes?

\begin{tabular}{|l|l|}
\hline$X$ & SIM \\
\hline & NÃO \\
\hline
\end{tabular}

9) Marque o seu grau de satisfação com relação ao curso oferecido pelo DATER: Considere a seguinte pontuação: 1 - MUITO RUIM; 2 - RUIM; 3 - REGULAR; 4 - BOM; 5 - MUITO BOM)

\begin{tabular}{|l|l|l|l|l|}
\hline 1 & $\times 2$ & 3 & 4 & 5 \\
\hline
\end{tabular}

10) Marque seu grau de satisfação com relação ao DATER: Considere a seguinte pontuação: 1 - MUITO RUIM; 2 - RUIM; 3 - REGULAR; 4 - BOM; 5 - MUITO BOM)

\begin{tabular}{|l|l|l|l|l|}
\hline 1 & 2 & 3 & $\times 4$ & 5 \\
\hline
\end{tabular}




\section{PESQUISA - IMPACTO DAS AÇÕES DE FORMAÇÃO REALIZADAS PELO \\ DATER/SAF/MDA NO PERÍODO 2004-2009}

Caros colaboradores,

Contamos com a sua atenção para preencher o formulário abaixo.

O mesmo tem por objetivo fornecer informações para avaliação da Eficiência, Efetividade e Eficácia da Política Pública de Formação de Agentes de Ater adotada pelo Departamento de Assistência Técnica e Extensão Rural, da Secretaria de Agricultura Familiar do Ministério do Desenvolvimento - DATER/SAF/MDA, no período de 2004 a 2009, tema escolhido para Monografia a ser apresentada à Universidade de Brasília (UnB) como requisito parcial para obtenção do grau de Bacharel em Administração.

Você poderá ou não se identificar no questionário e garantimos que todas as informações fornecidas serão confidenciais e utilizadas apenas de forma sistematizada

IDENTIFICAÇÃO

\begin{tabular}{|l|l|}
\hline Nome: ALINE MORAES CUNHA & $\begin{array}{l}\text { Sexo: } \\
(\quad) \text { masculino } \quad(x \quad \text { ) feminino }\end{array}$ \\
\hline $\begin{array}{l}\text { Instituição (nome e tipo de instituição: ONG, } \\
\text { Empresa Pública, etc.): } \\
\text { COODESTUR - Cooperativa/ONG. }\end{array}$ & $\begin{array}{l}\text { Local de trabalho (Cidade e Estado): } \\
\text { Porto Alegre/RS. }\end{array}$ \\
\hline $\begin{array}{l}\text { Curso/Encontro/Oficina do qual participou (caso tenha participado de mais de um curso, preencha } \\
\text { um formulário para cada um deles): } \\
\text { Metodologias Participativas }\end{array}$ \\
\hline Data do Curso/Encontro/Oficina (pelo menos mês e ano): dez/2006 \\
\hline
\end{tabular}

1. Indique sua área de atuação?

\begin{tabular}{|l|l|}
\hline$X$ & EXTENSÃO RURAL \\
\hline & PESQUISA \\
\hline & ENSINO \\
\hline & OUTROS \\
\hline
\end{tabular}

2) Qual o seu nível de escolaridade? (Considere apenas o nível mais alto) 


\begin{tabular}{|l|l|}
\hline & NÍVEL MÉDIO \\
\hline & NÍVEL SUPERIOR \\
\hline$X$ & PÓS-GRADUAÇÃO \\
\hline
\end{tabular}

3) Os conteúdos abordados foram condizentes com as demandas do seu dia-a-dia?

\begin{tabular}{|l|l|}
\hline$X$ & SIM \\
\hline & PARCIALMENTE \\
\hline & NÃO \\
\hline
\end{tabular}

3) O curso contribuiu para o seu aperfeiçoamento profissional?

\begin{tabular}{|l|l|}
\hline$X$ & SIM \\
\hline & NÃO \\
\hline
\end{tabular}

5) Os conhecimentos adquiridos estão sendo aplicados no seu trabalho? Em caso afirmativo, indique em que grau estes conhecimentos estão sendo aplicados. Em caso negativo, indique por que razão isto não ocorre:

\begin{tabular}{|c|c|c|}
\hline \multirow{3}{*}{$\begin{array}{l}\text { SIM (indique ao lado em } \\
\text { que grau) }\end{array}$} & $\mathrm{x}$ & MUITO APLICADOS \\
\hline & & MEDIAMENTE APLICADOS \\
\hline & & POUCO APLICADOS \\
\hline \multirow{5}{*}{$\begin{array}{l}\text { NÃO (indique ao lado a } \\
\text { razão da não aplicação) }\end{array}$} & & CONTEÚDO NÃO ADEQUADO ÀS NECESSIDADES \\
\hline & & $\begin{array}{llll}\text { CONTEÚDO NÂO } & \text { FOI } & \text { SUFICIENTEMENTE } \\
\text { APROFUNDADO } & \text { PARA } & \text { PERMITIR UMA APLICAÇÃO }\end{array}$ \\
\hline & & $\begin{array}{lcccccc}\text { FALTA } & \text { DE } & \text { APOIO } & \text { E } & \text { INCENTIVO } & \text { DA } & \text { MINHA } \\
\text { INSTITUICÃO } & & & & & \\
\end{array}$ \\
\hline & & FALTA DE INCENTIVO ÀS AÇÕES DE ATER \\
\hline & & NÃO TENHO INTERESSE EM APLICAR \\
\hline
\end{tabular}

6) A partir deste curso: 


\begin{tabular}{|l|l|}
\hline$x$ & $\begin{array}{l}\text { NÃO MUDOU NADA EM MEU TRABALHO. } \\
\text { FAMILIARES. }\end{array}$ \\
\hline & CONSEGUI INFLUENCIAR NAS ORIENTAÇÕES DA MINHA INSTITUIÇÃO. \\
\hline & PASSEI A TRABALHAR COM METODOLOGIAS PARTICIPATIVAS. \\
\hline & $\begin{array}{l}\text { CRESCEU A ÁREA DE AGRICULTURA DE BASE ECOLÓGICA NAS COMUNIDADES } \\
\text { ONDE ATUO. }\end{array}$ \\
\hline & CONTINUEI ME APERFEIÇOANDO SOBRE TEMAS ABORDADOS. \\
\hline
\end{tabular}

7) Depois do curso você apoiou atividades de capacitação de técnicos e agricultores com base nos princípios e diretrizes da Pnater? (Considere como apoio a atividades de capacitação a participação no planejamento, elaboração de ementas, seleção de participantes e de palestrantes.)

\begin{tabular}{|l|l|}
\hline$X$ & SIM \\
\hline & NÃO \\
\hline
\end{tabular}

8) Usou os conhecimentos para ministrar outros cursos com o mesmo conteúdo ou conteúdos semelhantes?

\begin{tabular}{|l|l|}
\hline$X$ & SIM \\
\hline & NÃO \\
\hline
\end{tabular}

9) Marque o seu grau de satisfação com relação ao curso oferecido pelo DATER: Considere a seguinte pontuação: 1 - MUITO RUIM; 2 - RUIM; 3 - REGULAR; 4 - BOM; 5 - MUITO BOM)

\begin{tabular}{|l|l|l|l|l|}
\hline 1 & 2 & 3 & 4 & 5 \\
\hline
\end{tabular}

10) Marque seu grau de satisfação com relação ao DATER: Considere a seguinte pontuação: 1 - MUITO RUIM; 2 - RUIM; 3 - REGULAR; 4 - BOM; 5 - MUITO BOM)

\begin{tabular}{|l|l|l|l|l|}
\hline 1 & 2 & 3 & 4 & 5 \\
\hline
\end{tabular}




\section{PESQUISA - IMPACTO DAS AÇÕES DE FORMAÇÃO REALIZADAS PELO \\ DATER/SAF/MDA NO PERÍODO 2004-2009}

Caros colaboradores,

Contamos com a sua atenção para preencher o formulário abaixo.

O mesmo tem por objetivo fornecer informações para avaliação da Eficiência, Efetividade e Eficácia da Política Pública de Formação de Agentes de Ater adotada pelo Departamento de Assistência Técnica e Extensão Rural, da Secretaria de Agricultura Familiar do Ministério do Desenvolvimento - DATER/SAF/MDA, no período de 2004 a 2009, tema escolhido para Monografia a ser apresentada à Universidade de Brasília (UnB) como requisito parcial para obtenção do grau de Bacharel em Administração.

Você poderá ou não se identificar no questionário e garantimos que todas as informações fornecidas serão confidenciais e utilizadas apenas de forma sistematizada

\section{IDENTIFICAÇÃO}

\begin{tabular}{|l|l|}
\hline Nome: Ricardo Vencato & $\begin{array}{l}\text { Sexo: } \\
(\mathrm{x}) \text { masculino } \quad(\quad \text { ) feminino }\end{array}$ \\
\hline $\begin{array}{l}\text { Instituição : UNEAGRO - Cooperativa dos } \\
\text { Engenheiros Agrônomos e de Profissionais em }\end{array}$ & Local de trabalho : Gravatal - SC \\
Desenvolvimento Rural e Ambiental de SC & \\
\hline $\begin{array}{l}\text { Curso/Encontro/Oficina do qual participou (caso tenha participado de mais de um curso, preencha } \\
\text { um formulário para cada um deles): ATER Quilombola }\end{array}$ \\
\hline Data do Curso/Encontro/Oficina (pelo menos mês e ano): Setembro - 2008 \\
\hline
\end{tabular}

1. Indique sua área de atuação?

\begin{tabular}{|l|l|}
\hline$X$ & EXTENSÃO RURAL \\
\hline & PESQUISA \\
\hline & ENSINO \\
\hline & OUTROS \\
\hline
\end{tabular}

2) Qual o seu nível de escolaridade? (Considere apenas o nível mais alto) 


\begin{tabular}{|l|l|}
\hline & NÍVEL MÉDIO \\
\hline$X$ & NÍVEL SUPERIOR \\
\hline & PÓS-GRADUAÇÃO \\
\hline
\end{tabular}

3) Os conteúdos abordados foram condizentes com as demandas do seu dia-a-dia?

\begin{tabular}{|l|l|}
\hline & SIM \\
\hline$X$ & PARCIALMENTE \\
\hline & NÃO \\
\hline
\end{tabular}

4) O curso contribuiu para o seu aperfeiçoamento profissional?

\begin{tabular}{|l|l|}
\hline$X$ & SIM \\
\hline & NÃO \\
\hline
\end{tabular}

5) Os conhecimentos adquiridos estão sendo aplicados no seu trabalho? Em caso afirmativo, indique em que grau estes conhecimentos estão sendo aplicados. Em caso negativo, indique por que razão isto não ocorre:

\begin{tabular}{|c|c|c|c|}
\hline \multirow{3}{*}{$X$} & \multirow{3}{*}{$\begin{array}{l}\text { SIM (indique ao lado em } \\
\text { que grau) }\end{array}$} & & MUITO APLICADOS \\
\hline & & & MEDIAMENTE APLICADOS \\
\hline & & $\bar{X}$ & POUCO APLICADOS \\
\hline & \multirow{5}{*}{$\begin{array}{l}\text { NÃO (indique ao lado a } \\
\text { razão da não aplicação) }\end{array}$} & & CONTEÚDO NÃO ADEQUADO ÀS NECESSIDADES \\
\hline & & & $\begin{array}{llll}\text { CONTEÚDO NÂO } & \text { FOI SUFICIENTEMENTE } \\
\text { APROFUNDADO PARA } & \text { PERMITIR UMA APLICAÇÃO }\end{array}$ \\
\hline & & & $\begin{array}{lcccccc}\text { FALTA } & \text { DE } & \text { APOIO } & \text { E } & \text { INCENTIVO } & \text { DA } & \text { MINHA } \\
\text { INSTITUICÃO } & & & & & \\
\end{array}$ \\
\hline & & & FALTA DE INCENTIVO ÀS AÇÕES DE ATER \\
\hline & & & NÃO TENHO INTERESSE EM APLICAR \\
\hline
\end{tabular}

6) A partir deste curso: 


\begin{tabular}{|l|l|}
\hline$X$ & NÃO MUDOU NADA EM MEU TRABALHO. \\
\hline & $\begin{array}{l}\text { MEU TRABALHO PASSOU A CONTRIBUIR MAIS COM OS AGRICULTORES(AS) } \\
\text { FAMILIARES. }\end{array}$ \\
\hline & CONSEGUI INFLUENCIAR NAS ORIENTAÇÕES DA MINHA INSTITUIÇÃO. \\
\hline & $\begin{array}{l}\text { CRESCEU A ÁREA DE AGRICULTURA DE BASE ECOLÓGICA NAS COMUNIDADES } \\
\text { ONDE ATUO. }\end{array}$ \\
\hline & CONTINUEI ME APERFEIÇOANDO SOBRE TEMAS ABORDADOS. \\
\hline
\end{tabular}

7) Depois do curso você apoiou atividades de capacitação de técnicos e agricultores com base nos princípios e diretrizes da Pnater? (Considere como apoio a atividades de capacitação a participação no planejamento, elaboração de ementas, seleção de participantes e de palestrantes.)

\begin{tabular}{|l|l|}
\hline$X$ & SIM \\
\hline & NÃO \\
\hline
\end{tabular}

8) Usou os conhecimentos para ministrar outros cursos com o mesmo conteúdo ou conteúdos semelhantes?

\begin{tabular}{|l|l|}
\hline & SIM \\
\hline$X$ & NÃO \\
\hline
\end{tabular}

9) Marque o seu grau de satisfação com relação ao curso oferecido pelo DATER: Considere a seguinte pontuação: 1 - MUITO RUIM; 2 - RUIM; 3 - REGULAR; 4 - BOM; 5 - MUITO BOM)

\begin{tabular}{|l|l|l|l|l|}
\hline 1 & 2 & 3 & $x$ & 5 \\
\hline
\end{tabular}

10) Marque seu grau de satisfação com relação ao DATER: Considere a seguinte pontuação: 1 - MUITO RUIM; 2 - RUIM; 3 - REGULAR; 4 - BOM; 5 - MUITO BOM)

\begin{tabular}{|l|l|l|l|l|}
\hline 1 & 2 & 3 & $X$ & 5 \\
\hline
\end{tabular}




\section{PESQUISA - IMPACTO DAS AÇÕES DE FORMAÇÃO REALIZADAS PELO \\ DATER/SAF/MDA NO PERÍODO 2004-2009}

Caros colaboradores,

Contamos com a sua atenção para preencher o formulário abaixo.

O mesmo tem por objetivo fornecer informações para avaliação da Eficiência, Efetividade e Eficácia da Política Pública de Formação de Agentes de Ater adotada pelo Departamento de Assistência Técnica e Extensão Rural, da Secretaria de Agricultura Familiar do Ministério do Desenvolvimento - DATER/SAF/MDA, no período de 2004 a 2009, tema escolhido para Monografia a ser apresentada à Universidade de Brasília (UnB) como requisito parcial para obtenção do grau de Bacharel em Administração.

Você poderá ou não se identificar no questionário e garantimos que todas as informações fornecidas serão confidenciais e utilizadas apenas de forma sistematizada

\section{IDENTIFICAÇÃO}

\begin{tabular}{|l|l|}
\hline $\begin{array}{l}\text { Nome: } \\
\text { Maciel Ernesto Budde }\end{array}$ & $\begin{array}{l}\text { Sexo: } \\
\left(\begin{array}{l}x\end{array}\right) \text { masculino } \quad(\quad) \text { feminino }\end{array}$ \\
\hline $\begin{array}{l}\text { Instituição (nome e tipo de instituição: ONG, } \\
\text { Empresa Pública, etc.): }\end{array}$ & $\begin{array}{l}\text { Local de trabalho (Cidade e Estado): } \\
\text { Arvoredo/SC }\end{array}$ \\
Epagri & $\begin{array}{l}\text { Curso/Encontro/Oficina do qual participou (caso tenha participado de mais de um curso, preencha } \\
\text { um formulário para cada um deles): } \\
\text { Sistemas Agroflorestais }\end{array}$ \\
\hline $\begin{array}{l}\text { Data do Curso/Encontro/Oficina (pelo menos mês e ano): } \\
\text { Maio/2008 }\end{array}$ \\
\hline
\end{tabular}

1. Indique sua área de atuação?

\begin{tabular}{|l|l|}
\hline$x$ & EXTENSÃO RURAL \\
\hline & PESQUISA \\
\hline & ENSINO \\
\hline & OUTROS \\
\hline
\end{tabular}

2) Qual o seu nível de escolaridade? (Considere apenas o nível mais alto) 


\begin{tabular}{|l|l|}
\hline & NÍVEL MÉDIO \\
\hline$x$ & NÍVEL SUPERIOR \\
\hline & PÓS-GRADUAÇÃO \\
\hline
\end{tabular}

3) Os conteúdos abordados foram condizentes com as demandas do seu dia-a-dia?

\begin{tabular}{|l|l|}
\hline & SIM \\
\hline$x$ & PARCIALMENTE \\
\hline & NÃO \\
\hline
\end{tabular}

4) O curso contribuiu para o seu aperfeiçoamento profissional?

\begin{tabular}{|l|l|}
\hline$x$ & SIM \\
\hline & NÃO \\
\hline
\end{tabular}

5) Os conhecimentos adquiridos estão sendo aplicados no seu trabalho? Em caso afirmativo, indique em que grau estes conhecimentos estão sendo aplicados. Em caso negativo, indique por que razão isto não ocorre:

\begin{tabular}{|c|c|c|}
\hline \multirow{3}{*}{$\begin{array}{l}\text { SIM (indique ao lado em } \\
\text { que grau) }\end{array}$} & & MUITO APLICADOS \\
\hline & & MEDIAMENTE APLICADOS \\
\hline & & POUCO APLICADOS \\
\hline \multirow{5}{*}{$\begin{array}{l}\text { NÃO (indique ao lado a } \\
\text { razão da não aplicação) }\end{array}$} & & $\begin{array}{l}\text { CONTEÚDO NÃO ADEQUADO ÀS NECESSIDADES } \\
\text { ESPFCÍFICAS } R \text { RFGIÃO }\end{array}$ \\
\hline & $\mathrm{x}$ & $\begin{array}{|lccr|}\text { CONTEUंDO } & \text { NÂO } & \text { FOI } & \text { SUFICIENTEMENTE } \\
\text { APROFUNDADO } & \text { PARA } & \text { PERMITIR UMA } & \text { APLICAÇÃO }\end{array}$ \\
\hline & & 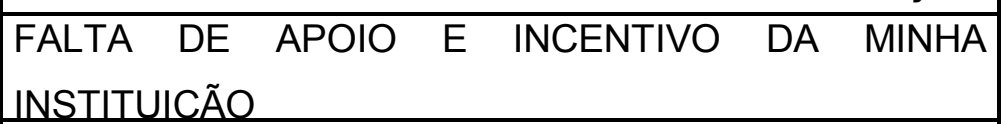 \\
\hline & & FALTA DE INCENTIVO ÀS AÇÕES DE ATER \\
\hline & & NÃO TENHO INTERESSE EM APLICAR \\
\hline
\end{tabular}

6) A partir deste curso: 


\begin{tabular}{|l|l|}
\hline & NÃO MUDOU NADA EM MEU TRABALHO. \\
\hline & $\begin{array}{l}\text { MEU TRABALHO PASSOU A CONTRIBUIR MAIS COM OS AGRICULTORES(AS) } \\
\text { FAMILIARES. }\end{array}$ \\
\hline & CONSEGUI INFLUENCIAR NAS ORIENTAÇÕES DA MINHA INSTITUIÇÃO. \\
\hline & $\begin{array}{l}\text { CRESSEI A TRABALHAR COM METODOLOGIAS PARTICIPATIVAS. } \\
\text { ONDE ATUO. AREA DE AGRICULTURA DE BASE ECOLÓGICA NAS COMUNIDADES }\end{array}$ \\
\hline$x$ & CONTINUEI ME APERFEIÇOANDO SOBRE TEMAS ABORDADOS. \\
\hline
\end{tabular}

7) Depois do curso você apoiou atividades de capacitação de técnicos e agricultores com base nos princípios e diretrizes da Pnater? (Considere como apoio a atividades de capacitação a participação no planejamento, elaboração de ementas, seleção de participantes e de palestrantes.)

\begin{tabular}{|l|l|}
\hline$x$ & SIM \\
\hline & NÃO \\
\hline
\end{tabular}

8) Usou os conhecimentos para ministrar outros cursos com o mesmo conteúdo ou conteúdos semelhantes?

\begin{tabular}{|l|l|}
\hline & SIM \\
\hline$x$ & NÃO \\
\hline
\end{tabular}

9) Marque o seu grau de satisfação com relação ao curso oferecido pelo DATER: Considere a seguinte pontuação: 1 - MUITO RUIM; 2 - RUIM; 3 - REGULAR; 4 - BOM; 5 - MUITO BOM)

\begin{tabular}{|l|l|l|l|l|}
\hline 1 & 2 & $x$ & 4 & 5 \\
\hline
\end{tabular}

10) Marque seu grau de satisfação com relação ao DATER: Considere a seguinte pontuação: 1 - MUITO RUIM; 2 - RUIM; 3 - REGULAR; 4 - BOM; 5 - MUITO BOM)

\begin{tabular}{|l|l|l|l|l|}
\hline 1 & 2 & 3 & $\mathrm{x}$ & 5 \\
\hline
\end{tabular}




\section{PESQUISA - IMPACTO DAS AÇÕES DE FORMAÇÃO REALIZADAS PELO \\ DATER/SAF/MDA NO PERÍODO 2004-2009}

Caros colaboradores,

Contamos com a sua atenção para preencher o formulário abaixo.

O mesmo tem por objetivo fornecer informações para avaliação da Eficiência, Efetividade e Eficácia da Política Pública de Formação de Agentes de Ater adotada pelo Departamento de Assistência Técnica e Extensão Rural, da Secretaria de Agricultura Familiar do Ministério do Desenvolvimento - DATER/SAF/MDA, no período de 2004 a 2009, tema escolhido para Monografia a ser apresentada à Universidade de Brasília (UnB) como requisito parcial para obtenção do grau de Bacharel em Administração.

Você poderá ou não se identificar no questionário e garantimos que todas as informações fornecidas serão confidenciais e utilizadas apenas de forma sistematizada

\section{IDENTIFICAÇÃO}

\begin{tabular}{|c|c|}
\hline Nome: Cláudio José Bertazzo & $\begin{array}{l}\text { Sexo: } \\
(x \quad) \text { masculino } \quad(\quad) \text { feminino }\end{array}$ \\
\hline $\begin{array}{l}\text { Instituição (nome e tipo de instituição: ONG, } \\
\text { Empresa Pública, etc.): Aluno de Doutorado de } \\
\text { Geografia da FCT - UNESP - Presidente Prudente }\end{array}$ & $\begin{array}{l}\text { Local de trabalho (Cidade e Estado): } \\
\text { Porto alegre (RS) }\end{array}$ \\
\hline \multicolumn{2}{|c|}{$\begin{array}{l}\text { Curso/Encontro/Oficina do qual participou (caso tenha participado de mais de um curso, preencha } \\
\text { um formulário para cada um deles): Curso de Aperfeiçoamento em Agroecologia }\end{array}$} \\
\hline
\end{tabular}

1. Indique sua área de atuação?

\begin{tabular}{|l|l|}
\hline & EXTENSÃO RURAL \\
\hline$X$ & PESQUISA \\
\hline$X$ & ENSINO \\
\hline & OUTROS \\
\hline
\end{tabular}

2) Qual o seu nível de escolaridade? (Considere apenas o nível mais alto) 


\begin{tabular}{|l|l|}
\hline & NÍVEL MÉDIO \\
\hline & NÍVEL SUPERIOR \\
\hline$X$ & PÓS-GRADUAÇÃO \\
\hline
\end{tabular}

3) Os conteúdos abordados foram condizentes com as demandas do seu dia-a-dia?

\begin{tabular}{|l|l|}
\hline$X$ & SIM \\
\hline & PARCIALMENTE \\
\hline & NÃO \\
\hline
\end{tabular}

4) O curso contribuiu para o seu aperfeiçoamento profissional?

\begin{tabular}{|l|l|}
\hline$X$ & SIM \\
\hline & NÃO \\
\hline
\end{tabular}

5) Os conhecimentos adquiridos estão sendo aplicados no seu trabalho? Em caso afirmativo, indique em que grau estes conhecimentos estão sendo aplicados. Em caso negativo, indique por que razão isto não ocorre:

\begin{tabular}{|c|c|c|c|}
\hline \multirow{3}{*}{$x$} & \multirow{3}{*}{$\begin{array}{l}\text { SIM (indique ao lado em } \\
\text { que grau) }\end{array}$} & $\mathrm{X}$ & MUITO APLICADOS \\
\hline & & & MEDIAMENTE APLICADOS \\
\hline & & & POUCO APLICADOS \\
\hline & \multirow{5}{*}{$\begin{array}{l}\text { NÃO (indique ao lado a } \\
\text { razão da não aplicação) }\end{array}$} & & CONTEÚDO NÃO ADEQUADO ÀS NECESSIDADES \\
\hline & & & $\begin{array}{lllr}\text { CONTEÚDO } & \text { NÃO } & \text { FOI } & \text { SUFICIENTEMENTE } \\
\text { APROFUNDADO } & \text { PARA } & \text { PERMITIR UMA } & \text { APLICACÃO }\end{array}$ \\
\hline & & & $\begin{array}{lcccccc}\text { FALTA } & \text { DE } & \text { APOIO } & \text { E } & \text { INCENTIVO } & \text { DA } & \text { MINHA } \\
\text { INSTITUICÃO } & & & & & \\
\end{array}$ \\
\hline & & & FALTA DE INCENTIVO ÀS AÇÕES DE ATER \\
\hline & & & NÃO TENHO INTERESSE EM APLICAR \\
\hline
\end{tabular}

6) A partir deste curso: 


\begin{tabular}{|l|l|}
\hline$x$ & $\begin{array}{l}\text { NÃO MUDOU NADA EM MEU TRABALHO. } \\
\text { FAMILIARES. }\end{array}$ \\
\hline & CONSEGUI INFLUENCIAR NAS ORIENTAÇÕES DA MINHA INSTITUIÇÃO. \\
\hline$x$ & PASSEI A TRABALHAR COM METODOLOGIAS PARTICIPATIVAS. \\
\hline & $\begin{array}{l}\text { CRESCEU A ÁREA DE AGRICULTURA DE BASE ECOLÓGICA NAS COMUNIDADES } \\
\text { ONDE ATUO. }\end{array}$ \\
\hline$x$ & CONTINUEI ME APERFEIÇOANDO SOBRE TEMAS ABORDADOS. \\
\hline
\end{tabular}

7) Depois do curso você apoiou atividades de capacitação de técnicos e agricultores com base nos princípios e diretrizes da Pnater? (Considere como apoio a atividades de capacitação a participação no planejamento, elaboração de ementas, seleção de participantes e de palestrantes.)

\begin{tabular}{|l|l|}
\hline$x$ & SIM \\
\hline & NÃO \\
\hline
\end{tabular}

8) Usou os conhecimentos para ministrar outros cursos com o mesmo conteúdo ou conteúdos semelhantes?

\begin{tabular}{|l|l|}
\hline$x$ & SIM \\
\hline & NÃO \\
\hline
\end{tabular}

9) Marque o seu grau de satisfação com relação ao curso oferecido pelo DATER: Considere a seguinte pontuação: 1 - MUITO RUIM; 2 - RUIM; 3 - REGULAR; 4 - BOM; 5 - MUITO BOM)

\begin{tabular}{|l|l|l|l|l|}
\hline 1 & 2 & 3 & 4 & 5 \\
\hline
\end{tabular}

10) Marque seu grau de satisfação com relação ao DATER: Considere a seguinte pontuação: 1 - MUITO RUIM; 2 - RUIM; 3 - REGULAR; 4 - BOM; 5 - MUITO BOM)

\begin{tabular}{|l|l|l|l|l|}
\hline 1 & 2 & 3 & 4 & 5 \\
\hline
\end{tabular}




\section{PESQUISA - IMPACTO DAS AÇÕES DE FORMAÇÃO REALIZADAS PELO \\ DATER/SAF/MDA NO PERÍODO 2004-2009}

Caros colaboradores,

Contamos com a sua atenção para preencher o formulário abaixo.

O mesmo tem por objetivo fornecer informações para avaliação da Eficiência, Efetividade e Eficácia da Política Pública de Formação de Agentes de Ater adotada pelo Departamento de Assistência Técnica e Extensão Rural, da Secretaria de Agricultura Familiar do Ministério do Desenvolvimento - DATER/SAF/MDA, no período de 2004 a 2009, tema escolhido para Monografia a ser apresentada à Universidade de Brasília (UnB) como requisito parcial para obtenção do grau de Bacharel em Administração.

Você poderá ou não se identificar no questionário e garantimos que todas as informações fornecidas serão confidenciais e utilizadas apenas de forma sistematizada

IDENTIFICAÇÃO

\begin{tabular}{|l|l|}
\hline Nome: & $\begin{array}{l}\text { Sexo: } \\
\text { VANICE MARLI FULBER }\end{array}$ \\
\hline $\begin{array}{l}\text { Instituição (nome e tipo de instituição: ONG, } \\
\text { Empresa Pública, etc.): }\end{array}$ & $\begin{array}{l}\text { Local de trabalho (Cidade e Estado): } \\
\text { Mal. Cdo. Rondon - Pr. }\end{array}$ \\
BIOLABORE - Coop. De Trabalho e Assistência \\
Técnica do Paraná
\end{tabular}

1. ndique sua área de atuação?

\begin{tabular}{|l|l|}
\hline$X$ & EXTENSÃO RURAL \\
\hline & PESQUISA \\
\hline & ENSINO \\
\hline
\end{tabular}




\begin{tabular}{|l|l|}
\hline OUTROS \\
\hline
\end{tabular}

2) Qual o seu nível de escolaridade? (Considere apenas o nível mais alto)

\begin{tabular}{|c|l|}
\hline & NÍVEL MÉDIO \\
\hline & NÍVEL SUPERIOR \\
\hline$X$ & PÓS-GRADUAÇÃO \\
\hline
\end{tabular}

3) Os conteúdos abordados foram condizentes com as demandas do seu dia-a-dia?

\begin{tabular}{|l|l|}
\hline & SIM \\
\hline$X$ & PARCIALMENTE \\
\hline & NÃO \\
\hline
\end{tabular}

4) O curso contribuiu para o seu aperfeiçoamento profissional?

\begin{tabular}{|l|l|}
\hline$X$ & SIM \\
\hline & NÃO \\
\hline
\end{tabular}

5) Os conhecimentos adquiridos estão sendo aplicados no seu trabalho? Em caso afirmativo, indique em que grau estes conhecimentos estão sendo aplicados. Em caso negativo, indique por que razão isto não ocorre:

\begin{tabular}{|c|c|c|c|}
\hline \multirow{3}{*}{$X$} & \multirow{3}{*}{$\begin{array}{l}\text { SIM (indique ao lado em } \\
\text { que grau) }\end{array}$} & & MUITO APLICADOS \\
\hline & & $\bar{X}$ & MEDIAMENTE APLICADOS \\
\hline & & & POUCO APLICADOS \\
\hline & \multirow{4}{*}{$\begin{array}{l}\text { NÃO (indique ao lado a } \\
\text { razão da não aplicação) }\end{array}$} & & CONTEÚDO NÃO ADEQUADO ÀS NECESSIDADES \\
\hline & & & $\begin{array}{llll}\text { CONTEÚDO NÂOO FOI SUFICIENTEMENTE } \\
\text { APROFUNDADO PARA }\end{array}$ \\
\hline & & & $\begin{array}{lcccccc}\text { FALTA } & \text { DE } & \text { APOIO } & \text { E } & \text { INCENTIVO } & \text { DA } & \text { MINHA } \\
\text { INSTITUICÃO } & & & & & \\
\end{array}$ \\
\hline & & & FALTA DE INCENTIVO ÀS AÇÕES DE ATER \\
\hline
\end{tabular}




\begin{tabular}{|l|l|l|l|}
\hline & & & NÃO TENHO INTERESSE EM APLICAR \\
\hline
\end{tabular}

6) A partir deste curso:

\begin{tabular}{|l|l|}
\hline & NÃO MUDOU NADA EM MEU TRABALHO. \\
\hline & $\begin{array}{l}\text { MEU TRABALHO PASSOU A CONTRIBUIR MAIS COM OS AGRICULTORES(AS) } \\
\text { FAMILIARES. }\end{array}$ \\
\hline & CONSEGUI INFLUENCIAR NAS ORIENTAÇÕES DA MINHA INSTITUIÇÃO. \\
\hline$X$ & PASSEI A TRABALHAR COM METODOLOGIAS PARTICIPATIVAS. \\
\hline & $\begin{array}{l}\text { CRESCEU A ÁREA DE AGRICULTURA DE BASE ECOLÓGICA NAS COMUNIDADES } \\
\text { ONDE ATUO. }\end{array}$ \\
\hline & CONTINUEI ME APERFEIÇOANDO SOBRE TEMAS ABORDADOS. \\
\hline
\end{tabular}

7) Depois do curso você apoiou atividades de capacitação de técnicos e agricultores com base nos princípios e diretrizes da Pnater? (Considere como apoio a atividades de capacitação a participação no planejamento, elaboração de ementas, seleção de participantes e de palestrantes.)

\begin{tabular}{|l|l|}
\hline$X$ & SIM \\
\hline & NÃO \\
\hline
\end{tabular}

8) Usou os conhecimentos para ministrar outros cursos com o mesmo conteúdo ou conteúdos semelhantes?

\begin{tabular}{|l|l|}
\hline$X$ & SIM \\
\hline & NÃO \\
\hline
\end{tabular}

9) Marque o seu grau de satisfação com relação ao curso oferecido pelo DATER: Considere a seguinte pontuação: 1 - MUITO RUIM; 2 - RUIM; 3 - REGULAR; 4 - BOM; 5 - MUITO BOM)

\begin{tabular}{|l|l|l|l|l|}
\hline 1 & 2 & 3 & 4 & 5 \\
\hline
\end{tabular}


10) Marque seu grau de satisfação com relação ao DATER: Considere a seguinte pontuação: 1

- MUITO RUIM; 2 - RUIM; 3 - REGULAR; 4 - BOM; 5 - MUITO BOM)

\begin{tabular}{|l|l|l|l|l|}
\hline 1 & 2 & 3 & 4 & 5 \\
\hline
\end{tabular}




\section{PESQUISA - IMPACTO DAS AÇÕES DE FORMAÇÃO REALIZADAS PELO \\ DATER/SAF/MDA NO PERÍODO 2004-2009}

Caros colaboradores,

Contamos com a sua atenção para preencher o formulário abaixo.

O mesmo tem por objetivo fornecer informações para avaliação da Eficiência, Efetividade e Eficácia da Política Pública de Formação de Agentes de Ater adotada pelo Departamento de Assistência Técnica e Extensão Rural, da Secretaria de Agricultura Familiar do Ministério do Desenvolvimento - DATER/SAF/MDA, no período de 2004 a 2009, tema escolhido para Monografia a ser apresentada à Universidade de Brasília (UnB) como requisito parcial para obtenção do grau de Bacharel em Administração.

Você poderá ou não se identificar no questionário e garantimos que todas as informações fornecidas serão confidenciais e utilizadas apenas de forma sistematizada

\section{IDENTIFICAÇÃO}

\begin{tabular}{|l|l|}
\hline $\begin{array}{l}\text { Nome: } \\
\text { Robson Luiz Polmann }\end{array}$ & $\begin{array}{l}\text { Sexo: } \\
(\mathrm{x}) \text { masculino } \quad(\quad) \text { feminino }\end{array}$ \\
\hline $\begin{array}{l}\text { Instituição (nome e tipo de instituição: ONG, } \\
\text { Empresa Pública, etc.): } \\
\text { Prefeitura de Blumenau }\end{array}$ & $\begin{array}{l}\text { Local de trabalho (Cidade e Estado): } \\
\text { Blumenau - SC }\end{array}$ \\
\hline $\begin{array}{l}\text { Curso: } \\
\text { Aprendizagem e Ação Participativa - teoria e prática sobre diagnóstico, planejamento e ação } \\
\text { participativa em extensão rural }\end{array}$ \\
\hline $\begin{array}{l}\text { Data do Curso (pelo menos mês e ano): } \\
\text { Abril/08 }\end{array}$ \\
\hline
\end{tabular}

1. Indique sua área de atuação?

\begin{tabular}{|l|l|}
\hline$x$ & EXTENSÃO RURAL \\
\hline & PESQUISA \\
\hline & ENSINO \\
\hline & OUTROS \\
\hline
\end{tabular}

2) Qual o seu nível de escolaridade? (Considere apenas o nível mais alto) 


\begin{tabular}{|l|l|}
\hline & NÍVEL MÉDIO \\
\hline & NÍVEL SUPERIOR \\
\hline$x$ & PÓS-GRADUAÇÃO \\
\hline
\end{tabular}

3) Os conteúdos abordados foram condizentes com as demandas do seu dia-a-dia?

\begin{tabular}{|l|l|}
\hline$x$ & SIM \\
\hline & PARCIALMENTE \\
\hline & NÃO \\
\hline
\end{tabular}

4) O curso contribuiu para o seu aperfeiçoamento profissional?

\begin{tabular}{|l|l|}
\hline$x$ & SIM \\
\hline & NÃO \\
\hline
\end{tabular}

5) Os conhecimentos adquiridos estão sendo aplicados no seu trabalho? Em caso afirmativo, indique em que grau estes conhecimentos estão sendo aplicados. Em caso negativo, indique por que razão isto não ocorre:

\begin{tabular}{|c|c|c|}
\hline \multirow{3}{*}{$\begin{array}{l}\text { SIM (indique ao lado em } \\
\text { que grau) }\end{array}$} & & MUITO APLICADOS \\
\hline & & MEDIAMENTE APLICADOS \\
\hline & & POUCO APLICADOS \\
\hline \multirow{5}{*}{$\begin{array}{l}\text { NÃO (indique ao lado a } \\
\text { razão da não aplicação) }\end{array}$} & & CONTEÚDO NÃO ADEQUADO ÀS NECESSIDADES \\
\hline & & $\begin{array}{llll}\text { CONTEÚDO NÃO } & \text { FOI } & \text { SUFICIENTEMENTE } \\
\text { APROFUNDADO PARA } & \text { PERMITIR UMA APLICAÇÃO }\end{array}$ \\
\hline & não & $\begin{array}{lcccccc}\text { FALTA } & \text { DE } & \text { APOIO } & \text { E } & \text { INCENTIVO } & \text { DA } & \text { MINHA } \\
\text { INSTITUICÃO } & & & & & \\
\end{array}$ \\
\hline & & FALTA DE INCENTIVO ÀS AÇÕES DE ATER \\
\hline & & NÃO TENHO INTERESSE EM APLICAR \\
\hline
\end{tabular}

6) A partir deste curso: 


\begin{tabular}{|l|l|}
\hline$x$ & NÃO MUDOU NADA EM MEU TRABALHO. \\
\hline & $\begin{array}{l}\text { MEU TRABALHO PASSOU A CONTRIBUIR MAIS COM OS AGRICULTORES(AS) } \\
\text { FAMILIARES. }\end{array}$ \\
\hline & CONSEGUI INFLUENCIAR NAS ORIENTAÇÕES DA MINHA INSTITUIÇÃO. \\
\hline & $\begin{array}{l}\text { PASSEI A TRABALHAR COM METODOLOGIAS PARTICIPATIVAS. } \\
\text { ONDE ATUO. }\end{array}$ \\
\hline & CONTINUEI ME APERFEIÇOANDO SOBRE TEMAS ABORDADOS. \\
\hline
\end{tabular}

7) Depois do curso você apoiou atividades de capacitação de técnicos e agricultores com base nos princípios e diretrizes da Pnater? (Considere como apoio a atividades de capacitação a participação no planejamento, elaboração de ementas, seleção de participantes e de palestrantes.)

\begin{tabular}{|l|l|}
\hline & SIM \\
\hline$x$ & NÃO \\
\hline
\end{tabular}

8) Usou os conhecimentos para ministrar outros cursos com o mesmo conteúdo ou conteúdos semelhantes?

\begin{tabular}{|l|l|}
\hline & SIM \\
\hline$x$ & NÃO \\
\hline
\end{tabular}

9) Marque o seu grau de satisfação com relação ao curso oferecido pelo DATER: Considere a seguinte pontuação: 1 - MUITO RUIM; 2 - RUIM; 3 - REGULAR; 4 - BOM; 5 - MUITO BOM)

\begin{tabular}{|l|l|l|l|l|}
\hline 1 & 2 & 3 & $x$ & 5 \\
\hline
\end{tabular}

10) Marque seu grau de satisfação com relação ao DATER: Considere a seguinte pontuação: 1 - MUITO RUIM; 2 - RUIM; 3 - REGULAR; 4 - BOM; 5 - MUITO BOM)

\begin{tabular}{|l|l|l|l|l|}
\hline 1 & 2 & 3 & $x$ & 5 \\
\hline
\end{tabular}


PESQUISA - IMPACTO DAS AÇÕES DE FORMAÇÃO REALIZADAS PELO DATER/SAF/MDA NO PERÍODO 2004-2009

Caros colaboradores,

Contamos com a sua atenção para preencher o formulário abaixo.

O mesmo tem por objetivo fornecer informações para avaliação da Eficiência, Efetividade e Eficácia da Política Pública de Formação de Agentes de Ater adotada pelo Departamento de Assistência Técnica e Extensão Rural, da Secretaria de Agricultura Familiar do Ministério do Desenvolvimento - DATER/SAF/MDA, no período de 2004 a 2009, tema escolhido para Monografia a ser apresentada à Universidade de Brasília (UnB) como requisito parcial para obtenção do grau de Bacharel em Administração.

Você poderá ou não se identificar no questionário e garantimos que todas as informações fornecidas serão confidenciais e utilizadas apenas de forma sistematizada

IDENTIFICAÇÃO

\begin{tabular}{|c|c|}
\hline Nome: JOSE MARIA VICENTE RODRIGUES & $\begin{array}{l}\text { Sexo: } \\
(\mathrm{x}) \text { masculino }\end{array}$ \\
\hline $\begin{array}{l}\text { Instituição (nome e tipo de instituição: ONG, } \\
\text { Empresa Pública, etc.): ARCAFAR SUL - } \\
\text { Associação Regional das Casas Familiares Rurais } \\
\text { do Sul do Brasil }\end{array}$ & Local de trabalho (Cidade e Estado): \\
\hline \multicolumn{2}{|c|}{$\begin{array}{l}\text { Curso/Encontro/Oficina do qual participou (caso tenha participado de mais de um curso, preencha } \\
\text { um formulário para cada um deles): } \\
\text { CONFERENCIA NACIONAL DE ATER - Brasília-DF }\end{array}$} \\
\hline $\begin{array}{l}\text { Data do Curso/Encontro/Oficina (pelo menos mês } \\
10 \text { e } 11 \text { de Novembro de } 2004\end{array}$ & \\
\hline
\end{tabular}

1. Indique sua área de atuação?

\begin{tabular}{|l|l|}
\hline$X$ & EXTENSÃO RURAL \\
\hline & PESQUISA \\
\hline$X$ & ENSINO \\
\hline & OUTROS \\
\hline
\end{tabular}


2) Qual o seu nível de escolaridade? (Considere apenas o nível mais alto)

\begin{tabular}{|l|l|}
\hline & NÍVEL MÉDIO \\
\hline$X$ & NÍVEL SUPERIOR \\
\hline & PÓS-GRADUAÇÃO \\
\hline
\end{tabular}

3) Os conteúdos abordados foram condizentes com as demandas do seu dia-a-dia?

\begin{tabular}{|l|l|}
\hline$X$ & SIM \\
\hline & PARCIALMENTE \\
\hline & NÃO \\
\hline
\end{tabular}

3) O curso contribuiu para o seu aperfeiçoamento profissional?

\begin{tabular}{|l|l|}
\hline$X$ & SIM \\
\hline & NÃO \\
\hline
\end{tabular}

5) Os conhecimentos adquiridos estão sendo aplicados no seu trabalho? Em caso afirmativo, indique em que grau estes conhecimentos estão sendo aplicados. Em caso negativo, indique por que razão isto não ocorre:

\begin{tabular}{|l|l|l|}
\hline \multirow{2}{*}{$\begin{array}{l}\text { SIM (indique ao lado em } \\
\text { que grau) }\end{array}$} & X & MUITO APLICADOS \\
\cline { 2 - 3 } & & MEDIAMENTE APLICADOS \\
\hline \multirow{2}{*}{$\begin{array}{l}\text { NÃO (indique ao lado a } \\
\text { razão da não aplicação) }\end{array}$} & $\begin{array}{l}\text { CONTEÜDO NÃO ADEQUADO ȦS NECESSIDADES } \\
\text { ESPECÍFICAS DA REGIÃO }\end{array}$ \\
\hline & $\begin{array}{l}\text { CONTEÚDO NÃO FOI SUFICIENTEMENTE } \\
\text { APROFUNDADO PARA PERMITIR UMA APLICAÇÃO } \\
\text { EFICAZ E EFICIENTE }\end{array}$ \\
\hline
\end{tabular}




\begin{tabular}{|l|l|l|}
\hline \multirow{2}{*}{} & & $\begin{array}{l}\text { FALTA DE APOIO E INCENTIVO DA MINHA } \\
\text { INSTITUIÇÃO }\end{array}$ \\
\cline { 2 - 3 } & & FALTA DE INCENTIVO ÀS AÇÕES DE ATER \\
\cline { 2 - 3 } & NÃO TENHO INTERESSE EM APLICAR \\
\hline
\end{tabular}

6) A partir deste curso:

\begin{tabular}{|l|l|}
\hline & NÃO MUDOU NADA EM MEU TRABALHO. \\
\hline$x$ & $\begin{array}{l}\text { MEU TRABALHO PASSOU A CONTRIBUIR MAIS COM OS AGRICULTORES(AS) } \\
\text { FAMILIARES. }\end{array}$ \\
\hline$X$ & CONSEGUI INFLUENCIAR NAS ORIENTAÇÕES DA MINHA INSTITUIÇÃO. \\
\hline$X$ & PASSEI A TRABALHAR COM METODOLOGIAS PARTICIPATIVAS. \\
\hline$X$ & $\begin{array}{l}\text { CRESCEU A ÁREA DE AGRICULTURA DE BASE ECOLÓGICA NAS COMUNIDADES } \\
\text { ONDE ATUO. }\end{array}$ \\
\hline$X$ & CONTINUEI ME APERFEIÇOANDO SOBRE TEMAS ABORDADOS. \\
\hline
\end{tabular}

7) Depois do curso você apoiou atividades de capacitação de técnicos e agricultores com base nos princípios e diretrizes da Pnater? (Considere como apoio a atividades de capacitação a participação no planejamento, elaboração de ementas, seleção de participantes e de palestrantes.)

\begin{tabular}{|l|l|}
\hline$X$ & SIM \\
\hline & NÃO \\
\hline
\end{tabular}

8) Usou os conhecimentos para ministrar outros cursos com o mesmo conteúdo ou conteúdos semelhantes?

\begin{tabular}{|l|l|}
\hline$X$ & SIM \\
\hline & NÃO \\
\hline
\end{tabular}


9) Marque o seu grau de satisfação com relação ao curso oferecido pelo DATER: Considere a seguinte pontuação: 1 - MUITO RUIM; 2 - RUIM; 3 - REGULAR; 4 - BOM; 5 - MUITO BOM)

\begin{tabular}{|l|l|l|l|l|}
\hline 1 & 2 & 3 & $4-X$ & 5 \\
\hline
\end{tabular}

10) Marque seu grau de satisfação com relação ao DATER: Considere a seguinte pontuação: 1

- MUITO RUIM; 2 - RUIM; 3 - REGULAR; 4 - BOM; 5 - MUITO BOM)

\begin{tabular}{|l|l|l|l|l|}
\hline 1 & 2 & 3 & 4 & $5-X$ \\
\hline
\end{tabular}


PESQUISA - IMPACTO DAS AÇÕES DE FORMAÇÃO REALIZADAS PELO DATER/SAF/MDA NO PERÍODO 2004-2009

Caros colaboradores,

Contamos com a sua atenção para preencher o formulário abaixo.

O mesmo tem por objetivo fornecer informações para avaliação da Eficiência, Efetividade e Eficácia da Política Pública de Formação de Agentes de Ater adotada pelo Departamento de Assistência Técnica e Extensão Rural, da Secretaria de Agricultura Familiar do Ministério do Desenvolvimento - DATER/SAF/MDA, no período de 2004 a 2009, tema escolhido para Monografia a ser apresentada à Universidade de Brasília (UnB) como requisito parcial para obtenção do grau de Bacharel em Administração.

Você poderá ou não se identificar no questionário e garantimos que todas as informações fornecidas serão confidenciais e utilizadas apenas de forma sistematizada

IDENTIFICAÇÃOdaterformacao@gmail.com

\begin{tabular}{|c|c|}
\hline $\begin{array}{l}\text { Nome: } \\
\text { Fernando Luiz Horn }\end{array}$ & $\begin{array}{l}\text { Sexo: } \\
(x) \text { masculino } \quad(\quad) \text { feminino }\end{array}$ \\
\hline $\begin{array}{l}\text { Instituição (nome e tipo de instituição: ONG, } \\
\text { Empresa Pública, etc.): } \\
\text { ASCAR / EMATER-RS }\end{array}$ & $\begin{array}{l}\text { Local de trabalho (Cidade e Estado): } \\
\text { Cerrito - RS }\end{array}$ \\
\hline $\begin{array}{l}\text { Curso/Encontro/Oficina do qual participou (caso tenl } \\
\text { um formulário para cada um deles): } \\
\text { Oficina de Nivelamento Conceitual em ATER }\end{array}$ & $\begin{array}{l}\text { la participado de mais de um curso, preencha } \\
\text { Florianópolis - SC }\end{array}$ \\
\hline $\begin{array}{l}\text { Data do Curso/Encontro/Oficina (pelo menos mês } \\
30 / 08 \text { a 03/09/2004 }\end{array}$ & \\
\hline
\end{tabular}

1. Indique sua área de atuação?

\begin{tabular}{|l|l|}
\hline$X$ & EXTENSÃO RURAL \\
\hline & PESQUISA \\
\hline & ENSINO \\
\hline & OUTROS \\
\hline
\end{tabular}


2) Qual o seu nível de escolaridade? (Considere apenas o nível mais alto)

\begin{tabular}{|l|l|}
\hline & NÍVEL MÉDIO \\
\hline & NÍVEL SUPERIOR \\
\hline$X$ & PÓS-GRADUAÇÃO \\
\hline
\end{tabular}

3) Os conteúdos abordados foram condizentes com as demandas do seu dia-a-dia?

\begin{tabular}{|l|l|}
\hline$X$ & SIM \\
\hline & PARCIALMENTE \\
\hline & NÃO \\
\hline
\end{tabular}

4) O curso contribuiu para o seu aperfeiçoamento profissional?

\begin{tabular}{|l|l|}
\hline$X$ & SIM \\
\hline & NÃO \\
\hline
\end{tabular}

5) Os conhecimentos adquiridos estão sendo aplicados no seu trabalho? Em caso afirmativo, indique em que grau estes conhecimentos estão sendo aplicados. Em caso negativo, indique por que razão isto não ocorre:

\begin{tabular}{|c|c|c|c|}
\hline \multirow{3}{*}{$X$} & \multirow{3}{*}{$\begin{array}{l}\text { SIM (indique ao lado em } \\
\text { que grau) }\end{array}$} & $\mathrm{X}$ & MUITO APLICADOS \\
\hline & & & MEDIAMENTE APLICADOS \\
\hline & & & POUCO APLICADOS \\
\hline & \multirow{3}{*}{$\begin{array}{l}\text { NÃO (indique ao lado a } \\
\text { razão da não aplicação) }\end{array}$} & & $\begin{array}{l}\text { CONTEÚDO NÃO ADEQUADO ȦS NECESSIDADES } \\
\text { ESPECÍFICAS DA REGIÃO }\end{array}$ \\
\hline & & & $\begin{array}{l}\text { CONTEÚDO NÃO } \quad \text { FOI SUFICIENTEMENTE } \\
\text { APROFUNDADO PARA } \\
\text { PERMITIR UMA APLICAÇÃO } \\
\text { EFICAZ E EFICIENTE }\end{array}$ \\
\hline & & & $\begin{array}{l}\text { FALTA DE APOIO } \\
\text { INSTITUIÇÃO }\end{array}$ \\
\hline
\end{tabular}




\begin{tabular}{|l|l|l|}
\hline \multirow{2}{*}{} & & FALTA DE INCENTIVO ÀS AÇÕES DE ATER \\
\cline { 3 - 4 } & & NÃO TENHO INTERESSE EM APLICAR \\
\hline
\end{tabular}

6) A partir deste curso:

\begin{tabular}{|l|l|}
\hline$x$ & $\begin{array}{l}\text { NÃO MUDOU NADA EM MEU TRABALHO. } \\
\text { FAMILIARES. }\end{array}$ \\
\hline & CONSEGUI INFLUENCIAR NAS ORIENTAÇÕES DA MINHA INSTITUIÇÃO. \\
\hline & PASSEI A TRABALHAR COM METODOLOGIAS PARTICIPATIVAS. \\
\hline & $\begin{array}{l}\text { CRESCEU A ÁREA DE AGRICULTURA DE BASE ECOLÓGICA NAS COMUNIDADES } \\
\text { ONDE ATUO. }\end{array}$ \\
\hline$X$ & CONTINUEI ME APERFEIÇOANDO SOBRE TEMAS ABORDADOS. \\
\hline
\end{tabular}

7) Depois do curso você apoiou atividades de capacitação de técnicos e agricultores com base nos princípios e diretrizes da Pnater? (Considere como apoio a atividades de capacitação a participação no planejamento, elaboração de ementas, seleção de participantes e de palestrantes.)

\begin{tabular}{|l|l|}
\hline$X$ & SIM \\
\hline & NÃO \\
\hline
\end{tabular}

8) Usou os conhecimentos para ministrar outros cursos com o mesmo conteúdo ou conteúdos semelhantes?

\begin{tabular}{|l|l|}
\hline$X$ & SIM \\
\hline & NÃO \\
\hline
\end{tabular}

9) Marque o seu grau de satisfação com relação ao curso oferecido pelo DATER: Considere a seguinte pontuação: 1 - MUITO RUIM; 2 - RUIM; 3 - REGULAR; 4 - BOM; 5 - MUITO BOM) 


\begin{tabular}{|l|l|l|l|l|}
\hline 1 & 2 & 3 & 4 & 5 \\
\hline
\end{tabular}

10) Marque seu grau de satisfação com relação ao DATER: Considere a seguinte pontuação: 1

- MUITO RUIM; 2 - RUIM; 3 - REGULAR; 4 - BOM; 5 - MUITO BOM)

\begin{tabular}{|l|l|l|l|l|}
\hline 1 & 2 & 3 & 4 & 5 \\
\hline
\end{tabular}


PESQUISA - IMPACTO DAS AÇÕES DE FORMAÇÃO REALIZADAS PELO DATER/SAF/MDA NO PERÍODO 2004-2009

Caros colaboradores,

Contamos com a sua atenção para preencher o formulário abaixo.

O mesmo tem por objetivo fornecer informações para avaliação da Eficiência, Efetividade e Eficácia da Política Pública de Formação de Agentes de Ater adotada pelo Departamento de Assistência Técnica e Extensão Rural, da Secretaria de Agricultura Familiar do Ministério do Desenvolvimento - DATER/SAF/MDA, no período de 2004 a 2009, tema escolhido para Monografia a ser apresentada à Universidade de Brasília (UnB) como requisito parcial para obtenção do grau de Bacharel em Administração.

Você poderá ou não se identificar no questionário e garantimos que todas as informações fornecidas serão confidenciais e utilizadas apenas de forma sistematizada

IDENTIFICAÇÃO

\begin{tabular}{|c|c|}
\hline $\begin{array}{l}\text { Nome: } \\
\\
\quad \text { Eberson Diedrich Eicholz }\end{array}$ & $\begin{array}{l}\text { Sexo: } \\
(x) \text { masculino } \quad(\quad) \text { feminino }\end{array}$ \\
\hline $\begin{array}{l}\text { Instituição } \\
\text { UNAIC (União das Associações Comunitárias do } \\
\text { Interior de Canguçu e região) }\end{array}$ & $\begin{array}{l}\text { Local de trabalho } \\
\text { Canguçu/RS }\end{array}$ \\
\hline $\begin{array}{l}\text { Curso/Encontro/Oficina do qual participou } \\
\text { Aperfeiçoame }\end{array}$ & nto em agroecologia \\
\hline $\begin{array}{l}\text { Data do Curso/Encontro/Oficina } \\
\qquad \text { Março a Julho de } 2006\end{array}$ & \\
\hline
\end{tabular}

1. Indique sua área de atuação?

\begin{tabular}{|l|l|}
\hline$x$ & EXTENSÃO RURAL \\
\hline & PESQUISA \\
\hline & ENSINO \\
\hline & OUTROS \\
\hline
\end{tabular}

2) Qual o seu nível de escolaridade? (Considere apenas o nível mais alto) 


\begin{tabular}{|c|l|}
\hline & NÍVEL MÉDIO \\
\hline & NÍVEL SUPERIOR \\
\hline$x$ & PÓS-GRADUAÇÃO \\
\hline
\end{tabular}

3) Os conteúdos abordados foram condizentes com as demandas do seu dia-a-dia?

\begin{tabular}{|l|l|}
\hline & SIM \\
\hline$x$ & PARCIALMENTE \\
\hline & NÃO \\
\hline
\end{tabular}

4) O curso contribuiu para o seu aperfeiçoamento profissional?

\begin{tabular}{|l|l|}
\hline$x$ & SIM \\
\hline & NÃO \\
\hline
\end{tabular}

5) Os conhecimentos adquiridos estão sendo aplicados no seu trabalho? Em caso afirmativo, indique em que grau estes conhecimentos estão sendo aplicados. Em caso negativo, indique por que razão isto não ocorre:

\begin{tabular}{|c|c|c|}
\hline \multirow{3}{*}{$\begin{array}{l}\text { SIM (indique ao lado em } \\
\text { que grau) }\end{array}$} & & MUITO APLICADOS \\
\hline & Sim & MEDIAMENTE APLICADOS \\
\hline & & POUCO APLICADOS \\
\hline \multirow{5}{*}{$\begin{array}{l}\text { NÃO (indique ao lado a } \\
\text { razão da não aplicação) }\end{array}$} & & $\begin{array}{l}\text { CONTEÚDO NĀO ADEQUADO ȦS NECESSIDADES } \\
\text { ESPECÍFICAS DA REGIÃO }\end{array}$ \\
\hline & & $\begin{array}{l}\text { CONTEÚDO NÃO FOI SUFICIENTEMENTE } \\
\text { APROFUNDADO PARA PERMITIR UMA APLICAÇÃO } \\
\text { EFICAZ E EFICIENTE }\end{array}$ \\
\hline & & $\begin{array}{lcccccc}\text { FALTA } & \text { DE } & \text { APOIO } & \text { E } & \text { INCENTIVO } & \text { DA } & \text { MINHA } \\
\text { INSTITUIÇÃO } & & & & & \\
\end{array}$ \\
\hline & & FALTA DE INCENTIVO ÀS AÇÕES DE ATER \\
\hline & & NÃO TENHO INTERESSE EM APLICAR \\
\hline
\end{tabular}


6) A partir deste curso:

\begin{tabular}{|c|l|}
\hline$x$ & $\begin{array}{l}\text { NÃO MUDOU NADA EM MEU TRABALHO. } \\
\text { FAMILIARES. }\end{array}$ \\
\hline & CONSEGUI INFLUENCIAR NAS ORIENTAÇÕES DA MINHA INSTITUIÇÃO. \\
\hline$x$ & PASSEI A TRABALHAR COM METODOLOGIAS PARTICIPATIVAS. \\
\hline & $\begin{array}{l}\text { CRESCEU A ÁREA DE AGRICULTURA DE BASE ECOLÓGICA NAS COMUNIDADES } \\
\text { ONDE ATUO. }\end{array}$ \\
\hline & CONTINUEI ME APERFEIÇOANDO SOBRE TEMAS ABORDADOS. \\
\hline
\end{tabular}

7) Depois do curso você apoiou atividades de capacitação de técnicos e agricultores com base nos princípios e diretrizes da Pnater? (Considere como apoio a atividades de capacitação a participação no planejamento, elaboração de ementas, seleção de participantes e de palestrantes.)

\begin{tabular}{|l|l|}
\hline$x$ & SIM \\
\hline & NÃO \\
\hline
\end{tabular}

8) Usou os conhecimentos para ministrar outros cursos com o mesmo conteúdo ou conteúdos semelhantes?

\begin{tabular}{|l|l|}
\hline$x$ & SIM \\
\hline & NÃO \\
\hline
\end{tabular}

9) Marque o seu grau de satisfação com relação ao curso oferecido pelo DATER: Considere a seguinte pontuação: 1 - MUITO RUIM; 2 - RUIM; 3 - REGULAR; 4 - BOM; 5 - MUITO BOM)

\begin{tabular}{|l|l|l|l|l|}
\hline 1 & 2 & 3 & $4 \times$ & 5 \\
\hline
\end{tabular}

10) Marque seu grau de satisfação com relação ao DATER: Considere a seguinte pontuação: 1

- MUITO RUIM; 2 - RUIM; 3 - REGULAR; 4 - BOM; 5 - MUITO BOM)

\begin{tabular}{|l|l|l|l|l|}
\hline 1 & 2 & 3 & $4 \times$ & 5 \\
\hline
\end{tabular}


PESQUISA - IMPACTO DAS AÇÕES DE FORMAÇÃO REALIZADAS PELO DATER/SAF/MDA NO PERÍODO 2004-2009

Caros colaboradores,

Contamos com a sua atenção para preencher o formulário abaixo.

O mesmo tem por objetivo fornecer informações para avaliação da Eficiência, Efetividade e Eficácia da Política Pública de Formação de Agentes de Ater adotada pelo Departamento de Assistência Técnica e Extensão Rural, da Secretaria de Agricultura Familiar do Ministério do Desenvolvimento - DATER/SAF/MDA, no período de 2004 a 2009, tema escolhido para Monografia a ser apresentada à Universidade de Brasília (UnB) como requisito parcial para obtenção do grau de Bacharel em Administração.

Você poderá ou não se identificar no questionário e garantimos que todas as informações fornecidas serão confidenciais e utilizadas apenas de forma sistematizada

IDENTIFICAÇÃO

\begin{tabular}{|c|c|}
\hline Nome: EDSON NEY BARBOSA & $\begin{array}{l}\text { Sexo: } \\
(x) \text { masculino } \quad(\quad) \text { feminino }\end{array}$ \\
\hline $\begin{array}{l}\text { Instituição }: \text { FETAESP/SINDICATO DOS } \\
\text { TRABALHADORES RURAIS DE ELDORADO }\end{array}$ & $\begin{array}{l}\text { Local de trabalho : SÃO PAULO } \mathrm{E} \\
\text { ELDORADO }\end{array}$ \\
\hline \multicolumn{2}{|c|}{$\begin{array}{l}\text { Curso/Encontro/Oficina do qual participou : ATER EM BIOMA DE MATA ATLANTICA - } \\
\text { FLORIANÓPOLIS SC }\end{array}$} \\
\hline Data do Curso/Encontro/Oficina : 11 A 15 DE DEZEI & MBRO DE 2006 \\
\hline
\end{tabular}

1. Indique sua área de atuação?

\begin{tabular}{|l|l|}
\hline$X$ & EXTENSÃO RURAL \\
\hline & PESQUISA \\
\hline & ENSINO \\
\hline & OUTROS \\
\hline
\end{tabular}


2) Qual o seu nível de escolaridade? (Considere apenas o nível mais alto)

\begin{tabular}{|l|l|}
\hline$X$ & NÍVEL MÉDIO \\
\hline & NÍVEL SUPERIOR \\
\hline & PÓS-GRADUAÇÃO \\
\hline
\end{tabular}

3) Os conteúdos abordados foram condizentes com as demandas do seu dia-a-dia?

\begin{tabular}{|l|l|}
\hline$X$ & SIM \\
\hline & PARCIALMENTE \\
\hline & NÃO \\
\hline
\end{tabular}

4) O curso contribuiu para o seu aperfeiçoamento profissional?

\begin{tabular}{|l|l|}
\hline$X$ & SIM \\
\hline & NÃO \\
\hline
\end{tabular}

5) Os conhecimentos adquiridos estão sendo aplicados no seu trabalho? Em caso afirmativo, indique em que grau estes conhecimentos estão sendo aplicados. Em caso negativo, indique por que razão isto não ocorre:

\begin{tabular}{|c|c|c|}
\hline \multirow{3}{*}{$\begin{array}{l}\text { SIM (indique ao lado em } \\
\text { que grau) }\end{array}$} & 4 & MUITO APLICADOS \\
\hline & & MEDIAMENTE APLICADOS \\
\hline & & POUCO APLICADOS \\
\hline \multirow{3}{*}{$\begin{array}{l}\text { NÃO (indique ao lado a } \\
\text { razão da não aplicação) }\end{array}$} & & $\begin{array}{l}\text { CONTEÚDO NÃO ADEQUADO ȦS NECESSIDADES } \\
\text { ESPECÍFICAS DA REGIÃO }\end{array}$ \\
\hline & & $\begin{array}{l}\text { CONTEÚDO NÃO } \text { FOI SUFICIENTEMENTE } \\
\text { APROFUNDADO PARA PERMITIR UMA APLICAÇÃO } \\
\text { EFICAZ E EFICIENTE }\end{array}$ \\
\hline & & $\begin{array}{lcccccc}\text { FALTA } & \text { DE } & \text { APOIO } & \text { E } & \text { INCENTIVO } & \text { DA } & \text { MINHA } \\
\text { INSTITUIÇÃO } & & & & & \end{array}$ \\
\hline
\end{tabular}




\begin{tabular}{|l|l|l|}
\hline \multirow{2}{*}{} & & FALTA DE INCENTIVO ÀS AÇÕES DE ATER \\
\cline { 3 - 4 } & & NÃO TENHO INTERESSE EM APLICAR \\
\hline
\end{tabular}

6) A partir deste curso:

\begin{tabular}{|l|l|}
\hline- & NÃO MUDOU NADA EM MEU TRABALHO. \\
\hline$X$ & $\begin{array}{l}\text { MEU TRABALHO PASSOU A CONTRIBUIR MAIS COM OS AGRICULTORES(AS) } \\
\text { FAMILIARES. }\end{array}$ \\
\hline$X$ & CONSEGUI INFLUENCIAR NAS ORIENTAÇÕES DA MINHA INSTITUIÇÃO. \\
\hline$X$ & PASSEI A TRABALHAR COM METODOLOGIAS PARTICIPATIVAS. \\
\hline$X$ & $\begin{array}{l}\text { CRESCEU A ÁREA DE AGRICULTURA DE BASE ECOLÓGICA NAS COMUNIDADES } \\
\text { ONDE ATUO. }\end{array}$ \\
\hline$X$ & CONTINUEI ME APERFEIÇOANDO SOBRE TEMAS ABORDADOS. \\
\hline
\end{tabular}

7) Depois do curso você apoiou atividades de capacitação de técnicos e agricultores com base nos princípios e diretrizes da Pnater? (Considere como apoio a atividades de capacitação a participação no planejamento, elaboração de ementas, seleção de participantes e de palestrantes.)

\begin{tabular}{|l|l|}
\hline$X$ & SIM \\
\hline & NÃO \\
\hline
\end{tabular}

8) Usou os conhecimentos para ministrar outros cursos com o mesmo conteúdo ou conteúdos semelhantes?

\begin{tabular}{|l|l|}
\hline$X$ & SIM \\
\hline & NÃO \\
\hline
\end{tabular}

9) Marque o seu grau de satisfação com relação ao curso oferecido pelo DATER: Considere a seguinte pontuação: 1 - MUITO RUIM; 2 - RUIM; 3 - REGULAR; 4 - BOM; 5 - MUITO BOM) 


\begin{tabular}{|l|l|l|l|l|}
\hline 1 & 2 & 3 & 4 & $5 \times$ \\
\hline
\end{tabular}

10) Marque seu grau de satisfação com relação ao DATER: Considere a seguinte pontuação: 1

- MUITO RUIM; 2 - RUIM; 3 - REGULAR; 4 - BOM; 5 - MUITO BOM)

\begin{tabular}{|l|l|l|l|l|}
\hline 1 & 2 & 3 & 4 & $5 \times$ \\
\hline
\end{tabular}


PESQUISA - IMPACTO DAS AÇÕES DE FORMAÇÃO REALIZADAS PELO DATER/SAF/MDA NO PERÍODO 2004-2009

Caros colaboradores,

Contamos com a sua atenção para preencher o formulário abaixo.

O mesmo tem por objetivo fornecer informações para avaliação da Eficiência, Efetividade e Eficácia da Política Pública de Formação de Agentes de Ater adotada pelo Departamento de Assistência Técnica e Extensão Rural, da Secretaria de Agricultura Familiar do Ministério do Desenvolvimento - DATER/SAF/MDA, no período de 2004 a 2009, tema escolhido para Monografia a ser apresentada à Universidade de Brasília (UnB) como requisito parcial para obtenção do grau de Bacharel em Administração.

Você poderá ou não se identificar no questionário e garantimos que todas as informações fornecidas serão confidenciais e utilizadas apenas de forma sistematizada

\section{IDENTIFICAÇÃO}

\begin{tabular}{|l|l|}
\hline Nome: Maurício Fabiano Biesek & $\begin{array}{l}\text { Sexo: } \\
(\mathrm{x}) \text { masculino } \quad(\quad) \text { feminino }\end{array}$ \\
\hline $\begin{array}{l}\text { Instituição (nome e tipo de instituição: ONG, } \\
\text { Empresa Pública, etc.): } \\
\text { Associação Instituto Agroecológico }\end{array}$ & $\begin{array}{l}\text { Local de trabalho (Cidade e Estado): } \\
\text { Curitiba-PR (SEDE), Vale do Ribeira } \\
\text { Paranaense }\end{array}$ \\
\hline $\begin{array}{l}\text { Curso/Encontro/Oficina do qual participou (caso tenha participado de mais de um curso, preencha } \\
\text { um formulário para cada um deles): Ater Pesqueira: ações de Ater com Pescadores Artesanais e } \\
\text { Aqüicultores familiares }\end{array}$ \\
\hline Data do Curso/Encontro/Oficina (pelo menos mês e ano): 11/08/2008 a 22/08/2008 \\
\hline
\end{tabular}

1. Indique sua área de atuação?

\begin{tabular}{|l|l|}
\hline$x$ & EXTENSÃO RURAL \\
\hline & PESQUISA \\
\hline & ENSINO \\
\hline$x$ & OUTROS \\
\hline
\end{tabular}

2) Qual o seu nível de escolaridade? (Considere apenas o nível mais alto) 


\begin{tabular}{|l|l|}
\hline & NÍVEL MÉDIO \\
\hline$x$ & NÍVEL SUPERIOR \\
\hline & PÓS-GRADUAÇÃO \\
\hline
\end{tabular}

3) Os conteúdos abordados foram condizentes com as demandas do seu dia-a-dia?

\begin{tabular}{|l|l|}
\hline & SIM \\
\hline$x$ & PARCIALMENTE \\
\hline & NÃO \\
\hline
\end{tabular}

4) O curso contribuiu para o seu aperfeiçoamento profissional?

\begin{tabular}{|l|l|}
\hline$x$ & SIM \\
\hline & NÃO \\
\hline
\end{tabular}

5) Os conhecimentos adquiridos estão sendo aplicados no seu trabalho? Em caso afirmativo, indique em que grau estes conhecimentos estão sendo aplicados. Em caso negativo, indique por que razão isto não ocorre:

\begin{tabular}{|c|c|c|}
\hline \multirow{3}{*}{$\begin{array}{l}\text { SIM (indique ao lado em } \\
\text { que grau) }\end{array}$} & & MUITO APLICADOS \\
\hline & & MEDIAMENTE APLICADOS \\
\hline & $x$ & POUCO APLICADOS \\
\hline \multirow{5}{*}{$\begin{array}{l}\text { NÃO (indique ao lado a } \\
\text { razão da não aplicação) }\end{array}$} & & $\begin{array}{l}\text { CONTEÚDO NÃO ADEQUADO ÀS NECESSIDADES } \\
\text { ESPECÍEICAS }\end{array}$ \\
\hline & & $\begin{array}{lllr}\text { CONTEUDO } & \text { NÂO } & \text { FOI } & \text { SUFICIENTEMENTE } \\
\text { APROFUNDADO } & \text { PARA } & \text { PERMITIR UMA } & \text { APLICACÃO }\end{array}$ \\
\hline & & 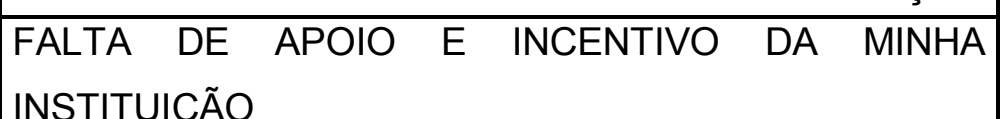 \\
\hline & & FALTA DE INCENTIVO ÀS AÇÕES DE ATER \\
\hline & & NÃO TENHO INTERESSE EM APLICAR \\
\hline
\end{tabular}

6) A partir deste curso: 


\begin{tabular}{|c|l|}
\hline$x$ & $\begin{array}{l}\text { MEU TRABALHO PASSOU A CONTRIBUIR MAIS COM OS AGRICULTORES(AS) } \\
\text { FAMILIARES. }\end{array}$ \\
\hline$x$ & CONSEGUI INFLUENCIAR NAS ORIENTAÇÕES DA MINHA INSTITUIÇÃO. \\
\hline$x$ & PASSEI A TRABALHAR COM METODOLOGIAS PARTICIPATIVAS. \\
\hline$x$ & $\begin{array}{l}\text { CRESCEU A ÁREA DE AGRICULTURA DE BASE ECOLÓGICA NAS COMUNIDADES } \\
\text { ONDE ATUO. }\end{array}$ \\
\hline$x$ & CONTINUEI ME APERFEIÇOANDO SOBRE TEMAS ABORDADOS. \\
\hline
\end{tabular}

7) Depois do curso você apoiou atividades de capacitação de técnicos e agricultores com base nos princípios e diretrizes da Pnater? (Considere como apoio a atividades de capacitação a participação no planejamento, elaboração de ementas, seleção de participantes e de palestrantes.)

\begin{tabular}{|l|l|}
\hline$x$ & SIM \\
\hline & NÃO \\
\hline
\end{tabular}

8) Usou os conhecimentos para ministrar outros cursos com o mesmo conteúdo ou conteúdos semelhantes?

\begin{tabular}{|l|l|}
\hline$x$ & SIM \\
\hline & NÃO \\
\hline
\end{tabular}

9) Marque o seu grau de satisfação com relação ao curso oferecido pelo DATER: Considere a seguinte pontuação: 1 - MUITO RUIM; 2 - RUIM; 3 - REGULAR; 4 - BOM; 5 - MUITO BOM)

\begin{tabular}{|l|l|l|l|l|}
\hline 1 & 2 & 3 & 4 & 5 \\
\hline
\end{tabular}

10) Marque seu grau de satisfação com relação ao DATER: Considere a seguinte pontuação: 1 - MUITO RUIM; 2 - RUIM; 3 - REGULAR; 4 - BOM; 5 - MUITO BOM)

\begin{tabular}{|l|l|l|l|l|}
\hline 1 & 2 & 3 & 4 & 5 \\
\hline
\end{tabular}


PESQUISA - IMPACTO DAS AÇÕES DE FORMAÇÃO REALIZADAS PELO DATER/SAF/MDA NO PERÍODO 2004-2009

Caros colaboradores,

Contamos com a sua atenção para preencher o formulário abaixo.

O mesmo tem por objetivo fornecer informações para avaliação da Eficiência, Efetividade e Eficácia da Política Pública de Formação de Agentes de Ater adotada pelo Departamento de Assistência Técnica e Extensão Rural, da Secretaria de Agricultura Familiar do Ministério do Desenvolvimento - DATER/SAF/MDA, no período de 2004 a 2009, tema escolhido para Monografia a ser apresentada à Universidade de Brasília (UnB) como requisito parcial para obtenção do grau de Bacharel em Administração.

Você poderá ou não se identificar no questionário e garantimos que todas as informações fornecidas serão confidenciais e utilizadas apenas de forma sistematizada

IDENTIFICAÇÃO

\begin{tabular}{|l|l|}
\hline Nome: PAULO ROBERTO GHISLANDI & $\begin{array}{l}\text { Sexo: } \\
(\mathrm{x}) \text { masculino } \quad(\quad) \text { feminino }\end{array}$ \\
\hline Instituição : EPAGRI & Local de trabalho : PORTO BELO - SC \\
\hline Curso/Encontro/Oficina do qual participou : ATER QUILOMBOLAS \\
\hline Data do Curso/Encontro/Oficina : 22/09/2008 À 26/09/2008 \\
\hline
\end{tabular}

1. Indique sua área de atuação?

\begin{tabular}{|l|l|}
\hline$X$ & EXTENSÃO RURAL \\
\hline & PESQUISA \\
\hline & ENSINO \\
\hline & OUTROS \\
\hline
\end{tabular}

2) Qual o seu nível de escolaridade? (Considere apenas o nível mais alto) 


\begin{tabular}{|l|l|}
\hline & NÍVEL MÉDIO \\
\hline$X$ & NÍVEL SUPERIOR \\
\hline & PÓS-GRADUAÇÃO \\
\hline
\end{tabular}

3) Os conteúdos abordados foram condizentes com as demandas do seu dia-a-dia?

\begin{tabular}{|l|l|}
\hline$X$ & SIM \\
\hline & PARCIALMENTE \\
\hline & NÃO \\
\hline
\end{tabular}

4) O curso contribuiu para o seu aperfeiçoamento profissional?

\begin{tabular}{|l|l|}
\hline$X$ & SIM \\
\hline & NÃO \\
\hline
\end{tabular}

5) Os conhecimentos adquiridos estão sendo aplicados no seu trabalho? Em caso afirmativo, indique em que grau estes conhecimentos estão sendo aplicados. Em caso negativo, indique por que razão isto não ocorre:

\begin{tabular}{|c|c|}
\hline \multirow{3}{*}{$\begin{array}{l}\text { SIM (indique ao lado em } \\
\text { que grau) }\end{array}$} & MUITO APLICADOS \\
\hline & MEDIAMENTE APLICADOS \\
\hline & POUCO APLICADOS \\
\hline \multirow{5}{*}{$\begin{array}{l}\text { NÃO (indique ao lado a } \\
\text { razão da não aplicação) }\end{array}$} & CONTEÚDO NÃO ADEQUADO ÀS NECESSIDADES \\
\hline & $\begin{array}{llll}\text { CONTEUUDO } & \text { NÂO } & \text { FOI } & \text { SUFICIENTEMENTE } \\
\text { APROFUNDADO } & \text { PARA } & \text { PERMITIR UMA APLICACCÃO }\end{array}$ \\
\hline & \begin{tabular}{|lllllll} 
FALTA & DE & APOIO & E & INCENTIVO & DA & MINHA \\
\end{tabular} \\
\hline & FALTA DE INCENTIVO ÀS AÇÕES DE ATER \\
\hline & \begin{tabular}{|l|l|} 
NÃO TENHO INTERESSE EM APLICAR \\
\end{tabular} \\
\hline
\end{tabular}

6) A partir deste curso: 


\begin{tabular}{|l|l|}
\hline & NÃO MUDOU NADA EM MEU TRABALHO. \\
\hline & $\begin{array}{l}\text { MEU TRABALHO PASSOU A CONTRIBUIR MAIS COM OS AGRICULTORES(AS) } \\
\text { FAMILIARES. }\end{array}$ \\
\hline $\mathrm{X}$ & CONSEGUI INFLUENCIAR NAS ORIENTAÇÕES DA MINHA INSTITUIÇÃO. \\
\hline & $\begin{array}{l}\text { CRESCEU A ÁREA DE AGRICULTURA DE BASE ECOLÓGICA NAS COMUNIDADES } \\
\text { ONDE ATUO. }\end{array}$ \\
\hline & CONTINUEI ME APERFEIÇOANDO SOBRE TEMAS ABORDADOS. \\
\hline
\end{tabular}

7) Depois do curso você apoiou atividades de capacitação de técnicos e agricultores com base nos princípios e diretrizes da Pnater? (Considere como apoio a atividades de capacitação a participação no planejamento, elaboração de ementas, seleção de participantes e de palestrantes.)

\begin{tabular}{|l|l|}
\hline & SIM \\
\hline$X$ & NÃO \\
\hline
\end{tabular}

8) Usou os conhecimentos para ministrar outros cursos com o mesmo conteúdo ou conteúdos semelhantes?

\begin{tabular}{|l|l|}
\hline & SIM \\
\hline$X$ & NÃO \\
\hline
\end{tabular}

9) Marque o seu grau de satisfação com relação ao curso oferecido pelo DATER: Considere a seguinte pontuação: 1 - MUITO RUIM; 2 - RUIM; 3 - REGULAR; 4 - BOM; 5 - MUITO BOM)

\begin{tabular}{|l|l|l|l|l|}
\hline 1 & 2 & 3 & $\times 4$ & 5 \\
\hline
\end{tabular}

10) Marque seu grau de satisfação com relação ao DATER: Considere a seguinte pontuação: 1 - MUITO RUIM; 2 - RUIM; 3 - REGULAR; 4 - BOM; 5 - MUITO BOM)

\begin{tabular}{|l|l|l|l|l|}
\hline 1 & 2 & 3 & $\times 4$ & 5 \\
\hline
\end{tabular}


PESQUISA - IMPACTO DAS AÇÕES DE FORMAÇÃO REALIZADAS PELO DATER/SAF/MDA NO PERÍODO 2004-2009

Caros colaboradores,

Contamos com a sua atenção para preencher o formulário abaixo.

O mesmo tem por objetivo fornecer informações para avaliação da Eficiência, Efetividade e Eficácia da Política Pública de Formação de Agentes de Ater adotada pelo Departamento de Assistência Técnica e Extensão Rural, da Secretaria de Agricultura Familiar do Ministério do Desenvolvimento - DATER/SAF/MDA, no período de 2004 a 2009, tema escolhido para Monografia a ser apresentada à Universidade de Brasília (UnB) como requisito parcial para obtenção do grau de Bacharel em Administração.

Você poderá ou não se identificar no questionário e garantimos que todas as informações fornecidas serão confidenciais e utilizadas apenas de forma sistematizada

IDENTIFICAÇÃO

\begin{tabular}{|l|l|}
\hline Nome: OSCAR SEOLA & $\begin{array}{l}\text { Sexo: } \\
(\mathrm{x}) \text { masculino } \quad(\quad) \text { feminino }\end{array}$ \\
\hline $\begin{array}{l}\text { Instituição (nome e tipo de instituição: ONG, } \\
\text { Empresa Pública, etc.): } \\
\text { EPAGRI }\end{array}$ & $\begin{array}{l}\text { Local de trabalho (Cidade e Estado): } \\
\text { IBIRAMA }\end{array}$ \\
\hline $\begin{array}{l}\text { Curso/Encontro/Oficina do qual participou (caso tenha participado de mais de um curso, preencha } \\
\text { um formulário para cada um deles): } \\
\text { SISTEMAS AGROFLORESTAIS. }\end{array}$ \\
\hline $\begin{array}{l}\text { Data do Curso/Encontro/Oficina (pelo menos mês e ano): } \\
\text { MAIO/2008 }\end{array}$ \\
\hline
\end{tabular}

1. Indique sua área de atuação?

\begin{tabular}{|l|l|}
\hline$X$ & EXTENSÃO RURAL \\
\hline & PESQUISA \\
\hline & ENSINO \\
\hline & OUTROS \\
\hline
\end{tabular}


2) Qual o seu nível de escolaridade? (Considere apenas o nível mais alto)

\begin{tabular}{|l|l|}
\hline$X$ & NÍVEL MÉDIO \\
\hline & NÍVEL SUPERIOR \\
\hline & PÓS-GRADUAÇÃO \\
\hline
\end{tabular}

3) Os conteúdos abordados foram condizentes com as demandas do seu dia-a-dia?

\begin{tabular}{|l|l|}
\hline & SIM \\
\hline$X$ & PARCIALMENTE \\
\hline & NÃO \\
\hline
\end{tabular}

4) O curso contribuiu para o seu aperfeiçoamento profissional?

\begin{tabular}{|l|l|}
\hline$X$ & SIM \\
\hline & NÃO \\
\hline
\end{tabular}

5) Os conhecimentos adquiridos estão sendo aplicados no seu trabalho? Em caso afirmativo, indique em que grau estes conhecimentos estão sendo aplicados. Em caso negativo, indique por que razão isto não ocorre:

\begin{tabular}{|c|c|c|c|}
\hline \multirow{3}{*}{$x$} & \multirow{3}{*}{$\begin{array}{l}\text { SIM (indique ao lado em } \\
\text { que grau) }\end{array}$} & & MUITO APLICADOS \\
\hline & & $\mathrm{X}$ & MEDIAMENTE APLICADOS \\
\hline & & & POUCO APLICADOS \\
\hline & & & $\begin{array}{l}\text { CONTEÚDO NÃO ADEQUADO ÀS NECESSIDADES } \\
\text { FSPFCÍFICAS DA RFGIÃO }\end{array}$ \\
\hline & & & CONTEÚDO NÂO FOI SUFICIENTEMENTE \\
\hline & NÃO (indique ao lado a & & APROFUNDADO PARA PERMITIR UMA APLICAÇÃO \\
\hline & razão da não aplicação) & & $\begin{array}{lcccccc}\text { FALTA } & \text { DE } & \text { APOIO } & \text { E } & \text { INCENTIVO } & \text { DA } & \text { MINHA } \\
\text { INSTITUICÃO } & & & & & \\
\end{array}$ \\
\hline & & & FALTA DE INCENTIVO ÀS AÇÕES DE ATER \\
\hline & & & NÃO TENHO INTERESSE EM APLICAR \\
\hline
\end{tabular}

6) A partir deste curso: 


\begin{tabular}{|l|l|}
\hline$x$ & $\begin{array}{l}\text { NÃO MUDOU NADA EM MEU TRABALHO. } \\
\text { FAMILIARES. }\end{array}$ \\
\hline & CONSEGUI INFLUENCIAR NAS ORIENTAÇÕES DA MINHA INSTITUIÇÃO. \\
\hline & PASSEI A TRABALHAR COM METODOLOGIAS PARTICIPATIVAS. \\
\hline & $\begin{array}{l}\text { CRESCEU A ÁREA DE AGRICULTURA DE BASE ECOLÓGICA NAS COMUNIDADES } \\
\text { ONDE ATUO. }\end{array}$ \\
\hline & CONTINUEI ME APERFEIÇOANDO SOBRE TEMAS ABORDADOS. \\
\hline
\end{tabular}

7) Depois do curso você apoiou atividades de capacitação de técnicos e agricultores com base nos princípios e diretrizes da Pnater? (Considere como apoio a atividades de capacitação a participação no planejamento, elaboração de ementas, seleção de participantes e de palestrantes.)

\begin{tabular}{|l|l|}
\hline$X$ & SIM \\
\hline & NÃO \\
\hline
\end{tabular}

8) Usou os conhecimentos para ministrar outros cursos com o mesmo conteúdo ou conteúdos semelhantes?

\begin{tabular}{|l|l|}
\hline$X$ & SIM \\
\hline & NÃO \\
\hline
\end{tabular}

9) Marque o seu grau de satisfação com relação ao curso oferecido pelo DATER: Considere a seguinte pontuação: 1 - MUITO RUIM; 2 - RUIM; 3 - REGULAR; 4 - BOM; 5 - MUITO BOM)

\begin{tabular}{|l|l|l|l|l|}
\hline 1 & 2 & $3 \times$ & 4 & 5 \\
\hline
\end{tabular}

10) Marque seu grau de satisfação com relação ao DATER: (Considere a seguinte pontuação:

1 - MUITO RUIM; 2 - RUIM; 3 - REGULAR; 4 - BOM; 5 - MUITO BOM)

\begin{tabular}{|l|l|l|l|l|}
\hline 1 & 2 & 3 & $4 X$ & 5 \\
\hline
\end{tabular}


PESQUISA - IMPACTO DAS AÇÕES DE FORMAÇÃO REALIZADAS PELO DATER/SAF/MDA NO PERÍODO 2004-2009

Caros colaboradores,

Contamos com a sua atenção para preencher o formulário abaixo.

O mesmo tem por objetivo fornecer informações para avaliação da Eficiência, Efetividade e Eficácia da Política Pública de Formação de Agentes de Ater adotada pelo Departamento de Assistência Técnica e Extensão Rural, da Secretaria de Agricultura Familiar do Ministério do Desenvolvimento - DATER/SAF/MDA, no período de 2004 a 2009, tema escolhido para Monografia a ser apresentada à Universidade de Brasília (UnB) como requisito parcial para obtenção do grau de Bacharel em Administração.

Você poderá ou não se identificar no questionário e garantimos que todas as informações fornecidas serão confidenciais e utilizadas apenas de forma sistematizada

IDENTIFICAÇÃO

\begin{tabular}{|c|c|}
\hline Nome: Miriam Fuckner & $\begin{array}{l}\text { Sexo: } \\
(\quad) \text { masculino } \quad(x) \text { feminino }\end{array}$ \\
\hline $\begin{array}{l}\text { Instituição (nome e tipo de instituição: ONG, } \\
\text { Empresa Pública, etc.): Emater }\end{array}$ & $\begin{array}{l}\text { Local de trabalho (Cidade e Estado): Curitiba } \\
\text { - PR }\end{array}$ \\
\hline \multicolumn{2}{|c|}{$\begin{array}{l}\text { Curso/Encontro/Oficina do qual participou (caso tenha participado de mais de um curso, preencha } \\
\text { um formulário para cada um deles): ATER para quilombolas }\end{array}$} \\
\hline Data do Curso/Encontro/Oficina (pelo menos mês $\epsilon$ & no): setembro 2008 \\
\hline
\end{tabular}

1) Indique sua área de atuação?

\begin{tabular}{|l|l|}
\hline$X$ & EXTENSÃO RURAL \\
\hline & PESQUISA \\
\hline & ENSINO \\
\hline & OUTROS \\
\hline
\end{tabular}

2) Qual o seu nível de escolaridade? (Considere apenas o nível mais alto) 


\begin{tabular}{|l|l|}
\hline & NÍVEL MÉDIO \\
\hline & NÍVEL SUPERIOR \\
\hline$X$ & PÓS-GRADUAÇÃO \\
\hline
\end{tabular}

3) Os conteúdos abordados foram condizentes com as demandas do seu dia-a-dia?

\begin{tabular}{|l|l|}
\hline & SIM \\
\hline$X$ & PARCIALMENTE \\
\hline & NÃO \\
\hline
\end{tabular}

4) O curso contribuiu para o seu aperfeiçoamento profissional?

\begin{tabular}{|l|l|}
\hline$X$ & SIM \\
\hline & NÃO \\
\hline
\end{tabular}

5) Os conhecimentos adquiridos estão sendo aplicados no seu trabalho? Em caso afirmativo, indique em que grau estes conhecimentos estão sendo aplicados. Em caso negativo, indique por que razão isto não ocorre:

\begin{tabular}{|c|c|c|}
\hline \multirow{3}{*}{$\begin{array}{l}\text { SIM (indique ao lado em } \\
\text { que grau) }\end{array}$} & & MUITO APLICADOS \\
\hline & & MEDIAMENTE APLICADOS \\
\hline & & POUCO APLICADOS \\
\hline \multirow{5}{*}{$\begin{array}{l}\text { NÃO (indique ao lado a } \\
\text { razão da não aplicação) }\end{array}$} & & $\begin{array}{l}\text { CONTEÚDO NÃO ADEQUADO ÀS NECESSIDADES } \\
\text { ESPECÍFICASمA REGIÃ }\end{array}$ \\
\hline & $\bar{x}$ & $\begin{array}{|lccr|}\text { CONTEÜDO } & \text { NÄO } & \text { FOI } & \text { SUFICIENTEMENTE } \\
\text { APROFUNDADO } & \text { PARA } & \text { PERMITIR UMA } & \text { APLICAÇÃO }\end{array}$ \\
\hline & & $\begin{array}{|lcccccc|}\text { FALTA } & \text { DE } & \text { APOIO } & \text { E } & \text { INCENTIVO } & \text { DA } & \text { MINHA } \\
\text { INSTITUICÃO } & & & & & \\
\end{array}$ \\
\hline & & FALTA DE INCENTIVO ÀS AÇÕES DE ATER \\
\hline & & NÃO TENHO INTERESSE EM APLICAR \\
\hline
\end{tabular}

6) A partir deste curso: 


\begin{tabular}{|l|l|}
\hline & NÃO MUDOU NADA EM MEU TRABALHO. \\
\hline & $\begin{array}{l}\text { MEU TRABALHO PASSOU A CONTRIBUIR MAIS COM OS AGRICULTORES(AS) } \\
\text { FAMILIARES. }\end{array}$ \\
\hline & CONSEGUI INFLUENCIAR NAS ORIENTAÇÕES DA MINHA INSTITUIÇÃO. \\
\hline & $\begin{array}{l}\text { CRESCEU A ÁREA DE AGRICULTURA DE BASE ECOLÓGICA NAS COMUNIDADES } \\
\text { ONDE ATUO. }\end{array}$ \\
\hline$X$ & CONTINUEI ME APERFEIÇOANDO SOBRE TEMAS ABORDADOS. \\
\hline
\end{tabular}

7) Depois do curso você apoiou atividades de capacitação de técnicos e agricultores com base nos princípios e diretrizes da Pnater? (Considere como apoio a atividades de capacitação a participação no planejamento, elaboração de ementas, seleção de participantes e de palestrantes.)

\begin{tabular}{|l|l|}
\hline & SIM \\
\hline$X$ & NÃO TIVE OPORTUNIDADE \\
\hline
\end{tabular}

8) Usou os conhecimentos para ministrar outros cursos com o mesmo conteúdo ou conteúdos semelhantes?

\begin{tabular}{|l|l|}
\hline & SIM \\
\hline$X$ & NÃO TIVE OPORTUNIDADE \\
\hline
\end{tabular}

9) Marque o seu grau de satisfação com relação ao curso oferecido pelo DATER: Considere a seguinte pontuação: 1 - MUITO RUIM; 2 - RUIM; 3 - REGULAR; 4 - BOM; 5 - MUITO BOM)

\begin{tabular}{|l|l|l|l|l|}
\hline 1 & 2 & 3 & 4 & 5 \\
\hline
\end{tabular}

10) Marque seu grau de satisfação com relação ao DATER: Considere a seguinte pontuação: 1 - MUITO RUIM; 2 - RUIM; 3 - REGULAR; 4 - BOM; 5 - MUITO BOM)

\begin{tabular}{|l|l|l|l|l|}
\hline 1 & 2 & 3 & 4 & 5 \\
\hline
\end{tabular}


PESQUISA - IMPACTO DAS AÇÕES DE FORMAÇÃO REALIZADAS PELO DATER/SAF/MDA NO PERÍODO 2004-2009

Caros colaboradores,

Contamos com a sua atenção para preencher o formulário abaixo.

O mesmo tem por objetivo fornecer informações para avaliação da Eficiência, Efetividade e Eficácia da Política Pública de Formação de Agentes de Ater adotada pelo Departamento de Assistência Técnica e Extensão Rural, da Secretaria de Agricultura Familiar do Ministério do Desenvolvimento - DATER/SAF/MDA, no período de 2004 a 2009, tema escolhido para Monografia a ser apresentada à Universidade de Brasília (UnB) como requisito parcial para obtenção do grau de Bacharel em Administração.

Você poderá ou não se identificar no questionário e garantimos que todas as informações fornecidas serão confidenciais e utilizadas apenas de forma sistematizada

IDENTIFICAÇÃO

\begin{tabular}{|l|l|}
\hline Nome: Metodio Sabatovski & $\begin{array}{l}\text { Sexo: } \\
(\mathrm{x}) \text { masculino } \quad(\quad) \text { feminino }\end{array}$ \\
\hline $\begin{array}{l}\text { Instituição: } \\
\text { Prefeitura Municipal de Guamiranga PR e EMATER }\end{array}$ & $\begin{array}{l}\text { Local de trabalho } \\
\text { Guamiranga, Paraná }\end{array}$ \\
\hline $\begin{array}{l}\text { Curso/Encontro/Oficina do qual participou (caso tenha participado de mais de um curso, preencha } \\
\text { um formulário para cada um deles): Análise de Cadeias Produtivas }\end{array}$ \\
\hline Data do Curso/Encontro/Oficina (pelo menos mês e ano): 16 a 27 de junho de 2008 \\
\hline
\end{tabular}

1. Indique sua área de atuação?

\begin{tabular}{|l|l|}
\hline$X$ & EXTENSÃO RURAL \\
\hline & PESQUISA \\
\hline & ENSINO \\
\hline & OUTROS \\
\hline
\end{tabular}

2) Qual o seu nível de escolaridade? (Considere apenas o nível mais alto) 


\begin{tabular}{|l|l|}
\hline$X$ & NÍVEL MÉDIO \\
\hline & NÍVEL SUPERIOR \\
\hline & PÓS-GRADUAÇÃO \\
\hline
\end{tabular}

3) Os conteúdos abordados foram condizentes com as demandas do seu dia-a-dia?

\begin{tabular}{|l|l|}
\hline$X$ & SIM \\
\hline & PARCIALMENTE \\
\hline & NÃO \\
\hline
\end{tabular}

4) O curso contribuiu para o seu aperfeiçoamento profissional?

\begin{tabular}{|l|l|}
\hline$X$ & SIM \\
\hline & NÃO \\
\hline
\end{tabular}

5) Os conhecimentos adquiridos estão sendo aplicados no seu trabalho? Em caso afirmativo, indique em que grau estes conhecimentos estão sendo aplicados. Em caso negativo, indique por que razão isto não ocorre:

\begin{tabular}{|c|c|c|c|}
\hline \multirow{3}{*}{ X } & \multirow{3}{*}{$\begin{array}{l}\text { SIM (indique ao lado em } \\
\text { que grau) }\end{array}$} & & MUITO APLICADOS \\
\hline & & $\mathrm{X}$ & MEDIAMENTE APLICADOS \\
\hline & & & POUCO APLICADOS \\
\hline & \multirow{6}{*}{$\begin{array}{l}\text { NÃO (indique ao lado a } \\
\text { razão da não aplicação) }\end{array}$} & & $\begin{array}{l}\text { CONTEÚDO NÃO ADEQUADO ÀS NECESSIDADES } \\
\text { FSPFCÍFICAS ARESIÃ }\end{array}$ \\
\hline & & & CONTEUDO NÂO FOI SUFICIENTEMENTE \\
\hline & & & APROFUNDADO PARA PERMITIR UMA APLICAÇĀO \\
\hline & & & $\begin{array}{lcccccc}\text { FALTA } & \text { DE } & \text { APOIO } & \text { E } & \text { INCENTIVO } & \text { DA } & \text { MINHA } \\
\text { INSTITUICÃO } & & & & & \\
\end{array}$ \\
\hline & & & FALTA DE INCENTIVO ÀS AÇÕES DE ATER \\
\hline & & & NÃO TENHO INTERESSE EM APLICAR \\
\hline
\end{tabular}

6) A partir deste curso:

NÃO MUDOU NADA EM MEU TRABALHO. 


\begin{tabular}{|l|l|}
\hline$X$ & $\begin{array}{l}\text { MEU TRABALHO PASSOU A CONTRIBUIR MAIS COM OS AGRICULTORES(AS) } \\
\text { FAMILIARES. }\end{array}$ \\
\hline & CONSEGUI INFLUENCIAR NAS ORIENTAÇÕES DA MINHA INSTITUIÇÃO. \\
\hline & $\begin{array}{l}\text { PASSEI A TRABALHAR COM METODOLOGIAS PARTICIPATIVAS. } \\
\text { ONDE ATUO. }\end{array}$ \\
\hline & CONTINUEI ME APERFEIÇOANDO SOBRE TEMAS ABORDADOS. \\
\hline
\end{tabular}

7) Depois do curso você apoiou atividades de capacitação de técnicos e agricultores com base nos princípios e diretrizes da Pnater? (Considere como apoio a atividades de capacitação a participação no planejamento, elaboração de ementas, seleção de participantes e de palestrantes.)

\begin{tabular}{|l|l|}
\hline$X$ & SIM \\
\hline & NÃO \\
\hline
\end{tabular}

8) Usou os conhecimentos para ministrar outros cursos com o mesmo conteúdo ou conteúdos semelhantes?

\begin{tabular}{|l|l|}
\hline & SIM \\
\hline$X$ & NÃO \\
\hline
\end{tabular}

9) Marque o seu grau de satisfação com relação ao curso oferecido pelo DATER: (Considere como apoio a atividades de capacitação a participação no planejamento, elaboração de ementas, seleção de participantes e de palestrantes.)

\begin{tabular}{|l|l|l|l|l|}
\hline 1 & 2 & 3 & 4 & 5 \\
\hline
\end{tabular}

10) Marque seu grau de satisfação com relação ao DATER: (Considere como apoio a atividades de capacitação a participação no planejamento, elaboração de ementas, seleção de participantes e de palestrantes.)

\begin{tabular}{|l|l|l|l|l|}
\hline 1 & 2 & 3 & 4 & 5 \\
\hline
\end{tabular}


PESQUISA - IMPACTO DAS AÇÕES DE FORMAÇÃO REALIZADAS PELO DATER/SAF/MDA NO PERÍODO 2004-2009

Caros colaboradores,

Contamos com a sua atenção para preencher o formulário abaixo.

O mesmo tem por objetivo fornecer informações para avaliação da Eficiência, Efetividade e Eficácia da Política Pública de Formação de Agentes de Ater adotada pelo Departamento de Assistência Técnica e Extensão Rural, da Secretaria de Agricultura Familiar do Ministério do Desenvolvimento - DATER/SAF/MDA, no período de 2004 a 2009, tema escolhido para Monografia a ser apresentada à Universidade de Brasília (UnB) como requisito parcial para obtenção do grau de Bacharel em Administração.

Você poderá ou não se identificar no questionário e garantimos que todas as informações fornecidas serão confidenciais e utilizadas apenas de forma sistematizada

\section{IDENTIFICAÇÃO}

\begin{tabular}{|l|l|}
\hline Nome: Mateus Farias de Mello & $\begin{array}{l}\text { Sexo: } \\
(\mathrm{x}) \text { masculino } \quad(\quad \text { ) feminino }\end{array}$ \\
\hline $\begin{array}{l}\text { Instituição (nome e tipo de instituição: ONG, } \\
\text { Empresa Pública, etc.): EMATER/RS ASCAR }\end{array}$ & $\begin{array}{l}\text { Local de trabalho (Cidade e Estado): } \\
\text { Encantado/RS }\end{array}$ \\
\hline $\begin{array}{l}\text { Curso/Encontro/Oficina do qual participou (caso tenha participado de mais de um curso, preencha } \\
\text { um formulário para cada um deles): Sistemas Agroflorestais no Bioma Mata Atlantica }\end{array}$ \\
\hline Data do Curso/Encontro/Oficina (pelo menos mês e ano): 11 a 15 de Dezembro de 2006 \\
\hline
\end{tabular}

1. Indique sua área de atuação?

\begin{tabular}{|l|l|}
\hline$X$ & EXTENSÃO RURAL \\
\hline & PESQUISA \\
\hline & ENSINO \\
\hline & OUTROS \\
\hline
\end{tabular}


2) Qual o seu nível de escolaridade? (Considere apenas o nível mais alto)

\begin{tabular}{|l|l|}
\hline & NÍVEL MÉDIO \\
\hline & NÍVEL SUPERIOR \\
\hline$X$ & PÓS-GRADUAÇÃO \\
\hline
\end{tabular}

3) Os conteúdos abordados foram condizentes com as demandas do seu dia-a-dia?

\begin{tabular}{|l|l|}
\hline & SIM \\
\hline$x$ & PARCIALMENTE \\
\hline & NÃO \\
\hline
\end{tabular}

4) O curso contribuiu para o seu aperfeiçoamento profissional?

\begin{tabular}{|l|l|}
\hline$X$ & SIM \\
\hline & NÃO \\
\hline
\end{tabular}

5) Os conhecimentos adquiridos estão sendo aplicados no seu trabalho? Em caso afirmativo, indique em que grau estes conhecimentos estão sendo aplicados. Em caso negativo, indique por que razão isto não ocorre:

\begin{tabular}{|c|c|c|}
\hline \multirow{3}{*}{$\begin{array}{l}\text { SIM (indique ao lado em } \\
\text { que grau) }\end{array}$} & & MUITO APLICADOS \\
\hline & $x$ & MEDIAMENTE APLICADOS \\
\hline & & POUCO APLICADOS \\
\hline \multirow{3}{*}{$\begin{array}{l}\text { NÃO (indique ao lado a } \\
\text { razão da não aplicação) }\end{array}$} & & $\begin{array}{l}\text { CONTEÚDO NÃO ADEQUADO ȦS NECESSIDADES } \\
\text { ESPECÍFICAS DA REGIÃO }\end{array}$ \\
\hline & & $\begin{array}{l}\text { CONTEÚDO NÃO } \quad \text { FOI SUFICIENTEMENTE } \\
\text { APROFUNDADO PARA } \\
\text { PERMITIR UMA APLICAÇÃO } \\
\text { EFICAZ E EFICIENTE }\end{array}$ \\
\hline & & $\begin{array}{l}\text { FALTA DE APOIO } \\
\text { INSTITUIÇÃO }\end{array}$ \\
\hline
\end{tabular}




\begin{tabular}{|l|l|l|}
\hline \multirow{2}{*}{} & & FALTA DE INCENTIVO ÀS AÇÕES DE ATER \\
\cline { 3 - 4 } & & NÃO TENHO INTERESSE EM APLICAR \\
\hline
\end{tabular}

6) A partir deste curso:

\begin{tabular}{|l|l|}
\hline$x$ & $\begin{array}{l}\text { NÃO MUDOU NADA EM MEU TRABALHO. } \\
\text { FAMILIARES. }\end{array}$ \\
\hline & CONSEGUI INFLUENCIAR NAS ORIENTAÇÕES DA MINHA INSTITUIÇÃO. \\
\hline & PASSEI A TRABALHAR COM METODOLOGIAS PARTICIPATIVAS. \\
\hline & $\begin{array}{l}\text { CRESCEU A ÁREA DE AGRICULTURA DE BASE ECOLÓGICA NAS COMUNIDADES } \\
\text { ONDE ATUO. }\end{array}$ \\
\hline$x$ & CONTINUEI ME APERFEIÇOANDO SOBRE TEMAS ABORDADOS. \\
\hline
\end{tabular}

7) Depois do curso você apoiou atividades de capacitação de técnicos e agricultores com base nos princípios e diretrizes da Pnater? (Considere como apoio a atividades de capacitação a participação no planejamento, elaboração de ementas, seleção de participantes e de palestrantes.)

\begin{tabular}{|l|l|}
\hline & SIM \\
\hline$x$ & NÃO \\
\hline
\end{tabular}

8) Usou os conhecimentos para ministrar outros cursos com o mesmo conteúdo ou conteúdos semelhantes?

\begin{tabular}{|l|l|}
\hline & SIM \\
\hline$x$ & NÃO \\
\hline
\end{tabular}

9) Marque o seu grau de satisfação com relação ao curso oferecido pelo DATER: Considere a seguinte pontuação: 1 - MUITO RUIM; 2 - RUIM; 3 - REGULAR; 4 - BOM; 5 - MUITO BOM) 


\begin{tabular}{|l|l|l|l|l|}
\hline 1 & 2 & 3 & 4 & 5 \\
\hline
\end{tabular}

10) Marque seu grau de satisfação com relação ao DATER: Considere a seguinte pontuação: 1

- MUITO RUIM; 2 - RUIM; 3 - REGULAR; 4 - BOM; 5 - MUITO BOM)

\begin{tabular}{|l|l|l|l|l|}
\hline 1 & 2 & 3 & 4 & 5 \\
\hline
\end{tabular}


PESQUISA - IMPACTO DAS AÇÕES DE FORMAÇÃO REALIZADAS PELO DATER/SAF/MDA NO PERÍODO 2004-2009

Caros colaboradores,

Contamos com a sua atenção para preencher o formulário abaixo.

O mesmo tem por objetivo fornecer informações para avaliação da Eficiência, Efetividade e Eficácia da Política Pública de Formação de Agentes de Ater adotada pelo Departamento de Assistência Técnica e Extensão Rural, da Secretaria de Agricultura Familiar do Ministério do Desenvolvimento - DATER/SAF/MDA, no período de 2004 a 2009, tema escolhido para Monografia a ser apresentada à Universidade de Brasília (UnB) como requisito parcial para obtenção do grau de Bacharel em Administração.

Você poderá ou não se identificar no questionário e garantimos que todas as informações fornecidas serão confidenciais e utilizadas apenas de forma sistematizada

\section{IDENTIFICAÇÃO}

\begin{tabular}{|l|l|}
\hline $\begin{array}{l}\text { Nome: } \\
\text { Marta Maria Mendes de Oliveira }\end{array}$ & $\begin{array}{l}\text { Sexo: } \\
(\quad) \text { masculino } \quad(x \quad \text { ) feminino }\end{array}$ \\
\hline $\begin{array}{l}\text { Instituição (nome e tipo de instituição: ONG, } \\
\text { Empresa Pública, etc.): } \\
\text { Epagri - Empresa de Pesquisa Agropecuária e } \\
\text { Extensão Rural de Santa Catarina } \\
\text { Gravatal-SC }\end{array}$ \\
\hline $\begin{array}{l}\text { Curso/Encontro/Oficina do qual participou (caso tenha participado de mais de um curso, preencha } \\
\text { um formulário para cada um deles): } \\
\text { Ater Quilombola }\end{array}$ \\
\hline $\begin{array}{l}\text { Data do Curso/Encontro/Oficina (pelo menos mês e ano): } \\
\text { Setembro/2008 }\end{array}$ \\
\hline
\end{tabular}

1.Indique sua área de atuação?

\begin{tabular}{|l|l|}
\hline$X$ & EXTENSÃO RURAL \\
\hline & PESQUISA \\
\hline & ENSINO \\
\hline & OUTROS \\
\hline
\end{tabular}


2) Qual o seu nível de escolaridade? (Considere apenas o nível mais alto)

\begin{tabular}{|l|l|}
\hline & NÍVEL MÉDIO \\
\hline & NÍVEL SUPERIOR \\
\hline$X$ & PÓS-GRADUAÇÃO \\
\hline
\end{tabular}

3) Os conteúdos abordados foram condizentes com as demandas do seu dia-a-dia?

\begin{tabular}{|l|l|}
\hline & SIM \\
\hline$X$ & PARCIALMENTE \\
\hline & NÃO \\
\hline
\end{tabular}

4) O curso contribuiu para o seu aperfeiçoamento profissional?

\begin{tabular}{|l|l|}
\hline$X$ & SIM \\
\hline & NÃO \\
\hline
\end{tabular}

5) Os conhecimentos adquiridos estão sendo aplicados no seu trabalho? Em caso afirmativo, indique em que grau estes conhecimentos estão sendo aplicados. Em caso negativo, indique por que razão isto não ocorre:

\begin{tabular}{|c|c|c|}
\hline \multirow{3}{*}{$\begin{array}{l}\text { SIM (indique ao lado em } \\
\text { que grau) }\end{array}$} & & MUITO APLICADOS \\
\hline & $\mathrm{x}$ & MEDIAMENTE APLICADOS \\
\hline & & POUCO APLICADOS \\
\hline \multirow{5}{*}{$\begin{array}{l}\text { NÃO (indique ao lado a } \\
\text { razão da não aplicação) }\end{array}$} & & $\begin{array}{l}\text { CONTEÚDO NÃO ADEQUADO ÀS NECESSIDADES } \\
\text { FSPFCÍFICAS DA RFGIÃO }\end{array}$ \\
\hline & & $\begin{array}{lllr}\text { CONTEÚDO } & \text { NÃO } & \text { FOI } & \text { SUFICIENTEMENTE } \\
\text { APROFUNDADO } & \text { PARA } & \text { PERMITIR UMA } & \text { APLICACÃO }\end{array}$ \\
\hline & & $\begin{array}{lllllll}\text { FALTA DE APOIO } & \text { E INCENTIVO } & \text { DA } & \text { MINHA } \\
\text { INSTITUICÃO } & & & & & \end{array}$ \\
\hline & & FALTA DE INCENTIVO ÀS AÇÕES DE ATER \\
\hline & & NÃO TENHO INTERESSE EM APLICAR \\
\hline
\end{tabular}

6) A partir deste curso: 


\begin{tabular}{|l|l|}
\hline$x$ & $\begin{array}{l}\text { NÃO MUDOU NADA EM MEU TRABALHO. } \\
\text { FAMILIARES. }\end{array}$ \\
\hline & CONSEGUI INFLUENCIAR NAS ORIENTAÇÕES DA MINHA INSTITUIÇÃO. \\
\hline & PASSEI A TRABALHAR COM METODOLOGIAS PARTICIPATIVAS. \\
\hline & $\begin{array}{l}\text { CRESCEU A ÁREA DE AGRICULTURA DE BASE ECOLÓGICA NAS COMUNIDADES } \\
\text { ONDE ATUO. }\end{array}$ \\
\hline & CONTINUEI ME APERFEIÇOANDO SOBRE TEMAS ABORDADOS. \\
\hline
\end{tabular}

7) Depois do curso você apoiou atividades de capacitação de técnicos e agricultores com base nos princípios e diretrizes da Pnater? (Considere como apoio a atividades de capacitação a participação no planejamento, elaboração de ementas, seleção de participantes e de palestrantes.)

\begin{tabular}{|l|l|}
\hline & SIM \\
\hline$X$ & NÃO \\
\hline
\end{tabular}

8) Usou os conhecimentos para ministrar outros cursos com o mesmo conteúdo ou conteúdos semelhantes?

\begin{tabular}{|l|l|}
\hline & SIM \\
\hline$X$ & NÃO \\
\hline
\end{tabular}

9) Marque o seu grau de satisfação com relação ao curso oferecido pelo DATER: Considere a seguinte pontuação: 1 - MUITO RUIM; 2 - RUIM; 3 - REGULAR; 4 - BOM; 5 - MUITO BOM)

\begin{tabular}{|l|l|l|l|l|}
\hline 1 & 2 & 3 & $4 X$ & 5 \\
\hline
\end{tabular}

10) Marque seu grau de satisfação com relação ao DATER: Considere a seguinte pontuação: 1 - MUITO RUIM; 2 - RUIM; 3 - REGULAR; 4 - BOM; 5 - MUITO BOM)

\begin{tabular}{|l|l|l|l|l|}
\hline 1 & 2 & 3 & $4 X$ & 5 \\
\hline
\end{tabular}


PESQUISA - IMPACTO DAS AÇÕES DE FORMAÇÃO REALIZADAS PELO DATER/SAF/MDA NO PERÍODO 2004-2009

Caros colaboradores,

Contamos com a sua atenção para preencher o formulário abaixo.

O mesmo tem por objetivo fornecer informações para avaliação da Eficiência, Efetividade e Eficácia da Política Pública de Formação de Agentes de Ater adotada pelo Departamento de Assistência Técnica e Extensão Rural, da Secretaria de Agricultura Familiar do Ministério do Desenvolvimento - DATER/SAF/MDA, no período de 2004 a 2009, tema escolhido para Monografia a ser apresentada à Universidade de Brasília (UnB) como requisito parcial para obtenção do grau de Bacharel em Administração.

Você poderá ou não se identificar no questionário e garantimos que todas as informações fornecidas serão confidenciais e utilizadas apenas de forma sistematizada

\section{IDENTIFICAÇÃO}

\begin{tabular}{|l|l|}
\hline Nome: Mário Lucio G. Rauli & $\begin{array}{l}\text { Sexo: } \\
(\mathrm{x}) \text { masculino } \quad(\quad) \text { feminino }\end{array}$ \\
\hline $\begin{array}{l}\text { Instituição (nome e tipo de instituição: ONG, } \\
\text { Empresa Pública, etc.): Emater }\end{array}$ & $\begin{array}{l}\text { Local de trabalho (Cidade e Estado): } \\
\text { Guaraqueçaba- pr }\end{array}$ \\
\hline $\begin{array}{l}\text { Curso/Encontro/Oficina do qual participou (caso tenha participado de mais de um curso, preencha } \\
\text { um formulário para cada um deles): } \\
\text { Quilombolas }\end{array}$ \\
\hline $\begin{array}{l}\text { Data do Curso/Encontro/Oficina (pelo menos mês e ano): } \\
\text { Setembro de 2008 }\end{array}$ \\
\hline
\end{tabular}

1) Indique sua área de atuação?

\begin{tabular}{|l|l|}
\hline$x$ & EXTENSÃO RURAL \\
\hline & PESQUISA \\
\hline & ENSINO \\
\hline & OUTROS \\
\hline
\end{tabular}

2) Qual o seu nível de escolaridade? (Considere apenas o nível mais alto) 


\begin{tabular}{|l|l|}
\hline & NÍVEL MÉDIO \\
\hline$x$ & NÍVEL SUPERIOR \\
\hline & PÓS-GRADUAÇÃO \\
\hline
\end{tabular}

3) Os conteúdos abordados foram condizentes com as demandas do seu dia-a-dia?

\begin{tabular}{|l|l|}
\hline & SIM \\
\hline & PARCIALMENTE \\
\hline$x$ & NÃO \\
\hline
\end{tabular}

4) O curso contribuiu para o seu aperfeiçoamento profissional?

\begin{tabular}{|l|l|}
\hline$x$ & SIM (parcialmente) \\
\hline & NÃO \\
\hline
\end{tabular}

5) Os conhecimentos adquiridos estão sendo aplicados no seu trabalho? Em caso afirmativo, indique em que grau estes conhecimentos estão sendo aplicados. Em caso negativo, indique por que razão isto não ocorre:

\begin{tabular}{|c|c|c|}
\hline \multirow{3}{*}{$\begin{array}{l}\text { SIM (indique ao lado em } \\
\text { que grau) }\end{array}$} & & MUITO APLICADOS \\
\hline & & MEDIAMENTE APLICADOS \\
\hline & $x$ & POUCO APLICADOS \\
\hline \multirow{5}{*}{$\begin{array}{l}\text { NÃO (indique ao lado a } \\
\text { razão da não aplicação) }\end{array}$} & & $\begin{array}{l}\text { CONTEÚDO NÃO ADEQUADO ÀS NECESSIDADES } \\
\text { FSPFCÍFICAS DA REGIÃO }\end{array}$ \\
\hline & & $\begin{array}{llll}\text { CONTEÜDO } & \text { NÂO } & \text { FOI } & \text { SUFICIENTEMENTE } \\
\text { APROFUNDADO } & \text { PARA } & \text { PERMITIR UMA } & \text { APLICACÃO }\end{array}$ \\
\hline & & 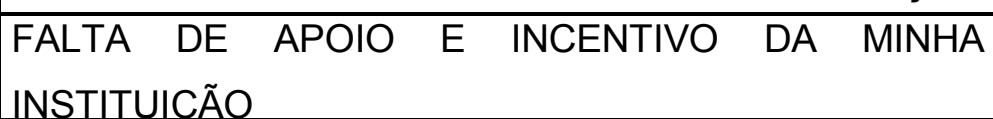 \\
\hline & & FALTA DE INCENTIVO ÀS AÇÕES DE ATER \\
\hline & & NÃO TENHO INTERESSE EM APLICAR \\
\hline
\end{tabular}

6) A partir deste curso: 


\begin{tabular}{|l|l|}
\hline$x$ & NÃO MUDOU NADA EM MEU TRABALHO. \\
\hline & $\begin{array}{l}\text { MEU TRABALHO PASSOU A CONTRIBUIR MAIS COM OS AGRICULTORES(AS) } \\
\text { FAMILIARES. }\end{array}$ \\
\hline & CONSEGUI INFLUENCIAR NAS ORIENTAÇÕES DA MINHA INSTITUIÇÃO. \\
\hline & $\begin{array}{l}\text { PASSEI A TRABALHAR COM METODOLOGIAS PARTICIPATIVAS. } \\
\text { ONDE ATUO. A ÁREA DE AGRICULTURA DE BASE ECOLÓGICA NAS COMUNIDADES }\end{array}$ \\
\hline$x$ & CONTINUEI ME APERFEIÇOANDO SOBRE TEMAS ABORDADOS. \\
\hline
\end{tabular}

7) Depois do curso você apoiou atividades de capacitação de técnicos e agricultores com base nos princípios e diretrizes da Pnater? (Considere como apoio a atividades de capacitação a participação no planejamento, elaboração de ementas, seleção de participantes e de palestrantes.)

\begin{tabular}{|l|l|}
\hline & SIM \\
\hline$x$ & NÃO \\
\hline
\end{tabular}

8) Usou os conhecimentos para ministrar outros cursos com o mesmo conteúdo ou conteúdos semelhantes?

\begin{tabular}{|l|l|}
\hline & SIM \\
\hline$x$ & NÃO \\
\hline
\end{tabular}

9) Marque o seu grau de satisfação com relação ao curso oferecido pelo DATER: Considere a seguinte pontuação: 1 - MUITO RUIM; 2 - RUIM; 3 - REGULAR; 4 - BOM; 5 - MUITO BOM)

\begin{tabular}{|l|l|l|l|l|}
\hline 1 & $\times 2 \times$ & 3 & 4 & 5 \\
\hline
\end{tabular}

10) Marque seu grau de satisfação com relação ao DATER: Considere a seguinte pontuação: 1 - MUITO RUIM; 2 - RUIM; 3 - REGULAR; 4 - BOM; 5 - MUITO BOM)

\begin{tabular}{|l|l|l|l|l|}
\hline 1 & 2 & 3 & $\times 4 \times$ & 5 \\
\hline
\end{tabular}


PESQUISA - IMPACTO DAS AÇÕES DE FORMAÇÃO REALIZADAS PELO DATER/SAF/MDA NO PERÍODO 2004-2009

Caros colaboradores,

Contamos com a sua atenção para preencher o formulário abaixo.

O mesmo tem por objetivo fornecer informações para avaliação da Eficiência, Efetividade e Eficácia da Política Pública de Formação de Agentes de Ater adotada pelo Departamento de Assistência Técnica e Extensão Rural, da Secretaria de Agricultura Familiar do Ministério do Desenvolvimento - DATER/SAF/MDA, no período de 2004 a 2009, tema escolhido para Monografia a ser apresentada à Universidade de Brasília (UnB) como requisito parcial para obtenção do grau de Bacharel em Administração.

Você poderá ou não se identificar no questionário e garantimos que todas as informações fornecidas serão confidenciais e utilizadas apenas de forma sistematizada

\section{IDENTIFICAÇÃO}

\begin{tabular}{|l|l|}
\hline Nome: Mário Lucio G. Rauli & $\begin{array}{l}\text { Sexo: } \\
(\mathrm{x}) \text { masculino } \quad(\quad) \text { feminino }\end{array}$ \\
\hline $\begin{array}{l}\text { Instituição (nome e tipo de instituição: ONG, } \\
\text { Empresa Pública, etc.): Emater }\end{array}$ & $\begin{array}{l}\text { Local de trabalho (Cidade e Estado): } \\
\text { Guaraqueçaba- pr }\end{array}$ \\
\hline $\begin{array}{l}\text { Curso/Encontro/Oficina do qual participou (caso tenha participado de mais de um curso, preencha } \\
\text { um formulário para cada um deles): } \\
\text { Agroecologia }\end{array}$ \\
\hline $\begin{array}{l}\text { Data do Curso/Encontro/Oficina (pelo menos mês e ano): } \\
\text { Setembro de 2008 }\end{array}$ \\
\hline
\end{tabular}

1. Indique sua área de atuação?

\begin{tabular}{|l|l|}
\hline$x$ & EXTENSÃO RURAL \\
\hline & PESQUISA \\
\hline & ENSINO \\
\hline & OUTROS \\
\hline
\end{tabular}

2) Qual o seu nível de escolaridade? (Considere apenas o nível mais alto) 


\begin{tabular}{|l|l|}
\hline & NÍVEL MÉDIO \\
\hline$x$ & NÍVEL SUPERIOR \\
\hline & PÓS-GRADUAÇÃO \\
\hline
\end{tabular}

3) Os conteúdos abordados foram condizentes com as demandas do seu dia-a-dia?

\begin{tabular}{|l|l|}
\hline & SIM \\
\hline$x$ & PARCIALMENTE \\
\hline & NÃO \\
\hline
\end{tabular}

4) O curso contribuiu para o seu aperfeiçoamento profissional?

\begin{tabular}{|l|l|}
\hline$x$ & SIM (parcialmente) \\
\hline & NÃO \\
\hline
\end{tabular}

5) Os conhecimentos adquiridos estão sendo aplicados no seu trabalho? Em caso afirmativo, indique em que grau estes conhecimentos estão sendo aplicados. Em caso negativo, indique por que razão isto não ocorre:

\begin{tabular}{|c|c|}
\hline \multirow{3}{*}{$\begin{array}{l}\text { SIM (indique ao lado em } \\
\text { que grau) }\end{array}$} & MUITO APLICADOS \\
\hline & MEDIAMENTE APLICADOS \\
\hline & POUCO APLICADOS \\
\hline \multirow{5}{*}{$\begin{array}{l}\text { NÃO (indique ao lado a } \\
\text { razão da não aplicação) }\end{array}$} & $\begin{array}{l}\text { CONTEÚDO NÃO ADEQUADO ÀS NECESSIDADES } \\
\text { ESPFCÍFICAS RA RFGĨ̃ }\end{array}$ \\
\hline & $\begin{array}{llll}\text { CONTEÚDO NÂO } & \text { FOI } & \text { SUFICIENTEMENTE } \\
\text { APROFUNDADO } & \text { PARA } & \text { PERMITIR UMA APLICAÇÃO }\end{array}$ \\
\hline & $\begin{array}{lcccccc}\text { FALTA } & \text { DE } & \text { APOIO } & \text { E } & \text { INCENTIVO } & \text { DA } & \text { MINHA } \\
\text { INSTITUICÃO } & & & & & \\
\end{array}$ \\
\hline & FALTA DE INCENTIVO ÀS AÇÕES DE ATER \\
\hline & NÃO TENHO INTERESSE EM APLICAR \\
\hline
\end{tabular}

6) A partir deste curso: 


\begin{tabular}{|l|l|}
\hline$x$ & $\begin{array}{l}\text { NÃO MUDOU NADA EM MEU TRABALHO. } \\
\text { FAMILIARES. }\end{array}$ \\
\hline & CONSEGUI INFLUENCIAR NAS ORIENTAÇÕES DA MINHA INSTITUIÇÃO. \\
\hline & PASSEI A TRABALHAR COM METODOLOGIAS PARTICIPATIVAS. \\
\hline & $\begin{array}{l}\text { ORESCEU A ÁREA DE AGRICULTURA DE BASE ECOLÓGICA NAS COMUNIDADES } \\
\mathrm{x}\end{array}$ \\
\hline
\end{tabular}

7) Depois do curso você apoiou atividades de capacitação de técnicos e agricultores com base nos princípios e diretrizes da Pnater? (Considere como apoio a atividades de capacitação a participação no planejamento, elaboração de ementas, seleção de participantes e de palestrantes.)

\begin{tabular}{|l|l|}
\hline & SIM \\
\hline$x$ & NÃO \\
\hline
\end{tabular}

8) Usou os conhecimentos para ministrar outros cursos com o mesmo conteúdo ou conteúdos semelhantes?

\begin{tabular}{|l|l|}
\hline & SIM \\
\hline$x$ & NÃO \\
\hline
\end{tabular}

9) Marque o seu grau de satisfação com relação ao curso oferecido pelo DATER: Considere a seguinte pontuação: 1 - MUITO RUIM; 2 - RUIM; 3 - REGULAR; 4 - BOM; 5 - MUITO BOM)

\begin{tabular}{|l|l|l|l|l|}
\hline 1 & 2 & $\times 3 \times$ & 4 & 5 \\
\hline
\end{tabular}

10) Marque seu grau de satisfação com relação ao DATER: Considere a seguinte pontuação: 1 - MUITO RUIM; 2 - RUIM; 3 - REGULAR; 4 - BOM; 5 - MUITO BOM)

\begin{tabular}{|l|l|l|l|l|}
\hline 1 & 2 & 3 & $\times 4 \times$ & 5 \\
\hline
\end{tabular}


PESQUISA - IMPACTO DAS AÇÕES DE FORMAÇÃO REALIZADAS PELO DATER/SAF/MDA NO PERÍODO 2004-2009

Caros colaboradores,

Contamos com a sua atenção para preencher o formulário abaixo.

O mesmo tem por objetivo fornecer informações para avaliação da Eficiência, Efetividade e Eficácia da Política Pública de Formação de Agentes de Ater adotada pelo Departamento de Assistência Técnica e Extensão Rural, da Secretaria de Agricultura Familiar do Ministério do Desenvolvimento - DATER/SAF/MDA, no período de 2004 a 2009, tema escolhido para Monografia a ser apresentada à Universidade de Brasília (UnB) como requisito parcial para obtenção do grau de Bacharel em Administração.

Você poderá ou não se identificar no questionário e garantimos que todas as informações fornecidas serão confidenciais e utilizadas apenas de forma sistematizada

\section{IDENTIFICAÇÃO}

\begin{tabular}{|c|c|}
\hline Nome: Roni Carlos Bonow & $\begin{array}{l}\text { Sexo: } \\
(x) \text { masculino } \quad(\quad) \text { feminino }\end{array}$ \\
\hline $\begin{array}{l}\text { Instituição (nome e tipo de instituição: ONG, } \\
\text { Empresa Pública, etc.): CAPA - Centro de Apoio ao } \\
\text { Pequeno Agricultor - ONG }\end{array}$ & $\begin{array}{l}\text { Local de trabalho (Cidade e Estado): São } \\
\text { Lourenço do Sul/RS }\end{array}$ \\
\hline $\begin{array}{l}\text { Curso/Encontro/Oficina do qual participou (caso tent } \\
\text { um formulário para cada um deles): Curso de } \\
\text { Desenvolvimento Sustentável }\end{array}$ & $\begin{array}{l}\text { ha participado de mais de um curso, preencha } \\
\text { Especialização em Extensão Rural para o }\end{array}$ \\
\hline \multicolumn{2}{|c|}{$\begin{array}{l}\text { Data do Curso/Encontro/Oficina (pelo menos mês e ano): Junho a novembro de } 2005 \text { - UFRPE - } \\
\text { Recife/PE }\end{array}$} \\
\hline
\end{tabular}

1. Indique sua área de atuação? (As opções não são excludentes: você poderá marcar mais de uma opção).

\begin{tabular}{|l|l|}
\hline$X$ & EXTENSÃO RURAL \\
\hline & PESQUISA \\
\hline & ENSINO \\
\hline & OUTROS \\
\hline
\end{tabular}


2) Qual o seu nível de escolaridade? ( Considere apenas o nível mais alto)

\begin{tabular}{|l|l|}
\hline & NÍVEL MÉDIO \\
\hline$X$ & NÍVEL SUPERIOR \\
\hline & PÓS-GRADUAÇÃO \\
\hline
\end{tabular}

3) Os conteúdos abordados foram condizentes com as demandas do seu dia-a-dia?

\begin{tabular}{|l|l|}
\hline & SIM \\
\hline$X$ & PARCIALMENTE \\
\hline & NÃO \\
\hline
\end{tabular}

4) O curso contribuiu para o seu aperfeiçoamento profissional?

\begin{tabular}{|l|l|}
\hline$X$ & SIM \\
\hline & NÃO \\
\hline
\end{tabular}

5) Os conhecimentos adquiridos estão sendo aplicados no seu trabalho? Em caso afirmativo, indique em que grau estes conhecimentos estão sendo aplicados. Em caso negativo, indique por que razão isto não ocorre: (As respostas não são excludentes: você poderá marcar mais de uma opção).

\begin{tabular}{|c|c|c|}
\hline \multirow{3}{*}{$\begin{array}{l}\text { SIM (indique ao lado em } \\
\text { que grau) }\end{array}$} & $\mathrm{X}$ & MUITO APLICADOS \\
\hline & & MEDIAMENTE APLICADOS \\
\hline & & POUCO APLICADOS \\
\hline \multirow{2}{*}{$\begin{array}{l}\text { NÃO (indique ao lado a } \\
\text { razão da não aplicação) }\end{array}$} & & $\begin{array}{l}\text { CONTEÚDO NÃO ADEQUADO ȦS NECESSIDADES } \\
\text { ESPECÍFICAS DA REGIÃO }\end{array}$ \\
\hline & & $\begin{array}{l}\text { CONTEÚDO NÃO FOI SUFICIENTEMENTE } \\
\text { APROFUNDADO PARA PERMITIR UMA APLICAÇÃO } \\
\text { EFICAZ E EFICIENTE }\end{array}$ \\
\hline
\end{tabular}




\begin{tabular}{|l|l|l|}
\hline \multirow{2}{*}{} & & $\begin{array}{l}\text { FALTA DE APOIO E INCENTIVO DA MINHA } \\
\text { INSTITUIÇÃO }\end{array}$ \\
\cline { 2 - 3 } & & FALTA DE INCENTIVO ÀS AÇÕES DE ATER \\
\cline { 2 - 3 } & NÃO TENHO INTERESSE EM APLICAR \\
\hline
\end{tabular}

6) A partir deste curso: (As opções não são excludentes: você poderá marcar mais de uma opção).

\begin{tabular}{|l|l|}
\hline$x$ & NÃO MUDOU NADA EM MEU TRABALHO. \\
\hline$X$ & $\begin{array}{l}\text { MEU TRABALHO PASSOU A CONTRIBUIR MAIS COM OS AGRICULTORES(AS) } \\
\text { FAMILIARES. }\end{array}$ \\
\hline$X$ & CONSEGUI INFLUENCIAR NAS ORIENTAÇÕES DA MINHA INSTITUIÇÃO. \\
\hline$X$ & $\begin{array}{l}\text { CRESCEU A ÁREA DE AGRICULTURA DE BASE ECOLÓGICA NAS COMUNIDADES } \\
\text { ONDE ATUO. }\end{array}$ \\
\hline & CONTINUEI ME APERFEIÇOANDO SOBRE TEMAS ABORDADOS. \\
\hline
\end{tabular}

7) Depois do curso você apoiou atividades de capacitação de técnicos e agricultores com base nos princípios e diretrizes da Pnater? (Considere como apoio a atividades de capacitação a participação no planejamento, elaboração de ementas, seleção de participantes e de palestrantes.)

\begin{tabular}{|l|l|}
\hline$X$ & SIM \\
\hline & NÃO \\
\hline
\end{tabular}

8) Usou os conhecimentos para ministrar outros cursos com o mesmo conteúdo ou conteúdos semelhantes?

\begin{tabular}{|l|l|}
\hline$X$ & SIM \\
\hline & NÃO \\
\hline
\end{tabular}

9) Marque o seu grau de satisfação com relação ao curso oferecido pelo DATER: (Considere a seguinte pontuação: 1 - MUITO RUIM; 2 - RUIM; 3 - REGULAR; 4 - BOM; 5 - MUITO BOM) 


\begin{tabular}{|l|l|l|l|l|}
\hline 1 & 2 & 3 & 4 & $x 5$ \\
\hline
\end{tabular}

10) Marque seu grau de satisfação com relação ao DATER: (Considere a seguinte pontuação:

1 - MUITO RUIM; 2 - RUIM; 3 - REGULAR; 4 - BOM; 5 - MUITO BOM)

\begin{tabular}{|l|l|l|l|l|}
\hline 1 & 2 & 3 & 4 & X5 \\
\hline
\end{tabular}


PESQUISA - IMPACTO DAS AÇÕES DE FORMAÇÃO REALIZADAS PELO DATER/SAF/MDA NO PERÍODO 2004-2009

Caros colaboradores,

Contamos com a sua atenção para preencher o formulário abaixo.

O mesmo tem por objetivo fornecer informações para avaliação da Eficiência, Efetividade e Eficácia da Política Pública de Formação de Agentes de Ater adotada pelo Departamento de Assistência Técnica e Extensão Rural, da Secretaria de Agricultura Familiar do Ministério do Desenvolvimento - DATER/SAF/MDA, no período de 2004 a 2009, tema escolhido para Monografia a ser apresentada à Universidade de Brasília (UnB) como requisito parcial para obtenção do grau de Bacharel em Administração.

Você poderá ou não se identificar no questionário e garantimos que todas as informações fornecidas serão confidenciais e utilizadas apenas de forma sistematizada

\section{IDENTIFICAÇÃO}

\begin{tabular}{|l|l|}
\hline Nome: Maurício Fabiano Biesek & $\begin{array}{l}\text { Sexo: } \\
(\mathrm{x}) \text { masculino } \quad(\quad) \text { feminino }\end{array}$ \\
\hline $\begin{array}{l}\text { Instituição (nome e tipo de instituição: ONG, } \\
\text { Empresa Pública, etc.): } \\
\text { Associação Instituto Agroecológico }\end{array}$ & $\begin{array}{l}\text { Local de trabalho (Cidade e Estado): } \\
\text { Curitiba-PR (SEDE), Vale do Ribeira } \\
\text { Paranaense }\end{array}$ \\
\hline $\begin{array}{l}\text { Curso/Encontro/Oficina do qual participou (caso tenha participado de mais de um curso, preencha } \\
\text { um formulário para cada um deles): Curso de Ater com Comunidades Quilombolas, enfoques e } \\
\text { especificidades }\end{array}$ \\
\hline Data do Curso/Encontro/Oficina (pelo menos mês e ano): 22/09/2008 a 26/09/2008 \\
\hline
\end{tabular}

1 Indique sua área de atuação? (As opções não são excludentes: você poderá marcar mais de uma opção).

\begin{tabular}{|l|l|}
\hline$x$ & EXTENSÃO RURAL \\
\hline & PESQUISA \\
\hline & ENSINO \\
\hline$x$ & OUTROS \\
\hline
\end{tabular}

2) Qual o seu nível de escolaridade? ( Considere apenas o nível mais alto) 


\begin{tabular}{|l|l|}
\hline & NÍVEL MÉDIO \\
\hline$x$ & NÍVEL SUPERIOR \\
\hline & PÓS-GRADUAÇÃO \\
\hline
\end{tabular}

3) Os conteúdos abordados foram condizentes com as demandas do seu dia-a-dia?

\begin{tabular}{|l|l|}
\hline & SIM \\
\hline$x$ & PARCIALMENTE \\
\hline & NÃO \\
\hline
\end{tabular}

4) O curso contribuiu para o seu aperfeiçoamento profissional?

\begin{tabular}{|l|l|}
\hline$x$ & SIM \\
\hline & NÃO \\
\hline
\end{tabular}

5) Os conhecimentos adquiridos estão sendo aplicados no seu trabalho? Em caso afirmativo, indique em que grau estes conhecimentos estão sendo aplicados. Em caso negativo, indique por que razão isto não ocorre: (As respostas não são excludentes: você poderá marcar mais de uma opção).

\begin{tabular}{|c|c|c|}
\hline \multirow{3}{*}{$\begin{array}{l}\text { SIM (indique ao lado em } \\
\text { que grau) }\end{array}$} & & MUITO APLICADOS \\
\hline & & MEDIAMENTE APLICADOS \\
\hline & $\mathrm{x}$ & POUCO APLICADOS \\
\hline \multirow{5}{*}{$\begin{array}{l}\text { NÃO (indique ao lado a } \\
\text { razão da não aplicação) }\end{array}$} & & $\begin{array}{l}\text { CONTEÚDO NÃO ADEQUADO ÀS NECESSIDADES } \\
\text { FSPFCÍFICAS RA REGIÃO }\end{array}$ \\
\hline & & $\begin{array}{llll}\text { CONTEÜDO NÂO } & \text { FOI } & \text { SUFICIENTEMENTE } \\
\text { APROFUNDADO } & \text { PARA } & \text { PERMITIR UMA APLICAÇÃO }\end{array}$ \\
\hline & & $\begin{array}{lcccccc}\text { FALTA } & \text { DE } & \text { APOIO } & \text { E } & \text { INCENTIVO } & \text { DA } & \text { MINHA } \\
\text { INSTITUICÃO } & & & & & \\
\end{array}$ \\
\hline & & FALTA DE INCENTIVO ÀS AÇÕES DE ATER \\
\hline & & NÃO TENHO INTERESSE EM APLICAR \\
\hline
\end{tabular}


6) A partir deste curso: (As opções não são excludentes: você poderá marcar mais de uma opção).

\begin{tabular}{|c|l|}
\hline$x$ & $\begin{array}{l}\text { NẼO MUDOU NADA EM MEU TRABALHO. } \\
\text { FAMILIARES. }\end{array}$ \\
\hline$x$ & CONSEGUI INFLUENCIAR NAS ORIENTAÇÕES DA MINHA INSTITUIÇÃO. \\
\hline$x$ & PASSEI A TRABALHAR COM METODOLOGIAS PARTICIPATIVAS. \\
\hline$x$ & $\begin{array}{l}\text { CRESCEU A ÁREA DE AGRICULTURA DE BASE ECOLÓGICA NAS COMUNIDADES } \\
\text { ONDE ATUO. }\end{array}$ \\
\hline$x$ & CONTINUEI ME APERFEIÇOANDO SOBRE TEMAS ABORDADOS. \\
\hline
\end{tabular}

7) Depois do curso você apoiou atividades de capacitação de técnicos e agricultores com base nos princípios e diretrizes da Pnater? (Considere como apoio a atividades de capacitação a participação no planejamento, elaboração de ementas, seleção de participantes e de palestrantes.)

\begin{tabular}{|l|l|}
\hline$x$ & SIM \\
\hline & NÃO \\
\hline
\end{tabular}

8) Usou os conhecimentos para ministrar outros cursos com o mesmo conteúdo ou conteúdos semelhantes?

\begin{tabular}{|l|l|}
\hline$x$ & SIM \\
\hline & NÃO \\
\hline
\end{tabular}

9) Marque o seu grau de satisfação com relação ao curso oferecido pelo DATER: (Considere a seguinte pontuação: 1 - MUITO RUIM; 2 - RUIM; 3 - REGULAR; 4 - BOM; 5 - MUITO BOM)

\begin{tabular}{|l|l|l|l|l|}
\hline 1 & 2 & 3 & 4 & 5 \\
\hline
\end{tabular}

10) Marque seu grau de satisfação com relação ao DATER: (Considere a seguinte pontuação:

1 - MUITO RUIM; 2 - RUIM; 3 - REGULAR; 4 - BOM; 5 - MUITO BOM)

\begin{tabular}{|l|l|l|l|l|}
\hline 1 & 2 & 3 & 4 & 5 \\
\hline
\end{tabular}


PESQUISA - IMPACTO DAS AÇÕES DE FORMAÇÃO REALIZADAS PELO DATER/SAF/MDA NO PERÍODO 2004-2009

Caros colaboradores,

Contamos com a sua atenção para preencher o formulário abaixo.

O mesmo tem por objetivo fornecer informações para avaliação da Eficiência, Efetividade e Eficácia da Política Pública de Formação de Agentes de Ater adotada pelo Departamento de Assistência Técnica e Extensão Rural, da Secretaria de Agricultura Familiar do Ministério do Desenvolvimento - DATER/SAF/MDA, no período de 2004 a 2009, tema escolhido para Monografia a ser apresentada à Universidade de Brasília (UnB) como requisito parcial para obtenção do grau de Bacharel em Administração.

Você poderá ou não se identificar no questionário e garantimos que todas as informações fornecidas serão confidenciais e utilizadas apenas de forma sistematizada

IDENTIFICAÇÃO

\begin{tabular}{|l|l|}
\hline Nome: Joana Mac Fadden & $\begin{array}{l}\text { Sexo: } \\
(\quad) \text { masculino } \quad(x \quad) \text { feminino }\end{array}$ \\
\hline $\begin{array}{l}\text { Instituição (nome e tipo de instituição: ONG, } \\
\text { Empresa Pública, etc.): ADM do Rio Sai Guaçu } \\
\text { Garuva/SC }\end{array}$ & $\begin{array}{l}\text { Local de trabalho (Cidade e Estado): } \\
\text { um formulário para cada um deles): SAFs }\end{array}$ \\
\hline Data do Curso/Encontro/Oficina (pelo menos mês e ano): 05 a 16 de maio de 2008 \\
\hline
\end{tabular}

1 Indique sua área de atuação? (As opções não são excludentes: você poderá marcar mais de uma opção).

\begin{tabular}{|l|l|}
\hline$x$ & EXTENSÃO RURAL \\
\hline & PESQUISA \\
\hline & ENSINO \\
\hline & OUTROS \\
\hline
\end{tabular}

2) Qual o seu nível de escolaridade? ( Considere apenas o nível mais alto) 


\begin{tabular}{|c|l|}
\hline & NÍVEL MÉDIO \\
\hline & NÍVEL SUPERIOR \\
\hline$x$ & PÓS-GRADUAÇÃO \\
\hline
\end{tabular}

3) Os conteúdos abordados foram condizentes com as demandas do seu dia-a-dia?

\begin{tabular}{|l|l|}
\hline & SIM \\
\hline$x$ & PARCIALMENTE \\
\hline & NÃO \\
\hline
\end{tabular}

4) O curso contribuiu para o seu aperfeiçoamento profissional?

\begin{tabular}{|l|l|}
\hline$x$ & SIM \\
\hline & NÃO \\
\hline
\end{tabular}

5) Os conhecimentos adquiridos estão sendo aplicados no seu trabalho? Em caso afirmativo, indique em que grau estes conhecimentos estão sendo aplicados. Em caso negativo, indique por que razão isto não ocorre: (As respostas não são excludentes: você poderá marcar mais de uma opção).

\begin{tabular}{|c|c|c|}
\hline \multirow{3}{*}{$\begin{array}{l}\text { SIM (indique ao lado em } \\
\text { que grau) }\end{array}$} & & MUITO APLICADOS \\
\hline & & MEDIAMENTE APLICADOS \\
\hline & $x$ & POUCO APLICADOS \\
\hline \multirow{5}{*}{$\begin{array}{l}\text { NÃO (indique ao lado a } \\
\text { razão da não aplicação) }\end{array}$} & & $\begin{array}{l}\text { CONTEÚDO NÃO ADEQUADO ÀS NECESSIDADES } \\
\text { ESPECÍFICAS RA RFGIÃO }\end{array}$ \\
\hline & & $\begin{array}{l}\text { CONTEUDDO NÂO FOI SUFICIENTEMENTE } \\
\text { APROFUNDADO PARA PERMITIR UMA APLICAÇÃO }\end{array}$ \\
\hline & & $\begin{array}{|lcccccc|}\text { FALTA } & \text { DE } & \text { APOIO } & \text { E } & \text { INCENTIVO } & \text { DA } & \text { MINHA } \\
\text { INSTITUICÃO } & & & & & \\
\end{array}$ \\
\hline & & FALTA DE INCENTIVO ÀS AÇÕES DE ATER \\
\hline & & NÃO TENHO INTERESSE EM APLICAR \\
\hline
\end{tabular}


6) A partir deste curso: (As opções não são excludentes: você poderá marcar mais de uma opção).

\begin{tabular}{|l|l|}
\hline & NÃO MUDOU NADA EM MEU TRABALHO. \\
\hline & $\begin{array}{l}\text { MEU TRABALHO PASSOU A CONTRIBUIR MAIS COM OS AGRICULTORES(AS) } \\
\text { FAMILIARES. }\end{array}$ \\
\hline & CONSEGUI INFLUENCIAR NAS ORIENTAÇÕES DA MINHA INSTITUIÇÃO. \\
\hline & $\begin{array}{l}\text { CRESCEU A ÁREA DE AGRICULTURA DE BASE ECOLÓGICA NAS COMUNIDADES } \\
\text { ONDE ATUO. }\end{array}$ \\
\hline$x$ & CONTINUEI ME APERFEIÇOANDO SOBRE TEMAS ABORDADOS. \\
\hline
\end{tabular}

7) Depois do curso você apoiou atividades de capacitação de técnicos e agricultores com base nos princípios e diretrizes da Pnater? (Considere como apoio a atividades de capacitação a participação no planejamento, elaboração de ementas, seleção de participantes e de palestrantes.)

\begin{tabular}{|l|l|}
\hline$x$ & SIM \\
\hline & NÃO \\
\hline
\end{tabular}

8) Usou os conhecimentos para ministrar outros cursos com o mesmo conteúdo ou conteúdos semelhantes?

\begin{tabular}{|l|l|}
\hline$x$ & SIM \\
\hline & NÃO \\
\hline
\end{tabular}

9) Marque o seu grau de satisfação com relação ao curso oferecido pelo DATER:

\begin{tabular}{|l|l|l|l|l|}
\hline 1 & 2 & $x 3$ & 4 & 5 \\
\hline
\end{tabular}

10) Marque seu grau de satisfação com relação ao DATER:

\begin{tabular}{|l|l|l|l|l|}
\hline 1 & 2 & 3 & $x 4$ & 5 \\
\hline
\end{tabular}


PESQUISA - IMPACTO DAS AÇÕES DE FORMAÇÃO REALIZADAS PELO DATER/SAF/MDA NO PERÍODO 2004-2009

Caros colaboradores,

Contamos com a sua atenção para preencher o formulário abaixo.

O mesmo tem por objetivo fornecer informações para avaliação da Eficiência, Efetividade e Eficácia da Política Pública de Formação de Agentes de Ater adotada pelo Departamento de Assistência Técnica e Extensão Rural, da Secretaria de Agricultura Familiar do Ministério do Desenvolvimento - DATER/SAF/MDA, no período de 2004 a 2009, tema escolhido para Monografia a ser apresentada à Universidade de Brasília (UnB) como requisito parcial para obtenção do grau de Bacharel em Administração.

Você poderá ou não se identificar no questionário e garantimos que todas as informações fornecidas serão confidenciais e utilizadas apenas de forma sistematizada

\section{IDENTIFICAÇÃO}

\begin{tabular}{|l|l|}
\hline $\begin{array}{l}\text { Nome: } \\
\text { Robson luiz polmann }\end{array}$ & $\begin{array}{l}\text { Sexo: } \\
(\mathrm{x}) \text { masculino } \quad(\quad \text { ) feminino }\end{array}$ \\
\hline $\begin{array}{l}\text { Instituição (nome e tipo de instituição: ONG, } \\
\text { Empresa Pública, etc.): } \\
\text { Prefeitura de blumenau }\end{array}$ & $\begin{array}{l}\text { Local de trabalho (Cidade e Estado): } \\
\text { Blumenau - SC }\end{array}$ \\
\hline $\begin{array}{l}\text { Curso/Encontro/Oficina do qual participou (caso tenha participado de mais de um curso, preencha } \\
\text { um formulário para cada um deles): } \\
\text { Capacitação em sistemas agro-florestais - bioma mata atlântica }\end{array}$ \\
\hline $\begin{array}{l}\text { Data do Curso/Encontro/Oficina (pelo menos mês e ano): } \\
\text { 11-15/11/06 }\end{array}$ \\
\hline
\end{tabular}

1. Indique sua área de atuação? (As opções não são excludentes: você poderá marcar mais de uma opção).

\begin{tabular}{|l|l|}
\hline$x$ & EXTENSÃO RURAL \\
\hline & PESQUISA \\
\hline & ENSINO \\
\hline & OUTROS \\
\hline
\end{tabular}


2) Qual o seu nível de escolaridade? ( Considere apenas o nível mais alto)

\begin{tabular}{|l|l|}
\hline & NÍVEL MÉDIO \\
\hline & NÍVEL SUPERIOR \\
\hline$x$ & PÓS-GRADUAÇÃO \\
\hline
\end{tabular}

3) Os conteúdos abordados foram condizentes com as demandas do seu dia-a-dia?

\begin{tabular}{|l|l|}
\hline$x$ & SIM \\
\hline & PARCIALMENTE \\
\hline & NÃO \\
\hline
\end{tabular}

4) O curso contribuiu para o seu aperfeiçoamento profissional?

\begin{tabular}{|l|l|}
\hline$x$ & SIM \\
\hline & NÃO \\
\hline
\end{tabular}

5) Os conhecimentos adquiridos estão sendo aplicados no seu trabalho? Em caso afirmativo, indique em que grau estes conhecimentos estão sendo aplicados. Em caso negativo, indique por que razão isto não ocorre: (As respostas não são excludentes: você poderá marcar mais de uma opção).

\begin{tabular}{|c|c|}
\hline \multirow{3}{*}{$\begin{array}{l}\text { SIM (indique ao lado em } \\
\text { que grau) }\end{array}$} & MUITO APLICADOS \\
\hline & MEDIAMENTE APLICADOS \\
\hline & POUCO APLICADOS \\
\hline \multirow{2}{*}{$\begin{array}{l}\text { NÃO (indique ao lado a } \\
\text { razão da não aplicação) }\end{array}$} & $\begin{array}{l}\text { CONTEÚDO NÃO ADEQUADO ȦS NECESSIDADES } \\
\text { ESPECÍFICAS DA REGIÃO }\end{array}$ \\
\hline & $\begin{array}{l}\text { CONTEÚDO NÃO } \text { FOI SUFICIENTEMENTE } \\
\text { APROFUNDADO PARA } \\
\text { EERMITIR UMA APLICAÇÃO } \\
\text { EFICAZ E EFICIENTE }\end{array}$ \\
\hline
\end{tabular}




\begin{tabular}{|l|l|l|}
\hline \multirow{2}{*}{} & $x$ & $\begin{array}{l}\text { FALTA DE APOIO E INCENTIVO DA MINHA } \\
\text { INSTITUIÇÃO }\end{array}$ \\
\cline { 2 - 4 } & & FALTA DE INCENTIVO ÀS AÇÕES DE ATER \\
\cline { 2 - 4 } & & NÃO TENHO INTERESSE EM APLICAR \\
\hline
\end{tabular}

6) A partir deste curso: (As opções não são excludentes: você poderá marcar mais de uma opção).

\begin{tabular}{|l|l|}
\hline & NÃO MUDOU NADA EM MEU TRABALHO. \\
\hline & $\begin{array}{l}\text { MEU TRABALHO PASSOU A CONTRIBUIR MAIS COM OS AGRICULTORES(AS) } \\
\text { FAMILIARES. }\end{array}$ \\
\hline & CONSEGUI INFLUENCIAR NAS ORIENTAÇÕES DA MINHA INSTITUIÇÃO. \\
\hline & $\begin{array}{l}\text { CRESSEI A TRABALHAR COM METODOLOGIAS PARTICIPATIVAS. } \\
\text { ONDE ATUO. ÁREA DE AGRICULTURA DE BASE ECOLÓGICA NAS COMUNIDADES }\end{array}$ \\
\hline$x$ & CONTINUEI ME APERFEIÇOANDO SOBRE TEMAS ABORDADOS. \\
\hline
\end{tabular}

7) Depois do curso você apoiou atividades de capacitação de técnicos e agricultores com base nos princípios e diretrizes da Pnater? (Considere como apoio a atividades de capacitação a participação no planejamento, elaboração de ementas, seleção de participantes e de palestrantes.)

\begin{tabular}{|l|l|}
\hline & SIM \\
\hline$x$ & NÃO \\
\hline
\end{tabular}

8) Usou os conhecimentos para ministrar outros cursos com o mesmo conteúdo ou conteúdos semelhantes?

\begin{tabular}{|l|l|}
\hline & SIM \\
\hline$x$ & NÃO \\
\hline
\end{tabular}


9) Marque o seu grau de satisfação com relação ao curso oferecido pelo DATER:

\begin{tabular}{|l|l|l|l|l|}
\hline 1 & 2 & 3 & 4 & $5 x$ \\
\hline
\end{tabular}

10) Marque seu grau de satisfação com relação ao DATER:

\begin{tabular}{|l|l|l|l|l|}
\hline 1 & 2 & 3 & $4 x$ & 5 \\
\hline
\end{tabular}


PESQUISA - IMPACTO DAS AÇÕES DE FORMAÇÃO REALIZADAS PELO DATER/SAF/MDA NO PERÍODO 2004-2009

Caros colaboradores,

Contamos com a sua atenção para preencher o formulário abaixo.

O mesmo tem por objetivo fornecer informações para avaliação da Eficiência, Efetividade e Eficácia da Política Pública de Formação de Agentes de Ater adotada pelo Departamento de Assistência Técnica e Extensão Rural, da Secretaria de Agricultura Familiar do Ministério do Desenvolvimento - DATER/SAF/MDA, no período de 2004 a 2009, tema escolhido para Monografia a ser apresentada à Universidade de Brasília (UnB) como requisito parcial para obtenção do grau de Bacharel em Administração.

Você poderá ou não se identificar no questionário e garantimos que todas as informações fornecidas serão confidenciais e utilizadas apenas de forma sistematizada

IDENTIFICAÇÃO

\begin{tabular}{|c|c|}
\hline Nome: SIGHARD EGON SEIDEL & $\begin{array}{l}\text { Sexo: } \\
(x) \text { masculino }\end{array}$ \\
\hline $\begin{array}{l}\text { Instituição (nome e tipo de instituição: ONG, } \\
\text { Empresa Pública, etc.): } \\
\text { PREFEITURA MUNICIPAL }\end{array}$ & $\begin{array}{l}\text { Local de trabalho (Cidade e Estado): } \\
\text { FRAIBURGO/SC }\end{array}$ \\
\hline $\begin{array}{l}\text { Curso/Encontro/Oficina do qual participou (caso ten } \\
\text { um formulário para cada um deles): } \\
\text { CAPACITAÇÃO PARA ELABORAÇÃO DE DEMAND }\end{array}$ & $\begin{array}{l}\text { ha participado de mais de um curso, preencha } \\
\text { AS E PROJETOS DE INVESTIMENTOS }\end{array}$ \\
\hline Data do Curso/Encontro/Oficina (pelo menos mês e & ano): \\
\hline $\begin{array}{l}\text { 2007/2008 ATRAVÉS DO TERRITÓRIO } \\
\text { NACIONAL/SALVADOR - BA }\end{array}$ & DE TERRITÓRIOS \\
\hline
\end{tabular}

1. Indique sua área de atuação? (As opções não são excludentes: você poderá marcar mais de uma opção).

\begin{tabular}{|l|l|}
\hline$X$ & EXTENSÃO RURAL \\
\hline & PESQUISA \\
\hline & ENSINO \\
\hline & OUTROS \\
\hline
\end{tabular}

2) Qual o seu nível de escolaridade? ( Considere apenas o nível mais alto) 


\begin{tabular}{|l|l|}
\hline$X$ & NÍVEL MÉDIO \\
\hline & NÍVEL SUPERIOR \\
\hline & PÓS-GRADUAÇÃO \\
\hline
\end{tabular}

3) Os conteúdos abordados foram condizentes com as demandas do seu dia-a-dia?

\begin{tabular}{|l|l|}
\hline & SIM \\
\hline$X$ & PARCIALMENTE \\
\hline & NÃO \\
\hline
\end{tabular}

4) O curso contribuiu para o seu aperfeiçoamento profissional?

\begin{tabular}{|l|l|}
\hline$X$ & SIM \\
\hline & NÃO \\
\hline
\end{tabular}

5) Os conhecimentos adquiridos estão sendo aplicados no seu trabalho? Em caso afirmativo, indique em que grau estes conhecimentos estão sendo aplicados. Em caso negativo, indique por que razão isto não ocorre: (As respostas não são excludentes: você poderá marcar mais de uma opção).

\begin{tabular}{|c|c|c|c|}
\hline \multirow{3}{*}{$x$} & \multirow{3}{*}{$\begin{array}{l}\text { SIM (indique ao lado em } \\
\text { que grau) }\end{array}$} & & MUITO APLICADOS \\
\hline & & & MEDIAMENTE APLICADOS \\
\hline & & $\bar{X}$ & POUCO APLICADOS \\
\hline & \multirow{4}{*}{$\begin{array}{l}\text { NÃO (indique ao lado a } \\
\text { razão da não aplicação) }\end{array}$} & & $\begin{array}{l}\text { CONTEÚDO NÃO ADEQUADO ÀS NECESSIDADES } \\
\text { FSPECÍFICAS SOA REGIÃO } \\
\text { CONTEUUDO NÂO FOI SUFICIENTEMENTE } \\
\text { APROFUNDADO PARA PERMITIR UMA APLICAÇÃO }\end{array}$ \\
\hline & & & \begin{tabular}{lcccccc|} 
FALTA & DE & APOIO & E & INCENTIVO & DA & MINHA \\
INSTITUICÃO & & & & & \\
\end{tabular} \\
\hline & & & FALTA DE INCENTIVO ÀS AÇÕES DE ATER \\
\hline & & & NÃO TENHO INTERESSE EM APLICAR \\
\hline
\end{tabular}


6) A partir deste curso: (As opções não são excludentes: você poderá marcar mais de uma opção).

\begin{tabular}{|l|l|}
\hline & NÃO MUDOU NADA EM MEU TRABALHO. \\
\hline & $\begin{array}{l}\text { MEU TRABALHO PASSOU A CONTRIBUIR MAIS COM OS AGRICULTORES(AS) } \\
\text { FAMILIARES. }\end{array}$ \\
\hline$X$ & CONSEGUI INFLUENCIAR NAS ORIENTAÇÕES DA MINHA INSTITUIÇÃO. \\
\hline & $\begin{array}{l}\text { PASSEI A TRABALHAR COM METODOLOGIAS PARTICIPATIVAS. } \\
\text { ONDE ATUO. }\end{array}$ \\
\hline & CONTINUEI ME APERFEIÇOANDO SOBRE TEMAS ABORDADOS. \\
\hline
\end{tabular}

7) Depois do curso você apoiou atividades de capacitação de técnicos e agricultores com base nos princípios e diretrizes da Pnater? (Considere como apoio a atividades de capacitação a participação no planejamento, elaboração de ementas, seleção de participantes e de palestrantes.)

\begin{tabular}{|l|l|}
\hline$X$ & SIM \\
\hline & NÃO \\
\hline
\end{tabular}

8) Usou os conhecimentos para ministrar outros cursos com o mesmo conteúdo ou conteúdos semelhantes?

\begin{tabular}{|l|l|}
\hline & SIM \\
\hline$X$ & NÃO \\
\hline
\end{tabular}

9) Marque o seu grau de satisfação com relação ao curso oferecido pelo DATER: (Considere a seguinte pontuação: 1 - MUITO RUIM; 2 - RUIM; 3 - REGULAR; 4 - BOM; 5 - MUITO BOM)

\begin{tabular}{|l|l|l|l|l|}
\hline 1 & 2 & 3 & $\mathrm{X} 4$ & 5 \\
\hline
\end{tabular}

10) Marque seu grau de satisfação com relação ao DATER: (Considere a seguinte pontuação: 1 - MUITO RUIM; 2 - RUIM; 3 - REGULAR; 4 - BOM; 5 - MUITO BOM)

\begin{tabular}{|l|l|l|l|l|}
\hline 1 & 2 & $X 3$ & 4 & 5 \\
\hline
\end{tabular}


PESQUISA - IMPACTO DAS AÇÕES DE FORMAÇÃO REALIZADAS PELO DATER/SAF/MDA NO PERÍODO 2004-2009

Caros colaboradores,

Contamos com a sua atenção para preencher o formulário abaixo.

O mesmo tem por objetivo fornecer informações para avaliação da Eficiência, Efetividade e Eficácia da Política Pública de Formação de Agentes de Ater adotada pelo Departamento de Assistência Técnica e Extensão Rural, da Secretaria de Agricultura Familiar do Ministério do Desenvolvimento - DATER/SAF/MDA, no período de 2004 a 2009, tema escolhido para Monografia a ser apresentada à Universidade de Brasília (UnB) como requisito parcial para obtenção do grau de Bacharel em Administração.

Você poderá ou não se identificar no questionário e garantimos que todas as informações fornecidas serão confidenciais e utilizadas apenas de forma sistematizada

\section{IDENTIFICAÇÃO}

\begin{tabular}{|l|l|}
\hline Nome: tatiana cristina guimarães kaminski & $\begin{array}{l}\text { Sexo: } \\
(\quad) \text { masculino } \quad(x) \text { feminino }\end{array}$ \\
\hline $\begin{array}{l}\text { Instituição (nome e tipo de instituição: ONG, } \\
\text { Empresa Pública, etc.): } \\
\text { Instituto a teia socioambiental }\end{array}$ & $\begin{array}{l}\text { Local de trabalho (Cidade e Estado): } \\
\text { Curitiba - pr }\end{array}$ \\
\hline $\begin{array}{l}\text { Curso/Encontro/Oficina do qual participou (caso tenha participado de mais de um curso, preencha } \\
\text { um formulário para cada um deles): } \\
\text { Curso de agentes de ater / SAF }\end{array}$ \\
\hline Data do Curso/Encontro/Oficina (pelo menos mês e ano): maio/2008 \\
\hline
\end{tabular}

1. Indique sua área de atuação? (As opções não são excludentes: você poderá marcar mais de uma opção).

\begin{tabular}{|l|l|}
\hline+ & EXTENSÃO RURAL \\
\hline+ & PESQUISA \\
\hline & ENSINO \\
\hline & OUTROS \\
\hline
\end{tabular}


2) Qual o seu nível de escolaridade? ( Considere apenas o nível mais alto)

\begin{tabular}{|l|l|}
\hline & NÍVEL MÉDIO \\
\hline & NÍVEL SUPERIOR \\
\hline+ & PÓS-GRADUAÇÃO \\
\hline
\end{tabular}

3) Os conteúdos abordados foram condizentes com as demandas do seu dia-a-dia?

\begin{tabular}{|c|c|}
\hline & SIM \\
\hline+ & $\begin{array}{l}\text { PARCIALMENTE } \\
\text { (considerando temas } \\
\text { específicos que reconheci } \\
\text { como demandas existente em } \\
\text { meus locais de trabalho para } \\
\text { mais ou para menos) }\end{array}$ \\
\hline & NÃO \\
\hline
\end{tabular}

3) O curso contribuiu para o seu aperfeiçoamento profissional?

\begin{tabular}{|l|l|}
\hline+ & SIM \\
\hline & NÃO \\
\hline
\end{tabular}

5) Os conhecimentos adquiridos estão sendo aplicados no seu trabalho? Em caso afirmativo, indique em que grau estes conhecimentos estão sendo aplicados. Em caso negativo, indique por que razão isto não ocorre: (As respostas não são excludentes: você poderá marcar mais de uma opção).

\begin{tabular}{|l|l|l|l|}
\hline \multirow{2}{*}{$\begin{array}{l}\text { SIM (indique ao lado em } \\
\text { que grau) }\end{array}$} & & MUITO APLICADOS \\
\cline { 3 - 3 } & & MEDIAMENTE APLICADOS \\
\hline
\end{tabular}




\begin{tabular}{|c|c|c|}
\hline & $\begin{array}{l}\mathrm{Na} \\
\text { medida } \\
\text { do } \\
\text { possível, } \\
\text { grau } \\
\text { elevado. }\end{array}$ & POUCO APLICADOS \\
\hline \multirow{6}{*}{$\begin{array}{l}\text { NÃO (indique ao lado a } \\
\text { razão da não aplicação) } \\
\text { A antiga instituição em } \\
\text { que trabalhava, na } \\
\text { época em que fiz o } \\
\text { curso, não prioriza } \\
\text { ações de SAF, mas sim } \\
\text { da agroecologia em } \\
\text { geral, não tendo projetos }\end{array}$} & & CONTEÚDO NÃO ADEQUADO ÀS NECESSIDADES \\
\hline & & 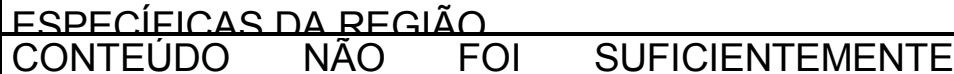 \\
\hline & & APROFUNDADO PARA PERMITIR UMA APLICAÇÃO \\
\hline & + & $\begin{array}{l}\text { FALTA DE APOIO E INCENTIVO DA MINHA (antiga) } \\
\text { INSTITUIÇÃO. A atual se chama instituto a teia }\end{array}$ \\
\hline & & FALTA DE INCENTIVO ÀS AÇÕES DE ATER \\
\hline & & \\
\hline nem ações que & & NÃO TENHO INTERESSE EM APLICAR \\
\hline incentivem diretamente & & \\
\hline a produção agroflorestal & & \\
\hline
\end{tabular}

6) A partir deste curso:

\begin{tabular}{|l|l|}
\hline+ & NÃO MUDOU NADA EM MEU TRABALHO. \\
\hline+ & $\begin{array}{l}\text { MEU TRABALHO PASSOU A CONTRIBUIR MAIS COM OS AGRICULTORES(AS) } \\
\text { FAMILIARES.(sensibilização e mobilização) }\end{array}$ \\
\hline & CONSEGUI INFLUENCIAR NAS ORIENTAÇÕES DA MINHA INSTITUIÇÃO. \\
\hline & $\begin{array}{l}\text { CRESCEU A ÁREA DE AGRICULTURA DE BASE ECOLÓGICA NAS COMUNIDADES } \\
\text { ONDE ATUO.(esSa é uma realidade que não existe graças a minha atuação) }\end{array}$ \\
\hline+ & CONTINUEI ME APERFEIÇOANDO SOBRE TEMAS ABORDADOS. \\
\hline
\end{tabular}

7) Depois do curso você apoiou atividades de capacitação de técnicos e agricultores com base nos princípios e diretrizes da Pnater? (Considere como apoio a atividades de capacitação a participação no planejamento, elaboração de ementas, seleção de participantes e de palestrantes.) 


\begin{tabular}{|l|l|}
\hline+ & $\begin{array}{l}\text { SIM, já os utilizava antes do } \\
\text { curso }\end{array}$ \\
\hline & NÃO \\
\hline
\end{tabular}

8) Usou os conhecimentos para ministrar outros cursos com o mesmo conteúdo ou conteúdos semelhantes?

\begin{tabular}{|l|l|}
\hline & SIM \\
\hline+ & $\begin{array}{l}\text { NÃO, pois geralmente não } \\
\text { ministro cursos }\end{array}$ \\
\hline
\end{tabular}

9) Marque o seu grau de satisfação com relação ao curso oferecido pelo DATER:

\begin{tabular}{|l|l|l|l|l|}
\hline 1 & 2 & 3 & $4+$ & 5 \\
\hline
\end{tabular}

10) Marque seu grau de satisfação com relação ao DATER:

\begin{tabular}{|l|l|l|l|l|}
\hline 1 & 2 & 3 & $4+$ & 5 \\
\hline
\end{tabular}


PESQUISA - IMPACTO DAS AÇÕES DE FORMAÇÃO REALIZADAS PELO DATER/SAF/MDA NO PERÍODO 2004-2009

Caros colaboradores,

Contamos com a sua atenção para preencher o formulário abaixo.

O mesmo tem por objetivo fornecer informações para avaliação da Eficiência, Efetividade e Eficácia da Política Pública de Formação de Agentes de Ater adotada pelo Departamento de Assistência Técnica e Extensão Rural, da Secretaria de Agricultura Familiar do Ministério do Desenvolvimento - DATER/SAF/MDA, no período de 2004 a 2009, tema escolhido para Monografia a ser apresentada à Universidade de Brasília (UnB) como requisito parcial para obtenção do grau de Bacharel em Administração.

Você poderá ou não se identificar no questionário e garantimos que todas as informações fornecidas serão confidenciais e utilizadas apenas de forma sistematizada

\section{IDENTIFICAÇÃO}

\begin{tabular}{|l|l|}
\hline Nome: Vinícius Carlos Freire & $\begin{array}{l}\text { Sexo: } \\
(\mathrm{x}) \text { masculino } \quad(\quad) \text { feminino }\end{array}$ \\
\hline $\begin{array}{l}\text { Instituição (nome e tipo de instituição: ONG, } \\
\text { Empresa Pública, etc.): EMATER - PR } \\
\text { Grossa }\end{array}$ \\
\hline $\begin{array}{l}\text { Curso/Encontro/Oficina do qual participou (caso tenha participado de mais de um curso, preencha } \\
\text { um formulário para cada um deles): Sistemas Agroflorestais }\end{array}$ \\
\hline Data do Curso/Encontro/Oficina (pelo menos mês e ano): maio/2008 \\
\hline
\end{tabular}

Indique sua área de atuação? (As opções não são excludentes: você poderá marcar mais de uma opção).

\begin{tabular}{|l|l|}
\hline$x$ & EXTENSÃO RURAL \\
\hline & PESQUISA \\
\hline & ENSINO \\
\hline & OUTROS \\
\hline
\end{tabular}

2) Qual o seu nível de escolaridade? ( Considere apenas o nível mais alto) 


\begin{tabular}{|l|l|}
\hline & NÍVEL MÉDIO \\
\hline$x$ & NÍVEL SUPERIOR \\
\hline & PÓS-GRADUAÇÃO \\
\hline
\end{tabular}

3) Os conteúdos abordados foram condizentes com as demandas do seu dia-a-dia?

\begin{tabular}{|l|l|}
\hline$x$ & SIM \\
\hline & PARCIALMENTE \\
\hline & NÃO \\
\hline
\end{tabular}

4) O curso contribuiu para o seu aperfeiçoamento profissional?

\begin{tabular}{|l|l|}
\hline$x$ & SIM \\
\hline & NÃO \\
\hline
\end{tabular}

5) Os conhecimentos adquiridos estão sendo aplicados no seu trabalho? Em caso afirmativo, indique em que grau estes conhecimentos estão sendo aplicados. Em caso negativo, indique por que razão isto não ocorre: (As respostas não são excludentes: você poderá marcar mais de uma opção).

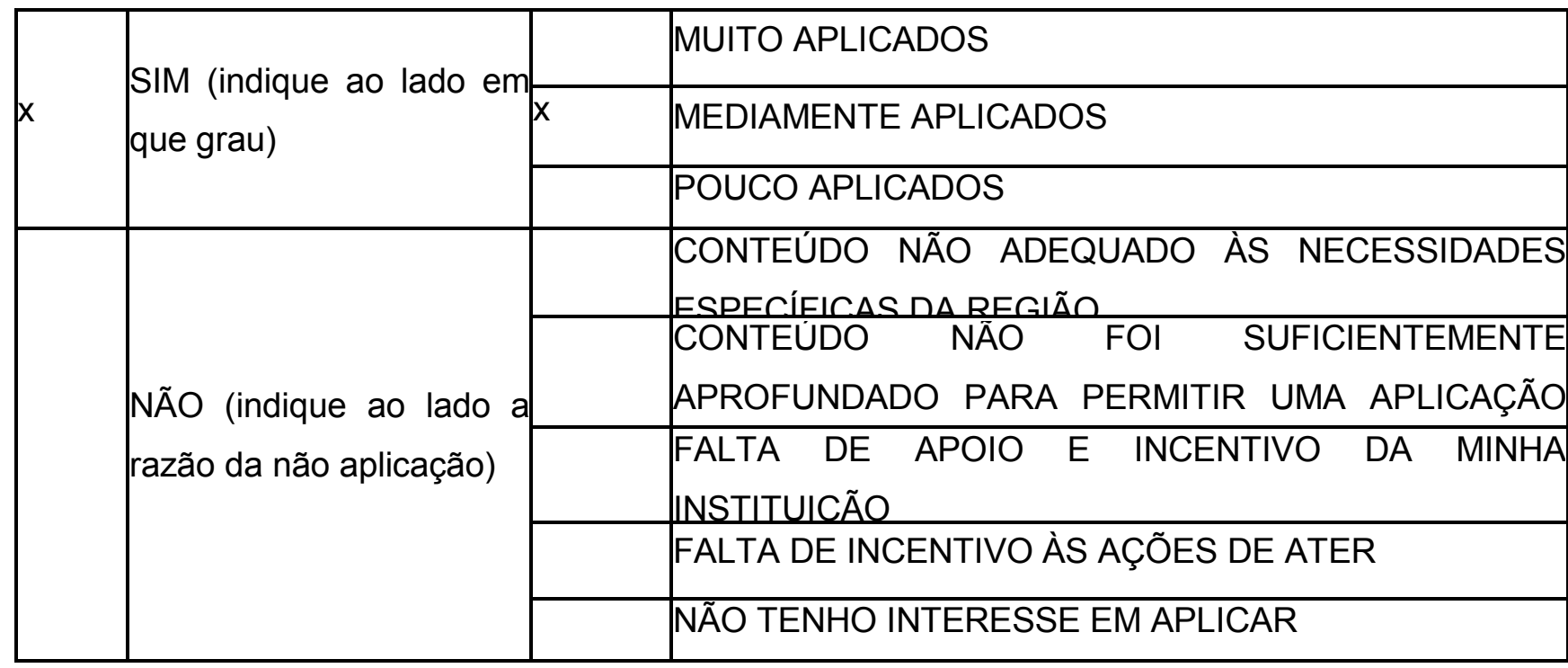


6) A partir deste curso: (As opções não são excludentes: você poderá marcar mais de uma opção).

\begin{tabular}{|l|l|}
\hline & NÃO MUDOU NADA EM MEU TRABALHO. \\
\hline & $\begin{array}{l}\text { MEU TRABALHO PASSOU A CONTRIBUIR MAIS COM OS AGRICULTORES(AS) } \\
\text { FAMILIARES. }\end{array}$ \\
\hline & CONSEGUI INFLUENCIAR NAS ORIENTAÇÕES DA MINHA INSTITUIÇÃO. \\
\hline & CASSEI A TRABALHAR COM METODOLOGIAS PARTICIPATIVAS. \\
& ONDE ATUO. \\
\hline$x$ & CONTINUEI ME APERFEIÇOANDO SOBRE TEMAS ABORDADOS. \\
\hline
\end{tabular}

7) Depois do curso você apoiou atividades de capacitação de técnicos e agricultores com base nos princípios e diretrizes da Pnater? (Considere como apoio a atividades de capacitação a participação no planejamento, elaboração de ementas, seleção de participantes e de palestrantes.)

\begin{tabular}{|l|l|}
\hline$x$ & SIM \\
\hline & NÃO \\
\hline
\end{tabular}

8) Usou os conhecimentos para ministrar outros cursos com o mesmo conteúdo ou conteúdos semelhantes?

\begin{tabular}{|l|l|}
\hline$x$ & SIM \\
\hline & NÃO \\
\hline
\end{tabular}

9) Marque o seu grau de satisfação com relação ao curso oferecido pelo DATER: (Considere a seguinte pontuação: 1 - MUITO RUIM; 2 - RUIM; 3 - REGULAR; 4 - BOM; 5 - MUITO BOM)

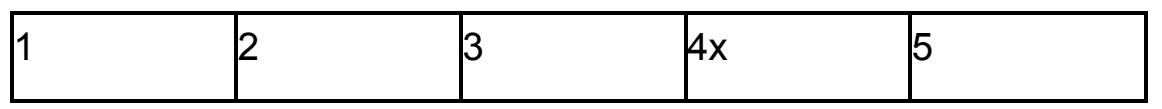

10) Marque seu grau de satisfação com relação ao DATER: (Considere a seguinte pontuação: 1 - MUITO RUIM; 2 - RUIM; 3 - REGULAR; 4 - BOM; 5 - MUITO BOM)

\begin{tabular}{|l|l|l|l|l|}
\hline 1 & 2 & 3 & $4 x$ & 5 \\
\hline
\end{tabular}


PESQUISA - IMPACTO DAS AÇÕES DE FORMAÇÃO REALIZADAS PELO DATER/SAF/MDA NO PERÍODO 2004-2009

Caros colaboradores,

Contamos com a sua atenção para preencher o formulário abaixo.

O mesmo tem por objetivo fornecer informações para avaliação da Eficiência, Efetividade e Eficácia da Política Pública de Formação de Agentes de Ater adotada pelo Departamento de Assistência Técnica e Extensão Rural, da Secretaria de Agricultura Familiar do Ministério do Desenvolvimento - DATER/SAF/MDA, no período de 2004 a 2009, tema escolhido para Monografia a ser apresentada à Universidade de Brasília (UnB) como requisito parcial para obtenção do grau de Bacharel em Administração.

Você poderá ou não se identificar no questionário e garantimos que todas as informações fornecidas serão confidenciais e utilizadas apenas de forma sistematizada

\section{IDENTIFICAÇÃO}

\begin{tabular}{|l|l|}
\hline Nome: Vitor Veiga Vasconcelos Neto & $\begin{array}{l}\text { Sexo: } \\
(\mathrm{x}) \text { masculino } \quad(\quad \text { ) feminino }\end{array}$ \\
\hline $\begin{array}{l}\text { Instituição (nome e tipo de instituição: ONG, } \\
\text { Empresa Pública, etc.): Coopescamar-cooperativa }\end{array}$ & $\begin{array}{l}\text { Local de trabalho (Cidade e Estado): } \\
\text { Guaraqueçaba - Paraná }\end{array}$ \\
\hline $\begin{array}{l}\text { Curso/Encontro/Oficina do qual participou (caso tenha participado de mais de um curso, preencha } \\
\text { um formulário para cada um deles): curso de ATER com comunidades quilombolas; enfoques e } \\
\text { especificidades. }\end{array}$ \\
\hline Data do Curso/Encontro/Oficina (pelo menos mês e ano): de 22 a 26 de setembro de 2008 \\
\hline
\end{tabular}

1. Indique sua área de atuação? (As opções não são excludentes: você poderá marcar mais de uma opção).

\begin{tabular}{|l|l|}
\hline$x$ & EXTENSÃO RURAL \\
\hline & PESQUISA \\
\hline & ENSINO \\
\hline & OUTROS \\
\hline
\end{tabular}

2) Qual o seu nível de escolaridade? ( Considere apenas o nível mais alto) 


\begin{tabular}{|l|l|}
\hline & NÍVEL MÉDIO \\
\hline$x$ & NÍVEL SUPERIOR \\
\hline & PÓS-GRADUAÇÃO \\
\hline
\end{tabular}

3) Os conteúdos abordados foram condizentes com as demandas do seu dia-a-dia?

\begin{tabular}{|l|l|}
\hline & SIM \\
\hline$x$ & PARCIALMENTE \\
\hline & NÃO \\
\hline
\end{tabular}

3) O curso contribuiu para o seu aperfeiçoamento profissional?

\begin{tabular}{|l|l|}
\hline$x$ & SIM \\
\hline & NÃO \\
\hline
\end{tabular}

5) Os conhecimentos adquiridos estão sendo aplicados no seu trabalho? Em caso afirmativo, indique em que grau estes conhecimentos estão sendo aplicados. Em caso negativo, indique por que razão isto não ocorre: (As respostas não são excludentes: você poderá marcar mais de uma opção).

\begin{tabular}{|c|c|c|c|}
\hline \multirow{3}{*}{$x$} & \multirow{3}{*}{$\begin{array}{l}\text { SIM (indique ao lado em } \\
\text { que grau) }\end{array}$} & & MUITO APLICADOS \\
\hline & & $\mathrm{x}$ & MEDIAMENTE APLICADOS \\
\hline & & & POUCO APLICADOS \\
\hline & \multirow{5}{*}{$\begin{array}{l}\text { NÃO (indique ao lado a } \\
\text { razão da não aplicação) }\end{array}$} & & CONTEÚDO NÃO ADEQUADO ÀS NECESSIDADES \\
\hline & & & $\begin{array}{l}\text { FSPECIFICAS DARFGIAO } \\
\text { CONTEUUDO NÂO FOI SUFICIENTEMENTE } \\
\text { APROFUNDADO PARA PERMITIR UMA APLICAÇÃO }\end{array}$ \\
\hline & & & 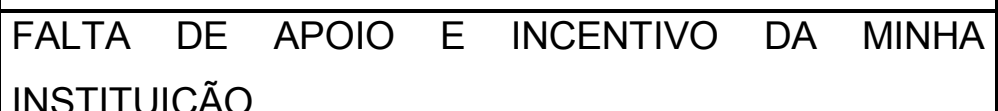 \\
\hline & & & FALTA DE INCENTIVO ÀS AÇÕES DE ATER \\
\hline & & & NÃO TENHO INTERESSE EM APLICAR \\
\hline
\end{tabular}


6) A partir deste curso: (As opções não são excludentes: você poderá marcar mais de uma opção).

\begin{tabular}{|l|l|}
\hline$x$ & $\begin{array}{l}\text { NÃO MUDOU NADA EM MEU TRABALHO. } \\
\text { FAMILIARES. }\end{array}$ \\
\hline & CONSEGUI INFLUENCIAR NAS ORIENTAÇÕES DA MINHA INSTITUIÇÃO. \\
\hline & PASSEI A TRABALHAR COM METODOLOGIAS PARTICIPATIVAS. \\
\hline & $\begin{array}{l}\text { ORESCEU A ÁREA DE AGRICULTURA DE BASE ECOLÓGICA NAS COMUNIDADES } \\
\text { CONTINUEI ME APERFEIÇOANDO SOBRE TEMAS ABORDADOS. }\end{array}$ \\
\hline
\end{tabular}

7) Depois do curso você apoiou atividades de capacitação de técnicos e agricultores com base nos princípios e diretrizes da Pnater? (Considere como apoio a atividades de capacitação a participação no planejamento, elaboração de ementas, seleção de participantes e de palestrantes.)

\begin{tabular}{|l|l|}
\hline & SIM \\
\hline$x$ & NÃO \\
\hline
\end{tabular}

8) Usou os conhecimentos para ministrar outros cursos com o mesmo conteúdo ou conteúdos semelhantes?

\begin{tabular}{|l|l|}
\hline & SIM \\
\hline$x$ & NÃO \\
\hline
\end{tabular}

9) Marque o seu grau de satisfação com relação ao curso oferecido pelo DATER: (Considere a seguinte pontuação: 1 - MUITO RUIM; 2 - RUIM; 3 - REGULAR; 4 - BOM; 5 - MUITO BOM)

\begin{tabular}{|l|l|l|l|l|}
\hline 1 & 2 & 3 & 4 & 5 \\
\hline
\end{tabular}

10) Marque seu grau de satisfação com relação ao DATER: (Considere a seguinte pontuação: 1 - MUITO RUIM; 2 - RUIM; 3 - REGULAR; 4 - BOM; 5 - MUITO BOM)

\begin{tabular}{|l|l|l|l|l|}
\hline 1 & 2 & 3 & 4 & 5 \\
\hline
\end{tabular}


PESQUISA - IMPACTO DAS AÇÕES DE FORMAÇÃO REALIZADAS PELO DATER/SAF/MDA NO PERÍODO 2004-2009

Caros colaboradores,

Contamos com a sua atenção para preencher o formulário abaixo.

O mesmo tem por objetivo fornecer informações para avaliação da Eficiência, Efetividade e Eficácia da Política Pública de Formação de Agentes de Ater adotada pelo Departamento de Assistência Técnica e Extensão Rural, da Secretaria de Agricultura Familiar do Ministério do Desenvolvimento - DATER/SAF/MDA, no período de 2004 a 2009, tema escolhido para Monografia a ser apresentada à Universidade de Brasília (UnB) como requisito parcial para obtenção do grau de Bacharel em Administração.

Você poderá ou não se identificar no questionário e garantimos que todas as informações fornecidas serão confidenciais e utilizadas apenas de forma sistematizada.

IDENTIFICAÇÃO

\begin{tabular}{|l|l|}
\hline $\begin{array}{l}\text { Nome: } \\
\text { Eberson Diedrich Eicholz }\end{array}$ & $\begin{array}{l}\text { Sexo: } \\
(\mathrm{x}) \text { masculino } \quad(\quad) \text { feminino }\end{array}$ \\
\hline $\begin{array}{l}\text { Instituição : UNAIC (União das Associações } \\
\text { Comunitárias do Interior de Canguçu e região) }\end{array}$ & $\begin{array}{l}\text { Local de trabalho: } \\
\text { Canguçu/RS }\end{array}$ \\
\hline $\begin{array}{l}\text { Curso/Encontro/Oficina do qual participou: } \\
\text { Aperfeiçoamento em agroecologia }\end{array}$ \\
\hline $\begin{array}{l}\text { Data do Curso/Encontro/Oficina: } \\
\text { Março a Julho de 2006 }\end{array}$ \\
\hline
\end{tabular}

1 Indique sua área de atuação? (As opções não são excludentes: você poderá marcar mais de uma opção).

\begin{tabular}{|l|l|}
\hline$x$ & EXTENSÃO RURAL \\
\hline & PESQUISA \\
\hline & ENSINO \\
\hline & OUTROS \\
\hline
\end{tabular}


2) Qual o seu nível de escolaridade? ( Considere apenas o nível mais alto)

\begin{tabular}{|l|l|}
\hline & NÍVEL MÉDIO \\
\hline & NÍVEL SUPERIOR \\
\hline$x$ & PÓS-GRADUAÇÃO \\
\hline
\end{tabular}

3) Os conteúdos abordados foram condizentes com as demandas do seu dia-a-dia?

\begin{tabular}{|l|l|}
\hline & SIM \\
\hline$x$ & PARCIALMENTE \\
\hline & NÃO \\
\hline
\end{tabular}

4) O curso contribuiu para o seu aperfeiçoamento profissional?

\begin{tabular}{|l|l|}
\hline$x$ & SIM \\
\hline & NÃO \\
\hline
\end{tabular}

5) Os conhecimentos adquiridos estão sendo aplicados no seu trabalho? Em caso afirmativo, indique em que grau estes conhecimentos estão sendo aplicados. Em caso negativo, indique por que razão isto não ocorre: (As respostas não são excludentes: você poderá marcar mais de uma opção).

\begin{tabular}{|c|c|c|c|}
\hline \multirow{3}{*}{$x$} & \multirow{3}{*}{$\begin{array}{l}\text { SIM (indique ao lado em } \\
\text { que grau) }\end{array}$} & & MUITO APLICADOS \\
\hline & & $x$ & MEDIAMENTE APLICADOS \\
\hline & & & POUCO APLICADOS \\
\hline & \multirow{5}{*}{$\begin{array}{l}\text { NÃO (indique ao lado a } \\
\text { razão da não aplicação) }\end{array}$} & & CONTEÚDO NÃO ADEQUADO ÀS NECESSIDADES \\
\hline & & & $\begin{array}{llll}\text { CONTEÚDO NÂO } & \text { FOI SUFICIENTEMENTE } \\
\text { APROFUNDADO } & \text { PARA } & \text { PERMITIR UMA APLICACÃO }\end{array}$ \\
\hline & & & 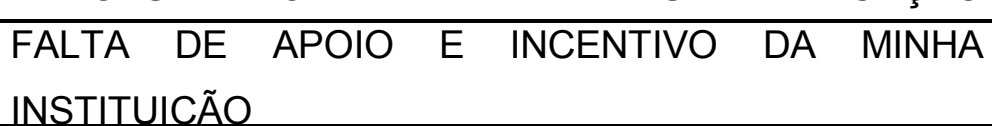 \\
\hline & & & FALTA DE INCENTIVO ÀS AÇÕES DE ATER \\
\hline & & & NÃO TENHO INTERESSE EM APLICAR \\
\hline
\end{tabular}


6) A partir deste curso: (As opções não são excludentes: você poderá marcar mais de uma opção).

\begin{tabular}{|l|l|}
\hline$x$ & $\begin{array}{l}\text { NÃO MUDOU NADA EM MEU TRABALHO. } \\
\text { FAMILIARES. }\end{array}$ \\
\hline$x$ & CONSEGUI INFLUENCIAR NAS ORIENTAÇÕES DA MINHA INSTITUIÇÃO. \\
\hline & $\begin{array}{l}\text { CRESCEU A ÁREA DE AGRICULTURA DE BASE ECOLÓGICA NAS COMUNIDADES } \\
\text { ONDE ATUO. }\end{array}$ \\
\hline & CONTINUEI ME APERFEIÇOANDO SOBRE TEMAS ABORDADOS. \\
\hline
\end{tabular}

7) Depois do curso você apoiou atividades de capacitação de técnicos e agricultores com base nos princípios e diretrizes da Pnater? (Considere como apoio a atividades de capacitação a participação no planejamento, elaboração de ementas, seleção de participantes e de palestrantes.)

\begin{tabular}{|l|l|}
\hline$x$ & SIM \\
\hline & NÃO \\
\hline
\end{tabular}

8) Usou os conhecimentos para ministrar outros cursos com o mesmo conteúdo ou conteúdos semelhantes?

\begin{tabular}{|l|l|}
\hline$x$ & SIM \\
\hline & NÃO \\
\hline
\end{tabular}

9) Marque o seu grau de satisfação com relação ao curso oferecido pelo DATER: (Considere a seguinte pontuação: 1 - MUITO RUIM; 2 - RUIM; 3 - REGULAR; 4 - BOM; 5 - MUITO BOM)

\begin{tabular}{|l|l|l|l|l|}
\hline 1 & 2 & 3 & $4 x$ & 5 \\
\hline
\end{tabular}


10) Marque seu grau de satisfação com relação ao DATER: (Considere a seguinte pontuação: 1 - MUITO RUIM; 2 - RUIM; 3 - REGULAR; 4 - BOM; 5 - MUITO BOM)

\begin{tabular}{|l|l|l|l|l|}
\hline 1 & 2 & 3 & $4 \times$ & 5 \\
\hline
\end{tabular}


PESQUISA - IMPACTO DAS AÇÕES DE FORMAÇÃO REALIZADAS PELO DATER/SAF/MDA NO PERÍODO 2004-2009

Caros colaboradores,

Contamos com a sua atenção para preencher o formulário abaixo.

O mesmo tem por objetivo fornecer informações para avaliação da Eficiência, Efetividade e Eficácia da Política Pública de Formação de Agentes de Ater adotada pelo Departamento de Assistência Técnica e Extensão Rural, da Secretaria de Agricultura Familiar do Ministério do Desenvolvimento - DATER/SAF/MDA, no período de 2004 a 2009, tema escolhido para Monografia a ser apresentada à Universidade de Brasília (UnB) como requisito parcial para obtenção do grau de Bacharel em Administração.

Você poderá ou não se identificar no questionário e garantimos que todas as informações fornecidas serão confidenciais e utilizadas apenas de forma sistematizada.

IDENTIFICAÇÃO

\begin{tabular}{|l|l|}
\hline $\begin{array}{l}\text { Nome: } \\
\text { Eliziana Vieira de Araújo }\end{array}$ & $\begin{array}{l}\text { Sexo: } \\
(\quad) \text { masculino } \quad(x x) \text { feminino }\end{array}$ \\
\hline Instituição : Rede Ecovida & $\begin{array}{l}\text { Local de trabalho: } \\
\text { Canguçu/RS }\end{array}$ \\
\hline $\begin{array}{l}\text { Curso/Encontro/Oficina do qual participou : } \\
\text { Aperfeiçoamento em agroecologia }\end{array}$ & \\
\hline $\begin{array}{l}\text { Data do Curso/Encontro/Oficina: } \\
\text { Março a Julho de 2006 }\end{array}$ \\
\hline
\end{tabular}

1 Indique sua área de atuação? (As opções não são excludentes: você poderá marcar mais de uma opção).

\begin{tabular}{|l|l|}
\hline$x$ & EXTENSÃO RURAL \\
\hline & PESQUISA \\
\hline & ENSINO \\
\hline$x$ & OUTROS \\
\hline
\end{tabular}


2) Qual o seu nível de escolaridade? ( Considere apenas o nível mais alto)

\begin{tabular}{|l|l|}
\hline & NÍVEL MÉDIO \\
\hline$x$ & NÍVEL SUPERIOR \\
\hline & PÓS-GRADUAÇÃO \\
\hline
\end{tabular}

3) Os conteúdos abordados foram condizentes com as demandas do seu dia-a-dia?

\begin{tabular}{|l|l|}
\hline & SIM \\
\hline$x$ & PARCIALMENTE \\
\hline & NÃO \\
\hline
\end{tabular}

4) O curso contribuiu para o seu aperfeiçoamento profissional?

\begin{tabular}{|l|l|}
\hline$x$ & SIM \\
\hline & NÃO \\
\hline
\end{tabular}

5) Os conhecimentos adquiridos estão sendo aplicados no seu trabalho? Em caso afirmativo, indique em que grau estes conhecimentos estão sendo aplicados. Em caso negativo, indique por que razão isto não ocorre: (As respostas não são excludentes: você poderá marcar mais de uma opção).

\begin{tabular}{|c|c|c|c|}
\hline \multirow{3}{*}{$x$} & \multirow{3}{*}{$\begin{array}{l}\text { SIM (indique ao lado em } \\
\text { que grau) }\end{array}$} & & MUITO APLICADOS \\
\hline & & $x$ & MEDIAMENTE APLICADOS \\
\hline & & & POUCO APLICADOS \\
\hline & & & $\begin{array}{l}\text { CONTEÚDO NÃO ADEQUADO ÀS NECESSIDADES } \\
\text { ESPFCÍFICAS RA RFGIÃO }\end{array}$ \\
\hline & & & $\begin{array}{llll}\text { CONTEÜDO NÂO } & \text { FOI SUFICIENTEMENTE } \\
\text { APROFUNDADO } & \text { PARA } & \text { PERMITIR UMA APLICACÃO }\end{array}$ \\
\hline & NAO (indique ao lado a & & EAITA DE APOIO F INCENTIVO DA MINHA \\
\hline & razão da não aplicação) & & $\begin{array}{l}\text { FALIA DE APOIO E INCENIIVO DA MINHA } \\
\text { INSTITUICÃO }\end{array}$ \\
\hline & & & FALTA DE INCENTIVO ÀS AÇÕES DE ATER \\
\hline & & & NÃO TENHO INTERESSE EM APLICAR \\
\hline
\end{tabular}


6) A partir deste curso: (As opções não são excludentes: você poderá marcar mais de uma opção).

\begin{tabular}{|l|l|}
\hline & NÃO MUDOU NADA EM MEU TRABALHO. \\
\hline & $\begin{array}{l}\text { MEU TRABALHO PASSOU A CONTRIBUIR MAIS COM OS AGRICULTORES(AS) } \\
\text { FAMILIARES. }\end{array}$ \\
\hline & CONSEGUI INFLUENCIAR NAS ORIENTAÇÕES DA MINHA INSTITUIÇÃO. \\
\hline & $\begin{array}{l}\text { CRESCEU A ÁREA DE AGRICULTURA DE BASE ECOLÓGICA NAS COMUNIDADES } \\
\text { ONDE ATUO. }\end{array}$ \\
\hline$x$ & CONTINUEI ME APERFEIÇOANDO SOBRE TEMAS ABORDADOS. \\
\hline
\end{tabular}

7) Depois do curso você apoiou atividades de capacitação de técnicos e agricultores com base nos princípios e diretrizes da Pnater? (Considere como apoio a atividades de capacitação a participação no planejamento, elaboração de ementas, seleção de participantes e de palestrantes.)

\begin{tabular}{|l|l|}
\hline$x$ & SIM \\
\hline & NÃO \\
\hline
\end{tabular}

8) Usou os conhecimentos para ministrar outros cursos com o mesmo conteúdo ou conteúdos semelhantes?

\begin{tabular}{|l|l|}
\hline$x$ & SIM \\
\hline & NÃO \\
\hline
\end{tabular}

9) Marque o seu grau de satisfação com relação ao curso oferecido pelo DATER: (Considere a seguinte pontuação: 1 - MUITO RUIM; 2 - RUIM; 3 - REGULAR; 4 - BOM; 5 - MUITO BOM)

\begin{tabular}{|l|l|l|l|l|}
\hline 1 & 2 & $x 3 x$ & 4 & 5 \\
\hline
\end{tabular}

10) Marque seu grau de satisfação com relação ao DATER: (Considere a seguinte pontuação:

1 - MUITO RUIM; 2 - RUIM; 3 - REGULAR; 4 - BOM; 5 - MUITO BOM)

\begin{tabular}{|l|l|l|l|l|}
\hline 1 & 2 & $\mathrm{x} 3 \mathrm{x}$ & 4 & 5 \\
\hline
\end{tabular}


PESQUISA - IMPACTO DAS AÇÕES DE FORMAÇÃO REALIZADAS PELO DATER/SAF/MDA NO PERÍODO 2004-2009

Caros colaboradores,

Contamos com a sua atenção para preencher o formulário abaixo.

O mesmo tem por objetivo fornecer informações para avaliação da Eficiência, Efetividade e Eficácia da Política Pública de Formação de Agentes de Ater adotada pelo Departamento de Assistência Técnica e Extensão Rural, da Secretaria de Agricultura Familiar do Ministério do Desenvolvimento - DATER/SAF/MDA, no período de 2004 a 2009, tema escolhido para Monografia a ser apresentada à Universidade de Brasília (UnB) como requisito parcial para obtenção do grau de Bacharel em Administração.

Você poderá ou não se identificar no questionário e garantimos que todas as informações fornecidas serão confidenciais e utilizadas apenas de forma sistematizada.

IDENTIFICAÇÃO

\begin{tabular}{|l|l|}
\hline $\begin{array}{l}\text { Nome: } \\
\text { GLEDES TERESINHA FORNECK }\end{array}$ & $\begin{array}{l}\text { Sexo: } \\
(\quad) \text { masculino } \quad(\quad \text { xx }) \text { feminino }\end{array}$ \\
\hline Instituição : EMATER/RS-ASCAR & Local de trabalho : SALVADOR DO SUL/RS \\
\hline $\begin{array}{l}\text { Curso/Encontro/Oficina do qual participou : } \\
\text { Curso de Formação de Formadores em Metodologias Participativas para a Extensão Rural }\end{array}$ \\
\hline $\begin{array}{l}\text { Data do Curso/Encontro/Oficina : } \\
20 \text { de novembro a 01 de dezembro de 2006. }\end{array}$ \\
\hline
\end{tabular}

1 Indique sua área de atuação? (As opções não são excludentes: você poderá marcar mais de uma opção).

\begin{tabular}{|l|l|}
\hline$x$ & EXTENSÃO RURAL \\
\hline & PESQUISA \\
\hline & ENSINO \\
\hline & OUTROS \\
\hline
\end{tabular}

2) Qual o seu nível de escolaridade? ( Considere apenas o nível mais alto) 


\begin{tabular}{|l|l|}
\hline & NÍVEL MÉDIO \\
\hline & NÍVEL SUPERIOR \\
\hline$x$ & PÓS-GRADUAÇÃO \\
\hline
\end{tabular}

3) Os conteúdos abordados foram condizentes com as demandas do seu dia-a-dia?

\begin{tabular}{|l|l|}
\hline$x$ & SIM \\
\hline & PARCIALMENTE \\
\hline & NÃO \\
\hline
\end{tabular}

4) O curso contribuiu para o seu aperfeiçoamento profissional?

\begin{tabular}{|l|l|}
\hline$x$ & SIM \\
\hline & NÃO \\
\hline
\end{tabular}

5) Os conhecimentos adquiridos estão sendo aplicados no seu trabalho? Em caso afirmativo, indique em que grau estes conhecimentos estão sendo aplicados. Em caso negativo, indique por que razão isto não ocorre: (As respostas não são excludentes: você poderá marcar mais de uma opção).

\begin{tabular}{|c|c|c|c|}
\hline \multirow{3}{*}{$x$} & \multirow{3}{*}{$\begin{array}{l}\text { SIM (indique ao lado em } \\
\text { que grau) }\end{array}$} & $x$ & MUITO APLICADOS \\
\hline & & & MEDIAMENTE APLICADOS \\
\hline & & & POUCO APLICADOS \\
\hline & \multirow{5}{*}{$\begin{array}{l}\text { NÃO (indique ao lado a } \\
\text { razão da não aplicação) }\end{array}$} & & CONTEÚDO NÃO ADEQUADO ÀS NECESSIDADES \\
\hline & & & $\begin{array}{llll}\text { CONTEÚDO NÂO } & \text { FOI SUFICIENTEMENTE } \\
\text { APROFUNDADO PARA } & \text { PERMITIR UMA APLICAÇÃO }\end{array}$ \\
\hline & & & $\begin{array}{lcccccc}\text { FALTA } & \text { DE } & \text { APOIO } & \text { E } & \text { INCENTIVO } & \text { DA } & \text { MINHA } \\
\text { INSTITUICÃO } & & & & & \\
\end{array}$ \\
\hline & & & FALTA DE INCENTIVO ÀS AÇÕES DE ATER \\
\hline & & & NÃO TENHO INTERESSE EM APLICAR \\
\hline
\end{tabular}


6) A partir deste curso: (As opções não são excludentes: você poderá marcar mais de uma opção).

\begin{tabular}{|l|l|}
\hline$x$ & $\begin{array}{l}\text { NÃO MUDOU NADA EM MEU TRABALHO. } \\
\text { FAMILIARES. }\end{array}$ \\
\hline & CONSEGUI INFLUENCIAR NAS ORIENTAÇÕES DA MINHA INSTITUIÇÃO. \\
\hline & PASSEI A TRABALHAR COM METODOLOGIAS PARTICIPATIVAS. \\
\hline & $\begin{array}{l}\text { CRESCEU A ÁREA DE AGRICULTURA DE BASE ECOLÓGICA NAS COMUNIDADES } \\
\text { ONDE ATUO. }\end{array}$ \\
\hline & CONTINUEI ME APERFEIÇOANDO SOBRE TEMAS ABORDADOS. \\
\hline
\end{tabular}

7) Depois do curso você apoiou atividades de capacitação de técnicos e agricultores com base nos princípios e diretrizes da Pnater? (Considere como apoio a atividades de capacitação a participação no planejamento, elaboração de ementas, seleção de participantes e de palestrantes.)

\begin{tabular}{|l|l|}
\hline$x$ & SIM \\
\hline & NÃO \\
\hline
\end{tabular}

8) Usou os conhecimentos para ministrar outros cursos com o mesmo conteúdo ou conteúdos semelhantes?

\begin{tabular}{|l|l|}
\hline$x$ & SIM \\
\hline & NÃO \\
\hline
\end{tabular}

9) Marque o seu grau de satisfação com relação ao curso oferecido pelo DATER: (Considere a seguinte pontuação: 1 - MUITO RUIM; 2 - RUIM; 3 - REGULAR; 4 - BOM; 5 - MUITO BOM)

\begin{tabular}{|l|l|l|l|l|}
\hline 1 & 2 & 3 & 4 & $x 5$ \\
\hline
\end{tabular}

10) Marque seu grau de satisfação com relação ao DATER: (Considere a seguinte pontuação: 1 - MUITO RUIM; 2 - RUIM; 3 - REGULAR; 4 - BOM; 5 - MUITO BOM)

\begin{tabular}{|l|l|l|l|l|}
\hline 1 & 2 & 3 & 4 & $x 5$ \\
\hline
\end{tabular}


PESQUISA - IMPACTO DAS AÇÕES DE FORMAÇÃO REALIZADAS PELO DATER/SAF/MDA NO PERÍODO 2004-2009

Caros colaboradores,

Contamos com a sua atenção para preencher o formulário abaixo.

O mesmo tem por objetivo fornecer informações para avaliação da Eficiência, Efetividade e Eficácia da Política Pública de Formação de Agentes de Ater adotada pelo Departamento de Assistência Técnica e Extensão Rural, da Secretaria de Agricultura Familiar do Ministério do Desenvolvimento - DATER/SAF/MDA, no período de 2004 a 2009, tema escolhido para Monografia a ser apresentada à Universidade de Brasília (UnB) como requisito parcial para obtenção do grau de Bacharel em Administração.

Você poderá ou não se identificar no questionário e garantimos que todas as informações fornecidas serão confidenciais e utilizadas apenas de forma sistematizada.

IDENTIFICAÇÃO

\begin{tabular}{|l|l|}
\hline $\begin{array}{l}\text { Nome: } \\
\text { JOÃO DE RIBEIRO REIS JUNIOR }\end{array}$ & $\begin{array}{l}\text { Sexo: } \\
(\mathrm{x}) \text { masculino } \quad(\quad) \text { feminino }\end{array}$ \\
\hline Instituição : EMATER & Local de trabalho : GUARAPUAVA - PR \\
\hline $\begin{array}{l}\text { Curso/Encontro/Oficina do qual participou : } \\
\text { CURSO DE PECUARIA ECOLOGICA - FLORIANÓPOLIS-SC }\end{array}$ \\
\hline $\begin{array}{l}\text { Data do Curso/Encontro/Oficina : } \\
\text { DE 21 A 25 DE AGOSTO DE 2006 }\end{array}$ \\
\hline
\end{tabular}

1 Indique sua área de atuação? (As opções não são excludentes: você poderá marcar mais de uma opção).

\begin{tabular}{|l|l|}
\hline$x$ & EXTENSÃO RURAL \\
\hline & PESQUISA \\
\hline & ENSINO \\
\hline & OUTROS \\
\hline
\end{tabular}


2) Qual o seu nível de escolaridade? ( Considere apenas o nível mais alto)

\begin{tabular}{|l|l|}
\hline & NÍVEL MÉDIO \\
\hline$x$ & NÍVEL SUPERIOR \\
\hline & PÓS-GRADUAÇÃO \\
\hline
\end{tabular}

3) Os conteúdos abordados foram condizentes com as demandas do seu dia-a-dia?

\begin{tabular}{|l|l|}
\hline & SIM \\
\hline$x$ & PARCIALMENTE \\
\hline & NÃO \\
\hline
\end{tabular}

4) O curso contribuiu para o seu aperfeiçoamento profissional?

\begin{tabular}{|l|l|}
\hline$x$ & SIM \\
\hline & NÃO \\
\hline
\end{tabular}

5) Os conhecimentos adquiridos estão sendo aplicados no seu trabalho? Em caso afirmativo, indique em que grau estes conhecimentos estão sendo aplicados. Em caso negativo, indique por que razão isto não ocorre: (As respostas não são excludentes: você poderá marcar mais de uma opção).

\begin{tabular}{|c|c|c|c|}
\hline \multirow{3}{*}{$\mathrm{x}$} & \multirow{3}{*}{$\begin{array}{l}\text { SIM (indique ao lado em } \\
\text { que grau) }\end{array}$} & & MUITO APLICADOS \\
\hline & & $x$ & MEDIAMENTE APLICADOS \\
\hline & & & POUCO APLICADOS \\
\hline & \multirow{6}{*}{$\begin{array}{l}\text { NÃO (indique ao lado a } \\
\text { razão da não aplicação) }\end{array}$} & & $\begin{array}{l}\text { CONTEÚDO NÃO ADEQUADO ÀS NECESSIDADES } \\
\text { FSPFCÍFICAS DA RFGIÃO }\end{array}$ \\
\hline & & & $\begin{array}{llll}\text { CONTEÚDO } & \text { NÃO } & \text { FOI } & \text { SUFICIENTEMENTE }\end{array}$ \\
\hline & & & APROFUNDADO PARA PERMITIR UMA APLICAÇÃO \\
\hline & & & $\begin{array}{lcccccc}\text { FALTA } & \text { DE } & \text { APOIO } & \text { E } & \text { INCENTIVO } & \text { DA } & \text { MINHA } \\
\text { INSTITUICÃO } & & & & & \\
\end{array}$ \\
\hline & & & FALTA DE INCENTIVO ÀS AÇÕES DE ATER \\
\hline & & & NÃO TENHO INTERESSE EM APLICAR \\
\hline
\end{tabular}


6) A partir deste curso: (As opções não são excludentes: você poderá marcar mais de uma opção).

\begin{tabular}{|l|l|}
\hline$x$ & $\begin{array}{l}\text { NÃO MUDOU NADA EM MEU TRABALHO. } \\
\text { FAMILIARES. }\end{array}$ \\
\hline & CONSEGUI INFLUENCIAR NAS ORIENTAÇÕES DA MINHA INSTITUIÇÃO. \\
\hline & PASSEI A TRABALHAR COM METODOLOGIAS PARTICIPATIVAS. \\
\hline & $\begin{array}{l}\text { CRESCEU A ÁREA DE AGRICULTURA DE BASE ECOLÓGICA NAS COMUNIDADES } \\
\text { ONDE ATUO. }\end{array}$ \\
\hline & CONTINUEI ME APERFEIÇOANDO SOBRE TEMAS ABORDADOS. \\
\hline
\end{tabular}

7) Depois do curso você apoiou atividades de capacitação de técnicos e agricultores com base nos princípios e diretrizes da Pnater? (Considere como apoio a atividades de capacitação a participação no planejamento, elaboração de ementas, seleção de participantes e de palestrantes.)

\begin{tabular}{|l|l|}
\hline$x$ & SIM \\
\hline & NÃO \\
\hline
\end{tabular}

8) Usou os conhecimentos para ministrar outros cursos com o mesmo conteúdo ou conteúdos semelhantes?

\begin{tabular}{|l|l|}
\hline$x$ & SIM \\
\hline & NÃO \\
\hline
\end{tabular}

9) Marque o seu grau de satisfação com relação ao curso oferecido pelo DATER: (Considere a seguinte pontuação: 1 - MUITO RUIM; 2 - RUIM; 3 - REGULAR; 4 - BOM; 5 - MUITO BOM)

\begin{tabular}{|l|l|l|l|l|}
\hline 1 & 2 & $x 3$ & 4 & 5 \\
\hline
\end{tabular}

10) Marque seu grau de satisfação com relação ao DATER: (Considere a seguinte pontuação:

1 - MUITO RUIM; 2 - RUIM; 3 - REGULAR; 4 - BOM; 5 - MUITO BOM)

\begin{tabular}{|l|l|l|l|l|}
\hline 1 & 2 & $x 3$ & 4 & 5 \\
\hline
\end{tabular}


PESQUISA - IMPACTO DAS AÇÕES DE FORMAÇÃO REALIZADAS PELO DATER/SAF/MDA NO PERÍODO 2004-2009

Caros colaboradores,

Contamos com a sua atenção para preencher o formulário abaixo.

O mesmo tem por objetivo fornecer informações para avaliação da Eficiência, Efetividade e Eficácia da Política Pública de Formação de Agentes de Ater adotada pelo Departamento de Assistência Técnica e Extensão Rural, da Secretaria de Agricultura Familiar do Ministério do Desenvolvimento - DATER/SAF/MDA, no período de 2004 a 2009, tema escolhido para Monografia a ser apresentada à Universidade de Brasília (UnB) como requisito parcial para obtenção do grau de Bacharel em Administração.

Você poderá ou não se identificar no questionário e garantimos que todas as informações fornecidas serão confidenciais e utilizadas apenas de forma sistematizada.

\section{IDENTIFICAÇÃO}

\begin{tabular}{|l|l|}
\hline $\begin{array}{l}\text { Nome: } \\
\text { Roni Carlos Bonow }\end{array}$ & $\begin{array}{l}\text { Sexo: } \\
(x) \text { masculino } \quad(\quad) \text { feminino }\end{array}$ \\
\hline $\begin{array}{l}\text { Instituição : CAPA - Centro de Apoio ao Pequeno } \\
\text { Agricultor - ONG }\end{array}$ & Local de trabalho : São Lourenço do Sul/RS \\
\hline $\begin{array}{l}\text { Curso/Encontro/Oficina do qual participou : } \\
\text { Curso de Especialização em Extensão Rural para o Desenvolvimento Sustentável }\end{array}$ \\
\hline $\begin{array}{l}\text { Data do Curso/Encontro/Oficina : } \\
\text { Junho a novembro de 2005 - UFRPE - Recife/PE }\end{array}$ \\
\hline
\end{tabular}

1 Indique sua área de atuação? (As opções não são excludentes: você poderá marcar mais de uma opção).

\begin{tabular}{|l|l|}
\hline$x$ & EXTENSÃO RURAL \\
\hline & PESQUISA \\
\hline & ENSINO \\
\hline & OUTROS \\
\hline
\end{tabular}

2) Qual o seu nível de escolaridade? ( Considere apenas o nível mais alto) 


\begin{tabular}{|l|l|}
\hline & NÍVEL MÉDIO \\
\hline$x$ & NÍVEL SUPERIOR \\
\hline & PÓS-GRADUAÇÃO \\
\hline
\end{tabular}

3) Os conteúdos abordados foram condizentes com as demandas do seu dia-a-dia?

\begin{tabular}{|l|l|}
\hline & SIM \\
\hline$x$ & PARCIALMENTE \\
\hline & NÃO \\
\hline
\end{tabular}

4) O curso contribuiu para o seu aperfeiçoamento profissional?

\begin{tabular}{|l|l|}
\hline$x$ & SIM \\
\hline & NÃO \\
\hline
\end{tabular}

5) Os conhecimentos adquiridos estão sendo aplicados no seu trabalho? Em caso afirmativo, indique em que grau estes conhecimentos estão sendo aplicados. Em caso negativo, indique por que razão isto não ocorre: (As respostas não são excludentes: você poderá marcar mais de uma opção).

\begin{tabular}{|c|c|c|c|}
\hline \multirow{3}{*}{$\mathrm{x}$} & \multirow{3}{*}{$\begin{array}{l}\text { SIM (indique ao lado em } \\
\text { que grau) }\end{array}$} & $\bar{x}$ & MUITO APLICADOS \\
\hline & & & MEDIAMENTE APLICADOS \\
\hline & & & POUCO APLICADOS \\
\hline & \multirow{4}{*}{$\begin{array}{l}\text { NÃO (indique ao lado a } \\
\text { razão da não aplicação) }\end{array}$} & & $\begin{array}{l}\text { CONTEÚDO NÃO ADEQUADO ÀS NECESSIDADES } \\
\text { FSPECÍFICAS SOA REGIÃO } \\
\text { CONTEUUDO NÂO FOI SUFICIENTEMENTE } \\
\text { APROFUNDADO PARA PERMITIR UMA APLICAÇÃO }\end{array}$ \\
\hline & & & \begin{tabular}{lcccccc|} 
FALTA & DE & APOIO & E & INCENTIVO & DA & MINHA \\
INSTITUICÃO & & & & & \\
\end{tabular} \\
\hline & & & FALTA DE INCENTIVO ÀS AÇÕES DE ATER \\
\hline & & & NÃO TENHO INTERESSE EM APLICAR \\
\hline
\end{tabular}


6) A partir deste curso: (As opções não são excludentes: você poderá marcar mais de uma opção).

\begin{tabular}{|l|l|}
\hline$x$ & $\begin{array}{l}\text { NÃO MUDOU NADA EM MEU TRABALHO. } \\
\text { FAMILIARES. }\end{array}$ \\
\hline$x$ & CONSEGUI INFLUENCIAR NAS ORIENTAÇÕES DA MINHA INSTITUIÇÃO. \\
\hline$x$ & $\begin{array}{l}\text { CRESCEU A ÁREA DE AGRICULTURA DE BASE ECOLÓGICA NAS COMUNIDADES } \\
\text { ONDE ATUO. }\end{array}$ \\
\hline & CONTINUEI ME APERFEIÇOANDO SOBRE TEMAS ABORDADOS. \\
\hline
\end{tabular}

7) Depois do curso você apoiou atividades de capacitação de técnicos e agricultores com base nos princípios e diretrizes da Pnater? (Considere como apoio a atividades de capacitação a participação no planejamento, elaboração de ementas, seleção de participantes e de palestrantes.)

\begin{tabular}{|l|l|}
\hline$x$ & SIM \\
\hline & NÃO \\
\hline
\end{tabular}

8) Usou os conhecimentos para ministrar outros cursos com o mesmo conteúdo ou conteúdos semelhantes?

\begin{tabular}{|l|l|}
\hline$x$ & SIM \\
\hline & NÃO \\
\hline
\end{tabular}

9) Marque o seu grau de satisfação com relação ao curso oferecido pelo DATER: (Considere a seguinte pontuação: 1 - MUITO RUIM; 2 - RUIM; 3 - REGULAR; 4 - BOM; 5 - MUITO BOM)

\begin{tabular}{|l|l|l|l|l|}
\hline 1 & 2 & 3 & 4 & $x 5$ \\
\hline
\end{tabular}

10) Marque seu grau de satisfação com relação ao DATER: (Considere a seguinte pontuação: 1 - MUITO RUIM; 2 - RUIM; 3 - REGULAR; 4 - BOM; 5 - MUITO BOM)

\begin{tabular}{|l|l|l|l|l|}
\hline 1 & 2 & 3 & 4 & $x 5$ \\
\hline
\end{tabular}


PESQUISA - IMPACTO DAS AÇÕES DE FORMAÇÃO REALIZADAS PELO DATER/SAF/MDA NO PERÍODO 2004-2009

Caros colaboradores,

Contamos com a sua atenção para preencher o formulário abaixo.

O mesmo tem por objetivo fornecer informações para avaliação da Eficiência, Efetividade e Eficácia da Política Pública de Formação de Agentes de Ater adotada pelo Departamento de Assistência Técnica e Extensão Rural, da Secretaria de Agricultura Familiar do Ministério do Desenvolvimento - DATER/SAF/MDA, no período de 2004 a 2009, tema escolhido para Monografia a ser apresentada à Universidade de Brasília (UnB) como requisito parcial para obtenção do grau de Bacharel em Administração.

Você poderá ou não se identificar no questionário e garantimos que todas as informações fornecidas serão confidenciais e utilizadas apenas de forma sistematizada.

\section{IDENTIFICAÇÃO}

\begin{tabular}{|l|l|}
\hline $\begin{array}{l}\text { Nome: } \\
\text { Jacinto Geraldo Tamiozzo }\end{array}$ & $\begin{array}{l}\text { Sexo: } \\
(\mathrm{x}) \text { masculino } \quad(\quad) \text { feminino }\end{array}$ \\
\hline Instituição : ASCAR/EMATER - RS & $\begin{array}{l}\text { Local de trabalho : Pirapó - Rio Grande do } \\
\text { Sul }\end{array}$ \\
\hline $\begin{array}{l}\text { Curso/Encontro/Oficina do qual participou : } \\
\text { Diagnóstico Rural Participativo DRP }\end{array}$ & \\
\hline $\begin{array}{l}\text { Data do Curso/Encontro/Oficina : } \\
16 \text { a } 27 \text { de Outubro de 2006 }\end{array}$ \\
\hline
\end{tabular}

1 Indique sua área de atuação? (As opções não são excludentes: você poderá marcar mais de uma opção).

\begin{tabular}{|l|l|}
\hline$x$ & EXTENSÃO RURAL \\
\hline & PESQUISA \\
\hline & ENSINO \\
\hline & OUTROS \\
\hline
\end{tabular}

2) Qual o seu nível de escolaridade? (Considere apenas o nível mais alto) 


\begin{tabular}{|l|l|}
\hline & NÍVEL MÉDIO \\
\hline & NÍVEL SUPERIOR \\
\hline$x$ & PÓS-GRADUAÇÃO \\
\hline
\end{tabular}

3) Os conteúdos abordados foram condizentes com as demandas do seu dia-a-dia?

\begin{tabular}{|l|l|}
\hline$x$ & SIM \\
\hline & PARCIALMENTE \\
\hline & NÃO \\
\hline
\end{tabular}

4) O curso contribuiu para o seu aperfeiçoamento profissional?

\begin{tabular}{|l|l|}
\hline$x$ & SIM \\
\hline & NÃO \\
\hline
\end{tabular}

5) Os conhecimentos adquiridos estão sendo aplicados no seu trabalho? Em caso afirmativo, indique em que grau estes conhecimentos estão sendo aplicados. Em caso negativo, indique por que razão isto não ocorre: (As respostas não são excludentes: você poderá marcar mais de uma opção).

\begin{tabular}{|c|c|c|c|}
\hline \multirow{3}{*}{$x$} & \multirow{3}{*}{$\begin{array}{l}\text { SIM (indique ao lado em } \\
\text { que grau) }\end{array}$} & $x$ & MUITO APLICADOS \\
\hline & & & MEDIAMENTE APLICADOS \\
\hline & & & POUCO APLICADOS \\
\hline & \multirow{4}{*}{$\begin{array}{l}\text { NÃO (indique ao lado a } \\
\text { razão da não aplicação) }\end{array}$} & & $\begin{array}{l}\text { CONTEÚDO NÃO ADEQUADO ÀS NECESSIDADES } \\
\text { ESPECÍFICAS DA REGIÃO }\end{array}$ \\
\hline & & & $\begin{array}{lccr}\text { CONTEÚDO NÃO } & \text { FOI } & \text { SUFICIENTEMENTE } \\
\text { APROFUNDADO } & \text { PARA } & \text { PERMITIR UMA } & \text { APLICAÇÃO }\end{array}$ \\
\hline & & & $\begin{array}{lcccccc}\text { FALTA } & \text { DE } & \text { APOIO } & \text { E } & \text { INCENTIVO } & \text { DA } & \text { MINHA } \\
\text { INSTITUICÃO } & & & & & \\
\end{array}$ \\
\hline & & & FALTA DE INCENTIVO ÀS AÇÕES DE ATER \\
\hline
\end{tabular}


\begin{tabular}{|l|l|l|} 
& NÃO TENHO INTERESSE EM APLICAR \\
\hline
\end{tabular}

6) A partir deste curso: (As opções não são excludentes: você poderá marcar mais de uma opção).

\begin{tabular}{|l|l|}
\hline$x$ & $\begin{array}{l}\text { NÃO MUDOU NADA EM MEU TRABALHO. } \\
\text { FAMILIARES. }\end{array}$ \\
\hline & CONSEGUI INFLUENCIAR NAS ORIENTAÇÕES DA MINHA INSTITUIÇÃO. \\
\hline$x$ & $\begin{array}{l}\text { CRASSEI A TRABALHAR COM METODOLOGIAS PARTICIPATIVAS. } \\
\text { ONDE ATUO. }\end{array}$ \\
\hline$x$ & CONTINUEI ME APERFEIÇOANDO SOBRE TEMAS ABORDADOS. \\
\hline
\end{tabular}

7) Depois do curso você apoiou atividades de capacitação de técnicos e agricultores com base nos princípios e diretrizes da Pnater? (Considere como apoio a atividades de capacitação a participação no planejamento, elaboração de ementas, seleção de participantes e de palestrantes.)

\begin{tabular}{|l|l|}
\hline$x$ & SIM \\
\hline & NÃO \\
\hline
\end{tabular}

8) Usou os conhecimentos para ministrar outros cursos com o mesmo conteúdo ou conteúdos semelhantes?

\begin{tabular}{|l|l|}
\hline$x$ & SIM \\
\hline & NÃO \\
\hline
\end{tabular}

9) Marque o seu grau de satisfação com relação ao curso oferecido pelo DATER: (Considere a seguinte pontuação: 1 - MUITO RUIM; 2 - RUIM; 3 - REGULAR; 4 - BOM; 5 - MUITO BOM)

\begin{tabular}{|l|l|l|l|l|}
\hline 1 & 2 & 3 & $4 x$ & 5 \\
\hline
\end{tabular}

10) Marque seu grau de satisfação com relação ao DATER: (Considere a seguinte pontuação: 1 - MUITO RUIM; 2 - RUIM; 3 - REGULAR; 4 - BOM; 5 - MUITO BOM)

\begin{tabular}{|l|l|l|l|l|}
\hline 1 & 2 & 3 & 4 & $x 5$ \\
\hline
\end{tabular}


PESQUISA - IMPACTO DAS AÇÕES DE FORMAÇÃO REALIZADAS PELO DATER/SAF/MDA NO PERÍODO 2004-2009

Caros colaboradores,

Contamos com a sua atenção para preencher o formulário abaixo.

O mesmo tem por objetivo fornecer informações para avaliação da Eficiência, Efetividade e Eficácia da Política Pública de Formação de Agentes de Ater adotada pelo Departamento de Assistência Técnica e Extensão Rural, da Secretaria de Agricultura Familiar do Ministério do Desenvolvimento - DATER/SAF/MDA, no período de 2004 a 2009, tema escolhido para Monografia a ser apresentada à Universidade de Brasília (UnB) como requisito parcial para obtenção do grau de Bacharel em Administração.

Você poderá ou não se identificar no questionário e garantimos que todas as informações fornecidas serão confidenciais e utilizadas apenas de forma sistematizada.

IDENTIFICAÇÃO

\begin{tabular}{|c|c|}
\hline $\begin{array}{l}\text { Nome: } \\
\text { Amanda Oliveira Santos }\end{array}$ & $\begin{array}{l}\text { Sexo: } \\
(\quad) \text { masculino }(x) \text { feminino }\end{array}$ \\
\hline $\begin{array}{l}\text { Instituição (nome e tipo de instituição: ONG, } \\
\text { Empresa Pública, etc.): } \\
\text { RURALTINS }\end{array}$ & $\begin{array}{l}\text { Local de trabalho (Cidade e Estado) } \\
\text { Palmas - TO }\end{array}$ \\
\hline \multicolumn{2}{|c|}{$\begin{array}{l}\text { Curso/Encontro/Oficina do qual participou (caso tenha participado de mais de um curso, preencha } \\
\text { um formulário para cada um deles): } \\
\text { Curso de Agroecologia - Alto Paraíso }\end{array}$} \\
\hline $\begin{array}{l}\text { Data do Curso/Encontro/Oficina (pelo menos mês e } \\
2007\end{array}$ & \\
\hline
\end{tabular}

Indique sua área de atuação? (As respostas não são excludentes: você poderá marcar mais de uma opção).

\begin{tabular}{|l|l|}
\hline$X$ & EXTENSÃO RURAL \\
\hline & PESQUISA \\
\hline
\end{tabular}




\begin{tabular}{|l|l|}
\hline & ENSINO \\
\hline & OUTROS \\
\hline
\end{tabular}

2) Qual o seu nível de escolaridade?

\begin{tabular}{|l|l|}
\hline & NÍVEL MÉDIO \\
\hline$x$ & NÍVEL SUPERIOR \\
\hline & PÓS-GRADUAÇÃO \\
\hline
\end{tabular}

3) Os conteúdos abordados foram condizentes com as demandas do seu dia-a-dia?

\begin{tabular}{|l|l|}
\hline$X$ & SIM \\
\hline & PARCIALMENTE \\
\hline & NÃO \\
\hline
\end{tabular}

4) O curso contribuiu para o seu aperfeiçoamento profissional?

\begin{tabular}{|l|l|}
\hline$X$ & SIM \\
\hline & NÃO \\
\hline
\end{tabular}

5) Os conhecimentos adquiridos estão sendo aplicados no seu trabalho? Em caso afirmativo, indique em que grau estes conhecimentos estão sendo aplicados. Em caso negativo, indique por que razão isto não ocorre:

\begin{tabular}{|l|l|l|l|}
\hline \multirow{2}{*}{$X$} & $\begin{array}{l}\text { SIM (indique ao lado em } \\
\text { que grau) }\end{array}$ & $X$ & MUITO APLICADOS \\
\cline { 2 - 4 } & & MEDIAMENTE APLICADOS \\
\hline & $\begin{array}{l}\text { NÃO (indique ao lado a } \\
\text { razão da não aplicação) }\end{array}$ & $\begin{array}{l}\text { CONTEÚDO NÃO ADEQUADO ÀS NECESSIDADES } \\
\text { ESPECÍFICAS DA REGIÃO }\end{array}$ \\
\hline
\end{tabular}




\begin{tabular}{|l|l|l|}
\hline \multirow{10}{*}{} & & $\begin{array}{l}\text { CONTEÚDO NÃO FOI SUFICIENTEMENTE } \\
\text { APROFUNDADO PARA PERMITIR UMA APLICAÇÃO } \\
\text { EFICAZ E EFICIENTE }\end{array}$ \\
\cline { 2 - 5 } & $\begin{array}{l}\text { FALTA DE APOIO E INCENTIVO DA MINHA } \\
\text { INSTITUIÇÃO }\end{array}$ \\
\cline { 2 - 4 } & FALTA DE INCENTIVO ÀS AÇÕES DE ATER \\
\hline & NÃO TENHO INTERESSE EM APLICAR \\
\hline
\end{tabular}

6) A partir deste curso: (As respostas não são excludentes: você poderá marcar mais de uma opção).

\begin{tabular}{|c|c|}
\hline & NÃO MUDOU NADA EM MEU TRABALHO. \\
\hline $\mathrm{X}$ & $\begin{array}{l}\text { MEU TRABALHO PASSOU A CONTRIBUIR MAIS COM OS AGRICULTORES(AS) } \\
\text { FAMILIARES. }\end{array}$ \\
\hline$x$ & CONSEGUI INFLUENCIAR NAS ORIENTAÇÕES DA MINHA INSTITUIÇÃO. \\
\hline $\mathrm{X}$ & PASSEI A TRABALHAR COM METODOLOGIAS PARTICIPATIVAS. \\
\hline $\mathrm{x}$ & $\begin{array}{l}\text { CRESCEU A ÁREA DE AGRICULTURA DE BASE ECOLÓGICA NAS COMUNIDADES } \\
\text { ONDE ATUO. }\end{array}$ \\
\hline$x$ & CONTINUEI ME APERFEIÇOANDO SOBRE TEMAS ABORDADOS. \\
\hline
\end{tabular}

7) Depois do curso você apoiou atividades de capacitação de técnicos e agricultores com base nos princípios e diretrizes da Pnater? (Considere como apoio a atividades de capacitação a participação no planejamento, elaboração de ementas, seleção de participantes e de palestrantes.)

\begin{tabular}{|l|l|}
\hline$X$ & SIM \\
\hline & NÃO \\
\hline
\end{tabular}

8) Usou os conhecimentos para ministrar outros cursos com o mesmo conteúdo ou conteúdos semelhantes? 


\begin{tabular}{|l|l|}
\hline$X$ & SIM \\
\hline & NÃO \\
\hline
\end{tabular}

9) Marque o seu grau de satisfação com relação ao curso oferecido pelo DATER: (Considere a seguinte pontuação: 1 - MUITO RUIM; 2 - RUIM; 3 - REGULAR; 4 - BOM; 5 - MUITO BOM)

\begin{tabular}{|l|l|l|l|l|}
\hline 1 & 2 & 3 & 4 & $x 5$ \\
\hline
\end{tabular}

10) Marque seu grau de satisfação com relação ao DATER: (Considere a seguinte pontuação:

1 - MUITO RUIM; 2 - RUIM; 3 - REGULAR; 4 - BOM; 5 - MUITO BOM)

\begin{tabular}{|l|l|l|l|l|}
\hline 1 & 2 & 3 & 4 & $\mathrm{x} 5$ \\
\hline
\end{tabular}


PESQUISA - IMPACTO DAS AÇÕES DE FORMAÇÃO REALIZADAS PELO DATER/SAF/MDA NO PERÍODO 2004-2009

Caros colaboradores,

Contamos com a sua atenção para preencher o formulário abaixo.

O mesmo tem por objetivo fornecer informações para avaliação da Eficiência, Efetividade e Eficácia da Política Pública de Formação de Agentes de Ater adotada pelo Departamento de Assistência Técnica e Extensão Rural, da Secretaria de Agricultura Familiar do Ministério do Desenvolvimento - DATER/SAF/MDA, no período de 2004 a 2009, tema escolhido para Monografia a ser apresentada à Universidade de Brasília (UnB) como requisito parcial para obtenção do grau de Bacharel em Administração.

Você poderá ou não se identificar no questionário e garantimos que todas as informações fornecidas serão confidenciais e utilizadas apenas de forma sistematizada.

IDENTIFICAÇÃO

\begin{tabular}{|l|l|}
\hline Nome: ALMIR CARLOS DE OLIVEIRA & $\begin{array}{l}\text { Sexo: } \\
(\mathrm{x}) \text { masculino } \quad(\quad) \text { feminino }\end{array}$ \\
\hline $\begin{array}{l}\text { Instituição (nome e tipo de instituição: ONG, } \\
\text { Empresa Pública, etc.): EMATER - RO }\end{array}$ & $\begin{array}{l}\text { Local de trabalho (Cidade e Estado): } \\
\text { MIRANTE DA SERRA }\end{array}$ \\
\hline $\begin{array}{l}\text { Curso/Encontro/Oficina do qual participou (caso tenha participado de mais de um curso, preencha } \\
\text { um formulário para cada um deles): MANEJO DE PASTAGEM COM ÊNFASE NO CONTROLE } \\
\text { BIOLOGICO DA CIGARRINHA, MELHORIA DA QUALIDADE SO LEITE. }\end{array}$ \\
\hline Data do Curso/Encontro/Oficina (pelo menos mês e ano): \\
\hline
\end{tabular}

1.Indique sua área de atuação? (As respostas não são excludentes: você poderá marcar mais de uma opção).

\begin{tabular}{|l|l|}
\hline$X$ & EXTENSÃO RURAL \\
\hline & PESQUISA \\
\hline & ENSINO \\
\hline & OUTROS \\
\hline
\end{tabular}

2) Qual o seu nível de escolaridade? 


\begin{tabular}{|l|l|}
\hline$X$ & NÍVEL MÉDIO \\
\hline & NÍVEL SUPERIOR \\
\hline & PÓS-GRADUAÇÃO \\
\hline
\end{tabular}

3) Os conteúdos abordados foram condizentes com as demandas do seu dia-a-dia?

\begin{tabular}{|l|l|}
\hline$X$ & SIM \\
\hline & PARCIALMENTE \\
\hline & NÃO \\
\hline
\end{tabular}

4) O curso contribuiu para o seu aperfeiçoamento profissional?

\begin{tabular}{|l|l|}
\hline$X$ & SIM \\
\hline & NÃO \\
\hline
\end{tabular}

5) Os conhecimentos adquiridos estão sendo aplicados no seu trabalho? Em caso afirmativo, indique em que grau estes conhecimentos estão sendo aplicados. Em caso negativo, indique por que razão isto não ocorre:

\begin{tabular}{|c|c|c|}
\hline \multirow{3}{*}{$\mathrm{X}$} & \multirow{3}{*}{$\begin{array}{l}\text { SIM (indique ao lado em } \\
\text { que grau) }\end{array}$} & MUITO APLICADOS \\
\hline & & MEDIAMENTE APLICADOS \\
\hline & & POUCO APLICADOS \\
\hline & \multirow{5}{*}{$\begin{array}{l}\text { NÃO (indique ao lado a } \\
\text { razão da não aplicação) }\end{array}$} & $\begin{array}{l}\text { CONTEÚDO NÃO ADEQUADO ÀS NECESSIDADES } \\
\text { ESPECÍFICAS DA REGIÃO }\end{array}$ \\
\hline & & $\begin{array}{l}\text { CONTEÚDO NÃO FOI SUFICIENTEMENTE } \\
\text { APROFUNDADO PARA } \\
\text { PERMITIR UMA APLICAÇÃO } \\
\text { EFICAZ E EFICIENTE }\end{array}$ \\
\hline & & $\begin{array}{llllll}\text { FALTA DE APOIO } & \text { E } & \text { INCENTIVO } & \text { DA } & \text { MINHA } \\
\text { INSTITUIÇÃO } & & & & & \end{array}$ \\
\hline & & FALTA DE INCENTIVO ÀS AÇÕES DE ATER \\
\hline & & NÃO TENHO INTERESSE EM APLICAR \\
\hline
\end{tabular}


6) A partir deste curso: (As respostas não são excludentes: você poderá marcar mais de uma opção).

\begin{tabular}{|l|l|}
\hline$x$ & $\begin{array}{l}\text { NÃO MUDOU NADA EM MEU TRABALHO. } \\
\text { FAMILIARES. }\end{array}$ \\
\hline & CONSEGUI INFLUENCIAR NAS ORIENTAÇÕES DA MINHA INSTITUIÇÃO. \\
\hline & PASSEI A TRABALHAR COM METODOLOGIAS PARTICIPATIVAS. \\
\hline & $\begin{array}{l}\text { ORESCEU A ÁREA DE AGRICULTURA DE BASE ECOLÓGICA NAS COMUNIDADES } \\
\text { ONDE ATUO. }\end{array}$ \\
\hline & CONTINUEI ME APERFEIÇOANDO SOBRE TEMAS ABORDADOS. \\
\hline
\end{tabular}

7) Depois do curso você apoiou atividades de capacitação de técnicos e agricultores com base nos princípios e diretrizes da Pnater? (Considere como apoio a atividades de capacitação a participação no planejamento, elaboração de ementas, seleção de participantes e de palestrantes.)

\begin{tabular}{|l|l|}
\hline & SIM \\
\hline$X$ & NÃO \\
\hline
\end{tabular}

8) Usou os conhecimentos para ministrar outros cursos com o mesmo conteúdo ou conteúdos semelhantes?

\begin{tabular}{|l|l|}
\hline & SIM \\
\hline$X$ & NÃO \\
\hline
\end{tabular}

9) Marque o seu grau de satisfação com relação ao curso oferecido pelo DATER: (Considere a seguinte pontuação: 1 - MUITO RUIM; 2 - RUIM; 3 - REGULAR; 4 - BOM; 5 - MUITO BOM)

\begin{tabular}{|l|l|l|l|l|}
\hline 1 & 2 & 3 & 4 & 5 \\
\hline
\end{tabular}

10) Marque seu grau de satisfação com relação ao DATER: (Considere a seguinte pontuação: 1 - MUITO RUIM; 2 - RUIM; 3 - REGULAR; 4 - BOM; 5 - MUITO BOM)

\begin{tabular}{|l|l|l|l|l|}
\hline 1 & 2 & 3 & 4 & 5 \\
\hline
\end{tabular}


PESQUISA - IMPACTO DAS AÇÕES DE FORMAÇÃO REALIZADAS PELO DATER/SAF/MDA NO PERÍODO 2004-2009

Caros colaboradores,

Contamos com a sua atenção para preencher o formulário abaixo.

O mesmo tem por objetivo fornecer informações para avaliação da Eficiência, Efetividade e Eficácia da Política Pública de Formação de Agentes de Ater adotada pelo Departamento de Assistência Técnica e Extensão Rural, da Secretaria de Agricultura Familiar do Ministério do Desenvolvimento - DATER/SAF/MDA, no período de 2004 a 2009, tema escolhido para Monografia a ser apresentada à Universidade de Brasília (UnB) como requisito parcial para obtenção do grau de Bacharel em Administração.

Você poderá ou não se identificar no questionário e garantimos que todas as informações fornecidas serão confidenciais e utilizadas apenas de forma sistematizada.

IDENTIFICAÇÃO Nome: JORGE ROQUE SANTANA DE AMARAL

Instituição (nome e tipo de instituição: ONG, $\begin{aligned} & \text { Local de trabalho (Cidade e Estado): } \\ & \text { Empresa Pública, etc.): EMATER - RO }\end{aligned}$
MIRANTE DA SERRA

Curso/Encontro/Oficina do qual participou (caso tenha participado de mais de um curso, preencha um formulário para cada um deles): CREDITO RURAL, MANEJO DE PASTAGEM COM ÊNFASE NO CONTROLE BIOLOGICO DA CIGARRINHA, MELHORIA DA QUALIDADE SO LEITE.

Data do Curso/Encontro/Oficina (pelo menos mês e ano): 2006

Indique sua área de atuação?

\begin{tabular}{|l|l|}
\hline$X$ & EXTENSÃO RURAL \\
\hline & PESQUISA \\
\hline & ENSINO \\
\hline & OUTROS \\
\hline
\end{tabular}

2) Qual o seu nível de escolaridade?

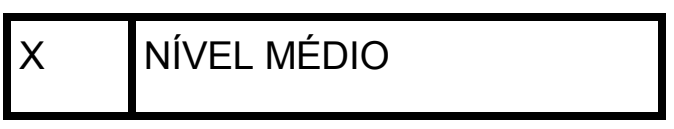




\begin{tabular}{|l|l|}
\hline & NÍVEL SUPERIOR \\
\hline & PÓS-GRADUAÇÃO \\
\hline
\end{tabular}

3) Os conteúdos abordados foram condizentes com as demandas do seu dia-a-dia?

\begin{tabular}{|l|l|}
\hline$X$ & SIM \\
\hline & PARCIALMENTE \\
\hline & NÃO \\
\hline
\end{tabular}

3) O curso contribuiu para o seu aperfeiçoamento profissional?

\begin{tabular}{|l|l|}
\hline$X$ & SIM \\
\hline & NÃO \\
\hline
\end{tabular}

5) Os conhecimentos adquiridos estão sendo aplicados no seu trabalho? Em caso afirmativo, indique em que grau estes conhecimentos estão sendo aplicados. Em caso negativo, indique por que razão isto não ocorre:

\begin{tabular}{|c|c|c|c|}
\hline \multirow{3}{*}{$\mathrm{X}$} & \multirow{3}{*}{$\begin{array}{l}\text { SIM (indique ao lado em } \\
\text { que grau) }\end{array}$} & $\mathrm{X}$ & MUITO APLICADOS \\
\hline & & & MEDIAMENTE APLICADOS \\
\hline & & & POUCO APLICADOS \\
\hline & \multirow{5}{*}{$\begin{array}{l}\text { NÃO (indique ao lado a } \\
\text { razão da não aplicação) }\end{array}$} & & $\begin{array}{l}\text { CONTEÚDO NÃO ADEQUADO ȦS NECESSIDADES } \\
\text { ESPECÍFICAS DA REGIÃO }\end{array}$ \\
\hline & & & $\begin{array}{l}\text { CONTEÚDO NÃO } \text { FOI SUFICIENTEMENTE } \\
\text { APROFUNDADO PARA } \\
\text { EERMITIR UMA APLICAÇÃO } \\
\text { EFICAZ E EFICIENTE }\end{array}$ \\
\hline & & & \begin{tabular}{|llllll} 
FALTA DE & APOIO & E & INCENTIVO & DA & MINHA \\
INSTITUIÇÃO & & & & &
\end{tabular} \\
\hline & & & FALTA DE INCENTIVO ÀS AÇÕES DE ATER \\
\hline & & & NÃO TENHO INTERESSE EM APLICAR \\
\hline
\end{tabular}

6) A partir deste curso: 


\begin{tabular}{|l|l|}
\hline & NÃO MUDOU NADA EM MEU TRABALHO. \\
\hline$X$ & $\begin{array}{l}\text { MEU TRABALHO PASSOU A CONTRIBUIR MAIS COM OS AGRICULTORES(AS) } \\
\text { FAMILIARES. }\end{array}$ \\
\hline & CONSEGUI INFLUENCIAR NAS ORIENTAÇÕES DA MINHA INSTITUIÇÃO. \\
\hline$X$ & $\begin{array}{l}\text { CRESCEU A ÁREA DE AGRICULTURA DE BASE ECOLÓGICA NAS COMUNIDADES } \\
\text { ONDE ATUO. }\end{array}$ \\
\hline & CONTINUEI ME APERFEIÇOANDO SOBRE TEMAS ABORDADOS. \\
\hline
\end{tabular}

7) Depois do curso você apoiou atividades de capacitação de técnicos e agricultores com base nos princípios e diretrizes da Pnater?

\begin{tabular}{|l|l|}
\hline & SIM \\
\hline$X$ & NÃO \\
\hline
\end{tabular}

8) Usou os conhecimentos para ministrar outros cursos com o mesmo conteúdo ou conteúdos semelhantes?

\begin{tabular}{|l|l|}
\hline & SIM \\
\hline$X$ & NÃO \\
\hline
\end{tabular}

9) Marque o seu grau de satisfação com relação ao curso oferecido pelo DATER:

\begin{tabular}{|l|l|l|l|l|}
\hline 1 & 2 & 3 & 4 & 5 \\
\hline
\end{tabular}

10) Marque seu grau de satisfação com relação ao DATER:

\begin{tabular}{|l|l|l|l|l|}
\hline 1 & 2 & 3 & 4 & 5 \\
\hline
\end{tabular}


PESQUISA - IMPACTO DAS AÇÕES DE FORMAÇÃO REALIZADAS PELO DATER/SAF/MDA NO PERÍODO 2004-2009

Caros colaboradores,

Contamos com a sua atenção para preencher o formulário abaixo.

O mesmo tem por objetivo fornecer informações para avaliação da Eficiência, Efetividade e Eficácia da Política Pública de Formação de Agentes de Ater adotada pelo Departamento de Assistência Técnica e Extensão Rural, da Secretaria de Agricultura Familiar do Ministério do Desenvolvimento - DATER/SAF/MDA, no período de 2004 a 2009, tema escolhido para Monografia a ser apresentada à Universidade de Brasília (UnB) como requisito parcial para obtenção do grau de Bacharel em Administração.

Você poderá ou não se identificar no questionário e garantimos que todas as informações fornecidas serão confidenciais e utilizadas apenas de forma sistematizada.

IDENTIFICAÇÃO

\begin{tabular}{|l|l|}
\hline Nome: MARTINHO FREIRE DA SILVA \\
\hline $\begin{array}{l}\text { Instituição (nome e tipo de instituição: ONG, } \\
\text { Empresa Pública, etc.): EMATER - RO }\end{array}$ & $\begin{array}{l}\text { MIRANTE de trabalho (Cidade e Estado): } \\
\text { Curso/Encontro/Oficina do qual participou (caso tenha participado de mais de um curso, preencha } \\
\text { um formulário para cada um deles): MANEJO DE PASTAGEM COM ÊNFASE NO CONTROLE } \\
\text { BIOLOGICO DA CIGARRINHA, MELHORIA DA QUALIDADE SO LEITE. }\end{array}$ \\
\hline Data do Curso/Encontro/Oficina (pelo menos mês e ano): 2006
\end{tabular}

Indique sua área de atuação?

\begin{tabular}{|l|l|}
\hline$X$ & EXTENSÃO RURAL \\
\hline & PESQUISA \\
\hline & ENSINO \\
\hline & OUTROS \\
\hline
\end{tabular}

2) Qual o seu nível de escolaridade?

\begin{tabular}{|l|l|}
\hline$X$ & NÍVEL MÉDIO \\
\hline
\end{tabular}




\begin{tabular}{|l|l|}
\hline & NÍVEL SUPERIOR \\
\hline & PÓS-GRADUAÇÃO \\
\hline
\end{tabular}

3) Os conteúdos abordados foram condizentes com as demandas do seu dia-a-dia?

\begin{tabular}{|l|l|}
\hline$X$ & SIM \\
\hline & PARCIALMENTE \\
\hline & NÃO \\
\hline
\end{tabular}

4) O curso contribuiu para o seu aperfeiçoamento profissional?

\begin{tabular}{|l|l|}
\hline$X$ & SIM \\
\hline & NÃO \\
\hline
\end{tabular}

5) Os conhecimentos adquiridos estão sendo aplicados no seu trabalho? Em caso afirmativo, indique em que grau estes conhecimentos estão sendo aplicados. Em caso negativo, indique por que razão isto não ocorre:

\begin{tabular}{|c|c|c|c|}
\hline \multirow{3}{*}{$\mathrm{X}$} & \multirow{3}{*}{$\begin{array}{l}\text { SIM (indique ao lado em } \\
\text { que grau) }\end{array}$} & $x$ & MUITO APLICADOS \\
\hline & & & MEDIAMENTE APLICADOS \\
\hline & & & POUCO APLICADOS \\
\hline & \multirow{5}{*}{$\begin{array}{l}\text { NÃO (indique ao lado a } \\
\text { razão da não aplicação) }\end{array}$} & & $\begin{array}{l}\text { CONTEÚDO NÃO ADEQUADO ȦS NECESSIDADES } \\
\text { ESPECÍFICAS DA REGIÃO }\end{array}$ \\
\hline & & & $\begin{array}{l}\text { CONTEÚDO NÃO } \text { FOI SUFICIENTEMENTE } \\
\text { APROFUNDADO PARA } \\
\text { PERMITIR UMA APLICAÇÃO } \\
\text { EFICAZ E EFICIENTE }\end{array}$ \\
\hline & & & \begin{tabular}{|lccccc} 
FALTA DE & APOIO & E & INCENTIVO & DA & MINHA \\
INSTITUIÇÃO & & & & & \\
INST
\end{tabular} \\
\hline & & & FALTA DE INCENTIVO ÀS AÇÕES DE ATER \\
\hline & & & NÃO TENHO INTERESSE EM APLICAR \\
\hline
\end{tabular}


6) A partir deste curso:

\begin{tabular}{|l|l|}
\hline & NÃO MUDOU NADA EM MEU TRABALHO. \\
\hline$x$ & $\begin{array}{l}\text { MEU TRABALHO PASSOU A CONTRIBUIR MAIS COM OS AGRICULTORES(AS) } \\
\text { FAMILIARES. }\end{array}$ \\
\hline$x$ & CONSEGUI INFLUENCIAR NAS ORIENTAÇÕES DA MINHA INSTITUIÇÃO. \\
\hline$x$ & PASSEI A TRABALHAR COM METODOLOGIAS PARTICIPATIVAS. \\
\hline & $\begin{array}{l}\text { CRESCEU A ÁREA DE AGRICULTURA DE BASE ECOLÓGICA NAS COMUNIDADES } \\
\mathrm{O}\end{array}$ \\
\hline
\end{tabular}

7) Depois do curso você apoiou atividades de capacitação de técnicos e agricultores com base nos princípios e diretrizes da Pnater?

\begin{tabular}{|l|l|}
\hline$x$ & SIM \\
\hline & NÃO \\
\hline
\end{tabular}

8) Usou os conhecimentos para ministrar outros cursos com o mesmo conteúdo ou conteúdos semelhantes?

\begin{tabular}{|l|l|}
\hline$x$ & SIM \\
\hline & NÃO \\
\hline
\end{tabular}

9) Marque o seu grau de satisfação com relação ao curso oferecido pelo DATER:

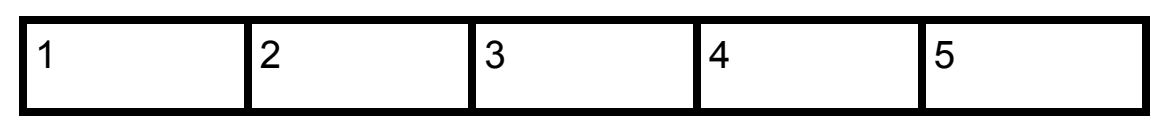

10) Marque seu grau de satisfação com relação ao DATER:

\begin{tabular}{|l|l|l|l|l|}
\hline 1 & 2 & 3 & 4 & 5 \\
\hline
\end{tabular}


PESQUISA - IMPACTO DAS AÇÕES DE FORMAÇÃO REALIZADAS PELO DATER/SAF/MDA NO PERÍODO 2004-2009

Caros colaboradores,

Contamos com a sua atenção para preencher o formulário abaixo.

O mesmo tem por objetivo fornecer informações para avaliação da Eficiência, Efetividade e Eficácia da Política Pública de Formação de Agentes de Ater adotada pelo Departamento de Assistência Técnica e Extensão Rural, da Secretaria de Agricultura Familiar do Ministério do Desenvolvimento - DATER/SAF/MDA, no período de 2004 a 2009, tema escolhido para Monografia a ser apresentada à Universidade de Brasília (UnB) como requisito parcial para obtenção do grau de Bacharel em Administração.

Você poderá ou não se identificar no questionário e garantimos que todas as informações fornecidas serão confidenciais e utilizadas apenas de forma sistematizada.

IDENTIFICAÇÃO

\begin{tabular}{|c|c|}
\hline $\begin{array}{l}\text { Nome: } \\
\text { ALEXSANDRO QUEIROZ DOS SANTOS }\end{array}$ & $\begin{array}{l}\text { Sexo: } \\
(x) \text { masculino } \quad(\quad) \text { feminino }\end{array}$ \\
\hline $\begin{array}{l}\text { Instituição (nome e tipo de instituição: ONG, } \\
\text { Empresa Pública, etc.): } \\
\text { EMATER-RO }\end{array}$ & $\begin{array}{l}\text { Local de trabalho (Cidade e Estado): } \\
\text { EXTREMA -PORTO VELHO-RO }\end{array}$ \\
\hline \multicolumn{2}{|c|}{$\begin{array}{l}\text { Curso/Encontro/Oficina do qual participou (caso tenha participado de mais de um curso, preencha } \\
\text { um formulário para cada um deles): } \\
\text { CURSO DE CREDITO RURAL }\end{array}$} \\
\hline \multicolumn{2}{|l|}{$\begin{array}{l}\text { Data do Curso/Encontro/Oficina (pelo menos mês e ano): } \\
02 \text { A 06/05/2006 }\end{array}$} \\
\hline
\end{tabular}

1. Indique sua área de atuação? (As respostas não são excludentes: você poderá marcar mais de uma opção).

\begin{tabular}{|l|l|}
\hline$X$ & EXTENSÃO RURAL \\
\hline & PESQUISA \\
\hline & ENSINO \\
\hline & OUTROS \\
\hline
\end{tabular}

2) Qual o seu nível de escolaridade? 


\begin{tabular}{|l|l|}
\hline$X$ & NÍVEL MÉDIO \\
\hline & NÍVEL SUPERIOR \\
\hline & PÓS-GRADUAÇÃO \\
\hline
\end{tabular}

3) Os conteúdos abordados foram condizentes com as demandas do seu dia-a-dia?

\begin{tabular}{|l|l|}
\hline$X$ & SIM \\
\hline & PARCIALMENTE \\
\hline & NÃO \\
\hline
\end{tabular}

4) O curso contribuiu para o seu aperfeiçoamento profissional?

\begin{tabular}{|l|l|}
\hline$X$ & SIM \\
\hline & NÃO \\
\hline
\end{tabular}

5) Os conhecimentos adquiridos estão sendo aplicados no seu trabalho? Em caso afirmativo, indique em que grau estes conhecimentos estão sendo aplicados. Em caso negativo, indique por que razão isto não ocorre:

\begin{tabular}{|c|c|c|c|}
\hline \multirow{3}{*}{$X$} & \multirow{3}{*}{$\begin{array}{l}\text { SIM (indique ao lado em } \\
\text { que grau) }\end{array}$} & & MUITO APLICADOS \\
\hline & & $\bar{x}$ & MEDIAMENTE APLICADOS \\
\hline & & & POUCO APLICADOS \\
\hline & \multirow{4}{*}{$\begin{array}{l}\text { NÃO (indique ao lado a } \\
\text { razão da não aplicação) }\end{array}$} & & $\begin{array}{l}\text { CONTEÚDO NĀO ADEQUADO ȦS NECESSIDADES } \\
\text { ESPECÍFICAS DA REGIÃO }\end{array}$ \\
\hline & & & $\begin{array}{l}\text { CONTEÚDO NÃO FOI SUFICIENTEMENTE } \\
\text { APROFUNDADO PARA } \\
\text { EERMITIR UMA APLICAÇÃO } \\
\text { EFICAZ E EFICIENTE }\end{array}$ \\
\hline & & & $\begin{array}{lccccc}\text { FALTA DE } & \text { APOIO } & \text { E } & \text { INCENTIVO } & \text { DA } & \text { MINHA } \\
\text { INSTITUIÇÃO } & & & & & \end{array}$ \\
\hline & & & FALTA DE INCENTIVO ÀS AÇÕES DE ATER \\
\hline
\end{tabular}




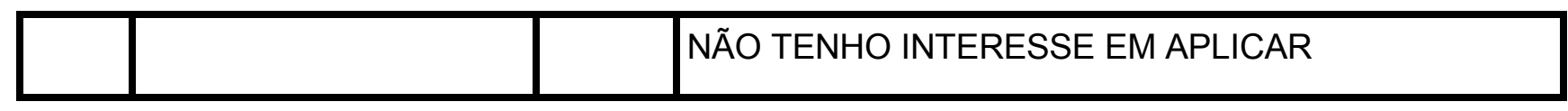

6) A partir deste curso: (As respostas não são excludentes: você poderá marcar mais de uma opção).

\begin{tabular}{|l|l|}
\hline$X$ & NÃO MUDOU NADA EM MEU TRABALHO. \\
\hline & $\begin{array}{l}\text { MEU TRABALHO PASSOU A CONTRIBUIR MAIS COM OS AGRICULTORES(AS) } \\
\text { FAMILIARES. }\end{array}$ \\
\hline & CONSEGUI INFLUENCIAR NAS ORIENTAÇÕES DA MINHA INSTITUIÇÃO. \\
\hline & $\begin{array}{l}\text { CRSSEI A TRABALHAR COM METODOLOGIAS PARTICIPATIVAS. } \\
\text { ONDE ATUO. ÁREA DE AGRICULTURA DE BASE ECOLÓGICA NAS COMUNIDADES }\end{array}$ \\
\hline & CONTINUEI ME APERFEIÇOANDO SOBRE TEMAS ABORDADOS. \\
\hline
\end{tabular}

7) Depois do curso você apoiou atividades de capacitação de técnicos e agricultores com base nos princípios e diretrizes da Pnater? (Considere como apoio a atividades de capacitação a participação no planejamento, elaboração de ementas, seleção de participantes e de palestrantes.)

\begin{tabular}{|l|l|}
\hline & SIM \\
\hline$X$ & NÃO \\
\hline
\end{tabular}

8) Usou os conhecimentos para ministrar outros cursos com o mesmo conteúdo ou conteúdos semelhantes?

\begin{tabular}{|l|l|}
\hline & SIM \\
\hline$X$ & NÃO \\
\hline
\end{tabular}

9) Marque o seu grau de satisfação com relação ao curso oferecido pelo DATER: (Considere a seguinte pontuação: 1 - MUITO RUIM; 2 - RUIM; 3 - REGULAR; 4 - BOM; 5 - MUITO BOM) 


\begin{tabular}{|l|l|l|l|l|}
\hline 1 & 2 & 3 & $4 X$ & 5 \\
\hline
\end{tabular}

10) Marque seu grau de satisfação com relação ao DATER: (Considere a seguinte pontuação: 1 - MUITO RUIM; 2 - RUIM; 3 - REGULAR; 4 - BOM; 5 - MUITO BOM)

\begin{tabular}{|l|l|l|l|l|}
\hline 1 & 2 & 3 & $4 X$ & 5 \\
\hline
\end{tabular}


PESQUISA - IMPACTO DAS AÇÕES DE FORMAÇÃO REALIZADAS PELO DATER/SAF/MDA NO PERÍODO 2004-2009

Caros colaboradores,

Contamos com a sua atenção para preencher o formulário abaixo.

O mesmo tem por objetivo fornecer informações para avaliação da Eficiência, Efetividade e Eficácia da Política Pública de Formação de Agentes de Ater adotada pelo Departamento de Assistência Técnica e Extensão Rural, da Secretaria de Agricultura Familiar do Ministério do Desenvolvimento - DATER/SAF/MDA, no período de 2004 a 2009, tema escolhido para Monografia a ser apresentada à Universidade de Brasília (UnB) como requisito parcial para obtenção do grau de Bacharel em Administração.

Você poderá ou não se identificar no questionário e garantimos que todas as informações fornecidas serão confidenciais e utilizadas apenas de forma sistematizada.

\section{IDENTIFICAÇÃO}

\begin{tabular}{|c|c|}
\hline $\begin{array}{l}\text { Nome: } \\
\text { ALEXSANDRO QUEIROZ DOS SANTOS }\end{array}$ & $\begin{array}{l}\text { Sexo: } \\
(\mathrm{x}) \text { masculino } \quad(\quad) \text { feminino }\end{array}$ \\
\hline $\begin{array}{l}\text { Instituição (nome e tipo de instituição: ONG, } \\
\text { Empresa Pública, etc.): } \\
\text { EMATER-RO }\end{array}$ & $\begin{array}{l}\text { Local de trabalho (Cidade e Estado): } \\
\text { EXTREMA -PORTO VELHO-RO }\end{array}$ \\
\hline $\begin{array}{l}\text { Curso/Encontro/Oficina do qual participou (caso tenh } \\
\text { um formulário para cada um deles): } \\
\text { CUROS DE MANEJO E PASTAGEM COM ÊN } \\
\text { CIGARRINHA }\end{array}$ & $\begin{array}{l}\text { Ia participado de mais de um curso, preencha } \\
\text { NFASE NO CONTROLE BIOLÓGICO DA }\end{array}$ \\
\hline $\begin{array}{l}\text { Data do Curso/Encontro/Oficina (pelo menos mês e } \\
19 \text { a 23/06/2006 }\end{array}$ & \\
\hline
\end{tabular}

1. Indique sua área de atuação? (As respostas não são excludentes: você poderá marcar mais de uma opção).

\begin{tabular}{|l|l|}
\hline$X$ & EXTENSÃO RURAL \\
\hline & PESQUISA \\
\hline & ENSINO \\
\hline & OUTROS \\
\hline
\end{tabular}


2) Qual o seu nível de escolaridade?

\begin{tabular}{|l|l|}
\hline$X$ & NÍVEL MÉDIO \\
\hline & NÍVEL SUPERIOR \\
\hline & PÓS-GRADUAÇÃO \\
\hline
\end{tabular}

3) Os conteúdos abordados foram condizentes com as demandas do seu dia-a-dia?

\begin{tabular}{|l|l|}
\hline$X$ & SIM \\
\hline & PARCIALMENTE \\
\hline & NÃO \\
\hline
\end{tabular}

4) O curso contribuiu para o seu aperfeiçoamento profissional?

\begin{tabular}{|l|l|}
\hline$X$ & SIM \\
\hline & NÃO \\
\hline
\end{tabular}

5) Os conhecimentos adquiridos estão sendo aplicados no seu trabalho? Em caso afirmativo, indique em que grau estes conhecimentos estão sendo aplicados. Em caso negativo, indique por que razão isto não ocorre:

\begin{tabular}{|c|c|c|c|}
\hline \multirow{3}{*}{$X$} & \multirow{3}{*}{$\begin{array}{l}\text { SIM (indique ao lado em } \\
\text { que grau) }\end{array}$} & & MUITO APLICADOS \\
\hline & & $\mathrm{X}$ & MEDIAMENTE APLICADOS \\
\hline & & & POUCO APLICADOS \\
\hline & \multirow{3}{*}{$\begin{array}{l}\text { NÃO (indique ao lado a } \\
\text { razão da não aplicação) }\end{array}$} & & $\begin{array}{l}\text { CONTEÚDO NÃO ADEQUADO ȦS NECESSIDADES } \\
\text { ESPECÍFICAS DA REGIÃO }\end{array}$ \\
\hline & & & $\begin{array}{l}\text { CONTEÚDO NÃO } \quad \text { FOI SUFICIENTEMENTE } \\
\text { APROFUNDADO PARA } \\
\text { PERMITIR UMA APLICAÇÃO } \\
\text { EFICAZ E EFICIENTE }\end{array}$ \\
\hline & & & $\begin{array}{l}\text { FALTA DE APOIO } \\
\text { INSTITUIÇÃO }\end{array}$ \\
\hline
\end{tabular}




\begin{tabular}{|l|l|l|}
\hline \multirow{2}{*}{} & & FALTA DE INCENTIVO ÀS AÇÕES DE ATER \\
\cline { 3 - 4 } & & NÃO TENHO INTERESSE EM APLICAR \\
\hline
\end{tabular}

6) A partir deste curso: (As respostas não são excludentes: você poderá marcar mais de uma opção).

\begin{tabular}{|l|l|}
\hline & NÃO MUDOU NADA EM MEU TRABALHO. \\
\hline & $\begin{array}{l}\text { MEU TRABALHO PASSOU A CONTRIBUIR MAIS COM OS AGRICULTORES(AS) } \\
\text { FAMILIARES. }\end{array}$ \\
\hline & CONSEGUI INFLUENCIAR NAS ORIENTAÇÕES DA MINHA INSTITUIÇÃO. \\
\hline & $\begin{array}{l}\text { CRESSEI A TRABALHAR COM METODOLOGIAS PARTICIPATIVAS. } \\
\text { ONDE ATUO. }\end{array}$ \\
\hline $\mathrm{x}$ & CONTINUEI ME APERFEIÇOANDO SOBRE TEMAS ABORDADOS. \\
\hline
\end{tabular}

7) Depois do curso você apoiou atividades de capacitação de técnicos e agricultores com base nos princípios e diretrizes da Pnater? (Considere como apoio a atividades de capacitação a participação no planejamento, elaboração de ementas, seleção de participantes e de palestrantes.)

\begin{tabular}{|l|l|}
\hline & SIM \\
\hline$X$ & NÃO \\
\hline
\end{tabular}

8) Usou os conhecimentos para ministrar outros cursos com o mesmo conteúdo ou conteúdos semelhantes?

\begin{tabular}{|l|l|}
\hline & SIM \\
\hline$X$ & NÃO \\
\hline
\end{tabular}

9) Marque o seu grau de satisfação com relação ao curso oferecido pelo DATER: (Considere a seguinte pontuação: 1 - MUITO RUIM; 2 - RUIM; 3 - REGULAR; 4 - BOM; 5 - MUITO BOM) 


\begin{tabular}{|l|l|l|l|l|}
\hline 1 & 2 & 3 & $4 X$ & 5 \\
\hline
\end{tabular}

10) Marque seu grau de satisfação com relação ao DATER: (Considere a seguinte pontuação:

1 - MUITO RUIM; 2 - RUIM; 3 - REGULAR; 4 - BOM; 5 - MUITO BOM)

\begin{tabular}{|l|l|l|l|l|}
\hline 1 & 2 & 3 & $4 X$ & 5 \\
\hline
\end{tabular}


PESQUISA - IMPACTO DAS AÇÕES DE FORMAÇÃO REALIZADAS PELO DATER/SAF/MDA NO PERÍODO 2004-2009

Caros colaboradores,

Contamos com a sua atenção para preencher o formulário abaixo.

O mesmo tem por objetivo fornecer informações para avaliação da Eficiência, Efetividade e Eficácia da Política Pública de Formação de Agentes de Ater adotada pelo Departamento de Assistência Técnica e Extensão Rural, da Secretaria de Agricultura Familiar do Ministério do Desenvolvimento - DATER/SAF/MDA, no período de 2004 a 2009, tema escolhido para Monografia a ser apresentada à Universidade de Brasília (UnB) como requisito parcial para obtenção do grau de Bacharel em Administração.

Você poderá ou não se identificar no questionário e garantimos que todas as informações fornecidas serão confidenciais e utilizadas apenas de forma sistematizada.

\section{IDENTIFICAÇÃO}

\begin{tabular}{|l|l|}
\hline \multicolumn{1}{|l|}{ Alessandro da Silva Barbosa Nunes } & $\begin{array}{l}\text { Sexo: } \\
(\mathrm{x}) \text { masculino } \quad(\quad \text { ) feminino }\end{array}$ \\
\hline $\begin{array}{l}\text { Instituição (nome e tipo de instituição: ONG, } \\
\text { Empresa Pública, etc.): }\end{array}$ & Local de trabalho (Cidade e Estado): \\
& Cacaulândia / RO \\
\hline $\begin{array}{l}\text { Curso/Encontro/Oficina do qual participou (caso tenha participado de mais de um curso, preencha } \\
\text { um formulário para cada um deles): Curso de Manejo de Pastagem com Ênfase no } \\
\text { Controle Biológico da Cigarrinha; }\end{array}$ \\
\hline $\begin{array}{l}\text { Data do Curso/Encontro/Oficina (pelo menos mês e ano): } \\
06 / 06\end{array}$ \\
\hline
\end{tabular}

1. Indique sua área de atuação? (As respostas não são excludentes: você poderá marcar mais de uma opção).

\begin{tabular}{|l|l|}
\hline$X$ & EXTENSÃO RURAL \\
\hline & PESQUISA \\
\hline & ENSINO \\
\hline & OUTROS \\
\hline
\end{tabular}


2) Qual o seu nível de escolaridade?

\begin{tabular}{|l|l|}
\hline$X$ & NÍVEL MÉDIO \\
\hline & NÍVEL SUPERIOR \\
\hline & PÓS-GRADUAÇÃO \\
\hline
\end{tabular}

3) Os conteúdos abordados foram condizentes com as demandas do seu dia-a-dia?

\begin{tabular}{|l|l|}
\hline & SIM \\
\hline$X$ & PARCIALMENTE \\
\hline & NÃO \\
\hline
\end{tabular}

4) O curso contribuiu para o seu aperfeiçoamento profissional?

\begin{tabular}{|l|l|}
\hline$X$ & SIM \\
\hline & NÃO \\
\hline
\end{tabular}

5) Os conhecimentos adquiridos estão sendo aplicados no seu trabalho? Em caso afirmativo, indique em que grau estes conhecimentos estão sendo aplicados. Em caso negativo, indique por que razão isto não ocorre:

\begin{tabular}{|c|c|c|}
\hline \multirow{3}{*}{$\begin{array}{l}\text { SIM (indique ao lado em } \\
\text { que grau) }\end{array}$} & & MUITO APLICADOS \\
\hline & & MEDIAMENTE APLICADOS \\
\hline & $\mathrm{X}$ & POUCO APLICADOS \\
\hline \multirow{3}{*}{$\begin{array}{l}\text { NÃO (indique ao lado a } \\
\text { razão da não aplicação) }\end{array}$} & & $\begin{array}{l}\text { CONTEÚDO NÃO ADEQUADO ȦS NECESSIDADES } \\
\text { ESPECÍFICAS DA REGIÃO }\end{array}$ \\
\hline & & $\begin{array}{l}\text { CONTEÚDO NÃO } \quad \text { FOI SUFICIENTEMENTE } \\
\text { APROFUNDADO PARA } \\
\text { PERMITIR UMA APLICAÇÃO } \\
\text { EFICAZ E EFICIENTE }\end{array}$ \\
\hline & & $\begin{array}{l}\text { FALTA DE APOIO } \\
\text { INSTITUIÇÃO }\end{array}$ \\
\hline
\end{tabular}




\begin{tabular}{|l|l|l|}
\hline \multirow{2}{*}{} & & FALTA DE INCENTIVO ÀS AÇÕES DE ATER \\
\cline { 3 - 4 } & & NÃO TENHO INTERESSE EM APLICAR \\
\hline
\end{tabular}

6) A partir deste curso: (As respostas não são excludentes: você poderá marcar mais de uma opção).

\begin{tabular}{|c|l|}
\hline$x$ & $\begin{array}{l}\text { NÃO MUDOU NADA EM MEU TRABALHO. } \\
\text { FAMILIARES. }\end{array}$ \\
\hline & CONSEGUI INFLUENCIAR NAS ORIENTAÇÕES DA MINHA INSTITUIÇÃO. \\
\hline & PASSEI A TRABALHAR COM METODOLOGIAS PARTICIPATIVAS. \\
\hline & $\begin{array}{l}\text { ORESCEU A ÁREA DE AGRICULTURA DE BASE ECOLÓGICA NAS COMUNIDADES } \\
\text { ONDE ATUO. }\end{array}$ \\
\hline & CONTINUEI ME APERFEIÇOANDO SOBRE TEMAS ABORDADOS. \\
\hline
\end{tabular}

7) Depois do curso você apoiou atividades de capacitação de técnicos e agricultores com base nos princípios e diretrizes da Pnater? (Considere como apoio a atividades de capacitação a participação no planejamento, elaboração de ementas, seleção de participantes e de palestrantes.)

\begin{tabular}{|l|l|}
\hline & SIM \\
\hline$X$ & NÃO \\
\hline
\end{tabular}

8) Usou os conhecimentos para ministrar outros cursos com o mesmo conteúdo ou conteúdos semelhantes?

\begin{tabular}{|l|l|}
\hline$X$ & SIM \\
\hline & NÃO \\
\hline
\end{tabular}


9) Marque o seu grau de satisfação com relação ao curso oferecido pelo DATER: (Considere a seguinte pontuação: 1 - MUITO RUIM; 2 - RUIM; 3 - REGULAR; 4 - BOM; 5 - MUITO BOM)

\begin{tabular}{|l|l|l|l|l|}
\hline 1 & 2 & 3 & 4 & $5 \times$ \\
\hline
\end{tabular}

10) Marque seu grau de satisfação com relação ao DATER: (Considere a seguinte pontuação: 1 - MUITO RUIM; 2 - RUIM; 3 - REGULAR; 4 - BOM; 5 - MUITO BOM)

\begin{tabular}{|l|l|l|l|l|}
\hline 1 & 2 & 3 & 4 & $5 X$ \\
\hline
\end{tabular}


PESQUISA - IMPACTO DAS AÇÕES DE FORMAÇÃO REALIZADAS PELO DATER/SAF/MDA NO PERÍODO 2004-2009

Caros colaboradores,

Contamos com a sua atenção para preencher o formulário abaixo.

O mesmo tem por objetivo fornecer informações para avaliação da Eficiência, Efetividade e Eficácia da Política Pública de Formação de Agentes de Ater adotada pelo Departamento de Assistência Técnica e Extensão Rural, da Secretaria de Agricultura Familiar do Ministério do Desenvolvimento - DATER/SAF/MDA, no período de 2004 a 2009, tema escolhido para Monografia a ser apresentada à Universidade de Brasília (UnB) como requisito parcial para obtenção do grau de Bacharel em Administração.

Você poderá ou não se identificar no questionário e garantimos que todas as informações fornecidas serão confidenciais e utilizadas apenas de forma sistematizada.

IDENTIFICAÇÃO

\begin{tabular}{|c|c|}
\hline \multicolumn{2}{|l|}{ José Antônio da Luz } \\
\hline $\begin{array}{l}\text { Instituição (nome e tipo de instituição: ONG, } \\
\text { Empresa Pública, etc.): } \\
\text { Emater / RO }\end{array}$ & $\begin{array}{l}\text { Local de trabalho (Cidade e Estado): } \\
\text { Cacaulândia / RO }\end{array}$ \\
\hline \multicolumn{2}{|c|}{$\begin{array}{l}\text { Curso/Encontro/Oficina do qual participou (caso tenha participado de mais de um curso, preencha } \\
\text { um formulário para cada um deles): Curso de Manejo de Pastagem com Ênfase no Controle } \\
\text { Biológico de Cigarrinhas }\end{array}$} \\
\hline Data do Curso/Encontro/Oficina (pelo menos mês e a & $10 / 06$ \\
\hline
\end{tabular}

1. Indique sua área de atuação?

\begin{tabular}{|l|l|}
\hline$X$ & EXTENSÃO RURAL \\
\hline & PESQUISA \\
\hline & ENSINO \\
\hline & OUTROS \\
\hline
\end{tabular}


2) Qual o seu nível de escolaridade?

\begin{tabular}{|l|l|}
\hline$X$ & NÍVEL MÉDIO \\
\hline & NÍVEL SUPERIOR \\
\hline & PÓS-GRADUAÇÃO \\
\hline
\end{tabular}

3) Os conteúdos abordados foram condizentes com as demandas do seu dia-a-dia?

\begin{tabular}{|l|l|}
\hline$X$ & SIM \\
\hline & PARCIALMENTE \\
\hline & NÃO \\
\hline
\end{tabular}

4) O curso contribuiu para o seu aperfeiçoamento profissional?

\begin{tabular}{|l|l|}
\hline$X$ & SIM \\
\hline & NÃO \\
\hline
\end{tabular}

5) Os conhecimentos adquiridos estão sendo aplicados no seu trabalho? Em caso afirmativo, indique em que grau estes conhecimentos estão sendo aplicados. Em caso negativo, indique por que razão isto não ocorre:

\begin{tabular}{|c|c|c|}
\hline \multirow{3}{*}{$\begin{array}{l}\text { SIM (indique ao lado em } \\
\text { que grau) }\end{array}$} & $\mathrm{x}$ & MUITO APLICADOS \\
\hline & & MEDIAMENTE APLICADOS \\
\hline & & POUCO APLICADOS \\
\hline \multirow{2}{*}{$\begin{array}{l}\text { NÃO (indique ao lado a } \\
\text { razão da não aplicação) }\end{array}$} & & $\begin{array}{l}\text { CONTEÚDO NĀO ADEQUADO ȦS NECESSIDADES } \\
\text { ESPECÍFICAS DA REGIÃO }\end{array}$ \\
\hline & & $\begin{array}{l}\text { CONTEÚDO NÃO FOI SUFICIENTEMENTE } \\
\text { APROFUNDADO PARA PERMITIR UMA APLICAÇÃO } \\
\text { EFICAZ E EFICIENTE }\end{array}$ \\
\hline
\end{tabular}




\begin{tabular}{|l|l|l|}
\hline \multirow{2}{*}{} & & $\begin{array}{l}\text { FALTA DE APOIO E INCENTIVO DA MINHA } \\
\text { INSTITUIÇÃO }\end{array}$ \\
\cline { 2 - 4 } & & FALTA DE INCENTIVO ÀS AÇÕES DE ATER \\
\cline { 2 - 3 } & & NÃO TENHO INTERESSE EM APLICAR \\
\hline
\end{tabular}

6) A partir deste curso:

\begin{tabular}{|c|l|}
\hline$x$ & $\begin{array}{l}\text { NÃO MUDOU NADA EM MEU TRABALHO. } \\
\text { FAMILIARES. }\end{array}$ \\
\hline$X$ & CONSEGUI INFLUENCIAR NAS ORIENTAÇÕES DA MINHA INSTITUIÇÃO. \\
\hline & PASSEI A TRABALHAR COM METODOLOGIAS PARTICIPATIVAS. \\
\hline & $\begin{array}{l}\text { CRESCEU A ÁREA DE AGRICULTURA DE BASE ECOLÓGICA NAS COMUNIDADES } \\
\text { ONDE ATUO. }\end{array}$ \\
\hline$X$ & CONTINUEI ME APERFEIÇOANDO SOBRE TEMAS ABORDADOS. \\
\hline
\end{tabular}

7) Depois do curso você apoiou atividades de capacitação de técnicos e agricultores com base nos princípios e diretrizes da Pnater?

\begin{tabular}{|l|l|}
\hline$X$ & SIM \\
\hline & NÃO \\
\hline
\end{tabular}

8) Usou os conhecimentos para ministrar outros cursos com o mesmo conteúdo ou conteúdos semelhantes?

\begin{tabular}{|l|l|}
\hline & SIM \\
\hline$X$ & NÃO \\
\hline
\end{tabular}

9) Marque o seu grau de satisfação com relação ao curso oferecido pelo DATER: 


\begin{tabular}{|l|l|l|l|l|}
\hline 1 & 2 & 3 & 4 & $5 X$ \\
\hline
\end{tabular}

10) Marque seu grau de satisfação com relação ao DATER:

\begin{tabular}{|l|l|l|l|l|}
\hline 1 & 2 & 3 & 4 & $5 \times$ \\
\hline
\end{tabular}


PESQUISA - IMPACTO DAS AÇÕES DE FORMAÇÃO REALIZADAS PELO DATER/SAF/MDA NO PERÍODO 2004-2009

Caros colaboradores,

Contamos com a sua atenção para preencher o formulário abaixo.

O mesmo tem por objetivo fornecer informações para avaliação da Eficiência, Efetividade e Eficácia da Política Pública de Formação de Agentes de Ater adotada pelo Departamento de Assistência Técnica e Extensão Rural, da Secretaria de Agricultura Familiar do Ministério do Desenvolvimento - DATER/SAF/MDA, no período de 2004 a 2009, tema escolhido para Monografia a ser apresentada à Universidade de Brasília (UnB) como requisito parcial para obtenção do grau de Bacharel em Administração.

Você poderá ou não se identificar no questionário e garantimos que todas as informações fornecidas serão confidenciais e utilizadas apenas de forma sistematizada.

IDENTIFICAÇÃO

\begin{tabular}{|c|c|}
\hline Nome: ALADIA FREGOLENTE & $\begin{array}{l}\text { Sexo: } \\
(\quad) \text { masculino }\end{array}$ \\
\hline $\begin{array}{l}\text { Instituição (nome e tipo de instituição: ONG, } \\
\text { Empresa Pública, etc.): ASSOCIAÇÃO DE } \\
\text { ASSISTENCIA TÉCNICA E EXTENSÃO RURAL } \\
\text { DO ESTADO DE RONDONIA - EMATER-RO. }\end{array}$ & $\begin{array}{l}\text { Local de trabalho (Cidade e Estado): } \\
\text { JI-PARANÁ-RO }\end{array}$ \\
\hline \multicolumn{2}{|c|}{$\begin{array}{l}\text { Curso/Encontro/Oficina do qual participou (caso tenha participado de mais de um curso, preencha } \\
\text { um formulário para cada um deles): CURSO DE FORMAÇÃO DE FORMADORES PARA } \\
\text { AGENTES DE ATER EM METODOLOGIAS PARTICIPATIVAS. }\end{array}$} \\
\hline$d r C$ & 2). \\
\hline
\end{tabular}

1. Indique sua área de atuação? (As respostas não são excludentes: você poderá marcar mais de uma opção).

\begin{tabular}{|l|l|}
\hline$X$ & EXTENSÃO RURAL \\
\hline & PESQUISA \\
\hline & ENSINO \\
\hline & OUTROS \\
\hline
\end{tabular}

2) Qual o seu nível de escolaridade? 


\begin{tabular}{|l|l|}
\hline & NÍVEL MÉDIO \\
\hline & NÍVEL SUPERIOR \\
\hline$X$ & PÓS-GRADUAÇÃO \\
\hline
\end{tabular}

3) Os conteúdos abordados foram condizentes com as demandas do seu dia-a-dia?

\begin{tabular}{|l|l|}
\hline$X$ & SIM \\
\hline & PARCIALMENTE \\
\hline & NÃO \\
\hline
\end{tabular}

4) O curso contribuiu para o seu aperfeiçoamento profissional?

\begin{tabular}{|l|l|}
\hline$X$ & SIM \\
\hline & NÃO \\
\hline
\end{tabular}

5) Os conhecimentos adquiridos estão sendo aplicados no seu trabalho? Em caso afirmativo, indique em que grau estes conhecimentos estão sendo aplicados. Em caso negativo, indique por que razão isto não ocorre:

\begin{tabular}{|c|c|c|}
\hline \multirow{3}{*}{$\begin{array}{l}\text { SIM (indique ao lado em } \\
\text { que grau) }\end{array}$} & $X$ & MUITO APLICADOS \\
\hline & & MEDIAMENTE APLICADOS \\
\hline & & POUCO APLICADOS \\
\hline \multirow{5}{*}{$\begin{array}{l}\text { NÃO (indique ao lado a } \\
\text { razão da não aplicação) }\end{array}$} & & $\begin{array}{l}\text { CONTEÚDO NÃO ADEQUADO ȦS NECESSIDADES } \\
\text { ESPECÍFICAS DA REGIÃO }\end{array}$ \\
\hline & & $\begin{array}{l}\text { CONTEÚDO NÃO FOI SUFICIENTEMENTE } \\
\text { APROFUNDADO PARA PERMITIR UMA APLICAÇÃO } \\
\text { EFICAZ E EFICIENTE }\end{array}$ \\
\hline & & $\begin{array}{lcccccc}\text { FALTA } & \text { DE } & \text { APOIO } & \text { E } & \text { INCENTIVO } & \text { DA } & \text { MINHA } \\
\text { INSTITUIÇÃO } & & & & & \\
\end{array}$ \\
\hline & & FALTA DE INCENTIVO ÀS AÇÕES DE ATER \\
\hline & & NÃO TENHO INTERESSE EM APLICAR \\
\hline
\end{tabular}


6) A partir deste curso: (As respostas não são excludentes: você poderá marcar mais de uma opção).

\begin{tabular}{|c|c|}
\hline & NÃO MUDOU NADA EM MEU TRABALHO. \\
\hline $\mathrm{X}$ & $\begin{array}{l}\text { MEU TRABALHO PASSOU A CONTRIBUIR MAIS COM OS AGRICULTORES (AS) } \\
\text { FAMILIARES. }\end{array}$ \\
\hline $\mathrm{X}$ & CONSEGUI INFLUENCIAR NAS ORIENTAÇÕES DA MINHA INSTITUIÇÃO. \\
\hline \multirow[t]{2}{*}{$\mathrm{X}$} & PASSEI A TRABALHAR COM METODOLOGIAS PARTICIPATIVAS. \\
\hline & $\begin{array}{l}\text { CRESCEU A ÁREA DE AGRICULTURA DE BASE ECOLÓGICA NAS COMUNIDADES } \\
\text { ONDE ATUO. }\end{array}$ \\
\hline$X$ & CONTINUEI ME APERFEIÇOANDO SOBRE TEMAS ABORDADOS. \\
\hline
\end{tabular}

7) Depois do curso você apoiou atividades de capacitação de técnicos e agricultores com base nos princípios e diretrizes da Pnater? (Considere como apoio a atividades de capacitação a participação no planejamento, elaboração de ementas, seleção de participantes e de palestrantes.)

\begin{tabular}{|l|l|}
\hline$X$ & SIM \\
\hline & NÃO \\
\hline
\end{tabular}

8) Usou os conhecimentos para ministrar outros cursos com o mesmo conteúdo ou conteúdos semelhantes?

\begin{tabular}{|l|l|}
\hline$X$ & SIM \\
\hline & NÃO \\
\hline
\end{tabular}

9) Marque o seu grau de satisfação com relação ao curso oferecido pelo DATER: (Considere a seguinte pontuação: 1 - MUITO RUIM; 2 - RUIM; 3 - REGULAR; 4 - BOM; 5 - MUITO BOM) 


\begin{tabular}{|l|l|l|l|l|}
\hline 1 & 2 & 3 & 4 & $x$ \\
\hline
\end{tabular}

10) Marque seu grau de satisfação com relação ao DATER: (Considere a seguinte pontuação: 1 - MUITO RUIM; 2 - RUIM; 3 - REGULAR; 4 - BOM; 5 - MUITO BOM)

\begin{tabular}{|l|l|l|l|l|}
\hline 1 & 2 & 3 & 4 & $X$ \\
\hline
\end{tabular}


PESQUISA - IMPACTO DAS AÇÕES DE FORMAÇÃO REALIZADAS PELO DATER/SAF/MDA NO PERÍODO 2004-2009

Caros colaboradores,

Contamos com a sua atenção para preencher o formulário abaixo.

O mesmo tem por objetivo fornecer informações para avaliação da Eficiência, Efetividade e Eficácia da Política Pública de Formação de Agentes de Ater adotada pelo Departamento de Assistência Técnica e Extensão Rural, da Secretaria de Agricultura Familiar do Ministério do Desenvolvimento - DATER/SAF/MDA, no período de 2004 a 2009, tema escolhido para Monografia a ser apresentada à Universidade de Brasília (UnB) como requisito parcial para obtenção do grau de Bacharel em Administração.

Você poderá ou não se identificar no questionário e garantimos que todas as informações fornecidas serão confidenciais e utilizadas apenas de forma sistematizada.

IDENTIFICAÇÃO

\begin{tabular}{|c|c|}
\hline Nome: ALADIA FREGOLENTE & $\begin{array}{l}\text { Sexo: } \\
(\quad) \text { masculino }\end{array}$ \\
\hline $\begin{array}{l}\text { Instituição (nome e tipo de instituição: ONG, } \\
\text { Empresa Pública, etc.): ASSOCIAÇÃO DE } \\
\text { ASSISTENCIA TÉCNICA E EXZTENSÃO RURAL } \\
\text { DO ESTADO DE RONDONIA - EMATER-RO. }\end{array}$ & $\begin{array}{l}\text { Local de trabalho (Cidade e Estado): } \\
\text { JI-PARANÁ-RO }\end{array}$ \\
\hline \multicolumn{2}{|c|}{$\begin{array}{l}\text { Curso/Encontro/Oficina do qual participou (caso tenha participado de mais de um curso, preencha } \\
\text { um formulário para cada um deles): OFICINA DE NIVELAMENTO CONCEITUAL DA POLITICA } \\
\text { NACIONAL DE ATER. }\end{array}$} \\
\hline $\operatorname{trn} / \cap$ fici & 2) $\mathrm{N}$ \\
\hline
\end{tabular}

1)Indique sua área de atuação? (As respostas não são excludentes: você poderá marcar mais de uma opção).

\begin{tabular}{|l|l|}
\hline$X$ & EXTENSÃO RURAL \\
\hline & PESQUISA \\
\hline & ENSINO \\
\hline & OUTROS \\
\hline
\end{tabular}

2) Qual o seu nível de escolaridade? 


\begin{tabular}{|l|l|}
\hline & NÍVEL MÉDIO \\
\hline & NÍVEL SUPERIOR \\
\hline$X$ & PÓS-GRADUAÇÃO \\
\hline
\end{tabular}

3) Os conteúdos abordados foram condizentes com as demandas do seu dia-a-dia?

\begin{tabular}{|l|l|}
\hline$X$ & SIM \\
\hline & PARCIALMENTE \\
\hline & NÃO \\
\hline
\end{tabular}

4) O curso contribuiu para o seu aperfeiçoamento profissional?

\begin{tabular}{|l|l|}
\hline$X$ & SIM \\
\hline & NÃO \\
\hline
\end{tabular}

5) Os conhecimentos adquiridos estão sendo aplicados no seu trabalho? Em caso afirmativo, indique em que grau estes conhecimentos estão sendo aplicados. Em caso negativo, indique por que razão isto não ocorre:

\begin{tabular}{|c|c|c|}
\hline \multirow{3}{*}{$\begin{array}{l}\text { SIM (indique ao lado em } \\
\text { que grau) }\end{array}$} & $X$ & MUITO APLICADOS \\
\hline & & MEDIAMENTE APLICADOS \\
\hline & & POUCO APLICADOS \\
\hline \multirow{5}{*}{$\begin{array}{l}\text { NÃO (indique ao lado a } \\
\text { razão da não aplicação) }\end{array}$} & & $\begin{array}{l}\text { CONTEÚDO NÃO ADEQUADO ȦS NECESSIDADES } \\
\text { ESPECÍFICAS DA REGIÃO }\end{array}$ \\
\hline & & $\begin{array}{l}\text { CONTEÚDO NÃO FOI SUFICIENTEMENTE } \\
\text { APROFUNDADO PARA PERMITIR UMA APLICAÇÃO } \\
\text { EFICAZ E EFICIENTE }\end{array}$ \\
\hline & & $\begin{array}{lcccccc}\text { FALTA } & \text { DE } & \text { APOIO } & \text { E } & \text { INCENTIVO } & \text { DA } & \text { MINHA } \\
\text { INSTITUIÇÃO } & & & & & \\
\end{array}$ \\
\hline & & FALTA DE INCENTIVO ÀS AÇÕES DE ATER \\
\hline & & NÃO TENHO INTERESSE EM APLICAR \\
\hline
\end{tabular}


6) A partir deste curso: (As respostas não são excludentes: você poderá marcar mais de uma opção).

\begin{tabular}{|l|l|}
\hline & NÃO MUDOU NADA EM MEU TRABALHO. \\
\hline$X$ & $\begin{array}{l}\text { MEU TRABALHO PASSOU A CONTRIBUIR MAIS COM OS AGRICULTORES (AS) } \\
\text { FAMILIARES. }\end{array}$ \\
\hline$X$ & CONSEGUI INFLUENCIAR NAS ORIENTAÇÕES DA MINHA INSTITUIÇÃO. \\
\hline$X$ & PASSEI A TRABALHAR COM METODOLOGIAS PARTICIPATIVAS. \\
\hline & $\begin{array}{l}\text { CRESCEU A ÁREA DE AGRICULTURA DE BASE ECOLÓGICA NAS COMUNIDADES } \\
\text { ONDE ATUO. }\end{array}$ \\
\hline$X$ & CONTINUEI ME APERFEIÇOANDO SOBRE TEMAS ABORDADOS. \\
\hline
\end{tabular}

7) Depois do curso você apoiou atividades de capacitação de técnicos e agricultores com base nos princípios e diretrizes da Pnater? (Considere como apoio a atividades de capacitação a participação no planejamento, elaboração de ementas, seleção de participantes e de palestrantes.)

\begin{tabular}{|l|l|}
\hline$X$ & SIM \\
\hline & NÃO \\
\hline
\end{tabular}

8) Usou os conhecimentos para ministrar outros cursos com o mesmo conteúdo ou conteúdos semelhantes?

\begin{tabular}{|l|l|}
\hline$X$ & SIM \\
\hline & NÃO \\
\hline
\end{tabular}

9) Marque o seu grau de satisfação com relação ao curso oferecido pelo DATER: (Considere a seguinte pontuação: 1 - MUITO RUIM; 2 - RUIM; 3 - REGULAR; 4 - BOM; 5 - MUITO BOM)

\begin{tabular}{|l|l|l|l|l|}
\hline 1 & 2 & 3 & 4 & $x$ \\
\hline
\end{tabular}


10) Marque seu grau de satisfação com relação ao DATER: (Considere a seguinte pontuação: 1 - MUITO RUIM; 2 - RUIM; 3 - REGULAR; 4 - BOM; 5 - MUITO BOM)

\begin{tabular}{|l|l|l|l|l|}
\hline 1 & 2 & 3 & 4 & $X$ \\
\hline
\end{tabular}


PESQUISA - IMPACTO DAS AÇÕES DE FORMAÇÃO REALIZADAS PELO DATER/SAF/MDA NO PERÍODO 2004-2009

Caros colaboradores,

Contamos com a sua atenção para preencher o formulário abaixo.

O mesmo tem por objetivo fornecer informações para avaliação da Eficiência, Efetividade e Eficácia da Política Pública de Formação de Agentes de Ater adotada pelo Departamento de Assistência Técnica e Extensão Rural, da Secretaria de Agricultura Familiar do Ministério do Desenvolvimento - DATER/SAF/MDA, no período de 2004 a 2009, tema escolhido para Monografia a ser apresentada à Universidade de Brasília (UnB) como requisito parcial para obtenção do grau de Bacharel em Administração.

Você poderá ou não se identificar no questionário e garantimos que todas as informações fornecidas serão confidenciais e utilizadas apenas de forma sistematizada.

IDENTIFICAÇÃO

\begin{tabular}{|l|l|}
\hline NOME: AILSON DOS SANTOS CARDOSO & $\begin{array}{l}\text { Sexo: } \\
(\mathrm{x}) \text { masculino } \quad(\quad \text { ) feminino }\end{array}$ \\
\hline $\begin{array}{l}\text { Instituição (nome e tipo de instituição: ONG, Empresa } \\
\text { Pública, etc). }\end{array}$ & Local de Trabalho (cidade, Estado). \\
•EMATER-PARÁ (Empresa Pública) & - Santo Antonio do Tauá - Pará \\
\hline $\begin{array}{l}\text { Curso,/Encontro/Oficina do qual participou (caso tenha participado de mais de um curso, preencha } \\
\text { um formulário para cada um deles) } \\
\text { - Curso de Formação de ADR. }\end{array}$ \\
\hline $\begin{array}{l}\text { Data do Curso/Encontro/Oficina (pelo menos mês e ano): } \\
\text { - Dezembro de 2006. }\end{array}$
\end{tabular}

Identifique sua área de atuação(As respostas não são excludentes: você poderá marcar mais de uma opção).

\begin{tabular}{|l|l|l|l|}
\hline$x$ & EXTENSÃO RURAL & & PESQUISA \\
\hline & ENSINO & OUTROS \\
\hline
\end{tabular}

2) Qual o seu nível de Escolaridade?

\begin{tabular}{|l|l|l|l|}
\hline$x$ & NÍVEL MÉDIO & & NIVEL SUPERIOR \\
\hline & PÓS GRADUAÇÃO & & \\
\hline
\end{tabular}


3) Os conteúdos abordados foram condizentes com as demandas do seu dia-a-dia?

\begin{tabular}{|l|l|l|l|}
\hline$x$ & SIM & & NÃO \\
\hline & PARCIALMENTE & & \\
\hline
\end{tabular}

4) O curso contribuiu para o aperfeiçoamento profissional?

\begin{tabular}{|l|l|l|l|}
\hline$x$ & SIM & & NÃO \\
\hline
\end{tabular}

5) Os conhecimentos adquiridos estão sendo aplicados no seu trabalho? Em caso afirmativo, indique em que grau estes conhecimentos estão sendo aplicados. Em caso negativo, indique por que razão isto não ocorre:

\begin{tabular}{|c|c|c|}
\hline \multirow{3}{*}{$\begin{array}{l}\text { SIM, indique ao } \\
\text { lado em que grau. }\end{array}$} & & MUITO APLICADOS \\
\hline & $\mathrm{x}$ & MEDIAMENTE APLICADOS \\
\hline & & POUCO APLICADOS \\
\hline \multirow{5}{*}{$\begin{array}{l}\text { NÃO, (indique ao } \\
\text { lado a razão da } \\
\text { não aplicação). }\end{array}$} & & $\begin{array}{l}\text { CONTEÚDO NÃO ADEQUADO ÀS NECESSIDADES ESPECÍFICAS } \\
\text { DA REGIÃO }\end{array}$ \\
\hline & & $\begin{array}{l}\text { CONTEÚDO NÃO FOI SUFICIENTEMENTE APROFUNDADO PARA } \\
\text { PERMITIR UMA APLICAÇÃO EFICAZ E EFICIENTE }\end{array}$ \\
\hline & & FALTA DE APOIO E INCENTIVO DA MINHA INSTITUIÇÃO \\
\hline & & FALTA DE INCENTIVO ÀS AÇÕES DE ATER \\
\hline & & NÃO TENHO INTERESSE EM APLICAR; \\
\hline
\end{tabular}

6) A partir deste Curso: (As respostas não são excludentes: você poderá marcar mais de uma opção).

\begin{tabular}{|l|l|}
\hline$x$ & $\begin{array}{l}\text { NÃO MUDOU NADA EM MEU TRABALHO } \\
\text { FAMILIARES }\end{array}$ \\
\hline & CONSEGUI INFLUENCIAR NAS ORIENTAÇÕES DA MINHA INSTITUIÇÃO \\
\hline$x$ & PASSEI A TRABALHAR COM METODOLOGIAS PARTICIPATIVAS \\
\hline & $\begin{array}{l}\text { CRESCEU A ÁREA DE AGRICULTURA DE BASE ECOLÓGICA NAS COMUNIDADES ONDE } \\
\text { ATUO CONTRIBUIR MAIS COM OS AGRICULTORES (AS ) }\end{array}$ \\
\hline & CONTINUEI ME APERFEIÇOANDO SOBRE TEMAS ABORDADOS \\
\hline
\end{tabular}

7) Depois do curso você apoiou atividades de capacitação de técnicos e agricultores com base nos princípios e diretrizes do PNATER? (Considere como apoio a atividades de capacitação a 
participação no planejamento, elaboração de ementas, seleção de participantes e de palestrantes.)

\begin{tabular}{|l|l|l|l|}
\hline$x$ & SIM & & NÃO \\
\hline
\end{tabular}

8) Usou conhecimentos para ministrar outros cursos com o mesmo conteúdo ou conteúdos semelhantes?

\begin{tabular}{|l|l|l|l|}
\hline & SIM & $x$ & NÃO \\
\hline & & & \\
\hline
\end{tabular}

9) Marque o seu grau de satisfação com relação ao curso oferecido pelo DATER(Considere a seguinte pontuação: 1 - MUITO RUIM; 2 - RUIM; 3 - REGULAR; 4 - BOM; 5 - MUITO BOM)

\begin{tabular}{|l|l|l|l|l|}
\hline 1 & 2 & 3 & $4(x)$ & 5 \\
\hline
\end{tabular}

10) Marque o seu grau de satisfação em relação ao DATER(Considere a seguinte pontuação:

1 - MUITO RUIM; 2 - RUIM; 3 - REGULAR; 4 - BOM; 5 - MUITO BOM)

\begin{tabular}{|l|l|l|l|l|}
\hline 1 & 2 & 3 & 4 & $5(x)$ \\
\hline
\end{tabular}


PESQUISA - IMPACTO DAS AÇÕES DE FORMAÇÃO REALIZADAS PELO DATER/SAF/MDA NO PERÍODO 2004-2009

Caros colaboradores,

Contamos com a sua atenção para preencher o formulário abaixo.

O mesmo tem por objetivo fornecer informações para avaliação da Eficiência, Efetividade e Eficácia da Política Pública de Formação de Agentes de Ater adotada pelo Departamento de Assistência Técnica e Extensão Rural, da Secretaria de Agricultura Familiar do Ministério do Desenvolvimento - DATER/SAF/MDA, no período de 2004 a 2009, tema escolhido para Monografia a ser apresentada à Universidade de Brasília (UnB) como requisito parcial para obtenção do grau de Bacharel em Administração.

Você poderá ou não se identificar no questionário e garantimos que todas as informações fornecidas serão confidenciais e utilizadas apenas de forma sistematizada.

IDENTIFICAÇÃO

\begin{tabular}{|l|l|}
\hline Nome: Adriano Alex S. e Rosário & $\begin{array}{l}\text { Sexo: } \\
(\mathrm{x}) \text { masculino } \quad(\quad \text { ) feminino }\end{array}$ \\
\hline $\begin{array}{l}\text { Instituição: Serviço Alemão de Cooperação Técnica } \\
\text { e Social - DED/CONDIAC }\end{array}$ & $\begin{array}{l}\text { Local de trabalho (Cidade e Estado): } \\
\text { Epitaciolândia/Acre }\end{array}$ \\
\hline $\begin{array}{l}\text { Curso/Encontro/Oficina do qual participou (caso tenha participado de mais de um curso, preencha } \\
\text { um formulário para cada um deles): } \\
\text { Curso de Nivelamento Técnicos para Técnicos Extensionaista da Região Norte }\end{array}$ \\
$\begin{array}{l}\text { Data do Curso/Encontro/Oficina (pelo menos mês e ano): Janeiro ou Fevereiro de 2005/ } \\
\text { Bélem/PA }\end{array}$
\end{tabular}

1. Indique sua área de atuação? (As respostas não são excludentes: você poderá marcar mais de uma opção).

\begin{tabular}{|l|l|}
\hline$x$ & EXTENSÃO RURAL \\
\hline & PESQUISA \\
\hline & ENSINO \\
\hline$x$ & OUTROS \\
\hline
\end{tabular}


2) Qual o seu nível de escolaridade?

\begin{tabular}{|l|l|}
\hline & NÍVEL MÉDIO \\
\hline$x$ & NÍVEL SUPERIOR \\
\hline & PÓS-GRADUAÇÃO \\
\hline
\end{tabular}

3) Os conteúdos abordados foram condizentes com as demandas do seu dia-a-dia?

\begin{tabular}{|l|l|}
\hline$x$ & SIM \\
\hline & PARCIALMENTE \\
\hline & NÃO \\
\hline
\end{tabular}

4) O curso contribuiu para o seu aperfeiçoamento profissional?

\begin{tabular}{|l|l|}
\hline$x$ & SIM \\
\hline & NÃO \\
\hline
\end{tabular}

5) Os conhecimentos adquiridos estão sendo aplicados no seu trabalho? Em caso afirmativo, indique em que grau estes conhecimentos estão sendo aplicados. Em caso negativo, indique por que razão isto não ocorre:

\begin{tabular}{|c|c|c|}
\hline \multirow{3}{*}{$\begin{array}{l}\text { SIM (indique ao lado em } \\
\text { que grau) }\end{array}$} & $x$ & MUITO APLICADOS \\
\hline & & MEDIAMENTE APLICADOS \\
\hline & & POUCO APLICADOS \\
\hline \multirow{3}{*}{$\begin{array}{l}\text { NÃO (indique ao lado a } \\
\text { razão da não aplicação) }\end{array}$} & & $\begin{array}{l}\text { CONTEÚDO NÃO ADEQUADO ȦS NECESSIDADES } \\
\text { ESPECÍFICAS DA REGIÃO }\end{array}$ \\
\hline & & $\begin{array}{l}\text { CONTEÚDO NÃO } \quad \text { FOI SUFICIENTEMENTE } \\
\text { APROFUNDADO PARA } \\
\text { PERMITIR UMA APLICAÇÃO } \\
\text { EFICAZ E EFICIENTE }\end{array}$ \\
\hline & & $\begin{array}{l}\text { FALTA DE APOIO } \\
\text { INSTITUIÇÃO }\end{array}$ \\
\hline
\end{tabular}




\begin{tabular}{|l|l|l|}
\hline \multirow{2}{*}{} & & FALTA DE INCENTIVO ÀS AÇÕES DE ATER \\
\cline { 3 - 4 } & & NÃO TENHO INTERESSE EM APLICAR \\
\hline
\end{tabular}

6) A partir deste curso: (As respostas não são excludentes: você poderá marcar mais de uma opção).

\begin{tabular}{|l|l|}
\hline & NÃO MUDOU NADA EM MEU TRABALHO. \\
\hline$x$ & $\begin{array}{l}\text { MEU TRABALHO PASSOU A CONTRIBUIR MAIS COM OS AGRICULTORES(AS) } \\
\text { FAMILIARES. }\end{array}$ \\
\hline$x$ & CONSEGUI INFLUENCIAR NAS ORIENTAÇÕES DA MINHA INSTITUIÇÃO. \\
\hline & $\begin{array}{l}\text { PASSEI A TRABALHAR COM METODOLOGIAS PARTICIPATIVAS. } \\
\text { ONDE ATUO. }\end{array}$ \\
\hline & CONTINUEI ME APERFEIÇOANDO SOBRE TEMAS ABORDADOS. \\
\hline
\end{tabular}

7) Depois do curso você apoiou atividades de capacitação de técnicos e agricultores com base nos princípios e diretrizes da Pnater? (Considere como apoio a atividades de capacitação a participação no planejamento, elaboração de ementas, seleção de participantes e de palestrantes.)

\begin{tabular}{|l|l|}
\hline$x$ & SIM \\
\hline & NÃO \\
\hline
\end{tabular}

8) Usou os conhecimentos para ministrar outros cursos com o mesmo conteúdo ou conteúdos semelhantes?

\begin{tabular}{|l|l|}
\hline$x$ & SIM \\
\hline & NÃO \\
\hline
\end{tabular}


9) Marque o seu grau de satisfação com relação ao curso oferecido pelo DATER: (Considere a seguinte pontuação: 1 - MUITO RUIM; 2 - RUIM; 3 - REGULAR; 4 - BOM; 5 - MUITO BOM)

\begin{tabular}{|l|l|l|l|l|}
\hline 1 & 2 & 3 & 4 & 5 \\
\hline
\end{tabular}

10) Marque seu grau de satisfação com relação ao DATER: (Considere a seguinte pontuação: 1 - MUITO RUIM; 2 - RUIM; 3 - REGULAR; 4 - BOM; 5 - MUITO BOM)

\begin{tabular}{|l|l|l|l|l|}
\hline 1 & 2 & 3 & 4 & 5 \\
\hline
\end{tabular}


PESQUISA - IMPACTO DAS AÇÕES DE FORMAÇÃO REALIZADAS PELO DATER/SAF/MDA NO PERÍODO 2004-2009

Caros colaboradores,

Contamos com a sua atenção para preencher o formulário abaixo.

O mesmo tem por objetivo fornecer informações para avaliação da Eficiência, Efetividade e Eficácia da Política Pública de Formação de Agentes de Ater adotada pelo Departamento de Assistência Técnica e Extensão Rural, da Secretaria de Agricultura Familiar do Ministério do Desenvolvimento - DATER/SAF/MDA, no período de 2004 a 2009, tema escolhido para Monografia a ser apresentada à Universidade de Brasília $(U n B)$ como requisito parcial para obtenção do grau de Bacharel em Administração.

Você poderá ou não se identificar no questionário e garantimos que todas as informações fornecidas serão confidenciais e utilizadas apenas de forma sistematizada.

\section{IDENTIFICAÇÃO}

\begin{tabular}{|c|c|}
\hline Nome: NEUDA MARIA DE LIMA & $\begin{array}{l}\text { Sexo: } \\
(\quad \text { ) masculino }\end{array}$ \\
\hline $\begin{array}{l}\text { Instituição (nome e tipo de instituição: ONG, } \\
\text { Empresa Pública, etc.): } \\
\text { Instituto de Desenvolvimento Agropecuário do } \\
\text { Estado do Amazonas - IDAM }\end{array}$ & $\begin{array}{l}\text { Local de trabalho (Cidade e Estado): } \\
\text { Manaus - AM }\end{array}$ \\
\hline \multicolumn{2}{|c|}{$\begin{array}{l}\text { Curso/Encontro/Oficina do qual participou (caso tenha participado de mais de um curso, preencha } \\
\text { um formulário para cada um deles): } \\
\text { Seminário - Agroecologia como Estratégia para a Construção do Desenvolvimento Rural } \\
\text { Sustentável. }\end{array}$} \\
\hline $\begin{array}{l}\text { Data do Curso/Encontro/Oficina (pelo menos mês e a } \\
10 \text { a } 11 \text { de agosto de } 2006 \text { - Manaus/AM }\end{array}$ & רo): \\
\hline
\end{tabular}

1. Indique sua área de atuação? (As opções não são excludentes: você poderá marcar mais de uma opção)

\begin{tabular}{|l|l}
\hline$X$ & EXTENSÃO RURAL \\
\hline
\end{tabular} 


\begin{tabular}{|l|l|}
\hline & PESQUISA \\
\hline & ENSINO \\
\hline & OUTROS \\
\hline
\end{tabular}

2) Qual o seu nível de escolaridade? (Considere apenas o nível mais alto)

\begin{tabular}{|l|l|}
\hline & NÍVEL MÉDIO \\
\hline & NÍVEL SUPERIOR \\
\hline$X$ & PÓS-GRADUAÇÃO \\
\hline
\end{tabular}

3) Os conteúdos abordados foram condizentes com as demandas do seu dia-a-dia?

\begin{tabular}{|l|l|}
\hline$X$ & SIM \\
\hline & PARCIALMENTE \\
\hline & NÃO \\
\hline
\end{tabular}

4) O curso contribuiu para o seu aperfeiçoamento profissional?

\begin{tabular}{|l|l|}
\hline$X$ & SIM \\
\hline & NÃO \\
\hline
\end{tabular}

5) Os conhecimentos adquiridos estão sendo aplicados no seu trabalho? Em caso afirmativo, indique em que grau estes conhecimentos estão sendo aplicados. Em caso negativo, indique por que razão isto não ocorre: (Em caso negativo, as respostas não são excludentes: você poderá marcar mais de uma opção).

\begin{tabular}{|l|l|l|l|}
\hline \multirow{2}{*}{$\begin{array}{l}\text { SIM (indique ao lado em } \\
\text { que grau) }\end{array}$} & $\mathrm{X}$ & MUITO APLICADOS \\
\cline { 2 - 3 } & & MEDIAMENTE APLICADOS \\
\hline & $\begin{array}{l}\text { NÃO (indique ao lado a } \\
\text { razão da não aplicação) }\end{array}$ & $\begin{array}{l}\text { CONTEÚDO NÃO ADEQUADO ÀS NECESSIDADES } \\
\text { ESPECÍFICAS DA REGIÃO }\end{array}$ \\
\hline
\end{tabular}




\begin{tabular}{|l|l|l|}
\hline \multirow{10}{*}{} & $\begin{array}{l}\text { CONTEÚDO NÃO FOI SUFICIENTEMENTE } \\
\text { APROFUNDADO PARA PERMITIR UMA APLICAÇÃO } \\
\text { EFICAZ E EFICIENTE }\end{array}$ \\
\cline { 2 - 4 } & $\begin{array}{l}\text { FALTA DE APOIO E INCENTIVO DA MINHA } \\
\text { INSTITUIÇÃO }\end{array}$ \\
\cline { 2 - 4 } & FALTA DE INCENTIVO ÀS AÇÕES DE ATER \\
\hline & NÃO TENHO INTERESSE EM APLICAR \\
\hline
\end{tabular}

6) A partir deste curso: (As opções não são excludentes: você poderá marcar mais de uma opção)

\begin{tabular}{|l|l|}
\hline & NÃO MUDOU NADA EM MEU TRABALHO. \\
\hline & $\begin{array}{l}\text { MEU TRABALHO PASSOU A CONTRIBUIR MAIS COM OS AGRICULTORES(AS) } \\
\text { FAMILIARES. }\end{array}$ \\
\hline & CONSEGUI INFLUENCIAR NAS ORIENTAÇÕES DA MINHA INSTITUIÇÃO. \\
\hline & $\begin{array}{l}\text { CRESESE A TRABALHAR COM METODOLOGIAS PARTICIPATIVAS. } \\
\text { ONDE ATUO. ÁREA DE AGRICULTURA DE BASE ECOLÓGICA NAS COMUNIDADES }\end{array}$ \\
\hline$X$ & CONTINUEI ME APERFEIÇOANDO SOBRE TEMAS ABORDADOS. \\
\hline
\end{tabular}

7) Depois do curso você apoiou atividades de capacitação de técnicos e agricultores com base nos princípios e diretrizes da Pnater? (Considere como apoio a atividades de capacitação a participação no planejamento, elaboração de ementas, seleção de participantes e de palestrantes.)

\begin{tabular}{|l|l|}
\hline$X$ & SIM \\
\hline & NÃO \\
\hline
\end{tabular}

8) Usou os conhecimentos para ministrar outros cursos com o mesmo conteúdo ou conteúdos semelhantes? 


\begin{tabular}{|l|l|}
\hline & SIM \\
\hline & NÃO \\
\hline
\end{tabular}

9) Marque o seu grau de satisfação com relação ao curso oferecido pelo DATER: (Considere a seguinte pontuação: 1 - MUITO RUIM; 2 - RUIM; 3 - REGULAR; 4 - BOM; 5 - MUITO BOM)

\begin{tabular}{|l|l|l|l|l|}
\hline 1 & 2 & 3 & 4 & 5 \\
\hline
\end{tabular}

10) Marque seu grau de satisfação com relação ao DATER: (Considere a seguinte pontuação: 1 - MUITO RUIM; 2 - RUIM; 3 - REGULAR; 4 - BOM; 5 - MUITO BOM)

\begin{tabular}{|l|l|l|l|l|}
\hline 1 & 2 & 3 & 4 & 5 \\
\hline
\end{tabular}


PESQUISA - IMPACTO DAS AÇÕES DE FORMAÇÃO REALIZADAS PELO DATER/SAF/MDA NO PERÍODO 2004-2009

Caros colaboradores,

Contamos com a sua atenção para preencher o formulário abaixo.

O mesmo tem por objetivo fornecer informações para avaliação da Eficiência, Efetividade e Eficácia da Política Pública de Formação de Agentes de Ater adotada pelo Departamento de Assistência Técnica e Extensão Rural, da Secretaria de Agricultura Familiar do Ministério do Desenvolvimento - DATER/SAF/MDA, no período de 2004 a 2009, tema escolhido para Monografia a ser apresentada à Universidade de Brasília (UnB) como requisito parcial para obtenção do grau de Bacharel em Administração.

Você poderá ou não se identificar no questionário e garantimos que todas as informações fornecidas serão confidenciais e utilizadas apenas de forma sistematizada.

IDENTIFICAÇÃO

\begin{tabular}{|c|c|}
\hline Nome: JOSÉ SILVA MICHILES & $\begin{array}{l}\text { Sexo: } \\
(x) \text { masculino } \quad(\quad) \text { feminino }\end{array}$ \\
\hline $\begin{array}{l}\text { Instituição (nome e tipo de instituição: ONG, } \\
\text { Empresa Pública, etc.): } \\
\text { Instituto de Desenvolvimento Agropecuário do } \\
\text { Estado do Amazonas - IDAM }\end{array}$ & $\begin{array}{l}\text { Local de trabalho (Cidade e Estado): } \\
\text { Unidade Local de Silves - Amazonas }\end{array}$ \\
\hline \multicolumn{2}{|c|}{$\begin{array}{l}\text { Curso/Encontro/Oficina do qual participou (caso tenha participado de mais de um curso, preencha } \\
\text { um formulário para cada um deles): } \\
\text { Curso Diagnóstico Rural Participativo - DRP }\end{array}$} \\
\hline $\begin{array}{l}\text { Data do Curso/Encontro/Oficina (pelo menos mês e a } \\
16 \text { a } 27 \text { de outubro de } 2006 \text { - Manaus/AM }\end{array}$ & \\
\hline
\end{tabular}

1. Indique sua área de atuação? (As opções não são excludentes: você poderá marcar mais de uma opção)

\begin{tabular}{|l|l|}
\hline$X$ & EXTENSÃO RURAL \\
\hline & PESQUISA \\
\hline
\end{tabular}




\begin{tabular}{|l|l|}
\hline & ENSINO \\
\hline & OUTROS \\
\hline
\end{tabular}

2) Qual o seu nível de escolaridade? (Considere apenas o nível mais alto)

\begin{tabular}{|l|l|}
\hline$X$ & NÍVEL MÉDIO \\
\hline & NÍVEL SUPERIOR \\
\hline & PÓS-GRADUAÇÃO \\
\hline
\end{tabular}

3) Os conteúdos abordados foram condizentes com as demandas do seu dia-a-dia?

\begin{tabular}{|l|l|}
\hline & SIM \\
\hline$X$ & PARCIALMENTE \\
\hline & NÃO \\
\hline
\end{tabular}

4) O curso contribuiu para o seu aperfeiçoamento profissional?

\begin{tabular}{|l|l|}
\hline$X$ & SIM \\
\hline & NÃO \\
\hline
\end{tabular}

5) Os conhecimentos adquiridos estão sendo aplicados no seu trabalho? Em caso afirmativo, indique em que grau estes conhecimentos estão sendo aplicados. Em caso negativo, indique por que razão isto não ocorre: (Em caso negativo, as respostas não são excludentes: você poderá marcar mais de uma opção).

\begin{tabular}{|l|l|l|l|}
\hline \multirow{2}{*}{$\begin{array}{l}\text { SIM (indique ao lado em } \\
\text { que grau) }\end{array}$} & & MUITO APLICADOS \\
\cline { 2 - 4 } & $\mathrm{X}$ & MEDIAMENTE APLICADOS \\
\hline & $\begin{array}{l}\text { NÃO (indique ao lado a } \\
\text { razão da não aplicação) }\end{array}$ & & $\begin{array}{l}\text { CONTEÚDO NÃO ADEQUADO ȦS NECESSIDADES } \\
\text { ESPECÍFICAS DA REGIÃO }\end{array}$ \\
\hline
\end{tabular}




\begin{tabular}{|l|l|l|}
\hline \multirow{10}{*}{} & $\begin{array}{l}\text { CONTEÚDO NÃO FOI SUFICIENTEMENTE } \\
\text { APROFUNDADO PARA PERMITIR UMA APLICAÇÃO } \\
\text { EFICAZ E EFICIENTE }\end{array}$ \\
\cline { 2 - 4 } & $\begin{array}{l}\text { FALTA DE APOIO E INCENTIVO DA MINHA } \\
\text { INSTITUIÇÃO }\end{array}$ \\
\cline { 2 - 4 } & FALTA DE INCENTIVO ÀS AÇÕES DE ATER \\
\hline & NÃO TENHO INTERESSE EM APLICAR \\
\hline
\end{tabular}

6) A partir deste curso: (As opções não são excludentes: você poderá marcar mais de uma opção)

\begin{tabular}{|l|l|}
\hline$x$ & $\begin{array}{l}\text { NÃO MUDOU NADA EM MEU TRABALHO. } \\
\text { FAMILIARES. }\end{array}$ \\
\hline & CONSEGUI INFLUENCIAR NAS ORIENTAÇÕES DA MINHA INSTITUIÇÃO. \\
\hline$X$ & PASSEI A TRABALHAR COM METODOLOGIAS PARTICIPATIVAS. \\
\hline & $\begin{array}{l}\text { CRESCEU A ÁREA DE AGRICULTURA DE BASE ECOLÓGICA NAS COMUNIDADES } \\
\text { ONDE ATUO. }\end{array}$ \\
\hline$X$ & CONTINUEI ME APERFEIÇOANDO SOBRE TEMAS ABORDADOS. \\
\hline
\end{tabular}

7) Depois do curso você apoiou atividades de capacitação de técnicos e agricultores com base nos princípios e diretrizes da Pnater? (Considere como apoio a atividades de capacitação a participação no planejamento, elaboração de ementas, seleção de participantes e de palestrantes.)

\begin{tabular}{|l|l|}
\hline$X$ & SIM \\
\hline & NÃO \\
\hline
\end{tabular}

8) Usou os conhecimentos para ministrar outros cursos com o mesmo conteúdo ou conteúdos semelhantes? 


\begin{tabular}{|l|l|}
\hline & SIM \\
\hline$X$ & NÃO \\
\hline
\end{tabular}

9) Marque o seu grau de satisfação com relação ao curso oferecido pelo DATER: (Considere a seguinte pontuação: 1 - MUITO RUIM; 2 - RUIM; 3 - REGULAR; 4 - BOM; 5 - MUITO BOM)

\begin{tabular}{|l|l|l|l|l|}
\hline 1 & 2 & 3 & 4 & 5 \\
\hline
\end{tabular}

10) Marque seu grau de satisfação com relação ao DATER: (Considere a seguinte pontuação: 1 - MUITO RUIM; 2 - RUIM; 3 - REGULAR; 4 - BOM; 5 - MUITO BOM)

\begin{tabular}{|l|l|l|l|l|}
\hline 1 & 2 & 3 & 4 & 5 \\
\hline
\end{tabular}


PESQUISA - IMPACTO DAS AÇÕES DE FORMAÇÃO REALIZADAS PELO DATER/SAF/MDA NO PERÍODO 2004-2009

Caros colaboradores,

Contamos com a sua atenção para preencher o formulário abaixo.

O mesmo tem por objetivo fornecer informações para avaliação da Eficiência, Efetividade e Eficácia da Política Pública de Formação de Agentes de Ater adotada pelo Departamento de Assistência Técnica e Extensão Rural, da Secretaria de Agricultura Familiar do Ministério do Desenvolvimento - DATER/SAF/MDA, no período de 2004 a 2009, tema escolhido para Monografia a ser apresentada à Universidade de Brasília (UnB) como requisito parcial para obtenção do grau de Bacharel em Administração.

Você poderá ou não se identificar no questionário e garantimos que todas as informações fornecidas serão confidenciais e utilizadas apenas de forma sistematizada.

IDENTIFICAÇÃO

\begin{tabular}{|c|c|}
\hline Nome: MȦRIO FRANCISCO CALDAS ONO & $\begin{array}{l}\text { Sexo: } \\
(x) \text { masculino } \quad(\quad) \text { feminino }\end{array}$ \\
\hline $\begin{array}{l}\text { Instituição (nome e tipo de } \\
\text { Empresa Pública, etc.): Instituão: ONG, } \\
\text { Desenvolvimento Agropecuário do Estado do } \\
\text { Amazonas - IDAM }\end{array}$ & $\begin{array}{l}\text { Local de trabalho (Cidade e Estado): } \\
\text { Manaus - AM }\end{array}$ \\
\hline \multicolumn{2}{|c|}{$\begin{array}{l}\text { Curso/Encontro/Oficina do qual participou (caso tenha participado de mais de um curso, preencha } \\
\text { um formulário para cada um deles): } \\
\text { Curso Diagnóstico Rural Participativo - DRP }\end{array}$} \\
\hline $\begin{array}{l}\text { Data do Curso/Encontro/Oficina (pelo menos mês } \\
16 \text { a } 27 \text { de outubro de } 2006 \text { - Manaus/AM }\end{array}$ & \\
\hline
\end{tabular}

1. Indique sua área de atuação? (As opções não são excludentes: você poderá marcar mais de uma opção)

\begin{tabular}{|l|l|}
\hline$X$ & EXTENSÃO RURAL \\
\hline & PESQUISA \\
\hline
\end{tabular}




\begin{tabular}{|l|l|}
\hline & ENSINO \\
\hline & OUTROS \\
\hline
\end{tabular}

2) Qual o seu nível de escolaridade? (Considere apenas o nível mais alto)

\begin{tabular}{|l|l|}
\hline$X$ & NÍVEL MÉDIO \\
\hline & NÍVEL SUPERIOR \\
\hline & PÓS-GRADUAÇÃO \\
\hline
\end{tabular}

3) Os conteúdos abordados foram condizentes com as demandas do seu dia-a-dia?

\begin{tabular}{|l|l|}
\hline$X$ & SIM \\
\hline & PARCIALMENTE \\
\hline & NÃO \\
\hline
\end{tabular}

4) O curso contribuiu para o seu aperfeiçoamento profissional?

\begin{tabular}{|l|l|}
\hline$X$ & SIM \\
\hline & NÃO \\
\hline
\end{tabular}

5) Os conhecimentos adquiridos estão sendo aplicados no seu trabalho? Em caso afirmativo, indique em que grau estes conhecimentos estão sendo aplicados. Em caso negativo, indique por que razão isto não ocorre:

\begin{tabular}{|l|l|l|l|}
\hline$x$ & $\begin{array}{l}\text { SIM (indique ao lado em } \\
\text { que grau) }\end{array}$ & $X$ & MUITO APLICADOS \\
\cline { 3 - 4 } & & MEDIAMENTE APLICADOS \\
\hline & $\begin{array}{l}\text { NÃO (indique ao lado a } \\
\text { razão da não aplicação) }\end{array}$ & $\begin{array}{l}\text { CONTEÚDO NÃO ADEQUADO ÀS NECESSIDADES } \\
\text { ESPECÍFICAS DA REGIÃO }\end{array}$ \\
\hline
\end{tabular}




\begin{tabular}{|l|l|l|}
\hline \multirow{10}{*}{} & $\begin{array}{l}\text { CONTEÚDO NÃO FOI SUFICIENTEMENTE } \\
\text { APROFUNDADO PARA PERMITIR UMA APLICAÇÃO } \\
\text { EFICAZ E EFICIENTE }\end{array}$ \\
\cline { 2 - 4 } & $\begin{array}{l}\text { FALTA DE APOIO E INCENTIVO DA MINHA } \\
\text { INSTITUIÇÃO }\end{array}$ \\
\cline { 2 - 4 } & FALTA DE INCENTIVO ÀS AÇÕES DE ATER \\
\hline & NÃO TENHO INTERESSE EM APLICAR \\
\hline
\end{tabular}

6) A partir deste curso: (As opções não são excludentes: você poderá marcar mais de uma opção)

\begin{tabular}{|l|l|}
\hline & NÃO MUDOU NADA EM MEU TRABALHO. \\
\hline$X$ & $\begin{array}{l}\text { MEU TRABALHO PASSOU A CONTRIBUIR MAIS COM OS AGRICULTORES(AS) } \\
\text { FAMILIARES. }\end{array}$ \\
\hline$x$ & CONSEGUI INFLUENCIAR NAS ORIENTAÇÕES DA MINHA INSTITUIÇÃO. \\
\hline & $\begin{array}{l}\text { CRESCEU A ÁREA DE AGRICULTURA DE BASE ECOLÓGICA NAS COMUNIDADES } \\
\text { ONDE ATUO. }\end{array}$ \\
\hline$X$ & CONTINUEI ME APERFEIÇOANDO SOBRE TEMAS ABORDADOS. \\
\hline
\end{tabular}

7) Depois do curso você apoiou atividades de capacitação de técnicos e agricultores com base nos princípios e diretrizes da Pnater? (Considere como apoio a atividades de capacitação a participação no planejamento, elaboração de ementas, seleção de participantes e de palestrantes.)

\begin{tabular}{|l|l|}
\hline$X$ & SIM \\
\hline & NÃO \\
\hline
\end{tabular}

8) Usou os conhecimentos para ministrar outros cursos com o mesmo conteúdo ou conteúdos semelhantes? 


\begin{tabular}{|l|l|}
\hline & SIM \\
\hline & NÃO \\
\hline
\end{tabular}

9) Marque o seu grau de satisfação com relação ao curso oferecido pelo DATER: (Considere a seguinte pontuação: 1 - MUITO RUIM; 2 - RUIM; 3 - REGULAR; 4 - BOM; 5 - MUITO BOM)

\begin{tabular}{|l|l|l|l|l|}
\hline 1 & 2 & 3 & 4 & 5 \\
\hline
\end{tabular}

10) Marque seu grau de satisfação com relação ao DATER: (Considere a seguinte pontuação: 1 - MUITO RUIM; 2 - RUIM; 3 - REGULAR; 4 - BOM; 5 - MUITO BOM)

\begin{tabular}{|l|l|l|l|l|}
\hline 1 & 2 & 3 & 4 & 5 \\
\hline
\end{tabular}


PESQUISA - IMPACTO DAS AÇÕES DE FORMAÇÃO REALIZADAS PELO DATER/SAF/MDA NO PERÍODO 2004-2009

Caros colaboradores,

Contamos com a sua atenção para preencher o formulário abaixo.

O mesmo tem por objetivo fornecer informações para avaliação da Eficiência, Efetividade e Eficácia da Política Pública de Formação de Agentes de Ater adotada pelo Departamento de Assistência Técnica e Extensão Rural, da Secretaria de Agricultura Familiar do Ministério do Desenvolvimento - DATER/SAF/MDA, no período de 2004 a 2009, tema escolhido para Monografia a ser apresentada à Universidade de Brasília (UnB) como requisito parcial para obtenção do grau de Bacharel em Administração.

Você poderá ou não se identificar no questionário e garantimos que todas as informações fornecidas serão confidenciais e utilizadas apenas de forma sistematizada.

IDENTIFICAÇÃO

\begin{tabular}{|c|c|}
\hline Nome: WASHINGTON LUIS AGUIAR & $\begin{array}{l}\text { Sexo: } \\
(x) \text { masculino } \quad(\quad) \text { feminino }\end{array}$ \\
\hline $\begin{array}{l}\text { Instituição (nome e tipo de instituição: ONG, } \\
\text { Empresa Pública, etc.): } \\
\text { Instituto de Desenvolvimento Agropecuário do } \\
\text { Estado do Amazonas - IDAM }\end{array}$ & $\begin{array}{l}\text { Local de trabalho (Cidade e Estado): } \\
\text { Manaus - Amazonas }\end{array}$ \\
\hline \multicolumn{2}{|c|}{$\begin{array}{l}\text { Curso/Encontro/Oficina do qual participou (caso tenha participado de mais de um curso, preencha } \\
\text { um formulário para cada um deles): } \\
\text { Curso Diagnóstico Rural Participativo - DRP }\end{array}$} \\
\hline $\begin{array}{l}\text { Data do Curso/Encontro/Oficina (pelo menos mês e a } \\
16 \text { a } 27 \text { de outubro de } 2006 \text { - Manaus/AM }\end{array}$ & \\
\hline
\end{tabular}

1. Indique sua área de atuação? (As opções não são excludentes: você poderá marcar mais de uma opção)

\begin{tabular}{|l|l|}
\hline$X$ & EXTENSÃO RURAL \\
\hline & PESQUISA \\
\hline & ENSINO \\
\hline
\end{tabular}




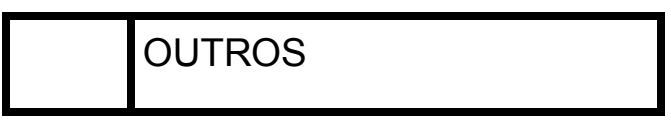

2) Qual o seu nível de escolaridade? (Considere apenas o nível mais alto)

\begin{tabular}{|l|l|}
\hline & NÍVEL MÉDIO \\
\hline$X$ & NÍVEL SUPERIOR \\
\hline & PÓS-GRADUAÇÃO \\
\hline
\end{tabular}

3) Os conteúdos abordados foram condizentes com as demandas do seu dia-a-dia?

\begin{tabular}{|l|l|}
\hline$X$ & SIM \\
\hline & PARCIALMENTE \\
\hline & NÃO \\
\hline
\end{tabular}

4) O curso contribuiu para o seu aperfeiçoamento profissional?

\begin{tabular}{|l|l|}
\hline$X$ & SIM \\
\hline & NÃO \\
\hline
\end{tabular}

5) Os conhecimentos adquiridos estão sendo aplicados no seu trabalho? Em caso afirmativo, indique em que grau estes conhecimentos estão sendo aplicados. Em caso negativo, indique por que razão isto não ocorre: (Em caso negativo, as respostas não são excludentes: você poderá marcar mais de uma opção).

\begin{tabular}{|l|l|l|l|}
\hline \multirow{2}{*}{$\begin{array}{l}\text { SIM (indique ao lado em } \\
\text { que grau) }\end{array}$} & M & MEDITO APLICADOS \\
\cline { 2 - 3 } & $\begin{array}{l}\text { NĀO (indique ao lado a } \\
\text { razão da não aplicação) }\end{array}$ & $\begin{array}{l}\text { COUCO APLICADOS } \\
\text { ESPECÍFICAS DA REGIÃO }\end{array}$ \\
\hline
\end{tabular}




\begin{tabular}{|l|l|l|}
\hline \multirow{10}{*}{} & $\begin{array}{l}\text { CONTEÚDO NÃO FOI SUFICIENTEMENTE } \\
\text { APROFUNDADO PARA PERMITIR UMA APLICAÇÃO } \\
\text { EFICAZ E EFICIENTE }\end{array}$ \\
\cline { 2 - 4 } & $\begin{array}{l}\text { FALTA DE APOIO E INCENTIVO DA MINHA } \\
\text { INSTITUIÇÃO }\end{array}$ \\
\cline { 2 - 4 } & FALTA DE INCENTIVO ÀS AÇÕES DE ATER \\
\hline & NÃO TENHO INTERESSE EM APLICAR \\
\hline
\end{tabular}

6) A partir deste curso: (As opções não são excludentes: você poderá marcar mais de uma opção)

\begin{tabular}{|l|l|}
\hline & NÃO MUDOU NADA EM MEU TRABALHO. \\
\hline & $\begin{array}{l}\text { MEU TRABALHO PASSOU A CONTRIBUIR MAIS COM OS AGRICULTORES(AS) } \\
\text { FAMILIARES. }\end{array}$ \\
\hline & CONSEGUI INFLUENCIAR NAS ORIENTAÇÕES DA MINHA INSTITUIÇÃO. \\
\hline & $\begin{array}{l}\text { CRESESE A TRABALHAR COM METODOLOGIAS PARTICIPATIVAS. } \\
\text { ONDE ATUO. ÁREA DE AGRICULTURA DE BASE ECOLÓGICA NAS COMUNIDADES }\end{array}$ \\
\hline$X$ & CONTINUEI ME APERFEIÇOANDO SOBRE TEMAS ABORDADOS. \\
\hline
\end{tabular}

7) Depois do curso você apoiou atividades de capacitação de técnicos e agricultores com base nos princípios e diretrizes da Pnater? (Considere como apoio a atividades de capacitação a participação no planejamento, elaboração de ementas, seleção de participantes e de palestrantes.)

\begin{tabular}{|l|l|}
\hline & SIM \\
\hline$X$ & NÃO \\
\hline
\end{tabular}

8) Usou os conhecimentos para ministrar outros cursos com o mesmo conteúdo ou conteúdos semelhantes? 


\begin{tabular}{|l|l|}
\hline & SIM \\
\hline$X$ & NÃO \\
\hline
\end{tabular}

9) Marque o seu grau de satisfação com relação ao curso oferecido pelo DATER: (Considere a seguinte pontuação: 1 - MUITO RUIM; 2 - RUIM; 3 - REGULAR; 4 - BOM; 5 - MUITO BOM)

\begin{tabular}{|l|l|l|l|l|}
\hline 1 & 2 & 3 & 4 & 5 \\
\hline
\end{tabular}

10) Marque seu grau de satisfação com relação ao DATER: (Considere a seguinte pontuação: 1 - MUITO RUIM; 2 - RUIM; 3 - REGULAR; 4 - BOM; 5 - MUITO BOM)

\begin{tabular}{|l|l|l|l|l|}
\hline 1 & 2 & 3 & 4 & 5 \\
\hline
\end{tabular}


PESQUISA - IMPACTO DAS AÇÕES DE FORMAÇÃO REALIZADAS PELO DATER/SAF/MDA NO PERÍODO 2004-2009

Caros colaboradores,

Contamos com a sua atenção para preencher o formulário abaixo.

O mesmo tem por objetivo fornecer informações para avaliação da Eficiência, Efetividade e Eficácia da Política Pública de Formação de Agentes de Ater adotada pelo Departamento de Assistência Técnica e Extensão Rural, da Secretaria de Agricultura Familiar do Ministério do Desenvolvimento - DATER/SAF/MDA, no período de 2004 a 2009, tema escolhido para Monografia a ser apresentada à Universidade de Brasília (UnB) como requisito parcial para obtenção do grau de Bacharel em Administração.

Você poderá ou não se identificar no questionário e garantimos que todas as informações fornecidas serão confidenciais e utilizadas apenas de forma sistematizada.

IDENTIFICAÇÃO

\begin{tabular}{|c|c|}
\hline Nome: TADEU VELOSO PACHECO & $\begin{array}{l}\text { Sexo: } \\
(\mathrm{x}) \text { masculino }\end{array}$ \\
\hline $\begin{array}{l}\text { Instituição (nome e tipo de instituição: ONG, } \\
\text { Empresa Pública, etc.): } \\
\text { Instituto de Desenvolvimento Agropecuário do } \\
\text { Estado do Amazonas - IDAM }\end{array}$ & $\begin{array}{l}\text { Local de trabalho (Cidade e Estado): } \\
\text { Unidade Local de Barreirinha - Amazonas }\end{array}$ \\
\hline \multicolumn{2}{|c|}{$\begin{array}{l}\text { Curso/Encontro/Oficina do qual participou (caso tenha participado de mais de um curso, preencha } \\
\text { um formulário para cada um deles): } \\
\text { Curso de Agroecologia }\end{array}$} \\
\hline $\begin{array}{l}\text { Data do Curso/Encontro/Oficina (pelo menos mês } \\
24 \text { a } 28 \text { de abril de } 2006 \text { - Manaus/AM }\end{array}$ & \\
\hline
\end{tabular}

1. Indique sua área de atuação? (As opções não são excludentes: você poderá marcar mais de uma opção)

\begin{tabular}{|l|l|}
\hline$X$ & EXTENSÃO RURAL \\
\hline & PESQUISA \\
\hline & ENSINO \\
\hline & OUTROS \\
\hline
\end{tabular}


2) Qual o seu nível de escolaridade? (Considere apenas o nível mais alto)

\begin{tabular}{|l|l|}
\hline$X$ & NÍVEL MÉDIO \\
\hline & NÍVEL SUPERIOR \\
\hline & PÓS-GRADUAÇÃO \\
\hline
\end{tabular}

3) Os conteúdos abordados foram condizentes com as demandas do seu dia-a-dia?

\begin{tabular}{|l|l|}
\hline$X$ & SIM \\
\hline & PARCIALMENTE \\
\hline & NÃO \\
\hline
\end{tabular}

4) O curso contribuiu para o seu aperfeiçoamento profissional?

\begin{tabular}{|l|l|}
\hline$X$ & SIM \\
\hline & NÃO \\
\hline
\end{tabular}

5) Os conhecimentos adquiridos estão sendo aplicados no seu trabalho? Em caso afirmativo, indique em que grau estes conhecimentos estão sendo aplicados. Em caso negativo, indique por que razão isto não ocorre: (Em caso negativo, as respostas não são excludentes: você poderá marcar mais de uma opção).

\begin{tabular}{|c|c|c|}
\hline \multirow{3}{*}{$\begin{array}{l}\text { SIM (indique ao lado em } \\
\text { que grau) }\end{array}$} & & MUITO APLICADOS \\
\hline & $X$ & MEDIAMENTE APLICADOS \\
\hline & & POUCO APLICADOS \\
\hline \multirow{2}{*}{$\begin{array}{l}\text { NÃO (indique ao lado a } \\
\text { razão da não aplicação) }\end{array}$} & & $\begin{array}{l}\text { CONTEÚDO NÃO ADEQUADO ȦS NECESSIDADES } \\
\text { ESPECÍFICAS DA REGIÃO }\end{array}$ \\
\hline & & $\begin{array}{l}\text { CONTEÚDO NÃO } \quad \text { FOI SUFICIENTEMENTE } \\
\text { APROFUNDADO PARA PERMITIR UMA APLICAÇÃO } \\
\text { EFICAZ E EFICIENTE }\end{array}$ \\
\hline
\end{tabular}




\begin{tabular}{|l|l|l|}
\hline \multirow{2}{*}{} & & $\begin{array}{l}\text { FALTA DE APOIO E INCENTIVO DA MINHA } \\
\text { INSTITUIÇÃO }\end{array}$ \\
\cline { 2 - 3 } & & FALTA DE INCENTIVO ÀS AÇÕES DE ATER \\
\cline { 2 - 3 } & NÃO TENHO INTERESSE EM APLICAR \\
\hline
\end{tabular}

6) A partir deste curso: (As opções não são excludentes: você poderá marcar mais de uma opção)

\begin{tabular}{|l|l|}
\hline & NÃO MUDOU NADA EM MEU TRABALHO. \\
\hline$X$ & $\begin{array}{l}\text { MEU TRABALHO PASSOU A CONTRIBUIR MAIS COM OS AGRICULTORES(AS) } \\
\text { FAMILIARES. }\end{array}$ \\
\hline$X$ & CONSEGUI INFLUENCIAR NAS ORIENTAÇÕES DA MINHA INSTITUIÇÃO. \\
\hline$X$ & PASSEI A TRABALHAR COM METODOLOGIAS PARTICIPATIVAS. \\
\hline$X$ & $\begin{array}{l}\text { CRESCEU A ÁREA DE AGRICULTURA DE BASE ECOLÓGICA NAS COMUNIDADES } \\
\text { ONDE ATUO. }\end{array}$ \\
\hline$X$ & CONTINUEI ME APERFEIÇOANDO SOBRE TEMAS ABORDADOS. \\
\hline
\end{tabular}

7) Depois do curso você apoiou atividades de capacitação de técnicos e agricultores com base nos princípios e diretrizes da Pnater? (Considere como apoio a atividades de capacitação a participação no planejamento, elaboração de ementas, seleção de participantes e de palestrantes.)

\begin{tabular}{|l|l|}
\hline$X$ & SIM \\
\hline & NÃO \\
\hline
\end{tabular}

8) Usou os conhecimentos para ministrar outros cursos com o mesmo conteúdo ou conteúdos semelhantes?

\begin{tabular}{|l|l|}
\hline & SIM \\
\hline$X$ & NÃO \\
\hline
\end{tabular}


9) Marque o seu grau de satisfação com relação ao curso oferecido pelo DATER: (Considere a seguinte pontuação: 1 - MUITO RUIM; 2 - RUIM; 3 - REGULAR; 4 - BOM; 5 - MUITO BOM)

\begin{tabular}{|l|l|l|l|l|}
\hline 1 & 2 & 3 & 4 & 5 \\
\hline
\end{tabular}

10) Marque seu grau de satisfação com relação ao DATER: (Considere a seguinte pontuação: 1 - MUITO RUIM; 2 - RUIM; 3 - REGULAR; 4 - BOM; 5 - MUITO BOM)

\begin{tabular}{|l|l|l|l|l|}
\hline 1 & 2 & 3 & 4 & 5 \\
\hline
\end{tabular}


PESQUISA - IMPACTO DAS AÇÕES DE FORMAÇÃO REALIZADAS PELO DATER/SAF/MDA NO PERÍODO 2004-2009

Caros colaboradores,

Contamos com a sua atenção para preencher o formulário abaixo.

O mesmo tem por objetivo fornecer informações para avaliação da Eficiência, Efetividade e Eficácia da Política Pública de Formação de Agentes de Ater adotada pelo Departamento de Assistência Técnica e Extensão Rural, da Secretaria de Agricultura Familiar do Ministério do Desenvolvimento - DATER/SAF/MDA, no período de 2004 a 2009, tema escolhido para Monografia a ser apresentada à Universidade de Brasília (UnB) como requisito parcial para obtenção do grau de Bacharel em Administração.

Você poderá ou não se identificar no questionário e garantimos que todas as informações fornecidas serão confidenciais e utilizadas apenas de forma sistematizada.

IDENTIFICAÇÃO

\begin{tabular}{|c|c|}
\hline Nome: SUELEM MIRANDA DOS SANTOS & $\begin{array}{l}\text { Sexo: } \\
(\quad) \text { masculino }\end{array}$ \\
\hline $\begin{array}{l}\text { Instituição (nome e tipo de instituição: ONG, } \\
\text { Empresa Pública, etc.): } \\
\text { Instituto de Desenvolvimento Agropecuário do } \\
\text { Estado do Amazonas - IDAM }\end{array}$ & $\begin{array}{l}\text { Local de trabalho (Cidade e Estado): } \\
\text { Unidade Local de Presidente Figueiredo - } \\
\text { Amazonas }\end{array}$ \\
\hline \multicolumn{2}{|c|}{$\begin{array}{l}\text { Curso/Encontro/Oficina do qual participou (caso tenha participado de mais de um curso, preencha } \\
\text { um formulário para cada um deles): } \\
\text { II Encontro para Socialização dos Conceitos Básicos da Política Nacional de ATER }\end{array}$} \\
\hline $\begin{array}{l}\text { Data do Curso/Encontro/Oficina (pelo menos mês } \\
04 \text { a } 08 \text { de dezembro de } 2006 \text { - Manaus/AM }\end{array}$ & \\
\hline
\end{tabular}

1. Indique sua área de atuação? (As opções não são excludentes: você poderá marcar mais de uma opção)

\begin{tabular}{|l|l|}
\hline$X$ & EXTENSÃO RURAL \\
\hline & PESQUISA \\
\hline & ENSINO \\
\hline
\end{tabular}




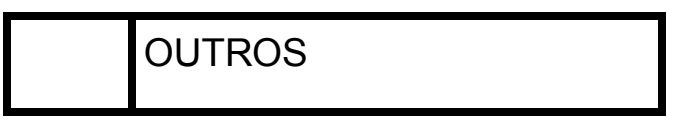

2) Qual o seu nível de escolaridade? (Considere apenas o nível mais alto)

\begin{tabular}{|l|l|}
\hline & NÍVEL MÉDIO \\
\hline & NÍVEL SUPERIOR \\
\hline$X$ & PÓS-GRADUAÇÃO \\
\hline
\end{tabular}

3) Os conteúdos abordados foram condizentes com as demandas do seu dia-a-dia?

\begin{tabular}{|l|l|}
\hline$X$ & SIM \\
\hline & PARCIALMENTE \\
\hline & NÃO \\
\hline
\end{tabular}

4) O curso contribuiu para o seu aperfeiçoamento profissional?

\begin{tabular}{|l|l|}
\hline$X$ & SIM \\
\hline & NÃO \\
\hline
\end{tabular}

5) Os conhecimentos adquiridos estão sendo aplicados no seu trabalho? Em caso afirmativo, indique em que grau estes conhecimentos estão sendo aplicados. Em caso negativo, indique por que razão isto não ocorre: (Em caso negativo, as respostas não são excludentes: você poderá marcar mais de uma opção).

\begin{tabular}{|l|l|l|l|}
\hline \multirow{2}{*}{$\begin{array}{l}\text { SIM (indique ao lado em } \\
\text { que grau) }\end{array}$} & & MUITO APLICADOS \\
\cline { 2 - 4 } & $\begin{array}{l}\text { NÃO (indique ao lado a } \\
\text { razão da não aplicação) }\end{array}$ & MEDIAMENTE APLICADOS \\
\hline
\end{tabular}




\begin{tabular}{|l|l|l|}
\hline \multirow{10}{*}{} & $\begin{array}{l}\text { CONTEÚDO NÃO FOI SUFICIENTEMENTE } \\
\text { APROFUNDADO PARA PERMITIR UMA APLICAÇÃO } \\
\text { EFICAZ E EFICIENTE }\end{array}$ \\
\cline { 2 - 4 } & $\begin{array}{l}\text { FALTA DE APOIO E INCENTIVO DA MINHA } \\
\text { INSTITUIÇÃO }\end{array}$ \\
\cline { 2 - 4 } & FALTA DE INCENTIVO ÀS AÇÕES DE ATER \\
\hline & NÃO TENHO INTERESSE EM APLICAR \\
\hline
\end{tabular}

6) A partir deste curso: (As opções não são excludentes: você poderá marcar mais de uma opção)

\begin{tabular}{|l|l|}
\hline & NÃO MUDOU NADA EM MEU TRABALHO. \\
\hline & $\begin{array}{l}\text { MEU TRABALHO PASSOU A CONTRIBUIR MAIS COM OS AGRICULTORES(AS) } \\
\text { FAMILIARES. }\end{array}$ \\
\hline$X$ & CONSEGUI INFLUENCIAR NAS ORIENTAÇÕES DA MINHA INSTITUIÇÃO. \\
\hline & $\begin{array}{l}\text { CRESCEU A ÁREA DE AGRICULTURA DE BASE ECOLÓGICA NAS COMUNIDADES } \\
\text { ONDE ATUO. }\end{array}$ \\
\hline & CONTINUEI ME APERFEIÇOANDO SOBRE TEMAS ABORDADOS. \\
\hline
\end{tabular}

7) Depois do curso você apoiou atividades de capacitação de técnicos e agricultores com base nos princípios e diretrizes da Pnater? (Considere como apoio a atividades de capacitação a participação no planejamento, elaboração de ementas, seleção de participantes e de palestrantes.)

\begin{tabular}{|l|l|}
\hline$X$ & SIM \\
\hline & NÃO \\
\hline
\end{tabular}

8) Usou os conhecimentos para ministrar outros cursos com o mesmo conteúdo ou conteúdos semelhantes? 


\begin{tabular}{|l|l|}
\hline & SIM \\
\hline$X$ & NÃO \\
\hline
\end{tabular}

9) Marque o seu grau de satisfação com relação ao curso oferecido pelo DATER: (Considere a seguinte pontuação: 1 - MUITO RUIM; 2 - RUIM; 3 - REGULAR; 4 - BOM; 5 - MUITO BOM)

\begin{tabular}{|l|l|l|l|l|}
\hline 1 & 2 & 3 & 4 & 5 \\
\hline
\end{tabular}

10) Marque seu grau de satisfação com relação ao DATER: (Considere a seguinte pontuação: 1 - MUITO RUIM; 2 - RUIM; 3 - REGULAR; 4 - BOM; 5 - MUITO BOM)

\begin{tabular}{|l|l|l|l|l|}
\hline 1 & 2 & 3 & 4 & 5 \\
\hline
\end{tabular}


PESQUISA - IMPACTO DAS AÇÕES DE FORMAÇÃO REALIZADAS PELO DATER/SAF/MDA NO PERÍODO 2004-2009

Caros colaboradores,

Contamos com a sua atenção para preencher o formulário abaixo.

O mesmo tem por objetivo fornecer informações para avaliação da Eficiência, Efetividade e Eficácia da Política Pública de Formação de Agentes de Ater adotada pelo Departamento de Assistência Técnica e Extensão Rural, da Secretaria de Agricultura Familiar do Ministério do Desenvolvimento - DATER/SAF/MDA, no período de 2004 a 2009, tema escolhido para Monografia a ser apresentada à Universidade de Brasília (UnB) como requisito parcial para obtenção do grau de Bacharel em Administração.

Você poderá ou não se identificar no questionário e garantimos que todas as informações fornecidas serão confidenciais e utilizadas apenas de forma sistematizada.

\section{IDENTIFICAÇÃO}

\begin{tabular}{|c|c|}
\hline Nome: SIDNEY SOUZA DE ARAÚJO & $\begin{array}{l}\text { Sexo: } \\
(x) \text { masculino } \quad(\quad) \text { feminino }\end{array}$ \\
\hline $\begin{array}{l}\text { Instituição (nome e tipo de instituição: ONG, } \\
\text { Empresa Pública, etc.): } \\
\text { Instituto de Desenvolvimento Agropecuário do } \\
\text { Estado do Amazonas - IDAM }\end{array}$ & $\begin{array}{l}\text { Local de trabalho (Cidade e Estado): } \\
\text { Unidade Local de Tefé - Amazonas }\end{array}$ \\
\hline \multicolumn{2}{|c|}{$\begin{array}{l}\text { Curso/Encontro/Oficina do qual participou (caso tenha participado de mais de um curso, preencha } \\
\text { um formulário para cada um deles): } \\
\text { Curso Diagnóstico Rural Participativo - DRP }\end{array}$} \\
\hline $\begin{array}{l}\text { Data do Curso/Encontro/Oficina (pelo menos mês e } \\
16 \text { a } 27 \text { de outubro de } 2006 \text { - Manaus/AM }\end{array}$ & \\
\hline
\end{tabular}

1. Indique sua área de atuação? (As opções não são excludentes: você poderá marcar mais de uma opção)

\begin{tabular}{|l|l|}
\hline$X$ & EXTENSÃO RURAL \\
\hline & PESQUISA \\
\hline
\end{tabular}




\begin{tabular}{|l|l|}
\hline & ENSINO \\
\hline & OUTROS \\
\hline
\end{tabular}

2) Qual o seu nível de escolaridade? (Considere apenas o nível mais alto)

\begin{tabular}{|l|l|}
\hline & NÍVEL MÉDIO \\
\hline$X$ & NÍVEL SUPERIOR \\
\hline & PÓS-GRADUAÇÃO \\
\hline
\end{tabular}

3) Os conteúdos abordados foram condizentes com as demandas do seu dia-a-dia?

\begin{tabular}{|l|l|}
\hline$X$ & SIM \\
\hline & PARCIALMENTE \\
\hline & NÃO \\
\hline
\end{tabular}

4) O curso contribuiu para o seu aperfeiçoamento profissional?

\begin{tabular}{|l|l|}
\hline$X$ & SIM \\
\hline & NÃO \\
\hline
\end{tabular}

5) Os conhecimentos adquiridos estão sendo aplicados no seu trabalho? Em caso afirmativo, indique em que grau estes conhecimentos estão sendo aplicados. Em caso negativo, indique por que razão isto não ocorre: (Em caso negativo, as respostas não são excludentes: você poderá marcar mais de uma opção).

\begin{tabular}{|l|l|l|}
\hline \multirow{2}{*}{$\begin{array}{l}\text { SIM (indique ao lado em } \\
\text { que grau) }\end{array}$} & & MUITO APLICADOS \\
\cline { 2 - 4 } & $x$ & POUCO APLICADOS \\
\hline
\end{tabular}




\begin{tabular}{|c|c|}
\hline \multirow{5}{*}{$\begin{array}{l}\text { NÃO (indique ao lado a } \\
\text { razão da não aplicação) }\end{array}$} & $\begin{array}{l}\text { CONTEÚDO NÃO ADEQUADO ȦS NECESSIDADES } \\
\text { ESPECÍFICAS DA REGIÃO }\end{array}$ \\
\hline & $\begin{array}{l}\text { CONTEÚDO NÃO FOI SUFICIENTEMENTE } \\
\text { APROFUNDADO PARA } \\
\text { PERMITIR UMA APLICAÇÃO } \\
\text { EFICAZ E EFICIENTE }\end{array}$ \\
\hline & $\begin{array}{l}\text { FALTA DE APOIO } \\
\text { INSTITUIÇÃO }\end{array}$ \\
\hline & FALTA DE INCENTIVO ÀS AÇÕES DE ATER \\
\hline & NÃO TENHO INTERESSE EM APLICAR \\
\hline
\end{tabular}

6) A partir deste curso: (As opções não são excludentes: você poderá marcar mais de uma opção)

\begin{tabular}{|l|l|}
\hline$x$ & $\begin{array}{l}\text { NÃO MUDOU NADA EM MEU TRABALHO. } \\
\text { FAMILIARES. }\end{array}$ \\
\hline$x$ & CONSEGUI INFLUENCIAR NAS ORIENTAÇÕES DA MINHA INSTITUIÇÃO. \\
\hline & $\begin{array}{l}\text { CRESCEU A ÁREA DE AGRICULTURA DE BASE ECOLÓGICA NAS COMUNIDADES } \\
\text { ONDE ATUO. }\end{array}$ \\
\hline & CONTINUEI ME APERFEIÇOANDO SOBRE TEMAS ABORDADOS. \\
\hline
\end{tabular}

7) Depois do curso você apoiou atividades de capacitação de técnicos e agricultores com base nos princípios e diretrizes da Pnater? (Considere como apoio a atividades de capacitação a participação no planejamento, elaboração de ementas, seleção de participantes e de palestrantes.)

\begin{tabular}{|l|l|}
\hline$X$ & SIM \\
\hline & NÃO \\
\hline
\end{tabular}

8) Usou os conhecimentos para ministrar outros cursos com o mesmo conteúdo ou conteúdos semelhantes? 


\begin{tabular}{|l|l|}
\hline & SIM \\
\hline$X$ & NÃO \\
\hline
\end{tabular}

Por que ainda não foi ministrado nenhum curso

9) Marque o seu grau de satisfação com relação ao curso oferecido pelo DATER: (Considere a seguinte pontuação: 1 - MUITO RUIM; 2 - RUIM; 3 - REGULAR; 4 - BOM; 5 - MUITO BOM)

\begin{tabular}{|l|l|l|l|l|}
\hline 1 & 2 & 3 & 4 & 5 \\
\hline
\end{tabular}

10) Marque seu grau de satisfação com relação ao DATER: (Considere a seguinte pontuação: 1 - MUITO RUIM; 2 - RUIM; 3 - REGULAR; 4 - BOM; 5 - MUITO BOM)

\begin{tabular}{|l|l|l|l|l|}
\hline 1 & 2 & 3 & 4 & 5 \\
\hline
\end{tabular}


PESQUISA - IMPACTO DAS AÇÕES DE FORMAÇÃO REALIZADAS PELO DATER/SAF/MDA NO PERÍODO 2004-2009

Caros colaboradores,

Contamos com a sua atenção para preencher o formulário abaixo.

O mesmo tem por objetivo fornecer informações para avaliação da Eficiência, Efetividade e Eficácia da Política Pública de Formação de Agentes de Ater adotada pelo Departamento de Assistência Técnica e Extensão Rural, da Secretaria de Agricultura Familiar do Ministério do Desenvolvimento - DATER/SAF/MDA, no período de 2004 a 2009, tema escolhido para Monografia a ser apresentada à Universidade de Brasília (UnB) como requisito parcial para obtenção do grau de Bacharel em Administração.

Você poderá ou não se identificar no questionário e garantimos que todas as informações fornecidas serão confidenciais e utilizadas apenas de forma sistematizada.

\section{IDENTIFICAÇÃO}

\begin{tabular}{|c|c|}
\hline Nome: SANDRO SOUZA MARTINS & $\begin{array}{l}\text { Sexo: } \\
(\mathrm{x}) \text { masculino }\end{array}$ \\
\hline $\begin{array}{l}\text { Instituição (nome e tipo de instituição: ONG, } \\
\text { Empresa Pública, etc.): } \\
\text { Instituto de Desenvolvimento Agropecuário do } \\
\text { Estado do Amazonas - IDAM }\end{array}$ & $\begin{array}{l}\text { Local de trabalho (Cidade e Estado): } \\
\text { Unidade Local de Barreirinha - Amazonas }\end{array}$ \\
\hline \multicolumn{2}{|c|}{$\begin{array}{l}\text { Curso/Encontro/Oficina do qual participou (caso tenha participado de mais de um curso, preencha } \\
\text { um formulário para cada um deles): } \\
\text { II Encontro para Socialização dos Conceitos Básicos da Política Nacional de Ater }\end{array}$} \\
\hline $\begin{array}{l}\text { Data do Curso/Encontro/Oficina (pelo menos mês } \\
04 \text { a } 08 \text { de dezembro de } 2006 \text { - Manaus/AM }\end{array}$ & \\
\hline
\end{tabular}

1. Indique sua área de atuação? (As opções não são excludentes: você poderá marcar mais de uma opção)

\begin{tabular}{|l|l|}
\hline$X$ & EXTENSÃO RURAL \\
\hline & PESQUISA \\
\hline & ENSINO \\
\hline
\end{tabular}




\section{OUTROS}

2) Qual o seu nível de escolaridade? (Considere apenas o nível mais alto)

\begin{tabular}{|l|l|}
\hline$X$ & NÍVEL MÉDIO \\
\hline & NÍVEL SUPERIOR \\
\hline & PÓS-GRADUAÇÃO \\
\hline
\end{tabular}

3) Os conteúdos abordados foram condizentes com as demandas do seu dia-a-dia?

\begin{tabular}{|l|l|}
\hline$X$ & SIM \\
\hline & PARCIALMENTE \\
\hline & NÃO \\
\hline
\end{tabular}

4) O curso contribuiu para o seu aperfeiçoamento profissional?

\begin{tabular}{|l|l|}
\hline$X$ & SIM \\
\hline & NÃO \\
\hline
\end{tabular}

5) Os conhecimentos adquiridos estão sendo aplicados no seu trabalho? Em caso afirmativo, indique em que grau estes conhecimentos estão sendo aplicados. Em caso negativo, indique por que razão isto não ocorre: (Em caso negativo, as respostas não são excludentes: você poderá marcar mais de uma opção).

\begin{tabular}{|l|l|l|l|}
\hline \multirow{2}{*}{$\begin{array}{l}\text { SIM (indique ao lado em } \\
\text { que grau) }\end{array}$} & & MUITO APLICADOS \\
\cline { 2 - 3 } & & MEDIAMENTE APLICADOS \\
\hline & $\begin{array}{l}\text { NÃO (indique ao lado a } \\
\text { razão da não aplicação) }\end{array}$ & $\begin{array}{l}\text { COUCO APLICADOS } \\
\text { ESPECÍFICAS DA REGIÃO }\end{array}$ \\
\hline
\end{tabular}




\begin{tabular}{|l|l|l|}
\hline \multirow{10}{*}{} & $\begin{array}{l}\text { CONTEÚDO NÃO FOI SUFICIENTEMENTE } \\
\text { APROFUNDADO PARA PERMITIR UMA APLICAÇÃO } \\
\text { EFICAZ E EFICIENTE }\end{array}$ \\
\cline { 2 - 4 } & $\begin{array}{l}\text { FALTA DE APOIO E INCENTIVO DA MINHA } \\
\text { INSTITUIÇÃO }\end{array}$ \\
\cline { 2 - 4 } & FALTA DE INCENTIVO ÀS AÇÕES DE ATER \\
\hline & NÃO TENHO INTERESSE EM APLICAR \\
\hline
\end{tabular}

6) A partir deste curso: (As opções não são excludentes: você poderá marcar mais de uma opção)

\begin{tabular}{|l|l|}
\hline & NÃO MUDOU NADA EM MEU TRABALHO. \\
\hline$x$ & $\begin{array}{l}\text { MEU TRABALHO PASSOU A CONTRIBUIR MAIS COM OS AGRICULTORES(AS) } \\
\text { FAMILIARES. }\end{array}$ \\
\hline$X$ & CONSEGUI INFLUENCIAR NAS ORIENTAÇÕES DA MINHA INSTITUIÇÃO. \\
\hline$X$ & PASSEI A TRABALHAR COM METODOLOGIAS PARTICIPATIVAS. \\
\hline$X$ & $\begin{array}{l}\text { CRESCEU A ÁREA DE AGRICULTURA DE BASE ECOLÓGICA NAS COMUNIDADES } \\
\text { ONDE ATUO. }\end{array}$ \\
\hline$X$ & CONTINUEI ME APERFEIÇOANDO SOBRE TEMAS ABORDADOS. \\
\hline
\end{tabular}

7) Depois do curso você apoiou atividades de capacitação de técnicos e agricultores com base nos princípios e diretrizes da Pnater? (Considere como apoio a atividades de capacitação a participação no planejamento, elaboração de ementas, seleção de participantes e de palestrantes.)

\begin{tabular}{|l|l|}
\hline$X$ & SIM \\
\hline & NÃO \\
\hline
\end{tabular}

8) Usou os conhecimentos para ministrar outros cursos com o mesmo conteúdo ou conteúdos semelhantes? 


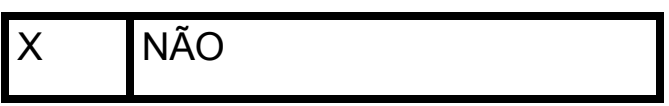

9) Marque o seu grau de satisfação com relação ao curso oferecido pelo DATER: (Considere a seguinte pontuação: 1 - MUITO RUIM; 2 - RUIM; 3 - REGULAR; 4 - BOM; 5 - MUITO BOM)

\begin{tabular}{|l|l|l|l|l|}
\hline 1 & 2 & 3 & 4 & 5 \\
\hline
\end{tabular}

10) Marque seu grau de satisfação com relação ao DATER: (Considere a seguinte pontuação: 1 - MUITO RUIM; 2 - RUIM; 3 - REGULAR; 4 - BOM; 5 - MUITO BOM)

\begin{tabular}{|l|l|l|l|l|}
\hline 1 & 2 & 3 & 4 & 5 \\
\hline
\end{tabular}


PESQUISA - IMPACTO DAS AÇÕES DE FORMAÇÃO REALIZADAS PELO DATER/SAF/MDA NO PERÍODO 2004-2009

Caros colaboradores,

Contamos com a sua atenção para preencher o formulário abaixo.

O mesmo tem por objetivo fornecer informações para avaliação da Eficiência, Efetividade e Eficácia da Política Pública de Formação de Agentes de Ater adotada pelo Departamento de Assistência Técnica e Extensão Rural, da Secretaria de Agricultura Familiar do Ministério do Desenvolvimento - DATER/SAF/MDA, no período de 2004 a 2009, tema escolhido para Monografia a ser apresentada à Universidade de Brasília (UnB) como requisito parcial para obtenção do grau de Bacharel em Administração.

Você poderá ou não se identificar no questionário e garantimos que todas as informações fornecidas serão confidenciais e utilizadas apenas de forma sistematizada.

IDENTIFICAÇÃO

\begin{tabular}{|c|c|}
\hline Nome: SANDRA NAGATA DA ROCHA & $\begin{array}{l}\text { Sexo: } \\
(\quad) \text { masculino }\end{array}$ \\
\hline $\begin{array}{l}\text { Instituição (nome e tipo de instituição: ONG, } \\
\text { Empresa Pública, etc.): } \\
\text { Instituto de Desenvolvimento Agropecuário do } \\
\text { Estado do Amazonas - IDAM }\end{array}$ & $\begin{array}{l}\text { Local de trabalho (Cidade e Estado): } \\
\text { Unidade Local de Autazes - Amazonas }\end{array}$ \\
\hline \multicolumn{2}{|c|}{$\begin{array}{l}\text { Curso/Encontro/Oficina do qual participou (caso tenha participado de mais de um curso, preencha } \\
\text { um formulário para cada um deles): } \\
\text { Seminário - Agroecologia como Estratégia para a Construção do Desenvolvimento Rural } \\
\text { Sustentável }\end{array}$} \\
\hline $\begin{array}{l}\text { Data do Curso/Encontro/Oficina (pelo menos mês } \\
10 \text { e } 11 \text { de agosto de } 2006 \text { - Manaus/AM }\end{array}$ & \\
\hline
\end{tabular}

1. Indique sua área de atuação? (As opções não são excludentes: você poderá marcar mais de uma opção)

\begin{tabular}{|l|l|}
\hline$X$ & EXTENSÃO RURAL \\
\hline & PESQUISA \\
\hline & ENSINO \\
\hline & OUTROS \\
\hline
\end{tabular}


2) Qual o seu nível de escolaridade? (Considere apenas o nível mais alto)

\begin{tabular}{|l|l|}
\hline & NÍVEL MÉDIO \\
\hline$X$ & NÍVEL SUPERIOR \\
\hline & PÓS-GRADUAÇÃO \\
\hline
\end{tabular}

3) Os conteúdos abordados foram condizentes com as demandas do seu dia-a-dia?

\begin{tabular}{|l|l|}
\hline$X$ & SIM \\
\hline & PARCIALMENTE \\
\hline & NÃO \\
\hline
\end{tabular}

4) O curso contribuiu para o seu aperfeiçoamento profissional?

\begin{tabular}{|l|l|}
\hline$X$ & SIM \\
\hline & NÃO \\
\hline
\end{tabular}

5) Os conhecimentos adquiridos estão sendo aplicados no seu trabalho? Em caso afirmativo, indique em que grau estes conhecimentos estão sendo aplicados. Em caso negativo, indique por que razão isto não ocorre: (Em caso negativo, as respostas não são excludentes: você poderá marcar mais de uma opção).

\begin{tabular}{|c|c|c|}
\hline \multirow{3}{*}{$\begin{array}{l}\text { SIM (indique ao lado em } \\
\text { que grau) }\end{array}$} & & MUITO APLICADOS \\
\hline & & MEDIAMENTE APLICADOS \\
\hline & $\mathrm{X}$ & POUCO APLICADOS \\
\hline \multirow{2}{*}{$\begin{array}{l}\text { NÃO (indique ao lado a } \\
\text { razão da não aplicação) }\end{array}$} & & $\begin{array}{l}\text { CONTEÚDO NÃO ADEQUADO ȦS NECESSIDADES } \\
\text { ESPECÍFICAS DA REGIÃO }\end{array}$ \\
\hline & & $\begin{array}{l}\text { CONTEÚDO NÃO } \text { FOI SUFICIENTEMENTE } \\
\text { APROFUNDADO PARA } \\
\text { PERMITIR UMA APLICAÇÃO } \\
\text { EFICAZ E EFICIENTE }\end{array}$ \\
\hline
\end{tabular}




\begin{tabular}{|l|l|l|}
\hline \multirow{2}{*}{} & & $\begin{array}{l}\text { FALTA DE APOIO E INCENTIVO DA MINHA } \\
\text { INSTITUIÇÃO }\end{array}$ \\
\cline { 2 - 3 } & & FALTA DE INCENTIVO ÀS AÇÕES DE ATER \\
\cline { 2 - 3 } & NÃO TENHO INTERESSE EM APLICAR \\
\hline
\end{tabular}

6) A partir deste curso: (As opções não são excludentes: você poderá marcar mais de uma opção)

\begin{tabular}{|l|l|}
\hline & NÃO MUDOU NADA EM MEU TRABALHO. \\
\hline & $\begin{array}{l}\text { MEU TRABALHO PASSOU A CONTRIBUIR MAIS COM OS AGRICULTORES(AS) } \\
\text { FAMILIARES. }\end{array}$ \\
\hline & CONSEGUI INFLUENCIAR NAS ORIENTAÇÕES DA MINHA INSTITUIÇÃO. \\
\hline & $\begin{array}{l}\text { CRESEI A TRABALHAR COM METODOLOGIAS PARTICIPATIVAS. } \\
\text { ONDE ATUO. ÁREA DE AGRICULTURA DE BASE ECOLÓGICA NAS COMUNIDADES }\end{array}$ \\
\hline$X$ & CONTINUEI ME APERFEIÇOANDO SOBRE TEMAS ABORDADOS. \\
\hline
\end{tabular}

7) Depois do curso você apoiou atividades de capacitação de técnicos e agricultores com base nos princípios e diretrizes da Pnater? (Considere como apoio a atividades de capacitação a participação no planejamento, elaboração de ementas, seleção de participantes e de palestrantes.)

\begin{tabular}{|l|l|}
\hline$X$ & SIM \\
\hline & NÃO \\
\hline
\end{tabular}

8) Usou os conhecimentos para ministrar outros cursos com o mesmo conteúdo ou conteúdos semelhantes?

\begin{tabular}{|l|l|}
\hline & SIM \\
\hline$X$ & NÃO \\
\hline
\end{tabular}


9) Marque o seu grau de satisfação com relação ao curso oferecido pelo DATER: (Considere a seguinte pontuação: 1 - MUITO RUIM; 2 - RUIM; 3 - REGULAR; 4 - BOM; 5 - MUITO BOM)

\begin{tabular}{|l|l|l|l|l|}
\hline 1 & 2 & 3 & 4 & 5 \\
\hline
\end{tabular}

10) Marque seu grau de satisfação com relação ao DATER: (Considere a seguinte pontuação: 1 - MUITO RUIM; 2 - RUIM; 3 - REGULAR; 4 - BOM; 5 - MUITO BOM)

\begin{tabular}{|l|l|l|l|l|}
\hline 1 & 2 & 3 & 4 & 5 \\
\hline
\end{tabular}


PESQUISA - IMPACTO DAS AÇÕES DE FORMAÇÃO REALIZADAS PELO DATER/SAF/MDA NO PERÍODO 2004-2009

Caros colaboradores,

Contamos com a sua atenção para preencher o formulário abaixo.

O mesmo tem por objetivo fornecer informações para avaliação da Eficiência, Efetividade e Eficácia da Política Pública de Formação de Agentes de Ater adotada pelo Departamento de Assistência Técnica e Extensão Rural, da Secretaria de Agricultura Familiar do Ministério do Desenvolvimento - DATER/SAF/MDA, no período de 2004 a 2009, tema escolhido para Monografia a ser apresentada à Universidade de Brasília (UnB) como requisito parcial para obtenção do grau de Bacharel em Administração.

Você poderá ou não se identificar no questionário e garantimos que todas as informações fornecidas serão confidenciais e utilizadas apenas de forma sistematizada.

\section{IDENTIFICAÇÃO}

\begin{tabular}{|c|c|}
\hline $\begin{array}{l}\text { Nome: } \\
\text { ABIGAIL DE CASTRO LIMA }\end{array}$ & $\begin{array}{l}\text { Sexo: } \\
(\quad) \text { masculino } \quad(x) \text { feminino }\end{array}$ \\
\hline $\begin{array}{l}\text { Instituição (nome e tipo de instituição: ONG, } \\
\text { Empresa Pública, etc.): } \\
\text { EMATER-PARÁ }\end{array}$ & $\begin{array}{l}\text { Local de trabalho (Cidade e Estado): } \\
\text { ESCRITÓRIO LOCAL DE CACHOEIRA DO } \\
\text { ARARI - MARAJÓ - PARÁ }\end{array}$ \\
\hline \multicolumn{2}{|c|}{$\begin{array}{l}\text { Curso/Encontro/Oficina do qual participou (caso tenha participado de mais de um curso, preencha } \\
\text { um formulário para cada um deles): } \\
\text { MODERAÇÃO E VISUALIZAÇÃO DE TRABALHOS PARTICIPATIVOS }\end{array}$} \\
\hline $\begin{array}{l}\text { Data do Curso/Encontro/Oficina (pelo menos mês } \\
07 \text { A } 11 \text { DE AGOSTO DE } 2006 .\end{array}$ & \\
\hline
\end{tabular}

Indique sua área de atuação? (As respostas não são excludentes: você poderá marcar mais de uma opção).

\begin{tabular}{|l|l|}
\hline$X$ & EXTENSÃO RURAL \\
\hline & PESQUISA \\
\hline
\end{tabular}




\begin{tabular}{|l|l|}
\hline & ENSINO \\
\hline & OUTROS \\
\hline
\end{tabular}

2) Qual o seu nível de escolaridade?

\begin{tabular}{|l|l|}
\hline & NÍVEL MÉDIO \\
\hline$X$ & NÍVEL SUPERIOR \\
\hline & PÓS-GRADUAÇÃO \\
\hline
\end{tabular}

3) Os conteúdos abordados foram condizentes com as demandas do seu dia-a-dia?

\begin{tabular}{|l|l|}
\hline$X$ & SIM \\
\hline & PARCIALMENTE \\
\hline & NÃO \\
\hline
\end{tabular}

4) O curso contribuiu para o seu aperfeiçoamento profissional?

\begin{tabular}{|l|l|}
\hline$X$ & SIM \\
\hline & NÃO \\
\hline
\end{tabular}

5) Os conhecimentos adquiridos estão sendo aplicados no seu trabalho? Em caso afirmativo, indique em que grau estes conhecimentos estão sendo aplicados. Em caso negativo, indique por que razão isto não ocorre:

\begin{tabular}{|l|l|l|l|}
\hline \multirow{2}{*}{$X$} & $\begin{array}{l}\text { SIM (indique ao lado em } \\
\text { que grau) }\end{array}$ & $X$ & MUITO APLICADOS \\
\cline { 2 - 4 } & & MEDIAMENTE APLICADOS \\
\hline & $\begin{array}{l}\text { NÃO (indique ao lado a } \\
\text { razão da não aplicação) }\end{array}$ & $\begin{array}{l}\text { CONTEÚDO NÃO ADEQUADO ÀS NECESSIDADES } \\
\text { ESPECÍFICAS DA REGIÃO }\end{array}$ \\
\hline
\end{tabular}




\begin{tabular}{|l|l|l|}
\hline \multirow{10}{*}{} & $\begin{array}{l}\text { CONTEÚDO NÃO FOI SUFICIENTEMENTE } \\
\text { APROFUNDADO PARA PERMITIR UMA APLICAÇÃO } \\
\text { EFICAZ E EFICIENTE }\end{array}$ \\
\cline { 2 - 4 } & $\begin{array}{l}\text { FALTA DE APOIO E INCENTIVO DA MINHA } \\
\text { INSTITUIÇÃO }\end{array}$ \\
\cline { 2 - 4 } & FALTA DE INCENTIVO ÀS AÇÕES DE ATER \\
\hline & NÃO TENHO INTERESSE EM APLICAR \\
\hline
\end{tabular}

6) A partir deste curso: (As respostas não são excludentes: você poderá marcar mais de uma opção).

\begin{tabular}{|l|l|}
\hline$x$ & $\begin{array}{l}\text { NÃO MUDOU NADA EM MEU TRABALHO. } \\
\text { FAMILIARES. }\end{array}$ \\
\hline & CONSEGUI INFLUENCIAR NAS ORIENTAÇÕES DA MINHA INSTITUIÇÃO. \\
\hline$X$ & PASSEI A TRABALHAR COM METODOLOGIAS PARTICIPATIVAS. \\
\hline & $\begin{array}{l}\text { CRESCEU A ÁREA DE AGRICULTURA DE BASE ECOLÓGICA NAS COMUNIDADES } \\
\text { ONDE ATUO. }\end{array}$ \\
\hline & CONTINUEI ME APERFEIÇOANDO SOBRE TEMAS ABORDADOS. \\
\hline
\end{tabular}

7) Depois do curso você apoiou atividades de capacitação de técnicos e agricultores com base nos princípios e diretrizes da Pnater? (Considere como apoio a atividades de capacitação a participação no planejamento, elaboração de ementas, seleção de participantes e de palestrantes.)

\begin{tabular}{|l|l|}
\hline$X$ & SIM \\
\hline & NÃO \\
\hline
\end{tabular}

8) Usou os conhecimentos para ministrar outros cursos com o mesmo conteúdo ou conteúdos semelhantes? 


\begin{tabular}{|l|l|}
\hline$X$ & SIM \\
\hline & NÃO \\
\hline
\end{tabular}

9) Marque o seu grau de satisfação com relação ao curso oferecido pelo DATER: (Considere a seguinte pontuação: 1 - MUITO RUIM; 2 - RUIM; 3 - REGULAR; 4 - BOM; 5 - MUITO BOM)

\begin{tabular}{|l|l|l|l|l|}
\hline 1 & 2 & 3 & $(4)$ & 5 \\
\hline
\end{tabular}

10) Marque seu grau de satisfação com relação ao DATER: (Considere a seguinte pontuação: 1 - MUITO RUIM; 2 - RUIM; 3 - REGULAR; 4 - BOM; 5 - MUITO BOM)

\begin{tabular}{|l|l|l|l|l|}
\hline 1 & 2 & 3 & $(4)$ & 5 \\
\hline
\end{tabular}


PESQUISA - IMPACTO DAS AÇÕES DE FORMAÇÃO REALIZADAS PELO DATER/SAF/MDA NO PERÍODO 2004-2009

Caros colaboradores,

Contamos com a sua atenção para preencher o formulário abaixo.

O mesmo tem por objetivo fornecer informações para avaliação da Eficiência, Efetividade e Eficácia da Política Pública de Formação de Agentes de Ater adotada pelo Departamento de Assistência Técnica e Extensão Rural, da Secretaria de Agricultura Familiar do Ministério do Desenvolvimento - DATER/SAF/MDA, no período de 2004 a 2009, tema escolhido para Monografia a ser apresentada à Universidade de Brasília (UnB) como requisito parcial para obtenção do grau de Bacharel em Administração.

Você poderá ou não se identificar no questionário e garantimos que todas as informações fornecidas serão confidenciais e utilizadas apenas de forma sistematizada.

IDENTIFICAÇÃO

\begin{tabular}{|c|c|}
\hline Nome: SANDRA NAGATA DA ROCHA & $\begin{array}{l}\text { Sexo: } \\
(\quad) \text { masculino }\end{array}$ \\
\hline $\begin{array}{l}\text { Instituição (nome e tipo de instituição: ONG, } \\
\text { Empresa Pública, etc.): } \\
\text { Instituto de Desenvolvimento Agropecuário do } \\
\text { Estado do Amazonas - IDAM }\end{array}$ & $\begin{array}{l}\text { Local de trabalho (Cidade e Estado): } \\
\text { Unidade Local de Autazes - Amazonas }\end{array}$ \\
\hline \multicolumn{2}{|c|}{$\begin{array}{l}\text { Curso/Encontro/Oficina do qual participou (caso tenha participado de mais de um curso, preencha } \\
\text { um formulário para cada um deles): } \\
\text { Seminário - Agroecologia como Estratégia para a Construção do Desenvolvimento Rural } \\
\text { Sustentável }\end{array}$} \\
\hline $\begin{array}{l}\text { Data do Curso/Encontro/Oficina (pelo menos mês } \\
10 \text { e } 11 \text { de agosto de } 2006 \text { - Manaus/AM }\end{array}$ & \\
\hline
\end{tabular}

Indique sua área de atuação? (As opções não são excludentes: você poderá marcar mais de uma opção)

\begin{tabular}{|l|l|}
\hline$X$ & EXTENSÃO RURAL \\
\hline & PESQUISA \\
\hline
\end{tabular}




\begin{tabular}{|l|l|}
\hline & ENSINO \\
\hline & OUTROS \\
\hline
\end{tabular}

2) Qual o seu nível de escolaridade? (Considere apenas o nível mais alto)

\begin{tabular}{|l|l|}
\hline & NÍVEL MÉDIO \\
\hline$X$ & NÍVEL SUPERIOR \\
\hline & PÓS-GRADUAÇÃO \\
\hline
\end{tabular}

3) Os conteúdos abordados foram condizentes com as demandas do seu dia-a-dia?

\begin{tabular}{|l|l|}
\hline$X$ & SIM \\
\hline & PARCIALMENTE \\
\hline & NÃO \\
\hline
\end{tabular}

3) O curso contribuiu para o seu aperfeiçoamento profissional?

\begin{tabular}{|l|l|}
\hline$X$ & SIM \\
\hline & NÃO \\
\hline
\end{tabular}

5) Os conhecimentos adquiridos estão sendo aplicados no seu trabalho? Em caso afirmativo, indique em que grau estes conhecimentos estão sendo aplicados. Em caso negativo, indique por que razão isto não ocorre: (Em caso negativo, as respostas não são excludentes: você poderá marcar mais de uma opção).

\begin{tabular}{|l|l|l|}
\hline \multirow{2}{*}{$\begin{array}{l}\text { SIM (indique ao lado em } \\
\text { que grau) }\end{array}$} & & MUITO APLICADOS \\
\cline { 2 - 3 } & $\mathrm{X}$ & MEDIAMENTE APLICADOS \\
\hline
\end{tabular}




\begin{tabular}{|c|c|}
\hline \multirow{5}{*}{$\begin{array}{l}\text { NÃO (indique ao lado a } \\
\text { razão da não aplicação) }\end{array}$} & $\begin{array}{l}\text { CONTEÚDO NÃO ADEQUADO ȦS NECESSIDADES } \\
\text { ESPECÍFICAS DA REGIÃO }\end{array}$ \\
\hline & $\begin{array}{l}\text { CONTEÚDO NÃO FOI SUFICIENTEMENTE } \\
\text { APROFUNDADO PARA } \\
\text { PERMITIR UMA APLICAÇÃO } \\
\text { EFICAZ E EFICIENTE }\end{array}$ \\
\hline & $\begin{array}{l}\text { FALTA DE APOIO } \\
\text { INSTITUIÇÃO }\end{array}$ \\
\hline & FALTA DE INCENTIVO ÀS AÇÕES DE ATER \\
\hline & NÃO TENHO INTERESSE EM APLICAR \\
\hline
\end{tabular}

6) A partir deste curso: (As opções não são excludentes: você poderá marcar mais de uma opção)

\begin{tabular}{|l|l|}
\hline & NÃO MUDOU NADA EM MEU TRABALHO. \\
\hline & $\begin{array}{l}\text { MEU TRABALHO PASSOU A CONTRIBUIR MAIS COM OS AGRICULTORES(AS) } \\
\text { FAMILIARES. }\end{array}$ \\
\hline & CONSEGUI INFLUENCIAR NAS ORIENTAÇÕES DA MINHA INSTITUIÇÃO. \\
\hline & $\begin{array}{l}\text { CRESESI A TRABALHAR COM METODOLOGIAS PARTICIPATIVAS. } \\
\text { ONDE ATUO. ÁREA DE AGRICULTURA DE BASE ECOLÓGICA NAS COMUNIDADES }\end{array}$ \\
\hline$X$ & CONTINUEI ME APERFEIÇOANDO SOBRE TEMAS ABORDADOS. \\
\hline
\end{tabular}

7) Depois do curso você apoiou atividades de capacitação de técnicos e agricultores com base nos princípios e diretrizes da Pnater? (Considere como apoio a atividades de capacitação a participação no planejamento, elaboração de ementas, seleção de participantes e de palestrantes.)

\begin{tabular}{|l|l|}
\hline$X$ & SIM \\
\hline & NÃO \\
\hline
\end{tabular}


8) Usou os conhecimentos para ministrar outros cursos com o mesmo conteúdo ou conteúdos semelhantes?

\begin{tabular}{|l|l|}
\hline & SIM \\
\hline$X$ & NÃO \\
\hline
\end{tabular}

9) Marque o seu grau de satisfação com relação ao curso oferecido pelo DATER: (Considere a seguinte pontuação: 1 - MUITO RUIM; 2 - RUIM; 3 - REGULAR; 4 - BOM; 5 - MUITO BOM)

\begin{tabular}{|l|l|l|l|l|}
\hline 1 & 2 & 3 & 4 & 5 \\
\hline
\end{tabular}

10) Marque seu grau de satisfação com relação ao DATER: (Considere a seguinte pontuação: 1 - MUITO RUIM; 2 - RUIM; 3 - REGULAR; 4 - BOM; 5 - MUITO BOM)

\begin{tabular}{|l|l|l|l|l|}
\hline 1 & 2 & 3 & 4 & 5 \\
\hline
\end{tabular}


PESQUISA - IMPACTO DAS AÇÕES DE FORMAÇÃO REALIZADAS PELO DATER/SAF/MDA NO PERÍODO 2004-2009

Caros colaboradores,

Contamos com a sua atenção para preencher o formulário abaixo.

O mesmo tem por objetivo fornecer informações para avaliação da Eficiência, Efetividade e Eficácia da Política Pública de Formação de Agentes de Ater adotada pelo Departamento de Assistência Técnica e Extensão Rural, da Secretaria de Agricultura Familiar do Ministério do Desenvolvimento - DATER/SAF/MDA, no período de 2004 a 2009, tema escolhido para Monografia a ser apresentada à Universidade de Brasília (UnB) como requisito parcial para obtenção do grau de Bacharel em Administração.

Você poderá ou não se identificar no questionário e garantimos que todas as informações fornecidas serão confidenciais e utilizadas apenas de forma sistematizada.

IDENTIFICAÇÃO

\begin{tabular}{|c|c|}
\hline Nome: RUI LIMA DE SOUZA & $\begin{array}{l}\text { Sexo: } \\
(\mathrm{x}) \text { masculino }\end{array}$ \\
\hline $\begin{array}{l}\text { Instituição (nome e tipo de instituição: ONG, } \\
\text { Empresa Pública, etc.): } \\
\text { Instituto de Desenvolvimento Agropecuário do } \\
\text { Estado do Amazonas - IDAM }\end{array}$ & $\begin{array}{l}\text { Local de trabalho (Cidade e Estado): } \\
\text { Unidade Local de Novo Airão - Amazonas }\end{array}$ \\
\hline \multicolumn{2}{|c|}{$\begin{array}{l}\text { Curso/Encontro/Oficina do qual participou (caso tenha participado de mais de um curso, preencha } \\
\text { um formulário para cada um deles): } \\
\text { II Encontro para Socialização dos Conceitos Básicos da Política Nacional de Ater }\end{array}$} \\
\hline $\begin{array}{l}\text { Data do Curso/Encontro/Oficina (pelo menos mês } \epsilon \\
04 \text { a } 08 \text { de dezembro de } 2006 \text { - Manaus/AM }\end{array}$ & \\
\hline
\end{tabular}

1. Indique sua área de atuação? (As opções não são excludentes: você poderá marcar mais de uma opção)

\begin{tabular}{|l|l|}
\hline$X$ & EXTENSÃO RURAL \\
\hline & PESQUISA \\
\hline & ENSINO \\
\hline & OUTROS \\
\hline
\end{tabular}


2) Qual o seu nível de escolaridade? (Considere apenas o nível mais alto)

\begin{tabular}{|l|l|}
\hline$X$ & NÍVEL MÉDIO \\
\hline & NÍVEL SUPERIOR \\
\hline & PÓS-GRADUAÇÃO \\
\hline
\end{tabular}

3) Os conteúdos abordados foram condizentes com as demandas do seu dia-a-dia?

\begin{tabular}{|l|l|}
\hline$X$ & SIM \\
\hline & PARCIALMENTE \\
\hline & NÃO \\
\hline
\end{tabular}

4) O curso contribuiu para o seu aperfeiçoamento profissional?

\begin{tabular}{|l|l|}
\hline$X$ & SIM \\
\hline & NÃO \\
\hline
\end{tabular}

5) Os conhecimentos adquiridos estão sendo aplicados no seu trabalho Em caso afirmativo, indique em que grau estes conhecimentos estão sendo aplicados. Em caso negativo, indique por que razão isto não ocorre: (Em caso negativo, as respostas não são excludentes: você poderá marcar mais de uma opção).

\begin{tabular}{|c|c|c|c|}
\hline \multirow{3}{*}{ X } & \multirow{3}{*}{$\begin{array}{l}\text { SIM (indique ao lado em } \\
\text { que grau) }\end{array}$} & $\bar{x}$ & MUITO APLICADOS \\
\hline & & & MEDIAMENTE APLICADOS \\
\hline & & & POUCO APLICADOS \\
\hline & \multirow{2}{*}{$\begin{array}{l}\text { NÃO (indique ao lado a } \\
\text { razão da não aplicação) }\end{array}$} & & $\begin{array}{l}\text { CONTEÚDO NÃO ADEQUADO ȦS NECESSIDADES } \\
\text { ESPECÍFICAS DA REGIÃO }\end{array}$ \\
\hline & & & $\begin{array}{l}\text { CONTEÚDO NÃO FOI SUFICIENTEMENTE } \\
\text { APROFUNDADO PARA } \\
\text { EERMITIR UMA APLICAÇÃO } \\
\text { EFICAZ E EFICIENTE }\end{array}$ \\
\hline
\end{tabular}




\begin{tabular}{|l|l|l|}
\hline \multirow{2}{*}{} & & $\begin{array}{l}\text { FALTA DE APOIO E INCENTIVO DA MINHA } \\
\text { INSTITUIÇÃO }\end{array}$ \\
\cline { 2 - 3 } & & FALTA DE INCENTIVO ÀS AÇÕES DE ATER \\
\cline { 2 - 3 } & & NÃO TENHO INTERESSE EM APLICAR \\
\hline
\end{tabular}

6) A partir deste curso: (As opções não são excludentes: você poderá marcar mais de uma opção)

\begin{tabular}{|l|l|}
\hline & NÃO MUDOU NADA EM MEU TRABALHO. \\
\hline$X$ & $\begin{array}{l}\text { MEU TRABALHO PASSOU A CONTRIBUIR MAIS COM OS AGRICULTORES(AS) } \\
\text { FAMILIARES. }\end{array}$ \\
\hline$X$ & CONSEGUI INFLUENCIAR NAS ORIENTAÇÕES DA MINHA INSTITUIÇÃO. \\
\hline$X$ & PASSEI A TRABALHAR COM METODOLOGIAS PARTICIPATIVAS. \\
\hline$X$ & $\begin{array}{l}\text { CRESCEU A ÁREA DE AGRICULTURA DE BASE ECOLÓGICA NAS COMUNIDADES } \\
\text { ONDE ATUO. }\end{array}$ \\
\hline$X$ & CONTINUEI ME APERFEIÇOANDO SOBRE TEMAS ABORDADOS. \\
\hline
\end{tabular}

7) Depois do curso você apoiou atividades de capacitação de técnicos e agricultores com base nos princípios e diretrizes da Pnater? (Considere como apoio a atividades de capacitação a participação no planejamento, elaboração de ementas, seleção de participantes e de palestrantes.)

\begin{tabular}{|l|l|}
\hline$X$ & SIM \\
\hline & NÃO \\
\hline
\end{tabular}

8) Usou os conhecimentos para ministrar outros cursos com o mesmo conteúdo ou conteúdos semelhantes?

\begin{tabular}{|l|l|}
\hline$X$ & SIM \\
\hline & NÃO \\
\hline
\end{tabular}


9) Marque o seu grau de satisfação com relação ao curso oferecido pelo DATER: (Considere a seguinte pontuação: 1 - MUITO RUIM; 2 - RUIM; 3 - REGULAR; 4 - BOM; 5 - MUITO BOM)

\begin{tabular}{|l|l|l|l|l|}
\hline 1 & 2 & 3 & 4 & 5 \\
\hline
\end{tabular}

10) Marque seu grau de satisfação com relação ao DATER: (Considere a seguinte pontuação: 1 - MUITO RUIM; 2 - RUIM; 3 - REGULAR; 4 - BOM; 5 - MUITO BOM)

\begin{tabular}{|l|l|l|l|l|}
\hline 1 & 2 & 3 & 4 & 5 \\
\hline
\end{tabular}


PESQUISA - IMPACTO DAS AÇÕES DE FORMAÇÃO REALIZADAS PELO DATER/SAF/MDA NO PERÍODO 2004-2009

Caros colaboradores,

Contamos com a sua atenção para preencher o formulário abaixo.

O mesmo tem por objetivo fornecer informações para avaliação da Eficiência, Efetividade e Eficácia da Política Pública de Formação de Agentes de Ater adotada pelo Departamento de Assistência Técnica e Extensão Rural, da Secretaria de Agricultura Familiar do Ministério do Desenvolvimento - DATER/SAF/MDA, no período de 2004 a 2009, tema escolhido para Monografia a ser apresentada à Universidade de Brasília (UnB) como requisito parcial para obtenção do grau de Bacharel em Administração.

Você poderá ou não se identificar no questionário e garantimos que todas as informações fornecidas serão confidenciais e utilizadas apenas de forma sistematizada.

IDENTIFICAÇÃO

\begin{tabular}{|c|c|}
\hline Nome: ROSINEIDE DA PAZ MACHADO & $\begin{array}{l}\text { Sexo: } \\
(\quad) \text { masculino }(x) \text { feminino }\end{array}$ \\
\hline $\begin{array}{l}\text { Instituição (nome e tipo de instituição: ONG, } \\
\text { Empresa Pública, etc.): } \\
\text { Instituto de Desenvolvimento Agropecuário do } \\
\text { Estado do Amazonas - IDAM }\end{array}$ & $\begin{array}{l}\text { Local de trabalho (Cidade e Estado): } \\
\text { Unidade Local de São Paulo de Olivença - } \\
\text { Amazonas }\end{array}$ \\
\hline \multicolumn{2}{|c|}{$\begin{array}{l}\text { Curso/Encontro/Oficina do qual participou (caso tenha participado de mais de um curso, preencha } \\
\text { um formulário para cada um deles): } \\
\text { Curso Diagnóstico Rural Participativo - DRP }\end{array}$} \\
\hline $\begin{array}{l}\text { Data do Curso/Encontro/Oficina (pelo menos mês } \\
16 \text { a } 27 \text { de outubro de } 2006 \text { - Manaus/AM }\end{array}$ & \\
\hline
\end{tabular}

1. Indique sua área de atuação? (As opções não são excludentes: você poderá marcar mais de uma opção)

\begin{tabular}{|l|l|}
\hline$X$ & EXTENSÃO RURAL \\
\hline & PESQUISA \\
\hline & ENSINO \\
\hline
\end{tabular}




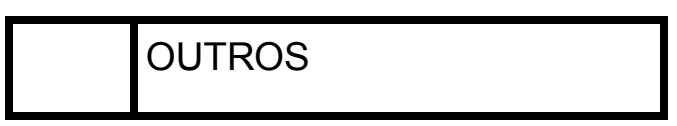

2) Qual o seu nível de escolaridade? (Considere apenas o nível mais alto)

\begin{tabular}{|l|l|}
\hline & NÍVEL MÉDIO \\
\hline & NÍVEL SUPERIOR \\
\hline$X$ & PÓS-GRADUAÇÃO \\
\hline
\end{tabular}

3) Os conteúdos abordados foram condizentes com as demandas do seu dia-a-dia?

\begin{tabular}{|l|l|}
\hline$X$ & SIM \\
\hline & PARCIALMENTE \\
\hline & NÃO \\
\hline
\end{tabular}

3) O curso contribuiu para o seu aperfeiçoamento profissional?

\begin{tabular}{|l|l|}
\hline$X$ & SIM \\
\hline & NÃO \\
\hline
\end{tabular}

5) Os conhecimentos adquiridos estão sendo aplicados no seu trabalho? Em caso afirmativo, indique em que grau estes conhecimentos estão sendo aplicados. Em caso negativo, indique por que razão isto não ocorre: (Em caso negativo, as respostas não são excludentes: você poderá marcar mais de uma opção).

\begin{tabular}{|l|l|l|l|}
\hline \multirow{2}{*}{$\begin{array}{l}\text { SIM (indique ao lado em } \\
\text { que grau) }\end{array}$} & $X$ & MUITO APLICADOS \\
\cline { 3 - 4 } & & MEDIAMENTE APLICADOS \\
\hline & $\begin{array}{l}\text { NÃO (indique ao lado a } \\
\text { razão da não aplicação) }\end{array}$ & & $\begin{array}{l}\text { CONTEÚDO NÃO ADEQUADO ȦS NECESSIDADES } \\
\text { ESPECÍFICAS DA REGIÃO }\end{array}$ \\
\hline
\end{tabular}




\begin{tabular}{|l|l|l|}
\hline \multirow{10}{*}{} & $\begin{array}{l}\text { CONTEÚDO NÃO FOI SUFICIENTEMENTE } \\
\text { APROFUNDADO PARA PERMITIR UMA APLICAÇÃO } \\
\text { EFICAZ E EFICIENTE }\end{array}$ \\
\cline { 2 - 4 } & $\begin{array}{l}\text { FALTA DE APOIO E INCENTIVO DA MINHA } \\
\text { INSTITUIÇÃO }\end{array}$ \\
\cline { 2 - 4 } & FALTA DE INCENTIVO ÀS AÇÕES DE ATER \\
\hline & NÃO TENHO INTERESSE EM APLICAR \\
\hline
\end{tabular}

6) A partir deste curso: (As opções não são excludentes: você poderá marcar mais de uma opção)

\begin{tabular}{|l|l|}
\hline & NÃO MUDOU NADA EM MEU TRABALHO. \\
\hline & $\begin{array}{l}\text { MEU TRABALHO PASSOU A CONTRIBUIR MAIS COM OS AGRICULTORES(AS) } \\
\text { FAMILIARES. }\end{array}$ \\
\hline$X$ & CONSEGUI INFLUENCIAR NAS ORIENTAÇÕES DA MINHA INSTITUIÇÃO. \\
\hline & $\begin{array}{l}\text { CRESCEU A ÁREA DE AGRICULTURA DE BASE ECOLÓGICA NAS COMUNIDADES } \\
\text { ONDE ATUO. }\end{array}$ \\
\hline & CONTINUEI ME APERFEIÇOANDO SOBRE TEMAS ABORDADOS. \\
\hline
\end{tabular}

7) Depois do curso você apoiou atividades de capacitação de técnicos e agricultores com base nos princípios e diretrizes da Pnater? (Considere como apoio a atividades de capacitação a participação no planejamento, elaboração de ementas, seleção de participantes e de palestrantes.)

\begin{tabular}{|l|l|}
\hline$X$ & SIM \\
\hline & NÃO \\
\hline
\end{tabular}

8) Usou os conhecimentos para ministrar outros cursos com o mesmo conteúdo ou conteúdos semelhantes? 


\begin{tabular}{|l|l|}
\hline & SIM \\
\hline$X$ & NÃO \\
\hline
\end{tabular}

9) Marque o seu grau de satisfação com relação ao curso oferecido pelo DATER: (Considere a seguinte pontuação: 1 - MUITO RUIM; 2 - RUIM; 3 - REGULAR; 4 - BOM; 5 - MUITO BOM)

\begin{tabular}{|l|l|l|l|l|}
\hline 1 & 2 & 3 & 4 & 5 \\
\hline
\end{tabular}

10) Marque seu grau de satisfação com relação ao DATER: (Considere a seguinte pontuação: 1 - MUITO RUIM; 2 - RUIM; 3 - REGULAR; 4 - BOM; 5 - MUITO BOM)

\begin{tabular}{|l|l|l|l|l|}
\hline 1 & 2 & 3 & 4 & 5 \\
\hline
\end{tabular}


PESQUISA - IMPACTO DAS AÇÕES DE FORMAÇÃO REALIZADAS PELO DATER/SAF/MDA NO PERÍODO 2004-2009

Caros colaboradores,

Contamos com a sua atenção para preencher o formulário abaixo.

O mesmo tem por objetivo fornecer informações para avaliação da Eficiência, Efetividade e Eficácia da Política Pública de Formação de Agentes de Ater adotada pelo Departamento de Assistência Técnica e Extensão Rural, da Secretaria de Agricultura Familiar do Ministério do Desenvolvimento - DATER/SAF/MDA, no período de 2004 a 2009, tema escolhido para Monografia a ser apresentada à Universidade de Brasília (UnB) como requisito parcial para obtenção do grau de Bacharel em Administração.

Você poderá ou não se identificar no questionário e garantimos que todas as informações fornecidas serão confidenciais e utilizadas apenas de forma sistematizada.

IDENTIFICAÇÃO

\begin{tabular}{|c|c|}
\hline Nome: ROLANGIO PEREIRA DE SOUSA & $\begin{array}{l}\text { Sexo: } \\
(\mathrm{x}) \text { masculino }\end{array}$ \\
\hline $\begin{array}{l}\text { Instituição (nome e tipo de instituição: ONG, } \\
\text { Empresa Pública, etc.): } \\
\text { Instituto de Desenvolvimento Agropecuário do } \\
\text { Estado do Amazonas - IDAM }\end{array}$ & $\begin{array}{l}\text { Local de trabalho (Cidade e Estado): } \\
\text { Unidade Local de Iranduba - Amazonas }\end{array}$ \\
\hline \multicolumn{2}{|c|}{$\begin{array}{l}\text { Curso/Encontro/Oficina do qual participou (caso tenha participado de mais de um curso, preencha } \\
\text { um formulário para cada um deles): } \\
\text { Seminário - Agroecologia como Estratégia para a Construção do Desenvolvimento Rural } \\
\text { Sustentável }\end{array}$} \\
\hline $\begin{array}{l}\text { Data do Curso/Encontro/Oficina (pelo menos mês } \\
10 \text { e } 11 \text { de agosto de } 2006 \text { - Manaus/AM }\end{array}$ & \\
\hline
\end{tabular}

1. Indique sua área de atuação? (As opções não são excludentes: você poderá marcar mais de uma opção)

\begin{tabular}{|l|l|}
\hline$X$ & EXTENSÃO RURAL \\
\hline & PESQUISA \\
\hline & ENSINO \\
\hline
\end{tabular}




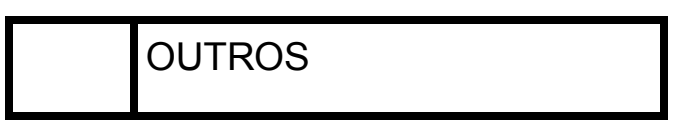

2) Qual o seu nível de escolaridade? (Considere apenas o nível mais alto)

\begin{tabular}{|l|l|}
\hline & NÍVEL MÉDIO \\
\hline$X$ & NÍVEL SUPERIOR \\
\hline & PÓS-GRADUAÇÃO \\
\hline
\end{tabular}

3) Os conteúdos abordados foram condizentes com as demandas do seu dia-a-dia?

\begin{tabular}{|l|l|}
\hline$X$ & SIM \\
\hline & PARCIALMENTE \\
\hline & NÃO \\
\hline
\end{tabular}

4) O curso contribuiu para o seu aperfeiçoamento profissional?

\begin{tabular}{|l|l|}
\hline$X$ & SIM \\
\hline & NÃO \\
\hline
\end{tabular}

5) Os conhecimentos adquiridos estão sendo aplicados no seu trabalho? Em caso afirmativo, indique em que grau estes conhecimentos estão sendo aplicados. Em caso negativo, indique por que razão isto não ocorre: (Em caso negativo, as respostas não são excludentes: você poderá marcar mais de uma opção).

\begin{tabular}{|l|l|l|l|}
\hline \multirow{2}{*}{$\begin{array}{l}\text { SIM (indique ao lado em } \\
\text { que grau) }\end{array}$} & $X$ & MUITO APLICADOS \\
\cline { 2 - 4 } & $\begin{array}{l}\text { NÃO (indique ao lado a } \\
\text { razão da não aplicação) }\end{array}$ & POUCO APLICADOS \\
\hline
\end{tabular}




\begin{tabular}{|l|l|l|}
\hline \multirow{10}{*}{} & $\begin{array}{l}\text { CONTEÚDO NÃO FOI SUFICIENTEMENTE } \\
\text { APROFUNDADO PARA PERMITIR UMA APLICAÇÃO } \\
\text { EFICAZ E EFICIENTE }\end{array}$ \\
\cline { 2 - 4 } & $\begin{array}{l}\text { FALTA DE APOIO E INCENTIVO DA MINHA } \\
\text { INSTITUIÇÃO }\end{array}$ \\
\cline { 2 - 4 } & FALTA DE INCENTIVO ÀS AÇÕES DE ATER \\
\hline & NÃO TENHO INTERESSE EM APLICAR \\
\hline
\end{tabular}

6) A partir deste curso: (As opções não são excludentes: você poderá marcar mais de uma opção)

\begin{tabular}{|l|l|}
\hline$x$ & $\begin{array}{l}\text { NÃO MUDOU NADA EM MEU TRABALHO. } \\
\text { FAMILIARES. }\end{array}$ \\
\hline & CONSEGUI INFLUENCIAR NAS ORIENTAÇÕES DA MINHA INSTITUIÇÃO. \\
\hline$X$ & PASSEI A TRABALHAR COM METODOLOGIAS PARTICIPATIVAS. \\
\hline & $\begin{array}{l}\text { CRESCEU A ÁREA DE AGRICULTURA DE BASE ECOLÓGICA NAS COMUNIDADES } \\
\text { ONDE ATUO. }\end{array}$ \\
\hline & CONTINUEI ME APERFEIÇOANDO SOBRE TEMAS ABORDADOS. \\
\hline
\end{tabular}

7) Depois do curso você apoiou atividades de capacitação de técnicos e agricultores com base nos princípios e diretrizes da Pnater? (Considere como apoio a atividades de capacitação a participação no planejamento, elaboração de ementas, seleção de participantes e de palestrantes.)

\begin{tabular}{|l|l|}
\hline$X$ & SIM \\
\hline & NÃO \\
\hline
\end{tabular}

8) Usou os conhecimentos para ministrar outros cursos com o mesmo conteúdo ou conteúdos semelhantes? 


\begin{tabular}{|l|l|}
\hline$X$ & SIM \\
\hline & NÃO \\
\hline
\end{tabular}

9) Marque o seu grau de satisfação com relação ao curso oferecido pelo DATER: (Considere a seguinte pontuação: 1 - MUITO RUIM; 2 - RUIM; 3 - REGULAR; 4 - BOM; 5 - MUITO BOM)

\begin{tabular}{|l|l|l|l|l|}
\hline 1 & 2 & 3 & 4 & 5 \\
\hline
\end{tabular}

10) Marque seu grau de satisfação com relação ao DATER: (Considere a seguinte pontuação: 1 - MUITO RUIM; 2 - RUIM; 3 - REGULAR; 4 - BOM; 5 - MUITO BOM)

\begin{tabular}{|l|l|l|l|l|}
\hline 1 & 2 & 3 & 4 & 5 \\
\hline
\end{tabular}


PESQUISA - IMPACTO DAS AÇÕES DE FORMAÇÃO REALIZADAS PELO DATER/SAF/MDA NO PERÍODO 2004-2009

Caros colaboradores,

Contamos com a sua atenção para preencher o formulário abaixo.

O mesmo tem por objetivo fornecer informações para avaliação da Eficiência, Efetividade e Eficácia da Política Pública de Formação de Agentes de Ater adotada pelo Departamento de Assistência Técnica e Extensão Rural, da Secretaria de Agricultura Familiar do Ministério do Desenvolvimento - DATER/SAF/MDA, no período de 2004 a 2009, tema escolhido para Monografia a ser apresentada à Universidade de Brasília (UnB) como requisito parcial para obtenção do grau de Bacharel em Administração.

Você poderá ou não se identificar no questionário e garantimos que todas as informações fornecidas serão confidenciais e utilizadas apenas de forma sistematizada.

IDENTIFICAÇÃO

Nome: FRANCISCO ROBERTO GUEDES DE
ANDRADE

Indique sua área de atuação? (As opções não são excludentes: você poderá marcar mais de uma opção)

\begin{tabular}{|l|l}
\hline$X$ & EXTENSÃO RURAL \\
\hline
\end{tabular} 


\begin{tabular}{|l|l|}
\hline & PESQUISA \\
\hline & ENSINO \\
\hline & OUTROS \\
\hline
\end{tabular}

2) Qual o seu nível de escolaridade? (Considere apenas o nível mais alto)

\begin{tabular}{|l|l|}
\hline & NÍVEL MÉDIO \\
\hline$X$ & NÍVEL SUPERIOR \\
\hline & PÓS-GRADUAÇÃO \\
\hline
\end{tabular}

3) Os conteúdos abordados foram condizentes com as demandas do seu dia-a-dia?

\begin{tabular}{|l|l|}
\hline$X$ & SIM \\
\hline & PARCIALMENTE \\
\hline & NÃO \\
\hline
\end{tabular}

3) O curso contribuiu para o seu aperfeiçoamento profissional?

\begin{tabular}{|l|l|}
\hline$X$ & SIM \\
\hline & NÃO \\
\hline
\end{tabular}

5) Os conhecimentos adquiridos estão sendo aplicados no seu trabalho? Em caso afirmativo, indique em que grau estes conhecimentos estão sendo aplicados. Em caso negativo, indique por que razão isto não ocorre: (Em caso negativo, as respostas não são excludentes: você poderá marcar mais de uma opção).

\begin{tabular}{|l|l|l|l|}
\hline $\begin{array}{l}\text { SIM (indique ao lado em } \\
\text { que grau) }\end{array}$ & $X$ & MUITO APLICADOS \\
\cline { 2 - 3 } & & MEDIAMENTE APLICADOS \\
\hline
\end{tabular}




\begin{tabular}{|c|c|}
\hline & POUCO APLICADOS \\
\hline \multirow{5}{*}{$\begin{array}{l}\text { NÃO (indique ao lado a } \\
\text { razão da não aplicação) }\end{array}$} & $\begin{array}{l}\text { CONTEÚDO NÃO ADEQUADO ÀS NECESSIDADES } \\
\text { ESPECÍFICAS DA REGIÃO }\end{array}$ \\
\hline & \begin{tabular}{lccr|} 
CONTEÚDO & NÃO & FOI & SUFICIENTEMENTE \\
APROFUNDADO PARA & PERMITIR UMA APLICAÇÃO \\
EFICAZ E EFICIENTE &
\end{tabular} \\
\hline & 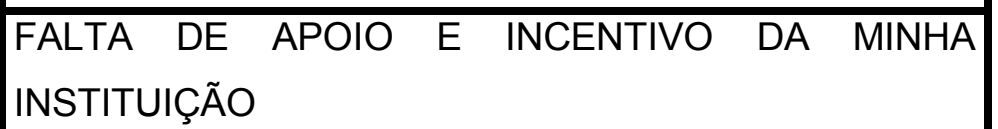 \\
\hline & FALTA DE INCENTIVO ÀS AÇÕES DE ATER \\
\hline & NÃO TENHO INTERESSE EM APLICAR \\
\hline
\end{tabular}

6) A partir deste curso: (As opções não são excludentes: você poderá marcar mais de uma opção)

\begin{tabular}{|l|l|}
\hline & NÃO MUDOU NADA EM MEU TRABALHO. \\
\hline & $\begin{array}{l}\text { MEU TRABALHO PASSOU A CONTRIBUIR MAIS COM OS AGRICULTORES(AS) } \\
\text { FAMILIARES. }\end{array}$ \\
\hline & CONSEGUI INFLUENCIAR NAS ORIENTAÇÕES DA MINHA INSTITUIÇÃO. \\
\hline & $\begin{array}{l}\text { CRASSEI A TRABALHAR COM METODOLOGIAS PARTICIPATIVAS. } \\
\text { ONDE ATUO. ÁREA DE AGRICULTURA DE BASE ECOLÓGICA NAS COMUNIDADES }\end{array}$ \\
\hline$X$ & CONTINUEI ME APERFEIÇOANDO SOBRE TEMAS ABORDADOS. \\
\hline
\end{tabular}

7) Depois do curso você apoiou atividades de capacitação de técnicos e agricultores com base nos princípios e diretrizes da Pnater? (Considere como apoio a atividades de capacitação a participação no planejamento, elaboração de ementas, seleção de participantes e de palestrantes.)

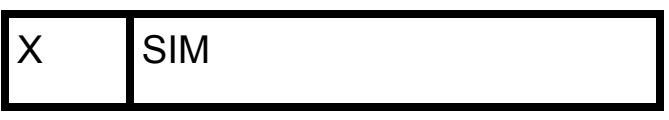


NÃO

8) Usou os conhecimentos para ministrar outros cursos com o mesmo conteúdo ou conteúdos semelhantes?

\begin{tabular}{|l|l|}
\hline & SIM \\
\hline$X$ & NÃO \\
\hline
\end{tabular}

9) Marque o seu grau de satisfação com relação ao curso oferecido pelo DATER: (Considere a seguinte pontuação: 1 - MUITO RUIM; 2 - RUIM; 3 - REGULAR; 4 - BOM; 5 - MUITO BOM)

\begin{tabular}{|l|l|l|l|l|}
\hline 1 & 2 & 3 & 4 & 5 \\
\hline
\end{tabular}

10) Marque seu grau de satisfação com relação ao DATER: (Considere a seguinte pontuação: 1 - MUITO RUIM; 2 - RUIM; 3 - REGULAR; 4 - BOM; 5 - MUITO BOM)

\begin{tabular}{|l|l|l|l|l|}
\hline 1 & 2 & 3 & 4 & 5 \\
\hline
\end{tabular}


PESQUISA - IMPACTO DAS AÇÕES DE FORMAÇÃO REALIZADAS PELO DATER/SAF/MDA NO PERÍODO 2004-2009

Caros colaboradores,

Contamos com a sua atenção para preencher o formulário abaixo.

O mesmo tem por objetivo fornecer informações para avaliação da Eficiência, Efetividade e Eficácia da Política Pública de Formação de Agentes de Ater adotada pelo Departamento de Assistência Técnica e Extensão Rural, da Secretaria de Agricultura Familiar do Ministério do Desenvolvimento - DATER/SAF/MDA, no período de 2004 a 2009, tema escolhido para Monografia a ser apresentada à Universidade de Brasília (UnB) como requisito parcial para obtenção do grau de Bacharel em Administração.

Você poderá ou não se identificar no questionário e garantimos que todas as informações fornecidas serão confidenciais e utilizadas apenas de forma sistematizada.

IDENTIFICAÇÃO

\begin{tabular}{|c|c|}
\hline Nome: RICKSON DA CRUZ VALENTE & $\begin{array}{l}\text { Sexo: } \\
(x) \text { masculino } \quad(\quad) \text { feminino }\end{array}$ \\
\hline $\begin{array}{l}\text { Instituição (nome e tipo de instituição: ONG, } \\
\text { Empresa Pública, etc.): } \\
\text { Instituto de Desenvolvimento Agropecuário do } \\
\text { Estado do Amazonas - IDAM }\end{array}$ & $\begin{array}{l}\text { Local de trabalho (Cidade e Estado): } \\
\text { Unidade Local de Parintins - Amazonas }\end{array}$ \\
\hline \multicolumn{2}{|c|}{$\begin{array}{l}\text { Curso/Encontro/Oficina do qual participou (caso tenha participado de mais de um curso, preencha } \\
\text { um formulário para cada um deles): } \\
\text { Seminário - Agroecologia como Estratégia para a Construção do Desenvolvimento Rural } \\
\text { Sustentável }\end{array}$} \\
\hline $\begin{array}{l}\text { Data do Curso/Encontro/Oficina (pelo menos mês } \\
10 \text { e } 11 \text { de agosto de } 2006 \text { - Manaus/AM }\end{array}$ & \\
\hline
\end{tabular}

Indique sua área de atuação? (As opções não são excludentes: você poderá marcar mais de uma opção)

\begin{tabular}{|l|l|}
\hline$X$ & EXTENSÃO RURAL \\
\hline & PESQUISA \\
\hline
\end{tabular}




\begin{tabular}{|l|l|}
\hline & ENSINO \\
\hline & OUTROS \\
\hline
\end{tabular}

2) Qual o seu nível de escolaridade? (Considere apenas o nível mais alto)

\begin{tabular}{|l|l|}
\hline$X$ & NÍVEL MÉDIO \\
\hline & NÍVEL SUPERIOR \\
\hline & PÓS-GRADUAÇÃO \\
\hline
\end{tabular}

3) Os conteúdos abordados foram condizentes com as demandas do seu dia-a-dia?

\begin{tabular}{|l|l|}
\hline$X$ & SIM \\
\hline & PARCIALMENTE \\
\hline & NÃO \\
\hline
\end{tabular}

3) O curso contribuiu para o seu aperfeiçoamento profissional?

\begin{tabular}{|l|l|}
\hline$X$ & SIM \\
\hline & NÃO \\
\hline
\end{tabular}

5) Os conhecimentos adquiridos estão sendo aplicados no seu trabalho? Em caso afirmativo, indique em que grau estes conhecimentos estão sendo aplicados. Em caso negativo, indique por que razão isto não ocorre: (Em caso negativo, as respostas não são excludentes: você poderá marcar mais de uma opção).

, indique por que razão isto não ocorre:

\begin{tabular}{|l|l|l|l|}
\hline \multirow{2}{*}{$\begin{array}{l}\text { SIM (indique ao lado em } \\
\text { que grau) }\end{array}$} & $\mathrm{X}$ & MUITO APLICADOS \\
\cline { 2 - 4 } & & MEDIAMENTE APLICADOS \\
\hline
\end{tabular}




\begin{tabular}{|c|c|}
\hline \multirow{5}{*}{$\begin{array}{l}\text { NÃO (indique ao lado a } \\
\text { razão da não aplicação) }\end{array}$} & $\begin{array}{l}\text { CONTEÚDO NÃO ADEQUADO ȦS NECESSIDADES } \\
\text { ESPECÍFICAS DA REGIÃO }\end{array}$ \\
\hline & $\begin{array}{l}\text { CONTEÚDO NÃO FOI SUFICIENTEMENTE } \\
\text { APROFUNDADO PARA PERMITIR UMA APLICAÇÃO } \\
\text { EFICAZ E EFICIENTE }\end{array}$ \\
\hline & $\begin{array}{l}\text { FALTA DE APOIO } \\
\text { INSTITUIÇÃO }\end{array}$ \\
\hline & FALTA DE INCENTIVO ÀS AÇÕES DE ATER \\
\hline & NÃO TENHO INTERESSE EM APLICAR \\
\hline
\end{tabular}

6) A partir deste curso: (As opções não são excludentes: você poderá marcar mais de uma opção)

\begin{tabular}{|l|l|}
\hline$x$ & $\begin{array}{l}\text { NÃO MUDOU NADA EM MEU TRABALHO. } \\
\text { FAMILIARES. }\end{array}$ \\
\hline$x$ & CONSEGUI INFLUENCIAR NAS ORIENTAÇÕES DA MINHA INSTITUIÇÃO. \\
\hline$X$ & $\begin{array}{l}\text { CRSSEI A TRABALHAR COM METODOLOGIAS PARTICIPATIVAS. } \\
\text { ONDE ATUO. A ÁREA DE AGRICULTURA DE BASE ECOLÓGICA NAS COMUNIDADES }\end{array}$ \\
\hline & CONTINUEI ME APERFEIÇOANDO SOBRE TEMAS ABORDADOS. \\
\hline
\end{tabular}

7) Depois do curso você apoiou atividades de capacitação de técnicos e agricultores com base nos princípios e diretrizes da Pnater? (Considere como apoio a atividades de capacitação a participação no planejamento, elaboração de ementas, seleção de participantes e de palestrantes.)

\begin{tabular}{|l|l|}
\hline$X$ & SIM \\
\hline & NÃO \\
\hline
\end{tabular}


8) Usou os conhecimentos para ministrar outros cursos com o mesmo conteúdo ou conteúdos semelhantes?

\begin{tabular}{|l|l|}
\hline & SIM \\
\hline$X$ & NÃO \\
\hline
\end{tabular}

9) Marque o seu grau de satisfação com relação ao curso oferecido pelo DATER: (Considere a seguinte pontuação: 1 - MUITO RUIM; 2 - RUIM; 3 - REGULAR; 4 - BOM; 5 - MUITO BOM)

\begin{tabular}{|l|l|l|l|l|}
\hline 1 & 2 & 3 & 4 & 5 \\
\hline
\end{tabular}

10) Marque seu grau de satisfação com relação ao DATER: (Considere a seguinte pontuação: 1 - MUITO RUIM; 2 - RUIM; 3 - REGULAR; 4 - BOM; 5 - MUITO BOM)

\begin{tabular}{|l|l|l|l|l|}
\hline 1 & 2 & 3 & 4 & 5 \\
\hline
\end{tabular}


PESQUISA - IMPACTO DAS AÇÕES DE FORMAÇÃO REALIZADAS PELO DATER/SAF/MDA NO PERÍODO 2004-2009

Caros colaboradores,

Contamos com a sua atenção para preencher o formulário abaixo.

O mesmo tem por objetivo fornecer informações para avaliação da Eficiência, Efetividade e Eficácia da Política Pública de Formação de Agentes de Ater adotada pelo Departamento de Assistência Técnica e Extensão Rural, da Secretaria de Agricultura Familiar do Ministério do Desenvolvimento - DATER/SAF/MDA, no período de 2004 a 2009, tema escolhido para Monografia a ser apresentada à Universidade de Brasília (UnB) como requisito parcial para obtenção do grau de Bacharel em Administração.

Você poderá ou não se identificar no questionário e garantimos que todas as informações fornecidas serão confidenciais e utilizadas apenas de forma sistematizada.

IDENTIFICAÇÃO

\begin{tabular}{|l|l|}
\hline Nome: JANE SANTIAGO BARBOSA & $\begin{array}{l}\text { Sexo: } \\
(\quad) \text { masculino } \quad(x \quad) \text { feminino }\end{array}$ \\
\hline $\begin{array}{l}\text { Instituição (nome e tipo de instituição: ONG, } \\
\text { Empresa Pública, etc.): EMATER-PA }\end{array}$ & $\begin{array}{l}\text { Local de trabalho (Cidade e Estado): } \\
\text { CONCEIÇÃO DO ARAGUAIA }\end{array}$ \\
\hline $\begin{array}{l}\text { Curso/Encontro/Oficina do qual participou (caso tenha participado de mais de um curso, preencha } \\
\text { um formulário para cada um deles): FORMAÇÃO DE AGENTE DE DESENVOLVIMENTO RURAL }\end{array}$ \\
\hline Data do Curso/Encontro/Oficina (pelo menos mês e ano): NOVEMBRO/2006 \\
\hline
\end{tabular}

Indique sua área de atuação? (As opções não são excludentes: você poderá marcar mais de uma opção)

\begin{tabular}{|l|l|}
\hline$X$ & EXTENSÃO RURAL \\
\hline & PESQUISA \\
\hline & ENSINO \\
\hline & OUTROS \\
\hline
\end{tabular}


2) Qual o seu nível de escolaridade? (Considere apenas o nível mais alto)

\begin{tabular}{|r|l|}
\hline & NÍVEL MÉDIO \\
\hline & NÍVEL SUPERIOR \\
\hline$X$ & PÓS-GRADUAÇÃO \\
\hline
\end{tabular}

3) Os conteúdos abordados foram condizentes com as demandas do seu dia-a-dia?

\begin{tabular}{|l|l|}
\hline$X$ & SIM \\
\hline & PARCIALMENTE \\
\hline & NÃO \\
\hline
\end{tabular}

3) O curso contribuiu para o seu aperfeiçoamento profissional?

\begin{tabular}{|l|l|}
\hline$X$ & SIM \\
\hline & NÃO \\
\hline
\end{tabular}

5) Os conhecimentos adquiridos estão sendo aplicados no seu trabalho? Em caso afirmativo, indique em que grau estes conhecimentos estão sendo aplicados. Em caso negativo, indique por que razão isto não ocorre: (Em caso negativo, as respostas não são excludentes: você poderá marcar mais de uma opção).

\begin{tabular}{|l|l|l|l|}
\hline$x$ & $\begin{array}{l}\text { SIM (indique ao lado em } \\
\text { que grau) }\end{array}$ & $\mathrm{X}$ & MUITO APLICADOS \\
\cline { 2 - 4 } & & POUIAMENTE APLICADOS APLICADOS \\
\hline & $\begin{array}{l}\text { NÃO (indique ao lado a } \\
\text { razão da não aplicação) }\end{array}$ & $\begin{array}{l}\text { CONTEU்DO NÃO ADEQUADO ȦS NECESSIDADES } \\
\text { ESPECÍFICAS DA REGIÃO }\end{array}$ \\
\hline
\end{tabular}




\begin{tabular}{|l|l|l|}
\hline \multirow{10}{*}{} & $\begin{array}{l}\text { CONTEÚDO NÃO FOI SUFICIENTEMENTE } \\
\text { APROFUNDADO PARA PERMITIR UMA APLICAÇÃO } \\
\text { EFICAZ E EFICIENTE }\end{array}$ \\
\cline { 2 - 4 } & $\begin{array}{l}\text { FALTA DE APOIO E INCENTIVO DA MINHA } \\
\text { INSTITUIÇÃO }\end{array}$ \\
\cline { 2 - 4 } & FALTA DE INCENTIVO ÀS AÇÕES DE ATER \\
\hline & NÃO TENHO INTERESSE EM APLICAR \\
\hline
\end{tabular}

6) A partir deste curso: (As opções não são excludentes: você poderá marcar mais de uma opção)

\begin{tabular}{|l|l|}
\hline & NÃO MUDOU NADA EM MEU TRABALHO. \\
\hline$X$ & $\begin{array}{l}\text { MEU TRABALHO PASSOU A CONTRIBUIR MAIS COM OS AGRICULTORES(AS) } \\
\text { FAMILIARES. }\end{array}$ \\
\hline & CONSEGUI INFLUENCIAR NAS ORIENTAÇÕES DA MINHA INSTITUIÇÃO. \\
\hline$X$ & $\begin{array}{l}\text { CRESCEU A ÁREA DE AGRICULTURA DE BASE ECOLÓGICA NAS COMUNIDADES } \\
\text { ONDE ATUO. }\end{array}$ \\
\hline$X$ & CONTINUEI ME APERFEIÇOANDO SOBRE TEMAS ABORDADOS. \\
\hline
\end{tabular}

7) Depois do curso você apoiou atividades de capacitação de técnicos e agricultores com base nos princípios e diretrizes da Pnater? (Considere como apoio a atividades de capacitação a participação no planejamento, elaboração de ementas, seleção de participantes e de palestrantes.)

\begin{tabular}{|l|l|}
\hline$X$ & SIM \\
\hline & NÃO \\
\hline
\end{tabular}


8) Usou os conhecimentos para ministrar outros cursos com o mesmo conteúdo ou conteúdos semelhantes?

\begin{tabular}{|l|l|}
\hline$X$ & SIM \\
\hline & NÃO \\
\hline
\end{tabular}

9) Marque o seu grau de satisfação com relação ao curso oferecido pelo DATER: : (Considere a seguinte pontuação: 1 - MUITO RUIM; 2 - RUIM; 3 - REGULAR; 4 - BOM; 5 - MUITO BOM)

\begin{tabular}{|l|l|l|l|l|}
\hline 1 & 2 & 3 & 4 & $5 \times$ \\
\hline
\end{tabular}

10) Marque seu grau de satisfação com relação ao DATER: : (Considere a seguinte pontuação: 1 - MUITO RUIM; 2 - RUIM; 3 - REGULAR; 4 - BOM; 5 - MUITO BOM)

\begin{tabular}{|l|l|l|l|l|}
\hline 1 & 2 & 3 & $4 \times$ & 5 \\
\hline
\end{tabular}




\section{PESQUISA - IMPACTO DAS AÇÕES DE FORMAÇÃO REALIZADAS PELO \\ DATER/SAF/MDA NO PERÍODO 2004-2009}

Caros colaboradores,

Contamos com a sua atenção para preencher o formulário abaixo.

O mesmo tem por objetivo fornecer informações para avaliação da Eficiência, Efetividade e Eficácia da Política Pública de Formação de Agentes de Ater adotada pelo Departamento de Assistência Técnica e Extensão Rural, da Secretaria de Agricultura Familiar do Ministério do Desenvolvimento - DATER/SAF/MDA, no período de 2004 a 2009, tema escolhido para Monografia a ser apresentada à Universidade de Brasília (UnB) como requisito parcial para obtenção do grau de Bacharel em Administração.

Você poderá ou não se identificar no questionário e garantimos que todas as informações fornecidas serão confidenciais e utilizadas apenas de forma sistematizada.

\section{IDENTIFICAÇÃO}

\begin{tabular}{|c|c|}
\hline $\begin{array}{l}\text { Nome: } \\
\text { James de Almeida Alves }\end{array}$ & $\begin{array}{l}\text { Sexo: } \\
(x \quad) \text { masculino } \quad(\quad) \text { feminino }\end{array}$ \\
\hline $\begin{array}{l}\text { Instituição (nome e tipo de instituição: ONG, } \\
\text { Empresa Pública, etc.): } \\
\text { Emater }\end{array}$ & $\begin{array}{l}\text { Local de trabalho (Cidade e Estado): } \\
\text { Castanheiras- RO }\end{array}$ \\
\hline \multicolumn{2}{|c|}{$\begin{array}{l}\text { Curso/Encontro/Oficina do qual participou (caso tenha participado de mais de um curso, preencha } \\
\text { um formulário para cada um deles): } \\
\text { Oficina Gênero Raça e Etnia }\end{array}$} \\
\hline $\begin{array}{l}\text { Data do Curso/Encontro/Oficina (pelo menos mês e } \\
2006\end{array}$ & \\
\hline
\end{tabular}

1. Indique sua área de atuação? (As opções não são excludentes: você poderá marcar mais de uma opção)

\begin{tabular}{|l|l|}
\hline$X$ & EXTENSÃO RURAL \\
\hline & PESQUISA \\
\hline & ENSINO \\
\hline
\end{tabular}




\section{OUTROS}

2) Qual o seu nível de escolaridade? (Considere apenas o nível mais alto)

\begin{tabular}{|l|l|}
\hline$X$ & NÍVEL MÉDIO \\
\hline & NÍVEL SUPERIOR \\
\hline & PÓS-GRADUAÇÃO \\
\hline
\end{tabular}

3) Os conteúdos abordados foram condizentes com as demandas do seu dia-a-dia?

\begin{tabular}{|l|l|}
\hline$X$ & SIM \\
\hline & PARCIALMENTE \\
\hline & NÃO \\
\hline
\end{tabular}

4) O curso contribuiu para o seu aperfeiçoamento profissional?

\begin{tabular}{|l|l|}
\hline & SIM \\
\hline$X$ & NÃO \\
\hline
\end{tabular}

5) Os conhecimentos adquiridos estão sendo aplicados no seu trabalho? Em caso afirmativo, indique em que grau estes conhecimentos estão sendo aplicados. Em caso negativo, indique por que razão isto não ocorre: (Em caso negativo, as respostas não são excludentes: você poderá marcar mais de uma opção).

\begin{tabular}{|l|l|l|l|}
\hline \multirow{2}{*}{$\begin{array}{l}\text { SIM (indique ao lado } \\
\text { em que grau) }\end{array}$} & X & MUITO APLICADOS \\
\cline { 2 - 3 } & & MEDIAMENTE APLICADOS \\
\cline { 2 - 3 } & & POUCO APLICADOS \\
\hline
\end{tabular}




\begin{tabular}{|c|c|}
\hline \multirow{5}{*}{$\begin{array}{l}\text { NÃO (indique ao lado } \\
\text { a razão da não } \\
\text { aplicação) }\end{array}$} & $\begin{array}{lccc}\text { CONTEÚDO NÃO } & \text { ADEQUADO } & \text { ȦS } \\
\text { NECESSIDADES ESPECÍFICAS DA REGIÃO } & \end{array}$ \\
\hline & $\begin{array}{lccc}\text { CONTEÚDO NÃO } & \text { FOI } & \text { SUFICIENTEMENTE } \\
\text { APROFUNDADO } & \text { PARA } & \text { PERMITIR } & \text { UMA } \\
\text { APLICAÇÃO EFICAZ E EFICIENTE }\end{array}$ \\
\hline & $\begin{array}{llllll}\text { FALTA DE APOIO } & \text { E } & \text { INCENTIVO } & \text { DA } & \text { MINHA } \\
\text { INSTITUIÇÃO } & & & & \\
\end{array}$ \\
\hline & FALTA DE INCENTIVO ÀS AÇÕES DE ATER \\
\hline & NÃO TENHO INTERESSE EM APLICAR \\
\hline
\end{tabular}

6) A partir deste curso: (As opções não são excludentes: você poderá marcar mais de uma opção)

\begin{tabular}{|l|l|l|}
\hline & NÃO MUDOU NADA EM MEU TRABALHO. \\
\hline$X$ & $\begin{array}{l}\text { MEU TRABALHO PASSOU A CONTRIBUIR MAIS COM OS AGRICULTORES(AS) } \\
\text { FAMILIARES. }\end{array}$ \\
\hline$X$ & CONSEGUI INFLUENCIAR NAS ORIENTAÇÕES DA MINHA INSTITUIÇÃO. & \\
\hline$X$ & PASSEI A TRABALHAR COM METODOLOGIAS PARTICIPATIVAS. & \\
\hline & $\begin{array}{l}\text { CRESCEU A ÁREA DE AGRICULTURA DE BASE ECOLÓGICA NAS } \\
\text { COMUNIDADES ONDE ATUO. }\end{array}$ \\
\hline & CONTINUEI ME APERFEIÇOANDO SOBRE TEMAS ABORDADOS. \\
\hline
\end{tabular}

7) Depois do curso você apoiou atividades de capacitação de técnicos e agricultores com base nos princípios e diretrizes da Pnater? (Considere como apoio a atividades de capacitação a participação no planejamento, elaboração de ementas, seleção de participantes e de palestrantes.)

\begin{tabular}{|l|l|}
\hline$X$ & SIM \\
\hline
\end{tabular}




\section{$\mathrm{NÃO}$}

8) Usou os conhecimentos para ministrar outros cursos com o mesmo conteúdo ou conteúdos semelhantes?

\begin{tabular}{|l|l|}
\hline$X$ & SIM \\
\hline & NÃO \\
\hline
\end{tabular}

9) Marque o seu grau de satisfação com relação ao curso oferecido pelo DATER: : (Considere a seguinte pontuação: 1 - MUITO RUIM; 2 - RUIM; 3 - REGULAR; 4 BOM; 5 - MUITO BOM)

\begin{tabular}{|l|l|l|l|l|}
\hline 1 & 2 & 3 & 4 & $(5)$ \\
\hline
\end{tabular}

10) Marque seu grau de satisfação com relação ao DATER: : (Considere a seguinte pontuação: 1 - MUITO RUIM; 2 - RUIM; 3 - REGULAR; 4 - BOM; 5 - MUITO BOM)

\begin{tabular}{|l|l|l|l|l|}
\hline 1 & 2 & 3 & 4 & $(5)$ \\
\hline
\end{tabular}

James de Almeida Alves

CREA- AP 276

Gerente

Emater castanheiras-RO. 
PESQUISA - IMPACTO DAS AÇÕES DE FORMAÇÃO REALIZADAS PELO DATER/SAF/MDA NO PERÍODO 2004-2009

Caros colaboradores,

Contamos com a sua atenção para preencher o formulário abaixo.

O mesmo tem por objetivo fornecer informações para avaliação da Eficiência, Efetividade e Eficácia da Política Pública de Formação de Agentes de Ater adotada pelo Departamento de Assistência Técnica e Extensão Rural, da Secretaria de Agricultura Familiar do Ministério do Desenvolvimento - DATER/SAF/MDA, no período de 2004 a 2009, tema escolhido para Monografia a ser apresentada à Universidade de Brasília (UnB) como requisito parcial para obtenção do grau de Bacharel em Administração.

Você poderá ou não se identificar no questionário e garantimos que todas as informações fornecidas serão confidenciais e utilizadas apenas de forma sistematizada.

IDENTIFICAÇÃO

\begin{tabular}{|l|l|}
\hline Nome: Jaime Martim Miranda Caldas & $\begin{array}{l}\text { Sexo: } \\
\left(\begin{array}{l}x\end{array}\right) \text { masculino } \quad(\quad \text { ) feminino }\end{array}$ \\
\hline Instituição (nome e tipo de instituição: ONG, & Local de trabalho (Cidade e Estado): \\
Empresa Pública, etc.): associaçõ de & CACOAL/RO \\
assistência técnica e Extensão Rural. & \\
EMATER_RO & \\
\hline Curso/Encontro/Oficina do qual participou (caso tenha participado de mais de um curso, \\
preencha um formulário para cada um deles): \\
II SEMINARIO DE AGROECOLOGIA \\
Data do Curso/Encontro/Oficina (pelo menos mês e ano):5 A6/12/2006 \\
\hline
\end{tabular}

1. Indique sua área de atuação? (As opções não são excludentes: você poderá marcar mais de uma opção) 


\begin{tabular}{|l|l|}
\hline & EXTENSÃO RURAL \\
\hline & PESQUISA \\
\hline & ENSINO \\
\hline & OUTROS \\
\hline
\end{tabular}

2) Qual o seu nível de escolaridade? (Considere apenas o nível mais alto)

\begin{tabular}{|l|l|}
\hline & NÍVEL MÉDIO \\
\hline & NÍVEL SUPERIOR \\
\hline$X$ & PÓS-GRADUAÇÃO \\
\hline
\end{tabular}

3) Os conteúdos abordados foram condizentes com as demandas do seu dia-a-dia?

\begin{tabular}{|l|l|}
\hline$X$ & SIM \\
\hline & PARCIALMENTE \\
\hline & NÃO \\
\hline
\end{tabular}

4) O curso contribuiu para o seu aperfeiçoamento profissional?

\begin{tabular}{|l|l|}
\hline$X$ & SIM \\
\hline & NÃO \\
\hline
\end{tabular}

5) Os conhecimentos adquiridos estão sendo aplicados no seu trabalho? Em caso afirmativo, indique em que grau estes conhecimentos estão sendo aplicados. Em caso negativo, indique por que razão isto não ocorre: (Em caso negativo, as respostas não são excludentes: você poderá marcar mais de uma opção).

\begin{tabular}{|l|l|l|l|}
\hline \multirow{2}{*}{$\begin{array}{l}\text { SIM (indique ao lado } \\
\text { em que grau) }\end{array}$} & $\mathrm{X}$ & MUITO APLICADOS \\
\cline { 2 - 4 } & & MEDIAMENTE APLICADOS \\
\hline
\end{tabular}




\begin{tabular}{|c|c|}
\hline & POUCO APLICADOS \\
\hline \multirow{5}{*}{$\begin{array}{l}\text { NÃO (indique ao lado } \\
\text { a razão da não } \\
\text { aplicação) }\end{array}$} & $\begin{array}{|lccc|}\text { CONTEÚDO } & \text { NÃO } & \text { ADEQUADO } & \text { ÀS } \\
\text { NECESSIDADES ESPECÍFICAS DA REGIÃO } & \end{array}$ \\
\hline & \begin{tabular}{lccc|} 
CONTEÚDO & NÃO & FOI & SUFICIENTEMENTE \\
APROFUNDADO & PARA & PERMITIR & UMA \\
APLICAÇÃO EFICAZ E EFICIENTE
\end{tabular} \\
\hline & 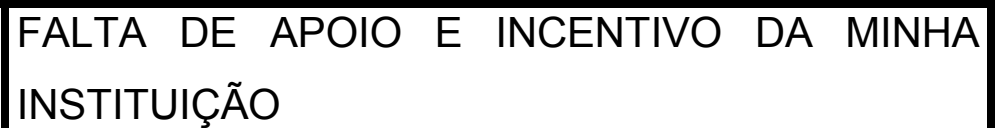 \\
\hline & FALTA DE INCENTIVO ÀS AÇÕES DE ATER \\
\hline & NÃO TENHO INTERESSE EM APLICAR \\
\hline
\end{tabular}

6) A partir deste curso: (As opções não são excludentes: você poderá marcar mais de uma opção)

\begin{tabular}{|l|l|l|}
\hline & NÃO MUDOU NADA EM MEU TRABALHO. \\
\hline$X$ & $\begin{array}{l}\text { MEU TRABALHO PASSOU A CONTRIBUIR MAIS COM OS AGRICULTORES(AS) } \\
\text { FAMILIARES. }\end{array}$ \\
\hline & CONSEGUI INFLUENCIAR NAS ORIENTAÇÕES DA MINHA INSTITUIÇÃO. & \\
\hline$X$ & PASSEI A TRABALHAR COM METODOLOGIAS PARTICIPATIVAS. & \\
\hline & $\begin{array}{l}\text { CRESCEU A ÁREA DE AGRICULTURA DE BASE ECOLÓGICA NAS } \\
\text { COMUNIDADES ONDE ATUO. }\end{array}$ \\
\hline$X$ & CONTINUEI ME APERFEIÇOANDO SOBRE TEMAS ABORDADOS. \\
\hline
\end{tabular}

7) Depois do curso você apoiou atividades de capacitação de técnicos e agricultores com base nos princípios e diretrizes da Pnater? (Considere como apoio a atividades de capacitação a participação no planejamento, elaboração de ementas, seleção de participantes e de palestrantes.)

\begin{tabular}{|l|l|}
\hline$X$ & SIM \\
\hline & NÃO \\
\hline
\end{tabular}


8) Usou os conhecimentos para ministrar outros cursos com o mesmo conteúdo ou conteúdos semelhantes?

\begin{tabular}{|l|l|}
\hline$X$ & SIM \\
\hline & NÃO \\
\hline
\end{tabular}

9) Marque o seu grau de satisfação com relação ao curso oferecido pelo DATER: : (Considere a seguinte pontuação: 1 - MUITO RUIM; 2 - RUIM; 3 - REGULAR; 4 BOM; 5 - MUITO BOM)

\begin{tabular}{|l|l|l|l|l|}
\hline 1 & 2 & 3 & $4 X$ & 5 \\
\hline
\end{tabular}

10) Marque seu grau de satisfação com relação ao DATER: : (Considere a seguinte pontuação: 1 - MUITO RUIM; 2 - RUIM; 3 - REGULAR; 4 - BOM; 5 - MUITO BOM)

\begin{tabular}{|l|l|l|l|l|}
\hline 1 & 2 & 3 & 4 & 5 \\
\hline
\end{tabular}


PESQUISA - IMPACTO DAS AÇÕES DE FORMAÇÃO REALIZADAS PELO DATER/SAF/MDA NO PERÍODO 2004-2009

Caros colaboradores,

Contamos com a sua atenção para preencher o formulário abaixo.

O mesmo tem por objetivo fornecer informações para avaliação da Eficiência, Efetividade e Eficácia da Política Pública de Formação de Agentes de Ater adotada pelo Departamento de Assistência Técnica e Extensão Rural, da Secretaria de Agricultura Familiar do Ministério do Desenvolvimento - DATER/SAF/MDA, no período de 2004 a 2009, tema escolhido para Monografia a ser apresentada à Universidade de Brasília (UnB) como requisito parcial para obtenção do grau de Bacharel em Administração.

Você poderá ou não se identificar no questionário e garantimos que todas as informações fornecidas serão confidenciais e utilizadas apenas de forma sistematizada.

IDENTIFICAÇÃO

\begin{tabular}{|l|l|}
\hline Nome: JAIME EMANUEL CABRAL E SILVA & $\begin{array}{l}\text { Sexo: } \\
(\mathrm{x}) \text { masculino } \quad(\quad) \text { feminino }\end{array}$ \\
\hline
\end{tabular}




\begin{tabular}{|c|c|}
\hline $\begin{array}{l}\text { Instituição (nome e tipo de instituição: ONG, } \\
\text { Empresa Pública, etc.): } \\
\text { EMATER-PARÁ }\end{array}$ & $\begin{array}{l}\text { Local de trabalho (Cidade e Estado): } \\
\text { ESCRITÓRIO LOCAL DE } \\
\text { ANANINDEUA - PARÁ }\end{array}$ \\
\hline \multicolumn{2}{|c|}{$\begin{array}{l}\text { Curso/Encontro/Oficina do qual participou (caso tenha participado de mais de um curso, } \\
\text { preencha um formulário para cada um deles): } \\
\text { DIAGNÓSTICO ORGANIZACIONAL PARTICIPATIVO }\end{array}$} \\
\hline \multicolumn{2}{|c|}{$\begin{array}{l}\text { Data do Curso/Encontro/Oficina (pelo menos mês e ano): } \\
\text { OUTUBRO/2006 }\end{array}$} \\
\hline
\end{tabular}

1. Indique sua área de atuação? (As opções não são excludentes: você poderá marcar mais de uma opção)

\begin{tabular}{|l|l|}
\hline$X$ & EXTENSÃO RURAL \\
\hline & PESQUISA \\
\hline & ENSINO \\
\hline & OUTROS \\
\hline
\end{tabular}

2) Qual o seu nível de escolaridade? (Considere apenas o nível mais alto)

\begin{tabular}{|l|l|}
\hline & NÍVEL MÉDIO \\
\hline$X$ & NÍVEL SUPERIOR \\
\hline & PÓS-GRADUAÇÃO \\
\hline
\end{tabular}

3) Os conteúdos abordados foram condizentes com as demandas do seu dia-a-dia?

\begin{tabular}{|l|l|}
\hline & SIM \\
\hline$X$ & PARCIALMENTE \\
\hline & NÃO \\
\hline
\end{tabular}

4) O curso contribuiu para o seu aperfeiçoamento profissional? 


\begin{tabular}{|l|l|}
\hline$X$ & SIM \\
\hline & NÃO \\
\hline
\end{tabular}

5) Os conhecimentos adquiridos estão sendo aplicados no seu trabalho? Em caso afirmativo, indique em que grau estes conhecimentos estão sendo aplicados. Em caso negativo, indique por que razão isto não ocorre: (Em caso negativo, as respostas não são excludentes: você poderá marcar mais de uma opção).

\begin{tabular}{|c|c|c|}
\hline \multirow{3}{*}{$\begin{array}{l}\text { SIM (indique ao lado } \\
\text { em que grau) }\end{array}$} & & MUITO APLICADOS \\
\hline & & MEDIAMENTE APLICADOS \\
\hline & $\mathrm{X}$ & POUCO APLICADOS \\
\hline \multirow{5}{*}{$\begin{array}{l}\text { NÃO (indique ao lado } \\
\text { a razão da não } \\
\text { aplicação) }\end{array}$} & & $\begin{array}{lccc}\text { CONTEÚDO } & \text { NÃO } & \text { ADEQUADO } & \text { ȦS } \\
\text { NECESSIDADES ESPECÍFICAS DA REGIÃO } & \end{array}$ \\
\hline & & \begin{tabular}{lccc|} 
CONTEÚDO & NÃO & FOI & SUFICIENTEMENTE \\
APROFUNDADO & PARA & PERMITIR & UMA \\
APLICAÇÃO EFICAZ E EFICIENTE
\end{tabular} \\
\hline & & 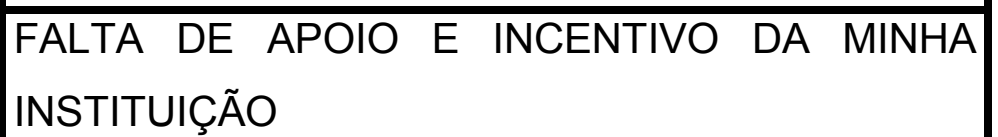 \\
\hline & & FALTA DE INCENTIVO ÀS AÇÕES DE ATER \\
\hline & & NÃO TENHO INTERESSE EM APLICAR \\
\hline
\end{tabular}

6) A partir deste curso: (As opções não são excludentes: você poderá marcar mais de uma opção)

\begin{tabular}{|l|l|}
\hline & NÃO MUDOU NADA EM MEU TRABALHO. \\
\hline & $\begin{array}{l}\text { MEU TRABALHO PASSOU A CONTRIBUIR MAIS COM OS AGRICULTORES(AS) } \\
\text { FAMILIARES. }\end{array}$ \\
\hline & CONSEGUI INFLUENCIAR NAS ORIENTAÇÕES DA MINHA INSTITUIÇÃO. \\
\hline$X$ & PASSEI A TRABALHAR COM METODOLOGIAS PARTICIPATIVAS. \\
\hline
\end{tabular}




\begin{tabular}{|l|l|l|}
\hline & $\begin{array}{l}\text { CRESCEU A ÁREA DE AGRICULTURA DE BASE ECOLÓGICA NAS } \\
\text { COMUNIDADES ONDE ATUO. }\end{array}$ \\
\hline & CONTINUEI ME APERFEIÇOANDO SOBRE TEMAS ABORDADOS. \\
\hline
\end{tabular}

7) Depois do curso você apoiou atividades de capacitação de técnicos e agricultores com base nos princípios e diretrizes da Pnater? (Considere como apoio a atividades de capacitação a participação no planejamento, elaboração de ementas, seleção de participantes e de palestrantes.)

\begin{tabular}{|l|l|}
\hline$X$ & SIM \\
\hline & NÃO \\
\hline
\end{tabular}

8) Usou os conhecimentos para ministrar outros cursos com o mesmo conteúdo ou conteúdos semelhantes?

\begin{tabular}{|l|l|}
\hline$X$ & SIM \\
\hline & NÃO \\
\hline
\end{tabular}

9) Marque o seu grau de satisfação com relação ao curso oferecido pelo DATER: : (Considere a seguinte pontuação: 1 - MUITO RUIM; 2 - RUIM; 3 - REGULAR; 4 BOM; 5 - MUITO BOM)

\begin{tabular}{|l|l|l|l|l|}
\hline 1 & 2 & 3 & $(4)$ & 5 \\
\hline
\end{tabular}

10) Marque seu grau de satisfação com relação ao DATER: : (Considere a seguinte pontuação: 1 - MUITO RUIM; 2 - RUIM; 3 - REGULAR; 4 - BOM; 5 - MUITO BOM)

\begin{tabular}{|l|l|l|l|l|}
\hline 1 & 2 & $(3)$ & 4 & 5 \\
\hline
\end{tabular}


PESQUISA - IMPACTO DAS AÇÕES DE FORMAÇÃO REALIZADAS PELO DATER/SAF/MDA NO PERÍODO 2004-2009

Caros colaboradores,

Contamos com a sua atenção para preencher o formulário abaixo.

O mesmo tem por objetivo fornecer informações para avaliação da Eficiência, Efetividade e Eficácia da Política Pública de Formação de Agentes de Ater adotada pelo Departamento de Assistência Técnica e Extensão Rural, da Secretaria de Agricultura Familiar do Ministério do Desenvolvimento - DATER/SAF/MDA, no período de 2004 a 2009, tema escolhido para Monografia a ser apresentada à Universidade de Brasília (UnB) como requisito parcial para obtenção do grau de Bacharel em Administração.

Você poderá ou não se identificar no questionário e garantimos que todas as informações fornecidas serão confidenciais e utilizadas apenas de forma sistematizada.

IDENTIFICAÇÃO

\begin{tabular}{|c|c|}
\hline Nome: Gildene Soares Carvalho & $\begin{array}{l}\text { Sexo: } \\
(\quad) \text { masculino } \quad(x) \text { feminino }\end{array}$ \\
\hline $\begin{array}{l}\text { Instituição - COOPTER - Cooperativa de } \\
\text { Trabalho, Prestação de Serviços, Assistência } \\
\text { Técnica e Extensão Rural. }\end{array}$ & $\begin{array}{l}\text { Local de trabalho (Cidade e Estado): } \\
\text { Palmas - Tocantins }\end{array}$ \\
\hline \multicolumn{2}{|c|}{ Curso/Encontro/Oficina do qual participou: Encontro de Saúde para população do Campo } \\
\hline Data do Curso/Encontro/Oficina - 05 a 09 de $n$ & io de 2006 \\
\hline
\end{tabular}

1. Indique sua área de atuação? (As opções não são excludentes: você poderá marcar mais de uma opção). 


\begin{tabular}{|l|l|}
\hline$X$ & EXTENSÃO RURAL \\
\hline & PESQUISA \\
\hline & ENSINO \\
\hline & OUTROS \\
\hline
\end{tabular}

2) Qual o seu nível de escolaridade?

\begin{tabular}{|l|l|}
\hline & NÍVEL MÉDIO \\
\hline$X$ & NÍVEL SUPERIOR \\
\hline & PÓS-GRADUAÇÃO \\
\hline
\end{tabular}

3) Os conteúdos abordados foram condizentes com as demandas do seu dia-a-dia?

\begin{tabular}{|l|l|}
\hline$X$ & SIM \\
\hline & PARCIALMENTE \\
\hline & NÃO \\
\hline
\end{tabular}

4) O curso contribuiu para o seu aperfeiçoamento profissional?

\begin{tabular}{|l|l|}
\hline$X$ & SIM \\
\hline & NÃO \\
\hline
\end{tabular}

5) Os conhecimentos adquiridos estão sendo aplicados no seu trabalho? Em caso afirmativo, indique em que grau estes conhecimentos estão sendo aplicados. Em caso negativo, indique por que razão isto não ocorre: (Em caso negativo, as respostas não são excludentes: você poderá marcar mais de uma opção).

\begin{tabular}{|l|l|l|l|}
\hline$X$ & $\begin{array}{l}\text { SIM (indique ao lado } \\
\text { em que grau) }\end{array}$ & $X$ & MUITO APLICADOS \\
\cline { 3 - 5 } & & MEDIAMENTE APLICADOS \\
\hline
\end{tabular}




\begin{tabular}{|c|c|}
\hline & POUCO APLICADOS \\
\hline \multirow{5}{*}{$\begin{array}{l}\text { NÃO (indique ao lado } \\
\text { a razão da não } \\
\text { aplicação) }\end{array}$} & $\begin{array}{|lccc|}\text { CONTEÚDO } & \text { NÃO } & \text { ADEQUADO } & \text { ASS } \\
\text { NECESSIDADES ESPECÍFICAS DA REGIÃO } & \end{array}$ \\
\hline & $\begin{array}{|lrcr|}\text { CONTEÚDO } & \text { NÃO } & \text { FOI } & \text { SUFICIENTEMENTE } \\
\text { APROFUNDADO } & \text { PARA } & \text { PERMITIR } & \text { UMA } \\
\text { APLICAÇÃO EFICAZ E EFICIENTE }\end{array}$ \\
\hline & 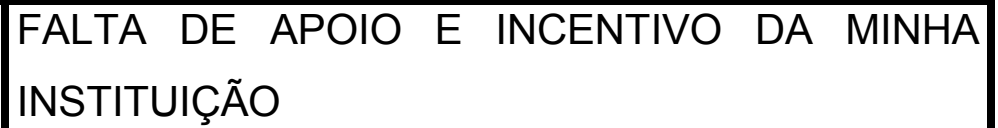 \\
\hline & FALTA DE INCENTIVO ÀS AÇÕES DE ATER \\
\hline & NÃO TENHO INTERESSE EM APLICAR \\
\hline
\end{tabular}

6) A partir deste curso: (As opções não são excludentes: você poderá marcar mais de uma opção).

\begin{tabular}{|l|l|}
\hline & NÃO MUDOU NADA EM MEU TRABALHO. \\
\hline$X$ & $\begin{array}{l}\text { MEU TRABALHO PASSOU A CONTRIBUIR MAIS COM OS AGRICULTORES(AS) } \\
\text { FAMILIARES. }\end{array}$ \\
\hline & CONSEGUI INFLUENCIAR NAS ORIENTAÇÕES DA MINHA INSTITUIÇÃO. \\
\hline & PASSEI A TRABALHAR COM METODOLOGIAS PARTICIPATIVAS. \\
\hline & $\begin{array}{l}\text { CRESCEU A ÁREA DE AGRICULTURA DE BASE ECOLÓGICA NAS } \\
\text { COMUNIDADES ONDE ATUO. }\end{array}$ \\
\hline & CONTINUEI ME APERFEIÇOANDO SOBRE TEMAS ABORDADOS. \\
\hline
\end{tabular}

7. Depois do curso você apoiou atividades de capacitação de técnicos e agricultores com base nos princípios e diretrizes do Pnater? (Considere como apoio a atividades de capacitação a participação no planejamento, elaboração de ementas, seleção de participantes e de palestrantes.)

\begin{tabular}{|l|l|}
\hline$X$ & SIM \\
\hline
\end{tabular}




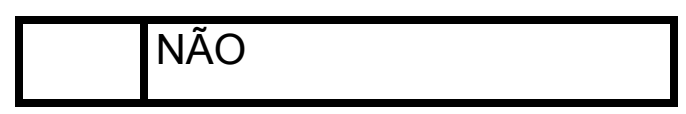

8) Usou os conhecimentos para ministrar outros cursos com o mesmo conteúdo ou conteúdos semelhantes?

\begin{tabular}{|l|l|}
\hline & SIM \\
\hline$X$ & NÃO \\
\hline
\end{tabular}

9) Marque o seu grau de satisfação com relação ao curso oferecido pelo DATER:

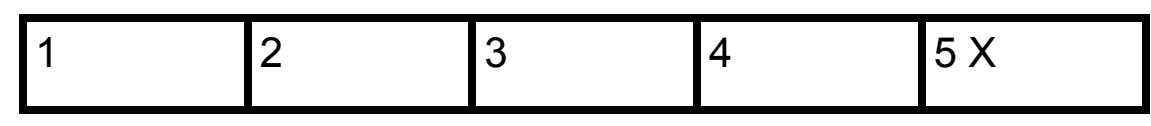

10) Marque seu grau de satisfação com relação ao DATER:

\begin{tabular}{|l|l|l|l|l|}
\hline 1 & 2 & $3 \times$ & 4 & 5 \\
\hline
\end{tabular}


PESQUISA - IMPACTO DAS AÇÕES DE FORMAÇÃO REALIZADAS PELO DATER/SAF/MDA NO PERÍODO 2004-2009

Caros colaboradores,

Contamos com a sua atenção para preencher o formulário abaixo.

O mesmo tem por objetivo fornecer informações para avaliação da Eficiência, Efetividade e Eficácia da Política Pública de Formação de Agentes de Ater adotada pelo Departamento de Assistência Técnica e Extensão Rural, da Secretaria de Agricultura Familiar do Ministério do Desenvolvimento - DATER/SAF/MDA, no período de 2004 a 2009, tema escolhido para Monografia a ser apresentada à Universidade de Brasília (UnB) como requisito parcial para obtenção do grau de Bacharel em Administração.

Você poderá ou não se identificar no questionário e garantimos que todas as informações fornecidas serão confidenciais e utilizadas apenas de forma sistematizada.

Nome: Jader Monteiro Moura

Instituição: Empresa de Assistência Técnica e Extensão Rural do Pará - EMATER

Sexo: Masculino

Local de Trabalho: Escritório Local Cametá

Curso: Agente de desenvolvimento Rural - ADR

Data do curso: Dezembro 2007

Local: Abaetetuba -Pa

1.Indique a sua área de atuação (As opções não são excludentes: você poderá marcar mais de uma opção)

\begin{tabular}{|l|l|}
\hline$X$ & $\begin{array}{l}\text { Extensão } \\
\text { Rural }\end{array}$ \\
\hline & Pesquisa \\
\hline & Ensino \\
\hline & Outros \\
\hline
\end{tabular}

2.Qual o seu nível de Escolaridade (Considere apenas o nível mais alto) 


\begin{tabular}{|l|l|}
\hline & Nível médio \\
\hline & Nível superior \\
\hline$X$ & $\begin{array}{l}\text { Pós- } \\
\text { graduação }\end{array}$ \\
\hline
\end{tabular}

3. Os conteúdos abordados foram condizentes com as demandas do seu dia-a-dia?

\begin{tabular}{|l|l|}
\hline & Sim \\
\hline$X$ & Parcialmente \\
\hline & Não \\
\hline
\end{tabular}

4.O curso contribuiu para o seu aperfeiçoamento profissional?

\begin{tabular}{|l|l|}
\hline$X$ & Sim \\
\hline & Não \\
\hline
\end{tabular}

5. Os conhecimentos adquiridos estão sendo aplicados no seu trabalho? Em caso afirmativo, indique em que grau estes conhecimentos estão sendo aplicados. Em caso negativo, indique por que razão isto não ocorre: (Em caso negativo, as respostas não são excludentes: você poderá marcar mais de uma opção).

\begin{tabular}{|c|c|c|c|}
\hline & Sim (indique ao & & Muito aplicados \\
\hline & lado em que grau) & & Mediamente aplicados \\
\hline & & & Pouco aplicados \\
\hline & $\begin{array}{l}\text { Não (indique ao } \\
\text { lado a razão da não } \\
\text { aplicação) }\end{array}$ & & $\begin{array}{l}\text { Conteúdos não adequado as } \\
\text { necessidades específicas da } \\
\text { região }\end{array}$ \\
\hline$X$ & & & $\begin{array}{l}\text { Conteúdo não foi } \\
\text { suficientemente aprofundado } \\
\text { para permitir uma aplicação } \\
\text { eficaz e eficiente }\end{array}$ \\
\hline & & $\bar{x}$ & $\begin{array}{l}\text { Falta de apoio e incentivo da } \\
\text { minha instituição }\end{array}$ \\
\hline & & $\bar{x}$ & $\begin{array}{l}\text { Falta de incentivo as ações de } \\
\text { ATER }\end{array}$ \\
\hline
\end{tabular}




\begin{tabular}{|l|l|l|l|}
\hline & & & Não tenho interesse em aplicar \\
\hline
\end{tabular}

6. A partir deste curso: (As opções não são excludentes: você poderá marcar mais de uma opção)

\begin{tabular}{|l|l|}
\hline & Não mudou em nada meu trabalho \\
\hline $\mathrm{X}$ & $\begin{array}{l}\text { Meu trabalho passou a contribuir mais com os agricultores(as) } \\
\text { familiares }\end{array}$ \\
\hline $\mathrm{X}$ & Consegui influenciar nas orientações da minha instituição \\
\hline $\mathrm{X}$ & Passei a trabalhar com metodologias participativas \\
\hline $\mathrm{X}$ & $\begin{array}{l}\text { Cresceu a área de agricultura de base ecológica nas comunidades } \\
\text { onde atuo }\end{array}$ \\
\hline $\mathrm{X}$ & Continuei me aperfeiçoando sobre temas abordados. \\
\hline
\end{tabular}

7. Depois do curso você apoiou atividades de capacitação de técnicos e agricultores com base nos princípios e diretrizes do Pnater? (Considere como apoio a atividades de capacitação a participação no planejamento, elaboração de ementas, seleção de participantes e de palestrantes.)

\begin{tabular}{|l|l|}
\hline$X$ & Sim \\
\hline & Não \\
\hline
\end{tabular}

8. Usou o conhecimento para ministrar outros cursos com o mesmo conteúdo ou conteúdos semelhantes?

\begin{tabular}{|l|l|}
\hline$X$ & Sim \\
\hline & Não \\
\hline
\end{tabular}

9. Marque o seu grau de satisfação com relação aos cursos oferecidos pelo DATER : (Considere a seguinte pontuação: 1 - MUITO RUIM; 2 - RUIM; 3 - REGULAR; 4 BOM; 5 - MUITO BOM)

\begin{tabular}{|l|l|l|l|l|}
\hline 1 & 2 & 3 & $X$ & 5 \\
\hline
\end{tabular}


10. Marque o seu grau de satisfação com relação ao DATER : (Considere a seguinte pontuação: 1 - MUITO RUIM; 2 - RUIM; 3 - REGULAR; 4 - BOM; 5 - MUITO BOM)

\begin{tabular}{|l|l|l|l|l|}
\hline 1 & 2 & 3 & $X$ & 5 \\
\hline
\end{tabular}


PESQUISA - IMPACTO DAS AÇÕES DE FORMAÇÃO REALIZADAS PELO DATER/SAF/MDA NO PERÍODO 2004-2009

Caros colaboradores,

Contamos com a sua atenção para preencher o formulário abaixo.

O mesmo tem por objetivo fornecer informações para avaliação da Eficiência, Efetividade e Eficácia da Política Pública de Formação de Agentes de Ater adotada pelo Departamento de Assistência Técnica e Extensão Rural, da Secretaria de Agricultura Familiar do Ministério do Desenvolvimento - DATER/SAF/MDA, no período de 2004 a 2009, tema escolhido para Monografia a ser apresentada à Universidade de Brasília (UnB) como requisito parcial para obtenção do grau de Bacharel em Administração.

Você poderá ou não se identificar no questionário e garantimos que todas as informações fornecidas serão confidenciais e utilizadas apenas de forma sistematizada.

IDENTIFICAÇÃO

\begin{tabular}{|l|l|}
\hline Nome: HUMBERTO BALBI REALE FILHO & $\begin{array}{l}\text { Sexo: } \\
(\mathrm{x}) \text { masculino } \quad(\quad \text { ) feminino }\end{array}$ \\
\hline $\begin{array}{l}\text { Instituição (nome e tipo de instituição: ONG, } \\
\text { Empresa Pública, etc.): EMATER-PARÁ }\end{array}$ & $\begin{array}{l}\text { Local de trabalho (Cidade e Estado): } \\
\text { CONCEIÇÃO DO ARAGUAIA-PA }\end{array}$ \\
\hline $\begin{array}{l}\text { Curso/Encontro/Oficina do qual participou (caso tenha participado de mais de um curso, } \\
\text { preencha um formulário para cada um deles): AGROECOLOGIA }\end{array}$ \\
\hline Data do Curso/Encontro/Oficina (pelo menos mês e ano): MAIO/2004 \\
\hline
\end{tabular}

1. Indique sua área de atuação? (As opções não são excludentes: você poderá marcar mais de uma opção)

\begin{tabular}{|l|l|}
\hline$X$ & EXTENSÃO RURAL \\
\hline & PESQUISA \\
\hline
\end{tabular}




\begin{tabular}{|l|l|}
\hline & ENSINO \\
\hline & OUTROS \\
\hline
\end{tabular}

2) Qual o seu nível de escolaridade? (Considere apenas o nível mais alto)

\begin{tabular}{|r|l|}
\hline & NÍVEL MÉDIO \\
\hline & NÍVEL SUPERIOR \\
\hline$X$ & PÓS-GRADUAÇÃO \\
\hline
\end{tabular}

3) Os conteúdos abordados foram condizentes com as demandas do seu dia-a-dia?

\begin{tabular}{|l|l|}
\hline$X$ & SIM \\
\hline & PARCIALMENTE \\
\hline & NÃO \\
\hline
\end{tabular}

4) O curso contribuiu para o seu aperfeiçoamento profissional?

\begin{tabular}{|l|l|}
\hline$X$ & SIM \\
\hline & NÃO \\
\hline
\end{tabular}

5) Os conhecimentos adquiridos estão sendo aplicados no seu trabalho? Em caso afirmativo, indique em que grau estes conhecimentos estão sendo aplicados. Em caso negativo, indique por que razão isto não ocorre:

\begin{tabular}{|l|l|l|l|}
\hline X & $\begin{array}{l}\text { SIM (indique ao lado } \\
\text { em que grau) }\end{array}$ & & MUITO APLICADOS \\
\cline { 2 - 4 } & $\begin{array}{l}\text { NÃO (indique ao lado } \\
\text { a razão da não }\end{array}$ & MEDIAMENTE APLICADOS \\
\hline
\end{tabular}




\begin{tabular}{|l|l|l|}
\hline aplicação) & $\begin{array}{l}\text { CONTEÚDO NÃO FOI SUFICIENTEMENTE } \\
\text { APROFUNDADO PARA PERMITIR UMA } \\
\text { APLICAÇÃO EFICAZ E EFICIENTE }\end{array}$ \\
\cline { 2 - 3 } & $\begin{array}{l}\text { FALTA DE APOIO E INCENTIVO DA MINHA } \\
\text { INSTITUIÇÃO }\end{array}$ \\
\hline & FALTA DE INCENTIVO ÀS AÇÕES DE ATER \\
\hline & NÃO TENHO INTERESSE EM APLICAR \\
\hline
\end{tabular}

6) A partir deste curso: (As opções não são excludentes: você poderá marcar mais de uma opção)

\begin{tabular}{|l|l|}
\hline$x$ & NÃO MUDOU NADA EM MEU TRABALHO. \\
\hline$X$ & $\begin{array}{l}\text { MEU TRABALHO PASSOU A CONTRIBUIR MAIS COM OS AGRICULTORES(AS) } \\
\text { FAMILIARES. }\end{array}$ \\
\hline & CONSEGUI INFLUENCIAR NAS ORIENTAÇÕES DA MINHA INSTITUIÇÃO. \\
\hline & $\begin{array}{l}\text { CASSEI A TRABALHAR COM METODOLOGIAS PARTICIPATIVAS. } \\
\text { COMUNIDADES ONDE ATUO. }\end{array}$ \\
\hline & CONTINUEI ME APERFEIÇOANDO SOBRE TEMAS ABORDADOS. \\
\hline
\end{tabular}

7) Depois do curso você apoiou atividades de capacitação de técnicos e agricultores com base nos princípios e diretrizes da Pnater? (Considere como apoio a atividades de capacitação a participação no planejamento, elaboração de ementas, seleção de participantes e de palestrantes.)

\begin{tabular}{|l|l|}
\hline$X$ & SIM \\
\hline & NÃO \\
\hline
\end{tabular}

8) Usou os conhecimentos para ministrar outros cursos com o mesmo conteúdo ou conteúdos semelhantes? 


\begin{tabular}{|l|l|}
\hline$X$ & SIM \\
\hline & NÃO \\
\hline
\end{tabular}

9) Marque o seu grau de satisfação com relação ao curso oferecido pelo DATER: : (Considere a seguinte pontuação: 1 - MUITO RUIM; 2 - RUIM; 3 - REGULAR; 4 BOM; 5 - MUITO BOM)

\begin{tabular}{|l|l|l|l|l|}
\hline 1 & 2 & 3 & 4 & $5 \times$ \\
\hline
\end{tabular}

10) Marque seu grau de satisfação com relação ao DATER: : (Considere a seguinte pontuação: 1 - MUITO RUIM; 2 - RUIM; 3 - REGULAR; 4 - BOM; 5 - MUITO BOM)

\begin{tabular}{|l|l|l|l|l|}
\hline 1 & 2 & $3 \times$ & 4 & 5 \\
\hline
\end{tabular}


PESQUISA - IMPACTO DAS AÇÕES DE FORMAÇÃO REALIZADAS PELO DATER/SAF/MDA NO PERÍODO 2004-2009

Caros colaboradores,

Contamos com a sua atenção para preencher o formulário abaixo.

O mesmo tem por objetivo fornecer informações para avaliação da Eficiência, Efetividade e Eficácia da Política Pública de Formação de Agentes de Ater adotada pelo Departamento de Assistência Técnica e Extensão Rural, da Secretaria de Agricultura Familiar do Ministério do Desenvolvimento - DATER/SAF/MDA, no período de 2004 a 2009, tema escolhido para Monografia a ser apresentada à Universidade de Brasília (UnB) como requisito parcial para obtenção do grau de Bacharel em Administração.

Você poderá ou não se identificar no questionário e garantimos que todas as informações fornecidas serão confidenciais e utilizadas apenas de forma sistematizada.

IDENTIFICAÇÃO

\begin{tabular}{|l|l|}
\hline Nome: HELDER SARMENTO DE FREITAS & $\begin{array}{l}\text { Sexo: } \\
(\mathrm{x}) \text { masculino } \quad(\quad \text { ) feminino }\end{array}$ \\
\hline $\begin{array}{l}\text { Instituição (nome e tipo de instituição: ONG, } \\
\text { Empresa Pública, etc.): AMAZOM FRUTAL }\end{array}$ & $\begin{array}{l}\text { Local de trabalho (Cidade e Estado): } \\
\text { JURUTI - PARÁ }\end{array}$ \\
\hline $\begin{array}{l}\text { Curso/Encontro/Oficina do qual participou (caso tenha participado de mais de um curso, } \\
\text { preencha um formulário para cada um deles): PÓs COLHEITA }\end{array}$ \\
\hline Data do Curso/Encontro/Oficina (pelo menos mês e ano): MAIO/2006 \\
\hline
\end{tabular}

1. Indique sua área de atuação? (As opções não são excludentes: você poderá marcar mais de uma opção)

\begin{tabular}{|l|l|}
\hline$X$ & EXTENSÃO RURAL \\
\hline & PESQUISA \\
\hline
\end{tabular}




\begin{tabular}{|l|l|}
\hline & ENSINO \\
\hline & OUTROS \\
\hline
\end{tabular}

2) Qual o seu nível de escolaridade? (Considere apenas o nível mais alto)

\begin{tabular}{|l|l|}
\hline$X$ & NÍVEL MÉDIO \\
\hline & NÍVEL SUPERIOR \\
\hline & PÓS-GRADUAÇÃO \\
\hline
\end{tabular}

3) Os conteúdos abordados foram condizentes com as demandas do seu dia-a-dia?

\begin{tabular}{|l|l|}
\hline$X$ & SIM \\
\hline & PARCIALMENTE \\
\hline & NÃO \\
\hline
\end{tabular}

4) O curso contribuiu para o seu aperfeiçoamento profissional?

\begin{tabular}{|l|l|}
\hline$X$ & SIM \\
\hline & NÃO \\
\hline
\end{tabular}

5) Os conhecimentos adquiridos estão sendo aplicados no seu trabalho? Em caso afirmativo, indique em que grau estes conhecimentos estão sendo aplicados. Em caso negativo, indique por que razão isto não ocorre: (Em caso negativo, as respostas não são excludentes: você poderá marcar mais de uma opção).

\begin{tabular}{|l|l|l|l|}
\hline$x$ & $\begin{array}{l}\text { SIM (indique ao lado } \\
\text { em que grau) }\end{array}$ & & MUITO APLICADOS \\
\cline { 3 - 4 } & & $X$ & POUCO APLICADOS \\
\hline
\end{tabular}




\begin{tabular}{|c|c|}
\hline \multirow{5}{*}{$\begin{array}{l}\text { NÃO (indique ao lado } \\
\text { a razão da não } \\
\text { aplicação) }\end{array}$} & $\begin{array}{lccc}\text { CONTEÚDO } & \text { NÃO } & \text { ADEQUADO } & \text { ÀS } \\
\text { NECESSIDADES ESPECÍFICAS DA REGIÃO } & \end{array}$ \\
\hline & $\begin{array}{lccc}\text { CONTEÚDO NÃO } & \text { FOI } & \text { SUFICIENTEMENTE } \\
\text { APROFUNDADO } & \text { PARA } & \text { PERMITIR } & \text { UMA } \\
\text { APLICAÇÃO EFICAZ E EFICIENTE } & \end{array}$ \\
\hline & $\begin{array}{l}\text { FALTA DE APOIO E INCENTIVO DA MINHA } \\
\text { INSTITUIÇÃO }\end{array}$ \\
\hline & FALTA DE INCENTIVO ÀS AÇÕES DE ATER \\
\hline & NÃO TENHO INTERESSE EM APLICAR \\
\hline
\end{tabular}

6) A partir deste curso: (As opções não são excludentes: você poderá marcar mais de uma opção)

\begin{tabular}{|c|l|}
\hline & NÃO MUDOU NADA EM MEU TRABALHO. \\
\hline & $\begin{array}{l}\text { MEU TRABALHO PASSOU A CONTRIBUIR MAIS COM OS AGRICULTORES(AS) } \\
\text { FAMILIARES. }\end{array}$ \\
\hline$X$ & CONSEGUI INFLUENCIAR NAS ORIENTAÇÕES DA MINHA INSTITUIÇÃO. \\
\hline$X$ & PASSEI A TRABALHAR COM METODOLOGIAS PARTICIPATIVAS. \\
\hline & $\begin{array}{l}\text { CRESCEU A ÁREA DE AGRICULTURA DE BASE ECOLÓGICA } \\
\text { COMAS }\end{array}$ \\
\hline$X$ & CONTINUEI ME APERFEIÇOANDO SOBRE TEMAS ABORDADOS. \\
\hline
\end{tabular}

7) Depois do curso você apoiou atividades de capacitação de técnicos e agricultores com base nos princípios e diretrizes da Pnater? (Considere como apoio a atividades de capacitação a participação no planejamento, elaboração de ementas, seleção de participantes e de palestrantes.)

\begin{tabular}{|l|l|}
\hline$X$ & SIM \\
\hline
\end{tabular}




\section{NÃO}

8) Usou os conhecimentos para ministrar outros cursos com o mesmo conteúdo ou conteúdos semelhantes?

\begin{tabular}{|l|l|}
\hline$X$ & SIM \\
\hline & NÃO \\
\hline
\end{tabular}

9) Marque o seu grau de satisfação com relação ao curso oferecido pelo DATER: : (Considere a seguinte pontuação: 1 - MUITO RUIM; 2 - RUIM; 3 - REGULAR; 4 BOM; 5 - MUITO BOM)

\begin{tabular}{|l|l|l|l|l|}
\hline 1 & 2 & 3 & $4 \times$ & 5 \\
\hline
\end{tabular}

10) Marque seu grau de satisfação com relação ao DATER: : (Considere a seguinte pontuação: 1 - MUITO RUIM; 2 - RUIM; 3 - REGULAR; 4 - BOM; 5 - MUITO BOM)

\begin{tabular}{|l|l|l|l|l|}
\hline 1 & 2 & 3 & $4 \times$ & 5 \\
\hline
\end{tabular}


PESQUISA - IMPACTO DAS AÇÕES DE FORMAÇÃO REALIZADAS PELO DATER/SAF/MDA NO PERÍODO 2004-2009

Caros colaboradores,

Contamos com a sua atenção para preencher o formulário abaixo.

O mesmo tem por objetivo fornecer informações para avaliação da Eficiência, Efetividade e Eficácia da Política Pública de Formação de Agentes de Ater adotada pelo Departamento de Assistência Técnica e Extensão Rural, da Secretaria de Agricultura Familiar do Ministério do Desenvolvimento - DATER/SAF/MDA, no período de 2004 a 2009, tema escolhido para Monografia a ser apresentada à Universidade de Brasília (UnB) como requisito parcial para obtenção do grau de Bacharel em Administração.

Você poderá ou não se identificar no questionário e garantimos que todas as informações fornecidas serão confidenciais e utilizadas apenas de forma sistematizada.

IDENTIFICAÇÃO

\begin{tabular}{|l|l|}
\hline Nome: CELSO DA PENA GIBSON & $\begin{array}{l}\text { Sexo: } \\
(\mathrm{x}) \text { masculino } \quad(\quad \text { ) feminino }\end{array}$ \\
\hline $\begin{array}{l}\text { Instituição (nome e tipo de instituição: ONG, } \\
\text { Empresa Pública, etc.): Emater - PA }\end{array}$ & $\begin{array}{l}\text { Local de trabalho (Cidade e Estado): } \\
\text { MARITUBA PA }\end{array}$ \\
\hline $\begin{array}{l}\text { Curso/Encontro/Oficina do qual participou (caso tenha participado de mais de um curso, } \\
\text { preencha um formulário para cada um deles): Curso de agroecologia }\end{array}$ \\
\hline Data do Curso/Encontro/Oficina (pelo menos mês e ano): 2006 - Altieri e Clara \\
\hline
\end{tabular}

1. Indique sua área de atuação? (As opções não são excludentes: você poderá marcar mais de uma opção)

\begin{tabular}{|l|l|}
\hline$x$ & EXTENSÃO RURAL \\
\hline & PESQUISA \\
\hline
\end{tabular}




\begin{tabular}{|l|l|}
\hline & ENSINO \\
\hline & OUTROS \\
\hline
\end{tabular}

2) Qual o seu nível de escolaridade? (Considere apenas o nível mais alto)

\begin{tabular}{|l|l|}
\hline & NÍVEL MÉDIO \\
\hline & NÍVEL SUPERIOR \\
\hline$x$ & PÓS-GRADUAÇÃO \\
\hline
\end{tabular}

3) Os conteúdos abordados foram condizentes com as demandas do seu dia-a-dia?

\begin{tabular}{|l|l|}
\hline$x$ & SIM \\
\hline & PARCIALMENTE \\
\hline & NÃO \\
\hline
\end{tabular}

4) O curso contribuiu para o seu aperfeiçoamento profissional?

\begin{tabular}{|l|l|}
\hline$x$ & SIM \\
\hline & NÃO \\
\hline
\end{tabular}

5) Os conhecimentos adquiridos estão sendo aplicados no seu trabalho? Em caso afirmativo, indique em que grau estes conhecimentos estão sendo aplicados. Em caso negativo, indique por que razão isto não ocorre: (Em caso negativo, as respostas não são excludentes: você poderá marcar mais de uma opção).

\begin{tabular}{|l|l|l|l|}
\hline$x$ & $\begin{array}{l}\text { SIM (indique ao lado } \\
\text { em que grau) }\end{array}$ & & MUITO APLICADOS \\
\cline { 3 - 4 } & & MEDIAMENTE APLICADOS \\
\cline { 2 - 4 } & & POUCO APLICADOS \\
\hline
\end{tabular}




\begin{tabular}{|l|l|l|l|}
\hline \multirow{3}{*}{$\begin{array}{l}\text { NÃO (indique ao lado } \\
\text { a razão da não } \\
\text { aplicação) }\end{array}$} & $\begin{array}{l}\text { CONTEÚDO NÃO ADEQUADO ÀS } \\
\text { NECESSIDADES ESPECÍFICAS DA REGIÃO }\end{array}$ \\
\cline { 2 - 5 } & $\begin{array}{l}\text { CONTEÚDO NÃO FOI SUFICIENTEMENTEE } \\
\text { APROFUNDADO PARA PERMITIR UMA } \\
\text { APLICAÇÃO EFICAZ E EFICIENTE }\end{array}$ \\
\hline & $\begin{array}{l}\text { FALTA DE APOIO E INCENTIVO DA MINHA } \\
\text { INSTITUIÇÃO }\end{array}$ \\
\hline & FALTA DE INCENTIVO ÀS AÇÕES DE ATER \\
\hline
\end{tabular}

6) A partir deste curso: (As opções não são excludentes: você poderá marcar mais de uma opção)

\begin{tabular}{|l|l|l|}
\hline & NÃO MUDOU NADA EM MEU TRABALHO. \\
\hline$x$ & $\begin{array}{l}\text { MEU TRABALHO PASSOU A CONTRIBUIR MAIS COM OS AGRICULTORES (AS) } \\
\text { FAMILIARES. }\end{array}$ \\
\hline & CONSEGUI INFLUENCIAR NAS ORIENTAÇÕES DA MINHA INSTITUIÇÃO. & \\
\hline & PASSEI A TRABALHAR COM METODOLOGIAS PARTICIPATIVAS. & \\
\hline$x$ & $\begin{array}{l}\text { CRESCEU A ÁREA DE AGRICULTURA DE BASE ECOLÓGICA NAS } \\
\text { COMUNIDADES ONDE ATUO. }\end{array}$ \\
\hline$x$ & CONTINUEI ME APERFEIÇOANDO SOBRE TEMAS ABORDADOS. & \\
\hline
\end{tabular}

7) Depois do curso você apoiou atividades de capacitação de técnicos e agricultores com base nos princípios e diretrizes da Pnater? (Considere como apoio a atividades de capacitação a participação no planejamento, elaboração de ementas, seleção de participantes e de palestrantes.)

\begin{tabular}{|l|l|}
\hline$x$ & $\operatorname{SIM}$ \\
\hline
\end{tabular}




\section{NÃO}

8) Usou os conhecimentos para ministrar outros cursos com o mesmo conteúdo ou conteúdos semelhantes?

\begin{tabular}{|l|l|}
\hline$x$ & SIM \\
\hline & NÃO \\
\hline
\end{tabular}

9) Marque o seu grau de satisfação com relação ao curso oferecido pelo DATER: : (Considere a seguinte pontuação: 1 - MUITO RUIM; 2 - RUIM; 3 - REGULAR; 4 BOM; 5 - MUITO BOM)

\begin{tabular}{|l|l|l|l|l|}
\hline 1 & 2 & 3 & 4 & $x 5$ \\
\hline
\end{tabular}

10) Marque seu grau de satisfação com relação ao DATER: : (Considere a seguinte pontuação: 1 - MUITO RUIM; 2 - RUIM; 3 - REGULAR; 4 - BOM; 5 - MUITO BOM)

\begin{tabular}{|l|l|l|l|l|}
\hline 1 & 2 & 3 & $4 \times$ & 5 \\
\hline
\end{tabular}


PESQUISA - IMPACTO DAS AÇÕES DE FORMAÇÃO REALIZADAS PELO DATER/SAF/MDA NO PERÍODO 2004-2009

Caros colaboradores,

Contamos com a sua atenção para preencher o formulário abaixo.

O mesmo tem por objetivo fornecer informações para avaliação da Eficiência, Efetividade e Eficácia da Política Pública de Formação de Agentes de Ater adotada pelo Departamento de Assistência Técnica e Extensão Rural, da Secretaria de Agricultura Familiar do Ministério do Desenvolvimento - DATER/SAF/MDA, no período de 2004 a 2009, tema escolhido para Monografia a ser apresentada à Universidade de Brasília (UnB) como requisito parcial para obtenção do grau de Bacharel em Administração.

Você poderá ou não se identificar no questionário e garantimos que todas as informações fornecidas serão confidenciais e utilizadas apenas de forma sistematizada.

IDENTIFICAÇÃO

\begin{tabular}{|c|c|}
\hline Nome: Maurício Alves dos Santos & $\begin{array}{l}\text { Sexo: } \\
\left(\begin{array}{ll}(x) \text { masculino } \quad(\quad) \text { feminino }\end{array}\right.\end{array}$ \\
\hline $\begin{array}{l}\text { Instituição (nome e tipo de instituição: ONG, } \\
\text { Empresa Pública, etc.): } \\
\text { EMATER- RO }\end{array}$ & $\begin{array}{l}\text { Local de trabalho (Cidade e Estado): } \\
\text { Estrela de Rondônia Município de } \\
\text { Presidente Médici-RO }\end{array}$ \\
\hline \multicolumn{2}{|c|}{$\begin{array}{l}\text { Curso/Encontro/Oficina do qual participou (caso tenha participado de mais de um curso, } \\
\text { preencha um formulário para cada um deles): } \\
\text { Cursos: Melhoria da qualidade do leite }\end{array}$} \\
\hline Data do Curso/Encontro/Oficina (pelo menos mê & s e ano): \\
\hline
\end{tabular}

1. Indique sua área de atuação? (As opções não são excludentes: você poderá marcar mais de uma opção) 


\begin{tabular}{|l|l|}
\hline$X$ & EXTENSÃO RURAL \\
\hline & PESQUISA \\
\hline & ENSINO \\
\hline & OUTROS \\
\hline
\end{tabular}

2) Qual o seu nível de escolaridade? (Considere apenas o nível mais alto)

\begin{tabular}{|l|l|}
\hline$X$ & NÍVEL MÉDIO \\
\hline & NÍVEL SUPERIOR \\
\hline & PÓS-GRADUAÇÃO \\
\hline
\end{tabular}

3) Os conteúdos abordados foram condizentes com as demandas do seu dia-a-dia?

\begin{tabular}{|l|l|}
\hline$X$ & SIM \\
\hline & PARCIALMENTE \\
\hline & NÃO \\
\hline
\end{tabular}

3) O curso contribuiu para o seu aperfeiçoamento profissional?

\begin{tabular}{|l|l|}
\hline$X$ & SIM \\
\hline & NÃO \\
\hline
\end{tabular}

5) Os conhecimentos adquiridos estão sendo aplicados no seu trabalho? Em caso afirmativo, indique em que grau estes conhecimentos estão sendo aplicados. Em caso negativo, indique por que razão isto não ocorre: (Em caso negativo, as respostas não são excludentes: você poderá marcar mais de uma opção).

\begin{tabular}{|l|l|l|l|}
\hline$X$ & $\begin{array}{l}\text { SIM (indique ao lado } \\
\text { em que grau) }\end{array}$ & $X$ & MUITO APLICADOS \\
\cline { 3 - 4 } & & POUCO APLICADOS \\
\hline
\end{tabular}




\begin{tabular}{|c|c|}
\hline \multirow{5}{*}{$\begin{array}{l}\text { NÃO (indique ao lado } \\
\text { a razão da não } \\
\text { aplicação) }\end{array}$} & $\begin{array}{lccc}\text { CONTEÚDO } & \text { NÃO } & \text { ADEQUADO } & \text { ÀS } \\
\text { NECESSIDADES ESPECÍFICAS DA REGIÃO } & \end{array}$ \\
\hline & $\begin{array}{lccc}\text { CONTEÚDO NÃO } & \text { FOI } & \text { SUFICIENTEMENTE } \\
\text { APROFUNDADO } \quad \text { PARA } & \text { PERMITIR } & \text { UMA } \\
\text { APLICAÇÃO EFICAZ E EFICIENTE } & \end{array}$ \\
\hline & $\begin{array}{l}\text { FALTA DE APOIO E INCENTIVO DA MINHA } \\
\text { INSTITUIÇÃO }\end{array}$ \\
\hline & FALTA DE INCENTIVO ÀS AÇÕES DE ATER \\
\hline & NÃO TENHO INTERESSE EM APLICAR \\
\hline
\end{tabular}

6) A partir deste curso: (As opções não são excludentes: você poderá marcar mais de uma opção)

\begin{tabular}{|c|c|}
\hline & NÃO MUDOU NADA EM MEU TRABALHO. \\
\hline$X$ & $\begin{array}{l}\text { MEU TRABALHO PASSOU A CONTRIBUIR MAIS COM OS AGRICULTORES(AS) } \\
\text { FAMILIARES. }\end{array}$ \\
\hline $\mathrm{X}$ & CONSEGUI INFLUENCIAR NAS ORIENTAÇÕES DA MINHA INSTITUIÇÃO. \\
\hline & PASSEI A TRABALHAR COM METODOLOGIAS PARTICIPATIVAS. \\
\hline & $\begin{array}{l}\text { CRESCEU A ÁREA DE AGRICULTURA DE BASE ECOLÓGICA NAS } \\
\text { COMUNIDADES ONDE ATUO. }\end{array}$ \\
\hline $\mathrm{X}$ & CONTINUEI ME APERFEIÇOANDO SOBRE TEMAS ABORDADOS. \\
\hline
\end{tabular}

7) Depois do curso você apoiou atividades de capacitação de técnicos e agricultores com base nos princípios e diretrizes da Pnater? (Considere como apoio a atividades de capacitação a participação no planejamento, elaboração de ementas, seleção de participantes e de palestrantes.)

\begin{tabular}{|l|l|}
\hline$X$ & SIM \\
\hline & NÃO \\
\hline
\end{tabular}


8) Usou os conhecimentos para ministrar outros cursos com o mesmo conteúdo ou conteúdos semelhantes?

\begin{tabular}{|l|l|}
\hline & SIM \\
\hline$X$ & NÃO \\
\hline
\end{tabular}

9) Marque o seu grau de satisfação com relação ao curso oferecido pelo DATER: (Considere a seguinte pontuação: 1 - MUITO RUIM; 2 - RUIM; 3 - REGULAR; 4 - BOM; 5 - MUITO BOM)

\begin{tabular}{|l|l|l|l|l|}
\hline 1 & 2 & 3 & 4 & $\times 5$ \\
\hline
\end{tabular}

10) Marque seu grau de satisfação com relação ao DATER: (Considere a seguinte pontuação: 1 - MUITO RUIM; 2 - RUIM; 3 - REGULAR; 4 - BOM; 5 - MUITO BOM)

\begin{tabular}{|l|l|l|l|l|}
\hline 1 & 2 & 3 & 4 & $x 5$ \\
\hline
\end{tabular}


PESQUISA - IMPACTO DAS AÇÕES DE FORMAÇÃO REALIZADAS PELO DATER/SAF/MDA NO PERÍODO 2004-2009

Caros colaboradores,

Contamos com a sua atenção para preencher o formulário abaixo.

O mesmo tem por objetivo fornecer informações para avaliação da Eficiência, Efetividade e Eficácia da Política Pública de Formação de Agentes de Ater adotada pelo Departamento de Assistência Técnica e Extensão Rural, da Secretaria de Agricultura Familiar do Ministério do Desenvolvimento - DATER/SAF/MDA, no período de 2004 a 2009, tema escolhido para Monografia a ser apresentada à Universidade de Brasília (UnB) como requisito parcial para obtenção do grau de Bacharel em Administração.

Você poderá ou não se identificar no questionário e garantimos que todas as informações fornecidas serão confidenciais e utilizadas apenas de forma sistematizada.

IDENTIFICAÇÃO

\begin{tabular}{|c|c|}
\hline $\begin{array}{l}\text { Nome: GERALDO DOS SANTOS } \\
\text { CONCEIÇÃO }\end{array}$ & $\begin{array}{l}\text { Sexo: } \\
(x) \text { masculino } \quad(\quad) \text { feminino }\end{array}$ \\
\hline $\begin{array}{l}\text { Instituição (nome e tipo de instituição: ONG, } \\
\text { Empresa Pública, etc.): } \\
\text { Instituto de Desenvolvimento Agropecuário do } \\
\text { Estado do Amazonas - IDAM }\end{array}$ & $\begin{array}{l}\text { Local de trabalho (Cidade e Estado): } \\
\text { Unidade Local de Manicoré - Amazonas }\end{array}$ \\
\hline \multicolumn{2}{|c|}{$\begin{array}{l}\text { Curso/Encontro/Oficina do qual participou (caso tenha participado de mais de um curso, preencha } \\
\text { um formulário para cada um deles): } \\
\text { Curso de Especialização em Extensão Rural, para o desenvolvimento sustentável da Amazônia. }\end{array}$} \\
\hline $\begin{array}{l}\text { Data do Curso/Encontro/Oficina (pelo menos mês e a } \\
11 \text { de outubro de } 2005 \text { a abril de } 2006 \text { - Belém/PA }\end{array}$ & \\
\hline
\end{tabular}

1. Indique sua área de atuação? (As opções não são excludentes: você poderá marcar mais de uma opção)

\begin{tabular}{|l|l|}
\hline$X$ & EXTENSÃO RURAL \\
\hline & PESQUISA \\
\hline & ENSINO \\
\hline
\end{tabular}




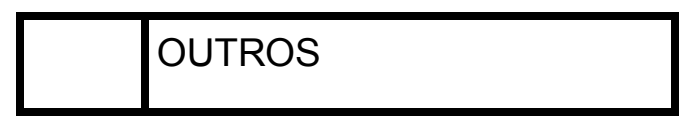

2) Qual o seu nível de escolaridade? (Considere apenas o nível mais alto)

\begin{tabular}{|l|l|}
\hline & NÍVEL MÉDIO \\
\hline & NÍVEL SUPERIOR \\
\hline$X$ & PÓS-GRADUAÇÃO \\
\hline
\end{tabular}

3) Os conteúdos abordados foram condizentes com as demandas do seu dia-a-dia?

\begin{tabular}{|l|l|}
\hline$X$ & SIM \\
\hline & PARCIALMENTE \\
\hline & NÃO \\
\hline
\end{tabular}

4) O curso contribuiu para o seu aperfeiçoamento profissional?

\begin{tabular}{|l|l|}
\hline$X$ & SIM \\
\hline & NÃO \\
\hline
\end{tabular}

5) Os conhecimentos adquiridos estão sendo aplicados no seu trabalho? Em caso afirmativo, indique em que grau estes conhecimentos estão sendo aplicados. Em caso negativo, indique por que razão isto não ocorre: (Em caso negativo, as respostas não são excludentes: você poderá marcar mais de uma opção).

\begin{tabular}{|l|l|l|l|}
\hline \multirow{2}{*}{$\begin{array}{l}\text { SIM (indique ao lado em } \\
\text { que grau) }\end{array}$} & X & MUITO APLICADOS \\
\cline { 2 - 4 } & $\begin{array}{l}\text { NÃO (indique ao lado a } \\
\text { razão da não aplicação) }\end{array}$ & POUCIAMENTE APLICADOS \\
\hline
\end{tabular}




\begin{tabular}{|l|l|l|}
\hline \multirow{10}{*}{} & $\begin{array}{l}\text { CONTEÚDO NÃO FOI SUFICIENTEMENTE } \\
\text { APROFUNDADO PARA PERMITIR UMA APLICAÇÃO } \\
\text { EFICAZ E EFICIENTE }\end{array}$ \\
\cline { 2 - 4 } & $\begin{array}{l}\text { FALTA DE APOIO E INCENTIVO DA MINHA } \\
\text { INSTITUIÇÃO }\end{array}$ \\
\cline { 2 - 4 } & FALTA DE INCENTIVO ÀS AÇÕES DE ATER \\
\hline & NÃO TENHO INTERESSE EM APLICAR \\
\hline
\end{tabular}

6) A partir deste curso: (As opções não são excludentes: você poderá marcar mais de uma opção)

\begin{tabular}{|l|l|}
\hline$x$ & $\begin{array}{l}\text { NÃO MUDOU NADA EM MEU TRABALHO. } \\
\text { FAMILIARES. }\end{array}$ \\
\hline & CONSEGUI INFLUENCIAR NAS ORIENTAÇÕES DA MINHA INSTITUIÇÃO. \\
\hline & PASSEI A TRABALHAR COM METODOLOGIAS PARTICIPATIVAS. \\
\hline & $\begin{array}{l}\text { CRESCEU A ÁREA DE AGRICULTURA DE BASE ECOLÓGICA NAS COMUNIDADES } \\
\text { ONDE ATUO. }\end{array}$ \\
\hline$X$ & CONTINUEI ME APERFEIÇOANDO SOBRE TEMAS ABORDADOS. \\
\hline
\end{tabular}

7) Depois do curso você apoiou atividades de capacitação de técnicos e agricultores com base nos princípios e diretrizes da Pnater? (Considere como apoio a atividades de capacitação a participação no planejamento, elaboração de ementas, seleção de participantes e de palestrantes.)

\begin{tabular}{|l|l|}
\hline$X$ & SIM \\
\hline & NÃO \\
\hline
\end{tabular}

8) Usou os conhecimentos para ministrar outros cursos com o mesmo conteúdo ou conteúdos semelhantes? 


\begin{tabular}{|l|l|}
\hline & SIM \\
\hline$X$ & Ainda NÃO \\
\hline
\end{tabular}

9) Marque o seu grau de satisfação com relação ao curso oferecido pelo DATER: : (Considere a seguinte pontuação: 1 - MUITO RUIM; 2 - RUIM; 3 - REGULAR; 4 - BOM; 5 - MUITO BOM)

\begin{tabular}{|l|l|l|l|l|}
\hline 1 & 2 & 3 & 4 & 5 \\
\hline
\end{tabular}

10) Marque seu grau de satisfação com relação ao DATER: : (Considere a seguinte pontuação: 1 - MUITO RUIM; 2 - RUIM; 3 - REGULAR; 4 - BOM; 5 - MUITO BOM)

\begin{tabular}{|l|l|l|l|l|}
\hline 1 & 2 & 3 & 4 & 5 \\
\hline
\end{tabular}


PESQUISA - IMPACTO DAS AÇÕES DE FORMAÇÃO REALIZADAS PELO DATER/SAF/MDA NO PERÍODO 2004-2009

Caros colaboradores,

Contamos com a sua atenção para preencher o formulário abaixo.

O mesmo tem por objetivo fornecer informações para avaliação da Eficiência, Efetividade e Eficácia da Política Pública de Formação de Agentes de Ater adotada pelo Departamento de Assistência Técnica e Extensão Rural, da Secretaria de Agricultura Familiar do Ministério do Desenvolvimento - DATER/SAF/MDA, no período de 2004 a 2009, tema escolhido para Monografia a ser apresentada à Universidade de Brasília (UnB) como requisito parcial para obtenção do grau de Bacharel em Administração.

Você poderá ou não se identificar no questionário e garantimos que todas as informações fornecidas serão confidenciais e utilizadas apenas de forma sistematizada.

IDENTIFICAÇÃO

\begin{tabular}{|l|l|}
\hline NOME: FRANCISCO LAERCIO AMORIM DE MENEZES & $\begin{array}{l}\text { Sexo: } \\
(\mathrm{x}) \text { masculino } \quad(\quad \text { ) feminino }\end{array}$ \\
\hline $\begin{array}{l}\text { Instituição (nome e tipo de instituição: ONG, Empresa } \\
\text { Pública, etc). }\end{array}$ & Local de Trabalho (cidade, Estado). \\
•EMATER-PARÁ (Empresa Pública) & Marapanim - Pará \\
\hline $\begin{array}{l}\text { Curso,/Encontro/Oficina do qual participou (caso tenha participado de mais de um curso, preencha } \\
\text { - Curso de Formação de ADR. }\end{array}$ \\
\hline $\begin{array}{l}\text { Data do Curso/Encontro/Oficina (pelo menos mês e ano): } \\
\text { - Outubro de 2006. }\end{array}$
\end{tabular}

1. Identifique sua área de atuação (As opções não são excludentes: você poderá marcar mais de uma opção)

\begin{tabular}{|l|l|l|l|}
\hline$x$ & EXTENSÃO RURAL & PESQUISA \\
\hline & ENSINO & OUTROS \\
\hline
\end{tabular}

2) Qual o seu nível de Escolaridade? (Considere apenas o nível mais alto)

\begin{tabular}{|l|l|l|l|}
\hline$x$ & NÍVEL MÉDIO & & NÍVEL SUPERIOR \\
\hline & PÓS GRADUAÇÃO & & \\
\hline
\end{tabular}


3) Os conteúdos abordados foram condizentes com as demandas do seu dia-a-dia?

\begin{tabular}{|l|l|l|l|}
\hline$x$ & SIM & & NÃO \\
\hline & PARCIALMENTE & & \\
\hline
\end{tabular}

4) O curso contribuiu para o aperfeiçoamento profissional?

\begin{tabular}{|l|l|l|l|}
\hline$x$ & SIM & & NÃO \\
\hline
\end{tabular}

5) Os conhecimentos adquiridos estão sendo aplicados no seu trabalho? Em caso afirmativo, indique em que grau estes conhecimentos estão sendo aplicados. Em caso negativo, indique por que razão isto não ocorre: (Em caso negativo, as respostas não são excludentes: você poderá marcar mais de uma opção).

\begin{tabular}{|c|c|c|}
\hline \multirow{3}{*}{$\begin{array}{l}\text { SIM, indique ao } \\
\text { lado em que grau. }\end{array}$} & & MUITO APLICADOS \\
\hline & & MEDIAMENTE APLICADOS \\
\hline & & POUCO APLICADOS \\
\hline \multirow{5}{*}{$\begin{array}{l}\text { NÃO, (indique ao } \\
\text { lado a razão da } \\
\text { não aplicação). }\end{array}$} & & $\begin{array}{l}\text { CONTEÚDO NÃO ADEQUADO ÀS NECESSIDADES ESPECÍFICAS } \\
\text { DA REGIÃO }\end{array}$ \\
\hline & $\mathrm{x}$ & $\begin{array}{l}\text { CONTEÚDO NÃO FOI SUFICIENTEMENTE APROFUNDADO PARA } \\
\text { PERMITIR UMA APLICAÇÃO EFICAZ E EFICIENTE }\end{array}$ \\
\hline & & FALTA DE APOIO E INCENTIVO DA MINHA INSTITUIÇÃO \\
\hline & & FALTA DE INCENTIVO ȦS AÇŌES DE ATER \\
\hline & & NÃO TENHO INTERESSE EM APLICAR; \\
\hline
\end{tabular}

6) A partir deste Curso: (As opções não são excludentes: você poderá marcar mais de uma opção)

\begin{tabular}{|l|l|}
\hline$x$ & $\begin{array}{l}\text { NÃO MUDOU NADA EM MEU TRABALHO } \\
\text { FAMILIARES }\end{array}$ \\
\hline & CONSEGUI INFLUENCIAR NAS ORIENTAÇÕES DA MINHA INSTITUIÇÃO \\
\hline & PASSEI A TRABALHAR COM METODOLOGIAS PARTICIPATIVAS A CONTRIBUIR MAIS COM OS AGRICULTORES (AS ) \\
\hline & $\begin{array}{l}\text { CRESCEU A ÁREA DE AGRICULTURA DE BASE ECOLÓGICA NAS COMUNIDADES ONDE } \\
\text { ATUO }\end{array}$ \\
\hline$x$ & CONTINUEI ME APERFEIÇOANDO SOBRE TEMAS ABORDADOS \\
\hline
\end{tabular}


7) Depois do curso você apoiou atividades de capacitação de técnicos e agricultores com base nos princípios e diretrizes do PNATER? (Considere como apoio a atividades de capacitação a participação no planejamento, elaboração de ementas, seleção de participantes e de palestrantes.)

\begin{tabular}{|l|l|l|l|}
\hline & SIM & $x$ & NÃO \\
\hline
\end{tabular}

8) Usou conhecimentos para ministrar outros cursos com o mesmo conteúdo ou conteúdos semelhantes?

\begin{tabular}{|l|l|l|l|}
\hline & SIM & X & NÃO \\
\hline & & & \\
\hline
\end{tabular}

9) Marque o seu grau de satisfação com relação ao curso oferecido pelo DATER : (Considere a seguinte pontuação: 1 - MUITO RUIM; 2 - RUIM; 3 - REGULAR; 4 - BOM; 5 - MUITO BOM)

\begin{tabular}{|l|l|l|l|l|}
\hline 1 & 2 & $3(x)$ & 4 & 5 \\
\hline
\end{tabular}

10) Marque o seu grau de satisfação em relação ao DATER: (Considere a seguinte pontuação: 1 - MUITO RUIM; 2 - RUIM; 3 - REGULAR; 4 - BOM; 5 - MUITO BOM)

\begin{tabular}{|l|l|l|l|l|}
\hline 1 & $2(\mathrm{x})$ & 3 & 4 & 5 \\
\hline
\end{tabular}


PESQUISA - IMPACTO DAS AÇÕES DE FORMAÇÃO REALIZADAS PELO DATER/SAF/MDA NO PERÍODO 2004-2009

Caros colaboradores,

Contamos com a sua atenção para preencher o formulário abaixo.

O mesmo tem por objetivo fornecer informações para avaliação da Eficiência, Efetividade e Eficácia da Política Pública de Formação de Agentes de Ater adotada pelo Departamento de Assistência Técnica e Extensão Rural, da Secretaria de Agricultura Familiar do Ministério do Desenvolvimento - DATER/SAF/MDA, no período de 2004 a 2009, tema escolhido para Monografia a ser apresentada à Universidade de Brasília (UnB) como requisito parcial para obtenção do grau de Bacharel em Administração.

Você poderá ou não se identificar no questionário e garantimos que todas as informações fornecidas serão confidenciais e utilizadas apenas de forma sistematizada.

\section{IDENTIFICAÇÃO}

\begin{tabular}{|c|c|}
\hline Nome: WESLEY DA SILVA MOURA & $\begin{array}{l}\text { Sexo: } \\
(x \quad) \text { masculino } \quad(\quad) \text { feminino }\end{array}$ \\
\hline $\begin{array}{l}\text { Instituição (nome e tipo de instituição: ONG, } \\
\text { Empresa Pública, etc.): } \\
\text { Instituto de Desenvolvimento Agropecuário do } \\
\text { Estado do Amazonas - IDAM }\end{array}$ & $\begin{array}{l}\text { Local de trabalho (Cidade e Estado): } \\
\text { Unidade Local de Manaquiri - Amazonas }\end{array}$ \\
\hline $\begin{array}{l}\text { Curso/Encontro/Oficina do qual participou (caso tent } \\
\text { um formulário para cada um deles): } \\
\text { Seminário - Agroecologia como Estratégia para } \\
\text { Sustentável }\end{array}$ & $\begin{array}{l}\text { a participado de mais de um curso, preencha } \\
\text { a Construção do Desenvolvimento Rural }\end{array}$ \\
\hline $\begin{array}{l}\text { Data do Curso/Encontro/Oficina (pelo menos mês } \\
10 \text { e } 11 \text { de agosto de } 2006 \text { - Manaus/AM }\end{array}$ & \\
\hline
\end{tabular}

1. Indique sua área de atuação? (As opções não são excludentes: você poderá marcar mais de uma opção)

\begin{tabular}{|l|l|}
\hline$X$ & EXTENSÃO RURAL \\
\hline & PESQUISA \\
\hline
\end{tabular}




\begin{tabular}{|l|l|}
\hline & ENSINO \\
\hline & OUTROS \\
\hline
\end{tabular}

2) Qual o seu nível de escolaridade? (Considere apenas o nível mais alto)

\begin{tabular}{|l|l|}
\hline$x$ & NÍVEL MÉDIO \\
\hline & NÍVEL SUPERIOR \\
\hline & PÓS-GRADUAÇÃO \\
\hline
\end{tabular}

3) Os conteúdos abordados foram condizentes com as demandas do seu dia-a-dia?

\begin{tabular}{|l|l|}
\hline$X$ & SIM \\
\hline & PARCIALMENTE \\
\hline & NÃO \\
\hline
\end{tabular}

4) O curso contribuiu para o seu aperfeiçoamento profissional?

\begin{tabular}{|l|l|}
\hline$X$ & SIM \\
\hline & NÃO \\
\hline
\end{tabular}

5) Os conhecimentos adquiridos estão sendo aplicados no seu trabalho? Em caso afirmativo, indique em que grau estes conhecimentos estão sendo aplicados. Em caso negativo, indique por que razão isto não ocorre: (Em caso negativo, as respostas não são excludentes: você poderá marcar mais de uma opção).

\begin{tabular}{|l|l|l|l|}
\hline \multirow{2}{*}{$\begin{array}{l}\text { SIM (indique ao lado em } \\
\text { que grau) }\end{array}$} & $\mathrm{X}$ & MUITO APLICADOS \\
\cline { 2 - 4 } & & MEDIAMENTE APLICADOS \\
\hline & $\begin{array}{l}\text { NÃO (indique ao lado a } \\
\text { razão da não aplicação) }\end{array}$ & & $\begin{array}{l}\text { CONTEÚDO NÃO ADEQUADO ȦS NECESSIDADES } \\
\text { ESPECÍFICAS DA REGIÃO }\end{array}$ \\
\hline
\end{tabular}




\begin{tabular}{|l|l|l|}
\hline \multirow{10}{*}{} & $\begin{array}{l}\text { CONTEÚDO NÃO FOI SUFICIENTEMENTE } \\
\text { APROFUNDADO PARA PERMITIR UMA APLICAÇÃO } \\
\text { EFICAZ E EFICIENTE }\end{array}$ \\
\cline { 2 - 4 } & $\begin{array}{l}\text { FALTA DE APOIO E INCENTIVO DA MINHA } \\
\text { INSTITUIÇÃO }\end{array}$ \\
\cline { 2 - 4 } & FALTA DE INCENTIVO ÀS AÇÕES DE ATER \\
\hline & NÃO TENHO INTERESSE EM APLICAR \\
\hline
\end{tabular}

6) A partir deste curso: (As opções não são excludentes: você poderá marcar mais de uma opção)

\begin{tabular}{|l|l|}
\hline$x$ & $\begin{array}{l}\text { NÃO MUDOU NADA EM MEU TRABALHO. } \\
\text { FAMILIARES. }\end{array}$ \\
\hline & CONSEGUI INFLUENCIAR NAS ORIENTAÇÕES DA MINHA INSTITUIÇÃO. \\
\hline & PASSEI A TRABALHAR COM METODOLOGIAS PARTICIPATIVAS. \\
\hline & $\begin{array}{l}\text { CRESCEU A ÁREA DE AGRICULTURA DE BASE ECOLÓGICA NAS COMUNIDADES } \\
\text { ONDE ATUO. }\end{array}$ \\
\hline & CONTINUEI ME APERFEIÇOANDO SOBRE TEMAS ABORDADOS. \\
\hline
\end{tabular}

7) Depois do curso você apoiou atividades de capacitação de técnicos e agricultores com base nos princípios e diretrizes da Pnater? (Considere como apoio a atividades de capacitação a participação no planejamento, elaboração de ementas, seleção de participantes e de palestrantes.)

\begin{tabular}{|l|l|}
\hline & SIM \\
\hline$X$ & NÃO \\
\hline
\end{tabular}

8) Usou os conhecimentos para ministrar outros cursos com o mesmo conteúdo ou conteúdos semelhantes? 


\begin{tabular}{|l|l|}
\hline & SIM \\
\hline$X$ & NÃO \\
\hline
\end{tabular}

9) Marque o seu grau de satisfação com relação ao curso oferecido pelo DATER: : (Considere a seguinte pontuação: 1 - MUITO RUIM; 2 - RUIM; 3 - REGULAR; 4 - BOM; 5 - MUITO BOM)

\begin{tabular}{|l|l|l|l|l|}
\hline 1 & 2 & 3 & 4 & 5 \\
\hline
\end{tabular}

10) Marque seu grau de satisfação com relação ao DATER: : (Considere a seguinte pontuação: 1 - MUITO RUIM; 2 - RUIM; 3 - REGULAR; 4 - BOM; 5 - MUITO BOM)

\begin{tabular}{|l|l|l|l|l|}
\hline 1 & 2 & 3 & 4 & 5 \\
\hline
\end{tabular}


PESQUISA - IMPACTO DAS AÇÕES DE FORMAÇÃO REALIZADAS PELO DATER/SAF/MDA NO PERÍODO 2004-2009

Caros colaboradores,

Contamos com a sua atenção para preencher o formulário abaixo.

O mesmo tem por objetivo fornecer informações para avaliação da Eficiência, Efetividade e Eficácia da Política Pública de Formação de Agentes de Ater adotada pelo Departamento de Assistência Técnica e Extensão Rural, da Secretaria de Agricultura Familiar do Ministério do Desenvolvimento - DATER/SAF/MDA, no período de 2004 a 2009, tema escolhido para Monografia a ser apresentada à Universidade de Brasília (UnB) como requisito parcial para obtenção do grau de Bacharel em Administração.

Você poderá ou não se identificar no questionário e garantimos que todas as informações fornecidas serão confidenciais e utilizadas apenas de forma sistematizada.

IDENTIFICAÇÃO

\begin{tabular}{|c|c|}
\hline Nome: Maurício Alves dos Santos & $\begin{array}{l}\text { Sexo: } \\
(x \quad) \text { masculino } \quad(\quad) \text { feminino }\end{array}$ \\
\hline $\begin{array}{l}\text { Instituição (nome e tipo de instituição: ONG, } \\
\text { Empresa Pública, etc.): } \\
\text { EMATER- RO }\end{array}$ & $\begin{array}{l}\text { Local de trabalho (Cidade e Estado): } \\
\text { Estrela de Rondônia Município de } \\
\text { Presidente Médici-RO }\end{array}$ \\
\hline \multicolumn{2}{|c|}{$\begin{array}{l}\text { Curso/Encontro/Oficina do qual participou (caso tenha participado de mais de um curso, preencha } \\
\text { um formulário para cada um deles): } \\
\text { Cursos: Agroecologia }\end{array}$} \\
\hline Data do Curso/Encontro/Oficina (pelo menos mês & רo): \\
\hline
\end{tabular}

1. Indique sua área de atuação? (As opções não são excludentes: você poderá marcar mais de uma opção)

\begin{tabular}{|l|l|}
\hline$X$ & EXTENSÃO RURAL \\
\hline & PESQUISA \\
\hline & ENSINO \\
\hline & OUTROS \\
\hline
\end{tabular}


2) Qual o seu nível de escolaridade? (Considere apenas o nível mais alto)

\begin{tabular}{|l|l|}
\hline$X$ & NÍVEL MÉDIO \\
\hline & NÍVEL SUPERIOR \\
\hline & PÓS-GRADUAÇÃO \\
\hline
\end{tabular}

3) Os conteúdos abordados foram condizentes com as demandas do seu dia-a-dia?

\begin{tabular}{|l|l|}
\hline$X$ & SIM \\
\hline & PARCIALMENTE \\
\hline & NÃO \\
\hline
\end{tabular}

4) O curso contribuiu para o seu aperfeiçoamento profissional?

\begin{tabular}{|l|l|}
\hline$X$ & SIM \\
\hline & NÃO \\
\hline
\end{tabular}

5) Os conhecimentos adquiridos estão sendo aplicados no seu trabalho? Em caso afirmativo, indique em que grau estes conhecimentos estão sendo aplicados. Em caso negativo, indique por que razão isto não ocorre: (Em caso negativo, as respostas não são excludentes: você poderá marcar mais de uma opção).

\begin{tabular}{|c|c|c|c|}
\hline \multirow{3}{*}{$\mathrm{X}$} & \multirow{3}{*}{$\begin{array}{l}\text { SIM (indique ao lado em } \\
\text { que grau) }\end{array}$} & & MUITO APLICADOS \\
\hline & & $\mathrm{X}$ & MEDIAMENTE APLICADOS \\
\hline & & & POUCO APLICADOS \\
\hline & \multirow{2}{*}{$\begin{array}{l}\text { NÃO (indique ao lado a } \\
\text { razão da não aplicação) }\end{array}$} & & $\begin{array}{l}\text { CONTEÚDO NÃO ADEQUADO ȦS NECESSIDADES } \\
\text { ESPECÍFICAS DA REGIÃO }\end{array}$ \\
\hline & & & $\begin{array}{l}\text { CONTEÚDO NÃO FOI SUFICIENTEMENTE } \\
\text { APROFUNDADO PARA } \\
\text { EERMITIR UMA APLICAÇÃO } \\
\text { EFICAZ E EFICIENTE }\end{array}$ \\
\hline
\end{tabular}




\begin{tabular}{|l|l|l|}
\hline \multirow{2}{*}{} & & $\begin{array}{l}\text { FALTA DE APOIO E INCENTIVO DA MINHA } \\
\text { INSTITUIÇÃO }\end{array}$ \\
\cline { 2 - 3 } & & FALTA DE INCENTIVO ÀS AÇÕES DE ATER \\
\cline { 2 - 3 } & NÃO TENHO INTERESSE EM APLICAR \\
\hline
\end{tabular}

6) A partir deste curso: (As opções não são excludentes: você poderá marcar mais de uma opção)

\begin{tabular}{|l|l|}
\hline & NÃO MUDOU NADA EM MEU TRABALHO. \\
\hline$X$ & $\begin{array}{l}\text { MEU TRABALHO PASSOU A CONTRIBUIR MAIS COM OS AGRICULTORES(AS) } \\
\text { FAMILIARES. }\end{array}$ \\
\hline$X$ & CONSEGUI INFLUENCIAR NAS ORIENTAÇÕES DA MINHA INSTITUIÇÃO. \\
\hline & PASSEI A TRABALHAR COM METODOLOGIAS PARTICIPATIVAS. \\
\hline $\mathrm{X}$ & ONESCEU A ÁREA DE AGRICULTURA DE BASE ECOLÓGICA NAS COMUNIDADES \\
\hline$X$ & CONTINUEI ME APERFEIÇOANDO SOBRE TEMAS ABORDADOS. \\
\hline
\end{tabular}

7) Depois do curso você apoiou atividades de capacitação de técnicos e agricultores com base nos princípios e diretrizes da Pnater? (Considere como apoio a atividades de capacitação a participação no planejamento, elaboração de ementas, seleção de participantes e de palestrantes.)

\begin{tabular}{|l|l|}
\hline$X$ & SIM \\
\hline & NÃO \\
\hline
\end{tabular}

8) Usou os conhecimentos para ministrar outros cursos com o mesmo conteúdo ou conteúdos semelhantes?

\begin{tabular}{|l|l|}
\hline & SIM \\
\hline$X$ & NÃO \\
\hline
\end{tabular}


9) Marque o seu grau de satisfação com relação ao curso oferecido pelo DATER: (Considere a seguinte pontuação: 1 - MUITO RUIM; 2 - RUIM; 3 - REGULAR; 4 - BOM; 5 - MUITO BOM)

\begin{tabular}{|l|l|l|l|l|}
\hline 1 & 2 & 3 & 4 & $\times 5$ \\
\hline
\end{tabular}

10) Marque seu grau de satisfação com relação ao DATER: (Considere a seguinte pontuação: 1 - MUITO RUIM; 2 - RUIM; 3 - REGULAR; 4 - BOM; 5 - MUITO BOM)

\begin{tabular}{|l|l|l|l|l|}
\hline 1 & 2 & 3 & 4 & $x 5$ \\
\hline
\end{tabular}


PESQUISA - IMPACTO DAS AÇÕES DE FORMAÇÃO REALIZADAS PELO DATER/SAF/MDA NO PERÍODO 2004-2009

Caros colaboradores,

Contamos com a sua atenção para preencher o formulário abaixo.

O mesmo tem por objetivo fornecer informações para avaliação da Eficiência, Efetividade e Eficácia da Política Pública de Formação de Agentes de Ater adotada pelo Departamento de Assistência Técnica e Extensão Rural, da Secretaria de Agricultura Familiar do Ministério do Desenvolvimento - DATER/SAF/MDA, no período de 2004 a 2009, tema escolhido para Monografia a ser apresentada à Universidade de Brasília (UnB) como requisito parcial para obtenção do grau de Bacharel em Administração.

Você poderá ou não se identificar no questionário e garantimos que todas as informações fornecidas serão confidenciais e utilizadas apenas de forma sistematizada.

\section{IDENTIFICAÇÃO}

\begin{tabular}{|l|l|}
\hline Nome: MARTINHO FREIRE DA SILVA & $\begin{array}{l}\text { Sexo: } \\
(x \quad) \text { masculino } \quad(\quad) \text { feminino }\end{array}$ \\
\hline $\begin{array}{l}\text { Instituição (nome e tipo de instituição: ONG, } \\
\text { Empresa Pública, etc.): EMATER - RO }\end{array}$ & $\begin{array}{l}\text { Local de trabalho (Cidade e Estado): } \\
\text { MIRANTE DA SERRA }\end{array}$ \\
\hline $\begin{array}{l}\text { Curso/Encontro/Oficina do qual participou (caso tenha participado de mais de um curso, preencha } \\
\text { um formulário para cada um deles): MANEJO DE PASTAGEM COM ÊNFASE NO CONTROLE } \\
\text { BIOLOGICO DA CIGARRINHA, MELHORIA DA QUALIDADE SO LEITE. }\end{array}$ \\
\hline Data do Curso/Encontro/Oficina (pelo menos mês e ano): 2006 \\
\hline
\end{tabular}

1. Indique sua área de atuação? (As opções não são excludentes: você poderá marcar mais de uma opção)

\begin{tabular}{|l|l|}
\hline$X$ & EXTENSÃO RURAL \\
\hline & PESQUISA \\
\hline & ENSINO \\
\hline & OUTROS \\
\hline
\end{tabular}

2) Qual o seu nível de escolaridade? (Considere apenas o nível mais alto) 


\begin{tabular}{|l|l|}
\hline$X$ & NÍVEL MÉDIO \\
\hline & NÍVEL SUPERIOR \\
\hline & PÓS-GRADUAÇÃO \\
\hline
\end{tabular}

3) Os conteúdos abordados foram condizentes com as demandas do seu dia-a-dia?

\begin{tabular}{|l|l|}
\hline$X$ & SIM \\
\hline & PARCIALMENTE \\
\hline & NÃO \\
\hline
\end{tabular}

4) O curso contribuiu para o seu aperfeiçoamento profissional?

\begin{tabular}{|l|l|}
\hline$X$ & SIM \\
\hline & NÃO \\
\hline
\end{tabular}

5) Os conhecimentos adquiridos estão sendo aplicados no seu trabalho? Em caso afirmativo, indique em que grau estes conhecimentos estão sendo aplicados. Em caso negativo, indique por que razão isto não ocorre: (Em caso negativo, as respostas não são excludentes: você poderá marcar mais de uma opção).

\begin{tabular}{|c|c|c|c|}
\hline \multirow{3}{*}{$\mathrm{X}$} & \multirow{3}{*}{$\begin{array}{l}\text { SIM (indique ao lado em } \\
\text { que grau) }\end{array}$} & $x$ & MUITO APLICADOS \\
\hline & & & MEDIAMENTE APLICADOS \\
\hline & & & POUCO APLICADOS \\
\hline & \multirow{2}{*}{$\begin{array}{l}\text { NÃO (indique ao lado a } \\
\text { razão da não aplicação) }\end{array}$} & & $\begin{array}{l}\text { CONTEÚDO NÃO ADEQUADO ȦS NECESSIDADES } \\
\text { ESPECÍFICAS DA REGIÃO }\end{array}$ \\
\hline & & & $\begin{array}{llcr}\text { CONTEÚDO NÃO } & \text { FOI SUFICIENTEMENTE } \\
\text { APROFUNDADO PARA } & \text { PERMITIR UMA APLICAÇÃO } \\
\text { EFICAZ E EFICIENTE }\end{array}$ \\
\hline
\end{tabular}




\begin{tabular}{|l|l|l|}
\hline \multirow{2}{*}{} & & $\begin{array}{l}\text { FALTA DE APOIO E INCENTIVO DA MINHA } \\
\text { INSTITUIÇÃO }\end{array}$ \\
\cline { 2 - 3 } & & FALTA DE INCENTIVO ÀS AÇÕES DE ATER \\
\cline { 2 - 3 } & NÃO TENHO INTERESSE EM APLICAR \\
\hline
\end{tabular}

6) A partir deste curso: (As opções não são excludentes: você poderá marcar mais de uma opção)

\begin{tabular}{|l|l|}
\hline & NÃO MUDOU NADA EM MEU TRABALHO. \\
\hline$x$ & $\begin{array}{l}\text { MEU TRABALHO PASSOU A CONTRIBUIR MAIS COM OS AGRICULTORES(AS) } \\
\text { FAMILIARES. }\end{array}$ \\
\hline$x$ & CONSEGUI INFLUENCIAR NAS ORIENTAÇÕES DA MINHA INSTITUIÇÃO. \\
\hline$x$ & PASSEI A TRABALHAR COM METODOLOGIAS PARTICIPATIVAS. \\
\hline & $\begin{array}{l}\text { CRESCEU A ÁREA DE AGRICULTURA DE BASE ECOLÓGICA NAS COMUNIDADES } \\
\text { ONDE ATUO. }\end{array}$ \\
\hline$x$ & CONTINUEI ME APERFEIÇOANDO SOBRE TEMAS ABORDADOS. \\
\hline
\end{tabular}

7) Depois do curso você apoiou atividades de capacitação de técnicos e agricultores com base nos princípios e diretrizes da Pnater? (Considere como apoio a atividades de capacitação a participação no planejamento, elaboração de ementas, seleção de participantes e de palestrantes.)

\begin{tabular}{|l|l|}
\hline$x$ & SIM \\
\hline & NÃO \\
\hline
\end{tabular}

8) Usou os conhecimentos para ministrar outros cursos com o mesmo conteúdo ou conteúdos semelhantes?

\begin{tabular}{|l|l|}
\hline$x$ & SIM \\
\hline & NÃO \\
\hline
\end{tabular}


9) Marque o seu grau de satisfação com relação ao curso oferecido pelo DATER: (Considere a seguinte pontuação: 1 - MUITO RUIM; 2 - RUIM; 3 - REGULAR; 4 - BOM; 5 - MUITO BOM)

\begin{tabular}{|l|l|l|l|l|}
\hline 1 & 2 & 3 & 4 & 5 \\
\hline
\end{tabular}

10) Marque seu grau de satisfação com relação ao DATER: (Considere a seguinte pontuação: 1 - MUITO RUIM; 2 - RUIM; 3 - REGULAR; 4 - BOM; 5 - MUITO BOM)

\begin{tabular}{|l|l|l|l|l|}
\hline 1 & 2 & 3 & 4 & 5 \\
\hline
\end{tabular}


PESQUISA - IMPACTO DAS AÇÕES DE FORMAÇÃO REALIZADAS PELO DATER/SAF/MDA NO PERÍODO 2004-2009

Caros colaboradores,

Contamos com a sua atenção para preencher o formulário abaixo.

O mesmo tem por objetivo fornecer informações para avaliação da Eficiência, Efetividade e Eficácia da Política Pública de Formação de Agentes de Ater adotada pelo Departamento de Assistência Técnica e Extensão Rural, da Secretaria de Agricultura Familiar do Ministério do Desenvolvimento - DATER/SAF/MDA, no período de 2004 a 2009, tema escolhido para Monografia a ser apresentada à Universidade de Brasília (UnB) como requisito parcial para obtenção do grau de Bacharel em Administração.

Você poderá ou não se identificar no questionário e garantimos que todas as informações fornecidas serão confidenciais e utilizadas apenas de forma sistematizada.

Nome: Cristina Progênio Miranda

Sexo: Feminino

Instituição: SEMADRE ( Secretaria Municipal de Agricultura)

Local de Trabalho: Cametá -Pa

Curso: Agente de desenvolvimento Rural - ADR

Data do curso: Dezembro 2007

Local: Abaetetuba -Pa

1.Indique a sua área de atuação (As opções não são excludentes: você poderá marcar mais de uma opção).

\begin{tabular}{|l|l|}
\hline$X$ & Extensão Rural \\
\hline & Pesquisa \\
\hline & Ensino \\
\hline & Outros \\
\hline
\end{tabular}

2.Qual o seu nível de Escolaridade

\begin{tabular}{|l|l|}
\hline & Nível médio \\
\hline & Nível superior \\
\hline$X$ & Pós-graduação \\
\hline
\end{tabular}

3. Os conteúdos abordados foram condizentes com as demandas do seu dia-a-dia? 


\begin{tabular}{|l|l|}
\hline & Sim \\
\hline$X$ & Parcialmente \\
\hline & Não \\
\hline
\end{tabular}

4.O curso contribuiu para o seu aperfeiçoamento profissional?

\begin{tabular}{|l|l|}
\hline$X$ & Sim \\
\hline & Não \\
\hline
\end{tabular}

5. Os conhecimentos adquiridos estão sendo aplicados no seu trabalho? Em caso afirmativo, indique em que grau estes conhecimentos estão sendo aplicados. Em caso negativo, indique por que razão isto não ocorre: (Em caso negativo, as respostas não são excludentes: você poderá marcar mais de uma opção).

\begin{tabular}{|c|c|c|c|}
\hline & Sim (indique ao lado & & Muito aplicados \\
\hline & em que grau) & & Mediamente aplicados \\
\hline & & & Pouco aplicados \\
\hline & $\begin{array}{l}\text { Não (indique ao lado } \\
\text { a razão da não } \\
\text { aplicação) }\end{array}$ & & $\begin{array}{l}\text { Conteúdos não adequado as } \\
\text { necessidades específicas da } \\
\text { região }\end{array}$ \\
\hline V & & & $\begin{array}{l}\text { Conteúdo não foi suficientemente } \\
\text { aprofundado para permitir uma } \\
\text { aplicação eficaz e eficiente }\end{array}$ \\
\hline i & & & $\begin{array}{l}\text { Falta de apoio e incentivo da } \\
\text { minha instituição }\end{array}$ \\
\hline & & $\mathrm{X}$ & $\begin{array}{l}\text { Falta de incentivo as ações de } \\
\text { ATER }\end{array}$ \\
\hline & & & Não tenho interesse em aplicar \\
\hline
\end{tabular}

6. A partir deste curso: (As opções não são excludentes: você poderá marcar mais de uma opção).

\begin{tabular}{|l|l|}
\hline & Não mudou em nada meu trabalho \\
\hline$X$ & Meu trabalho passou a contribuir mais com os agricultores(as) familiares \\
\hline$X$ & Consegui influenciar nas orientações da minha instituição \\
\hline$X$ & Passei a trabalhar com metodologias participativas \\
\hline
\end{tabular}




\begin{tabular}{|l|l|}
\hline $\mathrm{X}$ & Cresceu a área de agricultura de base ecológica nas comunidades onde atuo \\
\hline $\mathrm{X}$ & Continuei me aperfeiçoando sobre temas abordados. \\
\hline
\end{tabular}

7. Depois do curso você apoiou atividades de capacitação de técnicos e agricultores com base nos princípios e diretrizes do Pnater? 7. Depois do curso você apoiou atividades de capacitação de técnicos e agricultores com base nos princípios e diretrizes do Pnater? (Considere como apoio a atividades de capacitação a participação no planejamento, elaboração de ementas, seleção de participantes e de palestrantes.)

\begin{tabular}{|l|l|}
\hline$X$ & Sim \\
\hline & Não \\
\hline
\end{tabular}

8. Usou o conhecimento para ministrar outros cursos com o mesmo conteúdo ou conteúdos semelhantes?

\begin{tabular}{|l|l|}
\hline & Sim \\
\hline$X$ & Não \\
\hline
\end{tabular}

9. Marque o seu grau de satisfação com relação aos cursos oferecidos pelo DATER

\begin{tabular}{|l|l|l|l|l|}
\hline 1 & 2 & 3 & $X$ & 5 \\
\hline
\end{tabular}

10. Marque o seu grau de satisfação com relação ao DATER

\begin{tabular}{|l|l|l|l|l|}
\hline 1 & 2 & 3 & $X$ & 5 \\
\hline
\end{tabular}


PESQUISA - IMPACTO DAS AÇÕES DE FORMAÇÃO REALIZADAS PELO DATER/SAF/MDA NO PERÍODO 2004-2009

Caros colaboradores,

Contamos com a sua atenção para preencher o formulário abaixo.

O mesmo tem por objetivo fornecer informações para avaliação da Eficiência, Efetividade e Eficácia da Política Pública de Formação de Agentes de Ater adotada pelo Departamento de Assistência Técnica e Extensão Rural, da Secretaria de Agricultura Familiar do Ministério do Desenvolvimento - DATER/SAF/MDA, no período de 2004 a 2009, tema escolhido para Monografia a ser apresentada à Universidade de Brasília (UnB) como requisito parcial para obtenção do grau de Bacharel em Administração.

Você poderá ou não se identificar no questionário e garantimos que todas as informações fornecidas serão confidenciais e utilizadas apenas de forma sistematizada.

\section{IDENTIFICAÇÃO}

\begin{tabular}{|c|c|}
\hline $\begin{array}{l}\text { Nome: } \\
\text { MARLI DA CRUZ BANDEIRA }\end{array}$ & $\begin{array}{l}\text { Sexo: } \\
(\quad) \text { masculino } \quad(x) \text { feminino }\end{array}$ \\
\hline $\begin{array}{l}\text { Instituição (nome e tipo de instituição: ONG, } \\
\text { Empresa Pública, etc.): } \\
\text { EMATER-PARÁ }\end{array}$ & $\begin{array}{l}\text { Local de trabalho (Cidade e Estado): } \\
\text { SALVATERRA - PARÁ }\end{array}$ \\
\hline \multicolumn{2}{|c|}{$\begin{array}{l}\text { Curso/Encontro/Oficina do qual participou (caso tenha participado de mais de um curso, preencha } \\
\text { um formulário para cada um deles): }\end{array}$} \\
\hline $\begin{array}{l}\text { Data do Curso/Encontro/Oficina (pelo menos mês } \\
\text { DE } 10 \text { A } 14 \text { DE JULHO DE } 2006 .\end{array}$ & \\
\hline
\end{tabular}

1.ndique sua área de atuação? (As opções não são excludentes: você poderá marcar mais de uma opção)

\begin{tabular}{|l|l|}
\hline$X$ & EXTENSÃO RURAL \\
\hline & PESQUISA \\
\hline
\end{tabular}




\begin{tabular}{|l|l|}
\hline & ENSINO \\
\hline & OUTROS \\
\hline
\end{tabular}

2) Qual o seu nível de escolaridade? (Considere apenas o nível mais alto)

\begin{tabular}{|l|l|}
\hline & NÍVEL MÉDIO \\
\hline$X$ & NÍVEL SUPERIOR \\
\hline & PÓS-GRADUAÇÃO \\
\hline
\end{tabular}

3) Os conteúdos abordados foram condizentes com as demandas do seu dia-a-dia?

\begin{tabular}{|l|l|}
\hline$X$ & SIM \\
\hline & PARCIALMENTE \\
\hline & NÃO \\
\hline
\end{tabular}

4) O curso contribuiu para o seu aperfeiçoamento profissional?

\begin{tabular}{|l|l|}
\hline$X$ & SIM \\
\hline & NÃO \\
\hline
\end{tabular}

5) Os conhecimentos adquiridos estão sendo aplicados no seu trabalho? Em caso afirmativo, indique em que grau estes conhecimentos estão sendo aplicados. Em caso negativo, indique por que razão isto não ocorre: (Em caso negativo, as respostas não são excludentes: você poderá marcar mais de uma opção).

\begin{tabular}{|l|l|l|l|}
\hline$X$ & $\begin{array}{l}\text { SIM (indique ao lado em } \\
\text { que grau) }\end{array}$ & MUITO APLICADOS \\
\cline { 2 - 4 } & & MEDIAMENTE APLICADOS \\
\hline & $\begin{array}{l}\text { NÃO (indique ao lado a } \\
\text { razão da não aplicação) }\end{array}$ & $\begin{array}{l}\text { CONTEÚDO NÃO ADEQUADO ȦS NECESSIDADES } \\
\text { ESPECÍfICAS DA REGIÃO }\end{array}$ \\
\hline
\end{tabular}




\begin{tabular}{|l|l|l|}
\hline \multirow{10}{*}{} & $\begin{array}{l}\text { CONTEÚDO NÃO FOI SUFICIENTEMENTE } \\
\text { APROFUNDADO PARA PERMITIR UMA APLICAÇÃO } \\
\text { EFICAZ E EFICIENTE }\end{array}$ \\
\cline { 2 - 4 } & $\begin{array}{l}\text { FALTA DE APOIO E INCENTIVO DA MINHA } \\
\text { INSTITUIÇÃO }\end{array}$ \\
\cline { 2 - 4 } & FALTA DE INCENTIVO ÀS AÇÕES DE ATER \\
\hline & NÃO TENHO INTERESSE EM APLICAR \\
\hline
\end{tabular}

6) A partir deste curso: (As opções não são excludentes: você poderá marcar mais de uma opção)

\begin{tabular}{|l|l|}
\hline$x$ & NÃO MUDOU NADA EM MEU TRABALHO. \\
\hline$x$ & $\begin{array}{l}\text { MEU TRABALHO PASSOU A CONTRIBUIR MAIS COM OS AGRICULTORES(AS) } \\
\text { FAMILIARES. }\end{array}$ \\
\hline$x$ & PONSEGUI INFLUENCIAR NAS ORIENTAÇÕES DA MINHA INSTITUIÇÃO. \\
\hline & $\begin{array}{l}\text { CRESCEU A ÁREA DE AGRICULTURA DE BASE ECOLÓGICA NAS COMUNIDADES } \\
\text { ONDE ATUO. }\end{array}$ \\
\hline$X$ & CONTINUEI ME APERFEIÇOANDO SOBRE TEMAS ABORDADOS. \\
\hline
\end{tabular}

7) Depois do curso você apoiou atividades de capacitação de técnicos e agricultores com base nos princípios e diretrizes da Pnater? (Considere como apoio a atividades de capacitação a participação no planejamento, elaboração de ementas, seleção de participantes e de palestrantes.)

\begin{tabular}{|l|l|}
\hline & SIM \\
\hline$X$ & NÃO \\
\hline
\end{tabular}

8) Usou os conhecimentos para ministrar outros cursos com o mesmo conteúdo ou conteúdos semelhantes? 


\begin{tabular}{|l|l|}
\hline$X$ & SIM \\
\hline & NÃO \\
\hline
\end{tabular}

9) Marque o seu grau de satisfação com relação ao curso oferecido pelo DATER: (Considere a seguinte pontuação: 1 - MUITO RUIM; 2 - RUIM; 3 - REGULAR; 4 - BOM; 5 - MUITO BOM)

\begin{tabular}{|l|l|l|l|l|}
\hline 1 & 2 & 3 & 4 & $(5)$ \\
\hline
\end{tabular}

10) Marque seu grau de satisfação com relação ao DATER: (Considere a seguinte pontuação: 1 - MUITO RUIM; 2 - RUIM; 3 - REGULAR; 4 - BOM; 5 - MUITO BOM)

\begin{tabular}{|l|l|l|l|l|}
\hline 1 & 2 & 3 & 4 & $(5)$ \\
\hline
\end{tabular}


PESQUISA - IMPACTO DAS AÇÕES DE FORMAÇÃO REALIZADAS PELO DATER/SAF/MDA NO PERÍODO 2004-2009

Caros colaboradores,

Contamos com a sua atenção para preencher o formulário abaixo.

O mesmo tem por objetivo fornecer informações para avaliação da Eficiência, Efetividade e Eficácia da Política Pública de Formação de Agentes de Ater adotada pelo Departamento de Assistência Técnica e Extensão Rural, da Secretaria de Agricultura Familiar do Ministério do Desenvolvimento - DATER/SAF/MDA, no período de 2004 a 2009, tema escolhido para Monografia a ser apresentada à Universidade de Brasília (UnB) como requisito parcial para obtenção do grau de Bacharel em Administração.

Você poderá ou não se identificar no questionário e garantimos que todas as informações fornecidas serão confidenciais e utilizadas apenas de forma sistematizada.

IDENTIFICAÇÃO

\begin{tabular}{|l|l|}
\hline Nome: & $\begin{array}{l}\text { Sexo: } \\
\text { MÁRIO NEUMANN }\end{array}$ \\
$\begin{array}{l}\text { Instituição (nome e tipo de instituição: ONG, } \\
\text { Empresa Pública, etc.): } \\
\text { EMATER-RO }\end{array}$ & $\begin{array}{l}\text { Local de trabalho (Cidade e Estado): } \\
\text { VILA EXTREMA /PORTO VELHO-RO }\end{array}$ \\
\hline $\begin{array}{l}\text { Curso/Encontro/Oficina do qual participou (caso tenha participado de mais de um curso, preencha } \\
\text { um formulário para cada um deles): } \\
\text { CURSO DE TURISMO RURAL NA AGRICULTURA FAMILIAR }\end{array}$ \\
\hline $\begin{array}{l}\text { Data do Curso/Encontro/Oficina (pelo menos mês e ano): } \\
\text { 02 A 06/05/2005 }\end{array}$ \\
\hline
\end{tabular}

Indique sua área de atuação? (As opções não são excludentes: você poderá marcar mais de uma opção)

\begin{tabular}{|l|l|}
\hline$X$ & EXTENSÃO RURAL \\
\hline & PESQUISA \\
\hline & ENSINO \\
\hline & OUTROS \\
\hline
\end{tabular}


2) Qual o seu nível de escolaridade? (Considere apenas o nível mais alto)

\begin{tabular}{|c|l|}
\hline & NÍVEL MÉDIO \\
\hline & NÍVEL SUPERIOR \\
\hline$X$ & PÓS-GRADUAÇÃO \\
\hline
\end{tabular}

3) Os conteúdos abordados foram condizentes com as demandas do seu dia-a-dia?

\begin{tabular}{|l|l|}
\hline$X$ & SIM \\
\hline & PARCIALMENTE \\
\hline & NÃO \\
\hline
\end{tabular}

4) O curso contribuiu para o seu aperfeiçoamento profissional?

\begin{tabular}{|l|l|}
\hline$X$ & SIM \\
\hline & NÃO \\
\hline
\end{tabular}

5) Os conhecimentos adquiridos estão sendo aplicados no seu trabalho? Em caso afirmativo, indique em que grau estes conhecimentos estão sendo aplicados. Em caso negativo, indique por que razão isto não ocorre: (Em caso negativo, as respostas não são excludentes: você poderá marcar mais de uma opção).

\begin{tabular}{|l|l|l|l|}
\hline \multirow{2}{*}{$\begin{array}{l}\text { SIM (indique ao lado em } \\
\text { que grau) }\end{array}$} & & MUITO APLICADOS \\
\cline { 3 - 4 } & & MEDIAMENTE APLICADOS \\
\hline \multirow{2}{*}{$\begin{array}{l}\text { NÃO (indique ao lado a } \\
\text { razão da não aplicação) }\end{array}$} & & $\begin{array}{l}\text { CONTEÚDO NÃO ADEQUADO ÁS NECESSIDADES } \\
\text { ESPECÍFICAS DA REGIÃO }\end{array}$ \\
\cline { 3 - 4 } & $\begin{array}{l}\text { CONTEÚDO NÃO FOI SUFICIENTEMENTEE } \\
\text { APROFUNDADO PARA PERMITIR UMA APLICAÇÃO } \\
\text { EFICAZ E EFICIENTE }\end{array}$ \\
\hline
\end{tabular}




\begin{tabular}{|l|l|l|}
\hline \multirow{2}{*}{} & & $\begin{array}{l}\text { FALTA DE APOIO E INCENTIVO DA MINHA } \\
\text { INSTITUIÇÃO }\end{array}$ \\
\cline { 2 - 3 } & & FALTA DE INCENTIVO ÀS AÇÕES DE ATER \\
\cline { 2 - 3 } & NÃO TENHO INTERESSE EM APLICAR \\
\hline
\end{tabular}

6) A partir deste curso: (As opções não são excludentes: você poderá marcar mais de uma opção)

\begin{tabular}{|l|l|}
\hline & NÃO MUDOU NADA EM MEU TRABALHO. \\
\hline & $\begin{array}{l}\text { MEU TRABALHO PASSOU A CONTRIBUIR MAIS COM OS AGRICULTORES(AS) } \\
\text { FAMILIARES. }\end{array}$ \\
\hline & CONSEGUI INFLUENCIAR NAS ORIENTAÇÕES DA MINHA INSTITUIÇÃO. \\
\hline & $\begin{array}{l}\text { CRESEI A TRABALHAR COM METODOLOGIAS PARTICIPATIVAS. } \\
\text { ONDE ATUO. ÁREA DE AGRICULTURA DE BASE ECOLÓGICA NAS COMUNIDADES }\end{array}$ \\
\hline$X$ & CONTINUEI ME APERFEIÇOANDO SOBRE TEMAS ABORDADOS. \\
\hline
\end{tabular}

7) Depois do curso você apoiou atividades de capacitação de técnicos e agricultores com base nos princípios e diretrizes da Pnater? (Considere como apoio a atividades de capacitação a participação no planejamento, elaboração de ementas, seleção de participantes e de palestrantes.)

\begin{tabular}{|l|l|}
\hline & SIM \\
\hline$X$ & NÃO \\
\hline
\end{tabular}

8) Usou os conhecimentos para ministrar outros cursos com o mesmo conteúdo ou conteúdos semelhantes?

\begin{tabular}{|l|l|}
\hline & SIM \\
\hline$X$ & NÃO \\
\hline
\end{tabular}


9) Marque o seu grau de satisfação com relação ao curso oferecido pelo DATER: (Considere a seguinte pontuação: 1 - MUITO RUIM; 2 - RUIM; 3 - REGULAR; 4 - BOM; 5 - MUITO BOM)

\begin{tabular}{|l|l|l|l|l|}
\hline 1 & 2 & 3 & $4 X$ & 5 \\
\hline
\end{tabular}

10) Marque seu grau de satisfação com relação ao DATER: (Considere a seguinte pontuação: 1 - MUITO RUIM; 2 - RUIM; 3 - REGULAR; 4 - BOM; 5 - MUITO BOM)

\begin{tabular}{|l|l|l|l|l|}
\hline 1 & 2 & 3 & $4 X$ & 5 \\
\hline
\end{tabular}


PESQUISA - IMPACTO DAS AÇÕES DE FORMAÇÃO REALIZADAS PELO DATER/SAF/MDA NO PERÍODO 2004-2009

Caros colaboradores,

Contamos com a sua atenção para preencher o formulário abaixo.

O mesmo tem por objetivo fornecer informações para avaliação da Eficiência, Efetividade e Eficácia da Política Pública de Formação de Agentes de Ater adotada pelo Departamento de Assistência Técnica e Extensão Rural, da Secretaria de Agricultura Familiar do Ministério do Desenvolvimento - DATER/SAF/MDA, no período de 2004 a 2009, tema escolhido para Monografia a ser apresentada à Universidade de Brasília (UnB) como requisito parcial para obtenção do grau de Bacharel em Administração.

Você poderá ou não se identificar no questionário e garantimos que todas as informações fornecidas serão confidenciais e utilizadas apenas de forma sistematizada.

IDENTIFICAÇÃO

\begin{tabular}{|l|l|}
\hline $\begin{array}{l}\text { Nome: } \\
\text { MÁRIO NEUMANN }\end{array}$ & $\begin{array}{l}\text { Sexo: } \\
(x \quad) \text { masculino } \quad(\quad) \text { feminino }\end{array}$ \\
\hline $\begin{array}{l}\text { Instituição (nome e tipo de instituição: ONG, } \\
\text { Empresa Pública, etc.): } \\
\text { EMATER-RO }\end{array}$ & $\begin{array}{l}\text { Local de trabalho (Cidade e Estado): } \\
\text { VILA EXTREMA /PORTO VELHO-RO }\end{array}$ \\
\hline $\begin{array}{l}\text { Curso/Encontro/Oficina do qual participou (caso tenha participado de mais de um curso, preencha } \\
\text { um formulário para cada um deles): } \\
\text { II SEMINÁRIO DE AGROECOLOGIA: Agric. Construindo conhecim. p/ a vida }\end{array}$ \\
\hline $\begin{array}{l}\text { Data do Curso/Encontro/Oficina (pelo menos mês e ano): } \\
\text { 05 A 06/12/2006 }\end{array}$ \\
\hline
\end{tabular}

1.Indique sua área de atuação? (As opções não são excludentes: você poderá marcar mais de uma opção)

\begin{tabular}{|l|l|}
\hline$X$ & EXTENSÃO RURAL \\
\hline & PESQUISA \\
\hline & ENSINO \\
\hline & OUTROS \\
\hline
\end{tabular}


2) Qual o seu nível de escolaridade? (Considere apenas o nível mais alto)

\begin{tabular}{|c|l|}
\hline & NÍVEL MÉDIO \\
\hline & NÍVEL SUPERIOR \\
\hline$X$ & PÓS-GRADUAÇÃO \\
\hline
\end{tabular}

3) Os conteúdos abordados foram condizentes com as demandas do seu dia-a-dia?

\begin{tabular}{|l|l|}
\hline$X$ & SIM \\
\hline & PARCIALMENTE \\
\hline & NÃO \\
\hline
\end{tabular}

4) O curso contribuiu para o seu aperfeiçoamento profissional?

\begin{tabular}{|l|l|}
\hline$X$ & SIM \\
\hline & NÃO \\
\hline
\end{tabular}

5) Os conhecimentos adquiridos estão sendo aplicados no seu trabalho? Em caso afirmativo, indique em que grau estes conhecimentos estão sendo aplicados. Em caso negativo, indique por que razão isto não ocorre: (Em caso negativo, as respostas não são excludentes: você poderá marcar mais de uma opção).

\begin{tabular}{|c|c|c|c|}
\hline \multirow{3}{*}{ X } & \multirow{3}{*}{$\begin{array}{l}\text { SIM (indique ao lado em } \\
\text { que grau) }\end{array}$} & $\bar{x}$ & MUITO APLICADOS \\
\hline & & & MEDIAMENTE APLICADOS \\
\hline & & & POUCO APLICADOS \\
\hline & \multirow{2}{*}{$\begin{array}{l}\text { NÃO (indique ao lado a } \\
\text { razão da não aplicação) }\end{array}$} & & $\begin{array}{l}\text { CONTEÚDO NÃO ADEQUADO ȦS NECESSIDADES } \\
\text { ESPECÍFICAS DA REGIÃO }\end{array}$ \\
\hline & & & $\begin{array}{l}\text { CONTEÚDO NÃO FOI SUFICIENTEMENTE } \\
\text { APROFUNDADO PARA } \\
\text { EERMITIR UMA APLICAÇÃO } \\
\text { EFICAZ E EFICIENTE }\end{array}$ \\
\hline
\end{tabular}




\begin{tabular}{|l|l|l|}
\hline \multirow{2}{*}{} & & $\begin{array}{l}\text { FALTA DE APOIO E INCENTIVO DA MINHA } \\
\text { INSTITUIÇÃO }\end{array}$ \\
\cline { 2 - 3 } & & FALTA DE INCENTIVO ÀS AÇÕES DE ATER \\
\cline { 2 - 3 } & NÃO TENHO INTERESSE EM APLICAR \\
\hline
\end{tabular}

6) A partir deste curso: (As opções não são excludentes: você poderá marcar mais de uma opção)

\begin{tabular}{|c|l|}
\hline$x$ & $\begin{array}{l}\text { NÃO MUDOU NADA EM MEU TRABALHO. } \\
\text { FAMILIARES. }\end{array}$ \\
\hline & CONSEGUI INFLUENCIAR NAS ORIENTAÇÕES DA MINHA INSTITUIÇÃO. \\
\hline & PASSEI A TRABALHAR COM METODOLOGIAS PARTICIPATIVAS. \\
\hline $\mathrm{x}$ & $\begin{array}{l}\text { CRESCEU A ÁREA DE AGRICULTURA DE BASE ECOLÓGICA NAS COMUNIDADES } \\
\text { ONDE ATUO. }\end{array}$ \\
\hline $\mathrm{x}$ & CONTINUEI ME APERFEIÇOANDO SOBRE TEMAS ABORDADOS. \\
\hline
\end{tabular}

7) Depois do curso você apoiou atividades de capacitação de técnicos e agricultores com base nos princípios e diretrizes da Pnater? (Considere como apoio a atividades de capacitação a participação no planejamento, elaboração de ementas, seleção de participantes e de palestrantes.)

\begin{tabular}{|l|l|}
\hline$X$ & SIM \\
\hline & NÃO \\
\hline
\end{tabular}

8) Usou os conhecimentos para ministrar outros cursos com o mesmo conteúdo ou conteúdos semelhantes?

\begin{tabular}{|l|l|}
\hline & SIM \\
\hline$X$ & NÃO \\
\hline
\end{tabular}


9) Marque o seu grau de satisfação com relação ao curso oferecido pelo DATER: (Considere a seguinte pontuação: 1 - MUITO RUIM; 2 - RUIM; 3 - REGULAR; 4 - BOM; 5 - MUITO BOM)

\begin{tabular}{|l|l|l|l|l|}
\hline 1 & 2 & 3 & $4 \mathrm{X}$ & 5 \\
\hline
\end{tabular}

10) Marque seu grau de satisfação com relação ao DATER: (Considere a seguinte pontuação: 1 - MUITO RUIM; 2 - RUIM; 3 - REGULAR; 4 - BOM; 5 - MUITO BOM)

\begin{tabular}{|l|l|l|l|l|}
\hline 1 & 2 & 3 & $4 X$ & 5 \\
\hline
\end{tabular}


PESQUISA - IMPACTO DAS AÇÕES DE FORMAÇÃO REALIZADAS PELO DATER/SAF/MDA NO PERÍODO 2004-2009

Caros colaboradores,

Contamos com a sua atenção para preencher o formulário abaixo.

O mesmo tem por objetivo fornecer informações para avaliação da Eficiência, Efetividade e Eficácia da Política Pública de Formação de Agentes de Ater adotada pelo Departamento de Assistência Técnica e Extensão Rural, da Secretaria de Agricultura Familiar do Ministério do Desenvolvimento - DATER/SAF/MDA, no período de 2004 a 2009, tema escolhido para Monografia a ser apresentada à Universidade de Brasília (UnB) como requisito parcial para obtenção do grau de Bacharel em Administração.

Você poderá ou não se identificar no questionário e garantimos que todas as informações fornecidas serão confidenciais e utilizadas apenas de forma sistematizada.

IDENTIFICAÇÃO:

\begin{tabular}{|c|c|}
\hline $\begin{array}{l}\text { Nome: } \\
\text { MÁRIO NEUMANN }\end{array}$ & $\begin{array}{l}\text { Sexo: } \\
(x \quad) \text { masculino } \quad(\quad) \text { feminino }\end{array}$ \\
\hline $\begin{array}{l}\text { Instituição (nome e tipo de instituição: ONG, } \\
\text { Empresa Pública, etc.): } \\
\text { EMATER-RO }\end{array}$ & $\begin{array}{l}\text { Local de trabalho (Cidade e Estado): } \\
\text { VILA EXTREMA /PORTO VELHO-RO }\end{array}$ \\
\hline \multicolumn{2}{|c|}{$\begin{array}{l}\text { Curso/Encontro/Oficina do qual participou (caso tenha participado de mais de um curso, preencha } \\
\text { um formulário para cada um deles): } \\
\text { CURSO FORMAÇÃO CONTINUADA -METOLOGIA CEFE }\end{array}$} \\
\hline $\begin{array}{l}\text { Data do Curso/Encontro/Oficina (pelo menos mês } \\
05 \text { A 14/02/2006 }\end{array}$ & \\
\hline
\end{tabular}

1.Indique sua área de atuação? (As opções não são excludentes: você poderá marcar mais de uma opção)

\begin{tabular}{|l|l|}
\hline$X$ & EXTENSÃO RURAL \\
\hline & PESQUISA \\
\hline & ENSINO \\
\hline & OUTROS \\
\hline
\end{tabular}


2) Qual o seu nível de escolaridade? (Considere apenas o nível mais alto)

\begin{tabular}{|c|l|}
\hline & NÍVEL MÉDIO \\
\hline & NÍVEL SUPERIOR \\
\hline$X$ & PÓS-GRADUAÇÃO \\
\hline
\end{tabular}

3) Os conteúdos abordados foram condizentes com as demandas do seu dia-a-dia?

\begin{tabular}{|l|l|}
\hline$X$ & SIM \\
\hline & PARCIALMENTE \\
\hline & NÃO \\
\hline
\end{tabular}

4) O curso contribuiu para o seu aperfeiçoamento profissional?

\begin{tabular}{|l|l|}
\hline$X$ & SIM \\
\hline & NÃO \\
\hline
\end{tabular}

5) Os conhecimentos adquiridos estão sendo aplicados no seu trabalho? Em caso afirmativo, indique em que grau estes conhecimentos estão sendo aplicados. Em caso negativo, indique por que razão isto não ocorre: (Em caso negativo, as respostas não são excludentes: você poderá marcar mais de uma opção).

\begin{tabular}{|c|c|c|c|}
\hline \multirow{3}{*}{$\mathrm{x}$} & \multirow{3}{*}{$\begin{array}{l}\text { SIM (indique ao lado em } \\
\text { que grau) }\end{array}$} & $\mathrm{X}$ & MUITO APLICADOS \\
\hline & & & MEDIAMENTE APLICADOS \\
\hline & & & POUCO APLICADOS \\
\hline & & & $\begin{array}{l}\text { CONTEÚDO NĀO ADEQUADO ȦS NECESSIDADES } \\
\text { ESPECÍFICAS DA REGIÃO }\end{array}$ \\
\hline & razão da não aplicação) & & $\begin{array}{l}\text { CONTEÚDO NÃO FOI SUFICIENTEMENTE } \\
\text { APROFUNDADO PARA PERMITIR UMA APLICAÇÃO } \\
\text { EFICAZE EFICIENTE }\end{array}$ \\
\hline
\end{tabular}




\begin{tabular}{|l|l|l|}
\hline \multirow{2}{*}{} & & $\begin{array}{l}\text { FALTA DE APOIO E INCENTIVO DA MINHA } \\
\text { INSTITUIÇÃO }\end{array}$ \\
\cline { 2 - 3 } & & FALTA DE INCENTIVO ÀS AÇÕES DE ATER \\
\cline { 2 - 4 } & NÃO TENHO INTERESSE EM APLICAR \\
\hline
\end{tabular}

6) A partir deste curso: (As opções não são excludentes: você poderá marcar mais de uma opção)

\begin{tabular}{|r|l|}
\hline$x$ & $\begin{array}{l}\text { NÃO MUDOU NADA EM MEU TRABALHO. } \\
\text { FAMILIARES. }\end{array}$ \\
\hline$x$ & CONSEGUI INFLUENCIAR NAS ORIENTAÇÕES DA MINHA INSTITUIÇÃO. \\
\hline & $\begin{array}{l}\text { CRESCEU A ÁREA DE AGRICULTURA A CONTRIBUIR MAIS COM OS AGRICULTORES(AS) } \\
\text { ONDE ATUO. }\end{array}$ \\
\hline & CONTINUEI ME APERFEIÇOANDO SOBRE TEMAS ABORDADOS. \\
\hline
\end{tabular}

7) Depois do curso você apoiou atividades de capacitação de técnicos e agricultores com base nos princípios e diretrizes da Pnater? (Considere como apoio a atividades de capacitação a participação no planejamento, elaboração de ementas, seleção de participantes e de palestrantes.)

\begin{tabular}{|l|l|}
\hline$X$ & SIM \\
\hline & NÃO \\
\hline
\end{tabular}

8) Usou os conhecimentos para ministrar outros cursos com o mesmo conteúdo ou conteúdos semelhantes?

\begin{tabular}{|l|l|}
\hline & SIM \\
\hline$X$ & NÃO \\
\hline
\end{tabular}


9) Marque o seu grau de satisfação com relação ao curso oferecido pelo DATER: (Considere a seguinte pontuação: 1 - MUITO RUIM; 2 - RUIM; 3 - REGULAR; 4 - BOM; 5 - MUITO BOM)

\begin{tabular}{|l|l|l|l|l|}
\hline 1 & 2 & 3 & $4 X$ & 5 \\
\hline
\end{tabular}

10) Marque seu grau de satisfação com relação ao DATER: (Considere a seguinte pontuação: 1 - MUITO RUIM; 2 - RUIM; 3 - REGULAR; 4 - BOM; 5 - MUITO BOM)

\begin{tabular}{|l|l|l|l|l|}
\hline 1 & 2 & 3 & $4 X$ & 5 \\
\hline
\end{tabular}




\section{PESQUISA - IMPACTO DAS AÇÕES DE FORMAÇÃO REALIZADAS PELO DATER/SAF/MDA NO PERÍODO 2004-2009}

Caros colaboradores,

Contamos com a sua atenção para preencher o formulário abaixo.

O mesmo tem por objetivo fornecer informações para avaliação da Eficiência, Efetividade e Eficácia da Política Pública de Formação de Agentes de Ater adotada pelo Departamento de Assistência Técnica e Extensão Rural, da Secretaria de Agricultura Familiar do Ministério do Desenvolvimento - DATER/SAF/MDA, no período de 2004 a 2009, tema escolhido para Monografia a ser apresentada à Universidade de Brasília (UnB) como requisito parcial para obtenção do grau de Bacharel em Administração.

Você poderá ou não se identificar no questionário e garantimos que todas as informações fornecidas serão confidenciais e utilizadas apenas de forma sistematizada.

\section{IDENTIFICAÇÃO:}

\begin{tabular}{|l|l|}
\hline Nome: Maria de Lourdes Rodrigues da Silva & $\begin{array}{l}\text { Sexo: } \\
(\quad \text { ) masculino ( xxxx ) feminino }\end{array}$ \\
\hline $\begin{array}{l}\text { Instituição (nome e tipo de instituição: ONG, } \\
\text { Empresa Pública, etc.): Emater - Ro. }\end{array}$ & $\begin{array}{l}\text { Local de trabalho (Cidade e Estado): } \\
\text { Cerejeiras - Ro. }\end{array}$ \\
\hline $\begin{array}{l}\text { Curso/Encontro/Oficina do qual participou (caso tenha participado de mais de um curso, } \\
\text { preencha um formulário para cada um deles): Curso Processamento de Pescado. }\end{array}$ \\
\hline \begin{tabular}{l} 
Data do Curso/Encontro/Oficina (pelo menos mês e ano): 08 a 12/05/2006. \\
\hline
\end{tabular}
\end{tabular}

Indique sua área de atuação? (As opções não são excludentes: você poderá marcar mais de uma opção)

\begin{tabular}{|l|l|}
\hline$X$ & EXTENSÃO RURAL \\
\hline & PESQUISA \\
\hline & ENSINO \\
\hline & OUTROS \\
\hline
\end{tabular}


2) Qual o seu nível de escolaridade? (Considere apenas o nível mais alto)

\begin{tabular}{|l|l|}
\hline & NÍVEL MÉDIO \\
\hline$x$ & NÍVEL SUPERIOR \\
\hline & PÓS-GRADUAÇÃO \\
\hline
\end{tabular}

3) Os conteúdos abordados foram condizentes com as demandas do seu dia-a-dia?

\begin{tabular}{|l|l|}
\hline$x$ & SIM \\
\hline & PARCIALMENTE \\
\hline & NÃO \\
\hline
\end{tabular}

4) O curso contribuiu para o seu aperfeiçoamento profissional?

\begin{tabular}{|l|l|}
\hline$x$ & SIM \\
\hline & NÃO \\
\hline
\end{tabular}

5) Os conhecimentos adquiridos estão sendo aplicados no seu trabalho? Em caso afirmativo, indique em que grau estes conhecimentos estão sendo aplicados. Em caso negativo, indique por que razão isto não ocorre: (Em caso negativo, as respostas não são excludentes: você poderá marcar mais de uma opção). 


\begin{tabular}{|c|c|c|c|}
\hline & \multirow[t]{2}{*}{ em que grau) } & & MEDIAMENTE APLICADOS \\
\hline & & & POUCO APLICADOS \\
\hline \multirow{5}{*}{$\mathrm{x}$} & \multirow{5}{*}{$\begin{array}{l}\text { NÃO (indique ao lado a } \\
\text { razão da não aplicação) }\end{array}$} & $\bar{x}$ & $\begin{array}{l}\text { CONTEÚDO NÃO ADEQUADO ÀS NECESSIDADES } \\
\text { ESPECÍFICAS DA REGIÃO }\end{array}$ \\
\hline & & & $\begin{array}{l}\text { CONTEÚDO NÃO FOI SUFICIENTEMENTE } \\
\text { APROFUNDADO PARA PERMITIR UMA APLICAÇÃO } \\
\text { EFICAZ E EFICIENTE }\end{array}$ \\
\hline & & & $\begin{array}{llllll}\text { FALTA DE APOIO } & \text { E } & \text { INCENTIVO } & \text { DA } & \text { MINHA } \\
\text { INSTITUIÇÃO } & & & & & \\
\end{array}$ \\
\hline & & & FALTA DE INCENTIVO ÀS AÇÕES DE ATER \\
\hline & & & NÃO TENHO INTERESSE EM APLICAR \\
\hline
\end{tabular}

6) A partir deste curso: (As opções não são excludentes: você poderá marcar mais de uma opção)

\begin{tabular}{|l|l|}
\hline & NÃO MUDOU NADA EM MEU TRABALHO. \\
\hline & $\begin{array}{l}\text { MEU TRABALHO PASSOU A CONTRIBUIR MAIS COM OS AGRICULTORES (AS) } \\
\text { FAMILIARES. }\end{array}$ \\
\hline & CONSEGUI INFLUENCIAR NAS ORIENTAÇÕES DA MINHA INSTITUIÇÃO. \\
\hline & PASSEI A TRABALHAR COM METODOLOGIAS PARTICIPATIVAS. \\
\hline & $\begin{array}{l}\text { CRESCEU A ÁREA DE AGRICULTURA DE BASE ECOLÓGICA NAS COMUNIDADES } \\
\text { ONDE ATUO. }\end{array}$ \\
\hline $\mathrm{X}$ & CONTINUEI ME APERFEIÇOANDO SOBRE TEMAS ABORDADOS. \\
\hline
\end{tabular}

7) Depois do curso você apoiou atividades de capacitação de técnicos e agricultores com base nos princípios e diretrizes da Pnater? (Considere como apoio a atividades de capacitação a participação no planejamento, elaboração de ementas, seleção de participantes e de palestrantes.) 


\begin{tabular}{|l|l|}
\hline$X$ & SIM \\
\hline & NÃO \\
\hline
\end{tabular}

8) Usou os conhecimentos para ministrar outros cursos com o mesmo conteúdo ou conteúdos semelhantes?

\begin{tabular}{|l|l|}
\hline$x$ & SIM \\
\hline & NÃO \\
\hline
\end{tabular}

9) Marque o seu grau de satisfação com relação ao curso oferecido pelo DATER: (Considere a seguinte pontuação: 1 - MUITO RUIM; 2 - RUIM; 3 - REGULAR; 4 - BOM; 5 - MUITO BOM)

\begin{tabular}{|l|l|l|l|l|}
\hline 1 & 2 & 3 & 4 & $5 \times$ \\
\hline
\end{tabular}

10) Marque seu grau de satisfação com relação ao DATER: (Considere a seguinte pontuação: 1 - MUITO RUIM; 2 - RUIM; 3 - REGULAR; 4 - BOM; 5 - MUITO BOM)

\begin{tabular}{|l|l|l|l|l|}
\hline 1 & 2 & 3 & 4 & $5 \times$ \\
\hline
\end{tabular}




\section{PESQUISA - IMPACTO DAS AÇÕES DE FORMAÇÃO REALIZADAS PELO DATER/SAF/MDA NO PERÍODO 2004-2009}

Caros colaboradores,

Contamos com a sua atenção para preencher o formulário abaixo.

O mesmo tem por objetivo fornecer informações para avaliação da Eficiência, Efetividade e Eficácia da Política Pública de Formação de Agentes de Ater adotada pelo Departamento de Assistência Técnica e Extensão Rural, da Secretaria de Agricultura Familiar do Ministério do Desenvolvimento - DATER/SAF/MDA, no período de 2004 a 2009, tema escolhido para Monografia a ser apresentada à Universidade de Brasília (UnB) como requisito parcial para obtenção do grau de Bacharel em Administração.

Você poderá ou não se identificar no questionário e garantimos que todas as informações fornecidas serão confidenciais e utilizadas apenas de forma sistematizada.

IDENTIFICAÇÃO

\begin{tabular}{|c|c|}
\hline Nome: MARCOS DA SILVA RIBEIRO & $\begin{array}{l}\text { Sexo: } \\
(x \quad) \text { masculino } \quad(\quad) \text { feminino }\end{array}$ \\
\hline $\begin{array}{l}\text { Instituição (nome e tipo de instituição: ONG, } \\
\text { Empresa Pública, etc.): EMATER-RO }\end{array}$ & $\begin{array}{l}\text { Local de trabalho (Cidade e Estado): } \\
\text { MACHADINHO D`OESTE-RO }\end{array}$ \\
\hline \multicolumn{2}{|c|}{$\begin{array}{l}\text { Curso/Encontro/Oficina do qual participou (caso tenha participado de mais de um curso, } \\
\text { preencha um formulário para cada um deles): } \\
\text { CURSO: MANEJO DE PASTAGEM COM ÊNFASE NO CONTROLE BIOLÓGICO DA } \\
\text { CIGARRINHA. }\end{array}$} \\
\hline $\begin{array}{l}\text { Data do Curso/Encontro/Oficina (pelo menos mês } \\
\qquad 19 \text { a 23/06/2006. }\end{array}$ & \\
\hline
\end{tabular}

Indique sua área de atuação? (As opções não são excludentes: você poderá marcar mais de uma opção)

\begin{tabular}{|l|l|}
\hline$X$ & EXTENSÃO RURAL \\
\hline & PESQUISA \\
\hline & ENSINO \\
\hline & OUTROS \\
\hline
\end{tabular}


2) Qual o seu nível de escolaridade? (Considere apenas o nível mais alto)

\begin{tabular}{|l|l|}
\hline & NÍVEL MÉDIO \\
\hline$X$ & NÍVEL SUPERIOR \\
\hline & PÓS-GRADUAÇÃO \\
\hline
\end{tabular}

3) Os conteúdos abordados foram condizentes com as demandas do seu dia-a-dia?

\begin{tabular}{|l|l|}
\hline$X$ & SIM \\
\hline & PARCIALMENTE \\
\hline & NÃO \\
\hline
\end{tabular}

3) O curso contribuiu para o seu aperfeiçoamento profissional?

\begin{tabular}{|l|l|}
\hline$X$ & SIM \\
\hline & NÃO \\
\hline
\end{tabular}

5) Os conhecimentos adquiridos estão sendo aplicados no seu trabalho? Em caso afirmativo, indique em que grau estes conhecimentos estão sendo aplicados. Em caso negativo, indique por que razão isto não ocorre: (Em caso negativo, as respostas não são excludentes: você poderá marcar mais de uma opção).

\begin{tabular}{|c|c|c|c|}
\hline \multirow{3}{*}{$\mathrm{x}$} & \multirow{3}{*}{$\begin{array}{l}\text { SIM (indique ao lado } \\
\text { em que grau) }\end{array}$} & $\mathrm{x}$ & MUITO APLICADOS \\
\hline & & & MEDIAMENTE APLICADOS \\
\hline & & & POUCO APLICADOS \\
\hline & \begin{tabular}{|l|} 
NĀO (indique ao lado a \\
razão da não aplicação)
\end{tabular} & & $\begin{array}{l}\text { CONTEU்DO NĀO ADEQUADO ȦS NECESSIDADES } \\
\text { ESPECÍFICAS DA REGIÃO }\end{array}$ \\
\hline
\end{tabular}




\begin{tabular}{|l|l|l|}
\hline \multirow{2}{*}{} & & $\begin{array}{l}\text { CONTEÚDO NĀO FOI SUFICIENTEMENTE } \\
\text { APROFUNDADO PARA PERMITIR UMA APLICAÇÃo } \\
\text { EFICAZ E EFICIENTE }\end{array}$ \\
\cline { 2 - 4 } & $\begin{array}{l}\text { FALTA DE APOIO E INCENTIVO DA MINHA } \\
\text { INSTITUIÇÃO }\end{array}$ \\
\hline & FALTA DE INCENTIVO ÀS AÇÕES DE ATER \\
\hline & NÃO TENHO INTERESSE EM APLICAR \\
\hline
\end{tabular}

6) A partir deste curso: (As opções não são excludentes: você poderá marcar mais de uma opção)

\begin{tabular}{|l|l|}
\hline$x$ & $\begin{array}{l}\text { NÃO MUDOU NADA EM MEU TRABALHO. } \\
\text { FAMILIARES. }\end{array}$ \\
\hline & CONSEGUI INFLUENCIAR NAS ORIENTAÇÕES DA MINHA INSTITUIÇÃO. \\
\hline & PASSEI A TRABALHAR COM METODOLOGIAS PARTICIPATIVAS. \\
\hline & $\begin{array}{l}\text { CRESCEU A AREA DE AGRICULTURA DE BASE ECOLOGICA NAS COMUNIDADES } \\
\text { ONDE ATUO. }\end{array}$ \\
\hline & CONTINUEI ME APERFEIÇOANDO SOBRE TEMAS ABORDADOS. \\
\hline
\end{tabular}

7) Depois do curso você apoiou atividades de capacitação de técnicos e agricultores com base nos princípios e diretrizes da Pnater? (Considere como apoio a atividades de capacitação a participação no planejamento, elaboração de ementas, seleção de participantes e de palestrantes.)

\begin{tabular}{|l|l|}
\hline$X$ & SIM \\
\hline & NÃO \\
\hline
\end{tabular}

8) Usou os conhecimentos para ministrar outros cursos com o mesmo conteúdo ou conteúdos semelhantes? 


\begin{tabular}{|l|l|}
\hline$X$ & SIM \\
\hline & NÃO \\
\hline
\end{tabular}

9) Marque o seu grau de satisfação com relação ao curso oferecido pelo DATER: (Considere a seguinte pontuação: 1 - MUITO RUIM; 2 - RUIM; 3 - REGULAR; 4 - BOM; 5 - MUITO BOM)

\begin{tabular}{|l|l|l|l|l|}
\hline 1 & 2 & 3 & $4 \times$ & 5 \\
\hline
\end{tabular}

10) Marque seu grau de satisfação com relação ao DATER: (Considere a seguinte pontuação: 1 - MUITO RUIM; 2 - RUIM; 3 - REGULAR; 4 - BOM; 5 - MUITO BOM)

\begin{tabular}{|l|l|l|l|l|}
\hline 1 & 2 & 3 & $4 \times$ & 5 \\
\hline
\end{tabular}




\section{PESQUISA - IMPACTO DAS AÇÕES DE FORMAÇÃO REALIZADAS PELO DATER/SAF/MDA NO PERÍODO 2004-2009}

Caros colaboradores,

Contamos com a sua atenção para preencher o formulário abaixo.

O mesmo tem por objetivo fornecer informações para avaliação da Eficiência, Efetividade e Eficácia da Política Pública de Formação de Agentes de Ater adotada pelo Departamento de Assistência Técnica e Extensão Rural, da Secretaria de Agricultura Familiar do Ministério do Desenvolvimento - DATER/SAF/MDA, no período de 2004 a 2009, tema escolhido para Monografia a ser apresentada à Universidade de Brasília (UnB) como requisito parcial para obtenção do grau de Bacharel em Administração.

Você poderá ou não se identificar no questionário e garantimos que todas as informações fornecidas serão confidenciais e utilizadas apenas de forma sistematizada.

IDENTIFICAÇÃO

\begin{tabular}{|l|l|}
\hline Nome: Eliandro Marcio Perini & $\begin{array}{l}\text { Sexo: } \\
(x \quad) \text { masculino } \quad(\quad \text { ) feminino }\end{array}$ \\
\hline $\begin{array}{l}\text { Instituição (nome e tipo de instituição: ONG, } \\
\text { Empresa Pública, etc.): EMATER - RONDONIA }\end{array}$ & $\begin{array}{l}\text { Local de trabalho (Cidade e Estado): } \\
\text { EMATER CABIXI }\end{array}$ \\
\hline $\begin{array}{l}\text { Curso/Encontro/Oficina do qual participou (caso tenha participado de mais de um curso, } \\
\text { preencha um formulário para cada um deles): MANEJO DE PASTAGEM }\end{array}$ \\
\hline Data do Curso/Encontro/Oficina (pelo menos mês e ano): 08 a 10/09/2004 \\
\hline
\end{tabular}

Indique sua área de atuação? (As opções não são excludentes: você poderá marcar mais de uma opção)

\begin{tabular}{|l|l|}
\hline$X$ & EXTENSÃO RURAL \\
\hline & PESQUISA \\
\hline & ENSINO \\
\hline & OUTROS \\
\hline
\end{tabular}


2) Qual o seu nível de escolaridade? (Considere apenas o nível mais alto)

\begin{tabular}{|l|l|}
\hline$X$ & NÍVEL MÉDIO \\
\hline & NÍVEL SUPERIOR \\
\hline & PÓS-GRADUAÇÃO \\
\hline
\end{tabular}

3) Os conteúdos abordados foram condizentes com as demandas do seu dia-a-dia?

\begin{tabular}{|l|l|}
\hline$X$ & SIM \\
\hline & PARCIALMENTE \\
\hline & NÃO \\
\hline
\end{tabular}

3) O curso contribuiu para o seu aperfeiçoamento profissional?

\begin{tabular}{|l|l|}
\hline$X$ & SIM \\
\hline & NÃO \\
\hline
\end{tabular}

5) Os conhecimentos adquiridos estão sendo aplicados no seu trabalho? Em caso afirmativo, indique em que grau estes conhecimentos estão sendo aplicados. Em caso negativo, indique por que razão isto não ocorre: (Em caso negativo, as respostas não são excludentes: você poderá marcar mais de uma opção).

\begin{tabular}{|l|l|l|l|}
\hline \multirow{2}{*}{$\begin{array}{l}\text { SIM (indique ao lado } \\
\text { em que grau) }\end{array}$} & & \multicolumn{1}{c|}{ MUITO APLICADOS } \\
\cline { 2 - 3 } & $\begin{array}{l}\text { MẼ̃O (indique ao lado a } \\
\text { razão da não aplicação) }\end{array}$ & $\begin{array}{l}\text { CONTEÚDO NÃO ADEQUADO ÀS NECESSIDADES } \\
\text { ESPECÍfICAS DA REGIÃO }\end{array}$ \\
\hline
\end{tabular}




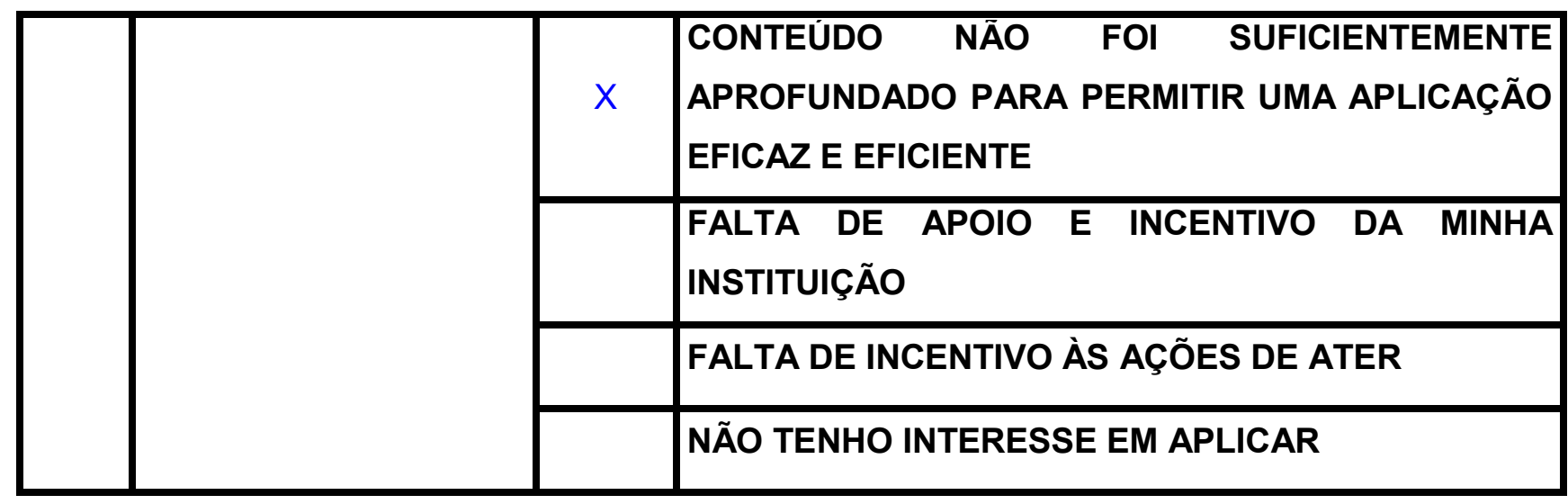

6) A partir deste curso: (As opções não são excludentes: você poderá marcar mais de uma opção)

\begin{tabular}{|c|l|}
\hline$X$ & $\begin{array}{l}\text { NÃO MUDOU NADA EM MEU TRABALHO. } \\
\text { FAMILIARES. }\end{array}$ \\
\hline & CONSEGUI INFLUENCIAR NAS ORIENTAÇÕES DA MINHA INSTITUIÇÃO. \\
\hline & PASSEI A TRABALHAR COM METODOLOGIAS PARTICIPATIVAS. \\
\hline & $\begin{array}{l}\text { CRESCEU A ÁREA DE AGRICULTURA DE BASE ECOLOGICA NAS COMUNIDADES } \\
\text { ONDE ATUO. }\end{array}$ \\
\hline$X$ & CONTINUEI ME APERFEIÇOANDO SOBRE TEMAS ABORDADOS. \\
\hline
\end{tabular}

7) Depois do curso você apoiou atividades de capacitação de técnicos e agricultores com base nos princípios e diretrizes da Pnater? (Considere como apoio a atividades de capacitação a participação no planejamento, elaboração de ementas, seleção de participantes e de palestrantes.) 


\section{NÃO}

8) Usou os conhecimentos para ministrar outros cursos com o mesmo conteúdo ou conteúdos semelhantes?

\begin{tabular}{|l|l|}
\hline & SIM \\
\hline$X$ & NÃO \\
\hline
\end{tabular}

9) Marque o seu grau de satisfação com relação ao curso oferecido pelo DATER: (Considere a seguinte pontuação: 1 - MUITO RUIM; 2 - RUIM; 3 - REGULAR; 4 - BOM; 5 - MUITO BOM)

\begin{tabular}{|l|l|l|l|l|}
\hline 1 & 2 & 3 & 4 & 5 \\
\hline
\end{tabular}

10) Marque seu grau de satisfação com relação ao DATER: (Considere a seguinte pontuação: 1 - MUITO RUIM; 2 - RUIM; 3 - REGULAR; 4 - BOM; 5 - MUITO BOM)

\begin{tabular}{|l|l|l|l|l|}
\hline 1 & 2 & 3 & 4 & 5 \\
\hline
\end{tabular}

4-BOM 4 - BOM 


\section{PESQUISA - IMPACTO DAS AÇÕES DE FORMAÇÃO REALIZADAS PELO DATER/SAF/MDA NO PERÍODO 2004-2009}

Caros colaboradores,

Contamos com a sua atenção para preencher o formulário abaixo.

O mesmo tem por objetivo fornecer informações para avaliação da Eficiência, Efetividade e Eficácia da Política Pública de Formação de Agentes de Ater adotada pelo Departamento de Assistência Técnica e Extensão Rural, da Secretaria de Agricultura Familiar do Ministério do Desenvolvimento - DATER/SAF/MDA, no período de 2004 a 2009, tema escolhido para Monografia a ser apresentada à Universidade de Brasília (UnB) como requisito parcial para obtenção do grau de Bacharel em Administração.

Você poderá ou não se identificar no questionário e garantimos que todas as informações fornecidas serão confidenciais e utilizadas apenas de forma sistematizada.

IDENTIFICAÇÃO

\begin{tabular}{|c|c|}
\hline Nome: Eliandro Marcio Perini & $\begin{array}{l}\text { Sexo: } \\
(x \quad) \text { masculino } \quad(\quad) \text { feminino }\end{array}$ \\
\hline $\begin{array}{l}\text { Instituição (nome e tipo de instituição: ONG, } \\
\text { Empresa Pública, etc.): EMATER - RONDONIA }\end{array}$ & $\begin{array}{l}\text { Local de trabalho (Cidade e Estado): } \\
\text { EMATER CABIXI }\end{array}$ \\
\hline \multicolumn{2}{|c|}{$\begin{array}{l}\text { Curso/Encontro/Oficina do qual participou (caso tenha participado de mais de um curso, } \\
\text { preencha um formulário para cada um deles): MELHORIA DA QUALIDADE DO LEITE }\end{array}$} \\
\hline Data do Curso/Encontro/Oficina (pelo menos mê & e ano): 12 a 16/06/2006 \\
\hline
\end{tabular}

Indique sua área de atuação? (As opções não são excludentes: você poderá marcar mais de uma opção)

\begin{tabular}{|l|l|}
\hline$X$ & EXTENSÃO RURAL \\
\hline & PESQUISA \\
\hline & ENSINO \\
\hline & OUTROS \\
\hline
\end{tabular}

2) Qual o seu nível de escolaridade? (Considere apenas o nível mais alto) 


\begin{tabular}{|l|l|}
\hline$X$ & NÍVEL MÉDIO \\
\hline & NÍVEL SUPERIOR \\
\hline & PÓS-GRADUAÇÃO \\
\hline
\end{tabular}

3) Os conteúdos abordados foram condizentes com as demandas do seu dia-a-dia?

\begin{tabular}{|l|l|}
\hline$X$ & SIM \\
\hline & PARCIALMENTE \\
\hline & NÃO \\
\hline
\end{tabular}

3) O curso contribuiu para o seu aperfeiçoamento profissional?

\begin{tabular}{|l|l|}
\hline$X$ & SIM \\
\hline & NÃO \\
\hline
\end{tabular}

5) Os conhecimentos adquiridos estão sendo aplicados no seu trabalho? Em caso afirmativo, indique em que grau estes conhecimentos estão sendo aplicados. Em caso negativo, indique por que razão isto não ocorre: (Em caso negativo, as respostas não são excludentes: você poderá marcar mais de uma opção).

\begin{tabular}{|l|l|l|l|}
\hline$X$ & $\begin{array}{l}\text { SIM (indique ao lado } \\
\text { em que grau) }\end{array}$ & $X$ & MUITO APLICADOS \\
\cline { 2 - 4 } & $\begin{array}{l}\text { NÃO (indique ao lado a } \\
\text { razão da não aplicação) }\end{array}$ & & $\begin{array}{l}\text { CONTEÚDO NÃO ADEQUADO ȦS NECESSIDADES } \\
\text { ESPECÍFICAS DA REGIÃO }\end{array}$ \\
\hline
\end{tabular}




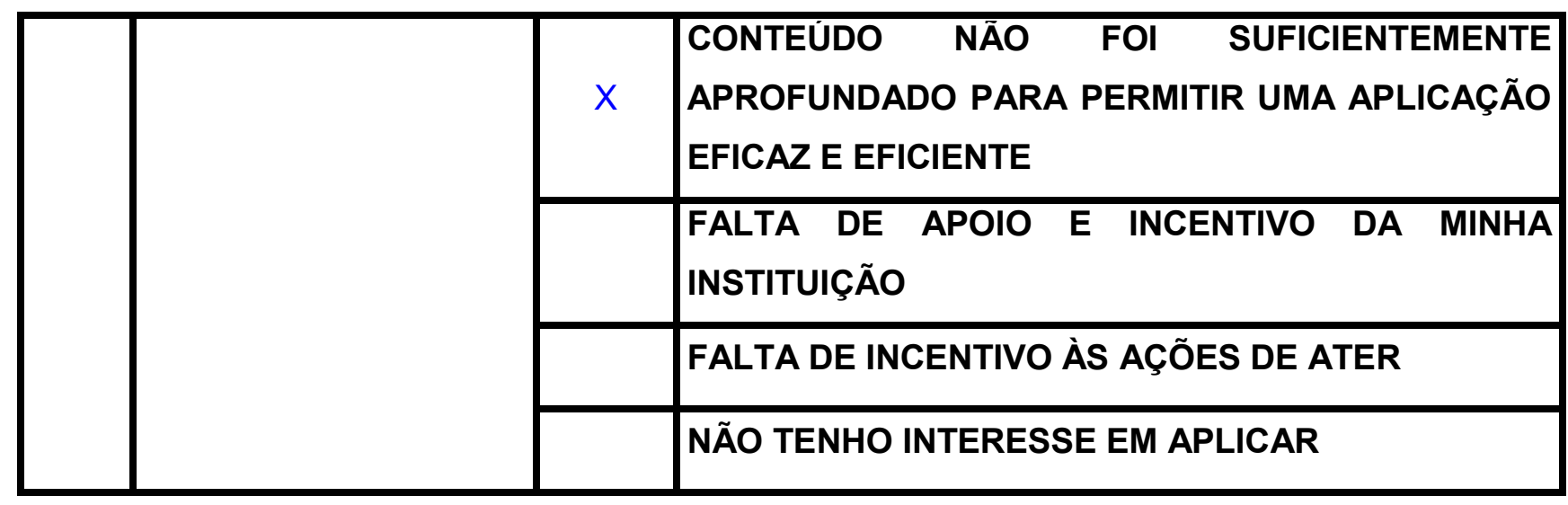

6) A partir deste curso: (As opções não são excludentes: você poderá marcar mais de uma opção)

\begin{tabular}{|c|l|}
\hline & NÃO MUDOU NADA EM MEU TRABALHO. \\
\hline$X$ & $\begin{array}{l}\text { MEU TRABALHO PASSOU A CONTRIBUIR MAIS COM OS AGRICULTORES(AS) } \\
\text { FAMILIARES. }\end{array}$ \\
\hline & CONSEGUI INFLUENCIAR NAS ORIENTAÇÕES DA MINHA INSTITUIÇÃO. \\
\hline & PASSEI A TRABALHAR COM METODOLOGIAS PARTICIPATIVAS. \\
\hline & $\begin{array}{l}\text { CRESCEU A AREA DE AGRICULTURA DE BASE ECOLÓGICA NAS COMUNIDADES } \\
\text { ONDE ATUO. }\end{array}$ \\
\hline$X$ & CONTINUEI ME APERFEIÇOANDO SOBRE TEMAS ABORDADOS. \\
\hline
\end{tabular}

7) Depois do curso você apoiou atividades de capacitação de técnicos e agricultores com base nos princípios e diretrizes da Pnater? (Considere como apoio a atividades de capacitação a participação no planejamento, elaboração de ementas, seleção de participantes e de palestrantes.)

\begin{tabular}{|l|l|}
\hline$X$ & SIM \\
\hline & NÃO \\
\hline
\end{tabular}

8) Usou os conhecimentos para ministrar outros cursos com o mesmo conteúdo ou conteúdos semelhantes? 


\begin{tabular}{|l|l|}
\hline & SIM \\
\hline$X$ & NÃO \\
\hline
\end{tabular}

9) Marque o seu grau de satisfação com relação ao curso oferecido pelo DATER: (Considere a seguinte pontuação: 1 - MUITO RUIM; 2 - RUIM; 3 - REGULAR; 4 - BOM; 5 - MUITO BOM)

\begin{tabular}{|l|l|l|l|l|}
\hline 1 & 2 & 3 & 4 & 5 \\
\hline
\end{tabular}

10) Marque seu grau de satisfação com relação ao DATER: (Considere a seguinte pontuação: 1 - MUITO RUIM; 2 - RUIM; 3 - REGULAR; 4 - BOM; 5 - MUITO BOM)

\begin{tabular}{|l|l|l|l|l|}
\hline 1 & 2 & 3 & 4 & 5 \\
\hline
\end{tabular}

4-BOM 4 - ВОМ 
PESQUISA - IMPACTO DAS AÇÕES DE FORMAÇÃO REALIZADAS PELO DATER/SAF/MDA NO PERÍODO 2004-2009

Caros colaboradores,

Contamos com a sua atenção para preencher o formulário abaixo.

O mesmo tem por objetivo fornecer informações para avaliação da Eficiência, Efetividade e Eficácia da Política Pública de Formação de Agentes de Ater adotada pelo Departamento de Assistência Técnica e Extensão Rural, da Secretaria de Agricultura Familiar do Ministério do Desenvolvimento - DATER/SAF/MDA, no período de 2004 a 2009, tema escolhido para Monografia a ser apresentada à Universidade de Brasília (UnB) como requisito parcial para obtenção do grau de Bacharel em Administração.

Você poderá ou não se identificar no questionário e garantimos que todas as informações fornecidas serão confidenciais e utilizadas apenas de forma sistematizada.

IDENTIFICAÇÃO

\begin{tabular}{|c|c|}
\hline Nome: MARCEONE LOPES SOUSA PEREIRA & $\begin{array}{l}\text { Sexo: } \\
(x \quad) \text { masculino } \quad(\quad) \text { feminino }\end{array}$ \\
\hline $\begin{array}{l}\text { Instituição (nome e tipo de instituição: ONG, } \\
\text { Empresa Pública, etc.): EMATER-PARÁ }\end{array}$ & $\begin{array}{l}\text { Local de trabalho (Cidade e Estado): } \\
\text { OURILÂNDIA DO NORTE-PARÁ }\end{array}$ \\
\hline \multicolumn{2}{|c|}{$\begin{array}{l}\text { Curso/Encontro/Oficina do qual participou (caso tenha participado de mais de um curso, } \\
\text { preencha um formulário para cada um deles): DIAGNÓSTICO RURAL PARTICIPATIVO E } \\
\text { METODOLOGIA EM EXTENSÃO RURAL }\end{array}$} \\
\hline רos m & ano): JANEIRO/ 2005 \\
\hline
\end{tabular}

Indique sua área de atuação? (As opções não são excludentes: você poderá marcar mais de uma opção)

\begin{tabular}{|l|l|}
\hline$X$ & EXTENSÃO RURAL \\
\hline & PESQUISA \\
\hline & ENSINO \\
\hline & OUTROS \\
\hline
\end{tabular}

2) Qual o seu nível de escolaridade? (Considere apenas o nível mais alto) 


\begin{tabular}{|l|l|}
\hline$X$ & NÍVEL MÉDIO \\
\hline & NÍVEL SUPERIOR \\
\hline & PÓS-GRADUAÇÃO \\
\hline
\end{tabular}

3) Os conteúdos abordados foram condizentes com as demandas do seu dia-a-dia?

\begin{tabular}{|l|l|}
\hline$X$ & SIM \\
\hline & PARCIALMENTE \\
\hline & NÃO \\
\hline
\end{tabular}

3) O curso contribuiu para o seu aperfeiçoamento profissional?

\begin{tabular}{|l|l|}
\hline$X$ & SIM \\
\hline & NÃO \\
\hline
\end{tabular}

5) Os conhecimentos adquiridos estão sendo aplicados no seu trabalho? Em caso afirmativo, indique em que grau estes conhecimentos estão sendo aplicados. Em caso negativo, indique por que razão isto não ocorre: (Em caso negativo, as respostas não são excludentes: você poderá marcar mais de uma opção).

\begin{tabular}{|c|c|c|c|}
\hline \multirow{3}{*}{$\mathrm{x}$} & \multirow{3}{*}{$\begin{array}{l}\text { SIM (indique ao lado } \\
\text { em que grau) }\end{array}$} & & MUITO APLICADOS \\
\hline & & $\mathrm{x}$ & MEDIAMENTE APLICADOS \\
\hline & & & POUCO APLICADOS \\
\hline & \multirow{2}{*}{$\begin{array}{l}\text { NÃO (indique ao lado a } \\
\text { razão da não aplicação) }\end{array}$} & & $\begin{array}{l}\text { CONTEUंDO NĀO ADEQUADO ÁS NECESSIDADES } \\
\text { ESPECÍFICAS DA REGIÃO }\end{array}$ \\
\hline & & & $\begin{array}{l}\text { CONTEÚDO NĀO FOI SUFICIENTEMENTE } \\
\text { APROFUNDADO PARA PERMITIR UMA APLICAÇÃO } \\
\text { EFICAZ E EFICIENTE }\end{array}$ \\
\hline
\end{tabular}




\begin{tabular}{|l|l|l|}
\hline \multirow{2}{*}{} & & $\begin{array}{l}\text { FALTA DE APOIO E INCENTIVO DA MINHA } \\
\text { INSTITUIÇÃO }\end{array}$ \\
\cline { 3 - 4 } & & FALTA DE INCENTIVO ÀS AÇÕES DE ATER \\
\cline { 2 - 3 } & NÃO TENHO INTERESSE EM APLICAR \\
\hline
\end{tabular}

6) A partir deste curso: (As opções não são excludentes: você poderá marcar mais de uma opção)

\begin{tabular}{|l|l|}
\hline$x$ & $\begin{array}{l}\text { NÃO MUDOU NADA EM MEU TRABALHO. } \\
\text { FAMILIARES. }\end{array}$ \\
\hline & CONSEGUI INFLUENCIAR NAS ORIENTAÇÕES DA MINHA INSTITUIÇÃO. \\
\hline & PASSEI A TRABALHAR COM METODOLOGIAS PARTICIPATIVAS. \\
\hline & $\begin{array}{l}\text { CRESCEU A ÁREA DE AGRICULTURA DE BASE ECOLÓGICA NAS COMUNIDADES } \\
\text { ONDE ATUO. }\end{array}$ \\
\hline & CONTINUEI ME APERFEIÇOANDO SOBRE TEMAS ABORDADOS. \\
\hline
\end{tabular}

7) Depois do curso você apoiou atividades de capacitação de técnicos e agricultores com base nos princípios e diretrizes da Pnater? (Considere como apoio a atividades de capacitação a participação no planejamento, elaboração de ementas, seleção de participantes e de palestrantes.)

\begin{tabular}{|l|l|}
\hline & SIM \\
\hline$X$ & NÃO \\
\hline
\end{tabular}

8) Usou os conhecimentos para ministrar outros cursos com o mesmo conteúdo ou conteúdos semelhantes?

\begin{tabular}{|l|l|}
\hline & SIM \\
\hline$X$ & NÃO \\
\hline
\end{tabular}


9) Marque o seu grau de satisfação com relação ao curso oferecido pelo DATER: (Considere a seguinte pontuação: 1 - MUITO RUIM; 2 - RUIM; 3 - REGULAR; 4 - BOM; 5 - MUITO BOM)

\begin{tabular}{|l|l|l|l|l|}
\hline 1 & 2 & 3 & 4 & $5 \times$ \\
\hline
\end{tabular}

10) Marque seu grau de satisfação com relação ao DATER: (Considere a seguinte pontuação: 1 - MUITO RUIM; 2 - RUIM; 3 - REGULAR; 4 - BOM; 5 - MUITO BOM)

\begin{tabular}{|l|l|l|l|l|}
\hline 1 & 2 & 3 & $4 \times$ & 5 \\
\hline
\end{tabular}


PESQUISA - IMPACTO DAS AÇÕES DE FORMAÇÃO REALIZADAS PELO DATER/SAF/MDA NO PERÍODO 2004-2009

Caros colaboradores,

Contamos com a sua atenção para preencher o formulário abaixo.

O mesmo tem por objetivo fornecer informações para avaliação da Eficiência, Efetividade e Eficácia da Política Pública de Formação de Agentes de Ater adotada pelo Departamento de Assistência Técnica e Extensão Rural, da Secretaria de Agricultura Familiar do Ministério do Desenvolvimento - DATER/SAF/MDA, no período de 2004 a 2009, tema escolhido para Monografia a ser apresentada à Universidade de Brasília (UnB) como requisito parcial para obtenção do grau de Bacharel em Administração.

Você poderá ou não se identificar no questionário e garantimos que todas as informações fornecidas serão confidenciais e utilizadas apenas de forma sistematizada.

IDENTIFICAÇÃO

\begin{tabular}{|c|c|}
\hline Nome: LUIS CARLOS FRANCISCATTO & $\begin{array}{l}\text { Sexo: } \\
\left(\begin{array}{l}x \quad) \text { masculino } \quad(\quad) \text { feminino }\end{array}\right.\end{array}$ \\
\hline $\begin{array}{l}\text { Instituição (nome e tipo de instituição: ONG, } \\
\text { Empresa Pública, etc.): } \\
\text { EMATER-PARÁ }\end{array}$ & $\begin{array}{l}\text { Local de trabalho (Cidade e Estado): } \\
\text { ESCRITÓRIO LOCAL DE ANANINDEUA - } \\
\text { PARÁ }\end{array}$ \\
\hline \multicolumn{2}{|c|}{$\begin{array}{l}\text { Curso/Encontro/Oficina do qual participou (caso tenha participado de mais de um curso, } \\
\text { preencha um formulário para cada um deles): } \\
\text { CURSO DE ECONOMIA POPULAR SOLIDÁRIA }\end{array}$} \\
\hline \multicolumn{2}{|c|}{$\begin{array}{l}\text { Data do Curso/Encontro/Oficina (pelo menos mês e ano): } \\
11 \text { A 15/09/2006 }\end{array}$} \\
\hline
\end{tabular}

Indique sua área de atuação? (As opções não são excludentes: você poderá marcar mais de uma opção)

\begin{tabular}{|l|l|}
\hline$X$ & EXTENSÃO RURAL \\
\hline & PESQUISA \\
\hline & ENSINO \\
\hline & OUTROS \\
\hline
\end{tabular}


2) Qual o seu nível de escolaridade? (Considere apenas o nível mais alto)

\begin{tabular}{|l|l|}
\hline$X$ & NÍVEL MÉDIO \\
\hline & NÍVEL SUPERIOR \\
\hline & PÓS-GRADUAÇÃO \\
\hline
\end{tabular}

3) Os conteúdos abordados foram condizentes com as demandas do seu dia-a-dia?

\begin{tabular}{|l|l|}
\hline$X$ & SIM \\
\hline & PARCIALMENTE \\
\hline & NÃO \\
\hline
\end{tabular}

4) O curso contribuiu para o seu aperfeiçoamento profissional?

\begin{tabular}{|l|l|}
\hline$X$ & SIM \\
\hline & NÃO \\
\hline
\end{tabular}

5) Os conhecimentos adquiridos estão sendo aplicados no seu trabalho? Em caso afirmativo, indique em que grau estes conhecimentos estão sendo aplicados. Em caso negativo, indique por que razão isto não ocorre: (Em caso negativo, as respostas não são excludentes: você poderá marcar mais de uma opção).

\begin{tabular}{|l|l|l|l|}
\hline$x$ & $\begin{array}{l}\text { SIM (indique ao lado } \\
\text { em que grau) }\end{array}$ & $X$ & MUITO APLICADOS \\
\cline { 2 - 4 } & & MEDIAMENTE APLICADOS \\
\hline & $\begin{array}{l}\text { NÃO (indique ao lado a } \\
\text { razão da não aplicação) }\end{array}$ & $\begin{array}{l}\text { CONTEÚDO NĀO ADEQUADO ȦS NECESSIDADES } \\
\text { ESPECíFICAS DA REGIÃO }\end{array}$ \\
\hline
\end{tabular}




\begin{tabular}{|l|l|l|}
\hline \multirow{10}{*}{} & $\begin{array}{l}\text { CONTEÚDO NÃO FOI SUFICIENTEMENTE } \\
\text { APROFUNDADO PARA PERMITIR UMA APLICAÇÃo } \\
\text { EFICAZ E EFICIENTE }\end{array}$ \\
\cline { 2 - 3 } & $\begin{array}{l}\text { FALTA DE APOIO E INCENTIVO DA MINHA } \\
\text { INSTITUIÇÃO }\end{array}$ \\
\hline & FALTA DE INCENTIVO ÀS AÇÕES DE ATER \\
\hline & NÃO TENHO INTERESSE EM APLICAR \\
\hline
\end{tabular}

6) A partir deste curso: (As opções não são excludentes: você poderá marcar mais de uma opção)

\begin{tabular}{|c|c|}
\hline & NÃO MUDOU NADA EM MEU TRABALHO. \\
\hline \multirow[t]{2}{*}{$\mathrm{X}$} & $\begin{array}{l}\text { MEU TRABALHO PASSOU A CONTRIBUIR MAIS COM OS AGRICULTORES(AS) } \\
\text { FAMILIARES. }\end{array}$ \\
\hline & CONSEGUI INFLUENCIAR NAS ORIENTAÇÕES DA MINHA INSTITUIÇÃO. \\
\hline $\mathrm{X}$ & PASSEI A TRABALHAR COM METODOLOGIAS PARTICIPATIVAS. \\
\hline \multirow[t]{2}{*}{ X } & $\begin{array}{l}\text { CRESCEU A ÁREA DE AGRICULTURA DE BASE ECOLÓGICA NAS COMUNIDADES } \\
\text { ONDE ATUO. }\end{array}$ \\
\hline & CONTINUEI ME APERFEIÇOANDO SOBRE TEMAS ABORDADOS. \\
\hline
\end{tabular}

7) Depois do curso você apoiou atividades de capacitação de técnicos e agricultores com base nos princípios e diretrizes da Pnater? (Considere como apoio a atividades de capacitação a participação no planejamento, elaboração de ementas, seleção de participantes e de palestrantes.)

\begin{tabular}{|l|l|}
\hline$X$ & SIM \\
\hline & NÃO \\
\hline
\end{tabular}

8) Usou os conhecimentos para ministrar outros cursos com o mesmo conteúdo ou conteúdos semelhantes? 


\begin{tabular}{|l|l|}
\hline & SIM \\
\hline$X$ & NÃO \\
\hline
\end{tabular}

9) Marque o seu grau de satisfação com relação ao curso oferecido pelo DATER: (Considere a seguinte pontuação: 1 - MUITO RUIM; 2 - RUIM; 3 - REGULAR; 4 - BOM; 5 - MUITO BOM)

\begin{tabular}{|l|l|l|l|l|}
\hline 1 & 2 & $(3)$ & 4 & 5 \\
\hline
\end{tabular}

10) Marque seu grau de satisfação com relação ao DATER: (Considere a seguinte pontuação: 1 - MUITO RUIM; 2 - RUIM; 3 - REGULAR; 4 - BOM; 5 - MUITO BOM)

\begin{tabular}{|l|l|l|l|l|}
\hline 1 & 2 & 3 & 4 & $(5)$ \\
\hline
\end{tabular}




\section{PESQUISA - IMPACTO DAS AÇÕES DE FORMAÇÃO REALIZADAS PELO DATER/SAF/MDA NO PERÍODO 2004-2009}

Caros colaboradores,

Contamos com a sua atenção para preencher o formulário abaixo.

O mesmo tem por objetivo fornecer informações para avaliação da Eficiência, Efetividade e Eficácia da Política Pública de Formação de Agentes de Ater adotada pelo Departamento de Assistência Técnica e Extensão Rural, da Secretaria de Agricultura Familiar do Ministério do Desenvolvimento - DATER/SAF/MDA, no período de 2004 a 2009, tema escolhido para Monografia a ser apresentada à Universidade de Brasília (UnB) como requisito parcial para obtenção do grau de Bacharel em Administração.

Você poderá ou não se identificar no questionário e garantimos que todas as informações fornecidas serão confidenciais e utilizadas apenas de forma sistematizada.

IDENTIFICAÇÃO

\begin{tabular}{|c|c|}
\hline Nome: Claudia Batista Soutinho & $\begin{array}{l}\text { Sexo: } \\
\left(\begin{array}{l}\text { ( ) masculino } \quad(x) \text { feminino }\end{array}\right.\end{array}$ \\
\hline $\begin{array}{l}\text { Instituição (nome e tipo de instituição: ONG, } \\
\text { Empresa Pública, etc.): } \\
\text { Instituto de Desenvolvimento Rural do Estado } \\
\text { do Tocantins -RURALTINS }\end{array}$ & $\begin{array}{l}\text { Local de trabalho (Cidade e Estado): } \\
\text { Palmas -TO }\end{array}$ \\
\hline \multicolumn{2}{|c|}{$\begin{array}{l}\text { Curso/Encontro/Oficina do qual participou (caso tenha participado de mais de um curso, } \\
\text { preencha um formulário para cada um deles): } \\
\text { Formadores de Agentes de ATER }\end{array}$} \\
\hline ontro/Oficir & $\overline{a n}$ \\
\hline
\end{tabular}

Indique sua área de atuação? (As opções não são excludentes: você poderá marcar mais de uma opção).

\begin{tabular}{|l|l|}
\hline$X$ & EXTENSÃO RURAL \\
\hline & PESQUISA \\
\hline & ENSINO \\
\hline
\end{tabular}




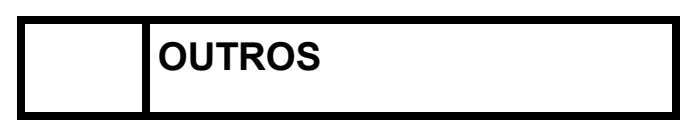

2) Qual o seu nível de escolaridade?

\begin{tabular}{|l|l|}
\hline & NÍVEL MÉDIO \\
\hline$X$ & NÍVEL SUPERIOR \\
\hline & PÓS-GRADUAÇÃO \\
\hline
\end{tabular}

3) Os conteúdos abordados foram condizentes com as demandas do seu dia-a-dia?

\begin{tabular}{|l|l|}
\hline$X$ & SIM \\
\hline & PARCIALMENTE \\
\hline & NÃO \\
\hline
\end{tabular}

3) O curso contribuiu para o seu aperfeiçoamento profissional?

\begin{tabular}{|l|l|}
\hline$X$ & SIM \\
\hline & NÃO \\
\hline
\end{tabular}

5) Os conhecimentos adquiridos estão sendo aplicados no seu trabalho? Em caso afirmativo, indique em que grau estes conhecimentos estão sendo aplicados. Em caso negativo, indique por que razão isto não ocorre: (Em caso negativo, as respostas não são excludentes: você poderá marcar mais de uma opção).

\begin{tabular}{|l|l|l|l|}
\hline X & $\begin{array}{l}\text { SIM (indique ao lado } \\
\text { em que grau) }\end{array}$ & X & MUITO APLICADOS \\
\cline { 2 - 4 } & & MEDIAMENTE APLICADOS \\
\hline & $\begin{array}{l}\text { NÃO (indique ao lado a } \\
\text { razão da não aplicação) }\end{array}$ & & $\begin{array}{l}\text { CONTEÚDO NĀO ADEQUADO ÁS NECESSIDADES } \\
\text { ESPECÍFICAS DA REGIÃO }\end{array}$ \\
\hline
\end{tabular}




\begin{tabular}{|l|l|l|}
\hline \multirow{2}{*}{} & & $\begin{array}{l}\text { CONTEÚDO NĀO FOI SUFICIENTEMENTE } \\
\text { APROFUNDADO PARA PERMITIR UMA APLICAÇÃo } \\
\text { EFICAZ E EFICIENTE }\end{array}$ \\
\cline { 2 - 4 } & $\begin{array}{l}\text { FALTA DE APOIO E INCENTIVO DA MINHA } \\
\text { INSTITUIÇÃO }\end{array}$ \\
\hline & FALTA DE INCENTIVO ÀS AÇÕES DE ATER \\
\hline & NÃO TENHO INTERESSE EM APLICAR \\
\hline
\end{tabular}

6) A partir deste curso: (As opções não são excludentes: você poderá marcar mais de uma opção).

\begin{tabular}{|l|l|}
\hline$X$ & $\begin{array}{l}\text { NÃO MUDOU NADA EM MEU TRABALHO. } \\
\text { FAMILIARES. }\end{array}$ \\
\hline & CONSEGUI INFLUENCIAR NAS ORIENTAÇÕES DA MINHA INSTITUIÇÃO. \\
\hline & PASSEI A TRABALHAR COM METODOLOGIAS PARTICIPATIVAS. \\
\hline & $\begin{array}{l}\text { CRESCEU A AREA DE AGRICULTURA DE BASE ECOLÓGICA NAS COMUNIDADES } \\
\text { ONDE ATUO. }\end{array}$ \\
\hline & CONTINUEI ME APERFEIÇOANDO SOBRE TEMAS ABORDADOS. COM OS AGRICULTORES(AS) \\
\hline
\end{tabular}

7) Depois do curso você apoiou atividades de capacitação de técnicos e agricultores com base nos princípios e diretrizes da Pnater? (Considere como apoio a atividades de capacitação a participação no planejamento, elaboração de ementas, seleção de participantes e de palestrantes.)

\begin{tabular}{|l|l|}
\hline & SIM \\
\hline$X$ & NÃO \\
\hline
\end{tabular}

8) Usou os conhecimentos para ministrar outros cursos com o mesmo conteúdo ou conteúdos semelhantes? 


\begin{tabular}{|l|l|}
\hline$X$ & SIM \\
\hline & NÃO \\
\hline
\end{tabular}

9) Marque o seu grau de satisfação com relação ao curso oferecido pelo DATER:

\begin{tabular}{|l|l|l|l|l|}
\hline 1 & 2 & 3 & 4 & $5 X$ \\
\hline
\end{tabular}

10) Marque seu grau de satisfação com relação ao DATER:

\begin{tabular}{|l|l|l|l|l|}
\hline 1 & 2 & 3 & 4 & $5 \times$ \\
\hline
\end{tabular}


PESQUISA - IMPACTO DAS AÇÕES DE FORMAÇÃO REALIZADAS PELO DATER/SAF/MDA NO PERÍODO 2004-2009

Caros colaboradores,

Contamos com a sua atenção para preencher o formulário abaixo.

O mesmo tem por objetivo fornecer informações para avaliação da Eficiência, Efetividade e Eficácia da Política Pública de Formação de Agentes de Ater adotada pelo Departamento de Assistência Técnica e Extensão Rural, da Secretaria de Agricultura Familiar do Ministério do Desenvolvimento - DATER/SAF/MDA, no período de 2004 a 2009, tema escolhido para Monografia a ser apresentada à Universidade de Brasília (UnB) como requisito parcial para obtenção do grau de Bacharel em Administração.

Você poderá ou não se identificar no questionário e garantimos que todas as informações fornecidas serão confidenciais e utilizadas apenas de forma sistematizada.

IDENTIFICAÇÃO

\begin{tabular}{|l|l|}
\hline Nome: Lílian Ferreira de Melo. & $\begin{array}{l}\text { Sexo: } \\
(\quad) \text { masculino (xx ) feminino }\end{array}$ \\
\hline $\begin{array}{l}\text { Instituição (nome e tipo de instituição: ONG, } \\
\text { Empresa Pública, etc.): Emater - Ro. }\end{array}$ & $\begin{array}{l}\text { Local de trabalho (Cidade e Estado): } \\
\text { Cerejeiras - Ro. }\end{array}$ \\
\hline $\begin{array}{l}\text { Curso/Encontro/Oficina do qual participou (caso tenha participado de mais de um curso, } \\
\text { preencha um formulário para cada um deles): Curso Controle das Cigarrinhas com Aplicação } \\
\text { de Fungo Metarhizium Anisopliae. }\end{array}$ \\
\hline \begin{tabular}{l} 
Data do Curso/Encontro/Oficina (pelo menos mês e ano): 29/05 a 02/06/2006. \\
\hline
\end{tabular}
\end{tabular}

Indique sua área de atuação? (As opções não são excludentes: você poderá marcar mais de uma opção)

\begin{tabular}{|l|l|}
\hline$X$ & EXTENSÃO RURAL \\
\hline & PESQUISA \\
\hline & ENSINO \\
\hline & OUTROS \\
\hline
\end{tabular}

2) Qual o seu nível de escolaridade? (Considere apenas o nível mais alto) 


\begin{tabular}{|l|l|}
\hline$x$ & NÍVEL MÉDIO \\
\hline & NÍVEL SUPERIOR \\
\hline & PÓS-GRADUAÇÃO \\
\hline
\end{tabular}

3) Os conteúdos abordados foram condizentes com as demandas do seu dia-a-dia?

\begin{tabular}{|l|l|}
\hline$x$ & SIM \\
\hline & PARCIALMENTE \\
\hline & NÃO \\
\hline
\end{tabular}

4) O curso contribuiu para o seu aperfeiçoamento profissional?

\begin{tabular}{|l|l|}
\hline$x$ & SIM \\
\hline & NÃO \\
\hline
\end{tabular}

5) Os conhecimentos adquiridos estão sendo aplicados no seu trabalho? Em caso afirmativo, indique em que grau estes conhecimentos estão sendo aplicados. Em caso negativo, indique por que razão isto não ocorre: (Em caso negativo, as respostas não são excludentes: você poderá marcar mais de uma opção).

\begin{tabular}{|l|l|l|l|}
\hline$x$ & $\begin{array}{l}\text { SIM (indique ao lado } \\
\text { em que grau) }\end{array}$ & $x$ & MEDIAMENTE APLICADOS \\
\cline { 2 - 4 } & &
\end{tabular}




\begin{tabular}{|c|c|}
\hline & POUCO APLICADOS \\
\hline \multirow{5}{*}{$\begin{array}{l}\text { NÃO (indique ao lado a } \\
\text { razão da não aplicação) }\end{array}$} & $\begin{array}{l}\text { CONTEÚDO NÃO ADEQUADO ÀS NECESSIDADES } \\
\text { ESPECÍFICAS DA REGIÃO }\end{array}$ \\
\hline & $\begin{array}{l}\text { CONTEÚDO NĀO } \quad \text { FOI } \text { SUFICIENTEMENTE } \\
\text { APROFUNDADO PARA PERMITIR UMA APLICAÇÃO } \\
\text { EFICAZ E EFICIENTE }\end{array}$ \\
\hline & $\begin{array}{|llllll|}\text { FALTA DE } & \text { APOIO } & \text { E } & \text { INCENTIVO } & \text { DA } & \text { MINHA } \\
\text { INSTITUIÇÃO } & & & & & \\
\end{array}$ \\
\hline & FALTA DE INCENTIVO ÀS AÇÕES DE ATER \\
\hline & NÃO TENHO INTERESSE EM APLICAR \\
\hline
\end{tabular}

6) A partir deste curso: (As opções não são excludentes: você poderá marcar mais de uma opção)

\begin{tabular}{|l|l|}
\hline & NÃO MUDOU NADA EM MEU TRABALHO. \\
\hline$x$ & $\begin{array}{l}\text { MEU TRABALHO PASSOU A CONTRIBUIR MAIS COM OS AGRICULTORES (AS) } \\
\text { FAMILIARES. }\end{array}$ \\
\hline$x$ & CONSEGUI INFLUENCIAR NAS ORIENTAÇÕES DA MINHA INSTITUIÇÃO. \\
\hline & PASSEI A TRABALHAR COM METODOLOGIAS PARTICIPATIVAS. \\
\hline $\mathrm{O}$ & ONESCEU A ÁREA DE AGRICULTURA DE BASE ECOLÓGICA NAS COMUNIDADES \\
\hline $\mathrm{C}$ & CONTINUEI ME APERFEIÇOANDO SOBRE TEMAS ABORDADOS. \\
\hline
\end{tabular}

7) Depois do curso você apoiou atividades de capacitação de técnicos e agricultores com base nos princípios e diretrizes da Pnater? (Considere como apoio a atividades de capacitação a participação no planejamento, elaboração de ementas, seleção de participantes e de palestrantes.) 


\begin{tabular}{|l|l|}
\hline & SIM \\
\hline$x$ & NÃO \\
\hline
\end{tabular}

8) Usou os conhecimentos para ministrar outros cursos com o mesmo conteúdo ou conteúdos semelhantes?

\begin{tabular}{|l|l|}
\hline & SIM \\
\hline$x$ & NÃO \\
\hline
\end{tabular}

9) Marque o seu grau de satisfação com relação ao curso oferecido pelo DATER: (Considere a seguinte pontuação: 1 - MUITO RUIM; 2 - RUIM; 3 - REGULAR; 4 - BOM; 5 - MUITO BOM)

\begin{tabular}{|l|l|l|l|l|}
\hline 1 & 2 & 3 & $4 \times$ & 5 \\
\hline
\end{tabular}

10) Marque seu grau de satisfação com relação ao DATER: (Considere a seguinte pontuação: 1 - MUITO RUIM; 2 - RUIM; 3 - REGULAR; 4 - BOM; 5 - MUITO BOM)

\begin{tabular}{|l|l|l|l|l|}
\hline 1 & 2 & 3 & $4 \times$ & 5 \\
\hline
\end{tabular}




\section{PESQUISA - IMPACTO DAS AÇÕES DE FORMAÇÃO REALIZADAS PELO DATER/SAF/MDA NO PERÍODO 2004-2009}

Caros colaboradores,

Contamos com a sua atenção para preencher o formulário abaixo.

O mesmo tem por objetivo fornecer informações para avaliação da Eficiência, Efetividade e Eficácia da Política Pública de Formação de Agentes de Ater adotada pelo Departamento de Assistência Técnica e Extensão Rural, da Secretaria de Agricultura Familiar do Ministério do Desenvolvimento - DATER/SAF/MDA, no período de 2004 a 2009, tema escolhido para Monografia a ser apresentada à Universidade de Brasília (UnB) como requisito parcial para obtenção do grau de Bacharel em Administração.

Você poderá ou não se identificar no questionário e garantimos que todas as informações fornecidas serão confidenciais e utilizadas apenas de forma sistematizada.

IDENTIFICAÇÃO

\begin{tabular}{|l|l|}
\hline Nome: Lílian França Ramos & $\begin{array}{l}\text { Sexo: } \\
\text { ( ) masculino ( xxx ) feminino }\end{array}$ \\
\hline $\begin{array}{l}\text { Instituição Emater- Associação de Assistência } \\
\text { Técnica e Extensão Rural do Estado de Rondônia }\end{array}$ & Local de trabalho Corumbiara- Rondônia \\
\hline $\begin{array}{l}\text { Curso/Encontro/Oficina do qual participou } \\
\text { Curso de Manejo e Pastagem em Ênfase no Controle Biológico da Cigarrinha }\end{array}$ \\
\hline Data do Curso/Encontro/Oficina Outubro de 2006 \\
\hline
\end{tabular}

Indique sua área de atuação? (As opções não são excludentes: você poderá marcar mais de uma opção)

\begin{tabular}{|l|l|}
\hline$X$ & EXTENSÃO RURAL \\
\hline & PESQUISA \\
\hline & ENSINO \\
\hline & OUTROS \\
\hline
\end{tabular}

2) Qual o seu nível de escolaridade? (Considere apenas o nível mais alto) 


\begin{tabular}{|c|l|}
\hline & NÍVEL MÉDIO \\
\hline$X$ & NÍVEL SUPERIOR \\
\hline & PÓS-GRADUAÇÃO \\
\hline
\end{tabular}

3) Os conteúdos abordados foram condizentes com as demandas do seu dia-a-dia?

\begin{tabular}{|l|l|}
\hline$X$ & SIM \\
\hline & PARCIALMENTE \\
\hline & NÃO \\
\hline
\end{tabular}

3) O curso contribuiu para o seu aperfeiçoamento profissional?

\begin{tabular}{|l|l|}
\hline$X$ & SIM \\
\hline & NÃO \\
\hline
\end{tabular}

5) Os conhecimentos adquiridos estão sendo aplicados no seu trabalho? Em caso afirmativo, indique em que grau estes conhecimentos estão sendo aplicados. Em caso negativo, indique por que razão isto não ocorre: (Em caso negativo, as respostas não são excludentes: você poderá marcar mais de uma opção).

\begin{tabular}{|l|l|l|l|}
\hline \multirow{2}{*}{$\begin{array}{l}\text { SIM (indique ao lado } \\
\text { em que grau) }\end{array}$} & $X$ & MUITO APLICADOS \\
\cline { 2 - 3 } & & MEDIAMENTE APLICADOS \\
\cline { 2 - 3 } & & POUCO APLICADOS \\
\hline \multirow{2}{*}{$\begin{array}{l}\text { NÃo (indique ao lado a } \\
\text { razão da não aplicação) }\end{array}$} & $\begin{array}{l}\text { CONTEÚDO NÃO ADEQUADO ȦS NECESSIDADES } \\
\text { ESPECÍFICAS DA REGIÃO }\end{array}$ \\
\cline { 3 - 4 } & $\begin{array}{l}\text { CONTEÚDO NÃO FOI SUFICIENTEMENTE } \\
\text { APROFUNDADO PARA PERMITIR UMA APLICAÇÃO } \\
\text { EFICAZ E EFICIENTE }\end{array}$ \\
\hline
\end{tabular}




\begin{tabular}{|l|l|l|}
\hline \multirow{2}{*}{} & & $\begin{array}{l}\text { FALTA DE APOIO E INCENTIVO DA MINHA } \\
\text { INSTITUIÇÃO }\end{array}$ \\
\cline { 2 - 3 } & FALTA DE INCENTIVO ÀS AÇÕES DE ATER \\
\cline { 2 - 3 } & NÃO TENHO INTERESSE EM APLICAR \\
\hline
\end{tabular}

6) A partir deste curso: (As opções não são excludentes: você poderá marcar mais de uma opção)

\begin{tabular}{|c|l|}
\hline$X$ & $\begin{array}{l}\text { MẼO MUDOU NADA EM MEU TRABALHO. } \\
\text { FAMILIARES. }\end{array}$ \\
\hline & CONSEGUI INFLUENCIAR NAS ORIENTAÇÕES DA MINHA INSTITUIÇÃO. \\
\hline & PASSEI A TRABALHAR COM METODOLOGIAS PARTICIPATIVAS. \\
\hline & $\begin{array}{l}\text { CRESCEU A ÁREA DE AGRICULTURA DE BASE ECOLÓGICA NAS COMUNIDADES } \\
\text { ONDE ATUO. }\end{array}$ \\
\hline & CONTINUEI ME APERFEIÇOANDO SOBRE TEMAS ABORDADOS. COM OS AGRICULTORES(AS) \\
\hline
\end{tabular}

7) Depois do curso você apoiou atividades de capacitação de técnicos e agricultores com base nos princípios e diretrizes da Pnater? (Considere como apoio a atividades de capacitação a participação no planejamento, elaboração de ementas, seleção de participantes e de palestrantes.)

\begin{tabular}{|l|l|}
\hline & SIM \\
\hline$X$ & NÃO \\
\hline
\end{tabular}

8) Usou os conhecimentos para ministrar outros cursos com o mesmo conteúdo ou conteúdos semelhantes?

\begin{tabular}{|l|l}
\hline$X$ & SIM \\
\hline
\end{tabular} 


\section{NÃO}

9) Marque o seu grau de satisfação com relação ao curso oferecido pelo DATER: (Considere a seguinte pontuação: 1 - MUITO RUIM; 2 - RUIM; 3 - REGULAR; 4 - BOM; 5 - MUITO BOM)

\begin{tabular}{|l|l|l|l|ll|}
\hline 1 & 2 & 3 & 4 & $x \quad 5$ \\
\hline
\end{tabular}

10) Marque seu grau de satisfação com relação ao DATER: (Considere a seguinte pontuação: 1 - MUITO RUIM; 2 - RUIM; 3 - REGULAR; 4 - BOM; 5 - MUITO BOM)

\begin{tabular}{|l|l|l|l|l|}
\hline 1 & 2 & 3 & 4 & $\times 5$ \\
\hline
\end{tabular}

Obs.: As notas atribuídas às duas últimas questões devem obedecer a ordem crescente: 1 muito ruim, 2 - ruim, 3 - regular, 4 - bom , 5 - muito bom. 


\section{PESQUISA - IMPACTO DAS AÇÕES DE FORMAÇÃO REALIZADAS PELO DATER/SAF/MDA NO PERÍODO 2004-2009}

Caros colaboradores,

Contamos com a sua atenção para preencher o formulário abaixo.

O mesmo tem por objetivo fornecer informações para avaliação da Eficiência, Efetividade e Eficácia da Política Pública de Formação de Agentes de Ater adotada pelo Departamento de Assistência Técnica e Extensão Rural, da Secretaria de Agricultura Familiar do Ministério do Desenvolvimento - DATER/SAF/MDA, no período de 2004 a 2009, tema escolhido para Monografia a ser apresentada à Universidade de Brasília (UnB) como requisito parcial para obtenção do grau de Bacharel em Administração.

Você poderá ou não se identificar no questionário e garantimos que todas as informações fornecidas serão confidenciais e utilizadas apenas de forma sistematizada.

IDENTIFICAÇÃO

\begin{tabular}{|c|c|}
\hline Nome: Leandro Martins & $\begin{array}{l}\text { Sexo: } \\
(x \quad) \text { masculino } \quad(\quad) \text { feminino }\end{array}$ \\
\hline $\begin{array}{l}\text { Instituição (nome e tipo de instituição: ONG, } \\
\text { Empresa Pública, etc.): EMATER- RO }\end{array}$ & $\begin{array}{l}\text { Local de trabalho (Cidade e Estado): } \\
\text { Rio Crespo }\end{array}$ \\
\hline \multicolumn{2}{|c|}{$\begin{array}{l}\text { Curso/Encontro/Oficina do qual participou (caso tenha participado de mais de um curso, } \\
\text { preencha um formulário para cada um deles): Curso sobre Criação de Pequenos Animais }\end{array}$} \\
\hline Data do Curso/Encontro/Oficina (pelo menos mê & e ano): 24 a 28/04/2006 \\
\hline
\end{tabular}

Indique sua área de atuação? (As opções não são excludentes: você poderá marcar mais de uma opção

\begin{tabular}{|l|l|}
\hline$X$ & EXTENSÃO RURAL \\
\hline & PESQUISA \\
\hline & ENSINO \\
\hline & OUTROS \\
\hline
\end{tabular}


2) Qual o seu nível de escolaridade? (Considere apenas o nível mais alto)

\begin{tabular}{|l|l|}
\hline$X$ & NÍVEL MÉDIO \\
\hline & NÍVEL SUPERIOR \\
\hline & PÓS-GRADUAÇÃO \\
\hline
\end{tabular}

3) Os conteúdos abordados foram condizentes com as demandas do seu dia-a-dia?

\begin{tabular}{|l|l|}
\hline$X$ & SIM \\
\hline & PARCIALMENTE \\
\hline & NÃO \\
\hline
\end{tabular}

3) O curso contribuiu para o seu aperfeiçoamento profissional?

\begin{tabular}{|l|l|}
\hline$X$ & SIM \\
\hline & NÃO \\
\hline
\end{tabular}

5) Os conhecimentos adquiridos estão sendo aplicados no seu trabalho? Em caso afirmativo, indique em que grau estes conhecimentos estão sendo aplicados. Em caso negativo, indique por que razão isto não ocorre: (Em caso negativo, as respostas não são excludentes: você poderá marcar mais de uma opção).

\begin{tabular}{|l|l|l|l|}
\hline$X$ & $\begin{array}{l}\text { SIM (indique ao lado } \\
\text { em que grau) }\end{array}$ & $X$ & MUITO APLICADOS \\
\cline { 2 - 4 } & & MEDIAMENTE APLICADOS \\
\hline & $\begin{array}{l}\text { NĀO (indique ao lado a } \\
\text { razão da não aplicação) }\end{array}$ & $\begin{array}{l}\text { CONTEU்DO NĀO ADEQUADO ȦS NECESSIDADES } \\
\text { ESPECÍFICAS DA REGIÃO }\end{array}$ \\
\hline
\end{tabular}




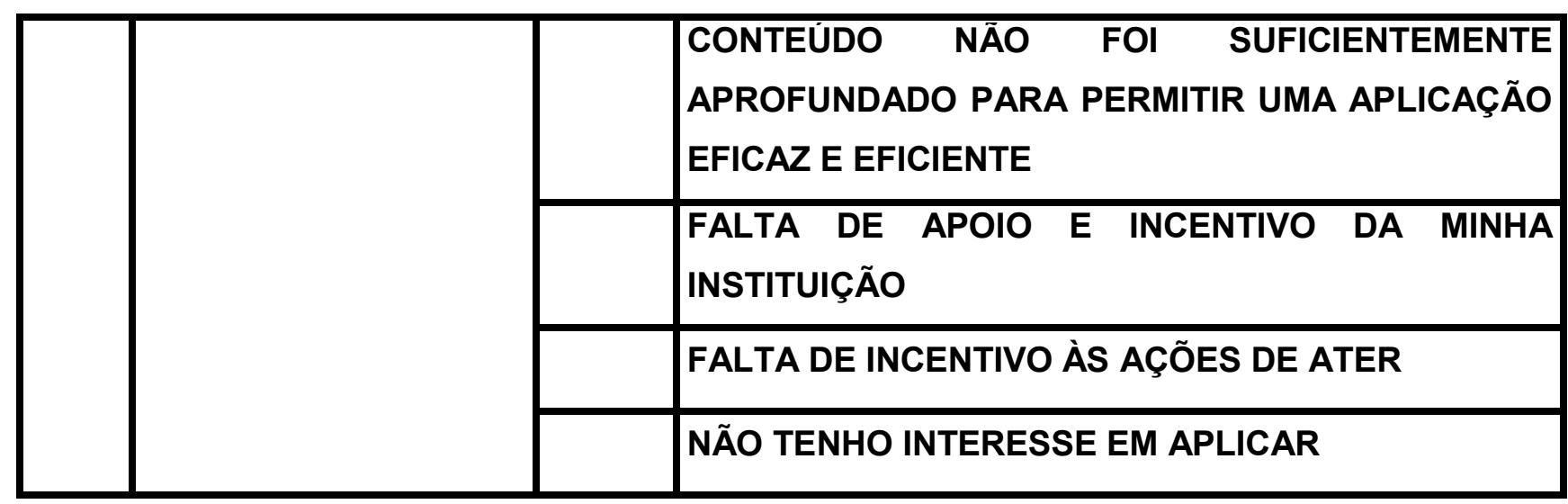

6) A partir deste curso: (As opções não são excludentes: você poderá marcar mais de uma opção)

\begin{tabular}{|l|l|}
\hline & NÃO MUDOU NADA EM MEU TRABALHO. \\
\hline$X$ & $\begin{array}{l}\text { MEU TRABALHO PASSOU A CONTRIBUIR MAIS COM OS AGRICULTORES(AS) } \\
\text { FAMILIARES. }\end{array}$ \\
\hline & CONSEGUI INFLUENCIAR NAS ORIENTAÇÕES DA MINHA INSTITUIÇÃO. \\
\hline & PASSEI A TRABALHAR COM METODOLOGIAS PARTICIPATIVAS. \\
\hline & $\begin{array}{l}\text { CRESCEU A ÁREA DE AGRICULTURA DE BASE ECOLÓGICA NAS COMUNIDADES } \\
\text { ONDE ATUO. }\end{array}$ \\
\hline & CONTINUEI ME APERFEIÇOANDO SOBRE TEMAS ABORDADOS. \\
\hline
\end{tabular}

7) Depois do curso você apoiou atividades de capacitação de técnicos e agricultores com base nos princípios e diretrizes da Pnater?

\begin{tabular}{|l|l|}
\hline & SIM \\
\hline$X$ & NÃO \\
\hline
\end{tabular}

8) Usou os conhecimentos para ministrar outros cursos com o mesmo conteúdo ou conteúdos semelhantes?

\begin{tabular}{|l|l|}
\hline & SIM \\
\hline$X$ & NÃO \\
\hline
\end{tabular}


9) Marque o seu grau de satisfação com relação ao curso oferecido pelo DATER: (Considere a seguinte pontuação: 1 - MUITO RUIM; 2 - RUIM; 3 - REGULAR; 4 - BOM; 5 - MUITO BOM)

\begin{tabular}{|l|l|l|l|l|}
\hline 1 & 2 & 3 & 4 & $5 \times$ \\
\hline
\end{tabular}

10) Marque seu grau de satisfação com relação ao DATER: (Considere a seguinte pontuação: 1 - MUITO RUIM; 2 - RUIM; 3 - REGULAR; 4 - BOM; 5 - MUITO BOM)

\begin{tabular}{|l|l|l|l|l|}
\hline 1 & 2 & 3 & 4 & $5 X$ \\
\hline
\end{tabular}




\section{PESQUISA - IMPACTO DAS AÇÕES DE FORMAÇÃO REALIZADAS PELO DATER/SAF/MDA NO PERÍODO 2004-2009}

Caros colaboradores,

Contamos com a sua atenção para preencher o formulário abaixo.

O mesmo tem por objetivo fornecer informações para avaliação da Eficiência, Efetividade e Eficácia da Política Pública de Formação de Agentes de Ater adotada pelo Departamento de Assistência Técnica e Extensão Rural, da Secretaria de Agricultura Familiar do Ministério do Desenvolvimento - DATER/SAF/MDA, no período de 2004 a 2009, tema escolhido para Monografia a ser apresentada à Universidade de Brasília (UnB) como requisito parcial para obtenção do grau de Bacharel em Administração.

Você poderá ou não se identificar no questionário e garantimos que todas as informações fornecidas serão confidenciais e utilizadas apenas de forma sistematizada.

IDENTIFICAÇÃO

\begin{tabular}{|c|c|}
\hline Nome: Leandro Martins & $\begin{array}{l}\text { Sexo: } \\
(x \quad) \text { masculino } \quad(\quad) \text { feminino }\end{array}$ \\
\hline $\begin{array}{l}\text { Instituição (nome e tipo de instituição: ONG, } \\
\text { Empresa Pública, etc.): EMATER- RO }\end{array}$ & $\begin{array}{l}\text { Local de trabalho (Cidade e Estado): } \\
\text { Rio Crespo }\end{array}$ \\
\hline \multicolumn{2}{|c|}{$\begin{array}{l}\text { Curso/Encontro/Oficina do qual participou (caso tenha participado de mais de um curso, } \\
\text { preencha um formulário para cada um deles): Curso de Manejo e Pastagem com Ênfase no } \\
\text { Controle Biológico da Cigarrinha }\end{array}$} \\
\hline Data do Cursol & ano): 19 a 23/06/2006 \\
\hline
\end{tabular}

Indique sua área de atuação? (As opções não são excludentes: você poderá marcar mais de uma opção)

\begin{tabular}{|l|l|}
\hline$X$ & EXTENSÃO RURAL \\
\hline & PESQUISA \\
\hline & ENSINO \\
\hline & OUTROS \\
\hline
\end{tabular}


2) Qual o seu nível de escolaridade? (Considere apenas o nível mais alto)

\begin{tabular}{|l|l|}
\hline$X$ & NÍVEL MÉDIO \\
\hline & NÍVEL SUPERIOR \\
\hline & PÓS-GRADUAÇÃO \\
\hline
\end{tabular}

3) Os conteúdos abordados foram condizentes com as demandas do seu dia-a-dia?

\begin{tabular}{|l|l|}
\hline$X$ & SIM \\
\hline & PARCIALMENTE \\
\hline & NÃO \\
\hline
\end{tabular}

3) O curso contribuiu para o seu aperfeiçoamento profissional?

\begin{tabular}{|l|l|}
\hline$X$ & SIM \\
\hline & NÃO \\
\hline
\end{tabular}

5) Os conhecimentos adquiridos estão sendo aplicados no seu trabalho? Em caso afirmativo, indique em que grau estes conhecimentos estão sendo aplicados. Em caso negativo, indique por que razão isto não ocorre: (Em caso negativo, as respostas não são excludentes: você poderá marcar mais de uma opção).

\begin{tabular}{|l|l|l|l|}
\hline$X$ & $\begin{array}{l}\text { SIM (indique ao lado } \\
\text { em que grau) }\end{array}$ & $X$ & MUITO APLICADOS \\
\cline { 2 - 4 } & & MEDIAMENTE APLICADOS \\
\hline & $\begin{array}{l}\text { NĀO (indique ao lado a } \\
\text { razão da não aplicação) }\end{array}$ & $\begin{array}{l}\text { CONTEU்DO NĀO ADEQUADO ȦS NECESSIDADES } \\
\text { ESPECÍFICAS DA REGIÃO }\end{array}$ \\
\hline
\end{tabular}




\begin{tabular}{|l|l|l|}
\hline \multirow{10}{*}{} & $\begin{array}{l}\text { CONTEÚDO NÃO FOI SUFICIENTEMENTE } \\
\text { APROFUNDADO PARA PERMITIR UMA APLICAÇÃo } \\
\text { EFICAZ E EFICIENTE }\end{array}$ \\
\cline { 2 - 3 } & $\begin{array}{l}\text { FALTA DE APOIO E INCENTIVO DA MINHA } \\
\text { INSTITUIÇÃO }\end{array}$ \\
\hline & FALTA DE INCENTIVO ÀS AÇÕES DE ATER \\
\hline & NÃO TENHO INTERESSE EM APLICAR \\
\hline
\end{tabular}

6) A partir deste curso: (As opções não são excludentes: você poderá marcar mais de uma opção)

\begin{tabular}{|l|l|}
\hline & NÃO MUDOU NADA EM MEU TRABALHO. \\
\hline$X$ & $\begin{array}{l}\text { MEU TRABALHO PASSOU A CONTRIBUIR MAIS COM OS AGRICULTORES(AS) } \\
\text { FAMILIARES. }\end{array}$ \\
\hline & CONSEGUI INFLUENCIAR NAS ORIENTAÇÕES DA MINHA INSTITUIÇÃO. \\
\hline & $\begin{array}{l}\text { CRASSEI A TRABALHAR COM METODOLOGIAS PARTICIPATIVAS. } \\
\text { ONDE ATUO. }\end{array}$ \\
\hline & CONTINUEI ME APERFEIÇOANDO SOBRE TEMAS ABORDADOS. \\
\hline
\end{tabular}

7) Depois do curso você apoiou atividades de capacitação de técnicos e agricultores com base nos princípios e diretrizes da Pnater? (Considere como apoio a atividades de capacitação a participação no planejamento, elaboração de ementas, seleção de participantes e de palestrantes.)

\begin{tabular}{|l|l|}
\hline & SIM \\
\hline$X$ & NÃO \\
\hline
\end{tabular}

8) Usou os conhecimentos para ministrar outros cursos com o mesmo conteúdo ou conteúdos semelhantes? 


\begin{tabular}{|l|l|}
\hline & SIM \\
\hline$X$ & NÃO \\
\hline
\end{tabular}

9) Marque o seu grau de satisfação com relação ao curso oferecido pelo DATER: (Considere a seguinte pontuação: 1 - MUITO RUIM; 2 - RUIM; 3 - REGULAR; 4 - BOM; 5 - MUITO BOM)

\begin{tabular}{|l|l|l|l|l|}
\hline 1 & 2 & 3 & 4 & $5 \times$ \\
\hline
\end{tabular}

10) Marque seu grau de satisfação com relação ao DATER: (Considere a seguinte pontuação: 1 - MUITO RUIM; 2 - RUIM; 3 - REGULAR; 4 - BOM; 5 - MUITO BOM)

\begin{tabular}{|l|l|l|l|l|}
\hline 1 & 2 & 3 & 4 & $5 \times$ \\
\hline
\end{tabular}




\section{PESQUISA - IMPACTO DAS AÇÕES DE FORMAÇÃO REALIZADAS PELO DATER/SAF/MDA NO PERÍODO 2004-2009}

Caros colaboradores,

Contamos com a sua atenção para preencher o formulário abaixo.

O mesmo tem por objetivo fornecer informações para avaliação da Eficiência, Efetividade e Eficácia da Política Pública de Formação de Agentes de Ater adotada pelo Departamento de Assistência Técnica e Extensão Rural, da Secretaria de Agricultura Familiar do Ministério do Desenvolvimento - DATER/SAF/MDA, no período de 2004 a 2009, tema escolhido para Monografia a ser apresentada à Universidade de Brasília (UnB) como requisito parcial para obtenção do grau de Bacharel em Administração.

Você poderá ou não se identificar no questionário e garantimos que todas as informações fornecidas serão confidenciais e utilizadas apenas de forma sistematizada.

IDENTIFICAÇÃO

\begin{tabular}{|c|c|}
\hline Nome: Leandro Martins & $\begin{array}{l}\text { Sexo: } \\
(x \quad) \text { masculino } \quad(\quad) \text { feminino }\end{array}$ \\
\hline $\begin{array}{l}\text { Instituição (nome e tipo de instituição: ONG, } \\
\text { Empresa Pública, etc.): EMATER- RO }\end{array}$ & $\begin{array}{l}\text { Local de trabalho (Cidade e Estado): } \\
\text { Rio Crespo }\end{array}$ \\
\hline \multicolumn{2}{|c|}{$\begin{array}{l}\text { Curso/Encontro/Oficina do qual participou (caso tenha participado de mais de um curso, } \\
\text { preencha um formulário para cada um deles): Curso de Manejo e Pastagem com Ênfase no } \\
\text { Controle Biológico da Cigarrinha }\end{array}$} \\
\hline Data do Cursol & ano): 19 a 23/06/2006 \\
\hline
\end{tabular}

Indique sua área de atuação? (As opções não são excludentes: você poderá marcar mais de uma opção)

\begin{tabular}{|l|l|}
\hline$X$ & EXTENSÃO RURAL \\
\hline & PESQUISA \\
\hline & ENSINO \\
\hline & OUTROS \\
\hline
\end{tabular}


2) Qual o seu nível de escolaridade? (Considere apenas o nível mais alto)

\begin{tabular}{|l|l|}
\hline$X$ & NÍVEL MÉDIO \\
\hline & NÍVEL SUPERIOR \\
\hline & PÓS-GRADUAÇÃO \\
\hline
\end{tabular}

3) Os conteúdos abordados foram condizentes com as demandas do seu dia-a-dia?

\begin{tabular}{|l|l|}
\hline$X$ & SIM \\
\hline & PARCIALMENTE \\
\hline & NÃO \\
\hline
\end{tabular}

3) O curso contribuiu para o seu aperfeiçoamento profissional?

\begin{tabular}{|l|l|}
\hline$X$ & SIM \\
\hline & NÃO \\
\hline
\end{tabular}

5) Os conhecimentos adquiridos estão sendo aplicados no seu trabalho? Em caso afirmativo, indique em que grau estes conhecimentos estão sendo aplicados. Em caso negativo, indique por que razão isto não ocorre: (Em caso negativo, as respostas não são excludentes: você poderá marcar mais de uma opção).

\begin{tabular}{|l|l|l|l|}
\hline$X$ & $\begin{array}{l}\text { SIM (indique ao lado } \\
\text { em que grau) }\end{array}$ & $X$ & MUITO APLICADOS \\
\cline { 2 - 4 } & & MEDIAMENTE APLICADOS \\
\hline & $\begin{array}{l}\text { NĀO (indique ao lado a } \\
\text { razão da não aplicação) }\end{array}$ & $\begin{array}{l}\text { CONTEU்DO NĀO ADEQUADO ȦS NECESSIDADES } \\
\text { ESPECÍFICAS DA REGIÃO }\end{array}$ \\
\hline
\end{tabular}




\begin{tabular}{|l|l|l|}
\hline \multirow{2}{*}{} & & $\begin{array}{l}\text { CONTEÚDO NĀO FOI SUFICIENTEMENTE } \\
\text { APROFUNDADO PARA PERMITIR UMA APLICAÇÃo } \\
\text { EFICAZ E EFICIENTE }\end{array}$ \\
\cline { 2 - 4 } & $\begin{array}{l}\text { FALTA DE APOIO E INCENTIVO DA MINHA } \\
\text { INSTITUIÇÃO }\end{array}$ \\
\hline & FALTA DE INCENTIVO ÀS AÇÕES DE ATER \\
\hline & NÃO TENHO INTERESSE EM APLICAR \\
\hline
\end{tabular}

6) A partir deste curso: (As opções não são excludentes: você poderá marcar mais de uma opção)

\begin{tabular}{|l|l|}
\hline & NÃO MUDOU NADA EM MEU TRABALHO. \\
\hline$X$ & $\begin{array}{l}\text { MEU TRABALHO PASSOU A CONTRIBUIR MAIS COM OS AGRICULTORES(AS) } \\
\text { FAMILIARES. }\end{array}$ \\
\hline & CONSEGUI INFLUENCIAR NAS ORIENTAÇÕES DA MINHA INSTITUIÇÃO. \\
\hline & $\begin{array}{l}\text { CRASSEI A TRABALHAR COM METODOLOGIAS PARTICIPATIVAS. } \\
\text { ONDE ATUO. }\end{array}$ \\
\hline & CONTINUEI ME APERFEIÇOANDO SOBRE TEMAS ABORDADOS. \\
\hline
\end{tabular}

7) Depois do curso você apoiou atividades de capacitação de técnicos e agricultores com base nos princípios e diretrizes da Pnater? (Considere como apoio a atividades de capacitação a participação no planejamento, elaboração de ementas, seleção de participantes e de palestrantes.)

\begin{tabular}{|l|l|}
\hline & SIM \\
\hline$X$ & NÃO \\
\hline
\end{tabular}

8) Usou os conhecimentos para ministrar outros cursos com o mesmo conteúdo ou conteúdos semelhantes? 


\begin{tabular}{|l|l|}
\hline & SIM \\
\hline$X$ & NÃO \\
\hline
\end{tabular}

9) Marque o seu grau de satisfação com relação ao curso oferecido pelo DATER: (Considere a seguinte pontuação: 1 - MUITO RUIM; 2 - RUIM; 3 - REGULAR; 4 - BOM; 5 - MUITO BOM)

\begin{tabular}{|l|l|l|l|l|}
\hline 1 & 2 & 3 & 4 & $5 \times$ \\
\hline
\end{tabular}

10) Marque seu grau de satisfação com relação ao DATER: (Considere a seguinte pontuação: 1 - MUITO RUIM; 2 - RUIM; 3 - REGULAR; 4 - BOM; 5 - MUITO BOM)

\begin{tabular}{|l|l|l|l|l|}
\hline 1 & 2 & 3 & 4 & $5 \times$ \\
\hline
\end{tabular}


PESQUISA - IMPACTO DAS AÇÕES DE FORMAÇÃO REALIZADAS PELO DATER/SAF/MDA NO PERÍODO 2004-2009

Caros colaboradores,

Contamos com a sua atenção para preencher o formulário abaixo.

O mesmo tem por objetivo fornecer informações para avaliação da Eficiência, Efetividade e Eficácia da Política Pública de Formação de Agentes de Ater adotada pelo Departamento de Assistência Técnica e Extensão Rural, da Secretaria de Agricultura Familiar do Ministério do Desenvolvimento - DATER/SAF/MDA, no período de 2004 a 2009, tema escolhido para Monografia a ser apresentada à Universidade de Brasília (UnB) como requisito parcial para obtenção do grau de Bacharel em Administração.

Você poderá ou não se identificar no questionário e garantimos que todas as informações fornecidas serão confidenciais e utilizadas apenas de forma sistematizada.

IDENTIFICAÇÃO

\begin{tabular}{|l|l|}
\hline Nome: Josué Linhares Carvalho & $\begin{array}{l}\text { Sexo: } \\
(x \quad) \text { masculino } \quad(\quad \text { ) feminino }\end{array}$ \\
\hline $\begin{array}{l}\text { Instituição (nome e tipo de instituição: ONG, } \\
\text { Empresa Pública, etc.): Centro de Apoio a } \\
\text { Projetos de Ação Comunitária - ONG }\end{array}$ & \begin{tabular}{l} 
Santarém - Pará \\
\hline Curso/Encontro/Oficina do qual participou (caso tenha participado de mais de um curso, \\
preencha um formulário para cada um deles): Curso de Aperfeiçoamento em Agroecologia
\end{tabular} \\
\hline Data do Curso/Encontro/Oficina (pelo menos mês e ano): Março a julho de 2006 \\
\hline
\end{tabular}

Indique sua área de atuação? (As opções não são excludentes: você poderá marcar mais de uma opção)

\begin{tabular}{|l|l|}
\hline$X$ & EXTENSÃO RURAL \\
\hline & PESQUISA \\
\hline$X$ & ENSINO \\
\hline & OUTROS \\
\hline
\end{tabular}


2) Qual o seu nível de escolaridade?

\begin{tabular}{|l|l|}
\hline & NÍVEL MÉDIO \\
\hline$X$ & NÍVEL SUPERIOR \\
\hline & PÓS-GRADUAÇÃO \\
\hline
\end{tabular}

3) Os conteúdos abordados foram condizentes com as demandas do seu dia-a-dia?

\begin{tabular}{|l|l|}
\hline$X$ & SIM \\
\hline & PARCIALMENTE \\
\hline & NÃO \\
\hline
\end{tabular}

3) O curso contribuiu para o seu aperfeiçoamento profissional?

\begin{tabular}{|l|l|}
\hline$X$ & SIM \\
\hline & NÃO \\
\hline
\end{tabular}

5) Os conhecimentos adquiridos estão sendo aplicados no seu trabalho? Em caso afirmativo, indique em que grau estes conhecimentos estão sendo aplicados. Em caso negativo, indique por que razão isto não ocorre: (Em caso negativo, as respostas não são excludentes: você poderá marcar mais de uma opção).

\begin{tabular}{|l|l|l|l|}
\hline \multirow{2}{*}{$\begin{array}{l}\text { SIM (indique ao lado } \\
\text { em que grau) }\end{array}$} & X & MUITO APLICADOS \\
\cline { 2 - 3 } & & MEDIAMENTE APLICADOS \\
\hline & $\begin{array}{l}\text { NĀO (indique ao lado a } \\
\text { razão da não aplicação) }\end{array}$ & & $\begin{array}{l}\text { CONTEÚDO NĀO ADEQUADO ÁS NECESSIDADES } \\
\text { ESPECÍFICAS DA REGIÃO }\end{array}$ \\
\hline
\end{tabular}




\begin{tabular}{|l|l|l|}
\hline \multirow{2}{*}{} & & $\begin{array}{l}\text { CONTEÚDO NĀO FOI SUFICIENTEMENTE } \\
\text { APROFUNDADO PARA PERMITIR UMA APLICAÇÃo } \\
\text { EFICAZ E EFICIENTE }\end{array}$ \\
\cline { 2 - 4 } & $\begin{array}{l}\text { FALTA DE APOIO E INCENTIVO DA MINHA } \\
\text { INSTITUIÇÃO }\end{array}$ \\
\hline & FALTA DE INCENTIVO ÀS AÇÕES DE ATER \\
\hline & NÃO TENHO INTERESSE EM APLICAR \\
\hline
\end{tabular}

6) A partir deste curso: (As opções não são excludentes: você poderá marcar mais de uma opção)

\begin{tabular}{|l|l|}
\hline & NÃO MUDOU NADA EM MEU TRABALHO. \\
\hline$X$ & $\begin{array}{l}\text { MEU TRABALHO PASSOU A CONTRIBUIR MAIS COM OS AGRICULTORES(AS) } \\
\text { FAMILIARES. }\end{array}$ \\
\hline$X$ & CONSEGUI INFLUENCIAR NAS ORIENTAÇÕES DA MINHA INSTITUIÇÃO. \\
\hline & PASSEI A TRABALHAR COM METODOLOGIAS PARTICIPATIVAS. \\
\hline$X$ & $\begin{array}{l}\text { CRESCEU A AREA DE AGRICULTURA DE BASE ECOLOGICA NAS COMUNIDADES } \\
\text { ONDE ATUO. }\end{array}$ \\
\hline$X$ & CONTINUEI ME APERFEIÇOANDO SOBRE TEMAS ABORDADOS. \\
\hline
\end{tabular}

7) Depois do curso você apoiou atividades de capacitação de técnicos e agricultores com base nos princípios e diretrizes da Pnater? (Considere como apoio a atividades de capacitação a participação no planejamento, elaboração de ementas, seleção de participantes e de palestrantes.)

\begin{tabular}{|l|l|}
\hline$X$ & SIM \\
\hline & NÃO \\
\hline
\end{tabular}

8) Usou os conhecimentos para ministrar outros cursos com o mesmo conteúdo ou conteúdos semelhantes? 


\begin{tabular}{|l|l|}
\hline$X$ & SIM \\
\hline & NÃO \\
\hline
\end{tabular}

9) Marque o seu grau de satisfação com relação ao curso oferecido pelo DATER: (Considere a seguinte pontuação: 1 - MUITO RUIM; 2 - RUIM; 3 - REGULAR; 4 - BOM; 5 - MUITO BOM)

\begin{tabular}{|l|l|l|l|l|}
\hline 1 & 2 & 3 & 4 & $5 \times$ \\
\hline
\end{tabular}

10) Marque seu grau de satisfação com relação ao DATER: (Considere a seguinte pontuação: 1 - MUITO RUIM; 2 - RUIM; 3 - REGULAR; 4 - BOM; 5 - MUITO BOM)

\begin{tabular}{|l|l|l|l|l|}
\hline 1 & 2 & 3 & 4 & $5 \times$ \\
\hline
\end{tabular}


PESQUISA - IMPACTO DAS AÇÕES DE FORMAÇÃO REALIZADAS PELO DATER/SAF/MDA NO PERÍODO 2004-2009

Caros colaboradores,

Contamos com a sua atenção para preencher o formulário abaixo.

O mesmo tem por objetivo fornecer informações para avaliação da Eficiência, Efetividade e Eficácia da Política Pública de Formação de Agentes de Ater adotada pelo Departamento de Assistência Técnica e Extensão Rural, da Secretaria de Agricultura Familiar do Ministério do Desenvolvimento - DATER/SAF/MDA, no período de 2004 a 2009, tema escolhido para Monografia a ser apresentada à Universidade de Brasília (UnB) como requisito parcial para obtenção do grau de Bacharel em Administração.

Você poderá ou não se identificar no questionário e garantimos que todas as informações fornecidas serão confidenciais e utilizadas apenas de forma sistematizada.

IDENTIFICAÇÃO

\begin{tabular}{|c|c|}
\hline Nome: Josué Nery Santos & $\begin{array}{l}\text { Sexo: } \\
(x \quad) \text { masculino } \quad(\quad) \text { feminino }\end{array}$ \\
\hline $\begin{array}{l}\text { Instituição (nome e tipo de instituição: ONG, } \\
\text { Empresa Pública, etc.): } \\
\text { EMATER- RO }\end{array}$ & $\begin{array}{l}\text { Local de trabalho (Cidade e Estado): } \\
\text { Estrela de Rondônia Município de } \\
\text { Presidente Médici-RO }\end{array}$ \\
\hline \multicolumn{2}{|c|}{$\begin{array}{l}\text { Curso/Encontro/Oficina do qual participou (caso tenha participado de mais de um curso, } \\
\text { preencha um formulário para cada um deles): } \\
\text { Cursos: sobre Credito Rural }\end{array}$} \\
\hline Data do Curso/Encontro/Oficina (pelo menos mê & e ano): \\
\hline
\end{tabular}

Indique sua área de atuação? (As opções não são excludentes: você poderá marcar mais de uma opção)

\begin{tabular}{|l|l|}
\hline$X$ & EXTENSÃO RURAL \\
\hline & PESQUISA \\
\hline & ENSINO \\
\hline
\end{tabular}




\section{OUTROS}

2) Qual o seu nível de escolaridade? (Considere apenas o nível mais alto)

\begin{tabular}{|l|l|}
\hline$X$ & NÍVEL MÉDIO \\
\hline & NÍVEL SUPERIOR \\
\hline & PÓS-GRADUAÇÃO \\
\hline
\end{tabular}

3) Os conteúdos abordados foram condizentes com as demandas do seu dia-a-dia?

\begin{tabular}{|l|l|}
\hline$X$ & SIM \\
\hline & PARCIALMENTE \\
\hline & NÃO \\
\hline
\end{tabular}

3) O curso contribuiu para o seu aperfeiçoamento profissional?

\begin{tabular}{|l|l|}
\hline$X$ & SIM \\
\hline & NÃO \\
\hline
\end{tabular}

5) Os conhecimentos adquiridos estão sendo aplicados no seu trabalho? Em caso afirmativo, indique em que grau estes conhecimentos estão sendo aplicados. Em caso negativo, indique por que razão isto não ocorre: (Em caso negativo, as respostas não são excludentes: você poderá marcar mais de uma opção).

\begin{tabular}{|c|c|c|c|}
\hline \multirow{3}{*}{$x$} & \multirow{3}{*}{$\begin{array}{l}\text { SIM (indique ao lado } \\
\text { em que grau) }\end{array}$} & $\bar{X}$ & MUITO APLICADOS \\
\hline & & & MEDIAMENTE APLICADOS \\
\hline & & & POUCO APLICADOS \\
\hline & $\begin{array}{l}\text { NĀO (indique ao lado a } \\
\text { razão da não aplicação) }\end{array}$ & & $\begin{array}{l}\text { CONTEÚDO NĀO ADEQUADO ÀS NECESSIDADES } \\
\text { ESPECÍFICAS DA REGIÃO }\end{array}$ \\
\hline
\end{tabular}




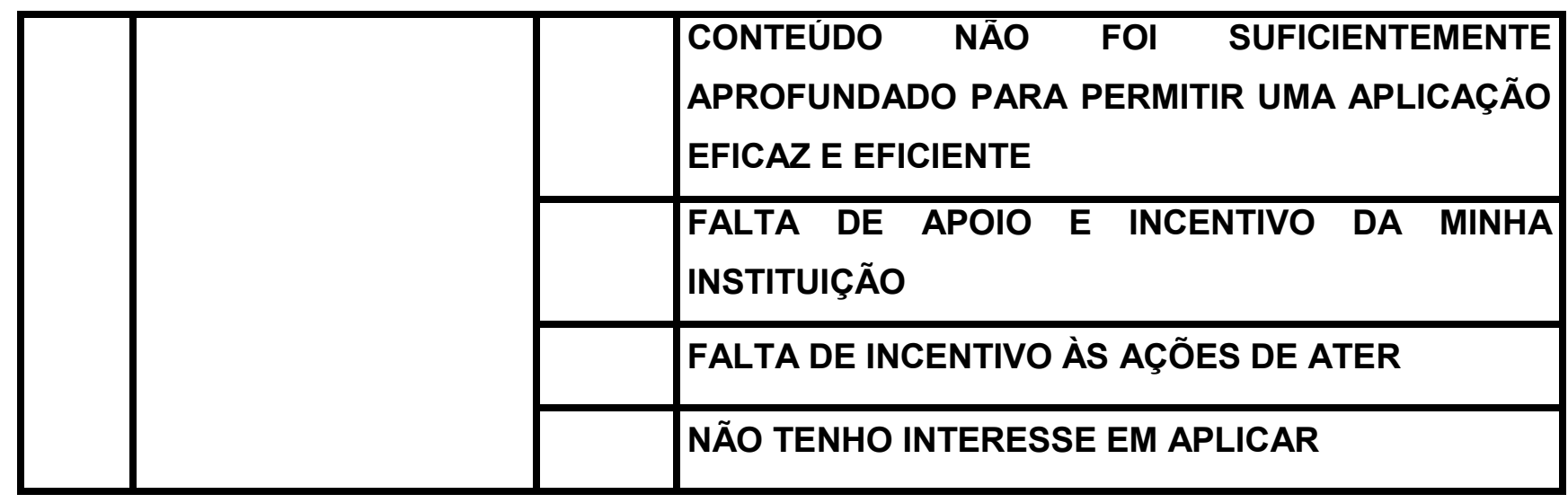

6) A partir deste curso: (As opções não são excludentes: você poderá marcar mais de uma opção)

\begin{tabular}{|l|l|}
\hline & NÃO MUDOU NADA EM MEU TRABALHO. \\
\hline$X$ & $\begin{array}{l}\text { MEU TRABALHO PASSOU A CONTRIBUIR MAIS COM OS AGRICULTORES(AS) } \\
\text { FAMILIARES. }\end{array}$ \\
\hline$X$ & CONSEGUI INFLUENCIAR NAS ORIENTAÇÕES DA MINHA INSTITUIÇÃO. \\
\hline & PASSEI A TRABALHAR COM METODOLOGIAS PARTICIPATIVAS. \\
\hline & $\begin{array}{l}\text { CRESCEU A ÁREA DE AGRICULTURA DE BASE ECOLOGICA NAS COMUNIDADES } \\
\text { ONDE ATUO. }\end{array}$ \\
\hline$X$ & CONTINUEI ME APERFEIÇOANDO SOBRE TEMAS ABORDADOS. \\
\hline
\end{tabular}

7) Depois do curso você apoiou atividades de capacitação de técnicos e agricultores com base nos princípios e diretrizes da Pnater? (Considere como apoio a atividades de capacitação a participação no planejamento, elaboração de ementas, seleção de participantes e de palestrantes.)

\begin{tabular}{|l|l|}
\hline & SIM \\
\hline$X$ & NÃO \\
\hline
\end{tabular}

8) Usou os conhecimentos para ministrar outros cursos com o mesmo conteúdo ou conteúdos semelhantes? 


\begin{tabular}{|l|l|}
\hline & SIM \\
\hline$X$ & NÃO \\
\hline
\end{tabular}

9) Marque o seu grau de satisfação com relação ao curso oferecido pelo DATER: (Considere a seguinte pontuação: 1 - MUITO RUIM; 2 - RUIM; 3 - REGULAR; 4 - BOM; 5 - MUITO BOM)

\begin{tabular}{|l|l|l|l|l|}
\hline 1 & 2 & 3 & 4 & $x 5$ \\
\hline
\end{tabular}

10) Marque seu grau de satisfação com relação ao DATER: (Considere a seguinte pontuação: 1 - MUITO RUIM; 2 - RUIM; 3 - REGULAR; 4 - BOM; 5 - MUITO BOM)

\begin{tabular}{|l|l|l|l|l|}
\hline 1 & 2 & 3 & 4 & $\times 5$ \\
\hline
\end{tabular}




\section{PESQUISA - IMPACTO DAS AÇÕES DE FORMAÇÃO REALIZADAS PELO DATER/SAF/MDA NO PERÍODO 2004-2009}

Caros colaboradores,

Contamos com a sua atenção para preencher o formulário abaixo.

O mesmo tem por objetivo fornecer informações para avaliação da Eficiência, Efetividade e Eficácia da Política Pública de Formação de Agentes de Ater adotada pelo Departamento de Assistência Técnica e Extensão Rural, da Secretaria de Agricultura Familiar do Ministério do Desenvolvimento - DATER/SAF/MDA, no período de 2004 a 2009, tema escolhido para Monografia a ser apresentada à Universidade de Brasília (UnB) como requisito parcial para obtenção do grau de Bacharel em Administração.

Você poderá ou não se identificar no questionário e garantimos que todas as informações fornecidas serão confidenciais e utilizadas apenas de forma sistematizada.

IDENTIFICAÇÃO

\begin{tabular}{|c|c|}
\hline Nome: Josué Nery Santos & $\begin{array}{l}\text { Sexo: } \\
\left(\begin{array}{ll}x & )\end{array}\right) \text { masculino }\end{array}$ \\
\hline $\begin{array}{l}\text { Instituição (nome e tipo de instituição: ONG, } \\
\text { Empresa Pública, etc.): } \\
\text { EMATER- RO }\end{array}$ & $\begin{array}{l}\text { Local de trabalho (Cidade e Estado): } \\
\text { Estrela de Rondônia Município de } \\
\text { Presidente Médici-RO }\end{array}$ \\
\hline \multicolumn{2}{|c|}{$\begin{array}{l}\text { Curso/Encontro/Oficina do qual participou (caso tenha participado de mais de um curso, } \\
\text { preencha um formulário para cada um deles): } \\
\text { Melhoria da qualidade do leite }\end{array}$} \\
\hline a (pelo menos $\mathrm{m}$ & ano): \\
\hline
\end{tabular}

Indique sua área de atuação? (As opções não são excludentes: você poderá marcar mais de uma opção)

\begin{tabular}{|l|l|}
\hline$X$ & EXTENSÃO RURAL \\
\hline & PESQUISA \\
\hline
\end{tabular}




\begin{tabular}{|l|l|}
\hline & ENSINO \\
\hline & OUTROS \\
\hline
\end{tabular}

2) Qual o seu nível de escolaridade? (Considere apenas o nível mais alto)

\begin{tabular}{|l|l|}
\hline$X$ & NÍVEL MÉDIO \\
\hline & NÍVEL SUPERIOR \\
\hline & PÓS-GRADUAÇÃO \\
\hline
\end{tabular}

3) Os conteúdos abordados foram condizentes com as demandas do seu dia-a-dia?

\begin{tabular}{|l|l|}
\hline$X$ & SIM \\
\hline & PARCIALMENTE \\
\hline & NÃO \\
\hline
\end{tabular}

3) O curso contribuiu para o seu aperfeiçoamento profissional?

\begin{tabular}{|l|l|}
\hline$X$ & SIM \\
\hline & NÃO \\
\hline
\end{tabular}

5) Os conhecimentos adquiridos estão sendo aplicados no seu trabalho? Em caso afirmativo, indique em que grau estes conhecimentos estão sendo aplicados. Em caso negativo, indique por que razão isto não ocorre: (Em caso negativo, as respostas não são excludentes: você poderá marcar mais de uma opção).

\begin{tabular}{|l|l|l|l|}
\hline$X$ & $\begin{array}{l}\text { SIM (indique ao lado } \\
\text { em que grau) }\end{array}$ & & MUITO APLICADOS \\
\cline { 2 - 4 } & & MEDIAMENTE APLICADOS \\
\hline
\end{tabular}




\begin{tabular}{|c|c|}
\hline \multirow{5}{*}{$\begin{array}{l}\text { NÃO (indique ao lado a } \\
\text { razão da não aplicação) }\end{array}$} & $\begin{array}{l}\text { CONTEÚDO NĀO ADEQUADO ȦS NECESSIDADES } \\
\text { ESPECÍFICAS DA REGIÃO }\end{array}$ \\
\hline & $\begin{array}{l}\text { CONTEÚDO NÃO FOI SUFICIENTEMENTE } \\
\text { APROFUNDADO PARA PERMITIR UMA APLICAÇÃO } \\
\text { EFICAZ E EFICIENTE }\end{array}$ \\
\hline & $\begin{array}{l}\text { FALTA DE APOIO E } \\
\text { INSTITUIÇÃO }\end{array}$ \\
\hline & FALTA DE INCENTIVO ÀS AÇÕES DE ATER \\
\hline & NÃO TENHO INTERESSE EM APLICAR \\
\hline
\end{tabular}

6) A partir deste curso: (As opções não são excludentes: você poderá marcar mais de uma opção)

\begin{tabular}{|l|l|}
\hline & NÃO MUDOU NADA EM MEU TRABALHO. \\
\hline$X$ & $\begin{array}{l}\text { MEU TRABALHO PASSOU A CONTRIBUIR MAIS COM OS AGRICULTORES(AS) } \\
\text { FAMILIARES. }\end{array}$ \\
\hline$X$ & CONSEGUI INFLUENCIAR NAS ORIENTAÇÕES DA MINHA INSTITUIÇÃO. \\
\hline & PASSEI A TRABALHAR COM METODOLOGIAS PARTICIPATIVAS. \\
\hline & $\begin{array}{l}\text { CRESCEU A ÁREA DE AGRICULTURA DE BASE ECOLÓGICA NAS COMUNIDADES } \\
\text { ONDE ATUO. }\end{array}$ \\
\hline$X$ & CONTINUEI ME APERFEIÇOANDO SOBRE TEMAS ABORDADOS. \\
\hline
\end{tabular}

7) Depois do curso você apoiou atividades de capacitação de técnicos e agricultores com base nos princípios e diretrizes da Pnater? (Considere como apoio a atividades de capacitação a participação no planejamento, elaboração de ementas, seleção de participantes e de palestrantes.)

\begin{tabular}{|l|l|}
\hline$X$ & SIM \\
\hline & NÃO \\
\hline
\end{tabular}


8) Usou os conhecimentos para ministrar outros cursos com o mesmo conteúdo ou conteúdos semelhantes?

\begin{tabular}{|l|l|}
\hline & SIM \\
\hline$X$ & NÃO \\
\hline
\end{tabular}

9) Marque o seu grau de satisfação com relação ao curso oferecido pelo DATER: (Considere a seguinte pontuação: 1 - MUITO RUIM; 2 - RUIM; 3 - REGULAR; 4 - BOM; 5 - MUITO BOM)

\begin{tabular}{|l|l|l|l|l|}
\hline 1 & 2 & 3 & 4 & $\times 5$ \\
\hline
\end{tabular}

10) Marque seu grau de satisfação com relação ao DATER: (Considere a seguinte pontuação: 1 - MUITO RUIM; 2 - RUIM; 3 - REGULAR; 4 - BOM; 5 - MUITO BOM)

\begin{tabular}{|l|l|l|l|l|}
\hline 1 & 2 & 3 & 4 & X5 \\
\hline
\end{tabular}




\section{PESQUISA - IMPACTO DAS AÇÕES DE FORMAÇÃO REALIZADAS PELO DATER/SAF/MDA NO PERÍODO 2004-2009}

Caros colaboradores,

Contamos com a sua atenção para preencher o formulário abaixo.

O mesmo tem por objetivo fornecer informações para avaliação da Eficiência, Efetividade e Eficácia da Política Pública de Formação de Agentes de Ater adotada pelo Departamento de Assistência Técnica e Extensão Rural, da Secretaria de Agricultura Familiar do Ministério do Desenvolvimento - DATER/SAF/MDA, no período de 2004 a 2009, tema escolhido para Monografia a ser apresentada à Universidade de Brasília (UnB) como requisito parcial para obtenção do grau de Bacharel em Administração.

Você poderá ou não se identificar no questionário e garantimos que todas as informações fornecidas serão confidenciais e utilizadas apenas de forma sistematizada.

\section{Nome: Josiete Cunha de Souza}

Instituição: SEMED ( Secretaria Municipal de Educação)

Sexo: Feminino

Local de Trabalho: Cametá -Pa

Curso: Agente de desenvolvimento Rural - ADR

Data do curso: Dezembro 2007

Local: Abaetetuba -Pa

1.Indique a sua área de atuação (As opções não são excludentes: você poderá marcar mais de uma opção)

\begin{tabular}{|l|l|}
\hline & Extensão Rural \\
\hline$X$ & Pesquisa \\
\hline & Ensino \\
\hline & Outros \\
\hline
\end{tabular}

2.Qual o seu nível de Escolaridade (Considere apenas o nível mais alto)

\begin{tabular}{|l|l|}
\hline & Nível médio \\
\hline$X$ & Nível superior \\
\hline & Pós-graduação \\
\hline
\end{tabular}


3. Os conteúdos abordados foram condizentes com as demandas do seu dia-a-dia?

\begin{tabular}{|l|l|}
\hline$X$ & Sim \\
\hline & Parcialmente \\
\hline & Não \\
\hline
\end{tabular}

4.O curso contribuiu para o seu aperfeiçoamento profissional?

\begin{tabular}{|l|l|}
\hline$X$ & Sim \\
\hline & Não \\
\hline
\end{tabular}

5. Os conhecimentos adquiridos estão sendo aplicados no seu trabalho? Em caso afirmativo, indique em que grau estes conhecimentos estão sendo aplicados. Em caso negativo, indique por que razão isto não ocorre: (Em caso negativo, as respostas não são excludentes: você poderá marcar mais de uma opção).

ocorre.

\begin{tabular}{|c|c|c|c|}
\hline & Sim (indique ao lado & & Muito aplicados \\
\hline & em que grau) & & Mediamente aplicados \\
\hline & & & Pouco aplicados \\
\hline & $\begin{array}{l}\text { Não (indique ao lado } \\
\text { a razão da não } \\
\text { aplicação) }\end{array}$ & & $\begin{array}{l}\text { Conteúdos não adequado as } \\
\text { necessidades específicas da } \\
\text { região }\end{array}$ \\
\hline & & & $\begin{array}{l}\text { Conteúdo não foi suficientemente } \\
\text { aprofundado para permitir uma } \\
\text { aplicação eficaz e eficiente }\end{array}$ \\
\hline$\lambda$ & & $\mathrm{X}$ & $\begin{array}{l}\text { Falta de apoio e incentivo da } \\
\text { minha instituição }\end{array}$ \\
\hline & & & $\begin{array}{l}\text { Falta de incentivo as ações de } \\
\text { ATER }\end{array}$ \\
\hline & & & Não tenho interesse em aplicar \\
\hline
\end{tabular}

6. A partir deste curso: (As opções não são excludentes: você poderá marcar mais de uma opção)

\begin{tabular}{|l|l|}
\hline & Não mudou em nada meu trabalho \\
\hline & Meu trabalho passou a contribuir mais com os agricultores(as) familiares \\
\hline & Consegui influenciar nas orientações da minha instituição \\
\hline$X$ & Passei a trabalhar com metodologias participativas \\
\hline
\end{tabular}




\begin{tabular}{|l|l|}
\hline $\mathrm{X}$ & Cresceu a área de agricultura de base ecológica nas comunidades onde atuo \\
\hline $\mathrm{X}$ & Continuei me aperfeiçoando sobre temas abordados. \\
\hline
\end{tabular}

7. Depois do curso você apoiou atividades de capacitação de técnicos e agricultores com base nos princípios e diretrizes do Pnater? (Considere como apoio a atividades de capacitação a participação no planejamento, elaboração de ementas, seleção de participantes e de palestrantes.)

\begin{tabular}{|l|l|}
\hline$X$ & Sim \\
\hline & Não \\
\hline
\end{tabular}

8. Usou o conhecimento para ministrar outros cursos com o mesmo conteúdo ou conteúdos semelhantes?

\begin{tabular}{|l|l|}
\hline$X$ & Sim \\
\hline & Não \\
\hline
\end{tabular}

9. Marque o seu grau de satisfação com relação aos cursos oferecidos pelo DATER (Considere a seguinte pontuação: 1 - MUITO RUIM; 2 - RUIM; 3 - REGULAR; 4 - BOM; 5 - MUITO BOM)

\begin{tabular}{|l|l|l|l|l|}
\hline 1 & 2 & 3 & $X$ & 5 \\
\hline
\end{tabular}

10. Marque o seu grau de satisfação com relação ao DATER( Considere a seguinte pontuação: 1 - MUITO RUIM; 2 - RUIM; 3 - REGULAR; 4 - BOM; 5 - MUITO BOM)

\begin{tabular}{|l|l|l|l|l|}
\hline 1 & 2 & 3 & $X$ & 5 \\
\hline
\end{tabular}

ENVIAR PARA O E-MAIL: daterformacao@gmail.com

Assunto: avaliação do curso de ADR 


\section{PESQUISA - IMPACTO DAS AÇÕES DE FORMAÇÃO REALIZADAS PELO DATER/SAF/MDA NO PERÍODO 2004-2009}

Caros colaboradores,

Contamos com a sua atenção para preencher o formulário abaixo.

O mesmo tem por objetivo fornecer informações para avaliação da Eficiência, Efetividade e Eficácia da Política Pública de Formação de Agentes de Ater adotada pelo Departamento de Assistência Técnica e Extensão Rural, da Secretaria de Agricultura Familiar do Ministério do Desenvolvimento - DATER/SAF/MDA, no período de 2004 a 2009, tema escolhido para Monografia a ser apresentada à Universidade de Brasília (UnB) como requisito parcial para obtenção do grau de Bacharel em Administração.

Você poderá ou não se identificar no questionário e garantimos que todas as informações fornecidas serão confidenciais e utilizadas apenas de forma sistematizada.

IDENTIFICAÇÃO

\begin{tabular}{|c|c|}
\hline Nome: JOSÉ DO EGITO ALVES & $\begin{array}{l}\text { Sexo: } \\
(x \quad) \text { masculino } \quad(\quad) \text { feminino }\end{array}$ \\
\hline $\begin{array}{l}\text { Instituição (nome e tipo de instituição: ONG, } \\
\text { Empresa Pública, etc.): } \\
\text { EMATER-PARÁ }\end{array}$ & $\begin{array}{l}\text { Local de trabalho (Cidade e Estado): } \\
\text { ESCRITÓRIO LOCAL DE ANANINDEUA - } \\
\text { PARÁ }\end{array}$ \\
\hline \multicolumn{2}{|c|}{$\begin{array}{l}\text { Curso/Encontro/Oficina do qual participou (caso tenha participado de mais de um curso, } \\
\text { preencha um formulário para cada um deles): } \\
\text { ELABORAÇÃO E GESTÃO DE PROJETOS PARTICIPATIVOS }\end{array}$} \\
\hline \multicolumn{2}{|c|}{$\begin{array}{l}\text { Data do Curso/Encontro/Oficina (pelo menos mês e ano): } \\
27 / 11 \text { A } 01 / 12 / 2006\end{array}$} \\
\hline
\end{tabular}

Indique sua área de atuação? (As opções não são excludentes: você poderá marcar mais de uma opção)

\begin{tabular}{|l|l|}
\hline$X$ & EXTENSÃO RURAL \\
\hline & PESQUISA \\
\hline & ENSINO \\
\hline & OUTROS \\
\hline
\end{tabular}


2) Qual o seu nível de escolaridade? (Considere apenas o nível mais alto)

\begin{tabular}{|l|l|}
\hline & NÍVEL MÉDIO \\
\hline & NÍVEL SUPERIOR \\
\hline$X$ & PÓS-GRADUAÇÃO \\
\hline
\end{tabular}

3) Os conteúdos abordados foram condizentes com as demandas do seu dia-a-dia?

\begin{tabular}{|l|l|}
\hline$X$ & SIM \\
\hline & PARCIALMENTE \\
\hline & NÃO \\
\hline
\end{tabular}

3) O curso contribuiu para o seu aperfeiçoamento profissional?

\begin{tabular}{|l|l|}
\hline$X$ & SIM \\
\hline & NÃO \\
\hline
\end{tabular}

5) Os conhecimentos adquiridos estão sendo aplicados no seu trabalho? Em caso afirmativo, indique em que grau estes conhecimentos estão sendo aplicados. Em caso negativo, indique por que razão isto não ocorre: (Em caso negativo, as respostas não são excludentes: você poderá marcar mais de uma opção).

\begin{tabular}{|l|l|l|l|}
\hline \multirow{2}{*}{ X } & $\begin{array}{l}\text { SIM (indique ao lado } \\
\text { em que grau) }\end{array}$ & & MUITO APLICADOS \\
\cline { 3 - 4 } & & $X$ & MEDIAMENTE APLICADOS \\
\hline & $\begin{array}{l}\text { NĀO (indique ao lado a } \\
\text { razão da não aplicação) }\end{array}$ & & $\begin{array}{l}\text { CONTEÚDO NĀO ADEQUADO ȦS NECESSIDADES } \\
\text { ESPECÍFICAS DA REGIÃO }\end{array}$ \\
\hline
\end{tabular}




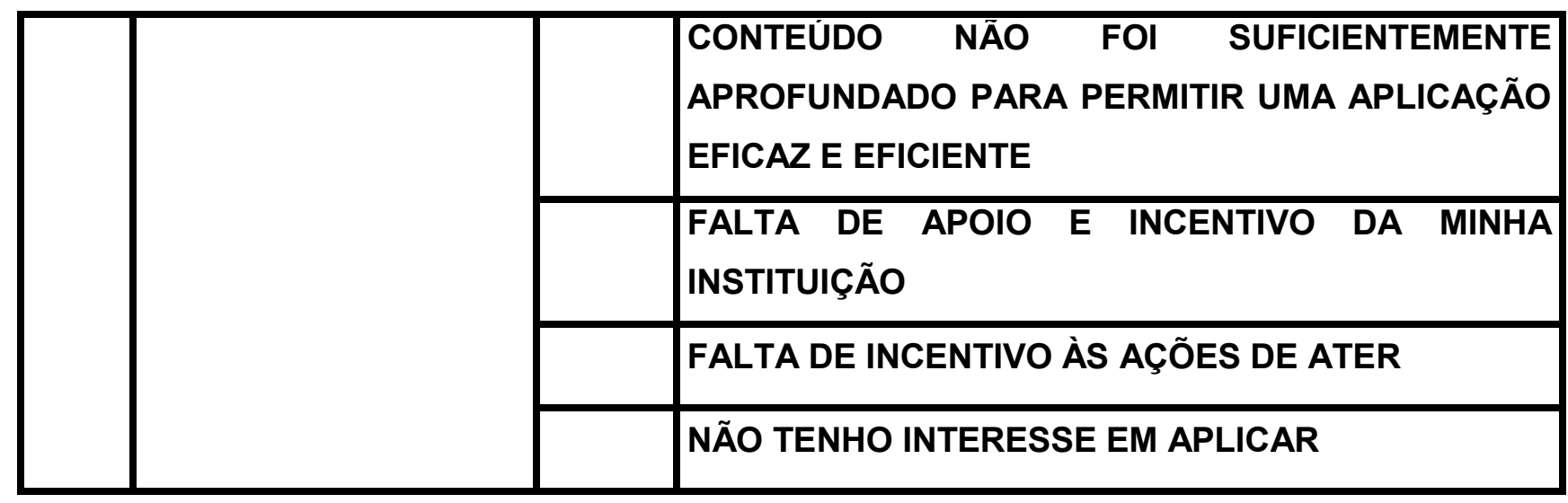

6) A partir deste curso: (As opções não são excludentes: você poderá marcar mais de uma opção)

\begin{tabular}{|l|l|}
\hline$x$ & $\begin{array}{l}\text { NÃO MUDOU NADA EM MEU TRABALHO. } \\
\text { FAMILIARES. }\end{array}$ \\
\hline & CONSEGUI INFLUENCIAR NAS ORIENTAÇÕES DA MINHA INSTITUIÇÃO. \\
\hline & PASSEI A TRABALHAR COM METODOLOGIAS PARTICIPATIVAS. \\
\hline & $\begin{array}{l}\text { CRESCEU A ÁREA DE AGRICULTURA DE BASE ECOLÓGICA NAS COMUNIDADES } \\
\text { ONDE ATUO. }\end{array}$ \\
\hline & CONTINUEI ME APERFEIÇOANDO SOBRE TEMAS ABORDADOS. \\
\hline
\end{tabular}

7) Depois do curso você apoiou atividades de capacitação de técnicos e agricultores com base nos princípios e diretrizes da Pnater? (Considere como apoio a atividades de capacitação a participação no planejamento, elaboração de ementas, seleção de participantes e de palestrantes.)

\begin{tabular}{|l|l|}
\hline$X$ & SIM \\
\hline & NÃO \\
\hline
\end{tabular}

8) Usou os conhecimentos para ministrar outros cursos com o mesmo conteúdo ou conteúdos semelhantes? 


\begin{tabular}{|l|l|}
\hline & SIM \\
\hline$X$ & NÃO \\
\hline
\end{tabular}

9) Marque o seu grau de satisfação com relação ao curso oferecido pelo DATER: (Considere a seguinte pontuação: 1 - MUITO RUIM; 2 - RUIM; 3 - REGULAR; 4 - BOM; 5 - MUITO BOM)

\begin{tabular}{|l|l|l|l|l|}
\hline 1 & 2 & 3 & $(4)$ & 5 \\
\hline
\end{tabular}

10) Marque seu grau de satisfação com relação ao DATER: (Considere a seguinte pontuação: 1 - MUITO RUIM; 2 - RUIM; 3 - REGULAR; 4 - BOM; 5 - MUITO BOM)

\begin{tabular}{|l|l|l|l|l|}
\hline 1 & 2 & 3 & $(4)$ & 5 \\
\hline
\end{tabular}




\section{PESQUISA - IMPACTO DAS AÇÕES DE FORMAÇÃO REALIZADAS PELO DATER/SAF/MDA NO PERÍODO 2004-2009}

Caros colaboradores,

Contamos com a sua atenção para preencher o formulário abaixo.

O mesmo tem por objetivo fornecer informações para avaliação da Eficiência, Efetividade e Eficácia da Política Pública de Formação de Agentes de Ater adotada pelo Departamento de Assistência Técnica e Extensão Rural, da Secretaria de Agricultura Familiar do Ministério do Desenvolvimento - DATER/SAF/MDA, no período de 2004 a 2009, tema escolhido para Monografia a ser apresentada à Universidade de Brasília (UnB) como requisito parcial para obtenção do grau de Bacharel em Administração.

Você poderá ou não se identificar no questionário e garantimos que todas as informações fornecidas serão confidenciais e utilizadas apenas de forma sistematizada.

IDENTIFICAÇÃO

\begin{tabular}{|c|c|}
\hline Nome: CICCERO BATISTA SOBRINHO & $\begin{array}{l}\text { Sexo: } \\
(x) \text { masculino } \quad(\quad) \text { feminino }\end{array}$ \\
\hline $\begin{array}{l}\text { Instituição (nome e tipo de instituição: ONG, } \\
\text { Empresa Pública, etc.): } \\
\text { EMATER }\end{array}$ & $\begin{array}{l}\text { Local de trabalho (Cidade e Estado): } \\
\text { EMATER - ESLOC. S.S.B.V } \\
\text { SÃO DEBASTIÃO DA BOA VISTA -PARÁ }\end{array}$ \\
\hline \multicolumn{2}{|c|}{$\begin{array}{l}\text { Curso/Encontro/Oficina do qual participou (caso tenha participado de mais de um curso, } \\
\text { preencha um formulário para cada um deles): } \\
\text { CURSO DE TEORIA E PRÁTICA DE MÉTODOS DE ATER }\end{array}$} \\
\hline \multicolumn{2}{|c|}{$\begin{array}{l}\text { Data do Curso/Encontro/Oficina (pelo menos mês e ano): } \\
20 \text { A } 24 \text { DE NOVEMBRO DE } 2006\end{array}$} \\
\hline
\end{tabular}

Indique sua área de atuação? (As opções não são excludentes: você poderá marcar mais de uma opção).

\begin{tabular}{|l|l|}
\hline$X$ & EXTENSÃO RURAL \\
\hline & PESQUISA \\
\hline
\end{tabular}




\begin{tabular}{|l|l|}
\hline & ENSINO \\
\hline & OUTROS \\
\hline
\end{tabular}

2) Qual o seu nível de escolaridade?

\begin{tabular}{|l|l|}
\hline & NÍVEL MÉDIO \\
\hline & NÍVEL SUPERIOR \\
\hline$X$ & PÓS-GRADUAÇÃO \\
\hline
\end{tabular}

3) Os conteúdos abordados foram condizentes com as demandas do seu dia-a-dia?

\begin{tabular}{|l|l|}
\hline$X$ & SIM \\
\hline & PARCIALMENTE \\
\hline & NÃO \\
\hline
\end{tabular}

4) O curso contribuiu para o seu aperfeiçoamento profissional?

\begin{tabular}{|l|l|}
\hline$X$ & SIM \\
\hline & NÃO \\
\hline
\end{tabular}

5) Os conhecimentos adquiridos estão sendo aplicados no seu trabalho? Em caso afirmativo, indique em que grau estes conhecimentos estão sendo aplicados. Em caso negativo, indique por que razão isto não ocorre: (Em caso negativo, as respostas não são excludentes: você poderá marcar mais de uma opção).

\begin{tabular}{|l|l|l|l|}
\hline$X$ & $\begin{array}{l}\text { SIM (indique ao lado } \\
\text { em que grau) }\end{array}$ & & MUITO APLICADOS \\
\cline { 2 - 3 } & & MEDIAMENTE APLICADOS \\
\hline
\end{tabular}




\begin{tabular}{|c|c|}
\hline \multirow{5}{*}{$\begin{array}{l}\text { NÃO (indique ao lado a } \\
\text { razão da não aplicação) }\end{array}$} & $\begin{array}{l}\text { CONTEÚDO NĀO ADEQUADO ȦS NECESSIDADES } \\
\text { ESPECÍFICAS DA REGIÃO }\end{array}$ \\
\hline & $\begin{array}{l}\text { CONTEÚDO NÃO FOI SUFICIENTEMENTE } \\
\text { APROFUNDADO PARA PERMITIR UMA APLICAÇÃO } \\
\text { EFICAZ E EFICIENTE }\end{array}$ \\
\hline & $\begin{array}{l}\text { FALTA DE APOIO E } \\
\text { INSTITUIÇÃO }\end{array}$ \\
\hline & FALTA DE INCENTIVO ÀS AÇÕES DE ATER \\
\hline & NÃO TENHO INTERESSE EM APLICAR \\
\hline
\end{tabular}

6) A partir deste curso: (As opções não são excludentes: você poderá marcar mais de uma opção).

\begin{tabular}{|l|l|}
\hline & NÃO MUDOU NADA EM MEU TRABALHO. \\
\hline$X$ & $\begin{array}{l}\text { MEU TRABALHO PASSOU A CONTRIBUIR MAIS COM OS AGRICULTORES(AS) } \\
\text { FAMILIARES. }\end{array}$ \\
\hline & CONSEGUI INFLUENCIAR NAS ORIENTAÇÕES DA MINHA INSTITUIÇÃO. \\
\hline & PASSEI A TRABALHAR COM METODOLOGIAS PARTICIPATIVAS. \\
\hline & $\begin{array}{l}\text { CRESCEU A ÁREA DE AGRICULTURA DE BASE ECOLÓGICA NAS COMUNIDADES } \\
\text { ONDEO ATUO. }\end{array}$ \\
\hline & CONTINUEI ME APERFEIÇOANDO SOBRE TEMAS ABORDADOS. \\
\hline
\end{tabular}

7) Depois do curso você apoiou atividades de capacitação de técnicos e agricultores com base nos princípios e diretrizes da Pnater? (Considere como apoio a atividades de capacitação a participação no planejamento, elaboração de ementas, seleção de participantes e de palestrantes.)

\begin{tabular}{|l|l|}
\hline$X$ & SIM \\
\hline & NÃO \\
\hline
\end{tabular}


8) Usou os conhecimentos para ministrar outros cursos com o mesmo conteúdo ou conteúdos semelhantes?

\begin{tabular}{|l|l|}
\hline$X$ & SIM \\
\hline & NÃO \\
\hline
\end{tabular}

9) Marque o seu grau de satisfação com relação ao curso oferecido pelo DATER:

\begin{tabular}{|l|l|l|l|l|}
\hline 1 & 2 & 3 & $(4)$ & 5 \\
\hline
\end{tabular}

10) Marque seu grau de satisfação com relação ao DATER:

\begin{tabular}{|l|l|l|l|l|}
\hline 1 & 2 & $(3)$ & 4 & 5 \\
\hline
\end{tabular}




\section{PESQUISA - IMPACTO DAS AÇÕES DE FORMAÇÃO REALIZADAS PELO DATER/SAF/MDA NO PERÍODO 2004-2009}

Caros colaboradores,

Contamos com a sua atenção para preencher o formulário abaixo.

O mesmo tem por objetivo fornecer informações para avaliação da Eficiência, Efetividade e Eficácia da Política Pública de Formação de Agentes de Ater adotada pelo Departamento de Assistência Técnica e Extensão Rural, da Secretaria de Agricultura Familiar do Ministério do Desenvolvimento - DATER/SAF/MDA, no período de 2004 a 2009, tema escolhido para Monografia a ser apresentada à Universidade de Brasília (UnB) como requisito parcial para obtenção do grau de Bacharel em Administração.

Você poderá ou não se identificar no questionário e garantimos que todas as informações fornecidas serão confidenciais e utilizadas apenas de forma sistematizada.

IDENTIFICAÇÃO

\begin{tabular}{|l|l|}
\hline Nome:JOSÉ ANTONIO PESSOA CRUZ & $\begin{array}{l}\text { Sexo: } \\
(x \quad) \text { masculino } \quad(\quad) \text { feminino }\end{array}$ \\
\hline $\begin{array}{l}\text { Instituição (nome e tipo de instituição: ONG, } \\
\text { Empresa Pública, etc.): EMATER-PARÁ }\end{array}$ & $\begin{array}{l}\text { Local de trabalho (Cidade e Estado): } \\
\text { SANTA LUZIA DO PARÁ }\end{array}$ \\
\hline $\begin{array}{l}\text { Curso/Encontro/Oficina do qual participou (caso tenha participado de mais de um curso, } \\
\text { preencha um formulário para cada um deles): PROGRAMA DE FORMAÇÃO DE AGENTES DE } \\
\text { DESENVOLVIMENTO RURAL }\end{array}$ \\
\hline Data do Curso/Encontro/Oficina (pelo menos mês e ano): \\
\hline
\end{tabular}

1) Indique sua área de atuação? (As opções não são excludentes: você poderá marcar mais de uma opção)

\begin{tabular}{|l|l|}
\hline$X$ & EXTENSÃO RURAL \\
\hline & PESQUISA \\
\hline & ENSINO \\
\hline & OUTROS \\
\hline
\end{tabular}


2) Qual o seu nível de escolaridade? (Considere apenas o nível mais alto)

\begin{tabular}{|l|l|}
\hline$X$ & NÍVEL MÉDIO \\
\hline & NÍVEL SUPERIOR \\
\hline & PÓS-GRADUAÇÃO \\
\hline
\end{tabular}

3) Os conteúdos abordados foram condizentes com as demandas do seu dia-a-dia?

\begin{tabular}{|l|l|}
\hline$X$ & SIM \\
\hline & PARCIALMENTE \\
\hline & NÃO \\
\hline
\end{tabular}

4) O curso contribuiu para o seu aperfeiçoamento profissional?

\begin{tabular}{|l|l|}
\hline$X$ & SIM \\
\hline & NÃO \\
\hline
\end{tabular}

5) Os conhecimentos adquiridos estão sendo aplicados no seu trabalho? Em caso afirmativo, indique em que grau estes conhecimentos estão sendo aplicados. Em caso negativo, indique por que razão isto não ocorre: (Em caso negativo, as respostas não são excludentes: você poderá marcar mais de uma opção).

\begin{tabular}{|c|c|c|c|}
\hline \multirow{3}{*}{ X } & \multirow{3}{*}{$\begin{array}{l}\text { SIM (indique ao lado } \\
\text { em que grau) }\end{array}$} & & MUITO APLICADOS \\
\hline & & $\mathrm{X}$ & MEDIAMENTE APLICADOS \\
\hline & & & POUCO APLICADOS \\
\hline & \multirow{2}{*}{$\begin{array}{l}\text { NÃO (indique ao lado a } \\
\text { razão da não aplicação) }\end{array}$} & & $\begin{array}{l}\text { CONTEỦDO NĀO ADEQUADO ȦS NECESSIDADES } \\
\text { ESPECÍFICAS DA REGIÃO }\end{array}$ \\
\hline & & & $\begin{array}{l}\text { CONTEÚDO NĀO FOI SUFICIENTEMENTE } \\
\text { APROFUNDADO PARA PERMITIR UMA APLICAÇÃO } \\
\text { EFICAZ E EFICIENTE }\end{array}$ \\
\hline
\end{tabular}




\begin{tabular}{|l|l|l|}
\hline \multirow{2}{*}{} & & $\begin{array}{l}\text { FALTA DE APOIO E INCENTIVO DA MINHA } \\
\text { INSTITUIÇÃO }\end{array}$ \\
\cline { 2 - 3 } & FALTA DE INCENTIVO ÀS AÇÕES DE ATER \\
\cline { 2 - 3 } & NÃO TENHO INTERESSE EM APLICAR \\
\hline
\end{tabular}

6) A partir deste curso: (As opções não são excludentes: você poderá marcar mais de uma opção)

\begin{tabular}{|l|l|}
\hline & NÃO MUDOU NADA EM MEU TRABALHO. \\
\hline$X$ & $\begin{array}{l}\text { MEU TRABALHO PASSOU A CONTRIBUIR MAIS COM OS AGRICULTORES(AS) } \\
\text { FAMILIARES. }\end{array}$ \\
\hline$X$ & CONSEGUI INFLUENCIAR NAS ORIENTAÇÕES DA MINHA INSTITUIÇÃO. \\
\hline$X$ & $\begin{array}{l}\text { PASSEI A TRABALHAR COM METODOLOGIAS PARTICIPATIVAS. } \\
\text { ONDE ATUO. }\end{array}$ \\
\hline & CONTINUEI ME APERFEIÇOANDO SOBRE TEMAS ABORDADOS. \\
\hline
\end{tabular}

7) Depois do curso você apoiou atividades de capacitação de técnicos e agricultores com base nos princípios e diretrizes da Pnater? (Considere como apoio a atividades de capacitação a participação no planejamento, elaboração de ementas, seleção de participantes e de palestrantes.)

\begin{tabular}{|l|l|}
\hline & SIM \\
\hline$X$ & NÃO \\
\hline
\end{tabular}

8) Usou os conhecimentos para ministrar outros cursos com o mesmo conteúdo ou conteúdos semelhantes?

\begin{tabular}{|l|l|}
\hline$X$ & SIM \\
\hline & NÃO \\
\hline
\end{tabular}


9) Marque o seu grau de satisfação com relação ao curso oferecido pelo DATER: (Considere a seguinte pontuação: 1 - MUITO RUIM; 2 - RUIM; 3 - REGULAR; 4 - BOM; 5 - MUITO BOM)

\begin{tabular}{|l|l|l|l|l|}
\hline 1 & 2 & 3 & $4 \times$ & 5 \\
\hline
\end{tabular}

10) Marque seu grau de satisfação com relação ao DATER: (Considere a seguinte pontuação: 1 - MUITO RUIM; 2 - RUIM; 3 - REGULAR; 4 - BOM; 5 - MUITO BOM)

\begin{tabular}{|l|l|l|l|l|}
\hline 1 & 2 & $3 \times$ & 4 & 5 \\
\hline
\end{tabular}


PESQUISA - IMPACTO DAS AÇÕES DE FORMAÇÃO REALIZADAS PELO DATER/SAF/MDA NO PERÍODO 2004-2009

Caros colaboradores,

Contamos com a sua atenção para preencher o formulário abaixo.

O mesmo tem por objetivo fornecer informações para avaliação da Eficiência, Efetividade e Eficácia da Política Pública de Formação de Agentes de Ater adotada pelo Departamento de Assistência Técnica e Extensão Rural, da Secretaria de Agricultura Familiar do Ministério do Desenvolvimento - DATER/SAF/MDA, no período de 2004 a 2009, tema escolhido para Monografia a ser apresentada à Universidade de Brasília (UnB) como requisito parcial para obtenção do grau de Bacharel em Administração.

Você poderá ou não se identificar no questionário e garantimos que todas as informações fornecidas serão confidenciais e utilizadas apenas de forma sistematizada.

IDENTIFICAÇÃO

\begin{tabular}{|c|c|}
\hline José Antônio da Luz & $\begin{array}{l}\text { Sexo: } \\
\left(\begin{array}{lll}(x & ) \text { masculino } \quad(\quad) \text { feminino }\end{array}\right.\end{array}$ \\
\hline 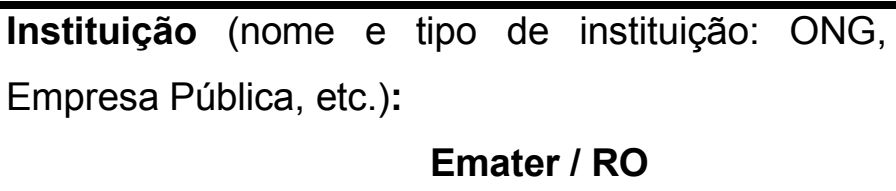 & $\begin{array}{l}\text { Local de trabalho (Cidade e Estado): } \\
\text { Cacaulândia / RO }\end{array}$ \\
\hline \multicolumn{2}{|c|}{$\begin{array}{l}\text { Curso/Encontro/Oficina do qual participou (caso tenha participado de mais de um curso, } \\
\text { preencha um formulário para cada um deles): Curso de Manejo de Pastagem com Énfase no } \\
\text { Controle Biológico de Cigarrinhas }\end{array}$} \\
\hline Data do Curso/Encontro/Oficina (pelo menos mês & $\begin{array}{l}\text { e ano): } \\
10 / 06\end{array}$ \\
\hline
\end{tabular}

1) Indique sua área de atuação? (As opções não são excludentes: você poderá marcar mais de uma opção)

\begin{tabular}{|l|l|}
\hline$X$ & EXTENSÃO RURAL \\
\hline & PESQUISA \\
\hline & ENSINO \\
\hline & OUTROS \\
\hline
\end{tabular}


2) Qual o seu nível de escolaridade? (Considere apenas o nível mais alto)

\begin{tabular}{|l|l|}
\hline$X$ & NÍVEL MÉDIO \\
\hline & NÍVEL SUPERIOR \\
\hline & PÓS-GRADUAÇÃO \\
\hline
\end{tabular}

4) Os conteúdos abordados foram condizentes com as demandas do seu dia-a-dia?

\begin{tabular}{|l|l|}
\hline$X$ & SIM \\
\hline & PARCIALMENTE \\
\hline & NÃO \\
\hline
\end{tabular}

3) O curso contribuiu para o seu aperfeiçoamento profissional?

\begin{tabular}{|l|l|}
\hline$X$ & SIM \\
\hline & NÃO \\
\hline
\end{tabular}

5) Os conhecimentos adquiridos estão sendo aplicados no seu trabalho? Em caso afirmativo, indique em que grau estes conhecimentos estão sendo aplicados. Em caso negativo, indique por que razão isto não ocorre: (Em caso negativo, as respostas não são excludentes: você poderá marcar mais de uma opção).

\begin{tabular}{|l|l|l|l|}
\hline \multirow{2}{*}{$\begin{array}{l}\text { SIM (indique ao lado } \\
\text { em que grau) }\end{array}$} & $X$ & MUITO APLICADOS \\
\cline { 2 - 3 } & & MEDIAMENTE APLICADOS \\
\hline $\begin{array}{l}\text { NĀO (indique ao lado a } \\
\text { razão da não aplicação) }\end{array}$ & & $\begin{array}{l}\text { CONTEU்DO NĀO ADEQUADO ÁS NECESSIDADES } \\
\text { ESPECÍFICAS DA REGIÃO }\end{array}$ \\
\hline
\end{tabular}




\begin{tabular}{|l|l|l|}
\hline \multirow{10}{*}{} & $\begin{array}{l}\text { CONTEÚDO NÃO FOI SUFICIENTEMENTE } \\
\text { APROFUNDADO PARA PERMITIR UMA APLICAÇÃo } \\
\text { EFICAZ E EFICIENTE }\end{array}$ \\
\cline { 2 - 3 } & $\begin{array}{l}\text { FALTA DE APOIO E INCENTIVO DA MINHA } \\
\text { INSTITUIÇÃO }\end{array}$ \\
\hline & FALTA DE INCENTIVO ÀS AÇÕES DE ATER \\
\hline & NÃO TENHO INTERESSE EM APLICAR \\
\hline
\end{tabular}

6) A partir deste curso: (As opções não são excludentes: você poderá marcar mais de uma opção)

\begin{tabular}{|c|l|}
\hline$x$ & $\begin{array}{l}\text { NẼO MUDOU NADA EM MEU TRABALHO. } \\
\text { FAMILIARES. }\end{array}$ \\
\hline$X$ & CONSEGUI INFLUENCIAR NAS ORIENTAÇÕES DA MINHA INSTITUIÇÃO. \\
\hline & PASSEI A TRABALHAR COM METODOLOGIAS PARTICIPATIVAS. \\
\hline & $\begin{array}{l}\text { CRESCEU A AREA DE AGRICULTURA DE BASE ECOLOGICA NAS COMUNIDADES } \\
\text { ONDE ATUO. }\end{array}$ \\
\hline$X$ & CONTINUEI ME APERFEIÇOANDO SOBRE TEMAS ABORDADOS. OS AGRICULTORES(AS) \\
\hline
\end{tabular}

7) Depois do curso você apoiou atividades de capacitação de técnicos e agricultores com base nos princípios e diretrizes da Pnater? (Considere como apoio a atividades de capacitação a participação no planejamento, elaboração de ementas, seleção de participantes e de palestrantes.)

\begin{tabular}{|l|l|}
\hline$X$ & SIM \\
\hline & NÃO \\
\hline
\end{tabular}

8) Usou os conhecimentos para ministrar outros cursos com o mesmo conteúdo ou conteúdos semelhantes? 


\begin{tabular}{|l|l|}
\hline & SIM \\
\hline$X$ & NÃO \\
\hline
\end{tabular}

9) Marque o seu grau de satisfação com relação ao curso oferecido pelo DATER: (Considere a seguinte pontuação: 1 - MUITO RUIM; 2 - RUIM; 3 - REGULAR; 4 - BOM; 5 - MUITO BOM)

\begin{tabular}{|l|l|l|l|l|}
\hline 1 & 2 & 3 & 4 & $5 \times$ \\
\hline
\end{tabular}

10) Marque seu grau de satisfação com relação ao DATER: (Considere a seguinte pontuação: 1 - MUITO RUIM; 2 - RUIM; 3 - REGULAR; 4 - BOM; 5 - MUITO BOM)

\begin{tabular}{|l|l|l|l|l|}
\hline 1 & 2 & 3 & 4 & $5 \times$ \\
\hline
\end{tabular}


PESQUISA - IMPACTO DAS AÇÕES DE FORMAÇÃO REALIZADAS PELO DATER/SAF/MDA NO PERÍODO 2004-2009

Caros colaboradores,

Contamos com a sua atenção para preencher o formulário abaixo.

O mesmo tem por objetivo fornecer informações para avaliação da Eficiência, Efetividade e Eficácia da Política Pública de Formação de Agentes de Ater adotada pelo Departamento de Assistência Técnica e Extensão Rural, da Secretaria de Agricultura Familiar do Ministério do Desenvolvimento - DATER/SAF/MDA, no período de 2004 a 2009, tema escolhido para Monografia a ser apresentada à Universidade de Brasília (UnB) como requisito parcial para obtenção do grau de Bacharel em Administração.

Você poderá ou não se identificar no questionário e garantimos que todas as informações fornecidas serão confidenciais e utilizadas apenas de forma sistematizada.

IDENTIFICAÇÃO

\begin{tabular}{|c|c|}
\hline Nome: JOSÉ AMILTON REIS DE CARVALHO & 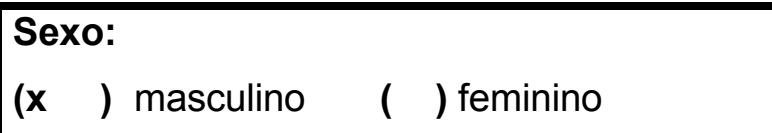 \\
\hline $\begin{array}{l}\text { Instituição (nome e tipo de instituição: ONG, } \\
\text { Empresa Pública, etc.): SECRETÁRIA DE } \\
\text { AGRICULTURA E MEIO AMBIENTE }\end{array}$ & $\begin{array}{l}\text { Local de trabalho (Cidade e Estado): } \\
\text { SANTARÉM NOVO }\end{array}$ \\
\hline \multicolumn{2}{|c|}{$\begin{array}{l}\text { Curso/Encontro/Oficina do qual participou (caso tenha participado de mais de um curso, } \\
\text { preencha um formulário para cada um deles): FORMAÇÃO DE AGENTES DE ATER }\end{array}$} \\
\hline Data do Curso/Encontro/Oficina (pelo & ano): NOVEMBRO/2006 \\
\hline
\end{tabular}

1)Indique sua área de atuação? (As opções não são excludentes: você poderá marcar mais de uma opção)

\begin{tabular}{|l|l|}
\hline & EXTENSÃO RURAL \\
\hline & PESQUISA \\
\hline & ENSINO \\
\hline$X$ & OUTROS \\
\hline
\end{tabular}


2) Qual o seu nível de escolaridade? (Considere apenas o nível mais alto)

\begin{tabular}{|l|l|}
\hline$X$ & NÍVEL MÉDIO \\
\hline & NÍVEL SUPERIOR \\
\hline & PÓS-GRADUAÇÃO \\
\hline
\end{tabular}

3) Os conteúdos abordados foram condizentes com as demandas do seu dia-a-dia?

\begin{tabular}{|l|l|}
\hline$X$ & SIM \\
\hline & PARCIALMENTE \\
\hline & NÃO \\
\hline
\end{tabular}

4) O curso contribuiu para o seu aperfeiçoamento profissional?

\begin{tabular}{|l|l|}
\hline$X$ & SIM \\
\hline & NÃO \\
\hline
\end{tabular}

5) Os conhecimentos adquiridos estão sendo aplicados no seu trabalho? Em caso afirmativo, indique em que grau estes conhecimentos estão sendo aplicados. Em caso negativo, indique por que razão isto não ocorre: (Em caso negativo, as respostas não são excludentes: você poderá marcar mais de uma opção).

\begin{tabular}{|l|l|l|l|}
\hline$X$ & $\begin{array}{l}\text { SIM (indique ao lado } \\
\text { em que grau) }\end{array}$ & MUITO APLICADOS \\
\cline { 2 - 4 } & $\mathrm{X}$ & MEDIAMENTE APLICADOS \\
\hline & $\begin{array}{l}\text { NĀO (indique ao lado a } \\
\text { razão da não aplicação) }\end{array}$ & $\begin{array}{l}\text { CONTEÚDO NĀO ADEQUADO ȦS NECESSIDADES } \\
\text { ESPECÍFICAS DA REGIÃO }\end{array}$ \\
\hline
\end{tabular}




\begin{tabular}{|l|l|l|}
\hline \multirow{10}{*}{} & $\begin{array}{l}\text { CONTEÚDO NÃO FOI SUFICIENTEMENTE } \\
\text { APROFUNDADO PARA PERMITIR UMA APLICAÇÃo } \\
\text { EFICAZ E EFICIENTE }\end{array}$ \\
\cline { 2 - 3 } & $\begin{array}{l}\text { FALTA DE APOIO E INCENTIVO DA MINHA } \\
\text { INSTITUIÇÃO }\end{array}$ \\
\hline & FALTA DE INCENTIVO ÀS AÇÕES DE ATER \\
\hline & NÃO TENHO INTERESSE EM APLICAR \\
\hline
\end{tabular}

6) A partir deste curso: (As opções não são excludentes: você poderá marcar mais de uma opção)

\begin{tabular}{|l|l|}
\hline & NÃO MUDOU NADA EM MEU TRABALHO. \\
\hline$X$ & $\begin{array}{l}\text { MEU TRABALHO PASSOU A CONTRIBUIR MAIS COM OS AGRICULTORES(AS) } \\
\text { FAMILIARES. }\end{array}$ \\
\hline & CONSEGUI INFLUENCIAR NAS ORIENTAÇÕES DA MINHA INSTITUIÇÃO. \\
\hline$X$ & $\begin{array}{l}\text { CRESCEU A TRABALHAR COM METODOLOGIAS PARTICIPATIVAS. } \\
\text { ONDE ATUO. }\end{array}$ \\
\hline & CONTINUEI ME APERFEIÇOANDO SOBRE TEMAS ABORDADOS. \\
\hline
\end{tabular}

7) Depois do curso você apoiou atividades de capacitação de técnicos e agricultores com base nos princípios e diretrizes da Pnater? (Considere como apoio a atividades de capacitação a participação no planejamento, elaboração de ementas, seleção de participantes e de palestrantes.)

\begin{tabular}{|l|l|}
\hline & SIM \\
\hline$X$ & NÃO \\
\hline
\end{tabular}

8) Usou os conhecimentos para ministrar outros cursos com o mesmo conteúdo ou conteúdos semelhantes? 


\begin{tabular}{|l|l|}
\hline & SIM \\
\hline$X$ & NÃO \\
\hline
\end{tabular}

9) Marque o seu grau de satisfação com relação ao curso oferecido pelo DATER: (Considere a seguinte pontuação: 1 - MUITO RUIM; 2 - RUIM; 3 - REGULAR; 4 - BOM; 5 - MUITO BOM)

\begin{tabular}{|l|l|l|l|l|}
\hline 1 & 2 & 3 & $4 \times$ & 5 \\
\hline
\end{tabular}

10) Marque seu grau de satisfação com relação ao DATER: (Considere a seguinte pontuação: 1 - MUITO RUIM; 2 - RUIM; 3 - REGULAR; 4 - BOM; 5 - MUITO BOM)

\begin{tabular}{|l|l|l|l|l|}
\hline 1 & 2 & 3 & $4 \times$ & 5 \\
\hline
\end{tabular}




\section{PESQUISA - IMPACTO DAS AÇÕES DE FORMAÇÃO REALIZADAS PELO DATER/SAF/MDA NO PERÍODO 2004-2009}

Caros colaboradores,

Contamos com a sua atenção para preencher o formulário abaixo.

O mesmo tem por objetivo fornecer informações para avaliação da Eficiência, Efetividade e Eficácia da Política Pública de Formação de Agentes de Ater adotada pelo Departamento de Assistência Técnica e Extensão Rural, da Secretaria de Agricultura Familiar do Ministério do Desenvolvimento - DATER/SAF/MDA, no período de 2004 a 2009, tema escolhido para Monografia a ser apresentada à Universidade de Brasília (UnB) como requisito parcial para obtenção do grau de Bacharel em Administração.

Você poderá ou não se identificar no questionário e garantimos que todas as informações fornecidas serão confidenciais e utilizadas apenas de forma sistematizada.

IDENTIFICAÇÃO

\begin{tabular}{|c|c|}
\hline Nome: JORGE ROQUE SANTANA DE AMARAL & $\begin{array}{l}\text { Sexo: } \\
(x \quad) \text { masculino } \quad(\quad) \text { feminino }\end{array}$ \\
\hline $\begin{array}{l}\text { Instituição (nome e tipo de instituição: ONG, } \\
\text { Empresa Pública, etc.): EMATER - RO }\end{array}$ & $\begin{array}{l}\text { Local de trabalho (Cidade e Estado): } \\
\text { MIRANTE DA SERRA }\end{array}$ \\
\hline \multicolumn{2}{|c|}{$\begin{array}{l}\text { Curso/Encontro/Oficina do qual participou (caso tenha participado de mais de um curso, } \\
\text { preencha um formulário para cada um deles): CREDITO RURAL, MANEJO DE PASTAGEM } \\
\text { COM ÊNFASE NO CONTROLE BIOLOGICO DA CIGARRINHA, MELHORIA DA QUALIDADE } \\
\text { SO LEITE. }\end{array}$} \\
\hline & \\
\hline
\end{tabular}

1)Indique sua área de atuação? (As opções não são excludentes: você poderá marcar mais de uma opção)

\begin{tabular}{|l|l|}
\hline$X$ & EXTENSÃO RURAL \\
\hline & PESQUISA \\
\hline & ENSINO \\
\hline & OUTROS \\
\hline
\end{tabular}


2) Qual o seu nível de escolaridade? (Considere apenas o nível mais alto)

\begin{tabular}{|l|l|}
\hline$X$ & NÍVEL MÉDIO \\
\hline & NÍVEL SUPERIOR \\
\hline & PÓS-GRADUAÇÃO \\
\hline
\end{tabular}

3) Os conteúdos abordados foram condizentes com as demandas do seu dia-a-dia?

\begin{tabular}{|l|l|}
\hline$X$ & SIM \\
\hline & PARCIALMENTE \\
\hline & NÃO \\
\hline
\end{tabular}

4) O curso contribuiu para o seu aperfeiçoamento profissional?

\begin{tabular}{|l|l|}
\hline$X$ & SIM \\
\hline & NÃO \\
\hline
\end{tabular}

5) Os conhecimentos adquiridos estão sendo aplicados no seu trabalho? Em caso afirmativo, indique em que grau estes conhecimentos estão sendo aplicados. Em caso negativo, indique por que razão isto não ocorre: (Em caso negativo, as respostas não são excludentes: você poderá marcar mais de uma opção).

\begin{tabular}{|c|c|c|c|}
\hline \multirow{3}{*}{$\mathrm{x}$} & \multirow{3}{*}{$\begin{array}{l}\text { SIM (indique ao lado } \\
\text { em que grau) }\end{array}$} & $\mathrm{X}$ & MUITO APLICADOS \\
\hline & & & MEDIAMENTE APLICADOS \\
\hline & & & POUCO APLICADOS \\
\hline & & & $\begin{array}{l}\text { CONTEÚDO NÃO ADEQUADO ÀS NECESSIDADES } \\
\text { ESPECÍFICAS DA REGIÃO }\end{array}$ \\
\hline & razão da não aplicação) & & $\begin{array}{l}\text { CONTEÚDO NÃO FOI SUFICIENTEMENTE } \\
\text { APROFUNDADO PARA PERMITIR UMA APLICAÇÃO } \\
\text { EFICAZ E EFICIENTE }\end{array}$ \\
\hline
\end{tabular}




\begin{tabular}{|l|l|l|}
\hline \multirow{2}{*}{} & & $\begin{array}{l}\text { FALTA DE APOIO E INCENTIVO DA MINHA } \\
\text { INSTITUIÇÃO }\end{array}$ \\
\cline { 2 - 3 } & FALTA DE INCENTIVO ÀS AÇÕES DE ATER \\
\hline & NÃO TENHO INTERESSE EM APLICAR \\
\hline
\end{tabular}

6) A partir deste curso: (As opções não são excludentes: você poderá marcar mais de uma opção)

\begin{tabular}{|l|l|}
\hline & NÃO MUDOU NADA EM MEU TRABALHO. \\
\hline$X$ & $\begin{array}{l}\text { MEU TRABALHO PASSOU A CONTRIBUIR MAIS COM OS AGRICULTORES(AS) } \\
\text { FAMILIARES. }\end{array}$ \\
\hline & CONSEGUI INFLUENCIAR NAS ORIENTAÇÕES DA MINHA INSTITUIÇÃO. \\
\hline$X$ & $\begin{array}{l}\text { CRESSEI A TRABALHAR COM METODOLOGIAS PARTICIPATIVAS. } \\
\text { ONDE ATUO. }\end{array}$ \\
\hline & CONTINUEI ME APERFEIÇOANDO SOBRE TEMAS ABORDADOS. \\
\hline
\end{tabular}

7) Depois do curso você apoiou atividades de capacitação de técnicos e agricultores com base nos princípios e diretrizes da Pnater? (Considere como apoio a atividades de capacitação a participação no planejamento, elaboração de ementas, seleção de participantes e de palestrantes.)

\begin{tabular}{|l|l|}
\hline & SIM \\
\hline$X$ & NÃO \\
\hline
\end{tabular}

8) Usou os conhecimentos para ministrar outros cursos com o mesmo conteúdo ou conteúdos semelhantes? 


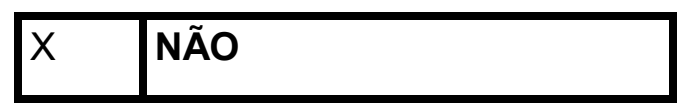

9) Marque o seu grau de satisfação com relação ao curso oferecido pelo DATER: (Considere a seguinte pontuação: 1 - MUITO RUIM; 2 - RUIM; 3 - REGULAR; 4 - BOM; 5 - MUITO BOM)

\begin{tabular}{|l|l|l|l|l|}
\hline 1 & 2 & 3 & 4 & 5 \\
\hline
\end{tabular}

10) Marque seu grau de satisfação com relação ao DATER: (Considere a seguinte pontuação: 1 - MUITO RUIM; 2 - RUIM; 3 - REGULAR; 4 - BOM; 5 - MUITO BOM)

\begin{tabular}{|l|l|l|l|l|}
\hline 1 & 2 & 3 & 4 & 5 \\
\hline
\end{tabular}


PESQUISA - IMPACTO DAS AÇÕES DE FORMAÇÃO REALIZADAS PELO DATER/SAF/MDA NO PERÍODO 2004-2009

Caros colaboradores,

Contamos com a sua atenção para preencher o formulário abaixo.

O mesmo tem por objetivo fornecer informações para avaliação da Eficiência, Efetividade e Eficácia da Política Pública de Formação de Agentes de Ater adotada pelo Departamento de Assistência Técnica e Extensão Rural, da Secretaria de Agricultura Familiar do Ministério do Desenvolvimento - DATER/SAF/MDA, no período de 2004 a 2009, tema escolhido para Monografia a ser apresentada à Universidade de Brasília (UnB) como requisito parcial para obtenção do grau de Bacharel em Administração.

Você poderá ou não se identificar no questionário e garantimos que todas as informações fornecidas serão confidenciais e utilizadas apenas de forma sistematizada.

IDENTIFICAÇÃO

\begin{tabular}{|l|l|}
\hline Nome: Jhonathan Gonçalves de Oliveira & $\begin{array}{l}\text { Sexo: } \\
\left(\begin{array}{l}x\end{array}\right) \text { masculino } \quad(\quad) \text { feminino }\end{array}$ \\
\hline $\begin{array}{l}\text { Instituição Emater- Associação de Assistência } \\
\text { Técnica e Extensão Rural do Estado de Rondônia }\end{array}$ & Local de trabalho Corumbiara- Rondônia \\
\hline $\begin{array}{l}\text { Curso/Encontro/Oficina do qual participou } \\
\text { Curso sobre Crédito Rural }\end{array}$ \\
\hline Data do Curso/Encontro/Oficina Julho de 2006 \\
\hline
\end{tabular}

1)Indique sua área de atuação? (As opções não são excludentes: você poderá marcar mais de uma opção)

\begin{tabular}{|l|l|}
\hline$X$ & EXTENSÃO RURAL \\
\hline & PESQUISA \\
\hline & ENSINO \\
\hline & OUTROS \\
\hline
\end{tabular}


2) Qual o seu nível de escolaridade? (Considere apenas o nível mais alto)

\begin{tabular}{|l|l|}
\hline$X$ & NÍVEL MÉDIO \\
\hline & NÍVEL SUPERIOR \\
\hline & PÓS-GRADUAÇÃO \\
\hline
\end{tabular}

3) Os conteúdos abordados foram condizentes com as demandas do seu dia-a-dia?

\begin{tabular}{|l|l|}
\hline & SIM \\
\hline$X$ & PARCIALMENTE \\
\hline & NÃO \\
\hline
\end{tabular}

4) O curso contribuiu para o seu aperfeiçoamento profissional?

\begin{tabular}{|l|l|}
\hline$X$ & SIM \\
\hline & NÃO \\
\hline
\end{tabular}

5) Os conhecimentos adquiridos estão sendo aplicados no seu trabalho? Em caso afirmativo, indique em que grau estes conhecimentos estão sendo aplicados. Em caso negativo, indique por que razão isto não ocorre: (Em caso negativo, as respostas não são excludentes: você poderá marcar mais de uma opção).

\begin{tabular}{|c|c|c|}
\hline \multirow{3}{*}{$\begin{array}{l}\text { SIM (indique ao lado } \\
\text { em que grau) }\end{array}$} & $x$ & MUITO APLICADOS \\
\hline & & MEDIAMENTE APLICADOS \\
\hline & & POUCO APLICADOS \\
\hline \multirow{2}{*}{$\begin{array}{l}\text { NÃo (indique ao lado a } \\
\text { razão da não aplicação) }\end{array}$} & & $\begin{array}{l}\text { CONTEÚDO NÃO ADEQUADO ÀS NECESSIDADES } \\
\text { ESPECÍFICAS DA REGIÃO }\end{array}$ \\
\hline & & $\begin{array}{l}\text { CONTEÚDO NÃO FOI SUFICIENTEMENTE } \\
\text { APROFUNDADO PARA PERMITIR UMA APLICAÇÃO } \\
\text { EFICAZ E EFICIENTE }\end{array}$ \\
\hline
\end{tabular}




\begin{tabular}{|l|l|l|}
\hline \multirow{2}{*}{} & & $\begin{array}{l}\text { FALTA DE APOIO E INCENTIVO DA MINHA } \\
\text { INSTITUIÇÃO }\end{array}$ \\
\cline { 2 - 3 } & FALTA DE INCENTIVO ÀS AÇÕES DE ATER \\
\hline & NÃO TENHO INTERESSE EM APLICAR \\
\hline
\end{tabular}

6) A partir deste curso: (As opções não são excludentes: você poderá marcar mais de uma opção)

\begin{tabular}{|c|l|}
\hline$X$ & $\begin{array}{l}\text { NÃO MUDOU NADA EM MEU TRABALHO. } \\
\text { FAMILIARES. }\end{array}$ \\
\hline & CONSEGUI INFLUENCIAR NAS ORIENTAÇÕES DA MINHA INSTITUIÇÃO. \\
\hline & PASSEI A TRABALHAR COM METODOLOGIAS PARTICIPATIVAS. \\
\hline & $\begin{array}{l}\text { CRESCEU A ÁREA DE AGRICULTURA DE BASE ECOLÓGICA NAS COMUNIDADES } \\
\text { ONDE ATUO. }\end{array}$ \\
\hline$X$ & CONTINUEI ME APERFEIÇOANDO SOBRE TEMAS ABORDADOS. COM OS AGRICULTORES(AS) \\
\hline
\end{tabular}

7) Depois do curso você apoiou atividades de capacitação de técnicos e agricultores com base nos princípios e diretrizes da Pnater? (Considere como apoio a atividades de capacitação a participação no planejamento, elaboração de ementas, seleção de participantes e de palestrantes.)

\begin{tabular}{|l|l|}
\hline$X$ & SIM \\
\hline & NÃO \\
\hline
\end{tabular}

8) Usou os conhecimentos para ministrar outros cursos com o mesmo conteúdo ou conteúdos semelhantes?

\begin{tabular}{|l|l|}
\hline & SIM \\
\hline$X$ & NÃO \\
\hline
\end{tabular}


9) Marque o seu grau de satisfação com relação ao curso oferecido pelo DATER: (Considere a seguinte pontuação: 1 - MUITO RUIM; 2 - RUIM; 3 - REGULAR; 4 - BOM; 5 - MUITO BOM)

\begin{tabular}{|l|l|l|l|l|}
\hline 1 & 2 & 3 & $\times 4$ & 5 \\
\hline
\end{tabular}

10) Marque seu grau de satisfação com relação ao DATER: (Considere a seguinte pontuação: 1 - MUITO RUIM; 2 - RUIM; 3 - REGULAR; 4 - BOM; 5 - MUITO BOM)

\begin{tabular}{|l|l|l|l|l|}
\hline 1 & 2 & 3 & 4 & $\times 5$ \\
\hline
\end{tabular}


PESQUISA - IMPACTO DAS AÇÕES DE FORMAÇÃO REALIZADAS PELO DATER/SAF/MDA NO PERÍODO 2004-2009

Caros colaboradores,

Contamos com a sua atenção para preencher o formulário abaixo.

O mesmo tem por objetivo fornecer informações para avaliação da Eficiência, Efetividade e Eficácia da Política Pública de Formação de Agentes de Ater adotada pelo Departamento de Assistência Técnica e Extensão Rural, da Secretaria de Agricultura Familiar do Ministério do Desenvolvimento - DATER/SAF/MDA, no período de 2004 a 2009, tema escolhido para Monografia a ser apresentada à Universidade de Brasília (UnB) como requisito parcial para obtenção do grau de Bacharel em Administração.

Você poderá ou não se identificar no questionário e garantimos que todas as informações fornecidas serão confidenciais e utilizadas apenas de forma sistematizada.

IDENTIFICAÇÃO

\begin{tabular}{|c|c|}
\hline Nome: JOĀO PINTO JUNIOR LEITE RAMALHO & $\begin{array}{l}\text { Sexo: } \\
\left(\begin{array}{lll}(x & ) \text { masculino } \quad(\quad) \text { feminino }\end{array}\right.\end{array}$ \\
\hline $\begin{array}{l}\text { Instituição: Cooperativa de Trabalho Agro- } \\
\text { Ambiental de Rondônia - COOTRARON; }\end{array}$ & $\begin{array}{l}\text { Local de trabalho (Cidade e Estado): } \\
\text { BURITIS/RONDONIA }\end{array}$ \\
\hline \multicolumn{2}{|c|}{$\begin{array}{l}\text { Curso/Encontro/Oficina do qual participou (caso tenha participado de mais de um curso, } \\
\text { preencha um formulário para cada um deles): CURSO DE ESPECIALIZAÇÃO EM EXTENSÃO } \\
\text { RURAL PARA O DESENVOLVIMENTO SUSTENTÁVEL }\end{array}$} \\
\hline ontro/Oficina & ano): OUT/2006 A ABRIL/2007 \\
\hline
\end{tabular}

1)Indique sua área de atuação? (As opções não são excludentes: você poderá marcar mais de uma opção)

\begin{tabular}{|l|l|}
\hline$X$ & EXTENSÃO RURAL \\
\hline & PESQUISA \\
\hline & ENSINO \\
\hline & OUTROS \\
\hline
\end{tabular}


2) Qual o seu nível de escolaridade? (Considere apenas o nível mais alto)

\begin{tabular}{|l|l|}
\hline & NÍVEL MÉDIO \\
\hline & NÍVEL SUPERIOR \\
\hline$X$ & PÓS-GRADUAÇÃO \\
\hline
\end{tabular}

3) Os conteúdos abordados foram condizentes com as demandas do seu dia-a-dia?

\begin{tabular}{|l|l|}
\hline$X$ & SIM \\
\hline & PARCIALMENTE \\
\hline & NÃO \\
\hline
\end{tabular}

4) O curso contribuiu para o seu aperfeiçoamento profissional?

\begin{tabular}{|l|l|}
\hline$X$ & SIM \\
\hline & NÃO \\
\hline
\end{tabular}

5) Os conhecimentos adquiridos estão sendo aplicados no seu trabalho? Em caso afirmativo, indique em que grau estes conhecimentos estão sendo aplicados. Em caso negativo, indique por que razão isto não ocorre: (Em caso negativo, as respostas não são excludentes: você poderá marcar mais de uma opção).

\begin{tabular}{|c|c|c|c|}
\hline \multirow{3}{*}{$\mathrm{x}$} & \multirow{3}{*}{$\begin{array}{l}\text { SIM (indique ao lado } \\
\text { em que grau) }\end{array}$} & & MUITO APLICADOS \\
\hline & & $x$ & MEDIAMENTE APLICADOS \\
\hline & & & POUCO APLICADOS \\
\hline & & & $\begin{array}{l}\text { CONTEÚDO NĀO ADEQUADO ȦS NECESSIDADES } \\
\text { ESPECÍFICAS DA REGIÃO }\end{array}$ \\
\hline & razão da não aplicação) & & $\begin{array}{l}\text { CONTEÚDO NĀO FOI SUFICIENTEMENTE } \\
\text { APROFUNDADO PARA PERMITIR UMA APLICAÇÃO } \\
\text { EFICAZ E EFICIENTE }\end{array}$ \\
\hline
\end{tabular}




\begin{tabular}{|l|l|l|}
\hline \multirow{2}{*}{} & & $\begin{array}{l}\text { FALTA DE APOIO E INCENTIVO DA MINHA } \\
\text { INSTITUIÇÃO }\end{array}$ \\
\cline { 2 - 3 } & FALTA DE INCENTIVO ÀS AÇÕES DE ATER \\
\hline & NÃO TENHO INTERESSE EM APLICAR \\
\hline
\end{tabular}

6) A partir deste curso: (As opções não são excludentes: você poderá marcar mais de uma opção)

\begin{tabular}{|l|l|}
\hline & NÃO MUDOU NADA EM MEU TRABALHO. \\
\hline$X$ & $\begin{array}{l}\text { MEU TRABALHO PASSOU A CONTRIBUIR MAIS COM OS AGRICULTORES(AS) } \\
\text { FAMILIARES. }\end{array}$ \\
\hline & CONSEGUI INFLUENCIAR NAS ORIENTAÇÕES DA MINHA INSTITUIÇÃO. \\
\hline & $\begin{array}{l}\text { CRASSEI A TRABALHAR COM METODOLOGIAS PARTICIPATIVAS. } \\
\text { ONDE ATUO. }\end{array}$ \\
\hline$X$ & CONTINUEI ME APERFEIÇOANDO SOBRE TEMAS ABORDADOS. \\
\hline
\end{tabular}

7) Depois do curso você apoiou atividades de capacitação de técnicos e agricultores com base nos princípios e diretrizes da Pnater? (Considere como apoio a atividades de capacitação a participação no planejamento, elaboração de ementas, seleção de participantes e de palestrantes.)

\begin{tabular}{|l|l|}
\hline & SIM \\
\hline$X$ & NÃO \\
\hline
\end{tabular}

8) Usou os conhecimentos para ministrar outros cursos com o mesmo conteúdo ou conteúdos semelhantes?

\begin{tabular}{|l|l|}
\hline$X$ & SIM \\
\hline & NÃO \\
\hline
\end{tabular}


9) Marque o seu grau de satisfação com relação ao curso oferecido pelo DATER: (Considere a seguinte pontuação: 1 - MUITO RUIM; 2 - RUIM; 3 - REGULAR; 4 - BOM; 5 - MUITO BOM)

\begin{tabular}{|l|l|l|l|ll|}
\hline 1 & 2 & 3 & 4 & 5 & $X$ \\
\hline
\end{tabular}

10) Marque seu grau de satisfação com relação ao DATER: (Considere a seguinte pontuação: 1 - MUITO RUIM; 2 - RUIM; 3 - REGULAR; 4 - BOM; 5 - MUITO BOM)

\begin{tabular}{|l|l|l|l|l|}
\hline 1 & 2 & $3 \times$ & 4 & 5 \\
\hline
\end{tabular}


PESQUISA - IMPACTO DAS AÇÕES DE FORMAÇÃO REALIZADAS PELO DATER/SAF/MDA NO PERÍODO 2004-2009

Caros colaboradores,

Contamos com a sua atenção para preencher o formulário abaixo.

O mesmo tem por objetivo fornecer informações para avaliação da Eficiência, Efetividade e Eficácia da Política Pública de Formação de Agentes de Ater adotada pelo Departamento de Assistência Técnica e Extensão Rural, da Secretaria de Agricultura Familiar do Ministério do Desenvolvimento - DATER/SAF/MDA, no período de 2004 a 2009, tema escolhido para Monografia a ser apresentada à Universidade de Brasília (UnB) como requisito parcial para obtenção do grau de Bacharel em Administração.

Você poderá ou não se identificar no questionário e garantimos que todas as informações fornecidas serão confidenciais e utilizadas apenas de forma sistematizada.

IDENTIFICAÇÃO

\begin{tabular}{|c|c|}
\hline Nome: JARDISON BARBOSA & $\begin{array}{l}\text { Sexo: } \\
(x \quad) \text { masculino } \quad(\quad) \text { feminino }\end{array}$ \\
\hline $\begin{array}{l}\text { Instituição (nome e tipo de instituição: ONG, } \\
\text { Empresa Pública, etc.): EMATER - PARÁ }\end{array}$ & $\begin{array}{l}\text { Local de trabalho (Cidade e Estado): } \\
\text { JURUTI - PARÁ }\end{array}$ \\
\hline \multicolumn{2}{|c|}{$\begin{array}{l}\text { Curso/Encontro/Oficina do qual participou (caso tenha participado de mais de um curso, } \\
\text { preencha um formulário para cada um deles): METODOLOGIA EM EXTENSÃO RURAL }\end{array}$} \\
\hline Data do Curso/Encontro/Oficina (pelo menos mê & ano): \\
\hline
\end{tabular}

1)Indique sua área de atuação? (As opções não são excludentes: você poderá marcar mais de uma opção)

\begin{tabular}{|l|l|}
\hline$X$ & EXTENSÃO RURAL \\
\hline & PESQUISA \\
\hline & ENSINO \\
\hline & OUTROS \\
\hline
\end{tabular}


2) Qual o seu nível de escolaridade? (Considere apenas o nível mais alto)

\begin{tabular}{|l|l|}
\hline$X$ & NÍVEL MÉDIO \\
\hline & NÍVEL SUPERIOR \\
\hline & PÓS-GRADUAÇÃO \\
\hline
\end{tabular}

3) Os conteúdos abordados foram condizentes com as demandas do seu dia-a-dia?

\begin{tabular}{|l|l|}
\hline$X$ & SIM \\
\hline & PARCIALMENTE \\
\hline & NÃO \\
\hline
\end{tabular}

4) O curso contribuiu para o seu aperfeiçoamento profissional?

\begin{tabular}{|l|l|}
\hline$X$ & SIM \\
\hline & NÃO \\
\hline
\end{tabular}

5) Os conhecimentos adquiridos estão sendo aplicados no seu trabalho? Em caso afirmativo, indique em que grau estes conhecimentos estão sendo aplicados. Em caso negativo, indique por que razão isto não ocorre: (Em caso negativo, as respostas não são excludentes: você poderá marcar mais de uma opção).

\begin{tabular}{|c|c|c|c|}
\hline \multirow{3}{*}{$\mathrm{X}$} & \multirow{3}{*}{$\begin{array}{l}\text { SIM (indique ao lado } \\
\text { em que grau) }\end{array}$} & & MUITO APLICADOS \\
\hline & & & MEDIAMENTE APLICADOS \\
\hline & & $\mathrm{X}$ & POUCO APLICADOS \\
\hline & \multirow{2}{*}{$\begin{array}{l}\text { NÃO (indique ao lado a } \\
\text { razão da não aplicação) }\end{array}$} & & $\begin{array}{l}\text { CONTEU்DO NÃO ADEQUADO ȦS NECESSIDADES } \\
\text { ESPECÍFICAS DA REGIÃO }\end{array}$ \\
\hline & & & $\begin{array}{l}\text { CONTEÚDO NĀO FOI SUFICIENTEMENTE } \\
\text { APROFUNDADO PARA PERMITIR UMA APLICAÇÃO } \\
\text { EFICAZ E EFICIENTE }\end{array}$ \\
\hline
\end{tabular}




\begin{tabular}{|l|l|l|}
\hline \multirow{2}{*}{} & & $\begin{array}{l}\text { FALTA DE APOIO E INCENTIVO DA MINHA } \\
\text { INSTITUIÇÃO }\end{array}$ \\
\cline { 2 - 3 } & FALTA DE INCENTIVO ÀS AÇÕES DE ATER \\
\cline { 2 - 3 } & NÃO TENHO INTERESSE EM APLICAR \\
\hline
\end{tabular}

6) A partir deste curso: (As opções não são excludentes: você poderá marcar mais de uma opção)

\begin{tabular}{|l|l|}
\hline & NÃO MUDOU NADA EM MEU TRABALHO. \\
\hline & $\begin{array}{l}\text { MEU TRABALHO PASSOU A CONTRIBUIR MAIS COM OS AGRICULTORES(AS) } \\
\text { FAMILIARES. }\end{array}$ \\
\hline$X$ & CONSEGUI INFLUENCIAR NAS ORIENTAÇÕES DA MINHA INSTITUIÇÃO. \\
\hline & $\begin{array}{l}\text { CRESCEU A ÁREA DE AGRICULTURA DE BASE ECOLÓGICA NAS COMUNIDADES } \\
\text { ONDE ATUO. }\end{array}$ \\
\hline & CONTINUEI ME APERFEIÇOANDO SOBRE TEMAS ABORDADOS. \\
\hline
\end{tabular}

7) Depois do curso você apoiou atividades de capacitação de técnicos e agricultores com base nos princípios e diretrizes da Pnater? (Considere como apoio a atividades de capacitação a participação no planejamento, elaboração de ementas, seleção de participantes e de palestrantes.)

\begin{tabular}{|l|l|}
\hline$X$ & SIM \\
\hline & NÃO \\
\hline
\end{tabular}

8) Usou os conhecimentos para ministrar outros cursos com o mesmo conteúdo ou conteúdos semelhantes?

\begin{tabular}{|l|l|}
\hline$X$ & SIM \\
\hline & NÃO \\
\hline
\end{tabular}


9) Marque o seu grau de satisfação com relação ao curso oferecido pelo DATER: (Considere a seguinte pontuação: 1 - MUITO RUIM; 2 - RUIM; 3 - REGULAR; 4 - BOM; 5 - MUITO BOM)

\begin{tabular}{|l|l|l|l|l|}
\hline 1 & 2 & 3 & 4 & $5 \times$ \\
\hline
\end{tabular}

10) Marque seu grau de satisfação com relação ao DATER: (Considere a seguinte pontuação: 1 - MUITO RUIM; 2 - RUIM; 3 - REGULAR; 4 - BOM; 5 - MUITO BOM)

\begin{tabular}{|l|l|l|l|l|}
\hline 1 & 2 & 3 & 4 & $5 \times$ \\
\hline
\end{tabular}




\section{PESQUISA - IMPACTO DAS AÇÕES DE FORMAÇÃO REALIZADAS PELO DATER/SAF/MDA NO PERÍODO 2004-2009}

Caros colaboradores,

Contamos com a sua atenção para preencher o formulário abaixo.

O mesmo tem por objetivo fornecer informações para avaliação da Eficiência, Efetividade e Eficácia da Política Pública de Formação de Agentes de Ater adotada pelo Departamento de Assistência Técnica e Extensão Rural, da Secretaria de Agricultura Familiar do Ministério do Desenvolvimento - DATER/SAF/MDA, no período de 2004 a 2009, tema escolhido para Monografia a ser apresentada à Universidade de Brasília (UnB) como requisito parcial para obtenção do grau de Bacharel em Administração.

Você poderá ou não se identificar no questionário e garantimos que todas as informações fornecidas serão confidenciais e utilizadas apenas de forma sistematizada.

IDENTIFICAÇÃO

\begin{tabular}{|c|c|}
\hline Nome: Valdir Matt & $\begin{array}{l}\text { Sexo: } \\
(\mathbf{x}) \text { masculino } \quad(\quad) \text { feminino }\end{array}$ \\
\hline Instituição: Emater-RO & Local de trabalho: Santa Luzia \\
\hline \multicolumn{2}{|c|}{$\begin{array}{l}\text { Curso/Encontro/Oficina do qual participou: Manejo de pastagem com ênfase no controle } \\
\text { biológico de cigarrinha }\end{array}$} \\
\hline \multicolumn{2}{|c|}{ Data do Curso/Encontro/Oficina: 19 a $23 / 23 / 06 / 06$} \\
\hline
\end{tabular}

1)Indique sua área de atuação? (As opções não são excludentes: você poderá marcar mais de uma opção)

\begin{tabular}{|l|l|}
\hline$x$ & EXTENSÃO RURAL \\
\hline & PESQUISA \\
\hline & ENSINO \\
\hline & OUTROS \\
\hline
\end{tabular}


2) Qual o seu nível de escolaridade?

\begin{tabular}{|l|l|}
\hline & NÍVEL MÉDIO \\
\hline$x$ & NÍVEL SUPERIOR \\
\hline & PÓS-GRADUAÇÃO \\
\hline
\end{tabular}

3) O curso contribuiu para o seu aperfeiçoamento profissional?

\begin{tabular}{|l|l|}
\hline$x$ & SIM \\
\hline & NÃO \\
\hline
\end{tabular}

5) Os conhecimentos adquiridos estão sendo aplicados no seu trabalho? Em caso afirmativo, indique em que grau estes conhecimentos estão sendo aplicados. Em caso negativo, indique por que razão isto não ocorre:

\begin{tabular}{|c|c|c|c|}
\hline \multirow{3}{*}{$x$} & \multirow{3}{*}{$\begin{array}{l}\text { SIM (indique ao lado } \\
\text { em que grau) }\end{array}$} & & MUITO APLICADOS \\
\hline & & $x$ & MEDIAMENTE APLICADOS \\
\hline & & & POUCO APLICADOS \\
\hline & & & $\begin{array}{l}\text { CONTEÚDO NÃO ADEQUADO ÀS NECESSIDADES } \\
\text { ESPECÍFICAS DA REGIÃO }\end{array}$ \\
\hline & NÃO (indique ao lado a & & $\begin{array}{l}\text { CONTEÚDO NÃO FOI SUFICIENTEMENTE } \\
\text { APROFUNDADO PARA PERMITIR UMA APLICAÇÃO } \\
\text { EFICAZ E EFICIENTE }\end{array}$ \\
\hline & razão da não aplicação) & & $\begin{array}{l}\text { FALTA DE APOIO } \\
\text { INSTITUIÇÃO }\end{array}$ \\
\hline & & & FALTA DE INCENTIVO ÀS AÇÕES DE ATER \\
\hline & & & NÃO TENHO INTERESSE EM APLICAR \\
\hline
\end{tabular}

6) A partir deste curso: (As opções não são excludentes: você poderá marcar mais de uma opção)

NÃO MUDOU NADA EM MEU TRABALHO. 


\begin{tabular}{|l|l|}
\hline$x$ & $\begin{array}{l}\text { MEU TRABALHO PASSOU A CONTRIBUIR MAIS COM OS AGRICULTORES(AS) } \\
\text { FAMILIARES. }\end{array}$ \\
\hline & CONSEGUI INFLUENCIAR NAS ORIENTAÇÕES DA MINHA INSTITUIÇÃO. \\
\hline & PASSEI A TRABALHAR COM METODOLOGIAS PARTICIPATIVAS. \\
\hline$x$ & $\begin{array}{l}\text { CRESCEU A AREA DE AGRICULTURA DE BASE ECOLOGGICA NAS COMUNIDADES } \\
\text { ONDE ATUO. }\end{array}$ \\
\hline & CONTINUEI ME APERFEIÇOANDO SOBRE TEMAS ABORDADOS. \\
\hline
\end{tabular}

7) Depois do curso você apoiou atividades de capacitação de técnicos e agricultores com base nos princípios e diretrizes da Pnater? (Considere como apoio a atividades de capacitação a participação no planejamento, elaboração de ementas, seleção de participantes e de palestrantes.)

\begin{tabular}{|l|l|}
\hline & SIM \\
\hline$x$ & NÃO \\
\hline
\end{tabular}

8) Usou os conhecimentos para ministrar outros cursos com o mesmo conteúdo ou conteúdos semelhantes?

\begin{tabular}{|l|l|}
\hline & SIM \\
\hline$x$ & NÃO \\
\hline
\end{tabular}

9) Marque o seu grau de satisfação com relação ao curso oferecido pelo DATER: (Considere a seguinte pontuação: 1 - MUITO RUIM; 2 - RUIM; 3 - REGULAR; 4 - BOM; 5 - MUITO BOM)

\begin{tabular}{|l|l|l|l|l|}
\hline 1 & 2 & 3 & $x 4$ & 5 \\
\hline
\end{tabular}

10) Marque seu grau de satisfação com relação ao DATER: (Considere a seguinte pontuação:

1 - MUITO RUIM; 2 - RUIM; 3 - REGULAR; 4 - BOM; 5 - MUITO BOM)

\begin{tabular}{|l|l|l|l|l|}
\hline 1 & 2 & 3 & $x 4$ & 5 \\
\hline
\end{tabular}


PESQUISA - IMPACTO DAS AÇÕES DE FORMAÇÃO REALIZADAS PELO DATER/SAF/MDA NO PERÍODO 2004-2009

Caros colaboradores,

Contamos com a sua atenção para preencher o formulário abaixo.

O mesmo tem por objetivo fornecer informações para avaliação da Eficiência, Efetividade e Eficácia da Política Pública de Formação de Agentes de Ater adotada pelo Departamento de Assistência Técnica e Extensão Rural, da Secretaria de Agricultura Familiar do Ministério do Desenvolvimento - DATER/SAF/MDA, no período de 2004 a 2009, tema escolhido para Monografia a ser apresentada à Universidade de Brasília (UnB) como requisito parcial para obtenção do grau de Bacharel em Administração.

Você poderá ou não se identificar no questionário e garantimos que todas as informações fornecidas serão confidenciais e utilizadas apenas de forma sistematizada.

IDENTIFICAÇÃO

\begin{tabular}{|c|c|}
\hline Nome: UBIRATAN DE PINA & $\begin{array}{l}\text { Sexo: } \\
(\mathrm{x}) \text { masculino } \quad(\quad) \text { feminino }\end{array}$ \\
\hline $\begin{array}{l}\text { Instituição (nome e tipo de instituição: ONG, } \\
\text { Empresa Pública, etc.): EMATER - PARÁ }\end{array}$ & $\begin{array}{l}\text { Local de trabalho (Cidade e Estado): } \\
\text { JURUTI - PARÁ }\end{array}$ \\
\hline \multicolumn{2}{|c|}{$\begin{array}{l}\text { Curso/Encontro/Oficina do qual participou (caso tenha participado de mais de um curso, } \\
\text { preencha um formulário para cada um deles): TEORIA E PRÁTICA DE MÉTODOS DE ATER }\end{array}$} \\
\hline Data do Curso/Encontro/Oficina (pelo menos mé & ano): 20 A 25 DE NOVEMBRO DE 2006 \\
\hline
\end{tabular}

1)Indique sua área de atuação? (As opções não são excludentes: você poderá marcar mais de uma opção)

\begin{tabular}{|l|l|}
\hline$X$ & EXTENSÃO RURAL \\
\hline & PESQUISA \\
\hline & ENSINO \\
\hline & OUTROS \\
\hline
\end{tabular}


2) Qual o seu nível de escolaridade?

\begin{tabular}{|c|l|}
\hline & NÍVEL MÉDIO \\
\hline$X$ & NÍVEL SUPERIOR \\
\hline & PÓS-GRADUAÇÃO \\
\hline
\end{tabular}

3) Os conteúdos abordados foram condizentes com as demandas do seu dia-a-dia?

\begin{tabular}{|l|l|}
\hline$X$ & SIM \\
\hline & PARCIALMENTE \\
\hline & NÃO \\
\hline
\end{tabular}

3) O curso contribuiu para o seu aperfeiçoamento profissional?

\begin{tabular}{|l|l|}
\hline$X$ & SIM \\
\hline & NÃO \\
\hline
\end{tabular}

5) Os conhecimentos adquiridos estão sendo aplicados no seu trabalho? Em caso afirmativo, indique em que grau estes conhecimentos estão sendo aplicados. Em caso negativo, indique por que razão isto não ocorre:

\begin{tabular}{|c|c|c|c|}
\hline \multirow{3}{*}{$\mathrm{X}$} & \multirow{3}{*}{$\begin{array}{l}\text { SIM (indique ao lado } \\
\text { em que grau) }\end{array}$} & & MUITO APLICADOS \\
\hline & & $\mathrm{X}$ & MEDIAMENTE APLICADOS \\
\hline & & & POUCO APLICADOS \\
\hline & \multirow{3}{*}{$\begin{array}{l}\text { NÃO (indique ao lado a } \\
\text { razão da não aplicação) }\end{array}$} & & $\begin{array}{l}\text { CONTEÚDO NĀO ADEQUADO ȦS NECESSIDADES } \\
\text { ESPECÍFICAS DA REGIÃO }\end{array}$ \\
\hline & & & $\begin{array}{l}\text { CONTEÚDO NĀO FOI SUFICIENTEMENTE } \\
\text { APROFUNDADO PARA PERMITIR UMA APLICAÇÃO } \\
\text { EFICAZ E EFICIENTE }\end{array}$ \\
\hline & & & $\begin{array}{lllllll}\text { FALTA DE } & \text { APOIO } & \text { E } & \text { INCENTIVO } & \text { DA } & \text { MINHA } \\
\text { INSTITUIÇÃO } & & & & \end{array}$ \\
\hline
\end{tabular}




\begin{tabular}{|l|l|l|}
\hline \multirow{2}{*}{} & & FALTA DE INCENTIVO ÀS AÇÕES DE ATER \\
\cline { 3 - 3 } & & NÃO TENHO INTERESSE EM APLICAR \\
\hline
\end{tabular}

6) A partir deste curso: (As opções não são excludentes: você poderá marcar mais de uma opção)

\begin{tabular}{|c|l|}
\hline & NÃO MUDOU NADA EM MEU TRABALHO. \\
\hline$X$ & $\begin{array}{l}\text { MEU TRABALHO PASSOU A CONTRIBUIR MAIS COM OS AGRICULTORES(AS) } \\
\text { FAMILIARES. }\end{array}$ \\
\hline$X$ & CONSEGUI INFLUENCIAR NAS ORIENTAÇÕES DA MINHA INSTITUIÇÃO. \\
\hline$X$ & PASSEI A TRABALHAR COM METODOLOGIAS PARTICIPATIVAS. \\
\hline & $\begin{array}{l}\text { CRESCEU A ÁREA DE AGRICULTURA DE BASE ECOLÓGICA NAS COMUNIDADES } \\
\text { ONDE ATUO. }\end{array}$ \\
\hline & CONTINUEI ME APERFEIÇOANDO SOBRE TEMAS ABORDADOS. \\
\hline
\end{tabular}

7) Depois do curso você apoiou atividades de capacitação de técnicos e agricultores com base nos princípios e diretrizes da Pnater? (Considere como apoio a atividades de capacitação a participação no planejamento, elaboração de ementas, seleção de participantes e de palestrantes.)

\begin{tabular}{|l|l|}
\hline$X$ & SIM \\
\hline & NÃO \\
\hline
\end{tabular}

8) Usou os conhecimentos para ministrar outros cursos com o mesmo conteúdo ou conteúdos semelhantes?

\begin{tabular}{|l|l|}
\hline & SIM \\
\hline$X$ & NÃO \\
\hline
\end{tabular}


9) Marque o seu grau de satisfação com relação ao curso oferecido pelo DATER: (Considere a seguinte pontuação: 1 - MUITO RUIM; 2 - RUIM; 3 - REGULAR; 4 - BOM; 5 - MUITO BOM)

\begin{tabular}{|l|l|l|l|l|}
\hline 1 & 2 & 3 & $4 \times$ & 5 \\
\hline
\end{tabular}

10) Marque seu grau de satisfação com relação ao DATER: (Considere a seguinte pontuação: 1 - MUITO RUIM; 2 - RUIM; 3 - REGULAR; 4 - BOM; 5 - MUITO BOM)

\begin{tabular}{|l|l|l|l|l|}
\hline 1 & 2 & 3 & $4 \times$ & 5 \\
\hline
\end{tabular}




\section{PESQUISA - IMPACTO DAS AÇÕES DE FORMAÇÃO REALIZADAS PELO DATER/SAF/MDA NO PERÍODO 2004-2009}

Caros colaboradores,

Contamos com a sua atenção para preencher o formulário abaixo.

O mesmo tem por objetivo fornecer informações para avaliação da Eficiência, Efetividade e Eficácia da Política Pública de Formação de Agentes de Ater adotada pelo Departamento de Assistência Técnica e Extensão Rural, da Secretaria de Agricultura Familiar do Ministério do Desenvolvimento - DATER/SAF/MDA, no período de 2004 a 2009, tema escolhido para Monografia a ser apresentada à Universidade de Brasília (UnB) como requisito parcial para obtenção do grau de Bacharel em Administração.

Você poderá ou não se identificar no questionário e garantimos que todas as informações fornecidas serão confidenciais e utilizadas apenas de forma sistematizada.

IDENTIFICAÇÃO

\begin{tabular}{|c|c|}
\hline $\begin{array}{l}\text { Nome: } \\
\text { SORAYA MARIA MENDONÇA ARAÚJO }\end{array}$ & $\begin{array}{l}\text { Sexo: } \\
(\quad) \text { masculino }(\mathbf{x}) \text { feminino }\end{array}$ \\
\hline $\begin{array}{l}\text { Instituição (nome e tipo de instituição: ONG, } \\
\text { Empresa Pública, etc.): } \\
\text { EMATER }\end{array}$ & $\begin{array}{l}\text { Local de trabalho (Cidade e Estado): } \\
\text { EMATER - ESLOC. BAGRE } \\
\text { BAGRE - PARÁ }\end{array}$ \\
\hline \multicolumn{2}{|c|}{$\begin{array}{l}\text { Curso/Encontro/Oficina do qual participou (caso tenha participado de mais de um curso, } \\
\text { preencha um formulário para cada um deles): } \\
\text { CURSO DE TEORIA E PRÁTICA DE MÉTODOS DE ATER }\end{array}$} \\
\hline \multicolumn{2}{|c|}{$\begin{array}{l}\text { Data do Curso/Encontro/Oficina (pelo menos mês e ano): } \\
20 \text { A } 24 \text { DE NOVEMBRO DE } 2006\end{array}$} \\
\hline
\end{tabular}

1) Indique sua área de atuação? (As opções não são excludentes: você poderá marcar mais de uma opção)

\begin{tabular}{|l|l|}
\hline$X$ & EXTENSÃO RURAL \\
\hline & PESQUISA \\
\hline
\end{tabular}




\begin{tabular}{|l|l|}
\hline & ENSINO \\
\hline & OUTROS \\
\hline
\end{tabular}

2) Qual o seu nível de escolaridade?

\begin{tabular}{|l|l|}
\hline & NÍVEL MÉDIO \\
\hline & NÍVEL SUPERIOR \\
\hline$X$ & PÓS-GRADUAÇÃO \\
\hline
\end{tabular}

3) Os conteúdos abordados foram condizentes com as demandas do seu dia-a-dia?

\begin{tabular}{|l|l|}
\hline$X$ & SIM \\
\hline & PARCIALMENTE \\
\hline & NÃO \\
\hline
\end{tabular}

4) O curso contribuiu para o seu aperfeiçoamento profissional?

\begin{tabular}{|l|l|}
\hline$X$ & SIM \\
\hline & NÃO \\
\hline
\end{tabular}

5) Os conhecimentos adquiridos estão sendo aplicados no seu trabalho? Em caso afirmativo, indique em que grau estes conhecimentos estão sendo aplicados. Em caso negativo, indique por que razão isto não ocorre:

\begin{tabular}{|l|l|l|l|}
\hline X & $\begin{array}{l}\text { SIM (indique ao lado } \\
\text { em que grau) }\end{array}$ & X & MUITO APLICADOS \\
\cline { 2 - 3 } & & MEDIAMENTE APLICADOS \\
\hline \multirow{2}{*}{$\begin{array}{l}\text { NÃO (indique ao lado a } \\
\text { razão da não aplicação) }\end{array}$} & POUCO APLICADOS \\
\hline
\end{tabular}




\begin{tabular}{|l|l|l|}
\hline \multirow{2}{*}{} & & $\begin{array}{l}\text { CONTEÚDO NĀO FOI SUFICIENTEMENTE } \\
\text { APROFUNDADO PARA PERMITIR UMA APLICAÇÃo } \\
\text { EFICAZ E EFICIENTE }\end{array}$ \\
\cline { 2 - 4 } & $\begin{array}{l}\text { FALTA DE APOIO E INCENTIVO DA MINHA } \\
\text { INSTITUIÇÃO }\end{array}$ \\
\hline & FALTA DE INCENTIVO ÀS AÇÕES DE ATER \\
\hline & NÃO TENHO INTERESSE EM APLICAR \\
\hline
\end{tabular}

6) A partir deste curso: (As opções não são excludentes: você poderá marcar mais de uma opção)

\begin{tabular}{|l|l|}
\hline$x$ & $\begin{array}{l}\text { NÃO MUDOU NADA EM MEU TRABALHO. } \\
\text { FAMILIARES. }\end{array}$ \\
\hline & CONSEGUI INFLUENCIAR NAS ORIENTAÇÕES DA MINHA INSTITUIÇÃO. \\
\hline & PASSEI A TRABALHAR COM METODOLOGIAS PARTICIPATIVAS. \\
\hline & $\begin{array}{l}\text { CRESCEU A ÁREA DE AGRICULTURA DE BASE ECOLÓGICA NAS COMUNIDADES } \\
\text { ONDE ATUO. }\end{array}$ \\
\hline & CONTINUEI ME APERFEIÇOANDO SOBRE TEMAS ABORDADOS. \\
\hline
\end{tabular}

7) Depois do curso você apoiou atividades de capacitação de técnicos e agricultores com base nos princípios e diretrizes da Pnater? (Considere como apoio a atividades de capacitação a participação no planejamento, elaboração de ementas, seleção de participantes e de palestrantes.)

\begin{tabular}{|l|l|}
\hline$X$ & SIM \\
\hline & NÃO \\
\hline
\end{tabular}

8) Usou os conhecimentos para ministrar outros cursos com o mesmo conteúdo ou conteúdos semelhantes?

\begin{tabular}{|l|l|}
\hline$X$ & SIM \\
\hline
\end{tabular}




\section{NÃO}

9) Marque o seu grau de satisfação com relação ao curso oferecido pelo DATER: (Considere a seguinte pontuação: 1 - MUITO RUIM; 2 - RUIM; 3 - REGULAR; 4 - BOM; 5 - MUITO BOM)

\begin{tabular}{|l|l|l|l|l|}
\hline 1 & 2 & 3 & 4 & $(5)$ \\
\hline
\end{tabular}

10) Marque seu grau de satisfação com relação ao DATER: (Considere a seguinte pontuação: 1 - MUITO RUIM; 2 - RUIM; 3 - REGULAR; 4 - BOM; 5 - MUITO BOM)

\begin{tabular}{|l|l|l|l|l|}
\hline 1 & 2 & 3 & 4 & $(5)$ \\
\hline
\end{tabular}


PESQUISA - IMPACTO DAS AÇÕES DE FORMAÇÃO REALIZADAS PELO DATER/SAF/MDA NO PERÍODO 2004-2009

Caros colaboradores,

Contamos com a sua atenção para preencher o formulário abaixo.

O mesmo tem por objetivo fornecer informações para avaliação da Eficiência, Efetividade e Eficácia da Política Pública de Formação de Agentes de Ater adotada pelo Departamento de Assistência Técnica e Extensão Rural, da Secretaria de Agricultura Familiar do Ministério do Desenvolvimento - DATER/SAF/MDA, no período de 2004 a 2009, tema escolhido para Monografia a ser apresentada à Universidade de Brasília (UnB) como requisito parcial para obtenção do grau de Bacharel em Administração.

Você poderá ou não se identificar no questionário e garantimos que todas as informações fornecidas serão confidenciais e utilizadas apenas de forma sistematizada.

IDENTIFICAÇÃO

\begin{tabular}{|c|c|}
\hline $\begin{array}{l}\text { Nome: Francisco Mende de Sá Barretos } \\
\text { Coutinho }\end{array}$ & $\begin{array}{l}\text { Sexo: } \\
(\mathbf{x x x}) \text { masculino } \quad(\quad) \text { feminino }\end{array}$ \\
\hline $\begin{array}{l}\text { Instituição (nome e tipo de instituição: ONG, } \\
\text { Empresa Pública, etc.): EMATER - RONDONIA }\end{array}$ & $\begin{array}{l}\text { Local de trabalho (Cidade e Estado): } \\
\text { EMATER CABIXI }\end{array}$ \\
\hline \multicolumn{2}{|c|}{$\begin{array}{l}\text { Curso/Encontro/Oficina do qual participou (caso tenha participado de mais de um curso, } \\
\text { preencha um formulário para cada um deles): CURSO DE CONTROLE DA CIGARRINHA DAS } \\
\text { PASTAGENS COM APLIC DE FUNGO METARHIZIUM ANISOPLIAE }\end{array}$} \\
\hline Data do Curso/Encontro/Oficina (pelo menos mês & e ano): 23 a $24 / 10 / 2006$ \\
\hline
\end{tabular}

1)Indique sua área de atuação? (As opções não são excludentes: você poderá marcar mais de uma opção).

\begin{tabular}{|l|l|}
\hline$X$ & EXTENSÃO RURAL \\
\hline & PESQUISA \\
\hline & ENSINO \\
\hline & OUTROS \\
\hline
\end{tabular}


2) Qual o seu nível de escolaridade?

\begin{tabular}{|c|l|}
\hline & NÍVEL MÉDIO \\
\hline$X$ & NÍVEL SUPERIOR \\
\hline & PÓS-GRADUAÇÃO \\
\hline
\end{tabular}

3) Os conteúdos abordados foram condizentes com as demandas do seu dia-a-dia?

\begin{tabular}{|l|l|}
\hline$X$ & SIM \\
\hline & PARCIALMENTE \\
\hline & NÃO \\
\hline
\end{tabular}

3) O curso contribuiu para o seu aperfeiçoamento profissional?

\begin{tabular}{|l|l|}
\hline$X$ & SIM \\
\hline & NÃO \\
\hline
\end{tabular}

5) Os conhecimentos adquiridos estão sendo aplicados no seu trabalho? Em caso afirmativo, indique em que grau estes conhecimentos estão sendo aplicados. Em caso negativo, indique por que razão isto não ocorre: (Em caso negativo, as respostas não são excludentes: você poderá marcar mais de uma opção).

\begin{tabular}{|l|l|l|l|}
\hline \multirow{2}{*}{$\begin{array}{l}\text { SIM (indique ao lado } \\
\text { em que grau) }\end{array}$} & $x$ & \multicolumn{1}{|c|}{ MUITO APLICADOS } \\
\cline { 3 - 4 } & & & \multicolumn{1}{|c|}{ POUCO APLICADOS } \\
\hline \multirow{2}{*}{$\begin{array}{l}\text { NÃo (indique ao lado a } \\
\text { razão da não aplicação) }\end{array}$} & & $\begin{array}{l}\text { CONTEÚDO NÃO ADEQUADO ȦS NECESSIDADES } \\
\text { ESPECÍFICAS DA REGIÃO }\end{array}$ \\
\cline { 3 - 4 } & $\begin{array}{l}\text { CONTEÚDO NÃO FOI SUFICIENTEMENTE } \\
\text { APROFUNDADO PARA PERMITIR UMA APLICAÇÃO } \\
\text { EFICAZ E EFICIENTE }\end{array}$ \\
\hline
\end{tabular}




\begin{tabular}{|l|l|l|}
\hline \multirow{2}{*}{} & & $\begin{array}{l}\text { FALTA DE APOIO E INCENTIVO DA MINHA } \\
\text { INSTITUIÇÃO }\end{array}$ \\
\cline { 2 - 3 } & FALTA DE INCENTIVO ÀS AÇÕES DE ATER \\
\cline { 2 - 3 } & NÃO TENHO INTERESSE EM APLICAR \\
\hline
\end{tabular}

6) A partir deste curso: (As opções não são excludentes: você poderá marcar mais de uma opção).

\begin{tabular}{|c|l|}
\hline$X$ & $\begin{array}{l}\text { MẼO MUDOU NADA EM MEU TRABALHO. } \\
\text { FAMILIARES. }\end{array}$ \\
\hline & CONSEGUI INFLUENCIAR NAS ORIENTAÇÕES DA MINHA INSTITUIÇÃO. \\
\hline & PASSEI A TRABALHAR COM METODOLOGIAS PARTICIPATIVAS. \\
\hline & $\begin{array}{l}\text { CRESCEU A ÁREA DE AGRICULTURA DE BASE ECOLÓGICA NAS COMUNIDADES } \\
\text { ONDE ATUO. }\end{array}$ \\
\hline$X$ & CONTINUEI ME APERFEIÇOANDO SOBRE TEMAS ABORDADOS. OS AGRICULTORES(AS) \\
\hline
\end{tabular}

7) Depois do curso você apoiou atividades de capacitação de técnicos e agricultores com base nos princípios e diretrizes da Pnater? (Considere como apoio a atividades de capacitação a participação no planejamento, elaboração de ementas, seleção de participantes e de palestrantes.)

\begin{tabular}{|l|l|}
\hline$X$ & SIM \\
\hline & NÃO \\
\hline
\end{tabular}

8) Usou os conhecimentos para ministrar outros cursos com o mesmo conteúdo ou conteúdos semelhantes? 


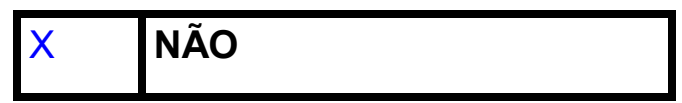

9) Marque o seu grau de satisfação com relação ao curso oferecido pelo DATER:

\begin{tabular}{|l|l|l|l|l|}
\hline 1 & 2 & 3 & 4 & 5 \\
\hline
\end{tabular}

10) Marque seu grau de satisfação com relação ao DATER:

\begin{tabular}{|l|l|l|l|l|}
\hline 1 & 2 & 3 & 4 & 5 \\
\hline
\end{tabular}

3-REGULAR 3 -REGULAR 


\section{PESQUISA - IMPACTO DAS AÇÕES DE FORMAÇÃO REALIZADAS PELO DATER/SAF/MDA NO PERÍODO 2004-2009}

Caros colaboradores,

Contamos com a sua atenção para preencher o formulário abaixo.

O mesmo tem por objetivo fornecer informações para avaliação da Eficiência, Efetividade e Eficácia da Política Pública de Formação de Agentes de Ater adotada pelo Departamento de Assistência Técnica e Extensão Rural, da Secretaria de Agricultura Familiar do Ministério do Desenvolvimento - DATER/SAF/MDA, no período de 2004 a 2009, tema escolhido para Monografia a ser apresentada à Universidade de Brasília (UnB) como requisito parcial para obtenção do grau de Bacharel em Administração.

Você poderá ou não se identificar no questionário e garantimos que todas as informações fornecidas serão confidenciais e utilizadas apenas de forma sistematizada.

IDENTIFICAÇÃO

\begin{tabular}{|c|c|}
\hline Nome: Silvia Aquino do Nascimento & $\begin{array}{l}\text { Sexo: } \\
(\quad) \text { masculino }\end{array}$ \\
\hline $\begin{array}{l}\text { Instituição (nome e tipo de instituição: ONG, } \\
\text { Empresa Pública, etc.): } \\
\text { EMATER- RO }\end{array}$ & $\begin{array}{l}\text { Local de trabalho (Cidade e Estado): } \\
\text { Estrela de Rondônia Município de } \\
\text { Presidente Médici-RO }\end{array}$ \\
\hline \multicolumn{2}{|c|}{$\begin{array}{l}\text { Curso/Encontro/Oficina do qual participou (caso tenha participado de mais de um curso, } \\
\text { preencha um formulário para cada um deles): } \\
\text { Cursos: Processamento de Pescado }\end{array}$} \\
\hline Data do Curso/Encontro/Oficina (pelo menos mês & e ano): \\
\hline
\end{tabular}

1)Indique sua área de atuação? (As opções não são excludentes: você poderá marcar mais de uma opção)

\begin{tabular}{|l|l|}
\hline$X$ & EXTENSÃO RURAL \\
\hline & PESQUISA \\
\hline & ENSINO \\
\hline
\end{tabular}




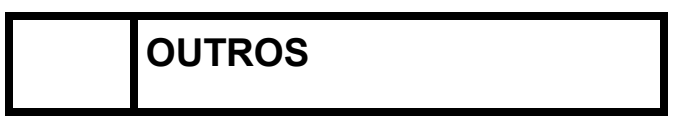

2) Qual o seu nível de escolaridade?

\begin{tabular}{|l|l|}
\hline$X$ & NÍVEL MÉDIO \\
\hline & NÍVEL SUPERIOR \\
\hline & PÓS-GRADUAÇÃO \\
\hline
\end{tabular}

3) Os conteúdos abordados foram condizentes com as demandas do seu dia-a-dia?

\begin{tabular}{|l|l|}
\hline$X$ & SIM \\
\hline & PARCIALMENTE \\
\hline & NÃO \\
\hline
\end{tabular}

3) O curso contribuiu para o seu aperfeiçoamento profissional?

\begin{tabular}{|l|l|}
\hline$X$ & SIM \\
\hline & NÃO \\
\hline
\end{tabular}

5) Os conhecimentos adquiridos estão sendo aplicados no seu trabalho? Em caso afirmativo, indique em que grau estes conhecimentos estão sendo aplicados. Em caso negativo, indique por que razão isto não ocorre:

\begin{tabular}{|c|c|c|c|}
\hline \multirow{3}{*}{$\mathrm{X}$} & \multirow{3}{*}{$\begin{array}{l}\text { SIM (indique ao lado } \\
\text { em que grau) }\end{array}$} & & MUITO APLICADOS \\
\hline & & $\mathrm{X}$ & MEDIAMENTE APLICADOS \\
\hline & & & POUCO APLICADOS \\
\hline & & & $\begin{array}{l}\text { CONTEU்DO NĀO ADEQUADO ȦS NECESSIDADES } \\
\text { ESPECÍFICAS DA REGIÃO }\end{array}$ \\
\hline & razão da não aplicação) & & $\begin{array}{l}\text { CONTEÚDO NÃO FOI SUFICIENTEMENTE } \\
\text { APROFUNDADO PARA PERMITIR UMA APLICAÇÃO } \\
\text { EFICAZ E EFICIENTE }\end{array}$ \\
\hline
\end{tabular}




\begin{tabular}{|l|l|l|}
\hline \multirow{2}{*}{} & & $\begin{array}{l}\text { FALTA DE APOIO E INCENTIVO DA MINHA } \\
\text { INSTITUIÇÃO }\end{array}$ \\
\cline { 3 - 4 } & FALTA DE INCENTIVO ÀS AÇÕES DE ATER \\
\hline & NÃO TENHO INTERESSE EM APLICAR \\
\hline
\end{tabular}

6) A partir deste curso: (As opções não são excludentes: você poderá marcar mais de uma opção)

\begin{tabular}{|l|l|}
\hline & NÃO MUDOU NADA EM MEU TRABALHO. \\
\hline$X$ & $\begin{array}{l}\text { MEU TRABALHO PASSOU A CONTRIBUIR MAIS COM OS AGRICULTORES(AS) } \\
\text { FAMILIARES. }\end{array}$ \\
\hline$X$ & CONSEGUI INFLUENCIAR NAS ORIENTAÇÕES DA MINHA INSTITUIÇÃO. \\
\hline & PASSEI A TRABALHAR COM METODOLOGIAS PARTICIPATIVAS. \\
\hline & $\begin{array}{l}\text { CRESCEU A ÁREA DE AGRICULTURA DE BASE ECOLÓGICA NAS COMUNIDADES } \\
\text { ONDE ATUO. }\end{array}$ \\
\hline$X$ & CONTINUEI ME APERFEIÇOANDO SOBRE TEMAS ABORDADOS. \\
\hline
\end{tabular}

7) Depois do curso você apoiou atividades de capacitação de técnicos e agricultores com base nos princípios e diretrizes da Pnater? (Considere como apoio a atividades de capacitação a participação no planejamento, elaboração de ementas, seleção de participantes e de palestrantes.)

\begin{tabular}{|l|l|}
\hline$X$ & SIM \\
\hline & NÃO \\
\hline
\end{tabular}

8) Usou os conhecimentos para ministrar outros cursos com o mesmo conteúdo ou conteúdos semelhantes?

\begin{tabular}{|l|l|}
\hline & SIM \\
\hline$X$ & NÃO \\
\hline
\end{tabular}


9) Marque o seu grau de satisfação com relação ao curso oferecido pelo DATER: (Considere a seguinte pontuação: 1 - MUITO RUIM; 2 - RUIM; 3 - REGULAR; 4 - BOM; 5 - MUITO BOM)

\begin{tabular}{|l|l|l|l|l|}
\hline 1 & 2 & 3 & $4 X$ & 5 \\
\hline
\end{tabular}

10) Marque seu grau de satisfação com relação ao DATER: (Considere a seguinte pontuação: 1 - MUITO RUIM; 2 - RUIM; 3 - REGULAR; 4 - BOM; 5 - MUITO BOM)

\begin{tabular}{|l|l|l|l|l|}
\hline 1 & 2 & 3 & $4 X$ & 5 \\
\hline
\end{tabular}




\section{PESQUISA - IMPACTO DAS AÇÕES DE FORMAÇÃO REALIZADAS PELO DATER/SAF/MDA NO PERÍODO 2004-2009}

Caros colaboradores,

Contamos com a sua atenção para preencher o formulário abaixo.

O mesmo tem por objetivo fornecer informações para avaliação da Eficiência, Efetividade e Eficácia da Política Pública de Formação de Agentes de Ater adotada pelo Departamento de Assistência Técnica e Extensão Rural, da Secretaria de Agricultura Familiar do Ministério do Desenvolvimento - DATER/SAF/MDA, no período de 2004 a 2009, tema escolhido para Monografia a ser apresentada à Universidade de Brasília (UnB) como requisito parcial para obtenção do grau de Bacharel em Administração.

Você poderá ou não se identificar no questionário e garantimos que todas as informações fornecidas serão confidenciais e utilizadas apenas de forma sistematizada.

IDENTIFICAÇÃO

\begin{tabular}{|l|l|}
\hline Nome: Sandro Malta Xavier & $\begin{array}{l}\text { Sexo: } \\
(\mathbf{x}) \text { masculino } \quad(\quad \text { ) feminino }\end{array}$ \\
\hline $\begin{array}{l}\text { Instituição (nome e tipo de instituição: ONG, } \\
\text { Empresa Pública, etc.): Emater - Ro. }\end{array}$ & $\begin{array}{l}\text { Local de trabalho (Cidade e Estado): } \\
\text { Cerejeiras - Ro. }\end{array}$ \\
\hline $\begin{array}{l}\text { Curso/Encontro/Oficina do qual participou (caso tenha participado de mais de um curso, } \\
\text { preencha um formulário para cada um deles): Curso Controle das Cigarrinhas com Aplicação } \\
\text { de Fungo Metarhizium Anisopliae. }\end{array}$ \\
\hline \begin{tabular}{l} 
Data do Curso/Encontro/Oficina (pelo menos mês e ano): 05 a 09/06/2006. \\
\hline
\end{tabular}
\end{tabular}

1)Indique sua área de atuação? (As opções não são excludentes: você poderá marcar mais de uma opção)

\begin{tabular}{|l|l|}
\hline$x$ & EXTENSÃO RURAL \\
\hline & PESQUISA \\
\hline & ENSINO \\
\hline
\end{tabular}




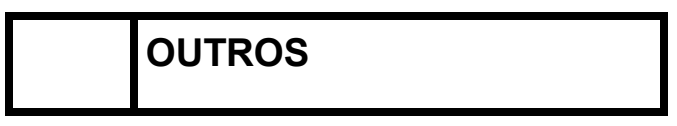

2) Qual o seu nível de escolaridade?

\begin{tabular}{|l|l|}
\hline$x$ & NÍVEL MÉDIO \\
\hline & NÍVEL SUPERIOR \\
\hline & PÓS-GRADUAÇÃO \\
\hline
\end{tabular}

3) Os conteúdos abordados foram condizentes com as demandas do seu dia-a-dia?

\begin{tabular}{|l|l|}
\hline$x$ & SIM \\
\hline & PARCIALMENTE \\
\hline & NÃO \\
\hline
\end{tabular}

4) O curso contribuiu para o seu aperfeiçoamento profissional?

\begin{tabular}{|l|l|}
\hline$x$ & SIM \\
\hline & NÃO \\
\hline
\end{tabular}

5) Os conhecimentos adquiridos estão sendo aplicados no seu trabalho? Em caso afirmativo, indique em que grau estes conhecimentos estão sendo aplicados. Em caso negativo, indique por que razão isto não ocorre:

\begin{tabular}{|c|c|c|c|}
\hline \multirow{3}{*}{$x$} & \multirow{3}{*}{$\begin{array}{l}\text { SIM (indique ao lado } \\
\text { em que grau) }\end{array}$} & & MUITO APLICADOS \\
\hline & & $x$ & MEDIAMENTE APLICADOS \\
\hline & & & POUCO APLICADOS \\
\hline & \multirow{2}{*}{$\begin{array}{l}\text { NÃO (indique ao lado a } \\
\text { razão da não aplicação) }\end{array}$} & & $\begin{array}{l}\text { CONTEÚDO NĀO ADEQUADO ȦS NECESSIDADES } \\
\text { ESPECÍFICAS DA REGIÃO }\end{array}$ \\
\hline & & & $\begin{array}{l}\text { CONTEÚDO NÃO FOI SUFICIENTEMENTE } \\
\text { APROFUNDADO PARA PERMITIR UMA APLICAÇÃO } \\
\text { EFICAZ E EFICIENTE }\end{array}$ \\
\hline
\end{tabular}




\begin{tabular}{|l|l|l|}
\hline \multirow{2}{*}{} & & $\begin{array}{l}\text { FALTA DE APOIO E INCENTIVO DA MINHA } \\
\text { INSTITUIÇÃO }\end{array}$ \\
\cline { 3 - 4 } & & FALTA DE INCENTIVO ÀS AÇÕES DE ATER \\
\cline { 2 - 3 } & NÃO TENHO INTERESSE EM APLICAR \\
\hline
\end{tabular}

6) A partir deste curso: (As opções não são excludentes: você poderá marcar mais de uma opção)

\begin{tabular}{|l|l|}
\hline & NÃO MUDOU NADA EM MEU TRABALHO. \\
\hline$x$ & $\begin{array}{l}\text { MEU TRABALHO PASSOU A CONTRIBUIR MAIS COM OS AGRICULTORES (AS) } \\
\text { FAMILIARES. }\end{array}$ \\
\hline & CONSEGUI INFLUENCIAR NAS ORIENTAÇÕES DA MINHA INSTITUIÇÃO. \\
\hline & PASSEI A TRABALHAR COM METODOLOGIAS PARTICIPATIVAS. \\
\hline & $\begin{array}{l}\text { CRESCEU A ÁREA DE AGRICULTURA DE BASE ECOLÓGICA NAS COMUNIDADES } \\
\text { ONDE ATUO. }\end{array}$ \\
\hline & CONTINUEI ME APERFEIÇOANDO SOBRE TEMAS ABORDADOS. \\
\hline
\end{tabular}

7) Depois do curso você apoiou atividades de capacitação de técnicos e agricultores com base nos princípios e diretrizes da Pnater? (Considere como apoio a atividades de capacitação a participação no planejamento, elaboração de ementas, seleção de participantes e de palestrantes.)

\begin{tabular}{|l|l|}
\hline & SIM \\
\hline$x$ & NÃO \\
\hline
\end{tabular}

8) Usou os conhecimentos para ministrar outros cursos com o mesmo conteúdo ou conteúdos semelhantes? 


\begin{tabular}{|l|l|}
\hline & SIM \\
\hline$x$ & NÃO \\
\hline
\end{tabular}

9) Marque o seu grau de satisfação com relação ao curso oferecido pelo DATER: (Considere a seguinte pontuação: 1 - MUITO RUIM; 2 - RUIM; 3 - REGULAR; 4 - BOM; 5 - MUITO BOM)

\begin{tabular}{|l|l|l|l|l|}
\hline 1 & 2 & 3 & $4 \times$ & 5 \\
\hline
\end{tabular}

10) Marque seu grau de satisfação com relação ao DATER: (Considere a seguinte pontuação: 1 - MUITO RUIM; 2 - RUIM; 3 - REGULAR; 4 - BOM; 5 - MUITO BOM)

\begin{tabular}{|l|l|l|l|l|}
\hline 1 & 2 & 3 & $4 \times$ & 5 \\
\hline
\end{tabular}




\section{PESQUISA - IMPACTO DAS AÇÕES DE FORMAÇÃO REALIZADAS PELO DATER/SAF/MDA NO PERÍODO 2004-2009}

Caros colaboradores,

Contamos com a sua atenção para preencher o formulário abaixo.

O mesmo tem por objetivo fornecer informações para avaliação da Eficiência, Efetividade e Eficácia da Política Pública de Formação de Agentes de Ater adotada pelo Departamento de Assistência Técnica e Extensão Rural, da Secretaria de Agricultura Familiar do Ministério do Desenvolvimento - DATER/SAF/MDA, no período de 2004 a 2009, tema escolhido para Monografia a ser apresentada à Universidade de Brasília (UnB) como requisito parcial para obtenção do grau de Bacharel em Administração.

Você poderá ou não se identificar no questionário e garantimos que todas as informações fornecidas serão confidenciais e utilizadas apenas de forma sistematizada.

\section{IDENTIFICAÇÃO}

Nome: Rui Ikegami

Sexo: MAsculino

Instituição: EMATER - PARÁ

Local de Trabalho: Monte Alegre - PA.

Curso/Encontro/Oficina do qual participou:

- Intercâmbio: Produtos Orgânicos da Agricultura Familiar/ RS.

\section{Data do Curso/Encontro/Oficina:}

$-2004$.

Indique sua área de atuação (As opções não são excludentes: você poderá marcar mais de uma opção)

\begin{tabular}{|l|l|}
\hline $\mathbf{X}$ & Extensão Rural. \\
\hline & Pesquisa \\
\hline & Ensino \\
\hline & Outros \\
\hline
\end{tabular}


Qual seu nível de escolaridade?

\begin{tabular}{|l|l|}
\hline & Nível Médio \\
\hline $\mathbf{X}$ & Nível Superior \\
\hline & Pós-Graduação \\
\hline
\end{tabular}

Os conteúdos abordados foram condizentes com as demandas do seu dia-a-dia?

\begin{tabular}{|l|l|}
\hline $\mathbf{X}$ & Sim \\
\hline & Parcialmente \\
\hline & Não \\
\hline
\end{tabular}

O curso contribuiu para o seu aperfeiçoamento profissional?

\begin{tabular}{|l|l|}
\hline $\mathbf{X}$ & Sim \\
\hline & Não \\
\hline
\end{tabular}

Os conhecimentos adquiridos estão sendo aplicados no seu trabalho? Em caso afirmativo, indique em que grau estes conhecimentos estão sendo aplicados. Em caso negativo, indique por que razão isto não ocorre.

\begin{tabular}{|l|l|l|l|}
\hline \multirow{2}{*}{$\begin{array}{l}\text { SIM (indique ao lado } \\
\text { em que grau) }\end{array}$} & & Muito aplicados \\
\cline { 2 - 3 } & $\mathbf{X}$ & Medianamente aplicados \\
\hline \multirow{2}{*}{$\begin{array}{l}\text { NÃO (indique ao } \\
\text { lado a razão da não } \\
\text { aplicação) }\end{array}$} & & $\begin{array}{l}\text { Conteúdo não adequado às necessidades } \\
\text { específicas da região }\end{array}$ \\
\cline { 2 - 3 } & & $\begin{array}{l}\text { Conteúdo não foi suficiente aprofundado para } \\
\text { permitir uma aplicação eficaz e eficiente. }\end{array}$ \\
\cline { 2 - 3 } & & Falta de apoio e incentivo da minha instituição. \\
\cline { 2 - 3 } & & Falta de incentivo às ações de ATER \\
\hline
\end{tabular}

A partir deste curso: (As opções não são excludentes: você poderá marcar mais de uma opção)

\begin{tabular}{|l|l|}
\hline & Não mudou nada em meu trabalho. \\
\hline $\mathbf{X}$ & Meu trabalho passou a contribuir mais com os agricultores(as) familiares. \\
\hline
\end{tabular}




\begin{tabular}{|l|l|}
\hline $\mathbf{X}$ & Consegui influenciar nas orientações de minha instituição. \\
\hline $\mathbf{X}$ & Passei a trabalhar com metodologias participativas. \\
\hline $\mathbf{X}$ & Cresceu a área de agricultura de base ecológica nas comunidades onde atuo. \\
\hline & Continuei me aperfeiçoando sobre temas abordados. \\
\hline
\end{tabular}

Depois do curso você apoiou atividades de capacitação de técnicos e agricultores com base nos princípios e diretrizes da Pnater? (Considere como apoio a atividades de capacitação a participação no planejamento, elaboração de ementas, seleção de participantes e de palestrantes.)

\begin{tabular}{|l|l|}
\hline $\mathbf{X}$ & Sim \\
\hline & Não \\
\hline
\end{tabular}

Usou os conhecimentos para ministrar outros cursos com o mesmo conteúdo ou conteúdos semelhantes?

\begin{tabular}{|l|l|}
\hline $\mathbf{X}$ & Sim \\
\hline & Não \\
\hline
\end{tabular}

Marque o seu grau de satisfação com relação ao curso oferecido pelo DATER: (Considere a seguinte pontuação: 1 - MUITO RUIM; 2 - RUIM; 3 - REGULAR; 4 - BOM; 5 - MUITO BOM)

\begin{tabular}{|l|l|l|l|l|}
\hline $\mathbf{1}$ & $\mathbf{2}$ & $\mathbf{3}$ & $\mathbf{X}$ & $\mathbf{5}$ \\
\hline
\end{tabular}

Marque seu grau de satisfação com relação ao DATER: (Considere a seguinte pontuação: 1 - MUITO RUIM; 2 - RUIM; 3 - REGULAR; 4 - BOM; 5 - MUITO BOM)

\begin{tabular}{|l|l|l|l|l|}
\hline $\mathbf{1}$ & $\mathbf{2}$ & $\mathbf{3}$ & $\mathbf{4}$ & $\mathrm{X}$ \\
\hline
\end{tabular}




\section{PESQUISA - IMPACTO DAS AÇÕES DE FORMAÇÃO REALIZADAS PELO DATER/SAF/MDA NO PERÍODO 2004-2009}

Caros colaboradores,

Contamos com a sua atenção para preencher o formulário abaixo.

O mesmo tem por objetivo fornecer informações para avaliação da Eficiência, Efetividade e Eficácia da Política Pública de Formação de Agentes de Ater adotada pelo Departamento de Assistência Técnica e Extensão Rural, da Secretaria de Agricultura Familiar do Ministério do Desenvolvimento - DATER/SAF/MDA, no período de 2004 a 2009, tema escolhido para Monografia a ser apresentada à Universidade de Brasília (UnB) como requisito parcial para obtenção do grau de Bacharel em Administração.

Você poderá ou não se identificar no questionário e garantimos que todas as informações fornecidas serão confidenciais e utilizadas apenas de forma sistematizada.

\section{IDENTIFICAÇÃO}

Nome: Rui Ikegami

Instituição: EMATER - PARÁ

Sexo: :Masculino

Local de Trabalho: Monte Alegre - PA.

Curso/Encontro/Oficina do qual participou:

- Curso de Agroecologia: Transição da Extensão Rural.

Data do Curso/Encontro/Oficina:

- 2003

Indique sua área de atuação (As opções não são excludentes: você poderá marcar mais de uma opção)

\begin{tabular}{|l|l|}
\hline $\mathbf{X}$ & Extensão Rural. \\
\hline & Pesquisa \\
\hline & Ensino \\
\hline & Outros \\
\hline
\end{tabular}


Qual seu nível de escolaridade?

\begin{tabular}{|l|l|}
\hline & Nível Médio \\
\hline $\mathbf{X}$ & Nível Superior \\
\hline & Pós-Graduação \\
\hline
\end{tabular}

Os conteúdos abordados foram condizentes com as demandas do seu dia-a-dia?

\begin{tabular}{|l|l|}
\hline $\mathbf{X}$ & Sim \\
\hline & Parcialmente \\
\hline & Não \\
\hline
\end{tabular}

O curso contribuiu para o seu aperfeiçoamento profissional?

\begin{tabular}{|l|l|}
\hline $\mathbf{X}$ & Sim \\
\hline & Não \\
\hline
\end{tabular}

Os conhecimentos adquiridos estão sendo aplicados no seu trabalho? Em caso afirmativo, indique em que grau estes conhecimentos estão sendo aplicados. Em caso negativo, indique por que razão isto não ocorre.

\begin{tabular}{|l|l|l|l|}
\hline \multirow{2}{*}{$\begin{array}{l}\text { SIM (indique ao lado } \\
\text { em que grau) }\end{array}$} & $\mathbf{X}$ & Muito aplicados \\
\cline { 3 - 3 } & & Medianamente aplicados \\
\hline \multirow{2}{*}{$\begin{array}{l}\text { NÃO (indique ao } \\
\text { lado a razão da não } \\
\text { aplicação) }\end{array}$} & & $\begin{array}{l}\text { Conteúdo não adequado às necessidades } \\
\text { específicas da região }\end{array}$ \\
\cline { 2 - 3 } & & $\begin{array}{l}\text { Conteúdo não foi suficiente aprofundado para } \\
\text { permitir uma aplicação eficaz e eficiente. }\end{array}$ \\
\cline { 2 - 3 } & & Falta de apoio e incentivo da minha instituição. \\
\hline & & Falta de incentivo às ações de ATER \\
\hline
\end{tabular}


A partir deste curso: (As opções não são excludentes: você poderá marcar mais de uma opção)

\begin{tabular}{|l|l|}
\hline & Não mudou nada em meu trabalho. \\
\hline $\mathbf{X}$ & Meu trabalho passou a contribuir mais com os agricultores(as) familiares. \\
\hline $\mathbf{X}$ & Consegui influenciar nas orientações de minha instituição. \\
\hline $\mathbf{X}$ & Passei a trabalhar com metodologias participativas. \\
\hline $\mathbf{X}$ & Cresceu a área de agricultura de base ecológica nas comunidades onde atuo. \\
\hline & Continuei me aperfeiçoando sobre temas abordados. \\
\hline
\end{tabular}

Depois do curso você apoiou atividades de capacitação de técnicos e agricultores com base nos princípios e diretrizes da Pnater? (Considere como apoio a atividades de capacitação a participação no planejamento, elaboração de ementas, seleção de participantes e de palestrantes.)

\begin{tabular}{|l|l|}
\hline $\mathbf{X}$ & Sim \\
\hline & Não \\
\hline
\end{tabular}

Usou os conhecimentos para ministrar outros cursos com o mesmo conteúdo ou conteúdos semelhantes?

\begin{tabular}{|l|l|}
\hline $\mathbf{X}$ & Sim \\
\hline & Não \\
\hline
\end{tabular}

Marque o seu grau de satisfação com relação ao curso oferecido pelo DATER: (Considere a seguinte pontuação: 1 - MUITO RUIM; 2 - RUIM; 3 - REGULAR; 4 - BOM; 5 - MUITO BOM)

\begin{tabular}{|l|l|l|l|l|}
\hline $\mathbf{1}$ & $\mathbf{2}$ & $\mathbf{3}$ & $\mathbf{X}$ & $\mathbf{5}$ \\
\hline
\end{tabular}

Marque seu grau de satisfação com relação ao DATER: (Considere a seguinte pontuação: 1 - MUITO RUIM; 2 - RUIM; 3 - REGULAR; 4 - BOM; 5 - MUITO BOM)

\begin{tabular}{|l|l|l|l|l|}
\hline 1 & 2 & 3 & 4 & $X$ \\
\hline
\end{tabular}




\section{PESQUISA - IMPACTO DAS AÇÕES DE FORMAÇÃO REALIZADAS PELO DATER/SAF/MDA NO PERÍODO 2004-2009}

Caros colaboradores,

Contamos com a sua atenção para preencher o formulário abaixo.

O mesmo tem por objetivo fornecer informações para avaliação da Eficiência, Efetividade e Eficácia da Política Pública de Formação de Agentes de Ater adotada pelo Departamento de Assistência Técnica e Extensão Rural, da Secretaria de Agricultura Familiar do Ministério do Desenvolvimento - DATER/SAF/MDA, no período de 2004 a 2009, tema escolhido para Monografia a ser apresentada à Universidade de Brasília (UnB) como requisito parcial para obtenção do grau de Bacharel em Administração.

Você poderá ou não se identificar no questionário e garantimos que todas as informações fornecidas serão confidenciais e utilizadas apenas de forma sistematizada.

\section{IDENTIFICAÇÃO}

Nome: Rui Ikegami

Instituição: EMATER - PARÁ

Sexo: :Masculino

Local de Trabalho: Monte Alegre - PA.

Curso/Encontro/Oficina do qual participou:

- Curso de Agroecologia: Transição da Extensão Rural.

Data do Curso/Encontro/Oficina:

- 2003

Indique sua área de atuação (As opções não são excludentes: você poderá marcar mais de uma opção)

\begin{tabular}{|l|l|}
\hline $\mathbf{X}$ & Extensão Rural. \\
\hline & Pesquisa \\
\hline & Ensino \\
\hline & Outros \\
\hline
\end{tabular}


Qual seu nível de escolaridade?

\begin{tabular}{|l|l|}
\hline & Nível Médio \\
\hline $\mathbf{X}$ & Nível Superior \\
\hline & Pós-Graduação \\
\hline
\end{tabular}

Os conteúdos abordados foram condizentes com as demandas do seu dia-a-dia?

\begin{tabular}{|l|l|}
\hline $\mathbf{X}$ & Sim \\
\hline & Parcialmente \\
\hline & Não \\
\hline
\end{tabular}

O curso contribuiu para o seu aperfeiçoamento profissional?

\begin{tabular}{|l|l|}
\hline $\mathbf{X}$ & Sim \\
\hline & Não \\
\hline
\end{tabular}

Os conhecimentos adquiridos estão sendo aplicados no seu trabalho? Em caso afirmativo, indique em que grau estes conhecimentos estão sendo aplicados. Em caso negativo, indique por que razão isto não ocorre.

\begin{tabular}{|l|l|l|l|}
\hline \multirow{2}{*}{$\begin{array}{l}\text { SIM (indique ao lado } \\
\text { em que grau) }\end{array}$} & $\mathbf{X}$ & Muito aplicados \\
\cline { 2 - 3 } & & \begin{tabular}{l} 
Pouco aplicados \\
\multirow{2}{*}{$\begin{array}{l}\text { NÃO (indique ao } \\
\text { lado a razão da não } \\
\text { aplicação) }\end{array}$}
\end{tabular} & $\begin{array}{l}\text { Conteúdo não adequado às necessidades } \\
\text { específicas da região }\end{array}$ \\
\cline { 2 - 3 } & $\begin{array}{l}\text { Conteúdo não foi suficiente aprofundado para } \\
\text { permitir uma aplicação eficaz e eficiente. }\end{array}$ \\
\cline { 2 - 3 } & Falta de apoio e incentivo da minha instituição. \\
\hline
\end{tabular}


\begin{tabular}{|l|l|l|l}
\hline & & & Não tenho interesse em aplicar. \\
\hline
\end{tabular}

A partir deste curso: (As opções não são excludentes: você poderá marcar mais de uma opção)

\begin{tabular}{|l|l|}
\hline & Não mudou nada em meu trabalho. \\
\hline $\mathbf{X}$ & Meu trabalho passou a contribuir mais com os agricultores(as) familiares. \\
\hline $\mathbf{X}$ & Consegui influenciar nas orientações de minha instituição. \\
\hline $\mathbf{X}$ & Passei a trabalhar com metodologias participativas. \\
\hline $\mathbf{X}$ & Cresceu a área de agricultura de base ecológica nas comunidades onde atuo. \\
\hline & Continuei me aperfeiçoando sobre temas abordados. \\
\hline
\end{tabular}

Depois do curso você apoiou atividades de capacitação de técnicos e agricultores com base nos princípios e diretrizes da Pnater? (Considere como apoio a atividades de capacitação a participação no planejamento, elaboração de ementas, seleção de participantes e de palestrantes.)

\begin{tabular}{|l|l|}
\hline $\mathbf{X}$ & Sim \\
\hline & Não \\
\hline
\end{tabular}

Usou os conhecimentos para ministrar outros cursos com o mesmo conteúdo ou conteúdos semelhantes?

\begin{tabular}{|l|l|}
\hline $\mathbf{X}$ & Sim \\
\hline & Não \\
\hline
\end{tabular}

Marque o seu grau de satisfação com relação ao curso oferecido pelo DATER: (Considere a seguinte pontuação: 1 - MUITO RUIM; 2 - RUIM; 3 - REGULAR; 4 - BOM; 5 - MUITO BOM)

\begin{tabular}{|l|l|l|l|l|}
\hline $\mathbf{1}$ & $\mathbf{2}$ & $\mathbf{3}$ & $\mathbf{X}$ & $\mathbf{5}$ \\
\hline
\end{tabular}

Marque seu grau de satisfação com relação ao DATER: (Considere a seguinte pontuação: 1 - MUITO RUIM; 2 - RUIM; 3 - REGULAR; 4 - BOM; 5 - MUITO BOM)

\begin{tabular}{|l|l|l|l|l|}
\hline $\mathbf{1}$ & $\mathbf{2}$ & $\mathbf{3}$ & $\mathbf{4}$ & $\mathbf{X}$ \\
\hline
\end{tabular}




\section{PESQUISA - IMPACTO DAS AÇÕES DE FORMAÇÃO REALIZADAS PELO DATER/SAF/MDA NO PERÍODO 2004-2009}

Caros colaboradores,

Contamos com a sua atenção para preencher o formulário abaixo.

O mesmo tem por objetivo fornecer informações para avaliação da Eficiência, Efetividade e Eficácia da Política Pública de Formação de Agentes de Ater adotada pelo Departamento de Assistência Técnica e Extensão Rural, da Secretaria de Agricultura Familiar do Ministério do Desenvolvimento - DATER/SAF/MDA, no período de 2004 a 2009, tema escolhido para Monografia a ser apresentada à Universidade de Brasília $(U n B)$ como requisito parcial para obtenção do grau de Bacharel em Administração.

Você poderá ou não se identificar no questionário e garantimos que todas as informações fornecidas serão confidenciais e utilizadas apenas de forma sistematizada.

IDENTIFICAÇÃO

\begin{tabular}{|c|c|}
\hline Nome: ROZENA FERREIRA & $\begin{array}{l}\text { Sexo: } \\
\left(\begin{array}{ll}(\quad) \text { masculino } \quad(x) \text { feminino }\end{array}\right.\end{array}$ \\
\hline $\begin{array}{l}\text { Instituição (nome e tipo de instituição: ONG, } \\
\text { Empresa Pública, etc.): } \\
\text { EMATER - RO }\end{array}$ & Local de trabalho (Cidade e Estado): \\
\hline \multicolumn{2}{|c|}{$\begin{array}{l}\text { Curso/Encontro/Oficina do qual participou (caso tenha participado de mais de um curso, } \\
\text { preencha um formulário para cada um deles): MANEJO DE PASTAGEM COM ÊNFASE NO } \\
\text { CONTROLE BIOLOGICO DA CIGARRINHA, MELHORIA DA QUALIDADE SO LEITE. }\end{array}$} \\
\hline & ano): \\
\hline
\end{tabular}

1)Indique sua área de atuação? (As opções não são excludentes: você poderá marcar mais de uma opção)

\begin{tabular}{|l|l|}
\hline$X$ & EXTENSÃO RURAL \\
\hline & PESQUISA \\
\hline & ENSINO \\
\hline & OUTROS \\
\hline
\end{tabular}


2) Qual o seu nível de escolaridade?

\begin{tabular}{|l|l|}
\hline & NÍVEL MÉDIO \\
\hline$X$ & NÍVEL SUPERIOR \\
\hline & PÓS-GRADUAÇÃO \\
\hline
\end{tabular}

3) Os conteúdos abordados foram condizentes com as demandas do seu dia-a-dia?

\begin{tabular}{|l|l|}
\hline$X$ & SIM \\
\hline & PARCIALMENTE \\
\hline & NÃO \\
\hline
\end{tabular}

4) O curso contribuiu para o seu aperfeiçoamento profissional?

\begin{tabular}{|l|l|}
\hline$X$ & SIM \\
\hline & NÃO \\
\hline
\end{tabular}

5) Os conhecimentos adquiridos estão sendo aplicados no seu trabalho? Em caso afirmativo, indique em que grau estes conhecimentos estão sendo aplicados. Em caso negativo, indique por que razão isto não ocorre:

\begin{tabular}{|c|c|c|c|}
\hline \multirow{3}{*}{$\mathrm{x}$} & \multirow{3}{*}{$\begin{array}{l}\text { SIM (indique ao lado } \\
\text { em que grau) }\end{array}$} & $\mathrm{X}$ & MUITO APLICADOS \\
\hline & & & MEDIAMENTE APLICADOS \\
\hline & & & POUCO APLICADOS \\
\hline & NÃO (indique ao lado & & $\begin{array}{lccc}\text { CONTEÚDO } & \text { NĀO } & \text { ADEQUADO } & \text { ÀS } \\
\text { NECESSIDADES ESPECIIFICAS DA REGIÃO } & \end{array}$ \\
\hline & $\begin{array}{lr}\text { a razão da não } \\
\text { aplicação) }\end{array}$ & & $\begin{array}{lrrr}\text { CONTEÚDO NÃO } & \text { FOI } & \text { SUFICIENTEMENTE } \\
\text { APROFUNDADO } & \text { PARA } & \text { PERMITIR } & \text { UMA } \\
\text { APLICAÇÃO EFICAZ E EFICIENTE } & \end{array}$ \\
\hline
\end{tabular}




\begin{tabular}{|l|l|l|}
\hline \multirow{2}{*}{} & & $\begin{array}{l}\text { FALTA DE APOIO E INCENTIVO DA MINHA } \\
\text { INSTITUIÇÃO }\end{array}$ \\
\hline & & FALTA DE INCENTIVO ÀS AÇÕES DE ATER \\
\cline { 3 - 4 } & NÃO TENHO INTERESSE EM APLICAR \\
\hline
\end{tabular}

6) A partir deste curso: (As opções não são excludentes: você poderá marcar mais de uma opção)

\begin{tabular}{|l|l|}
\hline & NÃO MUDOU NADA EM MEU TRABALHO. \\
\hline$X$ & $\begin{array}{l}\text { MEU TRABALHO PASSOU A CONTRIBUIR MAIS COM OS AGRICULTORES(AS) } \\
\text { FAMILIARES. }\end{array}$ \\
\hline & CONSEGUI INFLUENCIAR NAS ORIENTAÇÕES DA MINHA INSTITUIÇÃO. \\
\hline & PASSEI A TRABALHAR COM METODOLOGIAS PARTICIPATIVAS. \\
\hline & $\begin{array}{l}\text { CRESCEU A ÁREA DE AGRICULTURA DE BASE ECOLÓGICA NAS } \\
\text { COMUNIDADES ONDE ATUO. }\end{array}$ \\
\hline & CONTINUEI ME APERFEIÇOANDO SOBRE TEMAS ABORDADOS. \\
\hline
\end{tabular}

7) Depois do curso você apoiou atividades de capacitação de técnicos e agricultores com base nos princípios e diretrizes da Pnater? (Considere como apoio a atividades de capacitação a participação no planejamento, elaboração de ementas, seleção de participantes e de palestrantes.)

\begin{tabular}{|l|l|}
\hline$X$ & SIM \\
\hline & NÃO \\
\hline
\end{tabular}

8) Usou os conhecimentos para ministrar outros cursos com o mesmo conteúdo ou conteúdos semelhantes? 


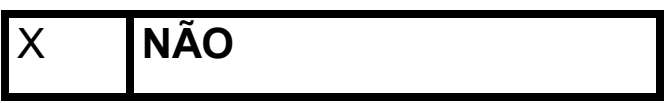

9) Marque o seu grau de satisfação com relação ao curso oferecido pelo DATER: (Considere a seguinte pontuação: 1 - MUITO RUIM; 2 - RUIM; 3 - REGULAR; 4 BOM; 5 - MUITO BOM)

\begin{tabular}{|l|l|l|l|l|}
\hline 1 & 2 & 3 & 4 & 5 \\
\hline
\end{tabular}

10) Marque seu grau de satisfação com relação ao DATER: (Considere a seguinte pontuação: 1 - MUITO RUIM; 2 - RUIM; 3 - REGULAR; 4 - BOM; 5 - MUITO BOM)

\begin{tabular}{|l|l|l|l|l|}
\hline 1 & 2 & 3 & 4 & 5 \\
\hline
\end{tabular}


PESQUISA - IMPACTO DAS AÇÕES DE FORMAÇÃO REALIZADAS PELO DATER/SAF/MDA NO PERÍODO 2004-2009

Caros colaboradores,

Contamos com a sua atenção para preencher o formulário abaixo.

O mesmo tem por objetivo fornecer informações para avaliação da Eficiência, Efetividade e Eficácia da Política Pública de Formação de Agentes de Ater adotada pelo Departamento de Assistência Técnica e Extensão Rural, da Secretaria de Agricultura Familiar do Ministério do Desenvolvimento - DATER/SAF/MDA, no período de 2004 a 2009, tema escolhido para Monografia a ser apresentada à Universidade de Brasília (UnB) como requisito parcial para obtenção do grau de Bacharel em Administração.

Você poderá ou não se identificar no questionário e garantimos que todas as informações fornecidas serão confidenciais e utilizadas apenas de forma sistematizada.

IDENTIFICAÇÃO

\begin{tabular}{|c|c|}
\hline Nome: Rodolfo Gustavo Teixeira Ribas & $\begin{array}{l}\text { Sexo: } \\
(x) \text { masculino } \quad(\quad) \text { feminino }\end{array}$ \\
\hline $\begin{array}{l}\text { Instituição (nome e tipo de instituição: ONG, } \\
\text { Empresa Pública, etc.): } \\
\text { Emater RO }\end{array}$ & $\begin{array}{l}\text { Local de trabalho (Cidade e Estado): } \\
\text { Cerejeiras RO }\end{array}$ \\
\hline \multicolumn{2}{|c|}{$\begin{array}{l}\text { Curso/Encontro/Oficina do qual participou (caso tenha participado de mais de um } \\
\text { curso, preencha um formulário para cada um deles): } \\
\text { Agroecologia }\end{array}$} \\
\hline $\begin{array}{l}\text { Data do Curso/Encontro/Oficina (pelo menos } \\
2008\end{array}$ & mês e ano): \\
\hline
\end{tabular}

Indique sua área de atuação? (As opções não são excludentes: você poderá marcar mais de uma opção)

\begin{tabular}{|l|l|}
\hline$X$ & EXTENSÃO RURAL \\
\hline & PESQUISA \\
\hline$x$ & ENSINO \\
\hline
\end{tabular}




\section{OUTROS}

2) Qual o seu nível de escolaridade?

\begin{tabular}{|l|l|}
\hline & NÍVEL MÉDIO \\
\hline & NÍVEL SUPERIOR \\
\hline$x$ & PÓS-GRADUAÇÃO \\
\hline
\end{tabular}

3) Os conteúdos abordados foram condizentes com as demandas do seu dia-a-dia?

\begin{tabular}{|l|l|}
\hline & SIM \\
\hline$x$ & PARCIALMENTE \\
\hline & NÃO \\
\hline
\end{tabular}

4) O curso contribuiu para o seu aperfeiçoamento profissional?

\begin{tabular}{|l|l|}
\hline$X$ & SIM \\
\hline & NÃO \\
\hline
\end{tabular}

5) Os conhecimentos adquiridos estão sendo aplicados no seu trabalho? Em caso afirmativo, indique em que grau estes conhecimentos estão sendo aplicados. Em caso negativo, indique por que razão isto não ocorre:

\begin{tabular}{|l|l|l|l|}
\hline \multirow{2}{*}{$\begin{array}{l}\text { SIM (indique ao lado } \\
\text { em que grau) }\end{array}$} & & MUITO APLICADOS \\
\cline { 2 - 4 } & & MEDIAMENTE APLICADOS \\
\hline x & $\begin{array}{l}\text { NÃO (indique ao lado } \\
\text { a razão da não }\end{array}$ & & $\begin{array}{l}\text { POUCO APLICADOS } \\
\text { NECESSIDADES ESPECÍFICAS DA REGIÃO }\end{array}$ \\
\hline
\end{tabular}




\begin{tabular}{|l|l|l|}
\hline aplicação) & $\begin{array}{l}\text { CONTEÚDO NÃO FOI SUFICIENTEMENTE } \\
\text { APROFUNDADO PARA PERMITIR UMA } \\
\text { APLICAÇÃO EFICAZ E EFICIENTE }\end{array}$ \\
\hline & $\begin{array}{l}\text { FALTA DE APOIO E INCENTIVO DA MINHA } \\
\text { INSTITUIÇÃO }\end{array}$ \\
\hline & FALTA DE INCENTIVO ÀS AÇÕES DE ATER \\
\cline { 2 - 4 } & NÃO TENHO INTERESSE EM APLICAR \\
\hline
\end{tabular}

6) A partir deste curso: (As opções não são excludentes: você poderá marcar mais de uma opção)

\begin{tabular}{|l|l|}
\hline & NÃO MUDOU NADA EM MEU TRABALHO. \\
\hline & $\begin{array}{l}\text { MEU TRABALHO PASSOU A CONTRIBUIR MAIS COM OS AGRICULTORES(AS) } \\
\text { FAMILIARES. }\end{array}$ \\
\hline$X$ & CONSEGUI INFLUENCIAR NAS ORIENTAÇÕES DA MINHA INSTITUIÇÃO. \\
\hline & PASSEI A TRABALHAR COM METODOLOGIAS PARTICIPATIVAS. \\
\hline & $\begin{array}{l}\text { CRESCEU A ÁREA DE AGRICULTURA DE BASE ECOLÓGICA NAS } \\
\text { COMUNIDADES ONDE ATUO. }\end{array}$ \\
\hline & CONTINUEI ME APERFEIÇOANDO SOBRE TEMAS ABORDADOS. \\
\hline
\end{tabular}

7) Depois do curso você apoiou atividades de capacitação de técnicos e agricultores com base nos princípios e diretrizes da Pnater?

\begin{tabular}{|l|l|}
\hline$x$ & SIM \\
\hline & NÃO \\
\hline
\end{tabular}

8) Usou os conhecimentos para ministrar outros cursos com o mesmo conteúdo ou conteúdos semelhantes?

\begin{tabular}{|l|l|}
\hline$x$ & SIM \\
\hline & NÃO \\
\hline
\end{tabular}


9) Marque o seu grau de satisfação com relação ao curso oferecido pelo DATER: (Considere a seguinte pontuação: 1 - MUITO RUIM; 2 - RUIM; 3 - REGULAR; 4 BOM; 5 - MUITO BOM)

\begin{tabular}{|l|l|l|l|l|}
\hline 1 & 2 & 3 & 4 & 5 \\
\hline
\end{tabular}

10) Marque seu grau de satisfação com relação ao DATER: (Considere a seguinte pontuação: 1 - MUITO RUIM; 2 - RUIM; 3 - REGULAR; 4 - BOM; 5 - MUITO BOM)

\begin{tabular}{|l|l|l|l|l|}
\hline 1 & 2 & 3 & 4 & 5 \\
\hline
\end{tabular}




\section{PESQUISA - IMPACTO DAS AÇÕES DE FORMAÇÃO REALIZADAS PELO DATER/SAF/MDA NO PERÍODO 2004-2009}

Caros colaboradores,

Contamos com a sua atenção para preencher o formulário abaixo.

O mesmo tem por objetivo fornecer informações para avaliação da Eficiência, Efetividade e Eficácia da Política Pública de Formação de Agentes de Ater adotada pelo Departamento de Assistência Técnica e Extensão Rural, da Secretaria de Agricultura Familiar do Ministério do Desenvolvimento - DATER/SAF/MDA, no período de 2004 a 2009, tema escolhido para Monografia a ser apresentada à Universidade de Brasília (UnB) como requisito parcial para obtenção do grau de Bacharel em Administração.

Você poderá ou não se identificar no questionário e garantimos que todas as informações fornecidas serão confidenciais e utilizadas apenas de forma sistematizada.

IDENTIFICAÇÃO

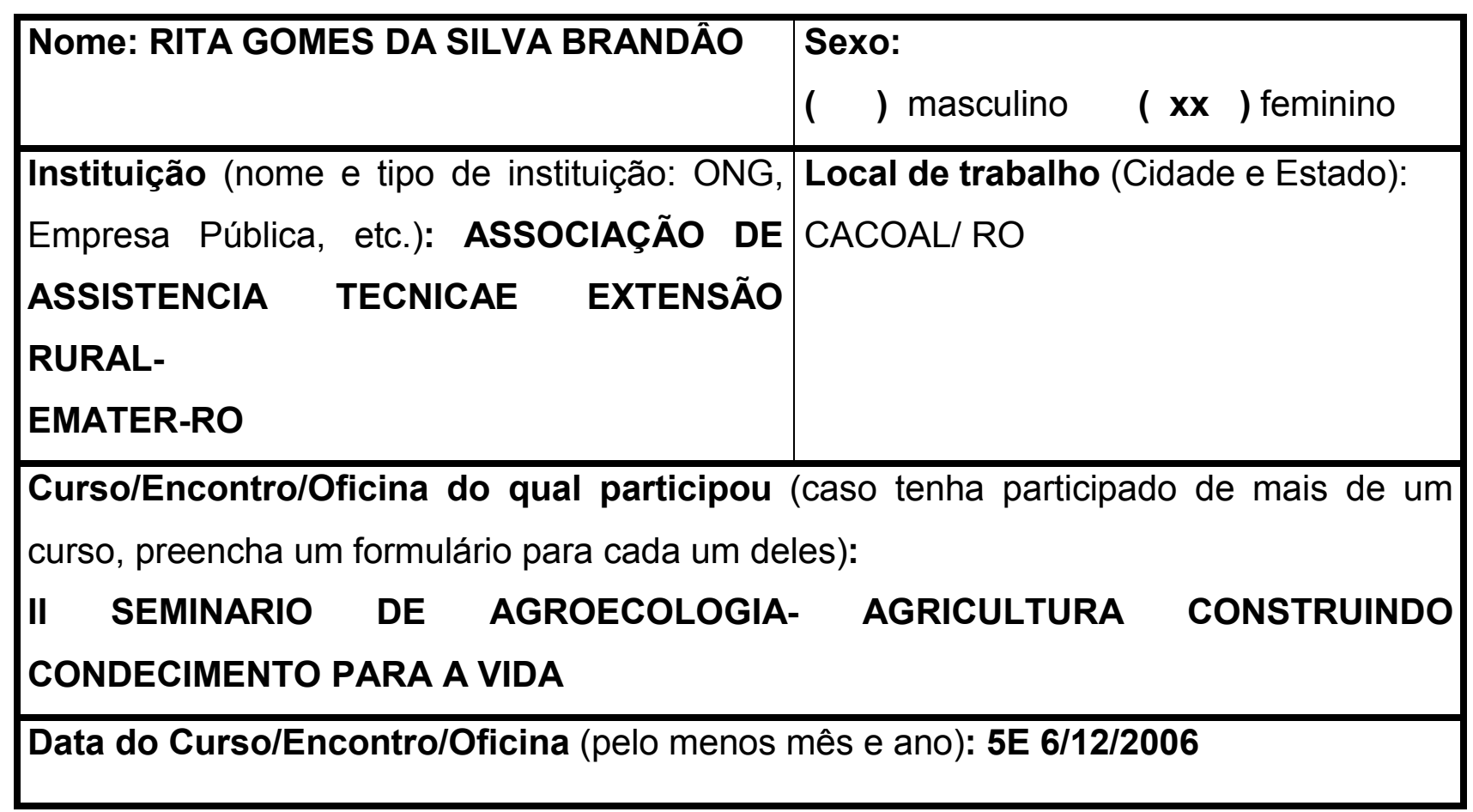

Indique sua área de atuação? (As opções não são excludentes: você poderá marcar mais de uma opção) 


\begin{tabular}{|l|l|}
\hline$X$ & EXTENSÃO RURAL \\
\hline & PESQUISA \\
\hline & ENSINO \\
\hline & OUTROS \\
\hline
\end{tabular}

2) Qual o seu nível de escolaridade?

\begin{tabular}{|l|l|}
\hline & NÍVEL MÉDIO \\
\hline$X$ & NÍVEL SUPERIOR \\
\hline & PÓS-GRADUAÇÃO \\
\hline
\end{tabular}

3) Os conteúdos abordados foram condizentes com as demandas do seu dia-a-dia?

\begin{tabular}{|l|l|}
\hline & SIM \\
\hline$X$ & PARCIALMENTE \\
\hline & NÃO \\
\hline
\end{tabular}

3) O curso contribuiu para o seu aperfeiçoamento profissional?

\begin{tabular}{|l|l|}
\hline$X$ & SIM \\
\hline & NÃO \\
\hline
\end{tabular}

5) Os conhecimentos adquiridos estão sendo aplicados no seu trabalho? Em caso afirmativo, indique em que grau estes conhecimentos estão sendo aplicados. Em caso negativo, indique por que razão isto não ocorre:

\begin{tabular}{|l|l|l|l|}
\hline $\begin{array}{l}\text { SIM (indique ao lado } \\
\text { em que grau) }\end{array}$ & $X$ & MUITO APLICADOS \\
\cline { 2 - 4 } & & MEDIAMENTE APLICADOS \\
\hline
\end{tabular}




\begin{tabular}{|l|l|l|l|}
\hline & & POUCO APLICADOS \\
\hline \multirow{5}{*}{$\begin{array}{l}\text { NÃo (indique ao lado } \\
\text { a razão da não } \\
\text { aplicação) }\end{array}$} & $\begin{array}{l}\text { CONTEÚDO NÃO ADEQUADO AS } \\
\text { NECESSIDADES ESPECÍFICAS DA REGIÃO }\end{array}$ \\
\cline { 2 - 4 } & $\begin{array}{l}\text { CONTEÚDO NÃO FOI SUFICIENTEMENTE } \\
\text { APROFUNDADO PARA PERMITIR UMA } \\
\end{array}$ & $\begin{array}{l}\text { APLICAÇÃO EFICAZ E EFICIENTE } \\
\text { INSTITUIÇÃO APOIO E INCENTIVO DA MINHA }\end{array}$ \\
\hline & & FALTA DE INCENTIVO ÀS AÇÕES DE ATER \\
\cline { 2 - 4 } & & NÃO TENHO INTERESSE EM APLICAR \\
\hline
\end{tabular}

6) A partir deste curso: (As opções não são excludentes: você poderá marcar mais de uma opção)

\begin{tabular}{|l|l|}
\hline & NÃO MUDOU NADA EM MEU TRABALHO. \\
\hline$X$ & $\begin{array}{l}\text { MEU TRABALHO PASSOU A CONTRIBUIR MAIS COM OS AGRICULTORES(AS) } \\
\text { FAMILIARES. }\end{array}$ \\
\hline$X$ & PONSEGUI INFLUENCIAR NAS ORIENTAÇÕES DA MINHA INSTITUIÇÃO. \\
\hline & $\begin{array}{l}\text { CRESCEU A ÁREA DE AGRICULTURA DE BASE ECOLÓGICA NAS } \\
\text { COMUNIDADES ONDE ATUO. }\end{array}$ \\
\hline$X$ & CONTINUEI ME APERFEIÇOANDO SOBRE TEMAS ABORDADOS. \\
\hline
\end{tabular}

7) Depois do curso você apoiou atividades de capacitação de técnicos e agricultores com base nos princípios e diretrizes da Pnater? (Considere como apoio a atividades de capacitação a participação no planejamento, elaboração de ementas, seleção de participantes e de palestrantes.)

\begin{tabular}{|l|l|}
\hline$X$ & SIM \\
\hline
\end{tabular}




\section{NÃO}

8) Usou os conhecimentos para ministrar outros cursos com o mesmo conteúdo ou conteúdos semelhantes?

\begin{tabular}{|l|l|}
\hline$X$ & SIM \\
\hline & NÃO \\
\hline
\end{tabular}

9) Marque o seu grau de satisfação com relação ao curso oferecido pelo DATER: (Considere a seguinte pontuação: 1 - MUITO RUIM; 2 - RUIM; 3 - REGULAR; 4 BOM; 5 - MUITO BOM)

\begin{tabular}{|l|l|l|l|l|}
\hline 1 & 2 & 3 & $4 X$ & 5 \\
\hline
\end{tabular}

10) Marque seu grau de satisfação com relação ao DATER: (Considere a seguinte pontuação: 1 - MUITO RUIM; 2 - RUIM; 3 - REGULAR; 4 - BOM; 5 - MUITO BOM)

\begin{tabular}{|l|l|l|l|l|}
\hline 1 & 2 & 3 & $4 X$ & 5 \\
\hline
\end{tabular}




\section{PESQUISA - IMPACTO DAS AÇÕES DE FORMAÇÃO REALIZADAS PELO DATER/SAF/MDA NO PERÍODO 2004-2009}

Caros colaboradores,

Contamos com a sua atenção para preencher o formulário abaixo.

O mesmo tem por objetivo fornecer informações para avaliação da Eficiência, Efetividade e Eficácia da Política Pública de Formação de Agentes de Ater adotada pelo Departamento de Assistência Técnica e Extensão Rural, da Secretaria de Agricultura Familiar do Ministério do Desenvolvimento - DATER/SAF/MDA, no período de 2004 a 2009, tema escolhido para Monografia a ser apresentada à Universidade de Brasília (UnB) como requisito parcial para obtenção do grau de Bacharel em Administração.

Você poderá ou não se identificar no questionário e garantimos que todas as informações fornecidas serão confidenciais e utilizadas apenas de forma sistematizada.

\section{IDENTIFICAÇÃO}

\begin{tabular}{|c|c|}
\hline $\begin{array}{l}\text { Nome: } \quad \text { RISALDO } \quad \text { MUNIZ DO } \\
\text { NASCIMENTO }\end{array}$ & $\begin{array}{l}\text { Sexo: } \\
(\mathbf{x}) \text { masculino }(\quad) \text { feminino }\end{array}$ \\
\hline $\begin{array}{l}\text { Instituição (nome e tipo de instituição: } \\
\text { ONG, Empresa Pública, etc): } \\
\text { EMATER-PARÁ }\end{array}$ & Local de trabalho (Cidade e Estado): \\
\hline \multicolumn{2}{|c|}{$\begin{array}{l}\text { Curso/Encontro/Oficina do qual participou ( caso tenha participado de mais de } \\
\text { um curso, } \\
\text { Preencha um formulário para cada um deles): } \\
\text { PROGRAMA DE FORMAÇÃO DE AGENTES DE DESENVOLVIMENTO RURAL }\end{array}$} \\
\hline $\begin{array}{l}\text { Data do Curso/Encontro/Oficina ( pelo } \\
\qquad 11 \text { A } 15 / 12 / 2006\end{array}$ & los mês e ano): \\
\hline
\end{tabular}

Indique sua área de atuação? (As opções não são excludentes: você poderá marcar mais de uma opção) 


\begin{tabular}{|l|l|}
\hline $\mathbf{X}$ & EXTENSÃO RURAL \\
\hline & PESQUISA \\
\hline & ENSINO \\
\hline & OUTROS \\
\hline
\end{tabular}

2) Qual o seu nível de escolaridade?

\begin{tabular}{|c|l|}
\hline & NÍVEL MÉDIO \\
\hline & NÍVEL SUPERIOR \\
\hline & PÓS-GRADUAÇÃO \\
\hline & \\
\hline
\end{tabular}

Os conteúdos abordados forma condizentes com as demandas do seu dia-a-dia?

\begin{tabular}{|c|c|}
\hline$x$ & SIM \\
\hline & PARCIALMENTE \\
\hline & NÃO \\
\hline
\end{tabular}

4) O curso contribuiu para o seu aperfeiçoamento profissional?

\begin{tabular}{|l|l|}
\hline$x$ & SIM \\
\hline & NÃO \\
\hline
\end{tabular}


5) Os conhecimentos adquiridos estão sendo aplicados no seu trabalho? Em caso afirmativo, indique em que grau estes conhecimentos estão sendo aplicados. Em caso negativo, indique por que razão isto não ocorre.

\begin{tabular}{|c|c|c|}
\hline \multirow{3}{*}{$\begin{array}{l}\text { SIM ( indique ao lado } \\
\text { em } \\
\text { que grau) }\end{array}$} & $x$ & MUITO APLICADOS \\
\hline & & MEDIAMENTE APLICADOS \\
\hline & & POUCO APLICADOS \\
\hline \multirow{5}{*}{$\begin{array}{l}\text { NÃO (indique ao lado a } \\
\text { razão da não } \\
\text { aplicação) }\end{array}$} & & $\begin{array}{lrr}\text { CONTEÚDO NÃO } & \text { ADEQUADO ÀS } \\
\text { NECESSIDADES } & \text { ESPECÍFICAS DA } \\
\text { REGIÃO } & \end{array}$ \\
\hline & & $\begin{array}{l}\text { CONTEÚDO NÃO FOI SUFICIENTEMENTE } \\
\text { APROFUNDADO PARA PERMITIR UMA } \\
\text { APLICAÇÃO EFICAZ E EFICIENTE }\end{array}$ \\
\hline & & $\begin{array}{l}\text { FALTA DE APOIO E INCENTIVO DA MINHA } \\
\text { INSTITUIÇÃO }\end{array}$ \\
\hline & & FALTA DE INCENTIVO ȦS AÇŌES DE ATER \\
\hline & & NĀO TENHO INTERESSE EM APLICAR \\
\hline
\end{tabular}

6) A partir deste curso: (As opções não são excludentes: você poderá marcar mais de uma opção)

\begin{tabular}{|l|lllllll|}
\hline & NÃO MUDOU NADA EM MEU TRABALHO & & & & \\
\hline & MEU TRABALHO & PASSOU & A & CONTRIBUIR & MAIS & COM & OS \\
AGRICULTORES(AS) & & & & & & \\
& & & FAMILIARES. & & & \\
\hline
\end{tabular}




\begin{tabular}{|c|c|c|}
\hline & $\begin{array}{c}\text { CONSEGUI INFLUENCIAR NAS ORIENTAÇÕES DA MINHA } \\
\text { INSTITUIÇÃO. }\end{array}$ \\
\hline$x$ & PASSEI A TRABALHAR COM METODOLOGIAS PARTICIPATIVAS \\
\hline
\end{tabular}

7) Depois do curso você apoio atividades de capacitação de técnicos e agricultores com base

Nos princípios e diretrizes da Pnater? (Considere como apoio a atividades de capacitação a participação no planejamento, elaboração de ementas, seleção de participantes e de palestrantes.)

\begin{tabular}{|l|l|}
\hline$x$ & SIM \\
\hline & NÃO \\
\hline
\end{tabular}

Usou os conhecimentos para ministrar outros cursos com o mesmo conteúdo ou conteúdos semelhantes?

\begin{tabular}{|c|c|}
\hline & SIM \\
\hline$X$ & NÃO \\
\hline
\end{tabular}

9) Marque o seu grau de satisfação com relação ao curso oferecido pelo DATER. (Considere a seguinte pontuação: 1 - MUITO RUIM; 2 - RUIM; 3 REGULAR; 4 - BOM; 5 - MUITO BOM)

\begin{tabular}{|l|l|l|l|l|}
\hline 1 & 2 & 3 & $x \quad 4$ & 5 \\
\hline
\end{tabular}


10)Marque seu grau de satisfação com relação ao DATER(Considere a seguinte pontuação: 1 - MUITO RUIM; 2 - RUIM; 3 - REGULAR; 4 - BOM; 5 - MUITO BOM)

\begin{tabular}{|l|l|l|l|l|}
\hline 1 & 2 & 3 & $\times 4$ & 5 \\
\hline
\end{tabular}




\section{PESQUISA - IMPACTO DAS AÇÕES DE FORMAÇÃO REALIZADAS PELO DATER/SAF/MDA NO PERÍODO 2004-2009}

Caros colaboradores,

Contamos com a sua atenção para preencher o formulário abaixo.

O mesmo tem por objetivo fornecer informações para avaliação da Eficiência, Efetividade e Eficácia da Política Pública de Formação de Agentes de Ater adotada pelo Departamento de Assistência Técnica e Extensão Rural, da Secretaria de Agricultura Familiar do Ministério do Desenvolvimento - DATER/SAF/MDA, no período de 2004 a 2009, tema escolhido para Monografia a ser apresentada à Universidade de Brasília (UnB) como requisito parcial para obtenção do grau de Bacharel em Administração.

Você poderá ou não se identificar no questionário e garantimos que todas as informações fornecidas serão confidenciais e utilizadas apenas de forma sistematizada.

\begin{tabular}{|c|c|}
\hline $\begin{array}{l}\text { Nome: Francisco Mende de Sá Barretos } \\
\text { Coutinho }\end{array}$ & $\begin{array}{l}\text { Sexo: } \\
(\quad x) \text { masculino }\end{array}$ \\
\hline 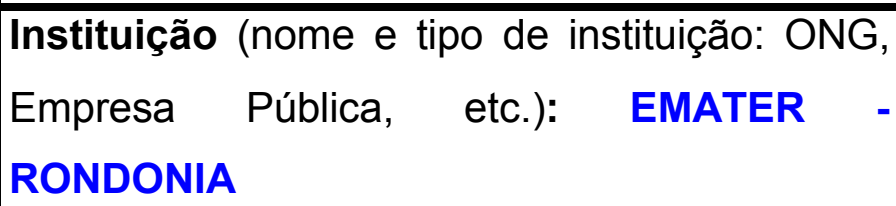 & $\begin{array}{l}\text { Local de trabalho (Cidade e Estado): } \\
\text { EMATER CABIXI }\end{array}$ \\
\hline \multicolumn{2}{|c|}{$\begin{array}{l}\text { Curso/Encontro/Oficina do qual participou (caso tenha participado de mais de um } \\
\text { curso, preencha um formulário para cada um deles): CURSO DE MANEJO DE } \\
\text { PASTAGENS COM ENFASE NO CONTROLE BIOLÓGICO DA CIGARRINHA. }\end{array}$} \\
\hline Data do Curso/Encontro/Oficina (pelo menos & hês e ano): 29/05 a 02/06/2006 \\
\hline
\end{tabular}

1)Indique sua área de atuação? (As opções não são excludentes: você poderá marcar mais de uma opção). 


\begin{tabular}{|l|l|}
\hline & PESQUISA \\
\hline & ENSINO \\
\hline & OUTROS \\
\hline
\end{tabular}

2) Qual o seu nível de escolaridade?

\begin{tabular}{|c|l|}
\hline & NÍVEL MÉDIO \\
\hline$X$ & NÍVEL SUPERIOR \\
\hline & PÓS-GRADUAÇÃO \\
\hline
\end{tabular}

3) Os conteúdos abordados foram condizentes com as demandas do seu dia-a-dia?

\begin{tabular}{|l|l|}
\hline$X$ & SIM \\
\hline & PARCIALMENTE \\
\hline & NÃO \\
\hline
\end{tabular}

4) O curso contribuiu para o seu aperfeiçoamento profissional?

\begin{tabular}{|l|l|}
\hline$X$ & SIM \\
\hline & NÃO \\
\hline
\end{tabular}

5) Os conhecimentos adquiridos estão sendo aplicados no seu trabalho? Em caso afirmativo, indique em que grau estes conhecimentos estão sendo aplicados. Em caso negativo, indique por que razão isto não ocorre: (Em caso negativo, as respostas não são excludentes: você poderá marcar mais de uma opção).

\begin{tabular}{|l|l|l|l|}
\hline$X$ & $\begin{array}{l}\text { SIM (indique ao lado } \\
\text { em que grau) }\end{array}$ & $X$ & MUITO APLICADOS \\
\hline
\end{tabular}




\begin{tabular}{|c|c|}
\hline & MEDIAMENTE APLICADOS \\
\hline & POUCO APLICADOS \\
\hline \multirow{5}{*}{$\begin{array}{l}\text { NÃO (indique ao lado } \\
\text { a razão da não } \\
\text { aplicação) }\end{array}$} & \begin{tabular}{lccc|} 
CONTEÚDO & NÃO & ADEQUADO & ÀS \\
NECESSIDADES ESPECÍFICAS DA REGIÃO &
\end{tabular} \\
\hline & \begin{tabular}{lccc|} 
CONTEÚDO & NÃO & FOI & \multicolumn{2}{c}{ SUFICIENTEMENTE } \\
APROFUNDADO & PARA & PERMITIR & UMA \\
APLICAÇÃO EFICAZ E EFICIENTE &
\end{tabular} \\
\hline & $\begin{array}{l}\text { FALTA DE APOIO E INCENTIVO DA MINHA } \\
\text { INSTITUIÇÃO }\end{array}$ \\
\hline & FALTA DE INCENTIVO ÀS AÇÕES DE ATER \\
\hline & NÃO TENHO INTERESSE EM APLICAR \\
\hline
\end{tabular}

6) A partir deste curso: (As opções não são excludentes: você poderá marcar mais de uma opção).

\begin{tabular}{|r|l|}
\hline & NÃO MUDOU NADA EM MEU TRABALHO. \\
\hline$X$ & $\begin{array}{l}\text { MEU TRABALHO PASSOU A CONTRIBUIR MAIS COM OS AGRICULTORES(AS) } \\
\text { FAMILIARES. }\end{array}$ \\
\hline$X$ & CONSEGUI INFLUENCIAR NAS ORIENTAÇÕES DA MINHA INSTITUIÇÃO. \\
\hline$X$ & PASSEI A TRABALHAR COM METODOLOGIAS PARTICIPATIVAS. \\
\hline & $\begin{array}{l}\text { CRESCEU A ÁREA DE AGRICULTURA DE BASE ECOLÓGICA NAS } \\
\text { COMUNIDADES ONDE ATUO. }\end{array}$ \\
\hline$X$ & CONTINUEI ME APERFEIÇOANDO SOBRE TEMAS ABORDADOS. \\
\hline
\end{tabular}

7) Depois do curso você apoiou atividades de capacitação de técnicos e agricultores com base nos princípios e diretrizes da Pnater? (Considere como apoio a atividades de capacitação a participação no planejamento, elaboração de ementas, seleção de participantes e de palestrantes.) 


\begin{tabular}{|l|l|}
\hline$X$ & SIM \\
\hline & NÃO \\
\hline
\end{tabular}

8) Usou os conhecimentos para ministrar outros cursos com o mesmo conteúdo ou conteúdos semelhantes?

\begin{tabular}{|l|l|}
\hline & SIM \\
\hline$X$ & NÃO \\
\hline
\end{tabular}

9) Marque o seu grau de satisfação com relação ao curso oferecido pelo DATER:

\begin{tabular}{|l|l|l|l|l|}
\hline 1 & 2 & 3 & 4 & 5 \\
\hline
\end{tabular}

10) Marque seu grau de satisfação com relação ao DATER:

\begin{tabular}{|l|l|l|l|l|}
\hline 1 & 2 & 3 & 4 & 5 \\
\hline
\end{tabular}

Obs.: As notas atribuídas às duas últimas questões devem obedecer a ordem crescente: 1 - muito ruim, 2 - ruim, 3 - regular, 4 - bom , 5 - muito bom.

\section{4-BOM 4 - BOM}




\section{PESQUISA - IMPACTO DAS AÇÕES DE FORMAÇÃO REALIZADAS PELO DATER/SAF/MDA NO PERÍODO 2004-2009}

Caros colaboradores,

Contamos com a sua atenção para preencher o formulário abaixo.

O mesmo tem por objetivo fornecer informações para avaliação da Eficiência, Efetividade e Eficácia da Política Pública de Formação de Agentes de Ater adotada pelo Departamento de Assistência Técnica e Extensão Rural, da Secretaria de Agricultura Familiar do Ministério do Desenvolvimento - DATER/SAF/MDA, no período de 2004 a 2009, tema escolhido para Monografia a ser apresentada à Universidade de Brasília (UnB) como requisito parcial para obtenção do grau de Bacharel em Administração.

Você poderá ou não se identificar no questionário e garantimos que todas as informações fornecidas serão confidenciais e utilizadas apenas de forma sistematizada.

IDENTIFICAÇÃO

\begin{tabular}{|l|l|}
\hline Nome: RAQUEL ARAÚJO AMARAL & $\begin{array}{l}\text { Sexo: } \\
(\mathbf{l}) \text { masculino ( } \mathbf{x} \text { ) feminino }\end{array}$ \\
\hline $\begin{array}{l}\text { Instituição (nome e tipo de instituição: ONG, } \\
\text { Empresa Pública, etc.): EMATER - PARÁ }\end{array}$ & $\begin{array}{l}\text { Local de trabalho (Cidade e Estado): } \\
\text { JURUTI - PARÁ }\end{array}$ \\
\hline $\begin{array}{l}\text { Curso/Encontro/Oficina do qual participou (caso tenha participado de mais de um } \\
\text { curso, preencha um formulário para cada um deles): TEORIA E PRÁTICA DE } \\
\text { MÉTODOS DE ATER }\end{array}$ \\
\hline Data do Curso/Encontro/Oficina (pelo menos mês e ano): 20 A 25 NOVEMBRO/2006 \\
\hline
\end{tabular}

1) Indique sua área de atuação? (As opções não são excludentes: você poderá marcar mais de uma opção)

\begin{tabular}{|l|l|}
\hline$X$ & EXTENSÃO RURAL \\
\hline & PESQUISA \\
\hline
\end{tabular}




\begin{tabular}{|l|l|}
\hline & ENSINO \\
\hline & OUTROS \\
\hline
\end{tabular}

2) Qual o seu nível de escolaridade?

\begin{tabular}{|r|l|}
\hline & NÍVEL MÉDIO \\
\hline & NÍVEL SUPERIOR \\
\hline$X$ & PÓS-GRADUAÇÃO \\
\hline
\end{tabular}

3) Os conteúdos abordados foram condizentes com as demandas do seu dia-a-dia?

\begin{tabular}{|l|l|}
\hline$X$ & SIM \\
\hline & PARCIALMENTE \\
\hline & NÃO \\
\hline
\end{tabular}

4) O curso contribuiu para o seu aperfeiçoamento profissional?

\begin{tabular}{|l|l|}
\hline$X$ & SIM \\
\hline & NÃO \\
\hline
\end{tabular}

5) Os conhecimentos adquiridos estão sendo aplicados no seu trabalho? Em caso afirmativo, indique em que grau estes conhecimentos estão sendo aplicados. Em caso negativo, indique por que razão isto não ocorre:

\begin{tabular}{|l|l|l|l|}
\hline$x$ & $\begin{array}{l}\text { SIM (indique ao lado } \\
\text { em que grau) }\end{array}$ & & MUITO APLICADOS \\
\cline { 3 - 4 } & & & MEDIAMENTE APLICADOS \\
\hline
\end{tabular}




\begin{tabular}{|l|l|l|l|}
\hline \multirow{3}{*}{$\begin{array}{l}\text { NÃO (indique ao lado } \\
\text { a razão da não } \\
\text { aplicação) }\end{array}$} & $\begin{array}{l}\text { CONTEÚDO NÃO ADEQUADO } \\
\text { NECESSIDADES ESPECÍFICAS DA REGIÃO }\end{array}$ \\
\cline { 2 - 5 } & $\begin{array}{l}\text { CONTEÚDO NÃO FOI SUFICIENTEMENTEE } \\
\text { APROFUNDADO PARA PERMITIR UMA } \\
\text { APLICAÇÃO EFICAZ E EFICIENTE }\end{array}$ \\
\hline & $\begin{array}{l}\text { FALTA DE APOIO E INCENTIVO DA MINHA } \\
\text { INSTITUIÇÃO }\end{array}$ \\
\hline & FALTA DE INCENTIVO ÀS AÇÕES DE ATER \\
\hline
\end{tabular}

6) A partir deste curso: (As opções não são excludentes: você poderá marcar mais de uma opção)

\begin{tabular}{|r|l|}
\hline & NÃO MUDOU NADA EM MEU TRABALHO. \\
\hline$X$ & $\begin{array}{l}\text { MEU TRABALHO PASSOU A CONTRIBUIR MAIS COM OS AGRICULTORES(AS) } \\
\text { FAMILIARES. }\end{array}$ \\
\hline & CONSEGUI INFLUENCIAR NAS ORIENTAÇÕES DA MINHA INSTITUIÇÃO. \\
\hline$X$ & PASSEI A TRABALHAR COM METODOLOGIAS PARTICIPATIVAS. \\
\hline & $\begin{array}{l}\text { CRESCEU A ÁREA DE AGRICULTURA DE BASE ECOLÓGICA NAS } \\
\text { COMUNIDADES ONDE ATUO. }\end{array}$ \\
\hline$X$ & CONTINUEI ME APERFEIÇOANDO SOBRE TEMAS ABORDADOS. \\
\hline
\end{tabular}

7) Depois do curso você apoiou atividades de capacitação de técnicos e agricultores com base nos princípios e diretrizes da Pnater? (Considere como apoio a atividades de capacitação a participação no planejamento, elaboração de ementas, seleção de participantes e de palestrantes.)

\begin{tabular}{|l|l|}
\hline$X$ & SIM \\
\hline & NÃO \\
\hline
\end{tabular}


8) Usou os conhecimentos para ministrar outros cursos com o mesmo conteúdo ou conteúdos semelhantes?

\begin{tabular}{|l|l|}
\hline & SIM \\
\hline$X$ & NÃO \\
\hline
\end{tabular}

9) Marque o seu grau de satisfação com relação ao curso oferecido pelo DATER: (Considere a seguinte pontuação: 1 - MUITO RUIM; 2 - RUIM; 3 - REGULAR; 4 BOM; 5 - MUITO BOM)

\begin{tabular}{|l|l|l|l|l|}
\hline 1 & 2 & 3 & 4 & $5 X$ \\
\hline
\end{tabular}

10) Marque seu grau de satisfação com relação ao DATER: (Considere a seguinte pontuação: 1 - MUITO RUIM; 2 - RUIM; 3 - REGULAR; 4 - BOM; 5 - MUITO BOM)

\begin{tabular}{|l|l|l|l|l|}
\hline 1 & 2 & 3 & 4 & $5 X$ \\
\hline
\end{tabular}




\section{PESQUISA - IMPACTO DAS AÇÕES DE FORMAÇÃO REALIZADAS PELO DATER/SAF/MDA NO PERÍODO 2004-2009}

Caros colaboradores,

Contamos com a sua atenção para preencher o formulário abaixo.

O mesmo tem por objetivo fornecer informações para avaliação da Eficiência, Efetividade e Eficácia da Política Pública de Formação de Agentes de Ater adotada pelo Departamento de Assistência Técnica e Extensão Rural, da Secretaria de Agricultura Familiar do Ministério do Desenvolvimento - DATER/SAF/MDA, no período de 2004 a 2009, tema escolhido para Monografia a ser apresentada à Universidade de Brasília (UnB) como requisito parcial para obtenção do grau de Bacharel em Administração.

Você poderá ou não se identificar no questionário e garantimos que todas as informações fornecidas serão confidenciais e utilizadas apenas de forma sistematizada.

IDENTIFICAÇÃO

\begin{tabular}{|c|c|}
\hline Nome: Raimundo Nonato Brabo Alves & $\begin{array}{l}\text { Sexo: } \\
(x) \text { masculino }\end{array}$ \\
\hline $\begin{array}{l}\text { Instituição (nome e tipo de instituição: ONG, } \\
\text { Empresa Pública, etc.): Embrapa }\end{array}$ & $\begin{array}{l}\text { Local de trabalho (Cidade e Estado): } \\
\text { Belém }\end{array}$ \\
\hline \multicolumn{2}{|c|}{$\begin{array}{l}\text { Curso/Encontro/Oficina do qual participou (caso tenha participado de mais de um } \\
\text { curso, preencha um formulário para cada um deles): } \\
\text { Curso de Transição Agroecológica }\end{array}$} \\
\hline $\begin{array}{l}\text { Data do Curso/Encontro/Oficina (pelo menos } \\
\text { Maio/2005 }\end{array}$ & ês e ano): \\
\hline
\end{tabular}

Indique sua área de atuação? (As opções não são excludentes: você poderá marcar mais de uma opção) 


\begin{tabular}{|l|l|}
\hline$X$ & PESQUISA \\
\hline & ENSINO \\
\hline & OUTROS \\
\hline
\end{tabular}

2) Qual o seu nível de escolaridade?

\begin{tabular}{|l|l|}
\hline & NÍVEL MÉDIO \\
\hline & NÍVEL SUPERIOR \\
\hline$x$ & PÓS-GRADUAÇÃO \\
\hline
\end{tabular}

3) Os conteúdos abordados foram condizentes com as demandas do seu dia-a-dia?

\begin{tabular}{|l|l|}
\hline$x$ & SIM \\
\hline & PARCIALMENTE \\
\hline & NÃO \\
\hline
\end{tabular}

3) O curso contribuiu para o seu aperfeiçoamento profissional?

\begin{tabular}{|l|l|}
\hline$x$ & SIM \\
\hline & NÃO \\
\hline
\end{tabular}

5) Os conhecimentos adquiridos estão sendo aplicados no seu trabalho? Em caso afirmativo, indique em que grau estes conhecimentos estão sendo aplicados. Em caso negativo, indique por que razão isto não ocorre:

\begin{tabular}{|l|l|l|}
\hline \multirow{2}{*}{$\begin{array}{l}\text { SIM (indique ao lado } \\
\text { em que grau) }\end{array}$} & $x$ & MUITO APLICADOS \\
\cline { 2 - 3 } & & MEDIAMENTE APLICADOS \\
\cline { 2 - 3 } & & POUCO APLICADOS \\
\hline
\end{tabular}




\begin{tabular}{|c|c|}
\hline \multirow{5}{*}{$\begin{array}{l}\text { NÃO (indique ao lado } \\
\text { a razão da não } \\
\text { aplicação) }\end{array}$} & \begin{tabular}{|lccc} 
CONTEÚDO & NÃO & ADEQUADO & ȦS \\
NECESSIDADES & ESPECÍFICAS DA REGIÃO &
\end{tabular} \\
\hline & $\begin{array}{llrl}\text { CONTEÚDO NÃO } & \text { FOI } & \text { SUFICIENTEMENTE } \\
\text { APROFUNDADO } & \text { PARA } & \text { PERMITIR } & \text { UMA } \\
\text { APLICAÇÃO EFICAZ E EFICIENTE }\end{array}$ \\
\hline & $\begin{array}{l}\text { FALTA DE APOIO E INCENTIVO DA MINHA } \\
\text { INSTITUIÇÃO }\end{array}$ \\
\hline & FALTA DE INCENTIVO ÀS AÇÕES DE ATER \\
\hline & NÃO TENHO INTERESSE EM APLICAR \\
\hline
\end{tabular}

6) A partir deste curso: (As opções não são excludentes: você poderá marcar mais de uma opção)

\begin{tabular}{|c|l|}
\hline & NÃO MUDOU NADA EM MEU TRABALHO. \\
\hline$x$ & $\begin{array}{l}\text { MEU TRABALHO PASSOU A CONTRIBUIR MAIS COM OS AGRICULTORES(AS) } \\
\text { FAMILIARES. }\end{array}$ \\
\hline$x$ & CONSEGUI INFLUENCIAR NAS ORIENTAÇÕES DA MINHA INSTITUIÇÃO. \\
\hline$x$ & PASSEI A TRABALHAR COM METODOLOGIAS PARTICIPATIVAS. \\
\hline$x$ & $\begin{array}{l}\text { CRESCEU A ÁREA DE AGRICULTURA DE BASE ECOLÓGICA NAS } \\
\text { COMUNIDADES ONDE ATUO. }\end{array}$ \\
\hline & CONTINUEI ME APERFEIÇOANDO SOBRE TEMAS ABORDADOS. \\
\hline
\end{tabular}

7) Depois do curso você apoiou atividades de capacitação de técnicos e agricultores com base nos princípios e diretrizes da Pnater? (Considere como apoio a atividades de capacitação a participação no planejamento, elaboração de ementas, seleção de participantes e de palestrantes.)

\begin{tabular}{|l|l|}
\hline$x$ & SIM \\
\hline & NÃO \\
\hline
\end{tabular}


8) Usou os conhecimentos para ministrar outros cursos com o mesmo conteúdo ou conteúdos semelhantes?

\begin{tabular}{|l|l|}
\hline$x$ & SIM \\
\hline & NÃO \\
\hline
\end{tabular}

9) Marque o seu grau de satisfação com relação ao curso oferecido pelo DATER: (Considere a seguinte pontuação: 1 - MUITO RUIM; 2 - RUIM; 3 - REGULAR; 4 BOM; 5 - MUITO BOM)

\begin{tabular}{|l|l|l|l|l|}
\hline 1 & 2 & 3 & 4 & $5 x$ \\
\hline
\end{tabular}

10) Marque seu grau de satisfação com relação ao DATER: (Considere a seguinte pontuação: 1 - MUITO RUIM; 2 - RUIM; 3 - REGULAR; 4 - BOM; 5 - MUITO BOM)

\begin{tabular}{|l|l|l|l|l|}
\hline 1 & 2 & 3 & $4 x$ & 5 \\
\hline
\end{tabular}




\section{PESQUISA - IMPACTO DAS AÇÕES DE FORMAÇÃO REALIZADAS PELO DATER/SAF/MDA NO PERÍODO 2004-2009}

Caros colaboradores,

Contamos com a sua atenção para preencher o formulário abaixo.

O mesmo tem por objetivo fornecer informações para avaliação da Eficiência, Efetividade e Eficácia da Política Pública de Formação de Agentes de Ater adotada pelo Departamento de Assistência Técnica e Extensão Rural, da Secretaria de Agricultura Familiar do Ministério do Desenvolvimento - DATER/SAF/MDA, no período de 2004 a 2009, tema escolhido para Monografia a ser apresentada à Universidade de Brasília (UnB) como requisito parcial para obtenção do grau de Bacharel em Administração.

Você poderá ou não se identificar no questionário e garantimos que todas as informações fornecidas serão confidenciais e utilizadas apenas de forma sistematizada.

IDENTIFICAÇÃO

\begin{tabular}{|c|c|}
\hline Nome: Geraldo Sousa Costa & $\begin{array}{l}\text { Sexo: } \\
(\mathbf{x}) \text { masculino } \quad(\quad) \text { feminino }\end{array}$ \\
\hline $\begin{array}{l}\text { Instituição: } \\
\text { Comissão Executiva do Plano da Lavoura } \\
\text { Cacaueira-CEPLAC. } \\
\text { Órgão singular do Ministério da Agricultura, } \\
\text { Pecuária e Abastecimento - MAPA }\end{array}$ & $\begin{array}{ll}\text { Local } & \text { de } \\
\text { trabalho:CEPLAC/SUPOR/SEREX } & \\
& \text { Altamira - Pará }\end{array}$ \\
\hline $\begin{array}{l}\text { Curso/Encontro/Oficina do qual participou: } \\
\text { Seminário sobre Princípios de Agroecologia } \\
\text { Carga horária de } 16 \text { horas }\end{array}$ & \\
\hline $\begin{array}{l}\text { Data do Curso/Encontro/Oficina: } \\
\text { Março/2004 na cidade de Belém-PA }\end{array}$ & \\
\hline
\end{tabular}

Indique sua área de atuação? (As opções não são excludentes: você poderá marcar mais de uma opção) 


\begin{tabular}{|l|l|}
\hline$X$ & EXTENSÃO RURAL \\
\hline & PESQUISA \\
\hline & ENSINO \\
\hline & OUTROS \\
\hline
\end{tabular}

Qual o seu nível de escolaridade?

\begin{tabular}{|l|l|}
\hline$X$ & NÍVEL MÉDIO \\
\hline$X$ & $\begin{array}{l}\text { NíVEL SUPERIOR (Em andamento - Administração de } \\
\text { Empresas) }\end{array}$ \\
\hline & PÓS-GRADUAÇÃO \\
\hline
\end{tabular}

3) Os conteúdos abordados foram condizentes com as demandas do seu dia-a-dia?

\begin{tabular}{|l|l|}
\hline$X$ & SIM \\
\hline & PARCIALMENTE \\
\hline & NÃO \\
\hline
\end{tabular}

4) O curso contribuiu para o seu aperfeiçoamento profissional?

\begin{tabular}{|l|l|}
\hline$X$ & SIM \\
\hline & NÃO \\
\hline
\end{tabular}

5) Os conhecimentos adquiridos estão sendo aplicados no seu trabalho? Em caso afirmativo, indique em que grau estes conhecimentos estão sendo aplicados. Em caso negativo, indique por que razão isto não ocorre: 


\begin{tabular}{|c|c|c|c|}
\hline \multirow{3}{*}{$\mathrm{x}$} & \multirow{3}{*}{$\begin{array}{l}\text { SIM (indique ao lado } \\
\text { em que grau) }\end{array}$} & $\mathbf{X}$ & MUITO APLICADOS \\
\hline & & & MEDIAMENTE APLICADOS \\
\hline & & & POUCO APLICADOS \\
\hline & \multirow{5}{*}{$\begin{array}{l}\text { NÃO (indique ao lado } \\
\text { a razão da não } \\
\text { aplicação) }\end{array}$} & & \begin{tabular}{lccc|} 
CONTEÚDO & NÃO & ADEQUADO & ÀS \\
NECESSIDADES ESPECÍFICAS DA REGIÃO &
\end{tabular} \\
\hline & & & \begin{tabular}{lccc|} 
CONTEÚDO & NÃO & FOI & \multicolumn{2}{c|}{ SUFICIENTEMENTE } \\
APROFUNDADO & PARA & PERMITIR & UMA \\
APLICAÇÃO EFICAZ E EFICIENTE &
\end{tabular} \\
\hline & & & $\begin{array}{l}\text { FALTA DE APOIO E INCENTIVO DA } \\
\text { INSTITUIÇÃO }\end{array}$ \\
\hline & & & FALTA DE INCENTIVO ÀS AÇÕES DE ATER \\
\hline & & & NÃO TENHO INTERESSE EM APLICAR \\
\hline
\end{tabular}

6) A partir deste curso: (As opções não são excludentes: você poderá marcar mais de uma opção)

\begin{tabular}{|l|l|}
\hline & NÃO MUDOU NADA EM MEU TRABALHO. \\
\hline$X$ & $\begin{array}{l}\text { MEU TRABALHO PASSOU A CONTRIBUIR MAIS COM OS AGRICULTORES(AS) } \\
\text { FAMILIARES. }\end{array}$ \\
\hline $\mathrm{X}$ & CONSEGUI INFLUENCIAR NAS ORIENTAÇÕES DA MINHA INSTITUIÇÃO. \\
\hline $\mathrm{X}$ & PASSEI A TRABALHAR COM METODOLOGIAS PARTICIPATIVAS. \\
\hline $\mathrm{X}$ & $\begin{array}{l}\text { CRESCEU A ÁREA DE AGRICULTURA DE BASE ECOLÓGICA NAS } \\
\text { COMUNIDADES ONDE ATUO. }\end{array}$ \\
\hline $\mathrm{X}$ & CONTINUEI ME APERFEIÇOANDO SOBRE TEMAS ABORDADOS. \\
\hline
\end{tabular}

7) Depois do curso você apoiou atividades de capacitação de técnicos e agricultores com base nos princípios e diretrizes da Pnater? (Considere como apoio a atividades de capacitação a participação no planejamento, elaboração de ementas, seleção de participantes e de palestrantes.) 


\begin{tabular}{|l|l|}
\hline$x$ & SIM \\
\hline & NÃO \\
\hline
\end{tabular}

8) Usou os conhecimentos para ministrar outros cursos com o mesmo conteúdo ou conteúdos semelhantes?

\begin{tabular}{|l|l|}
\hline$X$ & SIM \\
\hline & NÃO \\
\hline
\end{tabular}

9) Marque o seu grau de satisfação com relação ao curso oferecido pelo DATER: (Considere a seguinte pontuação: 1 - MUITO RUIM; 2 - RUIM; 3 - REGULAR; 4 BOM; 5 - MUITO BOM)

\begin{tabular}{|l|l|l|l|l|}
\hline 1 & 2 & 3 & 4 & $(X) 5$ \\
\hline
\end{tabular}

10) Marque seu grau de satisfação com relação ao DATER: (Considere a seguinte pontuação: 1 - MUITO RUIM; 2 - RUIM; 3 - REGULAR; 4 - BOM; 5 - MUITO BOM)

\begin{tabular}{|l|l|l|l|l|}
\hline 1 & 2 & 3 & 4 & $(X) 5$ \\
\hline
\end{tabular}




\section{PESQUISA - IMPACTO DAS AÇÕES DE FORMAÇÃO REALIZADAS PELO DATER/SAF/MDA NO PERÍODO 2004-2009}

Caros colaboradores,

Contamos com a sua atenção para preencher o formulário abaixo.

O mesmo tem por objetivo fornecer informações para avaliação da Eficiência, Efetividade e Eficácia da Política Pública de Formação de Agentes de Ater adotada pelo Departamento de Assistência Técnica e Extensão Rural, da Secretaria de Agricultura Familiar do Ministério do Desenvolvimento - DATER/SAF/MDA, no período de 2004 a 2009, tema escolhido para Monografia a ser apresentada à Universidade de Brasília (UnB) como requisito parcial para obtenção do grau de Bacharel em Administração.

Você poderá ou não se identificar no questionário e garantimos que todas as informações fornecidas serão confidenciais e utilizadas apenas de forma sistematizada.

IDENTIFICAÇÃO

\begin{tabular}{|c|c|}
\hline Nome: Geraldo Sousa Costa & $\begin{array}{l}\text { Sexo: } \\
(x) \text { masculino } \quad(\quad) \text { feminino }\end{array}$ \\
\hline $\begin{array}{l}\text { Instituição: } \\
\text { Comissão Executiva do Plano da Lavoura } \\
\text { Cacaueira-CEPLAC. } \\
\text { Órgão singular do Ministério da Agricultura, } \\
\text { Pecuária e Abastecimento - MAPA }\end{array}$ & $\begin{array}{l}\text { Local de trabalho: } \\
\text { CEPLAC/SUPOR/SEREX } \\
\text { Altamira - Pará }\end{array}$ \\
\hline \multicolumn{2}{|c|}{$\begin{array}{l}\text { Curso/Encontro/Oficina do qual participou: } \\
\text { Curso - Ater e Saúde no Meio Rural Carga horária de } 40 \text { horas }\end{array}$} \\
\hline $\begin{array}{l}\text { Data do Curso/Encontro/Oficina: } \\
\text { Maio/2005 na cidade de Brasília-DF }\end{array}$ & \\
\hline
\end{tabular}

Indique sua área de atuação? (As opções não são excludentes: você poderá marcar mais de uma opção) 


\begin{tabular}{|l|l|}
\hline$X$ & EXTENSÃO RURAL \\
\hline & PESQUISA \\
\hline & ENSINO \\
\hline & OUTROS \\
\hline
\end{tabular}

2) Qual o seu nível de escolaridade?

\begin{tabular}{|l|l|}
\hline$X$ & NÍVEL MÉDIO \\
\hline$X$ & NÍVEL SUPERIOR (Em andamento - Administração de Empresas) \\
\hline & PÓS-GRADUAÇÃO \\
\hline
\end{tabular}

Os conteúdos abordados foram condizentes com as demandas do seu dia-a-dia?

\begin{tabular}{|l|l|}
\hline$X$ & SIM \\
\hline & PARCIALMENTE \\
\hline & NÃO \\
\hline
\end{tabular}

O curso contribuiu para o seu aperfeiçoamento profissional?

\begin{tabular}{|l|l|}
\hline$X$ & SIM \\
\hline & NÃO \\
\hline
\end{tabular}

Os conhecimentos adquiridos estão sendo aplicados no seu trabalho? Em caso afirmativo, indique em que grau estes conhecimentos estão sendo aplicados. Em caso negativo, indique por que razão isto não ocorre: 


\begin{tabular}{|c|c|c|c|}
\hline \multirow{3}{*}{$\mathrm{x}$} & \multirow{3}{*}{$\begin{array}{l}\text { SIM (indique ao lado } \\
\text { em que grau) }\end{array}$} & $\mathbf{X}$ & MUITO APLICADOS \\
\hline & & & MEDIAMENTE APLICADOS \\
\hline & & & POUCO APLICADOS \\
\hline & \multirow{5}{*}{$\begin{array}{l}\text { NÃO (indique ao lado } \\
\text { a razão da não } \\
\text { aplicação) }\end{array}$} & & $\begin{array}{lccc}\text { CONTEÚDO } & \text { NÃO } & \text { ADEQUADO } & \text { ÀS } \\
\text { NECESSIDADES ESPECÍFICAS DA REGIÃO } & \end{array}$ \\
\hline & & & \begin{tabular}{lccc|} 
CONTEÚDO & NÃO & FOI & \multicolumn{2}{c}{ SUFICIENTEMENTE } \\
APROFUNDADO & PARA & PERMITIR & UMA \\
APLICAÇÃO EFICAZ E EFICIENTE &
\end{tabular} \\
\hline & & & $\begin{array}{l}\text { FALTA DE APOIO E INCENTIVO DA } \\
\text { INSTITUIÇÃO }\end{array}$ \\
\hline & & & FALTA DE INCENTIVO ÀS AÇÕES DE ATER \\
\hline & & & NÃO TENHO INTERESSE EM APLICAR \\
\hline
\end{tabular}

A partir deste curso: (As opções não são excludentes: você poderá marcar mais de uma opção)

\begin{tabular}{|l|l|}
\hline & NÃO MUDOU NADA EM MEU TRABALHO. \\
\hline$X$ & $\begin{array}{l}\text { MEU TRABALHO PASSOU A CONTRIBUIR MAIS COM OS AGRICULTORES(AS) } \\
\text { FAMILIARES. }\end{array}$ \\
\hline $\mathbf{X}$ & CONSEGUI INFLUENCIAR NAS ORIENTAÇÕES DA MINHA INSTITUIÇÃO. \\
\hline $\mathbf{X}$ & PASSEI A TRABALHAR COM METODOLOGIAS PARTICIPATIVAS. \\
\hline $\mathbf{X}$ & $\begin{array}{l}\text { CRESCEU A ÁREA DE AGRICULTURA DE BASE ECOLÓGICA NAS } \\
\text { COMUNIDADES ONDE ATUO. }\end{array}$ \\
\hline $\mathbf{X}$ & CONTINUEI ME APERFEIÇOANDO SOBRE TEMAS ABORDADOS. \\
\hline
\end{tabular}

Depois do curso você apoiou atividades de capacitação de técnicos e agricultores com base nos princípios e diretrizes da Pnater? (Considere como apoio a atividades de capacitação a participação no planejamento, elaboração de ementas, seleção de participantes e de palestrantes.) 


\begin{tabular}{|l|l|}
\hline$X$ & SIM \\
\hline & NÃO \\
\hline
\end{tabular}

Usou os conhecimentos para ministrar outros cursos com o mesmo conteúdo ou conteúdos semelhantes?

\begin{tabular}{|l|l|}
\hline$X$ & SIM \\
\hline & NÃO \\
\hline
\end{tabular}

Marque o seu grau de satisfação com relação ao curso oferecido pelo DATER: (Considere a seguinte pontuação: 1 - MUITO RUIM; 2 - RUIM; 3 - REGULAR; 4 BOM; 5 - MUITO BOM)

\begin{tabular}{|l|l|l|l|l|}
\hline 1 & 2 & 3 & 4 & $(X) 5$ \\
\hline
\end{tabular}

10) Marque seu grau de satisfação com relação ao DATER: (Considere a seguinte pontuação: 1 - MUITO RUIM; 2 - RUIM; 3 - REGULAR; 4 - BOM; 5 - MUITO BOM)

\begin{tabular}{|l|l|l|l|l|}
\hline 1 & 2 & 3 & 4 & $(X) 5$ \\
\hline
\end{tabular}




\section{PESQUISA - IMPACTO DAS AÇÕES DE FORMAÇÃO REALIZADAS PELO DATER/SAF/MDA NO PERÍODO 2004-2009}

Caros colaboradores,

Contamos com a sua atenção para preencher o formulário abaixo.

O mesmo tem por objetivo fornecer informações para avaliação da Eficiência, Efetividade e Eficácia da Política Pública de Formação de Agentes de Ater adotada pelo Departamento de Assistência Técnica e Extensão Rural, da Secretaria de Agricultura Familiar do Ministério do Desenvolvimento - DATER/SAF/MDA, no período de 2004 a 2009, tema escolhido para Monografia a ser apresentada à Universidade de Brasília (UnB) como requisito parcial para obtenção do grau de Bacharel em Administração.

Você poderá ou não se identificar no questionário e garantimos que todas as informações fornecidas serão confidenciais e utilizadas apenas de forma sistematizada.

IDENTIFICAÇÃO

\begin{tabular}{|l|l|}
\hline Nome: Geraldo Sousa Costa & $\begin{array}{l}\text { Sexo: } \\
(\mathbf{x}) \text { masculino }(\quad) \text { feminino }\end{array}$ \\
\hline $\begin{array}{l}\text { Instituição: } \\
\text { Comissão Executiva do Plano da Lavoura } \\
\text { Cacaueira - CEPLAC. }\end{array}$ & $\begin{array}{l}\text { Local de trabalho: } \\
\text { CEPLAC/SUPOR/SEREX }\end{array}$ \\
$\begin{array}{l}\text { Órgão singular do Ministério da Agricultura, } \\
\text { Pecuária e Abastecimento - MAPA }\end{array}$ & \multicolumn{1}{|c|}{ Altamira - Pará } \\
\hline $\begin{array}{l}\text { Curso/Encontro/Oficina do qual participou: } \\
\text { Curso - Bases Agroecolóligas da Agricultura Sustentável Carga horária de } 40 \text { horas }\end{array}$ \\
$\begin{array}{l}\text { Data do Curso/Encontro/Oficina: } \\
\text { Novembro/2004 na cidade de Belém-PA }\end{array}$ \\
\hline
\end{tabular}

Indique sua área de atuação? (As opções não são excludentes: você poderá marcar mais de uma opção) 


\begin{tabular}{|l|l|}
\hline$X$ & EXTENSÃO RURAL \\
\hline & PESQUISA \\
\hline & ENSINO \\
\hline & OUTROS \\
\hline
\end{tabular}

2) Qual o seu nível de escolaridade?

\begin{tabular}{|l|l|}
\hline$X$ & NÍVEL MÉDIO \\
\hline$X$ & NÍVEL SUPERIOR (Em andamento - Administração de Empresas) \\
\hline & PÓS-GRADUAÇÃO \\
\hline
\end{tabular}

3)Os conteúdos abordados foram condizentes com as demandas do seu dia-a-dia?

\begin{tabular}{|l|l|}
\hline$X$ & SIM \\
\hline & PARCIALMENTE \\
\hline & NÃO \\
\hline
\end{tabular}

4)O curso contribuiu para o seu aperfeiçoamento profissional?

\begin{tabular}{|l|l|}
\hline$X$ & SIM \\
\hline & NÃO \\
\hline
\end{tabular}

Os conhecimentos adquiridos estão sendo aplicados no seu trabalho? Em caso afirmativo, indique em que grau estes conhecimentos estão sendo aplicados. Em caso negativo, indique por que razão isto não ocorre:

\begin{tabular}{|l|l|l|l|}
\hline$X$ & $\begin{array}{l}\text { SIM (indique ao lado } \\
\text { em que grau) }\end{array}$ & MUITO APLICADOS \\
\hline
\end{tabular}




\begin{tabular}{|c|c|}
\hline & MEDIAMENTE APLICADOS \\
\hline & POUCO APLICADOS \\
\hline \multirow{5}{*}{$\begin{array}{l}\text { NÃO (indique ao lado } \\
\text { a razão da não } \\
\text { aplicação) }\end{array}$} & $\begin{array}{lccc}\text { CONTEÚDO } & \text { NÃO } & \text { ADEQUADO } & \text { ÀS } \\
\text { NECESSIDADES ESPECÍFICAS DA REGIÃO } & \end{array}$ \\
\hline & \begin{tabular}{lccc|} 
CONTEÚDO & NÃO & FOI & SUFICIENTEMENTE \\
APROFUNDADO & PARA & PERMITIR & UMA \\
APLICAÇÃO EFICAZ E EFICIENTE &
\end{tabular} \\
\hline & $\begin{array}{l}\text { FALTA DE APOIO E INCENTIVO DA MINHA } \\
\text { INSTITUIÇÃO }\end{array}$ \\
\hline & FALTA DE INCENTIVO ÀS AÇÕES DE ATER \\
\hline & NÃO TENHO INTERESSE EM APLICAR \\
\hline
\end{tabular}

A partir deste curso: (As opções não são excludentes: você poderá marcar mais de uma opção)

\begin{tabular}{|l|l|}
\hline & NÃO MUDOU NADA EM MEU TRABALHO. \\
\hline$X$ & $\begin{array}{l}\text { MEU TRABALHO PASSOU A CONTRIBUIR MAIS COM OS AGRICULTORES(AS) } \\
\text { FAMILIARES. }\end{array}$ \\
\hline$X$ & CONSEGUI INFLUENCIAR NAS ORIENTAÇÕES DA MINHA INSTITUIÇÃO. \\
\hline$X$ & PASSEI A TRABALHAR COM METODOLOGIAS PARTICIPATIVAS. \\
\hline$X$ & $\begin{array}{l}\text { CRESCEU A ÁREA DE AGRICULTURA DE BASE ECOLÓGICA NAS } \\
\text { COMUNIDADES ONDE ATUO. }\end{array}$ \\
\hline$X$ & CONTINUEI ME APERFEIÇOANDO SOBRE TEMAS ABORDADOS. \\
\hline
\end{tabular}

Depois do curso você apoiou atividades de capacitação de técnicos e agricultores com base nos princípios e diretrizes da Pnater? (Considere como apoio a atividades de capacitação a participação no planejamento, elaboração de ementas, seleção de participantes e de palestrantes.) 


\begin{tabular}{|l|l|}
\hline$X$ & SIM \\
\hline & NÃO \\
\hline
\end{tabular}

Usou os conhecimentos para ministrar outros cursos com o mesmo conteúdo ou conteúdos semelhantes?

\begin{tabular}{|l|l|}
\hline$X$ & SIM \\
\hline & NÃO \\
\hline
\end{tabular}

Marque o seu grau de satisfação com relação ao curso oferecido pelo DATER: (Considere a seguinte pontuação: 1 - MUITO RUIM; 2 - RUIM; 3 - REGULAR; 4 BOM; 5 - MUITO BOM)

\begin{tabular}{|l|l|l|l|l|}
\hline 1 & 2 & 3 & 4 & $(X) 5$ \\
\hline
\end{tabular}

10) Marque seu grau de satisfação com relação ao DATER: (Considere a seguinte pontuação: 1 - MUITO RUIM; 2 - RUIM; 3 - REGULAR; 4 - BOM; 5 - MUITO BOM)

\begin{tabular}{|l|l|l|l|l|}
\hline 1 & 2 & 3 & 4 & $(X) 5$ \\
\hline
\end{tabular}


PESQUISA - IMPACTO DAS AÇÕES DE FORMAÇÃO REALIZADAS PELO DATER/SAF/MDA NO PERÍODO 2004-2009

Caros colaboradores,

Contamos com a sua atenção para preencher o formulário abaixo.

O mesmo tem por objetivo fornecer informações para avaliação da Eficiência, Efetividade e Eficácia da Política Pública de Formação de Agentes de Ater adotada pelo Departamento de Assistência Técnica e Extensão Rural, da Secretaria de Agricultura Familiar do Ministério do Desenvolvimento - DATER/SAF/MDA, no período de 2004 a 2009, tema escolhido para Monografia a ser apresentada à Universidade de Brasília (UnB) como requisito parcial para obtenção do grau de Bacharel em Administração.

Você poderá ou não se identificar no questionário e garantimos que todas as informações fornecidas serão confidenciais e utilizadas apenas de forma sistematizada.

\section{IDENTIFICAÇÃO}

\begin{tabular}{|c|c|}
\hline Nome: Celso Franco Damasceno & $\begin{array}{l}\text { Sexo: } \\
(\mathrm{x}) \text { masculino }\end{array}$ \\
\hline $\begin{array}{l}\text { Instituição (nome e tipo de instituição: ONG, } \\
\text { Empresa Pública, etc.): } \\
\text { (na época) } \\
\text { Organização dos Seringueiros de Rondônia - OSR } \\
\text { (( }\end{array}$ & $\begin{array}{l}\text { Local de trabalho (Cidade e Estado): } \\
\text { Porto Velho, Rondônia }\end{array}$ \\
\hline \multicolumn{2}{|c|}{$\begin{array}{l}\text { Curso/Encontro/Oficina do qual participou (caso tenha participado de mais de um curso, preencha } \\
\text { um formulário para cada um deles): } \\
\text { Curso de agentes de ATER que atuam com populações extrativistas }\end{array}$} \\
\hline $\begin{array}{l}\text { Data do Curso/Encontro/Oficina (pelo menos mês } \\
\text { Fevereiro de } 2005 \text {, em Belém, PA }\end{array}$ & \\
\hline
\end{tabular}

1)Indique sua área de atuação? (As opções não são excludentes: você poderá marcar mais de uma opção)

\begin{tabular}{|l|l|}
\hline$X$ & EXTENSÃO RURAL \\
\hline & PESQUISA \\
\hline
\end{tabular}




\begin{tabular}{|l|l|}
\hline & ENSINO \\
\hline & OUTROS \\
\hline
\end{tabular}

2) Qual o seu nível de escolaridade?

\begin{tabular}{|l|l|}
\hline & NÍVEL MÉDIO \\
\hline & NÍVEL SUPERIOR \\
\hline$X$ & PÓS-GRADUAÇÃO \\
\hline
\end{tabular}

3) Os conteúdos abordados foram condizentes com as demandas do seu dia-a-dia?

\begin{tabular}{|l|l|}
\hline$X$ & SIM \\
\hline & PARCIALMENTE \\
\hline & NÃO \\
\hline
\end{tabular}

4) O curso contribuiu para o seu aperfeiçoamento profissional?

\begin{tabular}{|l|l|}
\hline$X$ & SIM \\
\hline & NÃO \\
\hline
\end{tabular}

5) Os conhecimentos adquiridos estão sendo aplicados no seu trabalho? Em caso afirmativo, indique em que grau estes conhecimentos estão sendo aplicados. Em caso negativo, indique por que razão isto não ocorre:

\begin{tabular}{|l|l|l|l|}
\hline \multirow{2}{*}{$\begin{array}{l}\text { SIM (indique ao lado em } \\
\text { que grau) }\end{array}$} & $X$ & MUITO APLICADOS \\
\cline { 2 - 3 } & & MEDIAMENTE APLICADOS \\
\hline & $\begin{array}{l}\text { NÃO (indique ao lado a } \\
\text { razão da não aplicação) }\end{array}$ & $\begin{array}{l}\text { CONTEÚDO NÃO ADEQUADO ÀS NECESSIDADES } \\
\text { ESPECÍFICAS DA REGIÃO }\end{array}$ \\
\hline
\end{tabular}




\begin{tabular}{|l|l|l|}
\hline \multirow{10}{*}{} & $\begin{array}{l}\text { CONTEÚDO NÃO FOI SUFICIENTEMENTE } \\
\text { APROFUNDADO PARA PERMITIR UMA APLICAÇÃO } \\
\text { EFICAZ E EFICIENTE }\end{array}$ \\
\cline { 2 - 4 } & $\begin{array}{l}\text { FALTA DE APOIO E INCENTIVO DA MINHA } \\
\text { INSTITUIÇÃO }\end{array}$ \\
\cline { 2 - 4 } & FALTA DE INCENTIVO ÀS AÇÕES DE ATER \\
\hline & NÃO TENHO INTERESSE EM APLICAR \\
\hline
\end{tabular}

6) A partir deste curso: (As opções não são excludentes: você poderá marcar mais de uma opção)

\begin{tabular}{|l|l|}
\hline & NÃO MUDOU NADA EM MEU TRABALHO. \\
\hline & $\begin{array}{l}\text { MEU TRABALHO PASSOU A CONTRIBUIR MAIS COM OS AGRICULTORES(AS) } \\
\text { FAMILIARES. }\end{array}$ \\
\hline $\mathrm{X}$ & CONSEGUI INFLUENCIAR NAS ORIENTAÇÕES DA MINHA INSTITUIÇÃO. \\
\hline & $\begin{array}{l}\text { CRESCEU A ÁREA DE AGRICULTURA DE BASE ECOLÓGICA NAS COMUNIDADES } \\
\text { ONDE ATUO. }\end{array}$ \\
\hline$X$ & CONTINUEI ME APERFEIÇOANDO SOBRE TEMAS ABORDADOS. \\
\hline
\end{tabular}

7) Depois do curso você apoiou atividades de capacitação de técnicos e agricultores com base nos princípios e diretrizes da Pnater? (Considere como apoio a atividades de capacitação a participação no planejamento, elaboração de ementas, seleção de participantes e de palestrantes.)

\begin{tabular}{|l|l|}
\hline$X$ & SIM \\
\hline$X$ & NÃO \\
\hline
\end{tabular}

8) Usou os conhecimentos para ministrar outros cursos com o mesmo conteúdo ou conteúdos semelhantes? 


\begin{tabular}{|l|l|}
\hline$X$ & SIM \\
\hline & NÃO \\
\hline
\end{tabular}

9) Marque o seu grau de satisfação com relação ao curso oferecido pelo DATER: (Considere a seguinte pontuação: 1 - MUITO RUIM; 2 - RUIM; 3 - REGULAR; 4 - BOM; 5 - MUITO BOM)

\begin{tabular}{|l|l|l|l|l|}
\hline 1 & 2 & 3 & 4 & $5 \times$ \\
\hline
\end{tabular}

10) Marque seu grau de satisfação com relação ao DATER: (Considere a seguinte pontuação: 1 - MUITO RUIM; 2 - RUIM; 3 - REGULAR; 4 - BOM; 5 - MUITO BOM)

\begin{tabular}{|l|l|l|l|l|}
\hline 1 & 2 & 3 & 4 & $5 \times$ \\
\hline
\end{tabular}


PESQUISA - IMPACTO DAS AÇÕES DE FORMAÇÃO REALIZADAS PELO DATER/SAF/MDA NO PERÍODO 2004-2009

Caros colaboradores,

Contamos com a sua atenção para preencher o formulário abaixo.

O mesmo tem por objetivo fornecer informações para avaliação da Eficiência, Efetividade e Eficácia da Política Pública de Formação de Agentes de Ater adotada pelo Departamento de Assistência Técnica e Extensão Rural, da Secretaria de Agricultura Familiar do Ministério do Desenvolvimento - DATER/SAF/MDA, no período de 2004 a 2009, tema escolhido para Monografia a ser apresentada à Universidade de Brasília (UnB) como requisito parcial para obtenção do grau de Bacharel em Administração.

Você poderá ou não se identificar no questionário e garantimos que todas as informações fornecidas serão confidenciais e utilizadas apenas de forma sistematizada.

IDENTIFICAÇÃO

\begin{tabular}{|c|c|}
\hline Nome: Otácia Emília Silva Cabral & $\begin{array}{l}\text { Sexo: } \\
(\quad) \text { masculino } \quad(x) \text { feminino }\end{array}$ \\
\hline $\begin{array}{l}\text { Instituição (nome e tipo de instituição: ONG, } \\
\text { Empresa Pública, etc.): Secretaria de Meio } \\
\text { Ambiente }\end{array}$ & $\begin{array}{l}\text { Local de trabalho (Cidade e Estado): Belém } \\
\text { - PA }\end{array}$ \\
\hline \multicolumn{2}{|c|}{$\begin{array}{l}\text { Curso/Encontro/Oficina do qual participou (caso tenha participado de mais de um curso, preencha } \\
\text { um formulário para cada um deles): Curso de Plantas Medicinais - ATER, em Fortaleza, } 2005 .\end{array}$} \\
\hline /Oficina $(p$ & 5 \\
\hline
\end{tabular}

1)Indique sua área de atuação? (As opções não são excludentes: você poderá marcar mais de uma opção)

\begin{tabular}{|l|l|}
\hline$X$ & EXTENSÃO RURAL \\
\hline$X$ & PESQUISA \\
\hline & ENSINO \\
\hline$X$ & OUTROS \\
\hline
\end{tabular}

2) Qual o seu nível de escolaridade? 


\begin{tabular}{|c|l|}
\hline & NÍVEL MÉDIO \\
\hline & NÍVEL SUPERIOR \\
\hline$X$ & PÓS-GRADUAÇÃO \\
\hline
\end{tabular}

3) Os conteúdos abordados foram condizentes com as demandas do seu dia-a-dia?

\begin{tabular}{|l|l|}
\hline$X$ & SIM \\
\hline & PARCIALMENTE \\
\hline & NÃO \\
\hline
\end{tabular}

4) O curso contribuiu para o seu aperfeiçoamento profissional?

\begin{tabular}{|l|l|}
\hline$X$ & SIM \\
\hline & NÃO \\
\hline
\end{tabular}

5) Os conhecimentos adquiridos estão sendo aplicados no seu trabalho? Em caso afirmativo, indique em que grau estes conhecimentos estão sendo aplicados. Em caso negativo, indique por que razão isto não ocorre:

\begin{tabular}{|c|c|c|}
\hline \multirow{3}{*}{$\begin{array}{l}\text { SIM (indique ao lado em } \\
\text { que grau) }\end{array}$} & & MUITO APLICADOS \\
\hline & $X$ & MEDIAMENTE APLICADOS \\
\hline & & POUCO APLICADOS \\
\hline \multirow{3}{*}{$\begin{array}{l}\text { NÃO (indique ao lado a } \\
\text { razão da não aplicação) }\end{array}$} & & $\begin{array}{l}\text { CONTEÚDO NÃO ADEQUADO ÀS NECESSIDADES } \\
\text { ESPECÍFICAS DA REGIÃO }\end{array}$ \\
\hline & & $\begin{array}{l}\text { CONTEÚDO NÃO } \quad \text { FOI SUFICIENTEMENTE } \\
\text { APROFUNDADO PARA } \\
\text { EERMITIR UMA APLICAÇÃO } \\
\text { EFICAZ E EFICIENTE }\end{array}$ \\
\hline & & $\begin{array}{l}\text { FALTA DE APOIO } \\
\text { INSTITUIÇÃO }\end{array}$ \\
\hline
\end{tabular}




\begin{tabular}{|l|l|l|}
\hline \multirow{2}{*}{} & & FALTA DE INCENTIVO ÀS AÇÕES DE ATER \\
\cline { 3 - 4 } & & NÃO TENHO INTERESSE EM APLICAR \\
\hline
\end{tabular}

6) A partir deste curso: (As opções não são excludentes: você poderá marcar mais de uma opção)

\begin{tabular}{|l|l|}
\hline$x$ & $\begin{array}{l}\text { NẼO MUDOU NADA EM MEU TRABALHO. } \\
\text { FAMILIARES. }\end{array}$ \\
\hline & CONSEGUI INFLUENCIAR NAS ORIENTAÇÕES DA MINHA INSTITUIÇÃO. \\
\hline & PASSEI A TRABALHAR COM METODOLOGIAS PARTICIPATIVAS. \\
\hline & $\begin{array}{l}\text { ORESCEU A ÁREA DE AGRICULTURA DE BASE ECOLÓGICA NAS COMUNIDADES } \\
\text { ONDE ATUO. }\end{array}$ \\
\hline & CONTINUEI ME APERFEIÇOANDO SOBRE TEMAS ABORDADOS. \\
\hline
\end{tabular}

7) Depois do curso você apoiou atividades de capacitação de técnicos e agricultores com base nos princípios e diretrizes da Pnater? (Considere como apoio a atividades de capacitação a participação no planejamento, elaboração de ementas, seleção de participantes e de palestrantes.)

\begin{tabular}{|l|l|}
\hline & SIM \\
\hline$X$ & NÃO \\
\hline
\end{tabular}

8) Usou os conhecimentos para ministrar outros cursos com o mesmo conteúdo ou conteúdos semelhantes?

\begin{tabular}{|l|l|}
\hline$X$ & SIM \\
\hline & NÃO \\
\hline
\end{tabular}

9) Marque o seu grau de satisfação com relação ao curso oferecido pelo DATER: (Considere a seguinte pontuação: 1 - MUITO RUIM; 2 - RUIM; 3 - REGULAR; 4 - BOM; 5 - MUITO BOM) 


\begin{tabular}{|l|l|l|l|l|}
\hline 1 & 2 & 3 & 4 & $5 \times$ \\
\hline
\end{tabular}

10) Marque seu grau de satisfação com relação ao DATER: (Considere a seguinte pontuação: 1 - MUITO RUIM; 2 - RUIM; 3 - REGULAR; 4 - BOM; 5 - MUITO BOM)

\begin{tabular}{|l|l|l|l|l|}
\hline 1 & 2 & 3 & 4 & $5 \times$ \\
\hline
\end{tabular}


PESQUISA - IMPACTO DAS AÇÕES DE FORMAÇÃO REALIZADAS PELO DATER/SAF/MDA NO PERÍODO 2004-2009

Caros colaboradores,

Contamos com a sua atenção para preencher o formulário abaixo.

O mesmo tem por objetivo fornecer informações para avaliação da Eficiência, Efetividade e Eficácia da Política Pública de Formação de Agentes de Ater adotada pelo Departamento de Assistência Técnica e Extensão Rural, da Secretaria de Agricultura Familiar do Ministério do Desenvolvimento - DATER/SAF/MDA, no período de 2004 a 2009, tema escolhido para Monografia a ser apresentada à Universidade de Brasília (UnB) como requisito parcial para obtenção do grau de Bacharel em Administração.

Você poderá ou não se identificar no questionário e garantimos que todas as informações fornecidas serão confidenciais e utilizadas apenas de forma sistematizada.

IDENTIFICAÇÃO

\begin{tabular}{|l|l|}
\hline Nome: Newton Garcia Gomes & $\begin{array}{l}\text { Sexo: } \\
(\mathrm{x}) \text { masculino } \quad(\quad \text { ) feminino }\end{array}$ \\
\hline $\begin{array}{l}\text { Instituição (nome e tipo de instituição: ONG, } \\
\text { Empresa Pública, etc.): EMATER - RONDONIA }\end{array}$ & $\begin{array}{l}\text { Local de trabalho (Cidade e Estado): } \\
\text { EMATER CABIXI }\end{array}$ \\
\hline $\begin{array}{l}\text { Curso/Encontro/Oficina do qual participou (caso tenha participado de mais de um curso, preencha } \\
\text { um formulário para cada um deles): OFICINA SOBRE SISTEMA DE PRODUÇÃO DE TAMBAQUI }\end{array}$ \\
\hline Data do Curso/Encontro/Oficina (pelo menos mês e ano): 09 e 10/08/2006 \\
\hline
\end{tabular}

Indique sua área de atuação? (As opções não são excludentes: você poderá marcar mais de uma opção)

\begin{tabular}{|l|l|}
\hline$X$ & EXTENSÃO RURAL \\
\hline & PESQUISA \\
\hline & ENSINO \\
\hline & OUTROS \\
\hline
\end{tabular}

2) Qual o seu nível de escolaridade? 


\begin{tabular}{|l|l|}
\hline$X$ & NÍVEL MÉDIO \\
\hline & NÍVEL SUPERIOR \\
\hline & PÓS-GRADUAÇÃO \\
\hline
\end{tabular}

3) Os conteúdos abordados foram condizentes com as demandas do seu dia-a-dia?

\begin{tabular}{|l|l|}
\hline$X$ & SIM \\
\hline & PARCIALMENTE \\
\hline & NÃO \\
\hline
\end{tabular}

4) O curso contribuiu para o seu aperfeiçoamento profissional?

\begin{tabular}{|l|l|}
\hline$X$ & SIM \\
\hline & NÃO \\
\hline
\end{tabular}

5) Os conhecimentos adquiridos estão sendo aplicados no seu trabalho? Em caso afirmativo, indique em que grau estes conhecimentos estão sendo aplicados. Em caso negativo, indique por que razão isto não ocorre:

\begin{tabular}{|c|c|c|c|}
\hline \multirow{3}{*}{ X } & \multirow{3}{*}{$\begin{array}{l}\text { SIM (indique ao lado em } \\
\text { que grau) }\end{array}$} & & MUITO APLICADOS \\
\hline & & $X$ & MEDIAMENTE APLICADOS \\
\hline & & & POUCO APLICADOS \\
\hline & \multirow{3}{*}{$\begin{array}{l}\text { NÃO (indique ao lado a } \\
\text { razão da não aplicação) }\end{array}$} & & $\begin{array}{l}\text { CONTEÚDO NÃO ADEQUADO ÀS NECESSIDADES } \\
\text { ESPECÍFICAS DA REGIÃO }\end{array}$ \\
\hline & & & $\begin{array}{l}\text { CONTEÚDO NÃO } \quad \text { FOI SUFICIENTEMENTE } \\
\text { APROFUNDADO PARA } \\
\text { EERMITIR UMA APLICAÇÃO } \\
\text { EFICAZ E EFICIENTE }\end{array}$ \\
\hline & & & $\begin{array}{lccccc}\text { FALTA DE APOIO } & \text { E } & \text { INCENTIVO } & \text { DA } & \text { MINHA } \\
\text { INSTITUIÇÃO } & & & & & \end{array}$ \\
\hline
\end{tabular}




\begin{tabular}{|l|l|l|}
\hline \multirow{2}{*}{} & & FALTA DE INCENTIVO ÀS AÇÕES DE ATER \\
\cline { 3 - 4 } & & NÃO TENHO INTERESSE EM APLICAR \\
\hline
\end{tabular}

6) A partir deste curso: (As opções não são excludentes: você poderá marcar mais de uma opção)

\begin{tabular}{|r|l|}
\hline$x$ & $\begin{array}{l}\text { NẼO MUDOU NADA EM MEU TRABALHO. } \\
\text { FAMILIARES. }\end{array}$ \\
\hline$X$ & CONSEGUI INFLUENCIAR NAS ORIENTAÇÕES DA MINHA INSTITUIÇÃO. \\
\hline & PASSEI A TRABALHAR COM METODOLOGIAS PARTICIPATIVAS. \\
\hline$X$ & $\begin{array}{l}\text { CRESCEU A ÁREA DE AGRICULTURA DE BASE ECOLÓGICA NAS COMUNIDADES } \\
\text { ONDE ATUO. }\end{array}$ \\
\hline$X$ & CONTINUEI ME APERFEIÇOANDO SOBRE TEMAS ABORDADOS. \\
\hline
\end{tabular}

7) Depois do curso você apoiou atividades de capacitação de técnicos e agricultores com base nos princípios e diretrizes da Pnater? (Considere como apoio a atividades de capacitação a participação no planejamento, elaboração de ementas, seleção de participantes e de palestrantes.)

\begin{tabular}{|l|l|}
\hline$X$ & SIM \\
\hline & NÃO \\
\hline
\end{tabular}

8) Usou os conhecimentos para ministrar outros cursos com o mesmo conteúdo ou conteúdos semelhantes?

\begin{tabular}{|l|l|}
\hline & SIM \\
\hline$X$ & NÃO \\
\hline
\end{tabular}

9) Marque o seu grau de satisfação com relação ao curso oferecido pelo DATER: (Considere a seguinte pontuação: 1 - MUITO RUIM; 2 - RUIM; 3 - REGULAR; 4 - BOM; 5 - MUITO BOM) 


\begin{tabular}{|l|l|l|l|l|}
\hline 1 & 2 & 3 & 4 & 5 \\
\hline
\end{tabular}

10) Marque seu grau de satisfação com relação ao DATER: (Considere a seguinte pontuação:

1 - MUITO RUIM; 2 - RUIM; 3 - REGULAR; 4 - BOM; 5 - MUITO BOM)

\begin{tabular}{|l|l|l|l|l|}
\hline 1 & 2 & 3 & 4 & 5 \\
\hline
\end{tabular}

$$
\text { 4-BOM } 4 \text { - BOM }
$$


PESQUISA - IMPACTO DAS AÇÕES DE FORMAÇÃO REALIZADAS PELO DATER/SAF/MDA NO PERÍODO 2004-2009

Caros colaboradores,

Contamos com a sua atenção para preencher o formulário abaixo.

O mesmo tem por objetivo fornecer informações para avaliação da Eficiência, Efetividade e Eficácia da Política Pública de Formação de Agentes de Ater adotada pelo Departamento de Assistência Técnica e Extensão Rural, da Secretaria de Agricultura Familiar do Ministério do Desenvolvimento - DATER/SAF/MDA, no período de 2004 a 2009, tema escolhido para Monografia a ser apresentada à Universidade de Brasília (UnB) como requisito parcial para obtenção do grau de Bacharel em Administração.

Você poderá ou não se identificar no questionário e garantimos que todas as informações fornecidas serão confidenciais e utilizadas apenas de forma sistematizada.

\section{IDENTIFICAÇÃO}

\begin{tabular}{|l|l|}
\hline Nome: Newton de Lucena Costa & $\begin{array}{l}\text { Sexo: } \\
(\mathrm{x}) \text { masculino } \quad(\quad \text { ) feminino }\end{array}$ \\
\hline $\begin{array}{l}\text { Instituição (nome e tipo de instituição: ONG, } \\
\text { Empresa Pública, etc.): Embrapa Amapá }\end{array}$ & $\begin{array}{l}\text { Local de trabalho (Cidade e Estado): } \\
\text { Macapá, Amapá }\end{array}$ \\
\hline $\begin{array}{l}\text { Curso/Encontro/Oficina do qual participou (caso tenha participado de mais de um curso, preencha } \\
\text { um formulário para cada um deles): Curso de Agroecologia }\end{array}$ \\
\hline Data do Curso/Encontro/Oficina (pelo menos mês e ano): março/agosto 2006 \\
\hline
\end{tabular}

1)Indique sua área de atuação? (As opções não são excludentes: você poderá marcar mais de uma opção)

\begin{tabular}{|l|l|}
\hline & EXTENSÃO RURAL \\
\hline$x$ & PESQUISA \\
\hline & ENSINO \\
\hline & OUTROS \\
\hline
\end{tabular}


2) Qual o seu nível de escolaridade?

\begin{tabular}{|l|l|}
\hline & NÍVEL MÉDIO \\
\hline & NÍVEL SUPERIOR \\
\hline$x$ & PÓS-GRADUAÇÃO \\
\hline
\end{tabular}

3) Os conteúdos abordados foram condizentes com as demandas do seu dia-a-dia?

\begin{tabular}{|l|l|}
\hline$x$ & SIM \\
\hline & PARCIALMENTE \\
\hline & NÃO \\
\hline
\end{tabular}

4) O curso contribuiu para o seu aperfeiçoamento profissional?

\begin{tabular}{|l|l|}
\hline$x$ & SIM \\
\hline & NÃO \\
\hline
\end{tabular}

5) Os conhecimentos adquiridos estão sendo aplicados no seu trabalho? Em caso afirmativo, indique em que grau estes conhecimentos estão sendo aplicados. Em caso negativo, indique por que razão isto não ocorre:

\begin{tabular}{|c|c|c|c|}
\hline \multirow{3}{*}{$x$} & \multirow{3}{*}{$\begin{array}{l}\text { SIM (indique ao lado em } \\
\text { que grau) }\end{array}$} & $x$ & MUITO APLICADOS \\
\hline & & & MEDIAMENTE APLICADOS \\
\hline & & & POUCO APLICADOS \\
\hline & \multirow{3}{*}{$\begin{array}{l}\text { NÃO (indique ao lado a } \\
\text { razão da não aplicação) }\end{array}$} & & $\begin{array}{l}\text { CONTEÚDO NÃO ADEQUADO ȦS NECESSIDADES } \\
\text { ESPECÍFICAS DA REGIÃO }\end{array}$ \\
\hline & & & $\begin{array}{l}\text { CONTEÚDO NÃO } \quad \text { FOI SUFICIENTEMENTE } \\
\text { APROFUNDADO PARA } \\
\text { PERMITIR UMA APLICAÇÃO } \\
\text { EFICAZ E EFICIENTE }\end{array}$ \\
\hline & & & $\begin{array}{l}\text { FALTA DE APOIO } \\
\text { INSTITUIÇÃO }\end{array}$ \\
\hline
\end{tabular}




\begin{tabular}{|l|l|l|}
\hline \multirow{2}{*}{} & & FALTA DE INCENTIVO ÀS AÇÕES DE ATER \\
\cline { 3 - 4 } & & NÃO TENHO INTERESSE EM APLICAR \\
\hline
\end{tabular}

6) A partir deste curso: (As opções não são excludentes: você poderá marcar mais de uma opção)

\begin{tabular}{|l|l|}
\hline$x$ & $\begin{array}{l}\text { NÃO MUDOU NADA EM MEU TRABALHO. } \\
\text { FAMILIARES. }\end{array}$ \\
\hline & CONSEGUI INFLUENCIAR NAS ORIENTAÇÕES DA MINHA INSTITUIÇÃO. \\
\hline & PASSEI A TRABALHAR COM METODOLOGIAS PARTICIPATIVAS. \\
\hline & \begin{tabular}{l} 
ORESCEU A ÁREA DE AGRICULTURA DE BASE ECOLÓGICA NAS COMUNIDADES \\
\hline
\end{tabular} \\
\hline
\end{tabular}

7) Depois do curso você apoiou atividades de capacitação de técnicos e agricultores com base nos princípios e diretrizes da Pnater? (Considere como apoio a atividades de capacitação a participação no planejamento, elaboração de ementas, seleção de participantes e de palestrantes.)

\begin{tabular}{|l|l|}
\hline$x$ & SIM \\
\hline & NÃO \\
\hline
\end{tabular}

8) Usou os conhecimentos para ministrar outros cursos com o mesmo conteúdo ou conteúdos semelhantes?

\begin{tabular}{|l|l|}
\hline$x$ & SIM \\
\hline & NÃO \\
\hline
\end{tabular}


9) Marque o seu grau de satisfação com relação ao curso oferecido pelo DATER: (Considere a seguinte pontuação: 1 - MUITO RUIM; 2 - RUIM; 3 - REGULAR; 4 - BOM; 5 - MUITO BOM)

\begin{tabular}{|l|l|l|l|l|}
\hline 1 & 2 & 3 & 4 & $5-x$ \\
\hline
\end{tabular}

10) Marque seu grau de satisfação com relação ao DATER: (Considere a seguinte pontuação: 1 - MUITO RUIM; 2 - RUIM; 3 - REGULAR; 4 - BOM; 5 - MUITO BOM)

\begin{tabular}{|l|l|l|l|l|}
\hline 1 & 2 & 3 & 4 & $5-x$ \\
\hline
\end{tabular}


PESQUISA - IMPACTO DAS AÇÕES DE FORMAÇÃO REALIZADAS PELO DATER/SAF/MDA NO PERÍODO 2004-2009

Caros colaboradores,

Contamos com a sua atenção para preencher o formulário abaixo.

O mesmo tem por objetivo fornecer informações para avaliação da Eficiência, Efetividade e Eficácia da Política Pública de Formação de Agentes de Ater adotada pelo Departamento de Assistência Técnica e Extensão Rural, da Secretaria de Agricultura Familiar do Ministério do Desenvolvimento - DATER/SAF/MDA, no período de 2004 a 2009, tema escolhido para Monografia a ser apresentada à Universidade de Brasília (UnB) como requisito parcial para obtenção do grau de Bacharel em Administração.

Você poderá ou não se identificar no questionário e garantimos que todas as informações fornecidas serão confidenciais e utilizadas apenas de forma sistematizada.

IDENTIFICAÇÃO

\begin{tabular}{|l|l|}
\hline Nome: Moacir Camera & $\begin{array}{l}\text { Sexo: } \\
(\mathrm{x}) \text { masculino } \quad(\quad \text { ) feminino }\end{array}$ \\
\hline $\begin{array}{l}\text { Instituição (nome e tipo de instituição: ONG, } \\
\text { Empresa Pública, etc.): EMATER - RONDONIA }\end{array}$ & $\begin{array}{l}\text { Local de trabalho (Cidade e Estado): } \\
\text { EMATER CABIXI }\end{array}$ \\
\hline $\begin{array}{l}\text { Curso/Encontro/Oficina do qual participou (caso tenha participado de mais de um curso, preencha } \\
\text { um formulário para cada um deles): OFICINA DE GENERO RAÇA E ETNIA. }\end{array}$ \\
\hline Data do Curso/Encontro/Oficina (pelo menos mês e ano): 01/2006 \\
\hline
\end{tabular}

1)Indique sua área de atuação? (As opções não são excludentes: você poderá marcar mais de uma opção)

\begin{tabular}{|l|l|}
\hline$X$ & EXTENSÃO RURAL \\
\hline & PESQUISA \\
\hline & ENSINO \\
\hline & OUTROS \\
\hline
\end{tabular}

2) Qual o seu nível de escolaridade? 


\begin{tabular}{|c|l|}
\hline & NÍVEL MÉDIO \\
\hline$X$ & NÍVEL SUPERIOR \\
\hline & PÓS-GRADUAÇÃO \\
\hline
\end{tabular}

3) Os conteúdos abordados foram condizentes com as demandas do seu dia-a-dia?

\begin{tabular}{|l|l|}
\hline$X$ & SIM \\
\hline & PARCIALMENTE \\
\hline & NÃO \\
\hline
\end{tabular}

4) O curso contribuiu para o seu aperfeiçoamento profissional?

\begin{tabular}{|l|l|}
\hline$X$ & SIM \\
\hline & NÃO \\
\hline
\end{tabular}

5) Os conhecimentos adquiridos estão sendo aplicados no seu trabalho? Em caso afirmativo, indique em que grau estes conhecimentos estão sendo aplicados. Em caso negativo, indique por que razão isto não ocorre:

\begin{tabular}{|c|c|c|c|}
\hline \multirow{3}{*}{$x$} & \multirow{3}{*}{$\begin{array}{l}\text { SIM (indique ao lado em } \\
\text { que grau) }\end{array}$} & & MUITO APLICADOS \\
\hline & & $X$ & MEDIAMENTE APLICADOS \\
\hline & & & POUCO APLICADOS \\
\hline & \multirow{3}{*}{$\begin{array}{l}\text { NÃO (indique ao lado a } \\
\text { razão da não aplicação) }\end{array}$} & & $\begin{array}{l}\text { CONTEÚDO NÃO ADEQUADO ÀS NECESSIDADES } \\
\text { ESPECÍFICAS DA REGIÃO }\end{array}$ \\
\hline & & & $\begin{array}{l}\text { CONTEÚDO NÃO FOI SUFICIENTEMENTE } \\
\text { APROFUNDADO PARA } \\
\text { PERMITIR UMA APLICAÇÃO } \\
\text { EFICAZ E EFICIENTE }\end{array}$ \\
\hline & & & $\begin{array}{llllll}\text { FALTA DE APOIO } & \text { E } & \text { INCENTIVO } & \text { DA } & \text { MINHA } \\
\text { INSTITUIÇÃO } & & & & & \end{array}$ \\
\hline
\end{tabular}




\begin{tabular}{|l|l|l|}
\hline \multirow{2}{*}{} & & FALTA DE INCENTIVO ÀS AÇÕES DE ATER \\
\cline { 3 - 4 } & & NÃO TENHO INTERESSE EM APLICAR \\
\hline
\end{tabular}

6) A partir deste curso: (As opções não são excludentes: você poderá marcar mais de uma opção)

\begin{tabular}{|r|l|}
\hline$x$ & $\begin{array}{l}\text { NÃO MUDOU NADA EM MEU TRABALHO. } \\
\text { FAMILIARES. }\end{array}$ \\
\hline$X$ & CONSEGUI INFLUENCIAR NAS ORIENTAÇÕES DA MINHA INSTITUIÇÃO. \\
\hline & PASSEI A TRABALHAR COM METODOLOGIAS PARTICIPATIVAS. \\
\hline & $\begin{array}{l}\text { CRESCEU A ÁREA DE AGRICULTURA DE BASE ECOLÓGICA NAS COMUNIDADES } \\
\text { ONDE ATUO. }\end{array}$ \\
\hline$X$ & CONTINUEI ME APERFEIÇOANDO SOBRE TEMAS ABORDADOS. \\
\hline
\end{tabular}

7) Depois do curso você apoiou atividades de capacitação de técnicos e agricultores com base nos princípios e diretrizes da Pnater? (Considere como apoio a atividades de capacitação a participação no planejamento, elaboração de ementas, seleção de participantes e de palestrantes.)

\begin{tabular}{|l|l|}
\hline & SIM \\
\hline$X$ & NÃO \\
\hline
\end{tabular}

8) Usou os conhecimentos para ministrar outros cursos com o mesmo conteúdo ou conteúdos semelhantes?

\begin{tabular}{|l|l|}
\hline & SIM \\
\hline$X$ & NÃO \\
\hline
\end{tabular}


9) Marque o seu grau de satisfação com relação ao curso oferecido pelo DATER: (Considere a seguinte pontuação: 1 - MUITO RUIM; 2 - RUIM; 3 - REGULAR; 4 - BOM; 5 - MUITO BOM)

\begin{tabular}{|l|l|l|l|l|}
\hline 1 & 2 & 3 & 4 & 5 \\
\hline
\end{tabular}

10) Marque seu grau de satisfação com relação ao DATER: (Considere a seguinte pontuação: 1 - MUITO RUIM; 2 - RUIM; 3 - REGULAR; 4 - BOM; 5 - MUITO BOM)

\begin{tabular}{|l|l|l|l|l|}
\hline 1 & 2 & 3 & 4 & 5 \\
\hline
\end{tabular}

4-BOM 4 - BOM 
PESQUISA - IMPACTO DAS AÇÕES DE FORMAÇÃO REALIZADAS PELO DATER/SAF/MDA NO PERÍODO 2004-2009

Caros colaboradores,

Contamos com a sua atenção para preencher o formulário abaixo.

O mesmo tem por objetivo fornecer informações para avaliação da Eficiência, Efetividade e Eficácia da Política Pública de Formação de Agentes de Ater adotada pelo Departamento de Assistência Técnica e Extensão Rural, da Secretaria de Agricultura Familiar do Ministério do Desenvolvimento - DATER/SAF/MDA, no período de 2004 a 2009, tema escolhido para Monografia a ser apresentada à Universidade de Brasília (UnB) como requisito parcial para obtenção do grau de Bacharel em Administração.

Você poderá ou não se identificar no questionário e garantimos que todas as informações fornecidas serão confidenciais e utilizadas apenas de forma sistematizada.

\begin{tabular}{|c|c|}
\hline Nome: Francisco Mende de Sá Barretos Coutinho & $\begin{array}{l}\text { Sexo: } \\
(x) \text { masculino } \quad(\quad) \text { feminino }\end{array}$ \\
\hline $\begin{array}{l}\text { Instituição (nome e tipo de instituição: ONG, } \\
\text { Empresa Pública, etc.): EMATER - RONDONIA }\end{array}$ & $\begin{array}{l}\text { Local de trabalho (Cidade e Estado): } \\
\text { EMATER CABIXI }\end{array}$ \\
\hline \multicolumn{2}{|c|}{$\begin{array}{l}\text { Curso/Encontro/Oficina do qual participou (caso tenha participado de mais de um curso, preencha } \\
\text { um formulário para cada um deles): SEMINÁRIO RONDONIA LEITE - PERRSPECTIVAS DO } \\
\text { LEITE NA AMAZONIA }\end{array}$} \\
\hline Data do Curso/Encontro/Oficina (pelo menos mês $\epsilon$ & no): 08 a 10/11/2006 \\
\hline
\end{tabular}

Indique sua área de atuação? (As opções não são excludentes: você poderá marcar mais de uma opção).

\begin{tabular}{|l|l|}
\hline$X$ & EXTENSÃO RURAL \\
\hline & PESQUISA \\
\hline & ENSINO \\
\hline & OUTROS \\
\hline
\end{tabular}


2) Qual o seu nível de escolaridade?

\begin{tabular}{|c|l|}
\hline & NÍVEL MÉDIO \\
\hline$X$ & NÍVEL SUPERIOR \\
\hline & PÓS-GRADUAÇÃO \\
\hline
\end{tabular}

3) Os conteúdos abordados foram condizentes com as demandas do seu dia-a-dia?

\begin{tabular}{|l|l|}
\hline$X$ & SIM \\
\hline & PARCIALMENTE \\
\hline & NÃO \\
\hline
\end{tabular}

3) O curso contribuiu para o seu aperfeiçoamento profissional?

\begin{tabular}{|l|l|}
\hline$X$ & SIM \\
\hline & NÃO \\
\hline
\end{tabular}

5) Os conhecimentos adquiridos estão sendo aplicados no seu trabalho? Em caso afirmativo, indique em que grau estes conhecimentos estão sendo aplicados. Em caso negativo, indique por que razão isto não ocorre: (Em caso negativo, as respostas não são excludentes: você poderá marcar mais de uma opção).

\begin{tabular}{|c|c|c|c|}
\hline \multirow{3}{*}{$\mathrm{x}$} & \multirow{3}{*}{$\begin{array}{l}\text { SIM (indique ao lado em } \\
\text { que grau) }\end{array}$} & $x$ & MUITO APLICADOS \\
\hline & & & MEDIAMENTE APLICADOS \\
\hline & & & POUCO APLICADOS \\
\hline & \multirow{2}{*}{$\begin{array}{l}\text { NÃO (indique ao lado a } \\
\text { razão da não aplicação) }\end{array}$} & & $\begin{array}{l}\text { CONTEÚDO NÃO ADEQUADO ȦS NECESSIDADES } \\
\text { ESPECÍFICAS DA REGIÃO }\end{array}$ \\
\hline & & & $\begin{array}{l}\text { CONTEÚDO NÃO } \\
\text { APROI }\end{array}$ \\
\hline
\end{tabular}




\begin{tabular}{|l|l|l|}
\hline \multirow{2}{*}{} & & $\begin{array}{l}\text { FALTA DE APOIO E INCENTIVO DA MINHA } \\
\text { INSTITUIÇÃO }\end{array}$ \\
\cline { 2 - 3 } & & FALTA DE INCENTIVO ÀS AÇÕES DE ATER \\
\cline { 2 - 3 } & NÃO TENHO INTERESSE EM APLICAR \\
\hline
\end{tabular}

6) A partir deste curso: (As opções não são excludentes: você poderá marcar mais de uma opção).

\begin{tabular}{|r|l|}
\hline & NÃO MUDOU NADA EM MEU TRABALHO. \\
\hline$X$ & $\begin{array}{l}\text { MEU TRABALHO PASSOU A CONTRIBUIR MAIS COM OS AGRICULTORES(AS) } \\
\text { FAMILIARES. }\end{array}$ \\
\hline$X$ & CONSEGUI INFLUENCIAR NAS ORIENTAÇÕES DA MINHA INSTITUIÇÃO. \\
\hline$X$ & PASSEI A TRABALHAR COM METODOLOGIAS PARTICIPATIVAS. \\
\hline & $\begin{array}{l}\text { CRESCEU A ÁREA DE AGRICULTURA DE BASE ECOLÓGICA NAS COMUNIDADES } \\
\text { ONDE ATUO. }\end{array}$ \\
\hline$X$ & CONTINUEI ME APERFEIÇOANDO SOBRE TEMAS ABORDADOS. \\
\hline
\end{tabular}

7) Depois do curso você apoiou atividades de capacitação de técnicos e agricultores com base nos princípios e diretrizes da Pnater? (Considere como apoio a atividades de capacitação a participação no planejamento, elaboração de ementas, seleção de participantes e de palestrantes.)

\begin{tabular}{|l|l|}
\hline$X$ & SIM \\
\hline & NÃO \\
\hline
\end{tabular}

8) Usou os conhecimentos para ministrar outros cursos com o mesmo conteúdo ou conteúdos semelhantes?

\begin{tabular}{|l|l|}
\hline & SIM \\
\hline$X$ & NÃO \\
\hline
\end{tabular}


9) Marque o seu grau de satisfação com relação ao curso oferecido pelo DATER:

\begin{tabular}{|l|l|l|l|l|}
\hline 1 & 2 & 3 & 4 & 5 \\
\hline
\end{tabular}

10) Marque seu grau de satisfação com relação ao DATER:

\begin{tabular}{|l|l|l|l|l|}
\hline 1 & 2 & 3 & 4 & 5 \\
\hline
\end{tabular}

Obs.: As notas atribuídas às duas últimas questões devem obedecer a ordem crescente: 1 muito ruim, 2 - ruim, 3 - regular, 4 - bom , 5 - muito bom.

4-BOM 4 - BOM 
PESQUISA - IMPACTO DAS AÇÕES DE FORMAÇÃO REALIZADAS PELO DATER/SAF/MDA NO PERÍODO 2004-2009

Caros colaboradores,

Contamos com a sua atenção para preencher o formulário abaixo.

O mesmo tem por objetivo fornecer informações para avaliação da Eficiência, Efetividade e Eficácia da Política Pública de Formação de Agentes de Ater adotada pelo Departamento de Assistência Técnica e Extensão Rural, da Secretaria de Agricultura Familiar do Ministério do Desenvolvimento - DATER/SAF/MDA, no período de 2004 a 2009, tema escolhido para Monografia a ser apresentada à Universidade de Brasília (UnB) como requisito parcial para obtenção do grau de Bacharel em Administração.

Você poderá ou não se identificar no questionário e garantimos que todas as informações fornecidas serão confidenciais e utilizadas apenas de forma sistematizada.

IDENTIFICAÇÃO

\begin{tabular}{|l|l|}
\hline Nome: Francisco de Assis Vieira Meireles & $\begin{array}{l}\text { Sexo: } \\
(\mathrm{x}) \text { masculino } \quad(\quad \text { ) feminino }\end{array}$ \\
\hline $\begin{array}{l}\text { Instituição (nome e tipo de instituição: ONG, } \\
\text { Empresa Pública, etc.): EMATER- Ro }\end{array}$ & $\begin{array}{l}\text { Local de trabalho (Cidade e Estado): } \\
\text { Rio Crespo }\end{array}$ \\
\hline $\begin{array}{l}\text { Curso/Encontro/Oficina do qual participou (caso tenha participado de mais de um curso, preencha } \\
\text { um formulário para cada um deles): Curso sobre Crédito Rural }\end{array}$ \\
\hline Data do Curso/Encontro/Oficina (pelo menos mês e ano): 02 a 05/05/2006 \\
\hline
\end{tabular}

1) Indique sua área de atuação? (As opções não são excludentes: você poderá marcar mais de uma opção)

\begin{tabular}{|l|l|}
\hline$X$ & EXTENSÃO RURAL \\
\hline & PESQUISA \\
\hline & ENSINO \\
\hline & OUTROS \\
\hline
\end{tabular}


2) Qual o seu nível de escolaridade?

\begin{tabular}{|l|l|}
\hline$X$ & NÍVEL MÉDIO \\
\hline & NÍVEL SUPERIOR \\
\hline & PÓS-GRADUAÇÃO \\
\hline
\end{tabular}

3) Os conteúdos abordados foram condizentes com as demandas do seu dia-a-dia?

\begin{tabular}{|l|l|}
\hline$X$ & SIM \\
\hline & PARCIALMENTE \\
\hline & NÃO \\
\hline
\end{tabular}

4) O curso contribuiu para o seu aperfeiçoamento profissional?

\begin{tabular}{|l|l|}
\hline$X$ & SIM \\
\hline & NÃO \\
\hline
\end{tabular}

5) Os conhecimentos adquiridos estão sendo aplicados no seu trabalho? Em caso afirmativo, indique em que grau estes conhecimentos estão sendo aplicados. Em caso negativo, indique por que razão isto não ocorre:

\begin{tabular}{|c|c|c|c|}
\hline \multirow{3}{*}{$X$} & \multirow{3}{*}{$\begin{array}{l}\text { SIM (indique ao lado em } \\
\text { que grau) }\end{array}$} & $\mathrm{X}$ & MUITO APLICADOS \\
\hline & & & MEDIAMENTE APLICADOS \\
\hline & & & POUCO APLICADOS \\
\hline & \multirow{2}{*}{$\begin{array}{l}\text { NÃO (indique ao lado a } \\
\text { razão da não aplicação) }\end{array}$} & & $\begin{array}{l}\text { CONTEU்DO NÃO ADEQUADO ȦS NECESSIDADES } \\
\text { ESPECÍFICAS DA REGIÃO }\end{array}$ \\
\hline & & & $\begin{array}{l}\text { CONTEÚDO NÃO } \quad \text { FOI SUFICIENTEMENTE } \\
\text { APROFUNDADO PARA PERMITIR UMA APLICAÇÃO } \\
\text { EFICAZ E EFICIENTE }\end{array}$ \\
\hline
\end{tabular}




\begin{tabular}{|l|l|l|}
\hline \multirow{2}{*}{} & & $\begin{array}{l}\text { FALTA DE APOIO E INCENTIVO DA MINHA } \\
\text { INSTITUIÇÃO }\end{array}$ \\
\cline { 2 - 3 } & & FALTA DE INCENTIVO ÀS AÇÕES DE ATER \\
\cline { 2 - 3 } & NÃO TENHO INTERESSE EM APLICAR \\
\hline
\end{tabular}

6) A partir deste curso: (As opções não são excludentes: você poderá marcar mais de uma opção)

\begin{tabular}{|l|l|}
\hline$x$ & $\begin{array}{l}\text { NÃO MUDOU NADA EM MEU TRABALHO. } \\
\text { FAMILIARES. }\end{array}$ \\
\hline & CONSEGUI INFLUENCIAR NAS ORIENTAÇÕES DA MINHA INSTITUIÇÃO. \\
\hline & PASSEI A TRABALHAR COM METODOLOGIAS PARTICIPATIVAS. \\
\hline & $\begin{array}{l}\text { CRESCEU A ÁREA DE AGRICULTURA DE BASE ECOLÓGICA NAS COMUNIDADES } \\
\text { ONDE ATUO. }\end{array}$ \\
\hline & CONTINUEI ME APERFEIÇOANDO SOBRE TEMAS ABORDADOS. \\
\hline
\end{tabular}

7) Depois do curso você apoiou atividades de capacitação de técnicos e agricultores com base nos princípios e diretrizes da Pnater? (Considere como apoio a atividades de capacitação a participação no planejamento, elaboração de ementas, seleção de participantes e de palestrantes.)

\begin{tabular}{|l|l|}
\hline & SIM \\
\hline$X$ & NÃO \\
\hline
\end{tabular}

8) Usou os conhecimentos para ministrar outros cursos com o mesmo conteúdo ou conteúdos semelhantes?

\begin{tabular}{|l|l|}
\hline & SIM \\
\hline$X$ & NÃO \\
\hline
\end{tabular}


9) Marque o seu grau de satisfação com relação ao curso oferecido pelo DATER: (Considere a seguinte pontuação: 1 - MUITO RUIM; 2 - RUIM; 3 - REGULAR; 4 - BOM; 5 - MUITO BOM)

\begin{tabular}{|l|l|l|l|l|}
\hline 1 & 2 & 3 & $4 \times$ & 5 \\
\hline
\end{tabular}

10) Marque seu grau de satisfação com relação ao DATER: (Considere a seguinte pontuação: 1 - MUITO RUIM; 2 - RUIM; 3 - REGULAR; 4 - BOM; 5 - MUITO BOM)

\begin{tabular}{|l|l|l|l|l|}
\hline 1 & 2 & 3 & $4 \times$ & 5 \\
\hline
\end{tabular}


PESQUISA - IMPACTO DAS AÇÕES DE FORMAÇÃO REALIZADAS PELO DATER/SAF/MDA NO PERÍODO 2004-2009

Caros colaboradores,

Contamos com a sua atenção para preencher o formulário abaixo.

O mesmo tem por objetivo fornecer informações para avaliação da Eficiência, Efetividade e Eficácia da Política Pública de Formação de Agentes de Ater adotada pelo Departamento de Assistência Técnica e Extensão Rural, da Secretaria de Agricultura Familiar do Ministério do Desenvolvimento - DATER/SAF/MDA, no período de 2004 a 2009, tema escolhido para Monografia a ser apresentada à Universidade de Brasília (UnB) como requisito parcial para obtenção do grau de Bacharel em Administração.

Você poderá ou não se identificar no questionário e garantimos que todas as informações fornecidas serão confidenciais e utilizadas apenas de forma sistematizada.

IDENTIFICAÇÃO

\begin{tabular}{|c|c|}
\hline $\begin{array}{l}\text { Nome: (opcional) } \\
\text { JOÃO BOSCO GORDIANO }\end{array}$ & $\begin{array}{l}\text { Sexo: } \\
(x) \text { masculino }(\quad) \text { feminino }\end{array}$ \\
\hline $\begin{array}{l}\text { Instituição (nome e tipo de instituição: ONG, } \\
\text { Empresa Pública, Cooperativa,etc.): } \\
\text { IDAM }\end{array}$ & $\begin{array}{l}\text { Local de trabalho (Cidade e Estado): } \\
\text { MANAUS - AM }\end{array}$ \\
\hline \multicolumn{2}{|c|}{$\begin{array}{l}\text { Curso/Encontro/Oficina do qual participou (caso tenha participado de mais de um evento de } \\
\text { formação, preencha um formulário para cada um deles): } \\
\text { SISTEMATIZAÇÃO DE EXPERIÊNCIAS }\end{array}$} \\
\hline Seminário (pelo $\mathrm{m}$ & s mês e ano): 2008 \\
\hline
\end{tabular}

1) Indique sua área de atuação? (As opções não são excludentes: você poderá marcar mais de uma opção).

\begin{tabular}{|l|l|}
\hline$X$ & EXTENSÃO RURAL \\
\hline & PESQUISA \\
\hline$x$ & ENSINO \\
\hline
\end{tabular}




\section{OUTROS}

2) Qual o seu nível de escolaridade? (Considere apenas o nível mais alto)

\begin{tabular}{|l|l|}
\hline & NÍVEL MÉDIO \\
\hline & NÍVEL SUPERIOR \\
\hline$x$ & PÓS-GRADUAÇÃO \\
\hline
\end{tabular}

3) Os conteúdos abordados na formação foram condizentes com as demandas do seu dia-adia?

\begin{tabular}{|l|l|}
\hline$X$ & SIM \\
\hline & PARCIALMENTE \\
\hline & NÃO \\
\hline
\end{tabular}

4) O curso ou atividade de formação da qual você participou contribuiu para o seu aperfeiçoamento profissional?

\begin{tabular}{|l|l|}
\hline$x$ & SIM \\
\hline & NÃO \\
\hline
\end{tabular}

5) Os conhecimentos adquiridos nesta formação estão sendo aplicados no seu trabalho? Em caso afirmativo, indique em que grau estes conhecimentos estão sendo aplicados. Em caso negativo, indique por que razão isto não ocorre: (Em caso negativo, as respostas não são excludentes: você poderá marcar mais de uma opção).

\begin{tabular}{|l|l|l|l|}
\hline \multirow{2}{*}{$\begin{array}{l}\text { SIM (indique ao lado } \\
\text { em que grau) }\end{array}$} & & MUITO APLICADOS \\
\cline { 2 - 4 } & $\begin{array}{l}\text { NÃO (indique ao lado a } \\
\text { razão da não }\end{array}$ & MEDIAMENTE APLICADOS \\
\hline
\end{tabular}




\begin{tabular}{|l|l|l|l|}
\hline \multirow{5}{*}{} & aplicação) & $\begin{array}{l}\text { CONTEÚDO NÃO FOI SUFICIENTEMENTE } \\
\text { APROFUNDADO PARA PERMITIR UMA } \\
\text { APLICAÇÃO EFICAZ E EFICIENTE }\end{array}$ \\
\hline & $\begin{array}{l}\text { FALTA DE APOIO E INCENTIVO DA MINHA } \\
\text { INSTITUIÇÃO }\end{array}$ \\
\hline & FALTA DE INCENTIVO ÀS AÇÕES DE ATER \\
\hline & NÃO TENHO INTERESSE EM APLICAR \\
\hline
\end{tabular}

6) A partir do evento de formação do qual você participou: (As respostas não são excludentes: você poderá marcar mais de uma opção).

\begin{tabular}{|l|l|}
\hline & NÃO MUDOU NADA EM MEU TRABALHO. \\
\hline & $\begin{array}{l}\text { MEU TRABALHO PASSOU A CONTRIBUIR MAIS COM OS AGRICULTORES(AS) } \\
\text { FAMILIARES. }\end{array}$ \\
\hline & CONSEGUI INFLUENCIAR NAS ORIENTAÇÕES DA MINHA INSTITUIÇÃO. \\
\hline & $\begin{array}{l}\text { CRESSEI A TRABALHAR COM METODOLOGIAS PARTICIPATIVAS. } \\
\text { COMUNIDADES ONDE ATUO. ÁREA DE AGRICULTURA DE BASE ECOLÓGICA NAS }\end{array}$ \\
\hline$X$ & CONTINUEI ME APERFEIÇOANDO SOBRE TEMAS ABORDADOS. \\
\hline
\end{tabular}

7) Depois do evento de capacitação do qual participou, você apoiou atividades de capacitação de técnicos e/ou agricultores com base nos princípios e diretrizes da Pnater? (Considere como apoio a atividades de capacitação a participação no planejamento, elaboração de ementas, seleção de participantes e de palestrantes.)

\begin{tabular}{|l|l|}
\hline$X$ & SIM \\
\hline & NÃO \\
\hline
\end{tabular}

8) Usou os conhecimentos para ministrar outros eventos de formação com o mesmo conteúdo ou conteúdos semelhantes? 


\begin{tabular}{|l|l|}
\hline$X$ & SIM \\
\hline & NÃO \\
\hline
\end{tabular}

9) Marque o seu grau de satisfação com relação a atividade de formação oferecida pelo DATER: (Considere a seguinte pontuação: 1 - MUITO RUIM; 2 - RUIM; 3 - REGULAR; 4 BOM; 5 - MUITO BOM)

\begin{tabular}{|l|l|l|l|l|}
\hline 1 & 2 & 3 & $4 \times$ & 5 \\
\hline
\end{tabular}

10) Marque seu grau de satisfação com relação ao DATER: (Considere a seguinte pontuação: 1 - MUITO RUIM; 2 - RUIM; 3 - REGULAR; 4 - BOM; 5 - MUITO BOM)

\begin{tabular}{|l|l|l|l|l|}
\hline 1 & 2 & 3 & $4 \times$ & 5 \\
\hline
\end{tabular}


PESQUISA - IMPACTO DAS AÇÕES DE FORMAÇÃO REALIZADAS PELO DATER/SAF/MDA NO PERÍODO 2004-2009

Caros colaboradores,

Contamos com a sua atenção para preencher o formulário abaixo.

O mesmo tem por objetivo fornecer informações para avaliação da Eficiência, Efetividade e Eficácia da Política Pública de Formação de Agentes de Ater adotada pelo Departamento de Assistência Técnica e Extensão Rural, da Secretaria de Agricultura Familiar do Ministério do Desenvolvimento - DATER/SAF/MDA, no período de 2004 a 2009, tema escolhido para Monografia a ser apresentada à Universidade de Brasília (UnB) como requisito parcial para obtenção do grau de Bacharel em Administração.

Você poderá ou não se identificar no questionário e garantimos que todas as informações fornecidas serão confidenciais e utilizadas apenas de forma sistematizada.

IDENTIFICAÇÃO

\begin{tabular}{|c|c|}
\hline $\begin{array}{l}\text { Nome:AQUILINO JOSÉ DE } \text { VASCONCELOS } \\
\text { SILVA }\end{array}$ & $\begin{array}{l}\text { Sexo: } \\
(x) \text { masculino } \quad(\quad) \text { feminino }\end{array}$ \\
\hline $\begin{array}{l}\text { Instituição (nome e tipo de instituição: ONG, } \\
\text { Empresa Pública, etc.): EMATER-PARÁ }\end{array}$ & $\begin{array}{l}\text { Local de trabalho (Cidade e Estado): } \\
\text { SANTA LUZIA DO PARÁ }\end{array}$ \\
\hline \multicolumn{2}{|c|}{$\begin{array}{l}\text { Curso/Encontro/Oficina do qual participou (caso tenha participado de mais de um curso, preencha } \\
\text { um formulário para cada um deles): AGROECOLOGIA }\end{array}$} \\
\hline Data do Curso/Encontro/Oficina (pelo menos mês $\epsilon$ & o): PERÍODO 29/11 A 03/12 \\
\hline
\end{tabular}

1)Indique sua área de atuação? (As opções não são excludentes: você poderá marcar mais de uma opção).

\begin{tabular}{|l|l|}
\hline$X$ & EXTENSÃO RURAL \\
\hline & PESQUISA \\
\hline & ENSINO \\
\hline & OUTROS \\
\hline
\end{tabular}


2) Qual o seu nível de escolaridade?

\begin{tabular}{|l|l|}
\hline$X$ & NÍVEL MÉDIO \\
\hline & NÍVEL SUPERIOR \\
\hline & PÓS-GRADUAÇÃO \\
\hline
\end{tabular}

3) Os conteúdos abordados foram condizentes com as demandas do seu dia-a-dia?

\begin{tabular}{|l|l|}
\hline$X$ & SIM \\
\hline & PARCIALMENTE \\
\hline & NÃO \\
\hline
\end{tabular}

4) O curso contribuiu para o seu aperfeiçoamento profissional?

\begin{tabular}{|l|l|}
\hline$X$ & SIM \\
\hline & NÃO \\
\hline
\end{tabular}

5) Os conhecimentos adquiridos estão sendo aplicados no seu trabalho? Em caso afirmativo, indique em que grau estes conhecimentos estão sendo aplicados. Em caso negativo, indique por que razão isto não ocorre: (Em caso negativo, as respostas não são excludentes: você poderá marcar mais de uma opção).

\begin{tabular}{|c|c|c|c|}
\hline \multirow{3}{*}{$X$} & \multirow{3}{*}{$\begin{array}{l}\text { SIM (indique ao lado em } \\
\text { que grau) }\end{array}$} & & MUITO APLICADOS \\
\hline & & $\mathrm{X}$ & MEDIAMENTE APLICADOS \\
\hline & & & POUCO APLICADOS \\
\hline & \multirow{2}{*}{$\begin{array}{l}\text { NÃO (indique ao lado a } \\
\text { razão da não aplicação) }\end{array}$} & & $\begin{array}{l}\text { CONTEÚDO NÃO ADEQUADO ȦS NECESSIDADES } \\
\text { ESPECÍFICAS DA REGIÃO }\end{array}$ \\
\hline & & & $\begin{array}{l}\text { CONTEÚDO NÃO } \quad \text { FOI SUFICIENTEMENTE } \\
\text { APROFUNDADO PARA } \\
\text { PERMITIR UMA APLICAÇÃO } \\
\text { EFICAZ E EFICIENTE }\end{array}$ \\
\hline
\end{tabular}




\begin{tabular}{|l|l|l|}
\hline \multirow{2}{*}{} & & $\begin{array}{l}\text { FALTA DE APOIO E INCENTIVO DA MINHA } \\
\text { INSTITUIÇÃO }\end{array}$ \\
\cline { 2 - 3 } & & FALTA DE INCENTIVO ÀS AÇÕES DE ATER \\
\cline { 2 - 3 } & NÃO TENHO INTERESSE EM APLICAR \\
\hline
\end{tabular}

6) A partir deste curso: (As opções não são excludentes: você poderá marcar mais de uma opção).

\begin{tabular}{|c|l|}
\hline$x$ & $\begin{array}{l}\text { NÃO MUDOU NADA EM MEU TRABALHO. } \\
\text { FAMILIARES. }\end{array}$ \\
\hline$X$ & CONSEGUI INFLUENCIAR NAS ORIENTAÇÕES DA MINHA INSTITUIÇÃO. \\
\hline & PASSEI A TRABALHAR COM METODOLOGIAS PARTICIPATIVAS. \\
\hline & $\begin{array}{l}\text { CRESCEU A ÁREA DE AGRICULTURA DE BASE ECOLÓGICA NAS COMUNIDADES } \\
\text { ONDE ATUO. }\end{array}$ \\
\hline & CONTINUEI ME APERFEIÇOANDO SOBRE TEMAS ABORDADOS. \\
\hline
\end{tabular}

7) Depois do curso você apoiou atividades de capacitação de técnicos e agricultores com base nos princípios e diretrizes da Pnater? (Considere como apoio a atividades de capacitação a participação no planejamento, elaboração de ementas, seleção de participantes e de palestrantes.)

\begin{tabular}{|l|l|}
\hline$X$ & SIM \\
\hline & NÃO \\
\hline
\end{tabular}

8) Usou os conhecimentos para ministrar outros cursos com o mesmo conteúdo ou conteúdos semelhantes?

\begin{tabular}{|l|l|}
\hline & SIM \\
\hline$X$ & NÃO \\
\hline
\end{tabular}


9) Marque o seu grau de satisfação com relação ao curso oferecido pelo DATER:

\begin{tabular}{|l|l|l|l|l|}
\hline 1 & 2 & 3 & $4 \times$ & 5 \\
\hline
\end{tabular}

10) Marque seu grau de satisfação com relação ao DATER:

\begin{tabular}{|l|l|l|l|l|}
\hline 1 & 2 & 3 & $4 \times$ & 5 \\
\hline
\end{tabular}


PESQUISA - IMPACTO DAS AÇÕES DE FORMAÇÃO REALIZADAS PELO DATER/SAF/MDA NO PERÍODO 2004-2009

Caros colaboradores,

Contamos com a sua atenção para preencher o formulário abaixo.

O mesmo tem por objetivo fornecer informações para avaliação da Eficiência, Efetividade e Eficácia da Política Pública de Formação de Agentes de Ater adotada pelo Departamento de Assistência Técnica e Extensão Rural, da Secretaria de Agricultura Familiar do Ministério do Desenvolvimento - DATER/SAF/MDA, no período de 2004 a 2009, tema escolhido para Monografia a ser apresentada à Universidade de Brasília (UnB) como requisito parcial para obtenção do grau de Bacharel em Administração.

Você poderá ou não se identificar no questionário e garantimos que todas as informações fornecidas serão confidenciais e utilizadas apenas de forma sistematizada.

IDENTIFICAÇÃO

\begin{tabular}{|c|c|}
\hline $\begin{array}{l}\text { Nome: } \\
\text { ANTONIO PEREIRA MATOS }\end{array}$ & $\begin{array}{l}\text { Sexo: } \\
(x) \text { masculino } \quad(\quad) \text { feminino }\end{array}$ \\
\hline $\begin{array}{l}\text { Instituição (nome e tipo de instituição: ONG, } \\
\text { Empresa Pública, etc.): } \\
\text { EMATER-PA }\end{array}$ & $\begin{array}{l}\text { Local de trabalho (Cidade e Estado): } \\
\text { ITAITUBA-PA }\end{array}$ \\
\hline \multicolumn{2}{|c|}{$\begin{array}{l}\text { Curso/Encontro/Oficina do qual participou (caso tenha participado de mais de um curso, preencha } \\
\text { um formulário para cada um deles): } \\
\text { CURSO DE TEORIA E PRÁTICAS DE MÉTODOS DE ATER }\end{array}$} \\
\hline $\begin{array}{l}\text { Data do Curso/Encontro/Oficina (pelo menos mês } \\
20 \text { A } 24 \text { DE NOVEMBRO }\end{array}$ & \\
\hline
\end{tabular}

Indique sua área de atuação? (As opções não são excludentes: você poderá marcar mais de uma opção).

\begin{tabular}{|l|l|}
\hline$X$ & EXTENSÃO RURAL \\
\hline & PESQUISA \\
\hline & ENSINO \\
\hline & OUTROS \\
\hline
\end{tabular}


2) Qual o seu nível de escolaridade?

\begin{tabular}{|l|l|}
\hline$X$ & NÍVEL MÉDIO \\
\hline & NÍVEL SUPERIOR \\
\hline & PÓS-GRADUAÇÃO \\
\hline
\end{tabular}

3) Os conteúdos abordados foram condizentes com as demandas do seu dia-a-dia?

\begin{tabular}{|l|l|}
\hline$X$ & SIM \\
\hline & PARCIALMENTE \\
\hline & NÃO \\
\hline
\end{tabular}

4) O curso contribuiu para o seu aperfeiçoamento profissional?

\begin{tabular}{|l|l|}
\hline$X$ & SIM \\
\hline & NÃO \\
\hline
\end{tabular}

5) Os conhecimentos adquiridos estão sendo aplicados no seu trabalho? Em caso afirmativo, indique em que grau estes conhecimentos estão sendo aplicados. Em caso negativo, indique por que razão isto não ocorre: (Em caso negativo, as respostas não são excludentes: você poderá marcar mais de uma opção).

\begin{tabular}{|c|c|c|c|}
\hline \multirow{3}{*}{$X$} & \multirow{3}{*}{$\begin{array}{l}\text { SIM (indique ao lado em } \\
\text { que grau) }\end{array}$} & $x$ & MUITO APLICADOS \\
\hline & & & MEDIAMENTE APLICADOS \\
\hline & & & POUCO APLICADOS \\
\hline & \multirow{2}{*}{$\begin{array}{l}\text { NÃO (indique ao lado a } \\
\text { razão da não aplicação) }\end{array}$} & & $\begin{array}{l}\text { CONTEU்DO NÃO ADEQUADO ȦS NECESSIDADES } \\
\text { ESPECÍFICAS DA REGIÃO }\end{array}$ \\
\hline & & & $\begin{array}{l}\text { CONTEÚDO NÃO } \quad \text { FOI SUFICIENTEMENTE } \\
\text { APROFUNDADO PARA PERMITIR UMA APLICAÇÃO } \\
\text { EFICAZ E EFICIENTE }\end{array}$ \\
\hline
\end{tabular}




\begin{tabular}{|l|l|l|}
\hline \multirow{2}{*}{} & & $\begin{array}{l}\text { FALTA DE APOIO E INCENTIVO DA MINHA } \\
\text { INSTITUIÇÃO }\end{array}$ \\
\cline { 2 - 3 } & & FALTA DE INCENTIVO ÀS AÇÕES DE ATER \\
\cline { 2 - 3 } & NÃO TENHO INTERESSE EM APLICAR \\
\hline
\end{tabular}

6) A partir deste curso: (As opções não são excludentes: você poderá marcar mais de uma opção).

\begin{tabular}{|r|l|}
\hline$x$ & $\begin{array}{l}\text { NẼO MUDOU NADA EM MEU TRABALHO. } \\
\text { FAMILIARES. }\end{array}$ \\
\hline$X$ & CONSEGUI INFLUENCIAR NAS ORIENTAÇÕES DA MINHA INSTITUIÇÃO. \\
\hline$X$ & PASSEI A TRABALHAR COM METODOLOGIAS PARTICIPATIVAS. \\
\hline$X$ & $\begin{array}{l}\text { CRESCEU A ÁREA DE AGRICULTURA DE BASE ECOLÓGICA NAS COMUNIDADES } \\
\text { ONDE ATUO. }\end{array}$ \\
\hline$X$ & CONTINUEI ME APERFEIÇOANDO SOBRE TEMAS ABORDADOS. \\
\hline
\end{tabular}

7) Depois do curso você apoiou atividades de capacitação de técnicos e agricultores com base nos princípios e diretrizes da Pnater? (Considere como apoio a atividades de capacitação a participação no planejamento, elaboração de ementas, seleção de participantes e de palestrantes.)

\begin{tabular}{|l|l|}
\hline$X$ & SIM \\
\hline & NÃO \\
\hline
\end{tabular}

8) Usou os conhecimentos para ministrar outros cursos com o mesmo conteúdo ou conteúdos semelhantes?

\begin{tabular}{|l|l|}
\hline & SIM \\
\hline$X$ & NÃO \\
\hline
\end{tabular}

9) Marque o seu grau de satisfação com relação ao curso oferecido pelo DATER: 


\begin{tabular}{|l|l|l|l|l|}
\hline 1 & 2 & 3 & 4 & $5 \times$ \\
\hline
\end{tabular}

10) Marque seu grau de satisfação com relação ao DATER:

\begin{tabular}{|l|l|l|l|l|}
\hline 1 & 2 & 3 & 4 & $5 \times$ \\
\hline
\end{tabular}


PESQUISA - IMPACTO DAS AÇÕES DE FORMAÇÃO REALIZADAS PELO DATER/SAF/MDA NO PERÍODO 2004-2009

Caros colaboradores,

Contamos com a sua atenção para preencher o formulário abaixo.

O mesmo tem por objetivo fornecer informações para avaliação da Eficiência, Efetividade e Eficácia da Política Pública de Formação de Agentes de Ater adotada pelo Departamento de Assistência Técnica e Extensão Rural, da Secretaria de Agricultura Familiar do Ministério do Desenvolvimento - DATER/SAF/MDA, no período de 2004 a 2009, tema escolhido para Monografia a ser apresentada à Universidade de Brasília (UnB) como requisito parcial para obtenção do grau de Bacharel em Administração.

Você poderá ou não se identificar no questionário e garantimos que todas as informações fornecidas serão confidenciais e utilizadas apenas de forma sistematizada.

\section{IDENTIFICAÇÃO}

\begin{tabular}{|c|c|}
\hline Nome: DERLAN DAMASCENO LIRA & $\begin{array}{l}\text { Sexo: } \\
(x) \text { masculino } \quad(\quad) \text { feminino }\end{array}$ \\
\hline $\begin{array}{l}\text { Instituição (nome e tipo de instituição: ONG, } \\
\text { Empresa Pública, etc.): } \\
\text { EMATER-PA }\end{array}$ & $\begin{array}{l}\text { Local de trabalho (Cidade e Estado): } \\
\text { ITAITUBA -PA }\end{array}$ \\
\hline \multicolumn{2}{|c|}{$\begin{array}{l}\text { Curso/Encontro/Oficina do qual participou (caso tenha participado de mais de um curso, preencha } \\
\text { um formulário para cada um deles): } \\
\text { TEORIA E PRÁTICA DE MÉTODOS DE ATER }\end{array}$} \\
\hline $\begin{array}{l}\text { Data do Curso/Encontro/Oficina (pelo menos mês } \\
20 \text { A } 24 \text { DE NOVEMBRO }\end{array}$ & \\
\hline
\end{tabular}

Indique sua área de atuação? (As opções não são excludentes: você poderá marcar mais de uma opção)

\begin{tabular}{|l|l|}
\hline$X$ & EXTENSÃO RURAL \\
\hline & PESQUISA \\
\hline & ENSINO \\
\hline & OUTROS \\
\hline
\end{tabular}


2) Qual o seu nível de escolaridade?

\begin{tabular}{|c|l|}
\hline & NÍVEL MÉDIO \\
\hline$X$ & NÍVEL SUPERIOR \\
\hline & PÓS-GRADUAÇÃO \\
\hline
\end{tabular}

3) Os conteúdos abordados foram condizentes com as demandas do seu dia-a-dia?

\begin{tabular}{|l|l|}
\hline$X$ & SIM \\
\hline & PARCIALMENTE \\
\hline & NÃO \\
\hline
\end{tabular}

3) O curso contribuiu para o seu aperfeiçoamento profissional?

\begin{tabular}{|l|l|}
\hline$X$ & SIM \\
\hline & NÃO \\
\hline
\end{tabular}

5) Os conhecimentos adquiridos estão sendo aplicados no seu trabalho? Em caso afirmativo, indique em que grau estes conhecimentos estão sendo aplicados. Em caso negativo, indique por que razão isto não ocorre: (Em caso negativo, as respostas não são excludentes: você poderá marcar mais de uma opção).

\begin{tabular}{|l|l|l|l|}
\hline$X$ & $\begin{array}{l}\text { SIM (indique ao lado em } \\
\text { que grau) }\end{array}$ & MUITO APLICADOS \\
\cline { 2 - 4 } & & MEDIAMENTE APLICADOS \\
\hline & $\begin{array}{l}\text { NÃO (indique ao lado a } \\
\text { razão da não aplicação) }\end{array}$ & $\begin{array}{l}\text { CONTEU்DO NÃO ADEQUADO ȦS NECESSIDADES } \\
\text { ESPECÍfICAS DA REGIÃO }\end{array}$ \\
\hline
\end{tabular}




\begin{tabular}{|l|l|l|}
\hline \multirow{10}{*}{} & $\begin{array}{l}\text { CONTEÚDO NÃO FOI SUFICIENTEMENTE } \\
\text { APROFUNDADO PARA PERMITIR UMA APLICAÇÃO } \\
\text { EFICAZ E EFICIENTE }\end{array}$ \\
\cline { 2 - 4 } & $\begin{array}{l}\text { FALTA DE APOIO E INCENTIVO DA MINHA } \\
\text { INSTITUIÇÃO }\end{array}$ \\
\cline { 2 - 4 } & FALTA DE INCENTIVO ÀS AÇÕES DE ATER \\
\hline & NÃO TENHO INTERESSE EM APLICAR \\
\hline
\end{tabular}

6) A partir deste curso: (As opções não são excludentes: você poderá marcar mais de uma opção)

\begin{tabular}{|r|l|}
\hline$x$ & $\begin{array}{l}\text { NÃO MUDOU NADA EM MEU TRABALHO. } \\
\text { FAMILIARES. }\end{array}$ \\
\hline & CONSEGUI INFLUENCIAR NAS ORIENTAÇÕES DA MINHA INSTITUIÇÃO. \\
\hline$X$ & PASSEI A TRABALHAR COM METODOLOGIAS PARTICIPATIVAS. \\
\hline$X$ & $\begin{array}{l}\text { CRESCEU A ÁREA DE AGRICULTURA DE BASE ECOLÓGICA NAS COMUNIDADES } \\
\text { ONDE ATUO. }\end{array}$ \\
\hline$X$ & CONTINUEI ME APERFEIÇOANDO SOBRE TEMAS ABORDADOS. \\
\hline
\end{tabular}

7) Depois do curso você apoiou atividades de capacitação de técnicos e agricultores com base nos princípios e diretrizes da Pnater? (Considere como apoio a atividades de capacitação a participação no planejamento, elaboração de ementas, seleção de participantes e de palestrantes.)

\begin{tabular}{|l|l|}
\hline$X$ & SIM \\
\hline & NÃO \\
\hline
\end{tabular}

8) Usou os conhecimentos para ministrar outros cursos com o mesmo conteúdo ou conteúdos semelhantes? 


\begin{tabular}{|l|l|}
\hline & SIM \\
\hline$X$ & NÃO \\
\hline
\end{tabular}

9) Marque o seu grau de satisfação com relação ao curso oferecido pelo DATER: (Considere a seguinte pontuação: 1 - MUITO RUIM; 2 - RUIM; 3 - REGULAR; 4 - BOM; 5 - MUITO BOM)

\begin{tabular}{|l|l|l|l|l|}
\hline 1 & 2 & 3 & 4 & $5 \times$ \\
\hline
\end{tabular}

10) Marque seu grau de satisfação com relação ao DATER: (Considere a seguinte pontuação: 1 - MUITO RUIM; 2 - RUIM; 3 - REGULAR; 4 - BOM; 5 - MUITO BOM)

\begin{tabular}{|l|l|l|l|l|}
\hline 1 & 2 & 3 & 4 & $5 \times$ \\
\hline
\end{tabular}


PESQUISA - IMPACTO DAS AÇÕES DE FORMAÇÃO REALIZADAS PELO DATER/SAF/MDA NO PERÍODO 2004-2009

Caros colaboradores,

Contamos com a sua atenção para preencher o formulário abaixo.

O mesmo tem por objetivo fornecer informações para avaliação da Eficiência, Efetividade e Eficácia da Política Pública de Formação de Agentes de Ater adotada pelo Departamento de Assistência Técnica e Extensão Rural, da Secretaria de Agricultura Familiar do Ministério do Desenvolvimento - DATER/SAF/MDA, no período de 2004 a 2009, tema escolhido para Monografia a ser apresentada à Universidade de Brasília (UnB) como requisito parcial para obtenção do grau de Bacharel em Administração.

Você poderá ou não se identificar no questionário e garantimos que todas as informações fornecidas serão confidenciais e utilizadas apenas de forma sistematizada.

IDENTIFICAÇÃO

\begin{tabular}{|l|l|}
\hline Nome: Dvandro Pedro de Oliveira & $\begin{array}{l}\text { Sexo: } \\
(x) \text { masculino } \quad(\quad) \text { feminino }\end{array}$ \\
\hline $\begin{array}{l}\text { Instituição: Laboratório Sócio-Agronômico do } \\
\text { Tocantins (LASAT) }\end{array}$ & Local de trabalho: Marabá - PA \\
\hline $\begin{array}{l}\text { Curso/Encontro/Oficina do qual participou: PRIMEIRA OFICINA DE NIVELAMENTO } \\
\text { CONCEITUAL SOBRE ASSISTÊNCIA TÉCNICA E EXTENSÃO RURAL - ATER }\end{array}$ \\
\hline Data do Curso/Encontro/Oficina: 09 a 13 de agosto de 2004 \\
\hline
\end{tabular}

1)Indique sua área de atuação? (As opções não são excludentes: você poderá marcar mais de uma opção)

\begin{tabular}{|c|l|}
\hline$x$ & EXTENSÃO RURAL \\
\hline$x$ & PESQUISA \\
\hline & ENSINO \\
\hline$x$ & OUTROS \\
\hline
\end{tabular}


2) Qual o seu nível de escolaridade?

\begin{tabular}{|c|l|}
\hline & NÍVEL MÉDIO \\
\hline & NÍVEL SUPERIOR \\
\hline$x$ & PÓS-GRADUAÇÃO \\
\hline
\end{tabular}

3) Os conteúdos abordados foram condizentes com as demandas do seu dia-a-dia?

\begin{tabular}{|l|l|}
\hline & SIM \\
\hline$x$ & PARCIALMENTE \\
\hline & NÃO \\
\hline
\end{tabular}

4) O curso contribuiu para o seu aperfeiçoamento profissional?

\begin{tabular}{|l|l|}
\hline$x$ & SIM \\
\hline & NÃO \\
\hline
\end{tabular}

5) Os conhecimentos adquiridos estão sendo aplicados no seu trabalho? Em caso afirmativo, indique em que grau estes conhecimentos estão sendo aplicados. Em caso negativo, indique por que razão isto não ocorre: (Em caso negativo, as respostas não são excludentes: você poderá marcar mais de uma opção).

\begin{tabular}{|c|c|c|c|}
\hline \multirow{3}{*}{$x$} & \multirow{3}{*}{$\begin{array}{l}\text { SIM (indique ao lado em } \\
\text { que grau) }\end{array}$} & & MUITO APLICADOS \\
\hline & & $x$ & MEDIAMENTE APLICADOS \\
\hline & & & POUCO APLICADOS \\
\hline & \multirow{2}{*}{$\begin{array}{l}\text { NÃO (indique ao lado a } \\
\text { razão da não aplicação) }\end{array}$} & & $\begin{array}{l}\text { CONTEÚDO NÃO ADEQUADO ÀS NECESSIDADES } \\
\text { ESPECÍFICAS DA REGIÃO }\end{array}$ \\
\hline & & & $\begin{array}{l}\text { CONTEÚDO NÃO } \quad \text { FOI SUFICIENTEMENTE } \\
\text { APROFUNDADO PARA } \\
\text { PERMITIR UMA APLICAÇÃO } \\
\text { EFICAZ E EFICIENTE }\end{array}$ \\
\hline
\end{tabular}




\begin{tabular}{|l|l|l|}
\hline \multirow{2}{*}{} & & $\begin{array}{l}\text { FALTA DE APOIO E INCENTIVO DA MINHA } \\
\text { INSTITUIÇÃO }\end{array}$ \\
\cline { 2 - 3 } & & FALTA DE INCENTIVO ÀS AÇÕES DE ATER \\
\cline { 2 - 3 } & & NÃO TENHO INTERESSE EM APLICAR \\
\hline
\end{tabular}

6) A partir deste curso: (As opções não são excludentes: você poderá marcar mais de uma opção)

\begin{tabular}{|c|l|}
\hline & NÃO MUDOU NADA EM MEU TRABALHO. \\
\hline & $\begin{array}{l}\text { MEU TRABALHO PASSOU A CONTRIBUIR MAIS COM OS AGRICULTORES(AS) } \\
\text { FAMILIARES. }\end{array}$ \\
\hline $\mathrm{x}$ & CONSEGUI INFLUENCIAR NAS ORIENTAÇÕES DA MINHA INSTITUIÇÃO. \\
\hline & $\begin{array}{l}\text { PASSEI A TRABALHAR COM METODOLOGIAS PARTICIPATIVAS. } \\
\text { ONDE ATUO. }\end{array}$ \\
\hline $\mathrm{x}$ & CONTINUEI ME APERFEIÇOANDO SOBRE TEMAS ABORDADOS. \\
\hline
\end{tabular}

7) Depois do curso você apoiou atividades de capacitação de técnicos e agricultores com base nos princípios e diretrizes da Pnater? (Considere como apoio a atividades de capacitação a participação no planejamento, elaboração de ementas, seleção de participantes e de palestrantes.)

\begin{tabular}{|l|l|}
\hline$x$ & SIM \\
\hline & NÃO \\
\hline
\end{tabular}

8) Usou os conhecimentos para ministrar outros cursos com o mesmo conteúdo ou conteúdos semelhantes?

\begin{tabular}{|l|l|}
\hline$x$ & SIM \\
\hline & NÃO \\
\hline
\end{tabular}


9) Marque o seu grau de satisfação com relação ao curso oferecido pelo DATER: (Considere a seguinte pontuação: 1 - MUITO RUIM; 2 - RUIM; 3 - REGULAR; 4 - BOM; 5 - MUITO BOM)

\begin{tabular}{|l|l|l|l|l|}
\hline 1 & 2 & 3 & 4 & 5 \\
\hline
\end{tabular}

10) Marque seu grau de satisfação com relação ao DATER: (Considere a seguinte pontuação: 1 - MUITO RUIM; 2 - RUIM; 3 - REGULAR; 4 - BOM; 5 - MUITO BOM)

\begin{tabular}{|l|l|l|l|l|}
\hline 1 & 2 & 3 & 4 & 5 \\
\hline
\end{tabular}


PESQUISA - IMPACTO DAS AÇÕES DE FORMAÇÃO REALIZADAS PELO DATER/SAF/MDA NO PERÍODO 2004-2009

Caros colaboradores,

Contamos com a sua atenção para preencher o formulário abaixo.

O mesmo tem por objetivo fornecer informações para avaliação da Eficiência, Efetividade e Eficácia da Política Pública de Formação de Agentes de Ater adotada pelo Departamento de Assistência Técnica e Extensão Rural, da Secretaria de Agricultura Familiar do Ministério do Desenvolvimento - DATER/SAF/MDA, no período de 2004 a 2009, tema escolhido para Monografia a ser apresentada à Universidade de Brasília (UnB) como requisito parcial para obtenção do grau de Bacharel em Administração.

Você poderá ou não se identificar no questionário e garantimos que todas as informações fornecidas serão confidenciais e utilizadas apenas de forma sistematizada.

\section{IDENTIFICAÇÃO}

\begin{tabular}{|c|c|}
\hline $\begin{array}{l}\text { Nome: } \\
\text { Edivania Ramos da Costa }\end{array}$ & $\begin{array}{l}\text { Sexo: } \\
(\quad) \text { masculino } \quad(x) \text { feminino }\end{array}$ \\
\hline $\begin{array}{l}\text { Instituição (nome e tipo de instituição: ONG, } \\
\text { Empresa Pública, etc.): } \\
\text { EMATER - RO }\end{array}$ & EXTREMA - PORTO VELHO - RO \\
\hline \multicolumn{2}{|c|}{$\begin{array}{l}\text { Curso/Encontro/Oficina do qual participou (caso tenha participado de mais de um curso, preencha } \\
\text { um formulário para cada um deles): }\end{array}$} \\
\hline $\begin{array}{l}\text { Data do Curso/Encontro/Oficina (pelo menos mês } € \\
17 \text { á } 20 / 04 / 2006\end{array}$ & \\
\hline
\end{tabular}

1)Indique sua área de atuação? (As opções não são excludentes: você poderá marcar mais de uma opção)

\begin{tabular}{|l|l|}
\hline$X$ & EXTENSÃO RURAL \\
\hline & PESQUISA \\
\hline
\end{tabular}




\begin{tabular}{|l|l|}
\hline & ENSINO \\
\hline & OUTROS \\
\hline
\end{tabular}

2) Qual o seu nível de escolaridade?

\begin{tabular}{|l|l|}
\hline & NÍVEL MÉDIO \\
\hline$X$ & NÍVEL SUPERIOR \\
\hline & PÓS-GRADUAÇÃO \\
\hline
\end{tabular}

3) Os conteúdos abordados foram condizentes com as demandas do seu dia-a-dia?

\begin{tabular}{|l|l|}
\hline$X$ & SIM \\
\hline & PARCIALMENTE \\
\hline & NÃO \\
\hline
\end{tabular}

4) O curso contribuiu para o seu aperfeiçoamento profissional?

\begin{tabular}{|l|l|}
\hline$X$ & SIM \\
\hline & NÃO \\
\hline
\end{tabular}

5) Os conhecimentos adquiridos estão sendo aplicados no seu trabalho? Em caso afirmativo, indique em que grau estes conhecimentos estão sendo aplicados. Em caso negativo, indique por que razão isto não ocorre: (Em caso negativo, as respostas não são excludentes: você poderá marcar mais de uma opção).

\begin{tabular}{|l|l|l|l|}
\hline \multirow{2}{*}{$\begin{array}{l}\text { SIM (indique ao lado em } \\
\text { que grau) }\end{array}$} & X & MUITO APLICADOS \\
\cline { 2 - 4 } & & MEDIAMENTE APLICADOS \\
\cline { 2 - 4 } & & POUCO APLICADOS \\
\hline
\end{tabular}




\begin{tabular}{|c|c|}
\hline \multirow{5}{*}{$\begin{array}{l}\text { NÃO (indique ao lado a } \\
\text { razão da não aplicação) }\end{array}$} & $\begin{array}{l}\text { CONTEÚDO NÃO ADEQUADO ÀS NECESSIDADES } \\
\text { ESPECÍFICAS DA REGIÃO }\end{array}$ \\
\hline & $\begin{array}{l}\text { CONTEÚDO NÃO } \text { FOI SUFICIENTEMENTE } \\
\text { APROFUNDADO PARA } \\
\text { PERMITIR UMA APLICAÇÃO } \\
\text { EFICAZ E EFICIENTE }\end{array}$ \\
\hline & $\begin{array}{lllllll}\text { FALTA DE } & \text { APOIO } & \text { E } & \text { INCENTIVO } & \text { DA } & \text { MINHA } \\
\text { INSTITUIÇÃO } & & & & & \end{array}$ \\
\hline & FALTA DE INCENTIVO ÀS AÇÕES DE ATER \\
\hline & NÃO TENHO INTERESSE EM APLICAR \\
\hline
\end{tabular}

6) A partir deste curso: (As opções não são excludentes: você poderá marcar mais de uma opção)

\begin{tabular}{|l|l|}
\hline & NÃO MUDOU NADA EM MEU TRABALHO. \\
\hline & $\begin{array}{l}\text { MEU TRABALHO PASSOU A CONTRIBUIR MAIS COM OS AGRICULTORES (AS) } \\
\text { FAMILIARES. }\end{array}$ \\
\hline & CONSEGUI INFLUENCIAR NAS ORIENTAÇÕES DA MINHA INSTITUIÇÃO. \\
\hline & $\begin{array}{l}\text { CASSEI A TRABALHAR COM METODOLOGIAS PARTICIPATIVAS. } \\
\text { ONDE ATUO. ÁREA DE AGRICULTURA DE BASE ECOLÓGICA NAS COMUNIDADES }\end{array}$ \\
\hline$X$ & CONTINUEI ME APERFEIÇOANDO SOBRE TEMAS ABORDADOS. \\
\hline
\end{tabular}

7) Depois do curso você apoiou atividades de capacitação de técnicos e agricultores com base nos princípios e diretrizes da Pnater? (Considere como apoio a atividades de capacitação a participação no planejamento, elaboração de ementas, seleção de participantes e de palestrantes.)

\begin{tabular}{|l|l|}
\hline & SIM \\
\hline$X$ & NÃO \\
\hline
\end{tabular}


8) Usou os conhecimentos para ministrar outros cursos com o mesmo conteúdo ou conteúdos semelhantes?

\begin{tabular}{|l|l|}
\hline$X$ & SIM \\
\hline & NÃO \\
\hline
\end{tabular}

9) Marque o seu grau de satisfação com relação ao curso oferecido pelo DATER: (Considere a seguinte pontuação: 1 - MUITO RUIM; 2 - RUIM; 3 - REGULAR; 4 - BOM; 5 - MUITO BOM)

\begin{tabular}{|l|l|l|l|l|}
\hline 1 & 2 & 3 & 4 & $\times 5$ \\
\hline
\end{tabular}

10) Marque seu grau de satisfação com relação ao DATER: (Considere a seguinte pontuação: 1 - MUITO RUIM; 2 - RUIM; 3 - REGULAR; 4 - BOM; 5 - MUITO BOM)

\begin{tabular}{|l|l|l|l|l|}
\hline 1 & 2 & 3 & $X 4$ & 5 \\
\hline
\end{tabular}

Obs.: As notas atribuídas às duas últimas questões devem obedecer a ordem crescente: 1 muito ruim, 2 - ruim, 3 - regular, 4 - bom , 5 - muito bom. 
PESQUISA - IMPACTO DAS AÇÕES DE FORMAÇÃO REALIZADAS PELO DATER/SAF/MDA NO PERÍODO 2004-2009

Caros colaboradores,

Contamos com a sua atenção para preencher o formulário abaixo.

O mesmo tem por objetivo fornecer informações para avaliação da Eficiência, Efetividade e Eficácia da Política Pública de Formação de Agentes de Ater adotada pelo Departamento de Assistência Técnica e Extensão Rural, da Secretaria de Agricultura Familiar do Ministério do Desenvolvimento - DATER/SAF/MDA, no período de 2004 a 2009, tema escolhido para Monografia a ser apresentada à Universidade de Brasília (UnB) como requisito parcial para obtenção do grau de Bacharel em Administração.

Você poderá ou não se identificar no questionário e garantimos que todas as informações fornecidas serão confidenciais e utilizadas apenas de forma sistematizada.

IDENTIFICAÇÃO

\begin{tabular}{|l|l|}
\hline Nome: Edowardo Muneaki Shimpo & $\begin{array}{l}\text { Sexo: } \\
(\mathrm{x}) \text { masculino } \quad(\quad) \text { feminino }\end{array}$ \\
\hline $\begin{array}{l}\text { Instituição (nome e tipo de instituição: ONG, } \\
\text { Empresa Pública, etc.): } \\
\text { EMATER-PARÁ } \\
\text { Curso/Encontro/Oficina do qual participou (caso tenha participado de mais de um curso, preencha } \\
\text { ES formulário para cada um deles): } \\
\text { ECONOMIA POPULAR SOLIDÁRIA }\end{array}$ \\
\hline $\begin{array}{l}\text { Data do Curso/Encontro/Oficina (pelo menos mês e ano): } \\
\text { 11 A 15 DE SETEMBRO DE } 2006\end{array}$ \\
\hline
\end{tabular}

Indique sua área de atuação? (As opções não são excludentes: você poderá marcar mais de uma opção)

\begin{tabular}{|l|l|}
\hline$X$ & EXTENSÃO RURAL \\
\hline & PESQUISA \\
\hline & ENSINO \\
\hline & OUTROS \\
\hline
\end{tabular}


2) Qual o seu nível de escolaridade?

\begin{tabular}{|l|l|}
\hline & NÍVEL MÉDIO \\
\hline$X$ & NÍVEL SUPERIOR \\
\hline & PÓS-GRADUAÇÃO \\
\hline
\end{tabular}

3) Os conteúdos abordados foram condizentes com as demandas do seu dia-a-dia?

\begin{tabular}{|l|l|}
\hline$X$ & SIM \\
\hline & PARCIALMENTE \\
\hline & NÃO \\
\hline
\end{tabular}

4) O curso contribuiu para o seu aperfeiçoamento profissional?

\begin{tabular}{|l|l|}
\hline$X$ & SIM \\
\hline & NÃO \\
\hline
\end{tabular}

5) Os conhecimentos adquiridos estão sendo aplicados no seu trabalho? Em caso afirmativo, indique em que grau estes conhecimentos estão sendo aplicados. Em caso negativo, indique por que razão isto não ocorre: (Em caso negativo, as respostas não são excludentes: você poderá marcar mais de uma opção).

\begin{tabular}{|c|c|c|c|}
\hline \multirow{3}{*}{$x$} & \multirow{3}{*}{$\begin{array}{l}\text { SIM (indique ao lado em } \\
\text { que grau) }\end{array}$} & & MUITO APLICADOS \\
\hline & & $x$ & MEDIAMENTE APLICADOS \\
\hline & & & POUCO APLICADOS \\
\hline & & & $\begin{array}{l}\text { CONTEÚDO NĀO ADEQUADO ȦS NECESSIDADES } \\
\text { ESPECÍFICAS DA REGIÃO }\end{array}$ \\
\hline & razão da não aplicação) & & $\begin{array}{l}\text { CONTEÚDO NÃO FOI SUFICIENTEMENTE } \\
\text { APROFUNDADO PARA PERMITIR UMA APLICAÇÃO } \\
\text { EFICAZE EFICIENTE }\end{array}$ \\
\hline
\end{tabular}




\begin{tabular}{|l|l|l|}
\hline \multirow{2}{*}{} & & $\begin{array}{l}\text { FALTA DE APOIO E INCENTIVO DA MINHA } \\
\text { INSTITUIÇÃO }\end{array}$ \\
\cline { 2 - 3 } & & FALTA DE INCENTIVO ÀS AÇÕES DE ATER \\
\cline { 2 - 3 } & NÃO TENHO INTERESSE EM APLICAR \\
\hline
\end{tabular}

6) A partir deste curso: (As opções não são excludentes: você poderá marcar mais de uma opção)

\begin{tabular}{|l|l|}
\hline$x$ & $\begin{array}{l}\text { NÃO MUDOU NADA EM MEU TRABALHO. } \\
\text { FAMILIARES. }\end{array}$ \\
\hline & CONSEGUI INFLUENCIAR NAS ORIENTAÇÕES DA MINHA INSTITUIÇÃO. \\
\hline & PASSEI A TRABALHAR COM METODOLOGIAS PARTICIPATIVAS. \\
\hline & $\begin{array}{l}\text { ORESCEU A ÁREA DE AGRICULTURA DE BASE ECOLÓGICA NAS COMUNIDADES } \\
\text { ONDE ATUO. }\end{array}$ \\
\hline &
\end{tabular}

7) Depois do curso você apoiou atividades de capacitação de técnicos e agricultores com base nos princípios e diretrizes da Pnater? (Considere como apoio a atividades de capacitação a participação no planejamento, elaboração de ementas, seleção de participantes e de palestrantes.)

\begin{tabular}{|l|l|}
\hline$X$ & SIM \\
\hline & NÃO \\
\hline
\end{tabular}

8) Usou os conhecimentos para ministrar outros cursos com o mesmo conteúdo ou conteúdos semelhantes? 


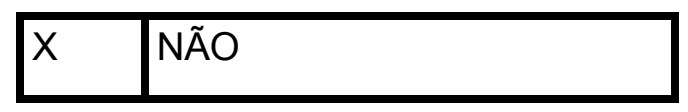

9) Marque o seu grau de satisfação com relação ao curso oferecido pelo DATER: (Considere a seguinte pontuação: 1 - MUITO RUIM; 2 - RUIM; 3 - REGULAR; 4 - BOM; 5 - MUITO BOM)

\begin{tabular}{|l|l|l|l|l|}
\hline 1 & 2 & 3 & $(4)$ & 5 \\
\hline
\end{tabular}

10) Marque seu grau de satisfação com relação ao DATER: (Considere a seguinte pontuação: 1 - MUITO RUIM; 2 - RUIM; 3 - REGULAR; 4 - BOM; 5 - MUITO BOM)

\begin{tabular}{|l|l|l|l|l|}
\hline 1 & 2 & 3 & $(4)$ & 5 \\
\hline
\end{tabular}


PESQUISA - IMPACTO DAS AÇÕES DE FORMAÇÃO REALIZADAS PELO DATER/SAF/MDA NO PERÍODO 2004-2009

Caros colaboradores,

Contamos com a sua atenção para preencher o formulário abaixo.

O mesmo tem por objetivo fornecer informações para avaliação da Eficiência, Efetividade e Eficácia da Política Pública de Formação de Agentes de Ater adotada pelo Departamento de Assistência Técnica e Extensão Rural, da Secretaria de Agricultura Familiar do Ministério do Desenvolvimento - DATER/SAF/MDA, no período de 2004 a 2009, tema escolhido para Monografia a ser apresentada à Universidade de Brasília (UnB) como requisito parcial para obtenção do grau de Bacharel em Administração.

Você poderá ou não se identificar no questionário e garantimos que todas as informações fornecidas serão confidenciais e utilizadas apenas de forma sistematizada.

IDENTIFICAÇÃO

\begin{tabular}{|c|c|}
\hline Nome: Edowardo Muneaki Shimpo & $\begin{array}{l}\text { Sexo: } \\
(x) \text { masculino } \quad(\quad) \text { feminino }\end{array}$ \\
\hline $\begin{array}{l}\text { Instituição (nome e tipo de instituição: ONG, } \\
\text { Empresa Pública, etc.): } \\
\text { EMATER-PARÁ }\end{array}$ & $\begin{array}{l}\text { Local de trabalho (Cidade e Estado): } \\
\text { ESCRITÓRIO LOCAL DE MARITUBA - PA }\end{array}$ \\
\hline \multicolumn{2}{|c|}{$\begin{array}{l}\text { Curso/Encontro/Oficina do qual participou (caso tenha participado de mais de um curso, preencha } \\
\text { um formulário para cada um deles): } \\
\text { ECONOMIA POPULAR SOLIDÁRIA }\end{array}$} \\
\hline \multicolumn{2}{|l|}{$\begin{array}{l}\text { Data do Curso/Encontro/Oficina (pelo menos mês e ano): } \\
11 \text { A } 15 \text { DE SETEMBRO DE } 2006\end{array}$} \\
\hline
\end{tabular}

1)Indique sua área de atuação? (As opções não são excludentes: você poderá marcar mais de uma opção)

\begin{tabular}{|l|l|}
\hline$X$ & EXTENSÃO RURAL \\
\hline & PESQUISA \\
\hline & ENSINO \\
\hline & OUTROS \\
\hline
\end{tabular}


2) Qual o seu nível de escolaridade?

\begin{tabular}{|l|l|}
\hline & NÍVEL MÉDIO \\
\hline$X$ & NÍVEL SUPERIOR \\
\hline & PÓS-GRADUAÇÃO \\
\hline
\end{tabular}

3) Os conteúdos abordados foram condizentes com as demandas do seu dia-a-dia?

\begin{tabular}{|l|l|}
\hline$X$ & SIM \\
\hline & PARCIALMENTE \\
\hline & NÃO \\
\hline
\end{tabular}

4) O curso contribuiu para o seu aperfeiçoamento profissional?

\begin{tabular}{|l|l|}
\hline$X$ & SIM \\
\hline & NÃO \\
\hline
\end{tabular}

5) Os conhecimentos adquiridos estão sendo aplicados no seu trabalho? Em caso afirmativo, indique em que grau estes conhecimentos estão sendo aplicados. Em caso negativo, indique por que razão isto não ocorre: (Em caso negativo, as respostas não são excludentes: você poderá marcar mais de uma opção).

\begin{tabular}{|c|c|c|c|}
\hline \multirow{3}{*}{$X$} & \multirow{3}{*}{$\begin{array}{l}\text { SIM (indique ao lado em } \\
\text { que grau) }\end{array}$} & & MUITO APLICADOS \\
\hline & & $\mathrm{X}$ & MEDIAMENTE APLICADOS \\
\hline & & & POUCO APLICADOS \\
\hline & \multirow{2}{*}{$\begin{array}{l}\text { NÃO (indique ao lado a } \\
\text { razão da não aplicação) }\end{array}$} & & $\begin{array}{l}\text { CONTEÚDO NÃO ADEQUADO ȦS NECESSIDADES } \\
\text { ESPECÍFICAS DA REGIÃO }\end{array}$ \\
\hline & & & $\begin{array}{l}\text { CONTEÚDO NÃO } \quad \text { FOI SUFICIENTEMENTE } \\
\text { APROFUNDADO PARA } \\
\text { PERMITIR UMA APLICAÇÃO } \\
\text { EFICAZ E EFICIENTE }\end{array}$ \\
\hline
\end{tabular}




\begin{tabular}{|l|l|l|}
\hline \multirow{2}{*}{} & & $\begin{array}{l}\text { FALTA DE APOIO E INCENTIVO DA MINHA } \\
\text { INSTITUIÇÃO }\end{array}$ \\
\cline { 2 - 4 } & & FALTA DE INCENTIVO ÀS AÇÕES DE ATER \\
\cline { 2 - 3 } & & NÃO TENHO INTERESSE EM APLICAR \\
\hline
\end{tabular}

6) A partir deste curso: (As opções não são excludentes: você poderá marcar mais de uma opção)

\begin{tabular}{|l|l|}
\hline$x$ & $\begin{array}{l}\text { NÃO MUDOU NADA EM MEU TRABALHO. } \\
\text { FAMILIARES. }\end{array}$ \\
\hline & CONSEGUI INFLUENCIAR NAS ORIENTAÇÕES DA MINHA INSTITUIÇÃO. \\
\hline & PASSEI A TRABALHAR COM METODOLOGIAS PARTICIPATIVAS. \\
\hline & $\begin{array}{l}\text { ORESCEU A ÁREA DE AGRICULTURA DE BASE ECOLÓGICA NAS COMUNIDADES } \\
\text { ONDE ATUO. }\end{array}$ \\
\hline &
\end{tabular}

7) Depois do curso você apoiou atividades de capacitação de técnicos e agricultores com base nos princípios e diretrizes da Pnater? (Considere como apoio a atividades de capacitação a participação no planejamento, elaboração de ementas, seleção de participantes e de palestrantes.)

\begin{tabular}{|l|l|}
\hline$X$ & SIM \\
\hline & NÃO \\
\hline
\end{tabular}

8) Usou os conhecimentos para ministrar outros cursos com o mesmo conteúdo ou conteúdos semelhantes?

\begin{tabular}{|l|l|}
\hline & SIM \\
\hline$X$ & NÃO \\
\hline
\end{tabular}


9) Marque o seu grau de satisfação com relação ao curso oferecido pelo DATER: (Considere a seguinte pontuação: 1 - MUITO RUIM; 2 - RUIM; 3 - REGULAR; 4 - BOM; 5 - MUITO BOM)

\begin{tabular}{|l|l|l|l|l|}
\hline 1 & 2 & 3 & $(4)$ & 5 \\
\hline
\end{tabular}

10) Marque seu grau de satisfação com relação ao DATER: (Considere a seguinte pontuação: 1 - MUITO RUIM; 2 - RUIM; 3 - REGULAR; 4 - BOM; 5 - MUITO BOM)

\begin{tabular}{|l|l|l|l|l|}
\hline 1 & 2 & 3 & $(4)$ & 5 \\
\hline
\end{tabular}


PESQUISA - IMPACTO DAS AÇÕES DE FORMAÇÃO REALIZADAS PELO DATER/SAF/MDA NO PERÍODO 2004-2009

Caros colaboradores,

Contamos com a sua atenção para preencher o formulário abaixo.

O mesmo tem por objetivo fornecer informações para avaliação da Eficiência, Efetividade e Eficácia da Política Pública de Formação de Agentes de Ater adotada pelo Departamento de Assistência Técnica e Extensão Rural, da Secretaria de Agricultura Familiar do Ministério do Desenvolvimento - DATER/SAF/MDA, no período de 2004 a 2009, tema escolhido para Monografia a ser apresentada à Universidade de Brasília (UnB) como requisito parcial para obtenção do grau de Bacharel em Administração.

Você poderá ou não se identificar no questionário e garantimos que todas as informações fornecidas serão confidenciais e utilizadas apenas de forma sistematizada.

\section{IDENTIFICAÇÃO}

\begin{tabular}{|l|l|}
\hline Nome: Eduardo Augusto Veras Marti & $\begin{array}{l}\text { Sexo: } \\
(\mathrm{x}) \text { masculino } \quad(\quad) \text { feminino }\end{array}$ \\
\hline $\begin{array}{l}\text { Instituição (nome e tipo de instituição: ONG, } \\
\text { Empresa Pública, etc.): EMATER- RO }\end{array}$ & $\begin{array}{l}\text { Local de trabalho (Cidade e Estado): } \\
\text { Rio Crespo }\end{array}$ \\
\hline $\begin{array}{l}\text { Curso/Encontro/Oficina do qual participou (caso tenha participado de mais de um curso, preencha } \\
\text { um formulário para cada um deles): Curso sobre Crédito Rural }\end{array}$ \\
\hline Data do Curso/Encontro/Oficina (pelo menos mês e ano): 02 a 05/05/2006 \\
\hline
\end{tabular}

1)Indique sua área de atuação? (As opções não são excludentes: você poderá marcar mais de uma opção)

\begin{tabular}{|l|l|}
\hline$X$ & EXTENSÃO RURAL \\
\hline & PESQUISA \\
\hline & ENSINO \\
\hline & OUTROS \\
\hline
\end{tabular}


2) Qual o seu nível de escolaridade?

\begin{tabular}{|l|l|}
\hline & NÍVEL MÉDIO \\
\hline$X$ & NÍVEL SUPERIOR \\
\hline & PÓS-GRADUAÇÃO \\
\hline
\end{tabular}

3) Os conteúdos abordados foram condizentes com as demandas do seu dia-a-dia?

\begin{tabular}{|l|l|}
\hline$X$ & SIM \\
\hline & PARCIALMENTE \\
\hline & NÃO \\
\hline
\end{tabular}

4) O curso contribuiu para o seu aperfeiçoamento profissional?

\begin{tabular}{|l|l|}
\hline$X$ & SIM \\
\hline & NÃO \\
\hline
\end{tabular}

5) Os conhecimentos adquiridos estão sendo aplicados no seu trabalho? Em caso afirmativo, indique em que grau estes conhecimentos estão sendo aplicados. Em caso negativo, indique por que razão isto não ocorre: (Em caso negativo, as respostas não são excludentes: você poderá marcar mais de uma opção).

\begin{tabular}{|c|c|c|c|}
\hline & \multirow{3}{*}{$\begin{array}{l}\text { SIM (indique ao lado em } \\
\text { que grau) }\end{array}$} & $\mathrm{X}$ & MUITO APLICADOS \\
\hline$x$ & & & MEDIAMENTE APLICADOS \\
\hline & & & POUCO APLICADOS \\
\hline & & & $\begin{array}{l}\text { CONTEÚDO NĀO ADEQUADO ȦS NECESSIDADES } \\
\text { ESPECÍFICAS DA REGIÃO }\end{array}$ \\
\hline & razão da não aplicação) & & $\begin{array}{l}\text { CONTEÚDO NÃO FOI SUFICIENTEMENTE } \\
\text { APROFUNDADO PARA PERMITIR UMA APLICAÇÃO } \\
\text { EFICAZE EFICIENTE }\end{array}$ \\
\hline
\end{tabular}




\begin{tabular}{|l|l|l|}
\hline \multirow{2}{*}{} & & $\begin{array}{l}\text { FALTA DE APOIO E INCENTIVO DA MINHA } \\
\text { INSTITUIÇÃO }\end{array}$ \\
\cline { 2 - 3 } & & FALTA DE INCENTIVO ÀS AÇÕES DE ATER \\
\cline { 2 - 3 } & & NÃO TENHO INTERESSE EM APLICAR \\
\hline
\end{tabular}

6) A partir deste curso: (As opções não são excludentes: você poderá marcar mais de uma opção)

\begin{tabular}{|l|l|}
\hline$x$ & $\begin{array}{l}\text { NÃO MUDOU NADA EM MEU TRABALHO. } \\
\text { FAMILIARES. }\end{array}$ \\
\hline & CONSEGUI INFLUENCIAR NAS ORIENTAÇÕES DA MINHA INSTITUIÇÃO. \\
\hline & PASSEI A TRABALHAR COM METODOLOGIAS PARTICIPATIVAS. \\
\hline & $\begin{array}{l}\text { CRESCEU A ÁREA DE AGRICULTURA DE BASE ECOLÓGICA NAS COMUNIDADES } \\
\text { ONDE ATUO. }\end{array}$ \\
\hline & CONTINUEI ME APERFEIÇOANDO SOBRE TEMAS ABORDADOS. \\
\hline
\end{tabular}

7) Depois do curso você apoiou atividades de capacitação de técnicos e agricultores com base nos princípios e diretrizes da Pnater? (Considere como apoio a atividades de capacitação a participação no planejamento, elaboração de ementas, seleção de participantes e de palestrantes.)

\begin{tabular}{|l|l|}
\hline & SIM \\
\hline$X$ & NÃO \\
\hline
\end{tabular}

8) Usou os conhecimentos para ministrar outros cursos com o mesmo conteúdo ou conteúdos semelhantes?

\begin{tabular}{|l|l|}
\hline & SIM \\
\hline$X$ & NÃO \\
\hline
\end{tabular}


9) Marque o seu grau de satisfação com relação ao curso oferecido pelo DATER: (Considere a seguinte pontuação: 1 - MUITO RUIM; 2 - RUIM; 3 - REGULAR; 4 - BOM; 5 - MUITO BOM)

\begin{tabular}{|l|l|l|l|l|}
\hline 1 & 2 & 3 & 4 & $5 \times$ \\
\hline
\end{tabular}

10) Marque seu grau de satisfação com relação ao DATER: (Considere a seguinte pontuação: 1 - MUITO RUIM; 2 - RUIM; 3 - REGULAR; 4 - BOM; 5 - MUITO BOM)

\begin{tabular}{|l|l|l|l|l|}
\hline 1 & 2 & 3 & 4 & $5 \times$ \\
\hline
\end{tabular}


PESQUISA - IMPACTO DAS AÇÕES DE FORMAÇÃO REALIZADAS PELO DATER/SAF/MDA NO PERÍODO 2004-2009

Caros colaboradores,

Contamos com a sua atenção para preencher o formulário abaixo.

O mesmo tem por objetivo fornecer informações para avaliação da Eficiência, Efetividade e Eficácia da Política Pública de Formação de Agentes de Ater adotada pelo Departamento de Assistência Técnica e Extensão Rural, da Secretaria de Agricultura Familiar do Ministério do Desenvolvimento - DATER/SAF/MDA, no período de 2004 a 2009, tema escolhido para Monografia a ser apresentada à Universidade de Brasília (UnB) como requisito parcial para obtenção do grau de Bacharel em Administração.

Você poderá ou não se identificar no questionário e garantimos que todas as informações fornecidas serão confidenciais e utilizadas apenas de forma sistematizada.

\section{IDENTIFICAÇÃO}

\begin{tabular}{|l|l|}
\hline Nome: Eduardo Augusto Veras Marti & $\begin{array}{l}\text { Sexo: } \\
(\mathrm{x}) \text { masculino } \quad(\quad) \text { feminino }\end{array}$ \\
\hline $\begin{array}{l}\text { Instituição (nome e tipo de instituição: ONG, } \\
\text { Empresa Pública, etc.): EMATER- RO }\end{array}$ & $\begin{array}{l}\text { Local de trabalho (Cidade e Estado): } \\
\text { Rio Crespo }\end{array}$ \\
\hline $\begin{array}{l}\text { Curso/Encontro/Oficina do qual participou (caso tenha participado de mais de um curso, preencha } \\
\text { um formulário para cada um deles): Curso sobre Crédito Rural }\end{array}$ \\
\hline Data do Curso/Encontro/Oficina (pelo menos mês e ano): 02 a 05/05/2006 \\
\hline
\end{tabular}

Indique sua área de atuação? (As opções não são excludentes: você poderá marcar mais de uma opção)

\begin{tabular}{|l|l|}
\hline$X$ & EXTENSÃO RURAL \\
\hline & PESQUISA \\
\hline & ENSINO \\
\hline & OUTROS \\
\hline
\end{tabular}


2) Qual o seu nível de escolaridade?

\begin{tabular}{|l|l|}
\hline & NÍVEL MÉDIO \\
\hline$X$ & NÍVEL SUPERIOR \\
\hline & PÓS-GRADUAÇÃO \\
\hline
\end{tabular}

3) Os conteúdos abordados foram condizentes com as demandas do seu dia-a-dia?

\begin{tabular}{|l|l|}
\hline$X$ & SIM \\
\hline & PARCIALMENTE \\
\hline & NÃO \\
\hline
\end{tabular}

3) O curso contribuiu para o seu aperfeiçoamento profissional?

\begin{tabular}{|l|l|}
\hline$X$ & SIM \\
\hline & NÃO \\
\hline
\end{tabular}

5) Os conhecimentos adquiridos estão sendo aplicados no seu trabalho? Em caso afirmativo, indique em que grau estes conhecimentos estão sendo aplicados. Em caso negativo, indique por que razão isto não ocorre: (Em caso negativo, as respostas não são excludentes: você poderá marcar mais de uma opção).

\begin{tabular}{|c|c|c|c|}
\hline \multirow{3}{*}{$\mathrm{X}$} & \multirow{3}{*}{$\begin{array}{l}\text { SIM (indique ao lado em } \\
\text { que grau) }\end{array}$} & $\mathrm{X}$ & MUITO APLICADOS \\
\hline & & & MEDIAMENTE APLICADOS \\
\hline & & & POUCO APLICADOS \\
\hline & \multirow{2}{*}{$\begin{array}{l}\text { NÃO (indique ao lado a } \\
\text { razão da não aplicação) }\end{array}$} & & $\begin{array}{l}\text { CONTEÚDO NÃO ADEQUADO ȦS NECESSIDADES } \\
\text { ESPECÍFICAS DA REGIÃO }\end{array}$ \\
\hline & & & $\begin{array}{llcr}\text { CONTEÚDO NÃO } & \text { FOI SUFICIENTEMENTE } \\
\text { APROFUNDADO PARA } & \text { PERMITIR UMA APLICAÇÃO } \\
\text { EFICAZ E EFICIENTE }\end{array}$ \\
\hline
\end{tabular}




\begin{tabular}{|l|l|l|}
\hline \multirow{2}{*}{} & & $\begin{array}{l}\text { FALTA DE APOIO E INCENTIVO DA MINHA } \\
\text { INSTITUIÇÃO }\end{array}$ \\
\cline { 2 - 3 } & & FALTA DE INCENTIVO ÀS AÇÕES DE ATER \\
\cline { 2 - 3 } & & NÃO TENHO INTERESSE EM APLICAR \\
\hline
\end{tabular}

6) A partir deste curso: (As opções não são excludentes: você poderá marcar mais de uma opção)

\begin{tabular}{|l|l|}
\hline$x$ & $\begin{array}{l}\text { NÃO MUDOU NADA EM MEU TRABALHO. } \\
\text { FAMILIARES. }\end{array}$ \\
\hline & CONSEGUI INFLUENCIAR NAS ORIENTAÇÕES DA MINHA INSTITUIÇÃO. \\
\hline & PASSEI A TRABALHAR COM METODOLOGIAS PARTICIPATIVAS. \\
\hline & $\begin{array}{l}\text { CRESCEU A ÁREA DE AGRICULTURA DE BASE ECOLÓGICA NAS COMUNIDADES } \\
\text { ONDE ATUO. }\end{array}$ \\
\hline & CONTINUEI ME APERFEIÇOANDO SOBRE TEMAS ABORDADOS. \\
\hline
\end{tabular}

7) Depois do curso você apoiou atividades de capacitação de técnicos e agricultores com base nos princípios e diretrizes da Pnater? (Considere como apoio a atividades de capacitação a participação no planejamento, elaboração de ementas, seleção de participantes e de palestrantes.)

\begin{tabular}{|l|l|}
\hline & SIM \\
\hline$X$ & NÃO \\
\hline
\end{tabular}

8) Usou os conhecimentos para ministrar outros cursos com o mesmo conteúdo ou conteúdos semelhantes?

\begin{tabular}{|l|l|}
\hline & SIM \\
\hline$X$ & NÃO \\
\hline
\end{tabular}


9) Marque o seu grau de satisfação com relação ao curso oferecido pelo DATER: (Considere a seguinte pontuação: 1 - MUITO RUIM; 2 - RUIM; 3 - REGULAR; 4 - BOM; 5 - MUITO BOM)

\begin{tabular}{|l|l|l|l|l|}
\hline 1 & 2 & 3 & 4 & $5 \times$ \\
\hline
\end{tabular}

10) Marque seu grau de satisfação com relação ao DATER: (Considere a seguinte pontuação: 1 - MUITO RUIM; 2 - RUIM; 3 - REGULAR; 4 - BOM; 5 - MUITO BOM)

\begin{tabular}{|l|l|l|l|l|}
\hline 1 & 2 & 3 & 4 & $5 \times$ \\
\hline
\end{tabular}

PESQUISA - IMPACTO DAS AÇÕES DE FORMAÇÃO REALIZADAS PELO DATER/SAF/MDA NO PERÍODO 2004-2009

Caros colaboradores,

Contamos com a sua atenção para preencher o formulário abaixo.

O mesmo tem por objetivo fornecer informações para avaliação da Eficiência, Efetividade e Eficácia da Política Pública de Formação de Agentes de Ater adotada pelo Departamento de Assistência Técnica e Extensão Rural, da Secretaria de Agricultura Familiar do Ministério do Desenvolvimento - DATER/SAF/MDA, no período de 2004 a 2009, tema escolhido para Monografia a ser apresentada à Universidade de Brasília (UnB) como requisito parcial para obtenção do grau de Bacharel em Administração.

Você poderá ou não se identificar no questionário e garantimos que todas as informações fornecidas serão confidenciais e utilizadas apenas de forma sistematizada.

\section{IDENTIFICAÇÃO}

\begin{tabular}{|l|l|}
\hline Nome: Eduardo Augusto Veras Marti & $\begin{array}{l}\text { Sexo: } \\
(\mathrm{x}) \text { masculino } \quad(\quad) \text { feminino }\end{array}$ \\
\hline $\begin{array}{l}\text { Instituição (nome e tipo de instituição: ONG, } \\
\text { Empresa Pública, etc.): EMATER- RO }\end{array}$ & $\begin{array}{l}\text { Local de trabalho (Cidade e Estado): } \\
\text { Rio Crespo }\end{array}$ \\
\hline $\begin{array}{l}\text { Curso/Encontro/Oficina do qual participou (caso tenha participado de mais de um curso, preencha } \\
\text { um formulário para cada um deles): Curso de Manejo e Pastagem com Ênfase no Controle } \\
\text { Biológico da Cigarrinha }\end{array}$
\end{tabular}


Data do Curso/Encontro/Oficina (pelo menos mês e ano): 19 a 23/06/2006

Indique sua área de atuação? (As opções não são excludentes: você poderá marcar mais de uma opção)

\begin{tabular}{|l|l|}
\hline$X$ & EXTENSÃO RURAL \\
\hline & PESQUISA \\
\hline & ENSINO \\
\hline & OUTROS \\
\hline
\end{tabular}

2) Qual o seu nível de escolaridade?

\begin{tabular}{|l|l|}
\hline & NÍVEL MÉDIO \\
\hline$X$ & NÍVEL SUPERIOR \\
\hline & PÓS-GRADUAÇÃO \\
\hline
\end{tabular}

3) Os conteúdos abordados foram condizentes com as demandas do seu dia-a-dia?

\begin{tabular}{|l|l|}
\hline$X$ & SIM \\
\hline & PARCIALMENTE \\
\hline & NÃO \\
\hline
\end{tabular}

3) O curso contribuiu para o seu aperfeiçoamento profissional?

\begin{tabular}{|l|l|}
\hline$X$ & SIM \\
\hline & NÃO \\
\hline
\end{tabular}

5) Os conhecimentos adquiridos estão sendo aplicados no seu trabalho? Em caso afirmativo, indique em que grau estes conhecimentos estão sendo aplicados. Em caso negativo, indique por que razão isto não ocorre: (Em caso negativo, as respostas não são excludentes: você poderá marcar mais de uma opção). 


\begin{tabular}{|c|c|c|c|}
\hline \multirow{3}{*}{$x$} & \multirow{3}{*}{$\begin{array}{l}\text { SIM (indique ao lado em } \\
\text { que grau) }\end{array}$} & & MUITO APLICADOS \\
\hline & & & MEDIAMENTE APLICADOS \\
\hline & & $\mathrm{x}$ & POUCO APLICADOS \\
\hline & \multirow{5}{*}{$\begin{array}{l}\text { NÃO (indique ao lado a } \\
\text { razão da não aplicação) }\end{array}$} & & $\begin{array}{l}\text { CONTEÚDO NÃO ADEQUADO ȦS NECESSIDADES } \\
\text { ESPECÍFICAS DA REGIÃO }\end{array}$ \\
\hline & & & $\begin{array}{l}\text { CONTEÚDO NÃ̃O } \\
\text { APROFUNDADO PARA }\end{array}$ \\
\hline & & & 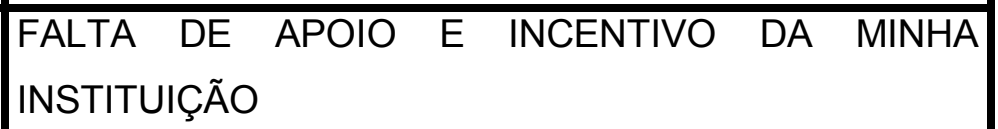 \\
\hline & & & FALTA DE INCENTIVO ÀS AÇÕES DE ATER \\
\hline & & & NÃO TENHO INTERESSE EM APLICAR \\
\hline
\end{tabular}

6) A partir deste curso: (As opções não são excludentes: você poderá marcar mais de uma opção)

\begin{tabular}{|l|l|}
\hline$x$ & $\begin{array}{l}\text { NÃO MUDOU NADA EM MEU TRABALHO. } \\
\text { FAMILIARES. }\end{array}$ \\
\hline & CONSEGUI INFLUENCIAR NAS ORIENTAÇÕES DA MINHA INSTITUIÇÃO. \\
\hline & PASSEI A TRABALHAR COM METODOLOGIAS PARTICIPATIVAS. \\
\hline & $\begin{array}{l}\text { CRESCEU A ÁREA DE AGRICULTURA DE BASE ECOLÓGICA NAS COMUNIDADES } \\
\text { ONDE ATUO. }\end{array}$ \\
\hline & CONTINUEI ME APERFEIÇOANDO SOBRE TEMAS ABORDADOS. \\
\hline
\end{tabular}

7) Depois do curso você apoiou atividades de capacitação de técnicos e agricultores com base nos princípios e diretrizes da Pnater? (Considere como apoio a atividades de capacitação a participação no planejamento, elaboração de ementas, seleção de participantes e de palestrantes.) 


\begin{tabular}{|l|l|}
\hline & SIM \\
\hline$X$ & NÃO \\
\hline
\end{tabular}

8) Usou os conhecimentos para ministrar outros cursos com o mesmo conteúdo ou conteúdos semelhantes?

\begin{tabular}{|l|l|}
\hline & SIM \\
\hline$X$ & NÃO \\
\hline
\end{tabular}

9) Marque o seu grau de satisfação com relação ao curso oferecido pelo DATER: (Considere a seguinte pontuação: 1 - MUITO RUIM; 2 - RUIM; 3 - REGULAR; 4 - BOM; 5 - MUITO BOM)

\begin{tabular}{|l|l|l|l|l|}
\hline 1 & 2 & 3 & $4 \times$ & 5 \\
\hline
\end{tabular}

10) Marque seu grau de satisfação com relação ao DATER: (Considere a seguinte pontuação: 1 - MUITO RUIM; 2 - RUIM; 3 - REGULAR; 4 - BOM; 5 - MUITO BOM)

\begin{tabular}{|l|l|l|l|l|}
\hline 1 & 2 & 3 & $4 \times$ & 5 \\
\hline
\end{tabular}


PESQUISA - IMPACTO DAS AÇÕES DE FORMAÇÃO REALIZADAS PELO DATER/SAF/MDA NO PERÍODO 2004-2009

Caros colaboradores,

Contamos com a sua atenção para preencher o formulário abaixo.

O mesmo tem por objetivo fornecer informações para avaliação da Eficiência, Efetividade e Eficácia da Política Pública de Formação de Agentes de Ater adotada pelo Departamento de Assistência Técnica e Extensão Rural, da Secretaria de Agricultura Familiar do Ministério do Desenvolvimento - DATER/SAF/MDA, no período de 2004 a 2009, tema escolhido para Monografia a ser apresentada à Universidade de Brasília (UnB) como requisito parcial para obtenção do grau de Bacharel em Administração.

Você poderá ou não se identificar no questionário e garantimos que todas as informações fornecidas serão confidenciais e utilizadas apenas de forma sistematizada.

IDENTIFICAÇÃO

\begin{tabular}{|c|c|}
\hline $\begin{array}{l}\text { Nome: } \\
\text { EVERTON LUIZ CANUTO DE SOUSA }\end{array}$ & $\begin{array}{l}\text { Sexo: } \\
(x) \text { masculino } \quad(\quad) \text { feminino }\end{array}$ \\
\hline $\begin{array}{l}\text { Instituição (nome e tipo de instituição: ONG, } \\
\text { Empresa Pública, etc.): } \\
\text { EMATER-PARÁ }\end{array}$ & $\begin{array}{l}\text { Local de trabalho (Cidade e Estado): } \\
\text { ESCRITÓRIO LOCAL DE CACHOEIRA DO } \\
\text { ARARI - MARAJÓ - PARÁ }\end{array}$ \\
\hline \multicolumn{2}{|c|}{$\begin{array}{l}\text { Curso/Encontro/Oficina do qual participou (caso tenha participado de mais de um curso, preencha } \\
\text { um formulário para cada um deles): } \\
\text { TEORIA E PRATICA DE MÉTODOS DE ATER }\end{array}$} \\
\hline $\begin{array}{l}\text { Data do Curso/Encontro/Oficina (pelo menos mês } \epsilon \\
20 \text { A } 24 \text { DE NOVEMBRO DE } 2006 \text {. }\end{array}$ & \\
\hline
\end{tabular}

Indique sua área de atuação? (As opções não são excludentes: você poderá marcar mais de uma opção)

\begin{tabular}{|l|l|}
\hline$X$ & EXTENSÃO RURAL \\
\hline & PESQUISA \\
\hline & ENSINO \\
\hline
\end{tabular}




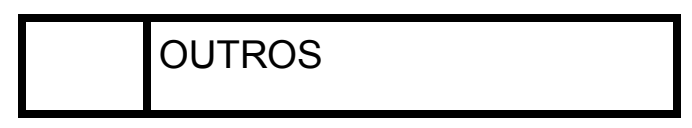

2) Qual o seu nível de escolaridade?

\begin{tabular}{|l|l|}
\hline & NÍVEL MÉDIO \\
\hline$X$ & NÍVEL SUPERIOR \\
\hline & PÓS-GRADUAÇÃO \\
\hline
\end{tabular}

3) Os conteúdos abordados foram condizentes com as demandas do seu dia-a-dia?

\begin{tabular}{|l|l|}
\hline$X$ & SIM \\
\hline & PARCIALMENTE \\
\hline & NÃO \\
\hline
\end{tabular}

4) O curso contribuiu para o seu aperfeiçoamento profissional?

\begin{tabular}{|l|l|}
\hline$X$ & SIM \\
\hline & NÃO \\
\hline
\end{tabular}

5) Os conhecimentos adquiridos estão sendo aplicados no seu trabalho? Em caso afirmativo, indique em que grau estes conhecimentos estão sendo aplicados. Em caso negativo, indique por que razão isto não ocorre: (Em caso negativo, as respostas não são excludentes: você poderá marcar mais de uma opção).

\begin{tabular}{|l|l|l|l|}
\hline X & $\begin{array}{l}\text { SIM (indique ao lado em } \\
\text { que grau) }\end{array}$ & & MUITO APLICADOS \\
\cline { 2 - 4 } & $\begin{array}{l}\text { NÃO (indique ao lado a } \\
\text { razão da não aplicação) }\end{array}$ & MEDIAMENTE APLICADOS \\
\hline
\end{tabular}




\begin{tabular}{|l|l|l|}
\hline \multirow{10}{*}{} & & $\begin{array}{l}\text { CONTEÚDO NÃO FOI SUFICIENTEMENTE } \\
\text { APROFUNDADO PARA PERMITIR UMA APLICAÇÃO } \\
\text { EFICAZ E EFICIENTE }\end{array}$ \\
\cline { 2 - 5 } & $\begin{array}{l}\text { FALTA DE APOIO E INCENTIVO DA MINHA } \\
\text { INSTITUIÇÃO }\end{array}$ \\
\cline { 2 - 4 } & FALTA DE INCENTIVO ÀS AÇÕES DE ATER \\
\hline & NÃO TENHO INTERESSE EM APLICAR \\
\hline
\end{tabular}

6) A partir deste curso: (As opções não são excludentes: você poderá marcar mais de uma opção)

\begin{tabular}{|l|l|}
\hline$x$ & $\begin{array}{l}\text { NÃO MUDOU NADA EM MEU TRABALHO. } \\
\text { FAMILIARES. }\end{array}$ \\
\hline & CONSEGUI INFLUENCIAR NAS ORIENTAÇÕES DA MINHA INSTITUIÇÃO. \\
\hline$X$ & PASSEI A TRABALHAR COM METODOLOGIAS PARTICIPATIVAS. \\
\hline & $\begin{array}{l}\text { CRESCEU A ÁREA DE AGRICULTURA DE BASE ECOLÓGICA NAS COMUNIDADES } \\
\text { ONDE ATUO. }\end{array}$ \\
\hline & CONTINUEI ME APERFEIÇOANDO SOBRE TEMAS ABORDADOS. \\
\hline
\end{tabular}

7) Depois do curso você apoiou atividades de capacitação de técnicos e agricultores com base nos princípios e diretrizes da Pnater? (Considere como apoio a atividades de capacitação a participação no planejamento, elaboração de ementas, seleção de participantes e de palestrantes.)

\begin{tabular}{|l|l|}
\hline$X$ & SIM \\
\hline & NÃO \\
\hline
\end{tabular}

8) Usou os conhecimentos para ministrar outros cursos com o mesmo conteúdo ou conteúdos semelhantes? 


\begin{tabular}{|l|l|}
\hline$X$ & SIM \\
\hline & NÃO \\
\hline
\end{tabular}

9) Marque o seu grau de satisfação com relação ao curso oferecido pelo DATER: (Considere a seguinte pontuação: 1 - MUITO RUIM; 2 - RUIM; 3 - REGULAR; 4 - BOM; 5 - MUITO BOM)

\begin{tabular}{|l|l|l|l|l|}
\hline 1 & 2 & 3 & $(4)$ & 5 \\
\hline
\end{tabular}

10) Marque seu grau de satisfação com relação ao DATER: (Considere a seguinte pontuação: 1 - MUITO RUIM; 2 - RUIM; 3 - REGULAR; 4 - BOM; 5 - MUITO BOM)

\begin{tabular}{|l|l|l|l|l|}
\hline 1 & 2 & 3 & $(4)$ & 5 \\
\hline
\end{tabular}


PESQUISA - IMPACTO DAS AÇÕES DE FORMAÇÃO REALIZADAS PELO DATER/SAF/MDA NO PERÍODO 2004-2009

Caros colaboradores,

Contamos com a sua atenção para preencher o formulário abaixo.

O mesmo tem por objetivo fornecer informações para avaliação da Eficiência, Efetividade e Eficácia da Política Pública de Formação de Agentes de Ater adotada pelo Departamento de Assistência Técnica e Extensão Rural, da Secretaria de Agricultura Familiar do Ministério do Desenvolvimento - DATER/SAF/MDA, no período de 2004 a 2009, tema escolhido para Monografia a ser apresentada à Universidade de Brasília (UnB) como requisito parcial para obtenção do grau de Bacharel em Administração.

Você poderá ou não se identificar no questionário e garantimos que todas as informações fornecidas serão confidenciais e utilizadas apenas de forma sistematizada.

IDENTIFICAÇÃO

\begin{tabular}{|c|c|}
\hline Nome: Fabiana Fernandes Tonon & $\begin{array}{l}\text { Sexo: } \\
(\quad) \text { masculino }(x) \text { feminino }\end{array}$ \\
\hline $\begin{array}{l}\text { Instituição (nome e tipo de instituição: ONG, } \\
\text { Empresa Pública, etc.): Emater - RO }\end{array}$ & $\begin{array}{l}\text { Local de trabalho (Cidade e Estado): } \\
\text { Cerejeiras - RO. }\end{array}$ \\
\hline \multicolumn{2}{|c|}{$\begin{array}{l}\text { Curso/Encontro/Oficina do qual participou (caso tenha participado de mais de um curso, preencha } \\
\text { um formulário para cada um deles): Curso de Manejo de Pastagem com Énfase no Controle } \\
\text { Biológico da Cigarrinha }\end{array}$} \\
\hline 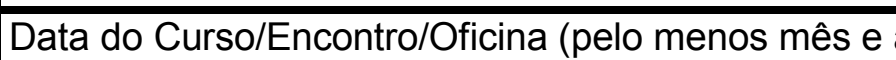 & $\overline{0): 2}$ \\
\hline
\end{tabular}

Indique sua área de atuação? (As opções não são excludentes: você poderá marcar mais de uma opção)

\begin{tabular}{|l|l|}
\hline$x$ & EXTENSÃO RURAL \\
\hline & PESQUISA \\
\hline & ENSINO \\
\hline & OUTROS \\
\hline
\end{tabular}

2) Qual o seu nível de escolaridade? 


\begin{tabular}{|l|l|}
\hline$x$ & NÍVEL MÉDIO \\
\hline & NÍVEL SUPERIOR \\
\hline & PÓS-GRADUAÇÃO \\
\hline
\end{tabular}

3) Os conteúdos abordados foram condizentes com as demandas do seu dia-a-dia?

\begin{tabular}{|l|l|}
\hline$x$ & SIM \\
\hline & PARCIALMENTE \\
\hline & NÃO \\
\hline
\end{tabular}

4) O curso contribuiu para o seu aperfeiçoamento profissional?

\begin{tabular}{|l|l|}
\hline$x$ & SIM \\
\hline & NÃO \\
\hline
\end{tabular}

5) Os conhecimentos adquiridos estão sendo aplicados no seu trabalho? Em caso afirmativo, indique em que grau estes conhecimentos estão sendo aplicados. Em caso negativo, indique por que razão isto não ocorre: (Em caso negativo, as respostas não são excludentes: você poderá marcar mais de uma opção).

\begin{tabular}{|c|c|c|c|}
\hline \multirow{3}{*}{$x$} & \multirow{3}{*}{$\begin{array}{l}\text { SIM (indique ao lado } \\
\text { em que grau) }\end{array}$} & & MUITO APLICADOS \\
\hline & & $x$ & MEDIAMENTE APLICADOS \\
\hline & & & POUCO APLICADOS \\
\hline & \multirow{3}{*}{$\begin{array}{l}\text { NÃO (indique ao lado a } \\
\text { razão da não aplicação) }\end{array}$} & & $\begin{array}{l}\text { CONTEÚDO NĀO ADEQUADO ȦS NECESSIDADES } \\
\text { ESPECÍFICAS DA REGIÃO }\end{array}$ \\
\hline & & & $\begin{array}{l}\text { CONTEÚDO NĀO FOI SUFICIENTEMENTE } \\
\text { APROFUNDADO PARA PERMITIR UMA APLICAÇÃO } \\
\text { EFICAZ E EFICIENTE }\end{array}$ \\
\hline & & & $\begin{array}{l}\text { FALTA DE APOIO E INCENTIVO DA MINHA } \\
\text { INSTITUIÇÃO }\end{array}$ \\
\hline
\end{tabular}




\begin{tabular}{|l|l|l|}
\hline \multirow{2}{*}{} & & FALTA DE INCENTIVO ÀS AÇÕES DE ATER \\
\hline & & NÃO TENHO INTERESSE EM APLICAR \\
\hline
\end{tabular}

6) A partir deste curso:

\begin{tabular}{|l|l|}
\hline & NÃO MUDOU NADA EM MEU TRABALHO. \\
\hline$x$ & $\begin{array}{l}\text { MEU TRABALHO PASSOU A CONTRIBUIR MAIS COM OS AGRICULTORES (AS) } \\
\text { FAMILIARES. }\end{array}$ \\
\hline$x$ & CONSEGUI INFLUENCIAR NAS ORIENTAÇÕES DA MINHA INSTITUIÇÃO. \\
\hline & PASSEI A TRABALHAR COM METODOLOGIAS PARTICIPATIVAS. \\
\hline & $\begin{array}{l}\text { CRESCEU A ÁREA DE AGRICULTURA DE BASE ECOLÓGICA NAS COMUNIDADES } \\
\text { ONDE ATUO. }\end{array}$ \\
\hline$x$ & CONTINUEI ME APERFEIÇOANDO SOBRE TEMAS ABORDADOS. \\
\hline
\end{tabular}

7) Depois do curso você apoiou atividades de capacitação de técnicos e agricultores com base nos princípios e diretrizes da Pnater? (Considere como apoio a atividades de capacitação a participação no planejamento, elaboração de ementas, seleção de participantes e de palestrantes.)

\begin{tabular}{|l|l|}
\hline & SIM \\
\hline$X$ & NÃO \\
\hline
\end{tabular}

8) Usou os conhecimentos para ministrar outros cursos com o mesmo conteúdo ou conteúdos semelhantes?

\begin{tabular}{|l|l|}
\hline & SIM \\
\hline$x$ & NÃO \\
\hline
\end{tabular}

9) Marque o seu grau de satisfação com relação ao curso oferecido pelo DATER: (Considere a seguinte pontuação: 1 - MUITO RUIM; 2 - RUIM; 3 - REGULAR; 4 - BOM; 5 - MUITO BOM) 


\begin{tabular}{|l|l|l|l|l|}
\hline 1 & 2 & 3 & $4 x$ & 5 \\
\hline
\end{tabular}

10) Marque seu grau de satisfação com relação ao DATER: (Considere a seguinte pontuação: 1 - MUITO RUIM; 2 - RUIM; 3 - REGULAR; 4 - BOM; 5 - MUITO BOM)

\begin{tabular}{|l|l|l|l|l|}
\hline 1 & 2 & 3 & $4 \times$ & 5 \\
\hline
\end{tabular}




\section{PESQUISA - IMPACTO DAS AÇÕES DE FORMAÇÃO REALIZADAS PELO DATER/SAF/MDA NO PERÍODO 2004-2009}

Caros colaboradores,

Contamos com a sua atenção para preencher o formulário abaixo.

O mesmo tem por objetivo fornecer informações para avaliação da Eficiência, Efetividade e Eficácia da Política Pública de Formação de Agentes de Ater adotada pelo Departamento de Assistência Técnica e Extensão Rural, da Secretaria de Agricultura Familiar do Ministério do Desenvolvimento - DATER/SAF/MDA, no período de 2004 a 2009, tema escolhido para Monografia a ser apresentada à Universidade de Brasília (UnB) como requisito parcial para obtenção do grau de Bacharel em Administração.

Você poderá ou não se identificar no questionário e garantimos que todas as informações fornecidas serão confidenciais e utilizadas apenas de forma sistematizada.

\section{IDENTIFICAÇÃO:}

\begin{tabular}{|l|l|}
\hline Nome: Fabiana Fernandes Tonon. & $\begin{array}{l}\text { Sexo: } \\
(\quad) \text { masculino ( xxx ) feminino }\end{array}$ \\
\hline $\begin{array}{l}\text { Instituição (nome e tipo de instituição: ONG, } \\
\text { Empresa Pública, etc.): Emater - Ro. }\end{array}$ & $\begin{array}{l}\text { Local de trabalho (Cidade e Estado): } \\
\text { Cerejeiras - Ro. }\end{array}$ \\
\hline $\begin{array}{l}\text { Curso/Encontro/Oficina do qual participou (caso tenha participado de mais de um curso, } \\
\text { preencha um formulário para cada um deles): Curso sobre Relatório de Controle Ambiental e } \\
\text { Plano de Controle Ambiental para Piscicultura. }\end{array}$ \\
\hline \begin{tabular}{l} 
Data do Curso/Encontro/Oficina (pelo menos mês e ano): 15 a 19/05/2006. \\
\hline
\end{tabular}
\end{tabular}

Indique sua área de atuação? (As opções não são excludentes: você poderá marcar mais de uma opção)

\begin{tabular}{|l|l|}
\hline$X$ & EXTENSÃO RURAL \\
\hline & PESQUISA \\
\hline & ENSINO \\
\hline & OUTROS \\
\hline
\end{tabular}


2) Qual o seu nível de escolaridade? (Considere apenas o nível mais alto)

\begin{tabular}{|l|l|}
\hline$x$ & NÍVEL MÉDIO \\
\hline & NÍVEL SUPERIOR \\
\hline & PÓS-GRADUAÇÃO \\
\hline
\end{tabular}

3) Os conteúdos abordados foram condizentes com as demandas do seu dia-a-dia?

\begin{tabular}{|l|l|}
\hline$x$ & SIM \\
\hline & PARCIALMENTE \\
\hline & NÃO \\
\hline
\end{tabular}

4) O curso contribuiu para o seu aperfeiçoamento profissional?

\begin{tabular}{|l|l|}
\hline$x$ & SIM \\
\hline & NÃO \\
\hline
\end{tabular}

5) Os conhecimentos adquiridos estão sendo aplicados no seu trabalho? Em caso afirmativo, indique em que grau estes conhecimentos estão sendo aplicados. Em caso negativo, indique por que razão isto não ocorre: (Em caso negativo, as respostas não são excludentes: você poderá marcar mais de uma opção).

\begin{tabular}{|c|c|c|c|}
\hline \multirow{3}{*}{$x$} & \multirow{3}{*}{$\begin{array}{l}\text { SIM (indique ao lado } \\
\text { em que grau) }\end{array}$} & & MUITO APLICADOS \\
\hline & & $x$ & MEDIAMENTE APLICADOS \\
\hline & & & POUCO APLICADOS \\
\hline & \multirow{2}{*}{$\begin{array}{l}\text { NÃO (indique ao lado a } \\
\text { razão da não aplicação) }\end{array}$} & & $\begin{array}{l}\text { CONTEU்DO NÃO ADEQUADO ȦS NECESSIDADES } \\
\text { ESPECÍFICAS DA REGIÃO }\end{array}$ \\
\hline & & & $\begin{array}{l}\text { CONTEÚDO NĀO FOI SUFICIENTEMENTE } \\
\text { APROFUNDADO PARA PERMITIR UMA APLICAÇÃO } \\
\text { EFICAZ E EFICIENTE }\end{array}$ \\
\hline
\end{tabular}




\begin{tabular}{|l|l|l|}
\hline \multirow{2}{*}{} & & $\begin{array}{l}\text { FALTA DE APOIO E INCENTIVO DA MINHA } \\
\text { INSTITUIÇÃO }\end{array}$ \\
\cline { 2 - 3 } & & FALTA DE INCENTIVO ÀS AÇÕES DE ATER \\
\cline { 2 - 3 } & NÃO TENHO INTERESSE EM APLICAR \\
\hline
\end{tabular}

6) A partir deste curso: (As opções não são excludentes: você poderá marcar mais de uma opção)

\begin{tabular}{|l|l|}
\hline & NÃO MUDOU NADA EM MEU TRABALHO. \\
\hline$x$ & $\begin{array}{l}\text { MEU TRABALHO PASSOU A CONTRIBUIR MAIS COM OS AGRICULTORES (AS) } \\
\text { FAMILIARES. }\end{array}$ \\
\hline & CONSEGUI INFLUENCIAR NAS ORIENTAÇÕES DA MINHA INSTITUIÇÃO. \\
\hline & $\begin{array}{l}\text { PASSEI A TRABALHAR COM METODOLOGIAS PARTICIPATIVAS. } \\
\text { ONDE ATUO. }\end{array}$ \\
\hline $\mathrm{X}$ & CONTINUEI ME APERFEIÇOANDO SOBRE TEMAS ABORDADOS. \\
\hline
\end{tabular}

7) Depois do curso você apoiou atividades de capacitação de técnicos e agricultores com base nos princípios e diretrizes da Pnater? (Considere como apoio a atividades de capacitação a participação no planejamento, elaboração de ementas, seleção de participantes e de palestrantes.)

\begin{tabular}{|l|l|}
\hline & SIM \\
\hline$x$ & NÃO \\
\hline
\end{tabular}

8) Usou os conhecimentos para ministrar outros cursos com o mesmo conteúdo ou conteúdos semelhantes?

\begin{tabular}{|l|l|}
\hline & SIM \\
\hline$x$ & NÃO \\
\hline
\end{tabular}


9) Marque o seu grau de satisfação com relação ao curso oferecido pelo DATER: (Considere a seguinte pontuação: 1 - MUITO RUIM; 2 - RUIM; 3 - REGULAR; 4 - BOM; 5 - MUITO BOM)

\begin{tabular}{|l|l|l|l|l|}
\hline 1 & 2 & 3 & $4 \times$ & 5 \\
\hline
\end{tabular}

10) Marque seu grau de satisfação com relação ao DATER: (Considere a seguinte pontuação: 1 - MUITO RUIM; 2 - RUIM; 3 - REGULAR; 4 - BOM; 5 - MUITO BOM)

\begin{tabular}{|l|l|l|l|l|}
\hline 1 & 2 & 3 & $4 \times$ & 5 \\
\hline
\end{tabular}




\section{PESQUISA - IMPACTO DAS AÇÕES DE FORMAÇÃO REALIZADAS PELO DATER/SAF/MDA NO PERÍODO 2004-2009}

Caros colaboradores,

Contamos com a sua atenção para preencher o formulário abaixo.

O mesmo tem por objetivo fornecer informações para avaliação da Eficiência, Efetividade e Eficácia da Política Pública de Formação de Agentes de Ater adotada pelo Departamento de Assistência Técnica e Extensão Rural, da Secretaria de Agricultura Familiar do Ministério do Desenvolvimento - DATER/SAF/MDA, no período de 2004 a 2009, tema escolhido para Monografia a ser apresentada à Universidade de Brasília (UnB) como requisito parcial para obtenção do grau de Bacharel em Administração.

Você poderá ou não se identificar no questionário e garantimos que todas as informações fornecidas serão confidenciais e utilizadas apenas de forma sistematizada.

IDENTIFICAÇÃO

\begin{tabular}{|c|c|}
\hline $\begin{array}{l}\text { Nome: ANTŌNIO CLARET MAGALHĀES } \\
\text { FERREIRA }\end{array}$ & $\begin{array}{l}\text { Sexo: } \\
(\quad \mathbf{x x}) \text { masculino }\end{array}$ \\
\hline $\begin{array}{l}\text { Instituição (nome e tipo de instituição: ONG, } \\
\text { Empresa Pública, etc.): } \\
\text { Instituto de Desenvolvimento Agropecuário do } \\
\text { Estado do Amazonas - IDAM }\end{array}$ & $\begin{array}{l}\text { Local de trabalho (Cidade e Estado): } \\
\text { Manaus - AM }\end{array}$ \\
\hline \multicolumn{2}{|c|}{$\begin{array}{l}\text { Curso/Encontro/Oficina do qual participou (caso tenha participado de mais de um curso, } \\
\text { preencha um formulário para cada um deles): } \\
\text { Oficina de Nivelamento Conceitual sobre a Política Nacional de Ater }\end{array}$} \\
\hline $\begin{array}{l}\text { Data do Curso/Encontro/Oficina (pelo menos mês } \\
08 \text { a } 12 \text { de novembro de } 2004 \text { - Rio Branco/AC }\end{array}$ & \\
\hline
\end{tabular}

Indique sua área de atuação? As opções não são excludentes: você poderá marcar mais de uma opção)

\begin{tabular}{|l|l|}
\hline$X$ & EXTENSÃO RURAL \\
\hline & PESQUISA \\
\hline
\end{tabular}




\begin{tabular}{|l|l|}
\hline & ENSINO \\
\hline & OUTROS \\
\hline
\end{tabular}

2) Qual o seu nível de escolaridade? (Considere apenas o nível mais alto)

\begin{tabular}{|l|l|}
\hline & NÍVEL MÉDIO \\
\hline$X$ & NÍVEL SUPERIOR \\
\hline & PÓS-GRADUAÇÃO \\
\hline
\end{tabular}

3) Os conteúdos abordados foram condizentes com as demandas do seu dia-a-dia?

\begin{tabular}{|l|l|}
\hline$X$ & SIM \\
\hline & PARCIALMENTE \\
\hline & NÃO \\
\hline
\end{tabular}

3) O curso contribuiu para o seu aperfeiçoamento profissional?

\begin{tabular}{|l|l|}
\hline$X$ & SIM \\
\hline & NÃO \\
\hline
\end{tabular}

5) Os conhecimentos adquiridos estão sendo aplicados no seu trabalho? Em caso afirmativo, indique em que grau estes conhecimentos estão sendo aplicados. Em caso negativo, indique por que razão isto não ocorre: (Em caso negativo, as respostas não são excludentes: você poderá marcar mais de uma opção).

\begin{tabular}{|c|c|c|}
\hline \multirow{3}{*}{$\begin{array}{l}\text { SIM (indique ao lado } \\
\text { em que grau) }\end{array}$} & & MUITO APLICADOS \\
\hline & $x$ & MEDIAMENTE APLICADOS \\
\hline & & POUCO APLICADOS \\
\hline
\end{tabular}




\begin{tabular}{|c|c|}
\hline \multirow{5}{*}{$\begin{array}{l}\text { NÃO (indique ao lado a } \\
\text { razão da não aplicação) }\end{array}$} & $\begin{array}{l}\text { CONTEÚDO NĀO ADEQUADO ȦS NECESSIDADES } \\
\text { ESPECÍFICAS DA REGIÃO }\end{array}$ \\
\hline & $\begin{array}{l}\text { CONTEÚDO NÃO FOI SUFICIENTEMENTE } \\
\text { APROFUNDADO PARA PERMITIR UMA APLICAÇÃO } \\
\text { EFICAZ E EFICIENTE }\end{array}$ \\
\hline & \begin{tabular}{|llllll} 
FALTA DE & APOIO & E & INCENTIVO & DA & MINHA \\
INSTITUIÇÃO & & & & &
\end{tabular} \\
\hline & FALTA DE INCENTIVO ÀS AÇÕES DE ATER \\
\hline & NÃO TENHO INTERESSE EM APLICAR \\
\hline
\end{tabular}

6) A partir deste curso: As opções não são excludentes: você poderá marcar mais de uma opção)

\begin{tabular}{|l|l|}
\hline & NÃO MUDOU NADA EM MEU TRABALHO. \\
\hline$X$ & $\begin{array}{l}\text { MEU TRABALHO PASSOU A CONTRIBUIR MAIS COM OS AGRICULTORES(AS) } \\
\text { FAMILIARES. }\end{array}$ \\
\hline$X$ & CONSEGUI INFLUENCIAR NAS ORIENTAÇÕES DA MINHA INSTITUIÇÃO. \\
\hline$X$ & PASSEI A TRABALHAR COM METODOLOGIAS PARTICIPATIVAS. \\
\hline & $\begin{array}{l}\text { CRESCEU A ÁREA DE AGRICULTURA DE BASE ECOLÓGICA NAS COMUNIDADES } \\
\text { ONDE ATUO. }\end{array}$ \\
\hline$X$ & CONTINUEI ME APERFEIÇOANDO SOBRE TEMAS ABORDADOS. \\
\hline
\end{tabular}

7) Depois do curso você apoiou atividades de capacitação de técnicos e agricultores com base nos princípios e diretrizes da Pnater? (Considere como apoio a atividades de capacitação a participação no planejamento, elaboração de ementas, seleção de participantes e de palestrantes.)

\begin{tabular}{|l|l|}
\hline$X$ & SIM \\
\hline & NÃO \\
\hline
\end{tabular}


8) Usou os conhecimentos para ministrar outros cursos com o mesmo conteúdo ou conteúdos semelhantes?

\begin{tabular}{|l|l|}
\hline$X$ & SIM \\
\hline & NÃO \\
\hline
\end{tabular}

9) Marque o seu grau de satisfação com relação ao curso oferecido pelo DATER: (Considere a seguinte pontuação: 1 - MUITO RUIM; 2 - RUIM; 3 - REGULAR; 4 - BOM; 5 - MUITO BOM)

\begin{tabular}{|l|l|l|l|l|}
\hline 1 & 2 & 3 & 4 & 5 \\
\hline
\end{tabular}

10) Marque seu grau de satisfação com relação ao DATER: (Considere a seguinte pontuação: 1 - MUITO RUIM; 2 - RUIM; 3 - REGULAR; 4 - BOM; 5 - MUITO BOM)

\begin{tabular}{|l|l|l|l|l|}
\hline 1 & 2 & 3 & 4 & 5 \\
\hline
\end{tabular}




\section{PESQUISA - IMPACTO DAS AÇÕES DE FORMAÇÃO REALIZADAS PELO DATER/SAF/MDA NO PERÍODO 2004-2009}

Caros colaboradores,

Contamos com a sua atenção para preencher o formulário abaixo.

O mesmo tem por objetivo fornecer informações para avaliação da Eficiência, Efetividade e Eficácia da Política Pública de Formação de Agentes de Ater adotada pelo Departamento de Assistência Técnica e Extensão Rural, da Secretaria de Agricultura Familiar do Ministério do Desenvolvimento - DATER/SAF/MDA, no período de 2004 a 2009, tema escolhido para Monografia a ser apresentada à Universidade de Brasília (UnB) como requisito parcial para obtenção do grau de Bacharel em Administração.

Você poderá ou não se identificar no questionário e garantimos que todas as informações fornecidas serão confidenciais e utilizadas apenas de forma sistematizada.

IDENTIFICAÇÃO

Nome: ANTÖNIO CLARET MAGALHĀES
FERREIRA

Indique sua área de atuação? As opções não são excludentes: você poderá marcar mais de uma opção) 


\begin{tabular}{|l|l|}
\hline$X$ & EXTENSÃO RURAL \\
\hline & PESQUISA \\
\hline & ENSINO \\
\hline & OUTROS \\
\hline
\end{tabular}

2) Qual o seu nível de escolaridade? (Considere apenas o nível mais alto)

\begin{tabular}{|l|l|}
\hline & NÍVEL MÉDIO \\
\hline$X$ & NÍVEL SUPERIOR \\
\hline & PÓS-GRADUAÇÃO \\
\hline
\end{tabular}

3) Os conteúdos abordados foram condizentes com as demandas do seu dia-a-dia?

\begin{tabular}{|l|l|}
\hline$X$ & SIM \\
\hline & PARCIALMENTE \\
\hline & NÃO \\
\hline
\end{tabular}

4) O curso contribuiu para o seu aperfeiçoamento profissional?

\begin{tabular}{|l|l|}
\hline$X$ & SIM \\
\hline & NÃO \\
\hline
\end{tabular}

5) Os conhecimentos adquiridos estão sendo aplicados no seu trabalho? Em caso afirmativo, indique em que grau estes conhecimentos estão sendo aplicados. Em caso negativo, indique por que razão isto não ocorre: (Em caso negativo, as respostas não são excludentes: você poderá marcar mais de uma opção).

\begin{tabular}{|l|l|l|l|}
\hline $\begin{array}{l}\text { SIM (indique ao lado } \\
\text { em que grau) }\end{array}$ & & MUITO APLICADOS \\
\cline { 2 - 3 } & & $X$ & MEDIAMENTE APLICADOS \\
\hline
\end{tabular}




\begin{tabular}{|c|c|}
\hline & POUCO APLICADOS \\
\hline \multirow{5}{*}{$\begin{array}{l}\text { NÃO (indique ao lado a } \\
\text { razão da não aplicação) }\end{array}$} & $\begin{array}{l}\text { CONTEÚDO NÃO ADEQUADO ÀS NECESSIDADES } \\
\text { ESPECÍFICAS DA REGIÃO }\end{array}$ \\
\hline & $\begin{array}{l}\text { CONTEUUDO NĀO } \quad \text { FOI } \text { SUFICIENTEMENTE } \\
\text { APROFUNDADO PARA PERMITIR UMA APLICAÇÃO } \\
\text { EFICAZ E EFICIENTE }\end{array}$ \\
\hline & 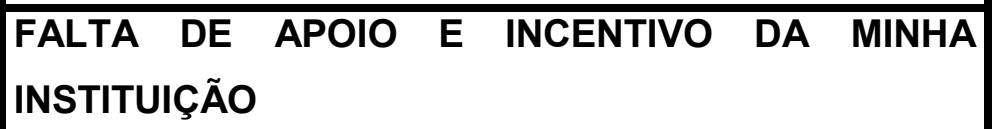 \\
\hline & FALTA DE INCENTIVO ÀS AÇÕES DE ATER \\
\hline & NÃO TENHO INTERESSE EM APLICAR \\
\hline
\end{tabular}

6) A partir deste curso: As opções não são excludentes: você poderá marcar mais de uma opção)

\begin{tabular}{|l|l|}
\hline & NÃO MUDOU NADA EM MEU TRABALHO. \\
\hline$X$ & $\begin{array}{l}\text { MEU TRABALHO PASSOU A CONTRIBUIR MAIS COM OS AGRICULTORES(AS) } \\
\text { FAMILIARES. }\end{array}$ \\
\hline$X$ & CONSEGUI INFLUENCIAR NAS ORIENTAÇÕES DA MINHA INSTITUIÇÃO. \\
\hline$X$ & PASSEI A TRABALHAR COM METODOLOGIAS PARTICIPATIVAS. \\
\hline & $\begin{array}{l}\text { CRESCEU A ÁREA DE AGRICULTURA DE BASE ECOLÓGICA NAS COMUNIDADES } \\
\text { ONDE ATUO. }\end{array}$ \\
\hline$X$ & CONTINUEI ME APERFEIÇOANDO SOBRE TEMAS ABORDADOS. \\
\hline
\end{tabular}

7) Depois do curso você apoiou atividades de capacitação de técnicos e agricultores com base nos princípios e diretrizes da Pnater? (Considere como apoio a atividades de capacitação a participação no planejamento, elaboração de ementas, seleção de participantes e de palestrantes.)

\begin{tabular}{|l|l|}
\hline$X$ & SIM \\
\hline & NÃO \\
\hline
\end{tabular}


8) Usou os conhecimentos para ministrar outros cursos com o mesmo conteúdo ou conteúdos semelhantes?

\begin{tabular}{|l|l|}
\hline$X$ & SIM \\
\hline & NÃO \\
\hline
\end{tabular}

9) Marque o seu grau de satisfação com relação ao curso oferecido pelo DATER: (Considere a seguinte pontuação: 1 - MUITO RUIM; 2 - RUIM; 3 - REGULAR; 4 - BOM; 5 - MUITO BOM)

\begin{tabular}{|l|l|l|l|l|}
\hline 1 & 2 & 3 & 4 & 5 \\
\hline
\end{tabular}

10) Marque seu grau de satisfação com relação ao DATER: (Considere a seguinte pontuação: 1 - MUITO RUIM; 2 - RUIM; 3 - REGULAR; 4 - BOM; 5 - MUITO BOM)

\begin{tabular}{|l|l|l|l|l|}
\hline 1 & 2 & 3 & 4 & 5 \\
\hline
\end{tabular}




\section{PESQUISA - IMPACTO DAS AÇÕES DE FORMAÇÃO REALIZADAS PELO DATER/SAF/MDA NO PERÍODO 2004-2009}

Caros colaboradores,

Contamos com a sua atenção para preencher o formulário abaixo.

O mesmo tem por objetivo fornecer informações para avaliação da Eficiência, Efetividade e Eficácia da Política Pública de Formação de Agentes de Ater adotada pelo Departamento de Assistência Técnica e Extensão Rural, da Secretaria de Agricultura Familiar do Ministério do Desenvolvimento - DATER/SAF/MDA, no período de 2004 a 2009, tema escolhido para Monografia a ser apresentada à Universidade de Brasília (UnB) como requisito parcial para obtenção do grau de Bacharel em Administração.

Você poderá ou não se identificar no questionário e garantimos que todas as informações fornecidas serão confidenciais e utilizadas apenas de forma sistematizada.

IDENTIFICAÇÃO

\begin{tabular}{|c|c|}
\hline $\begin{array}{l}\text { Nome: ANTÖNIO CLARET MAGALHĀES } \\
\text { FERREIRA }\end{array}$ & $\begin{array}{l}\text { Sexo: } \\
(\quad \mathbf{x x}) \text { masculino }\end{array}$ \\
\hline $\begin{array}{l}\text { Instituição (nome e tipo de instituição: ONG, } \\
\text { Empresa Pública, etc.): } \\
\text { Instituto de Desenvolvimento Agropecuário do } \\
\text { Estado do Amazonas - IDAM }\end{array}$ & $\begin{array}{l}\text { Local de trabalho (Cidade e Estado): } \\
\text { Manaus-AM }\end{array}$ \\
\hline \multicolumn{2}{|c|}{$\begin{array}{l}\text { Curso/Encontro/Oficina do qual participou (caso tenha participado de mais de um curso, } \\
\text { preencha um formulário para cada um deles): } \\
\text { Seminário Estadual de Extensão Rural - referências metodológicas para a ação extensionista }\end{array}$} \\
\hline $\begin{array}{l}\text { Data do Curso/Encontro/Oficina (pelo menos mês } \\
20 \text { a } 23 \text { de março de } 2006 \text { - Belo Horizonte/MG }\end{array}$ & \\
\hline
\end{tabular}

Indique sua área de atuação? As opções não são excludentes: você poderá marcar mais de uma opção)

\begin{tabular}{|l|l|}
\hline$X$ & EXTENSÃO RURAL \\
\hline & PESQUISA \\
\hline
\end{tabular}




\begin{tabular}{|l|l|}
\hline & ENSINO \\
\hline & OUTROS \\
\hline
\end{tabular}

2) Qual o seu nível de escolaridade? (Considere apenas o nível mais alto)

\begin{tabular}{|l|l|}
\hline & NÍVEL MÉDIO \\
\hline$X$ & NÍVEL SUPERIOR \\
\hline & PÓS-GRADUAÇÃO \\
\hline
\end{tabular}

3) Os conteúdos abordados foram condizentes com as demandas do seu dia-a-dia?

\begin{tabular}{|l|l|}
\hline$X$ & SIM \\
\hline & PARCIALMENTE \\
\hline & NÃO \\
\hline
\end{tabular}

4) O curso contribuiu para o seu aperfeiçoamento profissional?

\begin{tabular}{|l|l|}
\hline$X$ & SIM \\
\hline & NÃO \\
\hline
\end{tabular}

5) Os conhecimentos adquiridos estão sendo aplicados no seu trabalho? Em caso afirmativo, indique em que grau estes conhecimentos estão sendo aplicados. Em caso negativo, indique por que razão isto não ocorre: (Em caso negativo, as respostas não são excludentes: você poderá marcar mais de uma opção).

\begin{tabular}{|l|l|l|l|}
\hline \multirow{2}{*}{$\begin{array}{l}\text { SIM (indique ao lado } \\
\text { em que grau) }\end{array}$} & MUITO APLICADOS \\
\cline { 2 - 3 } & & MEDIAMENTE APLICADOS \\
\hline & $\begin{array}{l}\text { NÃO (indique ao lado a } \\
\text { razão da não aplicação) }\end{array}$ & & $\begin{array}{l}\text { CONTEÚDO NÃO ADEQUADO ÀS NECESSIDADES } \\
\text { ESPECÍFICAS DA REGIÃO }\end{array}$ \\
\hline
\end{tabular}




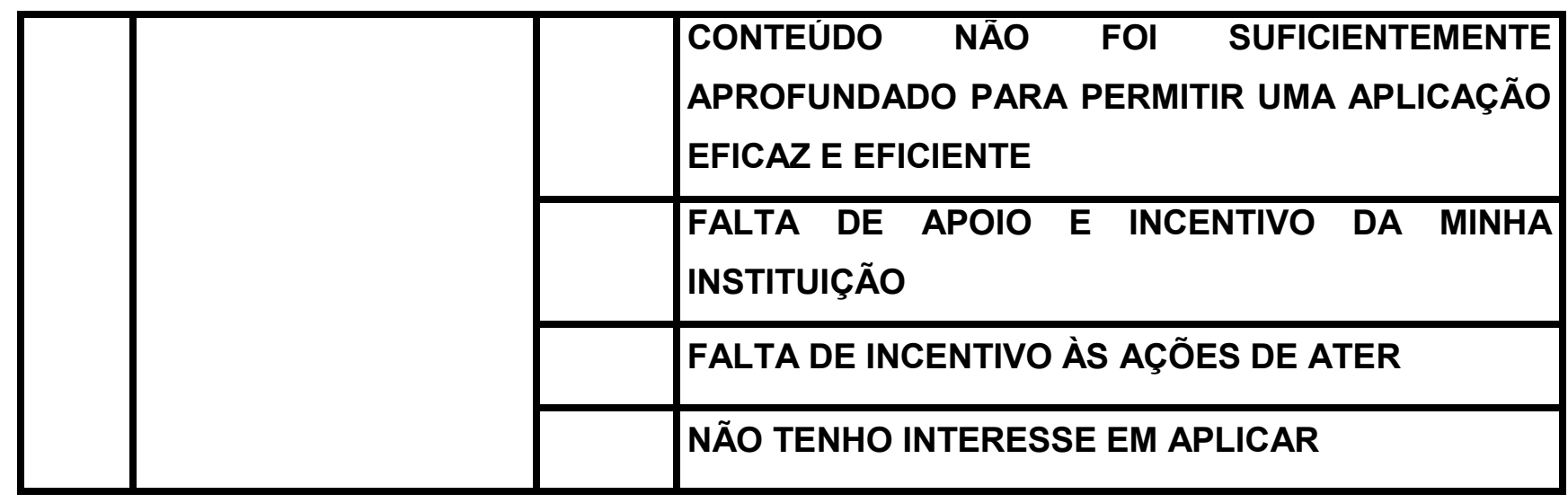

6) A partir deste curso: As opções não são excludentes: você poderá marcar mais de uma opção)

\begin{tabular}{|l|l|}
\hline & NÃO MUDOU NADA EM MEU TRABALHO. \\
\hline$X$ & $\begin{array}{l}\text { MEU TRABALHO PASSOU A CONTRIBUIR MAIS COM OS AGRICULTORES(AS) } \\
\text { FAMILIARES. }\end{array}$ \\
\hline$X$ & CONSEGUI INFLUENCIAR NAS ORIENTAÇÕES DA MINHA INSTITUIÇÃO. \\
\hline$X$ & PASSEI A TRABALHAR COM METODOLOGIAS PARTICIPATIVAS. \\
\hline & $\begin{array}{l}\text { CRESCEU A ÁREA DE AGRICULTURA DE BASE ECOLÓGICA NAS COMUNIDADES } \\
\text { ONDE ATUO. }\end{array}$ \\
\hline$X$ & CONTINUEI ME APERFEIÇOANDO SOBRE TEMAS ABORDADOS. \\
\hline
\end{tabular}

7) Depois do curso você apoiou atividades de capacitação de técnicos e agricultores com base nos princípios e diretrizes da Pnater? (Considere como apoio a atividades de capacitação a participação no planejamento, elaboração de ementas, seleção de participantes e de palestrantes.)

\begin{tabular}{|l|l|}
\hline$X$ & SIM \\
\hline & NÃO \\
\hline
\end{tabular}

8) Usou os conhecimentos para ministrar outros cursos com o mesmo conteúdo ou conteúdos semelhantes? 


\begin{tabular}{|l|l|}
\hline$X$ & SIM \\
\hline & NÃO \\
\hline
\end{tabular}

9) Marque o seu grau de satisfação com relação ao curso oferecido pelo DATER: (Considere a seguinte pontuação: 1 - MUITO RUIM; 2 - RUIM; 3 - REGULAR; 4 - BOM; 5 - MUITO BOM)

\begin{tabular}{|l|l|l|l|l|}
\hline 1 & 2 & 3 & 4 & 5 \\
\hline
\end{tabular}

10) Marque seu grau de satisfação com relação ao DATER: (Considere a seguinte pontuação: 1 - MUITO RUIM; 2 - RUIM; 3 - REGULAR; 4 - BOM; 5 - MUITO BOM)

\begin{tabular}{|l|l|l|l|l|}
\hline 1 & 2 & 3 & 4 & 5 \\
\hline
\end{tabular}




\section{PESQUISA - IMPACTO DAS AÇÕES DE FORMAÇÃO REALIZADAS PELO DATER/SAF/MDA NO PERÍODO 2004-2009}

Caros colaboradores,

Contamos com a sua atenção para preencher o formulário abaixo.

O mesmo tem por objetivo fornecer informações para avaliação da Eficiência, Efetividade e Eficácia da Política Pública de Formação de Agentes de Ater adotada pelo Departamento de Assistência Técnica e Extensão Rural, da Secretaria de Agricultura Familiar do Ministério do Desenvolvimento - DATER/SAF/MDA, no período de 2004 a 2009, tema escolhido para Monografia a ser apresentada à Universidade de Brasília (UnB) como requisito parcial para obtenção do grau de Bacharel em Administração.

Você poderá ou não se identificar no questionário e garantimos que todas as informações fornecidas serão confidenciais e utilizadas apenas de forma sistematizada.

IDENTIFICAÇÃO

\begin{tabular}{|c|c|}
\hline $\begin{array}{l}\text { Nome: CARLOS ALBERTO SOARES } \\
\text { MAGALHÃES }\end{array}$ & $\begin{array}{l}\text { Sexo: } \\
(\mathbf{x x}) \text { masculino }\end{array}$ \\
\hline $\begin{array}{l}\text { Instituição (nome e tipo de instituição: ONG, } \\
\text { Empresa Pública, etc.): } \\
\text { Instituto de Desenvolvimento Agropecuário do } \\
\text { Estado do Amazonas - IDAM }\end{array}$ & $\begin{array}{l}\text { Local de trabalho (Cidade e Estado): } \\
\text { Manaus - Amazonas }\end{array}$ \\
\hline $\begin{array}{l}\text { Curso/Encontro/Oficina do qual participou (casc } \\
\text { preencha um formulário para cada um deles): } \\
\text { Seminário - Agroecologia como Estratégia para } \\
\text { Sustentável }\end{array}$ & $\begin{array}{l}\text { o tenha participado de mais de um curso, } \\
\text { a Construção do Desenvolvimento Rural }\end{array}$ \\
\hline $\begin{array}{l}\text { Data do Curso/Encontro/Oficina (pelo menos mês } \\
10 \text { e } 11 \text { de agosto de } 2006 \text { - Manaus/AM }\end{array}$ & \\
\hline
\end{tabular}

Indique sua área de atuação? As opções não são excludentes: você poderá marcar mais de uma opção)

\begin{tabular}{|l|l}
\hline$X$ & EXTENSÃO RURAL \\
\hline
\end{tabular} 


\begin{tabular}{|l|l|}
\hline & PESQUISA \\
\hline & ENSINO \\
\hline & OUTROS \\
\hline
\end{tabular}

2) Qual o seu nível de escolaridade? (Considere apenas o nível mais alto)

\begin{tabular}{|l|l|}
\hline & NÍVEL MÉDIO \\
\hline$X$ & NÍVEL SUPERIOR \\
\hline & PÓS-GRADUAÇÃO \\
\hline
\end{tabular}

3) Os conteúdos abordados foram condizentes com as demandas do seu dia-a-dia?

\begin{tabular}{|l|l|}
\hline$X$ & SIM \\
\hline & PARCIALMENTE \\
\hline & NÃO \\
\hline
\end{tabular}

3) O curso contribuiu para o seu aperfeiçoamento profissional?

\begin{tabular}{|l|l|}
\hline$X$ & SIM \\
\hline & NÃO \\
\hline
\end{tabular}

5) Os conhecimentos adquiridos estão sendo aplicados no seu trabalho? Em caso afirmativo, indique em que grau estes conhecimentos estão sendo aplicados. Em caso negativo, indique por que razão isto não ocorre: (Em caso negativo, as respostas não são excludentes: você poderá marcar mais de uma opção).

\begin{tabular}{|l|l|l|l|}
\hline $\begin{array}{l}\text { SIM (indique ao lado } \\
\text { em que grau) }\end{array}$ & MUITO APLICADOS \\
\cline { 2 - 3 } & & MEDIAMENTE APLICADOS \\
\hline
\end{tabular}




\begin{tabular}{|c|c|c|}
\hline & $\bar{x}$ & POUCO APLICADOS \\
\hline \multirow{5}{*}{$\begin{array}{l}\text { NÃO (indique ao lado a } \\
\text { razão da não aplicação) }\end{array}$} & & $\begin{array}{l}\text { CONTEÚDO NÃO ADEQUADO ÀS NECESSIDADES } \\
\text { ESPECÍFICAS DA REGIÃO }\end{array}$ \\
\hline & & $\begin{array}{l}\text { CONTEUUDO NĀO } \quad \text { FOI } \text { SUFICIENTEMENTE } \\
\text { APROFUNDADO PARA PERMITIR UMA APLICAÇÃO } \\
\text { EFICAZ E EFICIENTE }\end{array}$ \\
\hline & & 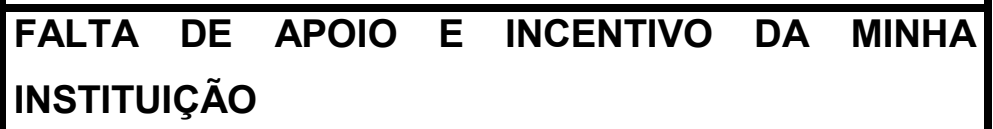 \\
\hline & & FALTA DE INCENTIVO ÀS AÇÕES DE ATER \\
\hline & & NÃO TENHO INTERESSE EM APLICAR \\
\hline
\end{tabular}

6) A partir deste curso: (As opções não são excludentes: você poderá marcar mais de uma opção)

\begin{tabular}{|l|l|}
\hline & NÃO MUDOU NADA EM MEU TRABALHO. \\
\hline$X$ & $\begin{array}{l}\text { MEU TRABALHO PASSOU A CONTRIBUIR MAIS COM OS AGRICULTORES(AS) } \\
\text { FAMILIARES. }\end{array}$ \\
\hline & CONSEGUI INFLUENCIAR NAS ORIENTAÇÕES DA MINHA INSTITUIÇÃO. \\
\hline & $\begin{array}{l}\text { PASSEI A TRABALHAR COM METODOLOGIAS PARTICIPATIVAS. } \\
\text { ONDE ATUO. }\end{array}$ \\
\hline & CONTINUEI ME APERFEIÇOANDO SOBRE TEMAS ABORDADOS. \\
\hline
\end{tabular}

7) Depois do curso você apoiou atividades de capacitação de técnicos e agricultores com base nos princípios e diretrizes da Pnater? (Considere como apoio a atividades de capacitação a participação no planejamento, elaboração de ementas, seleção de participantes e de palestrantes.)

\begin{tabular}{|l|l|}
\hline$x$ & $\operatorname{SIM}$ \\
\hline
\end{tabular}




\section{NÃO}

8) Usou os conhecimentos para ministrar outros cursos com o mesmo conteúdo ou conteúdos semelhantes?

\begin{tabular}{|l|l|}
\hline & SIM \\
\hline$X$ & NÃO \\
\hline
\end{tabular}

9) Marque o seu grau de satisfação com relação ao curso oferecido pelo DATER: (Considere a seguinte pontuação: 1 - MUITO RUIM; 2 - RUIM; 3 - REGULAR; 4 - BOM; 5 - MUITO BOM)

\begin{tabular}{|l|l|l|l|l|}
\hline 1 & 2 & 3 & 4 & 5 \\
\hline
\end{tabular}

10) Marque seu grau de satisfação com relação ao DATER: (Considere a seguinte pontuação: 1 - MUITO RUIM; 2 - RUIM; 3 - REGULAR; 4 - BOM; 5 - MUITO BOM)

\begin{tabular}{|l|l|l|l|l|}
\hline 1 & 2 & 3 & 4 & 5 \\
\hline
\end{tabular}




\section{PESQUISA - IMPACTO DAS AÇÕES DE FORMAÇÃO REALIZADAS PELO DATER/SAF/MDA NO PERÍODO 2004-2009}

Caros colaboradores,

Contamos com a sua atenção para preencher o formulário abaixo.

O mesmo tem por objetivo fornecer informações para avaliação da Eficiência, Efetividade e Eficácia da Política Pública de Formação de Agentes de Ater adotada pelo Departamento de Assistência Técnica e Extensão Rural, da Secretaria de Agricultura Familiar do Ministério do Desenvolvimento - DATER/SAF/MDA, no período de 2004 a 2009, tema escolhido para Monografia a ser apresentada à Universidade de Brasília (UnB) como requisito parcial para obtenção do grau de Bacharel em Administração.

Você poderá ou não se identificar no questionário e garantimos que todas as informações fornecidas serão confidenciais e utilizadas apenas de forma sistematizada.

IDENTIFICAÇÃO

\begin{tabular}{|c|c|}
\hline Nome: ÄNGELA SANDRA PINTO DE SOUZA & $\begin{array}{l}\text { Sexo: } \\
(\quad) \text { masculino }\end{array}$ \\
\hline $\begin{array}{l}\text { Instituição (nome e tipo de instituição: ONG, } \\
\text { Empresa Pública, etc.): } \\
\text { Instituto de Desenvolvimento Agropecuário do } \\
\text { Estado do Amazonas - IDAM }\end{array}$ & $\begin{array}{l}\text { Local de trabalho (Cidade e Estado): } \\
\text { Manaus - AM }\end{array}$ \\
\hline \multicolumn{2}{|c|}{$\begin{array}{l}\text { Curso/Encontro/Oficina do qual participou (caso tenha participado de mais de um curso, } \\
\text { preencha um formulário para cada um deles): } \\
\text { CURSO - ATER e Plantas Medicinais, Condimentares e Aromáticas. }\end{array}$} \\
\hline \multicolumn{2}{|c|}{$\begin{array}{l}\text { Data do Curso/Encontro/Oficina (pelo menos mês e ano): } \\
09 \text { a } 13 \text { de maio de } 2006 \text { - Manaus/AM }\end{array}$} \\
\hline
\end{tabular}

Indique sua área de atuação? (As opções não são excludentes: você poderá marcar mais de uma opção)

\begin{tabular}{|l|l|}
\hline$X$ & EXTENSÃO RURAL \\
\hline & PESQUISA \\
\hline & ENSINO \\
\hline
\end{tabular}




\section{OUTROS}

2) Qual o seu nível de escolaridade? (Considere apenas o nível mais alto)

\begin{tabular}{|l|l|}
\hline$X$ & NÍVEL MÉDIO \\
\hline & NÍVEL SUPERIOR \\
\hline & PÓS-GRADUAÇÃO \\
\hline
\end{tabular}

3) Os conteúdos abordados foram condizentes com as demandas do seu dia-a-dia?

\begin{tabular}{|l|l|}
\hline & SIM \\
\hline$X$ & PARCIALMENTE \\
\hline & NÃO \\
\hline
\end{tabular}

3) O curso contribuiu para o seu aperfeiçoamento profissional?

\begin{tabular}{|l|l|}
\hline$X$ & SIM \\
\hline & NÃO \\
\hline
\end{tabular}

5) Os conhecimentos adquiridos estão sendo aplicados no seu trabalho? Em caso afirmativo, indique em que grau estes conhecimentos estão sendo aplicados. Em caso negativo, indique por que razão isto não ocorre: (Em caso negativo, as respostas não são excludentes: você poderá marcar mais de uma opção).

\begin{tabular}{|c|c|c|}
\hline \multirow{3}{*}{$\begin{array}{l}\text { SIM (indique ao lado } \\
\text { em que grau) }\end{array}$} & $x$ & MUITO APLICADOS \\
\hline & & MEDIAMENTE APLICADOS \\
\hline & & POUCO APLICADOS \\
\hline $\begin{array}{l}\text { NĀO (indique ao lado a } \\
\text { razão da não aplicação) }\end{array}$ & & $\begin{array}{l}\text { CONTEÚDO NĀO ADEQUADO ÀS NECESSIDADES } \\
\text { ESPECÍFICAS DA REGIÃO }\end{array}$ \\
\hline
\end{tabular}




\begin{tabular}{|l|l|l|}
\hline \multirow{3}{*}{} & & $\begin{array}{l}\text { CONTEÚDO NĀO FOI SUFICIENTEMENTE } \\
\text { APROFUNDADO PARA PERMITIR UMA APLICAÇÃo } \\
\text { EFICAZ E EFICIENTE }\end{array}$ \\
\hline & $\begin{array}{l}\text { FALTA DE APOIO E INCENTIVO DA MINHA } \\
\text { INSTITUIÇÃO }\end{array}$ \\
\hline & FALTA DE INCENTIVO ÀS AÇÕES DE ATER \\
\hline & NÃO TENHO INTERESSE EM APLICAR \\
\hline
\end{tabular}


6) A partir deste curso: (As opções não são excludentes: você poderá marcar mais de uma opção)

\begin{tabular}{|l|l|}
\hline & NÃO MUDOU NADA EM MEU TRABALHO. \\
\hline$X$ & $\begin{array}{l}\text { MEU TRABALHO PASSOU A CONTRIBUIR MAIS COM OS AGRICULTORES(AS) } \\
\text { FAMILIARES. }\end{array}$ \\
\hline$X$ & CONSEGUI INFLUENCIAR NAS ORIENTAÇÕES DA MINHA INSTITUIÇÃO. \\
\hline$X$ & PASSEI A TRABALHAR COM METODOLOGIAS PARTICIPATIVAS. \\
\hline$X$ & $\begin{array}{l}\text { CRESCEU A ÁREA DE AGRICULTURA DE BASE ECOLÓGICA NAS COMUNIDADES } \\
\text { ONDE ATUO. }\end{array}$ \\
\hline$X$ & CONTINUEI ME APERFEIÇOANDO SOBRE TEMAS ABORDADOS. \\
\hline
\end{tabular}

7) Depois do curso você apoiou atividades de capacitação de técnicos e agricultores com base nos princípios e diretrizes da Pnater? (Considere como apoio a atividades de capacitação a participação no planejamento, elaboração de ementas, seleção de participantes e de palestrantes.)

\begin{tabular}{|l|l|}
\hline$X$ & SIM \\
\hline & NÃO \\
\hline
\end{tabular}

8) Usou os conhecimentos para ministrar outros cursos com o mesmo conteúdo ou conteúdos semelhantes?

\begin{tabular}{|l|l|}
\hline$X$ & SIM \\
\hline & NÃO \\
\hline
\end{tabular}

9) Marque o seu grau de satisfação com relação ao curso oferecido pelo DATER: (Considere a seguinte pontuação: 1 - MUITO RUIM; 2 - RUIM; 3 - REGULAR; 4 - BOM; 5 - MUITO BOM) 


\begin{tabular}{|l|l|l|l|l|}
\hline 1 & 2 & 3 & 4 & 5 \\
\hline
\end{tabular}

10) Marque seu grau de satisfação com relação ao DATER: (Considere a seguinte pontuação: 1 - MUITO RUIM; 2 - RUIM; 3 - REGULAR; 4 - BOM; 5 - MUITO BOM)

\begin{tabular}{|l|l|l|l|l|}
\hline 1 & 2 & 3 & 4 & 5 \\
\hline
\end{tabular}

Obs: As notas atribuídas as questões 9 e 10 devem obedecer a ordem crescente: 1 - muito ruim , 2 - ruim, 3 - regular, 4 - bom, 


\section{PESQUISA - IMPACTO DAS AÇÕES DE FORMAÇÃO REALIZADAS PELO DATER/SAF/MDA NO PERÍODO 2004-2009}

Caros colaboradores,

Contamos com a sua atenção para preencher o formulário abaixo.

O mesmo tem por objetivo fornecer informações para avaliação da Eficiência, Efetividade e Eficácia da Política Pública de Formação de Agentes de Ater adotada pelo Departamento de Assistência Técnica e Extensão Rural, da Secretaria de Agricultura Familiar do Ministério do Desenvolvimento - DATER/SAF/MDA, no período de 2004 a 2009, tema escolhido para Monografia a ser apresentada à Universidade de Brasília (UnB) como requisito parcial para obtenção do grau de Bacharel em Administração.

Você poderá ou não se identificar no questionário e garantimos que todas as informações fornecidas serão confidenciais e utilizadas apenas de forma sistematizada.

IDENTIFICAÇÃO

\begin{tabular}{|c|c|}
\hline Nome: ADRIANO JORGE PIRES DE OLIVEIRA & $\begin{array}{l}\text { Sexo: } \\
(\quad x x) \text { masculino }\end{array}$ \\
\hline $\begin{array}{l}\text { Instituição (nome e tipo de instituição: ONG, } \\
\text { Empresa Pública, etc.): } \\
\text { Instituto de Desenvolvimento Agropecuário do } \\
\text { Estado do Amazonas - IDAM }\end{array}$ & $\begin{array}{l}\text { Local de trabalho (Cidade e Estado): } \\
\text { Unidade Local de Iranduba - Amazonas }\end{array}$ \\
\hline \multicolumn{2}{|c|}{$\begin{array}{l}\text { Curso/Encontro/Oficina do qual participou (caso tenha participado de mais de um curso, } \\
\text { preencha um formulário para cada um deles): } \\
\text { Curso de Agroecologia }\end{array}$} \\
\hline $\begin{array}{l}\text { Data do Curso/Encontro/Oficina (pelo menos mês } \\
24 \text { a } 28 \text { de abril de } 2006 \text { - Manaus/AM }\end{array}$ & e ano): \\
\hline
\end{tabular}

Indique sua área de atuação? (As opções não são excludentes: você poderá marcar mais de uma opção)

\begin{tabular}{|l|l|}
\hline$X$ & EXTENSÃO RURAL \\
\hline & PESQUISA \\
\hline
\end{tabular}




\begin{tabular}{|l|l|}
\hline & ENSINO \\
\hline & OUTROS \\
\hline
\end{tabular}

2) Qual o seu nível de escolaridade? (Considere apenas o nível mais alto)

\begin{tabular}{|l|l|}
\hline$X$ & NÍVEL MÉDIO \\
\hline & NÍVEL SUPERIOR \\
\hline & PÓS-GRADUAÇÃO \\
\hline
\end{tabular}

3) Os conteúdos abordados foram condizentes com as demandas do seu dia-a-dia?

\begin{tabular}{|l|l|}
\hline$X$ & SIM \\
\hline & PARCIALMENTE \\
\hline & NÃO \\
\hline
\end{tabular}

3) O curso contribuiu para o seu aperfeiçoamento profissional?

\begin{tabular}{|l|l|}
\hline$X$ & SIM \\
\hline & NÃO \\
\hline
\end{tabular}

5) Os conhecimentos adquiridos estão sendo aplicados no seu trabalho? Em caso afirmativo, indique em que grau estes conhecimentos estão sendo aplicados. Em caso negativo, indique por que razão isto não ocorre: (Em caso negativo, as respostas não são excludentes: você poderá marcar mais de uma opção).

\begin{tabular}{|c|c|c|}
\hline \multirow{3}{*}{$\begin{array}{l}\text { SIM (indique ao lado } \\
\text { em que grau) }\end{array}$} & $\mathrm{x}$ & MUITO APLICADOS \\
\hline & & MEDIAMENTE APLICADOS \\
\hline & & POUCO APLICADOS \\
\hline
\end{tabular}




\begin{tabular}{|c|c|}
\hline \multirow{5}{*}{$\begin{array}{l}\text { NÃO (indique ao lado a } \\
\text { razão da não aplicação) }\end{array}$} & $\begin{array}{l}\text { CONTEÚDO NĀO ADEQUADO ȦS NECESSIDADES } \\
\text { ESPECÍFICAS DA REGIÃO }\end{array}$ \\
\hline & $\begin{array}{l}\text { CONTEÚDO NÃO FOI SUFICIENTEMENTE } \\
\text { APROFUNDADO PARA PERMITIR UMA APLICAÇÃO } \\
\text { EFICAZ E EFICIENTE }\end{array}$ \\
\hline & \begin{tabular}{|llllll} 
FALTA DE & APOIO & E & INCENTIVO & DA & MINHA \\
INSTITUIÇÃO & & & & &
\end{tabular} \\
\hline & FALTA DE INCENTIVO ÀS AÇÕES DE ATER \\
\hline & NÃO TENHO INTERESSE EM APLICAR \\
\hline
\end{tabular}

6) A partir deste curso: (As opções não são excludentes: você poderá marcar mais de uma opção)

\begin{tabular}{|l|l|}
\hline$x$ & $\begin{array}{l}\text { NÃO MUDOU NADA EM MEU TRABALHO. } \\
\text { FAMILIARES. }\end{array}$ \\
\hline & CONSEGUI INFLUENCIAR NAS ORIENTAÇÕES DA MINHA INSTITUIÇÃO. \\
\hline & PASSEI A TRABALHAR COM METODOLOGIAS PARTICIPATIVAS. \\
\hline & $\begin{array}{l}\text { CRESCEU A ÁREA DE AGRICULTURA DE BASE ECOLÓGICA NAS COMUNIDADES } \\
\text { ONDE ATUO. }\end{array}$ \\
\hline & CONTINUEI ME APERFEIÇOANDO SOBRE TEMAS ABORDADOS. \\
\hline
\end{tabular}

7) Depois do curso você apoiou atividades de capacitação de técnicos e agricultores com base nos princípios e diretrizes da Pnater? (Considere como apoio a atividades de capacitação a participação no planejamento, elaboração de ementas, seleção de participantes e de palestrantes.)

\begin{tabular}{|l|l|}
\hline & SIM \\
\hline$X$ & NÃO \\
\hline
\end{tabular}


8) Usou os conhecimentos para ministrar outros cursos com o mesmo conteúdo ou conteúdos semelhantes?

\begin{tabular}{|l|l|}
\hline & SIM \\
\hline$X$ & NÃO \\
\hline
\end{tabular}

9) Marque o seu grau de satisfação com relação ao curso oferecido pelo DATER: (Considere a seguinte pontuação: 1 - MUITO RUIM; 2 - RUIM; 3 - REGULAR; 4 - BOM; 5 - MUITO BOM)

\begin{tabular}{|l|l|l|l|l|}
\hline 1 & 2 & 3 & 4 & 5 \\
\hline
\end{tabular}

10) Marque seu grau de satisfação com relação ao DATER: (Considere a seguinte pontuação: 1 - MUITO RUIM; 2 - RUIM; 3 - REGULAR; 4 - BOM; 5 - MUITO BOM)

\begin{tabular}{|l|l|l|l|l|}
\hline 1 & 2 & 3 & 4 & 5 \\
\hline
\end{tabular}


PESQUISA - IMPACTO DAS AÇÕES DE FORMAÇÃO REALIZADAS PELO DATER/SAF/MDA NO PERÍODO 2004-2009

Caros colaboradores,

Contamos com a sua atenção para preencher o formulário abaixo.

O mesmo tem por objetivo fornecer informações para avaliação da Eficiência, Efetividade e Eficácia da Política Pública de Formação de Agentes de Ater adotada pelo Departamento de Assistência Técnica e Extensão Rural, da Secretaria de Agricultura Familiar do Ministério do Desenvolvimento - DATER/SAF/MDA, no período de 2004 a 2009, tema escolhido para Monografia a ser apresentada à Universidade de Brasília (UnB) como requisito parcial para obtenção do grau de Bacharel em Administração.

Você poderá ou não se identificar no questionário e garantimos que todas as informações fornecidas serão confidenciais e utilizadas apenas de forma sistematizada.

IDENTIFICAÇÃO

\begin{tabular}{|c|c|}
\hline Nome: ADONAI PEREIRA DE OLIVEIRA & $\begin{array}{l}\text { Sexo: } \\
(\mathrm{xx}) \text { masculino }\end{array}$ \\
\hline $\begin{array}{l}\text { Instituição (nome e tipo de instituição: ONG, } \\
\text { Empresa Pública, etc.): } \\
\text { Instituto de Desenvolvimento Agropecuário do } \\
\text { Estado do Amazonas - IDAM }\end{array}$ & $\begin{array}{l}\text { Local de trabalho (Cidade e Estado): } \\
\text { Unidade Local de Alvarães - Amazonas }\end{array}$ \\
\hline \multicolumn{2}{|c|}{$\begin{array}{l}\text { Curso/Encontro/Oficina do qual participou (caso tenha participado de mais de um curso, preencha } \\
\text { um formulário para cada um deles): } \\
\text { II Encontro para Socialização dos Conceitos Básicos da Política Nacional de ATER }\end{array}$} \\
\hline $\begin{array}{l}\text { Data do Curso/Encontro/Oficina (pelo menos mês } \\
04 \text { a } 08 \text { de dezembro de } 2006 \text { - Manaus/AM }\end{array}$ & \\
\hline
\end{tabular}

Indique sua área de atuação? (As opções não são excludentes: você poderá marcar mais de uma opção)

\begin{tabular}{|l|l|}
\hline$X$ & EXTENSÃO RURAL \\
\hline & PESQUISA \\
\hline & ENSINO \\
\hline
\end{tabular}




\section{OUTROS}

2) Qual o seu nível de escolaridade? (Considere apenas o nível mais alto)

\begin{tabular}{|l|l|}
\hline$X$ & NÍVEL MÉDIO \\
\hline & NÍVEL SUPERIOR \\
\hline & PÓS-GRADUAÇÃO \\
\hline
\end{tabular}

3) Os conteúdos abordados foram condizentes com as demandas do seu dia-a-dia?

\begin{tabular}{|l|l|}
\hline$X$ & SIM \\
\hline & PARCIALMENTE \\
\hline & NÃO \\
\hline
\end{tabular}

3) O curso contribuiu para o seu aperfeiçoamento profissional?

\begin{tabular}{|l|l|}
\hline$X$ & SIM \\
\hline & NÃO \\
\hline
\end{tabular}

5) Os conhecimentos adquiridos estão sendo aplicados no seu trabalho? Em caso afirmativo, indique em que grau estes conhecimentos estão sendo aplicados. Em caso negativo, indique por que razão isto não ocorre: (Em caso negativo, as respostas não são excludentes: você poderá marcar mais de uma opção).

\begin{tabular}{|l|l|l|l|}
\hline \multirow{2}{*}{$\begin{array}{l}\text { SIM (indique ao lado em } \\
\text { que grau) }\end{array}$} & & MUITO APLICADOS \\
\cline { 2 - 3 } & $\begin{array}{l}\text { NÃO (indique ao lado a } \\
\text { razão da não aplicação) }\end{array}$ & & $\begin{array}{l}\text { MEDIAMENTE APLICADOS } \\
\text { EONTEĆCÍFICAS DA REGIÃO }\end{array}$ \\
\hline
\end{tabular}




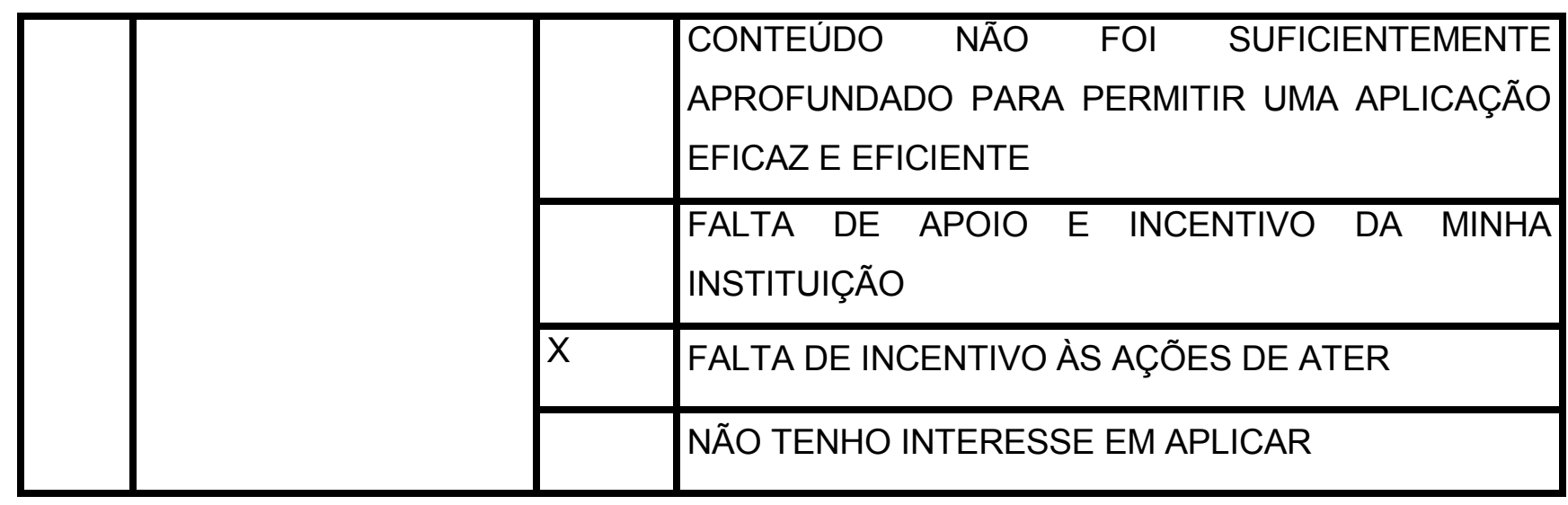

6) A partir deste curso: (As opções não são excludentes: você poderá marcar mais de uma opção)

\begin{tabular}{|l|l|}
\hline & NÃO MUDOU NADA EM MEU TRABALHO. \\
\hline & $\begin{array}{l}\text { MEU TRABALHO PASSOU A CONTRIBUIR MAIS COM OS AGRICULTORES(AS) } \\
\text { FAMILIARES. }\end{array}$ \\
\hline & CONSEGUI INFLUENCIAR NAS ORIENTAÇÕES DA MINHA INSTITUIÇÃO. \\
\hline & $\begin{array}{l}\text { CASSEI A TRABALHAR COM METODOLOGIAS PARTICIPATIVAS. } \\
\text { ONDE ATUO. }\end{array}$ \\
\hline$X$ & CONTINUEI ME APERFEIÇOANDO SOBRE TEMAS ABORDADOS. \\
\hline
\end{tabular}

7) Depois do curso você apoiou atividades de capacitação de técnicos e agricultores com base nos princípios e diretrizes da Pnater? (Considere como apoio a atividades de capacitação a participação no planejamento, elaboração de ementas, seleção de participantes e de palestrantes.)

\begin{tabular}{|l|l|}
\hline & SIM \\
\hline$X$ & NÃO \\
\hline
\end{tabular}

8) Usou os conhecimentos para ministrar outros cursos com o mesmo conteúdo ou conteúdos semelhantes? 


\begin{tabular}{|l|l|}
\hline & SIM \\
\hline$X$ & NÃO \\
\hline
\end{tabular}

9) Marque o seu grau de satisfação com relação ao curso oferecido pelo DATER: (Considere a seguinte pontuação: 1 - MUITO RUIM; 2 - RUIM; 3 - REGULAR; 4 - BOM; 5 - MUITO BOM)

\begin{tabular}{|l|l|l|l|l|}
\hline 1 & 2 & 3 & 4 & 5 \\
\hline
\end{tabular}

10) Marque seu grau de satisfação com relação ao DATER: (Considere a seguinte pontuação: 1 - MUITO RUIM; 2 - RUIM; 3 - REGULAR; 4 - BOM; 5 - MUITO BOM)

\begin{tabular}{|l|l|l|l|l|}
\hline 1 & 2 & 3 & 4 & 5 \\
\hline
\end{tabular}


PESQUISA - IMPACTO DAS AÇÕES DE FORMAÇÃO REALIZADAS PELO DATER/SAF/MDA NO PERÍODO 2004-2009

Caros colaboradores,

Contamos com a sua atenção para preencher o formulário abaixo.

O mesmo tem por objetivo fornecer informações para avaliação da Eficiência, Efetividade e Eficácia da Política Pública de Formação de Agentes de Ater adotada pelo Departamento de Assistência Técnica e Extensão Rural, da Secretaria de Agricultura Familiar do Ministério do Desenvolvimento - DATER/SAF/MDA, no período de 2004 a 2009, tema escolhido para Monografia a ser apresentada à Universidade de Brasília (UnB) como requisito parcial para obtenção do grau de Bacharel em Administração.

Você poderá ou não se identificar no questionário e garantimos que todas as informações fornecidas serão confidenciais e utilizadas apenas de forma sistematizada.

\section{IDENTIFICAÇÃO}

\begin{tabular}{|l|l|}
\hline Nome: $X X X X X X X X X X X X$ & $\begin{array}{l}\text { Sexo: } \\
(\mathrm{xx}) \text { masculino } \quad(\quad) \text { feminino }\end{array}$ \\
\hline $\begin{array}{l}\text { Instituição (nome e tipo de instituição: ONG, } \\
\text { Empresa Pública, etc.): EMATER - RO }\end{array}$ & $\begin{array}{l}\text { Local de trabalho (Cidade e Estado): } \\
\text { MIRANTE DA SERRA }\end{array}$ \\
\hline $\begin{array}{l}\text { Curso/Encontro/Oficina do qual participou (caso tenha participado de mais de um curso, preencha } \\
\text { um formulário para cada um deles): MANEJO DE PASTAGEM COM ÊNFASE NO CONTROLE } \\
\text { BIOLOGICO DA CIGARRINHA, MELHORIA DA QUALIDADE SO LEITE. }\end{array}$ \\
\hline Data do Curso/Encontro/Oficina (pelo menos mês e ano): 2006 \\
\hline
\end{tabular}

Indique sua área de atuação? (As opções não são excludentes: você poderá marcar mais de uma opção)

\begin{tabular}{|l|l|}
\hline$X$ & EXTENSÃO RURAL \\
\hline & PESQUISA \\
\hline & ENSINO \\
\hline & OUTROS \\
\hline
\end{tabular}


2) Qual o seu nível de escolaridade? (Considere apenas o nível mais alto)

\begin{tabular}{|l|l|}
\hline$X$ & NÍVEL MÉDIO \\
\hline & NÍVEL SUPERIOR \\
\hline & PÓS-GRADUAÇÃO \\
\hline
\end{tabular}

3) Os conteúdos abordados foram condizentes com as demandas do seu dia-a-dia?

\begin{tabular}{|l|l|}
\hline$X$ & SIM \\
\hline & PARCIALMENTE \\
\hline & NÃO \\
\hline
\end{tabular}

3) O curso contribuiu para o seu aperfeiçoamento profissional?

\begin{tabular}{|l|l|}
\hline$X$ & SIM \\
\hline & NÃO \\
\hline
\end{tabular}

5) Os conhecimentos adquiridos estão sendo aplicados no seu trabalho? Em caso afirmativo, indique em que grau estes conhecimentos estão sendo aplicados. Em caso negativo, indique por que razão isto não ocorre: (Em caso negativo, as respostas não são excludentes: você poderá marcar mais de uma opção).

\begin{tabular}{|l|l|l|l|}
\hline$x$ & $\begin{array}{l}\text { SIM (indique ao lado em } \\
\text { que grau) }\end{array}$ & MUITO APLICADOS \\
\cline { 2 - 4 } & & MEDIAMENTE APLICADOS \\
\hline & $\begin{array}{l}\text { NÃO (indique ao lado a } \\
\text { razão da não aplicação) }\end{array}$ & $\begin{array}{l}\text { CONTEÚDO NÃO ADEQUADO ȦS NECESSIDADES } \\
\text { ESPECÍFICAS DA REGIÃO }\end{array}$ \\
\hline
\end{tabular}




\begin{tabular}{|l|l|l|}
\hline \multirow{10}{*}{} & $\begin{array}{l}\text { CONTEÚDO NÃO FOI SUFICIENTEMENTE } \\
\text { APROFUNDADO PARA PERMITIR UMA APLICAÇÃO } \\
\text { EFICAZ E EFICIENTE }\end{array}$ \\
\cline { 2 - 4 } & $\begin{array}{l}\text { FALTA DE APOIO E INCENTIVO DA MINHA } \\
\text { INSTITUIÇÃO }\end{array}$ \\
\cline { 2 - 4 } & FALTA DE INCENTIVO ÀS AÇÕES DE ATER \\
\hline & NÃO TENHO INTERESSE EM APLICAR \\
\hline
\end{tabular}

6) A partir deste curso: (As opções não são excludentes: você poderá marcar mais de uma opção)

\begin{tabular}{|l|l|}
\hline & NÃO MUDOU NADA EM MEU TRABALHO. \\
\hline$x$ & $\begin{array}{l}\text { MEU TRABALHO PASSOU A CONTRIBUIR MAIS COM OS AGRICULTORES(AS) } \\
\text { FAMILIARES. }\end{array}$ \\
\hline$x$ & CONSEGUI INFLUENCIAR NAS ORIENTAÇÕES DA MINHA INSTITUIÇÃO. \\
\hline$x$ & PASSEI A TRABALHAR COM METODOLOGIAS PARTICIPATIVAS. \\
\hline & \begin{tabular}{l} 
ORESCEU A ÁREA DE AGRICULTURA DE BASE ECOLÓGICA NAS COMUNIDADES \\
\hline$x$
\end{tabular} \\
\hline
\end{tabular}

7) Depois do curso você apoiou atividades de capacitação de técnicos e agricultores com base nos princípios e diretrizes da Pnater? (Considere como apoio a atividades de capacitação a participação no planejamento, elaboração de ementas, seleção de participantes e de palestrantes.)

\begin{tabular}{|l|l|}
\hline$x$ & SIM \\
\hline & NÃO \\
\hline
\end{tabular}


8) Usou os conhecimentos para ministrar outros cursos com o mesmo conteúdo ou conteúdos semelhantes?

\begin{tabular}{|l|l|}
\hline$x$ & SIM \\
\hline & NÃO \\
\hline
\end{tabular}

9) Marque o seu grau de satisfação com relação ao curso oferecido pelo DATER: (Considere a seguinte pontuação: 1 - MUITO RUIM; 2 - RUIM; 3 - REGULAR; 4 - BOM; 5 - MUITO BOM)

\begin{tabular}{|l|l|l|l|l|}
\hline 1 & 2 & 3 & 4 & 5 \\
\hline
\end{tabular}

10) Marque seu grau de satisfação com relação ao DATER: (Considere a seguinte pontuação: 1 - MUITO RUIM; 2 - RUIM; 3 - REGULAR; 4 - BOM; 5 - MUITO BOM)

\begin{tabular}{|l|l|l|l|l|}
\hline 1 & 2 & 3 & 4 & 5 \\
\hline
\end{tabular}


PESQUISA - IMPACTO DAS AÇÕES DE FORMAÇÃO REALIZADAS PELO DATER/SAF/MDA NO PERÍODO 2004-2009

Caros colaboradores,

Contamos com a sua atenção para preencher o formulário abaixo.

O mesmo tem por objetivo fornecer informações para avaliação da Eficiência, Efetividade e Eficácia da Política Pública de Formação de Agentes de Ater adotada pelo Departamento de Assistência Técnica e Extensão Rural, da Secretaria de Agricultura Familiar do Ministério do Desenvolvimento - DATER/SAF/MDA, no período de 2004 a 2009, tema escolhido para Monografia a ser apresentada à Universidade de Brasília (UnB) como requisito parcial para obtenção do grau de Bacharel em Administração.

Você poderá ou não se identificar no questionário e garantimos que todas as informações fornecidas serão confidenciais e utilizadas apenas de forma sistematizada.

\section{IDENTIFICAÇÃO}

\begin{tabular}{|c|c|}
\hline $\begin{array}{l}\text { Nome: } \\
\text { Fabrício Nunes de Freitas }\end{array}$ & $\begin{array}{l}\text { Sexo: } \\
(x x) \text { masculino }\end{array}$ \\
\hline $\begin{array}{l}\text { Instituição (nome e tipo de instituição: ONG, } \\
\text { Empresa Pública, etc.): } \\
\text { Fundação Estadual de Meio Ambiente, Ciência e } \\
\text { Tecnologia }\end{array}$ & $\begin{array}{l}\text { Local de trabalho (Cidade e Estado): } \\
\text { Boa Vista - RR }\end{array}$ \\
\hline \multicolumn{2}{|c|}{$\begin{array}{l}\text { Curso/Encontro/Oficina do qual participou (caso tenha participado de mais de um curso, preencha } \\
\text { um formulário para cada um deles): } \\
\text { Agentes de ates com extrativistas }\end{array}$} \\
\hline $\begin{array}{l}\text { Data do Curso/Encontro/Oficina (pelo menos mês e } \\
\text { Fevereiro de } 2005 \text { em Belém - PA }\end{array}$ & \\
\hline
\end{tabular}

Indique sua área de atuação? (As opções não são excludentes: você poderá marcar mais de uma opção)

\begin{tabular}{|l|l|}
\hline & EXTENSÃO RURAL \\
\hline & PESQUISA \\
\hline
\end{tabular}




\begin{tabular}{|l|l|}
\hline & ENSINO \\
\hline$x$ & OUTROS \\
\hline
\end{tabular}

2) Qual o seu nível de escolaridade? (Considere apenas o nível mais alto)

\begin{tabular}{|l|l|}
\hline & NÍVEL MÉDIO \\
\hline & NÍVEL SUPERIOR \\
\hline$x$ & PÓS-GRADUAÇÃO \\
\hline
\end{tabular}

3) Os conteúdos abordados foram condizentes com as demandas do seu dia-a-dia?

\begin{tabular}{|l|l|}
\hline & SIM \\
\hline$X$ & PARCIALMENTE \\
\hline & NÃO \\
\hline
\end{tabular}

3) O curso contribuiu para o seu aperfeiçoamento profissional?

\begin{tabular}{|l|l|}
\hline$X$ & SIM \\
\hline & NÃO \\
\hline
\end{tabular}

5) Os conhecimentos adquiridos estão sendo aplicados no seu trabalho? Em caso afirmativo, indique em que grau estes conhecimentos estão sendo aplicados. Em caso negativo, indique por que razão isto não ocorre: (Em caso negativo, as respostas não são excludentes: você poderá marcar mais de uma opção).

\begin{tabular}{|l|l|l|}
\hline \multirow{2}{*}{$\begin{array}{l}\text { SIM (indique ao lado em } \\
\text { que grau) }\end{array}$} & X & MUITO APLICADOS \\
\cline { 2 - 3 } & & MEDIAMENTE APLICADOS \\
\cline { 2 - 3 } & & POUCO APLICADOS \\
\hline
\end{tabular}




\begin{tabular}{|c|c|}
\hline \multirow{5}{*}{$\begin{array}{l}\text { NÃO (indique ao lado a } \\
\text { razão da não aplicação) }\end{array}$} & $\begin{array}{l}\text { CONTEÚDO NÃO ADEQUADO ÀS NECESSIDADES } \\
\text { ESPECÍFICAS DA REGIÃO }\end{array}$ \\
\hline & $\begin{array}{l}\text { CONTEÚDO NÃO } \text { FOI SUFICIENTEMENTE } \\
\text { APROFUNDADO PARA } \\
\text { PERMITIR UMA APLICAÇÃO } \\
\text { EFICAZ E EFICIENTE }\end{array}$ \\
\hline & $\begin{array}{lllllll}\text { FALTA DE } & \text { APOIO } & \text { E } & \text { INCENTIVO } & \text { DA } & \text { MINHA } \\
\text { INSTITUIÇÃO } & & & & & \end{array}$ \\
\hline & FALTA DE INCENTIVO ÀS AÇÕES DE ATER \\
\hline & NÃO TENHO INTERESSE EM APLICAR \\
\hline
\end{tabular}

6) A partir deste curso: (As opções não são excludentes: você poderá marcar mais de uma opção)

\begin{tabular}{|l|l|}
\hline & NÃO MUDOU NADA EM MEU TRABALHO. \\
\hline & $\begin{array}{l}\text { MEU TRABALHO PASSOU A CONTRIBUIR MAIS COM OS AGRICULTORES(AS) } \\
\text { FAMILIARES. }\end{array}$ \\
\hline$X$ & CONSEGUI INFLUENCIAR NAS ORIENTAÇÕES DA MINHA INSTITUIÇÃO. \\
\hline & $\begin{array}{l}\text { PASSEI A TRABALHAR COM METODOLOGIAS PARTICIPATIVAS. } \\
\text { ONDE ATUO. }\end{array}$ \\
\hline & CONTINUEI ME APERFEIÇOANDO SOBRE TEMAS ABORDADOS. \\
\hline
\end{tabular}

7) Depois do curso você apoiou atividades de capacitação de técnicos e agricultores com base nos princípios e diretrizes da Pnater? (Considere como apoio a atividades de capacitação a participação no planejamento, elaboração de ementas, seleção de participantes e de palestrantes.)

\begin{tabular}{|l|l|}
\hline$X$ & SIM \\
\hline & NÃO \\
\hline
\end{tabular}


8) Usou os conhecimentos para ministrar outros cursos com o mesmo conteúdo ou conteúdos semelhantes?

\begin{tabular}{|l|l|}
\hline$X$ & SIM \\
\hline & NÃO \\
\hline
\end{tabular}

9) Marque o seu grau de satisfação com relação ao curso oferecido pelo DATER: (Considere a seguinte pontuação: 1 - MUITO RUIM; 2 - RUIM; 3 - REGULAR; 4 - BOM; 5 - MUITO BOM)

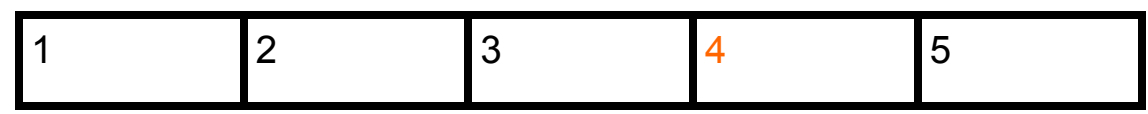

10) Marque seu grau de satisfação com relação ao DATER: (Considere a seguinte pontuação: 1 - MUITO RUIM; 2 - RUIM; 3 - REGULAR; 4 - BOM; 5 - MUITO BOM)

\begin{tabular}{|l|l|l|l|l|}
\hline 1 & 2 & 3 & 4 & 5 \\
\hline
\end{tabular}


DATER/SAF/MDA NO PERÍODO 2004-2009

Caros colaboradores,

Contamos com a sua atenção para preencher o formulário abaixo.

O mesmo tem por objetivo fornecer informações para avaliação da Eficiência, Efetividade e Eficácia da Política Pública de Formação de Agentes de Ater adotada pelo Departamento de Assistência Técnica e Extensão Rural, da Secretaria de Agricultura Familiar do Ministério do Desenvolvimento - DATER/SAF/MDA, no período de 2004 a 2009, tema escolhido para Monografia a ser apresentada à Universidade de Brasília (UnB) como requisito parcial para obtenção do grau de Bacharel em Administração.

Você poderá ou não se identificar no questionário e garantimos que todas as informações fornecidas serão confidenciais e utilizadas apenas de forma sistematizada.

IDENTIFICAÇÃO

\begin{tabular}{|c|c|}
\hline Nome: EZALDIR DE SOUZA & $\begin{array}{l}\text { Sexo: } \\
(\mathrm{x}) \text { masculino }\end{array}$ \\
\hline $\begin{array}{l}\text { Instituição (nome e tipo de instituição: ONG, } \\
\text { Empresa Pública, etc.): } \\
\text { Instituto de Desenvolvimento Agropecuário do } \\
\text { Estado do Amazonas - IDAM }\end{array}$ & $\begin{array}{l}\text { Local de trabalho (Cidade e Estado): } \\
\text { Unidade Local de Urucurituba - Amazonas }\end{array}$ \\
\hline \multicolumn{2}{|c|}{$\begin{array}{l}\text { Curso/Encontro/Oficina do qual participou (caso tenha participado de mais de um curso, preencha } \\
\text { um formulário para cada um deles): } \\
\text { Seminário - Agroecologia como Estratégia para a Construção do Desenvolvimento Rural } \\
\text { Sustentável }\end{array}$} \\
\hline $\begin{array}{l}\text { Data do Curso/Encontro/Oficina (pelo menos mês e a } \\
10 \text { e } 11 \text { de agosto de } 2006 \text { - Manaus/AM }\end{array}$ & \\
\hline
\end{tabular}

Indique sua área de atuação? (As opções não são excludentes: você poderá marcar mais de uma opção)

\begin{tabular}{|l|l|}
\hline$X$ & EXTENSÃO RURAL \\
\hline & PESQUISA \\
\hline & ENSINO \\
\hline
\end{tabular}




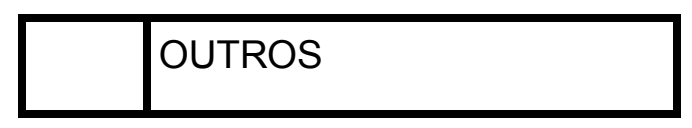

2) Qual o seu nível de escolaridade?

\begin{tabular}{|l|l|}
\hline$X$ & NÍVEL MÉDIO \\
\hline & NÍVEL SUPERIOR \\
\hline & PÓS-GRADUAÇÃO \\
\hline
\end{tabular}

3) Os conteúdos abordados foram condizentes com as demandas do seu dia-a-dia?

\begin{tabular}{|l|l|}
\hline$X$ & SIM \\
\hline & PARCIALMENTE \\
\hline & NÃO \\
\hline
\end{tabular}

3) O curso contribuiu para o seu aperfeiçoamento profissional?

\begin{tabular}{|l|l|}
\hline$X$ & SIM \\
\hline & NÃO \\
\hline
\end{tabular}

5) Os conhecimentos adquiridos estão sendo aplicados no seu trabalho? Em caso afirmativo, indique em que grau estes conhecimentos estão sendo aplicados. Em caso negativo, indique por que razão isto não ocorre: (Em caso negativo, as respostas não são excludentes: você poderá marcar mais de uma opção).

\begin{tabular}{|l|l|l|l|}
\hline \multirow{2}{*}{$\begin{array}{l}\text { SIM (indique ao lado em } \\
\text { que grau) }\end{array}$} & & MUITO APLICADOS \\
\cline { 2 - 3 } & $\begin{array}{l}\text { NÃO (indique ao lado a } \\
\text { razão da não aplicação) }\end{array}$ & $\begin{array}{l}\text { MEDIAMENTE APLICADOS } \\
\text { ESPECÍFICAS DA REGIÃO }\end{array}$ \\
\hline
\end{tabular}




\begin{tabular}{|l|l|l|l|}
\hline \multirow{10}{*}{} & $X$ & $\begin{array}{l}\text { CONTEÚDO NÃO FOI SUFICIENTEMENTE } \\
\text { APROFUNDADO PARA PERMITIR UMA APLICAÇÃO } \\
\text { EFICAZ E EFICIENTE }\end{array}$ \\
\cline { 2 - 5 } & $\begin{array}{l}\text { FALTA DE APOIO E INCENTIVO DA MINHA } \\
\text { INSTITUIÇÃO }\end{array}$ \\
\cline { 2 - 4 } & FALTA DE INCENTIVO ÀS AÇÕES DE ATER \\
\hline & NÃO TENHO INTERESSE EM APLICAR \\
\hline
\end{tabular}

6) A partir deste curso: (As opções não são excludentes: você poderá marcar mais de uma opção)

\begin{tabular}{|l|l|}
\hline$x$ & $\begin{array}{l}\text { NÃO MUDOU NADA EM MEU TRABALHO. } \\
\text { FAMILIARES. }\end{array}$ \\
\hline & CONSEGUI INFLUENCIAR NAS ORIENTAÇÕES DA MINHA INSTITUIÇÃO. \\
\hline & PASSEI A TRABALHAR COM METODOLOGIAS PARTICIPATIVAS. \\
\hline & $\begin{array}{l}\text { CRESCEU A ÁREA DE AGRICULTURA DE BASE ECOLÓGICA NAS COMUNIDADES } \\
\text { ONDE ATUO. }\end{array}$ \\
\hline$X$ & CONTINUEI ME APERFEIÇOANDO SOBRE TEMAS ABORDADOS. \\
\hline
\end{tabular}

7) Depois do curso você apoiou atividades de capacitação de técnicos e agricultores com base nos princípios e diretrizes da Pnater? (Considere como apoio a atividades de capacitação a participação no planejamento, elaboração de ementas, seleção de participantes e de palestrantes.)

\begin{tabular}{|l|l|}
\hline$X$ & SIM \\
\hline & NÃO \\
\hline
\end{tabular}

8) Usou os conhecimentos para ministrar outros cursos com o mesmo conteúdo ou conteúdos semelhantes? 


\begin{tabular}{|l|l|}
\hline & SIM \\
\hline$X$ & NÃO \\
\hline
\end{tabular}

9) Marque o seu grau de satisfação com relação ao curso oferecido pelo DATER: (Considere a seguinte pontuação: 1 - MUITO RUIM; 2 - RUIM; 3 - REGULAR; 4 - BOM; 5 - MUITO BOM)

\begin{tabular}{|l|l|l|l|l|}
\hline 1 & 2 & 3 & 4 & 5 \\
\hline
\end{tabular}

10) Marque seu grau de satisfação com relação ao DATER: (Considere a seguinte pontuação: 1 - MUITO RUIM; 2 - RUIM; 3 - REGULAR; 4 - BOM; 5 - MUITO BOM)

\begin{tabular}{|l|l|l|l|l|}
\hline 1 & 2 & 3 & 4 & 5 \\
\hline
\end{tabular}


PESQUISA - IMPACTO DAS AÇÕES DE FORMAÇÃO REALIZADAS PELO DATER/SAF/MDA NO PERÍODO 2004-2009

Caros colaboradores,

Contamos com a sua atenção para preencher o formulário abaixo.

O mesmo tem por objetivo fornecer informações para avaliação da Eficiência, Efetividade e Eficácia da Política Pública de Formação de Agentes de Ater adotada pelo Departamento de Assistência Técnica e Extensão Rural, da Secretaria de Agricultura Familiar do Ministério do Desenvolvimento - DATER/SAF/MDA, no período de 2004 a 2009, tema escolhido para Monografia a ser apresentada à Universidade de Brasília (UnB) como requisito parcial para obtenção do grau de Bacharel em Administração.

Você poderá ou não se identificar no questionário e garantimos que todas as informações fornecidas serão confidenciais e utilizadas apenas de forma sistematizada.

IDENTIFICAÇÃO

\begin{tabular}{|c|c|}
\hline Nome: EDNA BERNARDO MAIA & $\begin{array}{l}\text { Sexo: } \\
(\quad) \text { masculino } \quad(x) \text { feminino }\end{array}$ \\
\hline $\begin{array}{l}\text { Instituição (nome e tipo de instituição: ONG, } \\
\text { Empresa Pública, etc.): } \\
\text { Instituto de Desenvolvimento Agropecuário do } \\
\text { Estado do Amazonas - IDAM }\end{array}$ & $\begin{array}{l}\text { Local de trabalho (Cidade e Estado): } \\
\text { Unidade Local de Manacapuru - Amazonas }\end{array}$ \\
\hline $\begin{array}{l}\text { Curso/Encontro/Oficina do qual participou (caso tenh } \\
\text { um formulário para cada um deles): } \\
\text { Seminário - Agroecologia como Estratégia para } \\
\text { Sustentável }\end{array}$ & $\begin{array}{l}\text { la participado de mais de um curso, preencha } \\
\text { a Construção do Desenvolvimento Rura }\end{array}$ \\
\hline $\begin{array}{l}\text { Data do Curso/Encontro/Oficina (pelo menos mês } \\
10 \text { e } 11 \text { de agosto de } 2006 \text { - Manaus/AM }\end{array}$ & \\
\hline
\end{tabular}

Indique sua área de atuação? (As opções não são excludentes: você poderá marcar mais de uma opção)

\begin{tabular}{|l|l|}
\hline$X$ & EXTENSÃO RURAL \\
\hline & PESQUISA \\
\hline
\end{tabular}




\begin{tabular}{|l|l|}
\hline & ENSINO \\
\hline & OUTROS \\
\hline
\end{tabular}

2) Qual o seu nível de escolaridade?

\begin{tabular}{|l|l|}
\hline$X$ & NÍVEL MÉDIO \\
\hline & NÍVEL SUPERIOR \\
\hline & PÓS-GRADUAÇÃO \\
\hline
\end{tabular}

3) Os conteúdos abordados foram condizentes com as demandas do seu dia-a-dia?

\begin{tabular}{|l|l|}
\hline & SIM \\
\hline$X$ & PARCIALMENTE \\
\hline & NÃO \\
\hline
\end{tabular}

3) O curso contribuiu para o seu aperfeiçoamento profissional?

\begin{tabular}{|l|l|}
\hline$X$ & SIM \\
\hline & NÃO \\
\hline
\end{tabular}

5) Os conhecimentos adquiridos estão sendo aplicados no seu trabalho? Em caso afirmativo, indique em que grau estes conhecimentos estão sendo aplicados. Em caso negativo, indique por que razão isto não ocorre: (Em caso negativo, as respostas não são excludentes: você poderá marcar mais de uma opção).

\begin{tabular}{|l|l|l|}
\hline \multirow{2}{*}{$\begin{array}{l}\text { SIM (indique ao lado em } \\
\text { que grau) }\end{array}$} & $X$ & MEITO APLICADOS \\
\cline { 2 - 4 } & & POUCO APLICADOS \\
\hline
\end{tabular}




\begin{tabular}{|c|c|}
\hline \multirow{5}{*}{$\begin{array}{l}\text { NÃO (indique ao lado a } \\
\text { razão da não aplicação) }\end{array}$} & $\begin{array}{l}\text { CONTEÚDO NÃO ADEQUADO ÀS NECESSIDADES } \\
\text { ESPECÍFICAS DA REGIÃO }\end{array}$ \\
\hline & $\begin{array}{l}\text { CONTEÚDO NÃO } \text { FOI SUFICIENTEMENTE } \\
\text { APROFUNDADO PARA } \\
\text { EERMITIR UMA APLICAÇÃO } \\
\text { EFICAZ E EFICIENTE }\end{array}$ \\
\hline & $\begin{array}{llllll}\text { FALTA DE } & \text { APOIO } & \text { E } & \text { INCENTIVO } & \text { DA } & \text { MINHA } \\
\text { INSTITUIÇÃO } & & & & & \\
\end{array}$ \\
\hline & FALTA DE INCENTIVO ÀS AÇÕES DE ATER \\
\hline & NÃO TENHO INTERESSE EM APLICAR \\
\hline
\end{tabular}

6) A partir deste curso: (As opções não são excludentes: você poderá marcar mais de uma opção)

\begin{tabular}{|l|l|}
\hline$x$ & $\begin{array}{l}\text { NÃO MUDOU NADA EM MEU TRABALHO. } \\
\text { FAMILIARES. }\end{array}$ \\
\hline & CONSEGUI INFLUENCIAR NAS ORIENTAÇÕES DA MINHA INSTITUIÇÃO. \\
\hline & PASSEI A TRABALHAR COM METODOLOGIAS PARTICIPATIVAS. \\
\hline & $\begin{array}{l}\text { CRESCEU A ÁREA DE AGRICULTURA DE BASE ECOLÓGICA NAS COMUNIDADES } \\
\text { ONDE ATUO. }\end{array}$ \\
\hline$X$ & CONTINUEI ME APERFEIÇOANDO SOBRE TEMAS ABORDADOS. \\
\hline
\end{tabular}

7) Depois do curso você apoiou atividades de capacitação de técnicos e agricultores com base nos princípios e diretrizes da Pnater? (Considere como apoio a atividades de capacitação a participação no planejamento, elaboração de ementas, seleção de participantes e de palestrantes.)

\begin{tabular}{|l|l|}
\hline$X$ & SIM \\
\hline & NÃO \\
\hline
\end{tabular}


8) Usou os conhecimentos para ministrar outros cursos com o mesmo conteúdo ou conteúdos semelhantes?

\begin{tabular}{|l|l|}
\hline$X$ & SIM \\
\hline & NÃO \\
\hline
\end{tabular}

9) Marque o seu grau de satisfação com relação ao curso oferecido pelo DATER: (Considere a seguinte pontuação: 1 - MUITO RUIM; 2 - RUIM; 3 - REGULAR; 4 - BOM; 5 - MUITO BOM)

\begin{tabular}{|l|l|l|l|l|}
\hline 1 & 2 & 3 & 4 & 5 \\
\hline
\end{tabular}

10) Marque seu grau de satisfação com relação ao DATER: (Considere a seguinte pontuação: 1 - MUITO RUIM; 2 - RUIM; 3 - REGULAR; 4 - BOM; 5 - MUITO BOM)

\begin{tabular}{|l|l|l|l|l|}
\hline 1 & 2 & 3 & 4 & 5 \\
\hline
\end{tabular}


PESQUISA - IMPACTO DAS AÇÕES DE FORMAÇÃO REALIZADAS PELO DATER/SAF/MDA NO PERÍODO 2004-2009

Caros colaboradores,

Contamos com a sua atenção para preencher o formulário abaixo.

O mesmo tem por objetivo fornecer informações para avaliação da Eficiência, Efetividade e Eficácia da Política Pública de Formação de Agentes de Ater adotada pelo Departamento de Assistência Técnica e Extensão Rural, da Secretaria de Agricultura Familiar do Ministério do Desenvolvimento - DATER/SAF/MDA, no período de 2004 a 2009, tema escolhido para Monografia a ser apresentada à Universidade de Brasília (UnB) como requisito parcial para obtenção do grau de Bacharel em Administração.

Você poderá ou não se identificar no questionário e garantimos que todas as informações fornecidas serão confidenciais e utilizadas apenas de forma sistematizada.

\section{IDENTIFICAÇÃO}

\begin{tabular}{|c|c|}
\hline Nome: EDNA BERNARDO MAIA & $\begin{array}{l}\text { Sexo: } \\
(x) \text { masculino }(x) \text { feminino }\end{array}$ \\
\hline $\begin{array}{l}\text { Instituição (nome e tipo de instituição: ONG, } \\
\text { Empresa Pública, etc.): } \\
\text { Instituto de Desenvolvimento Agropecuário do } \\
\text { Estado do Amazonas - IDAM }\end{array}$ & $\begin{array}{l}\text { Local de trabalho (Cidade e Estado): } \\
\text { Unidade Local de Manacapuru - Amazonas }\end{array}$ \\
\hline \multicolumn{2}{|c|}{$\begin{array}{l}\text { Curso/Encontro/Oficina do qual participou (caso tenha participado de mais de um curso, preencha } \\
\text { um formulário para cada um deles): } \\
\text { Curso Diagnóstico Rural Participativo - DRP }\end{array}$} \\
\hline $\begin{array}{l}\text { Data do Curso/Encontro/Oficina (pelo menos mês e } \\
16 \text { a } 27 \text { de outubro de } 2006 \text { - Manaus/AM }\end{array}$ & \\
\hline
\end{tabular}

Indique sua área de atuação? (As opções não são excludentes: você poderá marcar mais de uma opção)

\begin{tabular}{|l|l|}
\hline$X$ & EXTENSÃO RURAL \\
\hline & PESQUISA \\
\hline
\end{tabular}




\begin{tabular}{|l|l|}
\hline & ENSINO \\
\hline & OUTROS \\
\hline
\end{tabular}

2) Qual o seu nível de escolaridade?

\begin{tabular}{|l|l|}
\hline$X$ & NÍVEL MÉDIO \\
\hline & NÍVEL SUPERIOR \\
\hline & PÓS-GRADUAÇÃO \\
\hline
\end{tabular}

3) Os conteúdos abordados foram condizentes com as demandas do seu dia-a-dia?

\begin{tabular}{|l|l|}
\hline$X$ & SIM \\
\hline & PARCIALMENTE \\
\hline & NÃO \\
\hline
\end{tabular}

3) O curso contribuiu para o seu aperfeiçoamento profissional?

\begin{tabular}{|l|l|}
\hline$X$ & SIM \\
\hline & NÃO \\
\hline
\end{tabular}

5) Os conhecimentos adquiridos estão sendo aplicados no seu trabalho? Em caso afirmativo, indique em que grau estes conhecimentos estão sendo aplicados. Em caso negativo, indique por que razão isto não ocorre: (Em caso negativo, as respostas não são excludentes: você poderá marcar mais de uma opção).

\begin{tabular}{|l|l|l|}
\hline \multirow{2}{*}{$\begin{array}{l}\text { SIM (indique ao lado em } \\
\text { que grau) }\end{array}$} & $X$ & MEITO APLICADOS \\
\cline { 2 - 4 } & & POUCO APLICADOS \\
\hline
\end{tabular}




\begin{tabular}{|c|c|}
\hline \multirow{5}{*}{$\begin{array}{l}\text { NÃO (indique ao lado a } \\
\text { razão da não aplicação) }\end{array}$} & $\begin{array}{l}\text { CONTEÚDO NÃO ADEQUADO ÀS NECESSIDADES } \\
\text { ESPECÍFICAS DA REGIÃO }\end{array}$ \\
\hline & $\begin{array}{l}\text { CONTEÚDO NÃO } \text { FOI SUFICIENTEMENTE } \\
\text { APROFUNDADO PARA } \\
\text { PERMITIR UMA APLICAÇÃO } \\
\text { EFICAZ E EFICIENTE }\end{array}$ \\
\hline & $\begin{array}{lllllll}\text { FALTA DE } & \text { APOIO } & \text { E } & \text { INCENTIVO } & \text { DA } & \text { MINHA } \\
\text { INSTITUIÇÃO } & & & & & \end{array}$ \\
\hline & FALTA DE INCENTIVO ÀS AÇÕES DE ATER \\
\hline & NÃO TENHO INTERESSE EM APLICAR \\
\hline
\end{tabular}

6) A partir deste curso: (As opções não são excludentes: você poderá marcar mais de uma opção)

\begin{tabular}{|l|l|}
\hline & NÃO MUDOU NADA EM MEU TRABALHO. \\
\hline & $\begin{array}{l}\text { MEU TRABALHO PASSOU A CONTRIBUIR MAIS COM OS AGRICULTORES(AS) } \\
\text { FAMILIARES. }\end{array}$ \\
\hline$X$ & CONSEGUI INFLUENCIAR NAS ORIENTAÇÕES DA MINHA INSTITUIÇÃO. \\
\hline & $\begin{array}{l}\text { CASSEI A TRABALHAR COM METODOLOGIAS PARTICIPATIVAS. } \\
\text { ONDE ATUO. }\end{array}$ \\
\hline$X$ & CONTINUEI ME APERFEIÇOANDO SOBRE TEMAS ABORDADOS. \\
\hline
\end{tabular}

7) Depois do curso você apoiou atividades de capacitação de técnicos e agricultores com base nos princípios e diretrizes da Pnater? (Considere como apoio a atividades de capacitação a participação no planejamento, elaboração de ementas, seleção de participantes e de palestrantes.)

\begin{tabular}{|l|l|}
\hline & SIM \\
\hline$X$ & NÃO \\
\hline
\end{tabular}


8) Usou os conhecimentos para ministrar outros cursos com o mesmo conteúdo ou conteúdos semelhantes?

\begin{tabular}{|l|l|}
\hline & SIM \\
\hline$X$ & NÃO \\
\hline
\end{tabular}

9) Marque o seu grau de satisfação com relação ao curso oferecido pelo DATER: (Considere a seguinte pontuação: 1 - MUITO RUIM; 2 - RUIM; 3 - REGULAR; 4 - BOM; 5 - MUITO BOM)

\begin{tabular}{|l|l|l|l|l|}
\hline 1 & 2 & 3 & 4 & 5 \\
\hline
\end{tabular}

10) Marque seu grau de satisfação com relação ao DATER: (Considere a seguinte pontuação: 1 - MUITO RUIM; 2 - RUIM; 3 - REGULAR; 4 - BOM; 5 - MUITO BOM)

\begin{tabular}{|l|l|l|l|l|}
\hline 1 & 2 & 3 & 4 & 5 \\
\hline
\end{tabular}


PESQUISA - IMPACTO DAS AÇÕES DE FORMAÇÃO REALIZADAS PELO DATER/SAF/MDA NO PERÍODO 2004-2009

Caros colaboradores,

Contamos com a sua atenção para preencher o formulário abaixo.

O mesmo tem por objetivo fornecer informações para avaliação da Eficiência, Efetividade e Eficácia da Política Pública de Formação de Agentes de Ater adotada pelo Departamento de Assistência Técnica e Extensão Rural, da Secretaria de Agricultura Familiar do Ministério do Desenvolvimento - DATER/SAF/MDA, no período de 2004 a 2009, tema escolhido para Monografia a ser apresentada à Universidade de Brasília (UnB) como requisito parcial para obtenção do grau de Bacharel em Administração.

Você poderá ou não se identificar no questionário e garantimos que todas as informações fornecidas serão confidenciais e utilizadas apenas de forma sistematizada.

IDENTIFICAÇÃO

\begin{tabular}{|c|c|}
\hline Nome: DJANEIDE DA SILVA LISBOA & $\begin{array}{l}\text { Sexo: } \\
(\quad) \text { masculino }\end{array}$ \\
\hline $\begin{array}{l}\text { Instituição (nome e tipo de instituição: ONG, } \\
\text { Empresa Pública, etc.): } \\
\text { Instituto de Desenvolvimento Agropecuário do } \\
\text { Estado do Amazonas - IDAM }\end{array}$ & $\begin{array}{l}\text { Local de trabalho (Cidade e Estado): } \\
\text { Manaus - AM }\end{array}$ \\
\hline \multicolumn{2}{|c|}{$\begin{array}{l}\text { Curso/Encontro/Oficina do qual participou (caso tenha participado de mais de um curso, preencha } \\
\text { um formulário para cada um deles): } \\
\text { Diagnóstico Rural Participativo - DRP. }\end{array}$} \\
\hline $\begin{array}{l}\text { Data do Curso/Encontro/Oficina (pelo menos mês e a } \\
16 \text { a } 27 \text { outubro de } 2006 \text { - Manaus/AM }\end{array}$ & \\
\hline
\end{tabular}

Indique sua área de atuação? (As opções não são excludentes: você poderá marcar mais de uma opção)

\begin{tabular}{|l|l|}
\hline$X$ & EXTENSÃO RURAL \\
\hline & PESQUISA \\
\hline & ENSINO \\
\hline
\end{tabular}




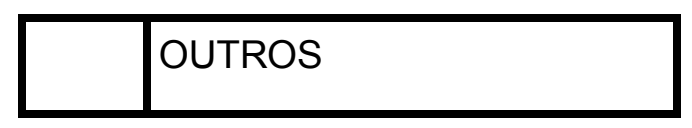

2) Qual o seu nível de escolaridade?

\begin{tabular}{|l|l|}
\hline$X$ & NÍVEL MÉDIO \\
\hline & NÍVEL SUPERIOR \\
\hline & PÓS-GRADUAÇÃO \\
\hline
\end{tabular}

3) Os conteúdos abordados foram condizentes com as demandas do seu dia-a-dia?

\begin{tabular}{|l|l|}
\hline$X$ & SIM \\
\hline & PARCIALMENTE \\
\hline & NÃO \\
\hline
\end{tabular}

3) O curso contribuiu para o seu aperfeiçoamento profissional?

\begin{tabular}{|l|l|}
\hline$X$ & SIM \\
\hline & NÃO \\
\hline
\end{tabular}

5) Os conhecimentos adquiridos estão sendo aplicados no seu trabalho? Em caso afirmativo, indique em que grau estes conhecimentos estão sendo aplicados. Em caso negativo, indique por que razão isto não ocorre: (Em caso negativo, as respostas não são excludentes: você poderá marcar mais de uma opção).

\begin{tabular}{|l|l|l|l|}
\hline X & $\begin{array}{l}\text { SIM (indique ao lado em } \\
\text { que grau) }\end{array}$ & & MUITO APLICADOS \\
\cline { 2 - 4 } & $\begin{array}{l}\text { NÃO (indique ao lado a } \\
\text { razão da não aplicação) }\end{array}$ & MEDIAMENTE APLICADOS \\
\hline
\end{tabular}




\begin{tabular}{|l|l|l|}
\hline \multirow{10}{*}{} & $\begin{array}{l}\text { CONTEÚDO NÃO FOI SUFICIENTEMENTE } \\
\text { APROFUNDADO PARA PERMITIR UMA APLICAÇÃO } \\
\text { EFICAZ E EFICIENTE }\end{array}$ \\
\cline { 2 - 4 } & $\begin{array}{l}\text { FALTA DE APOIO E INCENTIVO DA MINHA } \\
\text { INSTITUIÇÃO }\end{array}$ \\
\cline { 2 - 4 } & FALTA DE INCENTIVO ÀS AÇÕES DE ATER \\
\hline & NÃO TENHO INTERESSE EM APLICAR \\
\hline
\end{tabular}

6) A partir deste curso: (As opções não são excludentes: você poderá marcar mais de uma opção)

\begin{tabular}{|c|l|}
\hline & NÃO MUDOU NADA EM MEU TRABALHO. \\
\hline$x$ & $\begin{array}{l}\text { MEU TRABALHO PASSOU A CONTRIBUIR MAIS COM OS AGRICULTORES(AS) } \\
\text { FAMILIARES. }\end{array}$ \\
\hline$x$ & CONSEGUI INFLUENCIAR NAS ORIENTAÇÕES DA MINHA INSTITUIÇÃO. \\
\hline$x$ & PASSEI A TRABALHAR COM METODOLOGIAS PARTICIPATIVAS. \\
\hline$x$ & $\begin{array}{l}\text { CRESCEU A ÁREA DE AGRICULTURA DE BASE ECOLÓGICA NAS COMUNIDADES } \\
\text { ONDE ATUO. }\end{array}$ \\
\hline$x$ & CONTINUEI ME APERFEIÇOANDO SOBRE TEMAS ABORDADOS. \\
\hline
\end{tabular}

7) Depois do curso você apoiou atividades de capacitação de técnicos e agricultores com base nos princípios e diretrizes da Pnater? (Considere como apoio a atividades de capacitação a participação no planejamento, elaboração de ementas, seleção de participantes e de palestrantes.)

\begin{tabular}{|l|l|}
\hline$X$ & SIM \\
\hline & NÃO \\
\hline
\end{tabular}

8) Usou os conhecimentos para ministrar outros cursos com o mesmo conteúdo ou conteúdos semelhantes? 


\begin{tabular}{|l|l|}
\hline & SIM \\
\hline$X$ & NÃO \\
\hline
\end{tabular}

9) Marque o seu grau de satisfação com relação ao curso oferecido pelo DATER: (Considere a seguinte pontuação: 1 - MUITO RUIM; 2 - RUIM; 3 - REGULAR; 4 - BOM; 5 - MUITO BOM)

\begin{tabular}{|l|l|l|l|l|}
\hline 1 & 2 & 3 & 4 & 5 \\
\hline
\end{tabular}

10) Marque seu grau de satisfação com relação ao DATER: (Considere a seguinte pontuação: 1 - MUITO RUIM; 2 - RUIM; 3 - REGULAR; 4 - BOM; 5 - MUITO BOM)

\begin{tabular}{|l|l|l|l|l|}
\hline 1 & 2 & 3 & 4 & 5 \\
\hline
\end{tabular}


PESQUISA - IMPACTO DAS AÇÕES DE FORMAÇÃO REALIZADAS PELO DATER/SAF/MDA NO PERÍODO 2004-2009

Caros colaboradores,

Contamos com a sua atenção para preencher o formulário abaixo.

O mesmo tem por objetivo fornecer informações para avaliação da Eficiência, Efetividade e Eficácia da Política Pública de Formação de Agentes de Ater adotada pelo Departamento de Assistência Técnica e Extensão Rural, da Secretaria de Agricultura Familiar do Ministério do Desenvolvimento - DATER/SAF/MDA, no período de 2004 a 2009, tema escolhido para Monografia a ser apresentada à Universidade de Brasília (UnB) como requisito parcial para obtenção do grau de Bacharel em Administração.

Você poderá ou não se identificar no questionário e garantimos que todas as informações fornecidas serão confidenciais e utilizadas apenas de forma sistematizada.

\section{IDENTIFICAÇÃO}

\begin{tabular}{|c|c|}
\hline Nome: DJANEIDE DA SILVA LISBOA & $\begin{array}{l}\text { Sexo: } \\
(\quad) \text { masculino }\end{array}$ \\
\hline $\begin{array}{l}\text { Instituição (nome e tipo de instituição: ONG, } \\
\text { Empresa Pública, etc.): } \\
\text { Instituto de Desenvolvimento Agropecuário do } \\
\text { Estado do Amazonas - IDAM }\end{array}$ & $\begin{array}{l}\text { Local de trabalho (Cidade e Estado): } \\
\text { Manaus - AM. }\end{array}$ \\
\hline \multicolumn{2}{|c|}{$\begin{array}{l}\text { Curso/Encontro/Oficina do qual participou (caso tenha participado de mais de um curso, preencha } \\
\text { um formulário para cada um deles): } \\
\text { Curso de Agroecologia. }\end{array}$} \\
\hline $\begin{array}{l}\text { Data do Curso/Encontro/Oficina (pelo menos } r \\
24 \text { a 28/04/2006 - Manaus/AM }\end{array}$ & \\
\hline
\end{tabular}

Indique sua área de atuação? (As opções não são excludentes: você poderá marcar mais de uma opção)

\begin{tabular}{|l|l|}
\hline$X$ & EXTENSÃO RURAL \\
\hline & PESQUISA \\
\hline
\end{tabular}




\begin{tabular}{|l|l|}
\hline & ENSINO \\
\hline & OUTROS \\
\hline
\end{tabular}

2) Qual o seu nível de escolaridade?

\begin{tabular}{|l|l|}
\hline$X$ & NÍVEL MÉDIO \\
\hline & NÍVEL SUPERIOR \\
\hline & PÓS-GRADUAÇÃO \\
\hline
\end{tabular}

3) Os conteúdos abordados foram condizentes com as demandas do seu dia-a-dia?

\begin{tabular}{|l|l|}
\hline$X$ & SIM \\
\hline & PARCIALMENTE \\
\hline & NÃO \\
\hline
\end{tabular}

3) O curso contribuiu para o seu aperfeiçoamento profissional?

\begin{tabular}{|l|l|}
\hline$X$ & SIM \\
\hline & NÃO \\
\hline
\end{tabular}

Em caso afirmativo, indique em que grau estes conhecimentos estão sendo aplicados. Em caso negativo, indique por que razão isto não ocorre: (Em caso negativo, as respostas não são excludentes: você poderá marcar mais de uma opção).

\begin{tabular}{|l|l|l|l|}
\hline \multirow{2}{*}{$\begin{array}{l}\text { SIM (indique ao lado em } \\
\text { que grau) }\end{array}$} & $X$ & MUITO APLICADOS \\
\cline { 2 - 4 } & & MEDIAMENTE APLICADOS \\
\hline & $\begin{array}{l}\text { NÃO (indique ao lado a } \\
\text { razão da não aplicação) }\end{array}$ & & $\begin{array}{l}\text { CONTEÚDO NÃO ADEQUADO ȦS NECESSIDADES } \\
\text { ESPECÍFICAS DA REGIÃO }\end{array}$ \\
\hline
\end{tabular}




\begin{tabular}{|l|l|l|}
\hline \multirow{10}{*}{} & $\begin{array}{l}\text { CONTEÚDO NÃO FOI SUFICIENTEMENTE } \\
\text { APROFUNDADO PARA PERMITIR UMA APLICAÇÃO } \\
\text { EFICAZ E EFICIENTE }\end{array}$ \\
\cline { 2 - 4 } & $\begin{array}{l}\text { FALTA DE APOIO E INCENTIVO DA MINHA } \\
\text { INSTITUIÇÃO }\end{array}$ \\
\cline { 2 - 4 } & FALTA DE INCENTIVO ÀS AÇÕES DE ATER \\
\hline & NÃO TENHO INTERESSE EM APLICAR \\
\hline
\end{tabular}

6) A partir deste curso: (As opções não são excludentes: você poderá marcar mais de uma opção)

\begin{tabular}{|r|l|}
\hline$x$ & $\begin{array}{l}\text { NÃO MUDOU NADA EM MEU TRABALHO. } \\
\text { FAMILIARES. }\end{array}$ \\
\hline$x$ & CONSEGUI INFLUENCIAR NAS ORIENTAÇÕES DA MINHA INSTITUIÇÃO. \\
\hline$X$ & PASSEI A TRABALHAR COM METODOLOGIAS PARTICIPATIVAS. \\
\hline$X$ & $\begin{array}{l}\text { CRESCEU A ÁREA DE AGRICULTURA DE BASE ECOLÓGICA NAS COMUNIDADES } \\
\text { ONDE ATUO. }\end{array}$ \\
\hline$X$ & CONTINUEI ME APERFEIÇOANDO SOBRE TEMAS ABORDADOS. \\
\hline
\end{tabular}

7) Depois do curso você apoiou atividades de capacitação de técnicos e agricultores com base nos princípios e diretrizes da Pnater? (Considere como apoio a atividades de capacitação a participação no planejamento, elaboração de ementas, seleção de participantes e de palestrantes.)

\begin{tabular}{|l|l|}
\hline$X$ & SIM \\
\hline & NÃO \\
\hline
\end{tabular}

8) Usou os conhecimentos para ministrar outros cursos com o mesmo conteúdo ou conteúdos semelhantes? 


\begin{tabular}{|l|l|}
\hline$X$ & SIM \\
\hline & NÃO \\
\hline
\end{tabular}

9) Marque o seu grau de satisfação com relação ao curso oferecido pelo DATER: (Considere a seguinte pontuação: 1 - MUITO RUIM; 2 - RUIM; 3 - REGULAR; 4 - BOM; 5 - MUITO BOM)

\begin{tabular}{|l|l|l|l|l|}
\hline 1 & 2 & 3 & 4 & 5 \\
\hline
\end{tabular}

10) Marque seu grau de satisfação com relação ao DATER: (Considere a seguinte pontuação: 1 - MUITO RUIM; 2 - RUIM; 3 - REGULAR; 4 - BOM; 5 - MUITO BOM)

\begin{tabular}{|l|l|l|l|l|}
\hline 1 & 2 & 3 & 4 & 5 \\
\hline
\end{tabular}


PESQUISA - IMPACTO DAS AÇÕES DE FORMAÇÃO REALIZADAS PELO DATER/SAF/MDA NO PERÍODO 2004-2009

Caros colaboradores,

Contamos com a sua atenção para preencher o formulário abaixo.

O mesmo tem por objetivo fornecer informações para avaliação da Eficiência, Efetividade e Eficácia da Política Pública de Formação de Agentes de Ater adotada pelo Departamento de Assistência Técnica e Extensão Rural, da Secretaria de Agricultura Familiar do Ministério do Desenvolvimento - DATER/SAF/MDA, no período de 2004 a 2009, tema escolhido para Monografia a ser apresentada à Universidade de Brasília (UnB) como requisito parcial para obtenção do grau de Bacharel em Administração.

Você poderá ou não se identificar no questionário e garantimos que todas as informações fornecidas serão confidenciais e utilizadas apenas de forma sistematizada.

\section{IDENTIFICAÇÃO}

\begin{tabular}{|c|c|}
\hline Nome: DJANEIDE DA SILVA LISBOA & $\begin{array}{l}\text { Sexo: } \\
(\quad) \text { masculino }\end{array}$ \\
\hline $\begin{array}{l}\text { Instituição (nome e tipo de instituição: ONG, } \\
\text { Empresa Pública, etc.): } \\
\text { Instituto de Desenvolvimento Agropecuário do } \\
\text { Estado do Amazonas - IDAM }\end{array}$ & $\begin{array}{l}\text { Local de trabalho (Cidade e Estado): } \\
\text { Manaus - Am }\end{array}$ \\
\hline \multicolumn{2}{|c|}{$\begin{array}{l}\text { Curso/Encontro/Oficina do qual participou (caso tenha participado de mais de um curso, preencha } \\
\text { um formulário para cada um deles): } \\
\text { Seminário - Agroecologia como estratégia para a construção do desenvolvimento rural } \\
\text { sustentável. }\end{array}$} \\
\hline $\begin{array}{l}\text { Data do Curso/Encontro/Oficina (pelo menos mês } \\
0 \text { a } 11 \text { de agosto de } 2006 \text { - Manaus/AM }\end{array}$ & \\
\hline
\end{tabular}

Indique sua área de atuação? (As opções não são excludentes: você poderá marcar mais de uma opção)

\begin{tabular}{|l|l|}
\hline$X$ & EXTENSÃO RURAL \\
\hline
\end{tabular}




\begin{tabular}{|l|l|}
\hline & PESQUISA \\
\hline & ENSINO \\
\hline & OUTROS \\
\hline
\end{tabular}

2) Qual o seu nível de escolaridade?

\begin{tabular}{|l|l|}
\hline$X$ & NÍVEL MÉDIO \\
\hline & NÍVEL SUPERIOR \\
\hline & PÓS-GRADUAÇÃO \\
\hline
\end{tabular}

3) Os conteúdos abordados foram condizentes com as demandas do seu dia-a-dia?

\begin{tabular}{|l|l|}
\hline$X$ & SIM \\
\hline & PARCIALMENTE \\
\hline & NÃO \\
\hline
\end{tabular}

3) O curso contribuiu para o seu aperfeiçoamento profissional?

\begin{tabular}{|l|l|}
\hline$X$ & SIM \\
\hline & NÃO \\
\hline
\end{tabular}

5) Os conhecimentos adquiridos estão sendo aplicados no seu trabalho? Em caso afirmativo, indique em que grau estes conhecimentos estão sendo aplicados. Em caso negativo, indique por que razão isto não ocorre: (Em caso negativo, as respostas não são excludentes: você poderá marcar mais de uma opção).

\begin{tabular}{|l|l|l|l|}
\hline \multirow{2}{*}{$\begin{array}{l}\text { SIM (indique ao lado em } \\
\text { que grau) }\end{array}$} & & MUITO APLICADOS \\
\cline { 2 - 4 } & & MEDIAMENTE APLICADOS \\
\cline { 2 - 4 } & & POUCO APLICADOS \\
\hline
\end{tabular}




\begin{tabular}{|c|c|}
\hline \multirow{5}{*}{$\begin{array}{l}\text { NÃO (indique ao lado a } \\
\text { razão da não aplicação) }\end{array}$} & $\begin{array}{l}\text { CONTEÚDO NÃO ADEQUADO ÀS NECESSIDADES } \\
\text { ESPECÍFICAS DA REGIÃO }\end{array}$ \\
\hline & $\begin{array}{l}\text { CONTEÚDO NÃO } \text { FOI SUFICIENTEMENTE } \\
\text { APROFUNDADO PARA } \\
\text { EERMITIR UMA APLICAÇÃO } \\
\text { EFICAZ E EFICIENTE }\end{array}$ \\
\hline & $\begin{array}{llllll}\text { FALTA DE } & \text { APOIO } & \text { E } & \text { INCENTIVO } & \text { DA } & \text { MINHA } \\
\text { INSTITUIÇÃO } & & & & & \\
\end{array}$ \\
\hline & FALTA DE INCENTIVO ÀS AÇÕES DE ATER \\
\hline & NÃO TENHO INTERESSE EM APLICAR \\
\hline
\end{tabular}

6) A partir deste curso: (As opções não são excludentes: você poderá marcar mais de uma opção)

\begin{tabular}{|l|l|}
\hline & NÃO MUDOU NADA EM MEU TRABALHO. \\
\hline$X$ & $\begin{array}{l}\text { MEU TRABALHO PASSOU A CONTRIBUIR MAIS COM OS AGRICULTORES(AS) } \\
\text { FAMILIARES. }\end{array}$ \\
\hline$X$ & CONSEGUI INFLUENCIAR NAS ORIENTAÇÕES DA MINHA INSTITUIÇÃO. \\
\hline$X$ & PASSEI A TRABALHAR COM METODOLOGIAS PARTICIPATIVAS. \\
\hline$X$ & $\begin{array}{l}\text { CRESCEU A ÁREA DE AGRICULTURA DE BASE ECOLÓGICA NAS COMUNIDADES } \\
\text { ONDE ATUO. }\end{array}$ \\
\hline$X$ & CONTINUEI ME APERFEIÇOANDO SOBRE TEMAS ABORDADOS. \\
\hline
\end{tabular}

7) Depois do curso você apoiou atividades de capacitação de técnicos e agricultores com base nos princípios e diretrizes da Pnater? (Considere como apoio a atividades de capacitação a participação no planejamento, elaboração de ementas, seleção de participantes e de palestrantes.)

\begin{tabular}{|l|l|}
\hline$X$ & SIM \\
\hline & NÃO \\
\hline
\end{tabular}


8) Usou os conhecimentos para ministrar outros cursos com o mesmo conteúdo ou conteúdos semelhantes?

\begin{tabular}{|l|l|}
\hline & SIM \\
\hline$X$ & NÃO \\
\hline
\end{tabular}

9) Marque o seu grau de satisfação com relação ao curso oferecido pelo DATER: (Considere a seguinte pontuação: 1 - MUITO RUIM; 2 - RUIM; 3 - REGULAR; 4 - BOM; 5 - MUITO BOM)

\begin{tabular}{|l|l|l|l|l|}
\hline 1 & 2 & 3 & 4 & 5 \\
\hline
\end{tabular}

10) Marque seu grau de satisfação com relação ao DATER: (Considere a seguinte pontuação: 1 - MUITO RUIM; 2 - RUIM; 3 - REGULAR; 4 - BOM; 5 - MUITO BOM)

\begin{tabular}{|l|l|l|l|l|}
\hline 1 & 2 & 3 & 4 & 5 \\
\hline
\end{tabular}


PESQUISA - IMPACTO DAS AÇÕES DE FORMAÇÃO REALIZADAS PELO DATER/SAF/MDA NO PERÍODO 2004-2009

Caros colaboradores,

Contamos com a sua atenção para preencher o formulário abaixo.

O mesmo tem por objetivo fornecer informações para avaliação da Eficiência, Efetividade e Eficácia da Política Pública de Formação de Agentes de Ater adotada pelo Departamento de Assistência Técnica e Extensão Rural, da Secretaria de Agricultura Familiar do Ministério do Desenvolvimento - DATER/SAF/MDA, no período de 2004 a 2009, tema escolhido para Monografia a ser apresentada à Universidade de Brasília (UnB) como requisito parcial para obtenção do grau de Bacharel em Administração.

Você poderá ou não se identificar no questionário e garantimos que todas as informações fornecidas serão confidenciais e utilizadas apenas de forma sistematizada.

\section{IDENTIFICAÇÃO}

\begin{tabular}{|c|c|}
\hline Nome: DANIELY MEDEIROS ARLINDO & $\begin{array}{l}\text { Sexo: } \\
(\quad) \text { masculino } \quad(x x x) \text { feminino }\end{array}$ \\
\hline $\begin{array}{l}\text { Instituição (nome e tipo de instituição: ONG, } \\
\text { Empresa Pública, etc.): } \\
\text { Instituto de Desenvolvimento Agropecuário do } \\
\text { Estado do Amazonas - IDAM }\end{array}$ & $\begin{array}{l}\text { Local de trabalho (Cidade e Estado): } \\
\text { Unidade Local de Silves - Amazonas }\end{array}$ \\
\hline \multicolumn{2}{|c|}{$\begin{array}{l}\text { Curso/Encontro/Oficina do qual participou (caso tenha participado de mais de um curso, preencha } \\
\text { um formulário para cada um deles): } \\
\text { II Encontro para Socialização dos Conceitos Básicos da Política Nacional de Ater }\end{array}$} \\
\hline $\begin{array}{l}\text { Data do Curso/Encontro/Oficina (pelo menos mês } \\
04 \text { a } 08 \text { de dezembro de } 2006 \text { - Manaus/AM }\end{array}$ & \\
\hline
\end{tabular}

Indique sua área de atuação? (As opções não são excludentes: você poderá marcar mais de uma opção)

\begin{tabular}{|l|l|}
\hline$X$ & EXTENSÃO RURAL \\
\hline & PESQUISA \\
\hline
\end{tabular}




\begin{tabular}{|l|l|}
\hline & ENSINO \\
\hline & OUTROS \\
\hline
\end{tabular}

2) Qual o seu nível de escolaridade?

\begin{tabular}{|l|l|}
\hline & NÍVEL MÉDIO \\
\hline & NÍVEL SUPERIOR \\
\hline$X$ & PÓS-GRADUAÇÃO \\
\hline
\end{tabular}

3) Os conteúdos abordados foram condizentes com as demandas do seu dia-a-dia?

\begin{tabular}{|l|l|}
\hline & SIM \\
\hline$X$ & PARCIALMENTE \\
\hline & NÃO \\
\hline
\end{tabular}

3) O curso contribuiu para o seu aperfeiçoamento profissional?

\begin{tabular}{|l|l|}
\hline$X$ & SIM \\
\hline & NÃO \\
\hline
\end{tabular}

5) Os conhecimentos adquiridos estão sendo aplicados no seu trabalho? Em caso afirmativo, indique em que grau estes conhecimentos estão sendo aplicados. Em caso negativo, indique por que razão isto não ocorre: (Em caso negativo, as respostas não são excludentes: você poderá marcar mais de uma opção).

\begin{tabular}{|l|l|l|}
\hline \multirow{2}{*}{$\begin{array}{l}\text { SIM (indique ao lado em } \\
\text { que grau) }\end{array}$} & $X$ & MUITO APLICADOS \\
\cline { 2 - 4 } & & MEDIAMENTE APLICADOS \\
\cline { 2 - 4 } & & POUCO APLICADOS \\
\hline
\end{tabular}




\begin{tabular}{|c|c|}
\hline \multirow{5}{*}{$\begin{array}{l}\text { NÃO (indique ao lado a } \\
\text { razão da não aplicação) }\end{array}$} & $\begin{array}{l}\text { CONTEÚDO NÃO ADEQUADO ÀS NECESSIDADES } \\
\text { ESPECÍFICAS DA REGIÃO }\end{array}$ \\
\hline & $\begin{array}{l}\text { CONTEÚDO NÃO } \text { FOI SUFICIENTEMENTE } \\
\text { APROFUNDADO PARA } \\
\text { EERMITIR UMA APLICAÇÃO } \\
\text { EFICAZ E EFICIENTE }\end{array}$ \\
\hline & $\begin{array}{llllll}\text { FALTA DE } & \text { APOIO } & \text { E } & \text { INCENTIVO } & \text { DA } & \text { MINHA } \\
\text { INSTITUIÇÃO } & & & & & \\
\end{array}$ \\
\hline & FALTA DE INCENTIVO ÀS AÇÕES DE ATER \\
\hline & NÃO TENHO INTERESSE EM APLICAR \\
\hline
\end{tabular}

6) A partir deste curso:

\begin{tabular}{|l|l|}
\hline & NÃO MUDOU NADA EM MEU TRABALHO. \\
\hline & $\begin{array}{l}\text { MEU TRABALHO PASSOU A CONTRIBUIR MAIS COM OS AGRICULTORES(AS) } \\
\text { FAMILIARES. }\end{array}$ \\
\hline & CONSEGUI INFLUENCIAR NAS ORIENTAÇÕES DA MINHA INSTITUIÇÃO. \\
\hline & $\begin{array}{l}\text { CRESSEI A TRABALHAR COM METODOLOGIAS PARTICIPATIVAS. } \\
\text { ONDE ATUO. ÁREA DE AGRICULTURA DE BASE ECOLÓGICA NAS COMUNIDADES }\end{array}$ \\
\hline$X$ & CONTINUEI ME APERFEIÇOANDO SOBRE TEMAS ABORDADOS. \\
\hline
\end{tabular}

7) Depois do curso você apoiou atividades de capacitação de técnicos e agricultores com base nos princípios e diretrizes da Pnater? (Considere como apoio a atividades de capacitação a participação no planejamento, elaboração de ementas, seleção de participantes e de palestrantes.)

\begin{tabular}{|l|l|}
\hline & SIM \\
\hline$X$ & NÃO \\
\hline
\end{tabular}

8) Usou os conhecimentos para ministrar outros cursos com o mesmo conteúdo ou conteúdos semelhantes? 


\begin{tabular}{|l|l|}
\hline & SIM \\
\hline$X$ & NÃO \\
\hline
\end{tabular}

9) Marque o seu grau de satisfação com relação ao curso oferecido pelo DATER: (Considere a seguinte pontuação: 1 - MUITO RUIM; 2 - RUIM; 3 - REGULAR; 4 - BOM; 5 - MUITO BOM)

\begin{tabular}{|l|l|l|l|l|}
\hline 1 & 2 & 3 & 4 & 5 \\
\hline
\end{tabular}

10) Marque seu grau de satisfação com relação ao DATER: (Considere a seguinte pontuação: 1 - MUITO RUIM; 2 - RUIM; 3 - REGULAR; 4 - BOM; 5 - MUITO BOM)

\begin{tabular}{|l|l|l|l|l|}
\hline 1 & 2 & 3 & 4 & 5 \\
\hline
\end{tabular}


PESQUISA - IMPACTO DAS AÇÕES DE FORMAÇÃO REALIZADAS PELO DATER/SAF/MDA NO PERÍODO 2004-2009

Caros colaboradores,

Contamos com a sua atenção para preencher o formulário abaixo.

O mesmo tem por objetivo fornecer informações para avaliação da Eficiência, Efetividade e Eficácia da Política Pública de Formação de Agentes de Ater adotada pelo Departamento de Assistência Técnica e Extensão Rural, da Secretaria de Agricultura Familiar do Ministério do Desenvolvimento - DATER/SAF/MDA, no período de 2004 a 2009, tema escolhido para Monografia a ser apresentada à Universidade de Brasília (UnB) como requisito parcial para obtenção do grau de Bacharel em Administração.

Você poderá ou não se identificar no questionário e garantimos que todas as informações fornecidas serão confidenciais e utilizadas apenas de forma sistematizada.

IDENTIFICAÇÃO

\begin{tabular}{|c|c|}
\hline $\begin{array}{l}\text { Nome: CLAÚDIO ADRIANO CARDOSO } \\
\text { AMANAJÁS }\end{array}$ & $\begin{array}{l}\text { Sexo: } \\
(x) \text { masculino } \quad(\quad) \text { feminino }\end{array}$ \\
\hline $\begin{array}{l}\text { Instituição (nome e tipo de instituição: ONG, } \\
\text { Empresa Pública, etc.): } \\
\text { Instituto de Desenvolvimento Agropecuário do } \\
\text { Estado do Amazonas - IDAM }\end{array}$ & $\begin{array}{l}\text { Local de trabalho (Cidade e Estado): } \\
\text { Unidade Local de Caapiranga - Amazonas }\end{array}$ \\
\hline \multicolumn{2}{|c|}{$\begin{array}{l}\text { Curso/Encontro/Oficina do qual participou (caso tenha participado de mais de um curso, preencha } \\
\text { um formulário para cada um deles): } \\
\text { II Encontro para Socialização dos Conceitos Básicos da Política Nacional de Ater }\end{array}$} \\
\hline $\begin{array}{l}\text { Data do Curso/Encontro/Oficina (pelo menos mês } \\
04 \text { a } 08 \text { de dezembro de } 2006 \text { - Manaus/AM }\end{array}$ & \\
\hline
\end{tabular}

Indique sua área de atuação? (As opções não são excludentes: você poderá marcar mais de uma opção)

\begin{tabular}{|l|l|}
\hline$X$ & EXTENSÃO RURAL \\
\hline & PESQUISA \\
\hline
\end{tabular}




\begin{tabular}{|l|l|}
\hline & ENSINO \\
\hline & OUTROS \\
\hline
\end{tabular}

2) Qual o seu nível de escolaridade?

\begin{tabular}{|l|l|}
\hline$X$ & NÍVEL MÉDIO \\
\hline & NÍVEL SUPERIOR \\
\hline & PÓS-GRADUAÇÃO \\
\hline
\end{tabular}

3) Os conteúdos abordados foram condizentes com as demandas do seu dia-a-dia?

\begin{tabular}{|l|l|}
\hline$X$ & SIM \\
\hline & PARCIALMENTE \\
\hline & NÃO \\
\hline
\end{tabular}

3) O curso contribuiu para o seu aperfeiçoamento profissional?

\begin{tabular}{|l|l|}
\hline$X$ & SIM \\
\hline & NÃO \\
\hline
\end{tabular}

5) Os conhecimentos adquiridos estão sendo aplicados no seu trabalho? Em caso afirmativo, indique em que grau estes conhecimentos estão sendo aplicados. Em caso negativo, indique por que razão isto não ocorre: (Em caso negativo, as respostas não são excludentes: você poderá marcar mais de uma opção).

\begin{tabular}{|l|l|l|l|}
\hline \multirow{2}{*}{$\begin{array}{l}\text { SIM (indique ao lado em } \\
\text { que grau) }\end{array}$} & & MUITO APLICADOS \\
\cline { 2 - 4 } & $X$ & MEDIAMENTE APLICADOS \\
\cline { 2 - 4 } & & POUCO APLICADOS \\
\hline
\end{tabular}




\begin{tabular}{|c|c|}
\hline \multirow{5}{*}{$\begin{array}{l}\text { NÃO (indique ao lado a } \\
\text { razão da não aplicação) }\end{array}$} & $\begin{array}{l}\text { CONTEÚDO NÃO ADEQUADO ÀS NECESSIDADES } \\
\text { ESPECÍFICAS DA REGIÃO }\end{array}$ \\
\hline & $\begin{array}{l}\text { CONTEÚDO NÃO } \text { FOI SUFICIENTEMENTE } \\
\text { APROFUNDADO PARA } \\
\text { EERMITIR UMA APLICAÇÃO } \\
\text { EFICAZ E EFICIENTE }\end{array}$ \\
\hline & $\begin{array}{llllll}\text { FALTA DE } & \text { APOIO } & \text { E } & \text { INCENTIVO } & \text { DA } & \text { MINHA } \\
\text { INSTITUIÇÃO } & & & & & \\
\end{array}$ \\
\hline & FALTA DE INCENTIVO ÀS AÇÕES DE ATER \\
\hline & NÃO TENHO INTERESSE EM APLICAR \\
\hline
\end{tabular}

6) A partir deste curso: (As opções não são excludentes: você poderá marcar mais de uma opção)

\begin{tabular}{|l|l|}
\hline$x$ & $\begin{array}{l}\text { NÃO MUDOU NADA EM MEU TRABALHO. } \\
\text { FAMILIARES. }\end{array}$ \\
\hline & CONSEGUI INFLUENCIAR NAS ORIENTAÇÕES DA MINHA INSTITUIÇÃO. \\
\hline & PASSEI A TRABALHAR COM METODOLOGIAS PARTICIPATIVAS. \\
\hline & $\begin{array}{l}\text { ORESCEU A ÁREA DE AGRICULTURA DE BASE ECOLÓGICA NAS COMUNIDADES } \\
\text { CONTINUEI ME APERFEIÇOANDO SOBRE TEMAS ABORDADOS. }\end{array}$ \\
\hline
\end{tabular}

7) Depois do curso você apoiou atividades de capacitação de técnicos e agricultores com base nos princípios e diretrizes da Pnater? (Considere como apoio a atividades de capacitação a participação no planejamento, elaboração de ementas, seleção de participantes e de palestrantes.)

\begin{tabular}{|l|l|}
\hline$X$ & SIM \\
\hline & NÃO \\
\hline
\end{tabular}


8) Usou os conhecimentos para ministrar outros cursos com o mesmo conteúdo ou conteúdos semelhantes?

\begin{tabular}{|l|l|}
\hline$X$ & SIM \\
\hline & NÃO \\
\hline
\end{tabular}

9) Marque o seu grau de satisfação com relação ao curso oferecido pelo DATER: (Considere a seguinte pontuação: 1 - MUITO RUIM; 2 - RUIM; 3 - REGULAR; 4 - BOM; 5 - MUITO BOM)

\begin{tabular}{|l|l|l|l|l|}
\hline 1 & 2 & 3 & 4 & 5 \\
\hline
\end{tabular}

10) Marque seu grau de satisfação com relação ao DATER: (Considere a seguinte pontuação: 1 - MUITO RUIM; 2 - RUIM; 3 - REGULAR; 4 - BOM; 5 - MUITO BOM)

\begin{tabular}{|l|l|l|l|l|}
\hline 1 & 2 & 3 & 4 & 5 \\
\hline
\end{tabular}

Obs: As notas atribuídas as questões 9 e 10 devem obedecer a ordem crescente: 1 - muito ruim , 2 - ruim, 3 - regular, 4 - bom, 5 - muito bom. 
PESQUISA - IMPACTO DAS AÇÕES DE FORMAÇÃO REALIZADAS PELO DATER/SAF/MDA NO PERÍODO 2004-2009

Caros colaboradores,

Contamos com a sua atenção para preencher o formulário abaixo.

O mesmo tem por objetivo fornecer informações para avaliação da Eficiência, Efetividade e Eficácia da Política Pública de Formação de Agentes de Ater adotada pelo Departamento de Assistência Técnica e Extensão Rural, da Secretaria de Agricultura Familiar do Ministério do Desenvolvimento - DATER/SAF/MDA, no período de 2004 a 2009, tema escolhido para Monografia a ser apresentada à Universidade de Brasília (UnB) como requisito parcial para obtenção do grau de Bacharel em Administração.

Você poderá ou não se identificar no questionário e garantimos que todas as informações fornecidas serão confidenciais e utilizadas apenas de forma sistematizada.

IDENTIFICAÇÃO

\begin{tabular}{|c|c|}
\hline $\begin{array}{l}\text { Nome: ANTÕNIO CLARET MAGALHÃES } \\
\text { FERREIRA }\end{array}$ & $\begin{array}{l}\text { Sexo: } \\
(x) \text { masculino } \quad(\quad) \text { feminino }\end{array}$ \\
\hline $\begin{array}{l}\text { Instituição (nome e tipo de instituição: ONG, } \\
\text { Empresa Pública, etc.): } \\
\text { Instituto de Desenvolvimento Agropecuário do } \\
\text { Estado do Amazonas - IDAM }\end{array}$ & $\begin{array}{l}\text { Local de trabalho (Cidade e Estado): } \\
\text { Manaus - AM }\end{array}$ \\
\hline \multicolumn{2}{|c|}{$\begin{array}{l}\text { Curso/Encontro/Oficina do qual participou (caso tenha participado de mais de um curso, preencha } \\
\text { um formulário para cada um deles): } \\
\text { Oficina de Metodologia Participativa }\end{array}$} \\
\hline $\begin{array}{l}\text { Data do Curso/Encontro/Oficina (pelo menos mês e } \\
07 \text { e } 08 \text { de novembro de } 2005 \text { - Natal/RN }\end{array}$ & \\
\hline
\end{tabular}

Indique sua área de atuação? (As opções não são excludentes: você poderá marcar mais de uma opção)

\begin{tabular}{|l|l}
\hline$X$ & EXTENSÃO RURAL \\
\hline
\end{tabular} 


\begin{tabular}{|l|l|}
\hline & PESQUISA \\
\hline & ENSINO \\
\hline & OUTROS \\
\hline
\end{tabular}

2) Qual o seu nível de escolaridade?

\begin{tabular}{|l|l|}
\hline & NÍVEL MÉDIO \\
\hline$X$ & NÍVEL SUPERIOR \\
\hline & PÓS-GRADUAÇÃO \\
\hline
\end{tabular}

3) Os conteúdos abordados foram condizentes com as demandas do seu dia-a-dia?

\begin{tabular}{|l|l|}
\hline$X$ & SIM \\
\hline & PARCIALMENTE \\
\hline & NÃO \\
\hline
\end{tabular}

3) O curso contribuiu para o seu aperfeiçoamento profissional?

\begin{tabular}{|l|l|}
\hline & SIM \\
\hline & NÃO \\
\hline
\end{tabular}

5) Os conhecimentos adquiridos estão sendo aplicados no seu trabalho? Em caso afirmativo, indique em que grau estes conhecimentos estão sendo aplicados. Em caso negativo, indique por que razão isto não ocorre: (Em caso negativo, as respostas não são excludentes: você poderá marcar mais de uma opção).

\begin{tabular}{|l|l|l|}
\hline \multirow{2}{*}{$\begin{array}{l}\text { SIM (indique ao lado em } \\
\text { que grau) }\end{array}$} & $\mathrm{X}$ & MUITO APLICADOS \\
\cline { 2 - 3 } & & MEDIAMENTE APLICADOS \\
\hline
\end{tabular}




\begin{tabular}{|c|c|}
\hline \multirow{5}{*}{$\begin{array}{l}\text { NÃO (indique ao lado a } \\
\text { razão da não aplicação) }\end{array}$} & $\begin{array}{l}\text { CONTEÚDO NÃO ADEQUADO ȦS NECESSIDADES } \\
\text { ESPECÍFICAS DA REGIÃO }\end{array}$ \\
\hline & $\begin{array}{l}\text { CONTEÚDO NÃO FOI SUFICIENTEMENTE } \\
\text { APROFUNDADO PARA } \\
\text { PERMITIR UMA APLICAÇÃO } \\
\text { EFICAZ E EFICIENTE }\end{array}$ \\
\hline & $\begin{array}{l}\text { FALTA DE APOIO } \\
\text { INSTITUIÇÃO }\end{array}$ \\
\hline & FALTA DE INCENTIVO ÀS AÇÕES DE ATER \\
\hline & NÃO TENHO INTERESSE EM APLICAR \\
\hline
\end{tabular}

6) A partir deste curso: (As opções não são excludentes: você poderá marcar mais de uma opção)

\begin{tabular}{|c|c|}
\hline & NÃO MUDOU NADA EM MEU TRABALHO. \\
\hline $\mathrm{X}$ & $\begin{array}{l}\text { MEU TRABALHO PASSOU A CONTRIBUIR MAIS COM OS AGRICULTORES(AS) } \\
\text { FAMILIARES. }\end{array}$ \\
\hline$x$ & CONSEGUI INFLUENCIAR NAS ORIENTAÇÕES DA MINHA INSTITUIÇÃO. \\
\hline \multirow[t]{2}{*}{$\mathrm{X}$} & PASSEI A TRABALHAR COM METODOLOGIAS PARTICIPATIVAS. \\
\hline & $\begin{array}{l}\text { CRESCEU A ÁREA DE AGRICULTURA DE BASE ECOLÓGICA NAS COMUNIDADES } \\
\text { ONDE ATUO. }\end{array}$ \\
\hline $\mathrm{X}$ & CONTINUEI ME APERFEIÇOANDO SOBRE TEMAS ABORDADOS. \\
\hline
\end{tabular}

7) Depois do curso você apoiou atividades de capacitação de técnicos e agricultores com base nos princípios e diretrizes da Pnater? (Considere como apoio a atividades de capacitação a participação no planejamento, elaboração de ementas, seleção de participantes e de palestrantes.)

\begin{tabular}{|l|l|}
\hline$X$ & SIM \\
\hline & NÃO \\
\hline
\end{tabular}


8) Usou os conhecimentos para ministrar outros cursos com o mesmo conteúdo ou conteúdos semelhantes?

\begin{tabular}{|l|l|}
\hline$X$ & SIM \\
\hline & NÃO \\
\hline
\end{tabular}

9) Marque o seu grau de satisfação com relação ao curso oferecido pelo DATER: (Considere a seguinte pontuação: 1 - MUITO RUIM; 2 - RUIM; 3 - REGULAR; 4 - BOM; 5 - MUITO BOM)

\begin{tabular}{|l|l|l|l|l|}
\hline 1 & 2 & 3 & 4 & 5 \\
\hline
\end{tabular}

10) Marque seu grau de satisfação com relação ao DATER: (Considere a seguinte pontuação: 1 - MUITO RUIM; 2 - RUIM; 3 - REGULAR; 4 - BOM; 5 - MUITO BOM)

\begin{tabular}{|l|l|l|l|l|}
\hline 1 & 2 & 3 & 4 & 5 \\
\hline
\end{tabular}


PESQUISA - IMPACTO DAS AÇÕES DE FORMAÇÃO REALIZADAS PELO DATER/SAF/MDA NO PERÍODO 2004-2009

Caros colaboradores,

Contamos com a sua atenção para preencher o formulário abaixo.

O mesmo tem por objetivo fornecer informações para avaliação da Eficiência, Efetividade e Eficácia da Política Pública de Formação de Agentes de Ater adotada pelo Departamento de Assistência Técnica e Extensão Rural, da Secretaria de Agricultura Familiar do Ministério do Desenvolvimento - DATER/SAF/MDA, no período de 2004 a 2009, tema escolhido para Monografia a ser apresentada à Universidade de Brasília (UnB) como requisito parcial para obtenção do grau de Bacharel em Administração.

Você poderá ou não se identificar no questionário e garantimos que todas as informações fornecidas serão confidenciais e utilizadas apenas de forma sistematizada.

IDENTIFICAÇÃO

\begin{tabular}{|c|c|}
\hline $\begin{array}{l}\text { Nome: ANTÖNIO } \text { CLARET } \\
\text { FERREIRA }\end{array}$ & $\begin{array}{l}\text { Sexo: } \\
(x) \text { masculino } \quad(\quad) \text { feminino }\end{array}$ \\
\hline $\begin{array}{l}\text { Instituição (nome e tipo de instituição: ONG, } \\
\text { Empresa Pública, etc.): } \\
\text { Instituto de Desenvolvimento Agropecuário do } \\
\text { Estado do Amazonas - IDAM }\end{array}$ & $\begin{array}{l}\text { Local de trabalho (Cidade e Estado): } \\
\text { Manaus - AM }\end{array}$ \\
\hline \multicolumn{2}{|c|}{$\begin{array}{l}\text { Curso/Encontro/Oficina do qual participou (caso tenha participado de mais de um curso, preencha } \\
\text { um formulário para cada um deles): } \\
\text { Oficina de Implantação do Projeto Piloto de Comunicação e Metodologia, do Sub-Programa } \\
\text { nacional de Comunicação e Metodologia - MDA, em Minas Gerais e conhecer as experiências da } \\
\text { EMATER-MG em comunicação e metodologias. }\end{array}$} \\
\hline \multicolumn{2}{|l|}{$\begin{array}{l}\text { Data do Curso/Encontro/Oficina (pelo menos mês e ano): } \\
06 \text { a } 13 \text { de maio de } 2005 \text { - Minas Gerais/MG }\end{array}$} \\
\hline
\end{tabular}

Indique sua área de atuação? (As opções não são excludentes: você poderá marcar mais de uma opção) 


\begin{tabular}{|l|l|}
\hline$X$ & EXTENSÃO RURAL \\
\hline & PESQUISA \\
\hline & ENSINO \\
\hline & OUTROS \\
\hline
\end{tabular}

2) Qual o seu nível de escolaridade?

\begin{tabular}{|l|l|}
\hline & NÍVEL MÉDIO \\
\hline$X$ & NÍVEL SUPERIOR \\
\hline & PÓS-GRADUAÇÃO \\
\hline
\end{tabular}

3) Os conteúdos abordados foram condizentes com as demandas do seu dia-a-dia?

\begin{tabular}{|l|l|}
\hline$X$ & SIM \\
\hline & PARCIALMENTE \\
\hline & NÃO \\
\hline
\end{tabular}

3) O curso contribuiu para o seu aperfeiçoamento profissional?

\begin{tabular}{|l|l|}
\hline$X$ & SIM \\
\hline & NÃO \\
\hline
\end{tabular}

5) Os conhecimentos adquiridos estão sendo aplicados no seu trabalho? Em caso afirmativo, indique em que grau estes conhecimentos estão sendo aplicados. Em caso negativo, indique por que razão isto não ocorre: (Em caso negativo, as respostas não são excludentes: você poderá marcar mais de uma opção).

\begin{tabular}{|l|l|l|l|}
\hline \multirow{2}{*}{$\begin{array}{l}\text { SIM (indique ao lado em } \\
\text { que grau) }\end{array}$} & & MUITO APLICADOS \\
\cline { 3 - 4 } & & $X$ & MEDIAMENTE APLICADOS \\
\hline
\end{tabular}




\begin{tabular}{|c|c|}
\hline & POUCO APLICADOS \\
\hline \multirow{5}{*}{$\begin{array}{l}\text { NÃO (indique ao lado a } \\
\text { razão da não aplicação) }\end{array}$} & $\begin{array}{l}\text { CONTEÚDO NÃO ADEQUADO ÀS NECESSIDADES } \\
\text { ESPECÍFICAS DA REGIÃO }\end{array}$ \\
\hline & \begin{tabular}{lccr|} 
CONTEÚDO & NÃO & FOI & SUFICIENTEMENTE \\
APROFUNDADO PARA & PERMITIR UMA APLICAÇÃO \\
EFICAZ E EFICIENTE &
\end{tabular} \\
\hline & 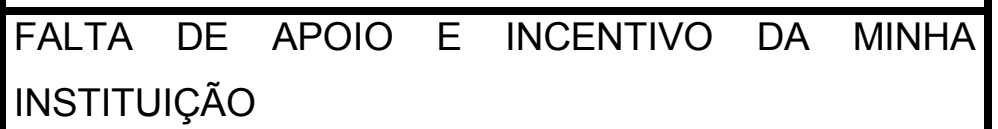 \\
\hline & FALTA DE INCENTIVO ÀS AÇÕES DE ATER \\
\hline & NÃO TENHO INTERESSE EM APLICAR \\
\hline
\end{tabular}

6) A partir deste curso: (As opções não são excludentes: você poderá marcar mais de uma opção)

\begin{tabular}{|l|l|}
\hline & NÃO MUDOU NADA EM MEU TRABALHO. \\
\hline$X$ & $\begin{array}{l}\text { MEU TRABALHO PASSOU A CONTRIBUIR MAIS COM OS AGRICULTORES(AS) } \\
\text { FAMILIARES. }\end{array}$ \\
\hline$X$ & CONSEGUI INFLUENCIAR NAS ORIENTAÇÕES DA MINHA INSTITUIÇÃO. \\
\hline$X$ & PASSEI A TRABALHAR COM METODOLOGIAS PARTICIPATIVAS. \\
\hline & $\begin{array}{l}\text { CRESCEU A ÁREA DE AGRICULTURA DE BASE ECOLÓGICA NAS COMUNIDADES } \\
\text { ONDE ATUO. }\end{array}$ \\
\hline$X$ & CONTINUEI ME APERFEIÇOANDO SOBRE TEMAS ABORDADOS. \\
\hline
\end{tabular}

7) Depois do curso você apoiou atividades de capacitação de técnicos e agricultores com base nos princípios e diretrizes da Pnater? (Considere como apoio a atividades de capacitação a participação no planejamento, elaboração de ementas, seleção de participantes e de palestrantes.)

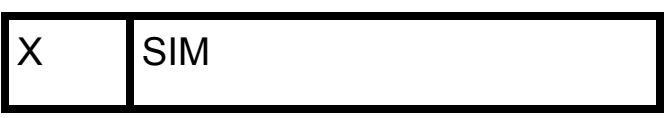


NÃO

8) Usou os conhecimentos para ministrar outros cursos com o mesmo conteúdo ou conteúdos semelhantes?

\begin{tabular}{|l|l|}
\hline$X$ & SIM \\
\hline & NÃO \\
\hline
\end{tabular}

9) Marque o seu grau de satisfação com relação ao curso oferecido pelo DATER: (Considere a seguinte pontuação: 1 - MUITO RUIM; 2 - RUIM; 3 - REGULAR; 4 - BOM; 5 - MUITO BOM)

\begin{tabular}{|l|l|l|l|l|}
\hline 1 & 2 & 3 & 4 & 5 \\
\hline
\end{tabular}

10) Marque seu grau de satisfação com relação ao DATER: (Considere a seguinte pontuação: 1 - MUITO RUIM; 2 - RUIM; 3 - REGULAR; 4 - BOM; 5 - MUITO BOM)

\begin{tabular}{|l|l|l|l|l|}
\hline 1 & 2 & 3 & 4 & 5 \\
\hline
\end{tabular}


PESQUISA - IMPACTO DAS AÇÕES DE FORMAÇÃO REALIZADAS PELO DATER/SAF/MDA NO PERÍODO 2004-2009

Caros colaboradores,

Contamos com a sua atenção para preencher o formulário abaixo.

O mesmo tem por objetivo fornecer informações para avaliação da Eficiência, Efetividade e Eficácia da Política Pública de Formação de Agentes de Ater adotada pelo Departamento de Assistência Técnica e Extensão Rural, da Secretaria de Agricultura Familiar do Ministério do Desenvolvimento - DATER/SAF/MDA, no período de 2004 a 2009, tema escolhido para Monografia a ser apresentada à Universidade de Brasília (UnB) como requisito parcial para obtenção do grau de Bacharel em Administração.

Você poderá ou não se identificar no questionário e garantimos que todas as informações fornecidas serão confidenciais e utilizadas apenas de forma sistematizada.

IDENTIFICAÇÃO

\begin{tabular}{|c|c|}
\hline Nome: FRANK LUIZ DE LIMA GADELHA & $\begin{array}{l}\text { Sexo: } \\
(\quad) \text { masculino } \quad(x x x) \text { feminino }\end{array}$ \\
\hline $\begin{array}{l}\text { Instituição (nome e tipo de instituição: ONG, } \\
\text { Empresa Pública, etc.): } \\
\text { Instituto de Desenvolvimento Agropecuário do } \\
\text { Estado do Amazonas - IDAM }\end{array}$ & $\begin{array}{l}\text { Local de trabalho (Cidade e Estado): } \\
\text { Unidade Local de Rio Preto da Eva - } \\
\text { Amazonas }\end{array}$ \\
\hline \multicolumn{2}{|c|}{$\begin{array}{l}\text { Curso/Encontro/Oficina do qual participou (caso tenha participado de mais de um curso, preencha } \\
\text { um formulário para cada um deles): } \\
\text { Seminário - Agroecologia como Estratégia para a Construção do Desenvolvimento Rural } \\
\text { Sustentável }\end{array}$} \\
\hline $\begin{array}{l}\text { Data do Curso/Encontro/Oficina (pelo menos mês e } \\
10 \text { e } 11 \text { de agosto de } 2006 \text { - Manaus/AM }\end{array}$ & \\
\hline
\end{tabular}

Indique sua área de atuação? (As opções não são excludentes: você poderá marcar mais de uma opção) 


\begin{tabular}{|l|l|}
\hline$X$ & EXTENSÃO RURAL \\
\hline & PESQUISA \\
\hline & ENSINO \\
\hline & OUTROS \\
\hline
\end{tabular}

2) Qual o seu nível de escolaridade? (Considere apenas o nível mais alto)

\begin{tabular}{|l|l|}
\hline$X$ & NÍVEL MÉDIO \\
\hline & NÍVEL SUPERIOR \\
\hline & PÓS-GRADUAÇÃO \\
\hline
\end{tabular}

3) Os conteúdos abordados foram condizentes com as demandas do seu dia-a-dia?

\begin{tabular}{|l|l|}
\hline$X$ & SIM \\
\hline & PARCIALMENTE \\
\hline & NÃO \\
\hline
\end{tabular}

3) O curso contribuiu para o seu aperfeiçoamento profissional?

\begin{tabular}{|l|l|}
\hline$x$ & SIM \\
\hline & NÃO \\
\hline
\end{tabular}

5) Os conhecimentos adquiridos estão sendo aplicados no seu trabalho? ? Em caso afirmativo, indique em que grau estes conhecimentos estão sendo aplicados. Em caso negativo, indique por que razão isto não ocorre: (Em caso negativo, as respostas não são excludentes: você poderá marcar mais de uma opção). 


\begin{tabular}{|c|c|c|}
\hline \multirow[t]{2}{*}{ que grau) } & & MEDIAMENTE APLICADOS \\
\hline & $x$ & POUCO APLICADOS \\
\hline \multirow{5}{*}{$\begin{array}{l}\text { NÃO (indique ao lado a } \\
\text { razão da não aplicação) }\end{array}$} & & $\begin{array}{l}\text { CONTEÚDO NÃO ADEQUADO ÀS NECESSIDADES } \\
\text { ESPECÍFICAS DA REGIÃO }\end{array}$ \\
\hline & & $\begin{array}{l}\text { CONTEÚDO NÃO } \text { FOI SUFICIENTEMENTE } \\
\text { APROFUNDADO PARA } \\
\text { EERMITIR UMA APLICAÇÃO } \\
\text { EFICAZ E EFICIENTE }\end{array}$ \\
\hline & & \begin{tabular}{|lccccc} 
FALTA DE & APOIO & E & INCENTIVO & DA & MINHA \\
INSTITUIÇÃO & & & & & \\
\end{tabular} \\
\hline & & FALTA DE INCENTIVO ÀS AÇÕES DE ATER \\
\hline & & NÃO TENHO INTERESSE EM APLICAR \\
\hline
\end{tabular}

6) A partir deste curso: (As opções não são excludentes: você poderá marcar mais de uma opção)

\begin{tabular}{|l|l|}
\hline$x$ & $\begin{array}{l}\text { NÃO MUDOU NADA EM MEU TRABALHO. } \\
\text { FAMILIARES. }\end{array}$ \\
\hline & CONSEGUI INFLUENCIAR NAS ORIENTAÇÕES DA MINHA INSTITUIÇÃO. \\
\hline & PASSEI A TRABALHAR COM METODOLOGIAS PARTICIPATIVAS. \\
\hline & $\begin{array}{l}\text { CRESCEU A ÁREA DE AGRICULTURA DE BASE ECOLÓGICA NAS COMUNIDADES } \\
\text { ONDE ATUO. }\end{array}$ \\
\hline & CONTINUEI ME APERFEIÇOANDO SOBRE TEMAS ABORDADOS. \\
\hline
\end{tabular}

7) Depois do curso você apoiou atividades de capacitação de técnicos e agricultores com base nos princípios e diretrizes da Pnater? (Considere como apoio a atividades de capacitação a participação no planejamento, elaboração de ementas, seleção de participantes e de palestrantes.) 


\begin{tabular}{|l|l|}
\hline$X$ & SIM \\
\hline & NÃO \\
\hline
\end{tabular}

8) Usou os conhecimentos para ministrar outros cursos com o mesmo conteúdo ou conteúdos semelhantes?

\begin{tabular}{|l|l|}
\hline & SIM \\
\hline$X$ & NÃO \\
\hline
\end{tabular}

9) Marque o seu grau de satisfação com relação ao curso oferecido pelo DATER: (Considere a seguinte pontuação: 1 - MUITO RUIM; 2 - RUIM; 3 - REGULAR; 4 - BOM; 5 - MUITO BOM)

\begin{tabular}{|l|l|l|l|l|}
\hline 1 & 2 & 3 & 4 & 5 \\
\hline
\end{tabular}

10) Marque seu grau de satisfação com relação ao DATER: (Considere a seguinte pontuação: 1 - MUITO RUIM; 2 - RUIM; 3 - REGULAR; 4 - BOM; 5 - MUITO BOM)

\begin{tabular}{|l|l|l|l|l|}
\hline 1 & 2 & 3 & 4 & 5 \\
\hline
\end{tabular}


PESQUISA - IMPACTO DAS AÇÕES DE FORMAÇÃO REALIZADAS PELO DATER/SAF/MDA NO PERÍODO 2004-2009

Caros colaboradores,

Contamos com a sua atenção para preencher o formulário abaixo.

O mesmo tem por objetivo fornecer informações para avaliação da Eficiência, Efetividade e Eficácia da Política Pública de Formação de Agentes de Ater adotada pelo Departamento de Assistência Técnica e Extensão Rural, da Secretaria de Agricultura Familiar do Ministério do Desenvolvimento - DATER/SAF/MDA, no período de 2004 a 2009, tema escolhido para Monografia a ser apresentada à Universidade de Brasília (UnB) como requisito parcial para obtenção do grau de Bacharel em Administração.

Você poderá ou não se identificar no questionário e garantimos que todas as informações fornecidas serão confidenciais e utilizadas apenas de forma sistematizada.

\section{IDENTIFICAÇÃO}

\begin{tabular}{|c|c|}
\hline $\begin{array}{llll}\text { Nome: } & \text { FRANCISCO } & \text { ROBERTO } & \text { FERREIRA } \\
\text { GOMES } & & & \\
\end{array}$ & $\begin{array}{l}\text { Sexo: } \\
(x x) \text { masculino } \quad(\quad) \text { feminino }\end{array}$ \\
\hline $\begin{array}{l}\text { Instituição (nome e tipo de instituição: ONG, } \\
\text { Empresa Pública, etc.): } \\
\text { Instituto de Desenvolvimento Agropecuário do } \\
\text { Estado do Amazonas - IDAM }\end{array}$ & $\begin{array}{l}\text { Local de trabalho (Cidade e Estado): } \\
\text { Unidade Local de Maraã - Amazonas }\end{array}$ \\
\hline \multicolumn{2}{|c|}{$\begin{array}{l}\text { Curso/Encontro/Oficina do qual participou (caso tenha participado de mais de um curso, preencha } \\
\text { um formulário para cada um deles): } \\
\text { Curso Diagnóstico Rural Participativo - DRP }\end{array}$} \\
\hline $\begin{array}{l}\text { Data do Curso/Encontro/Oficina (pelo menos mês e } \\
16 \text { a } 27 \text { de outubro de } 2006 \text { - Manaus/AM }\end{array}$ & \\
\hline
\end{tabular}

Indique sua área de atuação? (As opções não são excludentes: você poderá marcar mais de uma opção)

$\mathrm{X}$ EXTENSÃO RURAL 


\begin{tabular}{|l|l|}
\hline & PESQUISA \\
\hline & ENSINO \\
\hline & OUTROS \\
\hline
\end{tabular}

2) Qual o seu nível de escolaridade? (Considere apenas o nível mais alto)

\begin{tabular}{|l|l|}
\hline$X$ & NÍVEL MÉDIO \\
\hline & NÍVEL SUPERIOR \\
\hline & PÓS-GRADUAÇÃO \\
\hline
\end{tabular}

3) Os conteúdos abordados foram condizentes com as demandas do seu dia-a-dia?

\begin{tabular}{|l|l|}
\hline$X$ & SIM \\
\hline & PARCIALMENTE \\
\hline & NÃO \\
\hline
\end{tabular}

3) O curso contribuiu para o seu aperfeiçoamento profissional?

\begin{tabular}{|l|l|}
\hline$X$ & SIM \\
\hline & NÃO \\
\hline
\end{tabular}

5) Os conhecimentos adquiridos estão sendo aplicados no seu trabalho? ? Em caso afirmativo, indique em que grau estes conhecimentos estão sendo aplicados. Em caso negativo, indique por que razão isto não ocorre: (Em caso negativo, as respostas não são excludentes: você poderá marcar mais de uma opção).

\begin{tabular}{|l|l|l|l|}
\hline $\begin{array}{l}\text { SIM (indique ao lado em } \\
\text { que grau) }\end{array}$ & & MUITO APLICADOS \\
\cline { 2 - 3 } & & MEDIAMENTE APLICADOS \\
\hline
\end{tabular}




\begin{tabular}{|c|c|c|}
\hline & & POUCO APLICADOS \\
\hline \multirow{5}{*}{$\begin{array}{l}\text { NÃO (indique ao lado a } \\
\text { razão da não aplicação) }\end{array}$} & & $\begin{array}{l}\text { CONTEÚDO NÃO ADEQUADO ÀS NECESSIDADES } \\
\text { ESPECÍFICAS DA REGIÃO }\end{array}$ \\
\hline & $\bar{X}$ & $\begin{array}{l}\text { CONTEÚDO NÃO } \\
\text { APROFUNDADO PARA }\end{array}$ \\
\hline & & $\begin{array}{|lllllll|}\text { FALTA } & \text { DE } & \text { APOIO } & \text { E } & \text { INCENTIVO } & \text { DA } & \text { MINHA } \\
\text { INSTITUIÇÃO } & & & & \\
\end{array}$ \\
\hline & & FALTA DE INCENTIVO ÀS AÇÕES DE ATER \\
\hline & & NÃO TENHO INTERESSE EM APLICAR \\
\hline
\end{tabular}

6) A partir deste curso: (As opções não são excludentes: você poderá marcar mais de uma opção)

\begin{tabular}{|l|l|}
\hline$x$ & NÃO MUDOU NADA EM MEU TRABALHO. \\
\hline$X$ & $\begin{array}{l}\text { MEU TRABALHO PASSOU A CONTRIBUIR MAIS COM OS AGRICULTORES(AS) } \\
\text { FAMILIARES. }\end{array}$ \\
\hline & CONSEGUI INFLUENCIAR NAS ORIENTAÇÕES DA MINHA INSTITUIÇÃO. \\
\hline & $\begin{array}{l}\text { CRESSEI A TRABALHAR COM METODOLOGIAS PARTICIPATIVAS. } \\
\text { ONDE ATUO. }\end{array}$ \\
\hline & CONTINUEI ME APERFEIÇOANDO SOBRE TEMAS ABORDADOS. \\
\hline
\end{tabular}

7) Depois do curso você apoiou atividades de capacitação de técnicos e agricultores com base nos princípios e diretrizes da Pnater? (Considere como apoio a atividades de capacitação a participação no planejamento, elaboração de ementas, seleção de participantes e de palestrantes.) 


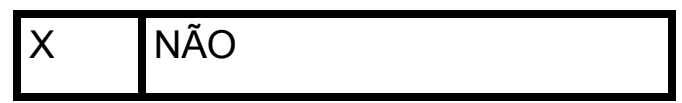

8) Usou os conhecimentos para ministrar outros cursos com o mesmo conteúdo ou conteúdos semelhantes?

\begin{tabular}{|l|l|}
\hline & SIM \\
\hline$X$ & NÃO \\
\hline
\end{tabular}

9) Marque o seu grau de satisfação com relação ao curso oferecido pelo DATER: (Considere a seguinte pontuação: 1 - MUITO RUIM; 2 - RUIM; 3 - REGULAR; 4 - BOM; 5 - MUITO BOM)

\begin{tabular}{|l|l|l|l|l|}
\hline 1 & 2 & 3 & 4 & 5 \\
\hline
\end{tabular}

10) Marque seu grau de satisfação com relação ao DATER: (Considere a seguinte pontuação: 1 - MUITO RUIM; 2 - RUIM; 3 - REGULAR; 4 - BOM; 5 - MUITO BOM)

\begin{tabular}{|l|l|l|l|l|}
\hline 1 & 2 & 3 & 4 & 5 \\
\hline
\end{tabular}


PESQUISA - IMPACTO DAS AÇÕES DE FORMAÇÃO REALIZADAS PELO DATER/SAF/MDA NO PERÍODO 2004-2009

Caros colaboradores,

Contamos com a sua atenção para preencher o formulário abaixo.

O mesmo tem por objetivo fornecer informações para avaliação da Eficiência, Efetividade e Eficácia da Política Pública de Formação de Agentes de Ater adotada pelo Departamento de Assistência Técnica e Extensão Rural, da Secretaria de Agricultura Familiar do Ministério do Desenvolvimento - DATER/SAF/MDA, no período de 2004 a 2009, tema escolhido para Monografia a ser apresentada à Universidade de Brasília (UnB) como requisito parcial para obtenção do grau de Bacharel em Administração.

Você poderá ou não se identificar no questionário e garantimos que todas as informações fornecidas serão confidenciais e utilizadas apenas de forma sistematizada.

\section{IDENTIFICAÇÃO}

\begin{tabular}{|c|c|}
\hline $\begin{array}{l}\text { Nome: FRANCISCO DE JESUS OLIVEIRA DE } \\
\text { ARAÚJO }\end{array}$ & $\begin{array}{l}\text { Sexo: } \\
(\quad x x) \text { masculino }\end{array}$ \\
\hline $\begin{array}{l}\text { Instituição (nome e tipo de instituição: ONG, } \\
\text { Empresa Pública, etc.): } \\
\text { Instituto de Desenvolvimento Agropecuário do } \\
\text { Estado do Amazonas - IDAM }\end{array}$ & $\begin{array}{l}\text { Local de trabalho (Cidade e Estado): } \\
\text { Unidade Local de Fonte Boa - Amazonas }\end{array}$ \\
\hline \multicolumn{2}{|c|}{$\begin{array}{l}\text { Curso/Encontro/Oficina do qual participou (caso tenha participado de mais de um curso, preencha } \\
\text { um formulário para cada um deles): } \\
\text { Curso de Agroecologia }\end{array}$} \\
\hline $\begin{array}{l}\text { Data do Curso/Encontro/Oficina (pelo menos mês } € \\
24 \text { a } 28 \text { de abril de } 2006 \text { - Manaus/AM }\end{array}$ & \\
\hline
\end{tabular}

Indique sua área de atuação? (As opções não são excludentes: você poderá marcar mais de uma opção)

\begin{tabular}{|l|l|}
\hline$X$ & EXTENSÃO RURAL \\
\hline & PESQUISA \\
\hline
\end{tabular}




\begin{tabular}{|l|l|}
\hline & ENSINO \\
\hline & OUTROS \\
\hline
\end{tabular}

2) Qual o seu nível de escolaridade? (Considere apenas o nível mais alto)

\begin{tabular}{|l|l|}
\hline$X$ & NÍVEL MÉDIO \\
\hline & NÍVEL SUPERIOR \\
\hline & PÓS-GRADUAÇÃO \\
\hline
\end{tabular}

3) Os conteúdos abordados foram condizentes com as demandas do seu dia-a-dia?

\begin{tabular}{|l|l|}
\hline$X$ & SIM \\
\hline & PARCIALMENTE \\
\hline & NÃO \\
\hline
\end{tabular}

3) O curso contribuiu para o seu aperfeiçoamento profissional?

\begin{tabular}{|l|l|}
\hline$X$ & SIM \\
\hline & NÃO \\
\hline
\end{tabular}

5) Os conhecimentos adquiridos estão sendo aplicados no seu trabalho? ? Em caso afirmativo, indique em que grau estes conhecimentos estão sendo aplicados. Em caso negativo, indique por que razão isto não ocorre: (Em caso negativo, as respostas não são excludentes: você poderá marcar mais de uma opção).

\begin{tabular}{|l|l|l|l|}
\hline \multirow{2}{*}{$\begin{array}{l}\text { SIM (indique ao lado em } \\
\text { que grau) }\end{array}$} & & MUITO APLICADOS \\
\cline { 2 - 3 } & & MEDIAMENTE APLICADOS \\
\cline { 2 - 3 } & & POUCO APLICADOS \\
\hline
\end{tabular}




\begin{tabular}{|c|c|c|}
\hline \multirow{5}{*}{$\begin{array}{l}\text { NÃO (indique ao lado a } \\
\text { razão da não aplicação) }\end{array}$} & & $\begin{array}{l}\text { CONTEÚDO NÃO ADEQUADO ȦS NECESSIDADES } \\
\text { ESPECÍFICAS DA REGIÃO }\end{array}$ \\
\hline & $\mathrm{X}$ & $\begin{array}{l}\text { CONTEÚDO NÃO } \quad \text { FOI SUFICIENTEMENTE } \\
\text { APROFUNDADO PARA } \\
\text { EERMITIR UMA APLICAÇÃO } \\
\text { EFICAZ E EFICIENTE }\end{array}$ \\
\hline & & $\begin{array}{|llllll|}\text { FALTA DE } & \text { APOIO } & \text { E } & \text { INCENTIVO } & \text { DA } & \text { MINHA } \\
\text { INSTITUIÇÃO } & & & & & \end{array}$ \\
\hline & & FALTA DE INCENTIVO ÀS AÇÕES DE ATER \\
\hline & & NÃO TENHO INTERESSE EM APLICAR \\
\hline
\end{tabular}

6) A partir deste curso: (As opções não são excludentes: você poderá marcar mais de uma opção)

\begin{tabular}{|l|l|}
\hline & NÃO MUDOU NADA EM MEU TRABALHO. \\
\hline & $\begin{array}{l}\text { MEU TRABALHO PASSOU A CONTRIBUIR MAIS COM OS AGRICULTORES(AS) } \\
\text { FAMILIARES. }\end{array}$ \\
\hline$X$ & CONSEGUI INFLUENCIAR NAS ORIENTAÇÕES DA MINHA INSTITUIÇÃO. \\
\hline & $\begin{array}{l}\text { CRESCEU A ÁREA DE AGRICULTURA DE BASE ECOLÓGICA NAS COMUNIDADES } \\
\text { ONDE ATUO. }\end{array}$ \\
\hline & CONTINUEI ME APERFEIÇOANDO SOBRE TEMAS ABORDADOS. \\
\hline
\end{tabular}

7) Depois do curso você apoiou atividades de capacitação de técnicos e agricultores com base nos princípios e diretrizes da Pnater? (Considere como apoio a atividades de capacitação a participação no planejamento, elaboração de ementas, seleção de participantes e de palestrantes.)

\begin{tabular}{|l|l|}
\hline & SIM \\
\hline & NÃO \\
\hline
\end{tabular}


8) Usou os conhecimentos para ministrar outros cursos com o mesmo conteúdo ou conteúdos semelhantes?

\begin{tabular}{|l|l|}
\hline & SIM \\
\hline$X$ & NÃO \\
\hline
\end{tabular}

9) Marque o seu grau de satisfação com relação ao curso oferecido pelo DATER: (Considere a seguinte pontuação: 1 - MUITO RUIM; 2 - RUIM; 3 - REGULAR; 4 - BOM; 5 - MUITO BOM)

\begin{tabular}{|l|l|l|l|l|}
\hline 1 & 2 & 3 & 4 & 5 \\
\hline
\end{tabular}

10) Marque seu grau de satisfação com relação ao DATER: (Considere a seguinte pontuação: 1 - MUITO RUIM; 2 - RUIM; 3 - REGULAR; 4 - BOM; 5 - MUITO BOM)

\begin{tabular}{|l|l|l|l|l|}
\hline 1 & 2 & 3 & 4 & 5 \\
\hline
\end{tabular}


PESQUISA - IMPACTO DAS AÇÕES DE FORMAÇÃO REALIZADAS PELO DATER/SAF/MDA NO PERÍODO 2004-2009

Caros colaboradores,

Contamos com a sua atenção para preencher o formulário abaixo.

O mesmo tem por objetivo fornecer informações para avaliação da Eficiência, Efetividade e Eficácia da Política Pública de Formação de Agentes de Ater adotada pelo Departamento de Assistência Técnica e Extensão Rural, da Secretaria de Agricultura Familiar do Ministério do Desenvolvimento - DATER/SAF/MDA, no período de 2004 a 2009, tema escolhido para Monografia a ser apresentada à Universidade de Brasília (UnB) como requisito parcial para obtenção do grau de Bacharel em Administração.

Você poderá ou não se identificar no questionário e garantimos que todas as informações fornecidas serão confidenciais e utilizadas apenas de forma sistematizada.

\section{IDENTIFICAÇÃO}

\begin{tabular}{|c|c|}
\hline Nome: FRANCISCO DA SILVA DANTAS & $\begin{array}{l}\text { Sexo: } \\
(\quad x x x) \text { masculino } \quad(\quad) \text { feminino }\end{array}$ \\
\hline $\begin{array}{l}\text { Instituição (nome e tipo de instituição: ONG, } \\
\text { Empresa Pública, etc.): } \\
\text { Instituto de Desenvolvimento Agropecuário do } \\
\text { Estado do Amazonas - IDAM }\end{array}$ & $\begin{array}{l}\text { Local de trabalho (Cidade e Estado): } \\
\text { Unidade Local de Codajás - Amazonas }\end{array}$ \\
\hline $\begin{array}{l}\text { Curso/Encontro/Oficina do qual participou (caso tenh } \\
\text { um formulário para cada um deles): } \\
\text { Seminário - Agroecologia como Estratégia para } \\
\text { Sustentável }\end{array}$ & $\begin{array}{l}\text { la participado de mais de um curso, preencha } \\
\text { a Construção do Desenvolvimento Rural }\end{array}$ \\
\hline $\begin{array}{l}\text { Data do Curso/Encontro/Oficina (pelo menos mês } \\
10 \text { e } 11 \text { de agosto de } 2006 \text { - Manaus/AM }\end{array}$ & \\
\hline
\end{tabular}

Indique sua área de atuação? (As opções não são excludentes: você poderá marcar mais de uma opção)

\begin{tabular}{|l|l|}
\hline$X$ & EXTENSÃO RURAL \\
\hline & PESQUISA \\
\hline
\end{tabular}




\begin{tabular}{|l|l|}
\hline & ENSINO \\
\hline & OUTROS \\
\hline
\end{tabular}

2) Qual o seu nível de escolaridade? (Considere apenas o nível mais alto)

\begin{tabular}{|l|l|}
\hline$X$ & NÍVEL MÉDIO \\
\hline & NÍVEL SUPERIOR \\
\hline & PÓS-GRADUAÇÃO \\
\hline
\end{tabular}

3) Os conteúdos abordados foram condizentes com as demandas do seu dia-a-dia?

\begin{tabular}{|l|l|}
\hline$X$ & SIM \\
\hline & PARCIALMENTE \\
\hline & NÃO \\
\hline
\end{tabular}

3) O curso contribuiu para o seu aperfeiçoamento profissional?

\begin{tabular}{|l|l|}
\hline$X$ & SIM \\
\hline & NÃO \\
\hline
\end{tabular}

5) Os conhecimentos adquiridos estão sendo aplicados no seu trabalho? Em caso afirmativo, indique em que grau estes conhecimentos estão sendo aplicados. Em caso negativo, indique por que razão isto não ocorre:

\begin{tabular}{|l|l|l|l|}
\hline \multirow{2}{*}{$\begin{array}{l}\text { SIM (indique ao lado em } \\
\text { que grau) }\end{array}$} & $X$ & MUITO APLICADOS \\
\cline { 2 - 4 } & & MEDIAMENTE APLICADOS \\
\cline { 2 - 4 } & & POUCO APLICADOS \\
\hline
\end{tabular}




\begin{tabular}{|c|c|}
\hline \multirow{5}{*}{$\begin{array}{l}\text { NÃO (indique ao lado a } \\
\text { razão da não aplicação) }\end{array}$} & $\begin{array}{l}\text { CONTEÚDO NÃO ADEQUADO ÀS NECESSIDADES } \\
\text { ESPECÍFICAS DA REGIÃO }\end{array}$ \\
\hline & $\begin{array}{l}\text { CONTEÚDO NÃO } \text { FOI SUFICIENTEMENTE } \\
\text { APROFUNDADO PARA } \\
\text { PERMITIR UMA APLICAÇÃO } \\
\text { EFICAZ E EFICIENTE }\end{array}$ \\
\hline & $\begin{array}{lllllll}\text { FALTA DE } & \text { APOIO } & \text { E } & \text { INCENTIVO } & \text { DA } & \text { MINHA } \\
\text { INSTITUIÇÃO } & & & & & \end{array}$ \\
\hline & FALTA DE INCENTIVO ÀS AÇÕES DE ATER \\
\hline & NÃO TENHO INTERESSE EM APLICAR \\
\hline
\end{tabular}

6) A partir deste curso: (As opções não são excludentes: você poderá marcar mais de uma opção)

\begin{tabular}{|l|l|}
\hline$x$ & $\begin{array}{l}\text { NÃO MUDOU NADA EM MEU TRABALHO. } \\
\text { FAMILIARES. }\end{array}$ \\
\hline$x$ & CONSEGUI INFLUENCIAR NAS ORIENTAÇÕES DA MINHA INSTITUIÇÃO. \\
\hline$X$ & $\begin{array}{l}\text { CRESCEU A ÁREA DE AGRICULTURA DE BASE ECOLÓGICA NAS COMUNIDADES } \\
\text { ONDE ATUO. }\end{array}$ \\
\hline & CONTINUEI ME APERFEIÇOANDO SOBRE TEMAS ABORDADOS. CONIBUIR MAIS COM OS AGRICULTORES(AS) \\
\hline
\end{tabular}

7) Depois do curso você apoiou atividades de capacitação de técnicos e agricultores com base nos princípios e diretrizes da Pnater? (Considere como apoio a atividades de capacitação a participação no planejamento, elaboração de ementas, seleção de participantes e de palestrantes.)

\begin{tabular}{|l|l|}
\hline$X$ & SIM \\
\hline & NÃO \\
\hline
\end{tabular}


8) Usou os conhecimentos para ministrar outros cursos com o mesmo conteúdo ou conteúdos semelhantes?

\begin{tabular}{|l|l|}
\hline$X$ & SIM \\
\hline & NÃO \\
\hline
\end{tabular}

9) Marque o seu grau de satisfação com relação ao curso oferecido pelo DATER: (Considere a seguinte pontuação: 1 - MUITO RUIM; 2 - RUIM; 3 - REGULAR; 4 - BOM; 5 - MUITO BOM)

\begin{tabular}{|l|l|l|l|l|}
\hline 1 & 2 & 3 & 4 & 5 \\
\hline
\end{tabular}

10) Marque seu grau de satisfação com relação ao DATER: (Considere a seguinte pontuação: 1 - MUITO RUIM; 2 - RUIM; 3 - REGULAR; 4 - BOM; 5 - MUITO BOM)

\begin{tabular}{|l|l|l|l|l|}
\hline 1 & 2 & 3 & 4 & 5 \\
\hline
\end{tabular}


PESQUISA - IMPACTO DAS AÇÕES DE FORMAÇÃO REALIZADAS PELO DATER/SAF/MDA NO PERÍODO 2004-2009

Caros colaboradores,

Contamos com a sua atenção para preencher o formulário abaixo.

O mesmo tem por objetivo fornecer informações para avaliação da Eficiência, Efetividade e Eficácia da Política Pública de Formação de Agentes de Ater adotada pelo Departamento de Assistência Técnica e Extensão Rural, da Secretaria de Agricultura Familiar do Ministério do Desenvolvimento - DATER/SAF/MDA, no período de 2004 a 2009, tema escolhido para Monografia a ser apresentada à Universidade de Brasília (UnB) como requisito parcial para obtenção do grau de Bacharel em Administração.

Você poderá ou não se identificar no questionário e garantimos que todas as informações fornecidas serão confidenciais e utilizadas apenas de forma sistematizada.

IDENTIFICAÇÃO

\begin{tabular}{|c|c|}
\hline Nome: FRANCISCO DE ASSIS DA SILVA COSTA & $\begin{array}{l}\text { Sexo: } \\
(x x) \text { masculino }\end{array}$ \\
\hline $\begin{array}{l}\text { Instituição (nome e tipo de instituição: ONG, } \\
\text { Empresa Pública, etc.): } \\
\text { Instituto de Desenvolvimento Agropecuário do } \\
\text { Estado do Amazonas - IDAM }\end{array}$ & $\begin{array}{l}\text { Local de trabalho (Cidade e Estado): } \\
\text { Unidade Local do Careiro da Várzea - } \\
\text { Amazonas }\end{array}$ \\
\hline \multicolumn{2}{|c|}{$\begin{array}{l}\text { Curso/Encontro/Oficina do qual participou (caso tenha participado de mais de um curso, preencha } \\
\text { um formulário para cada um deles): } \\
\text { Seminário - Agroecologia como Estratégia para a Construção do Desenvolvimento Rural } \\
\text { Sustentável }\end{array}$} \\
\hline $\begin{array}{l}\text { Data do Curso/Encontro/Oficina (pelo menos mês e } \\
16 \text { a } 27 \text { de outubro de } 2006 \text { - Manaus/AM }\end{array}$ & \\
\hline
\end{tabular}

Indique sua área de atuação? (As opções não são excludentes: você poderá marcar mais de uma opção)

\begin{tabular}{|l|l|}
\hline$X$ & EXTENSÃO RURAL \\
\hline & PESQUISA \\
\hline
\end{tabular}




\begin{tabular}{|l|l|}
\hline & ENSINO \\
\hline & OUTROS \\
\hline
\end{tabular}

2) Qual o seu nível de escolaridade? (Considere apenas o nível mais alto)

\begin{tabular}{|l|l|}
\hline$X$ & NÍVEL MÉDIO \\
\hline & NÍVEL SUPERIOR \\
\hline & PÓS-GRADUAÇÃO \\
\hline
\end{tabular}

3) Os conteúdos abordados foram condizentes com as demandas do seu dia-a-dia?

\begin{tabular}{|l|l|}
\hline$X$ & SIM \\
\hline & PARCIALMENTE \\
\hline & NÃO \\
\hline
\end{tabular}

3) O curso contribuiu para o seu aperfeiçoamento profissional?

\begin{tabular}{|l|l|}
\hline$X$ & SIM \\
\hline & NÃO \\
\hline
\end{tabular}

5) Os conhecimentos adquiridos estão sendo aplicados no seu trabalho? ? Em caso afirmativo, indique em que grau estes conhecimentos estão sendo aplicados. Em caso negativo, indique por que razão isto não ocorre: (Em caso negativo, as respostas não são excludentes: você poderá marcar mais de uma opção).

\begin{tabular}{|l|l|l|}
\hline \multirow{2}{*}{$\begin{array}{l}\text { SIM (indique ao lado em } \\
\text { que grau) }\end{array}$} & X & MUITO APLICADOS \\
\cline { 2 - 3 } & & MEDIAMENTE APLICADOS \\
\cline { 2 - 3 } & & POUCO APLICADOS \\
\hline
\end{tabular}




\begin{tabular}{|c|c|}
\hline \multirow{5}{*}{$\begin{array}{l}\text { NÃO (indique ao lado a } \\
\text { razão da não aplicação) }\end{array}$} & $\begin{array}{l}\text { CONTEÚDO NÃO ADEQUADO ȦS NECESSIDADES } \\
\text { ESPECÍFICAS DA REGIÃO }\end{array}$ \\
\hline & $\begin{array}{l}\text { CONTEÚDO NÃO FOI SUFICIENTEMENTE } \\
\text { APROFUNDADO PARA } \\
\text { PERMITIR UMA APLICAÇÃO } \\
\text { EFICAZ E EFICIENTE }\end{array}$ \\
\hline & $\begin{array}{l}\text { FALTA DE APOIO } \\
\text { INSTITUIÇÃO }\end{array}$ \\
\hline & FALTA DE INCENTIVO ÀS AÇÕES DE ATER \\
\hline & NÃO TENHO INTERESSE EM APLICAR \\
\hline
\end{tabular}

6) A partir deste curso: (As opções não são excludentes: você poderá marcar mais de uma opção)

\begin{tabular}{|l|l|}
\hline$x$ & $\begin{array}{l}\text { NÃO MUDOU NADA EM MEU TRABALHO. } \\
\text { FAMILIARES. }\end{array}$ \\
\hline & CONSEGUI INFLUENCIAR NAS ORIENTAÇÕES DA MINHA INSTITUIÇÃO. \\
\hline$X$ & PASSEI A TRABALHAR COM METODOLOGIAS PARTICIPATIVAS. \\
\hline & $\begin{array}{l}\text { CRESCEU A ÁREA DE AGRICULTURA DE BASE ECOLÓGICA NAS COMUNIDADES } \\
\text { ONDE ATUO. }\end{array}$ \\
\hline$X$ & CONTINUEI ME APERFEIÇOANDO SOBRE TEMAS ABORDADOS. \\
\hline
\end{tabular}

7) Depois do curso você apoiou atividades de capacitação de técnicos e agricultores com base nos princípios e diretrizes da Pnater? (Considere como apoio a atividades de capacitação a participação no planejamento, elaboração de ementas, seleção de participantes e de palestrantes.)

\begin{tabular}{|l|l|}
\hline$X$ & SIM \\
\hline & NÃO \\
\hline
\end{tabular}


8) Usou os conhecimentos para ministrar outros cursos com o mesmo conteúdo ou conteúdos semelhantes?

\begin{tabular}{|l|l|}
\hline$X$ & SIM \\
\hline & NÃO \\
\hline
\end{tabular}

9) Marque o seu grau de satisfação com relação ao curso oferecido pelo DATER: (Considere a seguinte pontuação: 1 - MUITO RUIM; 2 - RUIM; 3 - REGULAR; 4 - BOM; 5 - MUITO BOM)

\begin{tabular}{|l|l|l|l|l|}
\hline 1 & 2 & 3 & 4 & 5 \\
\hline
\end{tabular}

10) Marque seu grau de satisfação com relação ao DATER: (Considere a seguinte pontuação: 1 - MUITO RUIM; 2 - RUIM; 3 - REGULAR; 4 - BOM; 5 - MUITO BOM)

\begin{tabular}{|l|l|l|l|l|}
\hline 1 & 2 & 3 & 4 & 5 \\
\hline
\end{tabular}


PESQUISA - IMPACTO DAS AÇÕES DE FORMAÇÃO REALIZADAS PELO DATER/SAF/MDA NO PERÍODO 2004-2009

Caros colaboradores,

Contamos com a sua atenção para preencher o formulário abaixo.

O mesmo tem por objetivo fornecer informações para avaliação da Eficiência, Efetividade e Eficácia da Política Pública de Formação de Agentes de Ater adotada pelo Departamento de Assistência Técnica e Extensão Rural, da Secretaria de Agricultura Familiar do Ministério do Desenvolvimento - DATER/SAF/MDA, no período de 2004 a 2009, tema escolhido para Monografia a ser apresentada à Universidade de Brasília (UnB) como requisito parcial para obtenção do grau de Bacharel em Administração.

Você poderá ou não se identificar no questionário e garantimos que todas as informações fornecidas serão confidenciais e utilizadas apenas de forma sistematizada.

IDENTIFICAÇÃO

\begin{tabular}{|c|c|}
\hline Nome: FRANCISCO DE ASSIS DA SILVA COSTA & $\begin{array}{l}\text { Sexo: } \\
(x \quad) \text { masculino }\end{array}$ \\
\hline $\begin{array}{l}\text { Instituição (nome e tipo de instituição: ONG, } \\
\text { Empresa Pública, etc.): } \\
\text { Instituto de Desenvolvimento Agropecuário do } \\
\text { Estado do Amazonas - IDAM }\end{array}$ & $\begin{array}{l}\text { Local de trabalho (Cidade e Estado): } \\
\text { Unidade Local do Careiro da Várzea - } \\
\text { Amazonas }\end{array}$ \\
\hline \multicolumn{2}{|c|}{$\begin{array}{l}\text { Curso/Encontro/Oficina do qual participou (caso tenha participado de mais de um curso, preencha } \\
\text { um formulário para cada um deles): } \\
\text { II Encontro para Socialização dos Conceitos Básicos da Política Nacional de ATER }\end{array}$} \\
\hline $\begin{array}{l}\text { Data do Curso/Encontro/Oficina (pelo menos mês } \\
04 \text { a } 08 \text { de dezembro de } 2006 \text { - Manaus/AM }\end{array}$ & \\
\hline
\end{tabular}

Indique sua área de atuação? (As opções não são excludentes: você poderá marcar mais de uma opção)

\begin{tabular}{|l|l|}
\hline$X$ & EXTENSÃO RURAL \\
\hline & PESQUISA \\
\hline
\end{tabular}




\begin{tabular}{|l|l|}
\hline & ENSINO \\
\hline & OUTROS \\
\hline
\end{tabular}

2) Qual o seu nível de escolaridade? (Considere apenas o nível mais alto)

\begin{tabular}{|l|l|}
\hline$X$ & NÍVEL MÉDIO \\
\hline & NÍVEL SUPERIOR \\
\hline & PÓS-GRADUAÇÃO \\
\hline
\end{tabular}

3) Os conteúdos abordados foram condizentes com as demandas do seu dia-a-dia?

\begin{tabular}{|l|l|}
\hline$X$ & SIM \\
\hline & PARCIALMENTE \\
\hline & NÃO \\
\hline
\end{tabular}

3) O curso contribuiu para o seu aperfeiçoamento profissional?

\begin{tabular}{|l|l|}
\hline$X$ & SIM \\
\hline & NÃO \\
\hline
\end{tabular}

5) Os conhecimentos adquiridos estão sendo aplicados no seu trabalho? ? Em caso afirmativo, indique em que grau estes conhecimentos estão sendo aplicados. Em caso negativo, indique por que razão isto não ocorre: (Em caso negativo, as respostas não são excludentes: você poderá marcar mais de uma opção).

\begin{tabular}{|l|l|l|}
\hline \multirow{2}{*}{$\begin{array}{l}\text { SIM (indique ao lado em } \\
\text { que grau) }\end{array}$} & X & MUITO APLICADOS \\
\cline { 2 - 3 } & & MEDIAMENTE APLICADOS \\
\cline { 2 - 3 } & & POUCO APLICADOS \\
\hline
\end{tabular}




\begin{tabular}{|c|c|}
\hline \multirow{5}{*}{$\begin{array}{l}\text { NÃO (indique ao lado a } \\
\text { razão da não aplicação) }\end{array}$} & $\begin{array}{l}\text { CONTEÚDO NÃO ADEQUADO ÀS NECESSIDADES } \\
\text { ESPECÍFICAS DA REGIÃO }\end{array}$ \\
\hline & $\begin{array}{l}\text { CONTEÚDO NÃO } \text { FOI SUFICIENTEMENTE } \\
\text { APROFUNDADO PARA } \\
\text { EERMITIR UMA APLICAÇÃO } \\
\text { EFICAZ E EFICIENTE }\end{array}$ \\
\hline & $\begin{array}{llllll}\text { FALTA DE } & \text { APOIO } & \text { E } & \text { INCENTIVO } & \text { DA } & \text { MINHA } \\
\text { INSTITUIÇÃO } & & & & & \\
\end{array}$ \\
\hline & FALTA DE INCENTIVO ÀS AÇÕES DE ATER \\
\hline & NÃO TENHO INTERESSE EM APLICAR \\
\hline
\end{tabular}

6) A partir deste curso: (As opções não são excludentes: você poderá marcar mais de uma opção)

\begin{tabular}{|l|l|}
\hline & NÃO MUDOU NADA EM MEU TRABALHO. \\
\hline$X$ & $\begin{array}{l}\text { MEU TRABALHO PASSOU A CONTRIBUIR MAIS COM OS AGRICULTORES(AS) } \\
\text { FAMILIARES. }\end{array}$ \\
\hline$x$ & CONSEGUI INFLUENCIAR NAS ORIENTAÇÕES DA MINHA INSTITUIÇÃO. \\
\hline & $\begin{array}{l}\text { CRESCEU A ÁREA DE AGRICULTURA DE BASE ECOLÓGICA NAS COMUNIDADES } \\
\text { ONDE ATUO. }\end{array}$ \\
\hline$X$ & CONTINUEI ME APERFEIÇOANDO SOBRE TEMAS ABORDADOS. \\
\hline
\end{tabular}

7) Depois do curso você apoiou atividades de capacitação de técnicos e agricultores com base nos princípios e diretrizes da Pnater? (Considere como apoio a atividades de capacitação a participação no planejamento, elaboração de ementas, seleção de participantes e de palestrantes.)

\begin{tabular}{|l|l|}
\hline$X$ & SIM \\
\hline & NÃO \\
\hline
\end{tabular}


8) Usou os conhecimentos para ministrar outros cursos com o mesmo conteúdo ou conteúdos semelhantes?

\begin{tabular}{|l|l|}
\hline$X$ & SIM \\
\hline & NÃO \\
\hline
\end{tabular}

9) Marque o seu grau de satisfação com relação ao curso oferecido pelo DATER: (Considere a seguinte pontuação: 1 - MUITO RUIM; 2 - RUIM; 3 - REGULAR; 4 - BOM; 5 - MUITO BOM)

\begin{tabular}{|l|l|l|l|l|}
\hline 1 & 2 & 3 & 4 & 5 \\
\hline
\end{tabular}

10) Marque seu grau de satisfação com relação ao DATER: (Considere a seguinte pontuação: 1 - MUITO RUIM; 2 - RUIM; 3 - REGULAR; 4 - BOM; 5 - MUITO BOM)

\begin{tabular}{|l|l|l|l|l|}
\hline 1 & 2 & 3 & 4 & 5 \\
\hline
\end{tabular}


PESQUISA - IMPACTO DAS AÇÕES DE FORMAÇÃO REALIZADAS PELO DATER/SAF/MDA NO PERÍODO 2004-2009

Caros colaboradores,

Contamos com a sua atenção para preencher o formulário abaixo.

O mesmo tem por objetivo fornecer informações para avaliação da Eficiência, Efetividade e Eficácia da Política Pública de Formação de Agentes de Ater adotada pelo Departamento de Assistência Técnica e Extensão Rural, da Secretaria de Agricultura Familiar do Ministério do Desenvolvimento - DATER/SAF/MDA, no período de 2004 a 2009, tema escolhido para Monografia a ser apresentada à Universidade de Brasília (UnB) como requisito parcial para obtenção do grau de Bacharel em Administração.

Você poderá ou não se identificar no questionário e garantimos que todas as informações fornecidas serão confidenciais e utilizadas apenas de forma sistematizada.

\section{IDENTIFICAÇÃO}

\begin{tabular}{|c|c|}
\hline Nome: JOSÉ MARIA FRADE JÚNIOR & $\begin{array}{l}\text { Sexo: } \\
(\mathrm{x}) \text { masculino }\end{array}$ \\
\hline $\begin{array}{l}\text { Instituição (nome e tipo de instituição: ONG, } \\
\text { Empresa Pública, etc.): } \\
\text { Instituto de Desenvolvimento Agropecuário do } \\
\text { Estado do Amazonas - IDAM }\end{array}$ & $\begin{array}{l}\text { Local de trabalho (Cidade e Estado): } \\
\text { Manaus-AM }\end{array}$ \\
\hline \multicolumn{2}{|c|}{$\begin{array}{l}\text { Curso/Encontro/Oficina do qual participou (caso tenha participado de mais de um curso, preencha } \\
\text { um formulário para cada um deles): } \\
\text { Curso de Especialização em Extensão Rural, para o desenvolvimento sustentável da Amazônia. }\end{array}$} \\
\hline $\begin{array}{l}\text { Data do Curso/Encontro/Oficina (pelo menos mês e } \\
11 \text { de outubro de } 2005 \text { a abril de } 2006 \text { - Belém/PA }\end{array}$ & \\
\hline
\end{tabular}

Indique sua área de atuação? (As opções não são excludentes: você poderá marcar mais de uma opção)

\begin{tabular}{|l|l|}
\hline$X$ & EXTENSÃO RURAL \\
\hline & PESQUISA \\
\hline & ENSINO \\
\hline
\end{tabular}


OUTROS

2) Qual o seu nível de escolaridade? (Considere apenas o nível mais alto)

\begin{tabular}{|l|l|}
\hline & NÍVEL MÉDIO \\
\hline & NÍVEL SUPERIOR \\
\hline$X$ & PÓS-GRADUAÇÃO \\
\hline
\end{tabular}

3) Os conteúdos abordados foram condizentes com as demandas do seu dia-a-dia?

\begin{tabular}{|l|l|}
\hline$X$ & SIM \\
\hline & PARCIALMENTE \\
\hline & NÃO \\
\hline
\end{tabular}

3) O curso contribuiu para o seu aperfeiçoamento profissional?

\begin{tabular}{|l|l|}
\hline$X$ & SIM \\
\hline & NÃO \\
\hline
\end{tabular}

5) Os conhecimentos adquiridos estão sendo aplicados no seu trabalho? ? Em caso afirmativo, indique em que grau estes conhecimentos estão sendo aplicados. Em caso negativo, indique por que razão isto não ocorre: (Em caso negativo, as respostas não são excludentes: você poderá marcar mais de uma opção).

\begin{tabular}{|l|l|l|l|}
\hline \multirow{2}{*}{$\begin{array}{l}\text { SIM (indique ao lado } \\
\text { em que grau) }\end{array}$} & X & MUITO APLICADOS \\
\cline { 2 - 3 } & & MEDIAMENTE APLICADOS \\
\cline { 2 - 3 } & $\begin{array}{l}\text { NÃO (indique ao lado a } \\
\text { razão da não aplicação) }\end{array}$ & $\begin{array}{l}\text { CONCO APLICADOS } \\
\text { ESPECÍFICAS DA REGIÃO }\end{array}$ \\
\hline
\end{tabular}




\begin{tabular}{|l|l|l|}
\hline \multirow{3}{*}{} & & $\begin{array}{l}\text { CONTEÚDO NÃO FOI SUFICIENTEMENTE } \\
\text { APROFUNDADO PARA PERMITIR UMA APLICAÇÃO } \\
\text { EFICAZ E EFICIENTE }\end{array}$ \\
\cline { 2 - 4 } & $\begin{array}{l}\text { FALTA DE APOIO E INCENTIVO DA MINHA } \\
\text { INSTITUIÇÃO }\end{array}$ \\
\cline { 2 - 4 } & FALTA DE INCENTIVO ÀS AÇÕES DE ATER \\
\cline { 2 - 4 } & NÃO TENHO INTERESSE EM APLICAR \\
\hline
\end{tabular}

6) A partir deste curso: (As opções não são excludentes: você poderá marcar mais de uma opção)

\begin{tabular}{|l|l|}
\hline & NÃO MUDOU NADA EM MEU TRABALHO. \\
\hline$X$ & $\begin{array}{l}\text { MEU TRABALHO PASSOU A CONTRIBUIR MAIS COM OS AGRICULTORES(AS) } \\
\text { FAMILIARES. }\end{array}$ \\
\hline$X$ & CONSEGUI INFLUENCIAR NAS ORIENTAÇÕES DA MINHA INSTITUIÇÃO. \\
\hline$X$ & PASSEI A TRABALHAR COM METODOLOGIAS PARTICIPATIVAS. \\
\hline$X$ & $\begin{array}{l}\text { CRESCEU A ÁREA DE AGRICULTURA DE BASE ECOLÓGICA NAS COMUNIDADES } \\
\text { ONDE ATUO. }\end{array}$ \\
\hline
\end{tabular}

7) Depois do curso você apoiou atividades de capacitação de técnicos e agricultores com base nos princípios e diretrizes da Pnater? (Considere como apoio a atividades de capacitação a participação no planejamento, elaboração de ementas, seleção de participantes e de palestrantes.)

\begin{tabular}{|l|l|}
\hline$X$ & SIM \\
\hline & NÃO \\
\hline
\end{tabular}

8) Usou os conhecimentos para ministrar outros cursos com o mesmo conteúdo ou conteúdos semelhantes? 


\begin{tabular}{|l|l|}
\hline & SIM \\
\hline$X$ & Ainda NÃO \\
\hline
\end{tabular}

9) Marque o seu grau de satisfação com relação ao curso oferecido pelo DATER: (Considere a seguinte pontuação: 1 - MUITO RUIM; 2 - RUIM; 3 - REGULAR; 4 - BOM; 5 - MUITO BOM)

\begin{tabular}{|l|l|l|l|l|}
\hline 1 & 2 & 3 & 4 & 5 \\
\hline
\end{tabular}

10) Marque seu grau de satisfação com relação ao DATER: (Considere a seguinte pontuação:

1 - MUITO RUIM; 2 - RUIM; 3 - REGULAR; 4 - BOM; 5 - MUITO BOM)

\begin{tabular}{|l|l|l|l|l|}
\hline 1 & 2 & 3 & 4 & 5 \\
\hline
\end{tabular}




\section{PESQUISA - IMPACTO DAS AÇÕES DE FORMAÇÃO REALIZADAS PELO DATER/SAF/MDA NO PERÍODO 2004-2009}

Caros colaboradores,

Contamos com a sua atenção para preencher o formulário abaixo.

O mesmo tem por objetivo fornecer informações para avaliação da Eficiência, Efetividade e Eficácia da Política Pública de Formação de Agentes de Ater adotada pelo Departamento de Assistência Técnica e Extensão Rural, da Secretaria de Agricultura Familiar do Ministério do Desenvolvimento - DATER/SAF/MDA, no período de 2004 a 2009, tema escolhido para Monografia a ser apresentada à Universidade de Brasília (UnB) como requisito parcial para obtenção do grau de Bacharel em Administração.

Você poderá ou não se identificar no questionário e garantimos que todas as informações fornecidas serão confidenciais e utilizadas apenas de forma sistematizada.

IDENTIFICAÇÃO

\begin{tabular}{|c|c|}
\hline Nome: FERNANDO CORREIA LIMA & $\begin{array}{l}\text { Sexo: } \\
(\quad \mathbf{x x x}) \text { masculino }\end{array}$ \\
\hline $\begin{array}{l}\text { Instituição (nome e tipo de instituição: ONG, } \\
\text { Empresa Pública, etc.): } \\
\text { Instituto de Desenvolvimento Agropecuário do } \\
\text { Estado do Amazonas - IDAM }\end{array}$ & $\begin{array}{l}\text { Local de trabalho (Cidade e Estado): } \\
\text { Unidade Local de Itapiranga - Amazonas }\end{array}$ \\
\hline \multicolumn{2}{|c|}{$\begin{array}{l}\text { Curso/Encontro/Oficina do qual participou (caso tenha participado de mais de um curso, } \\
\text { preencha um formulário para cada um deles): } \\
\text { II Encontro para Socialização dos Conceitos Básicos da Política Nacional de ATER }\end{array}$} \\
\hline \multicolumn{2}{|c|}{$\begin{array}{l}\text { Data do Curso/Encontro/Oficina (pelo menos mês e ano): } \\
04 \text { a } 08 \text { de dezembro de } 2006 \text { - Manaus/AM }\end{array}$} \\
\hline
\end{tabular}

Indique sua área de atuação? (As opções não são excludentes: você poderá marcar mais de uma opção)

\begin{tabular}{|l|l|}
\hline$X$ & EXTENSÃO RURAL \\
\hline & PESQUISA \\
\hline
\end{tabular}




\begin{tabular}{|l|l|}
\hline & ENSINO \\
\hline & OUTROS \\
\hline
\end{tabular}

2) Qual o seu nível de escolaridade? (Considere apenas o nível mais alto)

\begin{tabular}{|l|l|}
\hline$X$ & NÍVEL MÉDIO \\
\hline & NÍVEL SUPERIOR \\
\hline & PÓS-GRADUAÇÃO \\
\hline
\end{tabular}

3) Os conteúdos abordados foram condizentes com as demandas do seu dia-a-dia?

\begin{tabular}{|l|l|}
\hline$X$ & SIM \\
\hline & PARCIALMENTE \\
\hline & NÃO \\
\hline
\end{tabular}

3) O curso contribuiu para o seu aperfeiçoamento profissional?

\begin{tabular}{|l|l|}
\hline$X$ & SIM \\
\hline & NÃO \\
\hline
\end{tabular}

5) Os conhecimentos adquiridos estão sendo aplicados no seu trabalho? ? Em caso afirmativo, indique em que grau estes conhecimentos estão sendo aplicados. Em caso negativo, indique por que razão isto não ocorre: (Em caso negativo, as respostas não são excludentes: você poderá marcar mais de uma opção).

\begin{tabular}{|l|l|l|l|}
\hline \multirow{2}{*}{$\begin{array}{l}\text { SIM (indique ao lado } \\
\text { em que grau) }\end{array}$} & $X$ & MUITO APLICADOS \\
\cline { 2 - 4 } & & MEDIAMENTE APLICADOS \\
\hline
\end{tabular}




\begin{tabular}{|c|c|}
\hline \multirow{5}{*}{$\begin{array}{l}\text { NÃO (indique ao lado a } \\
\text { razão da não aplicação) }\end{array}$} & $\begin{array}{l}\text { CONTEÚDO NĀO ADEQUADO ȦS NECESSIDADES } \\
\text { ESPECÍFICAS DA REGIÃO }\end{array}$ \\
\hline & $\begin{array}{l}\text { CONTEÚDO NÃO FOI SUFICIENTEMENTE } \\
\text { APROFUNDADO PARA PERMITIR UMA APLICAÇÃO } \\
\text { EFICAZ E EFICIENTE }\end{array}$ \\
\hline & \begin{tabular}{|llllll} 
FALTA DE & APOIO & E & INCENTIVO & DA & MINHA \\
INSTITUIÇÃO & & & & &
\end{tabular} \\
\hline & FALTA DE INCENTIVO ÀS AÇÕES DE ATER \\
\hline & NÃO TENHO INTERESSE EM APLICAR \\
\hline
\end{tabular}

6) A partir deste curso: (As opções não são excludentes: você poderá marcar mais de uma opção)

\begin{tabular}{|l|l|}
\hline & NÃO MUDOU NADA EM MEU TRABALHO. \\
\hline & $\begin{array}{l}\text { MEU TRABALHO PASSOU A CONTRIBUIR MAIS COM OS AGRICULTORES(AS) } \\
\text { FAMILIARES. }\end{array}$ \\
\hline & CONSEGUI INFLUENCIAR NAS ORIENTAÇÕES DA MINHA INSTITUIÇÃO. \\
\hline & $\begin{array}{l}\text { CASSEI A TRABALHAR COM METODOLOGIAS PARTICIPATIVAS. } \\
\text { ONDE ATUO. }\end{array}$ \\
\hline$X$ & CONTINUEI ME APERFEIÇOANDO SOBRE TEMAS ABORDADOS. \\
\hline
\end{tabular}

7) Depois do curso você apoiou atividades de capacitação de técnicos e agricultores com base nos princípios e diretrizes da Pnater? (Considere como apoio a atividades de capacitação a participação no planejamento, elaboração de ementas, seleção de participantes e de palestrantes.)

\begin{tabular}{|l|l|}
\hline$X$ & SIM \\
\hline & NÃO \\
\hline
\end{tabular}


8) Usou os conhecimentos para ministrar outros cursos com o mesmo conteúdo ou conteúdos semelhantes?

\begin{tabular}{|l|l|}
\hline & SIM \\
\hline$X$ & NÃO \\
\hline
\end{tabular}

9) Marque o seu grau de satisfação com relação ao curso oferecido pelo DATER: (Considere a seguinte pontuação: 1 - MUITO RUIM; 2 - RUIM; 3 - REGULAR; 4 - BOM; 5 - MUITO BOM)

\begin{tabular}{|l|l|l|l|l|}
\hline 1 & 2 & 3 & 4 & 5 \\
\hline
\end{tabular}

10) Marque seu grau de satisfação com relação ao DATER: (Considere a seguinte pontuação: 1 - MUITO RUIM; 2 - RUIM; 3 - REGULAR; 4 - BOM; 5 - MUITO BOM)

\begin{tabular}{|l|l|l|l|l|}
\hline 1 & 2 & 3 & 4 & 5 \\
\hline
\end{tabular}

Obs: As notas atribuídas as questões 9 e 10 devem obedecer a ordem crescente: 1 - muito ruim , 2 - ruim, 3 - regular, 4 - bom, 5 - muito bom. 


\section{PESQUISA - IMPACTO DAS AÇÕES DE FORMAÇÃO REALIZADAS PELO DATER/SAF/MDA NO PERÍODO 2004-2009}

Caros colaboradores,

Contamos com a sua atenção para preencher o formulário abaixo.

O mesmo tem por objetivo fornecer informações para avaliação da Eficiência, Efetividade e Eficácia da Política Pública de Formação de Agentes de Ater adotada pelo Departamento de Assistência Técnica e Extensão Rural, da Secretaria de Agricultura Familiar do Ministério do Desenvolvimento - DATER/SAF/MDA, no período de 2004 a 2009, tema escolhido para Monografia a ser apresentada à Universidade de Brasília (UnB) como requisito parcial para obtenção do grau de Bacharel em Administração.

Você poderá ou não se identificar no questionário e garantimos que todas as informações fornecidas serão confidenciais e utilizadas apenas de forma sistematizada.

IDENTIFICAÇÃO

\begin{tabular}{|c|c|}
\hline $\begin{array}{l}\text { Nome: FÁBIO HOLDER DE MORAIS HOLANDA } \\
\text { CAVALCANTI }\end{array}$ & $\begin{array}{l}\text { Sexo: } \\
(\mathbf{x x x}) \text { masculino } \quad(\quad) \text { feminino }\end{array}$ \\
\hline $\begin{array}{l}\text { Instituição (nome e tipo de instituição: ONG, } \\
\text { Empresa Pública, etc.): } \\
\text { Instituto de Desenvolvimento Agropecuário do } \\
\text { Estado do Amazonas - IDAM }\end{array}$ & $\begin{array}{l}\text { Local de trabalho (Cidade e Estado): } \\
\text { Manaus - AM }\end{array}$ \\
\hline $\begin{array}{l}\text { Curso/Encontro/Oficina do qual participou (cas } \\
\text { preencha um formulário para cada um deles): } \\
\text { Seminário - Agroecologia como Estratégia para } \\
\text { Sustentável. }\end{array}$ & $\begin{array}{l}\text { o tenha participado de mais de um curso, } \\
\text { a Construção do Desenvolvimento Rural }\end{array}$ \\
\hline $\begin{array}{l}\text { Data do Curso/Encontro/Oficina (pelo menos mê } \\
10 \text { a } 11 \text { de agosto de } 2006 \text { - Manaus/AM }\end{array}$ & \\
\hline
\end{tabular}

Indique sua área de atuação? (As opções não são excludentes: você poderá marcar mais de uma opção)

\begin{tabular}{|l|l|}
\hline$X$ & EXTENSÃO RURAL \\
\hline & PESQUISA \\
\hline
\end{tabular}




\begin{tabular}{|l|l|}
\hline & ENSINO \\
\hline & OUTROS \\
\hline
\end{tabular}

2) Qual o seu nível de escolaridade? (Considere apenas o nível mais alto)

\begin{tabular}{|l|l|}
\hline & NÍVEL MÉDIO \\
\hline$X$ & NÍVEL SUPERIOR \\
\hline & PÓS-GRADUAÇÃO \\
\hline
\end{tabular}

3) Os conteúdos abordados foram condizentes com as demandas do seu dia-a-dia?

\begin{tabular}{|l|l|}
\hline$X$ & SIM \\
\hline & PARCIALMENTE \\
\hline & NÃO \\
\hline
\end{tabular}

3) O curso contribuiu para o seu aperfeiçoamento profissional?

\begin{tabular}{|l|l|}
\hline$X$ & SIM \\
\hline & NÃO \\
\hline
\end{tabular}

5) Os conhecimentos adquiridos estão sendo aplicados no seu trabalho? ? Em caso afirmativo, indique em que grau estes conhecimentos estão sendo aplicados. Em caso negativo, indique por que razão isto não ocorre: (Em caso negativo, as respostas não são excludentes: você poderá marcar mais de uma opção).

\begin{tabular}{|l|l|l|l|}
\hline \multirow{2}{*}{$\begin{array}{l}\text { SIM (indique ao lado } \\
\text { em que grau) }\end{array}$} & MUITO APLICADOS \\
\cline { 2 - 3 } & & MEDIAMENTE APLICADOS \\
\hline & $\begin{array}{l}\text { NÃO (indique ao lado a } \\
\text { razão da não aplicação) }\end{array}$ & & $\begin{array}{l}\text { CONTEÚDO NÃO ADEQUADO ÀS NECESSIDADES } \\
\text { ESPECÍFICAS DA REGIÃO }\end{array}$ \\
\hline
\end{tabular}




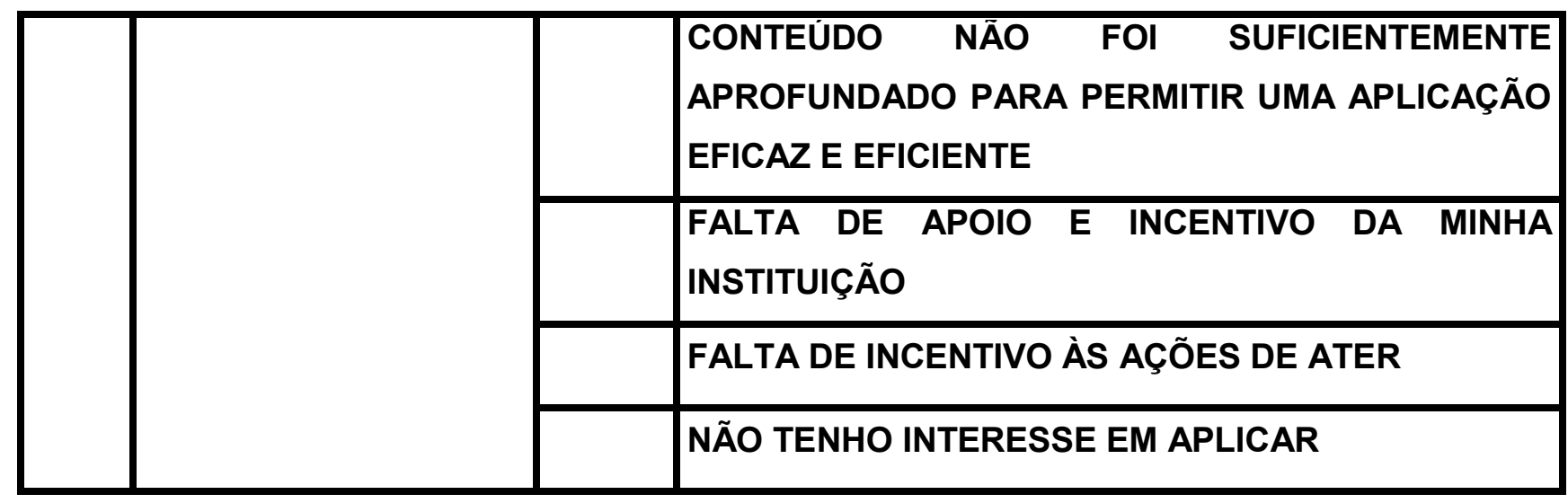

6) A partir deste curso: (As opções não são excludentes: você poderá marcar mais de uma opção)

\begin{tabular}{|l|l|}
\hline & NÃO MUDOU NADA EM MEU TRABALHO. \\
\hline$X$ & $\begin{array}{l}\text { MEU TRABALHO PASSOU A CONTRIBUIR MAIS COM OS AGRICULTORES(AS) } \\
\text { FAMILIARES. }\end{array}$ \\
\hline$X$ & CONSEGUI INFLUENCIAR NAS ORIENTAÇÕES DA MINHA INSTITUIÇÃO. \\
\hline$X$ & PASSEI A TRABALHAR COM METODOLOGIAS PARTICIPATIVAS. \\
\hline$X$ & $\begin{array}{l}\text { CRESCEU A AREA DE AGRICULTURA DE BASE ECOLÓGICA NAS COMUNIDADES } \\
\text { ONDE ATUO. }\end{array}$ \\
\hline$X$ & CONTINUEI ME APERFEIÇOANDO SOBRE TEMAS ABORDADOS. \\
\hline
\end{tabular}

7) Depois do curso você apoiou atividades de capacitação de técnicos e agricultores com base nos princípios e diretrizes da Pnater?

(Considere como apoio a atividades de capacitação a participação no planejamento, elaboração de ementas, seleção de participantes e de palestrantes.)

\begin{tabular}{|l|l|}
\hline$X$ & SIM \\
\hline & NÃO \\
\hline
\end{tabular}

8) Usou os conhecimentos para ministrar outros cursos com o mesmo conteúdo ou conteúdos semelhantes? 


\begin{tabular}{|l|l|}
\hline & SIM \\
\hline$X$ & NÃO \\
\hline
\end{tabular}

9) Marque o seu grau de satisfação com relação ao curso oferecido pelo DATER: (Considere a seguinte pontuação: 1 - MUITO RUIM; 2 - RUIM; 3 - REGULAR; 4 - BOM; 5 - MUITO BOM)

\begin{tabular}{|l|l|l|l|l|}
\hline 1 & 2 & 3 & 4 & 5 \\
\hline
\end{tabular}

10) Marque seu grau de satisfação com relação ao DATER: (Considere a seguinte pontuação:

1 - MUITO RUIM; 2 - RUIM; 3 - REGULAR; 4 - BOM; 5 - MUITO BOM)

\begin{tabular}{|l|l|l|l|l|}
\hline 1 & 2 & 3 & 4 & 5 \\
\hline
\end{tabular}




\section{PESQUISA - IMPACTO DAS AÇÕES DE FORMAÇÃO REALIZADAS PELO DATER/SAF/MDA NO PERÍODO 2004-2009}

Caros colaboradores,

Contamos com a sua atenção para preencher o formulário abaixo.

O mesmo tem por objetivo fornecer informações para avaliação da Eficiência, Efetividade e Eficácia da Política Pública de Formação de Agentes de Ater adotada pelo Departamento de Assistência Técnica e Extensão Rural, da Secretaria de Agricultura Familiar do Ministério do Desenvolvimento - DATER/SAF/MDA, no período de 2004 a 2009, tema escolhido para Monografia a ser apresentada à Universidade de Brasília (UnB) como requisito parcial para obtenção do grau de Bacharel em Administração.

Você poderá ou não se identificar no questionário e garantimos que todas as informações fornecidas serão confidenciais e utilizadas apenas de forma sistematizada.

IDENTIFICAÇÃO

\begin{tabular}{|c|c|}
\hline Nome: EZALDIR DE SOUZA & $\begin{array}{l}\text { Sexo: } \\
(\quad) \text { masculino }(\mathbf{x x x}) \text { feminino }\end{array}$ \\
\hline $\begin{array}{l}\text { Instituição (nome e tipo de instituição: ONG, } \\
\text { Empresa Pública, etc.): } \\
\text { Instituto de Desenvolvimento Agropecuário do } \\
\text { Estado do Amazonas - IDAM }\end{array}$ & $\begin{array}{l}\text { Local de trabalho (Cidade e Estado): } \\
\text { Unidade Local de Urucurituba - Amazonas }\end{array}$ \\
\hline $\begin{array}{l}\text { Curso/Encontro/Oficina do qual participou (casc } \\
\text { preencha um formulário para cada um deles): } \\
\text { Seminário - Agroecologia como Estratégia para } \\
\text { Sustentável }\end{array}$ & $\begin{array}{l}\text { o tenha participado de mais de um curso, } \\
\text { a Construção do Desenvolvimento Rura }\end{array}$ \\
\hline $\begin{array}{l}\text { Data do Curso/Encontro/Oficina (pelo menos mês } \\
11 \text { de agosto de } 2006 \text { - Manaus/AM }\end{array}$ & \\
\hline
\end{tabular}

Indique sua área de atuação? (As opções não são excludentes: você poderá marcar mais de uma opção)

\begin{tabular}{|l|l|}
\hline$X$ & EXTENSÃO RURAL \\
\hline & PESQUISA \\
\hline
\end{tabular}




\begin{tabular}{|l|l|}
\hline & ENSINO \\
\hline & OUTROS \\
\hline
\end{tabular}

2) Qual o seu nível de escolaridade? (Considere apenas o nível mais alto)

\begin{tabular}{|l|l|}
\hline$X$ & NÍVEL MÉDIO \\
\hline & NÍVEL SUPERIOR \\
\hline & PÓS-GRADUAÇÃO \\
\hline
\end{tabular}

3) Os conteúdos abordados foram condizentes com as demandas do seu dia-a-dia?

\begin{tabular}{|l|l|}
\hline$X$ & SIM \\
\hline & PARCIALMENTE \\
\hline & NÃO \\
\hline
\end{tabular}

3) O curso contribuiu para o seu aperfeiçoamento profissional?

\begin{tabular}{|l|l|}
\hline$X$ & SIM \\
\hline & NÃO \\
\hline
\end{tabular}

5) Os conhecimentos adquiridos estão sendo aplicados no seu trabalho? Em caso afirmativo, indique em que grau estes conhecimentos estão sendo aplicados. Em caso negativo, indique por que razão isto não ocorre: (Em caso negativo, as respostas não são excludentes: você poderá marcar mais de uma opção).

\begin{tabular}{|l|l|l|}
\hline \multirow{2}{*}{$\begin{array}{l}\text { SIM (indique ao lado } \\
\text { em que grau) }\end{array}$} & & MUITO APLICADOS \\
\cline { 2 - 3 } & & MEDIAMENTE APLICADOS \\
\hline
\end{tabular}




\begin{tabular}{|c|c|c|}
\hline \multirow{5}{*}{$\begin{array}{l}\text { NÃO (indique ao lado a } \\
\text { razão da não aplicação) }\end{array}$} & & $\begin{array}{l}\text { CONTEÚDO NĀO ADEQUADO ȦS NECESSIDADES } \\
\text { ESPECÍFICAS DA REGIÃO }\end{array}$ \\
\hline & $\bar{x}$ & $\begin{array}{l}\text { CONTEÚDO NÃO } \text { FOI SUFICIENTEMENTE } \\
\text { APROFUNDADO PARA PERMITIR UMA APLICAÇÃO } \\
\text { EFICAZ E EFICIENTE }\end{array}$ \\
\hline & & $\begin{array}{l}\text { FALTA DE APOIO E } \\
\text { INSTITUIÇÃO }\end{array}$ \\
\hline & & FALTA DE INCENTIVO ÀS AÇÕES DE ATER \\
\hline & & NÃO TENHO INTERESSE EM APLICAR \\
\hline
\end{tabular}

6) A partir deste curso: (As opções não são excludentes: você poderá marcar mais de uma opção)

\begin{tabular}{|l|l|}
\hline & NÃO MUDOU NADA EM MEU TRABALHO. \\
\hline$X$ & $\begin{array}{l}\text { MEU TRABALHO PASSOU A CONTRIBUIR MAIS COM OS AGRICULTORES(AS) } \\
\text { FAMILIARES. }\end{array}$ \\
\hline & CONSEGUI INFLUENCIAR NAS ORIENTAÇÕES DA MINHA INSTITUIÇÃO. \\
\hline & $\begin{array}{l}\text { PASSEI A TRABALHAR COM METODOLOGIAS PARTICIPATIVAS. } \\
\text { ONDE ATUO. }\end{array}$ \\
\hline$X$ & CONTINUEI ME APERFEIÇOANDO SOBRE TEMAS ABORDADOS. \\
\hline
\end{tabular}

7) Depois do curso você apoiou atividades de capacitação de técnicos e agricultores com base nos princípios e diretrizes da Pnater? (Considere como apoio a atividades de capacitação a participação no planejamento, elaboração de ementas, seleção de participantes e de palestrantes.)

\begin{tabular}{|l|l|}
\hline$X$ & SIM \\
\hline & NÃO \\
\hline
\end{tabular}


8) Usou os conhecimentos para ministrar outros cursos com o mesmo conteúdo ou conteúdos semelhantes?

\begin{tabular}{|l|l|}
\hline & SIM \\
\hline$X$ & NÃO \\
\hline
\end{tabular}

9) Marque o seu grau de satisfação com relação ao curso oferecido pelo DATER: (Considere a seguinte pontuação: 1 - MUITO RUIM; 2 - RUIM; 3 - REGULAR; 4 - BOM; 5 - MUITO BOM)

\begin{tabular}{|l|l|l|l|l|}
\hline 1 & 2 & 3 & 4 & 5 \\
\hline
\end{tabular}

10) Marque seu grau de satisfação com relação ao DATER: (Considere a seguinte pontuação: 1 - MUITO RUIM; 2 - RUIM; 3 - REGULAR; 4 - BOM; 5 - MUITO BOM)

\begin{tabular}{|l|l|l|l|l|}
\hline 1 & 2 & 3 & 4 & 5 \\
\hline
\end{tabular}




\section{PESQUISA - IMPACTO DAS AÇÕES DE FORMAÇÃO REALIZADAS PELO DATER/SAF/MDA NO PERÍODO 2004-2009}

Caros colaboradores,

Contamos com a sua atenção para preencher o formulário abaixo.

O mesmo tem por objetivo fornecer informações para avaliação da Eficiência, Efetividade e Eficácia da Política Pública de Formação de Agentes de Ater adotada pelo Departamento de Assistência Técnica e Extensão Rural, da Secretaria de Agricultura Familiar do Ministério do Desenvolvimento - DATER/SAF/MDA, no período de 2004 a 2009, tema escolhido para Monografia a ser apresentada à Universidade de Brasília (UnB) como requisito parcial para obtenção do grau de Bacharel em Administração.

Você poderá ou não se identificar no questionário e garantimos que todas as informações fornecidas serão confidenciais e utilizadas apenas de forma sistematizada.

IDENTIFICAÇÃO

\begin{tabular}{|c|c|}
\hline Nome: ANTŌNIO JANDIR CONTENTE MORAIS & $\begin{array}{l}\text { Sexo: } \\
(x \quad) \text { masculino }\end{array}$ \\
\hline $\begin{array}{l}\text { Instituição (nome e tipo de instituição: ONG, } \\
\text { Empresa Pública, etc.): } \\
\text { Instituto de Desenvolvimento Agropecuário do } \\
\text { Estado do Amazonas - IDAM }\end{array}$ & $\begin{array}{l}\text { Local de trabalho (Cidade e Estado): } \\
\text { Manaus - Amazonas }\end{array}$ \\
\hline \multicolumn{2}{|c|}{$\begin{array}{l}\text { Curso/Encontro/Oficina do qual participou (caso tenha participado de mais de um curso, } \\
\text { preencha um formulário para cada um deles): } \\
\text { Oficina de Implantação do Projeto Piloto de Comunicação e Metodologia - MDA }\end{array}$} \\
\hline $\begin{array}{l}\text { Data do Curso/Encontro/Oficina (pelo meno } \\
06 \text { a } 13 \text { de maio/2005 - Belo Horizonte/MG }\end{array}$ & \\
\hline
\end{tabular}

Indique sua área de atuação? (As opções não são excludentes: você poderá marcar mais de uma opção)

\begin{tabular}{|l|l|}
\hline$X$ & EXTENSÃO RURAL \\
\hline & PESQUISA \\
\hline & ENSINO \\
\hline
\end{tabular}




\begin{tabular}{|l|l|}
\hline OUTROS \\
\hline
\end{tabular}

2) Qual o seu nível de escolaridade? (Considere apenas o nível mais alto)

\begin{tabular}{|l|l|}
\hline & NÍVEL MÉDIO \\
\hline$X$ & NÍVEL SUPERIOR \\
\hline & PÓS-GRADUAÇÃO \\
\hline
\end{tabular}

3) Os conteúdos abordados foram condizentes com as demandas do seu dia-a-dia?

\begin{tabular}{|l|l|}
\hline$X$ & SIM \\
\hline & PARCIALMENTE \\
\hline & NÃO \\
\hline
\end{tabular}

3) O curso contribuiu para o seu aperfeiçoamento profissional?

\begin{tabular}{|l|l|}
\hline$X$ & SIM \\
\hline & NÃO \\
\hline
\end{tabular}

5) Os conhecimentos adquiridos estão sendo aplicados no seu trabalho? Em caso afirmativo, indique em que grau estes conhecimentos estão sendo aplicados. Em caso negativo, indique por que razão isto não ocorre: (Em caso negativo, as respostas não são excludentes: você poderá marcar mais de uma opção).

\begin{tabular}{|l|l|l|l|}
\hline \multirow{2}{*}{$\begin{array}{l}\text { SIM (indique ao lado } \\
\text { em que grau) }\end{array}$} & & MUITO APLICADOS \\
\cline { 2 - 3 } & $X$ & MEDIAMENTE APLICADOS \\
\hline & $\begin{array}{l}\text { NÃO (indique ao lado a } \\
\text { razão da não aplicação) }\end{array}$ & $\begin{array}{l}\text { CONTEÚDO NÃO ADEQUADO ȦS NECESSIDADES } \\
\text { ESPECÍFICAS DA REGIÃO }\end{array}$ \\
\hline
\end{tabular}




\begin{tabular}{|l|l|l|}
\hline \multirow{3}{*}{} & & $\begin{array}{l}\text { CONTEÚDO NÃO FOI SUFICIENTEMENTE } \\
\text { APROFUNDADO PARA PERMITIR UMA APLICAÇÃO } \\
\text { EFICAZ E EFICIENTE }\end{array}$ \\
\cline { 2 - 4 } & $\begin{array}{l}\text { FALTA DE APOIO E INCENTIVO DA MINHA } \\
\text { INSTITUIÇÃO }\end{array}$ \\
\cline { 2 - 3 } & FALTA DE INCENTIVO ÀS AÇÕES DE ATER \\
\cline { 2 - 4 } & NÃO TENHO INTERESSE EM APLICAR \\
\hline
\end{tabular}

6) A partir deste curso: (As opções não são excludentes: você poderá marcar mais de uma opção)

\begin{tabular}{|l|l|}
\hline$X$ & NÃO MUDOU NADA EM MEU TRABALHO. \\
\hline & $\begin{array}{l}\text { MEU TRABALHO PASSOU A CONTRIBUIR MAIS COM OS AGRICULTORES(AS) } \\
\text { FAMILIARES. }\end{array}$ \\
\hline & CONSEGUI INFLUENCIAR NAS ORIENTAÇÕES DA MINHA INSTITUIÇÃO. \\
\hline & $\begin{array}{l}\text { CRESCEU A ÁREA DE AGRICULTURA DE BASE ECOLÓGICA NAS COMUNIDADES } \\
\text { ONDE ATUO. }\end{array}$ \\
\hline & CONTINUEI ME APERFEIÇOANDO SOBRE TEMAS ABORDADOS. \\
\hline
\end{tabular}

7) Depois do curso você apoiou atividades de capacitação de técnicos e agricultores com base nos princípios e diretrizes da Pnater? ? (Considere como apoio a atividades de capacitação a participação no planejamento, elaboração de ementas, seleção de participantes e de palestrantes.)

\begin{tabular}{|l|l|}
\hline & SIM \\
\hline$X$ & NÃO \\
\hline
\end{tabular}

8) Usou os conhecimentos para ministrar outros cursos com o mesmo conteúdo ou conteúdos semelhantes? 


\begin{tabular}{|l|l|}
\hline & SIM \\
\hline$X$ & NÃO \\
\hline
\end{tabular}

9) Marque o seu grau de satisfação com relação ao curso oferecido pelo DATER: (Considere a seguinte pontuação: 1 - MUITO RUIM; 2 - RUIM; 3 - REGULAR; 4 - BOM; 5 - MUITO BOM)

\begin{tabular}{|l|l|l|l|l|}
\hline 1 & 2 & 3 & 4 & 5 \\
\hline
\end{tabular}

10) Marque seu grau de satisfação com relação ao DATER: (Considere a seguinte pontuação: 1 - MUITO RUIM; 2 - RUIM; 3 - REGULAR; 4 - BOM; 5 - MUITO BOM)

\begin{tabular}{|l|l|l|l|l|}
\hline 1 & 2 & 3 & 4 & 5 \\
\hline
\end{tabular}




\section{PESQUISA - IMPACTO DAS AÇÕES DE FORMAÇÃO REALIZADAS PELO DATER/SAF/MDA NO PERÍODO 2004-2009}

Caros colaboradores,

Contamos com a sua atenção para preencher o formulário abaixo.

O mesmo tem por objetivo fornecer informações para avaliação da Eficiência, Efetividade e Eficácia da Política Pública de Formação de Agentes de Ater adotada pelo Departamento de Assistência Técnica e Extensão Rural, da Secretaria de Agricultura Familiar do Ministério do Desenvolvimento - DATER/SAF/MDA, no período de 2004 a 2009, tema escolhido para Monografia a ser apresentada à Universidade de Brasília (UnB) como requisito parcial para obtenção do grau de Bacharel em Administração.

Você poderá ou não se identificar no questionário e garantimos que todas as informações fornecidas serão confidenciais e utilizadas apenas de forma sistematizada.

IDENTIFICAÇÃO

\begin{tabular}{|c|c|}
\hline Nome: IZAQUE EPIFÄNIO MARQUES & $\begin{array}{l}\text { Sexo: } \\
(x \quad) \text { masculino }(\quad) \text { feminino }\end{array}$ \\
\hline $\begin{array}{l}\text { Instituição (nome e tipo de instituição: ONG, } \\
\text { Empresa Pública, etc.): } \\
\text { Instituto de Desenvolvimento Agropecuário do } \\
\text { Estado do Amazonas - IDAM }\end{array}$ & $\begin{array}{l}\text { Local de trabalho (Cidade e Estado): } \\
\text { Unidade Local de Ipixuna - Amazonas }\end{array}$ \\
\hline \multicolumn{2}{|c|}{$\begin{array}{l}\text { Curso/Encontro/Oficina do qual participou (caso tenha participado de mais de um curso, } \\
\text { preencha um formulário para cada um deles): } \\
\text { Curso Diagnóstico Rural Participativo - DRP }\end{array}$} \\
\hline $\begin{array}{l}\text { Data do Curso/Encontro/Oficina (pelo menos mês } \\
16 \text { a } 27 \text { de outubro de } 2006 \text { - Manaus/AM }\end{array}$ & \\
\hline
\end{tabular}

Indique sua área de atuação? (As opções não são excludentes: você poderá marcar mais de uma opção)

\begin{tabular}{|l|l}
\hline & EXTENSÃO RURAL
\end{tabular} 


\begin{tabular}{|l|l|}
\hline & PESQUISA \\
\hline & ENSINO \\
\hline & OUTROS \\
\hline
\end{tabular}

2) Qual o seu nível de escolaridade? (Considere apenas o nível mais alto)

\begin{tabular}{|l|l|}
\hline$x$ & NÍVEL MÉDIO \\
\hline & NÍVEL SUPERIOR \\
\hline & PÓS-GRADUAÇÃO \\
\hline
\end{tabular}

3) Os conteúdos abordados foram condizentes com as demandas do seu dia-a-dia?

\begin{tabular}{|l|l|}
\hline & SIM \\
\hline$x$ & PARCIALMENTE \\
\hline & NÃO \\
\hline
\end{tabular}

3) O curso contribuiu para o seu aperfeiçoamento profissional?

\begin{tabular}{|l|l|}
\hline$x$ & SIM \\
\hline & NÃO \\
\hline
\end{tabular}

5) Os conhecimentos adquiridos estão sendo aplicados no seu trabalho? Em caso afirmativo, indique em que grau estes conhecimentos estão sendo aplicados. Em caso negativo, indique por que razão isto não ocorre: (Em caso negativo, as respostas não são excludentes: você poderá marcar mais de uma opção).

\begin{tabular}{|l|l|l|l|}
\hline \multirow{2}{*}{$\begin{array}{l}\text { SIM (indique ao lado } \\
\text { em que grau) }\end{array}$} & & MUITO APLICADOS \\
\cline { 3 - 4 } & $\mathrm{x}$ & MEDIAMENTE APLICADOS \\
\hline
\end{tabular}




\begin{tabular}{|c|c|}
\hline \multirow{5}{*}{$\begin{array}{l}\text { NÃO (indique ao lado a } \\
\text { razão da não aplicação) }\end{array}$} & $\begin{array}{l}\text { CONTEÚDO NÃO ADEQUADO ÀS NECESSIDADES } \\
\text { ESPECÍFICAS DA REGIÃO }\end{array}$ \\
\hline & $\begin{array}{l}\text { CONTEÚDO NÂO FOI SUFICIENTEMENTE } \\
\text { APROFUNDADO PARA PERMITIR UMA APLICAÇÃO } \\
\text { EFICAZ E EFICIENTE }\end{array}$ \\
\hline & $\begin{array}{lcccccc}\text { FALTA } & \text { DE } & \text { APOIO } & \text { E } & \text { INCENTIVO } & \text { DA } & \text { MINHA } \\
\text { INSTITUIÇÃO } & & & & & & \end{array}$ \\
\hline & FALTA DE INCENTIVO ÀS AÇÕES DE ATER \\
\hline & NÃO TENHO INTERESSE EM APLICAR \\
\hline
\end{tabular}

6) A partir deste curso: (As opções não são excludentes: você poderá marcar mais de uma opção)

\begin{tabular}{|l|l|}
\hline & NÃO MUDOU NADA EM MEU TRABALHO. \\
\hline & $\begin{array}{l}\text { MEU TRABALHO PASSOU A CONTRIBUIR MAIS COM OS AGRICULTORES(AS) } \\
\text { FAMILIARES. }\end{array}$ \\
\hline $\mathrm{X}$ & CONSEGUI INFLUENCIAR NAS ORIENTAÇÕES DA MINHA INSTITUIÇÃO. \\
\hline & $\begin{array}{l}\text { CRESCEU A ÁREA DE AGRICULTURA DE BASE ECOLÓGICA NAS COMUNIDADES } \\
\text { ONDE ATUO. }\end{array}$ \\
\hline & CONTINUEI ME APERFEIÇOANDO SOBRE TEMAS ABORDADOS. \\
\hline
\end{tabular}

7) Depois do curso você apoiou atividades de capacitação de técnicos e agricultores com base nos princípios e diretrizes da Pnater? ? (Considere como apoio a atividades de capacitação a participação no planejamento, elaboração de ementas, seleção de participantes e de palestrantes.)

\begin{tabular}{|l|l|}
\hline$x$ & SIM \\
\hline & NÃO \\
\hline
\end{tabular}


8) Usou os conhecimentos para ministrar outros cursos com o mesmo conteúdo ou conteúdos semelhantes?

\begin{tabular}{|l|l|}
\hline & SIM \\
\hline$x$ & NÃO \\
\hline
\end{tabular}

9) Marque o seu grau de satisfação com relação ao curso oferecido pelo DATER: (Considere a seguinte pontuação: 1 - MUITO RUIM; 2 - RUIM; 3 - REGULAR; 4 - BOM; 5 - MUITO BOM)

\begin{tabular}{|l|l|l|l|l|}
\hline 1 & 2 & 3 & 4 & 5 \\
\hline
\end{tabular}

10) Marque seu grau de satisfação com relação ao DATER: (Considere a seguinte pontuação: 1 - MUITO RUIM; 2 - RUIM; 3 - REGULAR; 4 - BOM; 5 - MUITO BOM)

\begin{tabular}{|l|l|l|l|l|}
\hline 1 & 2 & 3 & 4 & 5 \\
\hline
\end{tabular}




\section{PESQUISA - IMPACTO DAS AÇÕES DE FORMAÇÃO REALIZADAS PELO DATER/SAF/MDA NO PERÍODO 2004-2009}

Caros colaboradores,

Contamos com a sua atenção para preencher o formulário abaixo.

O mesmo tem por objetivo fornecer informações para avaliação da Eficiência, Efetividade e Eficácia da Política Pública de Formação de Agentes de Ater adotada pelo Departamento de Assistência Técnica e Extensão Rural, da Secretaria de Agricultura Familiar do Ministério do Desenvolvimento - DATER/SAF/MDA, no período de 2004 a 2009, tema escolhido para Monografia a ser apresentada à Universidade de Brasília (UnB) como requisito parcial para obtenção do grau de Bacharel em Administração.

Você poderá ou não se identificar no questionário e garantimos que todas as informações fornecidas serão confidenciais e utilizadas apenas de forma sistematizada.

IDENTIFICAÇÃO

\begin{tabular}{|c|c|}
\hline Nome: IVO ROBERTO PEREIRA DOS SANTOS & $\begin{array}{l}\text { Sexo: } \\
(x) \text { masculino }(\quad) \text { feminino }\end{array}$ \\
\hline $\begin{array}{l}\text { Instituição (nome e tipo de instituição: ONG, } \\
\text { Empresa Pública, etc.): } \\
\text { Instituto de Desenvolvimento Agropecuário do } \\
\text { Estado do Amazonas - IDAM }\end{array}$ & $\begin{array}{l}\text { Local de trabalho (Cidade e Estado): } \\
\text { Unidade Local de Maués - Amazonas }\end{array}$ \\
\hline $\begin{array}{l}\text { Curso/Encontro/Oficina do qual participou (casc } \\
\text { preencha um formulário para cada um deles): } \\
\text { Seminário - Agroecologia como Estratégia para } \\
\text { Sustentável }\end{array}$ & $\begin{array}{l}\text { o tenha participado de mais de um curso, } \\
\text { a Construção do Desenvolvimento Rural }\end{array}$ \\
\hline \multicolumn{2}{|c|}{$\begin{array}{l}\text { Data do Curso/Encontro/Oficina (pelo menos mês e ano): } \\
10 \text { e } 11 \text { de agosto de } 2006 \text { - Manaus/AM }\end{array}$} \\
\hline
\end{tabular}

Indique sua área de atuação?

\begin{tabular}{|l|l|}
\hline$X$ & EXTENSÃO RURAL \\
\hline & PESQUISA \\
\hline & ENSINO \\
\hline
\end{tabular}




\section{OUTROS}

2) Qual o seu nível de escolaridade? (Considere apenas o nível mais alto)

\begin{tabular}{|l|l|}
\hline$X$ & NÍVEL MÉDIO \\
\hline & NÍVEL SUPERIOR \\
\hline & PÓS-GRADUAÇÃO \\
\hline
\end{tabular}

3) Os conteúdos abordados foram condizentes com as demandas do seu dia-a-dia?

\begin{tabular}{|l|l|}
\hline$X$ & SIM \\
\hline & PARCIALMENTE \\
\hline & NÃO \\
\hline
\end{tabular}

3) O curso contribuiu para o seu aperfeiçoamento profissional?

\begin{tabular}{|l|l|}
\hline$X$ & SIM \\
\hline & NÃO \\
\hline
\end{tabular}

5) Os conhecimentos adquiridos estão sendo aplicados no seu trabalho? Em caso afirmativo, indique em que grau estes conhecimentos estão sendo aplicados. Em caso negativo, indique por que razão isto não ocorre: (Em caso negativo, as respostas não são excludentes: você poderá marcar mais de uma opção).

\begin{tabular}{|l|l|l|l|}
\hline \multirow{2}{*}{$\begin{array}{l}\text { SIM (indique ao lado } \\
\text { em que grau) }\end{array}$} & & MUITO APLICADOS \\
\cline { 2 - 3 } & $\begin{array}{l}\text { NĀO (indique ao lado a } \\
\text { razão da não aplicação) }\end{array}$ & MEDIAMENTE APLICADOS \\
\hline & $\begin{array}{l}\text { CONTEÚDO NĀO ADEQUADO ȦS NECESSIDADES } \\
\text { ESPECÍFICAS DA REGIÃO }\end{array}$ \\
\hline
\end{tabular}




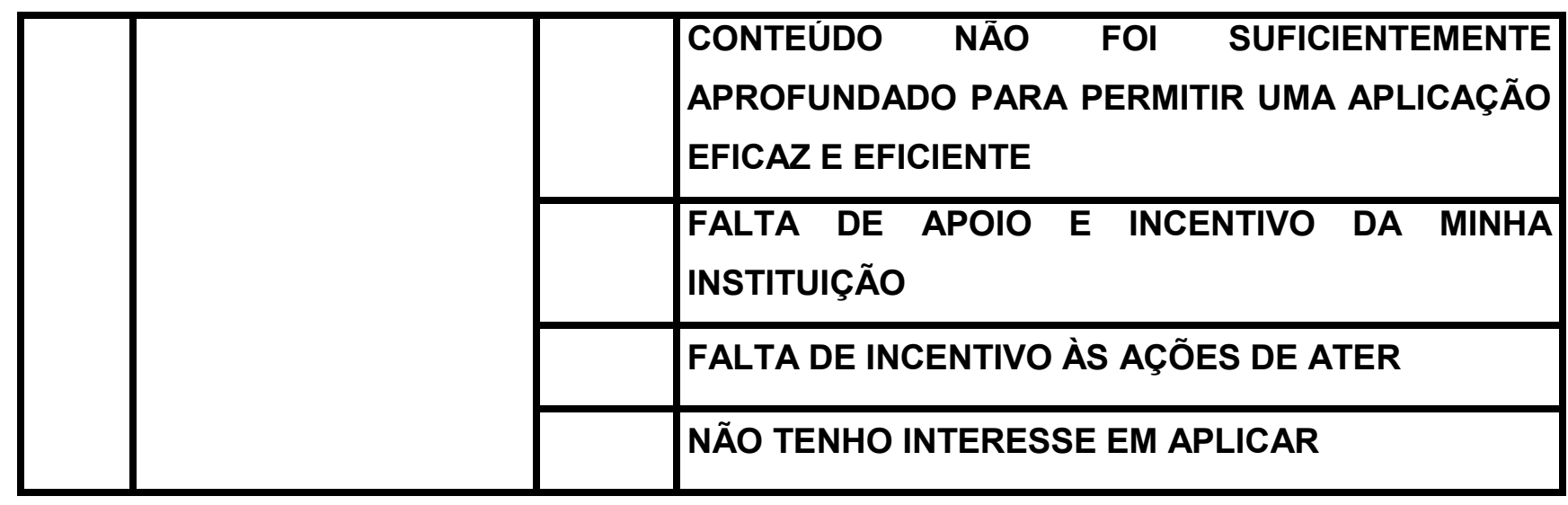

6) A partir deste curso: (As opções não são excludentes: você poderá marcar mais de uma opção)

\begin{tabular}{|l|l|}
\hline & NÃO MUDOU NADA EM MEU TRABALHO. \\
\hline & $\begin{array}{l}\text { MEU TRABALHO PASSOU A CONTRIBUIR MAIS COM OS AGRICULTORES(AS) } \\
\text { FAMILIARES. }\end{array}$ \\
\hline & CONSEGUI INFLUENCIAR NAS ORIENTAÇÕES DA MINHA INSTITUIÇÃO. \\
\hline$X$ & $\begin{array}{l}\text { CRESCEU A AREA DE AGRICULTURA DE BASE ECOLÓGICA NAS COMUNIDADES } \\
\text { ONDE ATUO. }\end{array}$ \\
\hline & CONTINUEI ME APERFEIÇOANDO SOBRE TEMAS ABORDADOS. \\
\hline
\end{tabular}

7) Depois do curso você apoiou atividades de capacitação de técnicos e agricultores com base nos princípios e diretrizes da Pnater? ? (Considere como apoio a atividades de capacitação a participação no planejamento, elaboração de ementas, seleção de participantes e de palestrantes.)

\begin{tabular}{|l|l|}
\hline$X$ & SIM \\
\hline & NÃO \\
\hline
\end{tabular}

8) Usou os conhecimentos para ministrar outros cursos com o mesmo conteúdo ou conteúdos semelhantes? 


\begin{tabular}{|l|l|}
\hline$X$ & SIM \\
\hline & NÃO \\
\hline
\end{tabular}

9) Marque o seu grau de satisfação com relação ao curso oferecido pelo DATER: (Considere a seguinte pontuação: 1 - MUITO RUIM; 2 - RUIM; 3 - REGULAR; 4 - BOM; 5 - MUITO BOM)

\begin{tabular}{|l|l|l|l|l|}
\hline 1 & 2 & 3 & 4 & 5 \\
\hline
\end{tabular}

10) Marque seu grau de satisfação com relação ao DATER: (Considere a seguinte pontuação: 1 - MUITO RUIM; 2 - RUIM; 3 - REGULAR; 4 - BOM; 5 - MUITO BOM)

\begin{tabular}{|l|l|l|l|l|}
\hline 1 & 2 & 3 & 4 & 5 \\
\hline
\end{tabular}




\section{PESQUISA - IMPACTO DAS AÇÕES DE FORMAÇÃO REALIZADAS PELO DATER/SAF/MDA NO PERÍODO 2004-2009}

Caros colaboradores,

Contamos com a sua atenção para preencher o formulário abaixo.

O mesmo tem por objetivo fornecer informações para avaliação da Eficiência, Efetividade e Eficácia da Política Pública de Formação de Agentes de Ater adotada pelo Departamento de Assistência Técnica e Extensão Rural, da Secretaria de Agricultura Familiar do Ministério do Desenvolvimento - DATER/SAF/MDA, no período de 2004 a 2009, tema escolhido para Monografia a ser apresentada à Universidade de Brasília (UnB) como requisito parcial para obtenção do grau de Bacharel em Administração.

Você poderá ou não se identificar no questionário e garantimos que todas as informações fornecidas serão confidenciais e utilizadas apenas de forma sistematizada.

IDENTIFICAÇÃO

\begin{tabular}{|c|c|}
\hline Nome: IVO ROBERTO PEREIRA DOS SANTOS & $\begin{array}{l}\text { Sexo: } \\
(x) \text { masculino }(1) \text { feminino }\end{array}$ \\
\hline $\begin{array}{l}\text { Instituição (nome e tipo de instituição: ONG, } \\
\text { Empresa Pública, etc.): } \\
\text { Instituto de Desenvolvimento Agropecuário do } \\
\text { Estado do Amazonas - IDAM }\end{array}$ & $\begin{array}{l}\text { Local de trabalho (Cidade e Estado): } \\
\text { Unidade Local de Maués - Amazonas }\end{array}$ \\
\hline \multicolumn{2}{|c|}{$\begin{array}{l}\text { Curso/Encontro/Oficina do qual participou (caso tenha participado de mais de um curso, } \\
\text { preencha um formulário para cada um deles): } \\
\text { Curso Diagnóstico Rural Participativo - DRP }\end{array}$} \\
\hline $\begin{array}{l}\text { Data do Curso/Encontro/Oficina (pelo menos mês } \\
16 \text { a } 27 \text { de outubro de } 2006 \text { - Manaus/AM }\end{array}$ & e ano): \\
\hline
\end{tabular}

Indique sua área de atuação? (As opções não são excludentes: você poderá marcar mais de uma opção)

\begin{tabular}{|l|l|}
\hline$X$ & EXTENSÃO RURAL \\
\hline & PESQUISA \\
\hline
\end{tabular}




\begin{tabular}{|l|l|}
\hline & ENSINO \\
\hline & OUTROS \\
\hline
\end{tabular}

2) Qual o seu nível de escolaridade? (Considere apenas o nível mais alto)

\begin{tabular}{|l|l|}
\hline$X$ & NÍVEL MÉDIO \\
\hline & NÍVEL SUPERIOR \\
\hline & PÓS-GRADUAÇÃO \\
\hline
\end{tabular}

3) Os conteúdos abordados foram condizentes com as demandas do seu dia-a-dia?

\begin{tabular}{|l|l|}
\hline$X$ & SIM \\
\hline & PARCIALMENTE \\
\hline & NÃO \\
\hline
\end{tabular}

3) O curso contribuiu para o seu aperfeiçoamento profissional?

\begin{tabular}{|l|l|}
\hline$X$ & SIM \\
\hline & NÃO \\
\hline
\end{tabular}

5) Os conhecimentos adquiridos estão sendo aplicados no seu trabalho? Em caso afirmativo, indique em que grau estes conhecimentos estão sendo aplicados. Em caso negativo, indique por que razão isto não ocorre: (Em caso negativo, as respostas não são excludentes: você poderá marcar mais de uma opção).

\begin{tabular}{|c|c|c|}
\hline \multirow{3}{*}{$\begin{array}{l}\text { SIM (indique ao lado } \\
\text { em que grau) }\end{array}$} & & MUITO APLICADOS \\
\hline & $x$ & MEDIAMENTE APLICADOS \\
\hline & & POUCO APLICADOS \\
\hline
\end{tabular}




\begin{tabular}{|c|c|}
\hline \multirow{5}{*}{$\begin{array}{l}\text { NÃO (indique ao lado a } \\
\text { razão da não aplicação) }\end{array}$} & $\begin{array}{l}\text { CONTEÚDO NĀO ADEQUADO ȦS NECESSIDADES } \\
\text { ESPECÍFICAS DA REGIÃO }\end{array}$ \\
\hline & $\begin{array}{l}\text { CONTEÚDO NÃO FOI SUFICIENTEMENTE } \\
\text { APROFUNDADO PARA PERMITIR UMA APLICAÇÃO } \\
\text { EFICAZ E EFICIENTE }\end{array}$ \\
\hline & \begin{tabular}{|llllll} 
FALTA DE & APOIO & E & INCENTIVO & DA & MINHA \\
INSTITUIÇÃO & & & & &
\end{tabular} \\
\hline & FALTA DE INCENTIVO ÀS AÇÕES DE ATER \\
\hline & NÃO TENHO INTERESSE EM APLICAR \\
\hline
\end{tabular}

6) A partir deste curso:

\begin{tabular}{|l|l|}
\hline & $\begin{array}{l}\text { NÃO MUDOU NADA EM MEU TRABALHO. } \\
\text { MEU TRABALHO PASSOU A CONTRIBUIR MAIS COM OS AGRICULTORES(AS) } \\
\text { FAMILIARES. }\end{array}$ \\
\hline & CONSEGUI INFLUENCIAR NAS ORIENTAÇÕES DA MINHA INSTITUIÇÃO. \\
\hline$X$ & $\begin{array}{l}\text { CRASSEI A TRABALHAR COM METODOLOGIAS PARTICIPATIVAS. } \\
\text { ONDE ATUO. }\end{array}$ \\
\hline & CONTINUEI ME APERFEIÇOANDO SOBRE TEMAS ABORDADOS. \\
\hline
\end{tabular}

7) Depois do curso você apoiou atividades de capacitação de técnicos e agricultores com base nos princípios e diretrizes da Pnater? ? (Considere como apoio a atividades de capacitação a participação no planejamento, elaboração de ementas, seleção de participantes e de palestrantes.)

\begin{tabular}{|l|l|}
\hline$X$ & SIM \\
\hline & NÃO \\
\hline
\end{tabular}


8) Usou os conhecimentos para ministrar outros cursos com o mesmo conteúdo ou conteúdos semelhantes?

\begin{tabular}{|l|l|}
\hline$X$ & SIM \\
\hline & NÃO \\
\hline
\end{tabular}

9) Marque o seu grau de satisfação com relação ao curso oferecido pelo DATER: (Considere a seguinte pontuação: 1 - MUITO RUIM; 2 - RUIM; 3 - REGULAR; 4 - BOM; 5 - MUITO BOM)

\begin{tabular}{|l|l|l|l|l|}
\hline 1 & 2 & 3 & 4 & 5 \\
\hline
\end{tabular}

10) Marque seu grau de satisfação com relação ao DATER: (Considere a seguinte pontuação: 1 - MUITO RUIM; 2 - RUIM; 3 - REGULAR; 4 - BOM; 5 - MUITO BOM)

\begin{tabular}{|l|l|l|l|l|}
\hline 1 & 2 & 3 & 4 & 5 \\
\hline
\end{tabular}




\section{PESQUISA - IMPACTO DAS AÇÕES DE FORMAÇÃO REALIZADAS PELO DATER/SAF/MDA NO PERÍODO 2004-2009}

Caros colaboradores,

Contamos com a sua atenção para preencher o formulário abaixo.

O mesmo tem por objetivo fornecer informações para avaliação da Eficiência, Efetividade e Eficácia da Política Pública de Formação de Agentes de Ater adotada pelo Departamento de Assistência Técnica e Extensão Rural, da Secretaria de Agricultura Familiar do Ministério do Desenvolvimento - DATER/SAF/MDA, no período de 2004 a 2009, tema escolhido para Monografia a ser apresentada à Universidade de Brasília (UnB) como requisito parcial para obtenção do grau de Bacharel em Administração.

Você poderá ou não se identificar no questionário e garantimos que todas as informações fornecidas serão confidenciais e utilizadas apenas de forma sistematizada.

IDENTIFICAÇÃO

\begin{tabular}{|c|c|}
\hline Nome: IVO ROBERTO PEREIRA DOS SANTOS & $\begin{array}{l}\text { Sexo: } \\
(x) \text { masculino }(\quad) \text { feminino }\end{array}$ \\
\hline $\begin{array}{l}\text { Instituição (nome e tipo de instituição: ONG, } \\
\text { Empresa Pública, etc.): } \\
\text { Instituto de Desenvolvimento Agropecuário do } \\
\text { Estado do Amazonas - IDAM }\end{array}$ & $\begin{array}{l}\text { Local de trabalho (Cidade e Estado): } \\
\text { Unidade Local de Maués - Amazonas }\end{array}$ \\
\hline \multicolumn{2}{|c|}{$\begin{array}{l}\text { Curso/Encontro/Oficina do qual participou (caso tenha participado de mais de um curso, } \\
\text { preencha um formulário para cada um deles): } \\
\text { Curso de Agroecologia }\end{array}$} \\
\hline $\begin{array}{l}\text { Data do Curso/Encontro/Oficina (pelo menos mês } \\
24 \text { a } 28 \text { de abril de } 2006 \text { - Manaus/AM }\end{array}$ & e ano): \\
\hline
\end{tabular}

Indique sua área de atuação? (As opções não são excludentes: você poderá marcar mais de uma opção)

\begin{tabular}{|l|l|}
\hline$X$ & EXTENSÃO RURAL \\
\hline & PESQUISA \\
\hline
\end{tabular}




\begin{tabular}{|l|l|}
\hline & ENSINO \\
\hline & OUTROS \\
\hline
\end{tabular}

2) Qual o seu nível de escolaridade? (Considere apenas o nível mais alto)

\begin{tabular}{|l|l|}
\hline$X$ & NÍVEL MÉDIO \\
\hline & NÍVEL SUPERIOR \\
\hline & PÓS-GRADUAÇÃO \\
\hline
\end{tabular}

3) Os conteúdos abordados foram condizentes com as demandas do seu dia-a-dia?

\begin{tabular}{|l|l|}
\hline$X$ & SIM \\
\hline & PARCIALMENTE \\
\hline & NÃO \\
\hline
\end{tabular}

3) O curso contribuiu para o seu aperfeiçoamento profissional?

\begin{tabular}{|l|l|}
\hline$X$ & SIM \\
\hline & NÃO \\
\hline
\end{tabular}

5) Os conhecimentos adquiridos estão sendo aplicados no seu trabalho? Em caso afirmativo, indique em que grau estes conhecimentos estão sendo aplicados. Em caso negativo, indique por que razão isto não ocorre: (Em caso negativo, as respostas não são excludentes: você poderá marcar mais de uma opção).

\begin{tabular}{|c|c|c|}
\hline \multirow{3}{*}{$\begin{array}{l}\text { SIM (indique ao lado } \\
\text { em que grau) }\end{array}$} & & MUITO APLICADOS \\
\hline & $x$ & MEDIAMENTE APLICADOS \\
\hline & & POUCO APLICADOS \\
\hline
\end{tabular}




\begin{tabular}{|c|c|}
\hline \multirow{5}{*}{$\begin{array}{l}\text { NÃO (indique ao lado a } \\
\text { razão da não aplicação) }\end{array}$} & $\begin{array}{l}\text { CONTEÚDO NĀO ADEQUADO ȦS NECESSIDADES } \\
\text { ESPECÍFICAS DA REGIÃO }\end{array}$ \\
\hline & $\begin{array}{l}\text { CONTEÚDO NÃO FOI SUFICIENTEMENTE } \\
\text { APROFUNDADO PARA PERMITIR UMA APLICAÇÃO } \\
\text { EFICAZ E EFICIENTE }\end{array}$ \\
\hline & \begin{tabular}{|llllll} 
FALTA DE & APOIO & E & INCENTIVO & DA & MINHA \\
INSTITUIÇÃO & & & & &
\end{tabular} \\
\hline & FALTA DE INCENTIVO ÀS AÇÕES DE ATER \\
\hline & NÃO TENHO INTERESSE EM APLICAR \\
\hline
\end{tabular}

6) A partir deste curso: (As opções não são excludentes: você poderá marcar mais de uma opção)

\begin{tabular}{|l|l|}
\hline & NÃO MUDOU NADA EM MEU TRABALHO. \\
\hline & $\begin{array}{l}\text { MEU TRABALHO PASSOU A CONTRIBUIR MAIS COM OS AGRICULTORES(AS) } \\
\text { FAMILIARES. }\end{array}$ \\
\hline & CONSEGUI INFLUENCIAR NAS ORIENTAÇÕES DA MINHA INSTITUIÇÃO. \\
\hline$X$ & $\begin{array}{l}\text { CRESSEI A TRABALHAR COM METODOLOGIAS PARTICIPATIVAS. } \\
\text { ONDE ATUO. }\end{array}$ \\
\hline & CONTINUEI ME APERFEIÇOANDO SOBRE TEMAS ABORDADOS. \\
\hline
\end{tabular}

7) Depois do curso você apoiou atividades de capacitação de técnicos e agricultores com base nos princípios e diretrizes da Pnater? ? (Considere como apoio a atividades de capacitação a participação no planejamento, elaboração de ementas, seleção de participantes e de palestrantes.)

\begin{tabular}{|l|l|}
\hline$X$ & SIM \\
\hline & NÃO \\
\hline
\end{tabular}


8) Usou os conhecimentos para ministrar outros cursos com o mesmo conteúdo ou conteúdos semelhantes?

\begin{tabular}{|l|l|}
\hline$X$ & SIM \\
\hline & NÃO \\
\hline
\end{tabular}

9) Marque o seu grau de satisfação com relação ao curso oferecido pelo DATER: (Considere a seguinte pontuação: 1 - MUITO RUIM; 2 - RUIM; 3 - REGULAR; 4 - BOM; 5 - MUITO BOM)

\begin{tabular}{|l|l|l|l|l|}
\hline 1 & 2 & 3 & 4 & 5 \\
\hline
\end{tabular}

10) Marque seu grau de satisfação com relação ao DATER: (Considere a seguinte pontuação: 1 - MUITO RUIM; 2 - RUIM; 3 - REGULAR; 4 - BOM; 5 - MUITO BOM)

\begin{tabular}{|l|l|l|l|l|}
\hline 1 & 2 & 3 & 4 & 5 \\
\hline
\end{tabular}




\section{PESQUISA - IMPACTO DAS AÇÕES DE FORMAÇÃO REALIZADAS PELO DATER/SAF/MDA NO PERÍODO 2004-2009}

Caros colaboradores,

Contamos com a sua atenção para preencher o formulário abaixo.

O mesmo tem por objetivo fornecer informações para avaliação da Eficiência, Efetividade e Eficácia da Política Pública de Formação de Agentes de Ater adotada pelo Departamento de Assistência Técnica e Extensão Rural, da Secretaria de Agricultura Familiar do Ministério do Desenvolvimento - DATER/SAF/MDA, no período de 2004 a 2009, tema escolhido para Monografia a ser apresentada à Universidade de Brasília (UnB) como requisito parcial para obtenção do grau de Bacharel em Administração.

Você poderá ou não se identificar no questionário e garantimos que todas as informações fornecidas serão confidenciais e utilizadas apenas de forma sistematizada.

IDENTIFICAÇÃO

\begin{tabular}{|c|c|}
\hline Nome: HUGO STËNIO GAMA DOS SANTOS & $\begin{array}{l}\text { Sexo: } \\
(x \quad) \text { masculino }(\quad) \text { feminino }\end{array}$ \\
\hline $\begin{array}{l}\text { Instituição (nome e tipo de instituição: ONG, } \\
\text { Empresa Pública, etc.): } \\
\text { Instituto de Desenvolvimento Agropecuário do } \\
\text { Estado do Amazonas - IDAM }\end{array}$ & $\begin{array}{l}\text { Local de trabalho (Cidade e Estado): } \\
\text { Manaus - Amazonas }\end{array}$ \\
\hline \multicolumn{2}{|c|}{$\begin{array}{l}\text { Curso/Encontro/Oficina do qual participou (caso tenha participado de mais de um curso, } \\
\text { preencha um formulário para cada um deles): } \\
\text { Curso de Agroecologia }\end{array}$} \\
\hline $\begin{array}{l}\text { Data do Curso/Encontro/Oficina (pelo menos mês } \\
24 \text { a } 28 \text { de abril de } 2006 \text { - Manaus/AM }\end{array}$ & \\
\hline
\end{tabular}

Indique sua área de atuação? (As opções não são excludentes: você poderá marcar mais de uma opção)

\begin{tabular}{|l|l|}
\hline$X$ & EXTENSÃO RURAL \\
\hline & PESQUISA \\
\hline
\end{tabular}




\begin{tabular}{|l|l|}
\hline & ENSINO \\
\hline & OUTROS \\
\hline
\end{tabular}

2) Qual o seu nível de escolaridade? (Considere apenas o nível mais alto)

\begin{tabular}{|l|l|}
\hline & NÍVEL MÉDIO \\
\hline$X$ & NÍVEL SUPERIOR \\
\hline & PÓS-GRADUAÇÃO \\
\hline
\end{tabular}

3) Os conteúdos abordados foram condizentes com as demandas do seu dia-a-dia?

\begin{tabular}{|l|l|}
\hline & SIM \\
\hline$X$ & PARCIALMENTE \\
\hline & NÃO \\
\hline
\end{tabular}

3) O curso contribuiu para o seu aperfeiçoamento profissional?

\begin{tabular}{|l|l|}
\hline$X$ & SIM \\
\hline & NÃO \\
\hline
\end{tabular}

5) Os conhecimentos adquiridos estão sendo aplicados no seu trabalho? Em caso afirmativo, indique em que grau estes conhecimentos estão sendo aplicados. Em caso negativo, indique por que razão isto não ocorre: (Em caso negativo, as respostas não são excludentes: você poderá marcar mais de uma opção).

\begin{tabular}{|l|l|l|l|}
\hline & $\begin{array}{l}\text { SIM (indique ao lado } \\
\text { em que grau) }\end{array}$ & $X$ & MUITO APLICADOS \\
\cline { 3 - 4 } & & POUCO APLICADOS \\
\hline
\end{tabular}




\begin{tabular}{|c|c|}
\hline \multirow{5}{*}{$\begin{array}{l}\text { NÃO (indique ao lado a } \\
\text { razão da não aplicação) }\end{array}$} & $\begin{array}{l}\text { CONTEÚDO NĀO ADEQUADO ȦS NECESSIDADES } \\
\text { ESPECÍFICAS DA REGIÃO }\end{array}$ \\
\hline & $\begin{array}{l}\text { CONTEÚDO NÃO FOI SUFICIENTEMENTE } \\
\text { APROFUNDADO PARA PERMITIR UMA APLICAÇÃO } \\
\text { EFICAZ E EFICIENTE }\end{array}$ \\
\hline & \begin{tabular}{|llllll} 
FALTA DE & APOIO & E & INCENTIVO & DA & MINHA \\
INSTITUIÇÃO & & & & &
\end{tabular} \\
\hline & FALTA DE INCENTIVO ÀS AÇÕES DE ATER \\
\hline & NÃO TENHO INTERESSE EM APLICAR \\
\hline
\end{tabular}

6) A partir deste curso: (As opções não são excludentes: você poderá marcar mais de uma opção)

\begin{tabular}{|l|l|}
\hline & NÃO MUDOU NADA EM MEU TRABALHO. \\
\hline$X$ & $\begin{array}{l}\text { MEU TRABALHO PASSOU A CONTRIBUIR MAIS COM OS AGRICULTORES(AS) } \\
\text { FAMILIARES. }\end{array}$ \\
\hline$X$ & CONSEGUI INFLUENCIAR NAS ORIENTAÇÕES DA MINHA INSTITUIÇÃO. \\
\hline & PASSEI A TRABALHAR COM METODOLOGIAS PARTICIPATIVAS. \\
\hline & $\begin{array}{l}\text { CRESCEU A ÁREA DE AGRICULTURA DE BASE ECOLÓGICA NAS COMUNIDADES } \\
\text { ONDE ATUO. }\end{array}$ \\
\hline$X$ & CONTINUEI ME APERFEIÇOANDO SOBRE TEMAS ABORDADOS. \\
\hline
\end{tabular}

7) Depois do curso você apoiou atividades de capacitação de técnicos e agricultores com base nos princípios e diretrizes da Pnater? ? (Considere como apoio a atividades de capacitação a participação no planejamento, elaboração de ementas, seleção de participantes e de palestrantes.)

\begin{tabular}{|l|l|}
\hline$X$ & SIM \\
\hline
\end{tabular}




\section{NÃO}

8) Usou os conhecimentos para ministrar outros cursos com o mesmo conteúdo ou conteúdos semelhantes?

\begin{tabular}{|l|l|}
\hline & SIM \\
\hline$X$ & NÃO \\
\hline
\end{tabular}

9) Marque o seu grau de satisfação com relação ao curso oferecido pelo DATER: (Considere a seguinte pontuação: 1 - MUITO RUIM; 2 - RUIM; 3 - REGULAR; 4 - BOM; 5 - MUITO BOM)

\begin{tabular}{|l|l|l|l|l|}
\hline 1 & 2 & 3 & 4 & 5 \\
\hline
\end{tabular}

10) Marque seu grau de satisfação com relação ao DATER: (Considere a seguinte pontuação: 1 - MUITO RUIM; 2 - RUIM; 3 - REGULAR; 4 - BOM; 5 - MUITO BOM)

\begin{tabular}{|l|l|l|l|l|}
\hline 1 & 2 & 3 & 4 & 5 \\
\hline
\end{tabular}




\section{PESQUISA - IMPACTO DAS AÇÕES DE FORMAÇÃO REALIZADAS PELO DATER/SAF/MDA NO PERÍODO 2004-2009}

Caros colaboradores,

Contamos com a sua atenção para preencher o formulário abaixo.

O mesmo tem por objetivo fornecer informações para avaliação da Eficiência, Efetividade e Eficácia da Política Pública de Formação de Agentes de Ater adotada pelo Departamento de Assistência Técnica e Extensão Rural, da Secretaria de Agricultura Familiar do Ministério do Desenvolvimento - DATER/SAF/MDA, no período de 2004 a 2009, tema escolhido para Monografia a ser apresentada à Universidade de Brasília (UnB) como requisito parcial para obtenção do grau de Bacharel em Administração.

Você poderá ou não se identificar no questionário e garantimos que todas as informações fornecidas serão confidenciais e utilizadas apenas de forma sistematizada.

IDENTIFICAÇÃO

\begin{tabular}{|c|c|}
\hline Nome: HÉLIO OMAR CONCEIÇĀO RIBEIRO & $\begin{array}{l}\text { Sexo: } \\
(x \quad) \text { masculino } \quad(\quad) \text { feminino }\end{array}$ \\
\hline $\begin{array}{l}\text { Instituição (nome e tipo de instituição: ONG, } \\
\text { Empresa Pública, etc.): } \\
\text { Instituto de Desenvolvimento Agropecuário do } \\
\text { Estado do Amazonas - IDAM }\end{array}$ & $\begin{array}{l}\text { Local de trabalho (Cidade e Estado): } \\
\text { Unidade Local de Boa Vista do Ramos - } \\
\text { Amazonas }\end{array}$ \\
\hline \multicolumn{2}{|c|}{$\begin{array}{l}\text { Curso/Encontro/Oficina do qual participou (caso tenha participado de mais de um curso, } \\
\text { preencha um formulário para cada um deles): } \\
\text { Ater e Saúde no meio Rural }\end{array}$} \\
\hline \multicolumn{2}{|c|}{$\begin{array}{l}\text { Data do Curso/Encontro/Oficina (pelo menos mês e ano): } \\
02 \text { a } 06 \text { de maio de } 2006 \text { - Brasília/DF }\end{array}$} \\
\hline
\end{tabular}

Indique sua área de atuação? (As opções não são excludentes: você poderá marcar mais de uma opção) 


\begin{tabular}{|l|l|}
\hline$x$ & EXTENSÃO RURAL \\
\hline & PESQUISA \\
\hline$x$ & ENSINO \\
\hline & OUTROS \\
\hline
\end{tabular}

2) Qual o seu nível de escolaridade? (Considere apenas o nível mais alto)

\begin{tabular}{|l|l|}
\hline & NÍVEL MÉDIO \\
\hline$x$ & NÍVEL SUPERIOR \\
\hline & PÓS-GRADUAÇÃO \\
\hline
\end{tabular}

3) Os conteúdos abordados foram condizentes com as demandas do seu dia-a-dia?

\begin{tabular}{|l|l|}
\hline$x$ & SIM \\
\hline & PARCIALMENTE \\
\hline & NÃO \\
\hline
\end{tabular}

3) O curso contribuiu para o seu aperfeiçoamento profissional?

\begin{tabular}{|l|l|}
\hline$x$ & SIM \\
\hline & NÃO \\
\hline
\end{tabular}

5) Os conhecimentos adquiridos estão sendo aplicados no seu trabalho? Em caso afirmativo, indique em que grau estes conhecimentos estão sendo aplicados. Em caso negativo, indique por que razão isto não ocorre: (Em caso negativo, as respostas não são excludentes: você poderá marcar mais de uma opção).

\begin{tabular}{|l|l|l|l|}
\hline $\begin{array}{l}\text { SIM (indique ao lado } \\
\text { em que grau) }\end{array}$ & $X$ & MUITO APLICADOS \\
\cline { 2 - 3 } & & MEDIAMENTE APLICADOS \\
\hline
\end{tabular}




\begin{tabular}{|c|c|}
\hline & POUCO APLICADOS \\
\hline \multirow{5}{*}{$\begin{array}{l}\text { NÃO (indique ao lado a } \\
\text { razão da não aplicação) }\end{array}$} & $\begin{array}{l}\text { CONTEÚDO NÃO ADEQUADO ÀS NECESSIDADES } \\
\text { ESPECÍFICAS DA REGIÃO }\end{array}$ \\
\hline & $\begin{array}{l}\text { CONTEUUDO NĀO } \quad \text { FOI } \text { SUFICIENTEMENTE } \\
\text { APROFUNDADO PARA PERMITIR UMA APLICAÇÃO } \\
\text { EFICAZ E EFICIENTE }\end{array}$ \\
\hline & 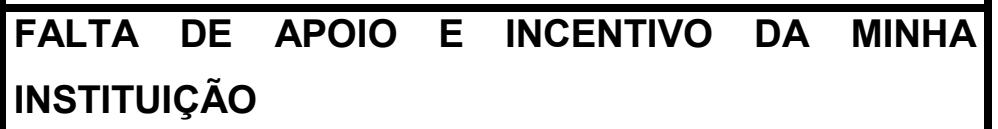 \\
\hline & FALTA DE INCENTIVO ÀS AÇÕES DE ATER \\
\hline & NÃO TENHO INTERESSE EM APLICAR \\
\hline
\end{tabular}

6) A partir deste curso: (As opções não são excludentes: você poderá marcar mais de uma opção)

\begin{tabular}{|l|l|}
\hline & NÃO MUDOU NADA EM MEU TRABALHO. \\
\hline$x$ & $\begin{array}{l}\text { MEU TRABALHO PASSOU A CONTRIBUIR MAIS COM OS AGRICULTORES(AS) } \\
\text { FAMILIARES. }\end{array}$ \\
\hline & CONSEGUI INFLUENCIAR NAS ORIENTAÇÕES DA MINHA INSTITUIÇÃO. \\
\hline$x$ & $\begin{array}{l}\text { PASSEI A TRABALHAR COM METODOLOGIAS PARTICIPATIVAS. } \\
\text { ONDE ATUO. }\end{array}$ \\
\hline & CONTINUEI ME APERFEIÇOANDO SOBRE TEMAS ABORDADOS. \\
\hline
\end{tabular}

7) Depois do curso você apoiou atividades de capacitação de técnicos e agricultores com base nos princípios e diretrizes da Pnater? ? (Considere como apoio a atividades de capacitação a participação no planejamento, elaboração de ementas, seleção de participantes e de palestrantes.) 


\section{NÃO}

8) Usou os conhecimentos para ministrar outros cursos com o mesmo conteúdo ou conteúdos semelhantes?

\begin{tabular}{|l|l|}
\hline$x$ & SIM \\
\hline & NÃO \\
\hline
\end{tabular}

9) Marque o seu grau de satisfação com relação ao curso oferecido pelo DATER: (Considere a seguinte pontuação: 1 - MUITO RUIM; 2 - RUIM; 3 - REGULAR; 4 - BOM; 5 - MUITO BOM)

\begin{tabular}{|l|l|l|l|l|}
\hline 1 & 2 & 3 & 4 & 5 \\
\hline
\end{tabular}

10) Marque seu grau de satisfação com relação ao DATER: (Considere a seguinte pontuação: 1 - MUITO RUIM; 2 - RUIM; 3 - REGULAR; 4 - BOM; 5 - MUITO BOM)

\begin{tabular}{|l|l|l|l|l|}
\hline 1 & 2 & 3 & 4 & 5 \\
\hline
\end{tabular}




\section{PESQUISA - IMPACTO DAS AÇÕES DE FORMAÇÃO REALIZADAS PELO DATER/SAF/MDA NO PERÍODO 2004-2009}

Caros colaboradores,

Contamos com a sua atenção para preencher o formulário abaixo.

O mesmo tem por objetivo fornecer informações para avaliação da Eficiência, Efetividade e Eficácia da Política Pública de Formação de Agentes de Ater adotada pelo Departamento de Assistência Técnica e Extensão Rural, da Secretaria de Agricultura Familiar do Ministério do Desenvolvimento - DATER/SAF/MDA, no período de 2004 a 2009, tema escolhido para Monografia a ser apresentada à Universidade de Brasília (UnB) como requisito parcial para obtenção do grau de Bacharel em Administração.

Você poderá ou não se identificar no questionário e garantimos que todas as informações fornecidas serão confidenciais e utilizadas apenas de forma sistematizada.

IDENTIFICAÇÃO

\begin{tabular}{|c|c|}
\hline Nome: HÉLIO SILVA PONTES & $\begin{array}{l}\text { Sexo: } \\
(x) \text { masculino }(\quad) \text { feminino }\end{array}$ \\
\hline $\begin{array}{l}\text { Instituição: Secretaria de Produção Rural do Estado } \\
\text { do Amazonas - SEPROR }\end{array}$ & $\begin{array}{l}\text { Local de trabalho (Cidade e Estado): } \\
\text { Manaus - AM. }\end{array}$ \\
\hline \multicolumn{2}{|c|}{$\begin{array}{l}\text { Curso/Encontro/Oficina do qual participou (caso tenha participado de mais de um curso, } \\
\text { preencha um formulário para cada um deles): } \\
\text { Curso de Diagnóstico Rural Participativo - DRP }\end{array}$} \\
\hline $\begin{array}{l}\text { Data do Curso/Encontro/Oficina (pelo menos mês } \\
16 \text { a } 27 \text { de outubro de } 2006 \text { - Manaus/AM }\end{array}$ & e ano): \\
\hline
\end{tabular}

Indique sua área de atuação? (As opções não são excludentes: você poderá marcar mais de uma opção)

\begin{tabular}{|l|l|}
\hline$X$ & EXTENSÃO RURAL \\
\hline & PESQUISA \\
\hline & ENSINO \\
\hline
\end{tabular}




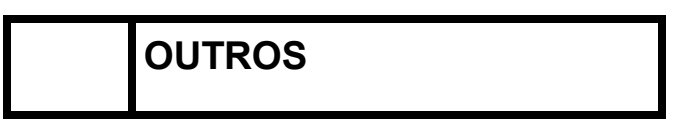

2) Qual o seu nível de escolaridade? (Considere apenas o nível mais alto)

\begin{tabular}{|c|l|}
\hline & NÍVEL MÉDIO \\
\hline$X$ & NÍVEL SUPERIOR \\
\hline & PÓS-GRADUAÇÃO \\
\hline
\end{tabular}

3) Os conteúdos abordados foram condizentes com as demandas do seu dia-a-dia?

\begin{tabular}{|l|l|}
\hline$X$ & SIM \\
\hline & PARCIALMENTE \\
\hline & NÃO \\
\hline
\end{tabular}

3) O curso contribuiu para o seu aperfeiçoamento profissional?

\begin{tabular}{|l|l|}
\hline$X$ & SIM \\
\hline & NÃO \\
\hline
\end{tabular}

5) Os conhecimentos adquiridos estão sendo aplicados no seu trabalho? Em caso afirmativo, indique em que grau estes conhecimentos estão sendo aplicados. Em caso negativo, indique por que razão isto não ocorre: (Em caso negativo, as respostas não são excludentes: você poderá marcar mais de uma opção).

\begin{tabular}{|c|c|c|c|}
\hline \multirow{3}{*}{$x$} & \multirow{3}{*}{$\begin{array}{l}\text { SIM (indique ao lado } \\
\text { em que grau) }\end{array}$} & $\mathrm{X}$ & MUITO APLICADOS \\
\hline & & & MEDIAMENTE APLICADOS \\
\hline & & & POUCO APLICADOS \\
\hline & $\begin{array}{l}\text { NĀO (indique ao lado a } \\
\text { razão da não aplicação) }\end{array}$ & & $\begin{array}{l}\text { CONTEỦDO NĀO ADEQUADO ȦS NECESSIDADES } \\
\text { ESPECÍFICAS DA REGIÃO }\end{array}$ \\
\hline
\end{tabular}




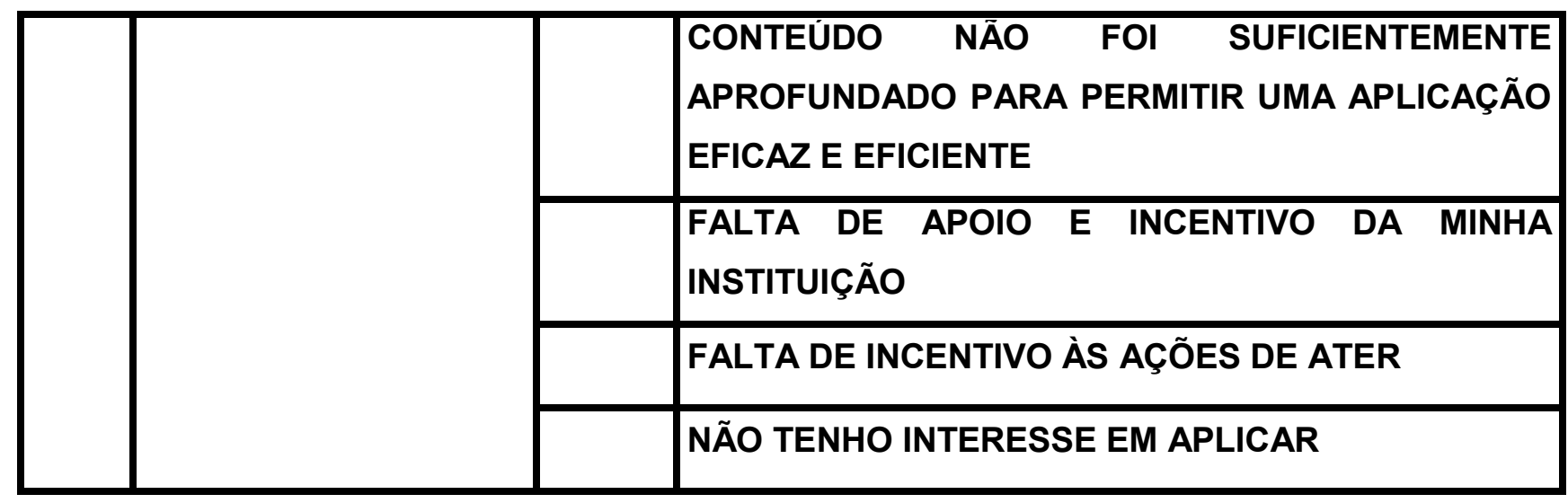

6) A partir deste curso: (As opções não são excludentes: você poderá marcar mais de uma opção)

\begin{tabular}{|l|l|}
\hline$x$ & $\begin{array}{l}\text { NÃO MUDOU NADA EM MEU TRABALHO. } \\
\text { FAMILIARES. }\end{array}$ \\
\hline & CONSEGUI INFLUENCIAR NAS ORIENTAÇÕES DA MINHA INSTITUIÇÃO. \\
\hline & PASSEI A TRABALHAR COM METODOLOGIAS PARTICIPATIVAS. \\
\hline & $\begin{array}{l}\text { CRESCEU A AREA DE AGRICULTURA DE BASE ECOLOGICA NAS COMUNIDADES } \\
\text { ONDE ATUO. }\end{array}$ \\
\hline & CONTINUEI ME APERFEIÇOANDO SOBRE TEMAS ABORDADOS. \\
\hline
\end{tabular}

7) Depois do curso você apoiou atividades de capacitação de técnicos e agricultores com base nos princípios e diretrizes da Pnater?

\begin{tabular}{|l|l|}
\hline$X$ & SIM \\
\hline & NÃO \\
\hline
\end{tabular}

8) Usou os conhecimentos para ministrar outros cursos com o mesmo conteúdo ou conteúdos semelhantes?

\begin{tabular}{|l|l|}
\hline$X$ & SIM \\
\hline & NÃO \\
\hline
\end{tabular}


9) Marque o seu grau de satisfação com relação ao curso oferecido pelo DATER: (Considere a seguinte pontuação: 1 - MUITO RUIM; 2 - RUIM; 3 - REGULAR; 4 - BOM; 5 - MUITO BOM)

\begin{tabular}{|l|l|l|l|l|}
\hline 1 & 2 & 3 & 4 & 5 \\
\hline
\end{tabular}

10) Marque seu grau de satisfação com relação ao DATER: (Considere a seguinte pontuação: 1 - MUITO RUIM; 2 - RUIM; 3 - REGULAR; 4 - BOM; 5 - MUITO BOM)

\begin{tabular}{|l|l|l|l|l|}
\hline 1 & 2 & 3 & 4 & 5 \\
\hline
\end{tabular}




\section{PESQUISA - IMPACTO DAS AÇÕES DE FORMAÇÃO REALIZADAS PELO DATER/SAF/MDA NO PERÍODO 2004-2009}

Caros colaboradores,

Contamos com a sua atenção para preencher o formulário abaixo.

O mesmo tem por objetivo fornecer informações para avaliação da Eficiência, Efetividade e Eficácia da Política Pública de Formação de Agentes de Ater adotada pelo Departamento de Assistência Técnica e Extensão Rural, da Secretaria de Agricultura Familiar do Ministério do Desenvolvimento - DATER/SAF/MDA, no período de 2004 a 2009, tema escolhido para Monografia a ser apresentada à Universidade de Brasília (UnB) como requisito parcial para obtenção do grau de Bacharel em Administração.

Você poderá ou não se identificar no questionário e garantimos que todas as informações fornecidas serão confidenciais e utilizadas apenas de forma sistematizada.

IDENTIFICAÇÃO

\begin{tabular}{|c|c|}
\hline Nome: GUILHERME MAGALHĀES DA COSTA & $\begin{array}{l}\text { Sexo: } \\
(x \quad) \text { masculino } \quad(\quad) \text { feminino }\end{array}$ \\
\hline $\begin{array}{l}\text { Instituição (nome e tipo de instituição: ONG, } \\
\text { Empresa Pública, etc.): } \\
\text { Instituto de Desenvolvimento Agropecuário do } \\
\text { Estado do Amazonas - IDAM }\end{array}$ & $\begin{array}{l}\text { Local de trabalho (Cidade e Estado): } \\
\text { Unidade Local de Santo Antônio do } \\
\text { Içá/Amazonas }\end{array}$ \\
\hline \multicolumn{2}{|c|}{$\begin{array}{l}\text { Curso/Encontro/Oficina do qual participou (caso tenha participado de mais de um curso, } \\
\text { preencha um formulário para cada um deles): } \\
\text { Curso de Agente de Ater que atuam com Comunidades Indígenas }\end{array}$} \\
\hline $\begin{array}{l}\text { Data do Curso/Encontro/Oficina (pelo menos mês } \\
13 \text { a } 17 \text { de dezembro de } 2004 \text { - Manaus/Amazonas }\end{array}$ & e ano): \\
\hline
\end{tabular}

Indique sua área de atuação? (As opções não são excludentes: você poderá marcar mais de uma opção)

$\mathrm{X}$ EXTENSÃO RURAL 


\begin{tabular}{|l|l|}
\hline & PESQUISA \\
\hline & ENSINO \\
\hline & OUTROS \\
\hline
\end{tabular}

2) Qual o seu nível de escolaridade? (Considere apenas o nível mais alto)

\begin{tabular}{|l|l|}
\hline$X$ & NÍVEL MÉDIO \\
\hline & NÍVEL SUPERIOR \\
\hline & PÓS-GRADUAÇÃO \\
\hline
\end{tabular}

3) Os conteúdos abordados foram condizentes com as demandas do seu dia-a-dia?

\begin{tabular}{|l|l|}
\hline$X$ & SIM \\
\hline & PARCIALMENTE \\
\hline & NÃO \\
\hline
\end{tabular}

3) O curso contribuiu para o seu aperfeiçoamento profissional?

\begin{tabular}{|l|l|}
\hline$X$ & SIM \\
\hline & NÃO \\
\hline
\end{tabular}

5) Os conhecimentos adquiridos estão sendo aplicados no seu trabalho Em caso afirmativo, indique em que grau estes conhecimentos estão sendo aplicados. Em caso negativo, indique por que razão isto não ocorre: (Em caso negativo, as respostas não são excludentes: você poderá marcar mais de uma opção).

\begin{tabular}{|l|l|l|l|}
\hline $\begin{array}{l}\text { SIM (indique ao lado } \\
\text { em que grau) }\end{array}$ & & MUITO APLICADOS \\
\cline { 2 - 4 } & $X$ & MEDIAMENTE APLICADOS \\
\hline
\end{tabular}




\begin{tabular}{|c|c|}
\hline & POUCO APLICADOS \\
\hline \multirow{5}{*}{$\begin{array}{l}\text { NÃO (indique ao lado a } \\
\text { razão da não aplicação) }\end{array}$} & $\begin{array}{l}\text { CONTEÚDO NÃO ADEQUADO ÀS NECESSIDADES } \\
\text { ESPECÍFICAS DA REGIÃO }\end{array}$ \\
\hline & $\begin{array}{l}\text { CONTEÚDO NĀO } \quad \text { FOI } \text { SUFICIENTEMENTE } \\
\text { APROFUNDADO PARA PERMITIR UMA APLICAÇÃO } \\
\text { EFICAZ E EFICIENTE }\end{array}$ \\
\hline & 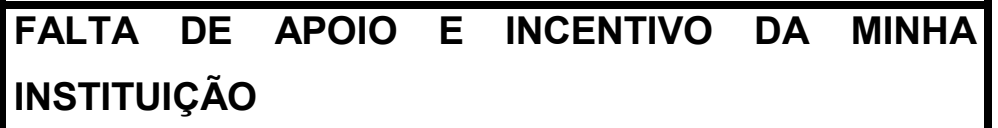 \\
\hline & FALTA DE INCENTIVO ÀS AÇÕES DE ATER \\
\hline & NÃO TENHO INTERESSE EM APLICAR \\
\hline
\end{tabular}

6) A partir deste curso: (As opções não são excludentes: você poderá marcar mais de uma opção)

\begin{tabular}{|l|l|}
\hline & NÃO MUDOU NADA EM MEU TRABALHO. \\
\hline$X$ & $\begin{array}{l}\text { MEU TRABALHO PASSOU A CONTRIBUIR MAIS COM OS AGRICULTORES(AS) } \\
\text { FAMILIARES. }\end{array}$ \\
\hline & CONSEGUI INFLUENCIAR NAS ORIENTAÇÕES DA MINHA INSTITUIÇÃO. \\
\hline & PASSEI A TRABALHAR COM METODOLOGIAS PARTICIPATIVAS. \\
\hline & $\begin{array}{l}\text { CRESCEU A ÁREA DE AGRICULTURA DE BASE ECOLÓGICA NAS COMUNIDADES } \\
\text { ONDE ATUO. }\end{array}$ \\
\hline & CONTINUEI ME APERFEIÇOANDO SOBRE TEMAS ABORDADOS. \\
\hline
\end{tabular}

7) Depois do curso você apoiou atividades de capacitação de técnicos e agricultores com base nos princípios e diretrizes da Pnater? ? (Considere como apoio a atividades de capacitação a participação no planejamento, elaboração de ementas, seleção de participantes e de palestrantes.) 


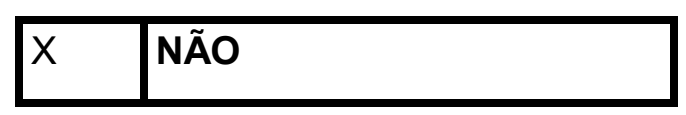

8) Usou os conhecimentos para ministrar outros cursos com o mesmo conteúdo ou conteúdos semelhantes?

\begin{tabular}{|l|l|}
\hline & SIM \\
\hline$X$ & NÃO \\
\hline
\end{tabular}

9) Marque o seu grau de satisfação com relação ao curso oferecido pelo DATER: (Considere a seguinte pontuação: 1 - MUITO RUIM; 2 - RUIM; 3 - REGULAR; 4 - BOM; 5 - MUITO BOM)

\begin{tabular}{|l|l|l|l|l|}
\hline 1 & 2 & 3 & 4 & 5 \\
\hline
\end{tabular}

10) Marque seu grau de satisfação com relação ao DATER: (Considere a seguinte pontuação: 1 - MUITO RUIM; 2 - RUIM; 3 - REGULAR; 4 - BOM; 5 - MUITO BOM)

\begin{tabular}{|l|l|l|l|l|}
\hline 1 & 2 & 3 & 4 & 5 \\
\hline
\end{tabular}




\section{PESQUISA - IMPACTO DAS AÇÕES DE FORMAÇÃO REALIZADAS PELO DATER/SAF/MDA NO PERÍODO 2004-2009}

Caros colaboradores,

Contamos com a sua atenção para preencher o formulário abaixo.

O mesmo tem por objetivo fornecer informações para avaliação da Eficiência, Efetividade e Eficácia da Política Pública de Formação de Agentes de Ater adotada pelo Departamento de Assistência Técnica e Extensão Rural, da Secretaria de Agricultura Familiar do Ministério do Desenvolvimento - DATER/SAF/MDA, no período de 2004 a 2009, tema escolhido para Monografia a ser apresentada à Universidade de Brasília (UnB) como requisito parcial para obtenção do grau de Bacharel em Administração.

Você poderá ou não se identificar no questionário e garantimos que todas as informações fornecidas serão confidenciais e utilizadas apenas de forma sistematizada.

IDENTIFICAÇÃO

\begin{tabular}{|c|c|}
\hline Nome: GILBERTO OLAVO COSTA DE OLIVEIRA & $\begin{array}{l}\text { Sexo: } \\
(x) \text { masculino } \quad(\quad) \text { feminino }\end{array}$ \\
\hline $\begin{array}{l}\text { Instituição (nome e tipo de instituição: ONG, } \\
\text { Empresa Pública, etc.): } \\
\text { Instituto de Desenvolvimento Agropecuário do } \\
\text { Estado do Amazonas - IDAM }\end{array}$ & $\begin{array}{l}\text { Local de trabalho (Cidade e Estado): } \\
\text { Unidade Local de Carauari - Amazonas }\end{array}$ \\
\hline \multicolumn{2}{|c|}{$\begin{array}{l}\text { Curso/Encontro/Oficina do qual participou (caso tenha participado de mais de um curso, } \\
\text { preencha um formulário para cada um deles): } \\
\text { Curso de Agente de Ater que atuam com Populações Extrativistas e ou em Atividades Florestais }\end{array}$} \\
\hline $\begin{array}{l}\text { Data do Curso/Encontro/Oficina (pelo menos mês } \\
14 \text { a } 18 \text { de fevereiro de } 2005 \text { - Belém/PA }\end{array}$ & e ano): \\
\hline
\end{tabular}

Indique sua área de atuação? (As opções não são excludentes: você poderá marcar mais de uma opção)

\begin{tabular}{|l|l|}
\hline$X$ & EXTENSÃO RURAL \\
\hline & PESQUISA \\
\hline
\end{tabular}




\begin{tabular}{|l|l|}
\hline & ENSINO \\
\hline & OUTROS \\
\hline
\end{tabular}

2) Qual o seu nível de escolaridade? (Considere apenas o nível mais alto)

\begin{tabular}{|l|l|}
\hline & NÍVEL MÉDIO \\
\hline$X$ & NÍVEL SUPERIOR \\
\hline & PÓS-GRADUAÇÃO \\
\hline
\end{tabular}

3) Os conteúdos abordados foram condizentes com as demandas do seu dia-a-dia?

\begin{tabular}{|l|l|}
\hline & SIM \\
\hline$X$ & PARCIALMENTE \\
\hline & NÃO \\
\hline
\end{tabular}

3) O curso contribuiu para o seu aperfeiçoamento profissional?

\begin{tabular}{|l|l|}
\hline$X$ & SIM \\
\hline & NÃO \\
\hline
\end{tabular}

5) Os conhecimentos adquiridos estão sendo aplicados no seu trabalho? Em caso afirmativo, indique em que grau estes conhecimentos estão sendo aplicados. Em caso negativo, indique por que razão isto não ocorre: (Em caso negativo, as respostas não são excludentes: você poderá marcar mais de uma opção).

\begin{tabular}{|l|l|l|l|}
\hline \multirow{2}{*}{$\begin{array}{l}\text { SIM (indique ao lado } \\
\text { em que grau) }\end{array}$} & & MUITO APLICADOS \\
\cline { 2 - 3 } & $\mathrm{X}$ & POUCO APLICADOS \\
\hline
\end{tabular}




\begin{tabular}{|c|c|}
\hline \multirow{5}{*}{$\begin{array}{l}\text { NÃO (indique ao lado a } \\
\text { razão da não aplicação) }\end{array}$} & $\begin{array}{l}\text { CONTEÚDO NĀO ADEQUADO ȦS NECESSIDADES } \\
\text { ESPECÍFICAS DA REGIÃO }\end{array}$ \\
\hline & $\begin{array}{l}\text { CONTEÚDO NÃO FOI SUFICIENTEMENTE } \\
\text { APROFUNDADO PARA PERMITIR UMA APLICAÇÃO } \\
\text { EFICAZ E EFICIENTE }\end{array}$ \\
\hline & \begin{tabular}{|llllll} 
FALTA DE & APOIO & E & INCENTIVO & DA & MINHA \\
INSTITUIÇÃO & & & & &
\end{tabular} \\
\hline & FALTA DE INCENTIVO ÀS AÇÕES DE ATER \\
\hline & NÃO TENHO INTERESSE EM APLICAR \\
\hline
\end{tabular}

6) A partir deste curso: (As opções não são excludentes: você poderá marcar mais de uma opção)

\begin{tabular}{|l|l|}
\hline & $\begin{array}{l}\text { NÃO MUDOU NADA EM MEU TRABALHO. } \\
\text { MEU TRABALHO PASSOU A CONTRIBUIR MAIS COM OS AGRICULTORES(AS) } \\
\text { FAMILIARES. }\end{array}$ \\
\hline$X$ & CONSEGUI INFLUENCIAR NAS ORIENTAÇÕES DA MINHA INSTITUIÇÃO. \\
\hline & $\begin{array}{l}\text { PASSEI A TRABALHAR COM METODOLOGIAS PARTICIPATIVAS. } \\
\text { ONDE ATUO. }\end{array}$ \\
\hline & CONTINUEI ME APERFEIÇOANDO SOBRE TEMAS ABORDADOS. \\
\hline
\end{tabular}

7) Depois do curso você apoiou atividades de capacitação de técnicos e agricultores com base nos princípios e diretrizes da Pnater? ? (Considere como apoio a atividades de capacitação a participação no planejamento, elaboração de ementas, seleção de participantes e de palestrantes.)

\begin{tabular}{|l|l|}
\hline$X$ & SIM \\
\hline & NÃO \\
\hline
\end{tabular}


8) Usou os conhecimentos para ministrar outros cursos com o mesmo conteúdo ou conteúdos semelhantes?

\begin{tabular}{|l|l|}
\hline$X$ & SIM \\
\hline & NÃO \\
\hline
\end{tabular}

9) Marque o seu grau de satisfação com relação ao curso oferecido pelo DATER: (Considere a seguinte pontuação: 1 - MUITO RUIM; 2 - RUIM; 3 - REGULAR; 4 - BOM; 5 - MUITO BOM)

\begin{tabular}{|l|l|l|l|l|}
\hline 1 & 2 & 3 & 4 & 5 \\
\hline
\end{tabular}

10) Marque seu grau de satisfação com relação ao DATER: (Considere a seguinte pontuação: 1 - MUITO RUIM; 2 - RUIM; 3 - REGULAR; 4 - BOM; 5 - MUITO BOM)

\begin{tabular}{|l|l|l|l|l|}
\hline 1 & 2 & 3 & 4 & 5 \\
\hline
\end{tabular}




\section{PESQUISA - IMPACTO DAS AÇÕES DE FORMAÇÃO REALIZADAS PELO DATER/SAF/MDA NO PERÍODO 2004-2009}

Caros colaboradores,

Contamos com a sua atenção para preencher o formulário abaixo.

O mesmo tem por objetivo fornecer informações para avaliação da Eficiência, Efetividade e Eficácia da Política Pública de Formação de Agentes de Ater adotada pelo Departamento de Assistência Técnica e Extensão Rural, da Secretaria de Agricultura Familiar do Ministério do Desenvolvimento - DATER/SAF/MDA, no período de 2004 a 2009, tema escolhido para Monografia a ser apresentada à Universidade de Brasília (UnB) como requisito parcial para obtenção do grau de Bacharel em Administração.

Você poderá ou não se identificar no questionário e garantimos que todas as informações fornecidas serão confidenciais e utilizadas apenas de forma sistematizada.

IDENTIFICAÇÃO

\begin{tabular}{|c|c|}
\hline Nome: GILBERTO FERREIRA DE GOUVÊA & $\begin{array}{l}\text { Sexo: } \\
(x \quad) \text { masculino } \quad(\quad) \text { feminino }\end{array}$ \\
\hline $\begin{array}{l}\text { Instituição (nome e tipo de instituição: ONG, } \\
\text { Empresa Pública, etc.): } \\
\text { Instituto de Desenvolvimento Agropecuário do } \\
\text { Estado do Amazonas - IDAM }\end{array}$ & $\begin{array}{l}\text { Local de trabalho (Cidade e Estado): } \\
\text { Unidade Local de Maraã - Amazonas }\end{array}$ \\
\hline \multicolumn{2}{|c|}{$\begin{array}{l}\text { Curso/Encontro/Oficina do qual participou (caso tenha participado de mais de um curso, } \\
\text { preencha um formulário para cada um deles): } \\
\text { II Encontro para Socialização dos Conceitos Básicos da Política Nacional de ATER }\end{array}$} \\
\hline $\begin{array}{l}\text { Data do Curso/Encontro/Oficina (pelo menos mês } \\
04 \text { a } 08 \text { de dezembro de } 2006 \text { - Manaus/AM }\end{array}$ & \\
\hline
\end{tabular}

Indique sua área de atuação? (As opções não são excludentes: você poderá marcar mais de uma opção)

\begin{tabular}{|l|l|}
\hline$X$ & EXTENSÃO RURAL \\
\hline & PESQUISA \\
\hline
\end{tabular}




\begin{tabular}{|l|l|}
\hline & ENSINO \\
\hline & OUTROS \\
\hline
\end{tabular}

2) Qual o seu nível de escolaridade? (Considere apenas o nível mais alto)

\begin{tabular}{|l|l|}
\hline$X$ & NÍVEL MÉDIO \\
\hline & NÍVEL SUPERIOR \\
\hline & PÓS-GRADUAÇÃO \\
\hline
\end{tabular}

3) Os conteúdos abordados foram condizentes com as demandas do seu dia-a-dia?

\begin{tabular}{|l|l|}
\hline & SIM \\
\hline$X$ & PARCIALMENTE \\
\hline & NÃO \\
\hline
\end{tabular}

3) O curso contribuiu para o seu aperfeiçoamento profissional?

\begin{tabular}{|l|l|}
\hline$X$ & SIM \\
\hline & NÃO \\
\hline
\end{tabular}

5) Os conhecimentos adquiridos estão sendo aplicados no seu trabalho? Em caso afirmativo, indique em que grau estes conhecimentos estão sendo aplicados. Em caso negativo, indique por que razão isto não ocorre: (Em caso negativo, as respostas não são excludentes: você poderá marcar mais de uma opção).

\begin{tabular}{|c|c|c|}
\hline \multirow{3}{*}{$\begin{array}{l}\text { SIM (indique ao lado } \\
\text { em que grau) }\end{array}$} & & MUITO APLICADOS \\
\hline & $x$ & MEDIAMENTE APLICADOS \\
\hline & & POUCO APLICADOS \\
\hline
\end{tabular}




\begin{tabular}{|c|c|}
\hline \multirow{5}{*}{$\begin{array}{l}\text { NÃO (indique ao lado a } \\
\text { razão da não aplicação) }\end{array}$} & $\begin{array}{l}\text { CONTEÚDO NĀO ADEQUADO ȦS NECESSIDADES } \\
\text { ESPECÍFICAS DA REGIÃO }\end{array}$ \\
\hline & $\begin{array}{l}\text { CONTEÚDO NÃO FOI SUFICIENTEMENTE } \\
\text { APROFUNDADO PARA PERMITIR UMA APLICAÇÃO } \\
\text { EFICAZ E EFICIENTE }\end{array}$ \\
\hline & \begin{tabular}{|llllll} 
FALTA DE & APOIO & E & INCENTIVO & DA & MINHA \\
INSTITUIÇÃO & & & & &
\end{tabular} \\
\hline & FALTA DE INCENTIVO ÀS AÇÕES DE ATER \\
\hline & NÃO TENHO INTERESSE EM APLICAR \\
\hline
\end{tabular}

6) A partir deste curso: (As opções não são excludentes: você poderá marcar mais de uma opção)

\begin{tabular}{|l|l|}
\hline$x$ & $\begin{array}{l}\text { NÃO MUDOU NADA EM MEU TRABALHO. } \\
\text { FAMILIARES. }\end{array}$ \\
\hline & CONSEGUI INFLUENCIAR NAS ORIENTAÇÕES DA MINHA INSTITUIÇÃO. \\
\hline & PASSEI A TRABALHAR COM METODOLOGIAS PARTICIPATIVAS. \\
\hline & $\begin{array}{l}\text { CRESCEU A ÁREA DE AGRICULTURA DE BASE ECOLÓGICA NAS COMUNIDADES } \\
\text { ONDE ATUO. }\end{array}$ \\
\hline & CONTINUEI ME APERFEIÇOANDO SOBRE TEMAS ABORDADOS. \\
\hline
\end{tabular}

7) Depois do curso você apoiou atividades de capacitação de técnicos e agricultores com base nos princípios e diretrizes da Pnater? ? (Considere como apoio a atividades de capacitação a participação no planejamento, elaboração de ementas, seleção de participantes e de palestrantes.)

\begin{tabular}{|l|l|}
\hline$X$ & SIM \\
\hline
\end{tabular}




\section{NÃO}

8) Usou os conhecimentos para ministrar outros cursos com o mesmo conteúdo ou conteúdos semelhantes?

\begin{tabular}{|l|l|}
\hline & SIM \\
\hline$X$ & NÃO \\
\hline
\end{tabular}

9) Marque o seu grau de satisfação com relação ao curso oferecido pelo DATER: (Considere a seguinte pontuação: 1 - MUITO RUIM; 2 - RUIM; 3 - REGULAR; 4 - BOM; 5 - MUITO BOM)

\begin{tabular}{|l|l|l|l|l|}
\hline 1 & 2 & 3 & 4 & 5 \\
\hline
\end{tabular}

10) Marque seu grau de satisfação com relação ao DATER: (Considere a seguinte pontuação: 1 - MUITO RUIM; 2 - RUIM; 3 - REGULAR; 4 - BOM; 5 - MUITO BOM)

\begin{tabular}{|l|l|l|l|l|}
\hline 1 & 2 & 3 & 4 & 5 \\
\hline
\end{tabular}




\section{PESQUISA - GRAU DE SATISFAÇÃO DOS PARTICIPANTES DOS CURSOS REALIZADOS PELO SAF/DATER}

Caros colaboradores,

Contamos com a sua atenção para preencher o formulário abaixo. Suas respostas serão úteis para que possamos aperfeiçoar cada vez mais as nossas ações de Formação de Agentes de ATER.

IDENTIFICAÇÃO

\begin{tabular}{|c|c|}
\hline Nome: LUIZ ALDINEY ALVES DE OLIVEIRA & $\begin{array}{l}\text { Sexo: } \\
\left(\begin{array}{l}\text { xx }) \text { masculino } \quad(\quad) \text { feminino }\end{array}\right.\end{array}$ \\
\hline $\begin{array}{l}\text { Instituição (nome e tipo de instituição: ONG, } \\
\text { Empresa Pública, etc.): } \\
\text { Instituto de Desenvolvimento Agropecuário do } \\
\text { Estado do Amazonas - IDAM }\end{array}$ & $\begin{array}{l}\text { Local de trabalho (Cidade e Estado): } \\
\text { Unidade Local de Presidente Figueiredo - } \\
\text { Amazonas }\end{array}$ \\
\hline $\begin{array}{l}\text { Curso/Encontro/Oficina do qual participou (cas } \\
\text { preencha um formulário para cada um deles): } \\
\text { II Encontro para Socialização dos Conceitos Básicos }\end{array}$ & $\begin{array}{l}\text { tenha participado de mais de um curso, } \\
\text { da Política Nacional de ATER }\end{array}$ \\
\hline
\end{tabular}

Indique sua área de atuação? (As opções não são excludentes: você poderá marcar mais de uma opção)

\begin{tabular}{|l|l|}
\hline$X$ & EXTENSÃO RURAL \\
\hline & PESQUISA \\
\hline & ENSINO \\
\hline & OUTROS \\
\hline
\end{tabular}

2) Qual o seu nível de escolaridade? (Considere apenas o nível mais alto) 


\begin{tabular}{|l|l|}
\hline$X$ & NÍVEL MÉDIO \\
\hline & NÍVEL SUPERIOR \\
\hline & PÓS-GRADUAÇÃO \\
\hline
\end{tabular}

3) Os conteúdos abordados foram condizentes com as demandas do seu dia-a-dia?

\begin{tabular}{|l|l|}
\hline$X$ & SIM \\
\hline & PARCIALMENTE \\
\hline & NÃO \\
\hline
\end{tabular}

3) O curso contribuiu para o seu aperfeiçoamento profissional?

\begin{tabular}{|l|l|}
\hline$X$ & SIM \\
\hline & NÃO \\
\hline
\end{tabular}

5) Os conhecimentos adquiridos estão sendo aplicados no seu trabalho? Em caso afirmativo, indique em que grau estes conhecimentos estão sendo aplicados. Em caso negativo, indique por que razão isto não ocorre: (Em caso negativo, as respostas não são excludentes: você poderá marcar mais de uma opção).

\begin{tabular}{|l|l|l|l|}
\hline \multirow{3}{*}{$\begin{array}{l}\text { SIM (indique ao lado } \\
\text { em que grau) }\end{array}$} & & MUITO APLICADOS \\
\cline { 2 - 3 } & & MEDIAMENTE APLICADOS \\
\hline \multirow{3}{*}{$\begin{array}{l}\text { Não (indique ao lado a } \\
\text { razão da não aplicação) }\end{array}$} & & $\begin{array}{l}\text { POUCO APLICADOS } \\
\text { ESPECÍFICAS DA REGIÃO }\end{array}$ \\
\cline { 2 - 3 } & $\begin{array}{l}\text { CONTEÚDO NÃO FOI SUFICIENTEMENTE } \\
\text { APROFUNDADO PARA PERMITIR UMA APLICAÇÃO } \\
\text { EFICAZ E EFICIENTE }\end{array}$ \\
\hline & $\begin{array}{l}\text { FALTA DE APOIO E INCENTIVO DA MINHA } \\
\text { INSTITUIÇÃO }\end{array}$ \\
\hline
\end{tabular}




\begin{tabular}{|l|l|l|}
\hline \multirow{2}{*}{} & & FALTA DE INCENTIVO ÀS AÇÕES DE ATER \\
\cline { 3 - 3 } & & NÃO TENHO INTERESSE EM APLICAR \\
\hline
\end{tabular}

6) A partir deste curso: (As opções não são excludentes: você poderá marcar mais de uma opção)

\begin{tabular}{|l|l|}
\hline & NÃO MUDOU NADA EM MEU TRABALHO. \\
\hline$X$ & $\begin{array}{l}\text { MEU TRABALHO PASSOU A CONTRIBUIR MAIS COM OS AGRICULTORES(AS) } \\
\text { FAMILIARES. }\end{array}$ \\
\hline & CONSEGUI INFLUENCIAR NAS ORIENTAÇÕES DA MINHA INSTITUIÇÃO. \\
\hline$X$ & PASSEI A TRABALHAR COM METODOLOGIAS PARTICIPATIVAS. \\
\hline & $\begin{array}{l}\text { CRESCEU A ÁREA DE AGRICULTURA DE BASE ECOLÓGICA NAS COMUNIDADES } \\
\text { ONDE ATUO. }\end{array}$ \\
\hline & CONTINUEI ME APERFEIÇOANDO SOBRE TEMAS ABORDADOS. \\
\hline
\end{tabular}

7) Depois do curso você apoiou atividades de capacitação de técnicos e agricultores com base nos princípios e diretrizes da Pnater? (Considere como apoio a atividades de capacitação a participação no planejamento, elaboração de ementas, seleção de participantes e de palestrantes.)

\begin{tabular}{|l|l|}
\hline$X$ & SIM \\
\hline & NÃO \\
\hline
\end{tabular}

8) Usou os conhecimentos para ministrar outros cursos com o mesmo conteúdo ou conteúdos semelhantes?

\begin{tabular}{|l|l|}
\hline & SIM \\
\hline$X$ & NÃO \\
\hline
\end{tabular}

9) Marque o seu grau de satisfação com relação ao curso oferecido pelo DATER: 


\begin{tabular}{|l|l|l|l|l|}
\hline 1 & 2 & 3 & 4 & 5 \\
\hline
\end{tabular}

10) Marque seu grau de satisfação com relação ao DATER:

\begin{tabular}{|l|l|l|l|l|}
\hline 1 & 2 & 3 & 4 & 5 \\
\hline
\end{tabular}

Obs: As notas atribuídas as questões 9 e 10 devem obedecer a ordem crescente: 1 - muito ruim , 2 - ruim, 3 - regular, 4 - bom, 5 - muito bom. 


\section{PESQUISA - IMPACTO DAS AÇÕES DE FORMAÇÃO REALIZADAS PELO DATER/SAF/MDA NO PERÍODO 2004-2009}

Caros colaboradores,

Contamos com a sua atenção para preencher o formulário abaixo.

O mesmo tem por objetivo fornecer informações para avaliação da Eficiência, Efetividade e Eficácia da Política Pública de Formação de Agentes de Ater adotada pelo Departamento de Assistência Técnica e Extensão Rural, da Secretaria de Agricultura Familiar do Ministério do Desenvolvimento - DATER/SAF/MDA, no período de 2004 a 2009, tema escolhido para Monografia a ser apresentada à Universidade de Brasília (UnB) como requisito parcial para obtenção do grau de Bacharel em Administração.

Você poderá ou não se identificar no questionário e garantimos que todas as informações fornecidas serão confidenciais e utilizadas apenas de forma sistematizada.

IDENTIFICAÇÃO

\begin{tabular}{|c|c|}
\hline Nome: LUCIVALDO GARCIA MONTERO & $\begin{array}{l}\text { Sexo: } \\
(x) \text { masculino } \quad(\quad) \text { feminino }\end{array}$ \\
\hline $\begin{array}{l}\text { Instituição (nome e tipo de instituição: ONG, } \\
\text { Empresa Pública, etc.): } \\
\text { Instituto de Desenvolvimento Agropecuário do } \\
\text { Estado do Amazonas - IDAM }\end{array}$ & $\begin{array}{l}\text { Local de trabalho (Cidade e Estado): } \\
\text { Unidade Local de Itacoatiara - Amazonas }\end{array}$ \\
\hline \multicolumn{2}{|c|}{$\begin{array}{l}\text { Curso/Encontro/Oficina do qual participou (caso tenha participado de mais de um curso, } \\
\text { preencha um formulário para cada um deles): } \\
\text { II Encontro para Socialização dos Conceitos Básicos da Política Nacional de Ater }\end{array}$} \\
\hline $\begin{array}{l}\text { Data do Curso/Encontro/Oficina (pelo menos me } \\
04 \text { a } 08 \text { de dezembro de } 2006 \text { - Manaus/AM }\end{array}$ & \\
\hline
\end{tabular}

Indique sua área de atuação?

1) (As opções não são excludentes: você poderá marcar mais de uma opção)

\begin{tabular}{|l|l|}
\hline$X$ & EXTENSÃO RURAL \\
\hline & PESQUISA \\
\hline
\end{tabular}




\begin{tabular}{|l|l|}
\hline & ENSINO \\
\hline & OUTROS \\
\hline
\end{tabular}

2) Qual o seu nível de escolaridade? (Considere apenas o nível mais alto)

\begin{tabular}{|l|l|}
\hline$X$ & NÍVEL MÉDIO \\
\hline & NÍVEL SUPERIOR \\
\hline & PÓS-GRADUAÇÃO \\
\hline
\end{tabular}

3) Os conteúdos abordados foram condizentes com as demandas do seu dia-a-dia?

\begin{tabular}{|l|l|}
\hline & SIM \\
\hline$X$ & PARCIALMENTE \\
\hline & NÃO \\
\hline
\end{tabular}

3) O curso contribuiu para o seu aperfeiçoamento profissional?

\begin{tabular}{|l|l|}
\hline$X$ & SIM \\
\hline & NÃO \\
\hline
\end{tabular}

5) Os conhecimentos adquiridos estão sendo aplicados no seu trabalho? Em caso afirmativo, indique em que grau estes conhecimentos estão sendo aplicados. Em caso negativo, indique por que razão isto não ocorre: (Em caso negativo, as respostas não são excludentes: você poderá marcar mais de uma opção).

\begin{tabular}{|l|l|l|l|}
\hline \multirow{2}{*}{$\begin{array}{l}\text { SIM (indique ao lado } \\
\text { em que grau) }\end{array}$} & & MUITO APLICADOS \\
\cline { 2 - 3 } & $X$ & MEDIAMENTE APLICADOS \\
\hline & $\begin{array}{l}\text { NÃO (indique ao lado a } \\
\text { razão da não aplicação) }\end{array}$ & $\begin{array}{l}\text { POUCO APLICADOS } \\
\text { ESPECÍFICAS DA REGIÃO }\end{array}$ \\
\hline
\end{tabular}




\begin{tabular}{|l|l|l|}
\hline \multirow{3}{*}{} & & $\begin{array}{l}\text { CONTEÚDO NÃO FOI SUFICIENTEMENTE } \\
\text { APROFUNDADO PARA PERMITIR UMA APLICAÇÃO } \\
\text { EFICAZ E EFICIENTE }\end{array}$ \\
\cline { 2 - 4 } & $\begin{array}{l}\text { FALTA DE APOIO E INCENTIVO DA MINHA } \\
\text { INSTITUIÇÃO }\end{array}$ \\
\cline { 2 - 3 } & FALTA DE INCENTIVO ÀS AÇÕES DE ATER \\
\cline { 2 - 4 } & NÃO TENHO INTERESSE EM APLICAR \\
\hline
\end{tabular}

6) A partir deste curso: (As opções não são excludentes: você poderá marcar mais de uma opção)

\begin{tabular}{|l|l|}
\hline & NÃO MUDOU NADA EM MEU TRABALHO. \\
\hline$X$ & $\begin{array}{l}\text { MEU TRABALHO PASSOU A CONTRIBUIR MAIS COM OS AGRICULTORES(AS) } \\
\text { FAMILIARES. }\end{array}$ \\
\hline & CONSEGUI INFLUENCIAR NAS ORIENTAÇÕES DA MINHA INSTITUIÇÃO. \\
\hline & $\begin{array}{l}\text { CRESCEU A ÁREA DE AGRICULTURA DE BASE ECOLÓGICA NAS COMUNIDADES } \\
\text { ONDE ATUO. }\end{array}$ \\
\hline & CONTINUEI ME APERFEIÇOANDO SOBRE TEMAS ABORDADOS. \\
\hline
\end{tabular}

7) Depois do curso você apoiou atividades de capacitação de técnicos e agricultores com base nos princípios e diretrizes da Pnater? (Considere como apoio a atividades de capacitação a participação no planejamento, elaboração de ementas, seleção de participantes e de palestrantes.)

\begin{tabular}{|l|l|}
\hline$X$ & SIM \\
\hline & NÃO \\
\hline
\end{tabular}

8) Usou os conhecimentos para ministrar outros cursos com o mesmo conteúdo ou conteúdos semelhantes? 


\begin{tabular}{|l|l|}
\hline & SIM \\
\hline$X$ & NÃO \\
\hline
\end{tabular}

9) Marque o seu grau de satisfação com relação ao curso oferecido pelo DATER:

\begin{tabular}{|l|l|l|l|l|}
\hline 1 & 2 & 3 & 4 & 5 \\
\hline
\end{tabular}

10) Marque seu grau de satisfação com relação ao DATER:

\begin{tabular}{|l|l|l|l|l|}
\hline 1 & 2 & 3 & 4 & 5 \\
\hline
\end{tabular}

Obs: As notas atribuídas as questões 9 e 10 devem obedecer a ordem crescente: 1 - muito ruim , 2 - ruim, 3 - regular, 4 - bom, 5 - muito bom. 


\section{PESQUISA - IMPACTO DAS AÇÕES DE FORMAÇÃO REALIZADAS PELO DATER/SAF/MDA NO PERÍODO 2004-2009}

Caros colaboradores,

Contamos com a sua atenção para preencher o formulário abaixo.

O mesmo tem por objetivo fornecer informações para avaliação da Eficiência, Efetividade e Eficácia da Política Pública de Formação de Agentes de Ater adotada pelo Departamento de Assistência Técnica e Extensão Rural, da Secretaria de Agricultura Familiar do Ministério do Desenvolvimento - DATER/SAF/MDA, no período de 2004 a 2009, tema escolhido para Monografia a ser apresentada à Universidade de Brasília (UnB) como requisito parcial para obtenção do grau de Bacharel em Administração.

Você poderá ou não se identificar no questionário e garantimos que todas as informações fornecidas serão confidenciais e utilizadas apenas de forma sistematizada.

IDENTIFICAÇÃO

\begin{tabular}{|c|c|}
\hline Nome: LUCIVALDO RIBEIRO PEREIRA & $\begin{array}{l}\text { Sexo: } \\
(x) \text { masculino } \quad(\quad) \text { feminino }\end{array}$ \\
\hline $\begin{array}{l}\text { Instituição (nome e tipo de instituição: ONG, } \\
\text { Empresa Pública, etc.): } \\
\text { Instituto de Desenvolvimento Agropecuário do } \\
\text { Estado do Amazonas - IDAM }\end{array}$ & $\begin{array}{l}\text { Local de trabalho (Cidade e Estado): } \\
\text { Unidade Local de Parintins - Amazonas }\end{array}$ \\
\hline \multicolumn{2}{|c|}{$\begin{array}{l}\text { Curso/Encontro/Oficina do qual participou (caso tenha participado de mais de um curso, } \\
\text { preencha um formulário para cada um deles): } \\
\text { Oficina de Nivelamento Conceitual sobre a Política Nacional de Ater }\end{array}$} \\
\hline \multicolumn{2}{|c|}{$\begin{array}{l}\text { Data do Curso/Encontro/Oficina (pelo menos mês e ano): } \\
08 \text { a } 12 \text { de novembro de } 2004 \text { - Rio Branco/AC }\end{array}$} \\
\hline
\end{tabular}

Indique sua área de atuação? (As opções não são excludentes: você poderá marcar mais de uma opção) 


\begin{tabular}{|l|l|}
\hline$X$ & EXTENSÃO RURAL \\
\hline & PESQUISA \\
\hline & ENSINO \\
\hline & OUTROS \\
\hline
\end{tabular}

2) Qual o seu nível de escolaridade? (Considere apenas o nível mais alto)

\begin{tabular}{|l|l|}
\hline & NÍVEL MÉDIO \\
\hline & NÍVEL SUPERIOR \\
\hline$X$ & PÓS-GRADUAÇÃO \\
\hline
\end{tabular}

3) Os conteúdos abordados foram condizentes com as demandas do seu dia-a-dia?

\begin{tabular}{|l|l|}
\hline$X$ & SIM \\
\hline & PARCIALMENTE \\
\hline & NÃO \\
\hline
\end{tabular}

3) O curso contribuiu para o seu aperfeiçoamento profissional?

\begin{tabular}{|l|l|}
\hline$X$ & SIM \\
\hline & NÃO \\
\hline
\end{tabular}

5) Os conhecimentos adquiridos estão sendo aplicados no seu trabalho? Em caso afirmativo, indique em que grau estes conhecimentos estão sendo aplicados. Em caso negativo, indique por que razão isto não ocorre: (Em caso negativo, as respostas não são excludentes: você poderá marcar mais de uma opção). 


\begin{tabular}{|c|c|c|}
\hline \multirow[t]{2}{*}{ em que grau) } & $\mathrm{X}$ & MEDIAMENTE APLICADOS \\
\hline & & POUCO APLICADOS \\
\hline \multirow{5}{*}{$\begin{array}{l}\text { NÃO (indique ao lado a } \\
\text { razão da não aplicação) }\end{array}$} & & $\begin{array}{l}\text { CONTEÚDO NÃO ADEQUADO ÀS NECESSIDADES } \\
\text { ESPECÍFICAS DA REGIÃO }\end{array}$ \\
\hline & & $\begin{array}{l}\text { CONTEÚDO NÃO FOI SUFICIENTEMENTE } \\
\text { APROFUNDADO PARA PERMITIR UMA APLICAÇÃO } \\
\text { EFICAZ E EFICIENTE }\end{array}$ \\
\hline & & $\begin{array}{l}\text { FALTA DE APOIO E INCENTIVO DA } \text { MINHA } \\
\text { INSTITUIÇÃO }\end{array}$ \\
\hline & & FALTA DE INCENTIVO ÀS AÇÕES DE ATER \\
\hline & & NÃO TENHO INTERESSE EM APLICAR \\
\hline
\end{tabular}

6) A partir deste curso: (As opções não são excludentes: você poderá marcar mais de uma opção)

\begin{tabular}{|l|l|}
\hline & NÃO MUDOU NADA EM MEU TRABALHO. \\
\hline$X$ & $\begin{array}{l}\text { MEU TRABALHO PASSOU A CONTRIBUIR MAIS COM OS AGRICULTORES(AS) } \\
\text { FAMILIARES. }\end{array}$ \\
\hline$X$ & CONSEGUI INFLUENCIAR NAS ORIENTAÇÕES DA MINHA INSTITUIÇÃO. \\
\hline$X$ & PASSEI A TRABALHAR COM METODOLOGIAS PARTICIPATIVAS. \\
\hline & $\begin{array}{l}\text { CRESCEU A ÁREA DE AGRICULTURA DE BASE ECOLÓGICA NAS COMUNIDADES } \\
\text { ONDE ATUO. }\end{array}$ \\
\hline & CONTINUEI ME APERFEIÇOANDO SOBRE TEMAS ABORDADOS. \\
\hline
\end{tabular}

7) Depois do curso você apoiou atividades de capacitação de técnicos e agricultores com base nos princípios e diretrizes da Pnater? (Considere como apoio a atividades de capacitação a participação no planejamento, elaboração de ementas, seleção de participantes e de palestrantes.) 


\begin{tabular}{|l|l|}
\hline$X$ & SIM \\
\hline & NÃO \\
\hline
\end{tabular}

8) Usou os conhecimentos para ministrar outros cursos com o mesmo conteúdo ou conteúdos semelhantes?

\begin{tabular}{|l|l|}
\hline$X$ & SIM \\
\hline & NÃO \\
\hline
\end{tabular}

9) Marque o seu grau de satisfação com relação ao curso oferecido pelo DATER:

\begin{tabular}{|l|l|l|l|l|}
\hline 1 & 2 & 3 & 4 & 5 \\
\hline
\end{tabular}

10) Marque seu grau de satisfação com relação ao DATER:

\begin{tabular}{|l|l|l|l|l|}
\hline 1 & 2 & 3 & 4 & 5 \\
\hline
\end{tabular}

Obs: As notas atribuídas as questões 9 e 10 devem obedecer a ordem crescente: 1 - muito ruim , 2 - ruim, 3 - regular, 4 - bom, 5 - muito bom. 


\section{PESQUISA - IMPACTO DAS AÇÕES DE FORMAÇÃO REALIZADAS PELO DATER/SAF/MDA NO PERÍODO 2004-2009}

Caros colaboradores,

Contamos com a sua atenção para preencher o formulário abaixo.

O mesmo tem por objetivo fornecer informações para avaliação da Eficiência, Efetividade e Eficácia da Política Pública de Formação de Agentes de Ater adotada pelo Departamento de Assistência Técnica e Extensão Rural, da Secretaria de Agricultura Familiar do Ministério do Desenvolvimento - DATER/SAF/MDA, no período de 2004 a 2009, tema escolhido para Monografia a ser apresentada à Universidade de Brasília (UnB) como requisito parcial para obtenção do grau de Bacharel em Administração.

Você poderá ou não se identificar no questionário e garantimos que todas as informações fornecidas serão confidenciais e utilizadas apenas de forma sistematizada.

IDENTIFICAÇÃO

\begin{tabular}{|c|c|}
\hline Nome: LAZARO MONTEIRO REIS & $\begin{array}{l}\text { Sexo: } \\
(x) \text { masculino } \quad(\quad) \text { feminino }\end{array}$ \\
\hline $\begin{array}{l}\text { Instituição (nome e tipo de instituição: ONG, } \\
\text { Empresa Pública, etc.): } \\
\text { Instituto de Desenvolvimento Agropecuário do } \\
\text { Estado do Amazonas - IDAM }\end{array}$ & $\begin{array}{l}\text { Local de trabalho (Cidade e Estado): } \\
\text { Unidade Local de Itacoatiara - Amazonas }\end{array}$ \\
\hline $\begin{array}{l}\text { Curso/Encontro/Oficina do qual participou (cas } \\
\text { preencha um formulário para cada um deles): } \\
\text { Seminário - Agroecologia como Estratégia para } \\
\text { Sustentável }\end{array}$ & $\begin{array}{l}\text { o tenha participado de mais de um curso, } \\
\text { a Construção do Desenvolvimento Rural }\end{array}$ \\
\hline \multicolumn{2}{|c|}{$\begin{array}{l}\text { Data do Curso/Encontro/Oficina (pelo menos mês e ano): } \\
10 \text { e } 11 \text { de agosto de } 2006 \text { - Manaus/AM }\end{array}$} \\
\hline
\end{tabular}

Indique sua área de atuação? (As opções não são excludentes: você poderá marcar mais de uma opção)

\begin{tabular}{|l|l}
\hline & EXTENSÃO RURAL \\
\hline
\end{tabular} 


\begin{tabular}{|l|l|}
\hline & PESQUISA \\
\hline & ENSINO \\
\hline & OUTROS \\
\hline
\end{tabular}

2) Qual o seu nível de escolaridade? (Considere apenas o nível mais alto)

\begin{tabular}{|l|l|}
\hline$X$ & NÍVEL MÉDIO \\
\hline & NÍVEL SUPERIOR \\
\hline & PÓS-GRADUAÇÃO \\
\hline
\end{tabular}

3) Os conteúdos abordados foram condizentes com as demandas do seu dia-a-dia?

\begin{tabular}{|l|l|}
\hline$X$ & SIM \\
\hline & PARCIALMENTE \\
\hline & NÃO \\
\hline
\end{tabular}

3) O curso contribuiu para o seu aperfeiçoamento profissional?

\begin{tabular}{|l|l|}
\hline$X$ & SIM \\
\hline & NÃO \\
\hline
\end{tabular}

5) Os conhecimentos adquiridos estão sendo aplicados no seu trabalho? Em caso afirmativo, indique em que grau estes conhecimentos estão sendo aplicados. Em caso negativo, indique por que razão isto não ocorre: (Em caso negativo, as respostas não são excludentes: você poderá marcar mais de uma opção).

\begin{tabular}{|l|l|l|l|}
\hline \multirow{2}{*}{\begin{tabular}{l} 
SIM (indique ao lado \begin{tabular}{l} 
em que grau) \\
\cline { 2 - 3 }
\end{tabular} \\
\cline { 2 - 3 }
\end{tabular}} & MUITO APLICADOS \\
\cline { 2 - 3 } & & POUCO APLICADOS \\
\hline
\end{tabular}




\begin{tabular}{|c|c|}
\hline \multirow{5}{*}{$\begin{array}{l}\text { NÃO (indique ao lado a } \\
\text { razão da não aplicação) }\end{array}$} & $\begin{array}{l}\text { CONTEÚDO NÃO ADEQUADO ÀS NECESSIDADES } \\
\text { ESPECÍFICAS DA REGIÃO }\end{array}$ \\
\hline & $\begin{array}{l}\text { CONTEÚDO NÂO FOI SUFICIENTEMENTE } \\
\text { APROFUNDADO PARA PERMITIR UMA APLICAÇÃO } \\
\text { EFICAZ E EFICIENTE }\end{array}$ \\
\hline & $\begin{array}{lcccccc}\text { FALTA } & \text { DE } & \text { APOIO } & \text { E } & \text { INCENTIVO } & \text { DA } & \text { MINHA } \\
\text { INSTITUIÇÃO } & & & & & & \end{array}$ \\
\hline & FALTA DE INCENTIVO ÀS AÇÕES DE ATER \\
\hline & NÃO TENHO INTERESSE EM APLICAR \\
\hline
\end{tabular}

6) A partir deste curso: (As opções não são excludentes: você poderá marcar mais de uma opção)

\begin{tabular}{|l|l|}
\hline & NÃO MUDOU NADA EM MEU TRABALHO. \\
\hline$X$ & $\begin{array}{l}\text { MEU TRABALHO PASSOU A CONTRIBUIR MAIS COM OS AGRICULTORES(AS) } \\
\text { FAMILIARES. }\end{array}$ \\
\hline$X$ & CONSEGUI INFLUENCIAR NAS ORIENTAÇÕES DA MINHA INSTITUIÇÃO. \\
\hline$X$ & $\begin{array}{l}\text { CRESCEU A ÁREA DE AGRICULTURA DE BASE ECOLÓGICA NAS COMUNIDADES } \\
\text { ONDE ATUO. }\end{array}$ \\
\hline$X$ & CONTINUEI ME APERFEIÇOANDO SOBRE TEMAS ABORDADOS. \\
\hline
\end{tabular}

7) Depois do curso você apoiou atividades de capacitação de técnicos e agricultores com base nos princípios e diretrizes da Pnater? (Considere como apoio a atividades de capacitação a participação no planejamento, elaboração de ementas, seleção de participantes e de palestrantes.)

\begin{tabular}{|l|l|}
\hline$X$ & SIM \\
\hline & NÃO \\
\hline
\end{tabular}

8) Usou os conhecimentos para ministrar outros cursos com o mesmo conteúdo ou conteúdos semelhantes? 


\begin{tabular}{|l|l|}
\hline$X$ & SIM \\
\hline & NÃO \\
\hline
\end{tabular}

9) Marque o seu grau de satisfação com relação ao curso oferecido pelo DATER:

\begin{tabular}{|l|l|l|l|l|}
\hline 1 & 2 & 3 & 4 & 5 \\
\hline
\end{tabular}

10) Marque seu grau de satisfação com relação ao DATER:

\begin{tabular}{|l|l|l|l|l|}
\hline 1 & 2 & 3 & 4 & 5 \\
\hline
\end{tabular}




\section{PESQUISA - IMPACTO DAS AÇÕES DE FORMAÇÃO REALIZADAS PELO DATER/SAF/MDA NO PERÍODO 2004-2009}

Caros colaboradores,

Contamos com a sua atenção para preencher o formulário abaixo.

O mesmo tem por objetivo fornecer informações para avaliação da Eficiência, Efetividade e Eficácia da Política Pública de Formação de Agentes de Ater adotada pelo Departamento de Assistência Técnica e Extensão Rural, da Secretaria de Agricultura Familiar do Ministério do Desenvolvimento - DATER/SAF/MDA, no período de 2004 a 2009, tema escolhido para Monografia a ser apresentada à Universidade de Brasília (UnB) como requisito parcial para obtenção do grau de Bacharel em Administração.

Você poderá ou não se identificar no questionário e garantimos que todas as informações fornecidas serão confidenciais e utilizadas apenas de forma sistematizada.

IDENTIFICAÇÃO

\begin{tabular}{|c|c|}
\hline \multicolumn{2}{|l|}{ Nome: LAZARO MONEIRO REIS } \\
\hline $\begin{array}{l}\text { Instituição (nome e tipo de instituição: ONG, } \\
\text { Empresa Pública, etc.): } \\
\text { Instituto de Desenvolvimento Agropecuário do } \\
\text { Estado do Amazonas - IDAM }\end{array}$ & $\begin{array}{l}\text { Local de trabalho (Cidade e Estado): } \\
\text { Unidade Local de Itacoatiara - Amazonas }\end{array}$ \\
\hline \multicolumn{2}{|c|}{$\begin{array}{l}\text { Curso/Encontro/Oficina do qual participou (caso tenha participado de mais de um curso } \\
\text { preencha um formulário para cada um deles): } \\
\text { Curso de Agroecologia }\end{array}$} \\
\hline \multicolumn{2}{|c|}{$\begin{array}{l}\text { Data do Curso/Encontro/Oficina (pelo menos mês e ano): } \\
24 \text { a } 28 \text { de abril de } 2006 \text { - Manaus/AM }\end{array}$} \\
\hline
\end{tabular}

Indique sua área de atuação?

\begin{tabular}{|l|l|}
\hline$X$ & EXTENSÃO RURAL \\
\hline & PESQUISA \\
\hline & ENSINO \\
\hline & OUTROS \\
\hline
\end{tabular}

2) Qual o seu nível de escolaridade? 


\begin{tabular}{|l|l|}
\hline$X$ & NÍVEL MÉDIO \\
\hline & NÍVEL SUPERIOR \\
\hline & PÓS-GRADUAÇÃO \\
\hline
\end{tabular}

3) Os conteúdos abordados foram condizentes com as demandas do seu dia-a-dia?

\begin{tabular}{|l|l|}
\hline$X$ & SIM \\
\hline & PARCIALMENTE \\
\hline & NÃO \\
\hline
\end{tabular}

3) O curso contribuiu para o seu aperfeiçoamento profissional?

\begin{tabular}{|l|l|}
\hline$X$ & SIM \\
\hline & NÃO \\
\hline
\end{tabular}

5) Os conhecimentos adquiridos estão sendo aplicados no seu trabalho? Em caso afirmativo, indique em que grau estes conhecimentos estão sendo aplicados. Em caso negativo, indique por que razão isto não ocorre:

\begin{tabular}{|c|c|c|}
\hline \multirow{3}{*}{$\begin{array}{l}\text { SIM (indique ao lado } \\
\text { em que grau) }\end{array}$} & $\mathrm{x}$ & MUITO APLICADOS \\
\hline & & MEDIAMENTE APLICADOS \\
\hline & & POUCO APLICADOS \\
\hline \multirow{4}{*}{$\begin{array}{l}\text { NÃO (indique ao lado a } \\
\text { razão da não aplicação) }\end{array}$} & & $\begin{array}{l}\text { CONTEÚDO NĀO ADEQUADO ÀS NECESSIDADES } \\
\text { ESPECÍFICAS DA REGIÃO }\end{array}$ \\
\hline & & $\begin{array}{l}\text { CONTEÚDO N NÃO } \quad \text { FOI } \text { SUFICIENTEMENTE } \\
\text { APROFUNDADO PARA } \\
\text { EFICRMITIR UMA APLICAÇÃO } \\
\text { EFICAZ EFICIENTE }\end{array}$ \\
\hline & & 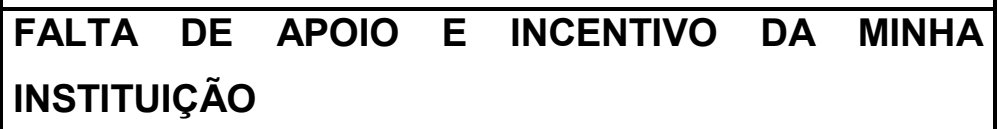 \\
\hline & & FALTA DE INCENTIVO ÀS AÇÕES DE ATER \\
\hline
\end{tabular}




\begin{tabular}{|l|l|l|l|}
\hline & & & NÃO TENHO INTERESSE EM APLICAR \\
\hline
\end{tabular}

6) A partir deste curso:

\begin{tabular}{|l|l|}
\hline & NÃO MUDOU NADA EM MEU TRABALHO. \\
\hline$X$ & $\begin{array}{l}\text { MEU TRABALHO PASSOU A CONTRIBUIR MAIS COM OS AGRICULTORES(AS) } \\
\text { FAMILIARES. }\end{array}$ \\
\hline $\mathrm{X}$ & PONSEGUI INFLUENCIAR NAS ORIENTAÇÕES DA MINHA INSTITUIÇÃO. \\
\hline $\mathrm{X}$ & $\begin{array}{l}\text { CRESCEU A AREA DE AGRICULTURA DE BASE ECOLOGICA NAS COMUNIDADES } \\
\text { ONDE ATUO. }\end{array}$ \\
\hline $\mathrm{X}$ & CONTINUEI ME APERFEIÇOANDO SOBRE TEMAS ABORDADOS. \\
\hline
\end{tabular}

7) Depois do curso você apoiou atividades de capacitação de técnicos e agricultores com base nos princípios e diretrizes da Pnater?

\begin{tabular}{|l|l|}
\hline$X$ & SIM \\
\hline & NÃO \\
\hline
\end{tabular}

8) Usou os conhecimentos para ministrar outros cursos com o mesmo conteúdo ou conteúdos semelhantes?

\begin{tabular}{|l|l|}
\hline$X$ & SIM \\
\hline & NÃO \\
\hline
\end{tabular}

9) Marque o seu grau de satisfação com relação ao curso oferecido pelo DATER:

\begin{tabular}{|l|l|l|l|l|}
\hline 1 & 2 & 3 & 4 & 5 \\
\hline
\end{tabular}

10) Marque seu grau de satisfação com relação ao DATER:

\begin{tabular}{|l|l|l|l|l|}
\hline 1 & 2 & 3 & 4 & 5 \\
\hline
\end{tabular}




\section{PESQUISA - GRAU DE SATISFAÇÃO DOS PARTICIPANTES DOS CURSOS REALIZADOS PELO SAF/DATER}

Caros colaboradores,

Contamos com a sua atenção para preencher o formulário abaixo. Suas respostas serão úteis para que possamos aperfeiçoar cada vez mais as nossas ações de Formação de Agentes de ATER.

IDENTIFICAÇÃO

\begin{tabular}{|c|c|}
\hline \multicolumn{2}{|l|}{ Nome: LAZARO MONEIRO REIS } \\
\hline $\begin{array}{l}\text { Instituição (nome e tipo de instituição: ONG, } \\
\text { Empresa Pública, etc.): } \\
\text { Instituto de Desenvolvimento Agropecuário do } \\
\text { Estado do Amazonas - IDAM }\end{array}$ & $\begin{array}{l}\text { Local de trabalho (Cidade e Estado): } \\
\text { Unidade Local de Itacoatiara - Amazonas }\end{array}$ \\
\hline \multicolumn{2}{|c|}{$\begin{array}{l}\text { Curso/Encontro/Oficina do qual participou (caso tenha participado de mais de um curso } \\
\text { preencha um formulário para cada um deles): } \\
\text { Curso Diagnóstico Rural Participativo - DRP }\end{array}$} \\
\hline $\begin{array}{l}\text { Data do Curso/Encontro/Oficina (pelo menos mês } \\
16 \text { a } 27 \text { de outubro de } 2006 \text { - Manaus/AM }\end{array}$ & e ano): \\
\hline
\end{tabular}

Indique sua área de atuação?

\begin{tabular}{|l|l|}
\hline$X$ & EXTENSÃO RURAL \\
\hline & PESQUISA \\
\hline & ENSINO \\
\hline & OUTROS \\
\hline
\end{tabular}

2) Qual o seu nível de escolaridade? 


\begin{tabular}{|l|l|}
\hline$X$ & NÍVEL MÉDIO \\
\hline & NÍVEL SUPERIOR \\
\hline & PÓS-GRADUAÇÃO \\
\hline
\end{tabular}

3) Os conteúdos abordados foram condizentes com as demandas do seu dia-a-dia?

\begin{tabular}{|l|l|}
\hline$X$ & SIM \\
\hline & PARCIALMENTE \\
\hline & NÃO \\
\hline
\end{tabular}

3) O curso contribuiu para o seu aperfeiçoamento profissional?

\begin{tabular}{|l|l|}
\hline$X$ & SIM \\
\hline & NÃO \\
\hline
\end{tabular}

5) Os conhecimentos adquiridos estão sendo aplicados no seu trabalho? Em caso afirmativo, indique em que grau estes conhecimentos estão sendo aplicados. Em caso negativo, indique por que razão isto não ocorre:

\begin{tabular}{|c|c|c|}
\hline \multirow{3}{*}{$\begin{array}{l}\text { SIM (indique ao lado } \\
\text { em que grau) }\end{array}$} & $\mathrm{x}$ & MUITO APLICADOS \\
\hline & & MEDIAMENTE APLICADOS \\
\hline & & POUCO APLICADOS \\
\hline \multirow{5}{*}{$\begin{array}{l}\text { NÃO (indique ao lado a } \\
\text { razão da não aplicação) }\end{array}$} & & $\begin{array}{l}\text { CONTEÚDO NĀO ADEQUADO ȦS NECESSIDADES } \\
\text { ESPECÍFICAS DA REGIÃO }\end{array}$ \\
\hline & & $\begin{array}{l}\text { CONTEÚDO NÃO } \quad \text { FOI } \quad \text { SUFICIENTEMENTE } \\
\text { APROFUNDADO PARA PERMITIR UMA APLICAÇÃO } \\
\text { EFICAZ E EFICIENTE }\end{array}$ \\
\hline & & \begin{tabular}{lllllll|} 
FALTA & DE & APOIO & E & INCENTIVO & DA & MINHA \\
INSTITUIÇÃO & & & & & \\
\end{tabular} \\
\hline & & FALTA DE INCENTIVO ÀS AÇÕES DE ATER \\
\hline & & NÃO TENHO INTERESSE EM APLICAR \\
\hline
\end{tabular}


6) A partir deste curso:

\begin{tabular}{|l|l|}
\hline & NÃO MUDOU NADA EM MEU TRABALHO. \\
\hline$X$ & $\begin{array}{l}\text { MEU TRABALHO PASSOU A CONTRIBUIR MAIS COM OS AGRICULTORES(AS) } \\
\text { FAMILIARES. }\end{array}$ \\
\hline$X$ & PONSEGUI INFLUENCIAR NAS ORIENTAÇÕES DA MINHA INSTITUIÇÃO. \\
\hline$X$ & $\begin{array}{l}\text { CRESCEU A ÁREA DE AGRICULTURA DE BASE ECOLÓGICA NAS COMUNIDADES } \\
\text { ONDE ATUO. }\end{array}$ \\
\hline$X$ & CONTINUEI ME APERFEIÇOANDO SOBRE TEMAS ABORDADOS. \\
\hline
\end{tabular}

7) Depois do curso você apoiou atividades de capacitação de técnicos e agricultores com base nos princípios e diretrizes da Pnater?

\begin{tabular}{|l|l|}
\hline$X$ & SIM \\
\hline & NÃO \\
\hline
\end{tabular}

8) Usou os conhecimentos para ministrar outros cursos com o mesmo conteúdo ou conteúdos semelhantes?

\begin{tabular}{|l|l|}
\hline & SIM \\
\hline$X$ & NÃO \\
\hline
\end{tabular}

9) Marque o seu grau de satisfação com relação ao curso oferecido pelo DATER:

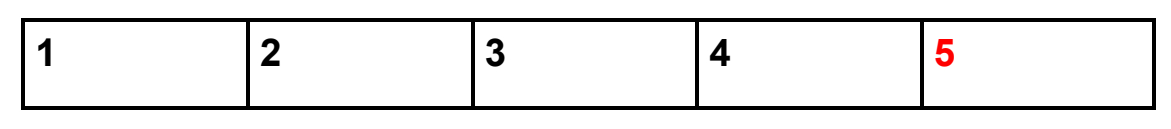

10) Marque seu grau de satisfação com relação ao DATER:

\begin{tabular}{|l|l|l|l|l|}
\hline 1 & 2 & 3 & 4 & 5 \\
\hline
\end{tabular}


Obs: As notas atribuídas as questões 9 e 10 devem obedecer a ordem crescente: 1 - muito ruim , 2 - ruim, 3 - regular, 4 - bom, 5 - muito bom. 


\section{PESQUISA - IMPACTO DAS AÇÕES DE FORMAÇÃO REALIZADAS PELO DATER/SAF/MDA NO PERÍODO 2004-2009}

Caros colaboradores,

Contamos com a sua atenção para preencher o formulário abaixo.

O mesmo tem por objetivo fornecer informações para avaliação da Eficiência, Efetividade e Eficácia da Política Pública de Formação de Agentes de Ater adotada pelo Departamento de Assistência Técnica e Extensão Rural, da Secretaria de Agricultura Familiar do Ministério do Desenvolvimento - DATER/SAF/MDA, no período de 2004 a 2009, tema escolhido para Monografia a ser apresentada à Universidade de Brasília (UnB) como requisito parcial para obtenção do grau de Bacharel em Administração.

Você poderá ou não se identificar no questionário e garantimos que todas as informações fornecidas serão confidenciais e utilizadas apenas de forma sistematizada.

IDENTIFICAÇÃO

\begin{tabular}{|l|l|}
\hline Nome: LADIMIL CANTO SALGADO JÚNIOR & $\begin{array}{l}\text { Sexo: } \\
(\mathbf{x}) \text { masculino } \quad(\quad \text { ) feminino }\end{array}$ \\
\hline $\begin{array}{l}\text { Instituição (nome e tipo de instituição: ONG, } \\
\text { Empresa Pública, etc.): }\end{array}$ & $\begin{array}{l}\text { Local de trabalho (Cidade e Estado): } \\
\text { Instituto de Desenvolvimento Agropecuário do } \\
\text { Estado do Amazonas - IDAM }\end{array}$ \\
\hline $\begin{array}{l}\text { Curso/Encontro/Oficina do qual participou (caso tenha participado de mais de um curso, } \\
\text { preencha um formulário para cada um deles): } \\
\text { II Encontro para Socialização dos Conceitos Básicos da Política Nacional de ATER }\end{array}$ \\
\hline $\begin{array}{l}\text { Data do Curso/Encontro/Oficina (pelo menos mês e ano): } \\
\text { 04 a 08 de dezembro de 2006 - Manaus/AM }\end{array}$ \\
\hline
\end{tabular}

Indique sua área de atuação? (As opções não são excludentes: você poderá marcar mais de uma opção)

\begin{tabular}{|l|l|}
\hline$X$ & EXTENSÃO RURAL \\
\hline & PESQUISA \\
\hline & ENSINO \\
\hline
\end{tabular}




\begin{tabular}{|l|l|}
\hline & OUTROS \\
\hline
\end{tabular}

2) Qual o seu nível de escolaridade? (Considere apenas o nível mais alto)

\begin{tabular}{|l|l|}
\hline$X$ & NÍVEL MÉDIO \\
\hline & NÍVEL SUPERIOR \\
\hline & PÓS-GRADUAÇÃO \\
\hline
\end{tabular}

3) Os conteúdos abordados foram condizentes com as demandas do seu dia-a-dia?

\begin{tabular}{|l|l|}
\hline$X$ & SIM \\
\hline & PARCIALMENTE \\
\hline & NÃO \\
\hline
\end{tabular}

4) O curso contribuiu para o seu aperfeiçoamento profissional?

\begin{tabular}{|l|l|}
\hline$X$ & SIM \\
\hline & NÃO \\
\hline
\end{tabular}

5) Os conhecimentos adquiridos estão sendo aplicados no seu trabalho? Em caso afirmativo, indique em que grau estes conhecimentos estão sendo aplicados. Em caso negativo, indique por que razão isto não ocorre: (Em caso negativo, as respostas não são excludentes: você poderá marcar mais de uma opção).

\begin{tabular}{|l|l|l|l|}
\hline \multirow{2}{*}{$\begin{array}{l}\text { SIM (indique ao lado } \\
\text { em que grau) }\end{array}$} & $X$ & MUITO APLICADOS \\
\cline { 2 - 3 } & $\begin{array}{l}\text { NÃO (indique ao lado a } \\
\text { razão da não aplicação) }\end{array}$ & $\begin{array}{l}\text { MOUIAMENTE APLICADOS APLICADOS } \\
\text { CONTEÚDO NÃO ADEQUADO ÀS NECESSIDADES } \\
\text { ESPECÍFICAS DA REGIÃO }\end{array}$ \\
\hline
\end{tabular}




\begin{tabular}{|l|l|l|}
\hline \multirow{3}{*}{} & & $\begin{array}{l}\text { CONTEÚDO NÃO FOI SUFICIENTEMENTE } \\
\text { APROFUNDADO PARA PERMITIR UMA APLICAÇÃO } \\
\text { EFICAZ E EFICIENTE }\end{array}$ \\
\cline { 2 - 4 } & $\begin{array}{l}\text { FALTA DE APOIO E INCENTIVO DA MINHA } \\
\text { INSTITUIÇÃO }\end{array}$ \\
\cline { 2 - 4 } & FALTA DE INCENTIVO ÀS AÇÕES DE ATER \\
\cline { 2 - 4 } & NÃO TENHO INTERESSE EM APLICAR \\
\hline
\end{tabular}

6) A partir deste curso: (As opções não são excludentes: você poderá marcar mais de uma opção)

\begin{tabular}{|l|l|}
\hline & NÃO MUDOU NADA EM MEU TRABALHO. \\
\hline$X$ & $\begin{array}{l}\text { MEU TRABALHO PASSOU A CONTRIBUIR MAIS COM OS AGRICULTORES(AS) } \\
\text { FAMILIARES. }\end{array}$ \\
\hline$X$ & CONSEGUI INFLUENCIAR NAS ORIENTAÇÕES DA MINHA INSTITUIÇÃO. \\
\hline$X$ & PASSEI A TRABALHAR COM METODOLOGIAS PARTICIPATIVAS. \\
\hline & $\begin{array}{l}\text { CRESCEU A ÁREA DE AGRICULTURA DE BASE ECOLÓGICA NAS COMUNIDADES } \\
X\end{array}$ \\
\hline
\end{tabular}

7) Depois do curso você apoiou atividades de capacitação de técnicos e agricultores com base nos princípios e diretrizes da Pnater? (Considere como apoio a atividades de capacitação a participação no planejamento, elaboração de ementas, seleção de participantes e de palestrantes.)

\begin{tabular}{|l|l|}
\hline$X$ & SIM \\
\hline & NÃO \\
\hline
\end{tabular}

8) Usou os conhecimentos para ministrar outros cursos com o mesmo conteúdo ou conteúdos semelhantes? 


\begin{tabular}{|l|l|}
\hline$X$ & NÃO \\
\hline
\end{tabular}

9) Marque o seu grau de satisfação com relação ao curso oferecido pelo DATER: (Considere a seguinte pontuação: 1 - MUITO RUIM; 2 - RUIM; 3 - REGULAR; 4 - BOM; 5 - MUITO BOM)

\begin{tabular}{|l|l|l|l|l|}
\hline 1 & 2 & 3 & 4 & 5 \\
\hline
\end{tabular}

10) Marque seu grau de satisfação com relação ao DATER: (Considere a seguinte pontuação:

1 - MUITO RUIM; 2 - RUIM; 3 - REGULAR; 4 - BOM; 5 - MUITO BOM)

\begin{tabular}{|l|l|l|l|l|}
\hline 1 & 2 & 3 & 4 & 5 \\
\hline
\end{tabular}




\section{PESQUISA - IMPACTO DAS AÇÕES DE FORMAÇÃO REALIZADAS PELO DATER/SAF/MDA NO PERÍODO 2004-2009}

Caros colaboradores,

Contamos com a sua atenção para preencher o formulário abaixo.

O mesmo tem por objetivo fornecer informações para avaliação da Eficiência, Efetividade e Eficácia da Política Pública de Formação de Agentes de Ater adotada pelo Departamento de Assistência Técnica e Extensão Rural, da Secretaria de Agricultura Familiar do Ministério do Desenvolvimento - DATER/SAF/MDA, no período de 2004 a 2009, tema escolhido para Monografia a ser apresentada à Universidade de Brasília (UnB) como requisito parcial para obtenção do grau de Bacharel em Administração.

Você poderá ou não se identificar no questionário e garantimos que todas as informações fornecidas serão confidenciais e utilizadas apenas de forma sistematizada.

IDENTIFICAÇÃO

\begin{tabular}{|c|c|}
\hline Nome: KELCEN BANDEIRA GUEDES & $\begin{array}{l}\text { Sexo: } \\
(x \quad) \text { masculino } \quad(\quad) \text { feminino }\end{array}$ \\
\hline $\begin{array}{l}\text { Instituição (nome e tipo de instituição: ONG, } \\
\text { Empresa Pública, etc.): } \\
\text { Instituto de Desenvolvimento Agropecuário do } \\
\text { Estado do Amazonas - IDAM }\end{array}$ & $\begin{array}{l}\text { Local de trabalho (Cidade e Estado): } \\
\text { Unidade Local de Manacapuru - Amazonas }\end{array}$ \\
\hline $\begin{array}{l}\text { Curso/Encontro/Oficina do qual participou (cas } \\
\text { preencha um formulário para cada um deles): } \\
\text { Seminário - Agroecologia como Estratégia para } \\
\text { Sustentável }\end{array}$ & $\begin{array}{l}\text { o tenha participado de mais de um curso, } \\
\text { a Construção do Desenvolvimento Rural }\end{array}$ \\
\hline $\begin{array}{l}\text { Data do Curso/Encontro/Oficina (pelo menos mê } \\
10 \text { e } 11 \text { de agosto de } 2006 \text { - Manaus/AM }\end{array}$ & ano): \\
\hline
\end{tabular}

Indique sua área de atuação? (As opções não são excludentes: você poderá marcar mais de uma opção)

\begin{tabular}{|l|l|}
\hline$X$ & EXTENSÃO RURAL \\
\hline & PESQUISA \\
\hline
\end{tabular}




\begin{tabular}{|l|l|}
\hline & ENSINO \\
\hline & OUTROS \\
\hline
\end{tabular}

2) Qual o seu nível de escolaridade? (Considere apenas o nível mais alto)

\begin{tabular}{|l|l|}
\hline$X$ & NÍVEL MÉDIO \\
\hline & NÍVEL SUPERIOR \\
\hline & PÓS-GRADUAÇÃO \\
\hline
\end{tabular}

3) Os conteúdos abordados foram condizentes com as demandas do seu dia-a-dia?

\begin{tabular}{|l|l|}
\hline$X$ & SIM \\
\hline & PARCIALMENTE \\
\hline & NÃO \\
\hline
\end{tabular}

4) O curso contribuiu para o seu aperfeiçoamento profissional?

\begin{tabular}{|l|l|}
\hline$X$ & SIM \\
\hline & NÃO \\
\hline
\end{tabular}

5) Os conhecimentos adquiridos estão sendo aplicados no seu trabalho? Em caso afirmativo, indique em que grau estes conhecimentos estão sendo aplicados. Em caso negativo, indique por que razão isto não ocorre: (Em caso negativo, as respostas não são excludentes: você poderá marcar mais de uma opção).

\begin{tabular}{|l|l|l|l|}
\hline \multirow{2}{*}{$\begin{array}{l}\text { SIM (indique ao lado } \\
\text { em que grau) }\end{array}$} & $X$ & MUITO APLICADOS \\
\cline { 3 - 4 } & $\begin{array}{l}\text { NÃO (indique ao lado a } \\
\text { razão da não aplicação) }\end{array}$ & MEDIAMENTE APLICADOS \\
\cline { 2 - 3 } & $\begin{array}{l}\text { COUCO APLICADOS } \\
\text { ESPECÍFICAS DA REGIÃO }\end{array}$ \\
\hline
\end{tabular}




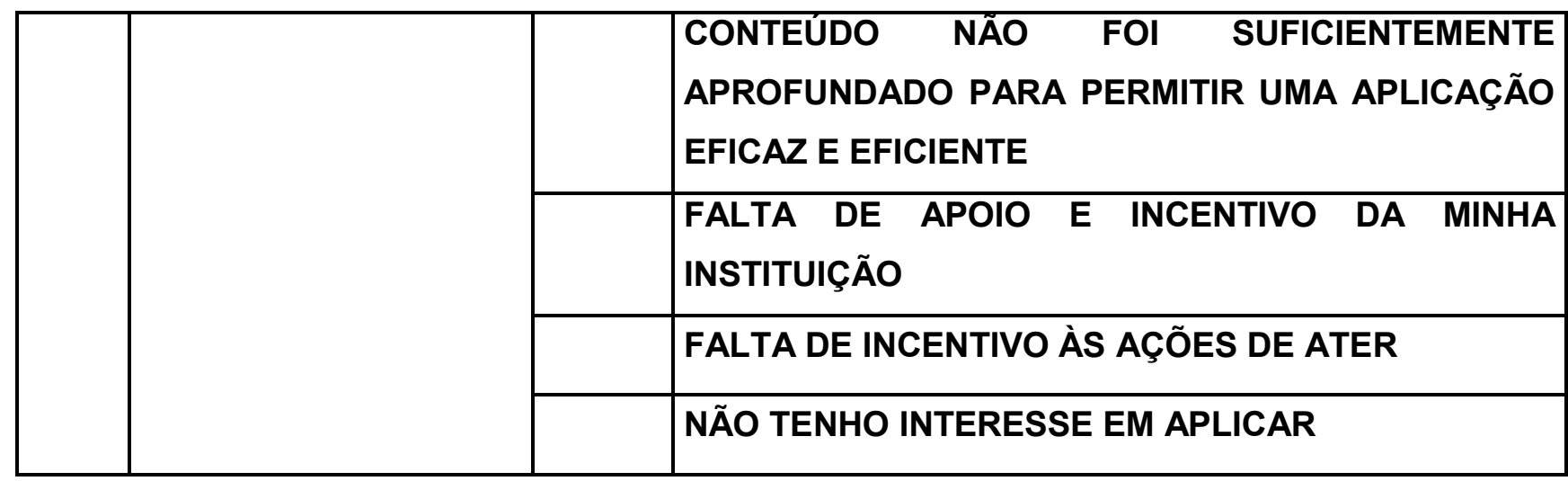

6) A partir deste curso: (As opções não são excludentes: você poderá marcar mais de uma opção)

\begin{tabular}{|l|l|}
\hline & NÃO MUDOU NADA EM MEU TRABALHO. \\
\hline$X$ & $\begin{array}{l}\text { MEU TRABALHO PASSOU A CONTRIBUIR MAIS COM OS AGRICULTORES(AS) } \\
\text { FAMILIARES. }\end{array}$ \\
\hline$X$ & CONSEGUI INFLUENCIAR NAS ORIENTAÇÕES DA MINHA INSTITUIÇÃO. \\
\hline$X$ & PASSEI A TRABALHAR COM METODOLOGIAS PARTICIPATIVAS. \\
\hline & $\begin{array}{l}\text { CRESCEU A ÁREA DE AGRICULTURA DE BASE ECOLÓGICA NAS COMUNIDADES } \\
X\end{array}$ \\
\hline
\end{tabular}

7) Depois do curso você apoiou atividades de capacitação de técnicos e agricultores com base nos princípios e diretrizes da Pnater? (Considere como apoio a atividades de capacitação a participação no planejamento, elaboração de ementas, seleção de participantes e de palestrantes.)

\begin{tabular}{|l|l|}
\hline$X$ & SIM \\
\hline & NÃO \\
\hline
\end{tabular}

8) Usou os conhecimentos para ministrar outros cursos com o mesmo conteúdo ou conteúdos semelhantes?

\begin{tabular}{|l|l|}
\hline$X$ & SIM \\
\hline
\end{tabular}




\begin{tabular}{|l|l|}
\hline NÃO \\
\hline
\end{tabular}

9) Marque o seu grau de satisfação com relação ao curso oferecido pelo DATER: (Considere a seguinte pontuação: 1 - MUITO RUIM; 2 - RUIM; 3 - REGULAR; 4 - BOM; 5 - MUITO BOM)

\begin{tabular}{|l|l|l|l|l|}
\hline 1 & 2 & 3 & 4 & 5 \\
\hline
\end{tabular}

10) Marque seu grau de satisfação com relação ao DATER: (Considere a seguinte pontuação:

1 - MUITO RUIM; 2 - RUIM; 3 - REGULAR; 4 - BOM; 5 - MUITO BOM)

\begin{tabular}{|l|l|l|l|l|}
\hline 1 & 2 & 3 & 4 & 5 \\
\hline
\end{tabular}




\section{PESQUISA - IMPACTO DAS AÇÕES DE FORMAÇÃO REALIZADAS PELO DATER/SAF/MDA NO PERÍODO 2004-2009}

Caros colaboradores,

Contamos com a sua atenção para preencher o formulário abaixo.

O mesmo tem por objetivo fornecer informações para avaliação da Eficiência, Efetividade e Eficácia da Política Pública de Formação de Agentes de Ater adotada pelo Departamento de Assistência Técnica e Extensão Rural, da Secretaria de Agricultura Familiar do Ministério do Desenvolvimento - DATER/SAF/MDA, no período de 2004 a 2009, tema escolhido para Monografia a ser apresentada à Universidade de Brasília (UnB) como requisito parcial para obtenção do grau de Bacharel em Administração.

Você poderá ou não se identificar no questionário e garantimos que todas as informações fornecidas serão confidenciais e utilizadas apenas de forma sistematizada.

IDENTIFICAÇÃO

\begin{tabular}{|c|c|}
\hline Nome: JOSIVAN VEZERRA PACHECO & $\begin{array}{l}\text { Sexo: } \\
(x) \text { masculino } \quad(\quad) \text { feminino }\end{array}$ \\
\hline $\begin{array}{l}\text { Instituição (nome e tipo de instituição: ONG, } \\
\text { Empresa Pública, etc.): } \\
\text { Instituto de Desenvolvimento Agropecuário do } \\
\text { Estado do Amazonas - IDAM }\end{array}$ & $\begin{array}{l}\text { Local de trabalho (Cidade e Estado): } \\
\text { Unidade Local de Presidente Figueiredo - } \\
\text { Amazonas }\end{array}$ \\
\hline $\begin{array}{l}\text { Curso/Encontro/Oficina do qual participou (cas } \\
\text { preencha um formulário para cada um deles): } \\
\text { Seminário - Agroecologia como Estratégia para } \\
\text { Sustentável }\end{array}$ & $\begin{array}{l}\text { o tenha participado de mais de um curso, } \\
\text { a Construção do Desenvolvimento Rural }\end{array}$ \\
\hline \multicolumn{2}{|c|}{$\begin{array}{l}\text { Data do Curso/Encontro/Oficina (pelo menos mês e ano): } \\
10 \text { e } 11 \text { de agosto de } 2006 \text { - Manaus/AM }\end{array}$} \\
\hline
\end{tabular}

Indique sua área de atuação? (As opções não são excludentes: você poderá marcar mais de uma opção)

\begin{tabular}{|l|l|}
\hline$X$ & EXTENSÃO RURAL \\
\hline & PESQUISA \\
\hline & ENSINO \\
\hline
\end{tabular}




\begin{tabular}{|l|l|}
\hline & OUTROS \\
\hline
\end{tabular}

2) Qual o seu nível de escolaridade? (Considere apenas o nível mais alto)

\begin{tabular}{|l|l|}
\hline$X$ & NÍVEL MÉDIO \\
\hline & NÍVEL SUPERIOR \\
\hline & PÓS-GRADUAÇÃO \\
\hline
\end{tabular}

3) Os conteúdos abordados foram condizentes com as demandas do seu dia-a-dia?

\begin{tabular}{|l|l|}
\hline$X$ & SIM \\
\hline & PARCIALMENTE \\
\hline & NÃO \\
\hline
\end{tabular}

4) O curso contribuiu para o seu aperfeiçoamento profissional?

\begin{tabular}{|l|l|}
\hline$X$ & SIM \\
\hline & NÃO \\
\hline
\end{tabular}

5) Os conhecimentos adquiridos estão sendo aplicados no seu trabalho? Em caso afirmativo, indique em que grau estes conhecimentos estão sendo aplicados. Em caso negativo, indique por que razão isto não ocorre: (Em caso negativo, as respostas não são excludentes: você poderá marcar mais de uma opção).

\begin{tabular}{|c|c|c|}
\hline \multirow{3}{*}{$\begin{array}{l}\text { SIM (indique ao lado } \\
\text { em que grau) }\end{array}$} & & MUITO APLICADOS \\
\hline & $x$ & MEDIAMENTE APLICADOS \\
\hline & & POUCO APLICADOS \\
\hline $\begin{array}{l}\text { NÃO } \text { (indique ao lado } \\
\text { a razão da não }\end{array}$ & & $\begin{array}{|lccc|}\text { CONTEÚDO } & \text { NÃO } & \text { ADEQUADO } & \text { ÀS } \\
\text { NECESSIDADES } & \text { ESPECÍFICAS DA REGIÃO } & \\
\end{array}$ \\
\hline
\end{tabular}




\begin{tabular}{|l|l|l|}
\hline \multirow{5}{*}{} & $\begin{array}{l}\text { aplicação) } \\
\text { APROFUNDADO PARA PERMITIR UMA } \\
\text { APLICAÇÃO EFICAZ E EFICIENTE }\end{array}$ \\
\hline & $\begin{array}{l}\text { FALTA DE APOIO E INCENTIVO DA MINHA } \\
\text { INSTITUIÇÃO }\end{array}$ \\
\hline & FALTA DE INCENTIVO ÀS AÇÕES DE ATER \\
\cline { 2 - 3 } & NÃO TENHO INTERESSE EM APLICAR \\
\hline
\end{tabular}

6) A partir deste curso: (As opções não são excludentes: você poderá marcar mais de uma opção)

\begin{tabular}{|l|l|}
\hline & NÃO MUDOU NADA EM MEU TRABALHO. \\
\hline$X$ & $\begin{array}{l}\text { MEU TRABALHO PASSOU A CONTRIBUIR MAIS COM OS AGRICULTORES(AS) } \\
\text { FAMILIARES. }\end{array}$ \\
\hline & CONSEGUI INFLUENCIAR NAS ORIENTAÇÕES DA MINHA INSTITUIÇÃO. \\
\hline & PASSEI A TRABALHAR COM METODOLOGIAS PARTICIPATIVAS. \\
\hline & $\begin{array}{l}\text { CRESCEU A ÁREA DE AGRICULTURA DE BASE ECOLÓGICA NAS } \\
\text { COMUNIDADES ONDE ATUO. }\end{array}$ \\
\hline & CONTINUEI ME APERFEIÇOANDO SOBRE TEMAS ABORDADOS. \\
\hline
\end{tabular}

7) Depois do curso você apoiou atividades de capacitação de técnicos e agricultores com base nos princípios e diretrizes da Pnater? (Considere como apoio a atividades de capacitação a participação no planejamento, elaboração de ementas, seleção de participantes e de palestrantes.)

\begin{tabular}{|l|l|}
\hline$X$ & SIM \\
\hline & NÃO \\
\hline
\end{tabular}

8) Usou os conhecimentos para ministrar outros cursos com o mesmo conteúdo ou conteúdos semelhantes? 


\begin{tabular}{|l|l|}
\hline & SIM \\
\hline$X$ & NÃO \\
\hline
\end{tabular}

9) Marque o seu grau de satisfação com relação ao curso oferecido pelo DATER: (Considere a seguinte pontuação: 1 - MUITO RUIM; 2 - RUIM; 3 - REGULAR; 4 BOM; 5 - MUITO BOM)

\begin{tabular}{|l|l|l|l|l|}
\hline 1 & 2 & 3 & 4 & 5 \\
\hline
\end{tabular}

10) Marque seu grau de satisfação com relação ao DATER: (Considere a seguinte pontuação: 1 - MUITO RUIM; 2 - RUIM; 3 - REGULAR; 4 - BOM; 5 - MUITO BOM)

\begin{tabular}{|l|l|l|l|l|}
\hline 1 & 2 & 3 & 4 & 5 \\
\hline
\end{tabular}




\section{PESQUISA - IMPACTO DAS AÇÕES DE FORMAÇÃO REALIZADAS PELO DATER/SAF/MDA NO PERÍODO 2004-2009}

Caros colaboradores,

Contamos com a sua atenção para preencher o formulário abaixo.

O mesmo tem por objetivo fornecer informações para avaliação da Eficiência, Efetividade e Eficácia da Política Pública de Formação de Agentes de Ater adotada pelo Departamento de Assistência Técnica e Extensão Rural, da Secretaria de Agricultura Familiar do Ministério do Desenvolvimento - DATER/SAF/MDA, no período de 2004 a 2009, tema escolhido para Monografia a ser apresentada à Universidade de Brasília (UnB) como requisito parcial para obtenção do grau de Bacharel em Administração.

Você poderá ou não se identificar no questionário e garantimos que todas as informações fornecidas serão confidenciais e utilizadas apenas de forma sistematizada.

IDENTIFICAÇÃO

\begin{tabular}{|c|c|}
\hline Nome: JOSÉ IVAN NEVES SERRÃO & $\begin{array}{l}\text { Sexo: } \\
(x) \text { masculino } \quad(\quad) \text { feminino }\end{array}$ \\
\hline $\begin{array}{l}\text { Instituição (nome e tipo de instituição: ONG, } \\
\text { Empresa Pública, etc.): } \\
\text { Instituto de Desenvolvimento Agropecuário do } \\
\text { Estado do Amazonas - IDAM }\end{array}$ & $\begin{array}{l}\text { Local de trabalho (Cidade e Estado): } \\
\text { Unidade Local de São Sebastião do } \\
\text { Uatumã - Amazonas }\end{array}$ \\
\hline \multicolumn{2}{|c|}{$\begin{array}{l}\text { Curso/Encontro/Oficina do qual participou (caso tenha participado de mais de um } \\
\text { curso, preencha um formulário para cada um deles): } \\
\text { II Encontro para Socialização dos Conceitos Básicos da Política Nacional de ATER }\end{array}$} \\
\hline $\begin{array}{l}\text { Data do Curso/Encontro/Oficina (pelo menos } \\
04 \text { a } 08 \text { de dezembro de } 2006 \text { - Manaus/AM }\end{array}$ & ês e ano): \\
\hline
\end{tabular}


Indique sua área de atuação? (As opções não são excludentes: você poderá marcar mais de uma opção)

\begin{tabular}{|l|l|}
\hline$X$ & EXTENSÃO RURAL \\
\hline & PESQUISA \\
\hline & ENSINO \\
\hline & OUTROS \\
\hline
\end{tabular}

2) Qual o seu nível de escolaridade? (Considere apenas o nível mais alto)

\begin{tabular}{|l|l|}
\hline$X$ & NÍVEL MÉDIO \\
\hline & NÍVEL SUPERIOR \\
\hline & PÓS-GRADUAÇÃO \\
\hline
\end{tabular}

3) Os conteúdos abordados foram condizentes com as demandas do seu dia-a-dia?

\begin{tabular}{|l|l|}
\hline$X$ & SIM \\
\hline & PARCIALMENTE \\
\hline & NÃO \\
\hline
\end{tabular}

4) O curso contribuiu para o seu aperfeiçoamento profissional?

\begin{tabular}{|l|l|}
\hline$X$ & SIM \\
\hline & NÃO \\
\hline
\end{tabular}

5) Os conhecimentos adquiridos estão sendo aplicados no seu trabalho Em caso afirmativo, indique em que grau estes conhecimentos estão sendo aplicados. Em caso negativo, indique por que razão isto não ocorre: (Em caso negativo, as respostas não são excludentes: você poderá marcar mais de uma opção). 


\begin{tabular}{|c|c|c|}
\hline \multirow{3}{*}{$\begin{array}{l}\text { SIM (indique ao lado } \\
\text { em que grau) }\end{array}$} & & MUITO APLICADOS \\
\hline & $\mathrm{X}$ & MEDIAMENTE APLICADOS \\
\hline & & POUCO APLICADOS \\
\hline \multirow{5}{*}{$\begin{array}{l}\text { NÃO (indique ao lado } \\
\text { a razão da não } \\
\text { aplicação) }\end{array}$} & & $\begin{array}{|lccc|}\text { CONTEÚDO } & \text { NÃO } & \text { ADEQUADO } & \text { ÀS } \\
\text { NECESSIDADES ESPECÍFICAS DA REGIÃO } & \end{array}$ \\
\hline & & \begin{tabular}{lccc|} 
CONTEÚDO & NÃO & FOI & SUFICIENTEMENTE \\
APROFUNDADO & PARA & PERMITIR & UMA \\
APLICAÇÃO EFICAZ E EFICIENTE
\end{tabular} \\
\hline & & $\begin{array}{l}\text { FALTA DE APOIO E INCENTIVO DA MINHA } \\
\text { INSTITUIÇÃO }\end{array}$ \\
\hline & & FALTA DE INCENTIVO ÀS AÇÕES DE ATER \\
\hline & & NÃO TENHO INTERESSE EM APLICAR \\
\hline
\end{tabular}

6) A partir deste curso: (As opções não são excludentes: você poderá marcar mais de uma opção)

\begin{tabular}{|l|l|}
\hline$x$ & $\begin{array}{l}\text { NÃO MUDOU NADA EM MEU TRABALHO. } \\
\text { FAMILIARES. }\end{array}$ \\
\hline & CONSEGUI INFLUENCIAR NAS ORIENTAÇÕES DA MINHA INSTITUIÇÃO. \\
\hline & PASSEI A TRABALHAR COM METODOLOGIAS PARTICIPATIVAS. \\
\hline & $\begin{array}{l}\text { CRESCEU A ÁREA DE AGRICULTURA DE BASE ECOLÓGICA NAS } \\
\text { COMUNIDADES ONDE ATUO. }\end{array}$ \\
\hline & CONTINUEI ME APERFEIÇOANDO SOBRE TEMAS ABORDADOS. \\
\hline
\end{tabular}

7) Depois do curso você apoiou atividades de capacitação de técnicos e agricultores com base nos princípios e diretrizes da Pnater? (Considere como apoio a atividades de 
capacitação a participação no planejamento, elaboração de ementas, seleção de participantes e de palestrantes.)

\begin{tabular}{|l|l|}
\hline & SIM \\
\hline$X$ & NÃO \\
\hline
\end{tabular}

8) Usou os conhecimentos para ministrar outros cursos com o mesmo conteúdo ou conteúdos semelhantes?

\begin{tabular}{|l|l|}
\hline & SIM \\
\hline$X$ & NÃO \\
\hline
\end{tabular}

9) Marque o seu grau de satisfação com relação ao curso oferecido pelo DATER: (Considere a seguinte pontuação: 1 - MUITO RUIM; 2 - RUIM; 3 - REGULAR; 4 BOM; 5 - MUITO BOM)

\begin{tabular}{|l|l|l|l|l|}
\hline 1 & 2 & 3 & 4 & 5 \\
\hline
\end{tabular}

10) Marque seu grau de satisfação com relação ao DATER: (Considere a seguinte pontuação: 1 - MUITO RUIM; 2 - RUIM; 3 - REGULAR; 4 - BOM; 5 - MUITO BOM)

\begin{tabular}{|l|l|l|l|l|}
\hline 1 & 2 & 3 & 4 & 5 \\
\hline
\end{tabular}


PESQUISA - IMPACTO DAS AÇÕES DE FORMAÇÃO REALIZADAS PELO DATER/SAF/MDA NO PERÍODO 2004-2009

Caros colaboradores,

Contamos com a sua atenção para preencher o formulário abaixo.

O mesmo tem por objetivo fornecer informações para avaliação da Eficiência, Efetividade e Eficácia da Política Pública de Formação de Agentes de Ater adotada pelo Departamento de Assistência Técnica e Extensão Rural, da Secretaria de Agricultura Familiar do Ministério do Desenvolvimento - DATER/SAF/MDA, no período de 2004 a 2009, tema escolhido para Monografia a ser apresentada à Universidade de Brasília (UnB) como requisito parcial para obtenção do grau de Bacharel em Administração.

Você poderá ou não se identificar no questionário e garantimos que todas as informações fornecidas serão confidenciais e utilizadas apenas de forma sistematizada.

\section{IDENTIFICAÇÃO}

\begin{tabular}{|c|c|}
\hline Nome: JOSÉ ELIZON ROCHA DA SILVA & $\begin{array}{l}\text { Sexo: } \\
\left(\begin{array}{l}x\end{array}\right) \text { masculino } \quad(\quad) \text { feminino }\end{array}$ \\
\hline $\begin{array}{l}\text { Instituição (nome e tipo de instituição: ONG, } \\
\text { Empresa Pública, etc.): } \\
\text { Instituto de Desenvolvimento Agropecuário do } \\
\text { Estado do Amazonas - IDAM }\end{array}$ & $\begin{array}{l}\text { Local de trabalho (Cidade e Estado): } \\
\text { Unidade Local de Uarini - Amazonas }\end{array}$ \\
\hline \multicolumn{2}{|c|}{$\begin{array}{l}\text { Curso/Encontro/Oficina do qual participou (caso tenha participado de mais de um curso, preencha } \\
\text { um formulário para cada um deles): } \\
\text { II Encontro para Socialização dos Conceitos Básicos da Política Nacional de ATER }\end{array}$} \\
\hline $\begin{array}{l}\text { Data do Curso/Encontro/Oficina (pelo menos mês } ~ \\
04 \text { a } 08 \text { de dezembro de } 2006 \text { - Manaus/AM }\end{array}$ & \\
\hline
\end{tabular}

Indique sua área de atuação? (As opções não são excludentes: você poderá marcar mais de uma opção)

\begin{tabular}{|l|l|}
\hline$X$ & EXTENSÃO RURAL \\
\hline & PESQUISA \\
\hline & ENSINO \\
\hline & OUTROS \\
\hline
\end{tabular}


2) Qual o seu nível de escolaridade? (Considere apenas o nível mais alto)

\begin{tabular}{|l|l|}
\hline$X$ & NÍVEL MÉDIO \\
\hline & NÍVEL SUPERIOR \\
\hline & PÓS-GRADUAÇÃO \\
\hline
\end{tabular}

3) Os conteúdos abordados foram condizentes com as demandas do seu dia-a-dia?

\begin{tabular}{|l|l|}
\hline$X$ & SIM \\
\hline & PARCIALMENTE \\
\hline & NÃO \\
\hline
\end{tabular}

3) O curso contribuiu para o seu aperfeiçoamento profissional?

\begin{tabular}{|l|l|}
\hline$X$ & SIM \\
\hline & NÃO \\
\hline
\end{tabular}

5) Os conhecimentos adquiridos estão sendo aplicados no seu trabalho? Em caso afirmativo, indique em que grau estes conhecimentos estão sendo aplicados. Em caso negativo, indique por que razão isto não ocorre: (Em caso negativo, as respostas não são excludentes: você poderá marcar mais de uma opção).

\begin{tabular}{|c|c|c|}
\hline \multirow{3}{*}{$\begin{array}{l}\text { SIM (indique ao lado em } \\
\text { que grau) }\end{array}$} & & MUITO APLICADOS \\
\hline & $\mathrm{x}$ & MEDIAMENTE APLICADOS \\
\hline & & POUCO APLICADOS \\
\hline \multirow[b]{2}{*}{$\begin{array}{l}\text { NÃO (indique ao lado a } \\
\text { razão da não aplicação) }\end{array}$} & & $\begin{array}{l}\text { CONTEÚDO NÃO ADEQUADO ÀS NECESSIDADES } \\
\text { ESPECÍFICAS DA REGIÃO }\end{array}$ \\
\hline & & $\begin{array}{lccr}\text { CONTEÚDO NÃO } & \text { FOI } & \text { SUFICIENTEMENTE } \\
\text { APROFUNDADO PARA } & \text { PERMITIR UMA APLICAÇÃO } \\
\text { EFICAZ E EFICIENTE } & & \end{array}$ \\
\hline
\end{tabular}




\begin{tabular}{|l|l|l|}
\hline \multirow{2}{*}{} & & $\begin{array}{l}\text { FALTA DE APOIO E INCENTIVO DA MINHA } \\
\text { INSTITUIÇÃO }\end{array}$ \\
\cline { 3 - 4 } & & FALTA DE INCENTIVO ÀS AÇÕES DE ATER \\
\cline { 2 - 4 } & & NÃO TENHO INTERESSE EM APLICAR \\
\hline
\end{tabular}

6) A partir deste curso: (As opções não são excludentes: você poderá marcar mais de uma opção)

\begin{tabular}{|l|l|}
\hline & NÃO MUDOU NADA EM MEU TRABALHO. \\
\hline$X$ & $\begin{array}{l}\text { MEU TRABALHO PASSOU A CONTRIBUIR MAIS COM OS AGRICULTORES(AS) } \\
\text { FAMILIARES. }\end{array}$ \\
\hline$X$ & CONSEGUI INFLUENCIAR NAS ORIENTAÇÕES DA MINHA INSTITUIÇÃO. \\
\hline$x$ & $\begin{array}{l}\text { CRESSEI A TRABALHAR COM METODOLOGIAS PARTICIPATIVAS. } \\
\text { ONDE ATUO. }\end{array}$ \\
\hline$X$ & CONTINUEI ME APERFEIÇOANDO SOBRE TEMAS ABORDADOS. \\
\hline
\end{tabular}

7) Depois do curso você apoiou atividades de capacitação de técnicos e agricultores com base nos princípios e diretrizes da Pnater? (Considere como apoio a atividades de capacitação a participação no planejamento, elaboração de ementas, seleção de participantes e de palestrantes.)

\begin{tabular}{|l|l|}
\hline$X$ & SIM \\
\hline & NÃO \\
\hline
\end{tabular}

8) Usou os conhecimentos para ministrar outros cursos com o mesmo conteúdo ou conteúdos semelhantes?

\begin{tabular}{|l|l|}
\hline & SIM \\
\hline$X$ & NÃO \\
\hline
\end{tabular}

9) Marque o seu grau de satisfação com relação ao curso oferecido pelo DATER: 


\begin{tabular}{|l|l|l|l|l|}
\hline 1 & 2 & 3 & 4 & 5 \\
\hline
\end{tabular}

10) Marque seu grau de satisfação com relação ao DATER:

\begin{tabular}{|l|l|l|l|l|}
\hline 1 & 2 & 3 & 4 & 5 \\
\hline
\end{tabular}

Obs: As notas atribuídas as questões 9 e 10 devem obedecer a ordem crescente: 1 - muito ruim , 2 - ruim, 3 - regular, 4 - bom, 5 - muito bom. 
PESQUISA - IMPACTO DAS AÇÕES DE FORMAÇÃO REALIZADAS PELO DATER/SAF/MDA NO PERÍODO 2004-2009

Caros colaboradores,

Contamos com a sua atenção para preencher o formulário abaixo.

O mesmo tem por objetivo fornecer informações para avaliação da Eficiência, Efetividade e Eficácia da Política Pública de Formação de Agentes de Ater adotada pelo Departamento de Assistência Técnica e Extensão Rural, da Secretaria de Agricultura Familiar do Ministério do Desenvolvimento - DATER/SAF/MDA, no período de 2004 a 2009, tema escolhido para Monografia a ser apresentada à Universidade de Brasília (UnB) como requisito parcial para obtenção do grau de Bacharel em Administração.

Você poderá ou não se identificar no questionário e garantimos que todas as informações fornecidas serão confidenciais e utilizadas apenas de forma sistematizada.

\section{IDENTIFICAÇÃO}

\begin{tabular}{|c|c|}
\hline Nome: JOSÉ ARIMATÉIA SIMŌES & $\begin{array}{l}\text { Sexo: } \\
(x) \text { masculino } \quad(\quad) \text { feminino }\end{array}$ \\
\hline $\begin{array}{l}\text { Instituição (nome e tipo de instituição: ONG, } \\
\text { Empresa Pública, etc.): } \\
\text { Instituto de Desenvolvimento Agropecuário do } \\
\text { Estado do Amazonas - IDAM }\end{array}$ & $\begin{array}{l}\text { Local de trabalho (Cidade e Estado): } \\
\text { Unidade Local de Urucará - Amazonas }\end{array}$ \\
\hline \multicolumn{2}{|c|}{$\begin{array}{l}\text { Curso/Encontro/Oficina do qual participou (caso tenha participado de mais de um curso, preencha } \\
\text { um formulário para cada um deles): } \\
\text { Seminário - Agroecologia como Estratégia para a Construção do Desenvolvimento Rural } \\
\text { Sustentável }\end{array}$} \\
\hline $\begin{array}{l}\text { Data do Curso/Encontro/Oficina (pelo menos mês e } \\
10 \text { e } 11 \text { de agosto de } 2006 \text { - Manaus/AM }\end{array}$ & \\
\hline
\end{tabular}

Indique sua área de atuação? (As opções não são excludentes: você poderá marcar mais de uma opção) 


\begin{tabular}{|l|l|}
\hline$X$ & EXTENSÃO RURAL \\
\hline & PESQUISA \\
\hline & ENSINO \\
\hline & OUTROS \\
\hline
\end{tabular}

2) Qual o seu nível de escolaridade? (Considere apenas o nível mais alto)

\begin{tabular}{|l|l|}
\hline & NÍVEL MÉDIO \\
\hline$X$ & NÍVEL SUPERIOR \\
\hline & PÓS-GRADUAÇÃO \\
\hline
\end{tabular}

3) Os conteúdos abordados foram condizentes com as demandas do seu dia-a-dia?

\begin{tabular}{|l|l|}
\hline$X$ & SIM \\
\hline & PARCIALMENTE \\
\hline & NÃO \\
\hline
\end{tabular}

3) O curso contribuiu para o seu aperfeiçoamento profissional?

\begin{tabular}{|l|l|}
\hline$X$ & SIM \\
\hline & NÃO \\
\hline
\end{tabular}

5) Os conhecimentos adquiridos estão sendo aplicados no seu trabalho? Em caso afirmativo, indique em que grau estes conhecimentos estão sendo aplicados. Em caso negativo, indique por que razão isto não ocorre: (Em caso negativo, as respostas não são excludentes: você poderá marcar mais de uma opção). 


\begin{tabular}{|c|c|c|}
\hline \multirow[t]{2}{*}{ que grau) } & $\mathrm{X}$ & MEDIAMENTE APLICADOS \\
\hline & & POUCO APLICADOS \\
\hline \multirow{5}{*}{$\begin{array}{l}\text { NÃO (indique ao lado a } \\
\text { razão da não aplicação) }\end{array}$} & & $\begin{array}{l}\text { CONTEÚDO NÃO ADEQUADO ÀS NECESSIDADES } \\
\text { ESPECÍFICAS DA REGIÃO }\end{array}$ \\
\hline & & $\begin{array}{l}\text { CONTEÚDO NÃO } \text { FOI SUFICIENTEMENTE } \\
\text { APROFUNDADO PARA PERMITIR UMA APLICAÇÃO } \\
\text { EFICAZ E EFICIENTE }\end{array}$ \\
\hline & & $\begin{array}{l}\text { FALTA DE APOIO } \\
\text { INSTITUIÇÃO }\end{array}$ \\
\hline & & FALTA DE INCENTIVO ÀS AÇÕES DE ATER \\
\hline & & NÃO TENHO INTERESSE EM APLICAR \\
\hline
\end{tabular}

6) A partir deste curso: (As opções não são excludentes: você poderá marcar mais de uma opção)

\begin{tabular}{|l|l|}
\hline$x$ & $\begin{array}{l}\text { NÃO MUDOU NADA EM MEU TRABALHO. } \\
\text { FAMILIARES. }\end{array}$ \\
\hline & CONSEGUI INFLUENCIAR NAS ORIENTAÇÕES DA MINHA INSTITUIÇÃO. \\
\hline & PASSEI A TRABALHAR COM METODOLOGIAS PARTICIPATIVAS. \\
\hline & $\begin{array}{l}\text { ORESCEU A ÁREA DE AGRICULTURA DE BASE ECOLÓGICA NAS COMUNIDADES } \\
\text { ONDE ATUO. }\end{array}$ \\
\hline & CONTINUEI ME APERFEIÇOANDO SOBRE TEMAS ABORDADOS. \\
\hline
\end{tabular}

7) Depois do curso você apoiou atividades de capacitação de técnicos e agricultores com base nos princípios e diretrizes da Pnater? (Considere como apoio a atividades de capacitação a participação no planejamento, elaboração de ementas, seleção de participantes e de palestrantes.) 


\begin{tabular}{|l|l|}
\hline$X$ & SIM \\
\hline & NÃO \\
\hline
\end{tabular}

8) Usou os conhecimentos para ministrar outros cursos com o mesmo conteúdo ou conteúdos semelhantes?

\begin{tabular}{|l|l|}
\hline & SIM \\
\hline$X$ & NÃO \\
\hline
\end{tabular}

9) Marque o seu grau de satisfação com relação ao curso oferecido pelo DATER: (Considere a seguinte pontuação: 1 - MUITO RUIM; 2 - RUIM; 3 - REGULAR; 4 - BOM; 5 - MUITO BOM)

\begin{tabular}{|l|l|l|l|l|}
\hline 1 & 2 & 3 & 4 & 5 \\
\hline
\end{tabular}

10) Marque seu grau de satisfação com relação ao DATER: (Considere a seguinte pontuação: 1 - MUITO RUIM; 2 - RUIM; 3 - REGULAR; 4 - BOM; 5 - MUITO BOM)

\begin{tabular}{|l|l|l|l|l|}
\hline 1 & 2 & 3 & 4 & 5 \\
\hline
\end{tabular}


PESQUISA - IMPACTO DAS AÇÕES DE FORMAÇÃO REALIZADAS PELO DATER/SAF/MDA NO PERÍODO 2004-2009

Caros colaboradores,

Contamos com a sua atenção para preencher o formulário abaixo.

O mesmo tem por objetivo fornecer informações para avaliação da Eficiência, Efetividade e Eficácia da Política Pública de Formação de Agentes de Ater adotada pelo Departamento de Assistência Técnica e Extensão Rural, da Secretaria de Agricultura Familiar do Ministério do Desenvolvimento - DATER/SAF/MDA, no período de 2004 a 2009, tema escolhido para Monografia a ser apresentada à Universidade de Brasília (UnB) como requisito parcial para obtenção do grau de Bacharel em Administração.

Você poderá ou não se identificar no questionário e garantimos que todas as informações fornecidas serão confidenciais e utilizadas apenas de forma sistematizada.

\section{IDENTIFICAÇÃO}

\begin{tabular}{|c|c|}
\hline Nome: JOSÉ ADOLFO REIS DOS SANTOS & $\begin{array}{l}\text { Sexo: } \\
(x x) \text { masculino } \quad(\quad) \text { feminino }\end{array}$ \\
\hline $\begin{array}{l}\text { Instituição (nome e tipo de instituição: ONG, } \\
\text { Empresa Pública, etc.): } \\
\text { Instituto de Desenvolvimento Agropecuário do } \\
\text { Estado do Amazonas - IDAM }\end{array}$ & $\begin{array}{l}\text { Local de trabalho (Cidade e Estado): } \\
\text { Unidade Local de Iranduba - Amazonas }\end{array}$ \\
\hline \multicolumn{2}{|c|}{$\begin{array}{l}\text { Curso/Encontro/Oficina do qual participou (caso tenha participado de mais de um curso, preencha } \\
\text { um formulário para cada um deles): } \\
\text { II Encontro para Socialização dos Conceitos Básicos da Política Nacional de Ater }\end{array}$} \\
\hline $\begin{array}{l}\text { Data do Curso/Encontro/Oficina (pelo menos mês e } \\
04 \text { a } 08 \text { de dezembro de } 2006 \text { - Manaus/AM }\end{array}$ & \\
\hline
\end{tabular}

Indique sua área de atuação? (As opções não são excludentes: você poderá marcar mais de uma opção) 


\begin{tabular}{|l|l|}
\hline & PESQUISA \\
\hline & ENSINO \\
\hline & OUTROS \\
\hline
\end{tabular}

2) Qual o seu nível de escolaridade? (Considere apenas o nível mais alto)

\begin{tabular}{|l|l|}
\hline$X$ & NÍVEL MÉDIO \\
\hline & NÍVEL SUPERIOR \\
\hline & PÓS-GRADUAÇÃO \\
\hline
\end{tabular}

3) Os conteúdos abordados foram condizentes com as demandas do seu dia-a-dia?

\begin{tabular}{|l|l|}
\hline$X$ & SIM \\
\hline & PARCIALMENTE \\
\hline & NÃO \\
\hline
\end{tabular}

3) O curso contribuiu para o seu aperfeiçoamento profissional?

\begin{tabular}{|l|l|}
\hline$X$ & SIM \\
\hline & NÃO \\
\hline
\end{tabular}

5) Os conhecimentos adquiridos estão sendo aplicados no seu trabalho? Em caso afirmativo, indique em que grau estes conhecimentos estão sendo aplicados. Em caso negativo, indique por que razão isto não ocorre: (Em caso negativo, as respostas não são excludentes: você poderá marcar mais de uma opção).

\begin{tabular}{|l|l|l|l|}
\hline $\begin{array}{l}\text { SIM (indique ao lado em } \\
\text { que grau) }\end{array}$ & & MUITO APLICADOS \\
\cline { 3 - 4 } & $\mathrm{X}$ & MEDIAMENTE APLICADOS \\
\hline
\end{tabular}




\begin{tabular}{|c|c|}
\hline & POUCO APLICADOS \\
\hline \multirow{5}{*}{$\begin{array}{l}\text { NÃO (indique ao lado a } \\
\text { razão da não aplicação) }\end{array}$} & $\begin{array}{l}\text { CONTEÚDO NÃO ADEQUADO ÀS NECESSIDADES } \\
\text { ESPECÍFICAS DA REGIÃO }\end{array}$ \\
\hline & $\begin{array}{l}\text { CONTEÚDO NÃO } \\
\text { APROFUNDADO PARA }\end{array}$ \\
\hline & $\begin{array}{|lllllll|}\text { FALTA } & \text { DE } & \text { APOIO } & \text { E } & \text { INCENTIVO } & \text { DA } & \text { MINHA } \\
\text { INSTITUIÇÃO } & & & & \\
\end{array}$ \\
\hline & FALTA DE INCENTIVO ÀS AÇÕES DE ATER \\
\hline & NÃO TENHO INTERESSE EM APLICAR \\
\hline
\end{tabular}

6) A partir deste curso: (As opções não são excludentes: você poderá marcar mais de uma opção)

\begin{tabular}{|l|l|}
\hline$x$ & $\begin{array}{l}\text { NÃO MUDOU NADA EM MEU TRABALHO. } \\
\text { FAMILIARES. }\end{array}$ \\
\hline & CONSEGUI INFLUENCIAR NAS ORIENTAÇÕES DA MINHA INSTITUIÇÃO. \\
\hline & PASSEI A TRABALHAR COM METODOLOGIAS PARTICIPATIVAS. \\
\hline & $\begin{array}{l}\text { CRESCEU A AREA DE AGRICULTURA DE BASE ECOLOGICA NAS COMUNIDADES } \\
\text { ONDE ATUO. }\end{array}$ \\
\hline & CONTINUEI ME APERFEIÇOANDO SOBRE TEMAS ABORDADOS. \\
\hline
\end{tabular}

7) Depois do curso você apoiou atividades de capacitação de técnicos e agricultores com base nos princípios e diretrizes da Pnater? (Considere como apoio a atividades de capacitação a participação no planejamento, elaboração de ementas, seleção de participantes e de palestrantes.) 


\begin{tabular}{|l|l|}
\hline & SIM \\
\hline$X$ & NÃO \\
\hline
\end{tabular}

8) Usou os conhecimentos para ministrar outros cursos com o mesmo conteúdo ou conteúdos semelhantes?

\begin{tabular}{|l|l|}
\hline & SIM \\
\hline$X$ & NÃO \\
\hline
\end{tabular}

9) Marque o seu grau de satisfação com relação ao curso oferecido pelo DATER: (Considere a seguinte pontuação: 1 - MUITO RUIM; 2 - RUIM; 3 - REGULAR; 4 - BOM; 5 - MUITO BOM)

\begin{tabular}{|l|l|l|l|l|}
\hline 1 & 2 & 3 & 4 & 5 \\
\hline
\end{tabular}

10) Marque seu grau de satisfação com relação ao DATER: (Considere a seguinte pontuação: 1 - MUITO RUIM; 2 - RUIM; 3 - REGULAR; 4 - BOM; 5 - MUITO BOM)

\begin{tabular}{|l|l|l|l|l|}
\hline 1 & 2 & 3 & 4 & 5 \\
\hline
\end{tabular}


PESQUISA - IMPACTO DAS AÇÕES DE FORMAÇÃO REALIZADAS PELO DATER/SAF/MDA NO PERÍODO 2004-2009

Caros colaboradores,

Contamos com a sua atenção para preencher o formulário abaixo.

O mesmo tem por objetivo fornecer informações para avaliação da Eficiência, Efetividade e Eficácia da Política Pública de Formação de Agentes de Ater adotada pelo Departamento de Assistência Técnica e Extensão Rural, da Secretaria de Agricultura Familiar do Ministério do Desenvolvimento - DATER/SAF/MDA, no período de 2004 a 2009, tema escolhido para Monografia a ser apresentada à Universidade de Brasília (UnB) como requisito parcial para obtenção do grau de Bacharel em Administração.

Você poderá ou não se identificar no questionário e garantimos que todas as informações fornecidas serão confidenciais e utilizadas apenas de forma sistematizada.

\section{IDENTIFICAÇÃO}

\begin{tabular}{|l|l|l|}
\hline Nome: MÁRIO FRANCISCO CALDAS ONO & Sexo: \\
& & \\
& & \\
&
\end{tabular}

Indique sua área de atuação? (As opções não são excludentes: você poderá marcar mais de uma opção) 


\begin{tabular}{|l|l|}
\hline$X$ & EXTENSÃO RURAL \\
\hline & PESQUISA \\
\hline & ENSINO \\
\hline & OUTROS \\
\hline
\end{tabular}

2) Qual o seu nível de escolaridade? (Considere apenas o nível mais alto)

\begin{tabular}{|l|l|}
\hline$X$ & NÍVEL MÉDIO \\
\hline & NÍVEL SUPERIOR \\
\hline & PÓS-GRADUAÇÃO \\
\hline
\end{tabular}

3) Os conteúdos abordados foram condizentes com as demandas do seu dia-a-dia?

\begin{tabular}{|l|l|}
\hline$X$ & SIM \\
\hline & PARCIALMENTE \\
\hline & NÃO \\
\hline
\end{tabular}

3) O curso contribuiu para o seu aperfeiçoamento profissional?

\begin{tabular}{|l|l|}
\hline$X$ & SIM \\
\hline & NÃO \\
\hline
\end{tabular}

5) Os conhecimentos adquiridos estão sendo aplicados no seu trabalho? Em caso afirmativo, indique em que grau estes conhecimentos estão sendo aplicados. Em caso negativo, indique por que razão isto não ocorre: (Em caso negativo, as respostas não são excludentes: você poderá marcar mais de uma opção).

\begin{tabular}{|l|l|l|l|}
\hline $\mathrm{X}$ & SIM (indique ao lado em & & MUITO APLICADOS \\
\hline
\end{tabular}




\begin{tabular}{|c|c|c|}
\hline \multirow[t]{2}{*}{ que grau) } & $\mathrm{X}$ & MEDIAMENTE APLICADOS \\
\hline & & POUCO APLICADOS \\
\hline \multirow{5}{*}{$\begin{array}{l}\text { NÃO (indique ao lado a } \\
\text { razão da não aplicação) }\end{array}$} & & $\begin{array}{l}\text { CONTEÚDO NÃO ADEQUADO ÀS NECESSIDADES } \\
\text { ESPECÍFICAS DA REGIÃO }\end{array}$ \\
\hline & & $\begin{array}{l}\text { CONTEÚDO NÃO } \text { FOI SUFICIENTEMENTE } \\
\text { APROFUNDADO PARA PERMITIR UMA APLICAÇÃO } \\
\text { EFICAZ E EFICIENTE }\end{array}$ \\
\hline & & $\begin{array}{l}\text { FALTA DE APOIO } \\
\text { INSTITUIÇÃO }\end{array}$ \\
\hline & & FALTA DE INCENTIVO ÀS AÇÕES DE ATER \\
\hline & & NÃO TENHO INTERESSE EM APLICAR \\
\hline
\end{tabular}

6) A partir deste curso: (As opções não são excludentes: você poderá marcar mais de uma opção)

\begin{tabular}{|l|l|}
\hline & NÃO MUDOU NADA EM MEU TRABALHO. \\
\hline$X$ & $\begin{array}{l}\text { MEU TRABALHO PASSOU A CONTRIBUIR MAIS COM OS AGRICULTORES(AS) } \\
\text { FAMILIARES. }\end{array}$ \\
\hline$x$ & CONSEGUI INFLUENCIAR NAS ORIENTAÇÕES DA MINHA INSTITUIÇÃO. \\
\hline & $\begin{array}{l}\text { CRESCEU A ÁREA DE AGRICULTURA DE BASE ECOLÓGICA NAS COMUNIDADES } \\
\text { ONDE ATUO. }\end{array}$ \\
\hline$X$ & CONTINUEI ME APERFEIÇOANDO SOBRE TEMAS ABORDADOS. \\
\hline
\end{tabular}

7) Depois do curso você apoiou atividades de capacitação de técnicos e agricultores com base nos princípios e diretrizes da Pnater? (Considere como apoio a atividades de capacitação a participação no planejamento, elaboração de ementas, seleção de participantes e de palestrantes.) 


\begin{tabular}{|l|l|}
\hline$X$ & SIM \\
\hline & NÃO \\
\hline
\end{tabular}

8) Usou os conhecimentos para ministrar outros cursos com o mesmo conteúdo ou conteúdos semelhantes?

\begin{tabular}{|l|l|}
\hline & SIM \\
\hline & NÃO \\
\hline
\end{tabular}

9) Marque o seu grau de satisfação com relação ao curso oferecido pelo DATER: (Considere a seguinte pontuação: 1 - MUITO RUIM; 2 - RUIM; 3 - REGULAR; 4 - BOM; 5 - MUITO BOM)

\begin{tabular}{|l|l|l|l|l|}
\hline 1 & 2 & 3 & 4 & 5 \\
\hline
\end{tabular}

10) Marque seu grau de satisfação com relação ao DATER: (Considere a seguinte pontuação: 1 - MUITO RUIM; 2 - RUIM; 3 - REGULAR; 4 - BOM; 5 - MUITO BOM)

\begin{tabular}{|l|l|l|l|l|}
\hline 1 & 2 & 3 & 4 & 5 \\
\hline
\end{tabular}


PESQUISA - IMPACTO DAS AÇÕES DE FORMAÇÃO REALIZADAS PELO DATER/SAF/MDA NO PERÍODO 2004-2009

Caros colaboradores,

Contamos com a sua atenção para preencher o formulário abaixo.

O mesmo tem por objetivo fornecer informações para avaliação da Eficiência, Efetividade e Eficácia da Política Pública de Formação de Agentes de Ater adotada pelo Departamento de Assistência Técnica e Extensão Rural, da Secretaria de Agricultura Familiar do Ministério do Desenvolvimento - DATER/SAF/MDA, no período de 2004 a 2009, tema escolhido para Monografia a ser apresentada à Universidade de Brasília (UnB) como requisito parcial para obtenção do grau de Bacharel em Administração.

Você poderá ou não se identificar no questionário e garantimos que todas as informações fornecidas serão confidenciais e utilizadas apenas de forma sistematizada.

\section{IDENTIFICAÇÃO}

\begin{tabular}{|c|c|}
\hline Nome: MÁRIO FRANCISCO CALDAS ONO & $\begin{array}{l}\text { Sexo: } \\
(\mathrm{x}) \text { masculino }\end{array}$ \\
\hline $\begin{array}{l}\text { Instituição (nome e tipo de instituição: ONG, } \\
\text { Empresa Pública, etc.): Instituto de } \\
\text { Desenvolvimento Agropecuário do Estado do } \\
\text { Amazonas - IDAM }\end{array}$ & $\begin{array}{l}\text { Local de trabalho (Cidade e Estado): } \\
\text { Manaus - AM }\end{array}$ \\
\hline \multicolumn{2}{|c|}{$\begin{array}{l}\text { Curso/Encontro/Oficina do qual participou (caso tenha participado de mais de um curso, preencha } \\
\text { um formulário para cada um deles): } \\
\text { Curso de Agroecologia }\end{array}$} \\
\hline $\begin{array}{l}\text { Data do Curso/Encontro/Oficina (pelo menos mês e } \\
24 \text { a } 28 \text { de abril de } 2006 \text { - Manaus/AM }\end{array}$ & \\
\hline
\end{tabular}

Indique sua área de atuação? (As opções não são excludentes: você poderá marcar mais de uma opção)

\begin{tabular}{|l|l|}
\hline$X$ & EXTENSÃO RURAL \\
\hline
\end{tabular}




\begin{tabular}{|l|l|}
\hline & PESQUISA \\
\hline & ENSINO \\
\hline & OUTROS \\
\hline
\end{tabular}

2) Qual o seu nível de escolaridade? (Considere apenas o nível mais alto)

\begin{tabular}{|l|l|}
\hline$X$ & NÍVEL MÉDIO \\
\hline & NÍVEL SUPERIOR \\
\hline & PÓS-GRADUAÇÃO \\
\hline
\end{tabular}

3) Os conteúdos abordados foram condizentes com as demandas do seu dia-a-dia?

\begin{tabular}{|l|l|}
\hline$X$ & SIM \\
\hline & PARCIALMENTE \\
\hline & NÃO \\
\hline
\end{tabular}

3) O curso contribuiu para o seu aperfeiçoamento profissional?

\begin{tabular}{|l|l|}
\hline$X$ & SIM \\
\hline & NÃO \\
\hline
\end{tabular}

5) Os conhecimentos adquiridos estão sendo aplicados no seu trabalho? Em caso afirmativo, indique em que grau estes conhecimentos estão sendo aplicados. Em caso negativo, indique por que razão isto não ocorre: (Em caso negativo, as respostas não são excludentes: você poderá marcar mais de uma opção).

\begin{tabular}{|l|l|l|l|}
\hline$X$ & $\begin{array}{l}\text { SIM (indique ao lado em } \\
\text { que grau) }\end{array}$ & & MUITO APLICADOS \\
\cline { 3 - 4 } & & $\mathrm{X}$ & MEDIAMENTE APLICADOS \\
\hline
\end{tabular}




\begin{tabular}{|c|c|}
\hline & POUCO APLICADOS \\
\hline \multirow{5}{*}{$\begin{array}{l}\text { NÃO (indique ao lado a } \\
\text { razão da não aplicação) }\end{array}$} & $\begin{array}{l}\text { CONTEÚDO NÃO ADEQUADO ÀS NECESSIDADES } \\
\text { ESPECÍFICAS DA REGIÃO }\end{array}$ \\
\hline & $\begin{array}{l}\text { CONTEÚDO NÃO } \\
\text { APROFUNDADO PARA }\end{array}$ \\
\hline & $\begin{array}{|lllllll|}\text { FALTA } & \text { DE } & \text { APOIO } & \text { E } & \text { INCENTIVO } & \text { DA } & \text { MINHA } \\
\text { INSTITUIÇÃO } & & & & \\
\end{array}$ \\
\hline & FALTA DE INCENTIVO ÀS AÇÕES DE ATER \\
\hline & NÃO TENHO INTERESSE EM APLICAR \\
\hline
\end{tabular}

6) A partir deste curso: (As opções não são excludentes: você poderá marcar mais de uma opção)

\begin{tabular}{|l|l|}
\hline & NÃO MUDOU NADA EM MEU TRABALHO. \\
\hline$X$ & $\begin{array}{l}\text { MEU TRABALHO PASSOU A CONTRIBUIR MAIS COM OS AGRICULTORES(AS) } \\
\text { FAMILIARES. }\end{array}$ \\
\hline & CONSEGUI INFLUENCIAR NAS ORIENTAÇÕES DA MINHA INSTITUIÇÃO. \\
\hline$X$ & $\begin{array}{l}\text { CRESSEI A TRABALHAR COM METODOLOGIAS PARTICIPATIVAS. } \\
\text { ONDE ATUO. }\end{array}$ \\
\hline$X$ & CONTINUEI ME APERFEIÇOANDO SOBRE TEMAS ABORDADOS. \\
\hline
\end{tabular}

7) Depois do curso você apoiou atividades de capacitação de técnicos e agricultores com base nos princípios e diretrizes da Pnater? (Considere como apoio a atividades de capacitação a participação no planejamento, elaboração de ementas, seleção de participantes e de palestrantes.)

\begin{tabular}{|l|l|}
\hline$X$ & SIM \\
\hline & NÃO \\
\hline
\end{tabular}


8) Usou os conhecimentos para ministrar outros cursos com o mesmo conteúdo ou conteúdos semelhantes?

\begin{tabular}{|l|l|}
\hline & SIM \\
\hline & NÃO \\
\hline
\end{tabular}

9) Marque o seu grau de satisfação com relação ao curso oferecido pelo DATER: (Considere a seguinte pontuação: 1 - MUITO RUIM; 2 - RUIM; 3 - REGULAR; 4 - BOM; 5 - MUITO BOM)

\begin{tabular}{|l|l|l|l|l|}
\hline 1 & 2 & 3 & 4 & 5 \\
\hline
\end{tabular}

10) Marque seu grau de satisfação com relação ao DATER: (Considere a seguinte pontuação: 1 - MUITO RUIM; 2 - RUIM; 3 - REGULAR; 4 - BOM; 5 - MUITO BOM)

\begin{tabular}{|l|l|l|l|l|}
\hline 1 & 2 & 3 & 4 & 5 \\
\hline
\end{tabular}


PESQUISA - IMPACTO DAS AÇÕES DE FORMAÇÃO REALIZADAS PELO DATER/SAF/MDA NO PERÍODO 2004-2009

Caros colaboradores,

Contamos com a sua atenção para preencher o formulário abaixo.

O mesmo tem por objetivo fornecer informações para avaliação da Eficiência, Efetividade e Eficácia da Política Pública de Formação de Agentes de Ater adotada pelo Departamento de Assistência Técnica e Extensão Rural, da Secretaria de Agricultura Familiar do Ministério do Desenvolvimento - DATER/SAF/MDA, no período de 2004 a 2009, tema escolhido para Monografia a ser apresentada à Universidade de Brasília (UnB) como requisito parcial para obtenção do grau de Bacharel em Administração.

Você poderá ou não se identificar no questionário e garantimos que todas as informações fornecidas serão confidenciais e utilizadas apenas de forma sistematizada.

\section{IDENTIFICAÇÃO}

\begin{tabular}{|l|l|}
\hline Nome: MARILUCE DOS REIS FERREIRA & $\begin{array}{l}\text { Sexo: } \\
(\mathrm{x}) \text { masculino } \quad(\quad \text { ) feminino }\end{array}$ \\
\hline $\begin{array}{l}\text { Instituição (nome e tipo de instituição: ONG, } \\
\begin{array}{l}\text { Empresa Pública, etc.): } \\
\text { Instituto de Desenvolvimento Agropecuário do de trabalho (Cidade e Estado): } \\
\text { Estado do Amazonas - IDAM }\end{array}\end{array}$ \\
$\begin{array}{l}\text { Curso/Encontro/Oficina do qual participou (caso tenha participado de mais de um curso, preencha } \\
\text { um formulário para cada um deles): } \\
\text { II Encontro para Socialização dos Conceitos Básicos da Política Nacional de Ater }\end{array}$ \\
\hline $\begin{array}{l}\text { Data do Curso/Encontro/Oficina (pelo menos mês e ano): } \\
04 \text { a 08 de dezembro de } 2006 \text { - Manaus/AM }\end{array}$ \\
\hline
\end{tabular}

Indique sua área de atuação? (As opções não são excludentes: você poderá marcar mais de uma opção)

\begin{tabular}{|l|l|}
\hline$X$ & EXTENSÃO RURAL \\
\hline & PESQUISA \\
\hline
\end{tabular}




\begin{tabular}{|l|l|}
\hline & ENSINO \\
\hline & OUTROS \\
\hline
\end{tabular}

2) Qual o seu nível de escolaridade? (Considere apenas o nível mais alto)

\begin{tabular}{|l|l|}
\hline & NÍVEL MÉDIO \\
\hline$X$ & NÍVEL SUPERIOR \\
\hline & PÓS-GRADUAÇÃO \\
\hline
\end{tabular}

3) Os conteúdos abordados foram condizentes com as demandas do seu dia-a-dia?

\begin{tabular}{|l|l|}
\hline$X$ & SIM \\
\hline & PARCIALMENTE \\
\hline & NÃO \\
\hline
\end{tabular}

3) O curso contribuiu para o seu aperfeiçoamento profissional?

\begin{tabular}{|l|l|}
\hline$X$ & SIM \\
\hline & NÃO \\
\hline
\end{tabular}

5) Os conhecimentos adquiridos estão sendo aplicados no seu trabalho? Em caso afirmativo, indique em que grau estes conhecimentos estão sendo aplicados. Em caso negativo, indique por que razão isto não ocorre: (Em caso negativo, as respostas não são excludentes: você poderá marcar mais de uma opção).

\begin{tabular}{|l|l|l|l|}
\hline \multirow{2}{*}{$\begin{array}{l}\text { SIM (indique ao lado em } \\
\text { que grau) }\end{array}$} & X & MUITO APLICADOS \\
\cline { 2 - 3 } & & MEDIAMENTE APLICADOS \\
\cline { 2 - 3 } & & POUCO APLICADOS \\
\hline
\end{tabular}




\begin{tabular}{|c|c|}
\hline \multirow{5}{*}{$\begin{array}{l}\text { NÃO (indique ao lado a } \\
\text { razão da não aplicação) }\end{array}$} & $\begin{array}{l}\text { CONTEÚDO NÃO ADEQUADO ÀS NECESSIDADES } \\
\text { ESPECÍFICAS DA REGIÃO }\end{array}$ \\
\hline & $\begin{array}{l}\text { CONTEÚDO NÃO } \text { FOI SUFICIENTEMENTE } \\
\text { APROFUNDADO PARA } \\
\text { EERMITIR UMA APLICAÇÃO } \\
\text { EFICAZ E EFICIENTE }\end{array}$ \\
\hline & $\begin{array}{llllll}\text { FALTA DE } & \text { APOIO } & \text { E } & \text { INCENTIVO } & \text { DA } & \text { MINHA } \\
\text { INSTITUIÇÃO } & & & & & \\
\end{array}$ \\
\hline & FALTA DE INCENTIVO ÀS AÇÕES DE ATER \\
\hline & NÃO TENHO INTERESSE EM APLICAR \\
\hline
\end{tabular}

6) A partir deste curso: (As opções não são excludentes: você poderá marcar mais de uma opção)

\begin{tabular}{|l|l|}
\hline$x$ & $\begin{array}{l}\text { NẼO MUDOU NADA EM MEU TRABALHO. } \\
\text { FAMILIARES. }\end{array}$ \\
\hline & CONSEGUI INFLUENCIAR NAS ORIENTAÇÕES DA MINHA INSTITUIÇÃO. \\
\hline & PASSEI A TRABALHAR COM METODOLOGIAS PARTICIPATIVAS. \\
\hline & ORESCEU A ÁREA DE AGRICULTURA DE BASE ECOLÓGICA NAS COMUNIDADES \\
\hline & CONTINUEI ME APERFEIÇOANDO SOBRE TEMAS ABORDADOS. \\
\hline
\end{tabular}

7) Depois do curso você apoiou atividades de capacitação de técnicos e agricultores com base nos princípios e diretrizes da Pnater? (Considere como apoio a atividades de capacitação a participação no planejamento, elaboração de ementas, seleção de participantes e de palestrantes.)

\begin{tabular}{|l|l|}
\hline & SIM \\
\hline$X$ & NÃO \\
\hline
\end{tabular}


8) Usou os conhecimentos para ministrar outros cursos com o mesmo conteúdo ou conteúdos semelhantes?

\begin{tabular}{|l|l|}
\hline & SIM \\
\hline$X$ & NÃO \\
\hline
\end{tabular}

9) Marque o seu grau de satisfação com relação ao curso oferecido pelo DATER: (Considere a seguinte pontuação: 1 - MUITO RUIM; 2 - RUIM; 3 - REGULAR; 4 - BOM; 5 - MUITO BOM)

\begin{tabular}{|l|l|l|l|l|}
\hline 1 & 2 & 3 & 4 & 5 \\
\hline
\end{tabular}

10) Marque seu grau de satisfação com relação ao DATER: (Considere a seguinte pontuação: 1 - MUITO RUIM; 2 - RUIM; 3 - REGULAR; 4 - BOM; 5 - MUITO BOM)

\begin{tabular}{|l|l|l|l|l|}
\hline 1 & 2 & 3 & 4 & 5 \\
\hline
\end{tabular}


PESQUISA - IMPACTO DAS AÇÕES DE FORMAÇÃO REALIZADAS PELO DATER/SAF/MDA NO PERÍODO 2004-2009

Caros colaboradores,

Contamos com a sua atenção para preencher o formulário abaixo.

O mesmo tem por objetivo fornecer informações para avaliação da Eficiência, Efetividade e Eficácia da Política Pública de Formação de Agentes de Ater adotada pelo Departamento de Assistência Técnica e Extensão Rural, da Secretaria de Agricultura Familiar do Ministério do Desenvolvimento - DATER/SAF/MDA, no período de 2004 a 2009, tema escolhido para Monografia a ser apresentada à Universidade de Brasília (UnB) como requisito parcial para obtenção do grau de Bacharel em Administração.

Você poderá ou não se identificar no questionário e garantimos que todas as informações fornecidas serão confidenciais e utilizadas apenas de forma sistematizada.

\section{IDENTIFICAÇÃO}

\begin{tabular}{|c|c|}
\hline Nome: MARILDO XIMENDES DA SILVA & Sexo: \\
\hline & $(\mathrm{x})$ masculino \\
\hline $\begin{array}{l}\text { Instituição (nome e tipo de instituição: ONG, } \\
\text { Empresa Pública, etc.): } \\
\text { Instituto de Desenvolvimento Agropecuário do } \\
\text { Estado do Amazonas - IDAM }\end{array}$ & $\begin{array}{l}\text { Local de trabalho (Cidade e Estado): } \\
\text { Unidade Local de Rio Preto da Eva } \\
\text { Amazonas }\end{array}$ \\
\hline \multicolumn{2}{|c|}{$\begin{array}{l}\text { Curso/Encontro/Oficina do qual participou (caso tenha participado de mais de um curso, preencha } \\
\text { um formulário para cada um deles): } \\
\text { Seminário - Agroecologia como Estratégia para a Construção do Desenvolvimento Rural } \\
\text { Sustentável }\end{array}$} \\
\hline $\begin{array}{l}\text { Data do Curso/Encontro/Oficina (pelo menos mês } e \\
10 \text { e } 11 \text { de agosto de } 2006 \text { - Manaus/AM }\end{array}$ & \\
\hline
\end{tabular}

Indique sua área de atuação? (As opções não são excludentes: você poderá marcar mais de uma opção)

\begin{tabular}{|l|l|}
\hline$X$ & EXTENSÃO RURAL \\
\hline
\end{tabular}




\begin{tabular}{|l|l|}
\hline & PESQUISA \\
\hline & ENSINO \\
\hline & OUTROS \\
\hline
\end{tabular}

2) Qual o seu nível de escolaridade? (Considere apenas o nível mais alto)

\begin{tabular}{|l|l|}
\hline$X$ & NÍVEL MÉDIO \\
\hline & NÍVEL SUPERIOR \\
\hline & PÓS-GRADUAÇÃO \\
\hline
\end{tabular}

3) Os conteúdos abordados foram condizentes com as demandas do seu dia-a-dia?

\begin{tabular}{|l|l|}
\hline$X$ & SIM \\
\hline & PARCIALMENTE \\
\hline & NÃO \\
\hline
\end{tabular}

3) O curso contribuiu para o seu aperfeiçoamento profissional?

\begin{tabular}{|l|l|}
\hline$X$ & SIM \\
\hline & NÃO \\
\hline
\end{tabular}

5) Os conhecimentos adquiridos estão sendo aplicados no seu trabalho? Em caso afirmativo, indique em que grau estes conhecimentos estão sendo aplicados. Em caso negativo, indique por que razão isto não ocorre: (Em caso negativo, as respostas não são excludentes: você poderá marcar mais de uma opção).

\begin{tabular}{|l|l|l|l|}
\hline \multirow{2}{*}{$\begin{array}{l}\text { SIM (indique ao lado em } \\
\text { que grau) }\end{array}$} & & MUITO APLICADOS \\
\cline { 3 - 4 } & & $\mathrm{X}$ & MEDIAMENTE APLICADOS \\
\hline
\end{tabular}




\begin{tabular}{|c|c|}
\hline & POUCO APLICADOS \\
\hline \multirow{5}{*}{$\begin{array}{l}\text { NÃO (indique ao lado a } \\
\text { razão da não aplicação) }\end{array}$} & $\begin{array}{l}\text { CONTEÚDO NÃO ADEQUADO ÀS NECESSIDADES } \\
\text { ESPECÍFICAS DA REGIÃO }\end{array}$ \\
\hline & $\begin{array}{l}\text { CONTEÚDO NÃO } \\
\text { APROFUNDADO PARA }\end{array}$ \\
\hline & $\begin{array}{|lllllll|}\text { FALTA } & \text { DE } & \text { APOIO } & \text { E } & \text { INCENTIVO } & \text { DA } & \text { MINHA } \\
\text { INSTITUIÇÃO } & & & & \\
\end{array}$ \\
\hline & FALTA DE INCENTIVO ÀS AÇÕES DE ATER \\
\hline & NÃO TENHO INTERESSE EM APLICAR \\
\hline
\end{tabular}

6) A partir deste curso: (As opções não são excludentes: você poderá marcar mais de uma opção)

\begin{tabular}{|l|l|}
\hline$x$ & $\begin{array}{l}\text { NÃO MUDOU NADA EM MEU TRABALHO. } \\
\text { FAMILIARES. }\end{array}$ \\
\hline & CONSEGUI INFLUENCIAR NAS ORIENTAÇÕES DA MINHA INSTITUIÇÃO. \\
\hline & PASSEI A TRABALHAR COM METODOLOGIAS PARTICIPATIVAS. \\
\hline & $\begin{array}{l}\text { CRESCEU A ÁREA DE AGRICULTURA DE BASE ECOLÓGICA NAS COMUNIDADES } \\
\text { ONDE ATUO. }\end{array}$ \\
\hline & CONTINUEI ME APERFEIÇOANDO SOBRE TEMAS ABORDADOS. \\
\hline
\end{tabular}

7) Depois do curso você apoiou atividades de capacitação de técnicos e agricultores com base nos princípios e diretrizes da Pnater? (Considere como apoio a atividades de capacitação a participação no planejamento, elaboração de ementas, seleção de participantes e de palestrantes.)

\begin{tabular}{|l|l|}
\hline$X$ & SIM \\
\hline & NÃO \\
\hline
\end{tabular}


8) Usou os conhecimentos para ministrar outros cursos com o mesmo conteúdo ou conteúdos semelhantes?

\begin{tabular}{|l|l|}
\hline$X$ & SIM \\
\hline & NÃO \\
\hline
\end{tabular}

9) Marque o seu grau de satisfação com relação ao curso oferecido pelo DATER: (Considere a seguinte pontuação: 1 - MUITO RUIM; 2 - RUIM; 3 - REGULAR; 4 - BOM; 5 - MUITO BOM)

\begin{tabular}{|l|l|l|l|l|}
\hline 1 & 2 & 3 & 4 & 5 \\
\hline
\end{tabular}

10) Marque seu grau de satisfação com relação ao DATER: (Considere a seguinte pontuação: 1 - MUITO RUIM; 2 - RUIM; 3 - REGULAR; 4 - BOM; 5 - MUITO BOM)

\begin{tabular}{|l|l|l|l|l|}
\hline 1 & 2 & 3 & 4 & 5 \\
\hline
\end{tabular}


PESQUISA - IMPACTO DAS AÇÕES DE FORMAÇÃO REALIZADAS PELO DATER/SAF/MDA NO PERÍODO 2004-2009

Caros colaboradores,

Contamos com a sua atenção para preencher o formulário abaixo.

O mesmo tem por objetivo fornecer informações para avaliação da Eficiência, Efetividade e Eficácia da Política Pública de Formação de Agentes de Ater adotada pelo Departamento de Assistência Técnica e Extensão Rural, da Secretaria de Agricultura Familiar do Ministério do Desenvolvimento - DATER/SAF/MDA, no período de 2004 a 2009, tema escolhido para Monografia a ser apresentada à Universidade de Brasília (UnB) como requisito parcial para obtenção do grau de Bacharel em Administração.

Você poderá ou não se identificar no questionário e garantimos que todas as informações fornecidas serão confidenciais e utilizadas apenas de forma sistematizada.

\section{IDENTIFICAÇÃO}

\begin{tabular}{|c|c|}
\hline Nome: MARIA SIMONE DA COSTA SOARES & $\begin{array}{l}\text { Sexo: } \\
(x) \text { masculino } \quad(\quad) \text { feminino }\end{array}$ \\
\hline $\begin{array}{l}\text { Instituição (nome e tipo de instituição: ONG, } \\
\text { Empresa Pública, etc.): } \\
\text { Instituto de Desenvolvimento Agropecuário do } \\
\text { Estado do Amazonas - IDAM }\end{array}$ & $\begin{array}{l}\text { Local de trabalho (Cidade e Estado): } \\
\text { Unidade Local de Rio Preto da Eva - } \\
\text { Amazonas }\end{array}$ \\
\hline \multicolumn{2}{|c|}{$\begin{array}{l}\text { Curso/Encontro/Oficina do qual participou (caso tenha participado de mais de um curso, preencha } \\
\text { um formulário para cada um deles): } \\
\text { II Encontro para Socialização dos Conceitos Básicos da Política Nacional de ATER }\end{array}$} \\
\hline \multicolumn{2}{|l|}{$\begin{array}{l}\text { Data do Curso/Encontro/Oficina (pelo menos mês e ano): } \\
04 \text { a } 08 \text { de dezembro de } 2006 \text { - Manaus/AM }\end{array}$} \\
\hline
\end{tabular}

Indique sua área de atuação? (As opções não são excludentes: você poderá marcar mais de uma opção)

$\mathrm{X}$ EXTENSÃO RURAL 


\begin{tabular}{|l|l|}
\hline & PESQUISA \\
\hline & ENSINO \\
\hline & OUTROS \\
\hline
\end{tabular}

2) Qual o seu nível de escolaridade? (Considere apenas o nível mais alto)

\begin{tabular}{|l|l|}
\hline & NÍVEL MÉDIO \\
\hline$X$ & NÍVEL SUPERIOR \\
\hline & PÓS-GRADUAÇÃO \\
\hline
\end{tabular}

3) Os conteúdos abordados foram condizentes com as demandas do seu dia-a-dia?

\begin{tabular}{|l|l|}
\hline$X$ & SIM \\
\hline & PARCIALMENTE \\
\hline & NÃO \\
\hline
\end{tabular}

3) O curso contribuiu para o seu aperfeiçoamento profissional?

\begin{tabular}{|l|l|}
\hline$X$ & SIM \\
\hline & NÃO \\
\hline
\end{tabular}

5) Os conhecimentos adquiridos estão sendo aplicados no seu trabalho? Em caso afirmativo, indique em que grau estes conhecimentos estão sendo aplicados. Em caso negativo, indique por que razão isto não ocorre: (Em caso negativo, as respostas não são excludentes: você poderá marcar mais de uma opção).

\begin{tabular}{|l|l|l|l|}
\hline $\begin{array}{l}\text { SIM (indique ao lado em } \\
\text { que grau) }\end{array}$ & $X$ & MUITO APLICADOS \\
\cline { 2 - 3 } & & MEDIAMENTE APLICADOS \\
\hline
\end{tabular}




\begin{tabular}{|c|c|}
\hline & POUCO APLICADOS \\
\hline \multirow{5}{*}{$\begin{array}{l}\text { NÃO (indique ao lado a } \\
\text { razão da não aplicação) }\end{array}$} & $\begin{array}{l}\text { CONTEÚDO NÃO ADEQUADO ÀS NECESSIDADES } \\
\text { ESPECÍFICAS DA REGIÃO }\end{array}$ \\
\hline & $\begin{array}{l}\text { CONTEÚDO NÃO } \\
\text { APROFUNDADO PARA }\end{array}$ \\
\hline & $\begin{array}{|lllllll|}\text { FALTA } & \text { DE } & \text { APOIO } & \text { E } & \text { INCENTIVO } & \text { DA } & \text { MINHA } \\
\text { INSTITUIÇÃO } & & & & \\
\end{array}$ \\
\hline & FALTA DE INCENTIVO ÀS AÇÕES DE ATER \\
\hline & NÃO TENHO INTERESSE EM APLICAR \\
\hline
\end{tabular}

6) A partir deste curso: (As opções não são excludentes: você poderá marcar mais de uma opção)

\begin{tabular}{|l|l|}
\hline$x$ & NÃO MUDOU NADA EM MEU TRABALHO. \\
\hline$X$ & $\begin{array}{l}\text { MEU TRABALHO PASSOU A CONTRIBUIR MAIS COM OS AGRICULTORES(AS) } \\
\text { FAMILIARES. }\end{array}$ \\
\hline$X$ & CONSEGUI INFLUENCIAR NAS ORIENTAÇÕES DA MINHA INSTITUIÇÃO. \\
\hline & $\begin{array}{l}\text { CRESCEU A ÁREA DE AGRICULTURA DE BASE ECOLÓGICA NAS COMUNIDADES } \\
\text { ONDE ATUO. }\end{array}$ \\
\hline$X$ & CONTINUEI ME APERFEIÇOANDO SOBRE TEMAS ABORDADOS. \\
\hline
\end{tabular}

7) Depois do curso você apoiou atividades de capacitação de técnicos e agricultores com base nos princípios e diretrizes da Pnater? (Considere como apoio a atividades de capacitação a participação no planejamento, elaboração de ementas, seleção de participantes e de palestrantes.)

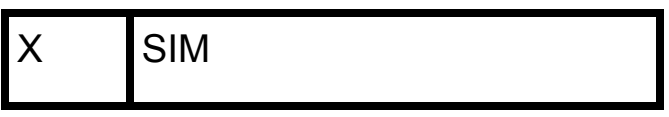


NÃO

8) Usou os conhecimentos para ministrar outros cursos com o mesmo conteúdo ou conteúdos semelhantes?

\begin{tabular}{|l|l|}
\hline & SIM \\
\hline$X$ & NÃO \\
\hline
\end{tabular}

9) Marque o seu grau de satisfação com relação ao curso oferecido pelo DATER: (Considere a seguinte pontuação: 1 - MUITO RUIM; 2 - RUIM; 3 - REGULAR; 4 - BOM; 5 - MUITO BOM)

\begin{tabular}{|l|l|l|l|l|}
\hline 1 & 2 & 3 & 4 & 5 \\
\hline
\end{tabular}

10) Marque seu grau de satisfação com relação ao DATER: (Considere a seguinte pontuação: 1 - MUITO RUIM; 2 - RUIM; 3 - REGULAR; 4 - BOM; 5 - MUITO BOM)

\begin{tabular}{|l|l|l|l|l|}
\hline 1 & 2 & 3 & 4 & 5 \\
\hline
\end{tabular}


PESQUISA - IMPACTO DAS AÇÕES DE FORMAÇÃO REALIZADAS PELO DATER/SAF/MDA NO PERÍODO 2004-2009

Caros colaboradores,

Contamos com a sua atenção para preencher o formulário abaixo.

O mesmo tem por objetivo fornecer informações para avaliação da Eficiência, Efetividade e Eficácia da Política Pública de Formação de Agentes de Ater adotada pelo Departamento de Assistência Técnica e Extensão Rural, da Secretaria de Agricultura Familiar do Ministério do Desenvolvimento - DATER/SAF/MDA, no período de 2004 a 2009, tema escolhido para Monografia a ser apresentada à Universidade de Brasília (UnB) como requisito parcial para obtenção do grau de Bacharel em Administração.

Você poderá ou não se identificar no questionário e garantimos que todas as informações fornecidas serão confidenciais e utilizadas apenas de forma sistematizada.

\section{IDENTIFICAÇÃO}

\begin{tabular}{|c|c|}
\hline Nome: MARIA LINDOMAR DIAS MESQUITA & $\begin{array}{l}\text { Sexo: } \\
(\mathrm{x}) \text { masculino }\end{array}$ \\
\hline $\begin{array}{l}\text { Instituição (nome e tipo de instituição: ONG, } \\
\text { Empresa Pública, etc.): } \\
\text { Instituto de Desenvolvimento Agropecuário do } \\
\text { Estado do Amazonas - IDAM }\end{array}$ & $\begin{array}{l}\text { Local de trabalho (Cidade e Estado): } \\
\text { Unidade Local de Beruri - Amazonas }\end{array}$ \\
\hline \multicolumn{2}{|c|}{$\begin{array}{l}\text { Curso/Encontro/Oficina do qual participou (caso tenha participado de mais de um curso, preencha } \\
\text { um formulário para cada um deles): } \\
\text { II Encontro para Socialização dos Conceitos Básicos da Política Nacional de Ater }\end{array}$} \\
\hline $\begin{array}{l}\text { Data do Curso/Encontro/Oficina (pelo menos mês e } \\
04 \text { a } 08 \text { de dezembro de } 2006 \text { - Manaus/AM }\end{array}$ & \\
\hline
\end{tabular}

Indique sua área de atuação? (As opções não são excludentes: você poderá marcar mais de uma opção)

\begin{tabular}{|l|l|}
\hline$X$ & EXTENSÃO RURAL \\
\hline & PESQUISA \\
\hline
\end{tabular}




\begin{tabular}{|l|l|}
\hline & ENSINO \\
\hline & OUTROS \\
\hline
\end{tabular}

2) Qual o seu nível de escolaridade? (Considere apenas o nível mais alto)

\begin{tabular}{|l|l|}
\hline$X$ & NÍVEL MÉDIO \\
\hline & NÍVEL SUPERIOR \\
\hline & PÓS-GRADUAÇÃO \\
\hline
\end{tabular}

3) Os conteúdos abordados foram condizentes com as demandas do seu dia-a-dia?

\begin{tabular}{|l|l|}
\hline$X$ & SIM \\
\hline & PARCIALMENTE \\
\hline & NÃO \\
\hline
\end{tabular}

3) O curso contribuiu para o seu aperfeiçoamento profissional?

\begin{tabular}{|l|l|}
\hline$X$ & SIM \\
\hline & NÃO \\
\hline
\end{tabular}

5) Os conhecimentos adquiridos estão sendo aplicados no seu trabalho? Em caso afirmativo, indique em que grau estes conhecimentos estão sendo aplicados. Em caso negativo, indique por que razão isto não ocorre:

\begin{tabular}{|l|l|l|l|}
\hline \multirow{2}{*}{$\begin{array}{l}\text { SIM (indique ao lado em } \\
\text { que grau) }\end{array}$} & & MUITO APLICADOS \\
\cline { 2 - 4 } & $X$ & MEDIAMENTE APLICADOS \\
\cline { 2 - 4 } & & POUCO APLICADOS \\
\hline
\end{tabular}




\begin{tabular}{|c|c|}
\hline \multirow{5}{*}{$\begin{array}{l}\text { NÃO (indique ao lado a } \\
\text { razão da não aplicação) }\end{array}$} & $\begin{array}{l}\text { CONTEÚDO NÃO ADEQUADO ȦS NECESSIDADES } \\
\text { ESPECÍFICAS DA REGIÃO }\end{array}$ \\
\hline & $\begin{array}{l}\text { CONTEÚDO NÃO FOI SUFICIENTEMENTE } \\
\text { APROFUNDADO PARA } \\
\text { PERMITIR UMA APLICAÇÃO } \\
\text { EFICAZ E EFICIENTE }\end{array}$ \\
\hline & $\begin{array}{l}\text { FALTA DE APOIO } \\
\text { INSTITUIÇÃO }\end{array}$ \\
\hline & FALTA DE INCENTIVO ÀS AÇÕES DE ATER \\
\hline & NÃO TENHO INTERESSE EM APLICAR \\
\hline
\end{tabular}

6) A partir deste curso: (As opções não são excludentes: você poderá marcar mais de uma opção)

\begin{tabular}{|l|l|}
\hline$x$ & $\begin{array}{l}\text { NÃO MUDOU NADA EM MEU TRABALHO. } \\
\text { FAMILIARES. }\end{array}$ \\
\hline & CONSEGUI INFLUENCIAR NAS ORIENTAÇÕES DA MINHA INSTITUIÇÃO. \\
\hline & PASSEI A TRABALHAR COM METODOLOGIAS PARTICIPATIVAS. \\
\hline & $\begin{array}{l}\text { ORESCEU A ÁREA DE AGRICULTURA DE BASE ECOLÓGICA NAS COMUNIDADES } \\
\text { CONTINUEI ME APERFEIÇOANDO SOBRE TEMAS ABORDADOS. }\end{array}$ \\
\hline
\end{tabular}

7) Depois do curso você apoiou atividades de capacitação de técnicos e agricultores com base nos princípios e diretrizes da Pnater? (Considere como apoio a atividades de capacitação a participação no planejamento, elaboração de ementas, seleção de participantes e de palestrantes.)

\begin{tabular}{|l|l|}
\hline$X$ & SIM \\
\hline & NÃO \\
\hline
\end{tabular}


8) Usou os conhecimentos para ministrar outros cursos com o mesmo conteúdo ou conteúdos semelhantes?

\begin{tabular}{|l|l|}
\hline & SIM \\
\hline$X$ & NÃO \\
\hline
\end{tabular}

9) Marque o seu grau de satisfação com relação ao curso oferecido pelo DATER: (Considere a seguinte pontuação: 1 - MUITO RUIM; 2 - RUIM; 3 - REGULAR; 4 - BOM; 5 - MUITO BOM)

\begin{tabular}{|l|l|l|l|l|}
\hline 1 & 2 & 3 & 4 & 5 \\
\hline
\end{tabular}

10) Marque seu grau de satisfação com relação ao DATER: (Considere a seguinte pontuação: 1 - MUITO RUIM; 2 - RUIM; 3 - REGULAR; 4 - BOM; 5 - MUITO BOM)

\begin{tabular}{|l|l|l|l|l|}
\hline 1 & 2 & 3 & 4 & 5 \\
\hline
\end{tabular}


PESQUISA - IMPACTO DAS AÇÕES DE FORMAÇÃO REALIZADAS PELO DATER/SAF/MDA NO PERÍODO 2004-2009

Caros colaboradores,

Contamos com a sua atenção para preencher o formulário abaixo.

O mesmo tem por objetivo fornecer informações para avaliação da Eficiência, Efetividade e Eficácia da Política Pública de Formação de Agentes de Ater adotada pelo Departamento de Assistência Técnica e Extensão Rural, da Secretaria de Agricultura Familiar do Ministério do Desenvolvimento - DATER/SAF/MDA, no período de 2004 a 2009, tema escolhido para Monografia a ser apresentada à Universidade de Brasília (UnB) como requisito parcial para obtenção do grau de Bacharel em Administração.

Você poderá ou não se identificar no questionário e garantimos que todas as informações fornecidas serão confidenciais e utilizadas apenas de forma sistematizada.

\section{IDENTIFICAÇÃO}

\begin{tabular}{|c|c|}
\hline Nome: MARIA ÉRICA LABORDO DA COSTA & $\begin{array}{l}\text { Sexo: } \\
(x) \text { masculino } \quad(\quad) \text { feminino }\end{array}$ \\
\hline $\begin{array}{l}\text { Instituição (nome e tipo de instituição: ONG, } \\
\text { Empresa Pública, etc.): } \\
\text { Instituto de Desenvolvimento Agropecuário do } \\
\text { Estado do Amazonas - IDAM }\end{array}$ & $\begin{array}{l}\text { Local de trabalho (Cidade e Estado): } \\
\text { Unidade Local de Beruri - Amazonas }\end{array}$ \\
\hline \multicolumn{2}{|c|}{$\begin{array}{l}\text { Curso/Encontro/Oficina do qual participou (caso tenha participado de mais de um curso, preencha } \\
\text { um formulário para cada um deles): } \\
\text { II Encontro para Socialização dos Conceitos Básicos da Política Nacional de Ater }\end{array}$} \\
\hline $\begin{array}{l}\text { Data do Curso/Encontro/Oficina (pelo menos mês e a } \\
04 \text { a } 08 \text { de dezembro de } 2006 \text { - Manaus/AM }\end{array}$ & \\
\hline
\end{tabular}

Indique sua área de atuação? (As opções não são excludentes: você poderá marcar mais de uma opção)

\begin{tabular}{|l|l|}
\hline$X$ & EXTENSÃO RURAL \\
\hline & PESQUISA \\
\hline
\end{tabular}




\begin{tabular}{|l|l|}
\hline & ENSINO \\
\hline & OUTROS \\
\hline
\end{tabular}

2) Qual o seu nível de escolaridade? (Considere apenas o nível mais alto)

\begin{tabular}{|l|l|}
\hline$X$ & NÍVEL MÉDIO \\
\hline & NÍVEL SUPERIOR \\
\hline & PÓS-GRADUAÇÃO \\
\hline
\end{tabular}

3) Os conteúdos abordados foram condizentes com as demandas do seu dia-a-dia?

\begin{tabular}{|l|l|}
\hline$X$ & SIM \\
\hline & PARCIALMENTE \\
\hline & NÃO \\
\hline
\end{tabular}

3) O curso contribuiu para o seu aperfeiçoamento profissional?

\begin{tabular}{|l|l|}
\hline$X$ & SIM \\
\hline & NÃO \\
\hline
\end{tabular}

5) Os conhecimentos adquiridos estão sendo aplicados no seu trabalho? Em caso afirmativo, indique em que grau estes conhecimentos estão sendo aplicados. Em caso negativo, indique por que razão isto não ocorre: (Em caso negativo, as respostas não são excludentes: você poderá marcar mais de uma opção).

\begin{tabular}{|l|l|l|}
\hline \multirow{2}{*}{$\begin{array}{l}\text { SIM (indique ao lado em } \\
\text { que grau) }\end{array}$} & $X$ & MUITO APLICADOS \\
\cline { 2 - 4 } & & MEDIAMENTE APLICADOS \\
\cline { 2 - 4 } & & POUCO APLICADOS \\
\hline
\end{tabular}




\begin{tabular}{|c|c|}
\hline \multirow{5}{*}{$\begin{array}{l}\text { NÃO (indique ao lado a } \\
\text { razão da não aplicação) }\end{array}$} & $\begin{array}{l}\text { CONTEÚDO NÃO ADEQUADO ÀS NECESSIDADES } \\
\text { ESPECÍFICAS DA REGIÃO }\end{array}$ \\
\hline & $\begin{array}{l}\text { CONTEÚDO NÃO } \text { FOI SUFICIENTEMENTE } \\
\text { APROFUNDADO PARA } \\
\text { EERMITIR UMA APLICAÇÃO } \\
\text { EFICAZ E EFICIENTE }\end{array}$ \\
\hline & $\begin{array}{llllll}\text { FALTA DE } & \text { APOIO } & \text { E } & \text { INCENTIVO } & \text { DA } & \text { MINHA } \\
\text { INSTITUIÇÃO } & & & & & \\
\end{array}$ \\
\hline & FALTA DE INCENTIVO ÀS AÇÕES DE ATER \\
\hline & NÃO TENHO INTERESSE EM APLICAR \\
\hline
\end{tabular}

6) A partir deste curso: (As opções não são excludentes: você poderá marcar mais de uma opção)

\begin{tabular}{|l|l|}
\hline$x$ & NÃO MUDOU NADA EM MEU TRABALHO. \\
\hline$X$ & $\begin{array}{l}\text { MEU TRABALHO PASSOU A CONTRIBUIR MAIS COM OS AGRICULTORES(AS) } \\
\text { FAMILIARES. }\end{array}$ \\
\hline$X$ & CONSEGUI INFLUENCIAR NAS ORIENTAÇÕES DA MINHA INSTITUIÇÃO. \\
\hline$X$ & $\begin{array}{l}\text { CRESCEU A ÁREA DE AGRICULTURA DE BASE ECOLÓGICA NAS COMUNIDADES } \\
\text { ONDE ATUO. }\end{array}$ \\
\hline & CONTINUEI ME APERFEIÇOANDO SOBRE TEMAS ABORDADOS. \\
\hline
\end{tabular}

7) Depois do curso você apoiou atividades de capacitação de técnicos e agricultores com base nos princípios e diretrizes da Pnater? (Considere como apoio a atividades de capacitação a participação no planejamento, elaboração de ementas, seleção de participantes e de palestrantes.)

\begin{tabular}{|l|l|}
\hline$X$ & SIM \\
\hline & NÃO \\
\hline
\end{tabular}


8) Usou os conhecimentos para ministrar outros cursos com o mesmo conteúdo ou conteúdos semelhantes?

\begin{tabular}{|l|l|}
\hline & SIM \\
\hline$X$ & NÃO \\
\hline
\end{tabular}

9) Marque o seu grau de satisfação com relação ao curso oferecido pelo DATER: (Considere a seguinte pontuação: 1 - MUITO RUIM; 2 - RUIM; 3 - REGULAR; 4 - BOM; 5 - MUITO BOM)

\begin{tabular}{|l|l|l|l|l|}
\hline 1 & 2 & 3 & 4 & 5 \\
\hline
\end{tabular}

10) Marque seu grau de satisfação com relação ao DATER: (Considere a seguinte pontuação: 1 - MUITO RUIM; 2 - RUIM; 3 - REGULAR; 4 - BOM; 5 - MUITO BOM)

\begin{tabular}{|l|l|l|l|l|}
\hline 1 & 2 & 3 & 4 & 5 \\
\hline
\end{tabular}


PESQUISA - IMPACTO DAS AÇÕES DE FORMAÇÃO REALIZADAS PELO DATER/SAF/MDA NO PERÍODO 2004-2009

Caros colaboradores,

Contamos com a sua atenção para preencher o formulário abaixo.

O mesmo tem por objetivo fornecer informações para avaliação da Eficiência, Efetividade e Eficácia da Política Pública de Formação de Agentes de Ater adotada pelo Departamento de Assistência Técnica e Extensão Rural, da Secretaria de Agricultura Familiar do Ministério do Desenvolvimento - DATER/SAF/MDA, no período de 2004 a 2009, tema escolhido para Monografia a ser apresentada à Universidade de Brasília (UnB) como requisito parcial para obtenção do grau de Bacharel em Administração.

Você poderá ou não se identificar no questionário e garantimos que todas as informações fornecidas serão confidenciais e utilizadas apenas de forma sistematizada.

IDENTIFICAÇÃO

\begin{tabular}{|c|c|}
\hline Nome: MARCÍLIO SANTOS DA SILVA & $\begin{array}{l}\text { Sexo: } \\
(x) \text { masculino } \quad(\quad) \text { feminino }\end{array}$ \\
\hline $\begin{array}{l}\text { Instituição (nome e tipo de instituição: ONG, } \\
\text { Empresa Pública, etc.): } \\
\text { Instituto de Desenvolvimento Agropecuário do } \\
\text { Estado do Amazonas - IDAM }\end{array}$ & $\begin{array}{l}\text { Local de trabalho (Cidade e Estado): } \\
\text { Unidade Local de Manaquiri - Amazonas }\end{array}$ \\
\hline \multicolumn{2}{|c|}{$\begin{array}{l}\text { Curso/Encontro/Oficina do qual participou (caso tenha participado de mais de um curso, preencha } \\
\text { um formulário para cada um deles): } \\
\text { II Encontro para Socialização dos Conceitos Básicos da Política Nacional de Ater }\end{array}$} \\
\hline $\begin{array}{l}\text { Data do Curso/Encontro/Oficina (pelo menos mês e a } \\
04 \text { a } 08 \text { de dezembro de } 2006 \text { - Manaus/AM }\end{array}$ & \\
\hline
\end{tabular}

Indique sua área de atuação? (As opções não são excludentes: você poderá marcar mais de uma opção)

\begin{tabular}{|l|l|}
\hline$X$ & EXTENSÃO RURAL \\
\hline & PESQUISA \\
\hline & ENSINO \\
\hline
\end{tabular}




\section{OUTROS}

2) Qual o seu nível de escolaridade? (Considere apenas o nível mais alto)

\begin{tabular}{|l|l|}
\hline$X$ & NÍVEL MÉDIO \\
\hline & NÍVEL SUPERIOR \\
\hline & PÓS-GRADUAÇÃO \\
\hline
\end{tabular}

3) Os conteúdos abordados foram condizentes com as demandas do seu dia-a-dia?

\begin{tabular}{|l|l|}
\hline$X$ & SIM \\
\hline & PARCIALMENTE \\
\hline & NÃO \\
\hline
\end{tabular}

3) O curso contribuiu para o seu aperfeiçoamento profissional?

\begin{tabular}{|l|l|}
\hline$X$ & SIM \\
\hline & NÃO \\
\hline
\end{tabular}

5) Os conhecimentos adquiridos estão sendo aplicados no seu trabalho? Em caso afirmativo, indique em que grau estes conhecimentos estão sendo aplicados. Em caso negativo, indique por que razão isto não ocorre: (Em caso negativo, as respostas não são excludentes: você poderá marcar mais de uma opção).

\begin{tabular}{|l|l|l|l|}
\hline \multirow{2}{*}{$\begin{array}{l}\text { SIM (indique ao lado em } \\
\text { que grau) }\end{array}$} & & MUITO APLICADOS \\
\cline { 2 - 3 } & $\begin{array}{l}\text { NÃO (indique ao lado a } \\
\text { razão da não aplicação) }\end{array}$ & MEDIAMENTE APLICADOS \\
\hline & $\begin{array}{l}\text { CONTEÚDO NÃO ADEQUADO ȦS NECESSIDADES } \\
\text { ESPECÍFICAS DA REGIÃO }\end{array}$ \\
\hline
\end{tabular}




\begin{tabular}{|l|l|l|}
\hline \multirow{10}{*}{} & $\begin{array}{l}\text { CONTEÚDO NÃO FOI SUFICIENTEMENTE } \\
\text { APROFUNDADO PARA PERMITIR UMA APLICAÇÃO } \\
\text { EFICAZ E EFICIENTE }\end{array}$ \\
\cline { 2 - 4 } & $\begin{array}{l}\text { FALTA DE APOIO E INCENTIVO DA MINHA } \\
\text { INSTITUIÇÃO }\end{array}$ \\
\cline { 2 - 4 } & FALTA DE INCENTIVO ÀS AÇÕES DE ATER \\
\hline & NÃO TENHO INTERESSE EM APLICAR \\
\hline
\end{tabular}

6) A partir deste curso: (As opções não são excludentes: você poderá marcar mais de uma opção)

\begin{tabular}{|l|l|}
\hline$x$ & $\begin{array}{l}\text { NÃO MUDOU NADA EM MEU TRABALHO. } \\
\text { FAMILIARES. }\end{array}$ \\
\hline & CONSEGUI INFLUENCIAR NAS ORIENTAÇÕES DA MINHA INSTITUIÇÃO. \\
\hline & PASSEI A TRABALHAR COM METODOLOGIAS PARTICIPATIVAS. \\
\hline & $\begin{array}{l}\text { CRESCEU A ÁREA DE AGRICULTURA DE BASE ECOLÓGICA NAS COMUNIDADES } \\
\text { ONDE ATUO. }\end{array}$ \\
\hline & CONTINUEI ME APERFEIÇOANDO SOBRE TEMAS ABORDADOS. \\
\hline
\end{tabular}

7) Depois do curso você apoiou atividades de capacitação de técnicos e agricultores com base nos princípios e diretrizes da Pnater? (Considere como apoio a atividades de capacitação a participação no planejamento, elaboração de ementas, seleção de participantes e de palestrantes.)

\begin{tabular}{|l|l|}
\hline & SIM \\
\hline$X$ & NÃO \\
\hline
\end{tabular}

8) Usou os conhecimentos para ministrar outros cursos com o mesmo conteúdo ou conteúdos semelhantes? 


\begin{tabular}{|l|l|}
\hline & SIM \\
\hline$X$ & NÃO \\
\hline
\end{tabular}

9) Marque o seu grau de satisfação com relação ao curso oferecido pelo DATER: (Considere a seguinte pontuação: 1 - MUITO RUIM; 2 - RUIM; 3 - REGULAR; 4 - BOM; 5 - MUITO BOM)

\begin{tabular}{|l|l|l|l|l|}
\hline 1 & 2 & 3 & 4 & 5 \\
\hline
\end{tabular}

10) Marque seu grau de satisfação com relação ao DATER: (Considere a seguinte pontuação: 1 - MUITO RUIM; 2 - RUIM; 3 - REGULAR; 4 - BOM; 5 - MUITO BOM)

\begin{tabular}{|l|l|l|l|l|}
\hline 1 & 2 & 3 & 4 & 5 \\
\hline
\end{tabular}


PESQUISA - IMPACTO DAS AÇÕES DE FORMAÇÃO REALIZADAS PELO DATER/SAF/MDA NO PERÍODO 2004-2009

Caros colaboradores,

Contamos com a sua atenção para preencher o formulário abaixo.

O mesmo tem por objetivo fornecer informações para avaliação da Eficiência, Efetividade e Eficácia da Política Pública de Formação de Agentes de Ater adotada pelo Departamento de Assistência Técnica e Extensão Rural, da Secretaria de Agricultura Familiar do Ministério do Desenvolvimento - DATER/SAF/MDA, no período de 2004 a 2009, tema escolhido para Monografia a ser apresentada à Universidade de Brasília (UnB) como requisito parcial para obtenção do grau de Bacharel em Administração.

Você poderá ou não se identificar no questionário e garantimos que todas as informações fornecidas serão confidenciais e utilizadas apenas de forma sistematizada.

\section{IDENTIFICAÇÃO}

\begin{tabular}{|c|c|}
\hline Nome: MARCELO FRANÇA GADELHA & $\begin{array}{l}\text { Sexo: } \\
(x) \text { masculino } \quad(\quad) \text { feminino }\end{array}$ \\
\hline $\begin{array}{l}\text { Instituição (nome e tipo de instituição: ONG, } \\
\text { Empresa Pública, etc.): } \\
\text { Instituto de Desenvolvimento Agropecuário do } \\
\text { Estado do Amazonas - IDAM }\end{array}$ & $\begin{array}{l}\text { Local de trabalho (Cidade e Estado): } \\
\text { Unidade Local de Itacoatiara - Amazonas }\end{array}$ \\
\hline \multicolumn{2}{|c|}{$\begin{array}{l}\text { Curso/Encontro/Oficina do qual participou (caso tenha participado de mais de um curso, preencha } \\
\text { um formulário para cada um deles): } \\
\text { Seminário - Agroecologia como Estratégia para a Construção do Desenvolvimento Rural } \\
\text { Sustentável }\end{array}$} \\
\hline $\begin{array}{l}\text { Data do Curso/Encontro/Oficina (pelo menos mês e a } \\
10 \text { e } 11 \text { de agosto de } 2006 \text { - Manaus/AM }\end{array}$ & \\
\hline
\end{tabular}

Indique sua área de atuação? (As opções não são excludentes: você poderá marcar mais de uma opção) 


\begin{tabular}{|l|l|}
\hline$X$ & EXTENSÃO RURAL \\
\hline & PESQUISA \\
\hline & ENSINO \\
\hline & OUTROS \\
\hline
\end{tabular}

2) Qual o seu nível de escolaridade? (Considere apenas o nível mais alto)

\begin{tabular}{|l|l|}
\hline$X$ & NÍVEL MÉDIO \\
\hline & NÍVEL SUPERIOR \\
\hline & PÓS-GRADUAÇÃO \\
\hline
\end{tabular}

3) Os conteúdos abordados foram condizentes com as demandas do seu dia-a-dia?

\begin{tabular}{|l|l|}
\hline & SIM \\
\hline$X$ & PARCIALMENTE \\
\hline & NÃO \\
\hline
\end{tabular}

3) O curso contribuiu para o seu aperfeiçoamento profissional?

\begin{tabular}{|l|l|}
\hline$X$ & SIM \\
\hline & NÃO \\
\hline
\end{tabular}

5) Os conhecimentos adquiridos estão sendo aplicados no seu trabalho? Em caso afirmativo, indique em que grau estes conhecimentos estão sendo aplicados. Em caso negativo, indique por que razão isto não ocorre: (Em caso negativo, as respostas não são excludentes: você poderá marcar mais de uma opção). 


\begin{tabular}{|c|c|c|}
\hline \multirow[t]{2}{*}{ que grau) } & $\bar{x}$ & MEDIAMENTE APLICADOS \\
\hline & & POUCO APLICADOS \\
\hline \multirow{5}{*}{$\begin{array}{l}\text { NÃO (indique ao lado a } \\
\text { razão da não aplicação) }\end{array}$} & & $\begin{array}{l}\text { CONTEÚDO NÃO ADEQUADO ÀS NECESSIDADES } \\
\text { ESPECÍFICAS DA REGIÃO }\end{array}$ \\
\hline & & $\begin{array}{l}\text { CONTEÚDO NÃO } \text { FOI SUFICIENTEMENTE } \\
\text { APROFUNDADO PARA } \\
\text { EERMITIR UMA APLICAÇÃO } \\
\text { EFICAZ E EFICIENTE }\end{array}$ \\
\hline & & \begin{tabular}{|llllll} 
FALTA DE & APOIO & E & INCENTIVO & DA & MINHA \\
INSTITUIÇÃO & & & & &
\end{tabular} \\
\hline & & FALTA DE INCENTIVO ÀS AÇÕES DE ATER \\
\hline & & NÃO TENHO INTERESSE EM APLICAR \\
\hline
\end{tabular}

6) A partir deste curso: (As opções não são excludentes: você poderá marcar mais de uma opção)

\begin{tabular}{|l|l|}
\hline$x$ & $\begin{array}{l}\text { NÃO MUDOU NADA EM MEU TRABALHO. } \\
\text { FAMILIARES. }\end{array}$ \\
\hline & CONSEGUI INFLUENCIAR NAS ORIENTAÇÕES DA MINHA INSTITUIÇÃO. \\
\hline & PASSEI A TRABALHAR COM METODOLOGIAS PARTICIPATIVAS. \\
\hline & $\begin{array}{l}\text { CRESCEU A ÁREA DE AGRICULTURA DE BASE ECOLÓGICA NAS COMUNIDADES } \\
\text { ONDE ATUO. }\end{array}$ \\
\hline & CONTINUEI ME APERFEIÇOANDO SOBRE TEMAS ABORDADOS. \\
\hline
\end{tabular}

7) Depois do curso você apoiou atividades de capacitação de técnicos e agricultores com base nos princípios e diretrizes da Pnater? (Considere como apoio a atividades de capacitação a participação no planejamento, elaboração de ementas, seleção de participantes e de palestrantes.) 


\begin{tabular}{|l|l|}
\hline$X$ & SIM \\
\hline & NÃO \\
\hline
\end{tabular}

8) Usou os conhecimentos para ministrar outros cursos com o mesmo conteúdo ou conteúdos semelhantes?

\begin{tabular}{|l|l|}
\hline & SIM \\
\hline$X$ & NÃO \\
\hline
\end{tabular}

9) Marque o seu grau de satisfação com relação ao curso oferecido pelo DATER: (Considere a seguinte pontuação: 1 - MUITO RUIM; 2 - RUIM; 3 - REGULAR; 4 - BOM; 5 - MUITO BOM)

\begin{tabular}{|l|l|l|l|l|}
\hline 1 & 2 & 3 & 4 & 5 \\
\hline
\end{tabular}

10) Marque seu grau de satisfação com relação ao DATER: (Considere a seguinte pontuação: 1 - MUITO RUIM; 2 - RUIM; 3 - REGULAR; 4 - BOM; 5 - MUITO BOM)

\begin{tabular}{|l|l|l|l|l|}
\hline 1 & 2 & 3 & 4 & 5 \\
\hline
\end{tabular}


PESQUISA - IMPACTO DAS AÇÕES DE FORMAÇÃO REALIZADAS PELO DATER/SAF/MDA NO PERÍODO 2004-2009

Caros colaboradores,

Contamos com a sua atenção para preencher o formulário abaixo.

O mesmo tem por objetivo fornecer informações para avaliação da Eficiência, Efetividade e Eficácia da Política Pública de Formação de Agentes de Ater adotada pelo Departamento de Assistência Técnica e Extensão Rural, da Secretaria de Agricultura Familiar do Ministério do Desenvolvimento - DATER/SAF/MDA, no período de 2004 a 2009, tema escolhido para Monografia a ser apresentada à Universidade de Brasília (UnB) como requisito parcial para obtenção do grau de Bacharel em Administração.

Você poderá ou não se identificar no questionário e garantimos que todas as informações fornecidas serão confidenciais e utilizadas apenas de forma sistematizada.

\section{IDENTIFICAÇÃO}

\begin{tabular}{|c|c|}
\hline Nome: MANOEL PEDRO BRAGA PAES & $\begin{array}{l}\text { Sexo: } \\
(\mathrm{x}) \text { masculino }\end{array}$ \\
\hline $\begin{array}{l}\text { Instituição (nome e tipo de instituição: ONG, } \\
\text { Empresa Pública, etc.): } \\
\text { Instituto de Desenvolvimento Agropecuário do } \\
\text { Estado do Amazonas - IDAM }\end{array}$ & $\begin{array}{l}\text { Local de trabalho (Cidade e Estado): } \\
\text { Unidade Local de Urucará - Amazonas }\end{array}$ \\
\hline \multicolumn{2}{|c|}{$\begin{array}{l}\text { Curso/Encontro/Oficina do qual participou (caso tenha participado de mais de um curso, preencha } \\
\text { um formulário para cada um deles): } \\
\text { II Encontro para Socialização dos Conceitos Básicos da Política Nacional de Ater }\end{array}$} \\
\hline $\begin{array}{l}\text { Data do Curso/Encontro/Oficina (pelo menos mês } \\
04 \text { a } 08 \text { de dezembro de } 2006 \text { - Manaus/AM }\end{array}$ & \\
\hline
\end{tabular}

Indique sua área de atuação? (As opções não são excludentes: você poderá marcar mais de uma opção

\begin{tabular}{|l|l|}
\hline$X$ & EXTENSÃO RURAL \\
\hline & PESQUISA \\
\hline & ENSINO \\
\hline
\end{tabular}




\begin{tabular}{|l|l|}
\hline & OUTROS \\
\hline
\end{tabular}

2) Qual o seu nível de escolaridade? (Considere apenas o nível mais alto)

\begin{tabular}{|l|l|}
\hline$X$ & NÍVEL MÉDIO \\
\hline & NÍVEL SUPERIOR \\
\hline & PÓS-GRADUAÇÃO \\
\hline
\end{tabular}

3) Os conteúdos abordados foram condizentes com as demandas do seu dia-a-dia?

\begin{tabular}{|l|l|}
\hline$X$ & SIM \\
\hline & PARCIALMENTE \\
\hline & NÃO \\
\hline
\end{tabular}

3) O curso contribuiu para o seu aperfeiçoamento profissional?

\begin{tabular}{|l|l|}
\hline$X$ & SIM \\
\hline & NÃO \\
\hline
\end{tabular}

5) Os conhecimentos adquiridos estão sendo aplicados no seu trabalho? Em caso afirmativo, indique em que grau estes conhecimentos estão sendo aplicados. Em caso negativo, indique por que razão isto não ocorre: (Em caso negativo, as respostas não são excludentes: você poderá marcar mais de uma opção).

\begin{tabular}{|l|l|l|l|}
\hline \multirow{2}{*}{$\begin{array}{l}\text { SIM (indique ao lado em } \\
\text { que grau) }\end{array}$} & & MUITO APLICADOS \\
\cline { 3 - 4 } & $X$ & MEDIAMENTE APLICADOS \\
\hline & $\begin{array}{l}\text { NÃO (indique ao lado a } \\
\text { razão da não aplicação) }\end{array}$ & $\begin{array}{l}\text { CONTEÚDO NÃO ADEQUADO ȦS NECESSIDADES } \\
\text { ESPECÍFICAS DA REGIÃO }\end{array}$ \\
\hline
\end{tabular}




\begin{tabular}{|l|l|l|l|}
\hline \multirow{3}{*}{} & & $\begin{array}{l}\text { CONTEÚDO NÃO FOI SUFICIENTEMENTE } \\
\text { APROFUNDADO PARA PERMITIR UMA APLICAÇÃO } \\
\text { EFICAZ E EFICIENTE }\end{array}$ \\
\cline { 2 - 5 } & $\begin{array}{l}\text { FALTA DE APOIO E INCENTIVO DA MINHA } \\
\text { INSTITUIÇÃO }\end{array}$ \\
\cline { 2 - 5 } & FALTA DE INCENTIVO ÀS AÇÕES DE ATER \\
\cline { 2 - 4 } & NÃO TENHO INTERESSE EM APLICAR \\
\hline
\end{tabular}

6) A partir deste curso: (As opções não são excludentes: você poderá marcar mais de uma opção)

\begin{tabular}{|l|l|}
\hline & NÃO MUDOU NADA EM MEU TRABALHO. \\
\hline$X$ & $\begin{array}{l}\text { MEU TRABALHO PASSOU A CONTRIBUIR MAIS COM OS AGRICULTORES(AS) } \\
\text { FAMILIARES. }\end{array}$ \\
\hline & CONSEGUI INFLUENCIAR NAS ORIENTAÇÕES DA MINHA INSTITUIÇÃO. \\
\hline & $\begin{array}{l}\text { CRESCEI A TRABALHAR COM METODOLOGIAS PARTICIPATIVAS. } \\
\text { ONDE ATUO. ÁREA DE AGRICULTURA DE BASE ECOLÓGICA NAS COMUNIDADES }\end{array}$ \\
\hline & CONTINUEI ME APERFEIÇOANDO SOBRE TEMAS ABORDADOS. \\
\hline
\end{tabular}

7) Depois do curso você apoiou atividades de capacitação de técnicos e agricultores com base nos princípios e diretrizes da Pnater? (Considere como apoio a atividades de capacitação a participação no planejamento, elaboração de ementas, seleção de participantes e de palestrantes.)

\begin{tabular}{|l|l|}
\hline$X$ & SIM \\
\hline & NÃO \\
\hline
\end{tabular}

8) Usou os conhecimentos para ministrar outros cursos com o mesmo conteúdo ou conteúdos semelhantes? 


\begin{tabular}{|l|l|}
\hline & SIM \\
\hline$X$ & NÃO \\
\hline
\end{tabular}

9) Marque o seu grau de satisfação com relação ao curso oferecido pelo DATER: (Considere a seguinte pontuação: 1 - MUITO RUIM; 2 - RUIM; 3 - REGULAR; 4 - BOM; 5 - MUITO BOM)

\begin{tabular}{|l|l|l|l|l|}
\hline 1 & 2 & 3 & 4 & 5 \\
\hline
\end{tabular}

10) Marque seu grau de satisfação com relação ao DATER: (Considere a seguinte pontuação: 1 - MUITO RUIM; 2 - RUIM; 3 - REGULAR; 4 - BOM; 5 - MUITO BOM)

\begin{tabular}{|l|l|l|l|l|}
\hline 1 & 2 & 3 & 4 & 5 \\
\hline
\end{tabular}


PESQUISA - IMPACTO DAS AÇÕES DE FORMAÇÃO REALIZADAS PELO DATER/SAF/MDA NO PERÍODO 2004-2009

Caros colaboradores,

Contamos com a sua atenção para preencher o formulário abaixo.

O mesmo tem por objetivo fornecer informações para avaliação da Eficiência, Efetividade e Eficácia da Política Pública de Formação de Agentes de Ater adotada pelo Departamento de Assistência Técnica e Extensão Rural, da Secretaria de Agricultura Familiar do Ministério do Desenvolvimento - DATER/SAF/MDA, no período de 2004 a 2009, tema escolhido para Monografia a ser apresentada à Universidade de Brasília (UnB) como requisito parcial para obtenção do grau de Bacharel em Administração.

Você poderá ou não se identificar no questionário e garantimos que todas as informações fornecidas serão confidenciais e utilizadas apenas de forma sistematizada.

\section{IDENTIFICAÇÃO}

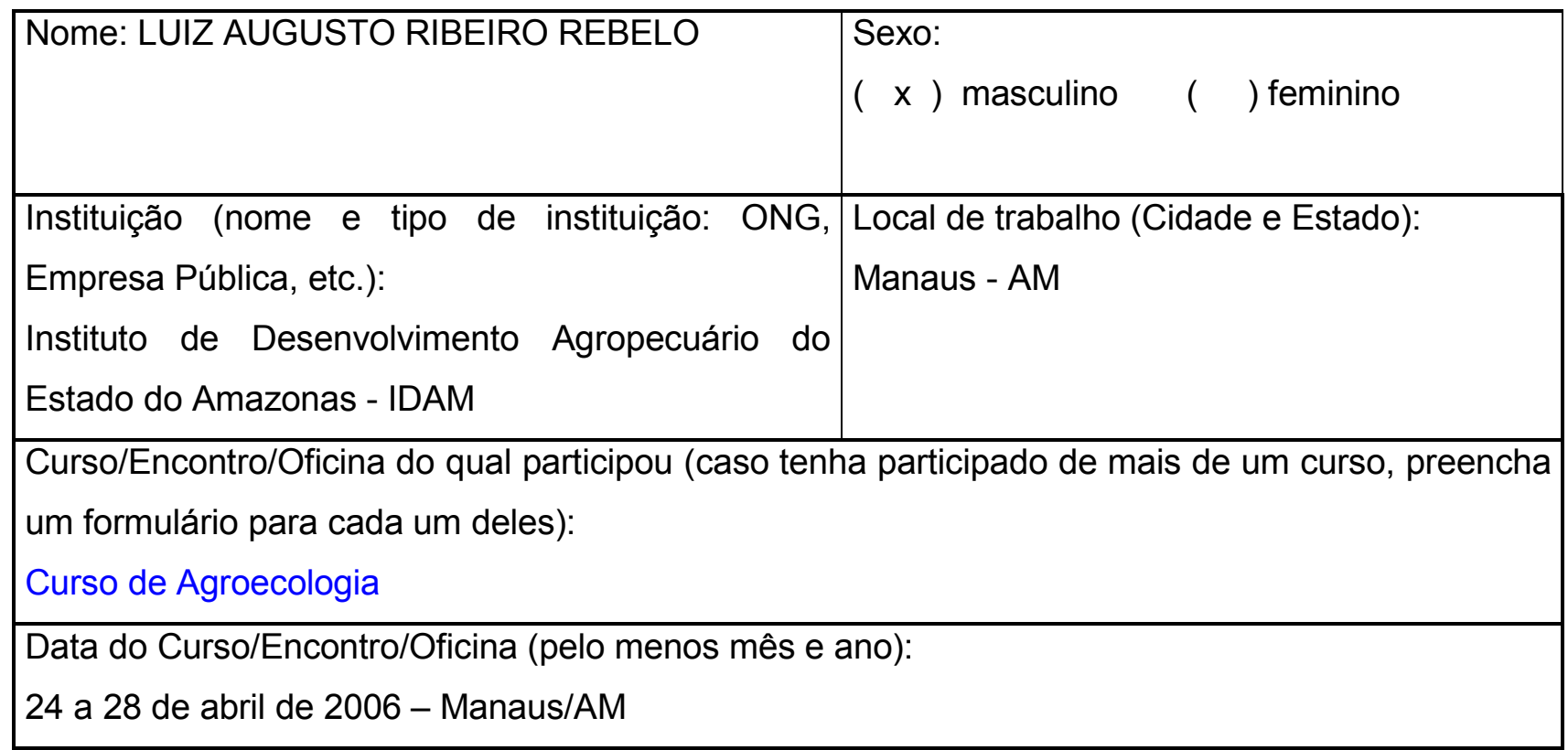

Indique sua área de atuação? (As opções não são excludentes: você poderá marcar mais de uma opção)

\begin{tabular}{|l|l|}
\hline$X$ & EXTENSÃO RURAL \\
\hline & PESQUISA \\
\hline & ENSINO \\
\hline
\end{tabular}




\begin{tabular}{|l|l|}
\hline & OUTROS \\
\hline
\end{tabular}

2) Qual o seu nível de escolaridade? (Considere apenas o nível mais alto)

\begin{tabular}{|l|l|}
\hline & NÍVEL MÉDIO \\
\hline$X$ & NÍVEL SUPERIOR \\
\hline & PÓS-GRADUAÇÃO \\
\hline
\end{tabular}

3) Os conteúdos abordados foram condizentes com as demandas do seu dia-a-dia?

\begin{tabular}{|l|l|}
\hline$X$ & SIM \\
\hline & PARCIALMENTE \\
\hline & NÃO \\
\hline
\end{tabular}

3) O curso contribuiu para o seu aperfeiçoamento profissional?

\begin{tabular}{|l|l|}
\hline$X$ & SIM \\
\hline & NÃO \\
\hline
\end{tabular}

5) Os conhecimentos adquiridos estão sendo aplicados no seu trabalho? Em caso afirmativo, indique em que grau estes conhecimentos estão sendo aplicados. Em caso negativo, indique por que razão isto não ocorre: (Em caso negativo, as respostas não são excludentes: você poderá marcar mais de uma opção).

\begin{tabular}{|c|c|c|}
\hline \multirow{3}{*}{$\begin{array}{l}\text { SIM (indique ao lado em } \\
\text { que grau) }\end{array}$} & & MUITO APLICADOS \\
\hline & $\bar{X}$ & MEDIAMENTE APLICADOS \\
\hline & & POUCO APLICADOS \\
\hline \begin{tabular}{|l|} 
NÃO (indique ao lado a \\
razão da não aplicação)
\end{tabular} & & $\begin{array}{l}\text { CONTEÚDO NÃO ADEQUADO ÀS NECESSIDADES } \\
\text { ESPECÍFICAS DA REGIÃO }\end{array}$ \\
\hline
\end{tabular}




\begin{tabular}{|l|l|l|l|}
\hline \multirow{3}{*}{} & & $\begin{array}{l}\text { CONTEÚDO NÃO FOI SUFICIENTEMENTE } \\
\text { APROFUNDADO PARA PERMITIR UMA APLICAÇÃO } \\
\text { EFICAZ E EFICIENTE }\end{array}$ \\
\cline { 2 - 5 } & $\begin{array}{l}\text { FALTA DE APOIO E INCENTIVO DA MINHA } \\
\text { INSTITUIÇÃO }\end{array}$ \\
\cline { 2 - 5 } & FALTA DE INCENTIVO ÀS AÇÕES DE ATER \\
\cline { 2 - 4 } & NÃO TENHO INTERESSE EM APLICAR \\
\hline
\end{tabular}

6) A partir deste curso: (As opções não são excludentes: você poderá marcar mais de uma opção)

\begin{tabular}{|l|l|}
\hline & NÃO MUDOU NADA EM MEU TRABALHO. \\
\hline & $\begin{array}{l}\text { MEU TRABALHO PASSOU A CONTRIBUIR MAIS COM OS AGRICULTORES(AS) } \\
\text { FAMILIARES. }\end{array}$ \\
\hline$X$ & CONSEGUI INFLUENCIAR NAS ORIENTAÇÕES DA MINHA INSTITUIÇÃO. \\
\hline & $\begin{array}{l}\text { CASSEI A TRABALHAR COM METODOLOGIAS PARTICIPATIVAS. } \\
\text { ONDE ATUO. }\end{array}$ \\
\hline & CONTINUEI ME APERFEIÇOANDO SOBRE TEMAS ABORDADOS. \\
\hline
\end{tabular}

7) Depois do curso você apoiou atividades de capacitação de técnicos e agricultores com base nos princípios e diretrizes da Pnater? (Considere como apoio a atividades de capacitação a participação no planejamento, elaboração de ementas, seleção de participantes e de palestrantes.)

\begin{tabular}{|l|l|}
\hline$X$ & SIM \\
\hline & NÃO \\
\hline
\end{tabular}

8) Usou os conhecimentos para ministrar outros cursos com o mesmo conteúdo ou conteúdos semelhantes? 


\begin{tabular}{|l|l|}
\hline & SIM \\
\hline$X$ & NÃO \\
\hline
\end{tabular}

9) Marque o seu grau de satisfação com relação ao curso oferecido pelo DATER: (Considere a seguinte pontuação: 1 - MUITO RUIM; 2 - RUIM; 3 - REGULAR; 4 - BOM; 5 - MUITO BOM)

\begin{tabular}{|l|l|l|l|l|}
\hline 1 & 2 & 3 & 4 & 5 \\
\hline
\end{tabular}

10) Marque seu grau de satisfação com relação ao DATER: (Considere a seguinte pontuação: 1 - MUITO RUIM; 2 - RUIM; 3 - REGULAR; 4 - BOM; 5 - MUITO BOM)

\begin{tabular}{|l|l|l|l|l|}
\hline 1 & 2 & 3 & 4 & 5 \\
\hline
\end{tabular}


PESQUISA - IMPACTO DAS AÇÕES DE FORMAÇÃO REALIZADAS PELO DATER/SAF/MDA NO PERÍODO 2004-2009

Caros colaboradores,

Contamos com a sua atenção para preencher o formulário abaixo.

O mesmo tem por objetivo fornecer informações para avaliação da Eficiência, Efetividade e Eficácia da Política Pública de Formação de Agentes de Ater adotada pelo Departamento de Assistência Técnica e Extensão Rural, da Secretaria de Agricultura Familiar do Ministério do Desenvolvimento - DATER/SAF/MDA, no período de 2004 a 2009, tema escolhido para Monografia a ser apresentada à Universidade de Brasília (UnB) como requisito parcial para obtenção do grau de Bacharel em Administração.

Você poderá ou não se identificar no questionário e garantimos que todas as informações fornecidas serão confidenciais e utilizadas apenas de forma sistematizada.

\section{IDENTIFICAÇÃO}

\begin{tabular}{|c|c|}
\hline Nome: JOSÉ DE OLIVEIRA RIBEIRO & $\begin{array}{l}\text { Sexo: } \\
(x) \text { masculino } \quad(\quad) \text { feminino }\end{array}$ \\
\hline $\begin{array}{l}\text { Instituição (nome e tipo de } \\
\text { Empresa Públituição: ONG, } \\
\text { Desenvolvimento Agropecuário do Estado do } \\
\text { Amazonas - IDAM }\end{array}$ & $\begin{array}{l}\text { Local de trabalho (Cidade e Estado): } \\
\text { Manaus - AM }\end{array}$ \\
\hline \multicolumn{2}{|c|}{$\begin{array}{l}\text { Curso/Encontro/Oficina do qual participou (caso tenha participado de mais de um curso, preencha } \\
\text { um formulário para cada um deles): } \\
\text { Curso de Agroecologia }\end{array}$} \\
\hline $\begin{array}{l}\text { Data do Curso/Encontro/Oficina (pelo menos mês } \\
24 \text { a } 28 \text { de abril de } 2006 \text { - Manaus/AM }\end{array}$ & \\
\hline
\end{tabular}

Indique sua área de atuação? (As opções não são excludentes: você poderá marcar mais de uma opção)

\begin{tabular}{|l|l|}
\hline$X$ & EXTENSÃO RURAL \\
\hline & PESQUISA \\
\hline
\end{tabular}




\begin{tabular}{|l|l|}
\hline & ENSINO \\
\hline & OUTROS \\
\hline
\end{tabular}

2) Qual o seu nível de escolaridade? (Considere apenas o nível mais alto)

\begin{tabular}{|l|l|}
\hline & NÍVEL MÉDIO \\
\hline$X$ & NÍVEL SUPERIOR \\
\hline & PÓS-GRADUAÇÃO \\
\hline
\end{tabular}

3) Os conteúdos abordados foram condizentes com as demandas do seu dia-a-dia?

\begin{tabular}{|l|l|}
\hline$X$ & SIM \\
\hline & PARCIALMENTE \\
\hline & NÃO \\
\hline
\end{tabular}

3) O curso contribuiu para o seu aperfeiçoamento profissional?

\begin{tabular}{|l|l|}
\hline$X$ & SIM \\
\hline & NÃO \\
\hline
\end{tabular}

5) Os conhecimentos adquiridos estão sendo aplicados no seu trabalho? Em caso afirmativo, indique em que grau estes conhecimentos estão sendo aplicados. Em caso negativo, indique por que razão isto não ocorre: (Em caso negativo, as respostas não são excludentes: você poderá marcar mais de uma opção).

\begin{tabular}{|l|l|l|}
\hline \multirow{2}{*}{$\begin{array}{l}\text { SIM (indique ao lado em } \\
\text { que grau) }\end{array}$} & $X$ & MUITO APLICADOS \\
\cline { 2 - 3 } & & MEDIAMENTE APLICADOS \\
\cline { 2 - 4 } & & POUCO APLICADOS \\
\hline
\end{tabular}




\begin{tabular}{|c|c|}
\hline \multirow{5}{*}{$\begin{array}{l}\text { NÃO (indique ao lado a } \\
\text { razão da não aplicação) }\end{array}$} & $\begin{array}{l}\text { CONTEÚDO NÃO ADEQUADO ÀS NECESSIDADES } \\
\text { ESPECÍFICAS DA REGIÃO }\end{array}$ \\
\hline & $\begin{array}{l}\text { CONTEÚDO NÃO } \text { FOI SUFICIENTEMENTE } \\
\text { APROFUNDADO PARA } \\
\text { PERMITIR UMA APLICAÇÃO } \\
\text { EFICAZ E EFICIENTE }\end{array}$ \\
\hline & $\begin{array}{lllllll}\text { FALTA DE } & \text { APOIO } & \text { E } & \text { INCENTIVO } & \text { DA } & \text { MINHA } \\
\text { INSTITUIÇÃO } & & & & & \end{array}$ \\
\hline & FALTA DE INCENTIVO ÀS AÇÕES DE ATER \\
\hline & NÃO TENHO INTERESSE EM APLICAR \\
\hline
\end{tabular}

6) A partir deste curso: (As opções não são excludentes: você poderá marcar mais de uma opção)

\begin{tabular}{|l|l|}
\hline & NÃO MUDOU NADA EM MEU TRABALHO. \\
\hline & $\begin{array}{l}\text { MEU TRABALHO PASSOU A CONTRIBUIR MAIS COM OS AGRICULTORES(AS) } \\
\text { FAMILIARES. }\end{array}$ \\
\hline$X$ & CONSEGUI INFLUENCIAR NAS ORIENTAÇÕES DA MINHA INSTITUIÇÃO. \\
\hline & $\begin{array}{l}\text { PASSEI A TRABALHAR COM METODOLOGIAS PARTICIPATIVAS. } \\
\text { ONDE ATUO. }\end{array}$ \\
\hline & CONTINUEI ME APERFEIÇOANDO SOBRE TEMAS ABORDADOS. \\
\hline
\end{tabular}

7) Depois do curso você apoiou atividades de capacitação de técnicos e agricultores com base nos princípios e diretrizes da Pnater? (Considere como apoio a atividades de capacitação a participação no planejamento, elaboração de ementas, seleção de participantes e de palestrantes.)

\begin{tabular}{|l|l|}
\hline & SIM \\
\hline$X$ & NÃO \\
\hline
\end{tabular}


8) Usou os conhecimentos para ministrar outros cursos com o mesmo conteúdo ou conteúdos semelhantes?

\begin{tabular}{|l|l|}
\hline & SIM \\
\hline$X$ & NÃO \\
\hline
\end{tabular}

9) Marque o seu grau de satisfação com relação ao curso oferecido pelo DATER: (Considere a seguinte pontuação: 1 - MUITO RUIM; 2 - RUIM; 3 - REGULAR; 4 - BOM; 5 - MUITO BOM)

\begin{tabular}{|l|l|l|l|l|}
\hline 1 & 2 & 3 & 4 & 5 \\
\hline
\end{tabular}

10) Marque seu grau de satisfação com relação ao DATER: (Considere a seguinte pontuação: 1 - MUITO RUIM; 2 - RUIM; 3 - REGULAR; 4 - BOM; 5 - MUITO BOM)

\begin{tabular}{|l|l|l|l|l|}
\hline 1 & 2 & 3 & 4 & 5 \\
\hline
\end{tabular}


PESQUISA - IMPACTO DAS AÇÕES DE FORMAÇÃO REALIZADAS PELO DATER/SAF/MDA NO PERÍODO 2004-2009

Caros colaboradores,

Contamos com a sua atenção para preencher o formulário abaixo.

O mesmo tem por objetivo fornecer informações para avaliação da Eficiência, Efetividade e Eficácia da Política Pública de Formação de Agentes de Ater adotada pelo Departamento de Assistência Técnica e Extensão Rural, da Secretaria de Agricultura Familiar do Ministério do Desenvolvimento - DATER/SAF/MDA, no período de 2004 a 2009, tema escolhido para Monografia a ser apresentada à Universidade de Brasília (UnB) como requisito parcial para obtenção do grau de Bacharel em Administração.

Você poderá ou não se identificar no questionário e garantimos que todas as informações fornecidas serão confidenciais e utilizadas apenas de forma sistematizada.

\section{IDENTIFICAÇÃO}

\begin{tabular}{|c|c|}
\hline Nome: JOSÉ DE OLIVEIRA RIBEIRO & $\begin{array}{l}\text { Sexo: } \\
(x) \text { masculino } \quad(\quad) \text { feminino }\end{array}$ \\
\hline $\begin{array}{l}\text { Instituição (nome e tipo de instituição: ONG, } \\
\text { Empresa Pública, etc.): } \\
\text { Instituto de Desenvolvimento Agropecuário do } \\
\text { Estado do Amazonas - IDAM. }\end{array}$ & $\begin{array}{l}\text { Local de trabalho (Cidade e Estado): } \\
\text { Manaus - AM }\end{array}$ \\
\hline \multicolumn{2}{|c|}{$\begin{array}{l}\text { Curso/Encontro/Oficina do qual participou (caso tenha participado de mais de um curso, preencha } \\
\text { um formulário para cada um deles): } \\
\text { Seminário - Agroecologia como Estratégia para a Construção do Desenvolvimento Rural } \\
\text { Sustentável }\end{array}$} \\
\hline $\begin{array}{l}\text { Data do Curso/Encontro/Oficina (pelo menos mês e } \\
10 \text { e } 11 \text { de agosto de } 2006 \text { - Manaus/AM }\end{array}$ & \\
\hline
\end{tabular}

Indique sua área de atuação? (As opções não são excludentes: você poderá marcar mais de uma opção) 


\begin{tabular}{|l|l|}
\hline$X$ & EXTENSÃO RURAL \\
\hline & PESQUISA \\
\hline & ENSINO \\
\hline & OUTROS \\
\hline
\end{tabular}

2) Qual o seu nível de escolaridade? (Considere apenas o nível mais alto)

\begin{tabular}{|l|l|}
\hline & NÍVEL MÉDIO \\
\hline$X$ & NÍVEL SUPERIOR \\
\hline & PÓS-GRADUAÇÃO \\
\hline
\end{tabular}

3) Os conteúdos abordados foram condizentes com as demandas do seu dia-a-dia?

\begin{tabular}{|l|l|}
\hline$X$ & SIM \\
\hline & PARCIALMENTE \\
\hline & NÃO \\
\hline
\end{tabular}

3) O curso contribuiu para o seu aperfeiçoamento profissional?

\begin{tabular}{|l|l|}
\hline$X$ & SIM \\
\hline & NÃO \\
\hline
\end{tabular}

5) Os conhecimentos adquiridos estão sendo aplicados no seu trabalho? Em caso afirmativo, indique em que grau estes conhecimentos estão sendo aplicados. Em caso negativo, indique por que razão isto não ocorre: (Em caso negativo, as respostas não são excludentes: você poderá marcar mais de uma opção). 


\begin{tabular}{|c|c|c|}
\hline \multirow[t]{2}{*}{ que grau) } & $\mathrm{x}$ & MEDIAMENTE APLICADOS \\
\hline & & POUCO APLICADOS \\
\hline \multirow{5}{*}{$\begin{array}{l}\text { NÃO (indique ao lado a } \\
\text { razão da não aplicação) }\end{array}$} & & $\begin{array}{l}\text { CONTEÚDO NÃO ADEQUADO ÀS NECESSIDADES } \\
\text { ESPECÍFICAS DA REGIÃO }\end{array}$ \\
\hline & & $\begin{array}{l}\text { CONTEÚDO NÃO } \text { FOI SUFICIENTEMENTE } \\
\text { APROFUNDADO PARA } \\
\text { EERMITIR UMA APLICAÇÃO } \\
\text { EFICAZ E EFICIENTE }\end{array}$ \\
\hline & & \begin{tabular}{|llllll} 
FALTA DE & APOIO & E & INCENTIVO & DA & MINHA \\
INSTITUIÇÃO & & & & &
\end{tabular} \\
\hline & & FALTA DE INCENTIVO ÀS AÇÕES DE ATER \\
\hline & & NÃO TENHO INTERESSE EM APLICAR \\
\hline
\end{tabular}

6) A partir deste curso: (As opções não são excludentes: você poderá marcar mais de uma opção)

\begin{tabular}{|l|l|}
\hline & NÃO MUDOU NADA EM MEU TRABALHO. \\
\hline & $\begin{array}{l}\text { MEU TRABALHO PASSOU A CONTRIBUIR MAIS COM OS AGRICULTORES(AS) } \\
\text { FAMILIARES. }\end{array}$ \\
\hline$X$ & CONSEGUI INFLUENCIAR NAS ORIENTAÇÕES DA MINHA INSTITUIÇÃO. \\
\hline & $\begin{array}{l}\text { CRESEI A TRABALHAR COM METODOLOGIAS PARTICIPATIVAS. } \\
\text { ONDE ATUO. ÁREA DE AGRICULTURA DE BASE ECOLÓGICA NAS COMUNIDADES }\end{array}$ \\
\hline & CONTINUEI ME APERFEIÇOANDO SOBRE TEMAS ABORDADOS. \\
\hline
\end{tabular}

7) Depois do curso você apoiou atividades de capacitação de técnicos e agricultores com base nos princípios e diretrizes da Pnater? (Considere como apoio a atividades de capacitação a participação no planejamento, elaboração de ementas, seleção de participantes e de palestrantes.) 


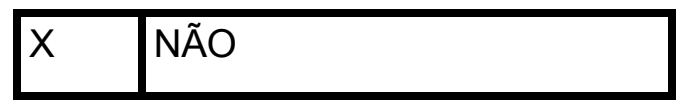

8) Usou os conhecimentos para ministrar outros cursos com o mesmo conteúdo ou conteúdos semelhantes?

\begin{tabular}{|l|l|}
\hline & SIM \\
\hline$X$ & NÃO \\
\hline
\end{tabular}

9) Marque o seu grau de satisfação com relação ao curso oferecido pelo DATER: (Considere a seguinte pontuação: 1 - MUITO RUIM; 2 - RUIM; 3 - REGULAR; 4 - BOM; 5 - MUITO BOM)

\begin{tabular}{|l|l|l|l|l|}
\hline 1 & 2 & 3 & 4 & 5 \\
\hline
\end{tabular}

10) Marque seu grau de satisfação com relação ao DATER: (Considere a seguinte pontuação: 1 - MUITO RUIM; 2 - RUIM; 3 - REGULAR; 4 - BOM; 5 - MUITO BOM)

\begin{tabular}{|l|l|l|l|l|}
\hline 1 & 2 & 3 & 4 & 5 \\
\hline
\end{tabular}


PESQUISA - IMPACTO DAS AÇÕES DE FORMAÇÃO REALIZADAS PELO DATER/SAF/MDA NO PERÍODO 2004-2009

Caros colaboradores,

Contamos com a sua atenção para preencher o formulário abaixo.

O mesmo tem por objetivo fornecer informações para avaliação da Eficiência, Efetividade e Eficácia da Política Pública de Formação de Agentes de Ater adotada pelo Departamento de Assistência Técnica e Extensão Rural, da Secretaria de Agricultura Familiar do Ministério do Desenvolvimento - DATER/SAF/MDA, no período de 2004 a 2009, tema escolhido para Monografia a ser apresentada à Universidade de Brasília (UnB) como requisito parcial para obtenção do grau de Bacharel em Administração.

Você poderá ou não se identificar no questionário e garantimos que todas as informações fornecidas serão confidenciais e utilizadas apenas de forma sistematizada.

\section{IDENTIFICAÇÃO}

\begin{tabular}{|c|c|}
\hline Nome: JOSÉ DE OLIVEIRA RIBEIRO & $\begin{array}{l}\text { Sexo: } \\
(x) \text { masculino } \quad(\quad) \text { feminino }\end{array}$ \\
\hline $\begin{array}{l}\text { Instituição (nome e tipo de instituição: ONG, } \\
\text { Empresa Pública, etc.): } \\
\text { Instituto de Desenvolvimento Agropecuário do } \\
\text { Estado do Amazonas - IDAM. }\end{array}$ & $\begin{array}{l}\text { Local de trabalho (Cidade e Estado): } \\
\text { Manaus - AM }\end{array}$ \\
\hline \multicolumn{2}{|c|}{$\begin{array}{l}\text { Curso/Encontro/Oficina do qual participou (caso tenha participado de mais de um curso, preencha } \\
\text { um formulário para cada um deles): } \\
\text { II Encontro para Socialização dos Conceitos Básicos da Política Nacional de ATER }\end{array}$} \\
\hline $\begin{array}{l}\text { Data do Curso/Encontro/Oficina (pelo menos mês e } \\
04 \text { a } 08 \text { de dezembro de } 2006 \text { - Manaus/AM }\end{array}$ & \\
\hline
\end{tabular}

Indique sua área de atuação? (As opções não são excludentes: você poderá marcar mais de uma opção)

\begin{tabular}{|l|l|}
\hline$X$ & EXTENSÃO RURAL \\
\hline
\end{tabular}




\begin{tabular}{|l|l|}
\hline & PESQUISA \\
\hline & ENSINO \\
\hline & OUTROS \\
\hline
\end{tabular}

2) Qual o seu nível de escolaridade? (Considere apenas o nível mais alto)

\begin{tabular}{|l|l|}
\hline & NÍVEL MÉDIO \\
\hline$X$ & NÍVEL SUPERIOR \\
\hline & PÓS-GRADUAÇÃO \\
\hline
\end{tabular}

3) Os conteúdos abordados foram condizentes com as demandas do seu dia-a-dia?

\begin{tabular}{|l|l|}
\hline$X$ & SIM \\
\hline & PARCIALMENTE \\
\hline & NÃO \\
\hline
\end{tabular}

3) O curso contribuiu para o seu aperfeiçoamento profissional?

\begin{tabular}{|l|l|}
\hline$X$ & SIM \\
\hline & NÃO \\
\hline
\end{tabular}

5) Os conhecimentos adquiridos estão sendo aplicados no seu trabalho? Em caso afirmativo, indique em que grau estes conhecimentos estão sendo aplicados. Em caso negativo, indique por que razão isto não ocorre: (Em caso negativo, as respostas não são excludentes: você poderá marcar mais de uma opção).

\begin{tabular}{|l|l|l|l|}
\hline \multirow{2}{*}{$\begin{array}{l}\text { SIM (indique ao lado em } \\
\text { que grau) }\end{array}$} & & MUITO APLICADOS \\
\cline { 3 - 4 } & & $\mathrm{X}$ & MEDIAMENTE APLICADOS \\
\hline
\end{tabular}




\begin{tabular}{|c|c|}
\hline & POUCO APLICADOS \\
\hline \multirow{5}{*}{$\begin{array}{l}\text { NÃO (indique ao lado a } \\
\text { razão da não aplicação) }\end{array}$} & $\begin{array}{l}\text { CONTEÚDO NÃO ADEQUADO ÀS NECESSIDADES } \\
\text { ESPECÍFICAS DA REGIÃO }\end{array}$ \\
\hline & $\begin{array}{l}\text { CONTEÚDO NÃO } \\
\text { APROFUNDADO PARA } \\
\text { EERMITIR UMA APLICAÇÃO } \\
\text { EFICAZ E EFICIENTE }\end{array}$ \\
\hline & $\begin{array}{|lllllll|}\text { FALTA } & \text { DE } & \text { APOIO } & \text { E } & \text { INCENTIVO } & \text { DA } & \text { MINHA } \\
\text { INSTITUIÇÃO } & & & & \\
\end{array}$ \\
\hline & FALTA DE INCENTIVO ÀS AÇÕES DE ATER \\
\hline & NÃO TENHO INTERESSE EM APLICAR \\
\hline
\end{tabular}

6) A partir deste curso: (As opções não são excludentes: você poderá marcar mais de uma opção)

\begin{tabular}{|l|l|}
\hline & NÃO MUDOU NADA EM MEU TRABALHO. \\
\hline & $\begin{array}{l}\text { MEU TRABALHO PASSOU A CONTRIBUIR MAIS COM OS AGRICULTORES(AS) } \\
\text { FAMILIARES. }\end{array}$ \\
\hline$X$ & CONSEGUI INFLUENCIAR NAS ORIENTAÇÕES DA MINHA INSTITUIÇÃO. \\
\hline & $\begin{array}{l}\text { CASSEI A TRABALHAR COM METODOLOGIAS PARTICIPATIVAS. } \\
\text { ONDE ATUO. }\end{array}$ \\
\hline & CONTINUEI ME APERFEIÇOANDO SOBRE TEMAS ABORDADOS. \\
\hline
\end{tabular}

7) Depois do curso você apoiou atividades de capacitação de técnicos e agricultores com base nos princípios e diretrizes da Pnater? (Considere como apoio a atividades de capacitação a participação no planejamento, elaboração de ementas, seleção de participantes e de palestrantes.)

\begin{tabular}{|l|l|}
\hline & SIM \\
\hline$X$ & NÃO \\
\hline
\end{tabular}


8) Usou os conhecimentos para ministrar outros cursos com o mesmo conteúdo ou conteúdos semelhantes?

\begin{tabular}{|l|l|}
\hline & SIM \\
\hline$X$ & NÃO \\
\hline
\end{tabular}

9) Marque o seu grau de satisfação com relação ao curso oferecido pelo DATER: (Considere a seguinte pontuação: 1 - MUITO RUIM; 2 - RUIM; 3 - REGULAR; 4 - BOM; 5 - MUITO BOM)

\begin{tabular}{|l|l|l|l|l|}
\hline 1 & 2 & 3 & 4 & 5 \\
\hline
\end{tabular}

10) Marque seu grau de satisfação com relação ao DATER: (Considere a seguinte pontuação: 1 - MUITO RUIM; 2 - RUIM; 3 - REGULAR; 4 - BOM; 5 - MUITO BOM)

\begin{tabular}{|l|l|l|l|l|}
\hline 1 & 2 & 3 & 4 & 5 \\
\hline
\end{tabular}


PESQUISA - IMPACTO DAS AÇÕES DE FORMAÇÃO REALIZADAS PELO DATER/SAF/MDA NO PERÍODO 2004-2009

Caros colaboradores,

Contamos com a sua atenção para preencher o formulário abaixo.

O mesmo tem por objetivo fornecer informações para avaliação da Eficiência, Efetividade e Eficácia da Política Pública de Formação de Agentes de Ater adotada pelo Departamento de Assistência Técnica e Extensão Rural, da Secretaria de Agricultura Familiar do Ministério do Desenvolvimento - DATER/SAF/MDA, no período de 2004 a 2009, tema escolhido para Monografia a ser apresentada à Universidade de Brasília (UnB) como requisito parcial para obtenção do grau de Bacharel em Administração.

Você poderá ou não se identificar no questionário e garantimos que todas as informações fornecidas serão confidenciais e utilizadas apenas de forma sistematizada.

\section{IDENTIFICAÇÃO}

\begin{tabular}{|c|c|}
\hline Nome: PEDRO CASTRO DA SILVA & $\begin{array}{l}\text { Sexo: } \\
(\mathrm{x}) \text { masculino } \quad(\quad) \text { feminino }\end{array}$ \\
\hline $\begin{array}{l}\text { Instituição (nome e tipo de instituição: ONG, } \\
\text { Empresa Pública, etc.): } \\
\text { Instituto de Desenvolvimento Agropecuário do } \\
\text { Estado do Amazonas - IDAM }\end{array}$ & $\begin{array}{l}\text { Local de trabalho (Cidade e Estado): } \\
\text { Unidade Local de Urucará - Amazonas }\end{array}$ \\
\hline \multicolumn{2}{|c|}{$\begin{array}{l}\text { Curso/Encontro/Oficina do qual participou (caso tenha participado de mais de um curso, preencha } \\
\text { um formulário para cada um deles): } \\
\text { Curso de Agroecologia }\end{array}$} \\
\hline $\begin{array}{l}\text { Data do Curso/Encontro/Oficina (pelo menos mês e } \\
24 \text { a } 28 \text { de abril de } 2006 \text { - Manaus/AM }\end{array}$ & \\
\hline
\end{tabular}

Indique sua área de atuação? (As opções não são excludentes: você poderá marcar mais de uma opção) 


\begin{tabular}{|l|l|}
\hline$X$ & EXTENSÃO RURAL \\
\hline & PESQUISA \\
\hline & ENSINO \\
\hline & OUTROS \\
\hline
\end{tabular}

2) Qual o seu nível de escolaridade? (Considere apenas o nível mais alto)

\begin{tabular}{|l|l|}
\hline$X$ & NÍVEL MÉDIO \\
\hline & NÍVEL SUPERIOR \\
\hline & PÓS-GRADUAÇÃO \\
\hline
\end{tabular}

3) Os conteúdos abordados foram condizentes com as demandas do seu dia-a-dia?

\begin{tabular}{|l|l|}
\hline$X$ & SIM \\
\hline & PARCIALMENTE \\
\hline & NÃO \\
\hline
\end{tabular}

3) O curso contribuiu para o seu aperfeiçoamento profissional?

\begin{tabular}{|l|l|}
\hline$X$ & SIM \\
\hline & NÃO \\
\hline
\end{tabular}

5) Os conhecimentos adquiridos estão sendo aplicados no seu trabalho? Em caso afirmativo, indique em que grau estes conhecimentos estão sendo aplicados. Em caso negativo, indique por que razão isto não ocorre: (Em caso negativo, as respostas não são excludentes: você poderá marcar mais de uma opção). 


\begin{tabular}{|c|c|c|}
\hline \multirow[t]{2}{*}{ que grau) } & $x$ & MEDIAMENTE APLICADOS \\
\hline & & POUCO APLICADOS \\
\hline \multirow{5}{*}{$\begin{array}{l}\text { NÃO (indique ao lado a } \\
\text { razão da não aplicação) }\end{array}$} & & $\begin{array}{l}\text { CONTEÚDO NÃO ADEQUADO ÀS NECESSIDADES } \\
\text { ESPECÍFICAS DA REGIÃO }\end{array}$ \\
\hline & & $\begin{array}{l}\text { CONTEÚDO NÃO } \text { FOI SUFICIENTEMENTE } \\
\text { APROFUNDADO PARA } \\
\text { PERMITIR UMA APLICAÇÃO } \\
\text { EFICAZ E EFICIENTE }\end{array}$ \\
\hline & & $\begin{array}{llllll}\text { FALTA DE APOIO } & \text { E } & \text { INCENTIVO } & \text { DA } & \text { MINHA } \\
\text { INSTITUIÇÃO } & & & & & \end{array}$ \\
\hline & & FALTA DE INCENTIVO ÀS AÇÕES DE ATER \\
\hline & & NÃO TENHO INTERESSE EM APLICAR \\
\hline
\end{tabular}

6) A partir deste curso: (As opções não são excludentes: você poderá marcar mais de uma opção)

\begin{tabular}{|l|l|}
\hline$x$ & $\begin{array}{l}\text { NÃO MUDOU NADA EM MEU TRABALHO. } \\
\text { FAMILIARES. }\end{array}$ \\
\hline & CONSEGUI INFLUENCIAR NAS ORIENTAÇÕES DA MINHA INSTITUIÇÃO. \\
\hline & PASSEI A TRABALHAR COM METODOLOGIAS PARTICIPATIVAS. \\
\hline & $\begin{array}{l}\text { CRESCEU A ÁREA DE AGRICULTURA DE BASE ECOLÓGICA NAS COMUNIDADES } \\
\text { ONDE ATUO. }\end{array}$ \\
\hline$X$ & CONTINUEI ME APERFEIÇOANDO SOBRE TEMAS ABORDADOS. \\
\hline
\end{tabular}

7) Depois do curso você apoiou atividades de capacitação de técnicos e agricultores com base nos princípios e diretrizes da Pnater? (Considere como apoio a atividades de capacitação a participação no planejamento, elaboração de ementas, seleção de participantes e de palestrantes.)

\begin{tabular}{|l|l|}
\hline$X$ & SIM \\
\hline & NÃO \\
\hline
\end{tabular}


8) Usou os conhecimentos para ministrar outros cursos com o mesmo conteúdo ou conteúdos semelhantes?

\begin{tabular}{|l|l|}
\hline & SIM \\
\hline$X$ & NÃO \\
\hline
\end{tabular}

9) Marque o seu grau de satisfação com relação ao curso oferecido pelo DATER: (Considere a seguinte pontuação: 1 - MUITO RUIM; 2 - RUIM; 3 - REGULAR; 4 - BOM; 5 - MUITO BOM)

\begin{tabular}{|l|l|l|l|l|}
\hline 1 & 2 & 3 & 4 & 5 \\
\hline
\end{tabular}

10) Marque seu grau de satisfação com relação ao DATER: (Considere a seguinte pontuação: 1 - MUITO RUIM; 2 - RUIM; 3 - REGULAR; 4 - BOM; 5 - MUITO BOM)

\begin{tabular}{|l|l|l|l|l|}
\hline 1 & 2 & 3 & 4 & 5 \\
\hline
\end{tabular}


PESQUISA - IMPACTO DAS AÇÕES DE FORMAÇÃO REALIZADAS PELO DATER/SAF/MDA NO PERÍODO 2004-2009

Caros colaboradores,

Contamos com a sua atenção para preencher o formulário abaixo.

O mesmo tem por objetivo fornecer informações para avaliação da Eficiência, Efetividade e Eficácia da Política Pública de Formação de Agentes de Ater adotada pelo Departamento de Assistência Técnica e Extensão Rural, da Secretaria de Agricultura Familiar do Ministério do Desenvolvimento - DATER/SAF/MDA, no período de 2004 a 2009, tema escolhido para Monografia a ser apresentada à Universidade de Brasília (UnB) como requisito parcial para obtenção do grau de Bacharel em Administração.

Você poderá ou não se identificar no questionário e garantimos que todas as informações fornecidas serão confidenciais e utilizadas apenas de forma sistematizada.

\section{IDENTIFICAÇÃO}

\begin{tabular}{|c|c|}
\hline Nome: PEDRO JORGE BENICIO BARROS & $\begin{array}{l}\text { Sexo: } \\
(x) \text { masculino } \quad(\quad) \text { feminino }\end{array}$ \\
\hline $\begin{array}{l}\text { Instituição (nome e tipo de instituição: ONG, } \\
\text { Empresa Pública, etc.): } \\
\text { Instituto de Desenvolvimento Agropecuário do } \\
\text { Estado do Amazonas - IDAM }\end{array}$ & $\begin{array}{l}\text { Local de trabalho (Cidade e Estado): } \\
\text { Unidade Local do Careiro da Várzea - } \\
\text { Amazonas }\end{array}$ \\
\hline \multicolumn{2}{|c|}{$\begin{array}{l}\text { Curso/Encontro/Oficina do qual participou (caso tenha participado de mais de um curso, preencha } \\
\text { um formulário para cada um deles): } \\
\text { Curso Diagnóstico Rural Participativo - DRP }\end{array}$} \\
\hline \multicolumn{2}{|l|}{$\begin{array}{l}\text { Data do Curso/Encontro/Oficina (pelo menos mês e ano): } \\
16 \text { a } 27 \text { de outubro de } 2006 \text { - Manaus/AM }\end{array}$} \\
\hline
\end{tabular}

Indique sua área de atuação? (As opções não são excludentes: você poderá marcar mais de uma opção) 


\begin{tabular}{|l|l|}
\hline$X$ & EXTENSÃO RURAL \\
\hline & PESQUISA \\
\hline & ENSINO \\
\hline & OUTROS \\
\hline
\end{tabular}

2) Qual o seu nível de escolaridade? (Considere apenas o nível mais alto)

\begin{tabular}{|l|l|}
\hline & NÍVEL MÉDIO \\
\hline$X$ & NÍVEL SUPERIOR \\
\hline & PÓS-GRADUAÇÃO \\
\hline
\end{tabular}

3) Os conteúdos abordados foram condizentes com as demandas do seu dia-a-dia?

\begin{tabular}{|l|l|}
\hline$X$ & SIM \\
\hline & PARCIALMENTE \\
\hline & NÃO \\
\hline
\end{tabular}

3) O curso contribuiu para o seu aperfeiçoamento profissional?

\begin{tabular}{|l|l|}
\hline$X$ & SIM \\
\hline & NÃO \\
\hline
\end{tabular}

5) Os conhecimentos adquiridos estão sendo aplicados no seu trabalho? Em caso afirmativo, indique em que grau estes conhecimentos estão sendo aplicados. Em caso negativo, indique por que razão isto não ocorre: (Em caso negativo, as respostas não são excludentes: você poderá marcar mais de uma opção). 


\begin{tabular}{|c|c|c|}
\hline \multirow[t]{2}{*}{ que grau) } & $\mathrm{X}$ & MEDIAMENTE APLICADOS \\
\hline & & POUCO APLICADOS \\
\hline \multirow{5}{*}{$\begin{array}{l}\text { NÃO (indique ao lado a } \\
\text { razão da não aplicação) }\end{array}$} & & $\begin{array}{l}\text { CONTEÚDO NÃO ADEQUADO ÀS NECESSIDADES } \\
\text { ESPECÍFICAS DA REGIÃO }\end{array}$ \\
\hline & & $\begin{array}{l}\text { CONTEÚDO NÃO } \quad \text { FOI SUFICIENTEMENTE } \\
\text { APROFUNDADO PARA } \\
\text { EERMITIR UMA APLICAÇÃO } \\
\text { EFICAZ E EFICIENTE }\end{array}$ \\
\hline & & $\begin{array}{llllll}\text { FALTA DE APOIO } & \text { E } & \text { INCENTIVO } & \text { DA } & \text { MINHA } \\
\text { INSTITUIÇÃO } & & & & & \end{array}$ \\
\hline & & FALTA DE INCENTIVO ÀS AÇÕES DE ATER \\
\hline & & NÃO TENHO INTERESSE EM APLICAR \\
\hline
\end{tabular}

6) A partir deste curso: (As opções não são excludentes: você poderá marcar mais de uma opção)

\begin{tabular}{|l|l|}
\hline$x$ & $\begin{array}{l}\text { NÃO MUDOU NADA EM MEU TRABALHO. } \\
\text { FAMILIARES. }\end{array}$ \\
\hline & CONSEGUI INFLUENCIAR NAS ORIENTAÇÕES DA MINHA INSTITUIÇÃO. \\
\hline$X$ & PASSEI A TRABALHAR COM METODOLOGIAS PARTICIPATIVAS. \\
\hline & $\begin{array}{l}\text { CRESCEU A ÁREA DE AGRICULTURA DE BASE ECOLÓGICA NAS COMUNIDADES } \\
\text { ONDE ATUO. }\end{array}$ \\
\hline & CONTINUEI ME APERFEIÇOANDO SOBRE TEMAS ABORDADOS. \\
\hline
\end{tabular}

7) Depois do curso você apoiou atividades de capacitação de técnicos e agricultores com base nos princípios e diretrizes da Pnater? (Considere como apoio a atividades de capacitação a participação no planejamento, elaboração de ementas, seleção de participantes e de palestrantes.)

\begin{tabular}{|l|l}
\hline$X$ & SIM
\end{tabular} 
NÃO

8) Usou os conhecimentos para ministrar outros cursos com o mesmo conteúdo ou conteúdos semelhantes?

\begin{tabular}{|l|l|}
\hline$X$ & SIM \\
\hline & NÃO \\
\hline
\end{tabular}

9) Marque o seu grau de satisfação com relação ao curso oferecido pelo DATER: (Considere a seguinte pontuação: 1 - MUITO RUIM; 2 - RUIM; 3 - REGULAR; 4 - BOM; 5 - MUITO BOM)

\begin{tabular}{|l|l|l|l|l|}
\hline 1 & 2 & 3 & 4 & 5 \\
\hline
\end{tabular}

10) Marque seu grau de satisfação com relação ao DATER: (Considere a seguinte pontuação: 1 - MUITO RUIM; 2 - RUIM; 3 - REGULAR; 4 - BOM; 5 - MUITO BOM)

\begin{tabular}{|l|l|l|l|l|}
\hline 1 & 2 & 3 & 4 & 5 \\
\hline
\end{tabular}


PESQUISA - IMPACTO DAS AÇÕES DE FORMAÇÃO REALIZADAS PELO DATER/SAF/MDA NO PERÍODO 2004-2009

Caros colaboradores,

Contamos com a sua atenção para preencher o formulário abaixo.

O mesmo tem por objetivo fornecer informações para avaliação da Eficiência, Efetividade e Eficácia da Política Pública de Formação de Agentes de Ater adotada pelo Departamento de Assistência Técnica e Extensão Rural, da Secretaria de Agricultura Familiar do Ministério do Desenvolvimento - DATER/SAF/MDA, no período de 2004 a 2009, tema escolhido para Monografia a ser apresentada à Universidade de Brasília (UnB) como requisito parcial para obtenção do grau de Bacharel em Administração.

Você poderá ou não se identificar no questionário e garantimos que todas as informações fornecidas serão confidenciais e utilizadas apenas de forma sistematizada.

\section{IDENTIFICAÇÃO}

\begin{tabular}{|c|c|}
\hline Nome: RAIMUNDO NONATO PEREIRA VIANA & $\begin{array}{l}\text { Sexo: } \\
(\mathrm{x}) \text { masculino } \quad(\quad) \text { feminino }\end{array}$ \\
\hline $\begin{array}{l}\text { Instituição (nome e tipo de instituição: ONG, } \\
\text { Empresa Pública, etc.): } \\
\text { Instituto de Desenvolvimento Agropecuário do } \\
\text { Estado do Amazonas - IDAM }\end{array}$ & $\begin{array}{l}\text { Local de trabalho (Cidade e Estado): } \\
\text { Unidade Local de Silves - Amazonas }\end{array}$ \\
\hline \multicolumn{2}{|c|}{$\begin{array}{l}\text { Curso/Encontro/Oficina do qual participou (caso tenha participado de mais de um curso, preencha } \\
\text { um formulário para cada um deles): } \\
\text { Curso de Agroecologia }\end{array}$} \\
\hline $\begin{array}{l}\text { Data do Curso/Encontro/Oficina (pelo menos mês e } \\
24 \text { a } 28 \text { de abril de } 2006 \text { - Manaus/AM }\end{array}$ & \\
\hline
\end{tabular}

Indique sua área de atuação? (As opções não são excludentes: você poderá marcar mais de uma opção)

\begin{tabular}{|l|l|}
\hline$X$ & EXTENSÃO RURAL \\
\hline & PESQUISA \\
\hline
\end{tabular}




\begin{tabular}{|l|l|}
\hline & ENSINO \\
\hline & OUTROS \\
\hline
\end{tabular}

2) Qual o seu nível de escolaridade? (Considere apenas o nível mais alto)

\begin{tabular}{|l|l|}
\hline$X$ & NÍVEL MÉDIO \\
\hline & NÍVEL SUPERIOR \\
\hline & PÓS-GRADUAÇÃO \\
\hline
\end{tabular}

3) Os conteúdos abordados foram condizentes com as demandas do seu dia-a-dia?

\begin{tabular}{|l|l|}
\hline$X$ & SIM \\
\hline & PARCIALMENTE \\
\hline & NÃO \\
\hline
\end{tabular}

3) O curso contribuiu para o seu aperfeiçoamento profissional?

\begin{tabular}{|l|l|}
\hline$X$ & SIM \\
\hline & NÃO \\
\hline
\end{tabular}

5) Os conhecimentos adquiridos estão sendo aplicados no seu trabalho? Em caso afirmativo, indique em que grau estes conhecimentos estão sendo aplicados. Em caso negativo, indique por que razão isto não ocorre:

\begin{tabular}{|l|l|l|l|}
\hline \multirow{2}{*}{$\begin{array}{l}\text { SIM (indique ao lado em } \\
\text { que grau) }\end{array}$} & & MUITO APLICADOS \\
\cline { 2 - 4 } & $X$ & MEDIAMENTE APLICADOS \\
\cline { 2 - 4 } & & POUCO APLICADOS \\
\hline
\end{tabular}




\begin{tabular}{|c|c|}
\hline \multirow{5}{*}{$\begin{array}{l}\text { NÃO (indique ao lado a } \\
\text { razão da não aplicação) }\end{array}$} & $\begin{array}{l}\text { CONTEÚDO NÃO ADEQUADO ÀS NECESSIDADES } \\
\text { ESPECÍFICAS DA REGIÃO }\end{array}$ \\
\hline & $\begin{array}{l}\text { CONTEÚDO NÃO } \text { FOI SUFICIENTEMENTE } \\
\text { APROFUNDADO PARA } \\
\text { PERMITIR UMA APLICAÇÃO } \\
\text { EFICAZ E EFICIENTE }\end{array}$ \\
\hline & $\begin{array}{lllllll}\text { FALTA DE } & \text { APOIO } & \text { E } & \text { INCENTIVO } & \text { DA } & \text { MINHA } \\
\text { INSTITUIÇÃO } & & & & & \end{array}$ \\
\hline & FALTA DE INCENTIVO ÀS AÇÕES DE ATER \\
\hline & NÃO TENHO INTERESSE EM APLICAR \\
\hline
\end{tabular}

6) A partir deste curso: (As opções não são excludentes: você poderá marcar mais de uma opção)

\begin{tabular}{|l|l|}
\hline$x$ & $\begin{array}{l}\text { NÃO MUDOU NADA EM MEU TRABALHO. } \\
\text { FAMILIARES. }\end{array}$ \\
\hline & CONSEGUI INFLUENCIAR NAS ORIENTAÇÕES DA MINHA INSTITUIÇÃO. \\
\hline & PASSEI A TRABALHAR COM METODOLOGIAS PARTICIPATIVAS. \\
\hline & $\begin{array}{l}\text { CRESCEU A ÁREA DE AGRICULTURA DE BASE ECOLÓGICA NAS COMUNIDADES } \\
\text { ONDE ATUO. }\end{array}$ \\
\hline$X$ & CONTINUEI ME APERFEIÇOANDO SOBRE TEMAS ABORDADOS. \\
\hline
\end{tabular}

7) Depois do curso você apoiou atividades de capacitação de técnicos e agricultores com base nos princípios e diretrizes da Pnater? (Considere como apoio a atividades de capacitação a participação no planejamento, elaboração de ementas, seleção de participantes e de palestrantes.)

\begin{tabular}{|l|l|}
\hline & SIM \\
\hline$x$ & NÃO \\
\hline
\end{tabular}


8) Usou os conhecimentos para ministrar outros cursos com o mesmo conteúdo ou conteúdos semelhantes?

\begin{tabular}{|l|l|}
\hline & SIM \\
\hline$X$ & NÃO \\
\hline
\end{tabular}

9) Marque o seu grau de satisfação com relação ao curso oferecido pelo DATER: (Considere a seguinte pontuação: 1 - MUITO RUIM; 2 - RUIM; 3 - REGULAR; 4 - BOM; 5 - MUITO BOM)

\begin{tabular}{|l|l|l|l|l|}
\hline 1 & 2 & 3 & 4 & 5 \\
\hline
\end{tabular}

10) Marque seu grau de satisfação com relação ao DATER: (Considere a seguinte pontuação: 1 - MUITO RUIM; 2 - RUIM; 3 - REGULAR; 4 - BOM; 5 - MUITO BOM)

\begin{tabular}{|l|l|l|l|l|}
\hline 1 & 2 & 3 & 4 & 5 \\
\hline
\end{tabular}


PESQUISA - IMPACTO DAS AÇÕES DE FORMAÇÃO REALIZADAS PELO DATER/SAF/MDA NO PERÍODO 2004-2009

Caros colaboradores,

Contamos com a sua atenção para preencher o formulário abaixo.

O mesmo tem por objetivo fornecer informações para avaliação da Eficiência, Efetividade e Eficácia da Política Pública de Formação de Agentes de Ater adotada pelo Departamento de Assistência Técnica e Extensão Rural, da Secretaria de Agricultura Familiar do Ministério do Desenvolvimento - DATER/SAF/MDA, no período de 2004 a 2009, tema escolhido para Monografia a ser apresentada à Universidade de Brasília (UnB) como requisito parcial para obtenção do grau de Bacharel em Administração.

Você poderá ou não se identificar no questionário e garantimos que todas as informações fornecidas serão confidenciais e utilizadas apenas de forma sistematizada.

\section{IDENTIFICAÇÃO}

\begin{tabular}{|c|c|}
\hline Nome: RAIMUNDO NONATO PEREIRA VIANA & $\begin{array}{l}\text { Sexo: } \\
(x) \text { masculino } \quad(\quad) \text { feminino }\end{array}$ \\
\hline $\begin{array}{l}\text { Instituição (nome e tipo de instituição: ONG, } \\
\text { Empresa Pública, etc.): } \\
\text { Instituto de Desenvolvimento Agropecuário do } \\
\text { Estado do Amazonas - IDAM }\end{array}$ & $\begin{array}{l}\text { Local de trabalho (Cidade e Estado): } \\
\text { Unidade Local de Silves - Amazonas }\end{array}$ \\
\hline \multicolumn{2}{|c|}{$\begin{array}{l}\text { Curso/Encontro/Oficina do qual participou (caso tenha participado de mais de um curso, preencha } \\
\text { um formulário para cada um deles): } \\
\text { Seminário - Agroecologia como Estratégia para a Construção do Desenvolvimento Rural } \\
\text { Sustentável }\end{array}$} \\
\hline $\begin{array}{l}\text { Data do Curso/Encontro/Oficina (pelo menos mês } \\
10 \text { e } 11 \text { de agosto de } 2006 \text { - Manaus/AM }\end{array}$ & \\
\hline
\end{tabular}

Indique sua área de atuação? (As opções não são excludentes: você poderá marcar mais de uma opção)

\begin{tabular}{|l|l|}
\hline$X$ & EXTENSÃO RURAL \\
\hline & PESQUISA \\
\hline
\end{tabular}




\begin{tabular}{|l|l|}
\hline & ENSINO \\
\hline & OUTROS \\
\hline
\end{tabular}

2) Qual o seu nível de escolaridade? (Considere apenas o nível mais alto)

\begin{tabular}{|l|l|}
\hline$X$ & NÍVEL MÉDIO \\
\hline & NÍVEL SUPERIOR \\
\hline & PÓS-GRADUAÇÃO \\
\hline
\end{tabular}

3) Os conteúdos abordados foram condizentes com as demandas do seu dia-a-dia?

\begin{tabular}{|l|l|}
\hline$X$ & SIM \\
\hline & PARCIALMENTE \\
\hline & NÃO \\
\hline
\end{tabular}

3) O curso contribuiu para o seu aperfeiçoamento profissional?

\begin{tabular}{|l|l|}
\hline$X$ & SIM \\
\hline & NÃO \\
\hline
\end{tabular}

5) Os conhecimentos adquiridos estão sendo aplicados no seu trabalho? Em caso afirmativo, indique em que grau estes conhecimentos estão sendo aplicados. Em caso negativo, indique por que razão isto não ocorre: (Em caso negativo, as respostas não são excludentes: você poderá marcar mais de uma opção).

\begin{tabular}{|l|l|l|}
\hline \multirow{2}{*}{$\begin{array}{l}\text { SIM (indique ao lado em } \\
\text { que grau) }\end{array}$} & $X$ & MUITO APLICADOS \\
\cline { 2 - 4 } & & MEDIAMENTE APLICADOS \\
\cline { 2 - 4 } & & POUCO APLICADOS \\
\hline
\end{tabular}




\begin{tabular}{|c|c|}
\hline \multirow{5}{*}{$\begin{array}{l}\text { NÃO (indique ao lado a } \\
\text { razão da não aplicação) }\end{array}$} & $\begin{array}{l}\text { CONTEÚDO NÃO ADEQUADO ȦS NECESSIDADES } \\
\text { ESPECÍFICAS DA REGIÃO }\end{array}$ \\
\hline & $\begin{array}{l}\text { CONTEÚDO NÃO FOI SUFICIENTEMENTE } \\
\text { APROFUNDADO PARA } \\
\text { PERMITIR UMA APLICAÇÃO } \\
\text { EFICAZ E EFICIENTE }\end{array}$ \\
\hline & $\begin{array}{l}\text { FALTA DE APOIO } \\
\text { INSTITUIÇÃO }\end{array}$ \\
\hline & FALTA DE INCENTIVO ÀS AÇÕES DE ATER \\
\hline & NÃO TENHO INTERESSE EM APLICAR \\
\hline
\end{tabular}

6) A partir deste curso: (As opções não são excludentes: você poderá marcar mais de uma opção)

\begin{tabular}{|l|l|}
\hline & NÃO MUDOU NADA EM MEU TRABALHO. \\
\hline & $\begin{array}{l}\text { MEU TRABALHO PASSOU A CONTRIBUIR MAIS COM OS AGRICULTORES(AS) } \\
\text { FAMILIARES. }\end{array}$ \\
\hline & CONSEGUI INFLUENCIAR NAS ORIENTAÇÕES DA MINHA INSTITUIÇÃO. \\
\hline & $\begin{array}{l}\text { CASSEI A TRABALHAR COM METODOLOGIAS PARTICIPATIVAS. } \\
\text { ONDE ATUO. ÁREA DE AGRICULTURA DE BASE ECOLÓGICA NAS COMUNIDADES }\end{array}$ \\
\hline$X$ & CONTINUEI ME APERFEIÇOANDO SOBRE TEMAS ABORDADOS. \\
\hline
\end{tabular}

7) Depois do curso você apoiou atividades de capacitação de técnicos e agricultores com base nos princípios e diretrizes da Pnater? (Considere como apoio a atividades de capacitação a participação no planejamento, elaboração de ementas, seleção de participantes e de palestrantes.)

\begin{tabular}{|l|l|}
\hline$X$ & SIM \\
\hline & NÃO \\
\hline
\end{tabular}


8) Usou os conhecimentos para ministrar outros cursos com o mesmo conteúdo ou conteúdos semelhantes?

\begin{tabular}{|l|l|}
\hline & SIM \\
\hline$X$ & NÃO \\
\hline
\end{tabular}

9) Marque o seu grau de satisfação com relação ao curso oferecido pelo DATER: (Considere a seguinte pontuação: 1 - MUITO RUIM; 2 - RUIM; 3 - REGULAR; 4 - BOM; 5 - MUITO BOM)

\begin{tabular}{|l|l|l|l|l|}
\hline 1 & 2 & 3 & 4 & 5 \\
\hline
\end{tabular}

10) Marque seu grau de satisfação com relação ao DATER: (Considere a seguinte pontuação: 1 - MUITO RUIM; 2 - RUIM; 3 - REGULAR; 4 - BOM; 5 - MUITO BOM)

\begin{tabular}{|l|l|l|l|l|}
\hline 1 & 2 & 3 & 4 & 5 \\
\hline
\end{tabular}

PESQUISA - IMPACTO DAS AÇÕES DE FORMAÇÃO REALIZADAS PELO DATER/SAF/MDA NO PERÍODO 2004-2009

Caros colaboradores,

Contamos com a sua atenção para preencher o formulário abaixo.

O mesmo tem por objetivo fornecer informações para avaliação da Eficiência, Efetividade e Eficácia da Política Pública de Formação de Agentes de Ater adotada pelo Departamento de Assistência Técnica e Extensão Rural, da Secretaria de Agricultura Familiar do Ministério do Desenvolvimento - DATER/SAF/MDA, no período de 2004 a 2009, tema escolhido para Monografia a ser apresentada à Universidade de Brasília (UnB) como requisito parcial para obtenção do grau de Bacharel em Administração.

Você poderá ou não se identificar no questionário e garantimos que todas as informações fornecidas serão confidenciais e utilizadas apenas de forma sistematizada. 


\section{IDENTIFICAÇÃO}

\begin{tabular}{|l|l|}
\hline Nome: Ivanildo Schmith Kuster & $\begin{array}{l}\text { Sexo: } \\
(x) \text { masculino } \quad(\quad \text { ) feminino }\end{array}$ \\
\hline $\begin{array}{l}\text { Instituição: INCAPER ( Instituto Capixaba de } \\
\text { Pesquisa, Assistência Técnica e Extensão Rural) }\end{array}$ & Local de trabalho: Nova Venécia - ES \\
\hline Curso/Encontro/Oficina do qual participou: Ater PeSqueira \\
\hline Data do Curso/Encontro/Oficina: 2008
\end{tabular}

Indique sua área de atuação? (As opções não são excludentes: você poderá marcar mais de uma opção).

\begin{tabular}{|l|l|}
\hline$x$ & EXTENSÃO RURAL \\
\hline & PESQUISA \\
\hline & ENSINO \\
\hline & OUTROS \\
\hline
\end{tabular}

2) Qual o seu nível de escolaridade? (Considere apenas o nível mais alto)

\begin{tabular}{|l|l|}
\hline$x$ & NÍVEL MÉDIO \\
\hline & NÍVEL SUPERIOR \\
\hline & PÓS-GRADUAÇÃO \\
\hline
\end{tabular}

3) Os conteúdos abordados foram condizentes com as demandas do seu dia-a-dia? 


\begin{tabular}{|l|l|}
\hline$x$ & SIM \\
\hline & PARCIALMENTE \\
\hline & NÃO \\
\hline
\end{tabular}

4) O curso contribuiu para o seu aperfeiçoamento profissional?

\begin{tabular}{|l|l|}
\hline$x$ & SIM \\
\hline & NÃO \\
\hline
\end{tabular}

5) Os conhecimentos adquiridos estão sendo aplicados no seu trabalho? Em caso afirmativo, indique em que grau estes conhecimentos estão sendo aplicados. Em caso negativo, indique por que razão isto não ocorre: (As respostas não são excludentes: você poderá marcar mais de uma opção).

\begin{tabular}{|c|c|c|c|}
\hline & \multirow{3}{*}{$\begin{array}{l}\text { SIM (indique ao lado em } \\
\text { que grau) }\end{array}$} & & MUITO APLICADOS \\
\hline & & $\mathrm{x}$ & MEDIAMENTE APLICADOS \\
\hline & & & POUCO APLICADOS \\
\hline & \multirow{5}{*}{$\begin{array}{l}\text { NÃO (indique ao lado a } \\
\text { razão da não aplicação) }\end{array}$} & & $\begin{array}{l}\text { CONTEÚDO NÃO ADEQUADO ȦS NECESSIDADES } \\
\text { ESPECÍFICAS DA REGIÃO }\end{array}$ \\
\hline & & & $\begin{array}{l}\text { CONTEÚDO NÃO FOI SUFICIENTEMENTE } \\
\text { APROFUNDADO PARA PERMITIR UMA APLICAÇÃO } \\
\text { EFICAZE EFICIENTE }\end{array}$ \\
\hline & & & 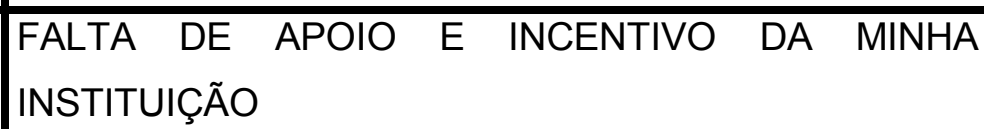 \\
\hline & & & FALTA DE INCENTIVO ÀS AÇÕES DE ATER \\
\hline & & & NÃO TENHO INTERESSE EM APLICAR \\
\hline
\end{tabular}

6) A partir deste curso: (As opções não são excludentes: você poderá marcar mais de uma opção). 


\begin{tabular}{|l|l|}
\hline & NÃO MUDOU NADA EM MEU TRABALHO. \\
\hline & $\begin{array}{l}\text { MEU TRABALHO PASSOU A CONTRIBUIR MAIS COM OS AGRICULTORES(AS) } \\
\text { FAMILIARES. }\end{array}$ \\
\hline & CONSEGUI INFLUENCIAR NAS ORIENTAÇÕES DA MINHA INSTITUIÇÃO. \\
\hline & $\begin{array}{l}\text { CRESCEU A ÁREA DE AGRICULTURA DE BASE ECOLÓGICA NAS COMUNIDADES } \\
\text { ONDE ATUO. }\end{array}$ \\
\hline$x$ & CONTINUEI ME APERFEIÇOANDO SOBRE TEMAS ABORDADOS. \\
\hline
\end{tabular}

7) Depois do curso você apoiou atividades de capacitação de técnicos e agricultores com base nos princípios e diretrizes da Pnater? (Considere como apoio a atividades de capacitação a participação no planejamento, elaboração de ementas, seleção de participantes e de palestrantes.)

\begin{tabular}{|l|l|}
\hline & SIM \\
\hline$x$ & NÃO \\
\hline
\end{tabular}

8) Usou os conhecimentos para ministrar outros cursos com o mesmo conteúdo ou conteúdos semelhantes?

\begin{tabular}{|l|l|}
\hline & SIM \\
\hline$x$ & NÃO \\
\hline
\end{tabular}

9) Marque o seu grau de satisfação com relação ao curso oferecido pelo DATER: (Considere a seguinte pontuação: 1 - MUITO RUIM; 2 - RUIM; 3 - REGULAR; 4 - BOM; 5 - MUITO BOM)

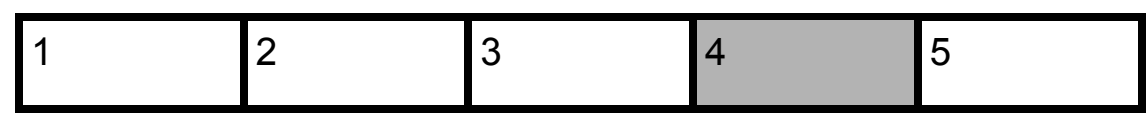

10) Marque seu grau de satisfação com relação ao DATER: (Considere a seguinte pontuação: 1 - MUITO RUIM; 2 - RUIM; 3 - REGULAR; 4 - BOM; 5 - MUITO BOM) 


\begin{tabular}{|l|l|l|l|l|}
\hline 1 & 2 & 3 & 4 & 5 \\
\hline
\end{tabular}


PESQUISA - IMPACTO DAS AÇÕES DE FORMAÇÃO REALIZADAS PELO DATER/SAF/MDA NO PERÍODO 2004-2009

Caros colaboradores,

Contamos com a sua atenção para preencher o formulário abaixo.

O mesmo tem por objetivo fornecer informações para avaliação da Eficiência, Efetividade e Eficácia da Política Pública de Formação de Agentes de Ater adotada pelo Departamento de Assistência Técnica e Extensão Rural, da Secretaria de Agricultura Familiar do Ministério do Desenvolvimento - DATER/SAF/MDA, no período de 2004 a 2009, tema escolhido para Monografia a ser apresentada à Universidade de Brasília (UnB) como requisito parcial para obtenção do grau de Bacharel em Administração.

Você poderá ou não se identificar no questionário e garantimos que todas as informações fornecidas serão confidenciais e utilizadas apenas de forma sistematizada.

\section{IDENTIFICAÇÃO}

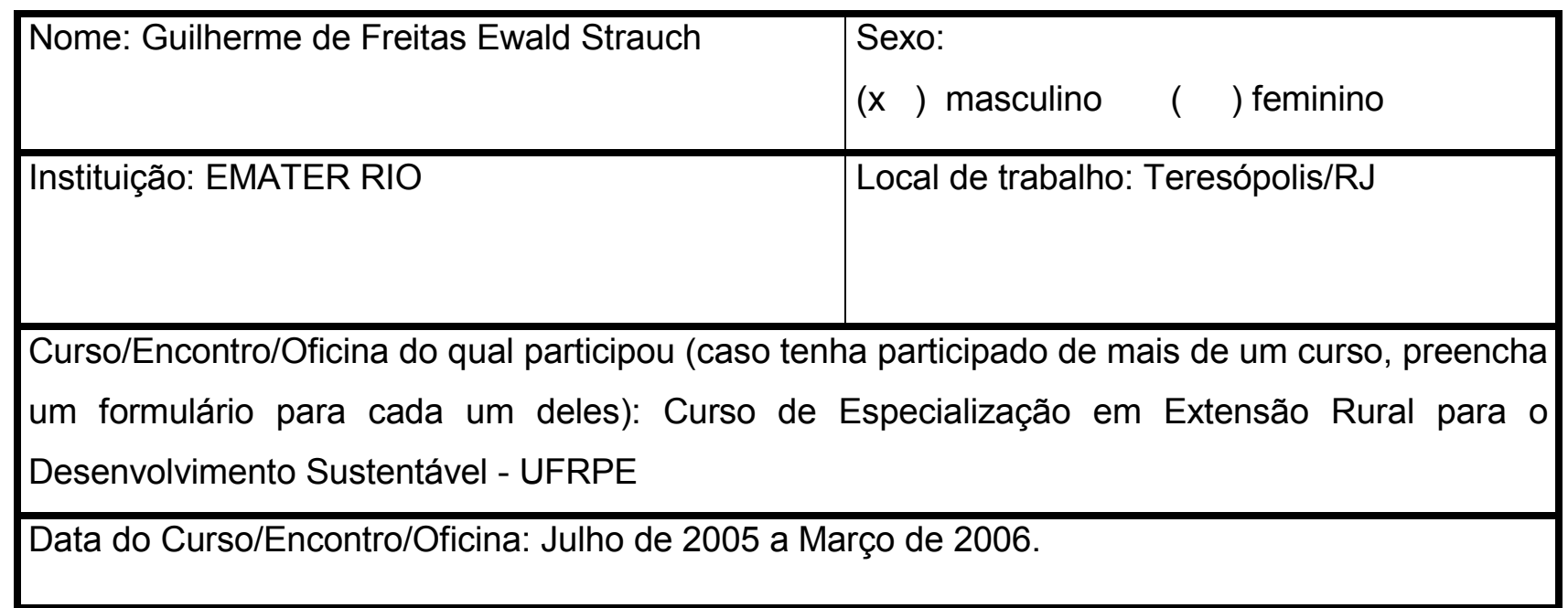

Indique sua área de atuação? (As opções não são excludentes: você poderá marcar mais de uma opção).

\begin{tabular}{|l|l|}
\hline$X$ & EXTENSÃO RURAL \\
\hline & PESQUISA \\
\hline & ENSINO \\
\hline & OUTROS \\
\hline
\end{tabular}


2) Qual o seu nível de escolaridade? (Considere apenas o nível mais alto)

\begin{tabular}{|l|l|}
\hline & NÍVEL MÉDIO \\
\hline$X$ & NÍVEL SUPERIOR \\
\hline & PÓS-GRADUAÇÃO \\
\hline
\end{tabular}

3) Os conteúdos abordados foram condizentes com as demandas do seu dia-a-dia?

\begin{tabular}{|l|l|}
\hline$X$ & SIM \\
\hline & PARCIALMENTE \\
\hline & NÃO \\
\hline
\end{tabular}

4) O curso contribuiu para o seu aperfeiçoamento profissional?

\begin{tabular}{|l|l|}
\hline$X$ & SIM (Muito) \\
\hline & NÃO \\
\hline
\end{tabular}

5) Os conhecimentos adquiridos estão sendo aplicados no seu trabalho? Em caso afirmativo, indique em que grau estes conhecimentos estão sendo aplicados. Em caso negativo, indique por que razão isto não ocorre: (As respostas não são excludentes: você poderá marcar mais de uma opção).

\begin{tabular}{|l|l|l|l|}
\hline \multirow{2}{*}{$\begin{array}{l}\text { SIM (indique ao lado em } \\
\text { que grau) }\end{array}$} & X & MUITO APLICADOS \\
\cline { 2 - 3 } & & MEDIAMENTE APLICADOS \\
\cline { 2 - 4 } & $\begin{array}{l}\text { NÃO (indique ao lado a } \\
\text { razão da não aplicação) }\end{array}$ & $\begin{array}{l}\text { COUCO APLICADOS } \\
\text { ESPECÍFICAS DA REGIÃO }\end{array}$ \\
\hline
\end{tabular}




\begin{tabular}{|l|l|l|}
\hline \multirow{10}{*}{} & $\begin{array}{l}\text { CONTEÚDO NÃO FOI SUFICIENTEMENTE } \\
\text { APROFUNDADO PARA PERMITIR UMA APLICAÇÃO } \\
\text { EFICAZ E EFICIENTE }\end{array}$ \\
\cline { 2 - 4 } & $\begin{array}{l}\text { FALTA DE APOIO E INCENTIVO DA MINHA } \\
\text { INSTITUIÇÃO }\end{array}$ \\
\cline { 2 - 4 } & FALTA DE INCENTIVO ÀS AÇÕES DE ATER \\
\hline & NÃO TENHO INTERESSE EM APLICAR \\
\hline
\end{tabular}

6) A partir deste curso: (As opções não são excludentes: você poderá marcar mais de uma opção).

\begin{tabular}{|l|l|}
\hline & NÃO MUDOU NADA EM MEU TRABALHO. \\
\hline$X$ & $\begin{array}{l}\text { MEU TRABALHO PASSOU A CONTRIBUIR MAIS COM OS AGRICULTORES(AS) } \\
\text { FAMILIARES. }\end{array}$ \\
\hline$x$ & CONSEGUI INFLUENCIAR NAS ORIENTAÇÕES DA MINHA INSTITUIÇÃO. \\
\hline & $\begin{array}{l}\text { CRESCEU A ÁREA DE AGRICULTURA DE BASE ECOLÓGICA NAS COMUNIDADES } \\
\text { ONDE ATUO. }\end{array}$ \\
\hline$X$ & CONTINUEI ME APERFEIÇOANDO SOBRE TEMAS ABORDADOS. \\
\hline
\end{tabular}

7) Depois do curso você apoiou atividades de capacitação de técnicos e agricultores com base nos princípios e diretrizes da Pnater? (Considere como apoio a atividades de capacitação a participação no planejamento, elaboração de ementas, seleção de participantes e de palestrantes.)

\begin{tabular}{|l|l|}
\hline$X$ & SIM (muitas) \\
\hline & NÃO \\
\hline
\end{tabular}

8) Usou os conhecimentos para ministrar outros cursos com o mesmo conteúdo ou conteúdos semelhantes? 


\begin{tabular}{|l|l|}
\hline$X$ & SIM \\
\hline & NÃO \\
\hline
\end{tabular}

9) Marque o seu grau de satisfação com relação ao curso oferecido pelo DATER: (Considere a seguinte pontuação: 1 - MUITO RUIM; 2 - RUIM; 3 - REGULAR; 4 - BOM; 5 - MUITO BOM)

\begin{tabular}{|l|l|l|l|l|}
\hline 1 & 2 & 3 & 4 & $\times 5$ \\
\hline
\end{tabular}

10) Marque seu grau de satisfação com relação ao DATER: (Considere a seguinte pontuação: 1 - MUITO RUIM; 2 - RUIM; 3 - REGULAR; 4 - BOM; 5 - MUITO BOM)

\begin{tabular}{|l|l|l|l|l|}
\hline 1 & 2 & 3 & 4 & $\times 5$ \\
\hline
\end{tabular}


PESQUISA - IMPACTO DAS AÇÕES DE FORMAÇÃO REALIZADAS PELO DATER/SAF/MDA NO PERÍODO 2004-2009

Caros colaboradores,

Contamos com a sua atenção para preencher o formulário abaixo.

O mesmo tem por objetivo fornecer informações para avaliação da Eficiência, Efetividade e Eficácia da Política Pública de Formação de Agentes de Ater adotada pelo Departamento de Assistência Técnica e Extensão Rural, da Secretaria de Agricultura Familiar do Ministério do Desenvolvimento - DATER/SAF/MDA, no período de 2004 a 2009, tema escolhido para Monografia a ser apresentada à Universidade de Brasília (UnB) como requisito parcial para obtenção do grau de Bacharel em Administração.

Você poderá ou não se identificar no questionário e garantimos que todas as informações fornecidas serão confidenciais e utilizadas apenas de forma sistematizada.

\section{IDENTIFICAÇÃO}

\begin{tabular}{|l|l|}
\hline Nome: Gérson José Yunes Antonio & $\begin{array}{l}\text { Sexo: } \\
(x) \text { masculino } \quad(\quad \text { ) feminino }\end{array}$ \\
\hline $\begin{array}{l}\text { Instituição (nome e tipo de instituição: ONG, } \\
\text { Empresa Pública, etc.): EMATER-RIO - Empresa } \\
\text { Pública }\end{array}$ & \begin{tabular}{l} 
Maria Madalena - RJ \\
\hline Curso/Encontro/Oficina do qual participou (caso tenha participado de mais de um curso, preencha \\
um formulário para cada um deles): Técnicas de Aprendizagem e Ação Participativa - DRP
\end{tabular} \\
\hline Data do Curso/Encontro/Oficina (pelo menos mês e ano): Dezembro/ 2006 \\
\hline
\end{tabular}

Indique sua área de atuação? (As opções não são excludentes: você poderá marcar mais de uma opção).

\begin{tabular}{|l|l|}
\hline$x$ & EXTENSÃO RURAL \\
\hline & PESQUISA \\
\hline & ENSINO \\
\hline & OUTROS \\
\hline
\end{tabular}


2) Qual o seu nível de escolaridade? (Considere apenas o nível mais alto)

\begin{tabular}{|l|l|}
\hline & NÍVEL MÉDIO \\
\hline$x$ & NÍVEL SUPERIOR \\
\hline & PÓS-GRADUAÇÃO \\
\hline
\end{tabular}

3) Os conteúdos abordados foram condizentes com as demandas do seu dia-a-dia?

\begin{tabular}{|l|l|}
\hline$x$ & SIM \\
\hline & PARCIALMENTE \\
\hline & NÃO \\
\hline
\end{tabular}

4) O curso contribuiu para o seu aperfeiçoamento profissional?

\begin{tabular}{|l|l|}
\hline$x$ & SIM \\
\hline & NÃO \\
\hline
\end{tabular}

5) Os conhecimentos adquiridos estão sendo aplicados no seu trabalho? Em caso afirmativo, indique em que grau estes conhecimentos estão sendo aplicados. Em caso negativo, indique por que razão isto não ocorre: (As respostas não são excludentes: você poderá marcar mais de uma opção).

\begin{tabular}{|c|c|c|c|}
\hline \multirow{3}{*}{$x$} & \multirow{3}{*}{$\begin{array}{l}\text { SIM (indique ao lado em } \\
\text { que grau) }\end{array}$} & $x$ & MUITO APLICADOS \\
\hline & & & MEDIAMENTE APLICADOS \\
\hline & & & POUCO APLICADOS \\
\hline & \multirow{2}{*}{$\begin{array}{l}\text { NÃO (indique ao lado a } \\
\text { razão da não aplicação) }\end{array}$} & & $\begin{array}{l}\text { CONTEU்DO NÃO ADEQUADO ȦS NECESSIDADES } \\
\text { ESPECÍFICAS DA REGIÃO }\end{array}$ \\
\hline & & & $\begin{array}{l}\text { CONTEÚDO NÃO } \quad \text { FOI SUFICIENTEMENTE } \\
\text { APROFUNDADO PARA } \\
\text { PERMITIR UMA APLICAÇÃO } \\
\text { EFICAZ E EFICIENTE }\end{array}$ \\
\hline
\end{tabular}




\begin{tabular}{|l|l|l|}
\hline \multirow{2}{*}{} & & $\begin{array}{l}\text { FALTA DE APOIO E INCENTIVO DA MINHA } \\
\text { INSTITUIÇÃO }\end{array}$ \\
\cline { 2 - 3 } & & FALTA DE INCENTIVO ÀS AÇÕES DE ATER \\
\cline { 2 - 3 } & NÃO TENHO INTERESSE EM APLICAR \\
\hline
\end{tabular}

6) A partir deste curso: (As opções não são excludentes: você poderá marcar mais de uma opção).

\begin{tabular}{|l|l|}
\hline$x$ & $\begin{array}{l}\text { NÃO MUDOU NADA EM MEU TRABALHO. } \\
\text { FAMILIARES. }\end{array}$ \\
\hline$x$ & CONSEGUI INFLUENCIAR NAS ORIENTAÇÕES DA MINHA INSTITUIÇÃO. \\
\hline$x$ & PASSEI A TRABALHAR COM METODOLOGIAS PARTICIPATIVAS. \\
\hline & $\begin{array}{l}\text { CRESCEU A ÁREA DE AGRICULTURA DE BASE ECOLÓGICA NAS COMUNIDADES } \\
\text { ONDE ATUO. }\end{array}$ \\
\hline$x$ & CONTINUEI ME APERFEIÇOANDO SOBRE TEMAS ABORDADOS. \\
\hline
\end{tabular}

7) Depois do curso você apoiou atividades de capacitação de técnicos e agricultores com base nos princípios e diretrizes da Pnater? (Considere como apoio a atividades de capacitação a participação no planejamento, elaboração de ementas, seleção de participantes e de palestrantes.)

\begin{tabular}{|l|l|}
\hline$x$ & SIM \\
\hline & NÃO \\
\hline
\end{tabular}

8) Usou os conhecimentos para ministrar outros cursos com o mesmo conteúdo ou conteúdos semelhantes?

\begin{tabular}{|l|l|}
\hline$x$ & SIM \\
\hline & NÃO \\
\hline
\end{tabular}


9) Marque o seu grau de satisfação com relação ao curso oferecido pelo DATER: (Considere a seguinte pontuação: 1 - MUITO RUIM; 2 - RUIM; 3 - REGULAR; 4 - BOM; 5 - MUITO BOM)

\begin{tabular}{|l|l|l|l|l|}
\hline 1 & 2 & 3 & 4 & $5 x$ \\
\hline
\end{tabular}

10) Marque seu grau de satisfação com relação ao DATER: (Considere a seguinte pontuação: 1 - MUITO RUIM; 2 - RUIM; 3 - REGULAR; 4 - BOM; 5 - MUITO BOM)

\begin{tabular}{|l|l|l|l|l|}
\hline 1 & 2 & 3 & 4 & $5 x$ \\
\hline
\end{tabular}


PESQUISA - IMPACTO DAS AÇÕES DE FORMAÇÃO REALIZADAS PELO DATER/SAF/MDA NO PERÍODO 2004-2009

Caros colaboradores,

Contamos com a sua atenção para preencher o formulário abaixo.

O mesmo tem por objetivo fornecer informações para avaliação da Eficiência, Efetividade e Eficácia da Política Pública de Formação de Agentes de Ater adotada pelo Departamento de Assistência Técnica e Extensão Rural, da Secretaria de Agricultura Familiar do Ministério do Desenvolvimento - DATER/SAF/MDA, no período de 2004 a 2009, tema escolhido para Monografia a ser apresentada à Universidade de Brasília (UnB) como requisito parcial para obtenção do grau de Bacharel em Administração.

Você poderá ou não se identificar no questionário e garantimos que todas as informações fornecidas serão confidenciais e utilizadas apenas de forma sistematizada.

\section{IDENTIFICAÇÃO}

\begin{tabular}{|c|c|}
\hline Nome: Fabíola Helena dos Santos Fogaça & $\begin{array}{l}\text { Sexo: } \\
(\quad) \text { masculino } \quad(x \quad) \text { feminino }\end{array}$ \\
\hline Instituição Instituto Giramundo Mutuando - ONG & Local de trabalho : Botucatu - SP \\
\hline \multicolumn{2}{|c|}{$\begin{array}{l}\text { Curso/Encontro/Oficina do qual participou : Capacitação de Agentes de ATER que atuem com } \\
\text { Pescadores Artesanais e Aqüicultores familiares. }\end{array}$} \\
\hline 2 de no & de 2004. \\
\hline
\end{tabular}

Indique sua área de atuação? (As opções não são excludentes: você poderá marcar mais de uma opção).

\begin{tabular}{|c|l|}
\hline$x$ & EXTENSÃO RURAL \\
\hline$x$ & PESQUISA \\
\hline & ENSINO \\
\hline
\end{tabular}




\section{OUTROS}

2) Qual o seu nível de escolaridade? (Considere apenas o nível mais alto)

\begin{tabular}{|l|l|}
\hline & NÍVEL MÉDIO \\
\hline & NÍVEL SUPERIOR \\
\hline$x$ & PÓS-GRADUAÇÃO \\
\hline
\end{tabular}

3) Os conteúdos abordados foram condizentes com as demandas do seu dia-a-dia?

\begin{tabular}{|l|l|}
\hline & SIM \\
\hline$x$ & PARCIALMENTE \\
\hline & NÃO \\
\hline
\end{tabular}

4) O curso contribuiu para o seu aperfeiçoamento profissional?

\begin{tabular}{|l|l|}
\hline$x$ & SIM \\
\hline & NÃO \\
\hline
\end{tabular}

5) Os conhecimentos adquiridos estão sendo aplicados no seu trabalho? Em caso afirmativo, indique em que grau estes conhecimentos estão sendo aplicados. Em caso negativo, indique por que razão isto não ocorre: (As respostas não são excludentes: você poderá marcar mais de uma opção).

\begin{tabular}{|c|c|c|c|}
\hline \multirow{3}{*}{$\mathrm{x}$} & \multirow{3}{*}{$\begin{array}{l}\text { SIM (indique ao lado em } \\
\text { que grau) }\end{array}$} & $\mathrm{x}$ & MUITO APLICADOS \\
\hline & & & MEDIAMENTE APLICADOS \\
\hline & & & POUCO APLICADOS \\
\hline & $\begin{array}{l}\text { NĀO (indique ao lado a } \\
\text { razão da não aplicação) }\end{array}$ & & $\begin{array}{l}\text { CONTEÚDO NĀO ADEQUADO ȦS NECESSIDADES } \\
\text { ESPECÍFICAS DA REGIÃO }\end{array}$ \\
\hline
\end{tabular}




\begin{tabular}{|l|l|l|}
\hline \multirow{10}{*}{} & $\begin{array}{l}\text { CONTEÚDO NÃO FOI SUFICIENTEMENTE } \\
\text { APROFUNDADO PARA PERMITIR UMA APLICAÇÃO } \\
\text { EFICAZ E EFICIENTE }\end{array}$ \\
\cline { 2 - 4 } & $\begin{array}{l}\text { FALTA DE APOIO E INCENTIVO DA MINHA } \\
\text { INSTITUIÇÃO }\end{array}$ \\
\cline { 2 - 4 } & FALTA DE INCENTIVO ÀS AÇÕES DE ATER \\
\hline & NÃO TENHO INTERESSE EM APLICAR \\
\hline
\end{tabular}

6) A partir deste curso: (As opções não são excludentes: você poderá marcar mais de uma opção).

\begin{tabular}{|l|l|}
\hline & NÃO MUDOU NADA EM MEU TRABALHO. \\
\hline & $\begin{array}{l}\text { MEU TRABALHO PASSOU A CONTRIBUIR MAIS COM OS AGRICULTORES(AS) } \\
\text { FAMILIARES. }\end{array}$ \\
\hline$x$ & CONSEGUI INFLUENCIAR NAS ORIENTAÇÕES DA MINHA INSTITUIÇÃO. \\
\hline & $\begin{array}{l}\text { CRESCEU A ÁREA DE AGRICULTURA DE BASE ECOLÓGICA NAS COMUNIDADES } \\
\text { ONDE ATUO. }\end{array}$ \\
\hline$x$ & CONTINUEI ME APERFEIÇOANDO SOBRE TEMAS ABORDADOS. \\
\hline
\end{tabular}

7) Depois do curso você apoiou atividades de capacitação de técnicos e agricultores com base nos princípios e diretrizes da Pnater? (Considere como apoio a atividades de capacitação a participação no planejamento, elaboração de ementas, seleção de participantes e de palestrantes.)

\begin{tabular}{|l|l|}
\hline$x$ & SIM \\
\hline & NÃO \\
\hline
\end{tabular}

8) Usou os conhecimentos para ministrar outros cursos com o mesmo conteúdo ou conteúdos semelhantes? 


\begin{tabular}{|l|l|}
\hline$x$ & SIM \\
\hline & NÃO \\
\hline
\end{tabular}

9) Marque o seu grau de satisfação com relação ao curso oferecido pelo DATER: (Considere a seguinte pontuação: 1 - MUITO RUIM; 2 - RUIM; 3 - REGULAR; 4 - BOM; 5 - MUITO BOM)

\begin{tabular}{|l|l|l|l|l|}
\hline 1 & 2 & 3 & 4 & 5 \\
\hline
\end{tabular}

10) Marque seu grau de satisfação com relação ao DATER: (Considere a seguinte pontuação: 1 - MUITO RUIM; 2 - RUIM; 3 - REGULAR; 4 - BOM; 5 - MUITO BOM)

\begin{tabular}{|l|l|l|l|l|}
\hline 1 & 2 & 3 & 4 & 5 \\
\hline
\end{tabular}


PESQUISA - IMPACTO DAS AÇÕES DE FORMAÇÃO REALIZADAS PELO DATER/SAF/MDA NO PERÍODO 2004-2009

Caros colaboradores,

Contamos com a sua atenção para preencher o formulário abaixo.

O mesmo tem por objetivo fornecer informações para avaliação da Eficiência, Efetividade e Eficácia da Política Pública de Formação de Agentes de Ater adotada pelo Departamento de Assistência Técnica e Extensão Rural, da Secretaria de Agricultura Familiar do Ministério do Desenvolvimento - DATER/SAF/MDA, no período de 2004 a 2009, tema escolhido para Monografia a ser apresentada à Universidade de Brasília (UnB) como requisito parcial para obtenção do grau de Bacharel em Administração.

Você poderá ou não se identificar no questionário e garantimos que todas as informações fornecidas serão confidenciais e utilizadas apenas de forma sistematizada.

\section{IDENTIFICAÇÃO}

\begin{tabular}{|l|l|}
\hline Nome: Cristiano Martins da Costa Guerra & $\begin{array}{l}\text { Sexo: } \\
(x) \text { masculino } \quad(\quad \text { ) feminino }\end{array}$ \\
\hline Instituição : EMATER-MG & $\begin{array}{l}\text { Local de trabalho: São Sebastião do } \\
\text { Maranhão-MG }\end{array}$ \\
\hline $\begin{array}{l}\text { Curso/Encontro/Oficina do qual participou (caso tenha participado de mais de um curso, preencha } \\
\text { um formulário para cada um deles): Curso a distância - Aperfeiçoamento em Agroecologia- } \\
\text { Redcapa }\end{array}$ \\
\hline Data do Curso/Encontro/Oficina (pelo menos mês e ano): março de 2006 \\
\hline
\end{tabular}

Indique sua área de atuação? (As opções não são excludentes: você poderá marcar mais de uma opção).

\begin{tabular}{|l|l|}
\hline$X$ & EXTENSÃO RURAL \\
\hline & PESQUISA \\
\hline & ENSINO \\
\hline & OUTROS \\
\hline
\end{tabular}


2) Qual o seu nível de escolaridade? (Considere apenas o nível mais alto)

\begin{tabular}{|l|l|}
\hline & NÍVEL MÉDIO \\
\hline$X$ & NÍVEL SUPERIOR \\
\hline & PÓS-GRADUAÇÃO \\
\hline
\end{tabular}

3) Os conteúdos abordados foram condizentes com as demandas do seu dia-a-dia?

\begin{tabular}{|l|l|}
\hline$X$ & SIM \\
\hline & PARCIALMENTE \\
\hline & NÃO \\
\hline
\end{tabular}

4) O curso contribuiu para o seu aperfeiçoamento profissional?

\begin{tabular}{|l|l|}
\hline$X$ & SIM \\
\hline & NÃO \\
\hline
\end{tabular}

5) Os conhecimentos adquiridos estão sendo aplicados no seu trabalho? Em caso afirmativo, indique em que grau estes conhecimentos estão sendo aplicados. Em caso negativo, indique por que razão isto não ocorre: (As respostas não são excludentes: você poderá marcar mais de uma opção).

\begin{tabular}{|l|l|l|l|}
\hline \multirow{2}{*}{$\begin{array}{l}\text { SIM (indique ao lado em } \\
\text { que grau) }\end{array}$} & & MUITO APLICADOS \\
\cline { 2 - 4 } & $\mathrm{X}$ & MEDIAMENTE APLICADOS \\
\hline & $\begin{array}{l}\text { NÃO (indique ao lado a } \\
\text { razão da não aplicação) }\end{array}$ & & $\begin{array}{l}\text { CONTEÚDO NÃO ADEQUADO ȦS NECESSIDADES } \\
\text { ESPECÍFICAS DA REGIÃO }\end{array}$ \\
\hline
\end{tabular}




\begin{tabular}{|l|l|l|}
\hline \multirow{10}{*}{} & $\begin{array}{l}\text { CONTEÚDO NÃO FOI SUFICIENTEMENTE } \\
\text { APROFUNDADO PARA PERMITIR UMA APLICAÇÃO } \\
\text { EFICAZ E EFICIENTE }\end{array}$ \\
\cline { 2 - 4 } & $\begin{array}{l}\text { FALTA DE APOIO E INCENTIVO DA MINHA } \\
\text { INSTITUIÇÃO }\end{array}$ \\
\cline { 2 - 4 } & FALTA DE INCENTIVO ÀS AÇÕES DE ATER \\
\hline & NÃO TENHO INTERESSE EM APLICAR \\
\hline
\end{tabular}

6) A partir deste curso: (As opções não são excludentes: você poderá marcar mais de uma opção).

\begin{tabular}{|l|l|}
\hline & NÃO MUDOU NADA EM MEU TRABALHO. \\
\hline$x$ & $\begin{array}{l}\text { MEU TRABALHO PASSOU A CONTRIBUIR MAIS COM OS AGRICULTORES(AS) } \\
\text { FAMILIARES. }\end{array}$ \\
\hline & CONSEGUI INFLUENCIAR NAS ORIENTAÇÕES DA MINHA INSTITUIÇÃO. \\
\hline & $\begin{array}{l}\text { CRESESE A TRABALHAR COM METODOLOGIAS PARTICIPATIVAS. } \\
\text { ONDE ATUO. ÁREA DE AGRICULTURA DE BASE ECOLÓGICA NAS COMUNIDADES }\end{array}$ \\
\hline$x$ & CONTINUEI ME APERFEIÇOANDO SOBRE TEMAS ABORDADOS. \\
\hline
\end{tabular}

7) Depois do curso você apoiou atividades de capacitação de técnicos e agricultores com base nos princípios e diretrizes da Pnater? (Considere como apoio a atividades de capacitação a participação no planejamento, elaboração de ementas, seleção de participantes e de palestrantes.)

\begin{tabular}{|l|l|}
\hline$X$ & SIM \\
\hline & NÃO \\
\hline
\end{tabular}

8) Usou os conhecimentos para ministrar outros cursos com o mesmo conteúdo ou conteúdos semelhantes? 


\begin{tabular}{|l|l|}
\hline$X$ & SIM \\
\hline & NÃO \\
\hline
\end{tabular}

9) Marque o seu grau de satisfação com relação ao curso oferecido pelo DATER: (Considere a seguinte pontuação: 1 - MUITO RUIM; 2 - RUIM; 3 - REGULAR; 4 - BOM; 5 - MUITO BOM)

\begin{tabular}{|l|l|l|l|l|}
\hline 1 & 2 & $3 \times$ & 4 & 5 \\
\hline
\end{tabular}

10) Marque seu grau de satisfação com relação ao DATER: (Considere a seguinte pontuação: 1 - MUITO RUIM; 2 - RUIM; 3 - REGULAR; 4 - BOM; 5 - MUITO BOM)

\begin{tabular}{|l|l|l|l|l|}
\hline 1 & 2 & 3 & $4 \times$ & 5 \\
\hline
\end{tabular}


PESQUISA - IMPACTO DAS AÇÕES DE FORMAÇÃO REALIZADAS PELO DATER/SAF/MDA NO PERÍODO 2004-2009

Caros colaboradores,

Contamos com a sua atenção para preencher o formulário abaixo.

O mesmo tem por objetivo fornecer informações para avaliação da Eficiência, Efetividade e Eficácia da Política Pública de Formação de Agentes de Ater adotada pelo Departamento de Assistência Técnica e Extensão Rural, da Secretaria de Agricultura Familiar do Ministério do Desenvolvimento - DATER/SAF/MDA, no período de 2004 a 2009, tema escolhido para Monografia a ser apresentada à Universidade de Brasília (UnB) como requisito parcial para obtenção do grau de Bacharel em Administração.

Você poderá ou não se identificar no questionário e garantimos que todas as informações fornecidas serão confidenciais e utilizadas apenas de forma sistematizada.

\section{IDENTIFICAÇÃO}

\begin{tabular}{|l|l|}
\hline Nome: Alexandre Magno Lopes Gollo & $\begin{array}{l}\text { Sexo: } \\
(x \quad) \text { masculino } \quad(\quad) \text { feminino }\end{array}$ \\
\hline Instituição CEDRO - Cooperativa de Serviços & $\begin{array}{l}\text { Local de trabalho Cidades do interior do } \\
\text { Estado do RJ. }\end{array}$ \\
\hline $\begin{array}{l}\text { Curso/Encontro/Oficina do qual participou Curso de Especialização em Extensão Rural para o } \\
\text { Desenvolvimento Sustentável - Turma de Recife. }\end{array}$ \\
\hline \begin{tabular}{l} 
Data do Curso/Encontro/Oficina Julho-agosto-novembro/2005 a fevereiro 2006. \\
\hline
\end{tabular}
\end{tabular}

Indique sua área de atuação? (As opções não são excludentes: você poderá marcar mais de uma opção).

\begin{tabular}{|l|l|}
\hline$X$ & EXTENSÃO RURAL \\
\hline & PESQUISA \\
\hline & ENSINO \\
\hline & OUTROS \\
\hline
\end{tabular}


2) Qual o seu nível de escolaridade? (Considere apenas o nível mais alto)

\begin{tabular}{|l|l|}
\hline & NÍVEL MÉDIO \\
\hline$X$ & NÍVEL SUPERIOR \\
\hline & PÓS-GRADUAÇÃO \\
\hline
\end{tabular}

3) Os conteúdos abordados foram condizentes com as demandas do seu dia-a-dia?

\begin{tabular}{|l|l|}
\hline$X$ & SIM \\
\hline & PARCIALMENTE \\
\hline & NÃO \\
\hline
\end{tabular}

4) O curso contribuiu para o seu aperfeiçoamento profissional?

\begin{tabular}{|l|l|}
\hline$X$ & SIM \\
\hline & NÃO \\
\hline
\end{tabular}

5) Os conhecimentos adquiridos estão sendo aplicados no seu trabalho? Em caso afirmativo, indique em que grau estes conhecimentos estão sendo aplicados. Em caso negativo, indique por que razão isto não ocorre: (As respostas não são excludentes: você poderá marcar mais de uma opção).

\begin{tabular}{|l|l|l|l|}
\hline \multirow{2}{*}{$\begin{array}{l}\text { SIM (indique ao lado em } \\
\text { que grau) }\end{array}$} & & MUITO APLICADOS \\
\cline { 2 - 3 } & & MEDIAMENTE APLICADOS \\
\hline & $\begin{array}{l}\text { NÃO (indique ao lado a } \\
\text { razão da não aplicação) }\end{array}$ & $\begin{array}{l}\text { CONTEÚDO NÃO ADEQUADO ȦS NECESSIDADES } \\
\text { ESPECÍFICAS DA REGIÃO }\end{array}$ \\
\hline
\end{tabular}




\begin{tabular}{|l|l|l|}
\hline \multirow{10}{*}{} & & $\begin{array}{l}\text { CONTEÚDO NÃO FOI SUFICIENTEMENTE } \\
\text { APROFUNDADO PARA PERMITIR UMA APLICAÇÃO } \\
\text { EFICAZ E EFICIENTE }\end{array}$ \\
\cline { 2 - 5 } & $\begin{array}{l}\text { FALTA DE APOIO E INCENTIVO DA MINHA } \\
\text { INSTITUIÇÃO }\end{array}$ \\
\cline { 2 - 4 } & FALTA DE INCENTIVO ÀS AÇÕES DE ATER \\
\hline & NÃO TENHO INTERESSE EM APLICAR \\
\hline
\end{tabular}

6) A partir deste curso: (As opções não são excludentes: você poderá marcar mais de uma opção).

\begin{tabular}{|l|l|}
\hline & NÃO MUDOU NADA EM MEU TRABALHO. \\
\hline$X$ & * Me senti mais firme para exercer o meu trabalho \\
\hline & CONSEGUI INFLUENCIAR NAS ORIENTAÇÕES DA MINHA INSTITUIÇÃO. \\
\hline & PASSEI A TRABALHAR COM METODOLOGIAS PARTICIPATIVAS. \\
\hline & $\begin{array}{l}\text { CRESCEU A ÁREA DE AGRICULTURA DE BASE ECOLÓGICA NAS COMUNIDADES } \\
\text { ONDE ATUO. }\end{array}$ \\
\hline & CONTINUEI ME APERFEIÇOANDO SOBRE TEMAS ABORDADOS. \\
\hline
\end{tabular}

7) Depois do curso você apoiou atividades de capacitação de técnicos e agricultores com base nos princípios e diretrizes da Pnater? (Considere como apoio a atividades de capacitação a participação no planejamento, elaboração de ementas, seleção de participantes e de palestrantes.)

\begin{tabular}{|l|l|}
\hline$X$ & SIM \\
\hline & NÃO \\
\hline
\end{tabular}

8) Usou os conhecimentos para ministrar outros cursos com o mesmo conteúdo ou conteúdos semelhantes? 


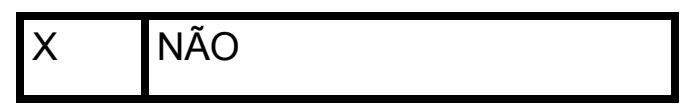

9) Marque o seu grau de satisfação com relação ao curso oferecido pelo DATER: (Considere a seguinte pontuação: 1 - MUITO RUIM; 2 - RUIM; 3 - REGULAR; 4 - BOM; 5 - MUITO BOM)

\begin{tabular}{|l|l|l|l|l|}
\hline 1 & 2 & 3 & $4-X$ & 5 \\
\hline
\end{tabular}

10) Marque seu grau de satisfação com relação ao DATER: (Considere a seguinte pontuação: 1 - MUITO RUIM; 2 - RUIM; 3 - REGULAR; 4 - BOM; 5 - MUITO BOM)

\begin{tabular}{|l|l|l|l|l|}
\hline 1 & 2 & $3-X$ & 4 & 5 \\
\hline
\end{tabular}

OBS: A expectativa com o curso e com o eventual aproveitamento na multiplicação dos conceitos da nova ATER não foi atendida. Tampouco o PEATER-RJ, que ajudamos a construir, encontra espaços concretos para fortalecer o setor não estatal. 
PESQUISA - IMPACTO DAS AÇÕES DE FORMAÇÃO REALIZADAS PELO DATER/SAF/MDA NO PERÍODO 2004-2009

Caros colaboradores,

Contamos com a sua atenção para preencher o formulário abaixo.

O mesmo tem por objetivo fornecer informações para avaliação da Eficiência, Efetividade e Eficácia da Política Pública de Formação de Agentes de Ater adotada pelo Departamento de Assistência Técnica e Extensão Rural, da Secretaria de Agricultura Familiar do Ministério do Desenvolvimento - DATER/SAF/MDA, no período de 2004 a 2009, tema escolhido para Monografia a ser apresentada à Universidade de Brasília (UnB) como requisito parcial para obtenção do grau de Bacharel em Administração.

Você poderá ou não se identificar no questionário e garantimos que todas as informações fornecidas serão confidenciais e utilizadas apenas de forma sistematizada.

\section{IDENTIFICAÇÃO}

\begin{tabular}{|c|c|}
\hline Nome: Miryam Terezinha Silva Belo & $\begin{array}{l}\text { Sexo: } \\
(\quad) \text { masculino }(x) \text { feminino }\end{array}$ \\
\hline $\begin{array}{l}\text { Instituição: atualmente estou na Comissão Pastoral } \\
\text { da Terra (CPT), mas quando fiz o curso de } \\
\text { Extensão estava na EMATER/MG. }\end{array}$ & $\begin{array}{l}\text { Local de trabalho: CPT (Salvador/BA) } \\
\text { EMATER (Medina/MG) }\end{array}$ \\
\hline \multicolumn{2}{|c|}{$\begin{array}{l}\text { Curso/Encontro/Oficina do qual participou (caso tenha participado de mais de um curso, preencha } \\
\text { um formulário para cada um deles): Especialização Desenvolvimento Sustentável (UNB) }\end{array}$} \\
\hline ficina: Outubro de 2005 & 06 \\
\hline
\end{tabular}

Indique sua área de atuação? (As opções não são excludentes: você poderá marcar mais de uma opção). Atualmente assessoria, lembrando que neste meio tempo fui para coordenação do ATES e uma conveniada na Bahia.

\begin{tabular}{|l|l|}
\hline$X$ & EXTENSÃO RURAL \\
\hline & PESQUISA \\
\hline & ENSINO \\
\hline
\end{tabular}




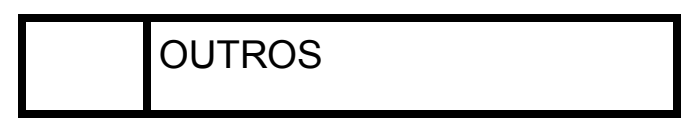

2) Qual o seu nível de escolaridade? (Considere apenas o nível mais alto)

\begin{tabular}{|c|l|}
\hline & NÍVEL MÉDIO \\
\hline & NÍVEL SUPERIOR \\
\hline$X$ & PÓS-GRADUAÇÃO \\
\hline
\end{tabular}

3) Os conteúdos abordados foram condizentes com as demandas do seu dia-a-dia?

\begin{tabular}{|l|l|}
\hline$X$ & SIM \\
\hline & PARCIALMENTE \\
\hline & NÃO \\
\hline
\end{tabular}

4) O curso contribuiu para o seu aperfeiçoamento profissional?

\begin{tabular}{|l|l|}
\hline$X$ & SIM \\
\hline & NÃO \\
\hline
\end{tabular}

5) Os conhecimentos adquiridos estão sendo aplicados no seu trabalho? Em caso afirmativo, indique em que grau estes conhecimentos estão sendo aplicados. Em caso negativo, indique por que razão isto não ocorre: (As respostas não são excludentes: você poderá marcar mais de uma opção).

\begin{tabular}{|c|c|c|}
\hline \multirow{3}{*}{$\begin{array}{l}\text { SIM (indique ao lado em } \\
\text { que grau) }\end{array}$} & $x$ & MUITO APLICADOS \\
\hline & & MEDIAMENTE APLICADOS \\
\hline & & POUCO APLICADOS \\
\hline \multirow{2}{*}{$\begin{array}{l}\text { NÃO (indique ao lado a } \\
\text { razão da não aplicação) }\end{array}$} & & $\begin{array}{l}\text { CONTEÚDO NÃO ADEQUADO ȦS NECESSIDADES } \\
\text { ESPECÍFICAS DA REGIÃO }\end{array}$ \\
\hline & & $\begin{array}{l}\text { CONTEÚDO NÃO } \quad \text { FOI SUFICIENTEMENTE } \\
\text { APROFUNDADO PARA } \\
\text { PERMITIR UMA APLICAÇÃO } \\
\text { EFICAZ E EFICIENTE }\end{array}$ \\
\hline
\end{tabular}




\begin{tabular}{|l|l|l|}
\hline \multirow{2}{*}{} & & $\begin{array}{l}\text { FALTA DE APOIO E INCENTIVO DA MINHA } \\
\text { INSTITUIÇÃO }\end{array}$ \\
\cline { 2 - 3 } & & FALTA DE INCENTIVO ÀS AÇÕES DE ATER \\
\cline { 2 - 3 } & & NÃO TENHO INTERESSE EM APLICAR \\
\hline
\end{tabular}

6) A partir deste curso: (As opções não são excludentes: você poderá marcar mais de uma opção).

\begin{tabular}{|c|l|}
\hline$x$ & $\begin{array}{l}\text { NÃO MUDOU NADA EM MEU TRABALHO. } \\
\text { FAMILIARES. }\end{array}$ \\
\hline$x$ & CONSEGUI INFLUENCIAR NAS ORIENTAÇÕES DA MINHA INSTITUIÇÃO. \\
\hline & PASSEI A TRABALHAR COM METODOLOGIAS PARTICIPATIVAS. \\
\hline$x$ & $\begin{array}{l}\text { CRESCEU A ÁREA DE AGRICULTURA DE BASE ECOLÓGICA NAS COMUNIDADES } \\
\text { ONDE ATUO. }\end{array}$ \\
\hline$x$ & CONTINUEI ME APERFEIÇOANDO SOBRE TEMAS ABORDADOS. \\
\hline
\end{tabular}

7) Depois do curso você apoiou atividades de capacitação de técnicos e agricultores com base nos princípios e diretrizes da Pnater? (Considere como apoio a atividades de capacitação a participação no planejamento, elaboração de ementas, seleção de participantes e de palestrantes.)

\begin{tabular}{|l|l|}
\hline$x$ & SIM \\
\hline & NÃO \\
\hline
\end{tabular}

8) Usou os conhecimentos para ministrar outros cursos com o mesmo conteúdo ou conteúdos semelhantes?

\begin{tabular}{|l|l|}
\hline$x$ & SIM \\
\hline & NÃO \\
\hline
\end{tabular}


9) Marque o seu grau de satisfação com relação ao curso oferecido pelo DATER: (Considere a seguinte pontuação: 1 - MUITO RUIM; 2 - RUIM; 3 - REGULAR; 4 - BOM; 5 - MUITO BOM)

\begin{tabular}{|l|l|l|l|l|}
\hline 1 & 2 & 3 & 4 & $5 \times$ \\
\hline
\end{tabular}

10) Marque seu grau de satisfação com relação ao DATER: (Considere a seguinte pontuação: 1 - MUITO RUIM; 2 - RUIM; 3 - REGULAR; 4 - BOM; 5 - MUITO BOM)

\begin{tabular}{|l|l|l|l|l|}
\hline 1 & 2 & 3 & $4 \times$ & 5 \\
\hline
\end{tabular}


PESQUISA - IMPACTO DAS AÇÕES DE FORMAÇÃO REALIZADAS PELO DATER/SAF/MDA NO PERÍODO 2004-2009

Caros colaboradores,

Contamos com a sua atenção para preencher o formulário abaixo.

O mesmo tem por objetivo fornecer informações para avaliação da Eficiência, Efetividade e Eficácia da Política Pública de Formação de Agentes de Ater adotada pelo Departamento de Assistência Técnica e Extensão Rural, da Secretaria de Agricultura Familiar do Ministério do Desenvolvimento - DATER/SAF/MDA, no período de 2004 a 2009, tema escolhido para Monografia a ser apresentada à Universidade de Brasília (UnB) como requisito parcial para obtenção do grau de Bacharel em Administração.

Você poderá ou não se identificar no questionário e garantimos que todas as informações fornecidas serão confidenciais e utilizadas apenas de forma sistematizada.

\section{IDENTIFICAÇÃO}

\begin{tabular}{|l|l|}
\hline Nome: Gérson José Yunes Antonio & $\begin{array}{l}\text { Sexo: } \\
(x) \text { masculino } \quad(\quad \text { ) feminino }\end{array}$ \\
\hline Instituição (nome e tipo de instituição: ONG, & $\begin{array}{l}\text { Local de trabalho (Cidade e Estado): Santa } \\
\text { Empresa Pública, etc.): EMATER-RIO - Empresa } \\
\text { Maria Madalena - RJ }\end{array}$ \\
\hline Cública & \\
\hline um formulário para cada um deles): Agentes de ATER \\
\hline Data do Curso/Encontro/Oficina (pelo menos mês e ano): Abril/ 2006 \\
\hline
\end{tabular}

Indique sua área de atuação? (As opções não são excludentes: você poderá marcar mais de uma opção).

\begin{tabular}{|l|l|}
\hline$x$ & EXTENSÃO RURAL \\
\hline & PESQUISA \\
\hline & ENSINO \\
\hline & OUTROS \\
\hline
\end{tabular}


2) Qual o seu nível de escolaridade? (Considere apenas o nível mais alto)

\begin{tabular}{|l|l|}
\hline & NÍVEL MÉDIO \\
\hline$x$ & NÍVEL SUPERIOR \\
\hline & PÓS-GRADUAÇÃO \\
\hline
\end{tabular}

3) Os conteúdos abordados foram condizentes com as demandas do seu dia-a-dia?

\begin{tabular}{|l|l|}
\hline$x$ & SIM \\
\hline & PARCIALMENTE \\
\hline & NÃO \\
\hline
\end{tabular}

4) O curso contribuiu para o seu aperfeiçoamento profissional?

\begin{tabular}{|l|l|}
\hline$x$ & SIM \\
\hline & NÃO \\
\hline
\end{tabular}

5) Os conhecimentos adquiridos estão sendo aplicados no seu trabalho? Em caso afirmativo, indique em que grau estes conhecimentos estão sendo aplicados. Em caso negativo, indique por que razão isto não ocorre: (As respostas não são excludentes: você poderá marcar mais de uma opção).

\begin{tabular}{|l|l|l|l|}
\hline \multirow{2}{*}{$\times$} & $\begin{array}{l}\text { SIM (indique ao lado em } \\
\text { que grau) }\end{array}$ & & MUITO APLICADOS \\
\cline { 2 - 4 } & & MEDIAMENTE APLICADOS \\
\hline & $\begin{array}{l}\text { NÃO (indique ao lado a } \\
\text { razão da não aplicação) }\end{array}$ & & $\begin{array}{l}\text { CONTEU்DO NÃO ADEQUADO ÁS NECESSIDADES } \\
\text { ESPECÍFICAS DA REGIÃO }\end{array}$ \\
\hline
\end{tabular}




\begin{tabular}{|l|l|l|}
\hline \multirow{10}{*}{} & $\begin{array}{l}\text { CONTEÚDO NÃO FOI SUFICIENTEMENTE } \\
\text { APROFUNDADO PARA PERMITIR UMA APLICAÇÃO } \\
\text { EFICAZ E EFICIENTE }\end{array}$ \\
\cline { 2 - 4 } & $\begin{array}{l}\text { FALTA DE APOIO E INCENTIVO DA MINHA } \\
\text { INSTITUIÇÃO }\end{array}$ \\
\cline { 2 - 4 } & FALTA DE INCENTIVO ÀS AÇÕES DE ATER \\
\hline & NÃO TENHO INTERESSE EM APLICAR \\
\hline
\end{tabular}

6) A partir deste curso: (As opções não são excludentes: você poderá marcar mais de uma opção).

\begin{tabular}{|r|l|}
\hline$x$ & $\begin{array}{l}\text { NẼO MUDOU NADA EM MEU TRABALHO. } \\
\text { FAMILIARES. }\end{array}$ \\
\hline & CONSEGUI INFLUENCIAR NAS ORIENTAÇÕES DA MINHA INSTITUIÇÃO. \\
\hline$x$ & PASSEI A TRABALHAR COM METODOLOGIAS PARTICIPATIVAS. \\
\hline & $\begin{array}{l}\text { CRESCEU A ÁREA DE AGRICULTURA DE BASE ECOLÓGICA NAS COMUNIDADES } \\
\text { ONDE ATUO. }\end{array}$ \\
\hline$x$ & CONTINUEI ME APERFEIÇOANDO SOBRE TEMAS ABORDADOS. \\
\hline
\end{tabular}

7) Depois do curso você apoiou atividades de capacitação de técnicos e agricultores com base nos princípios e diretrizes da Pnater? (Considere como apoio a atividades de capacitação a participação no planejamento, elaboração de ementas, seleção de participantes e de palestrantes.)

\begin{tabular}{|l|l|}
\hline$x$ & SIM \\
\hline & NÃO \\
\hline
\end{tabular}

8) Usou os conhecimentos para ministrar outros cursos com o mesmo conteúdo ou conteúdos semelhantes? 


\begin{tabular}{|l|l|}
\hline & SIM \\
\hline$x$ & NÃO \\
\hline
\end{tabular}

9) Marque o seu grau de satisfação com relação ao curso oferecido pelo DATER: (Considere a seguinte pontuação: 1 - MUITO RUIM; 2 - RUIM; 3 - REGULAR; 4 - BOM; 5 - MUITO BOM)

\begin{tabular}{|l|l|l|l|l|}
\hline 1 & 2 & 3 & 4 & $5 x$ \\
\hline
\end{tabular}

10) Marque seu grau de satisfação com relação ao DATER: (Considere a seguinte pontuação: 1 - MUITO RUIM; 2 - RUIM; 3 - REGULAR; 4 - BOM; 5 - MUITO BOM)

\begin{tabular}{|l|l|l|l|l|}
\hline 1 & 2 & 3 & 4 & $5 x$ \\
\hline
\end{tabular}


PESQUISA - IMPACTO DAS AÇÕES DE FORMAÇÃO REALIZADAS PELO DATER/SAF/MDA NO PERÍODO 2004-2009

Caros colaboradores,

Contamos com a sua atenção para preencher o formulário abaixo.

O mesmo tem por objetivo fornecer informações para avaliação da Eficiência, Efetividade e Eficácia da Política Pública de Formação de Agentes de Ater adotada pelo Departamento de Assistência Técnica e Extensão Rural, da Secretaria de Agricultura Familiar do Ministério do Desenvolvimento - DATER/SAF/MDA, no período de 2004 a 2009, tema escolhido para Monografia a ser apresentada à Universidade de Brasília (UnB) como requisito parcial para obtenção do grau de Bacharel em Administração.

Você poderá ou não se identificar no questionário e garantimos que todas as informações fornecidas serão confidenciais e utilizadas apenas de forma sistematizada.

\section{IDENTIFICAÇÃO}

\begin{tabular}{|l|l|}
\hline Nome: MAXWEL ASSIS DE SOUZA & $\begin{array}{l}\text { Sexo: } \\
(x) \text { masculino } \quad(\quad) \text { feminino }\end{array}$ \\
\hline $\begin{array}{l}\text { Instituição (nome e tipo de instituição: ONG, } \\
\text { Empresa Pública, etc.): INCAPER }\end{array}$ & $\begin{array}{l}\text { Local de trabalho (Cidade e Estado): } \\
\text { GUAÇUÍ - ES }\end{array}$ \\
\hline $\begin{array}{l}\text { Curso/Encontro/Oficina do qual participou (caso tenha participado de mais de um curso, preencha } \\
\text { um formulário para cada um deles): APERFEIÇOAMENTO EM AGROECOLOGIA }\end{array}$ \\
\hline Data do Curso/Encontro/Oficina (pelo menos mês e ano): 07/2006 \\
\hline
\end{tabular}

Indique sua área de atuação? (As opções não são excludentes: você poderá marcar mais de uma opção).

\begin{tabular}{|l|l|}
\hline$X$ & EXTENSÃO RURAL \\
\hline & PESQUISA \\
\hline & ENSINO \\
\hline
\end{tabular}




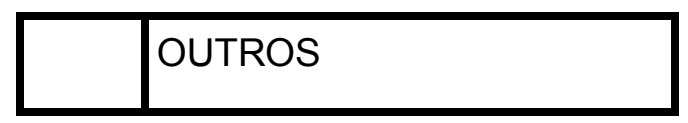

2) Qual o seu nível de escolaridade? (Considere apenas o nível mais alto)

\begin{tabular}{|l|l|}
\hline & NÍVEL MÉDIO \\
\hline & NÍVEL SUPERIOR \\
\hline$X$ & PÓS-GRADUAÇÃO \\
\hline
\end{tabular}

3) Os conteúdos abordados foram condizentes com as demandas do seu dia-a-dia?

\begin{tabular}{|l|l|}
\hline & SIM \\
\hline$X$ & PARCIALMENTE \\
\hline & NÃO \\
\hline
\end{tabular}

4) O curso contribuiu para o seu aperfeiçoamento profissional?

\begin{tabular}{|l|l|}
\hline$X$ & SIM \\
\hline & NÃO \\
\hline
\end{tabular}

5) Os conhecimentos adquiridos estão sendo aplicados no seu trabalho? Em caso afirmativo, indique em que grau estes conhecimentos estão sendo aplicados. Em caso negativo, indique por que razão isto não ocorre: (As respostas não são excludentes: você poderá marcar mais de uma opção).

\begin{tabular}{|l|l|l|l|}
\hline \multirow{2}{*}{$X$} & $\begin{array}{l}\text { SIM (indique ao lado em } \\
\text { que grau) }\end{array}$ & & MUITO APLICADOS \\
\cline { 2 - 4 } & $\begin{array}{l}\text { NÃO (indique ao lado a } \\
\text { razão da não aplicação) }\end{array}$ & & $\begin{array}{l}\text { MEDIAMENTE APLICADOS } \\
\text { EONTEÚDO NÃO ADEQUADO ÁS NECESSIDADES } \\
\text { ESPEAS DA REGIÃO }\end{array}$ \\
\hline
\end{tabular}




\begin{tabular}{|l|l|l|}
\hline \multirow{10}{*}{} & $\begin{array}{l}\text { CONTEÚDO NÃO FOI SUFICIENTEMENTE } \\
\text { APROFUNDADO PARA PERMITIR UMA APLICAÇÃO } \\
\text { EFICAZ E EFICIENTE }\end{array}$ \\
\cline { 2 - 4 } & $\begin{array}{l}\text { FALTA DE APOIO E INCENTIVO DA MINHA } \\
\text { INSTITUIÇÃO }\end{array}$ \\
\cline { 2 - 4 } & FALTA DE INCENTIVO ÀS AÇÕES DE ATER \\
\hline & NÃO TENHO INTERESSE EM APLICAR \\
\hline
\end{tabular}

6) A partir deste curso: (As opções não são excludentes: você poderá marcar mais de uma opção).

\begin{tabular}{|l|l|}
\hline$x$ & $\begin{array}{l}\text { NÃO MUDOU NADA EM MEU TRABALHO. } \\
\text { FAMILIARES. }\end{array}$ \\
\hline & CONSEGUI INFLUENCIAR NAS ORIENTAÇÕES DA MINHA INSTITUIÇÃO. \\
\hline & PASSEI A TRABALHAR COM METODOLOGIAS PARTICIPATIVAS. \\
\hline & $\begin{array}{l}\text { ORESCEU A ÁREA DE AGRICULTURA DE BASE ECOLÓGICA NAS COMUNIDADES } \\
\text { ONDE ATUO. }\end{array}$ \\
\hline &
\end{tabular}

7) Depois do curso você apoiou atividades de capacitação de técnicos e agricultores com base nos princípios e diretrizes da Pnater? (Considere como apoio a atividades de capacitação a participação no planejamento, elaboração de ementas, seleção de participantes e de palestrantes.)

\begin{tabular}{|l|l|}
\hline & SIM \\
\hline$X$ & NÃO \\
\hline
\end{tabular}

8) Usou os conhecimentos para ministrar outros cursos com o mesmo conteúdo ou conteúdos semelhantes? 


\begin{tabular}{|l|l|}
\hline & SIM \\
\hline$X$ & NÃO \\
\hline
\end{tabular}

9) Marque o seu grau de satisfação com relação ao curso oferecido pelo DATER: (Considere a seguinte pontuação: 1 - MUITO RUIM; 2 - RUIM; 3 - REGULAR; 4 - BOM; 5 - MUITO BOM)

\begin{tabular}{|l|l|l|l|l|}
\hline 1 & 2 & 3 & $4-X$ & 5 \\
\hline
\end{tabular}

10) Marque seu grau de satisfação com relação ao DATER: (Considere a seguinte pontuação: 1 - MUITO RUIM; 2 - RUIM; 3 - REGULAR; 4 - BOM; 5 - MUITO BOM)

\begin{tabular}{|l|l|l|l|l|}
\hline 1 & 2 & 3 & $4-X$ & 5 \\
\hline
\end{tabular}


PESQUISA - IMPACTO DAS AÇÕES DE FORMAÇÃO REALIZADAS PELO DATER/SAF/MDA NO PERÍODO 2004-2009

Caros colaboradores,

Contamos com a sua atenção para preencher o formulário abaixo.

O mesmo tem por objetivo fornecer informações para avaliação da Eficiência, Efetividade e Eficácia da Política Pública de Formação de Agentes de Ater adotada pelo Departamento de Assistência Técnica e Extensão Rural, da Secretaria de Agricultura Familiar do Ministério do Desenvolvimento - DATER/SAF/MDA, no período de 2004 a 2009, tema escolhido para Monografia a ser apresentada à Universidade de Brasília (UnB) como requisito parcial para obtenção do grau de Bacharel em Administração.

Você poderá ou não se identificar no questionário e garantimos que todas as informações fornecidas serão confidenciais e utilizadas apenas de forma sistematizada.

IDENTIFICAÇÃO

\begin{tabular}{|l|l|}
\hline Nome: Cristiano Martins da Costa Guerra & $\begin{array}{l}\text { Sexo: } \\
(x) \text { masculino } \quad(\quad \text { ) feminino }\end{array}$ \\
\hline Instituição : EMATER-MG & $\begin{array}{l}\text { Local de trabalho: São Sebastião do } \\
\text { Maranhão-MG }\end{array}$ \\
\hline $\begin{array}{l}\text { Curso/Encontro/Oficina do qual participou (caso tenha participado de mais de um curso, preencha } \\
\text { um formulário para cada um deles): Pós-graduação - Especialização em Agroecologia, Extensão } \\
\text { Rural e Desenvolvimento Sustentável - em Três Corações na Escola UNINCOR. }\end{array}$ \\
\hline Data do Curso/Encontro/Oficina (pelo menos mês e ano): março de 2006 a dezembro de 2006 \\
\hline
\end{tabular}

Indique sua área de atuação? (As opções não são excludentes: você poderá marcar mais de uma opção).

\begin{tabular}{|l|l|}
\hline$X$ & EXTENSÃO RURAL \\
\hline & PESQUISA \\
\hline & ENSINO \\
\hline & OUTROS \\
\hline
\end{tabular}

2) Qual o seu nível de escolaridade? (Considere apenas o nível mais alto) 


\begin{tabular}{|l|l|}
\hline & NÍVEL MÉDIO \\
\hline & NÍVEL SUPERIOR \\
\hline$X$ & PÓS-GRADUAÇÃO \\
\hline
\end{tabular}

3) Os conteúdos abordados foram condizentes com as demandas do seu dia-a-dia?

\begin{tabular}{|l|l|}
\hline$X$ & SIM \\
\hline & PARCIALMENTE \\
\hline & NÃO \\
\hline
\end{tabular}

4) O curso contribuiu para o seu aperfeiçoamento profissional?

\begin{tabular}{|l|l|}
\hline$X$ & SIM \\
\hline & NÃO \\
\hline
\end{tabular}

5) Os conhecimentos adquiridos estão sendo aplicados no seu trabalho? Em caso afirmativo, indique em que grau estes conhecimentos estão sendo aplicados. Em caso negativo, indique por que razão isto não ocorre: (As respostas não são excludentes: você poderá marcar mais de uma opção).

\begin{tabular}{|c|c|c|}
\hline \multirow{3}{*}{$\begin{array}{l}\text { SIM (indique ao lado em } \\
\text { que grau) }\end{array}$} & & MUITO APLICADOS \\
\hline & $x$ & MEDIAMENTE APLICADOS \\
\hline & & POUCO APLICADOS \\
\hline \multirow{3}{*}{$\begin{array}{l}\text { NÃO (indique ao lado a } \\
\text { razão da não aplicação) }\end{array}$} & & $\begin{array}{l}\text { CONTEÚDO NĀO ADEQUADO ȦS NECESSIDADES } \\
\text { ESPECÍFICAS DA REGIÃO }\end{array}$ \\
\hline & & $\begin{array}{l}\text { CONTEÚDO NÃO FOI SUFICIENTEMENTE } \\
\text { APROFUNDADO PARA PERMITIR UMA APLICAÇÃO } \\
\text { EFICAZ E EFICIENTE }\end{array}$ \\
\hline & & $\begin{array}{lllllll}\text { FALTA } & \text { DE } & \text { APOIO } & \text { E } & \text { INCENTIVO } & \text { DA } & \text { MINHA } \\
\text { INSTITUIÇÃO } & & & & \end{array}$ \\
\hline
\end{tabular}




\begin{tabular}{|l|l|l|}
\hline \multirow{2}{*}{} & & FALTA DE INCENTIVO ÀS AÇÕES DE ATER \\
\cline { 3 - 3 } & & NÃO TENHO INTERESSE EM APLICAR \\
\hline
\end{tabular}

6) A partir deste curso: (As opções não são excludentes: você poderá marcar mais de uma opção).

\begin{tabular}{|l|l|}
\hline & NÃO MUDOU NADA EM MEU TRABALHO. \\
\hline$x$ & $\begin{array}{l}\text { MEU TRABALHO PASSOU A CONTRIBUIR MAIS COM OS AGRICULTORES(AS) } \\
\text { FAMILIARES. }\end{array}$ \\
\hline & CONSEGUI INFLUENCIAR NAS ORIENTAÇÕES DA MINHA INSTITUIÇÃO. \\
\hline & $\begin{array}{l}\text { CRESCEU A ÁREA DE AGRICULTURA DE BASE ECOLÓGICA NAS COMUNIDADES } \\
\text { ONDE ATUO. }\end{array}$ \\
\hline$x$ & CONTINUEI ME APERFEIÇOANDO SOBRE TEMAS ABORDADOS. \\
\hline
\end{tabular}

7) Depois do curso você apoiou atividades de capacitação de técnicos e agricultores com base nos princípios e diretrizes da Pnater? (Considere como apoio a atividades de capacitação a participação no planejamento, elaboração de ementas, seleção de participantes e de palestrantes.)

\begin{tabular}{|l|l|}
\hline$X$ & SIM \\
\hline & NÃO \\
\hline
\end{tabular}

8) Usou os conhecimentos para ministrar outros cursos com o mesmo conteúdo ou conteúdos semelhantes?

\begin{tabular}{|l|l|}
\hline$X$ & SIM \\
\hline & NÃO \\
\hline
\end{tabular}


9) Marque o seu grau de satisfação com relação ao curso oferecido pelo DATER: (Considere a seguinte pontuação: 1 - MUITO RUIM; 2 - RUIM; 3 - REGULAR; 4 - BOM; 5 - MUITO BOM)

\begin{tabular}{|l|l|l|l|l|}
\hline 1 & 2 & 3 & $4 x$ & 5 \\
\hline
\end{tabular}

10) Marque seu grau de satisfação com relação ao DATER: (Considere a seguinte pontuação: 1 - MUITO RUIM; 2 - RUIM; 3 - REGULAR; 4 - BOM; 5 - MUITO BOM)

\begin{tabular}{|l|l|l|l|l|}
\hline 1 & 2 & 3 & $4 \times$ & 5 \\
\hline
\end{tabular}


PESQUISA - IMPACTO DAS AÇÕES DE FORMAÇÃO REALIZADAS PELO DATER/SAF/MDA NO PERÍODO 2004-2009

Caros colaboradores,

Contamos com a sua atenção para preencher o formulário abaixo.

O mesmo tem por objetivo fornecer informações para avaliação da Eficiência, Efetividade e Eficácia da Política Pública de Formação de Agentes de Ater adotada pelo Departamento de Assistência Técnica e Extensão Rural, da Secretaria de Agricultura Familiar do Ministério do Desenvolvimento - DATER/SAF/MDA, no período de 2004 a 2009, tema escolhido para Monografia a ser apresentada à Universidade de Brasília (UnB) como requisito parcial para obtenção do grau de Bacharel em Administração.

Você poderá ou não se identificar no questionário e garantimos que todas as informações fornecidas serão confidenciais e utilizadas apenas de forma sistematizada.

\section{IDENTIFICAÇÃO}

\begin{tabular}{|l|l|}
\hline Nome: Antônio Carlos Cavalcanti de Souza & $\begin{array}{l}\text { Sexo: } \\
(x) \text { masculino } \quad(\quad \text { ) feminino }\end{array}$ \\
\hline $\begin{array}{l}\text { Instituição (nome e tipo de instituição: ONG, } \\
\text { Empresa Pública, etc.): Instituto Capixaba de } \\
\text { Pesquisa Assistência Técnica e Extensão Rural }\end{array}$ & Anchieta - ES \\
\hline $\begin{array}{l}\text { Curso/Encontro/Oficina do qual participou (caso tenha participado de mais de um curso, preencha } \\
\text { um formulário para cada um deles): Oficina de Nivelamento Conceitual sobre a Política Nacional } \\
\text { de Assistência Técnica e Extensão Rural (Vitória - ES) }\end{array}$ \\
\hline Data do Curso/Encontro/Oficina (pelo menos mês e ano): 18 a 22 de outubro de 2004. \\
\hline
\end{tabular}

Indique sua área de atuação? (As opções não são excludentes: você poderá marcar mais de uma opção).

\begin{tabular}{|l|l|}
\hline$X$ & EXTENSÃO RURAL \\
\hline & PESQUISA \\
\hline & ENSINO \\
\hline
\end{tabular}




\section{OUTROS}

2) Qual o seu nível de escolaridade? (Considere apenas o nível mais alto)

\begin{tabular}{|l|l|}
\hline & NÍVEL MÉDIO \\
\hline & NÍVEL SUPERIOR \\
\hline$X$ & PÓS-GRADUAÇÃO \\
\hline
\end{tabular}

3) Os conteúdos abordados foram condizentes com as demandas do seu dia-a-dia?

\begin{tabular}{|l|l|}
\hline$X$ & SIM \\
\hline & PARCIALMENTE \\
\hline & NÃO \\
\hline
\end{tabular}

4) O curso contribuiu para o seu aperfeiçoamento profissional?

\begin{tabular}{|l|l|}
\hline$X$ & SIM \\
\hline & NÃO \\
\hline
\end{tabular}

5) Os conhecimentos adquiridos estão sendo aplicados no seu trabalho? Em caso afirmativo, indique em que grau estes conhecimentos estão sendo aplicados. Em caso negativo, indique por que razão isto não ocorre: (As respostas não são excludentes: você poderá marcar mais de uma opção).

\begin{tabular}{|l|l|l|l|}
\hline \multirow{2}{*}{$\begin{array}{l}\text { SIM (indique ao lado em } \\
\text { que grau) }\end{array}$} & X & MUITO APLICADOS \\
\cline { 2 - 3 } & $\begin{array}{l}\text { NÃO (indique ao lado a } \\
\text { razão da não aplicação) }\end{array}$ & $\begin{array}{l}\text { MEDIAMENTE APLICADOS } \\
\text { ESPECÍFICAS DA REGIÃO }\end{array}$ \\
\hline
\end{tabular}




\begin{tabular}{|l|l|l|}
\hline \multirow{10}{*}{} & $\begin{array}{l}\text { CONTEÚDO NÃO FOI SUFICIENTEMENTE } \\
\text { APROFUNDADO PARA PERMITIR UMA APLICAÇÃO } \\
\text { EFICAZ E EFICIENTE }\end{array}$ \\
\cline { 2 - 4 } & $\begin{array}{l}\text { FALTA DE APOIO E INCENTIVO DA MINHA } \\
\text { INSTITUIÇÃO }\end{array}$ \\
\cline { 2 - 4 } & FALTA DE INCENTIVO ÀS AÇÕES DE ATER \\
\hline & NÃO TENHO INTERESSE EM APLICAR \\
\hline
\end{tabular}

6) A partir deste curso: (As opções não são excludentes: você poderá marcar mais de uma opção).

\begin{tabular}{|c|c|}
\hline & NÃO MUDOU NADA EM MEU TRABALHO. \\
\hline $\mathrm{X}$ & $\begin{array}{l}\text { MEU TRABALHO PASSOU A CONTRIBUIR MAIS COM OS AGRICULTORES(AS) } \\
\text { FAMILIARES. }\end{array}$ \\
\hline $\mathrm{X}$ & CONSEGUI INFLUENCIAR NAS ORIENTAÇÕES DA MINHA INSTITUIÇÃO. \\
\hline \multirow[t]{2}{*}{$\mathrm{X}$} & PASSEI A TRABALHAR COM METODOLOGIAS PARTICIPATIVAS. \\
\hline & $\begin{array}{l}\text { CRESCEU A ÁREA DE AGRICULTURA DE BASE ECOLÓGICA NAS COMUNIDADES } \\
\text { ONDE ATUO. }\end{array}$ \\
\hline $\mathrm{X}$ & CONTINUEI ME APERFEIÇOANDO SOBRE TEMAS ABORDADOS. \\
\hline
\end{tabular}

7) Depois do curso você apoiou atividades de capacitação de técnicos e agricultores com base nos princípios e diretrizes da Pnater? (Considere como apoio a atividades de capacitação a participação no planejamento, elaboração de ementas, seleção de participantes e de palestrantes.)

\begin{tabular}{|l|l|}
\hline$X$ & SIM \\
\hline & NÃO \\
\hline
\end{tabular}

8) Usou os conhecimentos para ministrar outros cursos com o mesmo conteúdo ou conteúdos semelhantes? 


\begin{tabular}{|l|l|}
\hline$X$ & SIM \\
\hline & NÃO \\
\hline
\end{tabular}

9) Marque o seu grau de satisfação com relação ao curso oferecido pelo DATER: (Considere a seguinte pontuação: 1 - MUITO RUIM; 2 - RUIM; 3 - REGULAR; 4 - BOM; 5 - MUITO BOM)

\begin{tabular}{|l|l|l|l|l|}
\hline 1 & 2 & 3 & 4 & 5 ESTE \\
\hline
\end{tabular}

10) Marque seu grau de satisfação com relação ao DATER: (Considere a seguinte pontuação: 1 - MUITO RUIM; 2 - RUIM; 3 - REGULAR; 4 - BOM; 5 - MUITO BOM)

\begin{tabular}{|l|l|l|l|l|}
\hline 1 & 2 & 3 & 4 & 5 ESTE \\
\hline
\end{tabular}


PESQUISA - IMPACTO DAS AÇÕES DE FORMAÇÃO REALIZADAS PELO DATER/SAF/MDA NO PERÍODO 2004-2009

Caros colaboradores,

Contamos com a sua atenção para preencher o formulário abaixo.

O mesmo tem por objetivo fornecer informações para avaliação da Eficiência, Efetividade e Eficácia da Política Pública de Formação de Agentes de Ater adotada pelo Departamento de Assistência Técnica e Extensão Rural, da Secretaria de Agricultura Familiar do Ministério do Desenvolvimento - DATER/SAF/MDA, no período de 2004 a 2009, tema escolhido para Monografia a ser apresentada à Universidade de Brasília (UnB) como requisito parcial para obtenção do grau de Bacharel em Administração.

Você poderá ou não se identificar no questionário e garantimos que todas as informações fornecidas serão confidenciais e utilizadas apenas de forma sistematizada.

\section{IDENTIFICAÇÃO}

\begin{tabular}{|c|c|}
\hline Nome: Antônio Carlos Cavalcanti de Souza & $\begin{array}{l}\text { Sexo: } \\
(x \quad) \text { masculino } \quad(\quad) \text { feminino }\end{array}$ \\
\hline $\begin{array}{l}\text { Instituição (nome e tipo de instituição: ONG, } \\
\text { Empresa Pública, etc.): Instituto Capixaba de } \\
\text { Pesquisa Assistência Técnica e Extensão Rural }\end{array}$ & $\begin{array}{l}\text { Local de trabalho (Cidade e Estado): } \\
\text { Anchieta - ES }\end{array}$ \\
\hline \multicolumn{2}{|c|}{$\begin{array}{l}\text { Curso/Encontro/Oficina do qual participou (caso tenha participado de mais de um curso, preencha } \\
\text { um formulário para cada um deles): Curso de Agentes de Ater que atuam com Pescadores } \\
\text { Artesanais e Agricultores Familiares. (Florianópolis - SC) }\end{array}$} \\
\hline & \\
\hline
\end{tabular}

Indique sua área de atuação? (As opções não são excludentes: você poderá marcar mais de uma opção).

\begin{tabular}{|l|l|}
\hline$X$ & EXTENSÃO RURAL \\
\hline & PESQUISA \\
\hline & ENSINO \\
\hline & OUTROS \\
\hline
\end{tabular}


2) Qual o seu nível de escolaridade? (Considere apenas o nível mais alto)

\begin{tabular}{|l|l|}
\hline & NÍVEL MÉDIO \\
\hline & NÍVEL SUPERIOR \\
\hline$X$ & PÓS-GRADUAÇÃO \\
\hline
\end{tabular}

3) Os conteúdos abordados foram condizentes com as demandas do seu dia-a-dia?

\begin{tabular}{|l|l|}
\hline$X$ & SIM \\
\hline & PARCIALMENTE \\
\hline & NÃO \\
\hline
\end{tabular}

4) O curso contribuiu para o seu aperfeiçoamento profissional?

\begin{tabular}{|l|l|}
\hline$X$ & SIM \\
\hline & NÃO \\
\hline
\end{tabular}

5) Os conhecimentos adquiridos estão sendo aplicados no seu trabalho? Em caso afirmativo, indique em que grau estes conhecimentos estão sendo aplicados. Em caso negativo, indique por que razão isto não ocorre: (As respostas não são excludentes: você poderá marcar mais de uma opção).

\begin{tabular}{|l|l|l|l|}
\hline \multirow{2}{*}{$\begin{array}{l}\text { SIM (indique ao lado em } \\
\text { que grau) }\end{array}$} & X & MUITO APLICADOS \\
\cline { 2 - 4 } & & MEDIAMENTE APLICADOS \\
\cline { 2 - 4 } & $\begin{array}{l}\text { NÃO (indique ao lado a } \\
\text { razão da não aplicação) }\end{array}$ & & $\begin{array}{l}\text { CONTEÚDO NÃO ADEQUADO ȦS NECESSIDADES } \\
\text { ESPECÍFICAS DA REGIÃO }\end{array}$ \\
\hline
\end{tabular}




\begin{tabular}{|l|l|l|}
\hline \multirow{10}{*}{} & $\begin{array}{l}\text { CONTEÚDO NÃO FOI SUFICIENTEMENTE } \\
\text { APROFUNDADO PARA PERMITIR UMA APLICAÇÃO } \\
\text { EFICAZ E EFICIENTE }\end{array}$ \\
\cline { 2 - 4 } & $\begin{array}{l}\text { FALTA DE APOIO E INCENTIVO DA MINHA } \\
\text { INSTITUIÇÃO }\end{array}$ \\
\cline { 2 - 4 } & FALTA DE INCENTIVO ÀS AÇÕES DE ATER \\
\hline & NÃO TENHO INTERESSE EM APLICAR \\
\hline
\end{tabular}

6) A partir deste curso: (As opções não são excludentes: você poderá marcar mais de uma opção).

\begin{tabular}{|l|l|}
\hline & NÃO MUDOU NADA EM MEU TRABALHO. \\
\hline$X$ & $\begin{array}{l}\text { MEU TRABALHO PASSOU A CONTRIBUIR MAIS COM OS AGRICULTORES(AS) } \\
\text { FAMILIARES. }\end{array}$ \\
\hline$X$ & CONSEGUI INFLUENCIAR NAS ORIENTAÇÕES DA MINHA INSTITUIÇÃO. \\
\hline$X$ & PASSEI A TRABALHAR COM METODOLOGIAS PARTICIPATIVAS. \\
\hline & \begin{tabular}{l} 
ORESCEU A ÁREA DE AGRICULTURA DE BASE ECOLÓGICA NAS COMUNIDADES \\
\hline$X$
\end{tabular} \\
\hline
\end{tabular}

7) Depois do curso você apoiou atividades de capacitação de técnicos e agricultores com base nos princípios e diretrizes da Pnater? (Considere como apoio a atividades de capacitação a participação no planejamento, elaboração de ementas, seleção de participantes e de palestrantes.)

\begin{tabular}{|l|l|}
\hline$X$ & SIM \\
\hline & NÃO \\
\hline
\end{tabular}

8) Usou os conhecimentos para ministrar outros cursos com o mesmo conteúdo ou conteúdos semelhantes? 


\begin{tabular}{|l|l|}
\hline$X$ & SIM \\
\hline & NÃO \\
\hline
\end{tabular}

9) Marque o seu grau de satisfação com relação ao curso oferecido pelo DATER: (Considere a seguinte pontuação: 1 - MUITO RUIM; 2 - RUIM; 3 - REGULAR; 4 - BOM; 5 - MUITO BOM)

\begin{tabular}{|l|l|l|l|l|}
\hline 1 & 2 & 3 & 4 & 5 ESTE \\
\hline
\end{tabular}

10) Marque seu grau de satisfação com relação ao DATER: (Considere a seguinte pontuação: 1 - MUITO RUIM; 2 - RUIM; 3 - REGULAR; 4 - BOM; 5 - MUITO BOM)

\begin{tabular}{|l|l|l|l|l|}
\hline 1 & 2 & 3 & 4 & 5 ESTE \\
\hline
\end{tabular}


PESQUISA - IMPACTO DAS AÇÕES DE FORMAÇÃO REALIZADAS PELO DATER/SAF/MDA NO PERÍODO 2004-2009

Caros colaboradores,

Contamos com a sua atenção para preencher o formulário abaixo.

O mesmo tem por objetivo fornecer informações para avaliação da Eficiência, Efetividade e Eficácia da Política Pública de Formação de Agentes de Ater adotada pelo Departamento de Assistência Técnica e Extensão Rural, da Secretaria de Agricultura Familiar do Ministério do Desenvolvimento - DATER/SAF/MDA, no período de 2004 a 2009, tema escolhido para Monografia a ser apresentada à Universidade de Brasília (UnB) como requisito parcial para obtenção do grau de Bacharel em Administração.

Você poderá ou não se identificar no questionário e garantimos que todas as informações fornecidas serão confidenciais e utilizadas apenas de forma sistematizada.

\section{IDENTIFICAÇÃO}

\begin{tabular}{|c|c|}
\hline Nome: Antônio Carlos Cavalcanti de Souza & $\begin{array}{l}\text { Sexo: } \\
(x \quad) \text { masculino } \quad(\quad) \text { feminino }\end{array}$ \\
\hline $\begin{array}{l}\text { Instituição (nome e tipo de instituição: ONG, } \\
\text { Empresa Pública, etc.): Instituto Capixaba de } \\
\text { Pesquisa Assistência Técnica e Extensão Rural }\end{array}$ & $\begin{array}{l}\text { Local de trabalho (Cidade e Estado): } \\
\text { Anchieta - ES }\end{array}$ \\
\hline $\begin{array}{l}\text { Curso/Encontro/Oficina do qual participou (caso tent } \\
\text { um formulário para cada um deles): Curso de } \\
\text { Desenvolvimento Sustentável. (Recife-PE) }\end{array}$ & $\begin{array}{l}\text { ha participado de mais de um curso, preencha } \\
\text { Especialização em Extensão Rural para o }\end{array}$ \\
\hline
\end{tabular}

Indique sua área de atuação? (As opções não são excludentes: você poderá marcar mais de uma opção).

\begin{tabular}{|l|l|}
\hline$X$ & EXTENSÃO RURAL \\
\hline & PESQUISA \\
\hline & ENSINO \\
\hline & OUTROS \\
\hline
\end{tabular}


2) Qual o seu nível de escolaridade? (Considere apenas o nível mais alto)

\begin{tabular}{|l|l|}
\hline & NÍVEL MÉDIO \\
\hline & NÍVEL SUPERIOR \\
\hline$X$ & PÓS-GRADUAÇÃO \\
\hline
\end{tabular}

3) Os conteúdos abordados foram condizentes com as demandas do seu dia-a-dia?

\begin{tabular}{|l|l|}
\hline$X$ & SIM \\
\hline & PARCIALMENTE \\
\hline & NÃO \\
\hline
\end{tabular}

4) O curso contribuiu para o seu aperfeiçoamento profissional?

\begin{tabular}{|l|l|}
\hline$X$ & SIM \\
\hline & NÃO \\
\hline
\end{tabular}

5) Os conhecimentos adquiridos estão sendo aplicados no seu trabalho? Em caso afirmativo, indique em que grau estes conhecimentos estão sendo aplicados. Em caso negativo, indique por que razão isto não ocorre: (As respostas não são excludentes: você poderá marcar mais de uma opção).

\begin{tabular}{|l|l|l|l|}
\hline \multirow{2}{*}{$\begin{array}{l}\text { SIM (indique ao lado em } \\
\text { que grau) }\end{array}$} & X & MUITO APLICADOS \\
\cline { 2 - 3 } & & MEDIAMENTE APLICADOS \\
\hline & $\begin{array}{l}\text { NĀO (indique ao lado a } \\
\text { razão da não aplicação) }\end{array}$ & $\begin{array}{l}\text { CONTEÚDO NÃO ADEQUADO ȦS NECESSIDADES } \\
\text { ESPECÍFICAS DA REGIÃO }\end{array}$ \\
\hline
\end{tabular}




\begin{tabular}{|l|l|l|}
\hline \multirow{10}{*}{} & $\begin{array}{l}\text { CONTEÚDO NÃO FOI SUFICIENTEMENTE } \\
\text { APROFUNDADO PARA PERMITIR UMA APLICAÇÃO } \\
\text { EFICAZ E EFICIENTE }\end{array}$ \\
\cline { 2 - 4 } & $\begin{array}{l}\text { FALTA DE APOIO E INCENTIVO DA MINHA } \\
\text { INSTITUIÇÃO }\end{array}$ \\
\cline { 2 - 4 } & FALTA DE INCENTIVO ÀS AÇÕES DE ATER \\
\hline & NÃO TENHO INTERESSE EM APLICAR \\
\hline
\end{tabular}

6) A partir deste curso: (As opções não são excludentes: você poderá marcar mais de uma opção).

\begin{tabular}{|l|l|}
\hline & NÃO MUDOU NADA EM MEU TRABALHO. \\
\hline$X$ & $\begin{array}{l}\text { MEU TRABALHO PASSOU A CONTRIBUIR MAIS COM OS AGRICULTORES(AS) } \\
\text { FAMILIARES. }\end{array}$ \\
\hline$X$ & CONSEGUI INFLUENCIAR NAS ORIENTAÇÕES DA MINHA INSTITUIÇÃO. \\
\hline$X$ & PASSEI A TRABALHAR COM METODOLOGIAS PARTICIPATIVAS. \\
\hline & \begin{tabular}{l} 
ORESCEU A ÁREA DE AGRICULTURA DE BASE ECOLÓGICA NAS COMUNIDADES \\
\hline$X$
\end{tabular} \\
\hline
\end{tabular}

7) Depois do curso você apoiou atividades de capacitação de técnicos e agricultores com base nos princípios e diretrizes da Pnater? (Considere como apoio a atividades de capacitação a participação no planejamento, elaboração de ementas, seleção de participantes e de palestrantes.)

\begin{tabular}{|l|l|}
\hline$X$ & SIM \\
\hline & NÃO \\
\hline
\end{tabular}

8) Usou os conhecimentos para ministrar outros cursos com o mesmo conteúdo ou conteúdos semelhantes? 


\begin{tabular}{|l|l|}
\hline$X$ & SIM \\
\hline & NÃO \\
\hline
\end{tabular}

9) Marque o seu grau de satisfação com relação ao curso oferecido pelo DATER: (Considere a seguinte pontuação: 1 - MUITO RUIM; 2 - RUIM; 3 - REGULAR; 4 - BOM; 5 - MUITO BOM)

\begin{tabular}{|l|l|l|l|l|}
\hline 1 & 2 & 3 & 4 & 5 ESTE \\
\hline
\end{tabular}

10) Marque seu grau de satisfação com relação ao DATER: (Considere a seguinte pontuação: 1 - MUITO RUIM; 2 - RUIM; 3 - REGULAR; 4 - BOM; 5 - MUITO BOM)

\begin{tabular}{|l|l|l|l|l|}
\hline 1 & 2 & 3 & 4 & 5 ESTE \\
\hline
\end{tabular}


PESQUISA - IMPACTO DAS AÇÕES DE FORMAÇÃO REALIZADAS PELO DATER/SAF/MDA NO PERÍODO 2004-2009

Caros colaboradores,

Contamos com a sua atenção para preencher o formulário abaixo.

O mesmo tem por objetivo fornecer informações para avaliação da Eficiência, Efetividade e Eficácia da Política Pública de Formação de Agentes de Ater adotada pelo Departamento de Assistência Técnica e Extensão Rural, da Secretaria de Agricultura Familiar do Ministério do Desenvolvimento - DATER/SAF/MDA, no período de 2004 a 2009, tema escolhido para Monografia a ser apresentada à Universidade de Brasília (UnB) como requisito parcial para obtenção do grau de Bacharel em Administração.

Você poderá ou não se identificar no questionário e garantimos que todas as informações fornecidas serão confidenciais e utilizadas apenas de forma sistematizada.

\section{IDENTIFICAÇÃO}

\begin{tabular}{|l|l|}
\hline Nome: Antônio Carlos Cavalcanti de Souza & $\begin{array}{l}\text { Sexo: } \\
(x \quad) \text { masculino } \quad(\quad \text { ) feminino }\end{array}$ \\
\hline $\begin{array}{l}\text { Instituição (nome e tipo de instituição: ONG, } \\
\text { Empresa Pública, etc.): Instituto Capixaba de } \\
\text { Pesquisa Assistência Técnica e Extensão Rural }\end{array}$ & Anchieta - ES \\
\hline $\begin{array}{l}\text { Curso/Encontro/Oficina do qual participou (caso tenha participado de mais de um curso, preencha } \\
\text { um formulário para cada um deles): Oficina de Socialização dos Conceitos Básicos da Política } \\
\text { Nacional de Assistência Técnica e Extensão Rural. (Vila Velha -ES) }\end{array}$ \\
\hline Data do Curso/Encontro/Oficina (pelo menos mês e ano): 25 a 30 de junho de 2006. \\
\hline
\end{tabular}

Indique sua área de atuação? (As opções não são excludentes: você poderá marcar mais de uma opção).

\begin{tabular}{|l|l|}
\hline$X$ & EXTENSÃO RURAL \\
\hline & PESQUISA \\
\hline & ENSINO \\
\hline
\end{tabular}




\section{OUTROS}

2) Qual o seu nível de escolaridade? (Considere apenas o nível mais alto)

\begin{tabular}{|l|l|}
\hline & NÍVEL MÉDIO \\
\hline & NÍVEL SUPERIOR \\
\hline$X$ & PÓS-GRADUAÇÃO \\
\hline
\end{tabular}

3) Os conteúdos abordados foram condizentes com as demandas do seu dia-a-dia?

\begin{tabular}{|l|l|}
\hline$X$ & SIM \\
\hline & PARCIALMENTE \\
\hline & NÃO \\
\hline
\end{tabular}

4) O curso contribuiu para o seu aperfeiçoamento profissional?

\begin{tabular}{|l|l|}
\hline$X$ & SIM \\
\hline & NÃO \\
\hline
\end{tabular}

5) Os conhecimentos adquiridos estão sendo aplicados no seu trabalho? Em caso afirmativo, indique em que grau estes conhecimentos estão sendo aplicados. Em caso negativo, indique por que razão isto não ocorre:

\begin{tabular}{|l|l|l|l|}
\hline \multirow{2}{*}{$\begin{array}{l}\text { SIM (indique ao lado em } \\
\text { que grau) }\end{array}$} & X & MUITO APLICADOS \\
\cline { 2 - 3 } & & MEDIAMENTE APLICADOS \\
\cline { 2 - 3 } & $\begin{array}{l}\text { NÃO (indique ao lado a } \\
\text { razão da não aplicação) }\end{array}$ & & $\begin{array}{l}\text { CONCO APLICADOS } \\
\text { ESPECÍFICAS DA REGIÃO }\end{array}$ \\
\hline
\end{tabular}




\begin{tabular}{|l|l|l|}
\hline \multirow{10}{*}{} & $\begin{array}{l}\text { CONTEÚDO NÃO FOI SUFICIENTEMENTE } \\
\text { APROFUNDADO PARA PERMITIR UMA APLICAÇÃO } \\
\text { EFICAZ E EFICIENTE }\end{array}$ \\
\cline { 2 - 4 } & $\begin{array}{l}\text { FALTA DE APOIO E INCENTIVO DA MINHA } \\
\text { INSTITUIÇÃO }\end{array}$ \\
\cline { 2 - 4 } & FALTA DE INCENTIVO ÀS AÇÕES DE ATER \\
\hline & NÃO TENHO INTERESSE EM APLICAR \\
\hline
\end{tabular}

6) A partir deste curso: (As opções não são excludentes: você poderá marcar mais de uma opção).

\begin{tabular}{|l|l|}
\hline & NÃO MUDOU NADA EM MEU TRABALHO. \\
\hline$X$ & $\begin{array}{l}\text { MEU TRABALHO PASSOU A CONTRIBUIR MAIS COM OS AGRICULTORES(AS) } \\
\text { FAMILIARES. }\end{array}$ \\
\hline$X$ & CONSEGUI INFLUENCIAR NAS ORIENTAÇÕES DA MINHA INSTITUIÇÃO. \\
\hline$X$ & PASSEI A TRABALHAR COM METODOLOGIAS PARTICIPATIVAS. \\
\hline & \begin{tabular}{l} 
ORESCEU A ÁREA DE AGRICULTURA DE BASE ECOLÓGICA NAS COMUNIDADES \\
\hline$X$
\end{tabular} \\
\hline
\end{tabular}

7) Depois do curso você apoiou atividades de capacitação de técnicos e agricultores com base nos princípios e diretrizes da Pnater? (Considere como apoio a atividades de capacitação a participação no planejamento, elaboração de ementas, seleção de participantes e de palestrantes.)

\begin{tabular}{|l|l|}
\hline$X$ & SIM \\
\hline & NÃO \\
\hline
\end{tabular}

8) Usou os conhecimentos para ministrar outros cursos com o mesmo conteúdo ou conteúdos semelhantes? 


\begin{tabular}{|l|l|}
\hline$X$ & SIM \\
\hline & NÃO \\
\hline
\end{tabular}

9) Marque o seu grau de satisfação com relação ao curso oferecido pelo DATER: (Considere a seguinte pontuação: 1 - MUITO RUIM; 2 - RUIM; 3 - REGULAR; 4 - BOM; 5 - MUITO BOM)

\begin{tabular}{|l|l|l|l|l|}
\hline 1 & 2 & 3 & 4 & 5 ESTE \\
\hline
\end{tabular}

10) Marque seu grau de satisfação com relação ao DATER: (Considere a seguinte pontuação: 1 - MUITO RUIM; 2 - RUIM; 3 - REGULAR; 4 - BOM; 5 - MUITO BOM)

\begin{tabular}{|l|l|l|l|l|}
\hline 1 & 2 & 3 & 4 & 5 ESTE \\
\hline
\end{tabular}


PESQUISA - IMPACTO DAS AÇÕES DE FORMAÇÃO REALIZADAS PELO DATER/SAF/MDA NO PERÍODO 2004-2009

Caros colaboradores,

Contamos com a sua atenção para preencher o formulário abaixo.

O mesmo tem por objetivo fornecer informações para avaliação da Eficiência, Efetividade e Eficácia da Política Pública de Formação de Agentes de Ater adotada pelo Departamento de Assistência Técnica e Extensão Rural, da Secretaria de Agricultura Familiar do Ministério do Desenvolvimento - DATER/SAF/MDA, no período de 2004 a 2009, tema escolhido para Monografia a ser apresentada à Universidade de Brasília (UnB) como requisito parcial para obtenção do grau de Bacharel em Administração.

Você poderá ou não se identificar no questionário e garantimos que todas as informações fornecidas serão confidenciais e utilizadas apenas de forma sistematizada.

\section{IDENTIFICAÇÃO}

\begin{tabular}{|c|c|}
\hline Nome: Eugênio Martins de Sá Resende & $\begin{array}{l}\text { Sexo: } \\
(x \quad) \text { masculino } \quad(\quad) \text { feminino }\end{array}$ \\
\hline $\begin{array}{l}\text { Instituição (nome e tipo de instituição: ONG, } \\
\text { Empresa Pública, etc.): na época Centro } \\
\text { Agroecológico Tamanduá (CAT-GV) }\end{array}$ & $\begin{array}{l}\text { Local de trabalho (Cidade e } \\
\text { Governador Valadares-MG }\end{array}$ \\
\hline $\begin{array}{l}\text { Curso/Encontro/Oficina do qual participou (caso tenl } \\
\text { um formulário para cada um deles): Curso de Aperfe }\end{array}$ & $\begin{array}{l}\text { la participado de mais de um curso, preencha } \\
\text { içoamento em Agroecologia }\end{array}$ \\
\hline
\end{tabular}

Indique sua área de atuação? (As opções não são excludentes: você poderá marcar mais de uma opção).

\begin{tabular}{|l|l|}
\hline$X$ & EXTENSÃO RURAL \\
\hline & PESQUISA \\
\hline & ENSINO \\
\hline & OUTROS \\
\hline
\end{tabular}


2) Qual o seu nível de escolaridade? (Considere apenas o nível mais alto)

\begin{tabular}{|l|l|}
\hline & NÍVEL MÉDIO \\
\hline$X$ & NÍVEL SUPERIOR \\
\hline & PÓS-GRADUAÇÃO \\
\hline
\end{tabular}

3) Os conteúdos abordados foram condizentes com as demandas do seu dia-a-dia?

\begin{tabular}{|l|l|}
\hline & SIM \\
\hline$X$ & PARCIALMENTE \\
\hline & NÃO \\
\hline
\end{tabular}

4) O curso contribuiu para o seu aperfeiçoamento profissional?

\begin{tabular}{|l|l|}
\hline$X$ & SIM \\
\hline & NÃO \\
\hline
\end{tabular}

5) Os conhecimentos adquiridos estão sendo aplicados no seu trabalho? Em caso afirmativo, indique em que grau estes conhecimentos estão sendo aplicados. Em caso negativo, indique por que razão isto não ocorre: (As respostas não são excludentes: você poderá marcar mais de uma opção).

\begin{tabular}{|c|c|c|c|}
\hline \multirow{3}{*}{$\mathrm{x}$} & \multirow{3}{*}{$\begin{array}{l}\text { SIM (indique ao lado em } \\
\text { que grau) }\end{array}$} & & MUITO APLICADOS \\
\hline & & & MEDIAMENTE APLICADOS \\
\hline & & $\bar{x}$ & \begin{tabular}{|l|} 
POUCO APLICADOS \\
\end{tabular} \\
\hline & \multirow{3}{*}{$\begin{array}{l}\text { NÃO (indique ao lado a } \\
\text { razão da não aplicação) }\end{array}$} & & $\begin{array}{l}\text { CONTEÚDO NÃO ADEQUADO ÀS NECESSIDADES } \\
\text { ESPECÍFICAS DA REGIÃO }\end{array}$ \\
\hline & & & $\begin{array}{lccr}\text { CONTEÚDO } & \text { NÃO } & \text { FOI } & \text { SUFICIENTEMENTE } \\
\text { APROFUNDADO } & \text { PARA } & \text { PERMITIR UMA APLICAÇÃO }\end{array}$ \\
\hline & & & \begin{tabular}{|lllll} 
EFICA7 F EFICIENTE & & \\
FALTA DE APOIO & E & INCENTIVO & DA & MINHA \\
INSTITUICÃO & & & & \\
INSTIO
\end{tabular} \\
\hline
\end{tabular}


FALTA DE INCENTIVO ÀS AÇÕES DE ATER NÃO TENHO INTERESSE EM APLICAR

6) A partir deste curso: (As opções não são excludentes: você poderá marcar mais de uma opção).

\begin{tabular}{|l|l|}
\hline$X$ & NÃO MUDOU NADA EM MEU TRABALHO. \\
\hline & $\begin{array}{l}\text { MEU TRABALHO PASSOU A CONTRIBUIR MAIS COM OS AGRICULTORES(AS) } \\
\text { FAMILIARES. }\end{array}$ \\
\hline & CONSEGUI INFLUENCIAR NAS ORIENTAÇÕES DA MINHA INSTITUIÇÃO. \\
\hline & $\begin{array}{l}\text { CRESCEU A AREA DE AGRICULTURA DE BASE ECOLÓGICA NAS COMUNIDADES } \\
\text { ONDE ATUO. }\end{array}$ \\
\hline & CONTINUEI ME APERFEIÇOANDO SOBRE TEMAS ABORDADOS. \\
\hline
\end{tabular}

7) Depois do curso você apoiou atividades de capacitação de técnicos e agricultores com base nos princípios e diretrizes da Pnater? (Considere como apoio a atividades de capacitação a participação no planejamento, elaboração de ementas, seleção de participantes e de palestrantes.)

\begin{tabular}{|l|l|}
\hline$X$ & SIM \\
\hline & NÃO \\
\hline
\end{tabular}

8) Usou os conhecimentos para ministrar outros cursos com o mesmo conteúdo ou conteúdos semelhantes?

\begin{tabular}{|l|l|}
\hline$X$ & SIM \\
\hline & NÃO \\
\hline
\end{tabular}

9) Marque o seu grau de satisfação com relação ao curso oferecido pelo DATER: (Considere a seguinte pontuação: 1 - MUITO RUIM; 2 - RUIM; 3 - REGULAR; 4 - BOM; 5 - MUITO BOM) 


\begin{tabular}{|l|l|l|l|l|}
\hline 1 & 2 & $X 3$ & 4 & 5 \\
\hline
\end{tabular}

10) Marque seu grau de satisfação com relação ao DATER: (Considere a seguinte pontuação:

1 - MUITO RUIM; 2 - RUIM; 3 - REGULAR; 4 - BOM; 5 - MUITO BOM)

\begin{tabular}{|l|l|l|l|l|}
\hline 1 & 2 & 3 & $X 4$ & 5 \\
\hline
\end{tabular}


PESQUISA - IMPACTO DAS AÇÕES DE FORMAÇÃO REALIZADAS PELO DATER/SAF/MDA NO PERÍODO 2004-2009

Caros colaboradores,

Contamos com a sua atenção para preencher o formulário abaixo.

O mesmo tem por objetivo fornecer informações para avaliação da Eficiência, Efetividade e Eficácia da Política Pública de Formação de Agentes de Ater adotada pelo Departamento de Assistência Técnica e Extensão Rural, da Secretaria de Agricultura Familiar do Ministério do Desenvolvimento - DATER/SAF/MDA, no período de 2004 a 2009, tema escolhido para Monografia a ser apresentada à Universidade de Brasília (UnB) como requisito parcial para obtenção do grau de Bacharel em Administração.

Você poderá ou não se identificar no questionário e garantimos que todas as informações fornecidas serão confidenciais e utilizadas apenas de forma sistematizada.

\section{IDENTIFICAÇÃO}

\begin{tabular}{|l|l|}
\hline Nome: & $\begin{array}{l}\text { Sexo: } \\
(x) \text { masculino } \quad(\quad) \text { feminino }\end{array}$ \\
\hline $\begin{array}{l}\text { Eliziana Vieira de Araújo } \\
\text { Cooperafloresta } \\
\text { Rede Ecovida }\end{array}$ & $\begin{array}{l}\text { Local de trabalho: } \\
\text { Florianópolis/Sc }\end{array}$ \\
\hline $\begin{array}{l}\text { Curso/Encontro/Oficina do qual participou } \\
\text { Curso de Aperfeiçoamento em Agroecologia }\end{array}$ \\
\hline Data do Curso/Encontro/Oficina 04/07 2006 \\
\hline
\end{tabular}

Indique sua área de atuação? (As opções não são excludentes: você poderá marcar mais de uma opção).

\begin{tabular}{|l|l|}
\hline$X$ & EXTENSÃO RURAL \\
\hline & PESQUISA \\
\hline & ENSINO \\
\hline
\end{tabular}




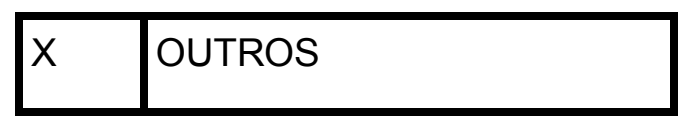

2) Qual o seu nível de escolaridade? (Considere apenas o nível mais alto)

\begin{tabular}{|l|l|}
\hline & NÍVEL MÉDIO \\
\hline$X$ & NÍVEL SUPERIOR \\
\hline & PÓS-GRADUAÇÃO \\
\hline
\end{tabular}

3) Os conteúdos abordados foram condizentes com as demandas do seu dia-a-dia?

\begin{tabular}{|l|l|}
\hline & SIM \\
\hline$X$ & PARCIALMENTE \\
\hline & NÃO \\
\hline
\end{tabular}

3) O curso contribuiu para o seu aperfeiçoamento profissional?

\begin{tabular}{|l|l|}
\hline$X$ & SIM \\
\hline & NÃO \\
\hline
\end{tabular}

5) Os conhecimentos adquiridos estão sendo aplicados no seu trabalho? Em caso afirmativo, indique em que grau estes conhecimentos estão sendo aplicados. Em caso negativo, indique por que razão isto não ocorre: (As respostas não são excludentes: você poderá marcar mais de uma opção).

\begin{tabular}{|l|l|l|l|}
\hline \multirow{2}{*}{$\begin{array}{l}\text { SIM (indique ao lado em } \\
\text { que grau) }\end{array}$} & & MUITO APLICADOS \\
\cline { 2 - 4 } & $\begin{array}{l}\text { NÃO (indique ao lado a } \\
\text { razão da não aplicação) }\end{array}$ & MEDIAMENTE APLICADOS \\
\hline
\end{tabular}




\begin{tabular}{|l|l|l|}
\hline \multirow{10}{*}{} & $\begin{array}{l}\text { CONTEÚDO NÃO FOI SUFICIENTEMENTE } \\
\text { APROFUNDADO PARA PERMITIR UMA APLICAÇÃO } \\
\text { EFICAZ E EFICIENTE }\end{array}$ \\
\cline { 2 - 4 } & $\begin{array}{l}\text { FALTA DE APOIO E INCENTIVO DA MINHA } \\
\text { INSTITUIÇÃO }\end{array}$ \\
\cline { 2 - 4 } & FALTA DE INCENTIVO ÀS AÇÕES DE ATER \\
\hline & NÃO TENHO INTERESSE EM APLICAR \\
\hline
\end{tabular}

6) A partir deste curso: (As opções não são excludentes: você poderá marcar mais de uma opção).

\begin{tabular}{|l|l|}
\hline & NÃO MUDOU NADA EM MEU TRABALHO. \\
\hline & $\begin{array}{l}\text { MEU TRABALHO PASSOU A CONTRIBUIR MAIS COM OS AGRICULTORES(AS) } \\
\text { FAMILIARES. }\end{array}$ \\
\hline & CONSEGUI INFLUENCIAR NAS ORIENTAÇÕES DA MINHA INSTITUIÇÃO. \\
\hline & $\begin{array}{l}\text { CRESCEI A TRABALHAR COM METODOLOGIAS PARTICIPATIVAS. } \\
\text { ONDE ATUO. ÁREA DE AGRICULTURA DE BASE ECOLÓGICA NAS COMUNIDADES }\end{array}$ \\
\hline$X$ & CONTINUEI ME APERFEIÇOANDO SOBRE TEMAS ABORDADOS. \\
\hline
\end{tabular}

7) Depois do curso você apoiou atividades de capacitação de técnicos e agricultores com base nos princípios e diretrizes da Pnater? (Considere como apoio a atividades de capacitação a participação no planejamento, elaboração de ementas, seleção de participantes e de palestrantes.)

\begin{tabular}{|l|l|}
\hline$X$ & SIM \\
\hline & NÃO \\
\hline
\end{tabular}

8) Usou os conhecimentos para ministrar outros cursos com o mesmo conteúdo ou conteúdos semelhantes? 


\begin{tabular}{|l|l|}
\hline$X$ & SIM \\
\hline & NÃO \\
\hline
\end{tabular}

9) Marque o seu grau de satisfação com relação ao curso oferecido pelo DATER: (Considere a seguinte pontuação: 1 - MUITO RUIM; 2 - RUIM; 3 - REGULAR; 4 - BOM; 5 - MUITO BOM)

\begin{tabular}{|l|l|l|l|l|}
\hline 1 & 2 & $3 X$ & 4 & 5 \\
\hline
\end{tabular}

10) Marque seu grau de satisfação com relação ao DATER: (Considere a seguinte pontuação: 1 - MUITO RUIM; 2 - RUIM; 3 - REGULAR; 4 - BOM; 5 - MUITO BOM)

\begin{tabular}{|l|l|l|l|l|}
\hline 1 & 2 & $3 X$ & 4 & 5 \\
\hline
\end{tabular}


PESQUISA - IMPACTO DAS AÇÕES DE FORMAÇÃO REALIZADAS PELO DATER/SAF/MDA NO PERÍODO 2004-2009

Caros colaboradores,

Contamos com a sua atenção para preencher o formulário abaixo.

O mesmo tem por objetivo fornecer informações para avaliação da Eficiência, Efetividade e Eficácia da Política Pública de Formação de Agentes de Ater adotada pelo Departamento de Assistência Técnica e Extensão Rural, da Secretaria de Agricultura Familiar do Ministério do Desenvolvimento - DATER/SAF/MDA, no período de 2004 a 2009, tema escolhido para Monografia a ser apresentada à Universidade de Brasília (UnB) como requisito parcial para obtenção do grau de Bacharel em Administração.

Você poderá ou não se identificar no questionário e garantimos que todas as informações fornecidas serão confidenciais e utilizadas apenas de forma sistematizada.

\section{IDENTIFICAÇÃO}

\begin{tabular}{|c|c|}
\hline $\begin{array}{l}\text { Nome: (opcional) } \\
\text { EDEGAR ANTONIO FORMENTINI }\end{array}$ & $\begin{array}{l}\text { Sexo: } \\
(x \quad) \text { masculino }(\quad) \text { feminino }\end{array}$ \\
\hline $\begin{array}{l}\text { Instituição (nome e tipo de instituição: ONG, } \\
\text { Empresa Pública, Cooperativa,etc.): } \\
\text { INCAPER }\end{array}$ & $\begin{array}{l}\text { Local de trabalho (Cidade e Estado): } \\
\text { VITORIA }\end{array}$ \\
\hline \multicolumn{2}{|c|}{$\begin{array}{l}\text { Curso/Encontro/Oficina do qual participou (caso tenha participado de mais de um evento d } \\
\text { formação, preencha um formulário para cada um deles): } \\
\text { AGROECOLOGIA A DISTÂNCIA }\end{array}$} \\
\hline Data do Curso/Encontro/Oficina/Seminário (pelo men & nos mês e ano): 2006 \\
\hline
\end{tabular}

1) Indique sua área de atuação? (As opções não são excludentes: você poderá marcar mais de uma opção).

\begin{tabular}{|l|l|}
\hline$X$ & EXTENSÃO RURAL \\
\hline & PESQUISA \\
\hline & ENSINO \\
\hline & OUTROS \\
\hline
\end{tabular}


2) Qual o seu nível de escolaridade? (Considere apenas o nível mais alto)

\begin{tabular}{|l|l|}
\hline & NÍVEL MÉDIO \\
\hline$X$ & NÍVEL SUPERIOR \\
\hline & PÓS-GRADUAÇÃO \\
\hline
\end{tabular}

3) Os conteúdos abordados na formação foram condizentes com as demandas do seu dia-adia?

\begin{tabular}{|l|l|}
\hline$X$ & SIM \\
\hline & PARCIALMENTE \\
\hline & NÃO \\
\hline
\end{tabular}

4) O curso ou atividade de formação da qual você participou contribuiu para o seu aperfeiçoamento profissional?

\begin{tabular}{|l|l|}
\hline$x$ & SIM \\
\hline & NÃO \\
\hline
\end{tabular}

5) Os conhecimentos adquiridos nesta formação estão sendo aplicados no seu trabalho? Em caso afirmativo, indique em que grau estes conhecimentos estão sendo aplicados. Em caso negativo, indique por que razão isto não ocorre: (As respostas não são excludentes: você poderá marcar mais de uma opção).

\begin{tabular}{|l|l|l|l|}
\hline \multirow{2}{*}{$\begin{array}{l}\text { SIM (indique ao lado } \\
\text { em que grau) }\end{array}$} & MUITO APLICADOS \\
\cline { 3 - 4 } & & MEDIAMENTE APLICADOS \\
\hline & & POUCO APLICADOS \\
\hline $\begin{array}{l}\text { NÃO (indique ao lado a } \\
\text { razão da não da } \\
\text { aplicação) }\end{array}$ & $\begin{array}{l}\text { CONTEÚDO NÃO ADEQUADO ÁS NECESSIDADES } \\
\text { ESPECÍFICAS DA REGIÃO }\end{array}$ \\
\cline { 3 - 4 } & & $\begin{array}{l}\text { CONTEÚDO NÄO FOI SUFICIENTEMENTE } \\
\text { APROFUNDADO PARA PERMITIR UMA } \\
\text { APLICAÇÃO EFICAZ E EFICIENTE }\end{array}$ \\
\hline
\end{tabular}




\begin{tabular}{|l|l|l|}
\hline \multirow{2}{*}{} & & $\begin{array}{l}\text { FALTA DE APOIO E INCENTIVO DA MINHA } \\
\text { INSTITUIÇÃO }\end{array}$ \\
\hline & FALTA DE INCENTIVO ÀS AÇÕES DE ATER \\
\hline & NÃO TENHO INTERESSE EM APLICAR \\
\hline
\end{tabular}

6) A partir do evento de formação do qual você participou: (As respostas não são excludentes: você poderá marcar mais de uma opção).

\begin{tabular}{|c|c|}
\hline & NÃO MUDOU NADA EM MEU TRABALHO. \\
\hline & $\begin{array}{l}\text { MEU TRABALHO PASSOU A CONTRIBUIR MAIS COM OS AGRICULTORES(AS) } \\
\text { FAMILIARES. }\end{array}$ \\
\hline \multirow[t]{3}{*}{$\mathrm{X}$} & CONSEGUI INFLUENCIAR NAS ORIENTAÇÕES DA MINHA INSTITUIÇÃO. \\
\hline & PASSEI A TRABALHAR COM METODOLOGIAS PARTICIPATIVAS. \\
\hline & $\begin{array}{l}\text { CRESCEU A ÁREA DE AGRICULTURA DE BASE ECOLÓGICA NAS } \\
\text { COMUNIDADES ONDE ATUO. }\end{array}$ \\
\hline $\mathrm{X}$ & CONTINUEI ME APERFEIÇOANDO SOBRE TEMAS ABORDADOS. \\
\hline
\end{tabular}

7) Depois do curso você apoiou atividades de capacitação de técnicos e agricultores com base nos princípios e diretrizes da Pnater? (Considere como apoio a atividades de capacitação a participação no planejamento, elaboração de ementas, seleção de participantes e de palestrantes.)

\begin{tabular}{|l|l|}
\hline$X$ & SIM \\
\hline & NÃO \\
\hline
\end{tabular}

8) Usou os conhecimentos para ministrar outros eventos de formação com o mesmo conteúdo ou conteúdos semelhantes?

\begin{tabular}{|l|l|}
\hline$X$ & SIM \\
\hline & NÃO \\
\hline
\end{tabular}


9) Marque o seu grau de satisfação com relação a atividade de formação oferecida pelo DATER: (Considere a seguinte pontuação: 1 - MUITO RUIM; 2 - RUIM; 3 - REGULAR; 4 BOM; 5 - MUITO BOM)

\begin{tabular}{|l|l|l|l|l|}
\hline 1 & 2 & 3 & 4 & $\times 5$ \\
\hline
\end{tabular}

10) Marque seu grau de satisfação com relação ao DATER: (Considere a seguinte pontuação: 1 - MUITO RUIM; 2 - RUIM; 3 - REGULAR; 4 - BOM; 5 - MUITO BOM)

\begin{tabular}{|l|l|l|l|l|}
\hline 1 & 2 & 3 & $X 4$ & 5 \\
\hline
\end{tabular}


PESQUISA - IMPACTO DAS AÇÕES DE FORMAÇÃO REALIZADAS PELO DATER/SAF/MDA NO PERÍODO 2004-2009

Caros colaboradores,

Contamos com a sua atenção para preencher o formulário abaixo.

O mesmo tem por objetivo fornecer informações para avaliação da Eficiência, Efetividade e Eficácia da Política Pública de Formação de Agentes de Ater adotada pelo Departamento de Assistência Técnica e Extensão Rural, da Secretaria de Agricultura Familiar do Ministério do Desenvolvimento - DATER/SAF/MDA, no período de 2004 a 2009, tema escolhido para Monografia a ser apresentada à Universidade de Brasília (UnB) como requisito parcial para obtenção do grau de Bacharel em Administração.

Você poderá ou não se identificar no questionário e garantimos que todas as informações fornecidas serão confidenciais e utilizadas apenas de forma sistematizada.

\section{IDENTIFICAÇÃO}

\begin{tabular}{|c|c|}
\hline Dario Magno de Miranda Maia & $\begin{array}{l}\text { Sexo: } \\
(x \quad) \text { masculino } \quad(\quad) \text { feminino }\end{array}$ \\
\hline $\begin{array}{l}\text { Instituição (nome e tipo de instituição: ONG, } \\
\text { Empresa Pública, etc.): EMATER-MG }\end{array}$ & $\begin{array}{l}\text { Local de trabalho (Cidade e Estado): } \\
\text { Belo Horizonte }\end{array}$ \\
\hline $\begin{array}{l}\text { Curso/Encontro/Oficina do qual participou (caso tent } \\
\text { um formulário para cada um deles): curso de espe } \\
\text { Rural, no CDS/UnB }\end{array}$ & $\begin{array}{l}\text { a participado de mais de um curso, preencha } \\
\text { cialização em Des. Sustentável e Extenssão }\end{array}$ \\
\hline
\end{tabular}

Indique sua área de atuação? (As opções não são excludentes: você poderá marcar mais de uma opção).

\begin{tabular}{|l|l|}
\hline$x$ & EXTENSÃO RURAL \\
\hline & PESQUISA \\
\hline & ENSINO \\
\hline & OUTROS \\
\hline
\end{tabular}

2) Qual o seu nível de escolaridade? (Considere apenas o nível mais alto) 


\begin{tabular}{|c|l|}
\hline & NÍVEL MÉDIO \\
\hline$x$ & NÍVEL SUPERIOR \\
\hline & PÓS-GRADUAÇÃO \\
\hline
\end{tabular}

3) Os conteúdos abordados foram condizentes com as demandas do seu dia-a-dia?

\begin{tabular}{|l|l|}
\hline & SIM \\
\hline$x$ & PARCIALMENTE \\
\hline & NÃO \\
\hline
\end{tabular}

4) O curso contribuiu para o seu aperfeiçoamento profissional?

\begin{tabular}{|l|l|}
\hline$x$ & SIM \\
\hline & NÃO \\
\hline
\end{tabular}

5) Os conhecimentos adquiridos estão sendo aplicados no seu trabalho? Em caso afirmativo, indique em que grau estes conhecimentos estão sendo aplicados. Em caso negativo, indique por que razão isto não ocorre: (As respostas não são excludentes: você poderá marcar mais de uma opção).

\begin{tabular}{|c|c|c|}
\hline \multirow{3}{*}{$\begin{array}{l}\text { SIM (indique ao lado em } \\
\text { que grau) }\end{array}$} & & MUITO APLICADOS \\
\hline & $\bar{x}$ & MEDIAMENTE APLICADOS \\
\hline & & POUCO APLICADOS \\
\hline \multirow{5}{*}{$\begin{array}{l}\text { NÃO (indique ao lado a } \\
\text { razão da não aplicação) }\end{array}$} & & $\begin{array}{l}\text { CONTEÚDO NÃO ADEQUADO ÀS NECESSIDADES } \\
\text { ESPECÍFICAS SA REGIÃO }\end{array}$ \\
\hline & & $\begin{array}{lllr}\text { CONTEÚDO } & \text { NÂO } & \text { FOI } & \text { SUFICIENTEMENTE } \\
\text { APROFUNDADO } & \text { PARA } & \text { PERMITIR UMA APLICAÇÃO }\end{array}$ \\
\hline & & $\begin{array}{|lcccccc|}\text { FALTA } & \text { DE } & \text { APOIO } & \text { E } & \text { INCENTIVO } & \text { DA } & \text { MINHA } \\
\text { INSTITUICÃO } & & & & & \\
\end{array}$ \\
\hline & & FALTA DE INCENTIVO ÀS AÇÕES DE ATER \\
\hline & & NÃO TENHO INTERESSE EM APLICAR \\
\hline
\end{tabular}


6) A partir deste curso: (As opções não são excludentes: você poderá marcar mais de uma opção).

\begin{tabular}{|c|l|}
\hline$x$ & $\begin{array}{l}\text { NÃO MUDOU NADA EM MEU TRABALHO. } \\
\text { FAMILIARES. }\end{array}$ \\
\hline$X$ & CONSEGUI INFLUENCIAR NAS ORIENTAÇÕES DA MINHA INSTITUIÇÃO. \\
\hline & PASSEI A TRABALHAR COM METODOLOGIAS PARTICIPATIVAS. \\
\hline & $\begin{array}{l}\text { CRESCEU A ÁREA DE AGRICULTURA DE BASE ECOLÓGICA NAS COMUNIDADES } \\
\text { ONDE ATUO. }\end{array}$ \\
\hline$X$ & CONTINUEI ME APERFEIÇOANDO SOBRE TEMAS ABORDADOS. \\
\hline
\end{tabular}

7) Depois do curso você apoiou atividades de capacitação de técnicos e agricultores com base nos princípios e diretrizes da Pnater? (Considere como apoio a atividades de capacitação a participação no planejamento, elaboração de ementas, seleção de participantes e de palestrantes.)

\begin{tabular}{|l|l|}
\hline$X$ & SIM \\
\hline & NÃO \\
\hline
\end{tabular}

8) Usou os conhecimentos para ministrar outros cursos com o mesmo conteúdo ou conteúdos semelhantes?

\begin{tabular}{|l|l|}
\hline$X$ & SIM \\
\hline & NÃO \\
\hline
\end{tabular}

9) Marque o seu grau de satisfação com relação ao curso oferecido pelo DATER: (Considere a seguinte pontuação: 1 - MUITO RUIM; 2 - RUIM; 3 - REGULAR; 4 - BOM; 5 - MUITO BOM)

\begin{tabular}{|l|l|l|l|l|}
\hline 1 & 2 & $3 X$ & 4 & 5 \\
\hline
\end{tabular}

10) Marque seu grau de satisfação com relação ao DATER: (Considere a seguinte pontuação:

1 - MUITO RUIM; 2 - RUIM; 3 - REGULAR; 4 - BOM; 5 - MUITO BOM) 


\begin{tabular}{|l|l|l|l|l|}
\hline 1 & 2 & 3 & $4 X$ & 5 \\
\hline
\end{tabular}


PESQUISA - IMPACTO DAS AÇÕES DE FORMAÇÃO REALIZADAS PELO DATER/SAF/MDA NO PERÍODO 2004-2009

Caros colaboradores,

Contamos com a sua atenção para preencher o formulário abaixo.

O mesmo tem por objetivo fornecer informações para avaliação da Eficiência, Efetividade e Eficácia da Política Pública de Formação de Agentes de Ater adotada pelo Departamento de Assistência Técnica e Extensão Rural, da Secretaria de Agricultura Familiar do Ministério do Desenvolvimento - DATER/SAF/MDA, no período de 2004 a 2009, tema escolhido para Monografia a ser apresentada à Universidade de Brasília (UnB) como requisito parcial para obtenção do grau de Bacharel em Administração.

Você poderá ou não se identificar no questionário e garantimos que todas as informações fornecidas serão confidenciais e utilizadas apenas de forma sistematizada.

\section{IDENTIFICAÇÃO}

\begin{tabular}{|l|l|}
\hline Nome: Daniel do Nascimento Duarte & $\begin{array}{l}\text { Sexo: } \\
(x) \text { masculino } \quad(\quad) \text { feminino }\end{array}$ \\
\hline $\begin{array}{l}\text { Instituição: Instituto Capixaba de Pesquisa, } \\
\text { Assistência Técnica e Extensão Rural - Incaper / } \\
\text { Empresa Pública }\end{array}$ & \begin{tabular}{l} 
Vitória / ES \\
\hline Curso/Encontro/Oficina do qual participou: Curso de Agroecologia/RedCapa
\end{tabular} \\
\hline Data do Curso/Encontro/Oficina: \\
Primeiro semestre de 2006
\end{tabular}

Indique sua área de atuação? (As opções não são excludentes: você poderá marcar mais de uma opção).

\begin{tabular}{|l|l|}
\hline$X$ & EXTENSÃO RURAL \\
\hline & PESQUISA \\
\hline & ENSINO \\
\hline
\end{tabular}




\section{OUTROS}

2) Qual o seu nível de escolaridade? (Considere apenas o nível mais alto)

\begin{tabular}{|l|l|}
\hline & NÍVEL MÉDIO \\
\hline$X$ & NÍVEL SUPERIOR \\
\hline & PÓS-GRADUAÇÃO \\
\hline
\end{tabular}

3) Os conteúdos abordados foram condizentes com as demandas do seu dia-a-dia?

\begin{tabular}{|l|l|}
\hline$X$ & SIM \\
\hline & PARCIALMENTE \\
\hline & NÃO \\
\hline
\end{tabular}

4) O curso contribuiu para o seu aperfeiçoamento profissional?

\begin{tabular}{|l|l|}
\hline$X$ & SIM \\
\hline & NÃO \\
\hline
\end{tabular}

5) Os conhecimentos adquiridos estão sendo aplicados no seu trabalho? Em caso afirmativo, indique em que grau estes conhecimentos estão sendo aplicados. Em caso negativo, indique por que razão isto não ocorre: (As respostas não são excludentes: você poderá marcar mais de uma opção).

\begin{tabular}{|l|l|l|l|}
\hline \multirow{2}{*}{$\begin{array}{l}\text { SIM (indique ao lado em } \\
\text { que grau) }\end{array}$} & X & MUITO APLICADOS \\
\cline { 2 - 3 } & $\begin{array}{l}\text { NÃO (indique ao lado a } \\
\text { razão da não aplicação) }\end{array}$ & $\begin{array}{l}\text { MEDIAMENTE APLICADOS } \\
\text { ESPECÍFICAS DA REGIÃO }\end{array}$ \\
\hline
\end{tabular}




\begin{tabular}{|l|l|l|}
\hline \multirow{10}{*}{} & $\begin{array}{l}\text { CONTEÚDO NÃO FOI SUFICIENTEMENTE } \\
\text { APROFUNDADO PARA PERMITIR UMA APLICAÇÃO } \\
\text { EFICAZ E EFICIENTE }\end{array}$ \\
\cline { 2 - 4 } & $\begin{array}{l}\text { FALTA DE APOIO E INCENTIVO DA MINHA } \\
\text { INSTITUIÇÃO }\end{array}$ \\
\cline { 2 - 4 } & FALTA DE INCENTIVO ÀS AÇÕES DE ATER \\
\hline & NÃO TENHO INTERESSE EM APLICAR \\
\hline
\end{tabular}

6) A partir deste curso: (As opções não são excludentes: você poderá marcar mais de uma opção).

\begin{tabular}{|l|l|}
\hline & NÃO MUDOU NADA EM MEU TRABALHO. \\
\hline & $\begin{array}{l}\text { MEU TRABALHO PASSOU A CONTRIBUIR MAIS COM OS AGRICULTORES(AS) } \\
\text { FAMILIARES. }\end{array}$ \\
\hline $\mathrm{X}$ & CONSEGUI INFLUENCIAR NAS ORIENTAÇÕES DA MINHA INSTITUIÇÃO. \\
\hline & PASSEI A TRABALHAR COM METODOLOGIAS PARTICIPATIVAS. \\
\hline & $\begin{array}{l}\text { CRESCEU A ÁREA DE AGRICULTURA DE BASE ECOLÓGICA NAS COMUNIDADES } \\
\text { ONDE ATUO. }\end{array}$ \\
\hline$X$ & CONTINUEI ME APERFEIÇOANDO SOBRE TEMAS ABORDADOS. \\
\hline
\end{tabular}

7) Depois do curso você apoiou atividades de capacitação de técnicos e agricultores com base nos princípios e diretrizes da Pnater? (Considere como apoio a atividades de capacitação a participação no planejamento, elaboração de ementas, seleção de participantes e de palestrantes.)

\begin{tabular}{|l|l|}
\hline$X$ & SIM \\
\hline & NÃO \\
\hline
\end{tabular}

8) Usou os conhecimentos para ministrar outros cursos com o mesmo conteúdo ou conteúdos semelhantes? 


\begin{tabular}{|l|l|}
\hline$X$ & SIM \\
\hline & NÃO \\
\hline
\end{tabular}

9) Marque o seu grau de satisfação com relação ao curso oferecido pelo DATER: (Considere a seguinte pontuação: 1 - MUITO RUIM; 2 - RUIM; 3 - REGULAR; 4 - BOM; 5 - MUITO BOM)

\begin{tabular}{|l|l|l|l|l|}
\hline 1 & 2 & 3 & $4(X)$ & 5 \\
\hline
\end{tabular}

10) Marque seu grau de satisfação com relação ao DATER: (Considere a seguinte pontuação: 1 - MUITO RUIM; 2 - RUIM; 3 - REGULAR; 4 - BOM; 5 - MUITO BOM)

\begin{tabular}{|l|l|l|l|l|}
\hline 1 & 2 & 3 & $4(X)$ & 5 \\
\hline
\end{tabular}


PESQUISA - IMPACTO DAS AÇÕES DE FORMAÇÃO REALIZADAS PELO DATER/SAF/MDA NO PERÍODO 2004-2009

Caros colaboradores,

Contamos com a sua atenção para preencher o formulário abaixo.

O mesmo tem por objetivo fornecer informações para avaliação da Eficiência, Efetividade e Eficácia da Política Pública de Formação de Agentes de Ater adotada pelo Departamento de Assistência Técnica e Extensão Rural, da Secretaria de Agricultura Familiar do Ministério do Desenvolvimento - DATER/SAF/MDA, no período de 2004 a 2009, tema escolhido para Monografia a ser apresentada à Universidade de Brasília (UnB) como requisito parcial para obtenção do grau de Bacharel em Administração.

Você poderá ou não se identificar no questionário e garantimos que todas as informações fornecidas serão confidenciais e utilizadas apenas de forma sistematizada.

\section{IDENTIFICAÇÃO}

\begin{tabular}{|l|l|l|}
\hline Nome: Claudia Moreira Dardaque Mucinhato & $\begin{array}{l}\text { Sexo: } \\
(\quad) \text { masculino } \quad(\mathrm{x}) \text { feminino }\end{array}$ \\
\hline $\begin{array}{l}\text { Instituição (nome e tipo de instituição: ONG, } \\
\text { Empresa Pública, etc.): Central de Orientação da } \\
\text { Pesca Responsável (COPERE) e Fundação São } \\
\text { Vicente (FUNDASV) }\end{array}$ & $\begin{array}{l}\text { Santos/ S Vicente/ Guarujá/ São Paulo } \\
\text { (COPERE), e Vera Cruz e Itaparica / BA }\end{array}$ \\
\hline $\begin{array}{l}\text { Curso/Encontro/Oficina do qual participou (caso tenha participado de mais de um curso, preencha } \\
\text { um formulário para cada um deles): ATER PESQUEIRA e AQUICOLA }\end{array}$ \\
\hline Data do Curso/Encontro/Oficina (pelo menos mês e ano): 09/2008; 2007;2005 \\
\hline
\end{tabular}

Indique sua área de atuação? (As opções não são excludentes: você poderá marcar mais de uma opção).

\begin{tabular}{|l|l|}
\hline$x$ & EXTENSÃO RURAL \\
\hline$x$ & PESQUISA \\
\hline & ENSINO \\
\hline
\end{tabular}




\section{\begin{tabular}{|l|l}
\hline$x$ & OUTROS
\end{tabular}}

2) Qual o seu nível de escolaridade? (Considere apenas o nível mais alto)

\begin{tabular}{|l|l|}
\hline & NÍVEL MÉDIO \\
\hline$x$ & NÍVEL SUPERIOR \\
\hline & PÓS-GRADUAÇÃO \\
\hline
\end{tabular}

3) Os conteúdos abordados foram condizentes com as demandas do seu dia-a-dia?

\begin{tabular}{|l|l|}
\hline & SIM \\
\hline$x$ & PARCIALMENTE \\
\hline & NÃO \\
\hline
\end{tabular}

4) O curso contribuiu para o seu aperfeiçoamento profissional?

\begin{tabular}{|l|l|}
\hline$x$ & SIM \\
\hline & NÃO \\
\hline
\end{tabular}

5) Os conhecimentos adquiridos estão sendo aplicados no seu trabalho? Em caso afirmativo, indique em que grau estes conhecimentos estão sendo aplicados. Em caso negativo, indique por que razão isto não ocorre: (As respostas não são excludentes: você poderá marcar mais de uma opção).

\begin{tabular}{|c|c|c|}
\hline \multirow{3}{*}{$\begin{array}{l}\text { SIM (indique ao lado em } \\
\text { que grau) }\end{array}$} & & MUITO APLICADOS \\
\hline & $\operatorname{sim}$ & MEDIAMENTE APLICADOS \\
\hline & & POUCO APLICADOS \\
\hline \multirow{2}{*}{$\begin{array}{l}\text { NÃO (indique ao lado a } \\
\text { razão da não aplicação) }\end{array}$} & & $\begin{array}{l}\text { CONTEÚDO NÃO ADEQUADO ÀS NECESSIDADES } \\
\text { ESPFCÍFICAS RA RFGIÃO }\end{array}$ \\
\hline & & $\begin{array}{llll}\text { CONTEÚDO NÂO } & \text { FOI } & \text { SUFICIENTEMENTE } \\
\text { APROFUNDADO } & \text { PARA } & \text { PERMITIR UMA APLICAÇÃO }\end{array}$ \\
\hline
\end{tabular}




\begin{tabular}{|l|l|l|l|}
\hline \multirow{2}{*}{} & & $\begin{array}{l}\text { FALTA DE APOIO E INCENTIVO DA MINHA } \\
\text { INSTITUICÃO }\end{array}$ \\
\cline { 3 - 5 } & & FALTA DE INCENTIVO ÀS AÇÕES DE ATER & \\
\cline { 2 - 5 } & & NÃO TENHO INTERESSE EM APLICAR \\
\hline
\end{tabular}

6) A partir deste curso: (As opções não são excludentes: você poderá marcar mais de uma opção).

\begin{tabular}{|l|l|}
\hline & NÃO MUDOU NADA EM MEU TRABALHO. \\
\hline$x$ & $\begin{array}{l}\text { MEU TRABALHO PASSOU A CONTRIBUIR MAIS COM OS AGRICULTORES(AS) } \\
\text { FAMILIARES. }\end{array}$ \\
\hline$x$ & CONSEGUI INFLUENCIAR NAS ORIENTAÇÕES DA MINHA INSTITUIÇÃO. \\
\hline$x$ & PASSEI A TRABALHAR COM METODOLOGIAS PARTICIPATIVAS. \\
\hline$x$ & $\begin{array}{l}\text { CRESCEU A ÁREA DE AGRICULTURA DE BASE ECOLÓGICA NAS COMUNIDADES } \\
\text { ONDE ATUO. }\end{array}$ \\
\hline & CONTINUEI ME APERFEIÇOANDO SOBRE TEMAS ABORDADOS. \\
\hline
\end{tabular}

7) Depois do curso você apoiou atividades de capacitação de técnicos e agricultores com base nos princípios e diretrizes da Pnater? (Considere como apoio a atividades de capacitação a participação no planejamento, elaboração de ementas, seleção de participantes e de palestrantes.)

\begin{tabular}{|l|l|}
\hline$x$ & SIM \\
\hline & NÃO \\
\hline
\end{tabular}

8) Usou os conhecimentos para ministrar outros cursos com o mesmo conteúdo ou conteúdos semelhantes?

\begin{tabular}{|l|l|}
\hline$x$ & SIM \\
\hline & NÃO \\
\hline
\end{tabular}


9) Marque o seu grau de satisfação com relação ao curso oferecido pelo DATER: (Considere a seguinte pontuação: 1 - MUITO RUIM; 2 - RUIM; 3 - REGULAR; 4 - BOM; 5 - MUITO BOM)

\begin{tabular}{|l|l|l|l|l|}
\hline 1 & 2 & $3 \times$ & 4 & 5 \\
\hline
\end{tabular}

10) Marque seu grau de satisfação com relação ao DATER: (Considere a seguinte pontuação:

1 - MUITO RUIM; 2 - RUIM; 3 - REGULAR; 4 - BOM; 5 - MUITO BOM)

\begin{tabular}{|l|l|l|l|l|}
\hline 1 & 2 & 3 & $4 \times$ & 5 \\
\hline
\end{tabular}


PESQUISA - IMPACTO DAS AÇÕES DE FORMAÇÃO REALIZADAS PELO DATER/SAF/MDA NO PERÍODO 2004-2009

Caros colaboradores,

Contamos com a sua atenção para preencher o formulário abaixo.

O mesmo tem por objetivo fornecer informações para avaliação da Eficiência, Efetividade e Eficácia da Política Pública de Formação de Agentes de Ater adotada pelo Departamento de Assistência Técnica e Extensão Rural, da Secretaria de Agricultura Familiar do Ministério do Desenvolvimento - DATER/SAF/MDA, no período de 2004 a 2009, tema escolhido para Monografia a ser apresentada à Universidade de Brasília (UnB) como requisito parcial para obtenção do grau de Bacharel em Administração.

Você poderá ou não se identificar no questionário e garantimos que todas as informações fornecidas serão confidenciais e utilizadas apenas de forma sistematizada.

\section{IDENTIFICAÇÃO}

\begin{tabular}{|c|c|}
\hline Nome: Célio Ricardo da Silva Alvarez & $\begin{array}{l}\text { Sexo: } \\
(x \quad) \text { masculino }\end{array}$ \\
\hline $\begin{array}{l}\text { Instituição (nome e tipo de instituição: ONG, } \\
\text { Empresa Pública, etc.): Prefeitura Municipal de } \\
\text { Alegre. }\end{array}$ & $\begin{array}{l}\text { Local de trabalho (Cidade e Estado): } \\
\text { Alegre/ES }\end{array}$ \\
\hline \multicolumn{2}{|c|}{$\begin{array}{l}\text { Curso/Encontro/Oficina do qual participou (caso tenha participado de mais de um curso, preencha } \\
\text { um formulário para cada um deles): Oficina de Nivelamento Conceitual sobre a Política Nacional } \\
\text { de Assistência técnica e Extensão Rural. }\end{array}$} \\
\hline
\end{tabular}

Indique sua área de atuação? (As opções não são excludentes: você poderá marcar mais de uma opção).

\begin{tabular}{|l|l|}
\hline$X$ & EXTENSÃO RURAL \\
\hline & PESQUISA \\
\hline & ENSINO \\
\hline
\end{tabular}




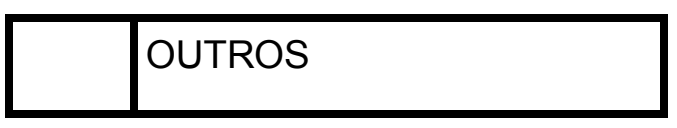

2) Qual o seu nível de escolaridade? (Considere apenas o nível mais alto)

\begin{tabular}{|l|l|}
\hline & NÍVEL MÉDIO \\
\hline$X$ & NÍVEL SUPERIOR \\
\hline & PÓS-GRADUAÇÃO \\
\hline
\end{tabular}

3) Os conteúdos abordados foram condizentes com as demandas do seu dia-a-dia?

\begin{tabular}{|l|l|}
\hline$X$ & SIM \\
\hline & PARCIALMENTE \\
\hline & NÃO \\
\hline
\end{tabular}

4) O curso contribuiu para o seu aperfeiçoamento profissional?

\begin{tabular}{|l|l|}
\hline$X$ & SIM \\
\hline & NÃO \\
\hline
\end{tabular}

5) Os conhecimentos adquiridos estão sendo aplicados no seu trabalho? Em caso afirmativo, indique em que grau estes conhecimentos estão sendo aplicados. Em caso negativo, indique por que razão isto não ocorre: (As respostas não são excludentes: você poderá marcar mais de uma opção).

\begin{tabular}{|l|l|l|l|}
\hline X & $\begin{array}{l}\text { SIM (indique ao lado em } \\
\text { que grau) }\end{array}$ & $X$ & MUITO APLICADOS \\
\cline { 2 - 4 } & & MEDIAMENTE APLICADOS \\
\hline & $\begin{array}{l}\text { NĀO (indique ao lado a } \\
\text { razão da não aplicação) }\end{array}$ & $\begin{array}{l}\text { CONTEÚDO NÃO ADEQUADO ȦS NECESSIDADES } \\
\text { ESPECÍFICAS DA REGIÃO }\end{array}$ \\
\hline
\end{tabular}




\begin{tabular}{|l|l|l|}
\hline \multirow{10}{*}{} & & $\begin{array}{l}\text { CONTEÚDO NÃO FOI SUFICIENTEMENTE } \\
\text { APROFUNDADO PARA PERMITIR UMA APLICAÇÃO } \\
\text { EFICAZ E EFICIENTE }\end{array}$ \\
\cline { 2 - 5 } & $\begin{array}{l}\text { FALTA DE APOIO E INCENTIVO DA MINHA } \\
\text { INSTITUIÇÃO }\end{array}$ \\
\cline { 2 - 4 } & FALTA DE INCENTIVO ÀS AÇÕES DE ATER \\
\hline & NÃO TENHO INTERESSE EM APLICAR \\
\hline
\end{tabular}

6) A partir deste curso: (As opções não são excludentes: você poderá marcar mais de uma opção).

\begin{tabular}{|l|l|}
\hline & NÃO MUDOU NADA EM MEU TRABALHO. \\
\hline & $\begin{array}{l}\text { MEU TRABALHO PASSOU A CONTRIBUIR MAIS COM OS AGRICULTORES(AS) } \\
\text { FAMILIARES. }\end{array}$ \\
\hline & CONSEGUI INFLUENCIAR NAS ORIENTAÇÕES DA MINHA INSTITUIÇÃO. \\
\hline & $\begin{array}{l}\text { CRESCEU A ÁREA DE AGRICULTURA DE BASE ECOLÓGICA NAS COMUNIDADES } \\
\text { ONDE ATUO. }\end{array}$ \\
\hline$X$ & CONTINUEI ME APERFEIÇOANDO SOBRE TEMAS ABORDADOS. \\
\hline
\end{tabular}

7) Depois do curso você apoiou atividades de capacitação de técnicos e agricultores com base nos princípios e diretrizes da Pnater? (Considere como apoio a atividades de capacitação a participação no planejamento, elaboração de ementas, seleção de participantes e de palestrantes.)

\begin{tabular}{|l|l|}
\hline$X$ & SIM \\
\hline & NÃO \\
\hline
\end{tabular}

8) Usou os conhecimentos para ministrar outros cursos com o mesmo conteúdo ou conteúdos semelhantes? 


\begin{tabular}{|l|l|}
\hline$X$ & SIM \\
\hline & NÃO \\
\hline
\end{tabular}

9) Marque o seu grau de satisfação com relação ao curso oferecido pelo DATER: (Considere a seguinte pontuação: 1 - MUITO RUIM; 2 - RUIM; 3 - REGULAR; 4 - BOM; 5 - MUITO BOM)

\begin{tabular}{|l|l|l|l|l|}
\hline 1 & 2 & 3 & 4 & $5 \times$ \\
\hline
\end{tabular}

10) Marque seu grau de satisfação com relação ao DATER: (Considere a seguinte pontuação: 1 - MUITO RUIM; 2 - RUIM; 3 - REGULAR; 4 - BOM; 5 - MUITO BOM)

\begin{tabular}{|l|l|l|l|l|}
\hline 1 & 2 & 3 & 4 & $5 \times$ \\
\hline
\end{tabular}


PESQUISA - IMPACTO DAS AÇÕES DE FORMAÇÃO REALIZADAS PELO DATER/SAF/MDA NO PERÍODO 2004-2009

Caros colaboradores,

Contamos com a sua atenção para preencher o formulário abaixo.

O mesmo tem por objetivo fornecer informações para avaliação da Eficiência, Efetividade e Eficácia da Política Pública de Formação de Agentes de Ater adotada pelo Departamento de Assistência Técnica e Extensão Rural, da Secretaria de Agricultura Familiar do Ministério do Desenvolvimento - DATER/SAF/MDA, no período de 2004 a 2009, tema escolhido para Monografia a ser apresentada à Universidade de Brasília (UnB) como requisito parcial para obtenção do grau de Bacharel em Administração.

Você poderá ou não se identificar no questionário e garantimos que todas as informações fornecidas serão confidenciais e utilizadas apenas de forma sistematizada.

\section{IDENTIFICAÇÃO}

\begin{tabular}{|l|l|}
\hline Nome: Ana Caldeira de Barros & $\begin{array}{l}\text { Sexo: } \\
(\quad) \text { masculino ( } \quad \text { ) feminino }\end{array}$ \\
\hline Instituição (nome e tipo de instituição: ONG, \\
Empresa Pública, etc.): Rede de Intercâmbio de \\
Tecnologias Alternativas - ONG
\end{tabular}

Indique sua área de atuação? (As opções não são excludentes: você poderá marcar mais de uma opção).

\begin{tabular}{|l|l|}
\hline & EXTENSÃO RURAL \\
\hline & PESQUISA \\
\hline & ENSINO \\
\hline$x$ & OUTROS \\
\hline
\end{tabular}


2) Qual o seu nível de escolaridade? (Considere apenas o nível mais alto)

\begin{tabular}{|l|l|}
\hline & NÍVEL MÉDIO \\
\hline$x$ & NÍVEL SUPERIOR \\
\hline & PÓS-GRADUAÇÃO \\
\hline
\end{tabular}

3) Os conteúdos abordados foram condizentes com as demandas do seu dia-a-dia?

\begin{tabular}{|l|l|}
\hline & SIM \\
\hline$x$ & PARCIALMENTE \\
\hline & NÃO \\
\hline
\end{tabular}

4) O curso contribuiu para o seu aperfeiçoamento profissional?

\begin{tabular}{|l|l|}
\hline$x$ & SIM \\
\hline & NÃO \\
\hline
\end{tabular}

5) Os conhecimentos adquiridos estão sendo aplicados no seu trabalho? Em caso afirmativo, indique em que grau estes conhecimentos estão sendo aplicados. Em caso negativo, indique por que razão isto não ocorre: (As respostas não são excludentes: você poderá marcar mais de uma opção).

\begin{tabular}{|c|c|c|}
\hline \multirow{3}{*}{$\begin{array}{l}\text { SIM (indique ao lado em } \\
\text { que grau) }\end{array}$} & $x$ & MUITO APLICADOS \\
\hline & & MEDIAMENTE APLICADOS \\
\hline & & POUCO APLICADOS \\
\hline \multirow{4}{*}{$\begin{array}{l}\text { NÃO (indique ao lado a } \\
\text { razão da não aplicação) }\end{array}$} & & $\begin{array}{l}\text { CONTEÚDO NÃO ADEQUADO ÀS NECESSIDADES } \\
\text { FSPFCÍFICAS SARFGIÃO } \\
\text { CONTEÚDO NÂO FOI } \\
\text { APROFUNDADO PARA PERMITIR UMA APLICAÇÃO }\end{array}$ \\
\hline & & $\begin{array}{lcccccc}\text { FALTA } & \text { DE } & \text { APOIO } & \text { E } & \text { INCENTIVO } & \text { DA } & \text { MINHA } \\
\text { INSTITUICÃO } & & & & & \\
\end{array}$ \\
\hline & & FALTA DE INCENTIVO ÀS AÇÕES DE ATER \\
\hline & & NÃO TENHO INTERESSE EM APLICAR \\
\hline
\end{tabular}


6) A partir deste curso: (As opções não são excludentes: você poderá marcar mais de uma opção).

\begin{tabular}{|l|l|}
\hline & NÃO MUDOU NADA EM MEU TRABALHO. \\
\hline & $\begin{array}{l}\text { MEU TRABALHO PASSOU A CONTRIBUIR MAIS COM OS AGRICULTORES(AS) } \\
\text { FAMILIARES. }\end{array}$ \\
\hline & CONSEGUI INFLUENCIAR NAS ORIENTAÇÕES DA MINHA INSTITUIÇÃO. \\
\hline & $\begin{array}{l}\text { CRESSEI A TRABALHAR COM METODOLOGIAS PARTICIPATIVAS. } \\
\text { ONDE ATUO. }\end{array}$ \\
\hline$x$ & CONTINUEI ME APERFEIÇOANDO SOBRE TEMAS ABORDADOS. \\
\hline
\end{tabular}

7) Depois do curso você apoiou atividades de capacitação de técnicos e agricultores com base nos princípios e diretrizes da Pnater? (Considere como apoio a atividades de capacitação a participação no planejamento, elaboração de ementas, seleção de participantes e de palestrantes.)

\begin{tabular}{|l|l|}
\hline & SIM \\
\hline$x$ & NÃO \\
\hline
\end{tabular}

8) Usou os conhecimentos para ministrar outros cursos com o mesmo conteúdo ou conteúdos semelhantes?

\begin{tabular}{|l|l|}
\hline & SIM \\
\hline$x$ & NÃO \\
\hline
\end{tabular}

9) Marque o seu grau de satisfação com relação ao curso oferecido pelo DATER: (Considere a seguinte pontuação: 1 - MUITO RUIM; 2 - RUIM; 3 - REGULAR; 4 - BOM; 5 - MUITO BOM)

\begin{tabular}{|l|l|l|l|l|}
\hline 1 & 2 & 3 & $4 x$ & 5 \\
\hline
\end{tabular}


10) Marque seu grau de satisfação com relação ao DATER: (Considere a seguinte pontuação: 1 - MUITO RUIM; 2 - RUIM; 3 - REGULAR; 4 - BOM; 5 - MUITO BOM)

\begin{tabular}{|l|l|l|l|l|}
\hline 1 & 2 & 3 & 4 & $5 \times$ \\
\hline
\end{tabular}


PESQUISA - IMPACTO DAS AÇÕES DE FORMAÇÃO REALIZADAS PELO DATER/SAF/MDA NO PERÍODO 2004-2009

Caros colaboradores,

Contamos com a sua atenção para preencher o formulário abaixo.

O mesmo tem por objetivo fornecer informações para avaliação da Eficiência, Efetividade e Eficácia da Política Pública de Formação de Agentes de Ater adotada pelo Departamento de Assistência Técnica e Extensão Rural, da Secretaria de Agricultura Familiar do Ministério do Desenvolvimento - DATER/SAF/MDA, no período de 2004 a 2009, tema escolhido para Monografia a ser apresentada à Universidade de Brasília (UnB) como requisito parcial para obtenção do grau de Bacharel em Administração.

Você poderá ou não se identificar no questionário e garantimos que todas as informações fornecidas serão confidenciais e utilizadas apenas de forma sistematizada.

\section{IDENTIFICAÇÃO}

\begin{tabular}{|l|l|}
\hline Nome: Alcione Miriam de Carvalho Teixeira & $\begin{array}{l}\text { Sexo: } \\
(\quad) \text { masculino } \quad(x \quad \text { ) feminino }\end{array}$ \\
\hline Instituição : EAMTER-MG & Local de trabalho : Sete Lagoas MG \\
\hline $\begin{array}{l}\text { Curso/Encontro/Oficina do qual participou : Especialização em Extensão Ruaral, Agroecologia e } \\
\text { Desenvolvimento Sustentável }\end{array}$ \\
\hline Data do Curso/Encontro/Oficina: Maio a dezembro de 2006 \\
\hline
\end{tabular}

Indique sua área de atuação? (As opções não são excludentes: você poderá marcar mais de uma opção).

\begin{tabular}{|l|l|}
\hline$x$ & EXTENSÃO RURAL \\
\hline & PESQUISA \\
\hline & ENSINO \\
\hline & OUTROS \\
\hline
\end{tabular}


2) Qual o seu nível de escolaridade? (Considere apenas o nível mais alto)

\begin{tabular}{|l|l|}
\hline & NÍVEL MÉDIO \\
\hline & NÍVEL SUPERIOR \\
\hline$x$ & PÓS-GRADUAÇÃO \\
\hline
\end{tabular}

3) Os conteúdos abordados foram condizentes com as demandas do seu dia-a-dia?

\begin{tabular}{|l|l|}
\hline$x$ & SIM \\
\hline & PARCIALMENTE \\
\hline & NÃO \\
\hline
\end{tabular}

4) O curso contribuiu para o seu aperfeiçoamento profissional?

\begin{tabular}{|l|l|}
\hline$x$ & SIM \\
\hline & NÃO \\
\hline
\end{tabular}

5) Os conhecimentos adquiridos estão sendo aplicados no seu trabalho? Em caso afirmativo, indique em que grau estes conhecimentos estão sendo aplicados. Em caso negativo, indique por que razão isto não ocorre: (As respostas não são excludentes: você poderá marcar mais de uma opção).

\begin{tabular}{|l|l|l|l|}
\hline \multirow{2}{*}{$\begin{array}{l}\text { SIM (indique ao lado em } \\
\text { que grau) }\end{array}$} & M & MUITO APLICADOS \\
\cline { 2 - 4 } & & MEDIAMENTE APLICADOS \\
\hline & $\begin{array}{l}\text { NÃO (indique ao lado a } \\
\text { razão da não aplicação) }\end{array}$ & $\begin{array}{l}\text { CONTEÚDO NÃO ADEQUADO ȦS NECESSIDADES } \\
\text { ESPECÍFICAS DA REGIÃO }\end{array}$ \\
\hline
\end{tabular}




\begin{tabular}{|l|l|l|}
\hline \multirow{10}{*}{} & & $\begin{array}{l}\text { CONTEÚDO NÃO FOI SUFICIENTEMENTE } \\
\text { APROFUNDADO PARA PERMITIR UMA APLICAÇÃO } \\
\text { EFICAZ E EFICIENTE }\end{array}$ \\
\cline { 2 - 5 } & $\begin{array}{l}\text { FALTA DE APOIO E INCENTIVO DA MINHA } \\
\text { INSTITUIÇÃO }\end{array}$ \\
\cline { 2 - 4 } & FALTA DE INCENTIVO ÀS AÇÕES DE ATER \\
\hline & NÃO TENHO INTERESSE EM APLICAR \\
\hline
\end{tabular}

6) A partir deste curso: (As opções não são excludentes: você poderá marcar mais de uma opção).

\begin{tabular}{|c|l|}
\hline$x$ & $\begin{array}{l}\text { NÃO MUDOU NADA EM MEU TRABALHO. } \\
\text { FAMILIARES. }\end{array}$ \\
\hline$x$ & CONSEGUI INFLUENCIAR NAS ORIENTAÇÕES DA MINHA INSTITUIÇÃO. \\
\hline$x$ & PASSEI A TRABALHAR COM METODOLOGIAS PARTICIPATIVAS. \\
\hline & $\begin{array}{l}\text { CRESCEU A ÁREA DE AGRICULTURA DE BASE ECOLÓGICA NAS COMUNIDADES } \\
\text { ONDE ATUO. }\end{array}$ \\
\hline & CONTINUEI ME APERFEIÇOANDO SOBRE TEMAS ABORDADOS. \\
\hline
\end{tabular}

7) Depois do curso você apoiou atividades de capacitação de técnicos e agricultores com base nos princípios e diretrizes da Pnater? (Considere como apoio a atividades de capacitação a participação no planejamento, elaboração de ementas, seleção de participantes e de palestrantes.)

\begin{tabular}{|l|l|}
\hline$x$ & SIM \\
\hline & NÃO \\
\hline
\end{tabular}

8) Usou os conhecimentos para ministrar outros cursos com o mesmo conteúdo ou conteúdos semelhantes? 


\begin{tabular}{|l|l|}
\hline$x$ & SIM \\
\hline & NÃO \\
\hline
\end{tabular}

9) Marque o seu grau de satisfação com relação ao curso oferecido pelo DATER: (Considere a seguinte pontuação: 1 - MUITO RUIM; 2 - RUIM; 3 - REGULAR; 4 - BOM; 5 - MUITO BOM)

\begin{tabular}{|l|l|l|l|l|}
\hline 1 & 2 & 3 & 4 & $x 5$ \\
\hline
\end{tabular}

10) Marque seu grau de satisfação com relação ao DATER: (Considere a seguinte pontuação: 1 - MUITO RUIM; 2 - RUIM; 3 - REGULAR; 4 - BOM; 5 - MUITO BOM)

\begin{tabular}{|l|l|l|l|l|}
\hline 1 & 2 & 3 & 4 & $x 5$ \\
\hline
\end{tabular}


PESQUISA - IMPACTO DAS AÇÕES DE FORMAÇÃO REALIZADAS PELO DATER/SAF/MDA NO PERÍODO 2004-2009

Caros colaboradores,

Contamos com a sua atenção para preencher o formulário abaixo.

O mesmo tem por objetivo fornecer informações para avaliação da Eficiência, Efetividade e Eficácia da Política Pública de Formação de Agentes de Ater adotada pelo Departamento de Assistência Técnica e Extensão Rural, da Secretaria de Agricultura Familiar do Ministério do Desenvolvimento - DATER/SAF/MDA, no período de 2004 a 2009, tema escolhido para Monografia a ser apresentada à Universidade de Brasília (UnB) como requisito parcial para obtenção do grau de Bacharel em Administração.

Você poderá ou não se identificar no questionário e garantimos que todas as informações fornecidas serão confidenciais e utilizadas apenas de forma sistematizada.

\section{IDENTIFICAÇÃO}

\begin{tabular}{|c|c|}
\hline Nome: Adriana Diniz de Magalhães Chaves & $\begin{array}{l}\text { Sexo: } \\
(\quad) \text { masculino }(x) \text { feminino }\end{array}$ \\
\hline $\begin{array}{l}\text { Instituição (nome e tipo de instituição: ONG, } \\
\text { Empresa Pública, etc.): Fundação ITESP - pública }\end{array}$ & $\begin{array}{l}\text { Local de trabalho (Cidade e Estado): } \\
\text { Pariquera-açu / SP }\end{array}$ \\
\hline \multicolumn{2}{|c|}{$\begin{array}{l}\text { Curso/Encontro/Oficina do qual participou (caso tenha participado de mais de um curso, preencha } \\
\text { um formulário para cada um deles): } \\
\text { Agroecologia }\end{array}$} \\
\hline nos & 2 \\
\hline
\end{tabular}

Indique sua área de atuação? (As opções não são excludentes: você poderá marcar mais de uma opção).

\begin{tabular}{|l|l|}
\hline$X$ & EXTENSÃO RURAL \\
\hline & PESQUISA \\
\hline & ENSINO \\
\hline
\end{tabular}




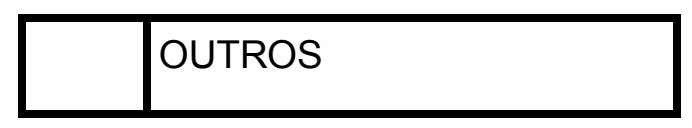

2) Qual o seu nível de escolaridade? (Considere apenas o nível mais alto)

\begin{tabular}{|l|l|}
\hline & NÍVEL MÉDIO \\
\hline$X$ & NÍVEL SUPERIOR \\
\hline & PÓS-GRADUAÇÃO \\
\hline
\end{tabular}

3) Os conteúdos abordados foram condizentes com as demandas do seu dia-a-dia?

\begin{tabular}{|l|l|}
\hline & SIM \\
\hline$X$ & PARCIALMENTE \\
\hline & NÃO \\
\hline
\end{tabular}

4) O curso contribuiu para o seu aperfeiçoamento profissional?

\begin{tabular}{|l|l|}
\hline$X$ & SIM \\
\hline & NÃO \\
\hline
\end{tabular}

5) Os conhecimentos adquiridos estão sendo aplicados no seu trabalho? Em caso afirmativo, indique em que grau estes conhecimentos estão sendo aplicados. Em caso negativo, indique por que razão isto não ocorre: (As respostas não são excludentes: você poderá marcar mais de uma opção).

\begin{tabular}{|l|l|l|l|}
\hline \multirow{2}{*}{$X$} & $\begin{array}{l}\text { SIM (indique ao lado em } \\
\text { que grau) }\end{array}$ & & MUITO APLICADOS \\
\cline { 3 - 4 } & & MEDIAMENTE APLICADOS \\
\hline & $\begin{array}{l}\text { NĀO (indique ao lado a } \\
\text { razão da não aplicação) }\end{array}$ & & $\begin{array}{l}\text { CONTEÚDO NÃO ADEQUADO ȦS NECESSIDADES } \\
\text { ESPECÍFICAS DA REGIÃO }\end{array}$ \\
\hline
\end{tabular}




\begin{tabular}{|l|l|l|}
\hline \multirow{10}{*}{} & $\begin{array}{l}\text { CONTEÚDO NÃO FOI SUFICIENTEMENTE } \\
\text { APROFUNDADO PARA PERMITIR UMA APLICAÇÃO } \\
\text { EFICAZ E EFICIENTE }\end{array}$ \\
\cline { 2 - 4 } & $\begin{array}{l}\text { FALTA DE APOIO E INCENTIVO DA MINHA } \\
\text { INSTITUIÇÃO }\end{array}$ \\
\cline { 2 - 4 } & FALTA DE INCENTIVO ÀS AÇÕES DE ATER \\
\hline & NÃO TENHO INTERESSE EM APLICAR \\
\hline
\end{tabular}

6) A partir deste curso: (As opções não são excludentes: você poderá marcar mais de uma opção).

\begin{tabular}{|l|l|}
\hline & NÃO MUDOU NADA EM MEU TRABALHO. \\
\hline & $\begin{array}{l}\text { MEU TRABALHO PASSOU A CONTRIBUIR MAIS COM OS AGRICULTORES(AS) } \\
\text { FAMILIARES. }\end{array}$ \\
\hline & CONSEGUI INFLUENCIAR NAS ORIENTAÇÕES DA MINHA INSTITUIÇÃO. \\
\hline & $\begin{array}{l}\text { CRESCEI A TRABALHAR COM METODOLOGIAS PARTICIPATIVAS. } \\
\text { ONDE ATUO. ÁREA DE AGRICULTURA DE BASE ECOLÓGICA NAS COMUNIDADES }\end{array}$ \\
\hline$X$ & CONTINUEI ME APERFEIÇOANDO SOBRE TEMAS ABORDADOS. \\
\hline
\end{tabular}

7) Depois do curso você apoiou atividades de capacitação de técnicos e agricultores com base nos princípios e diretrizes da Pnater? (Considere como apoio a atividades de capacitação a participação no planejamento, elaboração de ementas, seleção de participantes e de palestrantes.)

\begin{tabular}{|l|l|}
\hline$X$ & SIM \\
\hline & NÃO \\
\hline
\end{tabular}

8) Usou os conhecimentos para ministrar outros cursos com o mesmo conteúdo ou conteúdos semelhantes? 


\begin{tabular}{|l|l|}
\hline & SIM \\
\hline$X$ & NÃO \\
\hline
\end{tabular}

9) Marque o seu grau de satisfação com relação ao curso oferecido pelo DATER: (Considere a seguinte pontuação: 1 - MUITO RUIM; 2 - RUIM; 3 - REGULAR; 4 - BOM; 5 - MUITO BOM)

\begin{tabular}{|l|l|l|l|l|}
\hline 1 & 2 & $3 X$ & 4 & 5 \\
\hline
\end{tabular}

10) Marque seu grau de satisfação com relação ao DATER: (Considere a seguinte pontuação: 1 - MUITO RUIM; 2 - RUIM; 3 - REGULAR; 4 - BOM; 5 - MUITO BOM)

\begin{tabular}{|l|l|l|l|l|}
\hline 1 & 2 & $3 X$ & 4 & 5 \\
\hline
\end{tabular}


PESQUISA - IMPACTO DAS AÇÕES DE FORMAÇÃO REALIZADAS PELO DATER/SAF/MDA NO PERÍODO 2004-2009

Caros colaboradores,

Contamos com a sua atenção para preencher o formulário abaixo.

O mesmo tem por objetivo fornecer informações para avaliação da Eficiência, Efetividade e Eficácia da Política Pública de Formação de Agentes de Ater adotada pelo Departamento de Assistência Técnica e Extensão Rural, da Secretaria de Agricultura Familiar do Ministério do Desenvolvimento - DATER/SAF/MDA, no período de 2004 a 2009, tema escolhido para Monografia a ser apresentada à Universidade de Brasília (UnB) como requisito parcial para obtenção do grau de Bacharel em Administração.

Você poderá ou não se identificar no questionário e garantimos que todas as informações fornecidas serão confidenciais e utilizadas apenas de forma sistematizada.

\section{IDENTIFICAÇÃO}

\begin{tabular}{|c|c|}
\hline $\begin{array}{l}\text { Nome: } \\
\text { Vera Regina Santos Balbino }\end{array}$ & $\begin{array}{l}\text { Sexo: } \\
(\quad) \text { masculino } \quad(\quad x) \text { feminino }\end{array}$ \\
\hline $\begin{array}{l}\text { Instituição (nome e tipo de instituição: ONG, } \\
\text { Empresa Pública, etc.): } \\
\text { INCAPER }\end{array}$ & Local de trabalho (Cidade e Estado): \\
\hline \multicolumn{2}{|c|}{$\begin{array}{l}\text { Curso/Encontro/Oficina do qual participou (caso tenha participado de mais de um curso, preencha } \\
\text { um formulário para cada um deles): } \\
\text { Oficina MDA - Alegre / ES }\end{array}$} \\
\hline $\begin{array}{l}\text { Data do Curso/Encontro/Oficina (pelo menos mês e } \\
\text { 25/05/2006 }\end{array}$ & \\
\hline
\end{tabular}

Indique sua área de atuação? (As opções não são excludentes: você poderá marcar mais de uma opção).

\begin{tabular}{|l|l|}
\hline$X$ & EXTENSÃO RURAL \\
\hline & PESQUISA \\
\hline & ENSINO \\
\hline & OUTROS \\
\hline
\end{tabular}


2) Qual o seu nível de escolaridade? (Considere apenas o nível mais alto)

\begin{tabular}{|l|l|}
\hline & NÍVEL MÉDIO \\
\hline & NÍVEL SUPERIOR \\
\hline$X$ & PÓS-GRADUAÇÃO \\
\hline
\end{tabular}

3) Os conteúdos abordados foram condizentes com as demandas do seu dia-a-dia?

\begin{tabular}{|l|l|}
\hline$X$ & SIM \\
\hline & PARCIALMENTE \\
\hline & NÃO \\
\hline
\end{tabular}

4) O curso contribuiu para o seu aperfeiçoamento profissional?

\begin{tabular}{|l|l|}
\hline & SIM \\
\hline$X$ & NÃO \\
\hline
\end{tabular}

5) Os conhecimentos adquiridos estão sendo aplicados no seu trabalho? Em caso afirmativo, indique em que grau estes conhecimentos estão sendo aplicados. Em caso negativo, indique por que razão isto não ocorre: (As respostas não são excludentes: você poderá marcar mais de uma opção).

\begin{tabular}{|l|l|l|l|}
\hline \multirow{2}{*}{$\begin{array}{l}\text { SIM (indique ao lado em } \\
\text { que grau) }\end{array}$} & & MUITO APLICADOS \\
\cline { 3 - 4 } & & MEDIAMENTE APLICADOS \\
\hline$X$ & $\begin{array}{l}\text { NÃO (indique ao lado a } \\
\text { razão da não aplicação) }\end{array}$ & $\begin{array}{l}\text { CONTEÚDO NÃO ADEQUADO ȦS NECESSIDADES } \\
\text { ESPECÍFICAS DA REGIÃO }\end{array}$ \\
\hline
\end{tabular}




\begin{tabular}{|l|l|l|l|}
\hline$x$ & $\begin{array}{l}\text { CONTEÚDO NÃO FOI SUFICIENTEMENTE } \\
\text { APROFUNDADO PARA PERMITIR UMA APLICAÇÃO } \\
\text { EFICAZ E EFICIENTE }\end{array}$ \\
\cline { 2 - 5 } & $\begin{array}{l}\text { FALTA DE APOIO E INCENTIVO DA MINHA } \\
\text { INSTITUIÇÃO }\end{array}$ \\
\cline { 2 - 4 } & FALTA DE INCENTIVO ÀS AÇÕES DE ATER \\
\hline & NÃO TENHO INTERESSE EM APLICAR \\
\hline
\end{tabular}

6) A partir deste curso: (As opções não são excludentes: você poderá marcar mais de uma opção).

\begin{tabular}{|l|l|}
\hline$X$ & NÃO MUDOU NADA EM MEU TRABALHO. \\
\hline & $\begin{array}{l}\text { MEU TRABALHO PASSOU A CONTRIBUIR MAIS COM OS AGRICULTORES(AS) } \\
\text { FAMILIARES. }\end{array}$ \\
\hline & CONSEGUI INFLUENCIAR NAS ORIENTAÇÕES DA MINHA INSTITUIÇÃO. \\
\hline & $\begin{array}{l}\text { CRESESE A TRABALHAR COM METODOLOGIAS PARTICIPATIVAS. } \\
\text { ONDE ATUO. ÁREA DE AGRICULTURA DE BASE ECOLÓGICA NAS COMUNIDADES }\end{array}$ \\
\hline & CONTINUEI ME APERFEIÇOANDO SOBRE TEMAS ABORDADOS. \\
\hline
\end{tabular}

7) Depois do curso você apoiou atividades de capacitação de técnicos e agricultores com base nos princípios e diretrizes da Pnater? (Considere como apoio a atividades de capacitação a participação no planejamento, elaboração de ementas, seleção de participantes e de palestrantes.)

\begin{tabular}{|l|l|}
\hline$X$ & SIM \\
\hline & NÃO \\
\hline
\end{tabular}

8) Usou os conhecimentos para ministrar outros cursos com o mesmo conteúdo ou conteúdos semelhantes? 


\begin{tabular}{|l|l|}
\hline & SIM \\
\hline$X$ & NÃO \\
\hline
\end{tabular}

9) Marque o seu grau de satisfação com relação ao curso oferecido pelo DATER: (Considere a seguinte pontuação: 1 - MUITO RUIM; 2 - RUIM; 3 - REGULAR; 4 - BOM; 5 - MUITO BOM)

\begin{tabular}{|l|l|l|l|l|}
\hline 1 & 2 & $3 X$ & 4 & 5 \\
\hline
\end{tabular}

10) Marque seu grau de satisfação com relação ao DATER: (Considere a seguinte pontuação: 1 - MUITO RUIM; 2 - RUIM; 3 - REGULAR; 4 - BOM; 5 - MUITO BOM)

\begin{tabular}{|l|l|l|l|l|}
\hline 1 & 2 & 3 & $4 X$ & 5 \\
\hline
\end{tabular}


PESQUISA - IMPACTO DAS AÇÕES DE FORMAÇÃO REALIZADAS PELO DATER/SAF/MDA NO PERÍODO 2004-2009

Caros colaboradores,

Contamos com a sua atenção para preencher o formulário abaixo.

O mesmo tem por objetivo fornecer informações para avaliação da Eficiência, Efetividade e Eficácia da Política Pública de Formação de Agentes de Ater adotada pelo Departamento de Assistência Técnica e Extensão Rural, da Secretaria de Agricultura Familiar do Ministério do Desenvolvimento - DATER/SAF/MDA, no período de 2004 a 2009, tema escolhido para Monografia a ser apresentada à Universidade de Brasília (UnB) como requisito parcial para obtenção do grau de Bacharel em Administração.

Você poderá ou não se identificar no questionário e garantimos que todas as informações fornecidas serão confidenciais e utilizadas apenas de forma sistematizada.

\section{IDENTIFICAÇÃO}

\begin{tabular}{|l|l|}
\hline $\begin{array}{l}\text { Nome: (opcional) } \\
\text { Fernando Cassimiro Tinoco França }\end{array}$ & $\begin{array}{l}\text { Sexo: } \\
(x) \text { masculino } \quad(\quad) \text { feminino }\end{array}$ \\
\hline $\begin{array}{l}\text { Instituição (nome e tipo de instituição: ONG, } \\
\text { Empresa Pública, Cooperativa,etc.): } \\
\text { EMATER MG }\end{array}$ & $\begin{array}{l}\text { Local de trabalho (Cidade e Estado): } \\
\text { SETE LAGOAS }\end{array}$ \\
$\begin{array}{l}\text { Curso/Encontro/Oficina do qual participou (caso tenha participado de mais de um evento de } \\
\text { formação, preencha um formulário para cada um deles): } \\
\text { SAF'S }\end{array}$
\end{tabular}

Data do Curso/Encontro/Oficina/Seminário (pelo menos mês e ano): 2008

1) Indique sua área de atuação? (As opções não são excludentes: você poderá marcar mais de uma opção).

\begin{tabular}{|l|l|}
\hline$X$ & EXTENSÃO RURAL \\
\hline & PESQUISA \\
\hline & ENSINO \\
\hline & OUTROS \\
\hline
\end{tabular}


2) Qual o seu nível de escolaridade? (Considere apenas o nível mais alto)

\begin{tabular}{|l|l|}
\hline & NÍVEL MÉDIO \\
\hline & NÍVEL SUPERIOR \\
\hline$X$ & PÓS-GRADUAÇÃO \\
\hline
\end{tabular}

3) Os conteúdos abordados na formação foram condizentes com as demandas do seu dia-adia?

\begin{tabular}{|l|l|}
\hline$X$ & SIM \\
\hline & PARCIALMENTE \\
\hline & NÃO \\
\hline
\end{tabular}

4) O curso ou atividade de formação da qual você participou contribuiu para o seu aperfeiçoamento profissional?

\begin{tabular}{|l|l|}
\hline$x$ & SIM \\
\hline & NÃO \\
\hline
\end{tabular}

5) Os conhecimentos adquiridos nesta formação estão sendo aplicados no seu trabalho? Em caso afirmativo, indique em que grau estes conhecimentos estão sendo aplicados. Em caso negativo, indique por que razão isto não ocorre: (As respostas não são excludentes: você poderá marcar mais de uma opção).

\begin{tabular}{|c|c|c|}
\hline \multirow{3}{*}{$\begin{array}{l}\text { SIM (indique ao lado } \\
\text { em que grau) }\end{array}$} & & MUITO APLICADOS \\
\hline & $X$ & MEDIAMENTE APLICADOS \\
\hline & & POUCO APLICADOS \\
\hline \multirow{2}{*}{$\begin{array}{l}\text { NÃO (indique ao lado a } \\
\text { razão da } \quad \text { não } \\
\text { aplicação) }\end{array}$} & & $\begin{array}{l}\text { CONTEÚDO NÃO ADEQUADO ÀS NECESSIDADES } \\
\text { ESPECÍFICAS DA REGIÃO }\end{array}$ \\
\hline & & $\begin{array}{lccc}\text { CONTEÚDO NÃO } & \text { FOI } & \text { SUFICIENTEMENTE } \\
\text { APROFUNDADO } & \text { PARA } & \text { PERMITIR } & \text { UMA } \\
\text { APLICAÇÃO EFICAZ E EFICIENTE } & \end{array}$ \\
\hline
\end{tabular}




\begin{tabular}{|l|l|l|}
\hline \multirow{2}{*}{} & & $\begin{array}{l}\text { FALTA DE APOIO E INCENTIVO DA MINHA } \\
\text { INSTITUIÇÃO }\end{array}$ \\
\hline & & FALTA DE INCENTIVO ÀS AÇÕES DE ATER \\
\hline & NÃO TENHO INTERESSE EM APLICAR \\
\hline
\end{tabular}

6) A partir do evento de formação do qual você participou: (As respostas não são excludentes: você poderá marcar mais de uma opção).

\begin{tabular}{|l|l|}
\hline & NÃO MUDOU NADA EM MEU TRABALHO. \\
\hline & $\begin{array}{l}\text { MEU TRABALHO PASSOU A CONTRIBUIR MAIS COM OS AGRICULTORES(AS) } \\
\text { FAMILIARES. }\end{array}$ \\
\hline & CONSEGUI INFLUENCIAR NAS ORIENTAÇÕES DA MINHA INSTITUIÇÃO. \\
\hline$X$ & $\begin{array}{l}\text { CRESCEU A ÁREA DE AGRICULTURA DE BASE ECOLÓGICA NAS } \\
\text { COMUNIDADES ONDE ATUO. }\end{array}$ \\
\hline & CONTINUEI ME APERFEIÇOANDO SOBRE TEMAS ABORDADOS. \\
\hline
\end{tabular}

7) Depois do curso você apoiou atividades de capacitação de técnicos e agricultores com base nos princípios e diretrizes da Pnater? (Considere como apoio a atividades de capacitação a participação no planejamento, elaboração de ementas, seleção de participantes e de palestrantes.)

\begin{tabular}{|l|l|}
\hline$X$ & SIM \\
\hline & NÃO \\
\hline
\end{tabular}

8) Usou os conhecimentos para ministrar outros eventos de formação com o mesmo conteúdo ou conteúdos semelhantes?

\begin{tabular}{|l|l|}
\hline$X$ & SIM \\
\hline & NÃO \\
\hline
\end{tabular}


9) Marque o seu grau de satisfação com relação a atividade de formação oferecida pelo DATER: (Considere a seguinte pontuação: 1 - MUITO RUIM; 2 - RUIM; 3 - REGULAR; 4 BOM; 5 - MUITO BOM)

\begin{tabular}{|l|l|l|l|l|}
\hline 1 & 2 & 3 & $X 4$ & 5 \\
\hline
\end{tabular}

10) Marque seu grau de satisfação com relação ao DATER: (Considere a seguinte pontuação: 1 - MUITO RUIM; 2 - RUIM; 3 - REGULAR; 4 - BOM; 5 - MUITO BOM)

\begin{tabular}{|l|l|l|l|l|}
\hline 1 & 2 & 3 & 4 & $x 5$ \\
\hline
\end{tabular}


PESQUISA - IMPACTO DAS AÇÕES DE FORMAÇÃO REALIZADAS PELO DATER/SAF/MDA NO PERÍODO 2004-2009

Caros colaboradores,

Contamos com a sua atenção para preencher o formulário abaixo.

O mesmo tem por objetivo fornecer informações para avaliação da Eficiência, Efetividade e Eficácia da Política Pública de Formação de Agentes de Ater adotada pelo Departamento de Assistência Técnica e Extensão Rural, da Secretaria de Agricultura Familiar do Ministério do Desenvolvimento - DATER/SAF/MDA, no período de 2004 a 2009, tema escolhido para Monografia a ser apresentada à Universidade de Brasília (UnB) como requisito parcial para obtenção do grau de Bacharel em Administração.

Você poderá ou não se identificar no questionário e garantimos que todas as informações fornecidas serão confidenciais e utilizadas apenas de forma sistematizada.

\section{IDENTIFICAÇÃO}

\begin{tabular}{|l|l|}
\hline Nome: Thiago Carvalho Alves de Araújo & $\begin{array}{l}\text { Sexo: } \\
(x) \text { masculino } \quad(\quad \text { ) feminino }\end{array}$ \\
\hline Instituição EMATER-MG & Local de trabalho Jaíba-MG (Projeto Jaíba) \\
\hline $\begin{array}{l}\text { Curso/Encontro/Oficina do qual participou Pós-Graduação Lato sensu em Extensão Rural, } \\
\text { Agroecologia e Desenvolvimento Sustentável }\end{array}$ \\
\hline Data do Curso/Encontro/Oficina: Maio a Dezembro / 2006 \\
\hline
\end{tabular}

1) Indique sua área de atuação? (As opções não são excludentes: você poderá marcar mais de uma opção).

\begin{tabular}{|l|l|}
\hline$X$ & EXTENSÃO RURAL \\
\hline & PESQUISA \\
\hline & ENSINO \\
\hline & OUTROS \\
\hline
\end{tabular}


2) Qual o seu nível de escolaridade? (Considere apenas o nível mais alto)

\begin{tabular}{|l|l|}
\hline & NÍVEL MÉDIO \\
\hline$X$ & NÍVEL SUPERIOR \\
\hline & PÓS-GRADUAÇÃO \\
\hline
\end{tabular}

3) Os conteúdos abordados foram condizentes com as demandas do seu dia-a-dia?

\begin{tabular}{|l|l|}
\hline$X$ & SIM \\
\hline & PARCIALMENTE \\
\hline & NÃO \\
\hline
\end{tabular}

4) O curso contribuiu para o seu aperfeiçoamento profissional?

\begin{tabular}{|l|l|}
\hline$X$ & SIM \\
\hline & NÃO \\
\hline
\end{tabular}

5) Os conhecimentos adquiridos estão sendo aplicados no seu trabalho? Em caso afirmativo, indique em que grau estes conhecimentos estão sendo aplicados. Em caso negativo, indique por que razão isto não ocorre: (As respostas não são excludentes: você poderá marcar mais de uma opção).

\begin{tabular}{|l|l|l|l|}
\hline \multirow{2}{*}{$\begin{array}{l}\text { SIM (indique ao lado em } \\
\text { que grau) }\end{array}$} & X & MUITO APLICADOS \\
\cline { 2 - 3 } & & MEDIAMENTE APLICADOS \\
\hline & $\begin{array}{l}\text { NÃO (indique ao lado a } \\
\text { razão da não aplicação) }\end{array}$ & $\begin{array}{l}\text { CONTEÚDO NÃO ADEQUADO ȦS NECESSIDADES } \\
\text { ESPECÍFICAS DA REGIÃO }\end{array}$ \\
\hline
\end{tabular}




\begin{tabular}{|l|l|l|}
\hline \multirow{10}{*}{} & $\begin{array}{l}\text { CONTEÚDO NÃO FOI SUFICIENTEMENTE } \\
\text { APROFUNDADO PARA PERMITIR UMA APLICAÇÃO } \\
\text { EFICAZ E EFICIENTE }\end{array}$ \\
\cline { 2 - 4 } & $\begin{array}{l}\text { FALTA DE APOIO E INCENTIVO DA MINHA } \\
\text { INSTITUIÇÃO }\end{array}$ \\
\cline { 2 - 4 } & FALTA DE INCENTIVO ÀS AÇÕES DE ATER \\
\hline & NÃO TENHO INTERESSE EM APLICAR \\
\hline
\end{tabular}

6) A partir deste curso: (As opções não são excludentes: você poderá marcar mais de uma opção).

\begin{tabular}{|l|l|}
\hline & NÃO MUDOU NADA EM MEU TRABALHO. \\
\hline $1^{\circ}$ & $\begin{array}{l}\text { MEU TRABALHO PASSOU A CONTRIBUIR MAIS COM OS AGRICULTORES(AS) } \\
\text { FAMILIARES. }\end{array}$ \\
\hline $3^{\circ}$ & CONSEGUI INFLUENCIAR NAS ORIENTAÇÕES DA MINHA INSTITUIÇÃO. \\
\hline $2^{\circ}$ & PASSEI A TRABALHAR COM METODOLOGIAS PARTICIPATIVAS. \\
\hline & $\begin{array}{l}\text { CRESCEU A ÁREA DE AGRICULTURA DE BASE ECOLÓGICA NAS COMUNIDADES } \\
\text { ONDE ATUO. }\end{array}$ \\
\hline $4^{\circ}$ & CONTINUEI ME APERFEIÇOANDO SOBRE TEMAS ABORDADOS. \\
\hline
\end{tabular}

7) Depois do curso você apoiou atividades de capacitação de técnicos e agricultores com base nos princípios e diretrizes da Pnater? (Considere como apoio a atividades de capacitação a participação no planejamento, elaboração de ementas, seleção de participantes e de palestrantes.)

\begin{tabular}{|l|l|}
\hline$X$ & SIM \\
\hline & NÃO \\
\hline
\end{tabular}

8) Usou os conhecimentos para ministrar outros cursos com o mesmo conteúdo ou conteúdos semelhantes? 


\begin{tabular}{|l|l|}
\hline$X$ & SIM \\
\hline & NÃO \\
\hline
\end{tabular}

9) Marque o seu grau de satisfação com relação ao curso oferecido pelo DATER: (Considere a seguinte pontuação: 1 - MUITO RUIM; 2 - RUIM; 3 - REGULAR; 4 - BOM; 5 - MUITO BOM)

\begin{tabular}{|l|l|l|l|l|}
\hline 1 & 2 & 3 & 4 & 5 \\
\hline
\end{tabular}

10) Marque seu grau de satisfação com relação ao DATER: (Considere a seguinte pontuação: 1 - MUITO RUIM; 2 - RUIM; 3 - REGULAR; 4 - BOM; 5 - MUITO BOM)

\begin{tabular}{|l|l|l|l|l|}
\hline 1 & 2 & 3 & 4 & 5 \\
\hline
\end{tabular}

Acho apenas que a escolha da instituição de ensino não foi adequada para a realização do Curso de Pós-Graduação em Agroecologia, por se tratar de uma universidade conservadora, sem tradição alguma em trabalhos desenvolvimentos para a agricultora de base ecológica, que não possui a disciplina Extensão Rural no conteúdo programático do curso de Agronomia e realizado numa cidade com baixa consciência ambiental. O curso recebeu pouco apoio da reitoria. Mas, de tudo tem uma lado bom: após a realização de tantas bancas examinadoras com professores da UninCor, ficou evidenciado o aumento do interesse do corpo docente pelos assuntos abordados no Curso. Demonstraram interesse em lutar para a inclusão das disciplinas Agroecologia e Extensão Rural para o cu 
PESQUISA - IMPACTO DAS AÇÕES DE FORMAÇÃO REALIZADAS PELO DATER/SAF/MDA NO PERÍODO 2004-2009

Caros colaboradores,

Contamos com a sua atenção para preencher o formulário abaixo.

O mesmo tem por objetivo fornecer informações para avaliação da Eficiência, Efetividade e Eficácia da Política Pública de Formação de Agentes de Ater adotada pelo Departamento de Assistência Técnica e Extensão Rural, da Secretaria de Agricultura Familiar do Ministério do Desenvolvimento - DATER/SAF/MDA, no período de 2004 a 2009, tema escolhido para Monografia a ser apresentada à Universidade de Brasília (UnB) como requisito parcial para obtenção do grau de Bacharel em Administração.

Você poderá ou não se identificar no questionário e garantimos que todas as informações fornecidas serão confidenciais e utilizadas apenas de forma sistematizada.

\section{IDENTIFICAÇÃO}

\begin{tabular}{|c|c|}
\hline Nome: Sonia Emi Sato & $\begin{array}{l}\text { Sexo: } \\
(\quad) \text { masculino } \quad(x) \text { feminino }\end{array}$ \\
\hline $\begin{array}{l}\text { Instituição (nome e tipo de instituição: ONG, } \\
\text { Empresa Pública, etc.): Casa da Agricultura de } \\
\text { Regente Feijó - Instituição Publica }\end{array}$ & $\begin{array}{l}\text { Local de trabalho (Cidade e Estado): } \\
\text { Regente Feijo }\end{array}$ \\
\hline \multicolumn{2}{|c|}{$\begin{array}{l}\text { Curso/Encontro/Oficina do qual participou (caso tenha participado de mais de um curso, preencha } \\
\text { um formulário para cada um deles): } 1^{\text {a }} \text { Oficina ATER região Sudeste em Vila Velha -ES }\end{array}$} \\
\hline \multicolumn{2}{|l|}{ Data do Curso/Encontro/Oficina (pelo menos mês e ano): } \\
\hline
\end{tabular}

Indique sua área de atuação? (As opções não são excludentes: você poderá marcar mais de uma opção).

\begin{tabular}{|l|l|}
\hline$X$ & EXTENSÃO RURAL \\
\hline & PESQUISA \\
\hline & ENSINO \\
\hline & OUTROS \\
\hline
\end{tabular}


2) Qual o seu nível de escolaridade? (Considere apenas o nível mais alto)

\begin{tabular}{|l|l|}
\hline & NÍVEL MÉDIO \\
\hline$X$ & NÍVEL SUPERIOR \\
\hline & PÓS-GRADUAÇÃO \\
\hline
\end{tabular}

3) Os conteúdos abordados foram condizentes com as demandas do seu dia-a-dia?

\begin{tabular}{|l|l|}
\hline$X$ & SIM \\
\hline & PARCIALMENTE \\
\hline & NÃO \\
\hline
\end{tabular}

4) O curso contribuiu para o seu aperfeiçoamento profissional?

\begin{tabular}{|l|l|}
\hline$X$ & SIM \\
\hline & NÃO \\
\hline
\end{tabular}

5) Os conhecimentos adquiridos estão sendo aplicados no seu trabalho? Em caso afirmativo, indique em que grau estes conhecimentos estão sendo aplicados. Em caso negativo, indique por que razão isto não ocorre: (As respostas não são excludentes: você poderá marcar mais de uma opção).

\begin{tabular}{|l|l|l|l|}
\hline \multirow{2}{*}{$\mathrm{X}$} & $\begin{array}{l}\text { SIM (indique ao lado em } \\
\text { que grau) }\end{array}$ & $\mathrm{x}$ & MUITO APLICADOS \\
\cline { 2 - 4 } & & POUCIAMENTE APLICADOS APLICADOS \\
\hline & $\begin{array}{l}\text { NÃO (indique ao lado a } \\
\text { razão da não aplicação) }\end{array}$ & $\begin{array}{l}\text { CONTEÚDO NÃO ADEQUADO ȦS NECESSIDADES } \\
\text { ESPECÍFICAS DA REGIÃO }\end{array}$ \\
\hline
\end{tabular}




\begin{tabular}{|l|l|l|}
\hline \multirow{10}{*}{} & $\begin{array}{l}\text { CONTEÚDO NÃO FOI SUFICIENTEMENTE } \\
\text { APROFUNDADO PARA PERMITIR UMA APLICAÇÃO } \\
\text { EFICAZ E EFICIENTE }\end{array}$ \\
\cline { 2 - 4 } & $\begin{array}{l}\text { FALTA DE APOIO E INCENTIVO DA MINHA } \\
\text { INSTITUIÇÃO }\end{array}$ \\
\cline { 2 - 4 } & FALTA DE INCENTIVO ÀS AÇÕES DE ATER \\
\hline & NÃO TENHO INTERESSE EM APLICAR \\
\hline
\end{tabular}

6) A partir deste curso: (As opções não são excludentes: você poderá marcar mais de uma opção).

\begin{tabular}{|l|l|}
\hline$x$ & $\begin{array}{l}\text { NÃO MUDOU NADA EM MEU TRABALHO. } \\
\text { FAMILIARES. }\end{array}$ \\
\hline & CONSEGUI INFLUENCIAR NAS ORIENTAÇÕES DA MINHA INSTITUIÇÃO. \\
\hline & PASSEI A TRABALHAR COM METODOLOGIAS PARTICIPATIVAS. \\
\hline & $\begin{array}{l}\text { CRESCEU A ÁREA DE AGRICULTURA DE BASE ECOLÓGICA NAS COMUNIDADES } \\
\text { ONDE ATUO. }\end{array}$ \\
\hline & CONTINUEI ME APERFEIÇOANDO SOBRE TEMAS ABORDADOS. \\
\hline
\end{tabular}

7) Depois do curso você apoiou atividades de capacitação de técnicos e agricultores com base nos princípios e diretrizes da Pnater? (Considere como apoio a atividades de capacitação a participação no planejamento, elaboração de ementas, seleção de participantes e de palestrantes.)

\begin{tabular}{|l|l|}
\hline & SIM \\
\hline$x$ & NÃO \\
\hline
\end{tabular}

8) Usou os conhecimentos para ministrar outros cursos com o mesmo conteúdo ou conteúdos semelhantes? 


\begin{tabular}{|l|l|}
\hline & SIM \\
\hline$x$ & NÃO \\
\hline
\end{tabular}

9) Marque o seu grau de satisfação com relação ao curso oferecido pelo DATER: (Considere a seguinte pontuação: 1 - MUITO RUIM; 2 - RUIM; 3 - REGULAR; 4 - BOM; 5 - MUITO BOM)

\begin{tabular}{|l|l|l|l|l|}
\hline 1 & 2 & 3 & $4 x$ & 5 \\
\hline
\end{tabular}

10) Marque seu grau de satisfação com relação ao DATER: (Considere a seguinte pontuação: 1 - MUITO RUIM; 2 - RUIM; 3 - REGULAR; 4 - BOM; 5 - MUITO BOM)

\begin{tabular}{|l|l|l|l|l|}
\hline 1 & 2 & 3 & $4 x$ & 5 \\
\hline
\end{tabular}


PESQUISA - IMPACTO DAS AÇÕES DE FORMAÇÃO REALIZADAS PELO DATER/SAF/MDA NO PERÍODO 2004-2009

Caros colaboradores,

Contamos com a sua atenção para preencher o formulário abaixo.

O mesmo tem por objetivo fornecer informações para avaliação da Eficiência, Efetividade e Eficácia da Política Pública de Formação de Agentes de Ater adotada pelo Departamento de Assistência Técnica e Extensão Rural, da Secretaria de Agricultura Familiar do Ministério do Desenvolvimento - DATER/SAF/MDA, no período de 2004 a 2009, tema escolhido para Monografia a ser apresentada à Universidade de Brasília (UnB) como requisito parcial para obtenção do grau de Bacharel em Administração.

Você poderá ou não se identificar no questionário e garantimos que todas as informações fornecidas serão confidenciais e utilizadas apenas de forma sistematizada.

IDENTIFICAÇÃO

\begin{tabular}{|c|c|}
\hline Nome: SHOITI MILTON TAKEUCHI & $\begin{array}{l}\text { Sexo: } \\
(x \quad) \text { masculino } \quad(\quad) \text { feminino }\end{array}$ \\
\hline $\begin{array}{l}\text { Instituição (nome e tipo de instituição: ONG, } \\
\text { Empresa Pública, etc.): EMATER-MG / Empresa } \\
\text { pública }\end{array}$ & $\begin{array}{l}\text { Local de trabalho (Cidade e Estado): Sete } \\
\text { Lagoas-MG }\end{array}$ \\
\hline \multicolumn{2}{|c|}{$\begin{array}{l}\text { Curso/Encontro/Oficina do qual participou (caso tenha participado de mais de um curso, preencha } \\
\text { um formulário para cada um deles): Curso de especialização "Extensão Rural. Agroecologia e } \\
\text { Desenvolvimento Sustentável" }\end{array}$} \\
\hline & 2). Mailne \\
\hline
\end{tabular}

Indique sua área de atuação? (As opções não são excludentes: você poderá marcar mais de uma opção).

\begin{tabular}{|l|l|}
\hline$X$ & EXTENSÃO RURAL \\
\hline & PESQUISA \\
\hline & ENSINO \\
\hline & OUTROS \\
\hline
\end{tabular}


2) Qual o seu nível de escolaridade? (Considere apenas o nível mais alto)

\begin{tabular}{|l|l|}
\hline & NÍVEL MÉDIO \\
\hline$X$ & NÍVEL SUPERIOR \\
\hline & PÓS-GRADUAÇÃO \\
\hline
\end{tabular}

3) Os conteúdos abordados foram condizentes com as demandas do seu dia-a-dia?

\begin{tabular}{|l|l|}
\hline & SIM \\
\hline$X$ & PARCIALMENTE \\
\hline & NÃO \\
\hline
\end{tabular}

4) O curso contribuiu para o seu aperfeiçoamento profissional?

\begin{tabular}{|l|l|}
\hline$X$ & SIM \\
\hline & NÃO \\
\hline
\end{tabular}

5) Os conhecimentos adquiridos estão sendo aplicados no seu trabalho? Em caso afirmativo, indique em que grau estes conhecimentos estão sendo aplicados. Em caso negativo, indique por que razão isto não ocorre: (As respostas não são excludentes: você poderá marcar mais de uma opção).

\begin{tabular}{|l|l|l|l|}
\hline$x$ & $\begin{array}{l}\text { SIM (indique ao lado em } \\
\text { que grau) }\end{array}$ & $X$ & MUITO APLICADOS \\
\cline { 3 - 4 } & & MEDIAMENTE APLICADOS \\
\hline & $\begin{array}{l}\text { NÃO (indique ao lado a } \\
\text { razão da não aplicação) }\end{array}$ & $\begin{array}{l}\text { CONTEÚDO NÃO ADEQUADO ȦS NECESSIDADES } \\
\text { ESPECÍFICAS DA REGIÃO }\end{array}$ \\
\hline
\end{tabular}




\begin{tabular}{|l|l|l|}
\hline \multirow{10}{*}{} & $\begin{array}{l}\text { CONTEÚDO NÃO FOI SUFICIENTEMENTE } \\
\text { APROFUNDADO PARA PERMITIR UMA APLICAÇÃO } \\
\text { EFICAZ E EFICIENTE }\end{array}$ \\
\cline { 2 - 4 } & $\begin{array}{l}\text { FALTA DE APOIO E INCENTIVO DA MINHA } \\
\text { INSTITUIÇÃO }\end{array}$ \\
\cline { 2 - 4 } & FALTA DE INCENTIVO ÀS AÇÕES DE ATER \\
\hline & NÃO TENHO INTERESSE EM APLICAR \\
\hline
\end{tabular}

6) A partir deste curso: (As opções não são excludentes: você poderá marcar mais de uma opção).

\begin{tabular}{|l|l|}
\hline$x$ & $\begin{array}{l}\text { NÃO MUDOU NADA EM MEU TRABALHO. } \\
\text { FAMILIARES. }\end{array}$ \\
\hline & CONSEGUI INFLUENCIAR NAS ORIENTAÇÕES DA MINHA INSTITUIÇÃO. \\
\hline & PASSEI A TRABALHAR COM METODOLOGIAS PARTICIPATIVAS. \\
\hline & $\begin{array}{l}\text { CRESCEU A ÁREA DE AGRICULTURA DE BASE ECOLÓGICA NAS COMUNIDADES } \\
\text { ONDE ATUO. }\end{array}$ \\
\hline$X$ & CONTINUEI ME APERFEIÇOANDO SOBRE TEMAS ABORDADOS. \\
\hline
\end{tabular}

7) Depois do curso você apoiou atividades de capacitação de técnicos e agricultores com base nos princípios e diretrizes da Pnater? (Considere como apoio a atividades de capacitação a participação no planejamento, elaboração de ementas, seleção de participantes e de palestrantes.)

\begin{tabular}{|l|l|}
\hline & SIM \\
\hline$X$ & NÃO \\
\hline
\end{tabular}

8) Usou os conhecimentos para ministrar outros cursos com o mesmo conteúdo ou conteúdos semelhantes? 


\begin{tabular}{|l|l|}
\hline$X$ & SIM \\
\hline & NÃO \\
\hline
\end{tabular}

9) Marque o seu grau de satisfação com relação ao curso oferecido pelo DATER: (Considere a seguinte pontuação: 1 - MUITO RUIM; 2 - RUIM; 3 - REGULAR; 4 - BOM; 5 - MUITO BOM)

\begin{tabular}{|l|l|l|l|l|}
\hline 1 & 2 & 3 & $4 \times$ & 5 \\
\hline
\end{tabular}

10) Marque seu grau de satisfação com relação ao DATER: (Considere a seguinte pontuação: 1 - MUITO RUIM; 2 - RUIM; 3 - REGULAR; 4 - BOM; 5 - MUITO BOM)

\begin{tabular}{|l|l|l|l|l|l|}
\hline 1 & 2 & 3 & 4 & 5 \\
\hline
\end{tabular}


PESQUISA - IMPACTO DAS AÇÕES DE FORMAÇÃO REALIZADAS PELO DATER/SAF/MDA NO PERÍODO 2004-2009

Caros colaboradores,

Contamos com a sua atenção para preencher o formulário abaixo.

O mesmo tem por objetivo fornecer informações para avaliação da Eficiência, Efetividade e Eficácia da Política Pública de Formação de Agentes de Ater adotada pelo Departamento de Assistência Técnica e Extensão Rural, da Secretaria de Agricultura Familiar do Ministério do Desenvolvimento - DATER/SAF/MDA, no período de 2004 a 2009, tema escolhido para Monografia a ser apresentada à Universidade de Brasília (UnB) como requisito parcial para obtenção do grau de Bacharel em Administração.

Você poderá ou não se identificar no questionário e garantimos que todas as informações fornecidas serão confidenciais e utilizadas apenas de forma sistematizada.

IDENTIFICAÇÃO

\begin{tabular}{|c|c|}
\hline Nome:Sergio Corrêa Pimenta & $\begin{array}{l}\text { Sexo: } \\
(x \quad) \text { masculino } \quad(\quad) \text { feminino }\end{array}$ \\
\hline $\begin{array}{l}\text { Instituição (nome e tipo de instituição: ONG, } \\
\text { Empresa Pública, etc.): } \\
\text { Ecologia Aplicada }\end{array}$ & $\begin{array}{l}\text { Local de trabalho (Cidade e Estado): } \\
\text { Botucatu - SP }\end{array}$ \\
\hline \multicolumn{2}{|c|}{$\begin{array}{l}\text { Curso/Encontro/Oficina do qual participou (caso tenha participado de mais de um curso, preencha } \\
\text { um formulário para cada um deles): } \\
1^{\circ} \text { Curso a distância de Aperfeiçoamento em Agroecologia }\end{array}$} \\
\hline $\begin{array}{l}\text { Data do Curso/Encontro/Oficina (pelo menos mês } \epsilon \\
\text { Primeiro semestre } 2006\end{array}$ & \\
\hline
\end{tabular}

Indique sua área de atuação? (As opções não são excludentes: você poderá marcar mais de uma opção).

\begin{tabular}{|l|l|}
\hline$x$ & EXTENSÃO RURAL \\
\hline & PESQUISA \\
\hline & ENSINO \\
\hline
\end{tabular}




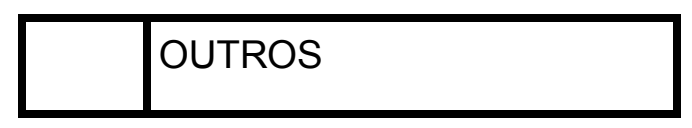

2) Qual o seu nível de escolaridade? (Considere apenas o nível mais alto)

\begin{tabular}{|l|l|}
\hline & NÍVEL MÉDIO \\
\hline$x$ & NÍVEL SUPERIOR \\
\hline & PÓS-GRADUAÇÃO \\
\hline
\end{tabular}

3) Os conteúdos abordados foram condizentes com as demandas do seu dia-a-dia?

\begin{tabular}{|l|l|}
\hline & SIM \\
\hline$x$ & PARCIALMENTE \\
\hline & NÃO \\
\hline
\end{tabular}

4) O curso contribuiu para o seu aperfeiçoamento profissional?

\begin{tabular}{|l|l|}
\hline & SIM \\
\hline$x$ & NÃO \\
\hline
\end{tabular}

5) Os conhecimentos adquiridos estão sendo aplicados no seu trabalho? Em caso afirmativo, indique em que grau estes conhecimentos estão sendo aplicados. Em caso negativo, indique por que razão isto não ocorre: (As respostas não são excludentes: você poderá marcar mais de uma opção).

\begin{tabular}{|l|l|l|l|}
\hline \multirow{2}{*}{$\begin{array}{l}\text { SIM (indique ao lado em } \\
\text { que grau) }\end{array}$} & & MUITO APLICADOS \\
\cline { 2 - 4 } & & MEDIAMENTE APLICADOS \\
\hline$x$ & $\begin{array}{l}\text { NĀO (indique ao lado a a } \\
\text { razão da não aplicação) }\end{array}$ & $x$ & $\begin{array}{l}\text { CONTEÚDO NÃO ADEQUADO ȦS NECESSIDADES } \\
\text { ESPECÍFICAS DA REGIÃO }\end{array}$ \\
\hline
\end{tabular}




\begin{tabular}{|l|l|l|l|}
\hline \multirow{10}{*}{} & $x$ & $\begin{array}{l}\text { CONTEÚDO NÃO FOI SUFICIENTEMENTE } \\
\text { APROFUNDADO PARA PERMITIR UMA APLICAÇÃO } \\
\text { EFICAZ E EFICIENTE }\end{array}$ \\
\cline { 2 - 5 } & $\begin{array}{l}\text { FALTA DE APOIO E INCENTIVO DA MINHA } \\
\text { INSTITUIÇÃO }\end{array}$ \\
\cline { 2 - 4 } & FALTA DE INCENTIVO ÀS AÇÕES DE ATER \\
\hline & NÃO TENHO INTERESSE EM APLICAR \\
\hline
\end{tabular}

6) A partir deste curso: (As opções não são excludentes: você poderá marcar mais de uma opção).

\begin{tabular}{|l|l|}
\hline$x$ & NÃO MUDOU NADA EM MEU TRABALHO. \\
\hline & $\begin{array}{l}\text { MEU TRABALHO PASSOU A CONTRIBUIR MAIS COM OS AGRICULTORES(AS) } \\
\text { FAMILIARES. }\end{array}$ \\
\hline & CONSEGUI INFLUENCIAR NAS ORIENTAÇÕES DA MINHA INSTITUIÇÃO. \\
\hline & $\begin{array}{l}\text { CRESCEI A TRABALHAR COM METODOLOGIAS PARTICIPATIVAS. } \\
\text { ONDE ATUO. ÁREA DE AGRICULTURA DE BASE ECOLÓGICA NAS COMUNIDADES }\end{array}$ \\
\hline & CONTINUEI ME APERFEIÇOANDO SOBRE TEMAS ABORDADOS. \\
\hline
\end{tabular}

7) Depois do curso você apoiou atividades de capacitação de técnicos e agricultores com base nos princípios e diretrizes da Pnater? (Considere como apoio a atividades de capacitação a participação no planejamento, elaboração de ementas, seleção de participantes e de palestrantes.)

\begin{tabular}{|l|l|}
\hline & SIM \\
\hline$x$ & NÃO \\
\hline
\end{tabular}

8) Usou os conhecimentos para ministrar outros cursos com o mesmo conteúdo ou conteúdos semelhantes? 


\begin{tabular}{|l|l|}
\hline$x$ & SIM \\
\hline & NÃO \\
\hline
\end{tabular}

9) Marque o seu grau de satisfação com relação ao curso oferecido pelo DATER: (Considere a seguinte pontuação: 1 - MUITO RUIM; 2 - RUIM; 3 - REGULAR; 4 - BOM; 5 - MUITO BOM)

\begin{tabular}{|l|l|l|l|l|}
\hline $1 X$ & 2 & 3 & 4 & 5 \\
\hline
\end{tabular}

10) Marque seu grau de satisfação com relação ao DATER: (Considere a seguinte pontuação: 1 - MUITO RUIM; 2 - RUIM; 3 - REGULAR; 4 - BOM; 5 - MUITO BOM)

\begin{tabular}{|l|l|l|l|l|}
\hline 1 & 2 & $3 \times$ & 4 & 5 \\
\hline
\end{tabular}

Pude perceber o grande esforço dos profissionais para desenvolverem o curso, mas a ferramenta de internet era muito ruim e dificultou demais. Os conteúdos variaram muito de qualidade. 
PESQUISA - IMPACTO DAS AÇÕES DE FORMAÇÃO REALIZADAS PELO DATER/SAF/MDA NO PERÍODO 2004-2009

Caros colaboradores,

Contamos com a sua atenção para preencher o formulário abaixo.

O mesmo tem por objetivo fornecer informações para avaliação da Eficiência, Efetividade e Eficácia da Política Pública de Formação de Agentes de Ater adotada pelo Departamento de Assistência Técnica e Extensão Rural, da Secretaria de Agricultura Familiar do Ministério do Desenvolvimento - DATER/SAF/MDA, no período de 2004 a 2009, tema escolhido para Monografia a ser apresentada à Universidade de Brasília (UnB) como requisito parcial para obtenção do grau de Bacharel em Administração.

Você poderá ou não se identificar no questionário e garantimos que todas as informações fornecidas serão confidenciais e utilizadas apenas de forma sistematizada.

\section{IDENTIFICAÇÃO}

\begin{tabular}{|l|l|}
\hline Nome: Sandra Maria Ramos & $\begin{array}{l}\text { Sexo: } \\
(\quad) \text { masculino } \quad(\quad \mathrm{x}) \text { feminino }\end{array}$ \\
\hline Instituição : CATI - SP & Local de trabalho : São Paulo \\
\hline $\begin{array}{l}\text { Curso/Encontro/Oficina do qual participou : Formação de Formadores do Projeto Cultivando } \\
\text { Saberes }\end{array}$ \\
\hline Data do Curso/Encontro/Oficina: julho 2009
\end{tabular}

Indique sua área de atuação? (As opções não são excludentes: você poderá marcar mais de uma opção).

\begin{tabular}{|l|l|}
\hline$x$ & EXTENSÃO RURAL \\
\hline & PESQUISA \\
\hline & ENSINO \\
\hline & OUTROS \\
\hline
\end{tabular}


2) Qual o seu nível de escolaridade? (Considere apenas o nível mais alto)

\begin{tabular}{|l|l|}
\hline & NÍVEL MÉDIO \\
\hline & NÍVEL SUPERIOR \\
\hline$x$ & PÓS-GRADUAÇÃO \\
\hline
\end{tabular}

3) Os conteúdos abordados foram condizentes com as demandas do seu dia-a-dia?

\begin{tabular}{|l|l|}
\hline$x$ & SIM \\
\hline & PARCIALMENTE \\
\hline & NÃO \\
\hline
\end{tabular}

4) O curso contribuiu para o seu aperfeiçoamento profissional?

\begin{tabular}{|l|l|}
\hline$x$ & SIM \\
\hline & NÃO \\
\hline
\end{tabular}

5) Os conhecimentos adquiridos estão sendo aplicados no seu trabalho? Em caso afirmativo, indique em que grau estes conhecimentos estão sendo aplicados. Em caso negativo, indique por que razão isto não ocorre: (As respostas não são excludentes: você poderá marcar mais de uma opção).

\begin{tabular}{|c|c|c|}
\hline \multirow{3}{*}{$\begin{array}{l}\text { SIM (indique ao lado em } \\
\text { que grau) }\end{array}$} & & MUITO APLICADOS \\
\hline & $\mathrm{x}$ & MEDIAMENTE APLICADOS \\
\hline & & POUCO APLICADOS \\
\hline $\begin{array}{l}\text { NÃO (indique ao lado a } \\
\text { razão da não aplicação) }\end{array}$ & & $\begin{array}{l}\text { CONTEÚDO NÃO ADEQUADO ȦS NECESSIDADES } \\
\text { ESPECÍFICAS DA REGIÃO }\end{array}$ \\
\hline
\end{tabular}




\begin{tabular}{|l|l|l|}
\hline \multirow{10}{*}{} & $\begin{array}{l}\text { CONTEÚDO NÃO FOI SUFICIENTEMENTE } \\
\text { APROFUNDADO PARA PERMITIR UMA APLICAÇÃO } \\
\text { EFICAZ E EFICIENTE }\end{array}$ \\
\cline { 2 - 4 } & $\begin{array}{l}\text { FALTA DE APOIO E INCENTIVO DA MINHA } \\
\text { INSTITUIÇÃO }\end{array}$ \\
\cline { 2 - 4 } & FALTA DE INCENTIVO ÀS AÇÕES DE ATER \\
\hline & NÃO TENHO INTERESSE EM APLICAR \\
\hline
\end{tabular}

6) A partir deste curso: (As opções não são excludentes: você poderá marcar mais de uma opção).

\begin{tabular}{|c|l|}
\hline$x$ & $\begin{array}{l}\text { NÃO MUDOU NADA EM MEU TRABALHO. } \\
\text { FAMILIARES. }\end{array}$ \\
\hline$x$ & CONSEGUI INFLUENCIAR NAS ORIENTAÇÕES DA MINHA INSTITUIÇÃO. \\
\hline$x$ & PASSEI A TRABALHAR COM METODOLOGIAS PARTICIPATIVAS. \\
\hline & $\begin{array}{l}\text { CRESCEU A ÁREA DE AGRICULTURA DE BASE ECOLÓGICA NAS COMUNIDADES } \\
\text { ONDE ATUO. }\end{array}$ \\
\hline$x$ & CONTINUEI ME APERFEIÇOANDO SOBRE TEMAS ABORDADOS. \\
\hline
\end{tabular}

7) Depois do curso você apoiou atividades de capacitação de técnicos e agricultores com base nos princípios e diretrizes da Pnater? (Considere como apoio a atividades de capacitação a participação no planejamento, elaboração de ementas, seleção de participantes e de palestrantes.)

\begin{tabular}{|l|l|}
\hline$x$ & SIM \\
\hline & NÃO \\
\hline
\end{tabular}

8) Usou os conhecimentos para ministrar outros cursos com o mesmo conteúdo ou conteúdos semelhantes? 


\begin{tabular}{|l|l|}
\hline$x$ & SIM \\
\hline & NÃO \\
\hline
\end{tabular}

9) Marque o seu grau de satisfação com relação ao curso oferecido pelo DATER: (Considere a seguinte pontuação: 1 - MUITO RUIM; 2 - RUIM; 3 - REGULAR; 4 - BOM; 5 - MUITO BOM)

\begin{tabular}{|l|l|l|l|l|}
\hline 1 & 2 & 3 & 4 & $x 5$ \\
\hline
\end{tabular}

10) Marque seu grau de satisfação com relação ao DATER: (Considere a seguinte pontuação: 1 - MUITO RUIM; 2 - RUIM; 3 - REGULAR; 4 - BOM; 5 - MUITO BOM)

\begin{tabular}{|l|l|l|l|l|}
\hline 1 & 2 & 3 & $x 4$ & 5 \\
\hline
\end{tabular}


PESQUISA - IMPACTO DAS AÇÕES DE FORMAÇÃO REALIZADAS PELO DATER/SAF/MDA NO PERÍODO 2004-2009

Caros colaboradores,

Contamos com a sua atenção para preencher o formulário abaixo.

O mesmo tem por objetivo fornecer informações para avaliação da Eficiência, Efetividade e Eficácia da Política Pública de Formação de Agentes de Ater adotada pelo Departamento de Assistência Técnica e Extensão Rural, da Secretaria de Agricultura Familiar do Ministério do Desenvolvimento - DATER/SAF/MDA, no período de 2004 a 2009, tema escolhido para Monografia a ser apresentada à Universidade de Brasília (UnB) como requisito parcial para obtenção do grau de Bacharel em Administração.

Você poderá ou não se identificar no questionário e garantimos que todas as informações fornecidas serão confidenciais e utilizadas apenas de forma sistematizada.

\section{IDENTIFICAÇÃO}

\begin{tabular}{|l|l|}
\hline Nome: Rodrigo de Souza Ferreira & $\begin{array}{l}\text { Sexo: } \\
(x) \text { masculino } \quad(\quad) \text { feminino }\end{array}$ \\
\hline Instituição : INCAPER & Local de trabalho : ALEGRE ES \\
\hline $\begin{array}{l}\text { Curso/Encontro/Oficina do qual participou : Formação de Formadores do Projeto Cultivando } \\
\text { Saberes }\end{array}$ & \\
\hline Data do Curso/Encontro/Oficina: julho 2009
\end{tabular}

Indique sua área de atuação? (As opções não são excludentes: você poderá marcar mais de uma opção).

\begin{tabular}{|l|l|}
\hline$x$ & EXTENSÃO RURAL \\
\hline & PESQUISA \\
\hline & ENSINO \\
\hline & OUTROS \\
\hline
\end{tabular}


2) Qual o seu nível de escolaridade? (Considere apenas o nível mais alto)

\begin{tabular}{|l|l|}
\hline & NÍVEL MÉDIO \\
\hline & NÍVEL SUPERIOR \\
\hline$x$ & PÓS-GRADUAÇÃO \\
\hline
\end{tabular}

3) Os conteúdos abordados foram condizentes com as demandas do seu dia-a-dia?

\begin{tabular}{|l|l|}
\hline$x$ & SIM \\
\hline & PARCIALMENTE \\
\hline & NÃO \\
\hline
\end{tabular}

4) O curso contribuiu para o seu aperfeiçoamento profissional?

\begin{tabular}{|l|l|}
\hline$x$ & SIM \\
\hline & NÃO \\
\hline
\end{tabular}

5) Os conhecimentos adquiridos estão sendo aplicados no seu trabalho? Em caso afirmativo, indique em que grau estes conhecimentos estão sendo aplicados. Em caso negativo, indique por que razão isto não ocorre: (As respostas não são excludentes: você poderá marcar mais de uma opção).

\begin{tabular}{|l|l|l|l|}
\hline \multirow{2}{*}{$\begin{array}{l}\text { SIM (indique ao lado em } \\
\text { que grau) }\end{array}$} & & MUITO APLICADOS \\
\cline { 2 - 3 } & $\mathrm{X}$ & MEDIAMENTE APLICADOS \\
\hline & $\begin{array}{l}\text { NÃO (indique ao lado a } \\
\text { razão da não aplicação) }\end{array}$ & $\begin{array}{l}\text { CONTEÚDO NÃO ADEQUADO ȦS NECESSIDADES } \\
\text { ESPECÍFICAS DA REGIÃO }\end{array}$ \\
\hline
\end{tabular}




\begin{tabular}{|l|l|l|}
\hline \multirow{10}{*}{} & & $\begin{array}{l}\text { CONTEÚDO NÃO FOI SUFICIENTEMENTE } \\
\text { APROFUNDADO PARA PERMITIR UMA APLICAÇÃO } \\
\text { EFICAZ E EFICIENTE }\end{array}$ \\
\cline { 2 - 5 } & $\begin{array}{l}\text { FALTA DE APOIO E INCENTIVO DA MINHA } \\
\text { INSTITUIÇÃO }\end{array}$ \\
\cline { 2 - 4 } & FALTA DE INCENTIVO ÀS AÇÕES DE ATER \\
\hline & NÃO TENHO INTERESSE EM APLICAR \\
\hline
\end{tabular}

6) A partir deste curso: (As opções não são excludentes: você poderá marcar mais de uma opção).

\begin{tabular}{|c|l|}
\hline & NÃO MUDOU NADA EM MEU TRABALHO. \\
\hline & $\begin{array}{l}\text { MEU TRABALHO PASSOU A CONTRIBUIR MAIS COM OS AGRICULTORES(AS) } \\
\text { FAMILIARES. }\end{array}$ \\
\hline$x$ & CONSEGUI INFLUENCIAR NAS ORIENTAÇÕES DA MINHA INSTITUIÇÃO. \\
\hline & $\begin{array}{l}\text { CRESEI A TRABALHAR COM METODOLOGIAS PARTICIPATIVAS. } \\
\text { ONDE ATUO. ÁREA DE AGRICULTURA DE BASE ECOLÓGICA NAS COMUNIDADES }\end{array}$ \\
\hline$x$ & CONTINUEI ME APERFEIÇOANDO SOBRE TEMAS ABORDADOS. \\
\hline
\end{tabular}

7) Depois do curso você apoiou atividades de capacitação de técnicos e agricultores com base nos princípios e diretrizes da Pnater? (Considere como apoio a atividades de capacitação a participação no planejamento, elaboração de ementas, seleção de participantes e de palestrantes.)

\begin{tabular}{|l|l|}
\hline$x$ & SIM \\
\hline & NÃO \\
\hline
\end{tabular}

8) Usou os conhecimentos para ministrar outros cursos com o mesmo conteúdo ou conteúdos semelhantes? 


\begin{tabular}{|l|l|}
\hline & SIM \\
\hline$X$ & NÃO \\
\hline
\end{tabular}

9) Marque o seu grau de satisfação com relação ao curso oferecido pelo DATER: (Considere a seguinte pontuação: 1 - MUITO RUIM; 2 - RUIM; 3 - REGULAR; 4 - BOM; 5 - MUITO BOM)

\begin{tabular}{|l|l|l|l|l|}
\hline 1 & 2 & 3 & $x 4$ & 5 \\
\hline
\end{tabular}

10) Marque seu grau de satisfação com relação ao DATER: (Considere a seguinte pontuação: 1 - MUITO RUIM; 2 - RUIM; 3 - REGULAR; 4 - BOM; 5 - MUITO BOM)

\begin{tabular}{|l|l|l|l|l|}
\hline 1 & 2 & 3 & $x 4$ & 5 \\
\hline
\end{tabular}


PESQUISA - IMPACTO DAS AÇÕES DE FORMAÇÃO REALIZADAS PELO DATER/SAF/MDA NO PERÍODO 2004-2009

Caros colaboradores,

Contamos com a sua atenção para preencher o formulário abaixo.

O mesmo tem por objetivo fornecer informações para avaliação da Eficiência, Efetividade e Eficácia da Política Pública de Formação de Agentes de Ater adotada pelo Departamento de Assistência Técnica e Extensão Rural, da Secretaria de Agricultura Familiar do Ministério do Desenvolvimento - DATER/SAF/MDA, no período de 2004 a 2009, tema escolhido para Monografia a ser apresentada à Universidade de Brasília (UnB) como requisito parcial para obtenção do grau de Bacharel em Administração.

Você poderá ou não se identificar no questionário e garantimos que todas as informações fornecidas serão confidenciais e utilizadas apenas de forma sistematizada.

\section{IDENTIFICAÇÃO}

\begin{tabular}{|c|c|}
\hline $\begin{array}{l}\text { Nome: } \\
\text { MÔNICA MARIZ DE JESUS CARVALHO }\end{array}$ & $\begin{array}{l}\text { Sexo: } \\
(\quad) \text { masculino } \quad(x \quad) \text { feminino }\end{array}$ \\
\hline $\begin{array}{l}\text { Instituição (nome e tipo de instituição: ONG, } \\
\text { Empresa Pública, etc.): } \\
\text { INCRA }\end{array}$ & $\begin{array}{l}\text { Local de trabalho (Cidade e Estado): } \\
\text { BELO HORIZONTE / MINAS GERAIS }\end{array}$ \\
\hline \multicolumn{2}{|c|}{$\begin{array}{l}\text { Curso/Encontro/Oficina do qual participou (caso tenha participado de mais de um curso, preencha } \\
\text { um formulário para cada um deles): } \\
\text { "A POLÍTICA NACIONAL DE ATER" }\end{array}$} \\
\hline $\begin{array}{l}\text { Data do Curso/Encontro/Oficina (pelo menos mês e } \\
\text { NOVEMBRO/04 - VILA VELHA (não tenho certeza c }\end{array}$ & $\begin{array}{l}\text { ano): } \\
\text { lo mês) }\end{array}$ \\
\hline
\end{tabular}

Indique sua área de atuação? (As opções não são excludentes: você poderá marcar mais de uma opção).

\begin{tabular}{|l|l|}
\hline & EXTENSÃO RURAL \\
\hline & PESQUISA \\
\hline
\end{tabular}




\begin{tabular}{|l|l|}
\hline & ENSINO \\
\hline$x$ & OUTROS \\
\hline
\end{tabular}

2) Qual o seu nível de escolaridade? (Considere apenas o nível mais alto)

\begin{tabular}{|l|l|}
\hline & NÍVEL MÉDIO \\
\hline & NÍVEL SUPERIOR \\
\hline$x$ & PÓS-GRADUAÇÃO \\
\hline
\end{tabular}

3) Os conteúdos abordados foram condizentes com as demandas do seu dia-a-dia?

\begin{tabular}{|l|l|}
\hline$x$ & SIM \\
\hline & PARCIALMENTE \\
\hline & NÃO \\
\hline
\end{tabular}

4) O curso contribuiu para o seu aperfeiçoamento profissional?

\begin{tabular}{|l|l|}
\hline$x$ & SIM \\
\hline & NÃO \\
\hline
\end{tabular}

5) Os conhecimentos adquiridos estão sendo aplicados no seu trabalho? Em caso afirmativo, indique em que grau estes conhecimentos estão sendo aplicados. Em caso negativo, indique por que razão isto não ocorre: (As respostas não são excludentes: você poderá marcar mais de uma opção).

\begin{tabular}{|l|l|l|l|}
\hline \multirow{2}{*}{$\mathrm{x}$} & $\begin{array}{l}\text { SIM (indique ao lado em } \\
\text { que grau) }\end{array}$ & $\mathrm{x}$ & MUITO APLICADOS \\
\cline { 3 - 4 } & & POUCOAMENTE APLICADOS \\
\cline { 2 - 4 } & & &
\end{tabular}




\begin{tabular}{|c|c|}
\hline \multirow{5}{*}{$\begin{array}{l}\text { NÃO (indique ao lado a } \\
\text { razão da não aplicação) }\end{array}$} & $\begin{array}{l}\text { CONTEÚDO NÃO ADEQUADO ȦS NECESSIDADES } \\
\text { ESPECÍFICAS DA REGIÃO }\end{array}$ \\
\hline & $\begin{array}{l}\text { CONTEÚDO NÃO FOI SUFICIENTEMENTE } \\
\text { APROFUNDADO PARA } \\
\text { PERMITIR UMA APLICAÇÃO } \\
\text { EFICAZ E EFICIENTE }\end{array}$ \\
\hline & $\begin{array}{l}\text { FALTA DE APOIO } \\
\text { INSTITUIÇÃO }\end{array}$ \\
\hline & FALTA DE INCENTIVO ÀS AÇÕES DE ATER \\
\hline & NÃO TENHO INTERESSE EM APLICAR \\
\hline
\end{tabular}

6) A partir deste curso: (As opções não são excludentes: você poderá marcar mais de uma opção).

\begin{tabular}{|l|l|}
\hline & NÃO MUDOU NADA EM MEU TRABALHO. \\
\hline$x$ & $\begin{array}{l}\text { MEU TRABALHO PASSOU A CONTRIBUIR MAIS COM OS AGRICULTORES(AS) } \\
\text { FAMILIARES. }\end{array}$ \\
\hline$x$ & CONSEGUI INFLUENCIAR NAS ORIENTAÇÕES DA MINHA INSTITUIÇÃO. \\
\hline & PASSEI A TRABALHAR COM METODOLOGIAS PARTICIPATIVAS. \\
\hline & ORESCEU A ÁREA DE AGRICULTURA DE BASE ECOLÓGICA NAS COMUNIDADES \\
\hline$x$ & CONTINUEI ME APERFEIÇOANDO SOBRE TEMAS ABORDADOS. \\
\hline
\end{tabular}

7) Depois do curso você apoiou atividades de capacitação de técnicos e agricultores com base nos princípios e diretrizes da Pnater? (Considere como apoio a atividades de capacitação a participação no planejamento, elaboração de ementas, seleção de participantes e de palestrantes.)

\begin{tabular}{|l|l|}
\hline$x$ & SIM \\
\hline & NÃO \\
\hline
\end{tabular}

8) Usou os conhecimentos para ministrar outros cursos com o mesmo conteúdo ou conteúdos semelhantes? 


\begin{tabular}{|l|l|}
\hline$x$ & SIM \\
\hline & NÃO \\
\hline
\end{tabular}

9) Marque o seu grau de satisfação com relação ao curso oferecido pelo DATER: (Considere a seguinte pontuação: 1 - MUITO RUIM; 2 - RUIM; 3 - REGULAR; 4 - BOM; 5 - MUITO BOM)

\begin{tabular}{|l|l|l|l|l|}
\hline 1 & 2 & 3 & $4 x$ & 5 \\
\hline
\end{tabular}

10) Marque seu grau de satisfação com relação ao DATER: (Considere a seguinte pontuação: 1 - MUITO RUIM; 2 - RUIM; 3 - REGULAR; 4 - BOM; 5 - MUITO BOM)

\begin{tabular}{|l|l|l|l|l|}
\hline 1 & 2 & 3 & $4 \times$ & 5 \\
\hline
\end{tabular}

P.S : GOSTARIA MUITO QUE FOSSE MINISTRADO O CURSO SOBRE "ATER E SAÚDE NO MEIO RURAL". 
PESQUISA - IMPACTO DAS AÇÕES DE FORMAÇÃO REALIZADAS PELO DATER/SAF/MDA NO PERÍODO 2004-2009

Caros colaboradores,

Contamos com a sua atenção para preencher o formulário abaixo.

O mesmo tem por objetivo fornecer informações para avaliação da Eficiência, Efetividade e Eficácia da Política Pública de Formação de Agentes de Ater adotada pelo Departamento de Assistência Técnica e Extensão Rural, da Secretaria de Agricultura Familiar do Ministério do Desenvolvimento - DATER/SAF/MDA, no período de 2004 a 2009, tema escolhido para Monografia a ser apresentada à Universidade de Brasília (UnB) como requisito parcial para obtenção do grau de Bacharel em Administração.

Você poderá ou não se identificar no questionário e garantimos que todas as informações fornecidas serão confidenciais e utilizadas apenas de forma sistematizada.

\section{IDENTIFICAÇÃO}

\begin{tabular}{|c|c|}
\hline Nome:Mauricio Rubio Pinto Alves & $\begin{array}{l}\text { Sexo: } \\
(x \quad) \text { masculino } \quad(\quad) \text { feminino }\end{array}$ \\
\hline $\begin{array}{l}\text { Instituição (nome e tipo de instituição: ONG, } \\
\text { Empresa Pública, etc.):CATI- Secretaria da } \\
\text { Agricultura e Abastecimento-Casa da Agricultura de } \\
\text { São Sebastião e Ilhabela }\end{array}$ & $\begin{array}{l}\text { Local de trabalho (Cidade e Estado): } \\
\text { São Sebastião e Ilhabela- SP }\end{array}$ \\
\hline $\begin{array}{l}\text { Curso/Encontro/Oficina do qual participou (caso tenh } \\
\text { um formulário para cada um deles): Formação de } \\
\text { Rural que atuam em comunidades indigenas }\end{array}$ & $\begin{array}{l}\text { Aa participado de mais de um curso, preencha } \\
\text { Agentes de Assistência Técnica e Extensão }\end{array}$ \\
\hline
\end{tabular}

Indique sua área de atuação? (As opções não são excludentes: você poderá marcar mais de uma opção).

\begin{tabular}{|l|l|}
\hline$X$ & EXTENSÃO RURAL \\
\hline & PESQUISA \\
\hline & ENSINO \\
\hline
\end{tabular}




\section{OUTROS}

2) Qual o seu nível de escolaridade? (Considere apenas o nível mais alto)

\begin{tabular}{|l|l|}
\hline & NÍVEL MÉDIO \\
\hline & NÍVEL SUPERIOR \\
\hline$x$ & $\begin{array}{l}\text { PÓS-GRADUAÇĀO } \\
\text { (latu-sensu em Pesca e } \\
\text { Aqüicultura) }\end{array}$ \\
\hline
\end{tabular}

3) Os conteúdos abordados foram condizentes com as demandas do seu dia-a-dia?

\begin{tabular}{|l|l|}
\hline$X$ & SIM \\
\hline & PARCIALMENTE \\
\hline & NÃO \\
\hline
\end{tabular}

4) O curso contribuiu para o seu aperfeiçoamento profissional?

\begin{tabular}{|l|l|}
\hline$X$ & SIM \\
\hline & NÃO \\
\hline
\end{tabular}

5) Os conhecimentos adquiridos estão sendo aplicados no seu trabalho? Em caso afirmativo, indique em que grau estes conhecimentos estão sendo aplicados. Em caso negativo, indique por que razão isto não ocorre: (As respostas não são excludentes: você poderá marcar mais de uma opção).

\begin{tabular}{|l|l|l|l|}
\hline \multirow{2}{*}{$\begin{array}{l}\text { SIM (indique ao lado em } \\
\text { que grau) }\end{array}$} & X & MUITO APLICADOS \\
\cline { 2 - 4 } & & MEDIAMENTE APLICADOS \\
\cline { 2 - 4 } & & POUCO APLICADOS \\
\hline
\end{tabular}




\begin{tabular}{|c|c|}
\hline \multirow{5}{*}{$\begin{array}{l}\text { NÃO (indique ao lado a } \\
\text { razão da não aplicação) }\end{array}$} & $\begin{array}{l}\text { CONTEÚDO NÃO ADEQUADO ÀS NECESSIDADES } \\
\text { ESPECÍFICAS DA REGIÃO }\end{array}$ \\
\hline & $\begin{array}{l}\text { CONTEÚDO NÃO } \text { FOI SUFICIENTEMENTE } \\
\text { APROFUNDADO PARA } \\
\text { PERMITIR UMA APLICAÇÃO } \\
\text { EFICAZ E EFICIENTE }\end{array}$ \\
\hline & $\begin{array}{lllllll}\text { FALTA DE } & \text { APOIO } & \text { E } & \text { INCENTIVO } & \text { DA } & \text { MINHA } \\
\text { INSTITUIÇÃO } & & & & & \end{array}$ \\
\hline & FALTA DE INCENTIVO ÀS AÇÕES DE ATER \\
\hline & NÃO TENHO INTERESSE EM APLICAR \\
\hline
\end{tabular}

6) A partir deste curso: (As opções não são excludentes: você poderá marcar mais de uma opção).

\begin{tabular}{|l|l|}
\hline & NÃO MUDOU NADA EM MEU TRABALHO. \\
\hline & $\begin{array}{l}\text { MEU TRABALHO PASSOU A CONTRIBUIR MAIS COM OS AGRICULTORES(AS) } \\
\text { FAMILIARES. }\end{array}$ \\
\hline$X$ & CONSEGUI INFLUENCIAR NAS ORIENTAÇÕES DA MINHA INSTITUIÇÃO. \\
\hline & $\begin{array}{l}\text { CASSEI A TRABALHAR COM METODOLOGIAS PARTICIPATIVAS. } \\
\text { ONDE ATUO. }\end{array}$ \\
\hline$X$ & CONTINUEI ME APERFEIÇOANDO SOBRE TEMAS ABORDADOS. \\
\hline
\end{tabular}

7) Depois do curso você apoiou atividades de capacitação de técnicos e agricultores com base nos princípios e diretrizes da Pnater? (Considere como apoio a atividades de capacitação a participação no planejamento, elaboração de ementas, seleção de participantes e de palestrantes.)

\begin{tabular}{|l|l|}
\hline$X$ & SIM \\
\hline & NÃO \\
\hline
\end{tabular}

8) Usou os conhecimentos para ministrar outros cursos com o mesmo conteúdo ou conteúdos semelhantes? 


\begin{tabular}{|l|l|}
\hline$X$ & SIM \\
\hline & NÃO \\
\hline
\end{tabular}

9) Marque o seu grau de satisfação com relação ao curso oferecido pelo DATER: (Considere a seguinte pontuação: 1 - MUITO RUIM; 2 - RUIM; 3 - REGULAR; 4 - BOM; 5 - MUITO BOM)

\begin{tabular}{|l|l|l|l|l|}
\hline 1 & 2 & 3 & 4 & 5 \\
\hline
\end{tabular}

10) Marque seu grau de satisfação com relação ao DATER: (Considere a seguinte pontuação: 1 - MUITO RUIM; 2 - RUIM; 3 - REGULAR; 4 - BOM; 5 - MUITO BOM)

\begin{tabular}{|l|l|l|l|l|}
\hline 1 & 2 & 3 & 4 & 5 \\
\hline
\end{tabular}


PESQUISA - IMPACTO DAS AÇÕES DE FORMAÇÃO REALIZADAS PELO DATER/SAF/MDA NO PERÍODO 2004-2009

Caros colaboradores,

Contamos com a sua atenção para preencher o formulário abaixo.

O mesmo tem por objetivo fornecer informações para avaliação da Eficiência, Efetividade e Eficácia da Política Pública de Formação de Agentes de Ater adotada pelo Departamento de Assistência Técnica e Extensão Rural, da Secretaria de Agricultura Familiar do Ministério do Desenvolvimento - DATER/SAF/MDA, no período de 2004 a 2009, tema escolhido para Monografia a ser apresentada à Universidade de Brasília (UnB) como requisito parcial para obtenção do grau de Bacharel em Administração.

Você poderá ou não se identificar no questionário e garantimos que todas as informações fornecidas serão confidenciais e utilizadas apenas de forma sistematizada.

\section{IDENTIFICAÇÃO}

\begin{tabular}{|c|c|}
\hline $\begin{array}{lll}\text { Nome: } & & \\
\text { MARIA } & \text { FERNANDA RODRIGUES } \\
\text { MIRANDA } & & \end{array}$ & $\begin{array}{l}\text { Sexo: } \\
(\quad) \text { masculino } \quad(x) \text { feminino }\end{array}$ \\
\hline $\begin{array}{l}\text { Instituição (nome e tipo de instituição: ONG, } \\
\text { Empresa Pública, etc.): EMATER-MG }\end{array}$ & $\begin{array}{l}\text { Local de trabalho (Cidade e Estado): } \\
\text { CAMPINA VERDE-MG }\end{array}$ \\
\hline \multicolumn{2}{|c|}{$\begin{array}{l}\text { Curso/Encontro/Oficina do qual participou (caso tenha participado de mais de um curso, preencha } \\
\text { um formulário para cada um deles): } \\
\text { CURSO PARA AGENTES DE ATER SOBRE TÉCNICAS PARA A APRENDIZAGEM E AÇÃO } \\
\text { PARTICIPATIVA -DRP }\end{array}$} \\
\hline ta do Cursc & \\
\hline
\end{tabular}

Indique sua área de atuação? (As opções não são excludentes: você poderá marcar mais de uma opção).

\begin{tabular}{|l|l|}
\hline$X$ & EXTENSÃO RURAL \\
\hline & PESQUISA \\
\hline & ENSINO \\
\hline
\end{tabular}




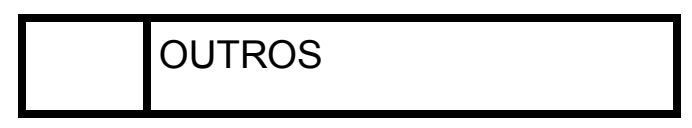

2) Qual o seu nível de escolaridade? (Considere apenas o nível mais alto)

\begin{tabular}{|l|l|}
\hline & NÍVEL MÉDIO \\
\hline$X$ & NÍVEL SUPERIOR \\
\hline & PÓS-GRADUAÇÃO \\
\hline
\end{tabular}

3) Os conteúdos abordados foram condizentes com as demandas do seu dia-a-dia?

\begin{tabular}{|l|l|}
\hline$X$ & SIM \\
\hline & PARCIALMENTE \\
\hline & NÃO \\
\hline
\end{tabular}

4) O curso contribuiu para o seu aperfeiçoamento profissional?

\begin{tabular}{|l|l|}
\hline$X$ & SIM \\
\hline & NÃO \\
\hline
\end{tabular}

5) Os conhecimentos adquiridos estão sendo aplicados no seu trabalho? Em caso afirmativo, indique em que grau estes conhecimentos estão sendo aplicados. Em caso negativo, indique por que razão isto não ocorre: (As respostas não são excludentes: você poderá marcar mais de uma opção).

\begin{tabular}{|l|l|l|l|}
\hline$X$ & $\begin{array}{l}\text { SIM (indique ao lado em } \\
\text { que grau) }\end{array}$ & MUITO APLICADOS \\
\cline { 3 - 4 } & & MEDIAMENTE APLICADOS \\
\hline & $\begin{array}{l}\text { NÃO (indique ao lado a } \\
\text { razão da não aplicação) }\end{array}$ & $\begin{array}{l}\text { CONTEÚDO NÃO ADEQUADO ȦS NECESSIDADES } \\
\text { ESPECÍFICAS DA REGIÃO }\end{array}$ \\
\hline
\end{tabular}




\begin{tabular}{|l|l|l|}
\hline \multirow{10}{*}{} & $\begin{array}{l}\text { CONTEÚDO NÃO FOI SUFICIENTEMENTE } \\
\text { APROFUNDADO PARA PERMITIR UMA APLICAÇÃO } \\
\text { EFICAZ E EFICIENTE }\end{array}$ \\
\cline { 2 - 4 } & $\begin{array}{l}\text { FALTA DE APOIO E INCENTIVO DA MINHA } \\
\text { INSTITUIÇÃO }\end{array}$ \\
\cline { 2 - 4 } & FALTA DE INCENTIVO ÀS AÇÕES DE ATER \\
\hline & NÃO TENHO INTERESSE EM APLICAR \\
\hline
\end{tabular}

6) A partir deste curso: (As opções não são excludentes: você poderá marcar mais de uma opção).

\begin{tabular}{|l|l|}
\hline$x$ & $\begin{array}{l}\text { NÃO MUDOU NADA EM MEU TRABALHO. } \\
\text { FAMILIARES. }\end{array}$ \\
\hline & CONSEGUI INFLUENCIAR NAS ORIENTAÇÕES DA MINHA INSTITUIÇÃO. \\
\hline & PASSEI A TRABALHAR COM METODOLOGIAS PARTICIPATIVAS. \\
\hline & $\begin{array}{l}\text { ORESCEU A ÁREA DE AGRICULTURA DE BASE ECOLÓGICA NAS COMUNIDADES } \\
\text { CONTINUEI ME APERFEIÇOANDO SOBRE TEMAS ABORDADOS. }\end{array}$ \\
\hline
\end{tabular}

7) Depois do curso você apoiou atividades de capacitação de técnicos e agricultores com base nos princípios e diretrizes da Pnater? (Considere como apoio a atividades de capacitação a participação no planejamento, elaboração de ementas, seleção de participantes e de palestrantes.)

\begin{tabular}{|l|l|}
\hline$X$ & SIM \\
\hline & NÃO \\
\hline
\end{tabular}

8) Usou os conhecimentos para ministrar outros cursos com o mesmo conteúdo ou conteúdos semelhantes? 


\begin{tabular}{|l|l|}
\hline$X$ & SIM \\
\hline & NÃO \\
\hline
\end{tabular}

9) Marque o seu grau de satisfação com relação ao curso oferecido pelo DATER: (Considere a seguinte pontuação: 1 - MUITO RUIM; 2 - RUIM; 3 - REGULAR; 4 - BOM; 5 - MUITO BOM)

\begin{tabular}{|l|l|l|l|l|}
\hline 1 & 2 & 3 & $X 4$ & 5 \\
\hline
\end{tabular}

10) Marque seu grau de satisfação com relação ao DATER: (Considere a seguinte pontuação: 1 - MUITO RUIM; 2 - RUIM; 3 - REGULAR; 4 - BOM; 5 - MUITO BOM)

\begin{tabular}{|l|l|l|l|l|}
\hline 1 & 2 & $\times 3$ & 4 & 5 \\
\hline
\end{tabular}


PESQUISA - IMPACTO DAS AÇÕES DE FORMAÇÃO REALIZADAS PELO DATER/SAF/MDA NO PERÍODO 2004-2009

Caros colaboradores,

Contamos com a sua atenção para preencher o formulário abaixo.

O mesmo tem por objetivo fornecer informações para avaliação da Eficiência, Efetividade e Eficácia da Política Pública de Formação de Agentes de Ater adotada pelo Departamento de Assistência Técnica e Extensão Rural, da Secretaria de Agricultura Familiar do Ministério do Desenvolvimento - DATER/SAF/MDA, no período de 2004 a 2009, tema escolhido para Monografia a ser apresentada à Universidade de Brasília (UnB) como requisito parcial para obtenção do grau de Bacharel em Administração.

Você poderá ou não se identificar no questionário e garantimos que todas as informações fornecidas serão confidenciais e utilizadas apenas de forma sistematizada.

\section{IDENTIFICAÇÃO}

\begin{tabular}{|c|c|}
\hline $\begin{array}{l}\text { Nome: } \\
\qquad \text { MARIA EDINICE SOARES SOUZA } \\
\text { RODRIGUES }\end{array}$ & $\begin{array}{l}\text { Sexo: } \\
(\quad) \text { masculino }(x) \text { feminino }\end{array}$ \\
\hline $\begin{array}{l}\text { Instituição (nome e tipo de instituição: ONG, } \\
\text { Empresa Pública, etc.): EMATER-MG }\end{array}$ & $\begin{array}{l}\text { Local de trabalho (Cidade e Estado): } \\
\text { CAMPINA VERDE-MG }\end{array}$ \\
\hline \multicolumn{2}{|c|}{$\begin{array}{l}\text { Curso/Encontro/Oficina do qual participou (caso tenha participado de mais de um curso, preencha } \\
\text { um formulário para cada um deles): } \\
\text { CURSO PARA AGENTES DE ATER SOBRE TÉCNICAS PARA A APRENDIZAGEM E AÇÃO } \\
\text { PARTICIPATIVA -DRP }\end{array}$} \\
\hline $\begin{array}{l}\text { Data do Curso/Encontro/Oficina (pelo menos mês e } \\
15 / 12 / 2.006\end{array}$ & no): \\
\hline
\end{tabular}

Indique sua área de atuação? (As opções não são excludentes: você poderá marcar mais de uma opção).

\begin{tabular}{|l|l|}
\hline$X$ & EXTENSÃO RURAL \\
\hline
\end{tabular}




\begin{tabular}{|l|l|}
\hline & PESQUISA \\
\hline & ENSINO \\
\hline & OUTROS \\
\hline
\end{tabular}

2) Qual o seu nível de escolaridade? (Considere apenas o nível mais alto)

\begin{tabular}{|l|l|}
\hline & NÍVEL MÉDIO \\
\hline$X$ & NÍVEL SUPERIOR \\
\hline & PÓS-GRADUAÇÃO \\
\hline
\end{tabular}

3) Os conteúdos abordados foram condizentes com as demandas do seu dia-a-dia?

\begin{tabular}{|l|l|}
\hline$X$ & SIM \\
\hline & PARCIALMENTE \\
\hline & NÃO \\
\hline
\end{tabular}

4) O curso contribuiu para o seu aperfeiçoamento profissional?

\begin{tabular}{|l|l|}
\hline$X$ & SIM \\
\hline & NÃO \\
\hline
\end{tabular}

5) Os conhecimentos adquiridos estão sendo aplicados no seu trabalho? Em caso afirmativo, indique em que grau estes conhecimentos estão sendo aplicados. Em caso negativo, indique por que razão isto não ocorre: (As respostas não são excludentes: você poderá marcar mais de uma opção).

\begin{tabular}{|l|l|l|l|}
\hline$X$ & $\begin{array}{l}\text { SIM (indique ao lado em } \\
\text { que grau) }\end{array}$ & $X$ & MUITO APLICADOS \\
\cline { 2 - 4 } & & MEDIAMENTE APLICADOS \\
\hline
\end{tabular}




\begin{tabular}{|c|c|}
\hline & POUCO APLICADOS \\
\hline \multirow{5}{*}{$\begin{array}{l}\text { NÃO (indique ao lado a } \\
\text { razão da não aplicação) }\end{array}$} & $\begin{array}{l}\text { CONTEÚDO NÃO ADEQUADO ÀS NECESSIDADES } \\
\text { ESPECÍFICAS DA REGIÃO }\end{array}$ \\
\hline & $\begin{array}{l}\text { CONTEÚDO NÃO } \\
\text { APROFUNDADO PARA }\end{array}$ \\
\hline & $\begin{array}{|lllllll|}\text { FALTA } & \text { DE } & \text { APOIO } & \text { E } & \text { INCENTIVO } & \text { DA } & \text { MINHA } \\
\text { INSTITUIÇÃO } & & & & \\
\end{array}$ \\
\hline & FALTA DE INCENTIVO ÀS AÇÕES DE ATER \\
\hline & NÃO TENHO INTERESSE EM APLICAR \\
\hline
\end{tabular}

6) A partir deste curso: (As opções não são excludentes: você poderá marcar mais de uma opção).

\begin{tabular}{|l|l|}
\hline$x$ & $\begin{array}{l}\text { NÃO MUDOU NADA EM MEU TRABALHO. } \\
\text { FAMILIARES. }\end{array}$ \\
\hline & CONSEGUI INFLUENCIAR NAS ORIENTAÇÕES DA MINHA INSTITUIÇÃO. \\
\hline & PASSEI A TRABALHAR COM METODOLOGIAS PARTICIPATIVAS. \\
\hline & $\begin{array}{l}\text { CRESCEU A ÁREA DE AGRICULTURA DE BASE ECOLÓGICA NAS COMUNIDADES } \\
\text { ONDE ATUO. }\end{array}$ \\
\hline & CONTINUEI ME APERFEIÇOANDO SOBRE TEMAS ABORDADOS. \\
\hline
\end{tabular}

7) Depois do curso você apoiou atividades de capacitação de técnicos e agricultores com base nos princípios e diretrizes da Pnater? (Considere como apoio a atividades de capacitação a participação no planejamento, elaboração de ementas, seleção de participantes e de palestrantes.)

\begin{tabular}{|l|l|}
\hline$X$ & SIM \\
\hline & NÃO \\
\hline
\end{tabular}


8) Usou os conhecimentos para ministrar outros cursos com o mesmo conteúdo ou conteúdos semelhantes?

\begin{tabular}{|l|l|}
\hline$X$ & SIM \\
\hline & NÃO \\
\hline
\end{tabular}

9) Marque o seu grau de satisfação com relação ao curso oferecido pelo DATER: (Considere a seguinte pontuação: 1 - MUITO RUIM; 2 - RUIM; 3 - REGULAR; 4 - BOM; 5 - MUITO BOM)

\begin{tabular}{|l|l|l|l|l|}
\hline 1 & 2 & 3 & $X 4$ & 5 \\
\hline
\end{tabular}

10) Marque seu grau de satisfação com relação ao DATER: (Considere a seguinte pontuação: 1 - MUITO RUIM; 2 - RUIM; 3 - REGULAR; 4 - BOM; 5 - MUITO BOM)

\begin{tabular}{|l|l|l|l|l|}
\hline 1 & 2 & $\times 3$ & 4 & 5 \\
\hline
\end{tabular}


PESQUISA - IMPACTO DAS AÇÕES DE FORMAÇÃO REALIZADAS PELO DATER/SAF/MDA NO PERÍODO 2004-2009

Caros colaboradores,

Contamos com a sua atenção para preencher o formulário abaixo.

O mesmo tem por objetivo fornecer informações para avaliação da Eficiência, Efetividade e Eficácia da Política Pública de Formação de Agentes de Ater adotada pelo Departamento de Assistência Técnica e Extensão Rural, da Secretaria de Agricultura Familiar do Ministério do Desenvolvimento - DATER/SAF/MDA, no período de 2004 a 2009, tema escolhido para Monografia a ser apresentada à Universidade de Brasília (UnB) como requisito parcial para obtenção do grau de Bacharel em Administração.

Você poderá ou não se identificar no questionário e garantimos que todas as informações fornecidas serão confidenciais e utilizadas apenas de forma sistematizada.

\section{IDENTIFICAÇÃO}

\begin{tabular}{|l|l|l|}
\hline Nome: Marco Barroso & $\begin{array}{l}\text { Sexo: } \\
(x) \text { masculino } \quad(\quad \text { ) feminino }\end{array}$ \\
\hline Instituição (nome e tipo de instituição: ONG, & Local de trabalho (Cidade e Estado): \\
Empresa Pública, etc.): INCAPER - Instituto & Linhares, Espírito Santo \\
Capixaba de Pesquisa, Assist. Técnica e Extensão & \\
Rural, instituição pública & \\
\hline Curso/Encontro/Oficina do qual participou (caso tenha participado de mais de um curso, preencha \\
um formulário para cada um deles): Formação de agentes de extensão aquícola e pesqueira
\end{tabular}

Indique sua área de atuação? (As opções não são excludentes: você poderá marcar mais de uma opção).

\begin{tabular}{|c|l|}
\hline & EXTENSÃO RURAL \\
\hline$x$ & PESQUISA \\
\hline & ENSINO \\
\hline & OUTROS \\
\hline
\end{tabular}


2) Qual o seu nível de escolaridade? (Considere apenas o nível mais alto)

\begin{tabular}{|c|l|}
\hline & NÍVEL MÉDIO \\
\hline & NÍVEL SUPERIOR \\
\hline$x$ & PÓS-GRADUAÇÃO \\
\hline
\end{tabular}

3) Os conteúdos abordados foram condizentes com as demandas do seu dia-a-dia?

\begin{tabular}{|l|l|}
\hline$x$ & SIM \\
\hline & PARCIALMENTE \\
\hline & NÃO \\
\hline
\end{tabular}

4) O curso contribuiu para o seu aperfeiçoamento profissional?

\begin{tabular}{|l|l|}
\hline$x$ & SIM \\
\hline & NÃO \\
\hline
\end{tabular}

5) Os conhecimentos adquiridos estão sendo aplicados no seu trabalho? Em caso afirmativo, indique em que grau estes conhecimentos estão sendo aplicados. Em caso negativo, indique por que razão isto não ocorre: (As respostas não são excludentes: você poderá marcar mais de uma opção).

\begin{tabular}{|l|l|l|l|}
\hline \multirow{2}{*}{$\begin{array}{l}\text { SIM (indique ao lado em } \\
\text { que grau) }\end{array}$} & \multicolumn{1}{|l|}{ MUITO APLICADOS } \\
\cline { 2 - 3 } & & MEDIAMENTE APLICADOS \\
\hline & $\begin{array}{l}\text { NÃO (indique ao lado a } \\
\text { razão da não aplicação) }\end{array}$ & & $\begin{array}{l}\text { CONTEÚDO NÃO ADEQUADO ȦS NECESSIDADES } \\
\text { ESPECÍFICAS DA REGIÃO }\end{array}$ \\
\hline
\end{tabular}




\begin{tabular}{|l|l|l|}
\hline \multirow{10}{*}{} & $\begin{array}{l}\text { CONTEÚDO NÃO FOI SUFICIENTEMENTE } \\
\text { APROFUNDADO PARA PERMITIR UMA APLICAÇÃO } \\
\text { EFICAZ E EFICIENTE }\end{array}$ \\
\cline { 2 - 4 } & $\begin{array}{l}\text { FALTA DE APOIO E INCENTIVO DA MINHA } \\
\text { INSTITUIÇÃO }\end{array}$ \\
\cline { 2 - 4 } & FALTA DE INCENTIVO ÀS AÇÕES DE ATER \\
\hline & NÃO TENHO INTERESSE EM APLICAR \\
\hline
\end{tabular}

6) A partir deste curso: (As opções não são excludentes: você poderá marcar mais de uma opção).

\begin{tabular}{|c|l|}
\hline$x$ & $\begin{array}{l}\text { NÃO MUDOU NADA EM MEU TRABALHO. } \\
\text { FAMILIARES E PESCADORES }\end{array}$ \\
\hline & CONSEGUI INFLUENCIAR NAS ORIENTAÇÕES DA MINHA INSTITUIÇÃO. \\
\hline & PASSEI A TRABALHAR COM METODOLOGIAS PARTICIPATIVAS. \\
\hline & \begin{tabular}{l} 
ORESCEU A ÁREA DE AGRICULTURA DE BASE ECOLÓGICA NAS COMUNIDADES \\
\hline
\end{tabular} \\
\hline
\end{tabular}

7) Depois do curso você apoiou atividades de capacitação de técnicos e agricultores com base nos princípios e diretrizes da Pnater? (Considere como apoio a atividades de capacitação a participação no planejamento, elaboração de ementas, seleção de participantes e de palestrantes.)

\begin{tabular}{|l|l|}
\hline & SIM \\
\hline$x$ & NÃO \\
\hline
\end{tabular}

8) Usou os conhecimentos para ministrar outros cursos com o mesmo conteúdo ou conteúdos semelhantes? 


\begin{tabular}{|l|l|}
\hline & SIM \\
\hline$x$ & NÃO \\
\hline
\end{tabular}

9) Marque o seu grau de satisfação com relação ao curso oferecido pelo DATER: (Considere a seguinte pontuação: 1 - MUITO RUIM; 2 - RUIM; 3 - REGULAR; 4 - BOM; 5 - MUITO BOM)

\begin{tabular}{|l|l|l|l|l|}
\hline 1 & 2 & 3 & 4 & $x 5$ \\
\hline
\end{tabular}

10) Marque seu grau de satisfação com relação ao DATER: (Considere a seguinte pontuação: 1 - MUITO RUIM; 2 - RUIM; 3 - REGULAR; 4 - BOM; 5 - MUITO BOM)

\begin{tabular}{|l|l|l|l|l|}
\hline 1 & 2 & 3 & 4 & $x 5$ \\
\hline
\end{tabular}

Observação: Estou afastada de minhas atividades de pesquisa e extensão aqüícola e pesqueira desde março de 2006, em função de estar participando do Programa de Pósgraduação em Aqüicultura da Universidade Federal de Santa Catarina. Por este motivo os conhecimentos adquiridos no treinamento não tiveram aplicação contínua. 
PESQUISA - IMPACTO DAS AÇÕES DE FORMAÇÃO REALIZADAS PELO DATER/SAF/MDA NO PERÍODO 2004-2009

Caros colaboradores,

Contamos com a sua atenção para preencher o formulário abaixo.

O mesmo tem por objetivo fornecer informações para avaliação da Eficiência, Efetividade e Eficácia da Política Pública de Formação de Agentes de Ater adotada pelo Departamento de Assistência Técnica e Extensão Rural, da Secretaria de Agricultura Familiar do Ministério do Desenvolvimento - DATER/SAF/MDA, no período de 2004 a 2009, tema escolhido para Monografia a ser apresentada à Universidade de Brasília (UnB) como requisito parcial para obtenção do grau de Bacharel em Administração.

Você poderá ou não se identificar no questionário e garantimos que todas as informações fornecidas serão confidenciais e utilizadas apenas de forma sistematizada.

\section{IDENTIFICAÇÃO}

\begin{tabular}{|c|c|}
\hline Nome: Marco Aurélio Borba Moreira & $\begin{array}{l}\text { Sexo: } \\
(x \quad) \text { masculino } \quad(\quad) \text { feminino }\end{array}$ \\
\hline $\begin{array}{l}\text { Instituição (nome e tipo de instituição: ONG, } \\
\text { Empresa Pública, etc.): EMATER MG, Empresa } \\
\text { Pública, de ATER de MG }\end{array}$ & $\begin{array}{l}\text { Local de trabalho (Cidade e Estado): } \\
\text { Santa Vitória - MG }\end{array}$ \\
\hline \multicolumn{2}{|c|}{$\begin{array}{l}\text { Curso/Encontro/Oficina do qual participou (caso tenha participado de mais de um curso, preencha } \\
\text { um formulário para cada um deles): } \\
\text { - Curso de Formação de Extensionistas Agroflorestais no Cerrado; }\end{array}$} \\
\hline $\begin{array}{l}\text { Data do Curso/Encontro/Oficina (pelo menos mês e } \\
\text { - Novembro, Dezembro de } 2006 \text { e Fevereiro, Março }\end{array}$ & $\begin{array}{l}\text { ano): } \\
\text { de 2007; }\end{array}$ \\
\hline
\end{tabular}

1) Indique sua área de atuação? (As opções não são excludentes: você poderá marcar mais de uma opção).

\begin{tabular}{|l|l|}
\hline$X$ & EXTENSÃO RURAL \\
\hline & PESQUISA \\
\hline & ENSINO \\
\hline
\end{tabular}




\section{OUTROS}

2) Qual o seu nível de escolaridade? (Considere apenas o nível mais alto)

\begin{tabular}{|l|l|}
\hline & NÍVEL MÉDIO \\
\hline & NÍVEL SUPERIOR \\
\hline$X$ & PÓS-GRADUAÇÃO \\
\hline
\end{tabular}

3) Os conteúdos abordados foram condizentes com as demandas do seu dia-a-dia?

\begin{tabular}{|l|l|}
\hline$X$ & SIM \\
\hline & PARCIALMENTE \\
\hline & NÃO \\
\hline
\end{tabular}

4) O curso contribuiu para o seu aperfeiçoamento profissional?

\begin{tabular}{|l|l|}
\hline$X$ & SIM \\
\hline & NÃO \\
\hline
\end{tabular}

5) Os conhecimentos adquiridos estão sendo aplicados no seu trabalho? Em caso afirmativo, indique em que grau estes conhecimentos estão sendo aplicados. Em caso negativo, indique por que razão isto não ocorre: (As respostas não são excludentes: você poderá marcar mais de uma opção).

\begin{tabular}{|c|c|c|c|}
\hline \multirow{3}{*}{$X$} & \multirow{3}{*}{$\begin{array}{l}\text { SIM (indique ao lado em } \\
\text { que grau) }\end{array}$} & $\bar{X}$ & MUITO APLICADOS \\
\hline & & & MEDIAMENTE APLICADOS \\
\hline & & & POUCO APLICADOS \\
\hline & $\begin{array}{l}\text { NĀO (indique ao lado a } \\
\text { razão da não aplicação) }\end{array}$ & & $\begin{array}{l}\text { CONTEÚDO NĀO ADEQUADO ȦS NECESSIDADES } \\
\text { ESPECÍFICAS DA REGIÃO }\end{array}$ \\
\hline
\end{tabular}




\begin{tabular}{|l|l|l|}
\hline \multirow{10}{*}{} & & $\begin{array}{l}\text { CONTEÚDO NÃO FOI SUFICIENTEMENTE } \\
\text { APROFUNDADO PARA PERMITIR UMA APLICAÇÃO } \\
\text { EFICAZ E EFICIENTE }\end{array}$ \\
\cline { 2 - 5 } & $\begin{array}{l}\text { FALTA DE APOIO E INCENTIVO DA MINHA } \\
\text { INSTITUIÇÃO }\end{array}$ \\
\cline { 2 - 4 } & FALTA DE INCENTIVO ÀS AÇÕES DE ATER \\
\hline & NÃO TENHO INTERESSE EM APLICAR \\
\hline
\end{tabular}

6) A partir deste curso: (As opções não são excludentes: você poderá marcar mais de uma opção).

\begin{tabular}{|l|l|}
\hline & NÃO MUDOU NADA EM MEU TRABALHO. \\
\hline$X$ & $\begin{array}{l}\text { MEU TRABALHO PASSOU A CONTRIBUIR MAIS COM OS AGRICULTORES(AS) } \\
\text { FAMILIARES. }\end{array}$ \\
\hline$X$ & CONSEGUI INFLUENCIAR NAS ORIENTAÇÕES DA MINHA INSTITUIÇÃO. \\
\hline & PASSEI A TRABALHAR COM METODOLOGIAS PARTICIPATIVAS. \\
\hline$X$ & $\begin{array}{l}\text { CRESCEU A ÁREA DE AGRICULTURA DE BASE ECOLÓGICA NAS COMUNIDADES } \\
\text { ONDE ATUO. }\end{array}$ \\
\hline$X$ & CONTINUEI ME APERFEIÇOANDO SOBRE TEMAS ABORDADOS. \\
\hline
\end{tabular}

7) Depois do curso você apoiou atividades de capacitação de técnicos e agricultores com base nos princípios e diretrizes da Pnater? (Considere como apoio a atividades de capacitação a participação no planejamento, elaboração de ementas, seleção de participantes e de palestrantes.)

\begin{tabular}{|l|l|}
\hline$X$ & SIM \\
\hline & NÃO \\
\hline
\end{tabular}

8) Usou os conhecimentos para ministrar outros cursos com o mesmo conteúdo ou conteúdos semelhantes? 


\begin{tabular}{|l|l|}
\hline & SIM \\
\hline$X$ & NÃO \\
\hline
\end{tabular}

9) Marque o seu grau de satisfação com relação ao curso oferecido pelo DATER: (Considere a seguinte pontuação: 1 - MUITO RUIM; 2 - RUIM; 3 - REGULAR; 4 - BOM; 5 - MUITO BOM)

\begin{tabular}{|l|l|l|l|l|}
\hline 1 & 2 & 3 & $4 X$ & 5 \\
\hline
\end{tabular}

10) Marque seu grau de satisfação com relação ao DATER: (Considere a seguinte pontuação: 1 - MUITO RUIM; 2 - RUIM; 3 - REGULAR; 4 - BOM; 5 - MUITO BOM)

\begin{tabular}{|l|l|l|l|l|}
\hline 1 & 2 & 3 & $\underline{4 X}$ & 5 \\
\hline
\end{tabular}


PESQUISA - IMPACTO DAS AÇÕES DE FORMAÇÃO REALIZADAS PELO DATER/SAF/MDA NO PERÍODO 2004-2009

Caros colaboradores,

Contamos com a sua atenção para preencher o formulário abaixo.

O mesmo tem por objetivo fornecer informações para avaliação da Eficiência, Efetividade e Eficácia da Política Pública de Formação de Agentes de Ater adotada pelo Departamento de Assistência Técnica e Extensão Rural, da Secretaria de Agricultura Familiar do Ministério do Desenvolvimento - DATER/SAF/MDA, no período de 2004 a 2009, tema escolhido para Monografia a ser apresentada à Universidade de Brasília (UnB) como requisito parcial para obtenção do grau de Bacharel em Administração.

Você poderá ou não se identificar no questionário e garantimos que todas as informações fornecidas serão confidenciais e utilizadas apenas de forma sistematizada.

\section{IDENTIFICAÇÃO}

\begin{tabular}{|c|c|}
\hline Nome: Marco Aurélio Borba Moreira & $\begin{array}{l}\text { Sexo: } \\
(x \quad) \text { masculino } \quad(\quad) \text { feminino }\end{array}$ \\
\hline $\begin{array}{l}\text { Instituição (nome e tipo de instituição: ONG, } \\
\text { Empresa Pública, etc.): EMATER MG, Empresa } \\
\text { Pública, de ATER de MG }\end{array}$ & $\begin{array}{l}\text { Local de trabalho (Cidade e Estado): } \\
\text { Santa Vitória - MG }\end{array}$ \\
\hline \multicolumn{2}{|c|}{$\begin{array}{l}\text { Curso/Encontro/Oficina do qual participou (caso tenha participado de mais de um curso, preencha } \\
\text { um formulário para cada um deles): } \\
\text { - Curso de Especialização em Extensão Rural para o Desenvolvimento Sustentável; }\end{array}$} \\
\hline $\begin{array}{l}\text { Data do Curso/Encontro/Oficina (pelo menos mês e } \\
\text { - Outubro, Novembro, Dezembro de } 2005 \text { e Junho de }\end{array}$ & 2006; \\
\hline
\end{tabular}

Indique sua área de atuação? (As opções não são excludentes: você poderá marcar mais de uma opção).

\begin{tabular}{|l|l|}
\hline$X$ & EXTENSÃO RURAL \\
\hline & PESQUISA \\
\hline & ENSINO \\
\hline
\end{tabular}




\section{OUTROS}

2) Qual o seu nível de escolaridade? (Considere apenas o nível mais alto)

\begin{tabular}{|l|l|}
\hline & NÍVEL MÉDIO \\
\hline & NÍVEL SUPERIOR \\
\hline$X$ & PÓS-GRADUAÇÃO \\
\hline
\end{tabular}

3) Os conteúdos abordados foram condizentes com as demandas do seu dia-a-dia?

\begin{tabular}{|l|l|}
\hline$X$ & SIM \\
\hline & PARCIALMENTE \\
\hline & NÃO \\
\hline
\end{tabular}

4) O curso contribuiu para o seu aperfeiçoamento profissional?

\begin{tabular}{|l|l|}
\hline$X$ & SIM \\
\hline & NÃO \\
\hline
\end{tabular}

5) Os conhecimentos adquiridos estão sendo aplicados no seu trabalho? Em caso afirmativo, indique em que grau estes conhecimentos estão sendo aplicados. Em caso negativo, indique por que razão isto não ocorre: (As respostas não são excludentes: você poderá marcar mais de uma opção).

\begin{tabular}{|l|l|l|l|}
\hline$x$ & $\begin{array}{l}\text { SIM (indique ao lado em } \\
\text { que grau) }\end{array}$ & & MUITO APLICADOS \\
\cline { 2 - 4 } & & MEDIAMENTE APLICADOS \\
\hline
\end{tabular}




\begin{tabular}{|c|c|}
\hline \multirow{5}{*}{$\begin{array}{l}\text { NÃO (indique ao lado a } \\
\text { razão da não aplicação) }\end{array}$} & $\begin{array}{l}\text { CONTEÚDO NÃO ADEQUADO ÀS NECESSIDADES } \\
\text { ESPECÍFICAS DA REGIÃO }\end{array}$ \\
\hline & $\begin{array}{l}\text { CONTEÚDO NÃO } \text { FOI SUFICIENTEMENTE } \\
\text { APROFUNDADO PARA } \\
\text { PERMITIR UMA APLICAÇÃO } \\
\text { EFICAZ E EFICIENTE }\end{array}$ \\
\hline & $\begin{array}{lllllll}\text { FALTA DE } & \text { APOIO } & \text { E } & \text { INCENTIVO } & \text { DA } & \text { MINHA } \\
\text { INSTITUIÇÃO } & & & & & \end{array}$ \\
\hline & FALTA DE INCENTIVO ÀS AÇÕES DE ATER \\
\hline & NÃO TENHO INTERESSE EM APLICAR \\
\hline
\end{tabular}

6) A partir deste curso: (As opções não são excludentes: você poderá marcar mais de uma opção).

\begin{tabular}{|l|l|}
\hline & NÃO MUDOU NADA EM MEU TRABALHO. \\
\hline$X$ & $\begin{array}{l}\text { MEU TRABALHO PASSOU A CONTRIBUIR MAIS COM OS AGRICULTORES(AS) } \\
\text { FAMILIARES. }\end{array}$ \\
\hline$X$ & CONSEGUI INFLUENCIAR NAS ORIENTAÇÕES DA MINHA INSTITUIÇÃO. \\
\hline$X$ & $\begin{array}{l}\text { CRESSEI A TRABALHAR COM METODOLOGIAS PARTICIPATIVAS. } \\
\text { ONDE ATUO. }\end{array}$ \\
\hline$X$ & CONTINUEI DE AGRICULTURA DE BASE ECOLÓGICA NAS COMUNIDADES \\
\hline
\end{tabular}

7) Depois do curso você apoiou atividades de capacitação de técnicos e agricultores com base nos princípios e diretrizes da Pnater? (Considere como apoio a atividades de capacitação a participação no planejamento, elaboração de ementas, seleção de participantes e de palestrantes.)

\begin{tabular}{|l|l|}
\hline$X$ & SIM \\
\hline & NÃO \\
\hline
\end{tabular}


8) Usou os conhecimentos para ministrar outros cursos com o mesmo conteúdo ou conteúdos semelhantes?

\begin{tabular}{|l|l|}
\hline & SIM \\
\hline$X$ & NÃO \\
\hline
\end{tabular}

9) Marque o seu grau de satisfação com relação ao curso oferecido pelo DATER: (Considere a seguinte pontuação: 1 - MUITO RUIM; 2 - RUIM; 3 - REGULAR; 4 - BOM; 5 - MUITO BOM)

\begin{tabular}{|l|l|l|l|l|}
\hline 1 & 2 & 3 & $\underline{4 X}$ & 5 \\
\hline
\end{tabular}

10) Marque seu grau de satisfação com relação ao DATER: (Considere a seguinte pontuação: 1 - MUITO RUIM; 2 - RUIM; 3 - REGULAR; 4 - BOM; 5 - MUITO BOM)

\begin{tabular}{|l|l|l|l|l|}
\hline 1 & 2 & 3 & $\underline{4}$ & 5 \\
\hline
\end{tabular}


PESQUISA - IMPACTO DAS AÇÕES DE FORMAÇÃO REALIZADAS PELO DATER/SAF/MDA NO PERÍODO 2004-2009

Caros colaboradores,

Contamos com a sua atenção para preencher o formulário abaixo.

O mesmo tem por objetivo fornecer informações para avaliação da Eficiência, Efetividade e Eficácia da Política Pública de Formação de Agentes de Ater adotada pelo Departamento de Assistência Técnica e Extensão Rural, da Secretaria de Agricultura Familiar do Ministério do Desenvolvimento - DATER/SAF/MDA, no período de 2004 a 2009, tema escolhido para Monografia a ser apresentada à Universidade de Brasília (UnB) como requisito parcial para obtenção do grau de Bacharel em Administração.

Você poderá ou não se identificar no questionário e garantimos que todas as informações fornecidas serão confidenciais e utilizadas apenas de forma sistematizada.

\section{IDENTIFICAÇÃO}

\begin{tabular}{|c|c|}
\hline Nome: Marcia Vanacor Barroso & $\begin{array}{l}\text { Sexo: } \\
(\quad) \text { masculino } \quad(x) \text { feminino }\end{array}$ \\
\hline $\begin{array}{l}\text { Instituição (nome e tipo de instituição: ONG, } \\
\text { Empresa Pública, etc.): INCAPER - Instituto } \\
\text { Capixaba de Pesquisa, Assist. Técnica e Extensão } \\
\text { Rural, instituição pública }\end{array}$ & $\begin{array}{l}\text { Local de trabalho (Cidade e Estado): } \\
\text { Linhares, Espírito Santo }\end{array}$ \\
\hline \multicolumn{2}{|c|}{$\begin{array}{l}\text { Curso/Encontro/Oficina do qual participou (caso tenha participado de mais de um curso, preencha } \\
\text { um formulário para cada um deles): Formação de agentes de extensão aquícola e pesqueira }\end{array}$} \\
\hline 10 & $\overline{4}$ \\
\hline
\end{tabular}

Indique sua área de atuação? (As opções não são excludentes: você poderá marcar mais de uma opção).

\begin{tabular}{|c|l|}
\hline & EXTENSÃO RURAL \\
\hline$x$ & PESQUISA \\
\hline & ENSINO \\
\hline & OUTROS \\
\hline
\end{tabular}


2) Qual o seu nível de escolaridade? (Considere apenas o nível mais alto)

\begin{tabular}{|c|l|}
\hline & NÍVEL MÉDIO \\
\hline & NÍVEL SUPERIOR \\
\hline$x$ & PÓS-GRADUAÇÃO \\
\hline
\end{tabular}

3) Os conteúdos abordados foram condizentes com as demandas do seu dia-a-dia?

\begin{tabular}{|l|l|}
\hline$x$ & SIM \\
\hline & PARCIALMENTE \\
\hline & NÃO \\
\hline
\end{tabular}

4) O curso contribuiu para o seu aperfeiçoamento profissional?

\begin{tabular}{|l|l|}
\hline$x$ & SIM \\
\hline & NÃO \\
\hline
\end{tabular}

5) Os conhecimentos adquiridos estão sendo aplicados no seu trabalho? Em caso afirmativo, indique em que grau estes conhecimentos estão sendo aplicados. Em caso negativo, indique por que razão isto não ocorre: (As respostas não são excludentes: você poderá marcar mais de uma opção).

\begin{tabular}{|c|c|c|}
\hline \multirow{3}{*}{$\begin{array}{l}\text { SIM (indique ao lado em } \\
\text { que grau) }\end{array}$} & & MUITO APLICADOS \\
\hline & $x$ & MEDIAMENTE APLICADOS \\
\hline & & POUCO APLICADOS \\
\hline $\begin{array}{l}\text { NÃO (indique ao lado a } \\
\text { razão da não aplicação) }\end{array}$ & & $\begin{array}{l}\text { CONTEÚDO NÃO ADEQUADO ȦS NECESSIDADES } \\
\text { ESPECÍFICAS DA REGIÃO }\end{array}$ \\
\hline
\end{tabular}




\begin{tabular}{|l|l|l|}
\hline \multirow{10}{*}{} & $\begin{array}{l}\text { CONTEÚDO NÃO FOI SUFICIENTEMENTE } \\
\text { APROFUNDADO PARA PERMITIR UMA APLICAÇÃO } \\
\text { EFICAZ E EFICIENTE }\end{array}$ \\
\cline { 2 - 4 } & $\begin{array}{l}\text { FALTA DE APOIO E INCENTIVO DA MINHA } \\
\text { INSTITUIÇÃO }\end{array}$ \\
\cline { 2 - 4 } & FALTA DE INCENTIVO ÀS AÇÕES DE ATER \\
\hline & NÃO TENHO INTERESSE EM APLICAR \\
\hline
\end{tabular}

6) A partir deste curso: (As opções não são excludentes: você poderá marcar mais de uma opção).

\begin{tabular}{|c|l|}
\hline$x$ & $\begin{array}{l}\text { NÃO MUDOU NADA EM MEU TRABALHO. } \\
\text { FAMILIARES E PESCADORES }\end{array}$ \\
\hline & CONSEGUI INFLUENCIAR NAS ORIENTAÇÕES DA MINHA INSTITUIÇÃO. \\
\hline & PASSEI A TRABALHAR COM METODOLOGIAS PARTICIPATIVAS. \\
\hline & $\begin{array}{l}\text { CRESCEU A ÁREA DE AGRICULTURA DE BASE ECOLÓGICA NAS COMUNIDADES } \\
\text { ONDE ATUO. }\end{array}$ \\
\hline & CONTINUEI ME APERFEIÇOANDO SOBRE TEMAS ABORDADOS. \\
\hline
\end{tabular}

7) Depois do curso você apoiou atividades de capacitação de técnicos e agricultores com base nos princípios e diretrizes da Pnater? (Considere como apoio a atividades de capacitação a participação no planejamento, elaboração de ementas, seleção de participantes e de palestrantes.)

\begin{tabular}{|l|l|}
\hline & SIM \\
\hline$x$ & NÃO \\
\hline
\end{tabular}

8) Usou os conhecimentos para ministrar outros cursos com o mesmo conteúdo ou conteúdos semelhantes? 


\begin{tabular}{|l|l|}
\hline & SIM \\
\hline$x$ & NÃO \\
\hline
\end{tabular}

9) Marque o seu grau de satisfação com relação ao curso oferecido pelo DATER: (Considere a seguinte pontuação: 1 - MUITO RUIM; 2 - RUIM; 3 - REGULAR; 4 - BOM; 5 - MUITO BOM)

\begin{tabular}{|l|l|l|l|l|}
\hline 1 & 2 & 3 & 4 & $x 5$ \\
\hline
\end{tabular}

10) Marque seu grau de satisfação com relação ao DATER: (Considere a seguinte pontuação: 1 - MUITO RUIM; 2 - RUIM; 3 - REGULAR; 4 - BOM; 5 - MUITO BOM)

\begin{tabular}{|l|l|l|l|l|}
\hline 1 & 2 & 3 & 4 & $x 5$ \\
\hline
\end{tabular}

Observação: Estou afastada de minhas atividades de pesquisa e extensão aqüícola e pesqueira desde março de 2006, em função de estar participando do Programa de Pósgraduação em Aqüicultura da Universidade Federal de Santa Catarina. Por este motivo os conhecimentos adquiridos no treinamento não tiveram aplicação contínua.

PESQUISA - IMPACTO DAS AÇÕES DE FORMAÇÃO REALIZADAS PELO DATER/SAF/MDA NO PERÍODO 2004-2009

Caros colaboradores,

Contamos com a sua atenção para preencher o formulário abaixo.

O mesmo tem por objetivo fornecer informações para avaliação da Eficiência, Efetividade e Eficácia da Política Pública de Formação de Agentes de Ater adotada pelo Departamento de Assistência Técnica e Extensão Rural, da Secretaria de Agricultura Familiar do Ministério do Desenvolvimento - DATER/SAF/MDA, no período de 2004 a 2009, tema escolhido para Monografia a ser apresentada à Universidade de Brasília (UnB) como requisito parcial para obtenção do grau de Bacharel em Administração.

Você poderá ou não se identificar no questionário e garantimos que todas as informações fornecidas serão confidenciais e utilizadas apenas de forma sistematizada. 


\begin{tabular}{|l|l|}
\hline Nome: Márcia Roziane Zumak & $\begin{array}{l}\text { Sexo: } \\
(\quad) \text { masculino } \quad(x \quad \text { ) feminino }\end{array}$ \\
\hline $\begin{array}{l}\text { Instituição : Prefeitura Municipal de Aracruz }- \\
\text { Secretaria de Agricultura. }\end{array}$ & Local de trabalho : Aracruz \\
\hline Curso/Encontro/Oficina do qual participação: Curso de Aperfeiçoamento em Agroecologia. \\
\hline Data do Curso/Encontro/Oficina :Fevereiro a Abril de 2006 \\
\hline
\end{tabular}

Indique sua área de atuação? (As opções não são excludentes: você poderá marcar mais de uma opção).

\begin{tabular}{|l|l|}
\hline$X$ & EXTENSÃO RURAL \\
\hline & PESQUISA \\
\hline & ENSINO \\
\hline & OUTROS \\
\hline
\end{tabular}

2) Qual o seu nível de escolaridade? (Considere apenas o nível mais alto)

\begin{tabular}{|l|l|}
\hline & NÍVEL MÉDIO \\
\hline & NÍVEL SUPERIOR \\
\hline$X$ & PÓS-GRADUAÇÃO \\
\hline
\end{tabular}

3) Os conteúdos abordados foram condizentes com as demandas do seu dia-a-dia?

\begin{tabular}{|l|l|}
\hline$X$ & SIM \\
\hline & PARCIALMENTE \\
\hline & NÃO \\
\hline
\end{tabular}


4) O curso contribuiu para o seu aperfeiçoamento profissional?

\begin{tabular}{|l|l|}
\hline$X$ & SIM \\
\hline & NÃO \\
\hline
\end{tabular}

5) Os conhecimentos adquiridos estão sendo aplicados no seu trabalho? Em caso afirmativo, indique em que grau estes conhecimentos estão sendo aplicados. Em caso negativo, indique por que razão isto não ocorre: (As respostas não são excludentes: você poderá marcar mais de uma opção).

\begin{tabular}{|c|c|c|}
\hline \multirow{3}{*}{$\begin{array}{l}\text { SIM (indique ao lado em } \\
\text { que grau) }\end{array}$} & & MUITO APLICADOS \\
\hline & $\bar{x}$ & MEDIAMENTE APLICADOS \\
\hline & & POUCO APLICADOS \\
\hline \multirow{5}{*}{$\begin{array}{l}\text { NÃO (indique ao lado a } \\
\text { razão da não aplicação) }\end{array}$} & & $\begin{array}{l}\text { CONTEÚDO NÃO ADEQUADO ȦS NECESSIDADES } \\
\text { ESPECÍFICAS DA REGIÃO }\end{array}$ \\
\hline & & $\begin{array}{l}\text { CONTEÚDO NÃO } \quad \text { FOI SUFICIENTEMENTE } \\
\text { APROFUNDADO PARA } \\
\text { PERMITIR UMA APLICAÇÃO } \\
\text { EFICAZ E EFICIENTE }\end{array}$ \\
\hline & & $\begin{array}{l}\text { FALTA DE APOIO } \\
\text { INSTITUIÇÃO }\end{array}$ \\
\hline & & FALTA DE INCENTIVO ÀS AÇÕES DE ATER \\
\hline & & NÃO TENHO INTERESSE EM APLICAR \\
\hline
\end{tabular}

6) A partir deste curso: (As opções não são excludentes: você poderá marcar mais de uma opção).

\begin{tabular}{|l|l|}
\hline & NÃO MUDOU NADA EM MEU TRABALHO. \\
\hline$X$ & $\begin{array}{l}\text { MEU TRABALHO PASSOU A CONTRIBUIR MAIS COM OS AGRICULTORES(AS) } \\
\text { FAMILIARES. }\end{array}$ \\
\hline$X$ & CONSEGUI INFLUENCIAR NAS ORIENTAÇÕES DA MINHA INSTITUIÇÃO. \\
\hline
\end{tabular}




\begin{tabular}{|l|l|}
\hline & PASSEI A TRABALHAR COM METODOLOGIAS PARTICIPATIVAS. \\
\hline$X$ & $\begin{array}{l}\text { CRESCEU A ÁREA DE AGRICULTURA DE BASE ECOLÓGICA NAS COMUNIDADES } \\
\text { ONDE ATUO. }\end{array}$ \\
\hline & CONTINUEI ME APERFEIÇOANDO SOBRE TEMAS ABORDADOS. \\
\hline
\end{tabular}

7) Depois do curso você apoiou atividades de capacitação de técnicos e agricultores com base nos princípios e diretrizes da Pnater? (Considere como apoio a atividades de capacitação a participação no planejamento, elaboração de ementas, seleção de participantes e de palestrantes.)

\begin{tabular}{|l|l|}
\hline$X$ & SIM \\
\hline & NÃO \\
\hline
\end{tabular}

8) Usou os conhecimentos para ministrar outros cursos com o mesmo conteúdo ou conteúdos semelhantes?

\begin{tabular}{|l|l|}
\hline$X$ & SIM \\
\hline & NÃO \\
\hline
\end{tabular}

9) Marque o seu grau de satisfação com relação ao curso oferecido pelo DATER: (Considere a seguinte pontuação: 1 - MUITO RUIM; 2 - RUIM; 3 - REGULAR; 4 - BOM; 5 - MUITO BOM)

\begin{tabular}{|l|l|l|l|l|}
\hline 1 & 2 & 3 & 4 & $\times 5$ \\
\hline
\end{tabular}

10) Marque seu grau de satisfação com relação ao DATER: (Considere a seguinte pontuação: 1 - MUITO RUIM; 2 - RUIM; 3 - REGULAR; 4 - BOM; 5 - MUITO BOM)

\begin{tabular}{|l|l|l|l|l|}
\hline 1 & 2 & 3 & 4 & $x 5$ \\
\hline
\end{tabular}


PESQUISA - IMPACTO DAS AÇÕES DE FORMAÇÃO REALIZADAS PELO DATER/SAF/MDA NO PERÍODO 2004-2009

Caros colaboradores,

Contamos com a sua atenção para preencher o formulário abaixo.

O mesmo tem por objetivo fornecer informações para avaliação da Eficiência, Efetividade e Eficácia da Política Pública de Formação de Agentes de Ater adotada pelo Departamento de Assistência Técnica e Extensão Rural, da Secretaria de Agricultura Familiar do Ministério do Desenvolvimento - DATER/SAF/MDA, no período de 2004 a 2009, tema escolhido para Monografia a ser apresentada à Universidade de Brasília (UnB) como requisito parcial para obtenção do grau de Bacharel em Administração.

Você poderá ou não se identificar no questionário e garantimos que todas as informações fornecidas serão confidenciais e utilizadas apenas de forma sistematizada.

\section{IDENTIFICAÇÃO}

\begin{tabular}{|c|c|}
\hline $\begin{array}{l}\text { Nome: } \\
\text { Luiz Carlos Teixeira Guimarães }\end{array}$ & $\begin{array}{l}\text { Sexo: } \\
(x \quad) \text { masculino } \quad(\quad) \text { feminino }\end{array}$ \\
\hline $\begin{array}{l}\text { Instituição (nome e tipo de instituição: ONG, } \\
\text { Empresa Pública, etc.): } \\
\text { EMATER-RIO }\end{array}$ & $\begin{array}{l}\text { Local de trabalho (Cidade e Estado): } \\
\text { Campos dos Goytacazes - RJ }\end{array}$ \\
\hline \multicolumn{2}{|c|}{$\begin{array}{l}\text { Curso/Encontro/Oficina do qual participou (caso tenha participado de mais de um curso, preencha } \\
\text { um formulário para cada um deles): }\end{array}$} \\
\hline $\begin{array}{l}\text { Data do Curso/Encontro/Oficina (pelo menos mês e } \\
\text { Março e Junho } 2006 \text { - } 130 \text { horas }\end{array}$ & \\
\hline
\end{tabular}

Indique sua área de atuação? (As opções não são excludentes: você poderá marcar mais de uma opção).

\begin{tabular}{|l|l}
\hline$X$ & EXTENSÃO RURAL \\
\hline
\end{tabular} 


\begin{tabular}{|l|l|}
\hline & PESQUISA \\
\hline & ENSINO \\
\hline & OUTROS \\
\hline
\end{tabular}

2) Qual o seu nível de escolaridade? (Considere apenas o nível mais alto)

\begin{tabular}{|c|l|}
\hline & NÍVEL MÉDIO \\
\hline$X$ & NÍVEL SUPERIOR \\
\hline & PÓS-GRADUAÇÃO \\
\hline
\end{tabular}

3) Os conteúdos abordados foram condizentes com as demandas do seu dia-a-dia?

\begin{tabular}{|l|l|}
\hline$X$ & SIM \\
\hline & PARCIALMENTE \\
\hline & NÃO \\
\hline
\end{tabular}

4) O curso contribuiu para o seu aperfeiçoamento profissional?

\begin{tabular}{|l|l|}
\hline$X$ & SIM \\
\hline & NÃO \\
\hline
\end{tabular}

5) Os conhecimentos adquiridos estão sendo aplicados no seu trabalho? Em caso afirmativo, indique em que grau estes conhecimentos estão sendo aplicados. Em caso negativo, indique por que razão isto não ocorre: (As respostas não são excludentes: você poderá marcar mais de uma opção).

\begin{tabular}{|l|l|l|l|}
\hline$x$ & $\begin{array}{l}\text { SIM (indique ao lado em } \\
\text { que grau) }\end{array}$ & $X$ & MUITO APLICADOS \\
\cline { 2 - 4 } & & MEDIAMENTE APLICADOS \\
\hline
\end{tabular}




\begin{tabular}{|c|c|}
\hline & POUCO APLICADOS \\
\hline \multirow{5}{*}{$\begin{array}{l}\text { NÃO (indique ao lado a } \\
\text { razão da não aplicação) }\end{array}$} & $\begin{array}{l}\text { CONTEÚDO NÃO ADEQUADO ÀS NECESSIDADES } \\
\text { ESPECÍFICAS DA REGIÃO }\end{array}$ \\
\hline & $\begin{array}{l}\text { CONTEÚDO NÃO } \\
\text { APROFUNDADO PARA }\end{array}$ \\
\hline & $\begin{array}{|lllllll|}\text { FALTA } & \text { DE } & \text { APOIO } & \text { E } & \text { INCENTIVO } & \text { DA } & \text { MINHA } \\
\text { INSTITUIÇÃO } & & & & \\
\end{array}$ \\
\hline & FALTA DE INCENTIVO ÀS AÇÕES DE ATER \\
\hline & NÃO TENHO INTERESSE EM APLICAR \\
\hline
\end{tabular}

6) A partir deste curso: (As opções não são excludentes: você poderá marcar mais de uma opção).

\begin{tabular}{|c|l|}
\hline$x$ & $\begin{array}{l}\text { NÃO MUDOU NADA EM MEU TRABALHO. } \\
\text { FAMILIARES. }\end{array}$ \\
\hline & CONSEGUI INFLUENCIAR NAS ORIENTAÇÕES DA MINHA INSTITUIÇÃO. \\
\hline & PASSEI A TRABALHAR COM METODOLOGIAS PARTICIPATIVAS. \\
\hline & $\begin{array}{l}\text { CRESCEU A ÁREA DE AGRICULTURA DE BASE ECOLÓGICA NAS COMUNIDADES } \\
\text { ONDE ATUO. }\end{array}$ \\
\hline & CONTINUEI ME APERFEIÇOANDO SOBRE TEMAS ABORDADOS. \\
\hline
\end{tabular}

7) Depois do curso você apoiou atividades de capacitação de técnicos e agricultores com base nos princípios e diretrizes da Pnater? (Considere como apoio a atividades de capacitação a participação no planejamento, elaboração de ementas, seleção de participantes e de palestrantes.)

\begin{tabular}{|l|l|}
\hline$X$ & SIM \\
\hline & NÃO \\
\hline
\end{tabular}


8) Usou os conhecimentos para ministrar outros cursos com o mesmo conteúdo ou conteúdos semelhantes?

\begin{tabular}{|l|l|}
\hline$X$ & SIM \\
\hline & NÃO \\
\hline
\end{tabular}

9) Marque o seu grau de satisfação com relação ao curso oferecido pelo DATER: (Considere a seguinte pontuação: 1 - MUITO RUIM; 2 - RUIM; 3 - REGULAR; 4 - BOM; 5 - MUITO BOM)

\begin{tabular}{|l|l|l|l|l|}
\hline 1 & 2 & 3 & 4 & 5 \\
\hline
\end{tabular}

10) Marque seu grau de satisfação com relação ao DATER: (Considere a seguinte pontuação: 1 - MUITO RUIM; 2 - RUIM; 3 - REGULAR; 4 - BOM; 5 - MUITO BOM)

\begin{tabular}{|l|l|l|l|l|}
\hline 1 & 2 & 3 & 4 & 5 \\
\hline
\end{tabular}


PESQUISA - IMPACTO DAS AÇÕES DE FORMAÇÃO REALIZADAS PELO DATER/SAF/MDA NO PERÍODO 2004-2009

Caros colaboradores,

Contamos com a sua atenção para preencher o formulário abaixo.

O mesmo tem por objetivo fornecer informações para avaliação da Eficiência, Efetividade e Eficácia da Política Pública de Formação de Agentes de Ater adotada pelo Departamento de Assistência Técnica e Extensão Rural, da Secretaria de Agricultura Familiar do Ministério do Desenvolvimento - DATER/SAF/MDA, no período de 2004 a 2009, tema escolhido para Monografia a ser apresentada à Universidade de Brasília (UnB) como requisito parcial para obtenção do grau de Bacharel em Administração.

Você poderá ou não se identificar no questionário e garantimos que todas as informações fornecidas serão confidenciais e utilizadas apenas de forma sistematizada.

\section{IDENTIFICAÇÃO}

\begin{tabular}{|l|l|}
\hline $\begin{array}{l}\text { Nome: } \\
\text { LUIZ AUGUSTO RIBEIRO SAMPAIO }\end{array}$ & $\begin{array}{l}\text { Sexo: } \\
(x) \text { masculino } \quad(\quad \text { ) feminino }\end{array}$ \\
\hline $\begin{array}{l}\text { Instituição (nome e tipo de instituição: ONG, } \\
\text { Empresa Pública, etc.): EMATER - MG }\end{array}$ & $\begin{array}{l}\text { Local de trabalho (Cidade e Estado): } \\
\text { ITUIUTABA - MG }\end{array}$ \\
\hline $\begin{array}{l}\text { Curso/Encontro/Oficina do qual participou (caso tenha participado de mais de um curso, preencha } \\
\text { um formulário para cada um deles): Curso de Especialização em Extensão Rural, Agroecologia e } \\
\text { Desenvolvimento Sustentável }\end{array}$ \\
\hline \begin{tabular}{l} 
Data do Curso/Encontro/Oficina (pelo menos mês e ano): 05/2006 - 12/2006 (UNINCOR-MG) \\
\hline
\end{tabular}
\end{tabular}

Indique sua área de atuação? (As opções não são excludentes: você poderá marcar mais de uma opção).

\begin{tabular}{|l|l|}
\hline$X$ & EXTENSÃO RURAL \\
\hline & PESQUISA \\
\hline & ENSINO \\
\hline & OUTROS \\
\hline
\end{tabular}


2) Qual o seu nível de escolaridade? (Considere apenas o nível mais alto)

\begin{tabular}{|l|l|}
\hline & NÍVEL MÉDIO \\
\hline & NÍVEL SUPERIOR \\
\hline$X$ & PÓS-GRADUAÇÃO \\
\hline
\end{tabular}

3) Os conteúdos abordados foram condizentes com as demandas do seu dia-a-dia?

\begin{tabular}{|l|l|}
\hline$X$ & SIM \\
\hline & PARCIALMENTE \\
\hline & NÃO \\
\hline
\end{tabular}

4) O curso contribuiu para o seu aperfeiçoamento profissional?

\begin{tabular}{|l|l|}
\hline$X$ & SIM \\
\hline & NÃO \\
\hline
\end{tabular}

5) Os conhecimentos adquiridos estão sendo aplicados no seu trabalho? Em caso afirmativo, indique em que grau estes conhecimentos estão sendo aplicados. Em caso negativo, indique por que razão isto não ocorre: (As respostas não são excludentes: você poderá marcar mais de uma opção).

\begin{tabular}{|l|l|l|l|}
\hline$X$ & $\begin{array}{l}\text { SIM (indique ao lado em } \\
\text { que grau) }\end{array}$ & MUITO APLICADOS \\
\cline { 2 - 4 } & & MEDIAMENTE APLICADOS \\
\hline & $\begin{array}{l}\text { NÃO (indique ao lado a } \\
\text { razão da não aplicação) }\end{array}$ & $\begin{array}{l}\text { CONTEÚDO NÃO ADEQUADO ȦS NECESSIDADES } \\
\text { ESPECÍFICAS DA REGIÃO }\end{array}$ \\
\hline
\end{tabular}




\begin{tabular}{|l|l|l|}
\hline \multirow{10}{*}{} & $\begin{array}{l}\text { CONTEÚDO NÃO FOI SUFICIENTEMENTE } \\
\text { APROFUNDADO PARA PERMITIR UMA APLICAÇÃO } \\
\text { EFICAZ E EFICIENTE }\end{array}$ \\
\cline { 2 - 4 } & $\begin{array}{l}\text { FALTA DE APOIO E INCENTIVO DA MINHA } \\
\text { INSTITUIÇÃO }\end{array}$ \\
\cline { 2 - 4 } & FALTA DE INCENTIVO ÀS AÇÕES DE ATER \\
\hline & NÃO TENHO INTERESSE EM APLICAR \\
\hline
\end{tabular}

6) A partir deste curso: (As opções não são excludentes: você poderá marcar mais de uma opção).

\begin{tabular}{|l|l|}
\hline & NÃO MUDOU NADA EM MEU TRABALHO. \\
\hline & $\begin{array}{l}\text { MEU TRABALHO PASSOU A CONTRIBUIR MAIS COM OS AGRICULTORES(AS) } \\
\text { FAMILIARES. }\end{array}$ \\
\hline & CONSEGUI INFLUENCIAR NAS ORIENTAÇÕES DA MINHA INSTITUIÇÃO. \\
\hline & $\begin{array}{l}\text { CRESCEI A TRABALHAR COM METODOLOGIAS PARTICIPATIVAS. } \\
\text { ONDE ATUO. ÁREA DE AGRICULTURA DE BASE ECOLÓGICA NAS COMUNIDADES }\end{array}$ \\
\hline$X$ & CONTINUEI ME APERFEIÇOANDO SOBRE TEMAS ABORDADOS. \\
\hline
\end{tabular}

7) Depois do curso você apoiou atividades de capacitação de técnicos e agricultores com base nos princípios e diretrizes da Pnater? (Considere como apoio a atividades de capacitação a participação no planejamento, elaboração de ementas, seleção de participantes e de palestrantes.)

\begin{tabular}{|l|l|}
\hline & SIM \\
\hline$X$ & NÃO \\
\hline
\end{tabular}

8) Usou os conhecimentos para ministrar outros cursos com o mesmo conteúdo ou conteúdos semelhantes? 


\begin{tabular}{|l|l|}
\hline$X$ & SIM \\
\hline & NÃO \\
\hline
\end{tabular}

9) Marque o seu grau de satisfação com relação ao curso oferecido pelo DATER: (Considere a seguinte pontuação: 1 - MUITO RUIM; 2 - RUIM; 3 - REGULAR; 4 - BOM; 5 - MUITO BOM)

\begin{tabular}{|l|l|l|l|ll|}
\hline 1 & 2 & 3 & $(4)$ & 5 & \\
\hline NOTA: TEMPO & MUITO & CURTO, & MUITO & ASSUNTO & EM \\
POUCO TEMPO & & & & & \\
\hline
\end{tabular}

10) Marque seu grau de satisfação com relação ao DATER: (Considere a seguinte pontuação: 1 - MUITO RUIM; 2 - RUIM; 3 - REGULAR; 4 - BOM; 5 - MUITO BOM)

\begin{tabular}{l|l|l|l|l|}
\hline 1 & 2 & 3 & 4 & $\frac{(5)}{1}$ \\
\hline NOTA: 19 VEZ QUE VEJO UMA AÇÃO POSITIVA, DIRETA E \\
EFETIVA DO GOVERNO FEDERAL SOBRE A EXTENSÃO \\
RURAL
\end{tabular}


PESQUISA - IMPACTO DAS AÇÕES DE FORMAÇÃO REALIZADAS PELO DATER/SAF/MDA NO PERÍODO 2004-2009

Caros colaboradores,

Contamos com a sua atenção para preencher o formulário abaixo.

O mesmo tem por objetivo fornecer informações para avaliação da Eficiência, Efetividade e Eficácia da Política Pública de Formação de Agentes de Ater adotada pelo Departamento de Assistência Técnica e Extensão Rural, da Secretaria de Agricultura Familiar do Ministério do Desenvolvimento - DATER/SAF/MDA, no período de 2004 a 2009, tema escolhido para Monografia a ser apresentada à Universidade de Brasília (UnB) como requisito parcial para obtenção do grau de Bacharel em Administração.

Você poderá ou não se identificar no questionário e garantimos que todas as informações fornecidas serão confidenciais e utilizadas apenas de forma sistematizada.

\section{IDENTIFICAÇÃO}

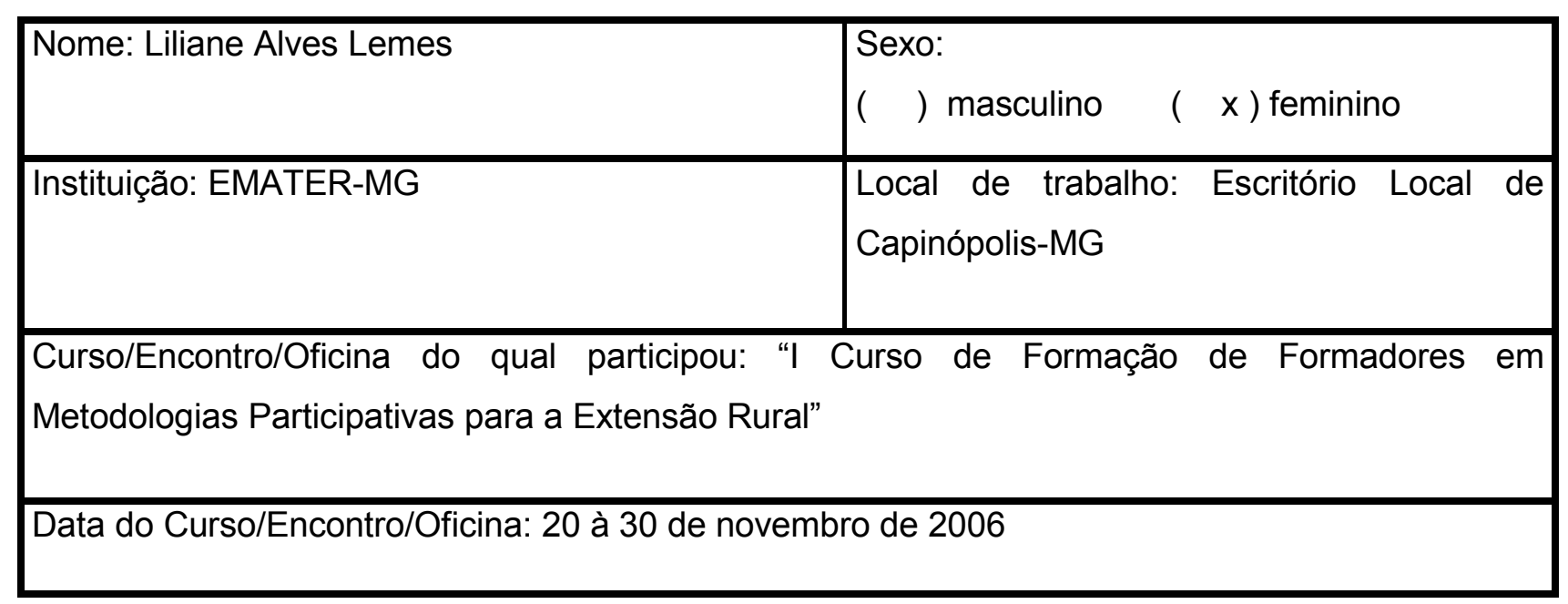

Indique sua área de atuação? (As opções não são excludentes: você poderá marcar mais de uma opção).

\begin{tabular}{|l|l|}
\hline$X$ & EXTENSÃO RURAL \\
\hline & PESQUISA \\
\hline & ENSINO \\
\hline & OUTROS \\
\hline
\end{tabular}


2) Qual o seu nível de escolaridade? (Considere apenas o nível mais alto)

\begin{tabular}{|l|l|}
\hline & NÍVEL MÉDIO \\
\hline$X$ & NÍVEL SUPERIOR \\
\hline & PÓS-GRADUAÇÃO \\
\hline
\end{tabular}

3) Os conteúdos abordados foram condizentes com as demandas do seu dia-a-dia?

\begin{tabular}{|l|l|}
\hline$X$ & SIM \\
\hline & PARCIALMENTE \\
\hline & NÃO \\
\hline
\end{tabular}

4) O curso contribuiu para o seu aperfeiçoamento profissional?

\begin{tabular}{|l|l|}
\hline$X$ & SIM \\
\hline & NÃO \\
\hline
\end{tabular}

5) Os conhecimentos adquiridos estão sendo aplicados no seu trabalho? Em caso afirmativo, indique em que grau estes conhecimentos estão sendo aplicados. Em caso negativo, indique por que razão isto não ocorre: (As respostas não são excludentes: você poderá marcar mais de uma opção).

\begin{tabular}{|l|l|l|l|}
\hline \multirow{2}{*}{$\begin{array}{l}\text { SIM (indique ao lado em } \\
\text { que grau) }\end{array}$} & X & MUITO APLICADOS \\
\cline { 2 - 3 } & & MEDIAMENTE APLICADOS \\
\hline & $\begin{array}{l}\text { NÃO (indique ao lado a } \\
\text { razão da não aplicação) }\end{array}$ & $\begin{array}{l}\text { CONTEÚDO NÃO ADEQUADO ȦS NECESSIDADES } \\
\text { ESPECÍFICAS DA REGIÃO }\end{array}$ \\
\hline
\end{tabular}




\begin{tabular}{|l|l|l|}
\hline \multirow{10}{*}{} & $\begin{array}{l}\text { CONTEÚDO NÃO FOI SUFICIENTEMENTE } \\
\text { APROFUNDADO PARA PERMITIR UMA APLICAÇÃO } \\
\text { EFICAZ E EFICIENTE }\end{array}$ \\
\cline { 2 - 4 } & $\begin{array}{l}\text { FALTA DE APOIO E INCENTIVO DA MINHA } \\
\text { INSTITUIÇÃO }\end{array}$ \\
\cline { 2 - 4 } & FALTA DE INCENTIVO ÀS AÇÕES DE ATER \\
\hline & NÃO TENHO INTERESSE EM APLICAR \\
\hline
\end{tabular}

6) A partir deste curso: (As opções não são excludentes: você poderá marcar mais de uma opção).

\begin{tabular}{|l|l|}
\hline$x$ & $\begin{array}{l}\text { NÃO MUDOU NADA EM MEU TRABALHO. } \\
\text { FAMILIARES. }\end{array}$ \\
\hline & CONSEGUI INFLUENCIAR NAS ORIENTAÇÕES DA MINHA INSTITUIÇÃO. \\
\hline & PASSEI A TRABALHAR COM METODOLOGIAS PARTICIPATIVAS. \\
\hline & $\begin{array}{l}\text { CRESCEU A ÁREA DE AGRICULTURA DE BASE ECOLÓGICA NAS COMUNIDADES } \\
\text { ONDE ATUO. }\end{array}$ \\
\hline & CONTINUEI ME APERFEIÇOANDO SOBRE TEMAS ABORDADOS. \\
\hline
\end{tabular}

7) Depois do curso você apoiou atividades de capacitação de técnicos e agricultores com base nos princípios e diretrizes da Pnater? (Considere como apoio a atividades de capacitação a participação no planejamento, elaboração de ementas, seleção de participantes e de palestrantes.)

\begin{tabular}{|l|l|}
\hline$X$ & SIM \\
\hline & NÃO \\
\hline
\end{tabular}

8) Usou os conhecimentos para ministrar outros cursos com o mesmo conteúdo ou conteúdos semelhantes? 


\begin{tabular}{|l|l|}
\hline$X$ & SIM \\
\hline & NÃO \\
\hline
\end{tabular}

9) Marque o seu grau de satisfação com relação ao curso oferecido pelo DATER: (Considere a seguinte pontuação: 1 - MUITO RUIM; 2 - RUIM; 3 - REGULAR; 4 - BOM; 5 - MUITO BOM)

\begin{tabular}{|l|l|l|l|l|}
\hline 1 & 2 & 3 & 4 & 5 \\
\hline
\end{tabular}

10) Marque seu grau de satisfação com relação ao DATER: (Considere a seguinte pontuação: 1 - MUITO RUIM; 2 - RUIM; 3 - REGULAR; 4 - BOM; 5 - MUITO BOM)

\begin{tabular}{|l|l|l|l|l|}
\hline 1 & 2 & 3 & 4 & 5 \\
\hline
\end{tabular}


PESQUISA - IMPACTO DAS AÇÕES DE FORMAÇÃO REALIZADAS PELO DATER/SAF/MDA NO PERÍODO 2004-2009

Caros colaboradores,

Contamos com a sua atenção para preencher o formulário abaixo.

O mesmo tem por objetivo fornecer informações para avaliação da Eficiência, Efetividade e Eficácia da Política Pública de Formação de Agentes de Ater adotada pelo Departamento de Assistência Técnica e Extensão Rural, da Secretaria de Agricultura Familiar do Ministério do Desenvolvimento - DATER/SAF/MDA, no período de 2004 a 2009, tema escolhido para Monografia a ser apresentada à Universidade de Brasília (UnB) como requisito parcial para obtenção do grau de Bacharel em Administração.

Você poderá ou não se identificar no questionário e garantimos que todas as informações fornecidas serão confidenciais e utilizadas apenas de forma sistematizada.

\section{IDENTIFICAÇÃO}

\begin{tabular}{|c|c|}
\hline $\begin{array}{l}\text { Nome: } \\
\text { LENISE LIMA RABELO }\end{array}$ & $\begin{array}{l}\text { Sexo: } \\
(x \quad) \text { masculino } \quad(\quad) \text { feminino }\end{array}$ \\
\hline $\begin{array}{l}\text { Instituição (nome e tipo de instituição: ONG, } \\
\text { Empresa Pública, etc.): } \\
\text { INCAPER (AUTARQUIA ESTADUAL DO ESTADO } \\
\text { DO ESPÍRITO SANTO) }\end{array}$ & $\begin{array}{l}\text { Local de trabalho (Cidade e Estado): } \\
\text { ÁGUIA BRANCA - ES }\end{array}$ \\
\hline \multicolumn{2}{|c|}{$\begin{array}{l}\text { Curso/Encontro/Oficina do qual participou (caso tenha participado de mais de um curso, preencha } \\
\text { um formulário para cada um deles): } \\
\text { Oficina de Nivelamento Conceitual de } 2004 \text { - Região Sudeste - Vitória - ES (na época, } \\
\text { selecionada pela FETAG/RJ). }\end{array}$} \\
\hline $\begin{array}{l}\text { Data do Curso/Encontro/Oficina (pelo menos mês e } \\
\text { 22/10/2004 }\end{array}$ & \\
\hline
\end{tabular}

Indique sua área de atuação? (As opções não são excludentes: você poderá marcar mais de uma opção).

\begin{tabular}{|l|l}
\hline$X$ & EXTENSÃO RURAL \\
\hline
\end{tabular} 


\begin{tabular}{|l|l|}
\hline & PESQUISA \\
\hline & ENSINO \\
\hline & OUTROS \\
\hline
\end{tabular}

2) Qual o seu nível de escolaridade? (Considere apenas o nível mais alto)

\begin{tabular}{|l|l|}
\hline & NÍVEL MÉDIO \\
\hline & NÍVEL SUPERIOR \\
\hline$X$ & PÓS-GRADUAÇÃO \\
\hline
\end{tabular}

3) Os conteúdos abordados foram condizentes com as demandas do seu dia-a-dia?

\begin{tabular}{|l|l|}
\hline$X$ & SIM \\
\hline & PARCIALMENTE \\
\hline & NÃO \\
\hline
\end{tabular}

4) O curso contribuiu para o seu aperfeiçoamento profissional?

\begin{tabular}{|l|l|}
\hline$X$ & SIM \\
\hline & NÃO \\
\hline
\end{tabular}

5) Os conhecimentos adquiridos estão sendo aplicados no seu trabalho? Em caso afirmativo, indique em que grau estes conhecimentos estão sendo aplicados. Em caso negativo, indique por que razão isto não ocorre: (As respostas não são excludentes: você poderá marcar mais de uma opção).

\begin{tabular}{|l|l|l|l|}
\hline$X$ & $\begin{array}{l}\text { SIM (indique ao lado em } \\
\text { que grau) }\end{array}$ & X & MUITO APLICADOS \\
\cline { 2 - 4 } & & MEDIAMENTE APLICADOS \\
\hline
\end{tabular}




\begin{tabular}{|c|c|}
\hline & POUCO APLICADOS \\
\hline \multirow{5}{*}{$\begin{array}{l}\text { NÃO (indique ao lado a } \\
\text { razão da não aplicação) }\end{array}$} & $\begin{array}{l}\text { CONTEÚDO NÃO ADEQUADO ÀS NECESSIDADES } \\
\text { ESPECÍFICAS DA REGIÃO }\end{array}$ \\
\hline & $\begin{array}{l}\text { CONTEÚDO NÃO } \\
\text { APROFUNDADO PARA }\end{array}$ \\
\hline & $\begin{array}{|lllllll|}\text { FALTA } & \text { DE } & \text { APOIO } & \text { E } & \text { INCENTIVO } & \text { DA } & \text { MINHA } \\
\text { INSTITUIÇÃO } & & & & \\
\end{array}$ \\
\hline & FALTA DE INCENTIVO ÀS AÇÕES DE ATER \\
\hline & NÃO TENHO INTERESSE EM APLICAR \\
\hline
\end{tabular}

6) A partir deste curso: (As opções não são excludentes: você poderá marcar mais de uma opção).

\begin{tabular}{|l|l|}
\hline & NÃO MUDOU NADA EM MEU TRABALHO. \\
\hline$X$ & $\begin{array}{l}\text { MEU TRABALHO PASSOU A CONTRIBUIR MAIS COM OS AGRICULTORES(AS) } \\
\text { FAMILIARES. }\end{array}$ \\
\hline$X$ & CONSEGUI INFLUENCIAR NAS ORIENTAÇÕES DA MINHA INSTITUIÇÃO. \\
\hline & $\begin{array}{l}\text { CASSEI A TRABALHAR COM METODOLOGIAS PARTICIPATIVAS. } \\
\text { ONDE ATUO. }\end{array}$ \\
\hline$X$ & CONTINUEI ME APERFEIÇOANDO SOBRE TEMAS ABORDADOS. \\
\hline
\end{tabular}

7) Depois do curso você apoiou atividades de capacitação de técnicos e agricultores com base nos princípios e diretrizes da Pnater? (Considere como apoio a atividades de capacitação a participação no planejamento, elaboração de ementas, seleção de participantes e de palestrantes.)

\begin{tabular}{|l|l|}
\hline$X$ & SIM \\
\hline & NÃO \\
\hline
\end{tabular}


8) Usou os conhecimentos para ministrar outros cursos com o mesmo conteúdo ou conteúdos semelhantes?

\begin{tabular}{|l|l|}
\hline$X$ & SIM \\
\hline & NÃO \\
\hline
\end{tabular}

9) Marque o seu grau de satisfação com relação ao curso oferecido pelo DATER: (Considere a seguinte pontuação: 1 - MUITO RUIM; 2 - RUIM; 3 - REGULAR; 4 - BOM; 5 - MUITO BOM)

\begin{tabular}{|l|l|l|l|l|}
\hline 1 & 2 & 3 & 4 & $5 \times$ \\
\hline
\end{tabular}

10) Marque seu grau de satisfação com relação ao DATER: (Considere a seguinte pontuação: 1 - MUITO RUIM; 2 - RUIM; 3 - REGULAR; 4 - BOM; 5 - MUITO BOM)

\begin{tabular}{|l|l|l|l|l|}
\hline 1 & 2 & 3 & 4 & $5 \times$ \\
\hline
\end{tabular}


PESQUISA - IMPACTO DAS AÇÕES DE FORMAÇÃO REALIZADAS PELO DATER/SAF/MDA NO PERÍODO 2004-2009

Caros colaboradores,

Contamos com a sua atenção para preencher o formulário abaixo.

O mesmo tem por objetivo fornecer informações para avaliação da Eficiência, Efetividade e Eficácia da Política Pública de Formação de Agentes de Ater adotada pelo Departamento de Assistência Técnica e Extensão Rural, da Secretaria de Agricultura Familiar do Ministério do Desenvolvimento - DATER/SAF/MDA, no período de 2004 a 2009, tema escolhido para Monografia a ser apresentada à Universidade de Brasília (UnB) como requisito parcial para obtenção do grau de Bacharel em Administração.

Você poderá ou não se identificar no questionário e garantimos que todas as informações fornecidas serão confidenciais e utilizadas apenas de forma sistematizada.

\section{IDENTIFICAÇÃO}

\begin{tabular}{|c|c|}
\hline $\begin{array}{l}\text { Nome: } \\
\text { LENISE LIMA RABELO }\end{array}$ & $\begin{array}{l}\text { Sexo: } \\
(x \quad) \text { masculino } \quad(\quad) \text { feminino }\end{array}$ \\
\hline $\begin{array}{l}\text { Instituição (nome e tipo de instituição: ONG, } \\
\text { Empresa Pública, etc.): } \\
\text { INCAPER (AUTARQUIA ESTADUAL DO ESTADO } \\
\text { DO ESPÍRITO SANTO) }\end{array}$ & $\begin{array}{l}\text { Local de trabalho (Cidade e Estado): } \\
\text { ÁGUIA BRANCA - ES }\end{array}$ \\
\hline \multicolumn{2}{|c|}{$\begin{array}{l}\text { Curso/Encontro/Oficina do qual participou (caso tenha participado de mais de um curso, preencha } \\
\text { um formulário para cada um deles): } \\
\text { Seminário Estadual sobre a Política Nacional de Assistência Técnica e Extensão Rural - Rio de } \\
\text { Janeiro (na época, selecionada pela FETAG/RJ). }\end{array}$} \\
\hline $\begin{array}{l}\text { Data do Curso/Encontro/Oficina (pelo menos mês } \\
\text { 14/09/2004 }\end{array}$ & \\
\hline
\end{tabular}

Indique sua área de atuação? (As opções não são excludentes: você poderá marcar mais de uma opção).

\begin{tabular}{|l|l}
\hline$X$ & EXTENSÃO RURAL \\
\hline
\end{tabular} 


\begin{tabular}{|l|l|}
\hline & PESQUISA \\
\hline & ENSINO \\
\hline & OUTROS \\
\hline
\end{tabular}

2) Qual o seu nível de escolaridade? (Considere apenas o nível mais alto)

\begin{tabular}{|l|l|}
\hline & NÍVEL MÉDIO \\
\hline & NÍVEL SUPERIOR \\
\hline$X$ & PÓS-GRADUAÇÃO \\
\hline
\end{tabular}

3) Os conteúdos abordados foram condizentes com as demandas do seu dia-a-dia?

\begin{tabular}{|l|l|}
\hline$X$ & SIM \\
\hline & PARCIALMENTE \\
\hline & NÃO \\
\hline
\end{tabular}

4) O curso contribuiu para o seu aperfeiçoamento profissional?

\begin{tabular}{|l|l|}
\hline$X$ & SIM \\
\hline & NÃO \\
\hline
\end{tabular}

5) Os conhecimentos adquiridos estão sendo aplicados no seu trabalho? Em caso afirmativo, indique em que grau estes conhecimentos estão sendo aplicados. Em caso negativo, indique por que razão isto não ocorre: (As respostas não são excludentes: você poderá marcar mais de uma opção).

\begin{tabular}{|l|l|l|l|}
\hline$X$ & $\begin{array}{l}\text { SIM (indique ao lado em } \\
\text { que grau) }\end{array}$ & X & MUITO APLICADOS \\
\cline { 2 - 4 } & & MEDIAMENTE APLICADOS \\
\hline
\end{tabular}




\begin{tabular}{|c|c|}
\hline & POUCO APLICADOS \\
\hline \multirow{5}{*}{$\begin{array}{l}\text { NÃO (indique ao lado a } \\
\text { razão da não aplicação) }\end{array}$} & $\begin{array}{l}\text { CONTEÚDO NÃO ADEQUADO ÀS NECESSIDADES } \\
\text { ESPECÍFICAS DA REGIÃO }\end{array}$ \\
\hline & \begin{tabular}{lccr|} 
CONTEÚDO & NÃO & FOI & SUFICIENTEMENTE \\
APROFUNDADO PARA & PERMITIR UMA APLICAÇÃO \\
EFICAZ E EFICIENTE &
\end{tabular} \\
\hline & 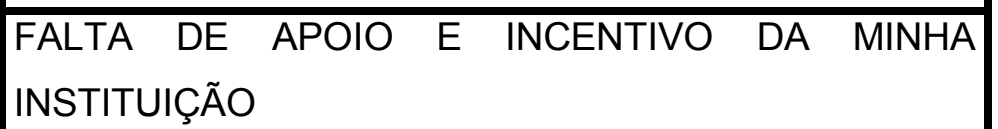 \\
\hline & FALTA DE INCENTIVO ÀS AÇÕES DE ATER \\
\hline & NÃO TENHO INTERESSE EM APLICAR \\
\hline
\end{tabular}

6) A partir deste curso: (As opções não são excludentes: você poderá marcar mais de uma opção).

\begin{tabular}{|l|l|}
\hline & NÃO MUDOU NADA EM MEU TRABALHO. \\
\hline$X$ & $\begin{array}{l}\text { MEU TRABALHO PASSOU A CONTRIBUIR MAIS COM OS AGRICULTORES(AS) } \\
\text { FAMILIARES. }\end{array}$ \\
\hline$X$ & CONSEGUI INFLUENCIAR NAS ORIENTAÇÕES DA MINHA INSTITUIÇÃO. \\
\hline & PASSEI A TRABALHAR COM METODOLOGIAS PARTICIPATIVAS. \\
\hline & $\begin{array}{l}\text { CRESCEU A ÁREA DE AGRICULTURA DE BASE ECOLÓGICA NAS COMUNIDADES } \\
\text { ONDE ATUO. }\end{array}$ \\
\hline$X$ & CONTINUEI ME APERFEIÇOANDO SOBRE TEMAS ABORDADOS. \\
\hline
\end{tabular}

7) Depois do curso você apoiou atividades de capacitação de técnicos e agricultores com base nos princípios e diretrizes da Pnater? (Considere como apoio a atividades de capacitação a participação no planejamento, elaboração de ementas, seleção de participantes e de palestrantes.)

\begin{tabular}{|l|l|}
\hline$X$ & SIM \\
\hline & NÃO \\
\hline
\end{tabular}


8) Usou os conhecimentos para ministrar outros cursos com o mesmo conteúdo ou conteúdos semelhantes?

\begin{tabular}{|l|l|}
\hline$X$ & SIM \\
\hline & NÃO \\
\hline
\end{tabular}

9) Marque o seu grau de satisfação com relação ao curso oferecido pelo DATER: (Considere a seguinte pontuação: 1 - MUITO RUIM; 2 - RUIM; 3 - REGULAR; 4 - BOM; 5 - MUITO BOM)

\begin{tabular}{|l|l|l|l|l|}
\hline 1 & 2 & 3 & 4 & $5 \times$ \\
\hline
\end{tabular}

10) Marque seu grau de satisfação com relação ao DATER: (Considere a seguinte pontuação: 1 - MUITO RUIM; 2 - RUIM; 3 - REGULAR; 4 - BOM; 5 - MUITO BOM)

\begin{tabular}{|l|l|l|l|l|}
\hline 1 & 2 & 3 & 4 & $5 \times$ \\
\hline
\end{tabular}


PESQUISA - IMPACTO DAS AÇÕES DE FORMAÇÃO REALIZADAS PELO DATER/SAF/MDA NO PERÍODO 2004-2009

Caros colaboradores,

Contamos com a sua atenção para preencher o formulário abaixo.

O mesmo tem por objetivo fornecer informações para avaliação da Eficiência, Efetividade e Eficácia da Política Pública de Formação de Agentes de Ater adotada pelo Departamento de Assistência Técnica e Extensão Rural, da Secretaria de Agricultura Familiar do Ministério do Desenvolvimento - DATER/SAF/MDA, no período de 2004 a 2009, tema escolhido para Monografia a ser apresentada à Universidade de Brasília (UnB) como requisito parcial para obtenção do grau de Bacharel em Administração.

Você poderá ou não se identificar no questionário e garantimos que todas as informações fornecidas serão confidenciais e utilizadas apenas de forma sistematizada.

\section{IDENTIFICAÇÃO}

\begin{tabular}{|c|c|}
\hline $\begin{array}{l}\text { Nome: } \\
\text { José Onofre Pereira }\end{array}$ & $\begin{array}{l}\text { Sexo: } \\
(x \quad) \text { masculino } \quad(\quad) \text { feminino }\end{array}$ \\
\hline $\begin{array}{l}\text { Instituição (nome e tipo de instituição: ONG, } \\
\text { Empresa Pública, etc.): } \\
\text { INCAPER }\end{array}$ & $\begin{array}{l}\text { Local de trabalho (Cidade e Estado): } \\
\text { Marechal Floriano ES }\end{array}$ \\
\hline \multicolumn{2}{|c|}{$\begin{array}{l}\text { Curso/Encontro/Oficina do qual participou (caso tenha participado de mais de um curso, preencha } \\
\text { um formulário para cada um deles): } \\
\text { Atualização em Agricultura Familiar e Territorialidade }\end{array}$} \\
\hline $\begin{array}{l}\text { Data do Curso/Encontro/Oficina (pelo menos mês } \\
\text { Junho/2004 }\end{array}$ & \\
\hline
\end{tabular}

Indique sua área de atuação? (As opções não são excludentes: você poderá marcar mais de uma opção).

\begin{tabular}{|l|l|}
\hline$x$ & EXTENSÃO RURAL \\
\hline & PESQUISA \\
\hline & ENSINO \\
\hline
\end{tabular}




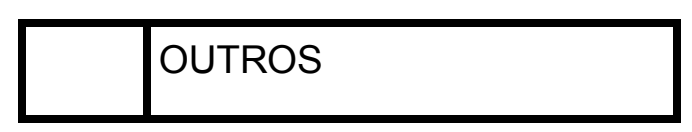

2) Qual o seu nível de escolaridade? (Considere apenas o nível mais alto)

\begin{tabular}{|l|l|}
\hline & NÍVEL MÉDIO \\
\hline$X$ & NÍVEL SUPERIOR \\
\hline & PÓS-GRADUAÇÃO \\
\hline
\end{tabular}

3) Os conteúdos abordados foram condizentes com as demandas do seu dia-a-dia?

\begin{tabular}{|l|l|}
\hline$x$ & SIM \\
\hline & PARCIALMENTE \\
\hline & NÃO \\
\hline
\end{tabular}

4) O curso contribuiu para o seu aperfeiçoamento profissional?

\begin{tabular}{|l|l|}
\hline$X$ & SIM \\
\hline & NÃO \\
\hline
\end{tabular}

5) Os conhecimentos adquiridos estão sendo aplicados no seu trabalho? Em caso afirmativo, indique em que grau estes conhecimentos estão sendo aplicados. Em caso negativo, indique por que razão isto não ocorre: (As respostas não são excludentes: você poderá marcar mais de uma opção).

\begin{tabular}{|l|l|l|l|}
\hline X & $\begin{array}{l}\text { SIM (indique ao lado em } \\
\text { que grau) }\end{array}$ & $X$ & MUITO APLICADOS \\
\cline { 2 - 4 } & $\begin{array}{l}\text { NÃO (indique ao lado a } \\
\text { razão da não aplicação) }\end{array}$ & & $\begin{array}{l}\text { MEDIAMENTE APLICADOS } \\
\text { ESPECÍFICAS DA REGIÃO }\end{array}$ \\
\hline
\end{tabular}




\begin{tabular}{|l|l|l|}
\hline \multirow{10}{*}{} & $\begin{array}{l}\text { CONTEÚDO NÃO FOI SUFICIENTEMENTE } \\
\text { APROFUNDADO PARA PERMITIR UMA APLICAÇÃO } \\
\text { EFICAZ E EFICIENTE }\end{array}$ \\
\cline { 2 - 4 } & $\begin{array}{l}\text { FALTA DE APOIO E INCENTIVO DA MINHA } \\
\text { INSTITUIÇÃO }\end{array}$ \\
\cline { 2 - 4 } & FALTA DE INCENTIVO ÀS AÇÕES DE ATER \\
\hline & NÃO TENHO INTERESSE EM APLICAR \\
\hline
\end{tabular}

6) A partir deste curso: (As opções não são excludentes: você poderá marcar mais de uma opção).

\begin{tabular}{|l|l|}
\hline$x$ & $\begin{array}{l}\text { NÃO MUDOU NADA EM MEU TRABALHO. } \\
\text { FAMILIARES. }\end{array}$ \\
\hline & CONSEGUI INFLUENCIAR NAS ORIENTAÇÕES DA MINHA INSTITUIÇÃO. \\
\hline & PASSEI A TRABALHAR COM METODOLOGIAS PARTICIPATIVAS. \\
\hline & $\begin{array}{l}\text { ORESCEU A ÁREA DE AGRICULTURA DE BASE ECOLÓGICA NAS COMUNIDADES } \\
\text { ONDE ATUO. }\end{array}$ \\
\hline &
\end{tabular}

7) Depois do curso você apoiou atividades de capacitação de técnicos e agricultores com base nos princípios e diretrizes da Pnater? (Considere como apoio a atividades de capacitação a participação no planejamento, elaboração de ementas, seleção de participantes e de palestrantes.)

\begin{tabular}{|l|l|}
\hline$X$ & SIM \\
\hline & NÃO \\
\hline
\end{tabular}

8) Usou os conhecimentos para ministrar outros cursos com o mesmo conteúdo ou conteúdos semelhantes? 


\begin{tabular}{|l|l|}
\hline$X$ & SIM \\
\hline & NÃO \\
\hline
\end{tabular}

9) Marque o seu grau de satisfação com relação ao curso oferecido pelo DATER: (Considere a seguinte pontuação: 1 - MUITO RUIM; 2 - RUIM; 3 - REGULAR; 4 - BOM; 5 - MUITO BOM)

\begin{tabular}{|l|l|l|l|l|}
\hline 1 & 2 & 3 & 4 & $x$ \\
\hline
\end{tabular}

10) Marque seu grau de satisfação com relação ao DATER: (Considere a seguinte pontuação: 1 - MUITO RUIM; 2 - RUIM; 3 - REGULAR; 4 - BOM; 5 - MUITO BOM)

\begin{tabular}{|l|l|l|l|l|}
\hline 1 & 2 & 3 & 4 & $x$ \\
\hline
\end{tabular}


PESQUISA - IMPACTO DAS AÇÕES DE FORMAÇÃO REALIZADAS PELO DATER/SAF/MDA NO PERÍODO 2004-2009

Caros colaboradores,

Contamos com a sua atenção para preencher o formulário abaixo.

O mesmo tem por objetivo fornecer informações para avaliação da Eficiência, Efetividade e Eficácia da Política Pública de Formação de Agentes de Ater adotada pelo Departamento de Assistência Técnica e Extensão Rural, da Secretaria de Agricultura Familiar do Ministério do Desenvolvimento - DATER/SAF/MDA, no período de 2004 a 2009, tema escolhido para Monografia a ser apresentada à Universidade de Brasília (UnB) como requisito parcial para obtenção do grau de Bacharel em Administração.

Você poderá ou não se identificar no questionário e garantimos que todas as informações fornecidas serão confidenciais e utilizadas apenas de forma sistematizada.

IDENTIFICAÇÃO

\begin{tabular}{|c|c|}
\hline $\begin{array}{l}\text { Nome: } \\
\text { José Alejandro Garcia Prado }\end{array}$ & $\begin{array}{l}\text { Sexo: } \\
(x \quad) \text { masculino }\end{array}$ \\
\hline $\begin{array}{l}\text { Instituição (nome e tipo de instituição: ONG, } \\
\text { Empresa Pública, etc.): } \\
\text { Incaper-Instituição Pública de Pesquisa e ATER }\end{array}$ & $\begin{array}{l}\text { Local de trabalho (Cidade e Estado): } \\
\text { São Mateus/E.S. }\end{array}$ \\
\hline \multicolumn{2}{|c|}{$\begin{array}{l}\text { Curso/Encontro/Oficina do qual participou (caso tenha participado de mais de um curso, preencha } \\
\text { um formulário para cada um deles): } \\
\text { Metodologias Participativas }\end{array}$} \\
\hline $\begin{array}{l}\text { Data do Curso/Encontro/Oficina (pelo menos mês e } \\
02 / 07\end{array}$ & \\
\hline
\end{tabular}

Indique sua área de atuação? (As opções não são excludentes: você poderá marcar mais de uma opção).

\begin{tabular}{|l|l|}
\hline$x$ & EXTENSÃO RURAL \\
\hline$x$ & PESQUISA \\
\hline & ENSINO \\
\hline & OUTROS \\
\hline
\end{tabular}


2) Qual o seu nível de escolaridade? (Considere apenas o nível mais alto)

\begin{tabular}{|l|l|}
\hline & NÍVEL MÉDIO \\
\hline & NÍVEL SUPERIOR \\
\hline$x$ & PÓS-GRADUAÇÃO \\
\hline
\end{tabular}

3) Os conteúdos abordados foram condizentes com as demandas do seu dia-a-dia?

\begin{tabular}{|l|l|}
\hline$x$ & SIM \\
\hline & PARCIALMENTE \\
\hline & NÃO \\
\hline
\end{tabular}

4) O curso contribuiu para o seu aperfeiçoamento profissional?

\begin{tabular}{|l|l|}
\hline$x$ & SIM \\
\hline & NÃO \\
\hline
\end{tabular}

5) Os conhecimentos adquiridos estão sendo aplicados no seu trabalho? Em caso afirmativo, indique em que grau estes conhecimentos estão sendo aplicados. Em caso negativo, indique por que razão isto não ocorre: (As respostas não são excludentes: você poderá marcar mais de uma opção).

\begin{tabular}{|c|c|c|}
\hline \multirow{3}{*}{$\begin{array}{l}\text { SIM (indique ao lado em } \\
\text { que grau) }\end{array}$} & & MUITO APLICADOS \\
\hline & $\mathrm{x}$ & MEDIAMENTE APLICADOS \\
\hline & & POUCO APLICADOS \\
\hline $\begin{array}{l}\text { NÃO (indique ao lado a } \\
\text { razão da não aplicação) }\end{array}$ & & $\begin{array}{l}\text { CONTEÚDO NÃO ADEQUADO ȦS NECESSIDADES } \\
\text { ESPECÍFICAS DA REGIÃO }\end{array}$ \\
\hline
\end{tabular}




\begin{tabular}{|l|l|l|}
\hline \multirow{10}{*}{} & $\begin{array}{l}\text { CONTEÚDO NÃO FOI SUFICIENTEMENTE } \\
\text { APROFUNDADO PARA PERMITIR UMA APLICAÇÃO } \\
\text { EFICAZ E EFICIENTE }\end{array}$ \\
\cline { 2 - 4 } & $\begin{array}{l}\text { FALTA DE APOIO E INCENTIVO DA MINHA } \\
\text { INSTITUIÇÃO }\end{array}$ \\
\cline { 2 - 4 } & FALTA DE INCENTIVO ÀS AÇÕES DE ATER \\
\hline & NÃO TENHO INTERESSE EM APLICAR \\
\hline
\end{tabular}

6) A partir deste curso: (As opções não são excludentes: você poderá marcar mais de uma opção).

\begin{tabular}{|l|l|}
\hline$x$ & $\begin{array}{l}\text { NÃO MUDOU NADA EM MEU TRABALHO. } \\
\text { FAMILIARES. }\end{array}$ \\
\hline & CONSEGUI INFLUENCIAR NAS ORIENTAÇÕES DA MINHA INSTITUIÇÃO. \\
\hline & PASSEI A TRABALHAR COM METODOLOGIAS PARTICIPATIVAS. \\
\hline & $\begin{array}{l}\text { ORESCEU A ÁREA DE AGRICULTURA DE BASE ECOLÓGICA NAS COMUNIDADES } \\
\text { CONTINUEI ME APERFEIÇOANDO SOBRE TEMAS ABORDADOS. }\end{array}$ \\
\hline
\end{tabular}

7) Depois do curso você apoiou atividades de capacitação de técnicos e agricultores com base nos princípios e diretrizes da Pnater? (Considere como apoio a atividades de capacitação a participação no planejamento, elaboração de ementas, seleção de participantes e de palestrantes.)

\begin{tabular}{|l|l|}
\hline$X$ & SIM \\
\hline & NÃO \\
\hline
\end{tabular}

8) Usou os conhecimentos para ministrar outros cursos com o mesmo conteúdo ou conteúdos semelhantes? 


\begin{tabular}{|l|l|}
\hline & SIM \\
\hline$X$ & NÃO \\
\hline
\end{tabular}

9) Marque o seu grau de satisfação com relação ao curso oferecido pelo DATER: (Considere a seguinte pontuação: 1 - MUITO RUIM; 2 - RUIM; 3 - REGULAR; 4 - BOM; 5 - MUITO BOM)

\begin{tabular}{|l|l|l|l|l|}
\hline 1 & 2 & 3 & $4 \times$ & 5 \\
\hline
\end{tabular}

10) Marque seu grau de satisfação com relação ao DATER: (Considere a seguinte pontuação: 1 - MUITO RUIM; 2 - RUIM; 3 - REGULAR; 4 - BOM; 5 - MUITO BOM)

\begin{tabular}{|l|l|l|l|l|}
\hline 1 & 2 & 3 & $4 \times$ & 5 \\
\hline
\end{tabular}


PESQUISA - IMPACTO DAS AÇÕES DE FORMAÇÃO REALIZADAS PELO DATER/SAF/MDA NO PERÍODO 2004-2009

Caros colaboradores,

Contamos com a sua atenção para preencher o formulário abaixo.

O mesmo tem por objetivo fornecer informações para avaliação da Eficiência, Efetividade e Eficácia da Política Pública de Formação de Agentes de Ater adotada pelo Departamento de Assistência Técnica e Extensão Rural, da Secretaria de Agricultura Familiar do Ministério do Desenvolvimento - DATER/SAF/MDA, no período de 2004 a 2009, tema escolhido para Monografia a ser apresentada à Universidade de Brasília (UnB) como requisito parcial para obtenção do grau de Bacharel em Administração.

Você poderá ou não se identificar no questionário e garantimos que todas as informações fornecidas serão confidenciais e utilizadas apenas de forma sistematizada.

IDENTIFICAÇÃO

\begin{tabular}{|l|l|}
\hline Nome: JORGE LUIZ DE BARROS & $\begin{array}{l}\text { Sexo: } \\
(\mathrm{x}) \text { masculino } \quad(\quad) \text { feminino }\end{array}$ \\
\hline \multicolumn{1}{|c|}{ EMATER-RIO } & $\begin{array}{l}\text { Local de trabalho } \\
\text { ARARUAMA - RJ }\end{array}$ \\
\hline $\begin{array}{l}\text { Curso/Encontro/Oficina do qual participou : } \\
\text { CURSO DE APERFEIÇOAMENTO EM AGROECOLOGIA - À DISTÂNCIA. } \\
\text { CURSO DE ATER PESQUEIRA - FLORIANÓPOLIS - SC }\end{array}$ \\
\hline $\begin{array}{l}\text { Data do CurSo/Encontro/Oficina } \\
\text { CURSO DE ATER PESQUEIRA - AGOSTO / 2008 }\end{array}$ \\
\hline
\end{tabular}

Indique sua área de atuação? (As opções não são excludentes: você poderá marcar mais de uma opção).

\begin{tabular}{|l|l|}
\hline$X$ & EXTENSÃO RURAL \\
\hline & PESQUISA \\
\hline & ENSINO \\
\hline & OUTROS \\
\hline
\end{tabular}


2) Qual o seu nível de escolaridade? (Considere apenas o nível mais alto)

\begin{tabular}{|c|l|}
\hline & NÍVEL MÉDIO \\
\hline & NÍVEL SUPERIOR \\
\hline$X$ & PÓS-GRADUAÇÃO \\
\hline
\end{tabular}

3) Os conteúdos abordados foram condizentes com as demandas do seu dia-a-dia?

\begin{tabular}{|l|l|}
\hline$X$ & SIM \\
\hline & PARCIALMENTE \\
\hline & NÃO \\
\hline
\end{tabular}

4) O curso contribuiu para o seu aperfeiçoamento profissional?

\begin{tabular}{|l|l|}
\hline$X$ & SIM \\
\hline & NÃO \\
\hline
\end{tabular}

5) Os conhecimentos adquiridos estão sendo aplicados no seu trabalho? Em caso afirmativo, indique em que grau estes conhecimentos estão sendo aplicados. Em caso negativo, indique por que razão isto não ocorre: (As respostas não são excludentes: você poderá marcar mais de uma opção).

\begin{tabular}{|c|c|c|}
\hline \multirow{3}{*}{ X } & \multirow{3}{*}{$\begin{array}{l}\text { SIM (indique ao lado em } \\
\text { que grau) }\end{array}$} & MUITO APLICADOS \\
\hline & & MEDIAMENTE APLICADOS \\
\hline & & POUCO APLICADOS \\
\hline & & CONTEÚDO NÃO ADEQUADO ÀS NECESSIDADES \\
\hline & NÃO (indique ao lado a & $\begin{array}{llll}\text { CONTEÜDO NÄO FOI SUFICIENTEMENTE } \\
\text { APROFUNDADO PARA }\end{array}$ \\
\hline & (razão da não aplicação) & $\begin{array}{lcccccc}\text { FALTA } & \text { DE } & \text { APOIO } & \text { E } & \text { INCENTIVO } & \text { DA } & \text { MINHA } \\
\text { INSTITUICÃO } & & & & & \\
\end{array}$ \\
\hline & & FALTA DE INCENTIVO ÀS AÇÕES DE ATER \\
\hline
\end{tabular}




\begin{tabular}{|l|l|l|l|}
\hline & & & NÃO TENHO INTERESSE EM APLICAR \\
\hline
\end{tabular}

6) A partir deste curso: (As opções não são excludentes: você poderá marcar mais de uma opção).

\begin{tabular}{|c|l|}
\hline$x$ & $\begin{array}{l}\text { NẼO MUDOU NADA EM MEU TRABALHO. } \\
\text { FAMILIARES. }\end{array}$ \\
\hline & CONSEGUI INFLUENCIAR NAS ORIENTAÇÕES DA MINHA INSTITUIÇÃO. \\
\hline & PASSEI A TRABALHAR COM METODOLOGIAS PARTICIPATIVAS.(JÁ TRABALHAVA) \\
\hline & $\begin{array}{l}\text { CRESCEU A ÁREA DE AGRICULTURA DE BASE ECOLÓGICA NAS COMUNIDADES } \\
\mathrm{X}\end{array}$ \\
\hline
\end{tabular}

7) Depois do curso você apoiou atividades de capacitação de técnicos e agricultores com base nos princípios e diretrizes da Pnater? (Considere como apoio a atividades de capacitação a participação no planejamento, elaboração de ementas, seleção de participantes e de palestrantes.)

\begin{tabular}{|l|l|}
\hline & SIM \\
\hline$X$ & NÃO \\
\hline
\end{tabular}

8) Usou os conhecimentos para ministrar outros cursos com o mesmo conteúdo ou conteúdos semelhantes?

\begin{tabular}{|l|l|}
\hline & SIM \\
\hline$X$ & NÃO \\
\hline
\end{tabular}

9) Marque o seu grau de satisfação com relação ao curso oferecido pelo DATER: (Considere a seguinte pontuação: 1 - MUITO RUIM; 2 - RUIM; 3 - REGULAR; 4 - BOM; 5 - MUITO BOM) 


\begin{tabular}{|l|l|l|l|l|}
\hline 1 & 2 & 3 & $X X X 4 X X X$ & 5 \\
\hline
\end{tabular}

10) Marque seu grau de satisfação com relação ao DATER: (Considere a seguinte pontuação: 1 - MUITO RUIM; 2 - RUIM; 3 - REGULAR; 4 - BOM; 5 - MUITO BOM)

\begin{tabular}{|l|l|l|l|l|}
\hline 1 & 2 & 3 & 4 & XXX5XXX \\
\hline
\end{tabular}


PESQUISA - IMPACTO DAS AÇÕES DE FORMAÇÃO REALIZADAS PELO DATER/SAF/MDA NO PERÍODO 2004-2009

Caros colaboradores,

Contamos com a sua atenção para preencher o formulário abaixo.

O mesmo tem por objetivo fornecer informações para avaliação da Eficiência, Efetividade e Eficácia da Política Pública de Formação de Agentes de Ater adotada pelo Departamento de Assistência Técnica e Extensão Rural, da Secretaria de Agricultura Familiar do Ministério do Desenvolvimento - DATER/SAF/MDA, no período de 2004 a 2009, tema escolhido para Monografia a ser apresentada à Universidade de Brasília (UnB) como requisito parcial para obtenção do grau de Bacharel em Administração.

Você poderá ou não se identificar no questionário e garantimos que todas as informações fornecidas serão confidenciais e utilizadas apenas de forma sistematizada.

\section{IDENTIFICAÇÃO}

\begin{tabular}{|l|l|}
\hline Nome: Ivanildo Schmith Kuster & $\begin{array}{l}\text { Sexo: } \\
(x) \text { masculino } \quad(\quad \text { ) feminino }\end{array}$ \\
\hline $\begin{array}{l}\text { Instituição: INCAPER ( Instituto Capixaba de } \\
\text { Pesquisa, Assistência Técnica e Extensão Rural) }\end{array}$ & Local de trabalho: Nova Venécia - ES \\
\hline $\begin{array}{l}\text { Curso/Encontro/Oficina do qual participou: Oficina de Socialização dos Conceitos Básicos da } \\
\text { Política Nacional de ATER }\end{array}$ \\
\hline Data do Curso/Encontro/Oficina: 08/05/2006 à 12/08/2006 \\
\hline
\end{tabular}

Indique sua área de atuação? (As opções não são excludentes: você poderá marcar mais de uma opção).

\begin{tabular}{|l|l|}
\hline$x$ & EXTENSÃO RURAL \\
\hline & PESQUISA \\
\hline & ENSINO \\
\hline & OUTROS \\
\hline
\end{tabular}


2) Qual o seu nível de escolaridade? (Considere apenas o nível mais alto)

\begin{tabular}{|l|l|}
\hline$x$ & NÍVEL MÉDIO \\
\hline & NÍVEL SUPERIOR \\
\hline & PÓS-GRADUAÇÃO \\
\hline
\end{tabular}

3) Os conteúdos abordados foram condizentes com as demandas do seu dia-a-dia?

\begin{tabular}{|l|l|}
\hline$x$ & SIM \\
\hline & PARCIALMENTE \\
\hline & NÃO \\
\hline
\end{tabular}

4) O curso contribuiu para o seu aperfeiçoamento profissional?

\begin{tabular}{|l|l|}
\hline$x$ & SIM \\
\hline & NÃO \\
\hline
\end{tabular}

5) Os conhecimentos adquiridos estão sendo aplicados no seu trabalho? Em caso afirmativo, indique em que grau estes conhecimentos estão sendo aplicados. Em caso negativo, indique por que razão isto não ocorre: (As respostas não são excludentes: você poderá marcar mais de uma opção).

\begin{tabular}{|l|l|l|l|}
\hline \multirow{2}{*}{$\times$} & $\begin{array}{l}\text { SIM (indique ao lado em } \\
\text { que grau) }\end{array}$ & $\mathrm{x}$ & MUITO APLICADOS \\
\cline { 2 - 4 } & $\begin{array}{l}\text { NÃO (indique ao lado a } \\
\text { razão da não aplicação) }\end{array}$ & $\begin{array}{l}\text { CONTEÚDO NÃO ADEQUADO ȦS NECESSIDADES } \\
\text { ESPECÍFICAS DA REGIÃO }\end{array}$ \\
\hline
\end{tabular}




\begin{tabular}{|l|l|l|}
\hline \multirow{10}{*}{} & $\begin{array}{l}\text { CONTEÚDO NÃO FOI SUFICIENTEMENTE } \\
\text { APROFUNDADO PARA PERMITIR UMA APLICAÇÃO } \\
\text { EFICAZ E EFICIENTE }\end{array}$ \\
\cline { 2 - 4 } & $\begin{array}{l}\text { FALTA DE APOIO E INCENTIVO DA MINHA } \\
\text { INSTITUIÇÃO }\end{array}$ \\
\cline { 2 - 4 } & FALTA DE INCENTIVO ÀS AÇÕES DE ATER \\
\hline & NÃO TENHO INTERESSE EM APLICAR \\
\hline
\end{tabular}

6) A partir deste curso: (As opções não são excludentes: você poderá marcar mais de uma opção).

\begin{tabular}{|l|l|}
\hline & NÃO MUDOU NADA EM MEU TRABALHO. \\
\hline & $\begin{array}{l}\text { MEU TRABALHO PASSOU A CONTRIBUIR MAIS COM OS AGRICULTORES(AS) } \\
\text { FAMILIARES. }\end{array}$ \\
\hline & CONSEGUI INFLUENCIAR NAS ORIENTAÇÕES DA MINHA INSTITUIÇÃO. \\
\hline & $\begin{array}{l}\text { CRESESE A TRABALHAR COM METODOLOGIAS PARTICIPATIVAS. } \\
\text { ONDE ATUO. ÁREA DE AGRICULTURA DE BASE ECOLÓGICA NAS COMUNIDADES }\end{array}$ \\
\hline$x$ & CONTINUEI ME APERFEIÇOANDO SOBRE TEMAS ABORDADOS. \\
\hline
\end{tabular}

7) Depois do curso você apoiou atividades de capacitação de técnicos e agricultores com base nos princípios e diretrizes da Pnater? (Considere como apoio a atividades de capacitação a participação no planejamento, elaboração de ementas, seleção de participantes e de palestrantes.)

\begin{tabular}{|l|l|}
\hline & SIM \\
\hline$x$ & NÃO \\
\hline
\end{tabular}

8) Usou os conhecimentos para ministrar outros cursos com o mesmo conteúdo ou conteúdos semelhantes? 


\begin{tabular}{|l|l|}
\hline & SIM \\
\hline$x$ & NÃO \\
\hline
\end{tabular}

9) Marque o seu grau de satisfação com relação ao curso oferecido pelo DATER: (Considere a seguinte pontuação: 1 - MUITO RUIM; 2 - RUIM; 3 - REGULAR; 4 - BOM; 5 - MUITO BOM)

\begin{tabular}{|l|l|l|l|l|}
\hline 1 & 2 & 3 & 4 & 5 \\
\hline
\end{tabular}

10) Marque seu grau de satisfação com relação ao DATER: (Considere a seguinte pontuação: 1 - MUITO RUIM; 2 - RUIM; 3 - REGULAR; 4 - BOM; 5 - MUITO BOM)

\begin{tabular}{|l|l|l|l|l|}
\hline 1 & 2 & 3 & 4 & 5 \\
\hline
\end{tabular}


PESQUISA - IMPACTO DAS AÇÕES DE FORMAÇÃO REALIZADAS PELO DATER/SAF/MDA NO PERÍODO 2004-2009

Caros colaboradores,

Contamos com a sua atenção para preencher o formulário abaixo.

O mesmo tem por objetivo fornecer informações para avaliação da Eficiência, Efetividade e Eficácia da Política Pública de Formação de Agentes de Ater adotada pelo Departamento de Assistência Técnica e Extensão Rural, da Secretaria de Agricultura Familiar do Ministério do Desenvolvimento - DATER/SAF/MDA, no período de 2004 a 2009, tema escolhido para Monografia a ser apresentada à Universidade de Brasília (UnB) como requisito parcial para obtenção do grau de Bacharel em Administração.

Você poderá ou não se identificar no questionário e garantimos que todas as informações fornecidas serão confidenciais e utilizadas apenas de forma sistematizada.

\section{IDENTIFICAÇÃO}

\begin{tabular}{|c|c|}
\hline $\begin{array}{l}\text { Nome: (opcional) } \\
\text { GISELE ALVES FERREIRA FARIAS }\end{array}$ & $\begin{array}{l}\text { Sexo: } \\
(\quad) \text { masculino }\end{array}$ \\
\hline $\begin{array}{l}\text { Instituição (nome e tipo de instituição: ONG, } \\
\text { Empresa Pública, Cooperativa,etc.): AGÊNCIA DE } \\
\text { DESENVOLVIMENTO AGRÁRIO E EXTENSÃO } \\
\text { RURAL / AGRAER (EXTINTO IDATERRA/MS) }\end{array}$ & $\begin{array}{l}\text { Local de trabalho (Cidade e Estado): } \\
\text { Campo Grande / MS }\end{array}$ \\
\hline \multicolumn{2}{|c|}{$\begin{array}{l}\text { Curso/Encontro/Oficina do qual participou (caso tenha participado de mais de um evento de } \\
\text { formação, preencha um formulário para cada um deles): Curso para Agentes de Assistência } \\
\text { Técnica e Extensão Rural sobre: "Técnicas para a Aprendizagem e Ação Participativa - DRP". }\end{array}$} \\
\hline $\begin{array}{l}\text { ata do Curso/Encontro/Oficina } \\
\text { ÍCIO DE DEZEMBRO } 2006\end{array}$ & o): \\
\hline
\end{tabular}

1) Indique sua área de atuação? (As opções não são excludentes: você poderá marcar mais de uma opção).

\begin{tabular}{|l|l|}
\hline$X$ & EXTENSÃO RURAL \\
\hline$X$ & PESQUISA \\
\hline & ENSINO \\
\hline & OUTROS \\
\hline
\end{tabular}


2) Qual o seu nível de escolaridade? (Considere apenas o nível mais alto)

\begin{tabular}{|l|l|}
\hline & NÍVEL MÉDIO \\
\hline$x$ & NÍVEL SUPERIOR \\
\hline & PÓS-GRADUAÇÃO \\
\hline
\end{tabular}

3) Os conteúdos abordados na formação foram condizentes com as demandas do seu dia-adia?

\begin{tabular}{|l|l|}
\hline$x$ & SIM \\
\hline & PARCIALMENTE \\
\hline & NÃO \\
\hline
\end{tabular}

4) O curso ou atividade de formação da qual você participou contribuiu para o seu aperfeiçoamento profissional?

\begin{tabular}{|l|l|}
\hline$x$ & SIM \\
\hline & NÃO \\
\hline
\end{tabular}

5) Os conhecimentos adquiridos nesta formação estão sendo aplicados no seu trabalho? Em caso afirmativo, indique em que grau estes conhecimentos estão sendo aplicados. Em caso negativo, indique por que razão isto não ocorre: (Em caso negativo, as respostas não são excludentes: você poderá marcar mais de uma opção).

\begin{tabular}{|c|c|c|c|}
\hline \multirow{3}{*}{$x$} & \multirow{3}{*}{$\begin{array}{l}\text { SIM (indique ao lado } \\
\text { em que grau) }\end{array}$} & & MUITO APLICADOS \\
\hline & & & MEDIAMENTE APLICADOS \\
\hline & & $\mathrm{x}$ & POUCO APLICADOS \\
\hline & \multirow{2}{*}{$\begin{array}{l}\text { NÃO (indique ao lado a } \\
\text { razão da não } \\
\text { aplicação) }\end{array}$} & & $\begin{array}{l}\text { CONTEÚDO NÃO ADEQUADO ÀS NECESSIDADES } \\
\text { ESPECÍFICAS DA REGIÃO }\end{array}$ \\
\hline & & & \begin{tabular}{lccc|} 
CONTEÚDO NÃO & FOI & SUFICIENTEMENTE \\
APROFUNDADO & PARA & PERMITIR & UMA \\
APLICAÇÃO EFICAZ E EFICIENTE &
\end{tabular} \\
\hline
\end{tabular}




\begin{tabular}{|l|l|l|}
\hline \multirow{2}{*}{} & & $\begin{array}{l}\text { FALTA DE APOIO E INCENTIVO DA MINHA } \\
\text { INSTITUIÇÃO }\end{array}$ \\
\hline & FALTA DE INCENTIVO ÀS AÇÕES DE ATER \\
\hline & NÃO TENHO INTERESSE EM APLICAR \\
\hline
\end{tabular}

6) A partir do evento de formação do qual você participou: (As respostas não são excludentes: você poderá marcar mais de uma opção).

\begin{tabular}{|l|l|}
\hline & NÃO MUDOU NADA EM MEU TRABALHO. \\
\hline & $\begin{array}{l}\text { MEU TRABALHO PASSOU A CONTRIBUIR MAIS COM OS AGRICULTORES(AS) } \\
\text { FAMILIARES. }\end{array}$ \\
\hline & CONSEGUI INFLUENCIAR NAS ORIENTAÇÕES DA MINHA INSTITUIÇÃO. \\
\hline $\mathrm{x}$ & PASSEI A TRABALHAR COM METODOLOGIAS PARTICIPATIVAS. \\
\hline & $\begin{array}{l}\text { CRESCEU A ÁREA DE AGRICULTURA DE BASE ECOLÓGICA NAS } \\
\text { COMUNIDADES ONDE ATUO. }\end{array}$ \\
\hline & CONTINUEI ME APERFEIÇOANDO SOBRE TEMAS ABORDADOS. \\
\hline
\end{tabular}

7) Depois do evento de capacitação do qual participou, você apoiou atividades de capacitação de técnicos e/ou agricultores com base nos princípios e diretrizes da Pnater? (Considere como apoio a atividades de capacitação a participação no planejamento, elaboração de ementas, seleção de participantes e de palestrantes.)

\begin{tabular}{|l|l|}
\hline$x$ & SIM \\
\hline & NÃO \\
\hline
\end{tabular}

8) Usou os conhecimentos adquiridos para ministrar outros eventos de formação com o mesmo conteúdo ou conteúdos semelhantes?

\begin{tabular}{|l|l|}
\hline & SIM \\
\hline$x$ & NÃO \\
\hline
\end{tabular}


9) Marque o seu grau de satisfação com relação a atividade de formação oferecida pelo DATER: (Considere a seguinte pontuação: 1 - MUITO RUIM; 2 - RUIM; 3 - REGULAR; 4 BOM; 5 - MUITO BOM)

\begin{tabular}{|l|l|l|l|l|}
\hline 1 & 2 & 3 & $x 4$ & 5 \\
\hline
\end{tabular}

10) Marque seu grau de satisfação com relação ao DATER: (Considere a seguinte pontuação: 1 - MUITO RUIM; 2 - RUIM; 3 - REGULAR; 4 - BOM; 5 - MUITO BOM)

\begin{tabular}{|l|l|l|l|l|}
\hline 1 & 2 & 3 & $x 4$ & 5 \\
\hline
\end{tabular}


PESQUISA - IMPACTO DAS AÇÕES DE FORMAÇÃO REALIZADAS PELO DATER/SAF/MDA NO PERÍODO 2004-2009

Caros colaboradores,

Contamos com a sua atenção para preencher o formulário abaixo.

O mesmo tem por objetivo fornecer informações para avaliação da Eficiência, Efetividade e Eficácia da Política Pública de Formação de Agentes de Ater adotada pelo Departamento de Assistência Técnica e Extensão Rural, da Secretaria de Agricultura Familiar do Ministério do Desenvolvimento - DATER/SAF/MDA, no período de 2004 a 2009, tema escolhido para Monografia a ser apresentada à Universidade de Brasília (UnB) como requisito parcial para obtenção do grau de Bacharel em Administração.

Você poderá ou não se identificar no questionário e garantimos que todas as informações fornecidas serão confidenciais e utilizadas apenas de forma sistematizada.

\section{IDENTIFICAÇÃO}

\begin{tabular}{|l|l|l|}
\hline Nome: (opcional) Mauro Brasil Dias Tofanelli & $\begin{array}{l}\text { Sexo: } \\
(\mathrm{x}) \text { masculino } \quad(\quad \text { ) feminino }\end{array}$ \\
\hline $\begin{array}{l}\text { Instituição (nome e tipo de instituição: ONG, } \\
\text { Empresa Pública, Cooperativa,etc.): Faculdades } \\
\text { Integradas de Mineiros/Fundação Integrada } \\
\text { Municipal de Ensino Superior (Fimes) }\end{array}$ & Local de trabalho (Cidade e Estado): \\
\hline $\begin{array}{l}\text { Curso/Encontro/Oficina do qual participou (caso tenha participado de mais de um evento de } \\
\text { formação, preencha um formulário para cada um deles): Agroecologia - Nível: Aperfeiçoamento }\end{array}$ \\
\hline Data do Curso/Encontro/Oficina/Seminário (pelo menos mês e ano): Maio a junho de 2006. \\
\hline
\end{tabular}

1) Indique sua área de atuação? (As opções não são excludentes: você poderá marcar mais de uma opção).

\begin{tabular}{|l|l|}
\hline & EXTENSÃO RURAL \\
\hline$X$ & PESQUISA \\
\hline$X$ & ENSINO \\
\hline & OUTROS \\
\hline
\end{tabular}


2) Qual o seu nível de escolaridade? (Considere apenas o nível mais alto)

\begin{tabular}{|l|l|}
\hline & NÍVEL MÉDIO \\
\hline & NÍVEL SUPERIOR \\
\hline$x$ & PÓS-GRADUAÇÃO \\
\hline
\end{tabular}

3) Os conteúdos abordados na formação foram condizentes com as demandas do seu dia-adia?

\begin{tabular}{|l|l|}
\hline & SIM \\
\hline$x$ & PARCIALMENTE \\
\hline & NÃO \\
\hline
\end{tabular}

4) O curso ou atividade de formação da qual você participou contribuiu para o seu aperfeiçoamento profissional?

\begin{tabular}{|l|l|}
\hline$x$ & SIM \\
\hline & NÃO \\
\hline
\end{tabular}

5) Os conhecimentos adquiridos nesta formação estão sendo aplicados no seu trabalho? Em caso afirmativo, indique em que grau estes conhecimentos estão sendo aplicados. Em caso negativo, indique por que razão isto não ocorre: (Em caso negativo, as respostas não são excludentes: você poderá marcar mais de uma opção).

\begin{tabular}{|c|c|c|c|}
\hline \multirow{3}{*}{$x$} & \multirow{3}{*}{$\begin{array}{l}\text { SIM (indique ao lado } \\
\text { em que grau) }\end{array}$} & & MUITO APLICADOS \\
\hline & & $x$ & MEDIAMENTE APLICADOS \\
\hline & & & POUCO APLICADOS \\
\hline & \multirow{2}{*}{$\begin{array}{l}\text { NÃO (indique ao lado a } \\
\text { razão da não } \\
\text { aplicação) }\end{array}$} & & $\begin{array}{l}\text { CONTEÚDO NÃO ADEQUADO ȦS NECESSIDADES } \\
\text { ESPECÍFICAS DA REGIÃO }\end{array}$ \\
\hline & & & $\begin{array}{lccc}\text { CONTEÚDO NÃO } & \text { FOI } & \text { SUFICIENTEMENTE } \\
\text { APROFUNDADO } & \text { PARA } & \text { PERMITIR } & \text { UMA } \\
\text { APLICAÇÃO EFICAZ E EFICIENTE } & \end{array}$ \\
\hline
\end{tabular}




\begin{tabular}{|l|l|l|}
\hline \multirow{2}{*}{} & & $\begin{array}{l}\text { FALTA DE APOIO E INCENTIVO DA MINHA } \\
\text { INSTITUIÇÃO }\end{array}$ \\
\hline & & FALTA DE INCENTIVO ÀS AÇÕES DE ATER \\
\hline & NÃO TENHO INTERESSE EM APLICAR \\
\hline
\end{tabular}

6) A partir do evento de formação do qual você participou: (As respostas não são excludentes: você poderá marcar mais de uma opção).

\begin{tabular}{|c|c|}
\hline & NÃO MUDOU NADA EM MEU TRABALHO. \\
\hline & $\begin{array}{l}\text { MEU TRABALHO PASSOU A CONTRIBUIR MAIS COM OS AGRICULTORES(AS) } \\
\text { FAMILIARES. }\end{array}$ \\
\hline$x$ & CONSEGUI INFLUENCIAR NAS ORIENTAÇÕES DA MINHA INSTITUIÇÃO. \\
\hline \multirow[t]{3}{*}{$x$} & PASSEI A TRABALHAR COM METODOLOGIAS PARTICIPATIVAS. \\
\hline & $\begin{array}{l}\text { CRESCEU A ÁREA DE AGRICULTURA DE BASE ECOLÓGICA NAS } \\
\text { COMUNIDADES ONDE ATUO. }\end{array}$ \\
\hline & CONTINUEI ME APERFEIÇOANDO SOBRE TEMAS ABORDADOS. \\
\hline
\end{tabular}

7) Depois do evento de capacitação do qual participou, você apoiou atividades de capacitação de técnicos e/ou agricultores com base nos princípios e diretrizes da Pnater? (Considere como apoio a atividades de capacitação a participação no planejamento, elaboração de ementas, seleção de participantes e de palestrantes.)

\begin{tabular}{|l|l|}
\hline & SIM \\
\hline$x$ & NÃO \\
\hline
\end{tabular}

8) Usou os conhecimentos adquiridos para ministrar outros eventos de formação com o mesmo conteúdo ou conteúdos semelhantes?

\begin{tabular}{|l|l|}
\hline$x$ & SIM \\
\hline & NÃO \\
\hline
\end{tabular}


9) Marque o seu grau de satisfação com relação a atividade de formação oferecida pelo DATER: (Considere a seguinte pontuação: 1 - MUITO RUIM; 2 - RUIM; 3 - REGULAR; 4 BOM; 5 - MUITO BOM)

\begin{tabular}{|l|l|l|l|l|}
\hline 1 & 2 & 3 & $x 4$ & 5 \\
\hline
\end{tabular}

10) Marque seu grau de satisfação com relação ao DATER: (Considere a seguinte pontuação: 1 - MUITO RUIM; 2 - RUIM; 3 - REGULAR; 4 - BOM; 5 - MUITO BOM)

\begin{tabular}{|l|l|l|l|l|}
\hline 1 & 2 & 3 & $x 4$ & 5 \\
\hline
\end{tabular}


PESQUISA - IMPACTO DAS AÇÕES DE FORMAÇÃO REALIZADAS PELO DATER/SAF/MDA NO PERÍODO 2004-2009

Caros colaboradores,

Contamos com a sua atenção para preencher o formulário abaixo.

O mesmo tem por objetivo fornecer informações para avaliação da Eficiência, Efetividade e Eficácia da Política Pública de Formação de Agentes de Ater adotada pelo Departamento de Assistência Técnica e Extensão Rural, da Secretaria de Agricultura Familiar do Ministério do Desenvolvimento - DATER/SAF/MDA, no período de 2004 a 2009, tema escolhido para Monografia a ser apresentada à Universidade de Brasília (UnB) como requisito parcial para obtenção do grau de Bacharel em Administração.

Você poderá ou não se identificar no questionário e garantimos que todas as informações fornecidas serão confidenciais e utilizadas apenas de forma sistematizada.

\section{IDENTIFICAÇÃO}

\begin{tabular}{|c|c|}
\hline $\begin{array}{l}\text { Nome: (opcional) GISELE ALVES FERREIRA } \\
\text { FARIAS }\end{array}$ & $\begin{array}{l}\text { Sexo: } \\
(\quad) \text { masculino }\end{array}$ \\
\hline $\begin{array}{l}\text { Instituição (nome e tipo de instituição: ONG, } \\
\text { Empresa Pública, Cooperativa,etc.): AGÊNCIA DE } \\
\text { DESENVOLVIMENTO AGRÁRIO E EXTENSÃO } \\
\text { RURAL / AGRAER (EXTINTO IDATERRA/MS) }\end{array}$ & $\begin{array}{l}\text { Local de trabalho (Cidade e Estado): Campo } \\
\text { Grande / MS }\end{array}$ \\
\hline \multicolumn{2}{|c|}{$\begin{array}{l}\text { Curso/Encontro/Oficina do qual participou (caso tenha participado de mais de um evento de } \\
\text { formação, preencha um formulário para cada um deles): SAF's Cerrado }\end{array}$} \\
\hline $\begin{array}{l}\text { Data do Curso/Encontro/Oficina/Seminário (pelo m } \\
\text { INÍCIO DE DEZEMBRO } 2006\end{array}$ & nos mês e ano): FINAL DE N( \\
\hline
\end{tabular}

1) Indique sua área de atuação? (As opções não são excludentes: você poderá marcar mais de uma opção).

\begin{tabular}{|l|l|}
\hline$x$ & EXTENSÃO RURAL \\
\hline$x$ & PESQUISA \\
\hline & ENSINO \\
\hline & OUTROS \\
\hline
\end{tabular}


2) Qual o seu nível de escolaridade? (Considere apenas o nível mais alto)

\begin{tabular}{|l|l|}
\hline$x$ & NÍVEL MÉDIO \\
\hline & NÍVEL SUPERIOR \\
\hline & PÓS-GRADUAÇÃO \\
\hline
\end{tabular}

3) Os conteúdos abordados na formação foram condizentes com as demandas do seu dia-adia?

\begin{tabular}{|l|l|}
\hline$x$ & SIM \\
\hline & PARCIALMENTE \\
\hline & NÃO \\
\hline
\end{tabular}

4) O curso ou atividade de formação da qual você participou contribuiu para o seu aperfeiçoamento profissional?

\begin{tabular}{|l|l|}
\hline$x$ & SIM \\
\hline & NÃO \\
\hline
\end{tabular}

5) Os conhecimentos adquiridos nesta formação estão sendo aplicados no seu trabalho? Em caso afirmativo, indique em que grau estes conhecimentos estão sendo aplicados. Em caso negativo, indique por que razão isto não ocorre: (Em caso negativo, as respostas não são excludentes: você poderá marcar mais de uma opção).

\begin{tabular}{|c|c|c|c|}
\hline \multirow{3}{*}{$\mathrm{x}$} & \multirow{3}{*}{$\begin{array}{l}\text { SIM (indique ao lado } \\
\text { em que grau) }\end{array}$} & & MUITO APLICADOS \\
\hline & & & MEDIAMENTE APLICADOS \\
\hline & & $\mathrm{x}$ & POUCO APLICADOS \\
\hline & \multirow{2}{*}{$\begin{array}{l}\text { NÃO (indique ao lado a } \\
\text { razão da não } \\
\text { aplicação) }\end{array}$} & & $\begin{array}{l}\text { CONTEÚDO NÃO ADEQUADO ÀS NECESSIDADES } \\
\text { ESPECÍFICAS DA REGIÃO }\end{array}$ \\
\hline & & & \begin{tabular}{lccc|} 
CONTEÚDO NÃO & FOI & SUFICIENTEMENTE \\
APROFUNDADO & PARA & PERMITIR & UMA \\
APLICAÇÃO EFICAZ E EFICIENTE &
\end{tabular} \\
\hline
\end{tabular}




\begin{tabular}{|l|l|l|}
\hline \multirow{2}{*}{} & & $\begin{array}{l}\text { FALTA DE APOIO E INCENTIVO DA MINHA } \\
\text { INSTITUIÇÃO }\end{array}$ \\
\hline & FALTA DE INCENTIVO ÀS AÇÕES DE ATER \\
\hline & NÃO TENHO INTERESSE EM APLICAR \\
\hline
\end{tabular}

6) A partir do evento de formação do qual você participou: (As respostas não são excludentes: você poderá marcar mais de uma opção).

\begin{tabular}{|c|c|}
\hline & NÃO MUDOU NADA EM MEU TRABALHO. \\
\hline & $\begin{array}{l}\text { MEU TRABALHO PASSOU A CONTRIBUIR MAIS COM OS AGRICULTORES(AS) } \\
\text { FAMILIARES. }\end{array}$ \\
\hline & CONSEGUI INFLUENCIAR NAS ORIENTAÇÕES DA MINHA INSTITUIÇÃO. \\
\hline$x$ & PASSEI A TRABALHAR COM METODOLOGIAS PARTICIPATIVAS. \\
\hline & $\begin{array}{l}\text { CRESCEU A ÁREA DE AGRICULTURA DE BASE ECOLÓGICA NAS } \\
\text { COMUNIDADES ONDE ATUO. }\end{array}$ \\
\hline & CONTINUEI ME APERFEIÇOANDO SOBRE TEMAS ABORDADOS. \\
\hline
\end{tabular}

7) Depois do evento de capacitação do qual participou, você apoiou atividades de capacitação de técnicos e/ou agricultores com base nos princípios e diretrizes da Pnater? (Considere como apoio a atividades de capacitação a participação no planejamento, elaboração de ementas, seleção de participantes e de palestrantes.)

\begin{tabular}{|l|l|}
\hline$x$ & SIM \\
\hline & NÃO \\
\hline
\end{tabular}

8) Usou os conhecimentos adquiridos para ministrar outros eventos de formação com o mesmo conteúdo ou conteúdos semelhantes?

\begin{tabular}{|l|l|}
\hline & SIM \\
\hline$x$ & NÃO \\
\hline
\end{tabular}


9) Marque o seu grau de satisfação com relação a atividade de formação oferecida pelo DATER: (Considere a seguinte pontuação: 1 - MUITO RUIM; 2 - RUIM; 3 - REGULAR; 4 BOM; 5 - MUITO BOM)

\begin{tabular}{|l|l|l|l|l|}
\hline 1 & 2 & 3 & $x 4$ & 5 \\
\hline
\end{tabular}

10) Marque seu grau de satisfação com relação ao DATER: (Considere a seguinte pontuação: 1 - MUITO RUIM; 2 - RUIM; 3 - REGULAR; 4 - BOM; 5 - MUITO BOM)

\begin{tabular}{|l|l|l|l|l|}
\hline 1 & 2 & 3 & $x 4$ & 5 \\
\hline
\end{tabular}


PESQUISA - IMPACTO DAS AÇÕES DE FORMAÇÃO REALIZADAS PELO DATER/SAF/MDA NO PERÍODO 2004-2009

Caros colaboradores,

Contamos com a sua atenção para preencher o formulário abaixo.

O mesmo tem por objetivo fornecer informações para avaliação da Eficiência, Efetividade e Eficácia da Política Pública de Formação de Agentes de Ater adotada pelo Departamento de Assistência Técnica e Extensão Rural, da Secretaria de Agricultura Familiar do Ministério do Desenvolvimento - DATER/SAF/MDA, no período de 2004 a 2009, tema escolhido para Monografia a ser apresentada à Universidade de Brasília (UnB) como requisito parcial para obtenção do grau de Bacharel em Administração.

Você poderá ou não se identificar no questionário e garantimos que todas as informações fornecidas serão confidenciais e utilizadas apenas de forma sistematizada.

\section{IDENTIFICAÇÃO}

\begin{tabular}{|l|l|l|}
\hline Nome: (opcional) Camila Miranda Michelin & $\begin{array}{l}\text { Sexo: } \\
() \text { masculino }(\mathrm{x}) \text { feminino }\end{array}$ \\
\hline $\begin{array}{l}\text { Instituição (nome e tipo de instituição: ONG, } \\
\text { Empresa Pública, Cooperativa,etc.): Instituto } \\
\text { Ambiental Brasil Sustentvel - IABS - OSCIP }\end{array}$ & $\begin{array}{l}\text { Bocal de traballia - DF } \\
\text { Curso/Encontro/Oficina do qual participou (caso tenha participado de mais de um evento de } \\
\text { formação, preencha um formulário para cada um deles): Aperfeiçoamento em Agroecologia }\end{array}$ \\
\hline Data do Curso/Encontro/Oficina/Seminário (pelo menos mês e ano): \\
\hline
\end{tabular}

1) Indique sua área de atuação? (As opções não são excludentes: você poderá marcar mais de uma opção).

\begin{tabular}{|l|l|}
\hline$x$ & EXTENSÃO RURAL \\
\hline$x$ & PESQUISA \\
\hline & ENSINO \\
\hline & OUTROS \\
\hline
\end{tabular}


2) Qual o seu nível de escolaridade? (Considere apenas o nível mais alto)

\begin{tabular}{|l|l|}
\hline & NÍVEL MÉDIO \\
\hline$x$ & NÍVEL SUPERIOR \\
\hline & PÓS-GRADUAÇÃO \\
\hline
\end{tabular}

3) Os conteúdos abordados na formação foram condizentes com as demandas do seu dia-adia?

\begin{tabular}{|l|l|}
\hline & SIM \\
\hline & PARCIALMENTE \\
\hline$x$ & NÃO \\
\hline
\end{tabular}

4) O curso ou atividade de formação da qual você participou contribuiu para o seu aperfeiçoamento profissional?

\begin{tabular}{|l|l|}
\hline$x$ & SIM \\
\hline & NÃO \\
\hline
\end{tabular}

5) Os conhecimentos adquiridos nesta formação estão sendo aplicados no seu trabalho? Em caso afirmativo, indique em que grau estes conhecimentos estão sendo aplicados. Em caso negativo, indique por que razão isto não ocorre: (Em caso negativo, as respostas não são excludentes: você poderá marcar mais de uma opção).

\begin{tabular}{|c|c|c|c|}
\hline \multirow{3}{*}{$\mathrm{x}$} & \multirow{3}{*}{$\begin{array}{l}\text { SIM (indique ao lado } \\
\text { em que grau) }\end{array}$} & & MUITO APLICADOS \\
\hline & & & MEDIAMENTE APLICADOS \\
\hline & & $\mathrm{x}$ & POUCO APLICADOS \\
\hline & \multirow{3}{*}{$\begin{array}{l}\text { NÃO (indique ao lado a } \\
\text { razão } \quad \text { da } \\
\text { aplicação) }\end{array}$} & & $\begin{array}{l}\text { CONTEÚDO NÃO ADEQUADO ȦS NECESSIDADES } \\
\text { ESPECÍFICAS DA REGIÃO }\end{array}$ \\
\hline & & & \begin{tabular}{lccc|} 
CONTEÚDO & NÃO & FOI & SUFICIENTEMENTE \\
APROFUNDADO & PARA & PERMITIR & UMA \\
APLICAÇÃO EFICAZ E EFICIENTE &
\end{tabular} \\
\hline & & & \begin{tabular}{|llllll} 
FALTA DE APOIO & E & INCENTIVO & DA & MINHA \\
INSTITUIÇÃO & & & & \\
\end{tabular} \\
\hline
\end{tabular}




\begin{tabular}{|l|l|l|}
\hline \multirow{2}{*}{} & & FALTA DE INCENTIVO ÀS AÇÕES DE ATER \\
\cline { 3 - 4 } & & NÃO TENHO INTERESSE EM APLICAR \\
\hline
\end{tabular}

6) A partir do evento de formação do qual você participou: (As respostas não são excludentes: você poderá marcar mais de uma opção).

\begin{tabular}{|l|l|}
\hline$x$ & NÃO MUDOU NADA EM MEU TRABALHO. \\
\hline & $\begin{array}{l}\text { MEU TRABALHO PASSOU A CONTRIBUIR MAIS COM OS AGRICULTORES(AS) } \\
\text { FAMILIARES. }\end{array}$ \\
\hline & CONSEGUI INFLUENCIAR NAS ORIENTAÇÕES DA MINHA INSTITUIÇÃO. \\
\hline & $\begin{array}{l}\text { CRESSEI A TRABALHAR COM METODOLOGIAS PARTICIPATIVAS. } \\
\text { COMUNIDADES ONDE ATUO. DE AGRICULTURA DE BASE ECOLÓGICA NAS }\end{array}$ \\
\hline & CONTINUEI ME APERFEIÇOANDO SOBRE TEMAS ABORDADOS. \\
\hline
\end{tabular}

7) Depois do evento de capacitação do qual participou, você apoiou atividades de capacitação de técnicos e/ou agricultores com base nos princípios e diretrizes da Pnater? (Considere como apoio a atividades de capacitação a participação no planejamento, elaboração de ementas, seleção de participantes e de palestrantes.)

\begin{tabular}{|l|l|}
\hline & SIM \\
\hline$x$ & NÃO \\
\hline
\end{tabular}

8) Usou os conhecimentos adquiridos para ministrar outros eventos de formação com o mesmo conteúdo ou conteúdos semelhantes?

\begin{tabular}{|l|l|}
\hline & SIM \\
\hline$x$ & NÃO \\
\hline
\end{tabular}

9) Marque o seu grau de satisfação com relação a atividade de formação oferecida pelo DATER: (Considere a seguinte pontuação: 1 - MUITO RUIM; 2 - RUIM; 3 - REGULAR; 4 BOM; 5 - MUITO BOM) 


\begin{tabular}{|l|l|l|l|l|}
\hline 1 & 2 & 3 & $x 4$ & 5 \\
\hline
\end{tabular}

10) Marque seu grau de satisfação com relação ao DATER: (Considere a seguinte pontuação: 1 - MUITO RUIM; 2 - RUIM; 3 - REGULAR; 4 - BOM; 5 - MUITO BOM)

\begin{tabular}{|l|l|l|l|l|}
\hline 1 & 2 & 3 & 4 & $x 5$ \\
\hline
\end{tabular}


PESQUISA - IMPACTO DAS AÇÕES DE FORMAÇÃO REALIZADAS PELO DATER/SAF/MDA NO PERÍODO 2004-2009

Caros colaboradores,

Contamos com a sua atenção para preencher o formulário abaixo.

O mesmo tem por objetivo fornecer informações para avaliação da Eficiência, Efetividade e Eficácia da Política Pública de Formação de Agentes de Ater adotada pelo Departamento de Assistência Técnica e Extensão Rural, da Secretaria de Agricultura Familiar do Ministério do Desenvolvimento - DATER/SAF/MDA, no período de 2004 a 2009, tema escolhido para Monografia a ser apresentada à Universidade de Brasília (UnB) como requisito parcial para obtenção do grau de Bacharel em Administração.

Você poderá ou não se identificar no questionário e garantimos que todas as informações fornecidas serão confidenciais e utilizadas apenas de forma sistematizada.

\section{IDENTIFICAÇÃO}

\begin{tabular}{|l|l|}
\hline $\begin{array}{l}\text { Nome: (opcional) } \\
\text { Begair Filipaldi }\end{array}$ & $\begin{array}{l}\text { Sexo: } \\
(\quad) \text { masculino } \quad(\mathrm{x}) \text { feminino }\end{array}$ \\
\hline $\begin{array}{l}\text { Instituição (nome e tipo de instituição: ONG, } \\
\text { Empresa Pública, Cooperativa,etc.): }\end{array}$ & $\begin{array}{l}\text { Local de trabalho (Cidade e Estado): } \\
\text { CUIABÁ }\end{array}$ \\
\hline EMPAER MT & \\
\hline $\begin{array}{l}\text { Curso/Encontro/Oficina do qual participou (caso tenha participado de mais de um evento de } \\
\text { formação, preencha um formulário para cada um deles): } \\
\text { ENCONTRO }\end{array}$ \\
\hline Data do Curso/Encontro/Oficina/Seminário (pelo menos mês e ano): 2008 \\
\hline
\end{tabular}

1) Indique sua área de atuação? (As opções não são excludentes: você poderá marcar mais de uma opção).

\begin{tabular}{|l|l|}
\hline$X$ & EXTENSÃO RURAL \\
\hline & PESQUISA \\
\hline & ENSINO \\
\hline & OUTROS \\
\hline
\end{tabular}


2) Qual o seu nível de escolaridade? (Considere apenas o nível mais alto)

\begin{tabular}{|l|l|}
\hline & NÍVEL MÉDIO \\
\hline & NÍVEL SUPERIOR \\
\hline$x$ & PÓS-GRADUAÇÃO \\
\hline
\end{tabular}

3) Os conteúdos abordados na formação foram condizentes com as demandas do seu dia-adia?

\begin{tabular}{|l|l|}
\hline$X$ & SIM \\
\hline & PARCIALMENTE \\
\hline & NÃO \\
\hline
\end{tabular}

4) O curso ou atividade de formação da qual você participou contribuiu para o seu aperfeiçoamento profissional?

\begin{tabular}{|l|l|}
\hline$x$ & SIM \\
\hline & NÃO \\
\hline
\end{tabular}

5) Os conhecimentos adquiridos nesta formação estão sendo aplicados no seu trabalho? Em caso afirmativo, indique em que grau estes conhecimentos estão sendo aplicados. Em caso negativo, indique por que razão isto não ocorre: (As respostas não são excludentes: você poderá marcar mais de uma opção).

\begin{tabular}{|c|c|c|}
\hline \multirow{3}{*}{$\begin{array}{l}\text { SIM (indique ao lado } \\
\text { em que grau) }\end{array}$} & & MUITO APLICADOS \\
\hline & $\bar{x}$ & MEDIAMENTE APLICADOS \\
\hline & & POUCO APLICADOS \\
\hline \multirow{3}{*}{$\begin{array}{l}\text { NÃO (indique ao lado a } \\
\text { razão da } \quad \text { não } \\
\text { aplicação) }\end{array}$} & & $\begin{array}{l}\text { CONTEÚDO NÃO ADEQUADO ÀS NECESSIDADES } \\
\text { ESPECÍFICAS DA REGIÃO }\end{array}$ \\
\hline & & 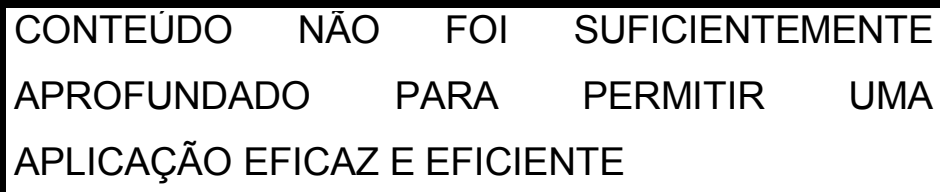 \\
\hline & & $\begin{array}{l}\text { FALTA DE APOIO E INCENTIVO DA } \\
\text { INSTITUIÇÃO }\end{array}$ \\
\hline
\end{tabular}




\begin{tabular}{|l|l|l|}
\hline \multirow{2}{*}{} & & FALTA DE INCENTIVO ÀS AÇÕES DE ATER \\
\cline { 3 - 4 } & & NÃO TENHO INTERESSE EM APLICAR \\
\hline
\end{tabular}

6) A partir do evento de formação do qual você participou: (As respostas não são excludentes: você poderá marcar mais de uma opção).

\begin{tabular}{|l|l|}
\hline & NÃO MUDOU NADA EM MEU TRABALHO. \\
\hline$X$ & $\begin{array}{l}\text { MEU TRABALHO PASSOU A CONTRIBUIR MAIS COM OS AGRICULTORES(AS) } \\
\text { FAMILIARES. }\end{array}$ \\
\hline & CONSEGUI INFLUENCIAR NAS ORIENTAÇÕES DA MINHA INSTITUIÇÃO. \\
\hline & PASSEI A TRABALHAR COM METODOLOGIAS PARTICIPATIVAS. \\
\hline & $\begin{array}{l}\text { CRESCEU A ÁREA DE AGRICULTURA DE BASE ECOLÓGICA NAS } \\
\text { COMUNIDADES ONDE ATUO. }\end{array}$ \\
\hline & CONTINUEI ME APERFEIÇOANDO SOBRE TEMAS ABORDADOS. \\
\hline
\end{tabular}

7) Depois do evento de capacitação do qual participou, você apoiou atividades de capacitação de técnicos e/ou agricultores com base nos princípios e diretrizes da Pnater?

\begin{tabular}{|l|l|}
\hline$X$ & SIM \\
\hline & NÃO \\
\hline
\end{tabular}

8) Usou os conhecimentos para ministrar outros eventos de formação com o mesmo conteúdo ou conteúdos semelhantes?

\begin{tabular}{|l|l|}
\hline$X$ & SIM \\
\hline & NÃO \\
\hline
\end{tabular}

9) Marque o seu grau de satisfação com relação a atividade de formação oferecida pelo DATER: (Considere a seguinte pontuação: 1 - MUITO RUIM; 2 - RUIM; 3 - REGULAR; 4 BOM; 5 - MUITO BOM) 


\begin{tabular}{|l|l|l|l|l|}
\hline 1 & 2 & 3 & $4 x$ & 5 \\
\hline
\end{tabular}

10) Marque seu grau de satisfação com relação ao DATER: (Considere a seguinte pontuação: 1 - MUITO RUIM; 2 - RUIM; 3 - REGULAR; 4 - BOM; 5 - MUITO BOM)

\begin{tabular}{|l|l|l|l|l|}
\hline 1 & 2 & 3 & $4 x$ & 5 \\
\hline
\end{tabular}


PESQUISA - IMPACTO DAS AÇÕES DE FORMAÇÃO REALIZADAS PELO DATER/SAF/MDA NO PERÍODO 2004-2009

Caros colaboradores,

Contamos com a sua atenção para preencher o formulário abaixo.

O mesmo tem por objetivo fornecer informações para avaliação da Eficiência, Efetividade e Eficácia da Política Pública de Formação de Agentes de Ater adotada pelo Departamento de Assistência Técnica e Extensão Rural, da Secretaria de Agricultura Familiar do Ministério do Desenvolvimento - DATER/SAF/MDA, no período de 2004 a 2009, tema escolhido para Monografia a ser apresentada à Universidade de Brasília (UnB) como requisito parcial para obtenção do grau de Bacharel em Administração.

Você poderá ou não se identificar no questionário e garantimos que todas as informações fornecidas serão confidenciais e utilizadas apenas de forma sistematizada.

IDENTIFICAÇÃO

\begin{tabular}{|l|l|}
\hline Nome: Caroline M. V. Turazi & $\begin{array}{l}\text { Sexo: } \\
(\quad) \text { masculino } \quad(\mathrm{x}) \text { feminino }\end{array}$ \\
\hline $\begin{array}{l}\text { Instituição (nome e tipo de instituição: ONG, } \\
\text { Empresa Pública, etc.): INCRA }\end{array}$ & $\begin{array}{l}\text { Local de trabalho (Cidade e Estado): } \\
\text { Brasília DF }\end{array}$ \\
\hline $\begin{array}{l}\text { Curso/Encontro/Oficina do qual participou (caso tenha participado de mais de um curso, preencha } \\
\text { um formulário para cada um deles): Curso de Aperfeiçoamento em Agroecologia }\end{array}$ \\
\hline Data do Curso/Encontro/Oficina (pelo menos mês e ano): março a junho de 2006 \\
\hline
\end{tabular}

Indique sua área de atuação?

\begin{tabular}{|l|l|}
\hline & EXTENSÃO RURAL \\
\hline & PESQUISA \\
\hline & ENSINO \\
\hline$x$ & $\begin{array}{l}\text { OUTROS - Programa de } \\
\text { Assessoria Técnica, Social e } \\
\text { Ambiental }\end{array}$ \\
\hline
\end{tabular}

2) Qual o seu nível de escolaridade? (Considere apenas o nível mais alto) 


\begin{tabular}{|l|l|}
\hline & NÍVEL MÉDIO \\
\hline & NÍVEL SUPERIOR \\
\hline$x$ & PÓS-GRADUAÇÃO \\
\hline
\end{tabular}

3) Os conteúdos abordados foram condizentes com as demandas do seu dia-a-dia?

\begin{tabular}{|l|l|}
\hline$x$ & SIM \\
\hline & PARCIALMENTE \\
\hline & NÃO \\
\hline
\end{tabular}

4) O curso contribuiu para o seu aperfeiçoamento profissional?

\begin{tabular}{|l|l|}
\hline$x$ & SIM \\
\hline & NÃO \\
\hline
\end{tabular}

5) Os conhecimentos adquiridos estão sendo aplicados no seu trabalho? Em caso afirmativo, indique em que grau estes conhecimentos estão sendo aplicados. Em caso negativo, indique por que razão isto não ocorre: (Em caso negativo, as respostas não são excludentes: você poderá marcar mais de uma opção).

\begin{tabular}{|c|c|c|}
\hline \multirow{3}{*}{$\begin{array}{l}\text { SIM (indique ao lado em } \\
\text { que grau) }\end{array}$} & & MUITO APLICADOS \\
\hline & & MEDIAMENTE APLICADOS \\
\hline & $\mathrm{x}$ & POUCO APLICADOS \\
\hline \multirow{4}{*}{$\begin{array}{l}\text { NÃO (indique ao lado a } \\
\text { razão da não aplicação) }\end{array}$} & & $\begin{array}{l}\text { CONTEÚDO NĀO ADEQUADO ȦS NECESSIDADES } \\
\text { ESPECÍFICAS DA REGIÃO }\end{array}$ \\
\hline & & $\begin{array}{l}\text { CONTEÚDO NÃO FOI SUFICIENTEMENTE } \\
\text { APROFUNDADO PARA PERMITIR UMA APLICAÇÃO } \\
\text { EFICAZ E EFICIENTE }\end{array}$ \\
\hline & & $\begin{array}{lllllll}\text { FALTA } & \text { DE } & \text { APOIO } & \text { E } & \text { INCENTIVO } & \text { DA } & \text { MINHA } \\
\text { INSTITUIÇÃO } & & & & \\
\end{array}$ \\
\hline & & FALTA DE INCENTIVO ÀS AÇÕES DE ATER \\
\hline
\end{tabular}




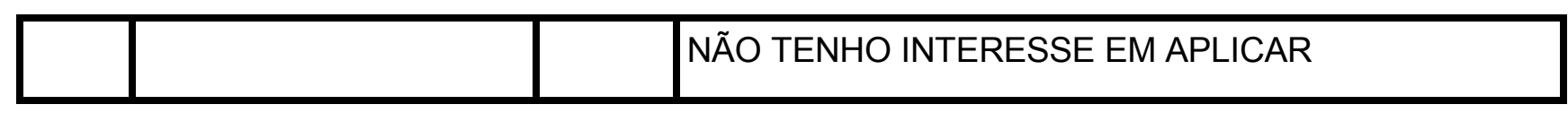

6) A partir deste curso: (As respostas não são excludentes: você poderá marcar mais de uma opção).

\begin{tabular}{|l|l|}
\hline$x$ & "por enquanto" NÃO MUDOU NADA EM MEU TRABALHO. \\
\hline & $\begin{array}{l}\text { MEU TRABALHO PASSOU A CONTRIBUIR MAIS COM OS AGRICULTORES(AS) } \\
\text { FAMILIARES. }\end{array}$ \\
\hline & CONSEGUI INFLUENCIAR NAS ORIENTAÇÕES DA MINHA INSTITUIÇÃO. \\
\hline & $\begin{array}{l}\text { CRESCEI A TRABALHAR COM METODOLOGIAS PARTICIPATIVAS. } \\
\text { ONDE ATUO. ÁREA DE AGRICULTURA DE BASE ECOLÓGICA NAS COMUNIDADES }\end{array}$ \\
\hline & CONTINUEI ME APERFEIÇOANDO SOBRE TEMAS ABORDADOS. \\
\hline
\end{tabular}

7) Depois do curso você apoiou atividades de capacitação de técnicos e agricultores com base nos princípios e diretrizes da Pnater? (Considere como apoio a atividades de capacitação a participação no planejamento, elaboração de ementas, seleção de participantes e de palestrantes.)

\begin{tabular}{|l|l|}
\hline & SIM \\
\hline$x$ & NÃO \\
\hline
\end{tabular}

8) Usou os conhecimentos para ministrar outros cursos com o mesmo conteúdo ou conteúdos semelhantes?

\begin{tabular}{|l|l|}
\hline & SIM \\
\hline$x$ & NÃO \\
\hline
\end{tabular}

9) Marque o seu grau de satisfação com relação ao curso oferecido pelo DATER: 


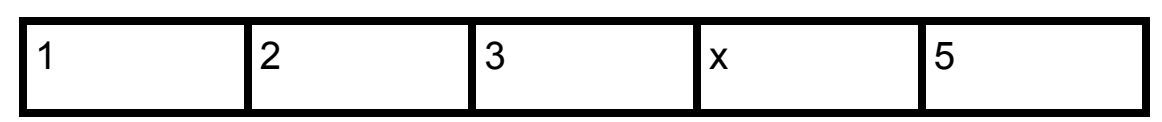

10) Marque seu grau de satisfação com relação ao DATER:

\begin{tabular}{|l|l|l|l|l|}
\hline 1 & 2 & 3 & 4 & 5 \\
\hline
\end{tabular}


PESQUISA - IMPACTO DAS AÇÕES DE FORMAÇÃO REALIZADAS PELO DATER/SAF/MDA NO PERÍODO 2004-2009

Caros colaboradores,

Contamos com a sua atenção para preencher o formulário abaixo.

O mesmo tem por objetivo fornecer informações para avaliação da Eficiência, Efetividade e Eficácia da Política Pública de Formação de Agentes de Ater adotada pelo Departamento de Assistência Técnica e Extensão Rural, da Secretaria de Agricultura Familiar do Ministério do Desenvolvimento - DATER/SAF/MDA, no período de 2004 a 2009, tema escolhido para Monografia a ser apresentada à Universidade de Brasília (UnB) como requisito parcial para obtenção do grau de Bacharel em Administração.

Você poderá ou não se identificar no questionário e garantimos que todas as informações fornecidas serão confidenciais e utilizadas apenas de forma sistematizada.

\section{IDENTIFICAÇÃO}

\begin{tabular}{|c|c|}
\hline Nome: CLARICE VALADARES DURÃES & $\begin{array}{l}\text { Sexo: } \\
(\quad) \text { masculino } \quad(x) \text { feminino }\end{array}$ \\
\hline $\begin{array}{l}\text { Instituição (nome e tipo de instituição: ONG, } \\
\text { Empresa Pública, etc.): } \\
\text { SEC. EDUCAÇÃO/ EMATER-DF (CONVENIO) }\end{array}$ & $\begin{array}{l}\text { Local de trabalho (Cidade e Estado): } \\
\text { BRASÍLIA-DF }\end{array}$ \\
\hline $\begin{array}{l}\text { Curso/Encontro/Oficina do qual participou (caso tent } \\
\text { um formulário para cada um deles): } \\
\text { CURSO DE FORMAÇÃO DE EXTENSIONISTAS } \\
\text { DO CERRADO }\end{array}$ & $\begin{array}{l}\text { ha participado de mais de um curso, preencha } \\
\text { COMO EDUCADORES AGROFLORESTAIS }\end{array}$ \\
\hline \multicolumn{2}{|c|}{ Data do Curso/Encontro/Oficina (pelo menos mês e ano): } \\
\hline
\end{tabular}

1) Indique sua área de atuação?

\begin{tabular}{|c|l|}
\hline$x$ & EXTENSÃO RURAL \\
\hline & PESQUISA \\
\hline$x$ & ENSINO \\
\hline & OUTROS \\
\hline
\end{tabular}


2) Qual o seu nível de escolaridade? (Considere apenas o nível mais alto)

\begin{tabular}{|c|l|}
\hline & NÍVEL MÉDIO \\
\hline & NÍVEL SUPERIOR \\
\hline$x$ & PÓS-GRADUAÇÃO \\
\hline
\end{tabular}

3) Os conteúdos abordados foram condizentes com as demandas do seu dia-a-dia?

\begin{tabular}{|l|l|}
\hline$x$ & SIM \\
\hline & PARCIALMENTE \\
\hline & NÃO \\
\hline
\end{tabular}

4) O curso contribuiu para o seu aperfeiçoamento profissional?

\begin{tabular}{|l|l|}
\hline$x$ & SIM \\
\hline & NÃO \\
\hline
\end{tabular}

5) Os conhecimentos adquiridos estão sendo aplicados no seu trabalho? Em caso afirmativo, indique em que grau estes conhecimentos estão sendo aplicados. Em caso negativo, indique por que razão isto não ocorre: (Em caso negativo, as respostas não são excludentes: você poderá marcar mais de uma opção).

\begin{tabular}{|c|c|c|}
\hline \multirow{3}{*}{$\begin{array}{l}\text { SIM (indique ao lado em } \\
\text { que grau) }\end{array}$} & $x$ & MUITO APLICADOS \\
\hline & & MEDIAMENTE APLICADOS \\
\hline & & POUCO APLICADOS \\
\hline \multirow{4}{*}{$\begin{array}{l}\text { NÃO (indique ao lado a } \\
\text { razão da não aplicação) }\end{array}$} & & $\begin{array}{l}\text { CONTEÚDO NÃO ADEQUADO ÀS NECESSIDADES } \\
\text { FSPFCÍFICAS RA RFGIÃO }\end{array}$ \\
\hline & & $\begin{array}{llll}\text { CONTEÚDO NÂO } & \text { FOI SUFICIENTEMENTE } \\
\text { APROFUNDADO PARA } & \text { PERMITIR UMA APLICAÇÃO }\end{array}$ \\
\hline & & $\begin{array}{lcccccc}\text { FALTA } & \text { DE } & \text { APOIO } & \text { E } & \text { INCENTIVO } & \text { DA } & \text { MINHA } \\
\text { INSTITUICÃO } & & & & & \\
\end{array}$ \\
\hline & & FALTA DE INCENTIVO ÀS AÇÕES DE ATER \\
\hline
\end{tabular}




\begin{tabular}{|l|l|l|l|}
\hline & & & NÃO TENHO INTERESSE EM APLICAR \\
\hline
\end{tabular}

6) A partir deste curso: (As respostas não são excludentes: você poderá marcar mais de uma opção).

\begin{tabular}{|l|l|}
\hline$x$ & $\begin{array}{l}\text { NÃO MUDOU NADA EM MEU TRABALHO. } \\
\text { FAMILIARES. }\end{array}$ \\
\hline & CONSEGUI INFLUENCIAR NAS ORIENTAÇÕES DA MINHA INSTITUIÇÃO. \\
\hline & PASSEI A TRABALHAR COM METODOLOGIAS PARTICIPATIVAS. \\
\hline & $\begin{array}{l}\text { CRESCEU A ÁREA DE AGRICULTURA DE BASE ECOLÓGICA NAS COMUNIDADES } \\
\text { ONDE ATUO. }\end{array}$ \\
\hline$x$ & CONTINUEI ME APERFEIÇOANDO SOBRE TEMAS ABORDADOS. \\
\hline
\end{tabular}

7) Depois do curso você apoiou atividades de capacitação de técnicos e agricultores com base nos princípios e diretrizes da Pnater? (Considere como apoio a atividades de capacitação a participação no planejamento, elaboração de ementas, seleção de participantes e de palestrantes.)

\begin{tabular}{|l|l|}
\hline$x$ & SIM \\
\hline & NÃO \\
\hline
\end{tabular}

8) Usou os conhecimentos para ministrar outros cursos com o mesmo conteúdo ou conteúdos semelhantes?

\begin{tabular}{|l|l|}
\hline & SIM \\
\hline$x$ & NÃO \\
\hline
\end{tabular}

9) Marque o seu grau de satisfação com relação ao curso oferecido pelo DATER:

\begin{tabular}{|l|l|l|l|l|}
\hline 1 & 2 & 3 & 4 & 5 \\
\hline
\end{tabular}

10) Marque seu grau de satisfação com relação ao DATER: 


\begin{tabular}{|l|l|l|l|l|}
\hline 1 & 2 & 3 & 4 & 5 \\
\hline
\end{tabular}


PESQUISA - IMPACTO DAS AÇÕES DE FORMAÇÃO REALIZADAS PELO DATER/SAF/MDA NO PERÍODO 2004-2009

Caros colaboradores,

Contamos com a sua atenção para preencher o formulário abaixo.

O mesmo tem por objetivo fornecer informações para avaliação da Eficiência, Efetividade e Eficácia da Política Pública de Formação de Agentes de Ater adotada pelo Departamento de Assistência Técnica e Extensão Rural, da Secretaria de Agricultura Familiar do Ministério do Desenvolvimento - DATER/SAF/MDA, no período de 2004 a 2009, tema escolhido para Monografia a ser apresentada à Universidade de Brasília (UnB) como requisito parcial para obtenção do grau de Bacharel em Administração.

Você poderá ou não se identificar no questionário e garantimos que todas as informações fornecidas serão confidenciais e utilizadas apenas de forma sistematizada.

\section{IDENTIFICAÇÃO}

\begin{tabular}{|c|c|}
\hline Nome: CLARICE VALADARES DURÃES & $\begin{array}{l}\text { Sexo: } \\
\text { ( ) masculino }\end{array}$ \\
\hline $\begin{array}{l}\text { Instituição (nome e tipo de instituição: ONG, } \\
\text { Empresa Pública, etc.): } \\
\text { SEC. EDUCAÇÃO/ EMATER-DF (CONVENIO) }\end{array}$ & $\begin{array}{l}\text { Local de trabalho (Cidade e Estado): } \\
\text { BRASÍLIA-DF }\end{array}$ \\
\hline \multicolumn{2}{|c|}{$\begin{array}{l}\text { Curso/Encontro/Oficina do qual participou (caso tenha participado de mais de um curso, preencha } \\
\text { um formulário para cada um deles): } \\
\text { II CURSO DE APERFEIÇOAMENTO EM AGROECOLOGIA A DISTÃNCIA( REDCAPA) }\end{array}$} \\
\hline \multicolumn{2}{|l|}{ Data do Curso/Encontro/Oficina (pelo menos mês e ano): } \\
\hline
\end{tabular}

1)Indique sua área de atuação?

\begin{tabular}{|l|l|}
\hline$X$ & EXTENSÃO RURAL \\
\hline & PESQUISA \\
\hline$X$ & ENSINO \\
\hline & OUTROS \\
\hline
\end{tabular}

2) Qual o seu nível de escolaridade? (Considere apenas o nível mais alto) 


\begin{tabular}{|l|l|}
\hline & NÍVEL MÉDIO \\
\hline & NÍVEL SUPERIOR \\
\hline$X$ & PÓS-GRADUAÇÃO \\
\hline
\end{tabular}

3) Os conteúdos abordados foram condizentes com as demandas do seu dia-a-dia?

\begin{tabular}{|l|l|}
\hline$X$ & SIM \\
\hline & PARCIALMENTE \\
\hline & NÃO \\
\hline
\end{tabular}

4) O curso contribuiu para o seu aperfeiçoamento profissional?

\begin{tabular}{|l|l|}
\hline$X$ & SIM \\
\hline & NÃO \\
\hline
\end{tabular}

5) Os conhecimentos adquiridos estão sendo aplicados no seu trabalho? Em caso afirmativo, indique em que grau estes conhecimentos estão sendo aplicados. Em caso negativo, indique por que razão isto não ocorre: (Em caso negativo, as respostas não são excludentes: você poderá marcar mais de uma opção).

\begin{tabular}{|c|c|c|}
\hline \multirow{3}{*}{$\begin{array}{l}\text { SIM (indique ao lado em } \\
\text { que grau) }\end{array}$} & & MUITO APLICADOS \\
\hline & $\bar{X}$ & MEDIAMENTE APLICADOS \\
\hline & & POUCO APLICADOS \\
\hline \multirow{5}{*}{$\begin{array}{l}\text { NÃO (indique ao lado a } \\
\text { razão da não aplicação) }\end{array}$} & & $\begin{array}{l}\text { CONTEÚDO NÃO ADEQUADO ÀS NECESSIDADES } \\
\text { ESPECÍFICAS } \cap A \text { REGIÃم }\end{array}$ \\
\hline & & $\begin{array}{lll}\text { CONTEUDO NA } & \text { FOI } & \text { SUFICIENTEMENTE } \\
\text { APROFUNDADO } & \text { PARA } & \text { PERMITIR UMA APLICAÇÃO }\end{array}$ \\
\hline & & \begin{tabular}{lllllll|} 
FALTA & DE & APOIO & E & INCENTIVO & DA & MINHA \\
INSTITUICÃO & & & & & \\
\end{tabular} \\
\hline & & FALTA DE INCENTIVO ÀS AÇÕES DE ATER \\
\hline & & NÃO TENHO INTERESSE EM APLICAR \\
\hline
\end{tabular}


6) A partir deste curso: (As respostas não são excludentes: você poderá marcar mais de uma opção).

\begin{tabular}{|l|l|}
\hline & NÃO MUDOU NADA EM MEU TRABALHO. \\
\hline & $\begin{array}{l}\text { MEU TRABALHO PASSOU A CONTRIBUIR MAIS COM OS AGRICULTORES(AS) } \\
\text { FAMILIARES. }\end{array}$ \\
\hline & CONSEGUI INFLUENCIAR NAS ORIENTAÇÕES DA MINHA INSTITUIÇÃO. \\
\hline & $\begin{array}{l}\text { PASSEI A TRABALHAR COM METODOLOGIAS PARTICIPATIVAS. } \\
\text { ONDE ATUO. }\end{array}$ \\
\hline$X$ & CONTINUEI ME APERFEIÇOANDO SOBRE TEMAS ABORDADOS. \\
\hline
\end{tabular}

7) Depois do curso você apoiou atividades de capacitação de técnicos e agricultores com base nos princípios e diretrizes da Pnater? (Considere como apoio a atividades de capacitação a participação no planejamento, elaboração de ementas, seleção de participantes e de palestrantes.)

\begin{tabular}{|l|l|}
\hline$X$ & SIM \\
\hline & NÃO \\
\hline
\end{tabular}

8) Usou os conhecimentos para ministrar outros cursos com o mesmo conteúdo ou conteúdos semelhantes?

\begin{tabular}{|l|l|}
\hline & SIM \\
\hline$X$ & NÃO \\
\hline
\end{tabular}

9) Marque o seu grau de satisfação com relação ao curso oferecido pelo DATER:

\begin{tabular}{|l|l|l|l|l|}
\hline 1 & 2 & 3 & 4 & 5 \\
\hline
\end{tabular}

10) Marque seu grau de satisfação com relação ao DATER: 


\begin{tabular}{|l|l|l|l|l|}
\hline 1 & 2 & 3 & 4 & 5 \\
\hline
\end{tabular}


2) Qual o seu nível de escolaridade? Considere apenas o nível mais alto)

\begin{tabular}{|l|l|}
\hline & NÍVEL MÉDIO \\
\hline & NÍVEL SUPERIOR \\
\hline$X$ & PÓS-GRADUAÇÃO \\
\hline
\end{tabular}

3) Os conteúdos abordados foram condizentes com as demandas do seu dia-a-dia?

\begin{tabular}{|l|l|}
\hline & SIM \\
\hline$X$ & PARCIALMENTE \\
\hline & NÃO \\
\hline
\end{tabular}

3) O curso contribuiu para o seu aperfeiçoamento profissional?

\begin{tabular}{|l|l|}
\hline$X$ & SIM \\
\hline & NÃO \\
\hline
\end{tabular}

5) Os conhecimentos adquiridos estão sendo aplicados no seu trabalho? Em caso afirmativo, indique em que grau estes conhecimentos estão sendo aplicados. Em caso negativo, indique por que razão isto não ocorre: (As respostas não são excludentes: você poderá marcar mais de uma opção).

\begin{tabular}{|c|c|c|c|}
\hline \multirow{3}{*}{$\mathrm{x}$} & \multirow{3}{*}{$\begin{array}{l}\text { SIM (indique ao lado em } \\
\text { que grau) }\end{array}$} & $\mathrm{X}$ & MUITO APLICADOS \\
\hline & & & MEDIAMENTE APLICADOS \\
\hline & & & POUCO APLICADOS \\
\hline & & & $\begin{array}{l}\text { CONTEÚDO NĀO ADEQUADO ȦS NECESSIDADES } \\
\text { ESPECÍFICAS DA REGIÃO }\end{array}$ \\
\hline & razão da não aplicação) & & $\begin{array}{l}\text { CONTEÚDO NÃO FOI SUFICIENTEMENTE } \\
\text { APROFUNDADO PARA PERMITIR UMA APLICAÇÃO } \\
\text { EFICAZ E EFICIENTE }\end{array}$ \\
\hline
\end{tabular}




\begin{tabular}{|l|l|l|}
\hline \multirow{2}{*}{} & & $\begin{array}{l}\text { FALTA DE APOIO E INCENTIVO DA MINHA } \\
\text { INSTITUIÇÃO }\end{array}$ \\
\cline { 2 - 3 } & & FALTA DE INCENTIVO ÀS AÇÕES DE ATER \\
\cline { 2 - 3 } & NÃO TENHO INTERESSE EM APLICAR \\
\hline
\end{tabular}

6) A partir deste curso: (As opções não são excludentes: você poderá marcar mais de uma opção).

\begin{tabular}{|l|l|}
\hline & NÃO MUDOU NADA EM MEU TRABALHO. \\
\hline$x$ & $\begin{array}{l}\text { MEU TRABALHO PASSOU A CONTRIBUIR MAIS COM OS AGRICULTORES(AS) } \\
\text { FAMILIARES. }\end{array}$ \\
\hline$X$ & CONSEGUI INFLUENCIAR NAS ORIENTAÇÕES DA MINHA INSTITUIÇÃO. \\
\hline$X$ & PASSEI A TRABALHAR COM METODOLOGIAS PARTICIPATIVAS. \\
\hline$X$ & \begin{tabular}{l} 
ORESCEU A ÁREA DE AGRICULTURA DE BASE ECOLÓGICA NAS COMUNIDADES \\
\hline
\end{tabular} \\
\hline
\end{tabular}

7) Depois do curso você apoiou atividades de capacitação de técnicos e agricultores com base nos princípios e diretrizes da Pnater? (Considere como apoio a atividades de capacitação a participação no planejamento, elaboração de ementas, seleção de participantes e de palestrantes.)

\begin{tabular}{|l|l|}
\hline$X$ & SIM \\
\hline & NÃO \\
\hline
\end{tabular}

8) Usou os conhecimentos para ministrar outros cursos com o mesmo conteúdo ou conteúdos semelhantes?

\begin{tabular}{|l|l|}
\hline$X$ & SIM \\
\hline & NÃO \\
\hline
\end{tabular}


9) Marque o seu grau de satisfação com relação ao curso oferecido pelo DATER: (Considere como apoio a atividades de capacitação a participação no planejamento, elaboração de ementas, seleção de participantes e de palestrantes.)

\begin{tabular}{|l|l|l|l|l|}
\hline 1 & 2 & 3 & 4 & $5 X$ \\
\hline
\end{tabular}

10) Marque seu grau de satisfação com relação ao DATER: (Considere como apoio a atividades de capacitação a participação no planejamento, elaboração de ementas, seleção de participantes e de palestrantes.)

\begin{tabular}{|l|l|l|l|l|}
\hline 1 & 2 & $x$ & 4 & 5 \\
\hline
\end{tabular}

Observação em relação a resposta da questão $n^{\circ} 3$. Minha resposta foi "parcialmente", pois, o público que atendo ainda tem que ser apresentado ao conteúdo do curso. Como ainda estou cursando preciso de mais tempo para que as pessoas tenham contato com essa tecnologia e vejam os resultados das áreas demonstrativas. Há muita resistência em relação a esse tipo de tecnologia principalmente dos dirigentes do órgão. Pois, não temos apoio para continuar o trabalho por que somos pressionados a continuar no que é convencional e tb somos ironizados no local de trabalho. Isso trás um profundo desgaste emocional aliados a outros fatores. 
PESQUISA - IMPACTO DAS AÇÕES DE FORMAÇÃO REALIZADAS PELO DATER/SAF/MDA NO PERÍODO 2004-2009

Caros colaboradores,

Contamos com a sua atenção para preencher o formulário abaixo.

O mesmo tem por objetivo fornecer informações para avaliação da Eficiência, Efetividade e Eficácia da Política Pública de Formação de Agentes de Ater adotada pelo Departamento de Assistência Técnica e Extensão Rural, da Secretaria de Agricultura Familiar do Ministério do Desenvolvimento - DATER/SAF/MDA, no período de 2004 a 2009, tema escolhido para Monografia a ser apresentada à Universidade de Brasília (UnB) como requisito parcial para obtenção do grau de Bacharel em Administração.

Você poderá ou não se identificar no questionário e garantimos que todas as informações fornecidas serão confidenciais e utilizadas apenas de forma sistematizada.

\section{IDENTIFICAÇÃO}

\begin{tabular}{|c|c|}
\hline Nome: CLARICE VALADARES DURÃES & $\begin{array}{l}\text { Sexo: } \\
(\quad) \text { masculino }(x) \text { feminino }\end{array}$ \\
\hline $\begin{array}{l}\text { Instituição (nome e tipo de instituição: ONG, } \\
\text { Empresa Pública, etc.): } \\
\text { SEC. EDUCAÇÃO/ EMATER-DF (CONVENIO }\end{array}$ & $\begin{array}{l}\text { Local de trabalho (Cidade e Estado): } \\
\text { BRASÍLIA-DF }\end{array}$ \\
\hline $\begin{array}{l}\text { Curso/Encontro/Oficina do qual participou (caso tent } \\
\text { um formulário para cada um deles): } \\
\text { MINI CURSO DE ECONOMIA ECOLÓGICA }\end{array}$ & na participado de mais de um curso, preencha \\
\hline
\end{tabular}

1) Indique sua área de atuação?

\begin{tabular}{|l|l|}
\hline$X$ & EXTENSÃO RURAL \\
\hline & PESQUISA \\
\hline$X$ & ENSINO \\
\hline & OUTROS \\
\hline
\end{tabular}

2) Qual o seu nível de escolaridade? (Considere apenas o nível mais alto) 


\begin{tabular}{|l|l|}
\hline & NÍVEL MÉDIO \\
\hline & NÍVEL SUPERIOR \\
\hline$X$ & PÓS-GRADUAÇÃO \\
\hline
\end{tabular}

3) Os conteúdos abordados foram condizentes com as demandas do seu dia-a-dia?

\begin{tabular}{|l|l|}
\hline & SIM \\
\hline$X$ & PARCIALMENTE \\
\hline & NÃO \\
\hline
\end{tabular}

4) O curso contribuiu para o seu aperfeiçoamento profissional?

\begin{tabular}{|l|l|}
\hline$X$ & SIM \\
\hline & NÃO \\
\hline
\end{tabular}

5) Os conhecimentos adquiridos estão sendo aplicados no seu trabalho? Em caso afirmativo, indique em que grau estes conhecimentos estão sendo aplicados. Em caso negativo, indique por que razão isto não ocorre: (Em caso negativo, as respostas não são excludentes: você poderá marcar mais de uma opção).

\begin{tabular}{|c|c|c|}
\hline \multirow{3}{*}{$\begin{array}{l}\text { SIM (indique ao lado em } \\
\text { que grau) }\end{array}$} & & MUITO APLICADOS \\
\hline & $\bar{x}$ & MEDIAMENTE APLICADOS \\
\hline & & POUCO APLICADOS \\
\hline \multirow{5}{*}{$\begin{array}{l}\text { NÃO (indique ao lado a } \\
\text { razão da não aplicação) }\end{array}$} & & $\begin{array}{l}\text { CONTEÚDO NÃO ADEQUADO ÀS NECESSIDADES } \\
\text { ESPECÍEICAS DA RFGIÃO }\end{array}$ \\
\hline & & $\begin{array}{llll}\text { CONTEUDO NÂO } & \text { FOI SUFICIENTEMENTE } \\
\text { APROFUNDADO PARA } & \text { PERMITIR UMA APLICAÇÃO }\end{array}$ \\
\hline & & \begin{tabular}{lcccccc|} 
FALTA & DE & APOIO & E & INCENTIVO & DA & MINHA \\
INSTITUICÃO & & & & & \\
\end{tabular} \\
\hline & & FALTA DE INCENTIVO ÀS AÇÕES DE ATER \\
\hline & & NÃO TENHO INTERESSE EM APLICAR \\
\hline
\end{tabular}


6) A partir deste curso: (As respostas não são excludentes: você poderá marcar mais de uma opção).

\begin{tabular}{|l|l|}
\hline$x$ & $\begin{array}{l}\text { NẼO MUDOU NADA EM MEU TRABALHO. } \\
\text { FAMILIARES. }\end{array}$ \\
\hline & CONSEGUI INFLUENCIAR NAS ORIENTAÇÕES DA MINHA INSTITUIÇÃO. \\
\hline & PASSEI A TRABALHAR COM METODOLOGIAS PARTICIPATIVAS. \\
\hline & \begin{tabular}{l} 
ORESCEU A ÁREA DE AGRICULTURA DE BASE ECOLÓGICA NAS COMUNIDADES \\
\hline
\end{tabular} \\
\hline
\end{tabular}

7) Depois do curso você apoiou atividades de capacitação de técnicos e agricultores com base nos princípios e diretrizes da Pnater? (Considere como apoio a atividades de capacitação a participação no planejamento, elaboração de ementas, seleção de participantes e de palestrantes.)

\begin{tabular}{|l|l|}
\hline$X$ & SIM \\
\hline & NÃO \\
\hline
\end{tabular}

8) Usou os conhecimentos para ministrar outros cursos com o mesmo conteúdo ou conteúdos semelhantes?

\begin{tabular}{|l|l|}
\hline & SIM \\
\hline$X$ & NÃO \\
\hline
\end{tabular}

9) Marque o seu grau de satisfação com relação ao curso oferecido pelo DATER:

\begin{tabular}{|l|l|l|l|l|}
\hline 1 & 2 & 3 & 4 & 5 \\
\hline
\end{tabular}

10) Marque seu grau de satisfação com relação ao DATER: 


\begin{tabular}{|l|l|l|l|l|}
\hline 1 & 2 & 3 & 4 & 5 \\
\hline
\end{tabular}


PESQUISA - IMPACTO DAS AÇÕES DE FORMAÇÃO REALIZADAS PELO DATER/SAF/MDA NO PERÍODO 2004-2009

Caros colaboradores,

Contamos com a sua atenção para preencher o formulário abaixo.

O mesmo tem por objetivo fornecer informações para avaliação da Eficiência, Efetividade e Eficácia da Política Pública de Formação de Agentes de Ater adotada pelo Departamento de Assistência Técnica e Extensão Rural, da Secretaria de Agricultura Familiar do Ministério do Desenvolvimento - DATER/SAF/MDA, no período de 2004 a 2009, tema escolhido para Monografia a ser apresentada à Universidade de Brasília (UnB) como requisito parcial para obtenção do grau de Bacharel em Administração.

Você poderá ou não se identificar no questionário e garantimos que todas as informações fornecidas serão confidenciais e utilizadas apenas de forma sistematizada.

\section{IDENTIFICAÇÃO}

\begin{tabular}{|c|c|}
\hline Nome:EDNA FERREIRA ROSA & $\begin{array}{l}\text { Sexo: } \\
(\quad) \text { masculino }\end{array}$ \\
\hline $\begin{array}{l}\text { Instituição (nome e tipo de instituição: ONG, } \\
\text { Empresa Pública, etc.):Agencia Goiana de } \\
\text { Desenvolvimento Rural e Fundiário- } \\
\text { Autarquia }\end{array}$ & $\begin{array}{l}\text { Local de trabalho (Cidade e Estado): } \\
\text { Goiania-Go }\end{array}$ \\
\hline \multicolumn{2}{|c|}{$\begin{array}{l}\text { Curso/Encontro/Oficina do qual participou (caso tenha participado de mais de um curso, } \\
\text { preencha um formulário para cada um deles):Extensão Rural para o Desenvolvimento } \\
\text { Sustentável-Curso de especialização }\end{array}$} \\
\hline \multicolumn{2}{|c|}{$\begin{array}{l}\text { Data do Curso/Encontro/Oficina (pelo menos mês e ano): } \\
\text { Julho/2006 }\end{array}$} \\
\hline
\end{tabular}

1) Indique sua área de atuação? (As opções não são excludentes: você poderá marcar mais de uma opção).

\begin{tabular}{|l|l|}
\hline$X$ & EXTENSÃO RURAL \\
\hline & PESQUISA \\
\hline & ENSINO \\
\hline
\end{tabular}




\section{OUTROS}

2) Qual o seu nível de escolaridade? (Considere apenas o nível mais alto)

\begin{tabular}{|l|l|}
\hline & NÍVEL MÉDIO \\
\hline$X$ & NÍVEL SUPERIOR \\
\hline & PÓS-GRADUAÇÃO \\
\hline
\end{tabular}

3) Os conteúdos abordados foram condizentes com as demandas do seu dia-a-dia?

\begin{tabular}{|l|l|}
\hline$X$ & SIM \\
\hline & PARCIALMENTE \\
\hline & NÃO \\
\hline
\end{tabular}

3) O curso contribuiu para o seu aperfeiçoamento profissional?

\begin{tabular}{|l|l|}
\hline$X$ & SIM \\
\hline NÃO \\
\hline
\end{tabular}

5) Os conhecimentos adquiridos estão sendo aplicados no seu trabalho? Em caso afirmativo, indique em que grau estes conhecimentos estão sendo aplicados. Em caso negativo, indique por que razão isto não ocorre: (As respostas não são excludentes: você poderá marcar mais de uma opção).

\begin{tabular}{|c|c|c|}
\hline \multirow{3}{*}{$\begin{array}{l}\text { SIM (indique ao lado } \\
\text { em que grau) }\end{array}$} & $\mathrm{X}$ & MUITO APLICADOS \\
\hline & & MEDIAMENTE APLICADOS \\
\hline & & POUCO APLICADOS \\
\hline \multirow{5}{*}{$\begin{array}{l}\text { NÃO (indique ao lado } \\
\text { a razão da não } \\
\text { aplicação) }\end{array}$} & & $\begin{array}{l}\text { CONTEÚDO NÃO ADEQUADO ÀS NECESSIDADES } \\
\text { FSPFCÍFICASA }\end{array}$ \\
\hline & & CONTEÚDO NÂO FOI SUFICIENTEMENTE \\
\hline & & APROFUNDADO PARA PERMITIR UMA APLICAÇÃO \\
\hline & & $\begin{array}{l}\text { FALTA DE APOIO E } \\
\text { INSTITUICÃO }\end{array}$ \\
\hline & & FALTA DE INCENTIVO ÀS AÇÕES DE ATER \\
\hline
\end{tabular}


6) A partir deste curso: (As respostas não são excludentes: você poderá marcar mais de uma opção).

\begin{tabular}{|l|l|}
\hline$x$ & $\begin{array}{l}\text { NÃO MUDOU NADA EM MEU TRABALHO. } \\
\text { FAMILIARES. }\end{array}$ \\
\hline$X$ & CONSEGUI INFLUENCIAR NAS ORIENTAÇÕES DA MINHA INSTITUIÇÃO. \\
\hline & PASSEI A TRABALHAR COM METODOLOGIAS PARTICIPATIVAS. \\
\hline & $\begin{array}{l}\text { CRESCEU A ÁREA DE AGRICULTURA DE BASE ECOLÓGICA NAS COMUNIDADES } \\
\text { ONDE ATUO. }\end{array}$ \\
\hline$X$ & CONTINUEI ME APERFEIÇOANDO SOBRE TEMAS ABORDADOS. \\
\hline
\end{tabular}

7) Depois do curso você apoiou atividades de capacitação de técnicos e agricultores com base nos princípios e diretrizes da Pnater? (Considere como apoio a atividades de capacitação a participação no planejamento, elaboração de ementas, seleção de participantes e de palestrantes.)

\begin{tabular}{|l|l|}
\hline$X$ & SIM \\
\hline & NÃO \\
\hline
\end{tabular}

8) Usou os conhecimentos para ministrar outros cursos com o mesmo conteúdo ou conteúdos semelhantes?

\begin{tabular}{|l|l|}
\hline$X$ & SIM \\
\hline & NÃO \\
\hline
\end{tabular}

9) Marque o seu grau de satisfação com relação ao curso oferecido pelo DATER: (Considere a seguinte pontuação: 1 - MUITO RUIM; 2 - RUIM; 3 - REGULAR; 4 - BOM; 5 - MUITO BOM)

\begin{tabular}{|l|l|l|l|l|}
\hline 1 & 2 & 3 & 4 & $\underline{5 X}$ \\
\hline
\end{tabular}


10) Marque seu grau de satisfação com relação ao DATER: (Considere a seguinte pontuação: 1 - MUITO RUIM; 2 - RUIM; 3 - REGULAR; 4 - BOM; 5 - MUITO BOM)

\begin{tabular}{|l|l|l|l|l|}
\hline 1 & 2 & 3 & 4 & $\underline{5}$ \\
\hline
\end{tabular}


PESQUISA - IMPACTO DAS AÇÕES DE FORMAÇÃO REALIZADAS PELO DATER/SAF/MDA NO PERÍODO 2004-2009

Caros colaboradores,

Contamos com a sua atenção para preencher o formulário abaixo.

O mesmo tem por objetivo fornecer informações para avaliação da Eficiência, Efetividade e Eficácia da Política Pública de Formação de Agentes de Ater adotada pelo Departamento de Assistência Técnica e Extensão Rural, da Secretaria de Agricultura Familiar do Ministério do Desenvolvimento - DATER/SAF/MDA, no período de 2004 a 2009, tema escolhido para Monografia a ser apresentada à Universidade de Brasília (UnB) como requisito parcial para obtenção do grau de Bacharel em Administração.

Você poderá ou não se identificar no questionário e garantimos que todas as informações fornecidas serão confidenciais e utilizadas apenas de forma sistematizada.

\section{IDENTIFICAÇÃO}

Nome:
JOANA D'ARC DE GODOY

Indique sua área de atuação? (As respostas não são excludentes: você poderá marcar mais de uma opção).

\begin{tabular}{|l|l|}
\hline$X$ & EXTENSÃO RURAL \\
\hline
\end{tabular}




\begin{tabular}{|l|l|}
\hline & PESQUISA \\
\hline$X$ & ENSINO \\
\hline & OUTROS \\
\hline
\end{tabular}

2) Qual o seu nível de escolaridade? (Considere apenas o nível mais alto)

\begin{tabular}{|l|l|}
\hline & NÍVEL MÉDIO \\
\hline$X$ & NÍVEL SUPERIOR \\
\hline & PÓS-GRADUAÇÃO \\
\hline
\end{tabular}

3) Os conteúdos abordados foram condizentes com as demandas do seu dia-a-dia?

\begin{tabular}{|l|l|}
\hline$X$ & SIM \\
\hline & PARCIALMENTE \\
\hline & NÃO \\
\hline
\end{tabular}

4) O curso contribuiu para o seu aperfeiçoamento profissional?

\begin{tabular}{|l|l|}
\hline$X$ & SIM \\
\hline & NÃO \\
\hline
\end{tabular}

5) Os conhecimentos adquiridos estão sendo aplicados no seu trabalho? Em caso afirmativo, indique em que grau estes conhecimentos estão sendo aplicados. Em caso negativo, indique por que razão isto não ocorre: (As respostas não são excludentes: você poderá marcar mais de uma opção).

\begin{tabular}{|l|l|l|}
\hline \multirow{2}{*}{$\begin{array}{l}\text { SIM (indique ao lado em } \\
\text { que grau) }\end{array}$} & $X$ & MUITO APLICADOS \\
\cline { 2 - 3 } & & MEDIAMENTE APLICADOS \\
\cline { 2 - 3 } & & POUCO APLICADOS \\
\hline
\end{tabular}




\begin{tabular}{|c|c|}
\hline \multirow{5}{*}{$\begin{array}{l}\text { NÃO (indique ao lado a } \\
\text { razão da não aplicação) }\end{array}$} & $\begin{array}{l}\text { CONTEÚDO NÃO ADEQUADO ÀS NECESSIDADES } \\
\text { ESPECÍFICAS DA REGIÃO }\end{array}$ \\
\hline & $\begin{array}{l}\text { CONTEÚDO NÃO } \text { FOI SUFICIENTEMENTE } \\
\text { APROFUNDADO PARA } \\
\text { PERMITIR UMA APLICAÇÃO } \\
\text { EFICAZ E EFICIENTE }\end{array}$ \\
\hline & $\begin{array}{lllllll}\text { FALTA DE } & \text { APOIO } & \text { E } & \text { INCENTIVO } & \text { DA } & \text { MINHA } \\
\text { INSTITUIÇÃO } & & & & & \end{array}$ \\
\hline & FALTA DE INCENTIVO ÀS AÇÕES DE ATER \\
\hline & NÃO TENHO INTERESSE EM APLICAR \\
\hline
\end{tabular}

6) A partir deste curso: (As respostas não são excludentes: você poderá marcar mais de uma opção).

\begin{tabular}{|l|l|}
\hline & NÃO MUDOU NADA EM MEU TRABALHO. \\
\hline$X$ & $\begin{array}{l}\text { MEU TRABALHO PASSOU A CONTRIBUIR MAIS COM OS AGRICULTORES(AS) } \\
\text { FAMILIARES. }\end{array}$ \\
\hline $\mathrm{X}$ & CONSEGUI INFLUENCIAR NAS ORIENTAÇÕES DA MINHA INSTITUIÇÃO. \\
\hline & $\begin{array}{l}\text { CRESCEU A ÁREA DE AGRICULTURA DE BASE ECOLÓGICA NAS COMUNIDADES } \\
\text { ONDE ATUO. }\end{array}$ \\
\hline$X$ & CONTINUEI ME APERFEIÇOANDO SOBRE TEMAS ABORDADOS. \\
\hline
\end{tabular}

7) Depois do curso você apoiou atividades de capacitação de técnicos e agricultores com base nos princípios e diretrizes da Pnater? (Considere como apoio a atividades de capacitação a participação no planejamento, elaboração de ementas, seleção de participantes e de palestrantes.)

\begin{tabular}{|l|l|}
\hline$X$ & SIM \\
\hline & NÃO \\
\hline
\end{tabular}


8) Usou os conhecimentos para ministrar outros cursos com o mesmo conteúdo ou conteúdos semelhantes?

\begin{tabular}{|l|l|}
\hline$X$ & SIM \\
\hline & NÃO \\
\hline
\end{tabular}

9) Marque o seu grau de satisfação com relação ao curso oferecido pelo DATER: (Considere a seguinte pontuação: 1 - MUITO RUIM; 2 - RUIM; 3 - REGULAR; 4 - BOM; 5 - MUITO BOM)

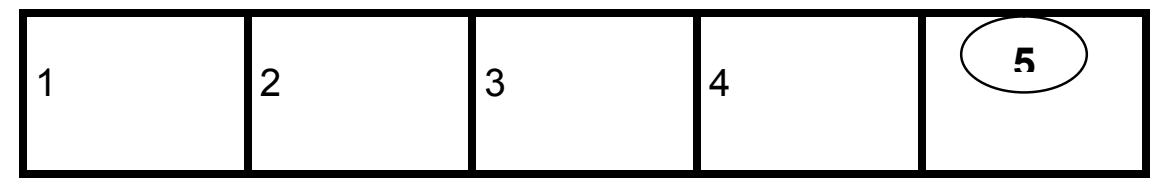

10) Marque seu grau de satisfação com relação ao DATER: (Considere a seguinte pontuação: 1 - MUITO RUIM; 2 - RUIM; 3 - REGULAR; 4 - BOM; 5 - MUITO BOM)

\begin{tabular}{|l|l|l|l|l|}
\hline 1 & 2 & 3 & 4 & 5 \\
\hline
\end{tabular}


PESQUISA - IMPACTO DAS AÇÕES DE FORMAÇÃO REALIZADAS PELO DATER/SAF/MDA NO PERÍODO 2004-2009

Caros colaboradores,

Contamos com a sua atenção para preencher o formulário abaixo.

O mesmo tem por objetivo fornecer informações para avaliação da Eficiência, Efetividade e Eficácia da Política Pública de Formação de Agentes de Ater adotada pelo Departamento de Assistência Técnica e Extensão Rural, da Secretaria de Agricultura Familiar do Ministério do Desenvolvimento - DATER/SAF/MDA, no período de 2004 a 2009, tema escolhido para Monografia a ser apresentada à Universidade de Brasília (UnB) como requisito parcial para obtenção do grau de Bacharel em Administração.

Você poderá ou não se identificar no questionário e garantimos que todas as informações fornecidas serão confidenciais e utilizadas apenas de forma sistematizada.

\section{IDENTIFICAÇÃO}

Nome: (opcional)

Jovelina Maria de Oliveira

Instituição (nome e tipo de instituição: ONG, Local de trabalho (Cidade e Estado):

Empresa Pública, Cooperativa,etc.):

Campo Grande MS

AGRAER

Curso/Encontro/Oficina do qual participou (caso tenha participado de mais de um evento de formação, preencha um formulário para cada um deles):

Oficina de sistematização de experiências

Data do Curso/Encontro/Oficina/Seminário (pelo menos mês e ano): 2008

1) Indique sua área de atuação? (As opções não são excludentes: você poderá marcar mais de uma opção).

\begin{tabular}{|l|l|}
\hline & EXTENSÃO RURAL \\
\hline & PESQUISA \\
\hline & ENSINO \\
\hline$x$ & OUTROS \\
\hline
\end{tabular}


2) Qual o seu nível de escolaridade? (Considere apenas o nível mais alto)

\begin{tabular}{|l|l|}
\hline & NÍVEL MÉDIO \\
\hline & NÍVEL SUPERIOR \\
\hline$x$ & PÓS-GRADUAÇÃO \\
\hline
\end{tabular}

3) Os conteúdos abordados na formação foram condizentes com as demandas do seu dia-adia?

\begin{tabular}{|l|l|}
\hline & SIM \\
\hline$x$ & PARCIALMENTE \\
\hline & NÃO \\
\hline
\end{tabular}

4) O curso ou atividade de formação da qual você participou contribuiu para o seu aperfeiçoamento profissional?

\begin{tabular}{|l|l|}
\hline$x$ & SIM \\
\hline & NÃO \\
\hline
\end{tabular}

5) Os conhecimentos adquiridos nesta formação estão sendo aplicados no seu trabalho? Em caso afirmativo, indique em que grau estes conhecimentos estão sendo aplicados. Em caso negativo, indique por que razão isto não ocorre: (As respostas não são excludentes: você poderá marcar mais de uma opção).

\begin{tabular}{|c|c|c|}
\hline \multirow{3}{*}{$\begin{array}{l}\text { SIM (indique ao lado } \\
\text { em que grau) }\end{array}$} & & MUITO APLICADOS \\
\hline & & MEDIAMENTE APLICADOS \\
\hline & & POUCO APLICADOS \\
\hline \multirow{3}{*}{$\begin{array}{l}\text { NÃO (indique ao lado a } \\
\text { razão da não } \\
\text { aplicação) }\end{array}$} & & $\begin{array}{l}\text { CONTEÚDO NÃO ADEQUADO ÀS NECESSIDADES } \\
\text { ESPECÍFICAS DA REGIÃO }\end{array}$ \\
\hline & & $\begin{array}{lccc}\text { CONTEÚDO NÃO } & \text { FOI } & \text { SUFICIENTEMENTE } \\
\text { APROFUNDADO } & \text { PARA } & \text { PERMITIR } & \text { UMA } \\
\text { APLICAÇÃO EFICAZ E EFICIENTE } & \end{array}$ \\
\hline & $\mathrm{X}$ & \begin{tabular}{|llllll} 
FALTA DE APOIO & E & INCENTIVO & DA & MINHA \\
INSTITUIÇÃO & & & & &
\end{tabular} \\
\hline
\end{tabular}




\begin{tabular}{|l|l|l|l|}
\hline \multirow{2}{*}{} & $x$ & FALTA DE INCENTIVO ÀS AÇÕES DE ATER \\
\cline { 3 - 4 } & & NÃO TENHO INTERESSE EM APLICAR \\
\hline
\end{tabular}

6) A partir do evento de formação do qual você participou: (As respostas não são excludentes: você poderá marcar mais de uma opção).

\begin{tabular}{|l|l|}
\hline & NÃO MUDOU NADA EM MEU TRABALHO. \\
\hline & $\begin{array}{l}\text { MEU TRABALHO PASSOU A CONTRIBUIR MAIS COM OS AGRICULTORES(AS) } \\
\text { FAMILIARES. }\end{array}$ \\
\hline$x$ & CONSEGUI INFLUENCIAR NAS ORIENTAÇÕES DA MINHA INSTITUIÇÃO. \\
\hline & $\begin{array}{l}\text { CRESSEI A TRABALHAR COM METODOLOGIAS PARTICIPATIVAS. } \\
\text { COMUNIDADES OAREA DE AGRICULTURA DE BASE ECOLÓGICA NAS }\end{array}$ \\
\hline & BONTINUEI ME APERFEIÇOANDO SOBRE TEMAS ABORDADOS. \\
\hline
\end{tabular}

7) Depois do evento de capacitação do qual participou, você apoiou atividades de capacitação de técnicos e/ou agricultores com base nos princípios e diretrizes da Pnater?

\begin{tabular}{|l|l|}
\hline$X$ & SIM \\
\hline & NÃO \\
\hline
\end{tabular}

8) Usou os conhecimentos para ministrar outros eventos de formação com o mesmo conteúdo ou conteúdos semelhantes?

\begin{tabular}{|l|l|}
\hline & SIM \\
\hline$X$ & NÃO \\
\hline
\end{tabular}

9) Marque o seu grau de satisfação com relação a atividade de formação oferecida pelo DATER: (Considere a seguinte pontuação: 1 - MUITO RUIM; 2 - RUIM; 3 - REGULAR; 4 BOM; 5 - MUITO BOM)

\begin{tabular}{|l|l|l|l|l|}
\hline 1 & 2 & 3 & $4 x$ & 5 \\
\hline
\end{tabular}


10) Marque seu grau de satisfação com relação ao DATER: (Considere a seguinte pontuação: 1 - MUITO RUIM; 2 - RUIM; 3 - REGULAR; 4 - BOM; 5 - MUITO BOM)

\begin{tabular}{|l|l|l|l|l|}
\hline 1 & 2 & 3 & $4 x$ & 5 \\
\hline
\end{tabular}


PESQUISA - IMPACTO DAS AÇÕES DE FORMAÇÃO REALIZADAS PELO DATER/SAF/MDA NO PERÍODO 2004-2009

Caros colaboradores,

Contamos com a sua atenção para preencher o formulário abaixo.

O mesmo tem por objetivo fornecer informações para avaliação da Eficiência, Efetividade e Eficácia da Política Pública de Formação de Agentes de Ater adotada pelo Departamento de Assistência Técnica e Extensão Rural, da Secretaria de Agricultura Familiar do Ministério do Desenvolvimento - DATER/SAF/MDA, no período de 2004 a 2009, tema escolhido para Monografia a ser apresentada à Universidade de Brasília (UnB) como requisito parcial para obtenção do grau de Bacharel em Administração.

Você poderá ou não se identificar no questionário e garantimos que todas as informações fornecidas serão confidenciais e utilizadas apenas de forma sistematizada.

\section{IDENTIFICAÇÃO}

\begin{tabular}{|c|c|}
\hline Nome: Juliana Elisa Napolitano & $\begin{array}{l}\text { Sexo: } \\
(\quad) \text { masculino }\end{array}$ \\
\hline $\begin{array}{l}\text { Instituição (nome e tipo de instituição: ONG, } \\
\text { Empresa Pública, etc.): Fundo Nacional do Meio } \\
\text { Ambiente- Ministério do Meio Ambiente }\end{array}$ & $\begin{array}{l}\text { Local de trabalho (Cidade e Estado): } \\
\text { Brasília-DF }\end{array}$ \\
\hline \multicolumn{2}{|c|}{$\begin{array}{l}\text { Curso/Encontro/Oficina do qual participou (caso tenha participado de mais de um curso, preencha } \\
\text { um formulário para cada um deles): Curso de Aperfeiçoamento em Agroecologia }\end{array}$} \\
\hline
\end{tabular}

1) Indique sua área de atuação? (As opções não são excludentes: você poderá marcar mais de uma opção).

\begin{tabular}{|l|l|}
\hline & EXTENSÃO RURAL \\
\hline & PESQUISA \\
\hline & ENSINO \\
\hline$x$ & OUTROS \\
\hline
\end{tabular}


2) Qual o seu nível de escolaridade? Considere apenas o nível mais alto)

\begin{tabular}{|l|l|}
\hline & NÍVEL MÉDIO \\
\hline$X$ & NÍVEL SUPERIOR \\
\hline & PÓS-GRADUAÇÃO \\
\hline
\end{tabular}

3) Os conteúdos abordados foram condizentes com as demandas do seu dia-a-dia?

\begin{tabular}{|l|l|}
\hline & SIM \\
\hline$X$ & PARCIALMENTE \\
\hline & NÃO \\
\hline
\end{tabular}

4) O curso contribuiu para o seu aperfeiçoamento profissional?

\begin{tabular}{|l|l|}
\hline$X$ & SIM \\
\hline & NÃO \\
\hline
\end{tabular}

5) Os conhecimentos adquiridos estão sendo aplicados no seu trabalho? Em caso afirmativo, indique em que grau estes conhecimentos estão sendo aplicados. Em caso negativo, indique por que razão isto não ocorre: (As respostas não são excludentes: você poderá marcar mais de uma opção).

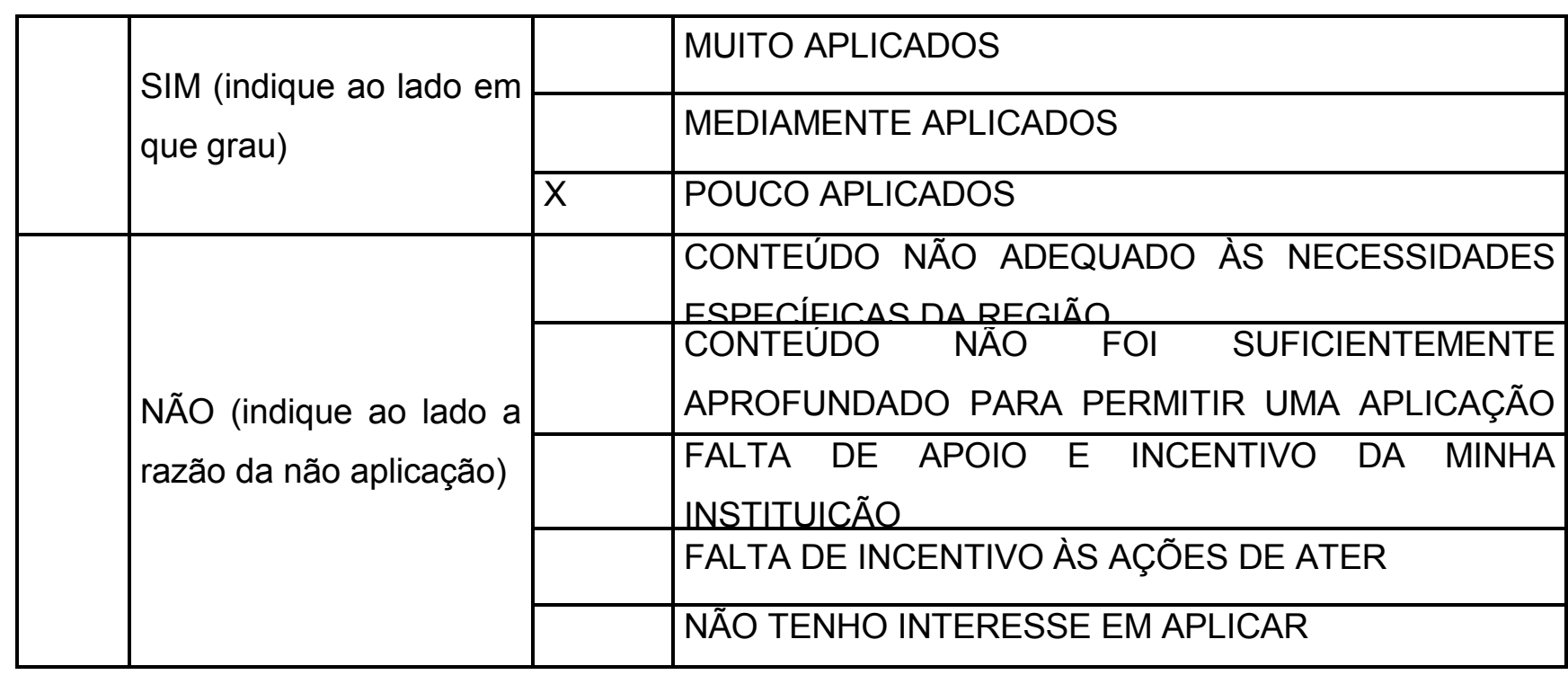


6) A partir deste curso: (As respostas não são excludentes: você poderá marcar mais de uma opção).

\begin{tabular}{|l|l|}
\hline & NÃO MUDOU NADA EM MEU TRABALHO. \\
\hline & $\begin{array}{l}\text { MEU TRABALHO PASSOU A CONTRIBUIR MAIS COM OS AGRICULTORES(AS) } \\
\text { FAMILIARES. }\end{array}$ \\
\hline & CONSEGUI INFLUENCIAR NAS ORIENTAÇÕES DA MINHA INSTITUIÇÃO. \\
\hline & $\begin{array}{l}\text { CRASSEI A TRABALHAR COM METODOLOGIAS PARTICIPATIVAS. } \\
\text { ONDE ATUO. ÁREA DE AGRICULTURA DE BASE ECOLÓGICA NAS COMUNIDADES }\end{array}$ \\
\hline$X$ & CONTINUEI ME APERFEIÇOANDO SOBRE TEMAS ABORDADOS. \\
\hline
\end{tabular}

7) Depois do curso você apoiou atividades de capacitação de técnicos e agricultores com base nos princípios e diretrizes da Pnater? (Considere como apoio a atividades de capacitação a participação no planejamento, elaboração de ementas, seleção de participantes e de palestrantes.)

\begin{tabular}{|l|l|}
\hline$X$ & SIM \\
\hline & NÃO \\
\hline
\end{tabular}

8) Usou os conhecimentos para ministrar outros cursos com o mesmo conteúdo ou conteúdos semelhantes?

\begin{tabular}{|l|l|}
\hline & SIM \\
\hline$X$ & NÃO \\
\hline
\end{tabular}

9) Marque o seu grau de satisfação com relação ao curso oferecido pelo DATER: (Considere a seguinte pontuação: 1 - MUITO RUIM; 2 - RUIM; 3 - REGULAR; 4 - BOM; 5 - MUITO BOM)

\begin{tabular}{|l|l|l|l|l|}
\hline 1 & 2 & 3 & $X 4$ & 5 \\
\hline
\end{tabular}


10) Marque seu grau de satisfação com relação ao DATER: (Considere a seguinte pontuação: 1 - MUITO RUIM; 2 - RUIM; 3 - REGULAR; 4 - BOM; 5 - MUITO BOM)

\begin{tabular}{|l|l|l|l|l|}
\hline 1 & 2 & 3 & 4 & $\times 5$ \\
\hline
\end{tabular}


PESQUISA - IMPACTO DAS AÇÕES DE FORMAÇÃO REALIZADAS PELO DATER/SAF/MDA NO PERÍODO 2004-2009

Caros colaboradores,

Contamos com a sua atenção para preencher o formulário abaixo.

O mesmo tem por objetivo fornecer informações para avaliação da Eficiência, Efetividade e Eficácia da Política Pública de Formação de Agentes de Ater adotada pelo Departamento de Assistência Técnica e Extensão Rural, da Secretaria de Agricultura Familiar do Ministério do Desenvolvimento - DATER/SAF/MDA, no período de 2004 a 2009, tema escolhido para Monografia a ser apresentada à Universidade de Brasília (UnB) como requisito parcial para obtenção do grau de Bacharel em Administração.

Você poderá ou não se identificar no questionário e garantimos que todas as informações fornecidas serão confidenciais e utilizadas apenas de forma sistematizada.

\section{IDENTIFICAÇÃO}

\begin{tabular}{|l|l|}
\hline $\begin{array}{l}\text { Nome: } \\
\text { Marçal Euzébio de Morais }\end{array}$ & $(\mathrm{x})$ masculino $\quad(\quad$ ) feminino \\
\hline $\begin{array}{l}\text { Instituição (nome e tipo de instituição: ONG, } \\
\text { Empresa Pública, etc.): } \\
\text { Solução Agronegócios }\end{array}$ & $\begin{array}{l}\text { Local de trabalho (Cidade e Estado): } \\
\text { Goiânia - Go }\end{array}$ \\
\hline $\begin{array}{l}\text { Curso/Encontro/Oficina do qual participou (caso tenha participado de mais de um curso, preencha } \\
\text { um formulário para cada um deles): } \\
\text { Aperfeiçoamento em Agroecologia }\end{array}$ \\
\hline $\begin{array}{l}\text { Data do Curso/Encontro/Oficina (pelo menos mês e ano): } \\
\text { Março a agosto de 2007 }\end{array}$ \\
\hline
\end{tabular}

Indique sua área de atuação? (As opções não são excludentes: você poderá marcar mais de uma opção).

\begin{tabular}{|l|l|}
\hline & EXTENSÃO RURAL \\
\hline & PESQUISA \\
\hline & ENSINO \\
\hline
\end{tabular}




\section{\begin{tabular}{|l|l}
\hline$x$ & OUTROS
\end{tabular}}

2) Qual o seu nível de escolaridade? Considere apenas o nível mais alto)

\begin{tabular}{|l|l|}
\hline & NÍVEL MÉDIO \\
\hline$x$ & NÍVEL SUPERIOR \\
\hline & PÓS-GRADUAÇÃO \\
\hline
\end{tabular}

3) Os conteúdos abordados foram condizentes com as demandas do seu dia-a-dia?

\begin{tabular}{|l|l|}
\hline & SIM \\
\hline$x$ & PARCIALMENTE \\
\hline & NÃO \\
\hline
\end{tabular}

3) O curso contribuiu para o seu aperfeiçoamento profissional?

\begin{tabular}{|l|l|}
\hline$x$ & SIM \\
\hline & NÃO \\
\hline
\end{tabular}

5) Os conhecimentos adquiridos estão sendo aplicados no seu trabalho? Em caso afirmativo, indique em que grau estes conhecimentos estão sendo aplicados. Em caso negativo, indique por que razão isto não ocorre: (As respostas não são excludentes: você poderá marcar mais de uma opção).

\begin{tabular}{|c|c|c|c|}
\hline & \multirow{3}{*}{$\begin{array}{l}\text { SIM (indique ao lado em } \\
\text { que grau) }\end{array}$} & & MUITO APLICADOS \\
\hline & & & MEDIAMENTE APLICADOS \\
\hline & & & POUCO APLICADOS \\
\hline \multirow[t]{2}{*}{$x$} & \multirow[t]{2}{*}{$\begin{array}{l}\text { NÃO (indique ao lado a } \\
\text { razão da não aplicação) }\end{array}$} & & 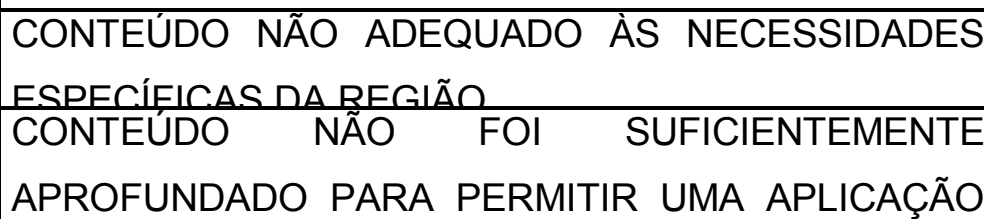 \\
\hline & & $\bar{x}$ & \begin{tabular}{|lcccccc} 
FALTA & DE & APOIO & E & INCENTIVO & DA & MINHA \\
INSTITUICÃO & & & & \\
\end{tabular} \\
\hline
\end{tabular}




\begin{tabular}{|l|l|l|l|}
\hline \multirow{2}{*}{} & \multirow{2}{*}{} & & FALTA DE INCENTIVO ÀS AÇÕES DE ATER \\
\cline { 3 - 3 } & & NÃO TENHO INTERESSE EM APLICAR \\
\hline
\end{tabular}

6) A partir deste curso: (As opções não são excludentes: você poderá marcar mais de uma opção).

\begin{tabular}{|l|l|}
\hline$x$ & NÃO MUDOU NADA EM MEU TRABALHO. \\
\hline & $\begin{array}{l}\text { MEU TRABALHO PASSOU A CONTRIBUIR MAIS COM OS AGRICULTORES(AS) } \\
\text { FAMILIARES. }\end{array}$ \\
\hline & CONSEGUI INFLUENCIAR NAS ORIENTAÇÕES DA MINHA INSTITUIÇÃO. \\
\hline & PASSEI A TRABALHAR COM METODOLOGIAS PARTICIPATIVAS. \\
\hline & $\begin{array}{l}\text { CRESCEU A AREA DE AGRICULTURA DE BASE ECOLOGICA NAS COMUNIDADES } \\
\text { ONDE ATUO. }\end{array}$ \\
\hline & CONTINUEI ME APERFEIÇOANDO SOBRE TEMAS ABORDADOS. \\
\hline
\end{tabular}

7) Depois do curso você apoiou atividades de capacitação de técnicos e agricultores com base nos princípios e diretrizes da Pnater? (Considere como apoio a atividades de capacitação a participação no planejamento, elaboração de ementas, seleção de participantes e de palestrantes.)

\begin{tabular}{|l|l|}
\hline & SIM \\
\hline$x$ & NÃO \\
\hline
\end{tabular}

8) Usou os conhecimentos para ministrar outros cursos com o mesmo conteúdo ou conteúdos semelhantes?

\begin{tabular}{|l|l|}
\hline & SIM \\
\hline$x$ & NÃO \\
\hline
\end{tabular}

9) Marque o seu grau de satisfação com relação ao curso oferecido pelo DATER: (Considere a seguinte pontuação: 1 - MUITO RUIM; 2 - RUIM; 3 - REGULAR; 4 - BOM; 5 - MUITO BOM) 


\begin{tabular}{|l|l|l|l|l|}
\hline 1 & 2 & 3 & $x 4$ & 5 \\
\hline
\end{tabular}

10) Marque seu grau de satisfação com relação ao DATER: (Considere a seguinte pontuação: 1 - MUITO RUIM; 2 - RUIM; 3 - REGULAR; 4 - BOM; 5 - MUITO BOM)

\begin{tabular}{|l|l|l|l|l|}
\hline 1 & $\mathrm{x} 2$ & 3 & 4 & 5 \\
\hline
\end{tabular}


PESQUISA - IMPACTO DAS AÇÕES DE FORMAÇÃO REALIZADAS PELO DATER/SAF/MDA NO PERÍODO 2004-2009

Caros colaboradores,

Contamos com a sua atenção para preencher o formulário abaixo.

O mesmo tem por objetivo fornecer informações para avaliação da Eficiência, Efetividade e Eficácia da Política Pública de Formação de Agentes de Ater adotada pelo Departamento de Assistência Técnica e Extensão Rural, da Secretaria de Agricultura Familiar do Ministério do Desenvolvimento - DATER/SAF/MDA, no período de 2004 a 2009, tema escolhido para Monografia a ser apresentada à Universidade de Brasília (UnB) como requisito parcial para obtenção do grau de Bacharel em Administração.

Você poderá ou não se identificar no questionário e garantimos que todas as informações fornecidas serão confidenciais e utilizadas apenas de forma sistematizada.

\section{IDENTIFICAÇÃO}

Nome: (opcional)

Oriçanga de Bastos Júnior

Instituição (nome e tipo de instituição: ONG, Local de trabalho (Cidade e Estado):

\begin{tabular}{l|l} 
Empresa Pública, Cooperativa,etc.): & Terezópolis de Goiás
\end{tabular}

EMATER GO

Curso/Encontro/Oficina do qual participou (caso tenha participado de mais de um evento de formação, preencha um formulário para cada um deles):

Oficina de metodologia de trabalho em redes

Data do Curso/Encontro/Oficina/Seminário (pelo menos mês e ano): 2009

1) Indique sua área de atuação? (As opções não são excludentes: você poderá marcar mais de uma opção).

\begin{tabular}{|l|l|}
\hline$x$ & EXTENSÃO RURAL \\
\hline & PESQUISA \\
\hline & ENSINO \\
\hline & OUTROS \\
\hline
\end{tabular}


2) Qual o seu nível de escolaridade? (Considere apenas o nível mais alto)

\begin{tabular}{|l|l|}
\hline & NÍVEL MÉDIO \\
\hline$x$ & NÍVEL SUPERIOR \\
\hline & PÓS-GRADUAÇÃO \\
\hline
\end{tabular}

3) Os conteúdos abordados na formação foram condizentes com as demandas do seu dia-adia?

\begin{tabular}{|l|l|}
\hline$x$ & SIM \\
\hline & PARCIALMENTE \\
\hline & NÃO \\
\hline
\end{tabular}

4) O curso ou atividade de formação da qual você participou contribuiu para o seu aperfeiçoamento profissional?

\begin{tabular}{|l|l|}
\hline$x$ & SIM \\
\hline & NÃO \\
\hline
\end{tabular}

5) Os conhecimentos adquiridos nesta formação estão sendo aplicados no seu trabalho? Em caso afirmativo, indique em que grau estes conhecimentos estão sendo aplicados. Em caso negativo, indique por que razão isto não ocorre: (As respostas não são excludentes: você poderá marcar mais de uma opção).

\begin{tabular}{|c|c|c|}
\hline \multirow{3}{*}{$\begin{array}{l}\text { SIM (indique ao lado } \\
\text { em que grau) }\end{array}$} & $\mathrm{x}$ & MUITO APLICADOS \\
\hline & & MEDIAMENTE APLICADOS \\
\hline & & POUCO APLICADOS \\
\hline \multirow{3}{*}{$\begin{array}{l}\text { NÃO (indique ao lado a } \\
\text { razão da } \quad \text { não } \\
\text { aplicação) }\end{array}$} & & $\begin{array}{l}\text { CONTEÚDO NÃO ADEQUADO ÀS NECESSIDADES } \\
\text { ESPECÍFICAS DA REGIÃO }\end{array}$ \\
\hline & & $\begin{array}{lccc}\text { CONTEÚDO NÃO } & \text { FOI } & \text { SUFICIENTEMENTE } \\
\text { APROFUNDADO } & \text { PARA } & \text { PERMITIR } & \text { UMA } \\
\text { APLICAÇÃO EFICAZ E EFICIENTE } & \end{array}$ \\
\hline & & $\begin{array}{l}\text { FALTA DE APOIO E INCENTIVO DA } \text { MINHA } \\
\text { INSTITUIÇÃO }\end{array}$ \\
\hline
\end{tabular}




\begin{tabular}{|l|l|l|}
\hline \multirow{2}{*}{} & & FALTA DE INCENTIVO ÀS AÇÕES DE ATER \\
\cline { 3 - 4 } & & NÃO TENHO INTERESSE EM APLICAR \\
\hline
\end{tabular}

6) A partir do evento de formação do qual você participou: (As respostas não são excludentes: você poderá marcar mais de uma opção).

\begin{tabular}{|l|l|}
\hline & NÃO MUDOU NADA EM MEU TRABALHO. \\
\hline & $\begin{array}{l}\text { MEU TRABALHO PASSOU A CONTRIBUIR MAIS COM OS AGRICULTORES(AS) } \\
\text { FAMILIARES. }\end{array}$ \\
\hline & CONSEGUI INFLUENCIAR NAS ORIENTAÇÕES DA MINHA INSTITUIÇÃO. \\
\hline $\mathrm{x}$ & PASSEI A TRABALHAR COM METODOLOGIAS PARTICIPATIVAS. \\
\hline $\mathrm{x}$ & $\begin{array}{l}\text { CRESCEU A ÁREA DE AGRICULTURA DE BASE ECOLÓGICA NAS } \\
\text { COMUNIDADES ONDE ATUO. }\end{array}$ \\
\hline $\mathrm{x}$ & CONTINUEI ME APERFEIÇOANDO SOBRE TEMAS ABORDADOS. \\
\hline
\end{tabular}

7) Depois do evento de capacitação do qual participou, você apoiou atividades de capacitação de técnicos e/ou agricultores com base nos princípios e diretrizes da Pnater? (Considere como apoio a atividades de capacitação a participação no planejamento, elaboração de ementas, seleção de participantes e de palestrantes.)

\begin{tabular}{|l|l|}
\hline$X$ & SIM \\
\hline & NÃO \\
\hline
\end{tabular}

8) Usou os conhecimentos para ministrar outros eventos de formação com o mesmo conteúdo ou conteúdos semelhantes?

\begin{tabular}{|l|l|}
\hline$X$ & SIM \\
\hline & NÃO \\
\hline
\end{tabular}

9) Marque o seu grau de satisfação com relação a atividade de formação oferecida pelo DATER: (Considere a seguinte pontuação: 1 - MUITO RUIM; 2 - RUIM; 3 - REGULAR; 4 BOM; 5 - MUITO BOM) 


\begin{tabular}{|l|l|l|l|l|}
\hline 1 & 2 & 3 & 4 & $x 5$ \\
\hline
\end{tabular}

10) Marque seu grau de satisfação com relação ao DATER: (Considere a seguinte pontuação: 1 - MUITO RUIM; 2 - RUIM; 3 - REGULAR; 4 - BOM; 5 - MUITO BOM)

\begin{tabular}{|l|l|l|l|l|}
\hline 1 & 2 & 3 & 4 & $x 5$ \\
\hline
\end{tabular}


PESQUISA - IMPACTO DAS AÇÕES DE FORMAÇÃO REALIZADAS PELO DATER/SAF/MDA NO PERÍODO 2004-2009

Caros colaboradores,

Contamos com a sua atenção para preencher o formulário abaixo.

O mesmo tem por objetivo fornecer informações para avaliação da Eficiência, Efetividade e Eficácia da Política Pública de Formação de Agentes de Ater adotada pelo Departamento de Assistência Técnica e Extensão Rural, da Secretaria de Agricultura Familiar do Ministério do Desenvolvimento - DATER/SAF/MDA, no período de 2004 a 2009, tema escolhido para Monografia a ser apresentada à Universidade de Brasília (UnB) como requisito parcial para obtenção do grau de Bacharel em Administração.

Você poderá ou não se identificar no questionário e garantimos que todas as informações fornecidas serão confidenciais e utilizadas apenas de forma sistematizada.

\section{IDENTIFICAÇÃO}

\begin{tabular}{|l|l|}
\hline Nome: João Roberto Correia & $\begin{array}{l}\text { Sexo: } \\
(\mathrm{x}) \text { masculino } \quad(\quad \text { ) feminino }\end{array}$ \\
\hline $\begin{array}{l}\text { Instituição (nome e tipo de instituição: ONG, } \\
\text { Empresa Pública, etc.): Embrapa Cerrados }\end{array}$ & $\begin{array}{l}\text { Local de trabalho (Cidade e Estado): } \\
\text { Planaltina - DF }\end{array}$ \\
\hline $\begin{array}{l}\text { Curso/Encontro/Oficina do qual participou (caso tenha participado de mais de um curso, preencha } \\
\text { um formulário para cada um deles): Curso de Agroecologia - REDCAPA }\end{array}$ \\
\hline Data do Curso/Encontro/Oficina (pelo menos mês e ano): março 2006 \\
\hline
\end{tabular}

1) Indique sua área de atuação? (As opções não são excludentes: você poderá marcar mais de uma opção).

\begin{tabular}{|l|l|}
\hline & EXTENSÃO RURAL \\
\hline$X$ & PESQUISA \\
\hline & ENSINO \\
\hline & OUTROS \\
\hline
\end{tabular}


2) Qual o seu nível de escolaridade?( Considere apenas o nível mais alto)

\begin{tabular}{|l|l|}
\hline & NÍVEL MÉDIO \\
\hline & NÍVEL SUPERIOR \\
\hline$X$ & PÓS-GRADUAÇÃO \\
\hline
\end{tabular}

3) Os conteúdos abordados foram condizentes com as demandas do seu dia-a-dia?

\begin{tabular}{|l|l|}
\hline$X$ & SIM \\
\hline & PARCIALMENTE \\
\hline & NÃO \\
\hline
\end{tabular}

4) O curso contribuiu para o seu aperfeiçoamento profissional?

\begin{tabular}{|l|l|}
\hline$X$ & SIM \\
\hline & NÃO \\
\hline
\end{tabular}

5) Os conhecimentos adquiridos estão sendo aplicados no seu trabalho? Em caso afirmativo, indique em que grau estes conhecimentos estão sendo aplicados. Em caso negativo, indique por que razão isto não ocorre: (As respostas não são excludentes: você poderá marcar mais de uma opção).

\begin{tabular}{|l|l|l|l|}
\hline \multirow{2}{*}{$\begin{array}{l}\text { SIM (indique ao lado em } \\
\text { que grau) }\end{array}$} & $X$ & MUITO APLICADOS \\
\cline { 2 - 3 } & & MEDIAMENTE APLICADOS \\
\hline & $\begin{array}{l}\text { NĀO (indique ao lado a } \\
\text { razão da não aplicação) }\end{array}$ & $\begin{array}{l}\text { CONTEÚDO NÃO ADEQUADO ȦS NECESSIDADES } \\
\text { ESPECÍFICAS DA REGIÃO }\end{array}$ \\
\hline
\end{tabular}




\begin{tabular}{|l|l|l|}
\hline \multirow{10}{*}{} & $\begin{array}{l}\text { CONTEÚDO NÃO FOI SUFICIENTEMENTE } \\
\text { APROFUNDADO PARA PERMITIR UMA APLICAÇÃO } \\
\text { EFICAZ E EFICIENTE }\end{array}$ \\
\cline { 2 - 4 } & $\begin{array}{l}\text { FALTA DE APOIO E INCENTIVO DA MINHA } \\
\text { INSTITUIÇÃO }\end{array}$ \\
\cline { 2 - 4 } & FALTA DE INCENTIVO ÀS AÇÕES DE ATER \\
\hline & NÃO TENHO INTERESSE EM APLICAR \\
\hline
\end{tabular}

6) A partir deste curso: (As opções não são excludentes: você poderá marcar mais de uma opção).

\begin{tabular}{|l|l|}
\hline$x$ & $\begin{array}{l}\text { NÃO MUDOU NADA EM MEU TRABALHO. } \\
\text { FAMILIARES. }\end{array}$ \\
\hline & CONSEGUI INFLUENCIAR NAS ORIENTAÇÕES DA MINHA INSTITUIÇÃO. \\
\hline & PASSEI A TRABALHAR COM METODOLOGIAS PARTICIPATIVAS. \\
\hline & \begin{tabular}{l} 
CRESCEU A ÁREA DE AGRICULTURA DE BASE ECOLÓGICA NAS COMUNIDADES \\
ONDE ATUO. \\
\hline
\end{tabular} \\
\hline
\end{tabular}

7) Depois do curso você apoiou atividades de capacitação de técnicos e agricultores com base nos princípios e diretrizes da Pnater? (Considere como apoio a atividades de capacitação a participação no planejamento, elaboração de ementas, seleção de participantes e de palestrantes.)

\begin{tabular}{|l|l|}
\hline$X$ & SIM \\
\hline & NÃO \\
\hline
\end{tabular}

8) Usou os conhecimentos para ministrar outros cursos com o mesmo conteúdo ou conteúdos semelhantes? 


\begin{tabular}{|l|l|}
\hline & SIM \\
\hline$X$ & NÃO \\
\hline
\end{tabular}

9) Marque o seu grau de satisfação com relação ao curso oferecido pelo DATER: (Considere a seguinte pontuação: 1 - MUITO RUIM; 2 - RUIM; 3 - REGULAR; 4 - BOM; 5 - MUITO BOM)

\begin{tabular}{|l|l|l|l|l|}
\hline 1 & 2 & 3 & $x 4$ & 5 \\
\hline
\end{tabular}

10) Marque seu grau de satisfação com relação ao DATER: (Considere a seguinte pontuação: 1 - MUITO RUIM; 2 - RUIM; 3 - REGULAR; 4 - BOM; 5 - MUITO BOM)

\begin{tabular}{|l|l|l|l|l|}
\hline 1 & 2 & 3 & $X 4$ & 5 \\
\hline
\end{tabular}


PESQUISA - IMPACTO DAS AÇÕES DE FORMAÇÃO REALIZADAS PELO DATER/SAF/MDA NO PERÍODO 2004-2009

Caros colaboradores,

Contamos com a sua atenção para preencher o formulário abaixo.

O mesmo tem por objetivo fornecer informações para avaliação da Eficiência, Efetividade e Eficácia da Política Pública de Formação de Agentes de Ater adotada pelo Departamento de Assistência Técnica e Extensão Rural, da Secretaria de Agricultura Familiar do Ministério do Desenvolvimento - DATER/SAF/MDA, no período de 2004 a 2009, tema escolhido para Monografia a ser apresentada à Universidade de Brasília (UnB) como requisito parcial para obtenção do grau de Bacharel em Administração.

Você poderá ou não se identificar no questionário e garantimos que todas as informações fornecidas serão confidenciais e utilizadas apenas de forma sistematizada.

IDENTIFICAÇÃO

\begin{tabular}{|c|c|}
\hline $\begin{array}{l}\text { Nome: } \\
\text { REGIANI APARECIDA ALEXANDRE OHLAND }\end{array}$ & $\begin{array}{l}\text { Sexo: } \\
(\quad) \text { masculino } \quad(x) \text { feminino }\end{array}$ \\
\hline $\begin{array}{l}\text { Instituição (nome e tipo de instituição: ONG, } \\
\text { Empresa Pública, etc.): } \\
\text { IDATERRRA - MS }\end{array}$ & $\begin{array}{l}\text { Local de trabalho (Cidade e Estado): } \\
\text { CAMPO GRANDE-MS }\end{array}$ \\
\hline \multicolumn{2}{|c|}{$\begin{array}{l}\text { Curso/Encontro/Oficina do qual participou (caso tenha participado de mais de um curso, preencha } \\
\text { um formulário para cada um deles): } \\
\text { ENCONTRO PARA SOCIALIZAÇÃO DOS CONCEITOS DA PNATER }\end{array}$} \\
\hline $\begin{array}{l}\text { Data do Curso/Encontro/Oficina (pelo menos mês } \\
\text { JULHO/2004 }\end{array}$ & \\
\hline
\end{tabular}

1) Indique sua área de atuação? (As opções não são excludentes: você poderá marcar mais de uma opção).

\begin{tabular}{|l|l}
\hline$X$ & EXTENSÃO RURAL \\
\hline
\end{tabular} 


\begin{tabular}{|l|l|}
\hline & PESQUISA \\
\hline & ENSINO \\
\hline & OUTROS \\
\hline
\end{tabular}

2) Qual o seu nível de escolaridade? (Considere apenas o nível mais alto)

\begin{tabular}{|l|l|}
\hline & NÍVEL MÉDIO \\
\hline & NÍVEL SUPERIOR \\
\hline$X$ & PÓS-GRADUAÇÃO \\
\hline
\end{tabular}

3) Os conteúdos abordados foram condizentes com as demandas do seu dia-a-dia?

\begin{tabular}{|l|l|}
\hline$X$ & SIM \\
\hline & PARCIALMENTE \\
\hline & NÃO \\
\hline
\end{tabular}

4) O curso contribuiu para o seu aperfeiçoamento profissional?

\begin{tabular}{|l|l|}
\hline$X$ & SIM \\
\hline & NÃO \\
\hline
\end{tabular}

5) Os conhecimentos adquiridos estão sendo aplicados no seu trabalho? Em caso afirmativo, indique em que grau estes conhecimentos estão sendo aplicados. Em caso negativo, indique por que razão isto não ocorre: (As respostas não são excludentes: você poderá marcar mais de uma opção).

\begin{tabular}{|l|l|l|l|}
\hline $\begin{array}{l}\text { SIM (indique ao lado em } \\
\text { que grau) }\end{array}$ & & MUITO APLICADOS \\
\cline { 3 - 4 } & $\mathrm{X}$ & MEDIAMENTE APLICADOS \\
\hline
\end{tabular}




\begin{tabular}{|c|c|}
\hline & POUCO APLICADOS \\
\hline \multirow{5}{*}{$\begin{array}{l}\text { NÃO (indique ao lado a } \\
\text { razão da não aplicação) }\end{array}$} & $\begin{array}{l}\text { CONTEÚDO NÃO ADEQUADO ÀS NECESSIDADES } \\
\text { ESPECÍFICAS DA REGIÃO }\end{array}$ \\
\hline & $\begin{array}{l}\text { CONTEÚDO NÃO } \\
\text { APROFUNDADO PARA }\end{array}$ \\
\hline & $\begin{array}{|lllllll|}\text { FALTA } & \text { DE } & \text { APOIO } & \text { E } & \text { INCENTIVO } & \text { DA } & \text { MINHA } \\
\text { INSTITUIÇÃO } & & & & \\
\end{array}$ \\
\hline & FALTA DE INCENTIVO ÀS AÇÕES DE ATER \\
\hline & NÃO TENHO INTERESSE EM APLICAR \\
\hline
\end{tabular}

6) A partir deste curso: (As opções não são excludentes: você poderá marcar mais de uma opção).

\begin{tabular}{|l|l|}
\hline & NÃO MUDOU NADA EM MEU TRABALHO. \\
\hline & $\begin{array}{l}\text { MEU TRABALHO PASSOU A CONTRIBUIR MAIS COM OS AGRICULTORES(AS) } \\
\text { FAMILIARES. }\end{array}$ \\
\hline & CONSEGUI INFLUENCIAR NAS ORIENTAÇÕES DA MINHA INSTITUIÇÃO. \\
\hline$X$ & $\begin{array}{l}\text { CRASSEI A TRABALHAR COM METODOLOGIAS PARTICIPATIVAS. } \\
\text { ONDE ATUO. }\end{array}$ \\
\hline$X$ & CONTINUEI ME APERFEIÇOANDO SOBRE TEMAS ABORDADOS. \\
\hline
\end{tabular}

7) Depois do curso você apoiou atividades de capacitação de técnicos e agricultores com base nos princípios e diretrizes da Pnater? (Considere como apoio a atividades de capacitação a participação no planejamento, elaboração de ementas, seleção de participantes e de palestrantes.)

\begin{tabular}{|l|l|}
\hline$X$ & SIM \\
\hline & NÃO \\
\hline
\end{tabular}


8) Usou os conhecimentos para ministrar outros cursos com o mesmo conteúdo ou conteúdos semelhantes?

\begin{tabular}{|l|l|}
\hline & SIM \\
\hline$X$ & NÃO \\
\hline
\end{tabular}

9) Marque o seu grau de satisfação com relação ao curso oferecido pelo DATER: (Considere a seguinte pontuação: 1 - MUITO RUIM; 2 - RUIM; 3 - REGULAR; 4 - BOM; 5 - MUITO BOM)

\begin{tabular}{|l|l|l|l|l|}
\hline 1 & 2 & 3 & $\times 4$ & 5 \\
\hline
\end{tabular}

10) Marque seu grau de satisfação com relação ao DATER: (Considere a seguinte pontuação: 1 - MUITO RUIM; 2 - RUIM; 3 - REGULAR; 4 - BOM; 5 - MUITO BOM)

\begin{tabular}{|l|l|l|l|l|}
\hline 1 & 2 & 3 & 4 & $x 5$ \\
\hline
\end{tabular}


PESQUISA - IMPACTO DAS AÇÕES DE FORMAÇÃO REALIZADAS PELO DATER/SAF/MDA NO PERÍODO 2004-2009

Caros colaboradores,

Contamos com a sua atenção para preencher o formulário abaixo.

O mesmo tem por objetivo fornecer informações para avaliação da Eficiência, Efetividade e Eficácia da Política Pública de Formação de Agentes de Ater adotada pelo Departamento de Assistência Técnica e Extensão Rural, da Secretaria de Agricultura Familiar do Ministério do Desenvolvimento - DATER/SAF/MDA, no período de 2004 a 2009, tema escolhido para Monografia a ser apresentada à Universidade de Brasília (UnB) como requisito parcial para obtenção do grau de Bacharel em Administração.

Você poderá ou não se identificar no questionário e garantimos que todas as informações fornecidas serão confidenciais e utilizadas apenas de forma sistematizada.

\section{IDENTIFICAÇÃO}

\begin{tabular}{|l|l|}
\hline Nome: Michelle Jorge Pantaleão & $\begin{array}{l}\text { Sexo: } \\
(\quad) \text { masculino } \quad(\quad \mathrm{x}) \text { feminino }\end{array}$ \\
\hline $\begin{array}{l}\text { Instituição: Movimento dos Pequenos Agricultores - } \\
\text { MPA }\end{array}$ & $\begin{array}{l}\text { Local de trabalho: Catalão - Estado de } \\
\text { Goiás }\end{array}$ \\
\hline Curso/Encontro/Oficina do qual participou: Oficina regional da Cadeia Leiteira \\
\hline Data do Curso/Encontro/Oficina: outubro de 2006 \\
\hline
\end{tabular}

1) Indique sua área de atuação? (As opções não são excludentes: você poderá marcar mais de uma opção).

\begin{tabular}{|l|l|}
\hline$X$ & EXTENSÃO RURAL \\
\hline & PESQUISA \\
\hline & ENSINO \\
\hline & OUTROS \\
\hline
\end{tabular}


2) Qual o seu nível de escolaridade? ( Considere apenas o nível mais alto)

\begin{tabular}{|l|l|}
\hline & NÍVEL MÉDIO \\
\hline$X$ & NÍVEL SUPERIOR \\
\hline & PÓS-GRADUAÇÃO \\
\hline
\end{tabular}

3) Os conteúdos abordados foram condizentes com as demandas do seu dia-a-dia?

\begin{tabular}{|l|l|}
\hline$X$ & SIM \\
\hline & PARCIALMENTE \\
\hline & NÃO \\
\hline
\end{tabular}

4) O curso contribuiu para o seu aperfeiçoamento profissional?

\begin{tabular}{|l|l|}
\hline$X$ & SIM \\
\hline & NÃO \\
\hline
\end{tabular}

5) Os conhecimentos adquiridos estão sendo aplicados no seu trabalho? Em caso afirmativo, indique em que grau estes conhecimentos estão sendo aplicados. Em caso negativo, indique por que razão isto não ocorre: (As respostas não são excludentes: você poderá marcar mais de uma opção).

\begin{tabular}{|l|l|l|l|}
\hline \multirow{2}{*}{$\begin{array}{l}\text { SIM (indique ao lado em } \\
\text { que grau) }\end{array}$} & & MUITO APLICADOS \\
\cline { 3 - 4 } & & MEDIAMENTE APLICADOS \\
\hline \multirow{2}{*}{$\begin{array}{l}\text { NÃO (indique ao lado a } \\
\text { razão da não aplicação) }\end{array}$} & & $\begin{array}{l}\text { CONTEÚDO NÃO ADEQUADO ÁS NECESSIDADES } \\
\text { ESPECÍFICAS DA REGIÃO }\end{array}$ \\
\cline { 3 - 4 } & $\begin{array}{l}\text { CONTEÚDO NÃO FOI SUFICIENTEMENTEE } \\
\text { APROFUNDADO PARA PERMITIR UMA APLICAÇÃO } \\
\text { EFICAZ E EFICIENTE }\end{array}$ \\
\hline
\end{tabular}




\begin{tabular}{|l|l|l|}
\hline \multirow{2}{*}{} & & $\begin{array}{l}\text { FALTA DE APOIO E INCENTIVO DA MINHA } \\
\text { INSTITUIÇÃO }\end{array}$ \\
\cline { 2 - 3 } & & FALTA DE INCENTIVO ÀS AÇÕES DE ATER \\
\cline { 2 - 3 } & & NÃO TENHO INTERESSE EM APLICAR \\
\hline
\end{tabular}

6) A partir deste curso: (As opções não são excludentes: você poderá marcar mais de uma opção).

\begin{tabular}{|l|l|}
\hline$x$ & $\begin{array}{l}\text { NÃO MUDOU NADA EM MEU TRABALHO. } \\
\text { FAMILIARES. }\end{array}$ \\
\hline & CONSEGUI INFLUENCIAR NAS ORIENTAÇÕES DA MINHA INSTITUIÇÃO. \\
\hline$X$ & PASSEI A TRABALHAR COM METODOLOGIAS PARTICIPATIVAS. \\
\hline & $\begin{array}{l}\text { CRESCEU A ÁREA DE AGRICULTURA DE BASE ECOLÓGICA NAS COMUNIDADES } \\
\text { ONDE ATUO. }\end{array}$ \\
\hline & CONTINUEI ME APERFEIÇOANDO SOBRE TEMAS ABORDADOS. \\
\hline
\end{tabular}

7) Depois do curso você apoiou atividades de capacitação de técnicos e agricultores com base nos princípios e diretrizes da Pnater? (Considere como apoio a atividades de capacitação a participação no planejamento, elaboração de ementas, seleção de participantes e de palestrantes.)

\begin{tabular}{|l|l|}
\hline$X$ & SIM \\
\hline & NÃO \\
\hline
\end{tabular}

8) Usou os conhecimentos para ministrar outros cursos com o mesmo conteúdo ou conteúdos semelhantes?

\begin{tabular}{|l|l|}
\hline$X$ & SIM \\
\hline & NÃO \\
\hline
\end{tabular}


9) Marque o seu grau de satisfação com relação ao curso oferecido pelo DATER: (Considere a seguinte pontuação: 1 - MUITO RUIM; 2 - RUIM; 3 - REGULAR; 4 - BOM; 5 - MUITO BOM)

\begin{tabular}{|l|l|l|l|l|}
\hline 1 & 2 & 3 & $\underline{x}$ & 5 \\
\hline
\end{tabular}

10) Marque seu grau de satisfação com relação ao DATER: (Considere a seguinte pontuação: 1 - MUITO RUIM; 2 - RUIM; 3 - REGULAR; 4 - BOM; 5 - MUITO BOM)

\begin{tabular}{|l|l|l|l|l|}
\hline 1 & 2 & 3 & $\underline{x}$ & 5 \\
\hline
\end{tabular}


PESQUISA - IMPACTO DAS AÇÕES DE FORMAÇÃO REALIZADAS PELO DATER/SAF/MDA NO PERÍODO 2004-2009

Caros colaboradores,

Contamos com a sua atenção para preencher o formulário abaixo.

O mesmo tem por objetivo fornecer informações para avaliação da Eficiência, Efetividade e Eficácia da Política Pública de Formação de Agentes de Ater adotada pelo Departamento de Assistência Técnica e Extensão Rural, da Secretaria de Agricultura Familiar do Ministério do Desenvolvimento - DATER/SAF/MDA, no período de 2004 a 2009, tema escolhido para Monografia a ser apresentada à Universidade de Brasília (UnB) como requisito parcial para obtenção do grau de Bacharel em Administração.

Você poderá ou não se identificar no questionário e garantimos que todas as informações fornecidas serão confidenciais e utilizadas apenas de forma sistematizada.

\section{IDENTIFICAÇÃO}

\begin{tabular}{|c|c|}
\hline $\begin{array}{l}\text { Nome: } \\
\text { Carla Maria Cartocci }\end{array}$ & $\begin{array}{l}\text { Sexo: } \\
(\quad) \text { masculino }(x) \text { feminino }\end{array}$ \\
\hline $\begin{array}{l}\text { Instituição (nome e tipo de instituição: ONG, } \\
\text { Empresa Pública, etc.): } \\
\text { Instituto para o Desenvolvimento Ambiental }\end{array}$ & $\begin{array}{l}\text { Local de trabalho (Cidade e Estado): } \\
\text { Brasília DF }\end{array}$ \\
\hline \multicolumn{2}{|c|}{$\begin{array}{l}\text { Curso/Encontro/Oficina do qual participou (caso tenha participado de mais de um curso, preencha } \\
\text { um formulário para cada um deles): } \\
\text { Agroecologia MDA/ Redecapa- a distancia }\end{array}$} \\
\hline
\end{tabular}

1) Indique sua área de atuação? (As opções não são excludentes: você poderá marcar mais de uma opção).

\begin{tabular}{|l|l|}
\hline & EXTENSÃO RURAL \\
\hline$X$ & PESQUISA \\
\hline$X$ & ENSINO \\
\hline
\end{tabular}




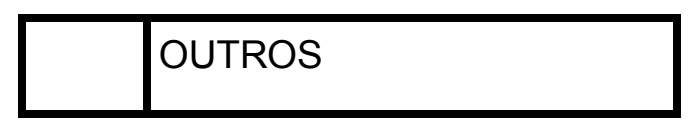

2) Qual o seu nível de escolaridade? ( Considere apenas o nível mais alto)

\begin{tabular}{|l|l|}
\hline & NÍVEL MÉDIO \\
\hline & NÍVEL SUPERIOR \\
\hline$x$ & PÓS-GRADUAÇÃO \\
\hline
\end{tabular}

3) Os conteúdos abordados foram condizentes com as demandas do seu dia-a-dia?

\begin{tabular}{|l|l|}
\hline$X$ & SIM \\
\hline & PARCIALMENTE \\
\hline & NÃO \\
\hline
\end{tabular}

4) O curso contribuiu para o seu aperfeiçoamento profissional?

\begin{tabular}{|l|l|}
\hline$x$ & SIM \\
\hline & NÃO \\
\hline
\end{tabular}

5) Os conhecimentos adquiridos estão sendo aplicados no seu trabalho? Em caso afirmativo, indique em que grau estes conhecimentos estão sendo aplicados. Em caso negativo, indique por que razão isto não ocorre: (As respostas não são excludentes: você poderá marcar mais de uma opção).

\begin{tabular}{|l|l|l|l|}
\hline \multirow{2}{*}{$\begin{array}{l}\text { SIM (indique ao lado em } \\
\text { que grau) }\end{array}$} & & MUITO APLICADOS \\
\cline { 2 - 4 } & $\begin{array}{l}\text { NÃO (indique ao lado a } \\
\text { razão da não aplicação) }\end{array}$ & MEDIAMENTE APLICADOS \\
\hline
\end{tabular}




\begin{tabular}{|l|l|l|}
\hline \multirow{10}{*}{} & $\begin{array}{l}\text { CONTEÚDO NÃO FOI SUFICIENTEMENTE } \\
\text { APROFUNDADO PARA PERMITIR UMA APLICAÇÃO } \\
\text { EFICAZ E EFICIENTE }\end{array}$ \\
\cline { 2 - 4 } & $\begin{array}{l}\text { FALTA DE APOIO E INCENTIVO DA MINHA } \\
\text { INSTITUIÇÃO }\end{array}$ \\
\cline { 2 - 4 } & FALTA DE INCENTIVO ÀS AÇÕES DE ATER \\
\hline & NÃO TENHO INTERESSE EM APLICAR \\
\hline
\end{tabular}

6) A partir deste curso: (As opções não são excludentes: você poderá marcar mais de uma opção).

\begin{tabular}{|l|l|}
\hline$x$ & NÃO MUDOU NADA EM MEU TRABALHO. \\
\hline$x$ & $\begin{array}{l}\text { MEU TRABALHO PASSOU A CONTRIBUIR MAIS COM OS AGRICULTORES(AS) } \\
\text { FAMILIARES. }\end{array}$ \\
\hline & CONSEGUI INFLUENCIAR NAS ORIENTAÇÕES DA MINHA INSTITUIÇÃO. \\
\hline & $\begin{array}{l}\text { CRESCEU A ÁREA DE AGRICULTURA DE BASE ECOLÓGICA NAS COMUNIDADES } \\
\text { ONDE ATUO. }\end{array}$ \\
\hline$x$ & CONTINUEI ME APERFEIÇOANDO SOBRE TEMAS ABORDADOS. \\
\hline
\end{tabular}

7) Depois do curso você apoiou atividades de capacitação de técnicos e agricultores com base nos princípios e diretrizes da Pnater? (Considere como apoio a atividades de capacitação a participação no planejamento, elaboração de ementas, seleção de participantes e de palestrantes.)

\begin{tabular}{|l|l|}
\hline & SIM \\
\hline$x$ & NÃO \\
\hline
\end{tabular}

8) Usou os conhecimentos para ministrar outros cursos com o mesmo conteúdo ou conteúdos semelhantes? 


\begin{tabular}{|l|l|}
\hline$x$ & SIM \\
\hline & NÃO \\
\hline
\end{tabular}

9) Marque o seu grau de satisfação com relação ao curso oferecido pelo DATER: : (Considere a seguinte pontuação: 1 - MUITO RUIM; 2 - RUIM; 3 - REGULAR; 4 - BOM; 5 - MUITO BOM)

\begin{tabular}{|l|l|l|l|l|}
\hline 1 & 2 & 3 & $\mathrm{x} 4$ & 5 \\
\hline
\end{tabular}

10) Marque seu grau de satisfação com relação ao DATER: : (Considere a seguinte pontuação: 1 - MUITO RUIM; 2 - RUIM; 3 - REGULAR; 4 - BOM; 5 - MUITO BOM)

\begin{tabular}{|l|l|l|l|l|}
\hline 1 & 2 & 3 & $x 4$ & 5 \\
\hline
\end{tabular}


PESQUISA - IMPACTO DAS AÇÕES DE FORMAÇÃO REALIZADAS PELO DATER/SAF/MDA NO PERÍODO 2004-2009

Caros colaboradores,

Contamos com a sua atenção para preencher o formulário abaixo.

O mesmo tem por objetivo fornecer informações para avaliação da Eficiência, Efetividade e Eficácia da Política Pública de Formação de Agentes de Ater adotada pelo Departamento de Assistência Técnica e Extensão Rural, da Secretaria de Agricultura Familiar do Ministério do Desenvolvimento - DATER/SAF/MDA, no período de 2004 a 2009, tema escolhido para Monografia a ser apresentada à Universidade de Brasília (UnB) como requisito parcial para obtenção do grau de Bacharel em Administração.

Você poderá ou não se identificar no questionário e garantimos que todas as informações fornecidas serão confidenciais e utilizadas apenas de forma sistematizada.

IDENTIFICAÇÃO

\begin{tabular}{|c|c|}
\hline $\begin{array}{l}\text { Nome: } \\
\text { Carolina Rizzi Starr }\end{array}$ & $\begin{array}{l}\text { Sexo: } \\
(\quad) \text { masculino }(x) \text { feminino }\end{array}$ \\
\hline $\begin{array}{l}\text { Instituição (nome e tipo de instituição: ONG, } \\
\text { Empresa Pública, etc.): } \\
\text { Ong - Instituto Ambiental Brasil Sustentavel }\end{array}$ & $\begin{array}{l}\text { Local de trabalho (Cidade e Estado): } \\
\text { Brasilia DF }\end{array}$ \\
\hline \multicolumn{2}{|c|}{$\begin{array}{l}\text { Curso/Encontro/Oficina do qual participou (caso tenha participado de mais de um curso, preencha } \\
\text { um formulário para cada um deles): } \\
\text { Aperfeiçoamento em Agroecologia REDCAPA }\end{array}$} \\
\hline $\begin{array}{l}\text { Data do Curso/Encontro/Oficina (pelo menos mês } \\
\text { Março a Julho de } 2006\end{array}$ & \\
\hline
\end{tabular}

Indique sua área de atuação? (As opções não são excludentes: você poderá marcar mais de uma opção).

\begin{tabular}{|l|l|}
\hline & EXTENSÃO RURAL \\
\hline & PESQUISA \\
\hline & ENSINO \\
\hline$x$ & OUTROS \\
\hline
\end{tabular}


2) Qual o seu nível de escolaridade? ( Considere apenas o nível mais alto)

\begin{tabular}{|l|l|}
\hline & NÍVEL MÉDIO \\
\hline$x$ & NÍVEL SUPERIOR \\
\hline & PÓS-GRADUAÇÃO \\
\hline
\end{tabular}

3) Os conteúdos abordados foram condizentes com as demandas do seu dia-a-dia?

\begin{tabular}{|l|l|}
\hline$x$ & SIM \\
\hline & PARCIALMENTE \\
\hline & NÃO \\
\hline
\end{tabular}

3) O curso contribuiu para o seu aperfeiçoamento profissional?

\begin{tabular}{|l|l|}
\hline$x$ & SIM \\
\hline & NÃO \\
\hline
\end{tabular}

5) Os conhecimentos adquiridos estão sendo aplicados no seu trabalho? Em caso afirmativo, indique em que grau estes conhecimentos estão sendo aplicados. Em caso negativo, indique por que razão isto não ocorre: (As respostas não são excludentes: você poderá marcar mais de uma opção).

\begin{tabular}{|c|c|c|}
\hline & \multirow{3}{*}{$\begin{array}{l}\text { SIM (indique ao lado em } \\
\text { que grau) }\end{array}$} & MUITO APLICADOS \\
\hline & & MEDIAMENTE APLICADOS \\
\hline & & POUCO APLICADOS \\
\hline \multirow[b]{2}{*}{$x$} & \multirow{2}{*}{$\begin{array}{l}\text { NÃO (indique ao lado a } \\
\text { razão da não aplicação) }\end{array}$} & $\begin{array}{l}\text { CONTEÚDO NÃO ADEQUADO ȦS NECESSIDADES } \\
\text { ESPECÍFICAS DA REGIÃO }\end{array}$ \\
\hline & & $\begin{array}{l}\text { CONTEÚDO NÃO } \quad \text { FOI SUFICIENTEMENTE } \\
\text { APROFUNDADO PARA } \\
\text { PERMITIR UMA APLICAÇÃO } \\
\text { EFICAZ E EFICIENTE }\end{array}$ \\
\hline
\end{tabular}




\begin{tabular}{|l|l|l|}
\hline \multirow{2}{*}{} & $x$ & $\begin{array}{l}\text { FALTA DE APOIO E INCENTIVO DA MINHA } \\
\text { INSTITUIÇÃO }\end{array}$ \\
\cline { 2 - 4 } & & FALTA DE INCENTIVO ÀS AÇÕES DE ATER \\
\cline { 2 - 4 } & & NÃO TENHO INTERESSE EM APLICAR \\
\hline
\end{tabular}

6) A partir deste curso: (As opções não são excludentes: você poderá marcar mais de uma opção).

\begin{tabular}{|l|l|}
\hline$x$ & NÃO MUDOU NADA EM MEU TRABALHO. \\
\hline & $\begin{array}{l}\text { MEU TRABALHO PASSOU A CONTRIBUIR MAIS COM OS AGRICULTORES(AS) } \\
\text { FAMILIARES. }\end{array}$ \\
\hline & CONSEGUI INFLUENCIAR NAS ORIENTAÇÕES DA MINHA INSTITUIÇÃO. \\
\hline & $\begin{array}{l}\text { CRESEEI A TRABALHAR COM METODOLOGIAS PARTICIPATIVAS. } \\
\text { ONDE ATUO. ÁREA DE AGRICULTURA DE BASE ECOLÓGICA NAS COMUNIDADES }\end{array}$ \\
\hline & CONTINUEI ME APERFEIÇOANDO SOBRE TEMAS ABORDADOS. \\
\hline
\end{tabular}

7) Depois do curso você apoiou atividades de capacitação de técnicos e agricultores com base nos princípios e diretrizes da Pnater? (Considere como apoio a atividades de capacitação a participação no planejamento, elaboração de ementas, seleção de participantes e de palestrantes.)

\begin{tabular}{|l|l|}
\hline & SIM \\
\hline$x$ & NÃO \\
\hline
\end{tabular}

8) Usou os conhecimentos para ministrar outros cursos com o mesmo conteúdo ou conteúdos semelhantes?

\begin{tabular}{|l|l|}
\hline$x$ & SIM \\
\hline & NÃO \\
\hline
\end{tabular}


9) Marque o seu grau de satisfação com relação ao curso oferecido pelo DATER: : (Considere a seguinte pontuação: 1 - MUITO RUIM; 2 - RUIM; 3 - REGULAR; 4 - BOM; 5 - MUITO BOM)

\begin{tabular}{|l|l|l|l|l|}
\hline 1 & 2 & 3 & $4 x$ & 5 \\
\hline
\end{tabular}

10) Marque seu grau de satisfação com relação ao DATER: : (Considere a seguinte pontuação:

1 - MUITO RUIM; 2 - RUIM; 3 - REGULAR; 4 - BOM; 5 - MUITO BOM)

\begin{tabular}{|l|l|l|l|l|}
\hline 1 & $2 x$ & 3 & 4 & 5 \\
\hline
\end{tabular}


PESQUISA - IMPACTO DAS AÇÕES DE FORMAÇÃO REALIZADAS PELO DATER/SAF/MDA NO PERÍODO 2004-2009

Caros colaboradores,

Contamos com a sua atenção para preencher o formulário abaixo.

O mesmo tem por objetivo fornecer informações para avaliação da Eficiência, Efetividade e Eficácia da Política Pública de Formação de Agentes de Ater adotada pelo Departamento de Assistência Técnica e Extensão Rural, da Secretaria de Agricultura Familiar do Ministério do Desenvolvimento - DATER/SAF/MDA, no período de 2004 a 2009, tema escolhido para Monografia a ser apresentada à Universidade de Brasília (UnB) como requisito parcial para obtenção do grau de Bacharel em Administração.

Você poderá ou não se identificar no questionário e garantimos que todas as informações fornecidas serão confidenciais e utilizadas apenas de forma sistematizada.

IDENTIFICAÇÃO

\begin{tabular}{|l|l|}
\hline Nome: & Sexo: \\
RODRIGO NOGUEIRA DE SOUZA & \begin{tabular}{l}
$(\mathrm{x})$ masculino $\quad(\quad)$ feminino \\
\hline Instituição:
\end{tabular} \\
CENTRO DE ORGANIZAÇÃO E APOIO AOS & P. A ITAMARATI, PONTA PORÃ, MS \\
ASSENTADOS DE MATO GROSSO DO SUL & \\
\hline $\begin{array}{l}\text { CurSo/Encontro/Oficina do qual participou: } \\
\text { DESENVOLVIMENTO RURAL PARTICIPATIVO }\end{array}$ \\
\hline $\begin{array}{l}\text { Data do CurSo/Encontro/Oficina: } \\
\text { NOVEMBRO DE 2006 }\end{array}$ \\
\hline
\end{tabular}

Indique sua área de atuação? (As opções não são excludentes: você poderá marcar mais de uma opção).

\begin{tabular}{|l|l|}
\hline$X$ & EXTENSÃO RURAL \\
\hline & PESQUISA \\
\hline & ENSINO \\
\hline & OUTROS \\
\hline
\end{tabular}


2) Qual o seu nível de escolaridade? ( Considere apenas o nível mais alto)

\begin{tabular}{|l|l|}
\hline$X$ & NÍVEL MÉDIO \\
\hline & NÍVEL SUPERIOR \\
\hline & PÓS-GRADUAÇÃO \\
\hline
\end{tabular}

3) Os conteúdos abordados foram condizentes com as demandas do seu dia-a-dia?

\begin{tabular}{|l|l|}
\hline$X$ & SIM \\
\hline & PARCIALMENTE \\
\hline & NÃO \\
\hline
\end{tabular}

4) O curso contribuiu para o seu aperfeiçoamento profissional?

\begin{tabular}{|l|l|}
\hline$X$ & SIM \\
\hline & NÃO \\
\hline
\end{tabular}

5) Os conhecimentos adquiridos estão sendo aplicados no seu trabalho? Em caso afirmativo, indique em que grau estes conhecimentos estão sendo aplicados. Em caso negativo, indique por que razão isto não ocorre: (As respostas não são excludentes: você poderá marcar mais de uma opção).

\begin{tabular}{|c|c|c|c|}
\hline \multirow{3}{*}{$x$} & \multirow{3}{*}{$\begin{array}{l}\text { SIM (indique ao lado em } \\
\text { que grau) }\end{array}$} & $X$ & MUITO APLICADOS \\
\hline & & & MEDIAMENTE APLICADOS \\
\hline & & & POUCO APLICADOS \\
\hline & & & $\begin{array}{l}\text { CONTEÚDO NĀO ADEQUADO ȦS NECESSIDADES } \\
\text { ESPECÍFICAS DA REGIÃO }\end{array}$ \\
\hline & $\begin{array}{l}\text { NAO (Indique ao lado a } \\
\text { razão da não aplicação) }\end{array}$ & & $\begin{array}{l}\text { CONTEÚDO NÃO FOI SUFICIENTEMENTE } \\
\text { APROFUNDADO PARA PERMITIR UMA APLICAÇÃO } \\
\text { EFICAZ E EFICIENTE }\end{array}$ \\
\hline
\end{tabular}




\begin{tabular}{|l|l|l|}
\hline \multirow{2}{*}{} & & $\begin{array}{l}\text { FALTA DE APOIO E INCENTIVO DA MINHA } \\
\text { INSTITUIÇÃO }\end{array}$ \\
\cline { 2 - 3 } & & FALTA DE INCENTIVO ÀS AÇÕES DE ATER \\
\cline { 2 - 3 } & NÃO TENHO INTERESSE EM APLICAR \\
\hline
\end{tabular}

6) A partir deste curso: (As opções não são excludentes: você poderá marcar mais de uma opção).

\begin{tabular}{|l|l|}
\hline & NÃO MUDOU NADA EM MEU TRABALHO. \\
\hline$X$ & $\begin{array}{l}\text { MEU TRABALHO PASSOU A CONTRIBUIR MAIS COM OS AGRICULTORES(AS) } \\
\text { FAMILIARES. }\end{array}$ \\
\hline $\mathrm{X}$ & CONSEGUI INFLUENCIAR NAS ORIENTAÇÕES DA MINHA INSTITUIÇÃO. \\
\hline & $\begin{array}{l}\text { CRESCEU A ÁREA DE AGRICULTURA DE BASE ECOLÓGICA NAS COMUNIDADES } \\
\text { ONDE ATUO. }\end{array}$ \\
\hline$X$ & CONTINUEI ME APERFEIÇOANDO SOBRE TEMAS ABORDADOS. \\
\hline
\end{tabular}

7) Depois do curso você apoiou atividades de capacitação de técnicos e agricultores com base nos princípios e diretrizes da Pnater? (Considere como apoio a atividades de capacitação a participação no planejamento, elaboração de ementas, seleção de participantes e de palestrantes.)

\begin{tabular}{|l|l|}
\hline$X$ & SIM \\
\hline & NÃO \\
\hline
\end{tabular}

8) Usou os conhecimentos para ministrar outros cursos com o mesmo conteúdo ou conteúdos semelhantes?

\begin{tabular}{|l|l|}
\hline$X$ & SIM \\
\hline & NÃO \\
\hline
\end{tabular}


9) Marque o seu grau de satisfação com relação ao curso oferecido pelo DATER: (Considere a seguinte pontuação: 1 - MUITO RUIM; 2 - RUIM; 3 - REGULAR; 4 - BOM; 5 - MUITO BOM)

\begin{tabular}{|l|l|l|l|l|}
\hline 1 & 2 & 3 & 4 & 5 \\
\hline
\end{tabular}

10) Marque seu grau de satisfação com relação ao DATER: (Considere a seguinte pontuação: 1 - MUITO RUIM; 2 - RUIM; 3 - REGULAR; 4 - BOM; 5 - MUITO BOM)

\begin{tabular}{|l|l|l|l|l|}
\hline 1 & 2 & 3 & 4 & 5 \\
\hline
\end{tabular}


PESQUISA - IMPACTO DAS AÇÕES DE FORMAÇÃO REALIZADAS PELO DATER/SAF/MDA NO PERÍODO 2004-2009

Caros colaboradores,

Contamos com a sua atenção para preencher o formulário abaixo.

O mesmo tem por objetivo fornecer informações para avaliação da Eficiência, Efetividade e Eficácia da Política Pública de Formação de Agentes de Ater adotada pelo Departamento de Assistência Técnica e Extensão Rural, da Secretaria de Agricultura Familiar do Ministério do Desenvolvimento - DATER/SAF/MDA, no período de 2004 a 2009, tema escolhido para Monografia a ser apresentada à Universidade de Brasília (UnB) como requisito parcial para obtenção do grau de Bacharel em Administração.

Você poderá ou não se identificar no questionário e garantimos que todas as informações fornecidas serão confidenciais e utilizadas apenas de forma sistematizada.

IDENTIFICAÇÃO

\begin{tabular}{|l|l|}
\hline Nome: & Sexo: \\
RODRIGO NOGUEIRA DE SOUZA & \begin{tabular}{l}
$(\mathrm{x})$ masculino $\quad(\quad)$ feminino \\
\hline Instituição:
\end{tabular} \\
CENTRO DE ORGANIZAÇÃO E APOIO AOS & P. A ITAMARATI, PONTA PORÃ, MS \\
ASSENTADOS DE MATO GROSSO DO SUL & \\
\hline $\begin{array}{l}\text { CurSo/Encontro/Oficina do qual participou: } \\
\text { DESENVOLVIMENTO RURAL PARTICIPATIVO }\end{array}$ \\
\hline $\begin{array}{l}\text { Data do CurSo/Encontro/Oficina: } \\
\text { NOVEMBRO DE 2006 }\end{array}$ \\
\hline
\end{tabular}

1)Indique sua área de atuação? (As opções não são excludentes: você poderá marcar mais de uma opção).

\begin{tabular}{|l|l|}
\hline$X$ & EXTENSÃO RURAL \\
\hline & PESQUISA \\
\hline & ENSINO \\
\hline & OUTROS \\
\hline
\end{tabular}


2) Qual o seu nível de escolaridade? ( Considere apenas o nível mais alto)

\begin{tabular}{|l|l|}
\hline$X$ & NÍVEL MÉDIO \\
\hline & NÍVEL SUPERIOR \\
\hline & PÓS-GRADUAÇÃO \\
\hline
\end{tabular}

3) Os conteúdos abordados foram condizentes com as demandas do seu dia-a-dia?

\begin{tabular}{|l|l|}
\hline$X$ & SIM \\
\hline & PARCIALMENTE \\
\hline & NÃO \\
\hline
\end{tabular}

4) O curso contribuiu para o seu aperfeiçoamento profissional?

\begin{tabular}{|l|l|}
\hline$X$ & SIM \\
\hline & NÃO \\
\hline
\end{tabular}

5) Os conhecimentos adquiridos estão sendo aplicados no seu trabalho? Em caso afirmativo, indique em que grau estes conhecimentos estão sendo aplicados. Em caso negativo, indique por que razão isto não ocorre: (As respostas não são excludentes: você poderá marcar mais de uma opção).

\begin{tabular}{|c|c|c|c|}
\hline \multirow{3}{*}{$\mathrm{X}$} & \multirow{3}{*}{$\begin{array}{l}\text { SIM (indique ao lado em } \\
\text { que grau) }\end{array}$} & $\mathrm{X}$ & MUITO APLICADOS \\
\hline & & & MEDIAMENTE APLICADOS \\
\hline & & & POUCO APLICADOS \\
\hline & \multirow{2}{*}{$\begin{array}{l}\text { NÃO (indique ao lado a } \\
\text { razão da não aplicação) }\end{array}$} & & $\begin{array}{l}\text { CONTEÚDO NÃO ADEQUADO ȦS NECESSIDADES } \\
\text { ESPECÍFICAS DA REGIÃO }\end{array}$ \\
\hline & & & $\begin{array}{llcr}\text { CONTEÚDO NÃO } & \text { FOI SUFICIENTEMENTE } \\
\text { APROFUNDADO PARA } & \text { PERMITIR UMA APLICAÇÃO } \\
\text { EFICAZ E EFICIENTE }\end{array}$ \\
\hline
\end{tabular}




\begin{tabular}{|l|l|l|}
\hline \multirow{2}{*}{} & & $\begin{array}{l}\text { FALTA DE APOIO E INCENTIVO DA MINHA } \\
\text { INSTITUIÇÃO }\end{array}$ \\
\cline { 2 - 3 } & & FALTA DE INCENTIVO ÀS AÇÕES DE ATER \\
\cline { 2 - 3 } & & NÃO TENHO INTERESSE EM APLICAR \\
\hline
\end{tabular}

6) A partir deste curso: (As opções não são excludentes: você poderá marcar mais de uma opção).

\begin{tabular}{|l|l|}
\hline & NÃO MUDOU NADA EM MEU TRABALHO. \\
\hline$X$ & $\begin{array}{l}\text { MEU TRABALHO PASSOU A CONTRIBUIR MAIS COM OS AGRICULTORES(AS) } \\
\text { FAMILIARES. }\end{array}$ \\
\hline$X$ & CONSEGUI INFLUENCIAR NAS ORIENTAÇÕES DA MINHA INSTITUIÇÃO. \\
\hline & $\begin{array}{l}\text { CRESCEU A ÁREA DE AGRICULTURA DE BASE ECOLÓGICA NAS COMUNIDADES } \\
\text { ONDE ATUO. }\end{array}$ \\
\hline$X$ & CONTINUEI ME APERFEIÇOANDO SOBRE TEMAS ABORDADOS. \\
\hline
\end{tabular}

7) Depois do curso você apoiou atividades de capacitação de técnicos e agricultores com base nos princípios e diretrizes da Pnater? (Considere como apoio a atividades de capacitação a participação no planejamento, elaboração de ementas, seleção de participantes e de palestrantes.)

\begin{tabular}{|l|l|}
\hline$X$ & SIM \\
\hline & NÃO \\
\hline
\end{tabular}

8) Usou os conhecimentos para ministrar outros cursos com o mesmo conteúdo ou conteúdos semelhantes?

\begin{tabular}{|l|l|}
\hline$X$ & SIM \\
\hline & NÃO \\
\hline
\end{tabular}


9) Marque o seu grau de satisfação com relação ao curso oferecido pelo DATER: (Considere a seguinte pontuação: 1 - MUITO RUIM; 2 - RUIM; 3 - REGULAR; 4 - BOM; 5 - MUITO BOM)

\begin{tabular}{|l|l|l|l|l|}
\hline 1 & 2 & 3 & 4 & 5 \\
\hline
\end{tabular}

10) Marque seu grau de satisfação com relação ao DATER: (Considere a seguinte pontuação: 1 - MUITO RUIM; 2 - RUIM; 3 - REGULAR; 4 - BOM; 5 - MUITO BOM)

\begin{tabular}{|l|l|l|l|l|}
\hline 1 & 2 & 3 & 4 & 5 \\
\hline
\end{tabular}

